João Luis Ribeiro Ulhôa

Biodiversidade, Meio Ambiente e Desenvolvimento Sustentável

$2^{\mathrm{a}}$ ed.

Piracanjuba-GO

Editora Conhecimento Livre

2020 
Ulhôa, João Luis Ribeiro

U38b Biodiversidade, Meio Ambiente e Desenvolvimento Sustentável.

/João Luis Ribeiro Ulhôa . - Piracanjuba - GO

Editora Conhecimento Livre, 2020

689 f.: il

DOI: $\quad 10.37423 / 2020 . \mathrm{a} 15$

ISBN: 978-65-86072-14-3

Modo de acesso: World Wide Web

Inclui bibliografia

1. Agronomia 2. Pecuária 3. Agricultura. I. Barbosa, Frederico Celestino. I. Título 


\section{EDITORA}

\section{CONHECIMENTO LIVRE}

\section{Corpo Editorial}

MSc. Frederico Celestino Barbosa

MSc. Carlos Eduardo de Oliveira Gontijo

MSc. Plínio Ferreira Pires

Editora Conhecimento Livre

Piracanjuba-GO

$\underline{2020}$ 
CAPÍTULO 1.

O PAPEL DOS PRODUTORES RURAIS NA GESTÃO DOS RECURSOS HÍDRICOS: UMA ANÁLISE PRELIMINAR DA BACIA DO RIO JUNDIAÍ-SP ${ }^{1} \ldots \ldots \ldots \ldots . . . . . .4$

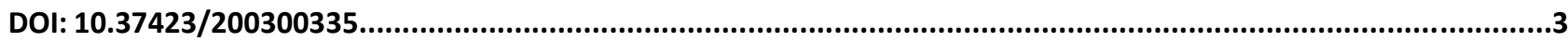

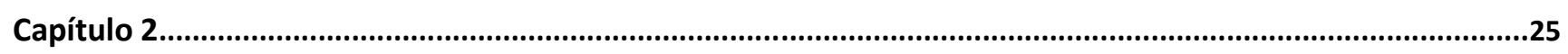

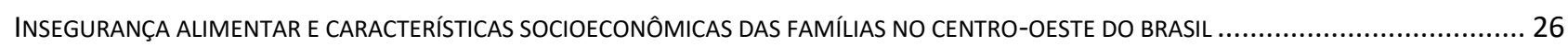

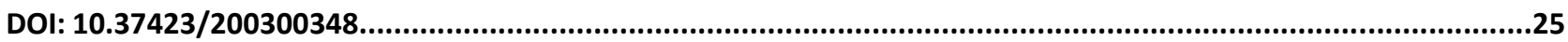

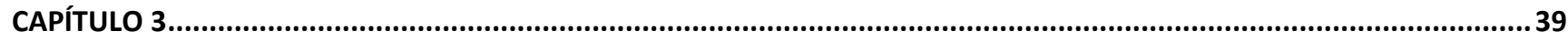

Evolução da balança comercial do estado de mato grosso do sul: uma análise pelo modelo constant market

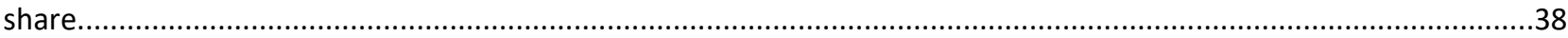

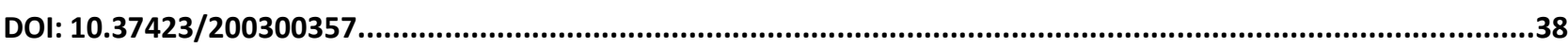

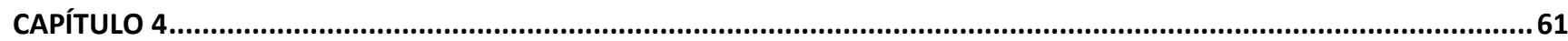

Singularidades do comércio interno de bovinos no brasil.estudo de caso sobre problema da barganha nas feiras

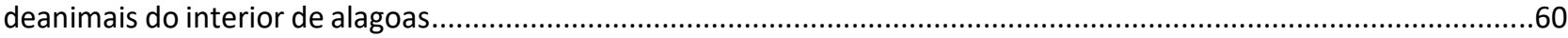

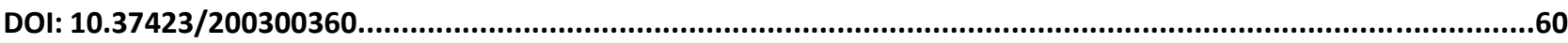

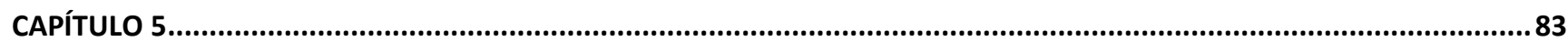

Programa de aquisição de alimentos (paa) no estado do amapá: contribuições ao desenvolvimento rural (2010 - 2017)

(n)

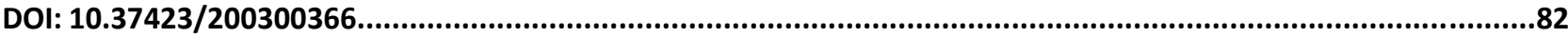

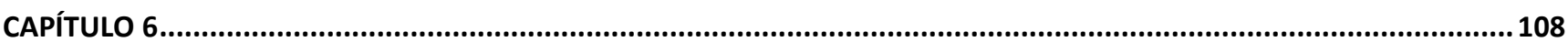

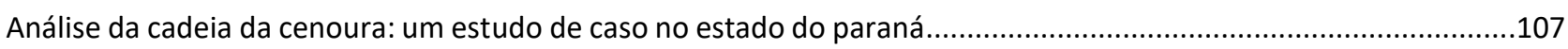

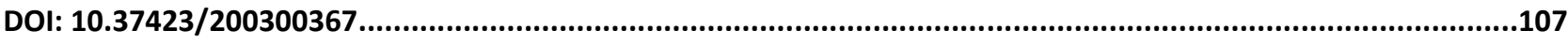

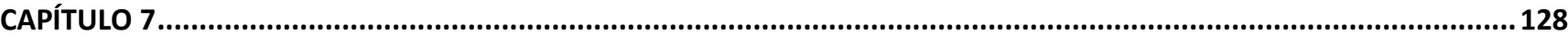

“Mata mato" e não mata gente? A comunicação dos riscos do glifosato na logística reversa das embalagens ${ }^{1} . . . . . . . . .127$

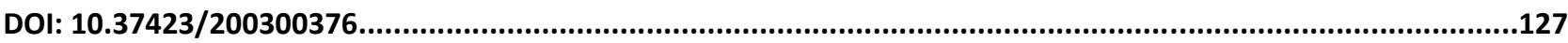

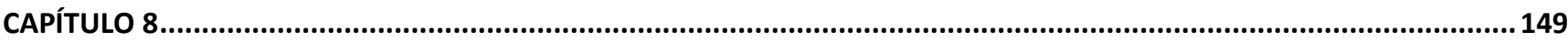

O comércio internacional brasileiro em clusters: aplicação do modelo de eaton e kortum.......................................148

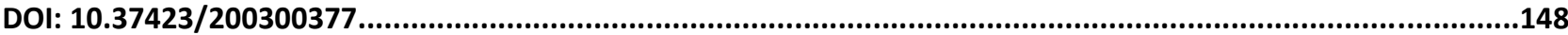

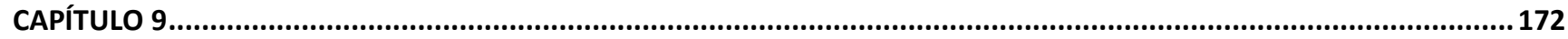

Sistemas agroalimentares em território da monocultura: alternativas locais de comercialização da agricultura

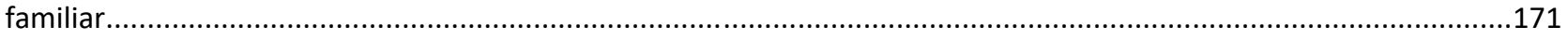

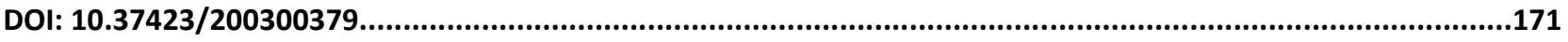

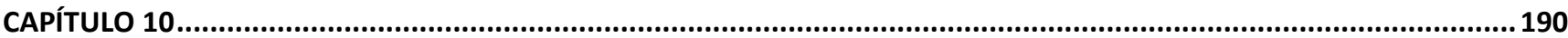

Fatores que incentivam a permanência dos jovens no meio rural: análise das características da gestão rural no município de são carlos - sc. 
Impactos de um possível acordo de liberalização comercial entre o brasil, eua, união europeia e a china sobre a economia brasileira: uma análise de equilíbrio geral computável.......................................................................205

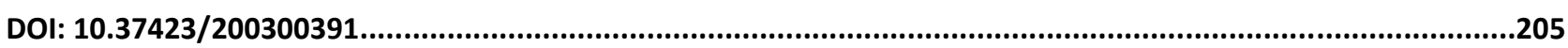

CAPÍTULO 12

Utilização do método ahp para análise da competitividade da agroindustria de filetagem de tilápias no oeste do paraná..

DOI: $10.37423 / 200300394$.

Dpsir como metodologia avaliadora dos impactos socioeconômicos e ambientais de usinas hidrelétricas no pará........246

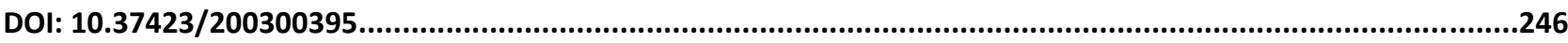

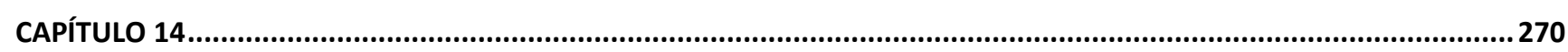

Circuitos alimentares: a dinâmica de abastecimento entre a agricultura familiar e a alimentação escolar...................269

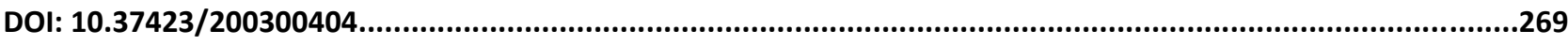

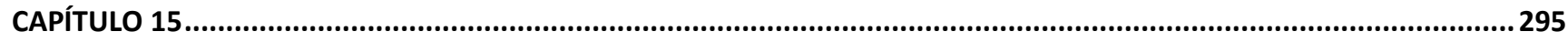

O processo de tomada de decisão e o efeito framing: um estudo de caso na comunidade quilombola do ramal do castelo

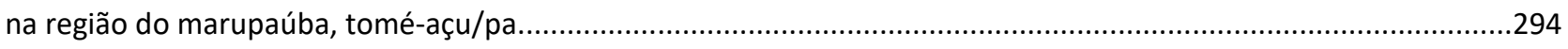

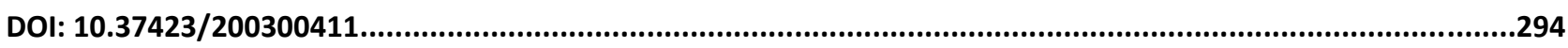

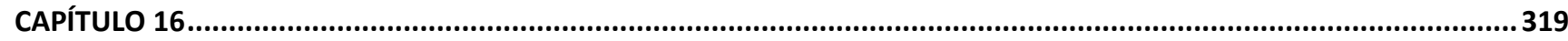

Indicação geográfica (ig) e sua relevância para a produção familiar inserida no mercado.........................................318

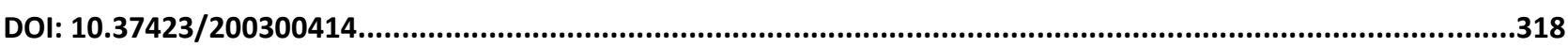

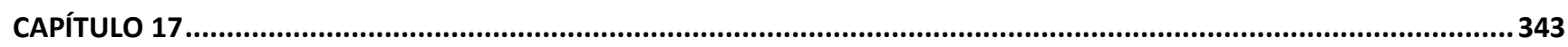

Custo de produção de suínos (fase recria) em uma propriedade rural familiar do oeste do paraná..........................342

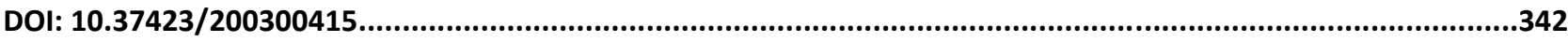

CAPÍTULO 18

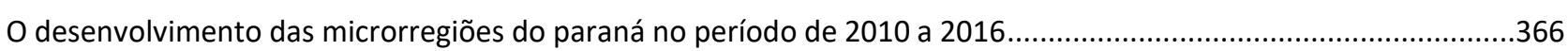

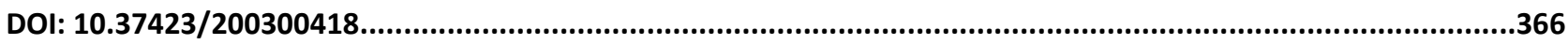

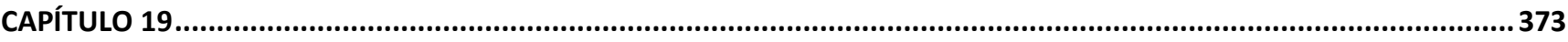

Agronegócio brasileiro: uma análise sob perspectiva da structure, dynamics and coordination approach (sdca)........372

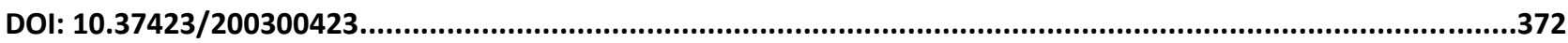

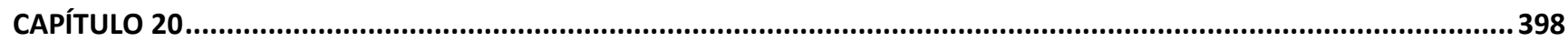

Nível de eficiência do programa bolsa floresta nas unidades de conservação do amazonas: uma análise envoltória de

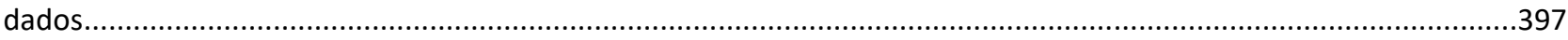

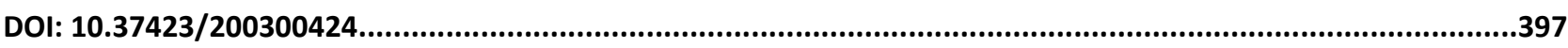

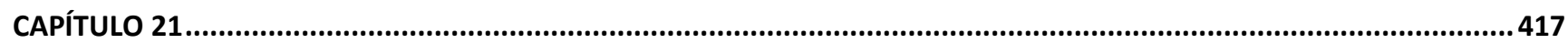

POTENCIAL FRUTíERO E DE BIOMASSA DAS PLANTAS DE MANGABA (HANCORNIA SPECIOSA GOMES) E MURICI (BYRSONIMA VERBASCIFOLIA) PELO

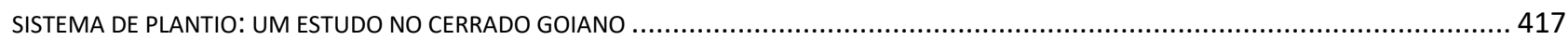

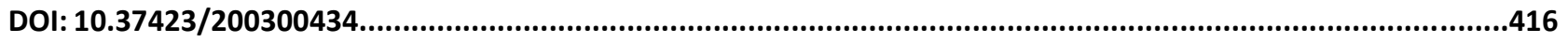

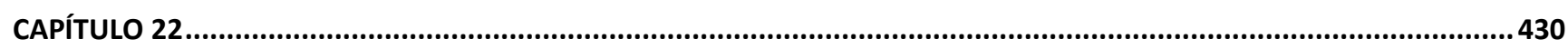

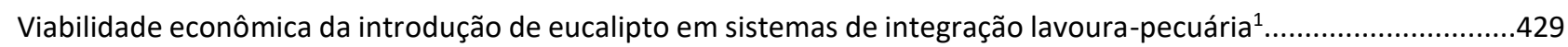




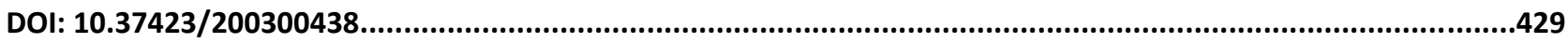

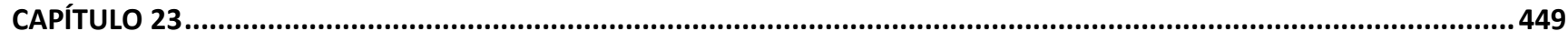

Redes interorganizacionais e agronegócio: uma revisão sistemática de literatura.....................................................448

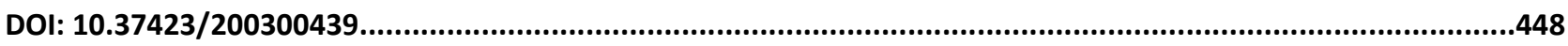

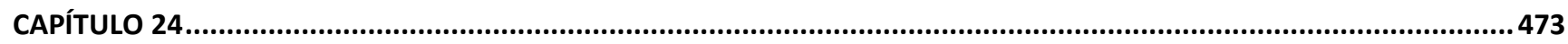

Consumo energético e emissão de co2 do agronegócio de mato grosso do sul.........................................................472

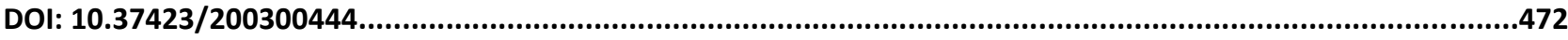

CAPÍTULO 25

A geração de riqueza na agroindústria - um estudo aplicado as maiores exportadoras de carne do brasil (2012 -

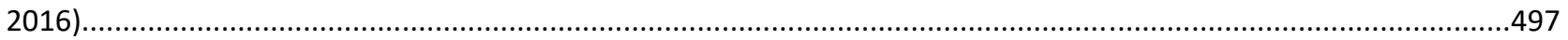

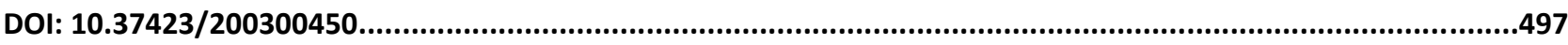

CAPÍTULO 26

Alinhamento estratégico de tecnologia da informação: um estudo em cooperativas agropecuárias............................519

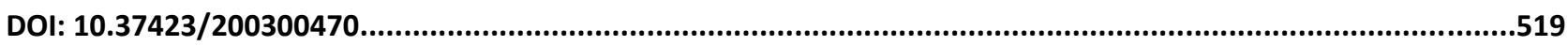

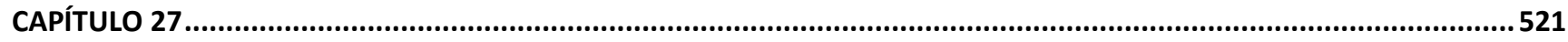

Uso de pneumáticos em logística reversa: um breve mosaico da realidade brasileira ...................................................545

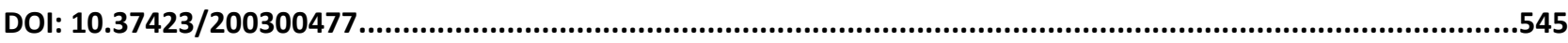

CAPÍTULO 28

Análise do efeito do crédito rural na produção agrícola dos assentamentos na região do mato grosso do sul................562

DOI: 10.37423/200300479............................................................................................................................562

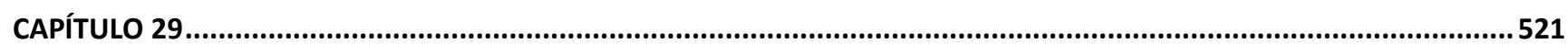

Trajetória e dinâmica comparada da agroecologia no brasil e na frança ${ }^{1}$.....................................................................58

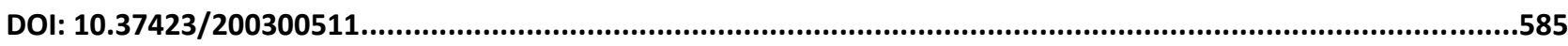

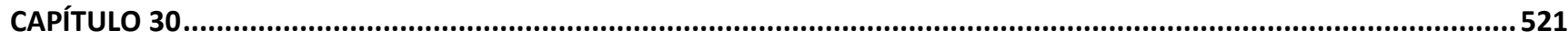

Análise comparativa do desenvolvimento sustentável na riba* utilizando o barômetro da sustentabilidade................611

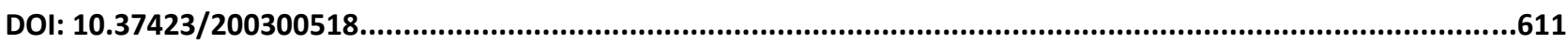

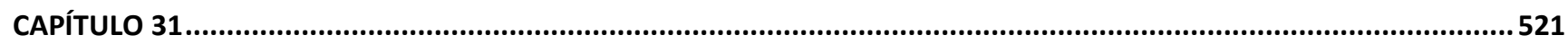

Teoria dos jogos e paradoxos de ação coletiva entre pecuaristas e pescadores profissionais de poconé-mt.................633

DOI: 10.37423/200300525...................................................................................................................................633

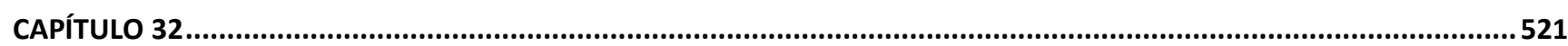

Mulheres na economia solidária: motivações, desafios e participação na rede mata atlântica no território baixo sul da

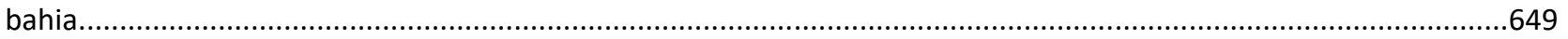

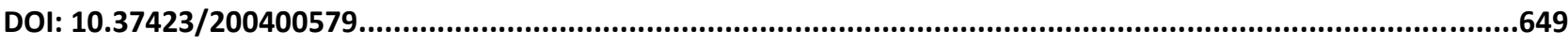

CAPÍTULO 33

Valoração ambiental do parque estadual do utinga - pa: analisando a disposição a pagar dos usuários.........................672

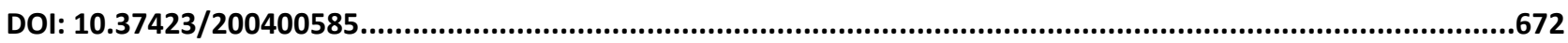




\section{Capítulo 1}

\section{O PAPEL DOS PRODUTORES RURAIS NA GESTÃO DOS RECURSOS HÍDRICOS: UMA ANÁLISE PRELIMINAR DA BACIA DO RIO JUNDIAÍ-SP ${ }^{1}$}

Junior Ruiz Garcia -jrgarcia1989@gmail.com

Alexandre Gori Maia - alexandregorimaia@gmail.com 


\section{INTRODUÇÃO}

Os municípios inseridos na Bacia hidrográfica do Rio Jundiaí (BHRJ) destacam-se pela expressiva atividade urbana, agrícola e industrial. Entretanto, a expansão industrial, unida à intensa ocupação urbana, implicou em crescente demanda por recursos hídricos e na degradação dos ecossistemas responsáveis pela sua oferta. Acrescenta-se a este cenário a falta de investimentos na gestão de recursos hídricos e a falta de unidades no tratamento de efluentes, que agravaram a poluição e a disponibilidade hídrica junto à BHRJ (NEVES, 2005). Estudos desenvolvidos nessa área demonstraram a sua fragilidade ambiental e a forte pressão do crescimento urbano-industrial sobre a qualidade e a quantidade de seus recursos hídricos (FADINI, 1998; PRADO, 2005).

O caso da BHRJ é particularmente interessante para o estudo da gestão hídrica pois esta região faz parte do território de atuação do Comitê das Bacias PCJ (CBH-PCJ), o mais organizado e atuante entre comitês das bacias paulistas e talvez do Brasil. Após a implantação da Lei № 79.663/91s, houve um aumento expressivo dos atores atuantes em todas as instâncias do CBH-PCJ, e a gestão da água dos setores industrial e urbano foi gradativamente regularizada. Apesar de seu pioneirismo na gestão hídrica no Brasil, a disponibilidade de água mostra-se crescentemente deficitária, que se refletiu na crise de abastecimento de água escassez de chuvas em 2014. É uma região populosa e com ritmo ainda intenso de crescimento demográfico nos próximos anos.

Este capítulo tem por objetivo desenvolver uma análise preliminar da contribuição dos produtores rurais na gestão dos recursos hídricos na BHRJ. O estudo utiliza dados das pesquisas agropecuárias realizadas pelo Instituto Brasileiro de Geografia e Estatística (IBGE), do Cadastro Ambiental Rural (CAR) e do Sistema Ambiental Paulista, para destacar que, apesar de os produtores rurais serem tratados como os grandes responsáveis pela degradação ambiental, esses prestam importantes serviços ambientais e socioeconômicos na BHRJ. Além de serem responsáveis pela geração de emprego e renda do estado de São Paulo, a manutenção dos estabelecimentos rurais contribui com a preservação de áreas permeáveis, importantes para receber a água da chuva dos sistemas de drenagem urbana, ou seja, contribuindo para o controle de cheias.

Para cumprir com os objetivos propostos, o capítulo está estruturado em três partes, além desta introdução e das conclusões finais. A primeira parte analisa a importância da agropecuária como provedora e recebedora de serviços ecossistêmicos, destacando a provisão de alimentos e a preservação da qualidade do solo quando adotadas as técnicas adequadas de manejo. A segunda parte descreve as características sociodemográficas da BHRJ, destacando a elevada taxa de urbanização e 
densidade populacional. A terceira parte apresenta os resultados principais do trabalho, destacando as características de uso do solo na região e a importância dos produtores rurais privados na preservação de áreas naturais, as quais contribuem para a provisão de importantes serviços ecossistêmicos.

\section{A AGROPECUÁRIA COMO PROVISÃO DE SERVIÇOS ECOSSISTÊMICOS}

A sobrevivência humana depende da dinâmica dos ecossistemas, especialmente, do fluxo contínuo e relativamente estável dos produtos da natureza, entendidos como bens e serviços ecossistêmicos (SEs) (DAILY; MATSON, 2008; FARLEY, 2012; GÓMEZ-BAGGETHUN et al., 2010; MEA, 2003)². Os SEs representam os benefícios providos pelos ecossistemas que contribuem para o bem-estar humano (MEA, 2003). Apesar das controvérsias (KROEGER; CASEY, 2007), os SEs têm sido agrupados em: serviços de suporte; serviços de regulação; serviços de provisão ou produção; serviços socioculturais (Figura 1).

Figura 1 - Grupos de Serviços Ecossistêmicos, suas relações e o bem-estar humano

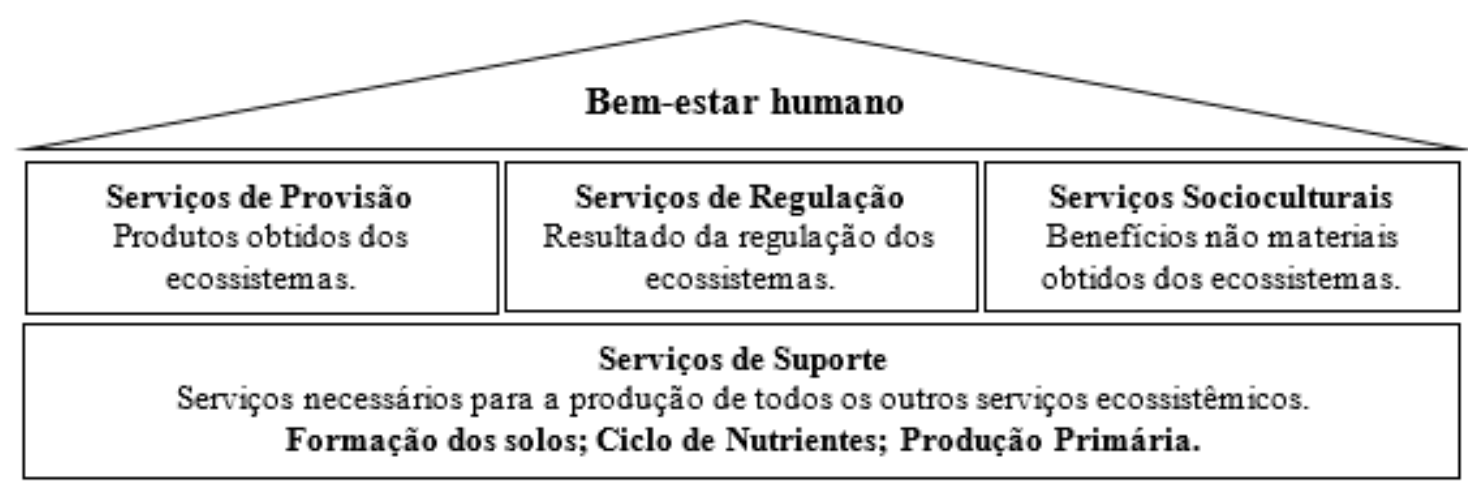

Fonte: preparado pelos autores com base em MEA (2003).

Os SEs representam o resultado da ação combinada de outros fatores, tais como o trabalho humano, o capital - meios de produção, por exemplo, máquinas e ferramentas produzidas pela sociedade - e o conhecimento (EDUARDO; OLIVEIRA; BERKES, 2014). Os frutos de um pomar disponíveis no meio ambiente, por exemplo, não significam que sejam SEs de provisão. É preciso que uma pessoa faça a coleta, ou seja, empregue trabalho, capital e o conhecimento para saciar sua fome. Dessa maneira, os SEs representam os resultados da ação humana combinada ou não ao capital, a qual pode ser entendida como o manejo dos ecossistemas (ARNOLD, 1993; FITZHUGH, 2003). A questão é que neste sistema a disponibilidade dos SEs depende tão somente da dinâmica natural. 
A ocorrência de uma estiagem mais severa, por exemplo, pode reduzir ou mesmo eliminar a provisão natural de frutas. Esse tipo de evento poderia ser caracterizado como um desserviço ecossistêmico (DE) (Erro! Fonte de referência não encontrada.), como o ataque de pragas e a competição natural $p$ elos recursos naturais (ZHANG et al., 2007). Contudo, o desenvolvimento da atividade agropecuária é uma estratégia humana para contornar esse tipo de limitação imposta pela dinâmica ecossistêmica, por exemplo, adotando sistemas de irrigação (MAZOYER; ROUDART, 2010). Outro exemplo é a expansão natural do SE de provisão de frutas que depende do número de plantas ou das condições ambientais favoráveis. A semeadura natural (dispersão de sementes) realizada por outros seres vivos que se alimentam das frutas (MCCONKEY et al., 2012), pode ser lenta e incerta. Cabe ressaltar que este não é o objetivo dos outros seres vivos que se alimentam das frutas, mas sim garantir a sua sobrevivência e de sua espécie (DARWIN, 1982).

Figura 2 - Serviços e Desserviços Ecossistêmicos, Agropecuária e Externalidade

\begin{tabular}{|l|}
\hline $\begin{array}{l}\text { Serviços Ecossistêmicos: } \\
\text { - De suporte: fertilidade do } \\
\text { solo; ciclagem de nutrientes; } \\
\text { diversidade genética. } \\
\text { - De regulação: retenção do } \\
\text { solo; polinização; } \\
\text { estabilidade climática. }\end{array}$ \\
\hline \hline $\begin{array}{l}\text { Desserviços Ecossistêmicos: } \\
\text { pestes; competição por } \\
\text { recursos de outros seres } \\
\text { vivos. }\end{array}$
\end{tabular}

Fonte: preparado pelos autores com base em (ZHANG et al., 2007).

Nota: os sistemas agropecuários também dependem dos fatores de produção convencionais, tais como trabalho, capital e tecnologia.

A realização do plantio de pomares pela sociedade é uma estratégia mais certa para garantir a expansão da quantidade de frutas. Nesta abordagem, a agropecuária pode ser entendida como a adoção de práticas de manejo dos ecossistemas pelo ser humano para maximizar os SEs de provisão, em especial a provisão de alimentos (GAGLIO et al., 2017; RUSCH et al., 2016). Essa ação está alinhada ao objetivo principal da agropecuária, que é garantir a segurança alimentar da sociedade (HORN; BREEZE, 1999). O problema é que esse sistema tem afetado o provimento de outros SEs, tais como a 
disponibilidade de água, a qualidade da água e da fertilidade do solo e de outros SEs de provisão a partir da redução da biodiversidade dos ecossistemas (POWER, 2010; ZHANG et al., 2007).

A atividade agropecuária tem posto em segundo plano os demais SEs, tais como de suporte, regulação e sociocultural, inclusive de provisão em função de que a seleção das culturas a serem cultivadas é dada pelo mercado, ou seja, o objetivo é a rentabilidade econômica. Essa dinâmica tem resultado na ocorrência de impactos ambientais, sociais e economicos negativos no bem-estar, os quais não têm sido incluídos na tomada de decisão da sociedade (COSTANZA et al., 2014; MEA, 2003) (Figura 2). Os impactos têm sido tratados como externalidades pela sociedade (IRWIN; BOCKSTAEL, 2004), externos a esfera privada e econômica.

Acontece que a adequada gestão dos sistemas agropecuários pode contribuir para manutenção, expansão ou conservação da provisão de SEs, em especial os serviços de suporte e de regulação (TURNER; DAILY, 2008). Observa-se, portanto, que os produtores rurais têm um importante papel na gestão das bacias hidrográficas. Contudo, parcela da sociedade tem tratado os produtores apenas como agentes degradadores do meio ambiente, ignorando sua contribuição como provedor de serviços ambientais. Desse modo, os produtores devem ser incluídos como agentes ativos da gestão ambiental e das bacias hidrográficas.

\section{A BACIA HIDROGRÁFICA DO RIO JUNDIAÍ: ASPECTOS SOCIOECONÔMICOS E AMBIENTAIS}

A área de estudo é a Bacia Hidrográfica do Rio Jundiaí (BHRJ), localizada nas Bacias Hidrográficas do Rio Piracicaba, Capivari e Jundiaí (PCJ), estado de São Paulo (DATAGEO, 2018) (Mapa 1). A área da BHRJ foi estimada em 118 mil hectares, inclui 11 municípios (Mapa 1). 
Mapa 1 - Bacia Hidrográfica do Rio Jundiaí

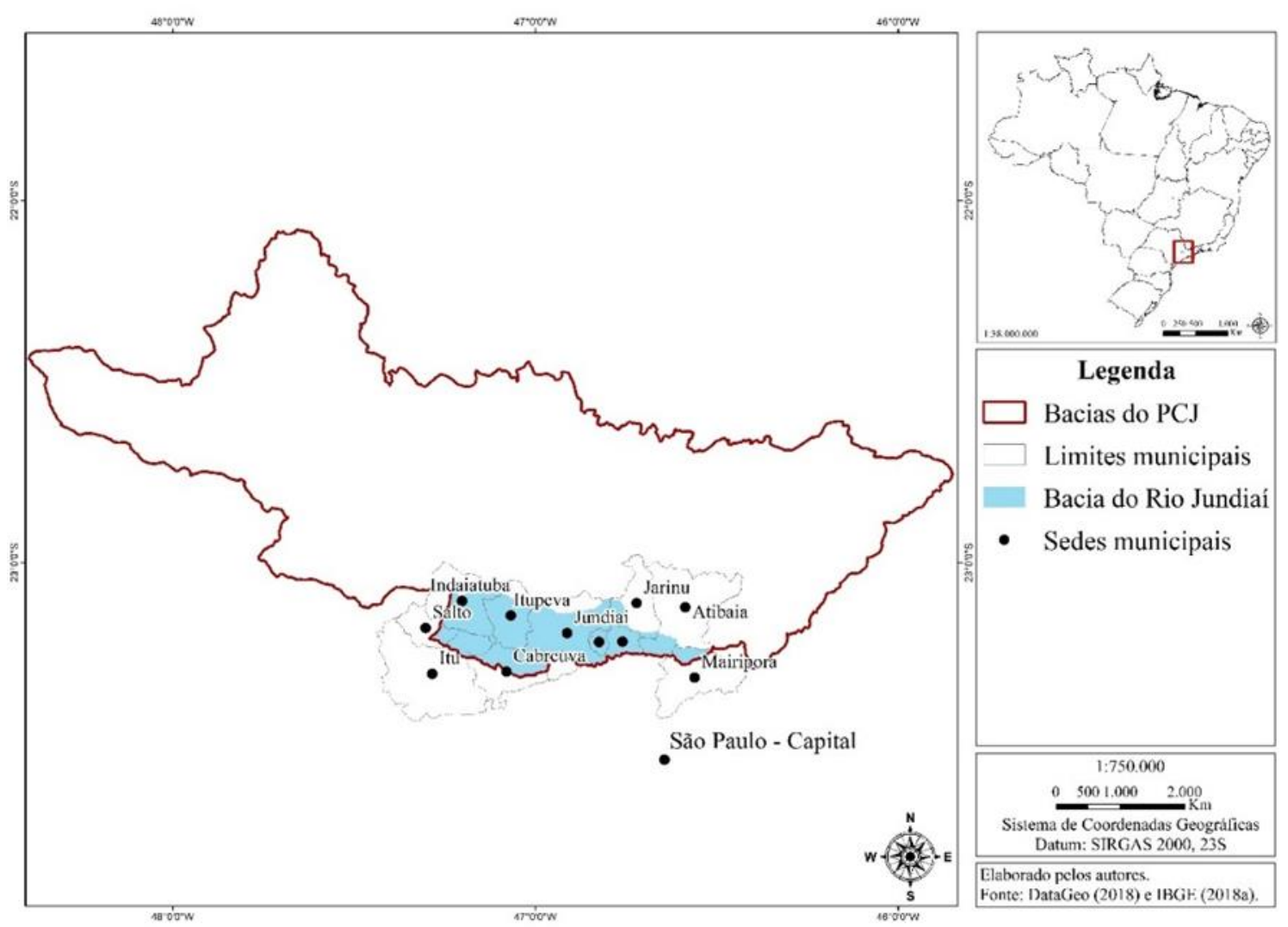

Fonte: preparado pelos autores com base em DATAGEO, 2018; IBGE, 2017.

A população da área de estudo foi estimada em 1,5 milhão de pessoas em 2017 (Tabela 1). Observase que os municípios de Jundiaí e de Indaiatuba concentram $43 \%$ da população. A densidade demográfica média foi estimada em 486 hab./km2 - variando de 137 hab.km² em Jarinu à 3.407 hab./km² em Várzea Paulista (Tabela 1). A população urbana dos municípios com sede na BHRJ era de 914 mil pessoas e a taxa de urbanização 96,7\% em 2010; nos municípios com sede fora da BHRJ foi estimada em 95\%. A região é altamente urbanizada, o que coloca mais pressão sobre os recursos hídricos e a qualidade ambiental. 
Tabela 1 - Informações demográficos do estado de São Paulo e da BHRJ por município: 2017

\begin{tabular}{|c|c|c|c|c|c|}
\hline \multirow{2}{*}{ Municípios } & \multicolumn{2}{|c|}{ População } & \multirow{2}{*}{$\begin{array}{l}\text { \% da } \\
\text { área }^{1}\end{array}$} & \multirow{2}{*}{$\begin{array}{c}\text { Taxa de } \\
\text { urbanização }{ }^{2}\end{array}$} & \multirow{2}{*}{$\begin{array}{c}\text { Densidade } \\
\text { Demográfica }(\text { hab.km²) }\end{array}$} \\
\hline & Pessoas & $\%$ & & & \\
\hline \multicolumn{6}{|c|}{ Município com sede na área da BHRJ } \\
\hline Cabreúva & 47.877 & $3,2 \%$ & $10,3 \%$ & $73,6 \%$ & 183,9 \\
\hline Campo Limpo Paulista & 82.520 & $5,5 \%$ & $6,7 \%$ & $89,8 \%$ & $1.040,6$ \\
\hline Indaiatuba & 239.602 & $15,9 \%$ & $15,4 \%$ & $83,3 \%$ & 769,7 \\
\hline Itupeva & 57.031 & $3,8 \%$ & $13,7 \%$ & $68,3 \%$ & 284,4 \\
\hline Jundiaí & 409.497 & $27,2 \%$ & $27,8 \%$ & $86,5 \%$ & 949,9 \\
\hline Salto & 116.191 & $7,7 \%$ & $5,0 \%$ & $90,2 \%$ & 873,0 \\
\hline Várzea Paulista & 118.917 & $7,9 \%$ & $3,0 \%$ & $90,1 \%$ & $3.407,4$ \\
\hline Subtotal & 1.071.635 & $71,2 \%$ & $81,9 \%$ & $85,3 \%$ & 738,8 \\
\hline \multicolumn{6}{|c|}{ Município com sede fora da área da BHRJ } \\
\hline$\overline{\mathrm{Itu}}$ & 170.157 & $11,3 \%$ & $5,9 \%$ & $84,8 \%$ & 265,6 \\
\hline Mairiporã & 95.601 & $6,3 \%$ & $3,3 \%$ & $74,0 \%$ & 298,0 \\
\hline Atibaia & 139.683 & $9,3 \%$ & $4,7 \%$ & $82,5 \%$ & 292,0 \\
\hline Jarinu & 28.540 & $1,9 \%$ & $4,2 \%$ & $64,6 \%$ & 137,5 \\
\hline Subtotal & 433.981 & $28,8 \%$ & $18,1 \%$ & $\mathbf{8 0 , 3 \%}$ & 263,4 \\
\hline Bacia do Rio Jundiaí ${ }^{3}$ & 1.505 .616 & $100,0 \%$ & $100,0 \%$ & $83,9 \%$ & 486,0 \\
\hline São Paulo & 45.094.866 & $3,3 \%$ & - & $87,8 \%$ & $\mathbf{1 8 1 , 7}$ \\
\hline
\end{tabular}

Em 2015, o Produto Interno Bruto (PIB) a preços correntes da BHRJ foi estimado em R\$ 86 bilhões: Jundiaí e Indaiatuba concentravam 60\% (IBGE, 2018b). O Valor Adicionado Bruto (VAB) a preços correntes foi estimado em R\$ 70 bilhões em 2015: 61,4\% serviços; 29,9\% indústria; 0,7\% agropecuária. Embora a contribuição relativa da agropecuária seja muito baixa, a sua área ocupada alcançava 107 mil hectares e o número de pessoas ocupadas foi estimado em 12,5 mil segundo dados do Censo Agropecuário de $2006^{3}$ (IBGE, 2018b). Cabe destacar que a área agropecuária representa o total dos municípios (Mapa 1). Em uma região com elevado de urbanização, apenas a manutenção dos estabelecimentos rurais pode contribuir para a gestão da BHRJ. Neste sentido, qual a importância dos produtores rurais para a BHRJ?

\section{O PAPEL DO SETOR AGROPECUÁRIO NA BHRJ}

A análise da importância do setor agropecuário na gestão dos recursos hídricos e na qualidade ambiental passa pela identificação do uso das terras e das práticas de manejo adotadas pelos produtores. Em uma região densamente povoada (Tabela 1), as mudanças no uso terras podem determinar a sustentabilidade das atividades econômicas e mesmo o grau de bem-estar da sociedade (MEA, 2003). Isto porque o bem-estar humano depende direta e indiretamente da manutenção do 
fluxo de serviços econômicos e também dos SEs (DANLEY; WIDMARK, 2016; EGOH et al., 2012; HJERPE; HUSSAIN; PHILLIPS, 2015; MEA, 2003).

O setor agropecuário é um importante usuário direto das terras, ocupando parcela expressiva do território das bacias hidrográficas, portanto, as práticas de manejo adotadas pelos produtores podem influenciar de maneira decisiva a qualidade ambiental da região (PALM et al., 2014; SWINTON et al., 2007; THEROND et al., 2017). A manutenção do produtor rural na área rural por si só já pode servir como uma barreira para a expansão urbana em regiões densamente ocupadas, processo que amplia sem precedentes o grau de degradação dos ecossistemas e a demanda por recursos naturais.

O mapa de uso e ocupação das terras 2007-20094 revelou que a cobertura florestal ocupava 33,8 mil hectares, representa 30,5\% da BHRJ, seguida pelas pastagens (27,9 mil hectares), pela área construída ou urbana (25,8 mil hectares) e pelo campo natural (7 mil hectares) (Mapa 2). 0 interessante é que a agricultura ocupava apenas 5,9 mil hectares, ou seja, 5,3\% da área da BHRJ, equivalente ao reflorestamento $(5,8$ mil hectares).

Mapa 2 - Uso e cobertura das terras na Bacia Hidrográfica do Rio Jundiaí: 2007-2009
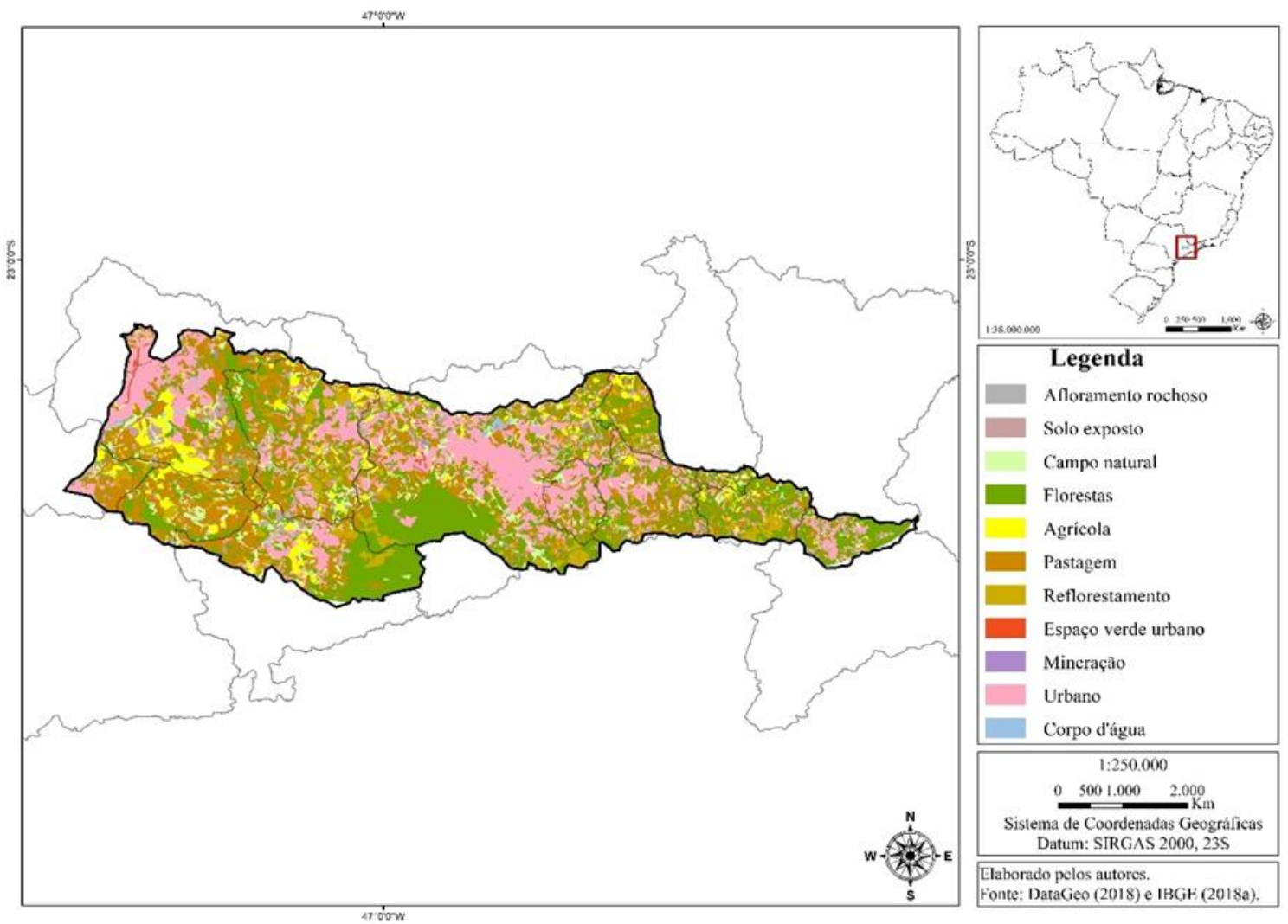

Fonte: preparado pelo autor com base em DATAGEO (2018) e IBGE (2018a). Nota: a legenda de cores segue a sugestão apresentada pelo IBGE (2013, p. 151). 
Para auxiliar na análise da importância da agropecuária para a gestão ambiental em bacias hidrográficas, além do mapa de uso e cobertura das terras, utilizam-se os dados do Censo Agropecuário 2006, da Pesquisa Agrícola e Pecuária Municipal e da Produção da Extração Vegetal e da Silvicultura do Instituto Brasileiro de Geografia e Estatística (IBGE) e do Instituto de Economia Agrícola do estado de São Paulo por município para o período 2014-2016.

As estimativas indicam que a área em uso agropecuário nos municípios da BHRJ alcançaria 132 mil hectares (IBGE, 2018b). A pastagem representava o principal uso das terras, com mais de 106 mil hectares e um efetivo de rebanho bovino de 80,5 mil cabeças (IBGE, 2018b); as lavouras temporárias ocupavam 12,8 mil hectares e a silvicultura 8 mil hectares. Como as estimativas foram realizadas por município, a área agropecuária é maior que a área da BHRJ. No entanto, como os ecossistemas não respeitam a divisão político-administrativa, essa limitação não inviabiliza ou mesmo fragiliza a análise, mas reforça os resultados do mapa de uso e ocupação das terras (Mapa 2).

O Censo Agropecuário 2006 revelou que existiam 4.726 estabelecimentos rurais nos municípios da BHRJ, ocupando 107 mil hectares $^{5}$, área média por estabelecimento de 35,2 hectares (IBGE, 2018b). Os agricultores familiares eram 1.836, ocupando apenas 12,9 mil hectares, média de 7 hectares por estabelecimento e os não-familiares eram 1.203 e área média de 78,2 hectares por estabelecimento. Diante desse quadro, a incorporação de todos os produtores rurais - familiares ou não - na gestão dos recursos hídricos é imprescindível para que seja alcançada a melhoria da qualidade ambiental e hídrica na região. Isso é necessário, porque o produtor rural além de produzir alimentos e insumos agropecuários, também é um provedor de serviços ambientais, os quais contribuem direta ou indiretamente para a recuperação, expansão e/ou manutenção o fluxo de SE's (PALM et al., 2014; SWINTON et al., 2007b; THEROND et al., 2017).

O quadro ambiental do uso das terras agropecuárias pode ser complementado com base nos dados do Censo Agropecuário 2006 por tipo de utilização das terras, o que inclui a situação das pastagens, e nos dados do Cadastro Ambiental Rural (CAR). Conforme já apresentado, a área ocupada pelos estabelecimentos agropecuários era de 107 mil hectares em 2006 (Tabela 2), as com pastagens ocupavam 37,7 mil hectares (65\% naturais e 35\% plantadas). Em 2006, o rebanho bovino alcançava 44,4 mil cabeças, portanto, média de 1,18 cabeças por hectare (IBGE, 2006), ou seja, uma pecuária de baixa produtividade e extensiva (DIAS-FILHO, 2016). As áreas com pastagens degradadas na BHRJ eram 4,5\% das pastagens (1.686 hectares), além de 505 hectares em terras degradadas (Tabela 2). 
Tabela 2 - Área dos estabelecimentos agropecuário por tipo de utilização das terras na BHRJ: 2006 (em hectares)

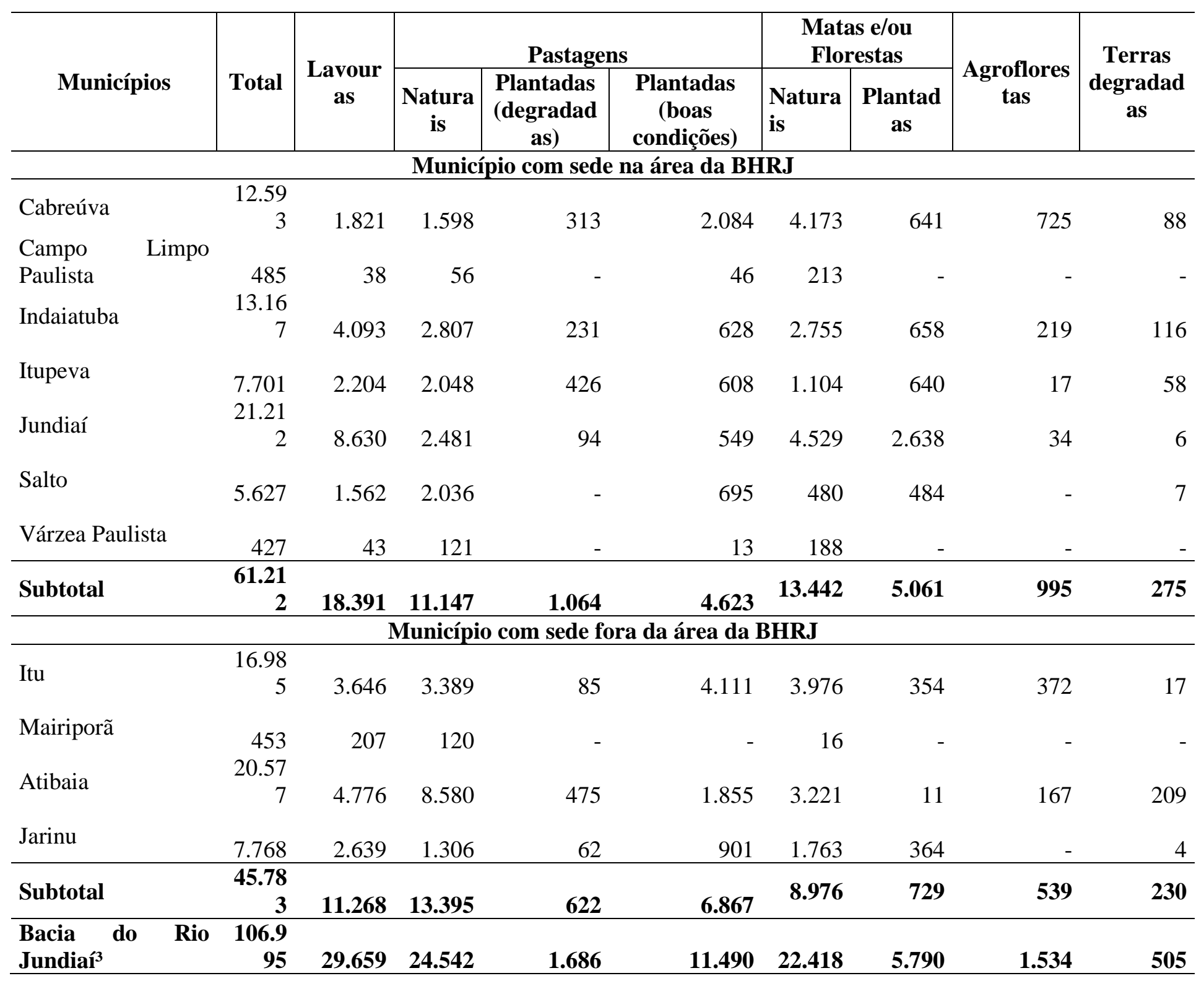

Fonte: preparado pelos autores com base em IBGE (2018b).

Notas: as lavouras incluem as permanentes, temporárias, forrageiras para corte e flores, viveiros de mudas, estufas e casas de vegetação; as matas e/ou florestas incluem as destinadas à preservação permanente ou reserva legal; as matas e/ou florestas plantadas incluem as com essências florestais; as terras degradadas incluem áreas erodidas, desertificadas etc.

Segundo (DIAS-FILHO, 2016), a pecuária bovina realizada em pastagens naturais tem sido praticada sem qualquer manejo (stricto sensu) no Brasil; mesmo nas pastagens plantadas, a atividade tem sido desenvolvida com baixo investimento em insumos e tecnologia. Um agravante destacado por DiasFilho (2016, p. 25) é que: "as pastagens naturais brasileiras normalmente carecem de espécies com 
melhor aptidão forrageira, isto é, com alta adaptação ao pastejo [...] e com produtividade e valor nutritivo relativamente mais elevados. Ademais, [...] grande parte das áreas de pastagens naturais no Brasil" estão em "locais com solos mais pobres em nutrientes". Essa é uma das características do solo na BHRJ observadas a partir da aptidão das terras (FENGLER et al., 2015; PRADO, 2005). As evidências mostram que as pastagens naturais apresentam uma produtividade ainda menor que as plantadas (DIAS-FILHO, 2014, 2016). Essa é uma característica marcante da pecuária brasileira, identificada na BHRJ (IBGE, 2018b).

Apesar das limitações no uso das pastagens naturais e plantadas, as informações revelam a importância do setor agropecuário para a BHRJ como provedor de serviços ambientais, tais como a manutenção de áreas permeáveis que recebem o escoamento superficial das áreas mais urbanizadas e da cobertura vegetal com remanescentes de Mata Atlântica. Contudo, sua contribuição poderia ser ampliada com a adoção de práticas de manejo conservacionistas e a regularização das áreas de proteção ambiental. Isto porque uma característica ambiental relevante da BHRJ é a presença de remanescentes florestais do Bioma ${ }^{6}$ Mata Atlântica. Neste aspecto, cabe destacar as Áreas de Proteção Ambiental (APAs) localizadas em Jundiaí e Cabreúva (SÃO PAULO, 1998). A Mata Atlântica é composta por florestas Ombrófila Densa, Ombrófila Mista, Estacional Semidecidual, Estacional Decidual e Ombrófila Aberta, restingas, manguezais, campos de altitude, brejos interioranos e encraves florestais (BRASIL, 2006, 2008; MMA, [s.d.]). Na BHRJ predomina a Floresta Secundária Ombrófila Densa (DATAGEO, 2018).

A área original de ocorrência da Mata Atlântica no Brasil era de $1.110 .182 \mathrm{~km}^{2}\left(\right.$ IBGE, 2004) ${ }^{7}$, mas restam apenas 8,5\% de remanescentes florestais com área maior que 100 hectares (SOSMA, [s.d.]) . Apesar do alto grau de degradação, os relatórios "Atlas dos Remanescentes Florestais da Mata Atlântica" preparados pela ONG SOSMA (SOS Mata Atlântica), em parceria com o Instituto Nacional de Pesquisas Espaciais (INPE), continuam indicando que ainda persiste a supressão da cobertura florestal (SOSMA, [s.d.]) ${ }^{8}$. Entre anos de 2014 e 2015, a área total desmatada na Mata Atlântica alcançou 184 km² (18.433 hectares) (SOSMA, 2016). A manutenção dos estabelecimentos rurais abre espaço para a adoção de planos de recuperação da cobertura vegetal, ação praticamente impossível caso ocorra a urbanização dessas áreas.

Mesmo muito degradada, os remanescentes de Mata Atlântica abrigam mais de 20 mil espécies vegetais, que representam 35\% das espécies brasileiras, 849 espécies de aves, 370 de anfíbios, 200 de répteis, 270 de mamíferos e 350 de peixes (CAMPANILI; SCHAFFER, 2010; MMA, [s.d.]). Essas 
informações revelam uma parte da importância da Mata Atlântica para a sociedade, que abriga uma elevada biodiversidade com elevado grau de endemismo. Apesar disso, a Mata Atlântica continua sofrendo fortes pressões das ações humanas (CAMPANILI; SCHAFFER, 2010; CUNHA; GUEDES, 2013). A maior parcela da população brasileira reside no Bioma Mata Atlântica, por volta de 120 milhões de pessoas (MMA, [s.d.]), por conseguinte, também a estrutura econômica brasileira. Esta característica eleva o grau de pressão sobre a preservação da Mata Atlântica, além da própria expansão demográfica e urbana, aspecto verificado na BHRJ (Tabela 1).

A taxa de cobertura vegetal da BHRJ era de 25,7\% em 2010, reforçando a situação de elevado grau de degradação ambiental (DATAGEO, 2018). No município de Salto a taxa era de apenas 9,4\%, seguido por Indaiatuba com 10\%; em Cabreúva era de 48\%. Cabe ressaltar que a presença da cobertura vegetal representa um dos mais importantes atributos da qualidade ambiental de um ecossistema (IPARDES, $2010)^{10}$. Neste sentido, o estado de conservação e de continuidade da cobertura vegetal influenciam na presença ou não de hábitats e em sua qualidade, no grau de biodiversidade e no fluxo de SEs para a sociedade e para a economia (MEA, 2003). Desse modo, a recuperação e a manutenção de áreas florestais são ações fundamentais para garantir ou ampliar o fluxo de serviços ecossistêmicos em bacias hidrográficas. Neste processo, os agricultores têm um papel central uma vez que ocupam parcela expressiva das bacias hidrográficas.

Apesar do elevado grau de degradação da cobertura vegetal, as informações sobre o uso das terras revelam alguns dos papeis da agropecuário para a BHRJ. A manutenção de remanescentes florestais representa um importante serviço ambiental prestado pelos produtores rurais para a sociedade (LAVELLE et al., 2014). A cobertura florestal no meio rural contribui para a manutenção das áreas permeáveis que pode receber o escoamento superficial resultante da precipitação nas áreas mais urbanizadas da BHRJ; recarga de aquíferos; proteção dos corpos d'água; entre outros benefícios.

Na tentativa de promover a regularização ambiental das propriedades rurais foi aprovado em 2012 o novo código florestal brasileiro (BRASIL, 2012a). Um importante avanço foi a criação do Cadastro Ambiental Rural (CAR) - artigo 29 da Lei no 12.651 de 2012, regulamentado pela Instrução Normativa do Ministério do Meio Ambiente (MMA) no 2, de 5 de maio de 2014. A finalidade do CAR é promover a integração das informações dos estabelecimentos rurais a respeito das Áreas de Preservação Permanente (APP), de uso restrito, Reserva Legal, remanescentes florestais nativos e das áreas consolidadas (BRASIL, 2012a). O CAR é um registro georreferenciado das informações referentes ao perímetro do imóvel rural, áreas de interesse social, de utilidade pública e ambientais de acordo com 
o texto do Novo Código Florestal. Para auxiliar na operacionalização do CAR foi criado o SICAR (Sistema Nacional de Cadastro Ambiental Rural) (BRASIL, 2012b).

O Boletim Informativo do CAR, com dados gerais atualizados até 16 de fevereiro de 2018, indicava o registro de 4,8 milhões de imóveis rurais brasileiros, totalizando uma área de 435,8 milhões de hectares (MMA, 2018). A área cadastrada é 9,5\% maior que a área passível de cadastro, estimada em 397,8 milhões de hectares ${ }^{11}$. A área das Unidades de Conservação da Natureza de Uso Sustentável (BRASIL, 2000), nas quais admite-se o uso por populações tradicionais (BRASIL, 2007), totalizou 30,7 milhões de hectares em 22,5 mil imóveis (MMA, 2018b). O cadastro na região sudeste já alcançou 100\% da área rural, 65,1 milhões de hectares - 15,4\% maior que a área cadastrável. No estado de São Paulo, a área cadastrada alcançou 19,2 milhões de hectares - 13,2\% maior que a área cadastrável -, distribuída em 328,7 mil imóveis rurais (MMA, 2018). Em resumo, o CAR tem se revelado um importante instrumento para aprimorar a gestão ambiental no Brasil, inclusive para regularização fundiária, porque pode fornecer informações mais adequadas para a elaboração de políticas ambientais e a adoção de estratégias para a recuperação da área degradada.

O formato dos dados disponibilizados no SICAR permite que a análise seja apenas realizada para o território da BHRJ. Nos municípios a área total cadastrada alcançou 137,5 mil hectares em 5.348 imóveis rurais (BRASIL, 2018), mas apenas 44,2 mil hectares estão localizados na BHRJ em 1.763 imóveis (Tabela 3). A área com vegetação nativa existente em imóveis rurais na BHRJ é da ordem de 10 mil hectares (Tabela 3). Apesar de que existe uma sobreposição entre as áreas cadastradas no SICAR, vale destacar que as APPs estavam em 4.794 hectares e a Reserva Legal Averbada em 1.312 hectares, além da proposta de regularização da Reserva Legal em mais 7.499 hectares (BRASIL, 2018). Os produtores também informaram a existência de 1.040 nascentes em suas propriedades. Os dados do SICAR reforçam o importante papel desempenhado pelos produtores rurais na gestão da BHRJ. Além disso, o valor bruto da produção agropecuária (VBPa) alcançou R\$ 214 milhões em 2016 (Tabela $3)$, indicando que o custo de oportunidade de uso das terras seria relativamente baixo. 
Tabela 3 - Informações do Cadastro Ambiental Rural (CAR) e do Valor Bruto da Produção Agropecuária $(\mathrm{VBPa})^{1}$ da BHRJ por município²: dados até 16 de fevereiro de 2018

\begin{tabular}{|c|c|c|c|c|c|}
\hline \multirow[b]{2}{*}{ Municípios } & \multicolumn{4}{|c|}{ Hectares } & \multirow{2}{*}{$\begin{array}{c}\text { Mil R\$ } \\
\text { VBP }\end{array}$} \\
\hline & APP & $\begin{array}{c}\text { Reserva } \\
\text { Legal }\end{array}$ & $\begin{array}{c}\text { Vegetaçãa } \\
\text { Nativa }\end{array}$ & $\begin{array}{l}\text { Área do } \\
\text { Imóvel }\end{array}$ & \\
\hline \multicolumn{6}{|c|}{ Município com sede na área da BHRJ } \\
\hline Cabreúva & 695,8 & 1708,6 & $1.118,0$ & $3.019,0$ & $2.860,0$ \\
\hline Campo Limpo Paulista & 108,1 & 181 & 332,7 & 837,5 & 116,0 \\
\hline Indaiatuba & 703,5 & 1264,1 & $1.210,0$ & $7.243,0$ & $36.013,0$ \\
\hline Itupeva & 728,6 & 1016,7 & $1.597,0$ & $7.702,0$ & $12.054,0$ \\
\hline Jundiaí & $1.212,4$ & 2717,9 & $2.747,0$ & $11.240,0$ & $63.186,0$ \\
\hline Salto & 178,1 & 155,1 & 208,8 & $1.408,0$ & $11.225,0$ \\
\hline Várzea Paulista & 38,8 & 87,7 & 179,0 & 584,2 & 43,0 \\
\hline Subtotal & $3.665,3$ & $7.131,1$ & $7.392,5$ & 32.033,7 & 125.497,0 \\
\hline \multicolumn{6}{|c|}{ Município com sede fora da área da BHRJ } \\
\hline Itu & 455,2 & 837 & 963,9 & $6.907,0$ & $25.713,0$ \\
\hline Mairiporã & 60,5 & 90,4 & 184,4 & 626,5 & $2.860,0$ \\
\hline Atibaia & 312,8 & 384,4 & 717,7 & $2.693,0$ & $44.128,0$ \\
\hline Jarinu & 300,4 & 400,5 & 694,8 & $1.971,0$ & $15.808,0$ \\
\hline Subtotal & $1.128,9$ & $1.712,3$ & $2.560,8$ & $\mathbf{1 2 . 1 9 7 , 5}$ & $88.509,0$ \\
\hline Bacia do Rio Jundiaí & $4.794,2$ & $8.843,4$ & $9.953,3$ & $44.231,2$ & $214.006,0$ \\
\hline
\end{tabular}

Fonte: preparado pelos autores com base em Brasil (2018) e IBGE (2018b).

Notas: ${ }^{1}$ inclui o Valor Bruto da Produção (VBP) das Lavouras Temporárias e Permanentes, da Silvicultura e de Origem Animal (leite, ovos de galinha e de codornas e mel de abelha); ${ }^{2}$ considera apenas a área do município inserida na BBHRJ; APP - Área de Preservação Permanente conforme rege o Novo Código Florestal Brasileiro (BRASIL, 2012a); Reserva Legal inclui as áreas averbadas, reserva legal aprovada, mas não averbada e a proposta de regularização.

Embora existam várias informações sobre o uso e ocupação das terras, a sociedade não tem reconhecido o papel dos produtores rurais na gestão de bacias hidrográficas. A sociedade ignora que as ações que contribuem para a melhoria da qualidade ambiental dos imóveis rurais - provimento de serviços ambientais - representam um custo privado para os produtores, infelizmente não compensado pela sociedade e nem pelos mercados (CHIODI; SARCINELLE; UEZU, 2013). Cabe destacar que o bem-estar humano provido pelos SEs no sistema capitalista compreendem "bens" privados e públicos, associados a uma variedade de direitos de propriedade e de outros arranjos institucionais. A localização no espaço dos recursos naturais, o que inclui os SEs, por exemplo, pode assumir a propriedade privada, propriedade pública (de um país), que constitui propriedade comum, ou mesmo ser objeto de tratados e acordos internacionais (TURNER; DAILY, 2008).

No caso da atividade agropecuária, como uma provedora de serviços ambientais, a adoção de práticas mais conservacionistas pode contribuir para a recuperação, expansão e manutenção de SEs na BHRJ. A recuperação da cobertura vegetal e a manutenção dos produtores rurais representam importantes 
ações para a melhoria da qualidade ambiental da BHRJ e os dados apresentados nesta análise reforçam essa conclusão. Como o custo da provisão de serviços ambientais tem sido suportado apenas pelos produtores, embora os benefícios sejam públicos, o aprimoramento da gestão ambiental da BHRJ passa pela valoração dos serviços ambientais prestados e dos SEs, além de uma ampla discussão e pela instituição de um programa de Pagamento por Serviços Ambientais (PSA). A melhoria da gestão de bacias hidrográficas passa pelo protagonismo da sociedade e dos produtores rurais na busca pela recuperação e preservação dos SEs.

\section{CONCLUSÕES}

Apesar das elevadas taxas de urbanização dos municípios da bacia do rio Jundiaí, a agricultura cumpre um importante papel na estabilidade econômica, social e ambiental na região. Os produtores rurais na região geram mais de 12 mil empregos e geram um valor adicionado total da ordem de $\mathrm{R} \$ 454$ milhões na econômica. Ademais, parcela relevante da preservação ambiental está nas propriedades privadas, cerca de 22,4 mil hectares de matas e/ou florestas naturais.

A manutenção dos estabelecimentos rurais contribui com a manutenção de áreas permeáveis, importantes para receber a água da chuva dos sistemas de drenagem urbana, contribuindo ainda para o controle de cheias. Este é um importante serviço ecossistêmico a ser considerado na gestão dos recursos hídricos. Entretanto, falhas no atual sistema de gestão, que tem privilegiado fatores associados à demanda, como a distribuição de água entre os atores da bacia, ficaram evidentes em 2014. Neste ano, o estado enfrentou uma grave crise de abastecimento de água com a escassez de chuvas.

Ademais, a adoção de práticas de manejo conservacionistas pode contribuir para a provisão de outros serviços ecossistêmicos, como o controle da erosão e da amenidade climática local. Todavia, esses serviços dependem em grande medida de práticas adequadas de manejo do solo, aumento a responsabilidade de um sistema eficaz de gestão hidrográfica na região. O problema que a melhoria da gestão ambiental nas propriedades rurais impõe um custo privado para o produtor, não compensado pelo mercado e nem pela sociedade.

Neste sentido, pode-se afirmar que o produtor rural cumpre um importante papel na provisão de serviços ambientais na região, contribuindo para a gestão dos recursos hídricos. Grande parte desses resultados ambientais positivos se deve ao novo Código Florestal, aprovado em 2012, por exemplo, com a instituição do CAR, além da abertura de possibilidade do uso de mecanismos de compensação 
pelo provimento de serviços ambientais. Entretanto, deve-se destacar que, apesar de gerar benefícios para toda a sociedade, a manutenção dessas áreas traz custos constantes para o produtor rural. Além do próprio custo de manutenção das áreas preservadas, reservar essas áreas também implica renunciar a boa parte do seu potencial produtivo (custo de oportunidade). Apesar de esses aspectos não serem explorados neste trabalho, trata-se de uma importante agenda de pesquisa para desdobramento desta pesquisa.

\section{REFERÊNCIAS}

ARNOLD, J. E. Labor and the Rise of Complex Hunter-Gatherers. Journal of Anthropological Archaeology, v. 12, n. 1, p. 75-119, 1 mar. 1993.

ATLAS BRASIL. Atlas do Desenvolvimento Humano no Brasil. Disponível

em: <http://atlasbrasil.org.br/2013/>. Acesso em: 3 mar. 2018.

BRASIL. Lei no 9.985, de 18 de julho de 2000Brasília-DF, 2000. Disponível em: <http://www.planalto.gov.br/ccivil_03/Leis/L9985.htm>. Acesso em: 1 mar. 2018

BRASIL. Lei no 11.428, de 22 de dezembro de 2006. Dispõe sobre a utilização e proteção da vegetação nativa do Bioma Mata Atlântica, e dá outras providênciasBrasília-DF, 2006. Disponível em: <http://www.planalto.gov.br/ccivil_03/_ato2004-2006/2006/lei/l11428.htm>. Acesso em: 25 fev. 2018

BRASIL. Decreto no 6.040, de 7 de fevereiro de 2007Brasília-DF, 2007. Disponível em: <http://www.planalto.gov.br/ccivil_03/_ato2007-2010/2007/decreto/d6040.htm>. Acesso em: 1 mar. 2018

BRASIL. Decreto no 6.660, de 21 de novembro de 2008. Regulamenta os dispositivos da Lei no 11.428, de 22 de dezembro de 2006, que dispõe sobre a utilização e proteção da vegetação nativa do Bioma Mata AtlânticaBrasília-DF, 2008. Disponível em: <http://www.planalto.gov.br/ccivil_03/_ato20072010/2008/decreto/d6660.htm>. Acesso em: 25 fev. 2018

BRASIL. Lei no 12.651, de 25 de maio de 2012, 2012a. Disponível em: <http://www.planalto.gov.br/ccivil_03/_ato2011-2014/2012/lei/L12651compilado.htm>. Acesso em: 1 mar. 2018

BRASIL. Decreto no 7.830, de 17 de outubro de 2012. Disponível

em: <http://www.planalto.gov.br/ccivil_03/_ato2011-2014/2012/decreto/D7830.htm>. Acesso em: 1 mar. 2018b.

BRASIL. Sicar - Sistema Nacional de Cadastro Ambiental Rural. Disponível em: <http://www.car.gov.br/\#/>. Acesso em: 1 mar. 2018. 
CAMPANILI, M.; SCHAFFER, B. W. Mata Atlântica: manual de adequação ambientalBrasíliaDFMinistério do Meio Ambiente - Secretaria de Biodiversidade e Florestas, , 2010. Disponível em: <http://www.mma.gov.br/estruturas/202/_arquivos/adequao_ambiental_publicao_web_202.pdf>

CHIODI, R. E.; SARCINELLE, O.; UEZU, A. Gest??o dos recursos h??dricos na ??rea do sistema produtor de ??gua Cantareira: Um olhar para o contexto rural. Revista Ambiente e Agua, 2013.

COSTANZA, R. et al. Changes in the global value of ecosystem services. Global Environmental Change, v. 26, p. 152-158, 2014.

CUNHA, A. A.; GUEDES, F. B. Mapeamentos para a conservação e recuperação da biodiversidade na Mata Atlântica: em busca de uma estratégia espacial integradora para orientar ações aplicadasBrasíliaDFMinistério do Meio Ambiente - MMA, , 2013. Disponível

em: <http://www.mma.gov.br/publicacoes/biomas/category/63-mata-atlantica>

DAILY, G. C.; MATSON, P. A. Ecosystem Services: From Theory to Implementation. Proceedings of the National Academy of Sciences, v. 105, n. 28, p. 9455-9456, 2008.

DANLEY, B.; WIDMARK, C. Evaluating conceptual definitions of ecosystem services and their implications. Ecological Economics, 2016.

DARWIN, C. A origem das espécies. Brasília-DF: Universidade de Brasília - UNB, 1982.

DATAGEO - SISTEMA AMBIENTAL PAULISTA. Infraestrutura de Dados Espaciais Ambientais do Estado de São Paulo - IDEA-SP - DataGeo. Disponível em: <http://datageo.ambiente.sp.gov.br/>. Acesso em: 3 mar. 2018.

DIAS-FILHO, M. B. Diagnóstico das Pastagens no Brasil: Documentos. Belém: [s.n.]. Disponível em: <https://www.infoteca.cnptia.embrapa.br/bitstream/doc/986147/1/DOC402.pdf>.

DIAS-FILHO, M. B. Uso de Pastagens para a Produção de Bovinos de Corte no Brasil: Passado, Presente e Futuro: Documentos. Belém: [s.n.]. Disponível

em: <https://ainfo.cnptia.embrapa.br/digital/bitstream/item/141771/1/DOCUMENTOS-418.pdf>.

EDUARDO, L.; OLIVEIRA, C. DE; BERKES, F. What value São Pedro â€TM s procession ? Ecosystem services from local people â€TM s perceptions. Ecological Economics, v. 107, p. 114-121, 2014.

EGOH, B. et al. Indicators for mapping ecosystem services : a review. [s.I: s.n.].

FADINI, A. A. B. Impactos do uso das terras na bacia hidrográfica do rio Jundiaí (SP). [s.I.] Universidade Estadual Paulista, 1998.

FARLEY, J. Ecosystem services : The economics debate. Ecosystem Services, v. 1, n. 1, p. 40-49, 2012.

FENGLER, F. H. et al. Qualidade ambiental dos fragmentos florestais na Bacia Hidrográfica do Rio Jundiaí-Mirim entre 1972 e 2013. Revista Brasileira de Engenharia Agrícola e Ambiental, v. 19, n. 4, p. 402-408, abr. 2015. 
FITZHUGH, B. The Evolution of Complex Hunter-Gatherers BT - The Evolution of Complex HunterGatherers: Archaeological Evidence from the North Pacific. In: FITZHUGH, B. (Ed.). . Boston, MA: Springer US, 2003. p. 1-10.

GAGLIO, M. et al. Changes in land use and ecosystem services in tropical forest areas: a case study in Andes mountains of Ecuador. International Journal of Biodiversity Science, Ecosystem Services \& Management, v. 13, n. 1, p. 264-279, 1 jan. 2017.

GARIBALDI, L. A. et al. Global growth and stability of agricultural yield decrease with pollinator dependence. Proceedings of the National Academy of Sciences of the United States of America, v. 108, n. 14, p. 5909-14, 5 abr. 2011.

GÓMEZ-BAGGETHUN, E. et al. The history of ecosystem services in economic theory and practice: From early notions to markets and payment schemes. Ecological Economics, v. 69, n. 6, p. 1209-1218, abr. 2010.

GORDON, L. J.; FINLAYSON, C. M.; FALKENMARK, M. Managing water in agriculture for food production and other ecosystem services. Agricultural Water Management, v. 97, n. 4, p. 512-519, 2010.

HJERPE, E.; HUSSAIN, A.; PHILLIPS, S. Valuing type and scope of ecosystem conservation: A metaanalysis. Journal of Forest Economics, 2015.

HORN, F. P.; BREEZE, R. G. Agriculture and Food Security. Annals of the New York Academy of Sciences, v. 894, n. 1 FOOD AND AGRI, p. 9-17, 1 dez. 1999.

HOWE, H. F.; SMALLWOOD, J. Ecology of Seed Dispersal. Annual Review of Ecology and Systematics, v. 13, n. 1, p. 201-228, 1 nov. 1982.

IBGE. Manual técnico de uso da terra. 3a ed. Rio de Janeiro: IBGE - Instituto Brasileiro de Geografia e Estatística, 2013.

IBGE, I. B. DE G. E. Censo Agropecuário 2006, 2006. Disponível em: <http://www.ibge.gov.br/home/estatistica/economia/agropecuaria/censoagro/2006_segunda_apur acao/default.shtm>

IBGE - INSTITUTO BRASILEIRO DE GEOGRAFIA E ESTATÍSTICA. Mapa de Biomas e de Vegetação. Disponível em: <http://goo.gl/iUSfTR>. Acesso em: 5 set. 2017.

IBGE - INSTITUTO BRASILEIRO DE GEOGRAFIA E ESTATÍSTICA. IBGE | mapas. Disponível em: $<$ http://mapas.ibge.gov.br/>. Acesso em: 3 mar. 2018a.

IBGE - INSTITUTO BRASILEIRO DE GEOGRAFIA E ESTATÍSTICA. Sistema IBGE de Recuperação Automática - SIDRA. Disponível em: <https://sidra.ibge.gov.br/home/scnt/brasil>. Acesso em: 3 mar. 2018b.

IPARDES. Indicadores de sustentabilidade ambiental por bacias hidrográficas do estado do Paraná. Curitiba: [s.n.]. Disponível em: <http://www.ipardes.gov.br/biblioteca/docs/Apresentacao.pdf>.

IRWIN, E. G.; BOCKSTAEL, N. E. Land use externalities, open space preservation, and urban sprawl. v. 34, p. 705-725, 2004. 
KROEGER, T.; CASEY, F. An assessment of market-based approaches to providing ecosystem services on agricultural lands. v. 4, 2007.

LAVELLE, P. et al. Agriculture, Ecosystems and Environment Soil ecosystem services and land use in the rapidly changing Orinoco River Basin of Colombia. "Agriculture, Ecosystems and Environment", $v$. 185, p. 106-117, 2014.

MAZOYER, M.; ROUDART, L. História das agriculturas no mundo: do neolítico à crise contemporânea. [s.l: s.n.].

MCCONKEY, K. R. et al. Seed dispersal in changing landscapes. Biological Conservation, v. 146, n. 1, p. 1-13, 1 fev. 2012.

MEA. Ecosystems and Human Well-being: A framework for Assessment. In: MA Conceptual framework. [s.l: s.n.]. p. 1-25.

MMA - MINISTÉRIO DO MEIO AMBIENTE. CAR - Boletim Informativo: dados até 16 de fevereiro de 2018Brasília-DFMinistério do Meio Ambiente - MMA, , 2018. Disponível em: <http://www.florestal.gov.br/documentos/car/boletim-do-car/3294-boletim-informativo-janeiro-de2018/file>. Acesso em: 1 mar. 2018

MMA - MINISTÉRIO DO MEIO AMBIENTE. Mata Atlântica. Disponível

em: <http://www.mma.gov.br/biomas/mata-atlantica>. Acesso em: 25 fev. 2018.

NEVES, M. A. Análise integrada aplicada à exploração de água subterrânea na Bacia do Rio Jundiaí (SP). [s.I.] Universidade Estadual Paulista, 2005.

PALM, C. et al. Conservation agriculture and ecosystem services: An overview. Agriculture, Ecosystems and Environment, 2014.

POWER, A. G. Ecosystem services and agriculture : tradeoffs and synergies. p. 2959-2971, 2010.

PRADO, T. B. G. Evolução do uso das terras e produção de sedimentos na bacia hidrográfica do rio Jundiaí-Mirim. [s.I.] Instituto Agronômico de Campinas, 2005.

RUSCH, A. et al. Agricultural landscape simplification reduces natural pest control: A quantitative synthesis. Agriculture, Ecosystems \& Environment, v. 221, p. 198-204, abr. 2016.

SÃO PAULO. Decreto no 43.284, de 3 de julho de 1998São Paulo, 1998. Disponível em: <https://www.jundiai.sp.gov.br/planejamento-e-meio-ambiente/wpcontent/uploads/sites/15/2014/09/Decreto-43.284.pdf>

SCHUPP, E. W. Quantity, quality and the effectiveness of seed dispersal by animals BT - Frugivory and seed dispersal: ecological and evolutionary aspects. In: FLEMING, T. H.; ESTRADA, A. (Eds.). . Dordrecht: Springer Netherlands, 1993. p. 15-29.

SOSMA. Florestas: A Mata Atlântica. Disponível em: <https://www.sosma.org.br/nossa-causa/a-mataatlantica/>. Acesso em: 25 fev. 2018a. 
SOSMA. Atlas da Mata Atlântica. Disponível em: <https://www.sosma.org.br/projeto/atlas-da-mataatlantica/>. Acesso em: 25 fev. 2018b.

SOSMA. Atlas dos Remanescentes Florestais da Mata Atlântica, 2014-2015. São Paulo: [s.n.]. Disponível em: <http://goo.gl/RLr1WR>.

SWINTON, S. M. et al. Ecosystem services and agriculture: Cultivating agricultural ecosystems for diverse benefits. Ecological Economics, v. 64, n. 2, p. 245-252, 2007.

THEROND, O. et al. A new analytical framework of farming system and agriculture model diversities. A review. Agronomy for Sustainable Development, v. 37, n. 3, p. 21, jun. 2017.

TURNER, R. K.; DAILY, G. C. The Ecosystem Services Framework and Natural Capital Conservation. Environmental and Resource Economics, v. 39, n. 1, p. 25-35, 2008.

ZHANG, W. et al. Ecosystem services and dis-services to agriculture. Ecological Economics, v. 64, n. 2, p. 253-260, 2007. 


\section{NOTAS}

\section{Nota 1}

Este trabalho foi preparado no âmbito do projeto Abordagem simultânea e inter-relacionada das dimensões de sustentabilidade para a melhoria da gestão de recursos hídricos: o caso da bacia do Rio Jundiaí, 2016-2021, financiado pelo Programa de Apoio à Pós-graduação e à Pesquisa Científica e Tecnológica em Desenvolvimento Socioeconômico no Brasil (PGPSE) da Capes, edital no 42/2014. Este capítulo uma versão do artigo publicado na Revista de Política Agrícola, ano XXVIII, no 3, jul./Ago./Set. 2019. Garcia, J. R.; Maia, A. G. Agricultores e a Gestão da Bacia do Rio Jundiaí. Revista de Política Agrícola, ano XXVIII, no 3, jul./Ago./Set. 2019. Uma versão preliminar foi apresentada no 56으 Congresso da Sociedade Brasileira de Economia, Administração e Sociologia Rural (Sober).

\section{Nota 2}

A Avaliação Ecossistêmica do Milênio (Millennium Ecosystem Assessment) foi um programa de quatro anos concebido para responder às necessidades de tomadores de decisão política e científica sobre a relação entre as alterações presenciadas nas últimas décadas do século XX na relação entre os ecossistemas e o bem-estar humano. Esse programa foi uma iniciativa do então Secretário Geral das Organizações das Nações Unidas (ONU), Kofi Annan, em junho de 2001 (MEA, 2003).

\section{Nota 3}

Último dado disponível sobre a área agropecuária total no Brasil por município.

Nota 4

O mapa de uso e cobertura das terras da BHRJ foi extraído do mapeamento realizada na Unidade Hidrográfica de Gerenciamento de Recursos Hídricos (UGRHI) 5 - Piracicaba, Capivari e Jundiaí (PCJ), que abrange as Bacias Hidrográficas dos Rios Piracicaba, Capivari e Jundiaí. O mapeamento foi realizado pela Empresa Tecnogeo Informáticas S/S Ltda. - EPP, validado pelos técnicos da Coordenadoria de Planejamento Ambiental (CPLA) em parceria com o Instituto Geológico. O método adotado foi a interpretação visual de recortes da imagem SPOT, ortorretificados, mosaicados e separados de acordo com o limite das cartas do IBGE 1:25.000, com 2,5 metros de resolução espacial com bandas fusionadas e cenas multiespectral com resolução espacial de 10 metros variando entre 2007 e 2009 (DATAGEO, 2018).

\section{Nota 5}

A área total dos estabelecimentos agropecuários é superior à da BHRJ, porque os dados são municipais.

Nota 6

O Bioma representa um agrupamento com diversos tipos de vegetação contíguos, mas identificáveis na escala regional, inclui ainda características geoclimáticas similares e processos históricos compartilhados, resultando em diversidade biológica própria (IBGE, 2004).

\section{Nota 7}

A delimitação oficial do Bioma Mata Atlântica é aquela apresentada pelo IBGE, publicada no "mapa dos biomas brasileiros", na escala 1:5.000.000 (IBGE, 2004).

Nota 8

Fundação SOS Mata Atlântica. 
Nota 9

Organização Não-governamental.

Nota 10

Instituto Paranaense de Desenvolvimento Econômico e Social.

Nota 11

A área passível de cadastro no CAR foi estimada a partir do Censo Agropecuário 2006 e nas atualizações do Distrito Federal e dos estados Amapá, Amazonas, Espírito Santo, Pará e Mato Grosso (MMA, 2018). 


\section{Capítulo 2}

\section{INSEGURANÇA ALIMENTAR E CARACTERÍSTICAS SOCIOECONÔMICAS DAS FAMÍLIAS NO CENTRO-OESTE DO BRASIL}

DOI: $10.37423 / 200300348$

Carlos Leão (PUC GO) cleao17@gmail.com

Júlia Pereira de Sousa Cunha (PUC GO) juliaps11@hotmail.com

Henrique Ribeiro Leão (PUC GO) - hrl@gmail.com

Ivahy Santos Moreira (PUC GO) ivahysm@gmail.com

Resumo: O objetivo geral deste estudo foi o de analisar a intensidade e natureza da relação entre características sociais e econômicas de grupos de indivíduos e a experiência de insegurança alimentar. Foi considerado que variáveis tais como: etnia, escolaridade, desemprego, sexo conforme classificação do IBGE, renda mensal per capta domiciliar, renda mensal do domicílio e beneficiários de programas de transferência de renda, entre outras, afetam a probabilidade de os indivíduos e suas famílias experimentarem insegurança alimentar. Os dados utilizados no estudo referem-se a PNAD anual de 2013 e a região estudada se limitou ao Centro-oeste do Brasil. Foi utilizado ainda como modelo empírico o logit multinomial ordenado, dado que a variável latente assume gradações em forma de ordenação. Os resultados permitiram concluir que características definidoras da posição socioeconômica do individuo e sua família, de fato aumenta a probabilidade de experiência de insegurança alimentar.

Palavras-chave: Segurança alimentar, Logit Multinomial, Centro-oeste. 


\section{INTRODUÇÃO}

As discussões sobre insegurança alimentar vêm assumindo importância crescente nos debates sobre bem-estar social. O provimento de condições adequadas de alimentação e nutrição compõe o conjunto de necessidades vitais do indivíduo e de sua família e, portanto, a insuficiência de alimentação em quantidade e qualidade adequadas pode comprometer de forma dramática suas condições de vida. Do ponto de vista do indivíduo a nutrição insuficiente e a baixa disponibilidade de alimentos pode elevar sua propensão a contrair enfermidades além de expô-lo à degradante experiência da fome. Do ponto de vista da sociedade, o comprometimento da integridade física e de saúde do indivíduo pode resultar na elevação dos gastos públicos no combate à doenças, além de reduzir sua capacidade laboral, com consequências sobre produtividade e, consequentemente, sobre as taxas de crescimento econômico do país.

Apesar de ser um direito constitucional o agravamento do problema de insuficiência alimentar no Brasil tem levado o governo a formular políticas públicas com a tentativa de mitigar suas consequências. Neste sentido, em 2006 foi instituído o Sistema Nacional de Segurança Alimentar e Nutricional - SISAN cujo objetivo era o de assegurar o direito à alimentação adequada a partir da formulação e execução da "Política de Segurança Alimentar e Nutricional". O Programa Bolsa Família formulado sob a estrutura da macro política de segurança alimentar é um exemplo do esforço do governo brasileiro de prover segurança alimentar para as famílias de baixa renda. Segundo Santana (2007), especificamente, os programas de transferência de renda foram criados com o intuito de combater a fome e suas causas estruturais no país.

O quadro 1 apresenta a distribuição por modalidade das famílias que foram beneficiárias de algum instrumento da política de proteção do governo federal na região Centro-oeste. Constata-se que modalidades de auxílios moradia e educação forma inexpressivos com as menores participações relativas, 6,4\% e 2,4\%, respectivamente, das 13969 famílias contempladas com algum tipo de transferência de renda do governo federal. Por outro lado, observa-se que cerca de $40,3 \%$ e 37,9\% das famílias foram beneficiadas pelo programas de auxílio alimentação e transporte. 
Quadro 1 - Participação absoluta e relativa de beneficiários das políticas de transferência de renda do governo federal na região Centro-oeste (valores amostrais válidos)

\begin{tabular}{|l|c|c|c|c|}
\hline Modalidade & \multicolumn{2}{|c|}{ Valores Absolutos } & \multicolumn{2}{c|}{ Proporções amostrais } \\
\hline & Sim & Não & Sim & Não \\
\hline Auxílio Moradia & 893 & 13076 & 6,4 & 93,6 \\
\hline Auxílio Alimentação & 5626 & 8343 & 40,3 & 59,7 \\
\hline Auxílio Transporte & 5293 & 8676 & 37,9 & 62,1 \\
\hline Auxílio Educação & 334 & 13635 & 2,4 & 97,6 \\
\hline Auxílio Saúde & 2012 & 11957 & 14,4 & 85,6 \\
\hline
\end{tabular}

Fonte: PNAD 2013

Este estudo assume como hipótese que os programas de transferências de renda podem ter contribuído para reduzir os efeitos perversos do problema de insegurança alimentar na região Centro-oeste. Pretende-se verificar também se características específicas de grupos de pessoas os propendem à sujeição de situações de insegurança alimentar. $\mathrm{N}$ este sentido $\mathrm{s}$ ã o c o $\mathrm{n} \mathrm{s}$ id e ra d o s que atributos tais como: sexo, idade, escolaridade, condição na atividade, desemprego, etnia, migração, renda, número de componentes, sejam fatores determinantes na condição de segurança quanto ao provimento adequado de abastecimento alimentar.

Neste sentido, os objetivos desta pesquisa são os de averiguar se as características particulares de determinados grupos familiares são determinantes da sua vulnerabilidade em relação ao provimento da segurança alimentar. Pretende-se examinar também se os programas de transferência de renda foram eficazes no sentido de diminuir a extensão do problema na região Centro-oeste do Brasil.

A variável "segurança alimentar" foi definida operacionalmente pela garantia de acesso contínuo à quantidade e qualidade suficientes de alimentos, obtidos por meio socialmente aceitável, de forma a assegurar o bem-estar e saúde do indivíduo e sua família. A intensidade da "insegurança alimentar" existente no domicílio, no período de referência dos últimos 3 meses, foi classificada em: insegurança alimentar leve, insegurança alimentar moderada e insegurança alimentar grave com ou sem existência de residente menor de 18 anos, tal classificação foi obtida a partir da Escala Brasileira de Medida de Insegurança Alimentar (EBIA). 
A Escala Brasileira de Medida de Insegurança Alimentar (EBIA) é um método aprimorado pelo grupo de pesquisa Rede Alimenta, da Faculdade de Ciências Médicas da Universidade Estadual de Campinas (UNICAMP) a partir de validação de escala similar utilizada pelo Departamento de Agricultura dos Estados Unidos. A EBIA é utilizada, atualmente, para informações oficiais sobre segurança alimentar no Brasil, sendo incorporada, por exemplo, à Pesquisa Nacional de Amostra de Domicílios (PNAD), do Instituto Brasileiro de Geografia e Estatística (IBGE).

Quadro 2 - Situação de segurança alimentar e composição da família - Centro-oeste

\begin{tabular}{|l|l|l|}
\hline Existe morador menor de 18 anos e tem segurança alimentar & 18427 & 49,1 \\
\hline Existe morador menor de 18 anos e tem insegurança alimentar leve & 4211 & 11,2 \\
\hline Existe morador menor de 18 anos e insegurança alimentar & 717 & 1,9 \\
\hline Existe morador menor de 18 anos e tem insegurança alimentar & 564 & 1,5 \\
\hline Não existe morador menor de 18 anos e tem segurança alimentar & 11714 & 31,2 \\
\hline Não existe morador menor de 18 anos e tem segurança alimentar & 1154 & 3,1 \\
\hline Não existe morador menor de 18 anos e segurança alimentar & 444 & 1,2 \\
\hline Não existe morador menor de 18 anos e tem segurança alimentar & 295 & 0,8 \\
\hline Total & 37526 & 100,0 \\
\hline
\end{tabular}

Fonte: PNAD - 2013

A EBIA dispõe de quinze questões, que conduzem à estimação de prevalência de segurança alimentar, classificando os domicílios em quatro níveis: 1 - Segurança Alimentar (SA), quando não há restrição alimentar de qualquer natureza, ou mesmo preocupação com a falta de alimentos no futuro; 2 Insegurança Alimentar Leve (IAL), quando existe preocupação ou incerteza quanto ao acesso aos alimentos, e, portanto, risco para a sustentação e qualidade da dieta; 3 -Insegurança Alimentar Moderada (IAM), quando aparecem restrições quantitativas especialmente relevantes entre pessoas adultas; e 4 - Insegurança Alimentar Grave (IAG), quando existe redução importante da quantidade de alimentos disponíveis, tanto para a alimentação de adultos, como das crianças (SEGALL- CORRÊA, 2007, p. 96).

O quadro 2 dispõe a distribuição dos valores absolutos e relativos da situação de segurança alimentar em famílias com e sem existência de menor de 18 anos e famílias sujeitas à situação de insegurança alimentar leve, moderada e grave, também considerando a existência de menor de 18 anos na região Centro-oeste do Brasil. 


\section{MODELO TEÓRICO}

Em situações empíricas em que a variável dependente é discreta, qualitativa e ordenada, é inapropriada a utilização de modelos lineares dado que não é possível captar a natureza descontínua das unidades observacionais. Além disto, modelos lineares consideram que diferença entre dois valores, como exemplo 1 e 2, são tratados da mesma forma que diferenças entre 3 e 4, o que na verdade pode não refletir a característica do fenômeno.

Neste estudo serão utilizados os modelos Logit Multinomial Ordenado e Probit Multinomial Ordenado dado que a variável dependente considerada se caracteriza por ser descontínua e qualitativa e assumir valores que refletem ordenamento de respostas, de forma a permitir o ranqueamento dos resultados possíveis e, portanto, de forma não linear. Neste caso a variável latente $\mathrm{G}$ associa números $(0,1,2$, 3,4 . ) às unidades observacionais, sendo que serão consideradas as seguintes categorias:

a. 1 "possui segurança alimentar";

b. 2 "possui insegurança alimentar leve";

c. 3 "possui insegurança alimentar moderada";

d. 4 "possui insegurança alimentar grave".

O modelo é construído a partir da regressão linear entre a variável latente Gi* e um vetor de regressores Xi da mesma maneira que o modelo Probit binomial tradicional, a partir da função:

$\mathrm{Gi}^{*}=\beta^{\prime} \mathrm{Xi}+\varepsilon i$,

$\mathrm{Gi}=\mathrm{j}$ se $\alpha \mathrm{j}-1<\mathrm{G}^{*} \leq \alpha \mathrm{j}$

Gi* não é observada, no entanto, é possível observar: $\mathrm{G}=1$, se $\mathrm{G}^{*} \leq \mathrm{e} 1$

$G=2$, se e $1<G^{*} \leq e 2 G=3$, se e $2<G^{*} \leq e 3 G=4$, se e3 $\leq G^{*} \quad$.

$G=k$, se ek-1<G*

Os e's são parâmetros desconhecidos a serem estimados juntamente com os $\beta$ i's. As unidades observadas têm sua própria avaliação introspectiva em relação à experiência de insegurança alimentar. Esta experiência por sua vez é condicionada tanto por fatores observáveis quanto por fatores não observáveis عi. A estratégia aqui é fazer com que o indivíduo utilize uma escala de mensuração objetiva para expressar sua avaliação subjetiva de experiência de insegurança alimentar, ou seja, cada indivíduo observado poderia ter seu $\mathrm{F}^{*}$ e utilizar uma escala particular para expressa-lo, 
no entanto dada a escala que lhe é apresentada ele escolhe aquela que está mais se aproxima da sua verdadeira opinião. É pressuposto, portanto, que $\varepsilon$ é normalmente distribuído na amostra, com média zero e variância constante. Têm-se assim os seguintes efeitos marginais:

$$
\begin{gathered}
\partial \operatorname{Prob}(y=1) / \partial x=-\Phi\left(-\beta^{\prime} X\right) \beta \\
\partial \operatorname{Prob}(y=2) / \partial x=\left\{\Phi\left(-\beta^{\prime} X\right)-\Phi\left(\mu 1-\beta^{\prime} X\right)\right\} \beta \\
\partial \operatorname{Prob}(y=3) / \partial x=\left\{\Phi\left(\mu 1-\beta^{\prime} X\right)-\Phi\left(\mu 2-\beta^{\prime} X\right)\right\} \beta \\
\partial \operatorname{Prob}(y=4) / \partial x=\Phi\left(\mu 2-\beta^{\prime} X\right) \beta
\end{gathered}
$$

A função de densidade de probabilidade acumulada para $G$ para o modelo logit ordenado é a função logística dada por $\mathrm{G}(\mathrm{z})=\mathrm{ez} /(1+\mathrm{ez})$, enquanto que para o modelo probit ordenado, $\mathrm{G}$ é a normal padrão. Tanto o modelo logit ordenado quanto o modelo probit ordenado com $\mathrm{j}$ alternativas de repostas terá um conjunto j de efeitos marginais. A interpretação destes coeficientes está relacionada ao seu sinal e mostrará se a variável latente $\mathrm{G}^{*}$ se comportará com a variação do regressor.

Esta pesquisa se propõe a verificar se existe, e com que intensidade, relação evidente entre a tipologia de acesso à alimentação e algumas características particulares dos indivíduos. Será examinada com ênfase maior a evidência de sujeição à condição de insegurança alimentar de grupos de indivíduos e ou famílias que tenham acesso aos programas de transferência de renda do governo.

Mais especificamente, a proposta principal é verificar qual é a probabilidade de indivíduos beneficiados por algum programa de transferência de renda experimentarem insegurança alimentar em qualquer dos três níveis considerados pelo IBGE. Será examinado ainda se outras características individuais - tais como escolaridade, sexo, cor ou raça, migração, condição econômica expressa através da renda e tipo de emprego - predispõem o indivíduo ou família a serem vítimas de insegurança alimentar em Goiás.

\section{3 - DADOS}

Os dados utilizados nesta pesquisa referem-se ao levantamento da Pesquisa Nacional de Amostras de Domicílios - PNAD do IBGE. No ano de 2009, além da pesquisa básica foi divulgada ainda um suplemento sobre segurança alimentar. Quando algum atributo, cuja variabilidade se quer explicar, assume uma dentre duas categorias distintas, pode-se assumir como pressuposto, que as respostas sejam condicionadas pela presença de uma ou mais características individuais. 
Tabela 4 - Análise exploratória das variáveis incluídas na análise de regressão

\begin{tabular}{|c|c|c|c|}
\hline Variável & Nível da variável & Média & Desvio Padrão \\
\hline AS & Segurança Alimentar & 1,23 & 0,57 \\
\hline V0302 & Sexo & 0,55 & 0,50 \\
\hline V8005 & Idade do morador na data de referência & 35,49 & 12,04 \\
\hline V0404 & Cor ou raça & 0,59 & 0,49 \\
\hline V0601 & Sabe ler e escrever & 0,03 & 0,16 \\
\hline V9001 & Trabalhou na semana de referência & 0,02 & 0,14 \\
\hline V9008 & Posição na ocupação & 0,92 & 0,26 \\
\hline V9058 & Número de horas trabalhadas & 40,47 & 10,67 \\
\hline V2103 & Preocupação de que os alimentos acabassem & 0,86 & 0,36 \\
\hline W1 & Dummy transferência de renda & 0,55 & 0,50 \\
\hline V9044 & Recebeu auxílio alimentação & 1,23 & 0,58 \\
\hline V9005 & Número de trabalhos & 1,06 & 0,368 \\
\hline V4614 & Renda mensal domiciliar & 4015,81 & 4059,34 \\
\hline V4803 & Anos de estudo & 10,59 & 4,153 \\
\hline V9059 & Contribuía para previdência & 0,224 & 0,417 \\
\hline V4742 & Renda mensal domiciliar per capita & 1321,81 & 1585,56 \\
\hline V9892 & Idade com que começou a trabalhar & 15,24 & 4,125 \\
\hline V9115 & Tomou providência para conseguir trabalho & 0,91 & 0,276 \\
\hline
\end{tabular}

Fonte: PNAD 2013

A tabela 4 apresenta a descrição e a análise exploratória das variáveis utilizadas no modelo Logit Multinomial Ordenado, enquanto que a Tabela 5 mostra as distribuições de frequência absoluta e relativa da situação de segurança e insegurança alimentar na região Centro-oeste do Brasil. 
Tabela 5 - Distribuição da situação de segurança/insegurança alimentar - Centro-oeste

\begin{tabular}{lcr}
\hline SA - ABIA & Frequência & Percentual \\
\hline Segurança Alimentar & 10744 & 82,58 \\
Insegurança Alimentar Leve & 1699 & 13,06 \\
Insegurança Alimentar Moderada & 353 & 2,71 \\
Insegurança Alimentar Grave & 215 & 1,65
\end{tabular}

Fonte: PNAD 2013

\section{4- ANÁLISE DOS RESULTADOS}

A tabela 6 apresenta os resultados da análise de regressão logit multinomial ordenada. Com exceção do coeficiente da variável V0302, todas as demais se mostraram significativas a pelo menos $5 \%$ de probabilidade. Os coeficientes de cut1, cut2, cut3, representam os interceptos de três categorias: Insuficiência Alimentar Leve, Insuficiência Alimentar Moderada e Insuficiência Alimentar Grave. Isto significa que a categoria de referência ou base é Segurança Alimentar. Os valores dos coeficientes das variáveis utilizadas no modelo indicam que a insegurança alimentar diminui para os indivíduos que receberam auxílio alimentação da mesma forma para aqueles indivíduos que receberam alguma forma de transferência de renda considerada no estudo. Os resultados mostram ainda que não brancoamarelos, analfabetos, pessoas desempregadas e com trabalho informal também eleva substancialmente a probabilidade do indivíduo experimentar insegurança alimentar. Por outro lado, os coeficientes negativos das variáveis V4742 e V4614 que se referem, respectivamente, a rendimento mensal domiciliar per capta e rendimento mensal do domicílio, indicam que elevação da renda está relacionada com redução da insegurança alimentar.

Deve-se observar que a variável dependente considerada neste estudo é uma variável ordenada que toma os seguintes valores: 1 - segurança alimentar; 2 - insegurança alimentar leve; 3 - insegurança alimentar moderada; e 4 - insegurança alimentar grave. Por outro lado, como no caso das variáveis dummies, a categoria de referência e que, portanto, assume valor zero, é aquela que propende o indivíduo a não experimentar insegurança alimentar. Assim, se foi adotado como hipótese que indivíduos de etnia negra ou parda são mais vulneráveis a experimentarem insegurança alimentar, 
então o sinal positivo do coeficiente indica que os dois atributos de relacionam positivamente e se deslocam no mesma direção.

Tabela 6 - Equação de regressão Logit Multinomial Ordenada

\begin{tabular}{|c|c|c|c|c|c|c|}
\hline \multicolumn{7}{|c|}{ Ordered Logistic Regression } \\
\hline \multicolumn{3}{|c|}{$\operatorname{LR} \operatorname{chi} 2(14)=1328,06$} & \multicolumn{4}{|c|}{ Log likelihood = -7007,0607 } \\
\hline Prob > chi2 & \multicolumn{2}{|c|}{$=0,0000$} & \multicolumn{2}{|c|}{ Number of obs $=$} & 13011 & \\
\hline SA & Coef. & Std. Err & Z & $P>|z|$ & {$[95 \%$ Co } & Interval] \\
\hline V9044 & $-0,14406$ & 0,0747137 & $-1,930$ & 0,0540 & $-0,00237$ & 0,29049 \\
\hline V0302 & $-0,02606$ & 0,0500776 & $-0,520$ & 0,6030 & $-0,12421$ & $-0,00721$ \\
\hline V8005 & $-0,00676$ & 0,0022024 & $-3,070$ & 0,0020 & $-0,01108$ & $-0,00244$ \\
\hline V0404 & 0,15818 & 0,0516612 & 3,060 & 0,0020 & 0,05693 & 0,25944 \\
\hline V0601 & 0,34238 & 0,1307366 & 2,620 & 0,0090 & 0,08614 & 0,59862 \\
\hline V9001 & 0,47150 & 0,1636134 & 2,880 & 0,0040 & 0,15082 & 0,79218 \\
\hline V9005 & 0,28373 & 0,0685575 & 4,140 & 0,0000 & 0,14936 & 0,41810 \\
\hline V9059 & 0,31385 & 0,0565478 & 5,550 & 0,0000 & 0,20302 & 0,42468 \\
\hline V9892 & $-0,02758$ & 0,0067388 & $-4,090$ & 0,0000 & $-0,04079$ & $-0,01434$ \\
\hline V9115 & $-0,63367$ & 0,0763720 & 0,080 & 0,0000 & $-0,78335$ & $-0,48396$ \\
\hline V4803 & $-0,04191$ & 0,0074264 & $-5,640$ & 0,0000 & $-0,05646$ & $-0,02735$ \\
\hline V4742 & $-0,00123$ & 0,0000810 & $-15,18$ & 0,0000 & $-0,00138$ & $-0,00107$ \\
\hline V4614 & $-0,00006$ & 0,0000200 & $-3,170$ & 0,0020 & 0,0000 & 0,0001 \\
\hline W1 & $-0,15702$ & 0,0721003 & $-2,180$ & 0,0290 & $-0,29833$ & $-0,01571$ \\
\hline cut1 & $-0,53440$ & 0,1943747 & & & $-0,91537$ & $-0,15343$ \\
\hline cut2 & 1,09297 & 0,1966299 & & & 0,70758 & 1,47836 \\
\hline cut3 & 2,11930 & 0,2035669 & & & 1,72031 & 2,51828 \\
\hline
\end{tabular}


Tabela 7 - Distribuição de Probabilidade das Quatro Categorias de Insegurança Alimentar

\begin{tabular}{llll}
\hline Variável & Observações & Média & Desvio Padrão \\
\hline p1ologit & 13011 & 0,824772 & 0,116196 \\
p2ologit & 13011 & 0,131407 & 0,081893 \\
p3ologit & 13011 & 0,027340 & 0,021305 \\
p4ologit & 13011 & 0,016479 & 0,013949 \\
\hline
\end{tabular}

Fonte: Resultados da pesquisa

A tabela 7 apresenta a distribuição de probabilidades associadas a cada valor possível de nível da variável dependente: segurança alimentar, insegurança alimentar leve, insegurança alimentar moderada e insegurança alimentar grave, para a região Centro-oeste do Brasil. A probabilidade de uma observação escolhida ao acaso considerar-se com segurança alimentar é de 82,47\%, com insegurança grave de $1,64 \%$, enquanto que esta probabilidade aumenta para cerca de $13,14 \%$ para indivíduos que experimentam insegurança alimentar leve. Ainda que valores associados à insegurança alimentar sejam pequenos, o problema assume gravidade dado a natureza da questão.

No anexo são apresentadas as tabelas dispondo as probabilidades marginais relacionadas às gradações da variável dependente. Pode-se concluir que receber auxílio alimentação reduz em 14,24\% a experiência de insegurança alimentar. Os demais resultados devem ser interpretados da mesma maneira.

\section{5 - CONCLUSÕES}

O presente estudo permite concluir que, de forma geral, características relacionadas à baixa escolaridade, desemprego, etnia negra ou parda, baixa renda e que normalmente comprometem o bem-estar social, são aquelas que também tornam determinados grupos sociais vulneráveis a experiência de insegurança alimentar. Reconhece-se que novas hipóteses e formulações de modelos alternativos devam ser testadas, mas ainda que de forma provisória, este estudo permite concluir que é necessária a reorientação da política pública como forma de mitigar um problema que é de extrema gravidade. 


\section{REFERÊNCIAS BIBLIOGRÁFICAS}

BRASIL. Lei no 11.346, de 15 de setembro de 2006. Cria o Sistema Nacional de Segurança Alimentar e Nutricional - SISAN com vistas em assegurar o direito humano à alimentação adequada e dá outras providências. Diário Oficial da República Federativa do Brasil, Poder Executivo, Brasília, DF, 2006. Disponível em: http://www.planalto.gov.br/ccivil_03/_a to2004-2006/2006/lei/l11346.htm, Acesso em: 25 abril 2016.

GUJARATI, D.N.; PORTER, D.C. Econometria básica. 5 edição, Porto Alegre: AMGH, 2006.

INSTITUTO BRASILEIRO DE GEOGRAFIA E ESTATístICA-IBGE. Pesquisa Nacional por

Amostra de Domicílios - PNAD - Segurança Alimentar. 2010. Disponível em: http://www.ibge.gov.br/home/estatistica /populacao /seguranca_alimentar_2004_2009/pnad alimentar.pdf. Acesso em: 29 abril 2016.

JOHNSTON, B.F. \& MELLOR, J.W. El Papel de la Agricultura em el Desarrollo Econômico. In: American Economic Review, vol LI, 04, set. 1961

PINDYCK, R. S.; RUBINFELD, D. L. Econometria: Modelos e previsões. Ed.Campus, São Paulo, 2004.

SANTANA, J. Á. A evolução dos programas de transferência de renda e o Programa Bolsa Família. In: Seminário População, Pobreza e Desigualdade, 1., 2007, Belo Horizonte/ MG. RESUMOS... Belo Horizonte/ MG: Cedeplar/ UFMG, 2007.

SEGALL-CORRÊA, A. M. et al. Validación de instrumento de medida de la inseguridad alimentaria y hambre, en el contexto de las políticas brasileñas de combate el hambre. Perspectivas en nutrición humana, v. 2, 2007. 


\section{ANEXOS}

Tabela 7 - Efeitos marginais - Suficiência Alimentar

\begin{tabular}{r|rrrrrr}
\hline & \multicolumn{7}{|c}{ Delta-method } & & & \\
& dy/dx & Std. Err. & $z$ & P $>|z|$ & {$[95 \%$ Conf. } & Interval] \\
\hline V9044 & -.0142358 & .0073866 & -1.93 & 0.054 & -.0287132 & .0002416 \\
V0302 & .0025752 & .0049504 & 0.52 & 0.603 & -.0071274 & .0122779 \\
V8005 & .0006681 & .0002188 & 3.05 & 0.002 & .0002393 & .0010969 \\
V0404 & -.0156318 & .0051225 & -3.05 & 0.002 & -.0256717 & -.0055918 \\
V0601 & -.0338336 & .0129536 & -2.61 & 0.009 & -.0592222 & -.0084449 \\
V9001 & -.0465933 & .0161994 & -2.88 & 0.004 & -.0783436 & -.0148431 \\
V9005 & -.0280382 & .0067581 & -4.15 & 0.000 & -.0412837 & -.0147927 \\
V9059 & -.0310144 & .0056669 & -5.47 & 0.000 & -.0421213 & -.0199075 \\
V9892 & .0027258 & .0006679 & 4.08 & 0.000 & .0014168 & .0040349 \\
V9115 & .0626182 & .007688 & 8.14 & 0.000 & .0475501 & .0776864 \\
V4803 & .0041414 & .0007482 & 5.54 & 0.000 & .002675 & .0056079 \\
V4742 & .0001215 & $6.38 e-06$ & 19.05 & 0.000 & .000109 & .000134 \\
V4614 & $-6.33 e-06$ & $1.98 e-06$ & -3.20 & 0.001 & -.0000102 & $-2.45 e-06$ \\
W1 & .0155165 & .0071322 & 2.18 & 0.030 & .0015377 & .0294953 \\
& & & & & &
\end{tabular}

Tabela 8 - Efeitos marginais - Insuficiência Alimentar Leve

\begin{tabular}{r|rrrrrr}
\hline & \multicolumn{7}{|c}{ Delta-method } \\
& dy/dx & Std. Err. & $z$ & P $>|z|$ & [95\% Conf. & Interval] \\
\hline V9044 & .0108636 & .0056386 & 1.93 & 0.054 & -.0001879 & .0219152 \\
V0302 & -.0019652 & .0037778 & -0.52 & 0.603 & -.0093695 & .0054391 \\
V8005 & -.0005098 & .000167 & -3.05 & 0.002 & -.0008372 & -.0001825 \\
V0404 & .0119289 & .0039111 & 3.05 & 0.002 & .0042633 & .0195946 \\
V0601 & .0258191 & .009892 & 2.61 & 0.009 & .0064312 & .045207 \\
V9001 & .0355563 & .0123702 & 2.87 & 0.004 & .0113111 & .0598015 \\
V9005 & .0213965 & .005166 & 4.14 & 0.000 & .0112714 & .0315217 \\
V9059 & .0236677 & .0043336 & 5.46 & 0.000 & .0151739 & .0321615 \\
V9892 & -.0020801 & .0005103 & -4.08 & 0.000 & -.0030803 & -.00108 \\
V9115 & -.0477853 & .0058973 & -8.10 & 0.000 & -.0593438 & -.0362267 \\
V4803 & -.0031604 & .0005716 & -5.53 & 0.000 & -.0042807 & -.0020401 \\
V4742 & -.0000927 & $5.10 e-06$ & -18.20 & 0.000 & -.0001027 & -.0000828 \\
V4614 & $4.83 e-06$ & $1.51 e-06$ & 3.20 & 0.001 & $1.87 e-06$ & $7.79 e-06$ \\
W1 & -.0118409 & .0054446 & -2.17 & 0.030 & -.0225122 & -.0011697 \\
\hline
\end{tabular}


Tabela 8 - Efeitos marginais - Insuficiência Alimentar Moderada

\begin{tabular}{r|rrrrrr}
\hline & \multicolumn{7}{|c}{ Delta-method } & & \\
& dy/dx & Std. Err. & $z$ & P $>|z|$ & {$[95 \%$ Conf. } & Interval] \\
\hline V9044 & .0021258 & .001108 & 1.92 & 0.055 & -.0000459 & .0042974 \\
V0302 & -.0003845 & .0007395 & -0.52 & 0.603 & -.001834 & .0010649 \\
V8005 & -.0000998 & .0000331 & -3.02 & 0.003 & -.0001646 & -.000035 \\
V0404 & .0023342 & .0007743 & 3.01 & 0.003 & .0008167 & .0038518 \\
V0601 & .0050522 & .0019509 & 2.59 & 0.010 & .0012286 & .0088759 \\
V9001 & .0069576 & .0024439 & 2.85 & 0.004 & .0021677 & .0117475 \\
V9005 & .0041868 & .0010293 & 4.07 & 0.000 & .0021695 & .0062042 \\
V9059 & .0046312 & .0008777 & 5.28 & 0.000 & .002911 & .0063515 \\
V9892 & -.000407 & .0001018 & -4.00 & 0.000 & -.0006065 & -.0002075 \\
V9115 & -.0093505 & .0012399 & -7.54 & 0.000 & -.0117806 & -.0069204 \\
V4803 & -.0006184 & .0001163 & -5.32 & 0.000 & -.0008463 & -.0003905 \\
V4742 & -.0000181 & $1.27 e-06$ & -14.30 & 0.000 & -.0000206 & -.0000157 \\
V4614 & $9.45 e-07$ & $2.98 e-07$ & 3.17 & 0.002 & $3.61 e-07$ & $1.53 e-06$ \\
W1 & -.002317 & .0010713 & -2.16 & 0.031 & -.0044167 & -.0002173 \\
\hline
\end{tabular}

Tabela 9 - Efeitos marginais - Insuficiência Alimentar Grave

\begin{tabular}{|c|c|c|c|c|c|c|}
\hline & $d y / d x$ & $\begin{array}{l}\text { elta-method } \\
\text { Std. Err. }\end{array}$ & z & $P>|z|$ & [95\% Conf. & Interval ] \\
\hline V9044 & .0012464 & .0006518 & 1.91 & 0.056 & -.000031 & .0025238 \\
\hline V0302 & -.0002255 & .0004337 & -0.52 & 0.603 & -.0010756 & $.000624 \epsilon$ \\
\hline V8005 & -.0000585 & .0000196 & -2.99 & 0.003 & -.0000968 & -.0000202 \\
\hline V0 404 & .0013686 & .0004576 & 2.99 & 0.003 & .0004717 & .0022655 \\
\hline V0601 & .0029622 & .0011488 & 2.58 & 0.010 & .0007105 & $.005213 \mathrm{c}$ \\
\hline V9001 & .0040794 & .0014429 & 2.83 & 0.005 & .0012513 & .0069074 \\
\hline V9005 & .0024548 & .0006125 & 4.01 & 0.000 & .0012543 & .0036553 \\
\hline V9059 & .0027154 & .0005274 & 5.15 & 0.000 & .0016817 & $.00374 \mathrm{C}$ \\
\hline V9892 & -.0002387 & .0000606 & -3.94 & 0.000 & -.0003574 & -.0001199 \\
\hline V9115 & -.0054824 & .0007618 & -7.20 & 0.000 & -.0069755 & -.0039893 \\
\hline V4803 & -.0003626 & .00007 & -5.18 & 0.000 & -.0004999 & -.0002253 \\
\hline V4742 & -.0000106 & $8.70 e-07$ & -12.23 & 0.000 & -.0000123 & $-8.94 e-06$ \\
\hline V4 614 & $5.54 e-07$ & $1.76 e-07$ & 3.14 & 0.002 & $2.08 e-07$ & $8.99 e-07$ \\
\hline W1 & -.0013585 & .0006308 & -2.15 & 0.031 & -.0025949 & -.0001221 \\
\hline
\end{tabular}




\section{Capítulo 3}

\section{EVOLUÇÃO DA BALANÇA COMERCIAL DO ESTADO DE MATO GROSSO DO SUL: UMA ANÁLISE PELO MODELO CONSTANT MARKET SHARE}

DOI: $10.37423 / 200300357$

Wagner Luis Bertoldo (ESAN-UFMS) - wagner_bertoldo@hotmail.com Mayra Batista Bitencourt Fagundes (ESAN-UFMS) - bitencourtmayra@gmail.com; Adriano Marcos Rodrigues Figueiredo (ESAN-UFMS) - amrofi@gmail.com; Daniel Massen Frainer (UEMS/UNIDERP-Anhanguera) - danielfrainer@gmail.com

Resumo: O objetivo deste estudo foi analisar a evolução da balança comercial interestadual e internacional do estado do Mato Grosso do Sul para os períodos de 2012 a 2017. O estudo teve como base teórica os trabalhos sobre desenvolvimento regional de Perroux, Hirschman e em especial da teoria da base exportadora de Douglass North. A metodologia quantitativa adotada para se alcançar o objetivo proposto foi o modelo constant market share. Além disso, a fonte dos dados utilizados é secundária e proveniente do Ministério do Desenvolvimento, da Indústria e do Comércio Exterior (MDIC) e Secretaria de Estado de Meio Ambiente, Desenvolvimento Econômico, Produção e Agricultura (SEMAGRO/MS). Os resultados mostram que, no que tange o fluxo comercial agregado, Mato Grosso do Sul tem ganhado espaço no mercado interno e externo ao apresentar um crescimento das exportações de quase $50 \%$ no período. . Não obstante, nas relações interestaduais o estado de São Paulo e a região sul ainda são os principais parceiros comerciais com saldo positivo para o estado, embora a região Norte e Nordeste tenham aumentado a participação na exportação e na importação de produtos provenientes da região Sul-Mato-Grossense. 
Conclui-se que a maior participação do estado, tanto nas exportações interestaduais quanto nas internacionais, mostra ganhos de competitividade dos produtos produzidos na região.

Palavras-chave: Competitividade; Comércio Internacional; Agronegócio. 


\section{INTRODUÇÃO}

A importância do estado de Mato Grosso do Sul na balança comercial brasileira vem ganhando destaque ao longo dos últimos anos. Em 2017, as exportações do estado cresceram 17,45\% em comparação com o mesmo período do ano anterior, gerando um superávit de aproximadamente US\$ 2,25 bilhões para o estado. Esta variação de 17,45\% do biênio (2016-2017) foi impulsionada principalmente pela soja em grão, pela celulose, carne de bovinos, açúcar, milho, carne de aves e minério de ferro. Destes, é importante salientar o papel da soja em grão no incremento das exportações, uma vez que o produto obteve um crescimento de $29,38 \%$ no volume exportado, enquanto a celulose cresceu 9,98\%, saindo de 2,34 milhões de toneladas exportadas para 2,57 milhões de toneladas (SEMAGRO, 2018).

Segundo o Ministério do Desenvolvimento, Indústria e Comércio Exterior (MDIC), o estado de Mato Grosso do Sul importou aproximadamente US\$ 2,52 bilhões em produtos e serviços provenientes de outros países, representando uma variação de 9,7\% em relação a 2016.

Até o ano de 2014 o saldo da balança comercial do estado era deficitário em US\$21,99 milhões, ao passo que a partir de 2015 Mato Grosso do Sul inverteu este quadro com uma sucessão de superávits, sendo US\$ 1,31 bilhões em 2015, US\$ 1,77 bilhões em 2016 e US\$ 2,25 bilhões em 2017 conforme anteriormente apresentado. Em termos percentuais, entre 2015 e 2017 o estado acumulou uma variação positiva de aproximadamente $71,8 \%$ nas suas transações comerciais internacionais. Esta inversão expressiva e repentina de perfil na dinâmica comercial do Estado pode ser atribuída a políticas econômicas mais ativas por parte do governo estadual. Além disso, o forte crescimento do agronegócio, em 2017, contribuiu de forma significativa para o superávit da região. Enquanto, o Produto Interno Bruto (PIB) cresceu apenas 1\% em 2017, o setor agropecuário registrou um aumento de $13 \%$ no período (IBGE, 2018).

Segundo o Ministério do Desenvolvimento, Indústria e Comércio Exterior (MDIC), há três grandes classes nos quais os produtos são agrupados segundo a intensidade e complexidade de transformação (agregação de valor) em que estes produtos são submetidos desde o processo produtivo até a venda ao consumidor final. São eles: i) Produtos Básicos: produtos de baixo valor, cuja cadeia produtiva é simples e que sofrem poucas transformações, como por exemplo o minério de ferro, grãos, agricultura, etc.; ii) Semimanufaturados: produto que passou por alguma transformação como o suco de laranja congelado e produtos de couro; e, iii) Manufaturados: produto normalmente de maior tecnologia, com alto valor agregado, como por exemplo o televisor, chip de computador, automóvel, CD com programa de computador, etc. 
Dentro desta classificação, os produtos básicos representaram 62,9\% das exportações em 2017 e $52,7 \%$ das importações no mesmo período. Já os produtos semimanufaturados representaram $35,1 \%$ das exportações e $6,85 \%$ das importações. Cabe também destacar que os produtos manufaturados foram responsáveis por aproximadamente $2 \%$ das exportações enquanto os mesmos compuseram $40,5 \%$ dos produtos importados pelo estado. A expressiva representatividade de produtos manufaturados comprados pode explicar em partes a grande dependência do estado por produtos de alto valor agregado, ao passo que a pauta de exportação é predominantemente composta por produtos de baixo valor agregado (MDIC, 2019). Porém, as exportações de produtos semimanufaturados vêm ganhando espaço na pauta exportadora do estado, passando de 32,5\% em 2012 para 35,1\% em 2017, um aumento de 8,0\% no período (SEMAGRO, 2018).

A partir deste panorama, este trabalho tem por objetivo principal analisar o fluxo comercial do estado de Mato Grosso do Sul no período de 2012 a 2017, tanto no âmbito interestadual quanto internacional, com a finalidade de identificar quais produtos apresentaram maior competitividade na balança comercial no período, utilizando-se do modelo Constant Market Share. Por interestadual entende-se o comércio por vias internas, no qual o estado exporta e importa produtos e serviços a outros estados do Brasil, e por internacional lê-se o fluxo comercial do estado com outros países. Além disso, a decomposição da balança do estado também é analisada com a finalidade de identificar quais foram os produtos que mais se destacaram. A decomposição permite visualizar, na análise da evolução da balança do estado no período em questão, se houve mudança significativa no perfil da pauta importadora e exportadora. Desta forma, é possível desenvolver políticas públicas que fomentem o desenvolvimento e o crescimento econômico baseado no perfil comercial encontrado.

Alguns estudos já foram feitos anteriormente com o mesmo intuito. Estes trabalhos abordam diferentes produtos, como o mercado brasileiro de camarão, de melão, de melão potiguar e Cearense e de mel natural, e procuram analisar a competitividade e o market share destes produtos no mercado global. Além disso, estudos sobre as exportações do agronegócio e o fluxo de comércio interestadual gaúcho também foram feitos (SILVA; SCHMALTZ, 2010; SOUZA et al. 2016; PENHA; ALVES, 2018; DE PAULA et al. 2016; FRIES et al. 2014; TATSCH; BATISTI, 2013). O presente trabalho se diversifica ao analisar a competitividade e a parcela de mercado do estado de Mato Grosso do sul através do fluxo comercial interestadual por meio do método Constant Market Share (CMS).

O trabalho está organizado em cinco seções, contando com esta introdução. Na próxima seção os aspectos teóricos serão abordados. Na terceira seção, o procedimento metodológico é detalhado e conceituado. Na quarta seção, serão apresentados os resultados e as conclusões auferidas através do 
arcabouço teórico e metodológico apresentado nas seções anteriores. Já na quinta seção as considerações finais enfatizarão de forma sucinta os detalhes do presente trabalho assim como possíveis indagações acerca da problemática apresentada com a finalidade de instigar o pesquisador a dar continuidade ao estudo.

\section{REFERENCIAL TEÓRICO}

\subsection{DESENVOLVIMENTO REGIONAL}

O trabalho tem como base teórica a teoria da base de exportação, desenvolvida, a priori, por Douglass Cecil North (1955). Anteriormente ao artigo escrito por North acerca da base de exportação, haviam outras teorias bem consolidadas e bem difundidas que procuraram explicar o desenvolvimento e o crescimento econômico das regiões.

Entre eles é possível citar Weber, Lösch e Thünen que ganharam destaque por suas contribuições na literatura econômica, em especial para o desenvolvimento e crescimento regional ao afirmarem que, em linhas gerais, uma região ou uma economia, ao longo do curso de seu desenvolvimento e crescimento, passam por uma série de estágios. Este compilado de teorias ficou conhecido na literatura como "teoria dos estágios". De forma sucinta, a teoria defendia que as economias evoluíam em razão da superação do sistema de subsistência agrícola, passo pelo estágio de substituição de importação até atingirem o ápice quando o serviço é a principal atividade econômica.

Entretanto, North enxergava algumas limitações e falhas na teoria dos estágios. Uma das limitações mais difundidas por North dizia respeito ao fato de que as etapas do estágio de desenvolvimento não eram aplicáveis a todos os países e regiões e que historicamente, esta sequência não era fielmente reproduzida. Isso implica em dizer que a teoria dos estágios não deveria ser vista como uma receita a ser seguida para que os países se desenvolvam, era necessário levar em consideração as particularidades regionais, culturais, históricas e econômicas de cada país e a partir destas características únicas elaboram um planejamento de longo prazo compatível.

Em seu livro intitulado “A estratégia do desenvolvimento econômico" de 1958, Hirschman argumenta que o crescimento só é alcançado quando há uma sequência de desajustes. Desajustes estes que por sua vez provocam desequilíbrios nos fatores produção e investimento de uma economia (região) periférica. A consequência do desequilíbrio seria uma forma de estímulo para que estas economias otimizassem seus recursos escassos (fatores de produção). Segundo Hirschman (1958, p.36) “...As desigualdades internacionais e inter-regionais de crescimento são condição inevitável e concomitante 
do próprio processo de crescimento". Este trecho da obra do autor expressa de forma clara e sucinta a ideia de que é necessário que haja heterogeneidade nas relações de troca entre regiões para que as mesmas buscam se desenvolver através dos desajustes.

A dinâmica heterogênea tanto interna quanto externa à região provoca o que Hirschman chama de efeitos para frente (forward linkages) e efeitos para trás (backward linkages). Em poucas palavras, estes efeitos expressam a dinâmica do processo de desenvolvimento e crescimento econômico ao considerar que não é possível se desenvolver ao mesmo tempo e em todas as partes. Sendo assim, a propagação do crescimento ocorre em torno de um ponto inicial espacialmente pré-estabelecido. Desta forma, o planejamento do desenvolvimento local deve focar na alocação ótima dos recursos produtivos ao longo do processo de produção, dado que não é a escassez o problema, mas sim a dinamização dos mesmos. Em outras palavras, o desenvolvimento não é observado em países que falham em organizar seus recursos e aloca-los de forma eficiente. Hirschman defende mecanismos de intervenção para que os investimentos locais aconteçam e enfatiza que as próprias decisões de investimento dos agentes econômicos é a variável chave para o crescimento, além de ser o principal objetivo da política econômica de uma região. A capacidade de investir em setores estratégicos e mais modernos da economia e o empreendedorismo local são exemplos de decisões de investimentos e de políticas de incentivo.

Perroux (1955) compartilhava do pensamento de Hirschman ao afirmar que o crescimento e o desenvolvimento em uma economia (região) não aconteciam de forma simultânea e uniforme em toda a parte. Justamente ao contrário, o start inicial ocorria em centros ou polos de crescimento, de formas e intensidades variadas. Ademais, os efeitos decorrentes do crescimento inicial advindos dos polos ramificavam-se por diversos canais de propagação com resultados diferentes sobre a vida econômica como um todo.

Os efeitos mencionados acima podem ser entendidos como uma indústria nova que, através de preços diferenciados, fluxos de capital e insumos de produção, desempenham o papel de indústria motriz. As indústrias motrizes são aquelas que "mais cedo do que outras, desenvolvem-se segundo formas que são as da grande indústria moderna" (Perroux, 1967, p.166). Isso quer dizer que as taxas de crescimento dos produtos destas indústrias são superiores à taxa média de crescimento da indústria e da economia agregada, em um certo período. Fica evidente a importância das indústrias motrizes no ambiente econômico na medida em que o volume de produção, o volume de oferta e o volume de serviços, seja através da aquisição de insumos ou oferta de mão-de-obra, resulta em uma interdependência com empresas menores. 
Portanto, a dinâmica do processo de crescimento, na visão de Perroux, depende em grande parte da demanda e da oferta de produtos e serviços advindos das indústrias motrizes que, ao crescerem, geram uma reação em cadeia proporcionando crescimento em menor grau às indústrias dependentes. Como consequência, um polo industrial complexo e geograficamente aglomerado é gerado, ampliando o diâmetro de alcance das indústrias motrizes através das indústrias satélites. Esta ampliação é conhecida como um efeito de disparidade inter-regional. A depender do poder do impacto dos polos industriais, que ao chegar ao alcance de outro polo industrial via meios de transporte ou por vias intelectuais, é capaz de afetar a economia na sua totalidade ao modernizar a pauta produtiva do país. O autor ainda destaca os efeitos das inovações ao processo de desenvolvimento e de crescimento econômico, dando ênfase ao impacto das mesmas na estrutura econômica como um todo ao intensificar os efeitos nas atividades exercidas pelas indústrias ou ao adicionar tecnologia ao capital humano através da especialização da mão-de-obra.

A partir deste contexto, os resultados deste estudo poderão indicar as indústrias motrizes, ou as potenciais indústrias motrizes, que foram responsáveis pela propagação do crescimento e do desenvolvimento da região. Isto será feito ao identificar, através da analise de competitividade e da parcela do mercado, os produtos que apresentaram uma maior representatividade na pauta exportadora do estado, refletindo, deste modo, a indústria de destaque.

\subsection{A TEORIA DA BASE DE EXPORTAÇÃO}

A teoria da base de exportação ganhou relevância na literatura econômica quando North procurou mostrar em seu artigo publicado em 1955 (conforme mencionado na seção anterior) a inconsistência das teorias de crescimento e desenvolvimento regional que até então tentavam explicar a dinâmica do processo evolutivo das economias. A referência de North para validar seus argumentos em contraposição às teorias foi o estudo analítico aplicado as regiões norte-americanas.

Ao fazer isso, o autor constata o pressuposto das teorias regionais clássicas de que o desenvolvimento acontece por meio de uma cadeia sucessiva de estágios ao argumentar que estes "estágios" de desenvolvimento podem não ser aplicáveis a todas as regiões, em especial a região norte-americana analisada. Segundo North (1955), a região noroeste dos Estados Unidos foi colonizada na época a partir de um perfil empreendedor e capitalista de negócios, no qual o principal determinante de seu crescimento era o mercado externo, assim (North 1955, p.295) “o objetivo básico era explorar a terra e seus recursos, com o fim de produzir bens que pudessem ser comercializados fora e que se transformaria em renda monetária". 
Na região analisada por North, o crescimento se deu basicamente pela produção e pela exportação de três produtos essenciais, sendo eles o trigo, a farinha e a madeira. Este perfil estrutural da região não convergia com a teoria do crescimento regional outrora difundida e, além disso, os altos custos de transporte decorrentes das limitações produtivas e logísticas da época fizeram com que as regiões norte-americanas analisadas ampliassem e diversificassem sua base produtiva somente após a redução destes custos, o que levou North a defender a ideia de que a taxa de crescimento de um país (região) estava diretamente ligada à capacidade de exportação, seja ela de produtos primários, secundários ou terciários.

Dado que a demanda por produtos de exportação era um fator exógeno, isto é, independente da região de produção, as indústrias exportadoras se defrontavam com a necessidade de reduzir seus custos de produção em razão de um produto relativamente mais competitivo. Desta forma, os demais setores da atividade econômica, lê-se os demais setores como aqueles que não estavam voltados à exportação, desempenhavam um papel secundário ao produzir para atender a demanda das indústrias de exportação. Esta dinâmica cíclica entre empresas produtoras de produtos exportáveis e as empresas coadjuvantes gera novas regiões de aglomerados de empresas com a mesma finalidade. Ao gerar um certo grau de competição entre os aglomerados regionais, as próprias regiões sentem a necessidade da redução de custos, seja dos insumos usados na produção dos produtos exportáveis, seja nos custos com mão-de-obra ou transporte, a fim de exportarem produtos competitivos. A redução dos custos mencionados anteriormente pode ser observada com o desenvolvimento de economias externas advindas das próprias regiões. As economias externas são, portanto, empresas ou indústrias resultantes da demanda das indústrias exportadoras por fatores de produção, ou seja, são externalidades positivas consequentes da relação inter-regional que rege a necessidade de exportação da região.

Tendo em mente esta dinâmica, o crescimento e o desenvolvimento de uma região depende essencialmente do desempenho de sua capacidade de exportação, que se intensifica com o desenvolvimento de novos produtos para a exportação e com a melhoria de produtos exportáveis já existentes, melhoria feita por meio da redução de custos inerentes ao ambiente de concorrência interna. Como consequência, North (1955) argumenta que a base de exportação é relevante para determinar o nível de renda agregada e o nível de renda per capita de uma região.

Outro ponto importante abordado por North (1955) diz respeito a fase de industrialização. Para o autor, uma região pode continuar a crescer e a se desenvolver sem abandonar as atividades agrícolas como principal pauta econômica. Sendo assim, não necessariamente um país deve passar pela fase de 
industrialização. A vantagem locacional de cada região permite que atividades secundárias e terciárias se desenvolvem a partir de uma pauta exportadora de base agrícola. North (1955) aponta também para existência de fatores determinantes para o crescimento e o declínio da base de exportação. Segundo North $(1955$, p.308) "o declínio de um produto de exportação deve ser acompanhado pelo crescimento de outros, ou então a região ficará encalhada". Isto explicita a importância dada pelo autor às exportações, independentemente de a pauta ser norteada por produtos industrializados ou de base agrícola.

Diante do exposto, o presente trabalho se apoia na teoria da base de exportação de North e na concepção de Perroux de indústrias motrizes para analisar a evolução da pauta exportadora do estado de Mato Grosso do Sul no período de 2012 a 2017. É também objetivo deste trabalho decompor a balança comercial estadual no período em questão e, a partir da análise de seus componentes, argumentar se houve ou não crescimento econômico, sustentado pela teoria de North.

\section{METODOLOGIA}

\subsection{MÉTODO E COLETA DE DADOS}

O método quantitativo adotado neste trabalho, em especial a metodologia baseada no modelo Constant Market Share, permite atingir o objetivo proposto inicialmente, uma vez que, segundo Carvalho (1995), os estudos norteados por esse modelo permitem uma análise mais abrangente e mais detalhada da parcela de participação de uma economia no fluxo comercial global ou regional. Além disso, as eventuais alterações ocorridas no market share ao longo do tempo estarão implícitas nos resultados oriundos da aplicação do modelo (LEAMER; STERN, 1970).

Os dados deste trabalho são de fonte secundária para o período de 2012 a 2017. Para o fluxo de comércio interestadual, os dados foram coletados da SEMAGRO/MS e traduzidos de CNAE 2.0 para o código SCN 110 por classificação segundo o IBGE. A fim de evitar dupla contagem, os dados referentes ao fluxo internacional e às devoluções foram excluídos.

Já para o fluxo internacional, as informações também são de fonte secundária. As estatísticas foram coletadas do site do Ministério do Desenvolvimento, da Indústria e do Comércio Exterior (MDIC). A tabulação também foi desagregada em uma planilha da Microsoft Excel para a mesma finalidade dos dados do fluxo comercial interestadual. Cada produto e serviço exportado ou importado também foi 
traduzido para o código SCN 110 para que tanto os dados interestaduais como internacionais fiquem com a mesma classificação, facilitando assim a análise e a comparação.

\subsection{O MODELO CONSTANT MARKET SHARE}

O modelo Constant Market Share (CMS) vem sendo utilizado em diversos estudos com a finalidade de avaliar e analisar a competitividade, o market share (parcela do mercado) e os setores exportadores de diferentes produtos e serviços em um determinado país em um definido período de tempo.

A metodologia foi desenvolvida inicialmente por Tyszynski (1951), onde o autor fez um estudo sobre os fatores que influenciaram as mudanças no market share dos países exportadores de bens industrializados. Desde então o modelo vem sendo aprimorado e utilizado em trabalhos aplicados ao caso brasileiro para analisar o comportamento dos bens exportados ao mercado mundial (ALVES; PENHA, 2018; SILVA; SCHMALTZ, 2010; FRIES, et al. 2013; CARVALHO; LEITE, 2008).

A decomposição matemática do modelo é apresentada a seguir, conforme Silva e Martins (2012):

Admite-se que:

- $\quad X_{c j}^{0}=$ Valor total das exportações de Mato Grosso do Sul para o mercado $j$ no período inicial 0;

- $X_{c j}^{f}=$ Valor total das exportações de Mato Grosso do Sul para o mercado $j$ no período final $f$;

- $g_{c}=$ Taxa de crescimento das exportações globais;

- $g_{c j}=$ Taxa de crescimento das exportações do estado por estado de destino;

- $\quad m_{c}=$ Taxa de crescimento das importações globais; e,

- $\quad m_{c j}=$ Taxa de crescimento das importações do estado por estado de destino.

A partir destas variáveis, a decomposição do crescimento efetivo das exportações do estado de Mato Grosso do Sul pode ser dada pela equação:

$$
\sum\left(X_{c j}^{f}-X_{c j}^{0}\right)=\sum m_{c} X_{c j}^{0}+\sum\left(m_{c j}-m_{c}\right) X_{c j}^{0}+\sum\left(X_{c j}^{f}-X_{c j}^{0}-m_{c j} X_{c j}^{0}\right)
$$

$\mathrm{ET}=\mathrm{ECE}+\mathrm{EDE}+\mathrm{ECO}$

em que: 
- $\mathrm{ET}=\sum\left(X_{c j}^{f}-X_{c j}^{0}\right)$ : Representa o crescimento efetivo das exportações do estado em um determinado período;

- $\quad \mathrm{ECE}=\sum m_{c} X_{c j}^{0}$ : Corresponde ao crescimento do comércio mundial do estado, representa o crescimento que seria observado se as exportações do estado crescessem a taxa de crescimento das exportações mundiais;

- $\mathrm{EDE}=\sum\left(m_{c j}-m_{c}\right) X_{c j}^{0}$ : É atribuído ao efeito destino das exportações. Corresponde ao ganho (perda), em percentagem de crescimento, considerando que o estado exporta para mercados que crescem a taxas superiores (ou inferiores) àquelas observadas para os demais mercados. Uma variação positiva implica em dizer que as exportações do estado foram direcionadas para mercados que possuem taxas de crescimento superiores aos demais mercados. O contrário também é observado; e,

- $\mathrm{ECO}=\sum\left(X_{c j}^{f}-X_{c j}^{0}-m_{c j} X_{c j}^{0}\right)$ : Corresponde ao efeito competitividade. É a parcela de crescimento dos ganhos (ou perdas) de participação das exportações do estado nos diversos mercados devido aos ganhos (ou perdas) de competitividade.

Portanto, a equação (1) é decomposta em 3 efeitos de modo que a soma destes efeitos explica a variação do crescimento das exportações do estado no período analisado. Neste trabalho o período inicial (0) determinado pelo modelo será o ano de 2012, ao passo que o período final (1) será o ano de 2017. A partir deste recorte temporal, a aplicação do método aos dados procura mostrar a evolução tanto da pauta quanto do valor total importado e exportado pelo estado no período analisado, além de analisar se houve ganhos de competitividade.

\section{RESULTADOS E DISCUSSÃO}

O gráfico 01 mostra a evolução da balança comercial agregada (compilado do fluxo comercial interestadual e internacional) do estado de Mato Grosso do Sul para o período analisado. O gráfico evidencia o aumento significativo das exportações do estado, crescendo de um pouco menos de R\$ 60 bilhões, em 2012, para para um pouco mais de R\$ 97 bilhões em 2017, variando 70,8\% no período de 5 anos. Da mesma forma, houve incremento das importações, porém de forma menos acentuada. 
A variação positiva foi de $36,8 \%$, passando de aproximadamente $\mathrm{R} \$ 52$ bilhões para um pouco mais de R\$ 71 bilhões. É importante destacar o efeito da taxa de câmbio tanto para as importações como para as exportações. Nos agregados de 2012 e de 2017, foram utilizados as médias das taxas de câmbio comercial dos anos, sendo R\$/US\$2,07 e R\$/US\$3,29, respectivamente, para incorporar os efeitos do fluxo comercial internacional na balança comercial total do estado. A tendência de um aumento mais agressivo das exportações em relação às importações reflete o compromisso do estado com uma política comercial superavitária, onde tanto no ano de 2012 quanto no ano de 2017 houve saldo positivo na balança, mas em 2017 o superávit foi mais expressivo.

Gráfico 01 - Evolução da balança comercial interestadual e internacional

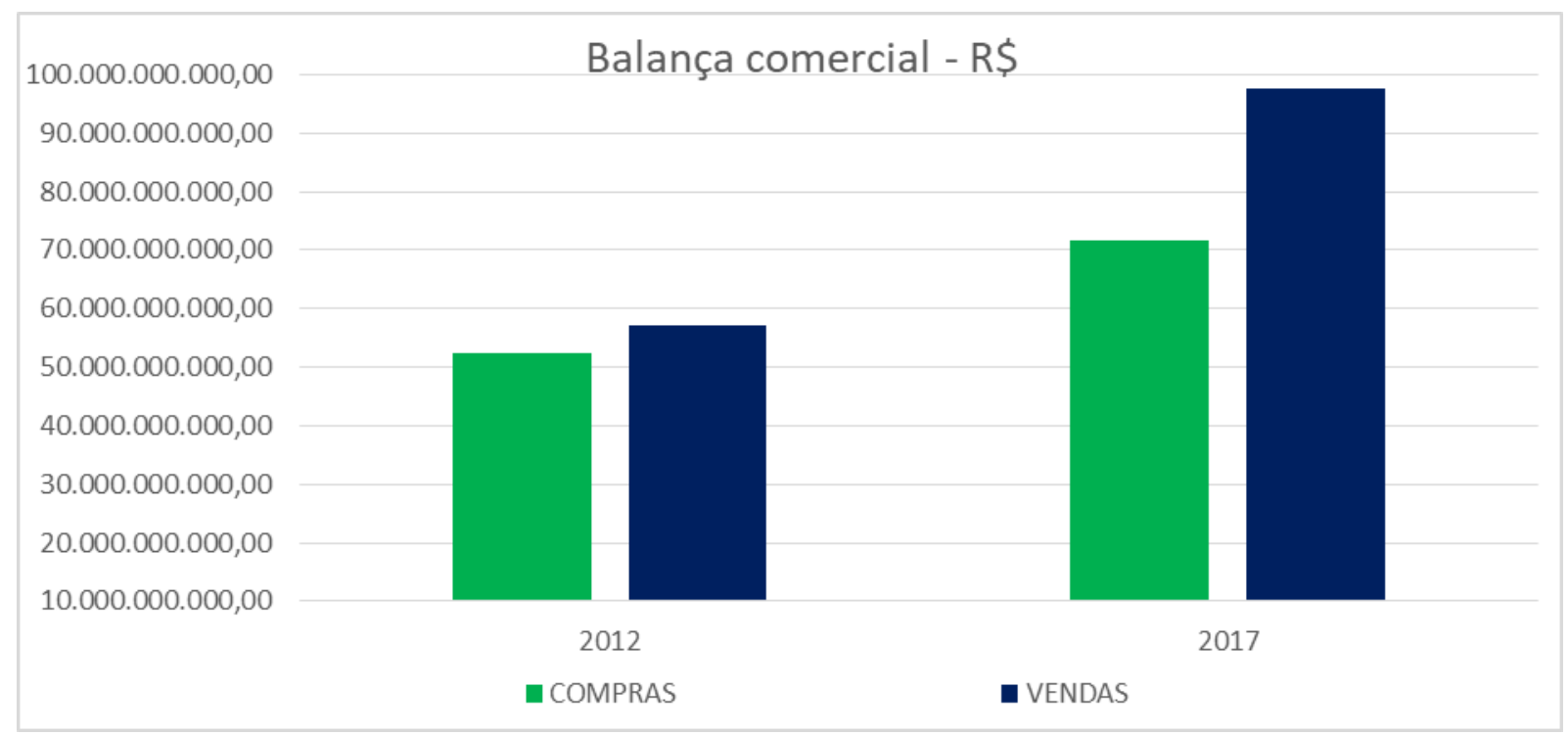

Fonte: Elaboração própria.

Ao desagregar a balança estadual e analisar somente o fluxo internacional, percebe-se uma inversão no perfil comercial no período. Na medida em que, no ano de 2012 , o estado apresentava um déficit de aproximadamente US\$ 2,2 bilhões, no ano de 2017 a balança comercial se inverteu e a região passou a ser superavitária em US\$ 950 milhões. Isto representa uma variação negativa de 51,3\% nas importações e uma variação positiva de 18,9\% nas exportações no período de 5 anos. Em relação aos produtos exportados, a soma percentual dos cinco produtos mais vendidos ao exterior acumulou 63,1\% do total em 2012, ao passo que em 2017 a soma dos cinco produtos mais vendidos representaram 71,1\%. Já em relação aos produtos importados, os cinco mais comprados em 2012 somaram 75,3\%, e em 2017 acumularam 63.5\% do total dos produtos comprados pelo estado. 0 critério dos cincos primeiros produtos foi adotado apenas para demonstrar o grau de concentração tanto das exportações quanto das importações, além de destacar quais foram estes produtos. As 
tabelas $01,02,03$ e 04 mostram a representatividade de cada um dos cinco primeiros produtos juntamente com os respectivos códigos CNAE 2.0.

A tabela 01 mostra que a principal pauta de exportação do estado no ano foi a de bens primários com baixo valor agregado. A carne de animais de espécie bovina e a soja representam juntos quase um quarto do total exportado. Já os produtos derivados de químicos representaram quase $15 \%$ do total no ano.

Tabela 01 - Produtos exportados de MS para outros países - 2012.

\begin{tabular}{|c|c|c|c|}
\hline CNAE 2.0 & $\begin{array}{c}\text { DESCRIÇÃO DO } \\
\text { PRODUTO }\end{array}$ & VALOR FOB - US\$ & \% TOTAL \\
\hline 1011.2 & $\begin{array}{l}\text { Pastas químicas de } \\
\text { madeira, à soda ou ao } \\
\text { sulfato, exceto pastas } \\
\text { para dissolução }\end{array}$ & $435,433,277$ & $14.9 \%$ \\
\hline 0141.5 & $\begin{array}{l}\text { Carnes de animais da } \\
\text { espécie bovina, } \\
\text { congeladas }\end{array}$ & $416,137,196$ & $14.2 \%$ \\
\hline 1072.4 & $\begin{array}{c}\text { Açúcares de cana ou } \\
\text { de beterraba e } \\
\text { sacarose } \\
\text { quimicamente pura, } \\
\text { no estado sólido }\end{array}$ & $370,310,027$ & $12.7 \%$ \\
\hline 0710.3 & $\begin{array}{l}\text { Minérios de ferro e } \\
\text { seus concentrados, } \\
\text { incluídas as pirites de } \\
\text { ferro ustuladas } \\
\text { (cinzas de pirites) }\end{array}$ & $327,009,187$ & $11.2 \%$ \\
\hline 1710.9 & Soja, mesmo triturada & $299,165,351$ & $10.2 \%$ \\
\hline SUBTOTAL & & $1,848,055,038$ & $63,1 \%$ \\
\hline
\end{tabular}




$$
\text { Demais produtos } \quad 1,078,734,496 \quad 36,9 \%
$$

\section{TOTAL}

$2,926,789,534$

$100 \%$

Na tabela 02 é possível perceber que a carne de animais da espécie bovina e a soja ainda representam um pouco mais de um quarto das exportações cinco anos depois. Porém, é evidente o aumento relevante da participação dos produtos derivados de pastas químicas, sendo que o produto praticamente dobrou sua representação em 2017. A tendência de mudança da pauta voltada para produtos de maior valor agregado, embora ainda de base agrícola, converge com a discussão levantada por North (1955) que defende que o declínio de um produto na pauta deve ser acompanhado por um aumento de outro produto para que uma região mantenha o seu crescimento.

Tabela 02 - Produtos exportados de MS para outros países - 2017

\begin{tabular}{|c|c|c|c|}
\hline CNAE 2.0 & DESCRIÇÃO DO PRODUTO & $\begin{array}{c}\text { VALOR FOB } \\
- \text { US\$ }\end{array}$ & $\begin{array}{c}\% \\
\text { TOTAL }\end{array}$ \\
\hline 1011.2 & $\begin{array}{l}\text { Pastas químicas de madeira, à soda ou ao } \\
\text { sulfato, exceto pastas para dissolução }\end{array}$ & $1,050,709,946$ & $30.2 \%$ \\
\hline 1012.1 & Soja, mesmo triturada & $682,098,225$ & $19.6 \%$ \\
\hline 0141.5 & $\begin{array}{c}\text { Carnes de animais da espécie bovina, } \\
\text { congeladas }\end{array}$ & $356,610,616$ & $10.2 \%$ \\
\hline 0141.5 & Milho & $197,347,446$ & $5.7 \%$ \\
\hline 1710.9 & $\begin{array}{l}\text { Carnes e miudezas comestíveis, frescas, } \\
\text { refrigeradas ou congeladas, das aves da } \\
\text { posição } 0105\end{array}$ & $188,847,785$ & $5.4 \%$ \\
\hline \multirow[t]{2}{*}{ SUBTOTAL } & & $2,475,614,018$ & $71,1 \%$ \\
\hline & Demais produtos & $1,005,681,225$ & $28,9 \%$ \\
\hline TOTAL & & $3,481,295,243$ & $100 \%$ \\
\hline
\end{tabular}

Fonte: Elaboração própria.

Já em relação aos produtos adquiridos pelo estado em 2012, na tabela 03 fica claro a diversidade de produtos que compõem a pauta importadora, dado que a concentração dos cinco produtos mais importados não é tão representativa quando comparado com as exportações. O cobre representa uma importante parcela das importações do ano, sendo responsável por 5,8\% do total, ao passo que é 
relevante destacar também a participação da importação de máquinas e aparelhos para a fabricação de celulose e papel pois esta diversificação reforça o argumento teórico abordado no presente trabalho de que uma maior industrialização da pauta foca em produtos agrícolas também é válido se o objetivo é desenvolver uma região.

Tabela 03 - Produtos importados de outros páises - Mato Grosso do Sul - 2012

$\begin{array}{cccc}\text { CNAE 2.0 } & \text { DESCRIÇÃO DO PRODUTO } & \text { VALOR FOB } & \% \\ & - \text { US\$ } & \text { TOTAL }\end{array}$

2443.1 Cobre afinado e ligas de cobre, em formas brutas

$301,274,825 \quad 5.80 \%$

1323.5 Tecidos de fios de filamentos sintéticos,

$115,701,053 \quad 2.23 \%$

incluídos os tecidos obtidos a partir dos produtos

da posição 5404

1313.8 Fios de filamentos sintéticos (exceto linhas para $\quad 95,273,872 \quad 1.84 \%$

costurar), não acondicionados para venda a

retalho, incluídos os monofilamentos sintéticos

com menos de 67 decitex

2013.4 Adubos (fertilizantes) minerais ou químicos, $\quad 77,183,708 \quad 1.49 \%$

potássicos

2865.8 Máquinas e aparelhos, para fabricação de pasta $\quad 75,916,584 \quad 1.46 \%$

de matérias fibrosas celulósicas ou para

fabricação ou acabamento de papel ou cartão

\section{SUBTOTAL}

$665,350,042 \quad 12.8 \%$

Demais produtos

$4,524,700,734 \quad 87.2 \%$ 
Ao comparar a pauta importadora do estado entre os anos analisados na tabela 04, nota-se um aumento na concentração, embora tenha ocorrido uma mudança na pauta com a inserção de produtos derivados do ferro e do aço e de máquinas. Além disso, percebe-se também a significativa participação da importação de máquinas e aparelhos para a fabricação de papel ou cartão que anteriormente não tinha representatividade relevante. Este aumento de participação está diretamente ligado à ascensão da indústria de papel e celulose na região do bolsão do estado. Isto implica em dizer que o estado está a caminho de uma modernização do seu processo produtivo e dos seus produtos vendidos e que a indústria de papel e celulose se configura como indústria responsável pelo crescimento da região (indústria motriz).

Tabela 04 - Produtos importados de outros páises - Mato Grosso do Sul - 2017.

\begin{tabular}{|c|c|c|c|}
\hline CNAE 2.0 & DESCRIÇÃO DO PRODUTO & $\begin{array}{c}\text { VALOR FOB - } \\
\text { US\$ }\end{array}$ & $\%$ TOTAL \\
\hline 2443.1 & $\begin{array}{l}\text { Cobre afinado e ligas de cobre, em } \\
\text { formas brutas }\end{array}$ & $115,820,386$ & $4.6 \%$ \\
\hline 2422.9 & $\begin{array}{l}\text { Produtos laminados planos de ferro ou } \\
\text { aço não ligado, de largura igual ou } \\
\text { superior a } 600 \mathrm{~mm} \text {, folheados ou } \\
\text { chapeados, ou revestidos }\end{array}$ & $111,104,059$ & $4.4 \%$ \\
\hline 2865.8 & $\begin{array}{c}\text { Máquinas e aparelhos, para fabricação } \\
\text { de pasta de matérias fibrosas celulósicas } \\
\text { ou para fabricação ou acabamento de } \\
\text { papel ou cartão }\end{array}$ & $106,402,751$ & $4.2 \%$ \\
\hline 1323.5 & $\begin{array}{l}\text { Tecidos de fios de filamentos sintéticos, } \\
\text { incluídos os tecidos obtidos a partir dos } \\
\text { produtos da posição } 5404\end{array}$ & $70,499,230$ & $2.8 \%$ \\
\hline 2013.4 & $\begin{array}{l}\text { Adubos (fertilizantes) minerais ou } \\
\text { químicos, contendo dois ou três dos } \\
\text { seguintes elementos fertilizantes: azoto } \\
\text { (nitrogénio), fósforo e potássio; outros } \\
\text { adubos (fertilizantes); produtos do } \\
\text { presente capítulo apresentados em } \\
\text { tabletes ou formas semelhantes, }\end{array}$ & $68,202,441$ & $2.7 \%$ \\
\hline
\end{tabular}




\section{SUBTOTAL}

$472,028,867$

$18.7 \%$

Demais produtos

$2,054,451,858$

$81.3 \%$

\section{TOTAL}

$2,526,480,725$

$100 \%$

\section{Fonte: Elaboração própria}

A tabela 05 decompõe a balança comercial interestadual ao mostrar as exportações e importações por unidade da federação. Ao analisar o fluxo individualmente, fica evidente que São Paulo foi o principal parceiro comercial do estado nos anos analisados. Em 2012, São Paulo foi responsável por 47,5\% do fluxo total, enquanto em 2017 o mesmo representou 67,7\%. O crescimento pode ser atribuído ao incremento no fluxo de produtos como grãos (soja, milho e trigo) e à participação maior da importação de bovinos para corte. A taxa de crescimento das exportações para o estado foi de 50,6\% no acumulado dos 5 anos. Boa parte da variação positiva advém de produtos da indústria agrícola, mas com alto valor agregado, como por exemplo a celulose e o papel. Na sequência, seguem os estados do Paraná (PR), Santa Catarina (SC) e Rio Grande do Sul (RS) como importantes parceiros comerciais do estado, representando 33,2\%, 13,2\% e 10,6\% do fluxo, respectivamente. Embora a participação do estado do Amapá (AP) tenha sido baixa tanto para as exportações quanto para as importações, é importante destacar a variação percentual das exportações para o estado. No ano de 2012 o estado do Amapá importou mais de US\$ 9 milhões, ao passo que em 2017 o valor comprado saltou para US\$ 39,5 milhões, uma variação positiva de quase $300 \%$.

Tabela 05 - Participação das exportações e importações de Mato Grosso do Sul por Unidade da Federação, 2012 e 2017.

\begin{tabular}{|c|c|c|c|c|c|}
\hline \multirow[t]{2}{*}{$\mathbf{U F}$} & \multicolumn{2}{|c|}{ EXPORTAÇÕES } & \multicolumn{2}{|c|}{ IMPORTAÇÕES } & \multirow{2}{*}{\begin{tabular}{c} 
TAXA DE \\
CRESCIMENTO \\
DAS \\
EXPORTAÇÕES \\
\multicolumn{1}{c}{$(\%)$}
\end{tabular}} \\
\hline & $\begin{array}{l}2012 / \\
\mathrm{em} \%\end{array}$ & $\begin{array}{l}2017 / \\
\mathrm{em} \%\end{array}$ & $\begin{array}{l}2012 / \\
\text { em \% }\end{array}$ & $\begin{array}{l}2017 \text { / } \\
\text { em \% }\end{array}$ & \\
\hline $\mathbf{A C}$ & 0.12 & 0.18 & 0.03 & 0.05 & 149.13 \\
\hline $\mathbf{A L}$ & 0.10 & 0.13 & 0.05 & 0.02 & 105.79 \\
\hline $\mathbf{A M}$ & 0.26 & 0.26 & 0.95 & 1.22 & 68.19 \\
\hline $\mathbf{A P}$ & 0.02 & 0.05 & 0.00 & 0.00 & 299.40 \\
\hline $\mathbf{B A}$ & 1.03 & 1.11 & 0.89 & 0.69 & 80.72 \\
\hline $\mathbf{C E}$ & 0.45 & 0.62 & 0.43 & 0.39 & 129.89 \\
\hline DF & 0.74 & 0.77 & 0.47 & 0.74 & 76.16 \\
\hline ES & 0.63 & 0.76 & 1.28 & 1.55 & 102.59 \\
\hline GO & 2.85 & 3.35 & 3.74 & 5.35 & 97.98 \\
\hline
\end{tabular}




\begin{tabular}{cccccc}
\hline MA & 0.32 & 0.39 & 0.25 & 0.12 & 108.14 \\
MG & 3.48 & 5.31 & 5.03 & 5.50 & 157.49 \\
MT & 2.62 & 2.97 & 3.33 & 3.17 & 91.53 \\
PA & 0.47 & 0.52 & 0.21 & 0.26 & 86.13 \\
PB & 0.15 & 0.31 & 0.07 & 0.08 & 245.23 \\
PE & 0.70 & 0.88 & 0.44 & 0.68 & 110.53 \\
PI & 0.12 & 0.23 & 0.02 & 0.03 & 220.44 \\
PR & 18.87 & 20.73 & 18.35 & 20.47 & 85.38 \\
RJ & 4.76 & 3.52 & 3.27 & 2.68 & 24.63 \\
RN & 0.21 & 0.23 & 0.12 & 0.15 & 83.28 \\
RO & 0.84 & 0.51 & 0.53 & 0.42 & 2.77 \\
RR & 0.04 & 0.05 & 0.01 & 0.00 & 104.05 \\
RS & 6.45 & 6.15 & 5.86 & 6.34 & 60.93 \\
SC & 8.47 & 9.40 & 4.98 & 6.53 & 87.10 \\
SE & 0.11 & 0.20 & 0.06 & 0.05 & 198.52 \\
SP & 45.97 & 41.04 & 49.51 & 43.28 & 50.60 \\
TO & 0.20 & 0.36 & 0.10 & 0.19 & 199.72 \\
\hline TOTAL & $\mathbf{1 0 0}$ & $\mathbf{1 0 0}$ & $\mathbf{1 0 0}$ & $\mathbf{1 0 0}$ & $\mathbf{6 8 . 7 1}$ \\
\hline
\end{tabular}

Fonte: Elaboração própria.

Já em relação às importações, a região sul do país juntamente com o estado de São Paulo ainda é importante para o estado de Mato Grosso do Sul. Em 2012, a região sul somou 29,2\% do total importado pelo estado, enquanto o estado de São Paulo representou 49,5\%. Entretanto, em 2017 os estados do Rio Grande do Sul, Santa Catarina e Paraná foram responsáveis por 33,4\% do total comprado, um incremento de 4,2 pontos percentuais no período, com destaque para a criação de bovinos para corte (PR e SC) e o cultivo de soja (RS). Por outro lado, São Paulo teve uma queda acentuada de 6,2\% no total de participação. Esta perda de representatividade do estado de São Paulo foi parcialmente recompensada pelo avanço de alguns estados da região Centro-Oeste como Goiás e Mato Grosso e o estado de Minas Gerais, que apresentaram, em conjunto, um aumento de aproximadamente $2 \%$ em 5 anos.

A tabela 06 apresenta a decomposição do crescimento das exportações de Mato Grosso do Sul por estado de destino e para o resto do mundo (ROW). Em relação ao crescimento efetivo, fica evidente que o crescimento total das exportações do estado pode ser atribuída, em grande parte, ao crescimento efetivo das importações dos estados de São Paulo, que foi responsável por $20,8 \%$ do total, e da região sul do país, com $24,5 \%$ de participação. O crescimento observado por sua vez apresentou resultados negativos devido ao fato de que tanto as exportações quanto as importações mundiais terem mostrado taxas de crescimento negativas para o período entre 2012 e 2017 , com -4,3\% para as exportações e -3,5\% para as importações. 
Tabela 06 - Decomposição do crescimento das exportações de Mato Grosso do Sul por Unidade da Federação e resto do mundo - em \%

\begin{tabular}{|c|c|c|c|c|}
\hline UF & $\begin{array}{c}\text { CRESCIMENTO } \\
\text { EFETIVO }\end{array}$ & $\begin{array}{l}\text { CRESCIMENTO } \\
\text { OBSERVADO }\end{array}$ & $\begin{array}{c}\text { EFEITO } \\
\text { DESTINO }\end{array}$ & $\begin{array}{c}\text { EFEITO } \\
\text { COMPETITIVIDADE }\end{array}$ \\
\hline & $\sum\left(X_{c j}^{f}-X_{c j}^{0}\right)$ & $\sum m_{c} X_{c j}^{0}$ & $\sum_{\left.-m_{c}\right) X_{c j}^{0}}\left(m_{c j}\right.$ & $\sum_{\left.-m_{c j} X_{c j}^{0}\right)}\left(X_{c j}^{f}-X_{c j}^{0}\right.$ \\
\hline AC & 149.1 & -2.3 & 119.6 & -17.3 \\
\hline $\mathbf{A L}$ & 105.8 & -3.3 & -28.6 & 131.9 \\
\hline $\mathbf{A M}$ & 68.2 & -5.1 & 144.9 & -39.9 \\
\hline $\mathbf{A P}$ & 299.4 & -1.2 & 51.8 & 49.3 \\
\hline BA & 80.7 & -4.3 & 25.8 & 78.4 \\
\hline $\mathrm{CE}$ & 129.9 & -2.7 & 31.5 & 71.1 \\
\hline DF & 76.2 & -4.5 & 190.5 & -85.9 \\
\hline ES & 102.6 & -3.4 & 86.6 & 16.8 \\
\hline GO & 98.0 & -3.5 & 123.4 & -19.9 \\
\hline MA & 108.1 & -3.2 & -23.4 & 126.6 \\
\hline MG & 157.5 & -2.2 & 44.5 & 57.7 \\
\hline MT & 91.5 & -3.8 & 52.9 & 50.9 \\
\hline PA & 86.1 & -4.0 & 98.6 & 5.4 \\
\hline PB & 245.2 & -1.4 & 31.0 & 70.4 \\
\hline PE & 110.5 & -3.1 & 124.6 & -21.5 \\
\hline PI & 220.4 & -1.6 & 46.2 & 55.3 \\
\hline PR & 85.4 & -4.0 & 85.9 & 18.1 \\
\hline RJ & 24.6 & -14.0 & 115.7 & -1.7 \\
\hline $\mathbf{R N}$ & 83.3 & -4.2 & 106.8 & -2.6 \\
\hline RO & 2.8 & -125.0 & 887.3 & -662.3 \\
\hline $\mathbf{R R}$ & 104.0 & -3.3 & -39.5 & 142.8 \\
\hline $\mathbf{R S}$ & 60.9 & -5.7 & 112.1 & -6.4 \\
\hline SC & 87.1 & -4.0 & 118.7 & -14.7 \\
\hline SE & 198.5 & -1.7 & 14.1 & 87.7 \\
\hline SP & 50.6 & -6.8 & 72.3 & 34.5 \\
\hline TO & 199.7 & -1.7 & 99.7 & 2.0 \\
\hline ROW & 89.0 & -3.9 & -21.5 & 125.4 \\
\hline TOTAL & 70.9 & -4.9 & 56.9 & 47.9 \\
\hline
\end{tabular}

Fonte: Elaboração própria

Entretanto, os resultados observados para o efeito destino mostram que, de um modo geral, o estado de Mato Grosso do Sul exportou seus produtos para estados nos quais a demanda efetiva por estes produtos cresceu à taxas superiores aos demais. Em outras palavras, os estados destino para os quais o estado do MS está exportando seus produtos possuem uma demanda pelos produtos estaduais crescente. Ademais, o efeito competitividade mostra ganhos expressivos de participação das exportações do estado para outros estados, como por exemplo o estado de Roraima (RR), Maranhão (MA) e Alagoas (AL), com 142,8\%, 126,6\% e 131,9\%, respectivamente. Além disso, cabe destacar também o relevante aumento de participação de Mato Grosso do Sul nas exportações internacionais. 
Isso implica em dizer, de acordo com o modelo Constant Market Share, que houve ganhos de participação nas parcelas estadual e mundial devido a ganhos de competitividade do estado.

A análise da evolução das compras e das vendas feitas pelo estado mostra que, apesar de alguns estados da região Centro-Oeste e Sudeste terem ganhado participação como parceiros comerciais do estado, Mato Grosso do Sul ainda depende em grande parte da região sul e do estado de São Paulo para manter a sua balança comercial estável. Ademais, algumas indústrias-chaves como a de papel e celulose e a de produtos químicos e seus derivados corroboraram para o aumento da competitividade do estado tanto no mercado interestadual quanto no mercado internacional ao apresentarem ganhos de participação no fluxo comercial estadual. Estas indústrias, ao industrializarem a pauta exportadora agrícola do estado, convergem com a abordagem de North (1955) que argumenta que uma economia não precisa abandonar as atividades agrícolas para se desenvolver e crescer.

Gráfico 02 - Decomposição do crescimento das exportações de Mato Grosso do Sul por Unidade da Federação e resto do mundo - em \%

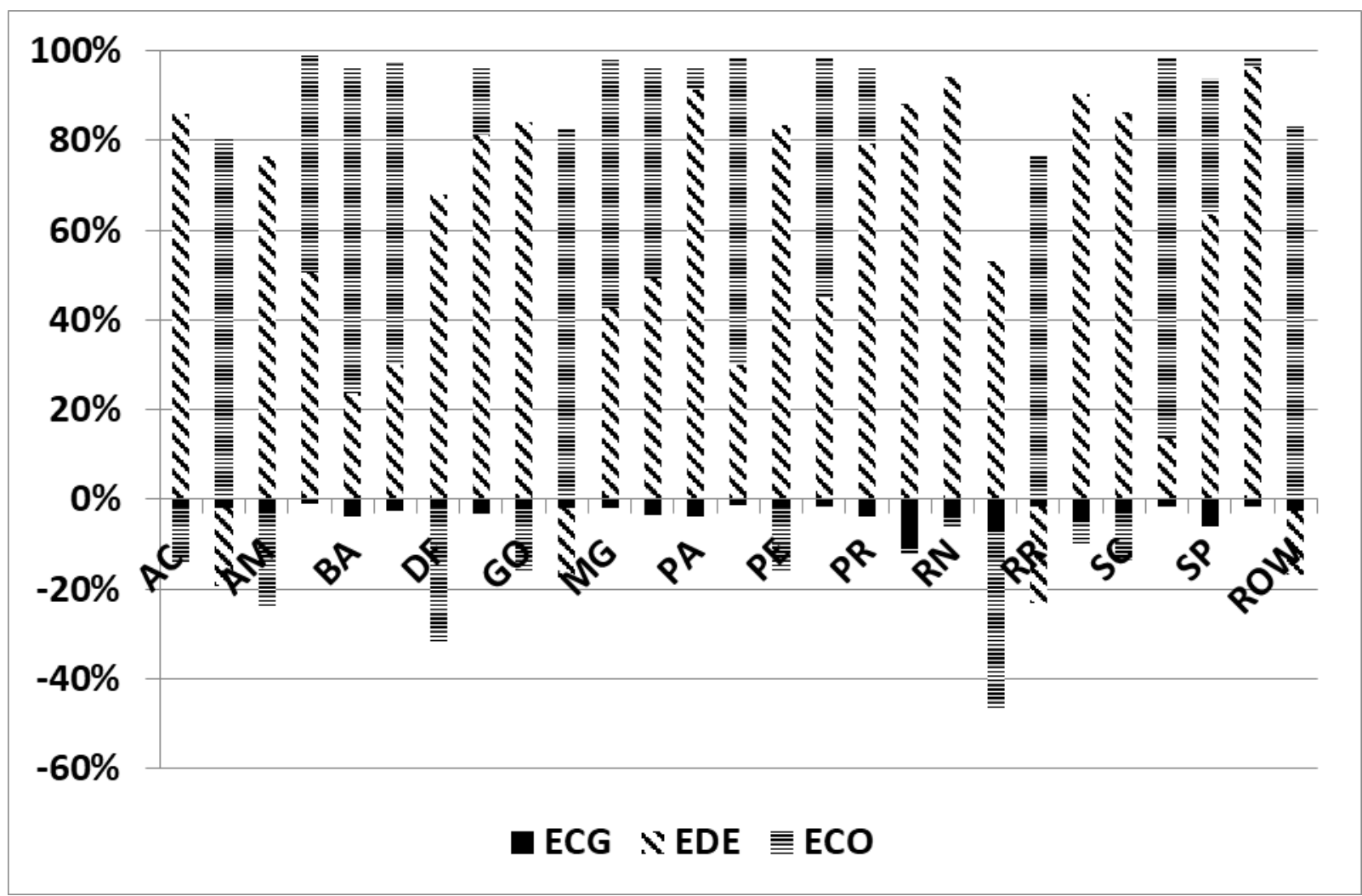

Fonte: Elaboração própria a partir dos dados da tabela 06

\section{CONSIDERAÇÕES FINAIS}


O estado de Mato Grosso do Sul vem ampliando o seu fluxo comercial agregado (interestadual e internacional). Tanto que, entre os anos de 2012 e 2017, a variação foi positiva em 45,2\%. As importações agregadas variaram $40,7 \%$ no período, enquanto as exportações agregadas acumularam uma variação positiva de $48,7 \%$. O fato de que as vendas cresceram mais que proporcional às compras demonstram que o estado tem implementado políticas comerciais mais agressivas, com a finalidade de fomentar o crescimento e o desenvolvimento da economia local, convergindo, deste modo, com a teoria da base de exportação apresentada neste trabalho.

A inversão de uma balança com saldo negativo em 2012 para uma balança comercial superavitária em 2017, no que tange o fluxo comercial internacional, vai de encontro com o que foi procurado mostrar ao longo deste estudo. Entretanto, ao desagregar as exportações do estado na seção anterior, ficou evidente que Mato Grosso do Sul ainda tem como principal pauta exportadora bens de baixo valor agregado e como principal pauta importadora bens e insumos necessários à produção destes.

Já na análise interestadual, a comparação entre os anos de 2012 e 2017 mostrou que Mato Grosso do Sul tem como principais parceiros comerciais o estado de São Paulo e a região sul do país. Porém, os resultados evidenciaram que em 2017 os estados da região Norte e Nordeste ganharam espaço na parcela de participação das exportações e das importações com o estado.

É necessário salientar a alta dependência econômica estadual da exportação de bens primários, além da alta dependência também da importação de produtos e insumos para a produção e comercialização destes bens de baixo valor agregado. Apesar disso, o ganho de competitividade apresentado pelo estado é reforçado pela pauta econômica que, apesar de ter havido mudanças, é focada no agronegócio e que conta com grandes indústrias, como a de papel e celulose, responsáveis pela dinâmica do crescimento ao demandarem produtos e serviços das demais, o que vai de encontro com a teoria do crescimento baseada em indústrias motrizes apresentada no trabalho.

\section{REFERÊNCIAS BIBLIOGRÁFICAS}

CARVALHO, M. A., e LEITE, C. R. Mudanças na pauta das exportações agrícolas brasileiras. RER, Rio de Janeiro, vol. 46, no 01, p. 53-73, jan/mar, 2008.

DE PAULA, M. F.; DOS SANTOS, A. J.; JUNIOR, R. T.; HOEFLICH, V. A.; DA SILVA, J. C. G. L.; ANGELO, H. Análise da competitividade das exportações brasileiras de mel natural, segundo o modelo constant market share e o índice de vantagem comparativa relativa. Rev. Ceres, Viçosa, v. 63, n. 5, p. 614-620, set/out 2016. 
FRIES, C. D.; CORONEL, D. A.; VIEIRA, K. M.; FILHO, R. B. Avaliação do crescimento das exportações do agronegócio gaúcho: uma aplicação do método constant market share. Revista do Centro de Ciências Naturais e Exatas - UFSM, Santa Maria, v.17, n. 17, p. 3388 - 3400, Dez 2013.

LEAMER, E. E.; STERN, R. M. Quatitative internacional economics.2 ed. New Jersey: Transaction Publisher, 2008.

MARCHIORO, L. W.; GUBERT, D.; GUBERT, V. A teoria dos polos de crescimento e desenvolvimento de Perroux, e a implementação na Zona Franca de Manaus na Região Norte do Brasil. Revista de Estudos Sociais, v. 16, n. 31, p. 186-202, 2014.

MINISTÉRIO DO DESENVOLIMENTO INDÚSTRIA E COMERCIO EXTERIOR (MDIC). Secretaria do Comércio Exterior (SECEX). Disponível em: <http://comexstat.mdic.gov.br/pt/municipio>. Acesso em: 30 de janeiro de 2019.

NORTH, D. Location theory a regional economic growth. Journal of Political Economy, v. 63, n. 3, p. 243-58, Jun. 1955.

PENHA, T. A. M.; ALVES, H. C. Desempenho das exportações do melão potiguar e cearense: uma análise de constant market share. Revista de Estudos Sociais, Cuiabá, v. 20, n. 41, p. 11-15, 2018.

SCHWARTZMAN, J. (Org.). Economia regional: textos selecionados. Belo Horizonte: CEDEPLAR, 1977a.

SECRETARIA DE ESTADO DE MEIO AMBIENTE, DESENVOLVIMENTO ECONÔMICO, PRODUÇÃO E AGRICULTURA (SEMAGRO). Disponível em: <http://www.semagro.ms.gov.br/>. Acesso em: 25 de janeiro de 2019.

SILVA, J. L. M.; SCHMALTZ, J. M. Competitividade e parcela de mercado: uma análise do constant market share para o mercado de camarão brasileiro. Revista Economia do Nordeste, Natal, v. 43, n. 1, p. 125-137, jan/mar 2012.

SOUZA, S. F. de; MORAIS, A. C. dos S.; FERREIRA, F. D. da S.; LIMA, J. R. F. de. Competitividade e parcelas de mercado: um estudo do modelo constant market share para as exportações de melão brasileiro. In: CONGRESSO DA SOCIEDADE BRASILEIRA DE ECONOMIA, ADMINISTRAÇÃO E SOCIOLOGIA RURAL, 54., 2016, Maceió. Desenvolvimento, território e biodiversidade. Maceió: UFAL: SOBER, 2016.

TATSCH, A. L.; BATISTI, V. S. Os fluxos de comércio do Rio Grande do Sul: Trocas interestaduais e com o resto do mundo. Revista Econômica Ensaios, Uberlândia, v. 28, n. 1, p. 27-46, jul/dez 2013.

TYSZYNSKI H. World Trade in Manufactured Commodities, 1899-1950 1. The Manchester School. 1951 Sep;19(3):272-304. 


\section{Capítulo 4}

\section{SINGULARIDADES DO COMÉRCIO INTERNO DE BOVINOS NO BRASIL.ESTUDO DE CASO SOBRE PROBLEMA DA BARGANHA NAS FEIRAS DEANIMAIS DO INTERIOR DE ALAGOAS}

DOI: $10.37423 / 200300360$

José Adeilton da Silva Filho (Universidade Federal de Alagoas, Faculdade de Economia Adm. e Contabilidade-FEAC, Maceió Brasil).

adeilltonfilho@gmail.com

André Maia Gomes Lages (2Universidade Federal de Alagoas, Faculdade de Economia Adm. e Contabilidade-FEAC, Maceió, Brasil).

andre_lages@msn.com

Maria da Graça Derengowski Fonseca (3Universidade Federal do Rio de Janeiro, Instituto de Economia-IE, Rio de Janeiro, Brasil).

derengow@ie.ufrj.br,

Resumo: Este trabalho apresenta uma análise sobre os efeitos da barganha em mercados agropecuários, mais especificamente o mercado bovino, a partir de um método de análise teórico e empírico. Utilizando-se de dados primários e secundários, e das teorias dos jogos cooperativos, por meio da solução de Nash e o teorema de Rubinstein, para assim evidenciar a desigualdade, que pode ocorrer nas negociações em feiras agropecuárias. Os resultados mostram uma desigualdade entre os possíveis preços entre comprador e vendedor, como também, o trabalho diagnosticou, por meio das teorias, que para adequação do preço correspondente com uma situação de igualdade no poder de barganha, seria necessária uma virtual flexibilização do ponto de desacordo do comprador, portanto em comparação com o modelo da solução de Nash haveria uma diferença no poder de barganha desfavorável ao vendedor. 
Os resultados mostram também uma diferença na paciência do vendedor logo confirmando também a existência de desvantagem para o vendedor durante as comercializações pelo modelo de Rubinstein.

Palavras-chave: Barganha. Agronegócio. Bovinos. Feiras. Alagoas. 


\section{Introdução}

Este trabalho aborda uma análise, por meio de dados empíricos e teóricos a respeito do processo de comercialização, entre vendedores e compradores de bovinos em feiras. Especificamente, o problema da barganha existente nessas comercializações. Sendo a análise realizada por um estudo in loco nas feiras de gado em Alagoas, onde usa como recorte a feira de gado de Canafístula localizada no município de Palmeira dos Índios - AL, mesorregião do agreste de Alagoas, área de transição entre os biomas da Caatinga e a Mata Atlântica.

O trabalho aborda a problemática do poder desigual de barganha, ao realizar um estudo sobre esse mecanismo nas feiras de gado, que ocorrem no interior do estado de Alagoas, e a reflexão de dois principais questionamentos norteadores:

- Como o problema da barganha afeta o preço final, nas feiras comparando os preços médios propostos e acordados entre vendedor e comprador; e

- Se os resultados analisados auferem diferenças significativas no poder de comercialização, como podem ser contextualizados, e, portanto correlacionados com o que afirma a teoria dos jogos cooperativos.

O estado de Alagoas contém um total de 1.264 .053 animais (IBGE, 2016), no qual a região Nordeste concentra aproximadamente $22 \%$ do rebanho brasileiro.

Consequentemente, os municípios do interior de Alagoas têm na pecuária uma de suas principais atividades econômicas. Segundo Lira (2007) adveio desde a concepção de Alagoas, quando os senhores de engenho precisavam criar animais, dentre os quais bovinos para auxiliar na produção de açúcar e na pecuária. "Os senhores de engenho, necessitando de muitos animais para exercerem várias tarefas nos canaviais, passaram a criar cavalos, burros e bovinos [...]" (LIRA, 2007, p. 14, grifo nosso).

As tradicionais feiras de animais, conhecidas também como feira de gado, é um comércio popular presente em grande parte desses municípios interioranos do Estado de Alagoas, assim como em outras partes do Brasil, que serve como meio de transacionar os animais excedentes, produzidos nas fazendas, para outras finalidades, como, por exemplo; engorda, recria e abate. 
Na feira de gado, operários da construção civil, comerciantes, vigilantes, motoristas de ônibus, médicos, advogados e pecuaristas, que têm em comum o "gosto pelo gado", aproveitam a manhã de domingo para se encontrar, conversar, "olhar o gado" e também fazer negócios (MAIA, 2007, p.22).

A Feira de Gado se mostra como um mercado de grande significado cultural e econômico para a população do Nordeste do Brasil, consequentemente para Alagoas. Como em toda a feira, pessoas de diversas classes sociais buscam se socializar no ambiente de comércio, por meio das trocas, para assim viabilizar suas produções e suas demandas. Utilizando-se, assim, da feira como importante canal de comercialização.

O problema da barganha é tratado dentro da teoria dos jogos, mais precisamente nos jogos cooperativos. Tais jogos cooperativos, segundo Nash (1950), podem ser retratado por meio de uma situação de barganha entre duas pessoas, ou seja, que representa dois indivíduos que podem se beneficiar, em mais de um modo, mutuamente em cooperação. Um caso simples ocorre quando nenhuma ação de um dos indivíduos pode afetar o bem-estar do outro sem que isso seja de conhecimento do outro indivíduo.

Diante dessa realidade, o objetivo essencial deste estudo é apresentar como a barganha pode ser representativa no preço final acordado nas negociações, onde nem sempre o resultado, demonstrese satisfatório, portanto de maneira igual para ambas as partes, logo apresentando uma significativa diferença no poder de barganha, e dessa maneira, por meio da teoria dos jogos podem dar respaldo aos resultados de dados empíricos coletados em pesquisa.

Para alcançar esses objetivos se fará uma breve explicação da feira, posteriormente das teorias que envolvem a barganha, onde serão abordadas duas teorias, a denominada solução de Nash (1950) e o Teorema de Rubinstein (1982).

Como também a bibliografia de outros autores, além de dados primários realizados em pesquisa local, e dados secundários, por meio da Agência de Defesa e Inspeção Agropecuária de Alagoas - ADEAL, e seus dados do Sistema de Defesa Agropecuária - SIDAGRO.

O Problema da Barganha e A Solução de Nash A solução de Nash está implícita pelos seguintes axiomas: Axioma da Eficiência de Pareto (EP), Axioma da Racionalidade Individual (RI), Axioma da Invariância a Transformações Afins Positivas (ITAP), Axioma da Independência das Alternativas Irrelevantes (IAI), Axioma da Simetria (SM). O grande mérito desse modelo é conseguir a unicidade de solucionar o problema da barganha satisfazendo todos esses axiomas. 
O axioma EP imprime que a solução compete ao conjunto $S$, assim cada jogador pertence ao conjunto de utilidades viáveis para ambos, assegurando que não há outra rota para a solução cooperativa além do conjunto $S$, desse modo não há nada que os jogadores possam fazer que melhore o resultado para ambos. O axioma RI afirma que os jogadores são racionais, sendo assim buscam sempre obter o maior valor possível, caso o valor da discórdia superar o valor de uma possível negociação, será preferível o jogo não-cooperativo. $\mathrm{O}$ axioma ITAP, referese ao fato da negociação passar por uma mudança afim positiva com valor dos pontos de desacordo, assim um novo jogo é criado, embora o resultado da divisão das partes continue sendo a mesma. O axioma IAI significa que ao se eliminar alternativas do conjunto de utilidades, cria-se um novo jogo, embora não se altera o resultado da divisão da barganha, permanecendo a mesma divisão do jogo original.

O último axioma é o da SM, que afirma que ambos os jogadores devem receber a divisão em partes iguais, pois tendo os jogadores posições simétricas, tanto no ponto de discórdia, como também no conjunto de utilidades, o resultado da solução de Nash corresponderá $50 \%$ para cada jogador (SANTOS, 2009).

Sendo U a união dos ganhos de dois jogadores, e assim UV e UC os valores, respectivamente, de vendedor e comprador resultantes de um jogo de barganha cooperativo. Seja WV a participação do vendedor e WC a participação do comprador, com $W V+W C=1$, e $U$ a união dos ganhos, assim:

$$
W V . U=U V \text { e WC.U = UC. (1) }
$$

Segundo Dias (2005), um jogo cooperativo de barganha é definido pelo conjunto factível e pelo ponto de desacordo, o par $(S, d)$, sendo $S$ um conjunto convexo, limitado, fechado e com, pelo menos, um ponto dominando estritamente o ponto $d, d \in S$, pode se definir as participações na solução de Nash com a seguinte equação:

$$
W V=1 / 2+(d V-d C) /(2 U), U>0 \text { eWV } \in(0,1) \cdot(2)
$$

Já para WC pode ser representado assim:

$$
W C=1-W V .(3)
$$

Formalmente, além de ser a única a atender aos axiomas anteriormente mencionados, a solução de Nash N(S, d) é o resultado do seguinte problema de maximização (DIAS, 2005):

$$
N(S, d)=\operatorname{argmax}\{(U V-d V)(U C-d C) \mid(U V, U C) \in S, U V \geq d V, U C \geq d C\}(4)
$$


Portanto em uma situação, onde o ponto de desacordo d não for preferível para o vendedor dV, tão pouco para o comprador $\mathrm{dC}$, dentre o conjunto de soluções possíveis $\mathrm{S}$, a solução de Nash, respeitando os axiomas descritos anteriormente, consegue identificar o ponto ótimo, que consequentemente representa o resultado do jogo.

\title{
O MODELO DE RUBINSTEIN
}

Para Rubinstein, a solução do jogo de barganha decorre de uma visão, onde para especificar a barganha, o processo deve decorrer sem utilização da abordagem axiomática de Nash, mas sim, através de um modelo dinâmico com a solução decorrente de ofertas alternadas. Surgindo, deste modo, o seu teorema presente no trabalho intitulado "Perferct equilibrium in a bargaining model" de 1982. (BIERMAN, 2013)

\begin{abstract}
Neste artigo, adotarei a abordagem estratégica. Considerarei a seguinte situação de barganha: dois jogadores devem chegar a um acordo sobre a partição de uma torta de tamanho 1 . Cada uma deve fazer, por sua vez, uma proposta sobre como deve ser dividida. Depois que uma das partes fez essa oferta, a outra deve decidir, quer para aceitá-la, quer rejeitá-la, e continuar com a barganha. As relações de preferência dos jogadores são definidas no conjunto de pares ordenados do tipo $(x, t)$ (onde 0 ' $x$ ' -1 e t é um inteiro não negativo). 0 par $(\mathrm{x}, \mathrm{t})$ é interpretado como "1 recebe $\mathrm{x}$ e 2 recebe 1 - $\mathrm{x}$ no tempo t"(RUBINSTEIN, 1982, p.98, tradução nossa ${ }^{1}$ ).
\end{abstract}

No referido modelo desenvolvido, presume-se que ambos têm informações completas, como também, que além de um custo de negociação exista um fator de desconto a cada rodada, sendo ambos fixos. Supondo que dois jogadores, V e C, estejam barganhando, por meio de ofertas que se alternam (como na feira de gado), um valor que corresponde a um excedente. $\mathrm{O}$ jogador $\mathrm{C}$ faz a primeira oferta sem um limite definido de ofertas com um fator de desconto no tempo para cada oferta de $0<\delta v<1$ e $0<\delta c<1$, sendo que aceitam ofertas quando se tornam indiferentes a elas.

Deste modo, existe apenas um equilíbrio perfeito em subjogos no qual $\mathrm{C}$ oferece de imediato a $\mathrm{V}$ a fração:

$$
\delta v .(1-\delta c) /(1-\delta v . \delta c)(5)
$$

do excedente e retém:

$$
(1-\delta v) /(1-\delta v . \delta c)(6)
$$

para si mesmo, sendo essa a oferta que o jogador $V$ acolhe. (BIERMAN, 2013) 
Deste modo, ao contrário do modelo de Nash, que focou sua solução na determinação do ponto de desacordo. Rubinstein mostra nos resultados presentes nas fórmulas 5 e 6 , que o fator de desconto no tempo, ou seja, a paciência do jogador, torna-se determinante para a solução do jogo, assim como a decisão do primeiro a se mover.

\section{METODOLOGIA}

O tipo de pesquisa constitui-se de caráter descritivo e exploratório com estudo de caso, nesse quadro, o estudo preserva certa dose pioneirismo em nível local. A aplicação do método será feita através de visitas in loco, na feira de gado do povoado de Canafístula de Frei Damião no município de Palmeira dos Índios - AL.

Foi também utilizado, além dos dados primários da feira de Canafístula, dados secundários coletados no Sistema de Defesa Agropecuária de Alagoas (SIDAGROAL) das três feiras mais importantes do estado, que segundo a Agência de Defesa e Inspeção Agropecuária de Alagoas (ADEAL) tratam-se das Feiras de Dois Riachos, Canafístula e Canapi.

Os dados secundários do SIDAGRO-AL advêm da necessidade de mensurar o número real de negociações realizadas na feira, sendo as negociações a população estudada, e, assim encontrar o número finito amostral factível para aplicação do questionário quantitativo com dados referentes aos preços pagos por grupo de consumidores existentes nas negociações, para determinados tipos de animais, sendo um critério para a inferência da amostra, que foi obtida na ADEAL.

Além de apresentar o volume de saídas e entradas, finalidades de compra das três maiores feiras do estado, para melhor contextualizar o objeto de estudo.

Para descrever o ambiente de comércio e os tipos de agentes (vendedor e comprador), assim como os valores pagos por eles, através dos questionários aplicados na feira estudada, se seguiram as consecutivas etapas:

- Realização de visitas in loco para o conhecimento da feira de gado de Canafístula, e as suas práticas comerciais;

- Aplicação de questionário aos vendedores e compradores, que somente fecharam acordo de compra e venda, nas feiras; e 
- Levantamento de dados sobre as feiras, no Sistema de Defesa Agropecuária de Alagoas (SIDAGRO-AL), para tomar conhecimento da quantidade de negociações realizadas nas feiras, cujo objetivo é extrair a amostra finita de negociações.

\section{AMOSTRAGEM}

Amostragem Aleatória Simples, onde cada negociação foi coletada de maneira randômica, com a utilização da entropia existente no processo e percurso das negociações, mediante entrevistas na sala de emissão da Guia de Trânsito Animal (GTA), localizada na própria feira, deste modo oferecendo a cada negociação, oriunda da população, a mesma probabilidade de ser incluída na extração.

A determinação do valor médio pago de cada consumidor para um conjunto específico de animais na feira foi obtida com base na estimativa da variável quantitativa, com desvio padrão desconhecido e população finita, através da seguinte fórmula:

$$
n=\frac{Z^{2} \cdot S^{2} \cdot N}{Z^{2} \cdot S^{2}+e^{2} \cdot(N-1)}
$$

(7)

onde:

$\mathrm{N}=$ tamanho da população

$Z$ = nível de confiança

$S^{2}=$ Desvio padrão da amostra piloto

e = erro do estudo piloto

Deste modo $\mathrm{N}$ foi originário do número de negociações realizadas nos dias de feira, no qual foi aplicado o questionário. Entretanto os dados só foram disponibilizados ao final de cada feira, quando a pesquisa já tinha sido completada, porém, utilizou-se como base a quantidade de negociações realizadas na pesquisa piloto. A amostra piloto foi realizada no dia 28 de agosto de 2017, na feira de gado de Canafístula. As pesquisas com aplicação do questionário foram realizadas durante os eventos das feiras, que o correram durante todo o mês de novembro de 2017, em Canafístula de Frei Damião, povoado do município de Palmeira dos Índios, Alagoas.

Para diagnosticar o diferencial de poder de barganha do produtor em relação ao consumidor, utilizouse o método desenvolvido por John Forbers Nash Jr, denominado solução de Nash para jogos 
cooperativos, como também o modelo de Rubinstein. No modelo da solução de Nash, os dados coletados a partir dos questionários, foram introduzidos na fórmula 01 , onde os valores do ponto de desacordo do vendedor se convencionaram pelo preço inicial do comprador, e para o comprador o preço inicial do vendedor, obtido no questionário sobre a forma das seguintes perguntas, qual o "valor pedido", "qual o valor ofertado", e por fim "qual o valor comprado", sendo esse último o parâmetro, comparou-se com o ponto ótimo da solução de Nash.

Para o modelo de Rubinstein foi feita uma verificação na diferença de paciência entre os jogadores, através de perguntas feitas com relação ao custo de espera, ou seja, foi questionado aos vendedores, qual seu custo caso não venda o animal, e ao comprador qual o seu custo caso não compre o animal, posteriormente se fez a comparação da validade teórica com os resultados obtidos, logo de modo empírico, através da diferença entre os custos relatados pelo comprador e pelo vendedor.

\section{CARACTERIZAÇÃO DO OBJETO DE ESTUDO}

As três principais feiras de gado segundo a ADEAL são as feiras de Dois Riachos, Canafístula e Canapi, A feira de Dois Riachos está localizada no município de mesmo nome na margem esquerda da BR-316 sentido Leste para Oeste, já a feira de Canafístula se encontra no povoado de Canafístula de Frei Damião no Município de Palmeira dos Índios/AL, ficando também no mesmo sentido da margem esquerda da BR-316, enquanto a feira de Canapi situa-se um pouco afasta dada cidade, de mesmo nome, na margem direita no mesmo sentido da BR-316.

Figura 1: Localização aproximada das feiras no mapa político do estado de Alagoas

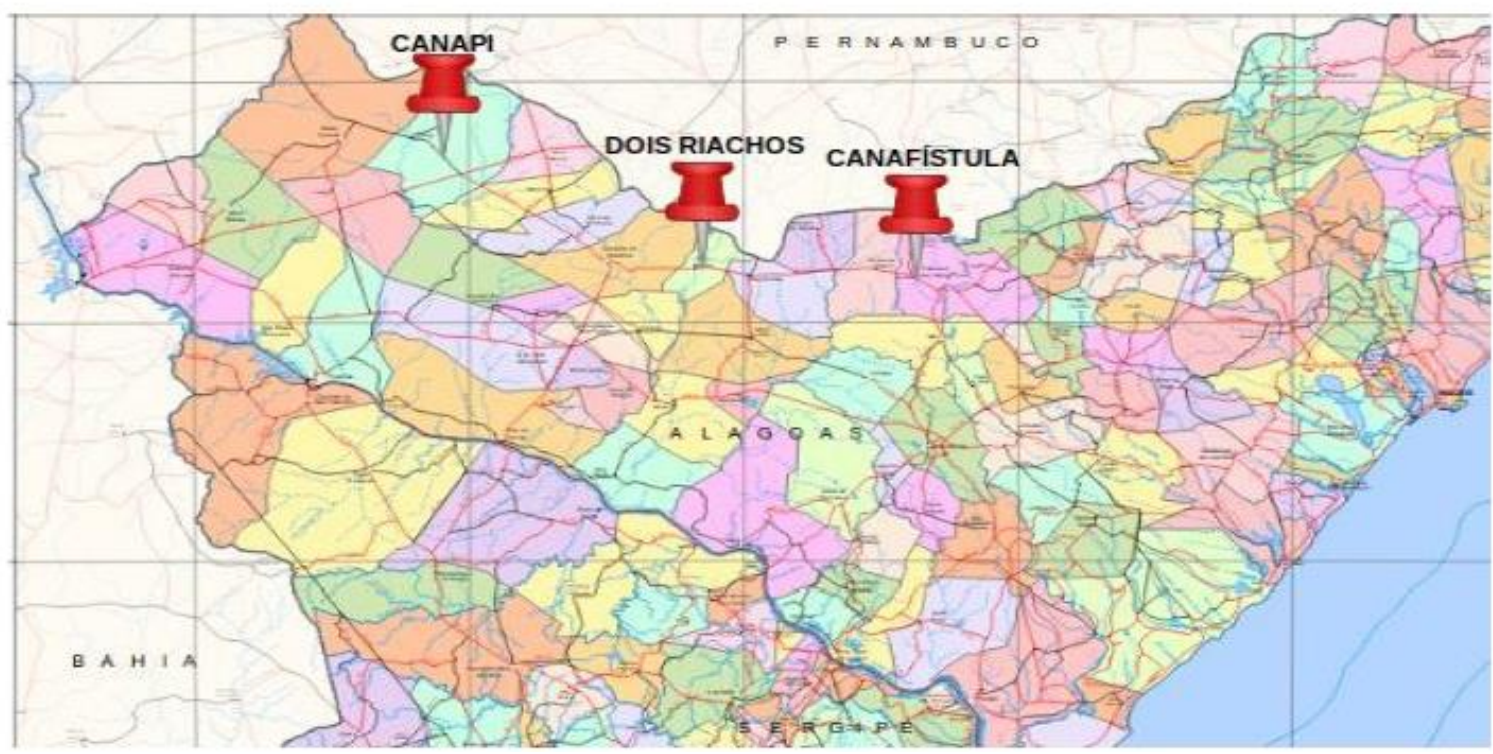

Fonte: IBGE, 2015. Adaptada pelos autores. 
A feira de Dois Riachos ocorre, assim como na feira de Canapi, toda quarta feira, já a feira de Canafístula ocorre toda a segunda-feira. Segundo os dados adquiridos na ADEAL, o maior volume de entradas (oferta) e saídas (vendas) de animais, encontra-se na feira de Dois Riachos que é, sem dúvida, a maior feira de gado em volume de todo estado de Alagoas. As feiras de Canafístula e Canapi representam em volume o segundo e terceiro lugar respectivamente, conforme os dados disponibilizados. Os dados, que foram entregues, correspondem ao período de 2014 até 2016, com os dados de entrada, saída, destino e finalidade de compra.

Tabela 1- Total de entradas de bovinos separados em sexo, nas três feiras nos anos de 2014, 2015 e 2016.

\begin{tabular}{c|c|c|c|c|}
\hline $\begin{array}{c}\text { Feira de } \\
\text { gado }\end{array}$ & Ano & $\begin{array}{c}\text { Entrada } \\
\text { de } \\
\text { Machos }\end{array}$ & $\begin{array}{c}\text { Entrada } \\
\text { de } \\
\text { Fêmeas }\end{array}$ & $\begin{array}{c}\text { Entradas } \\
\text { totais }\end{array}$ \\
\hline \multirow{4}{*}{$\begin{array}{c}\text { Dois } \\
\text { Riachos }\end{array}$} & 2014 & 41130 & 20161 & 61291 \\
\cline { 2 - 5 } & 2015 & 43667 & 27953 & 71620 \\
\cline { 2 - 5 } & 2016 & 83551 & 49489 & 133040 \\
\hline \multirow{3}{*}{ Canafístula } & 2014 & 1984 & 1071 & 3055 \\
\cline { 2 - 5 } & 2015 & 17302 & 13240 & 30542 \\
\cline { 2 - 5 } & 2016 & 26800 & 19014 & 45814 \\
\hline \multirow{4}{*}{ Canapi } & 2014 & 6130 & 2142 & 8272 \\
\cline { 2 - 5 } & 2015 & 6105 & 2816 & 8921 \\
\cline { 2 - 5 } & 2016 & 6667 & 3857 & 10524 \\
\hline
\end{tabular}

Fonte: ADEAL, 2017

Por meio da tabela 01, pode-se evidenciar o quanto pode ser expressiva a quantidade de bovinos que se dirigem todos os anos para os currais das feiras de gado em cada um dos municípios. Somente nos três anos analisados, se somados todas as três feiras, resultaram no valor de 373.079 animais, que representa aproximadamente $30 \%$ do rebanho alagoano, esse número poderia ser maior se a feira de Canafístula em 2014 estivesse com os cadastros dos produtores no SIDAGRO em sua plenitude de adesão e funcionamento, o que só foi possível em 2015, por isso a discrepância dos dados, enquanto que, nas demais feiras tudo está constante. Em outras palavras, acontecia, de na feira de Canafístula, 
ter ocorrido até 2014, comercialização em parte menor dos casos sem uso da GTA (Guia de Trânsito Animal). Esse problema foi rapidamente corrigido pelas exigências feitas nesse quadro pela ADEAL. Nas outras duas feiras tudo tinha ficado como dantes por conta de que não havia registro de problema.

Tabela 2- Total de bovinos negociados separados em sexo, nas três feiras nos anos de 2014, 2015 e 2016.

\begin{tabular}{c|c|c|c|c|}
\hline $\begin{array}{c}\text { Feira de } \\
\text { gado }\end{array}$ & Ano & $\begin{array}{c}\text { Saída de } \\
\text { Machos }\end{array}$ & $\begin{array}{c}\text { Saídas } \\
\text { de } \\
\text { Fêmeas }\end{array}$ & $\begin{array}{c}\text { Saídas } \\
\text { totais }\end{array}$ \\
\hline \multirow{2}{*}{$\begin{array}{c}\text { Dois } \\
\text { Riachos }\end{array}$} & 2014 & 15924 & 6847 & 22771 \\
\cline { 2 - 5 } & 2016 & 17451 & 9977 & 27429 \\
\cline { 2 - 5 } & 2014 & 628 & 383 & 1011 \\
\hline \multirow{3}{*}{ Canafístula } & 2015 & 5636 & 3901 & 9537 \\
\cline { 2 - 5 } & 2016 & 7082 & 5173 & 12255 \\
\cline { 2 - 5 } & 2014 & 2537 & 903 & 3440 \\
\hline \multirow{3}{*}{ Canapi } & 2015 & 2913 & 1314 & 4227 \\
\cline { 2 - 5 } & 2016 & 2610 & 1445 & 4055 \\
\cline { 2 - 5 } & & & 15234 & 42306 \\
\hline
\end{tabular}

Fonte: ADEAL, 2017

Após observar a oferta de animais nas feiras, a tabela 02 apresenta a demanda, ou seja, a saída dos animais que foram comprados nos currais das trêsfeiras de gado, nos anos analisados, separados em sexo, como também a sua soma total. Dois Riachos representa, obviamente, o maior número de vendas com um total de 42.306 animais, seguido de Canafístula com 12.255 e Canapi com 4.055 animais no ano de 2016. Desta forma, observa-se que ao todo somando se os três anos analisados a venda total foi de 127.031 animais, logo a demanda por animais é menor que a oferta nos currais da 
feira de gado, no comparativo com a oferta de 373.079 quando somados os valores totais da tabela 01.

A tabela 02 mostras também que as quantidades de machos vendidos em 2016 em Dois Riachos foram de 27.070 animais, enquanto as vendas de animais fêmeas foram de 15.234 , seguido de Canafístula com 7.082 machos e 5.173 fêmeas, enquanto Canapi com uma venda de 2.610 machos e 1.445 fêmeas.

Quando comparado com a tabela 01 machos e fêmeas têm um rendimento muito próximo em vendas, pois ambos representam em média aproximadamente $30 \%$ de vendas em comparação com a oferta total.

Gráfico1-Os municípios com quantidade acima de 1\% do total de animais adquiridos em Alagoas de 2014 até 2016.

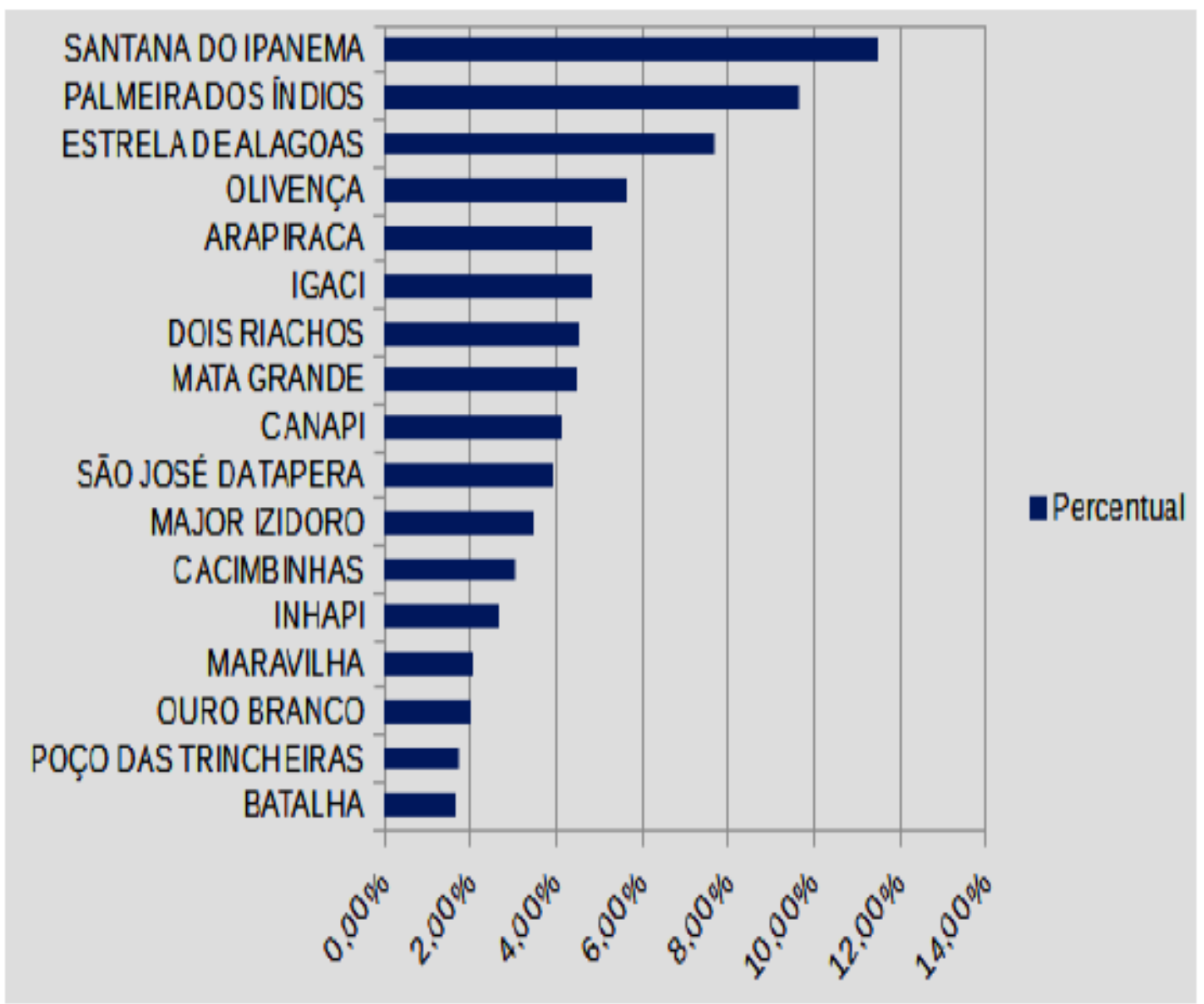

Fonte: ADEAL, 2017

Os municípios alagoanos que adquirem os animais nas três feiras de gado são ao todo 88, somente no período analisado. Isso corresponde a $86,27 \%$ dos 102 municípios do estado. O município que 
apresenta o maior destino dos animais comercializados nas feiras fica na mesorregião do sertão alagoano: Santana do Ipanema, com quase $12 \%$ do total adquirido dentro do estado. Seguido por Palmeira dos Índios e Estrela de Alagoas, com mais de $8 \%$ e $6 \%$ do volume total de saídas durante o período analisado, respectivamente, conforme apresenta o gráfico 01.

Gráfico 2 - Municípios com quantidade acima de $1 \%$ do total de animais adquiridos por Pernambuco de 2014 até 2016.

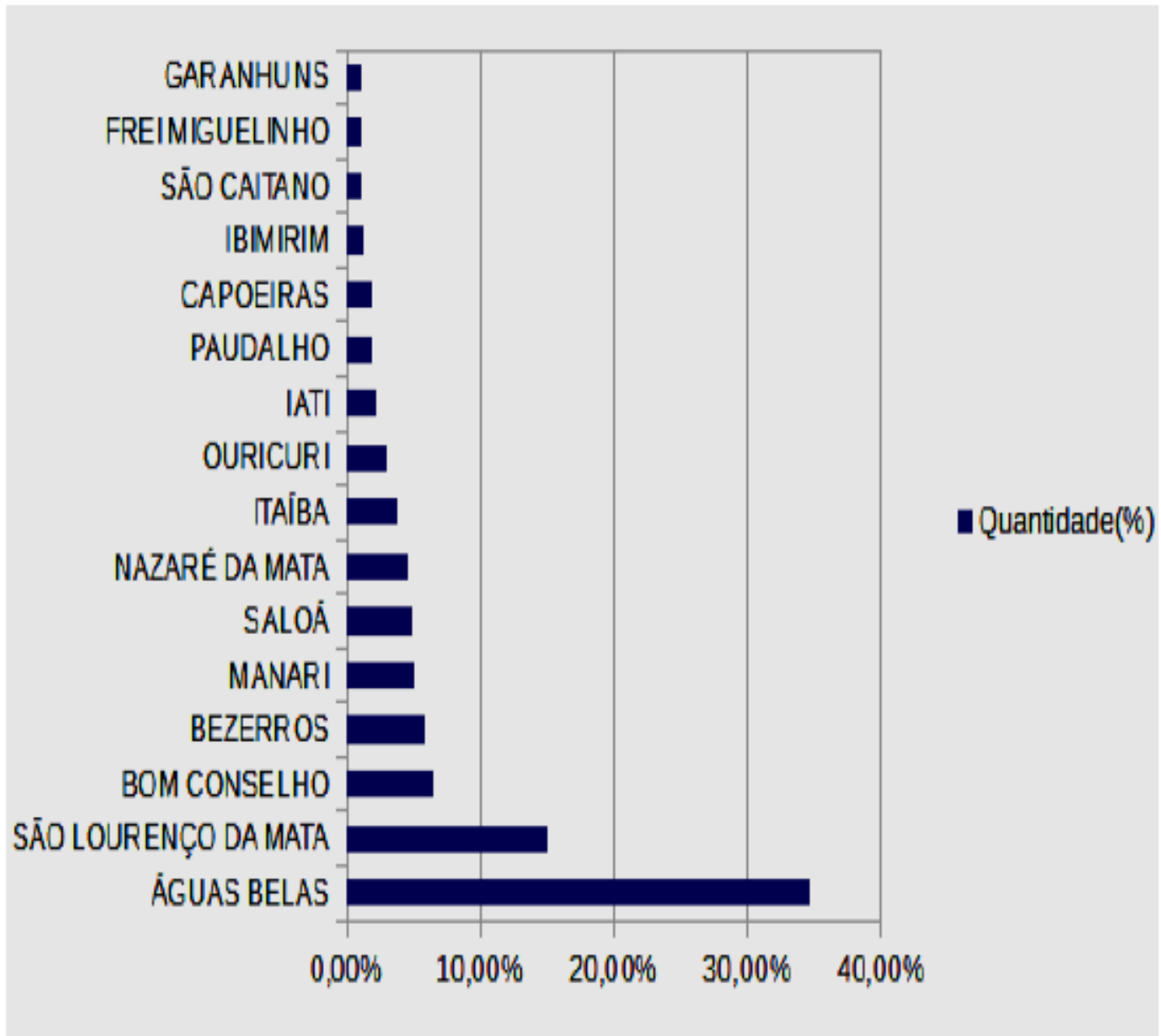

Fonte: ADEAL, 2017

O estado nordestino que mais importa animais das três feiras alagoanas é Pernambuco, com um total de 36 municípios registrados durante o período analisado. O município pernambucano com o maior volume de compra é Águas Belas que representa mais de 30\% das importações do estado. O gráfico 02 apresenta os demais municípios que importam gados oriundos das feiras alagoanas com um volume mínimo de 1\%, onde, além de Águas Belas, nota-se a importância de municípios como São Lourenço da Mata, (bem próxima de Recife); Bom Conselho e Bezerros, que juntas somam mais de $20 \%$ de importações. Tal fato se deve a proximidade de Pernambuco com Alagoas. O município de Bom 
Conselho, por exemplo, fica apenas aproximadamente $33 \mathrm{~km}$ da feira de Canafístula, como também Águas Belas, que fica à aproximadamente 61 km de Canapi.

Gráfico 3 - Volume de saída para municípios de Sergipe de 2014 até 2016.

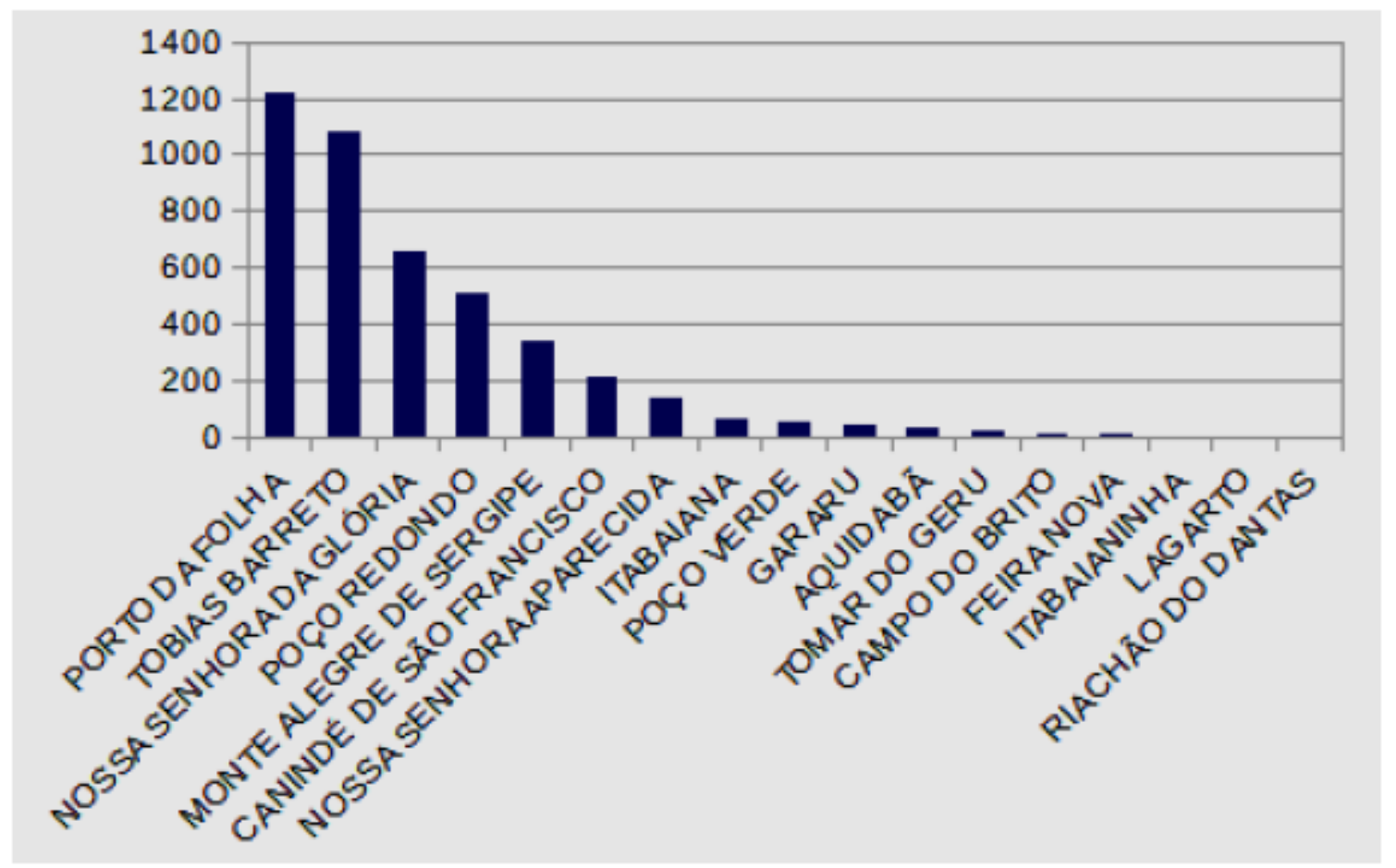

Fonte: ADEAL, 2017

O Gráfico 03 apresenta todos os 17 municípios de Sergipe que adquiriram animais da feira de Dois Riachos durante o período analisado. Os três maiores municípios em volume de compra foram Porto da Folha com valores acima de 1.200 animais, seguido de Tobias Barreto com valores acima de 1.000 animais e Nossa Senhora da Glória com valores acima de 600 animais. Nota-se que a feira é ponto de visita por parte de alguns negociadores de bovinos sergipanos, a exemplos dos compradores com destino ao município de Tobias Barreto, que fica a $287 \mathrm{~km}$ dos currais da feira de Dois Riachos.

\section{RESULTADOS E DISCUSSÕES}

O mecanismo de mercado spot existente nas feiras de gado no interior de Alagoas, assim como todo mercado, tem no preço um referencial para as realizações das trocas, deste modo o preço exibe papel fundamental para coordenação e funcionamento do evento. Nas feiras, o preço da arroba é a principal referência, exibindo um valor que é construído no mercado entre frigoríficos e consumidores, logo, pode-se denominar tal mercado de "o mercado das carnes". 
Deste modo, pode ser observado que tal referência para o comércio da feira de gado é mais tangível para os consumidores com finalidade de abate, do que para os demais consumidores existentes na feira, onde o objetivo do comprador está em adquirir o animal, por no mínimo, seu preço de arroba.

É importante salientar, também, que tal preço de arroba vai depender do rendimento de carcaça, onde tal rendimento consiste na interpretação de ambos, onde a solução se dá mediante apenas o mecanismo de barganha. Todo processo ocorre baseado apenas na visualização dos animais e baseado na experiência e intenções de cada agente envolvido na negociação.

Em muitas ocasiões o vendedor tenta mostra especificidades de seus animais para poder distanciar para cima seu preço do preço da arroba, e assim, poder obter um lucro maior, porém isso é bastante difícil, afinal decorre de subjetividades, logo, torna-se difícil para o vendedor saber qual o real preço de reserva do potencial consumidor, durante a negociação. Os vendedores comumente entram com um preço mais alto, e vão decaindo o preço até que ambos (compradores e vendedores) cooperativamente acertem um acordo. Porém nem sempre esse jogo termina em uma situação justa, ou seja, em uma divisão igual das partes. No intuito de observar essa diferença, foram adquiridos os valores de preço de oferta e demanda, além do preço de compra por arroba, das negociações a fim de comparação.

Os valores, de oferta e demanda, servem como comparativo entre a diferença do poder de barganha existente entre compradores e vendedores na feira de gado.

O valor médio do preço por arroba ofertado, durante o período analisado, foi de $R \$ 162,80$ já o preço médio demandado por arroba foi de $\mathrm{R} \$ 142,30$, e o preço médio de compra por arroba foi de $\mathrm{R} \$ 145,34$, logo, nota-se que o valor tende a estar mais próximo do preço do comprador que do vendedor. De forma mais precisa, essa diferença do poder de barganha, pode ser explicada, por meio do modelo da solução de Nash (NASH, 1950) para jogos cooperativos, usando a fórmula 01, onde se obteve o seguinte resultado:

O valor que está em disputa é o payoff 20,50 dado dc - dv (R\$162,80 - R\$142,30).

Sendo $W_{V}$ encontrado por meio da fórmula 04, ao atribuir os valores, a parte que o vendedor deve ceder é encontrada do seguinte modo;

$W_{V}=1 / 2+(20,50-20,50) /(2 \cdot 20,50)$

logo; 
$W_{V}=0,5$

portanto, deve-se ceder $1 / 2$, ou seja -

0,5 assim;

$-0,5 \cdot 20,50+162,80=152,55$

Deste modo, conforme o modelo acima, o resultado que apresentaria uma divisão igual das partes seria $\mathrm{R} \$ 152,55$ neste caso, nota-se que o comprador exibe um maior poder de barganha em comparação com o vendedor, deste modo para se encontrar a diferença do poder de barganha, podese analisar o ponto de desacordo, pois, o ponto de desacordo de uma das partes, mais próximo do preço acordado, sugere o menor poder de barganha.

Diante de uma igualdade no poder de barganha, para o caso da feira, o preço real de venda, como mostrado anteriormente, foi de $\mathrm{R} \$ 145,34$, onde para se alcançar tal resultado, utilizando-se a mesma solução de Nash, o ponto de desacordo do comprador seria de $R \$ 148,38$ e não de $R \$ 162,80$, dessa forma, sabese que o poder de barganha do vendedor é menor que o do comprador, pois ao flexibilizar o ponto de desacordo do comprador para baixo, o vendedor cedeu vantagens ao comprador para assim poder apregoar a venda.

Outra explicação para os jogos cooperativos foi dada por Rubinstein, o seu modelo consegue explicar o motivo dessa diferença do poder de barganha e consequentemente essa flexibilização do pondo de desacordo, por meio da paciência de cada jogador, atribuída por um fator de desconto. Em seu teorema nas fórmulas 05 e 06 Rubinstein (1982) explica, que ambos os jogadores, que no caso da feira retratam o comprador e o vendedor de gado, diante de paciências distintas acabam tendo resultados que diferem no poder de barganha.

Para modelar essa situação de impaciência, Rubinstein adiciona um fator de desconto $\delta$ no tempo, onde para cada oferta do vendedor e do comprador $(\delta v, \delta c)$, na qual $0<\delta v<1$ e $0<\delta c<1$ seria adicionado esse custo. Assim seu teorema mostra, que, caso haja um desconto maior no tempo para um dos jogadores, o jogador com maior desconto apresentaria uma paciência maior e consequentemente seu poder de barganhar também.

No ambiente da feira, por meio dos próprios consumidores e vendedores, foram obtidas as médias de quanto perdem ambos, caso não negociem um animal. 
Com os dados referentes às médias de custo de não negociar os animas, é possível inferir quais dos jogadores apresentam maior impaciência, sendo tal custo à representação do fator de desconto de Rubinstein no tempo, tendendo ao infinito, ou seja, quanto maior o custo, caso não negocie o animal, maior a impaciência e menor o fator, e consequentemente menor poder de barganha, contribuindo, por exemplo, para uma flexibilização do ponto de desacordo do modelo de Nash, deste modo forçando um dos jogadores a uma negociação injusta.

Tabela 3- Custo médio caso não haja acordo de venda para vendedor e comprador. Feira de Canafístula, Palmeira dos índios, 2017

\begin{tabular}{c|c|c|c|}
\hline Jogador & $\begin{array}{c}\text { Média do custo } \\
\text { caso não haja } \\
\text { negociação }\end{array}$ & $\begin{array}{c}\text { Desvio } \\
\text { padrão }\end{array}$ & $\begin{array}{c}\text { Erro } \\
\text { amostra } \\
\text { I }\end{array}$ \\
\hline Comprador & 20,5684 & 21,8412 & $\pm 5,263$ \\
\hline Vendedor & 72,5469 & 64,0077 & $\pm 32,23$ \\
\hline
\end{tabular}

Fonte: Autores a partir de dados primarios da pesquisa.

Nota: Precos correntes em Reais de novembro de 2017.

A tabela 3 mostra as médias de cada um dos jogadores, que correspondem a seus custos por animal, caso não haja negociação, evidenciando assim um maior custo para o vendedor em comparação ao comprador. A tabela 3 também apresenta o desvio padrão e o erro amostral. Nota-se que o desvio padrão e o erro amostral do vendedor, encontram-se altos, devido ao menor número de entrevistas obtidas com vendedores, por conta da dificuldade durante a sua atividade de negociação no evento, onde nem todos permitiram que a entrevista fosse realizada. Embora o erro seja bastante alto, notase que a diferença media é estatisticamente relevante, conforme os erros amostrais, evidenciando a grande disparidade entre o customédio do animal não negociado do vendedor, e do comprador. 


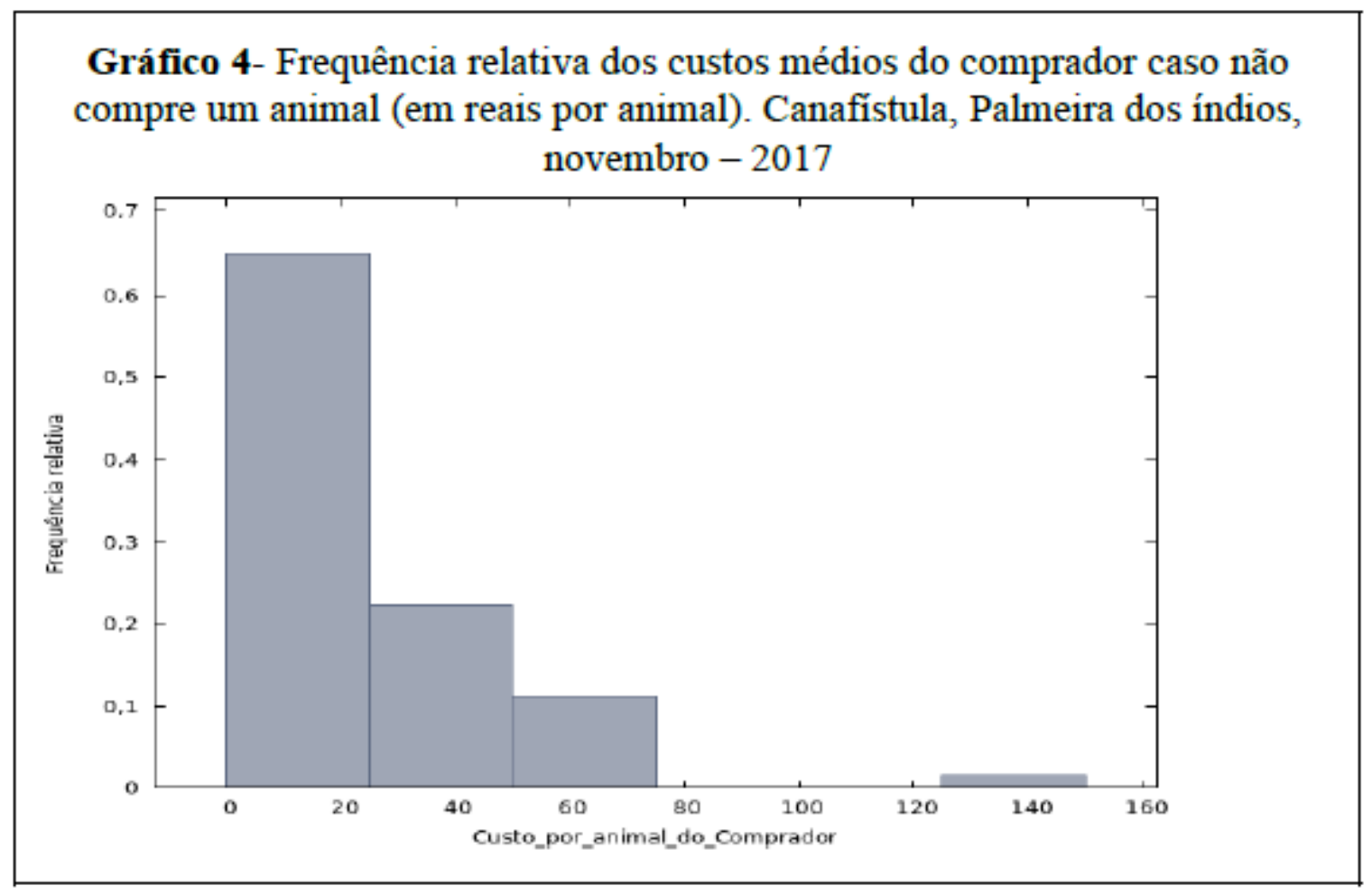

Fonte: Autores, 2017, a partir de dados primários da pesquisa.

O gráfico 4 acima mostra os valores por custo do animal do comprador, caso não compre o animal, ou seja, seu custo de oportunidade, somada as despesas com transporte e alimentação. O resultado aponta muito fortemente para uma frequência, onde os custos encontram-se bastante próximos de zero a vinte reais. A frequência relativa cai severamente para custos acima de quarenta reais.

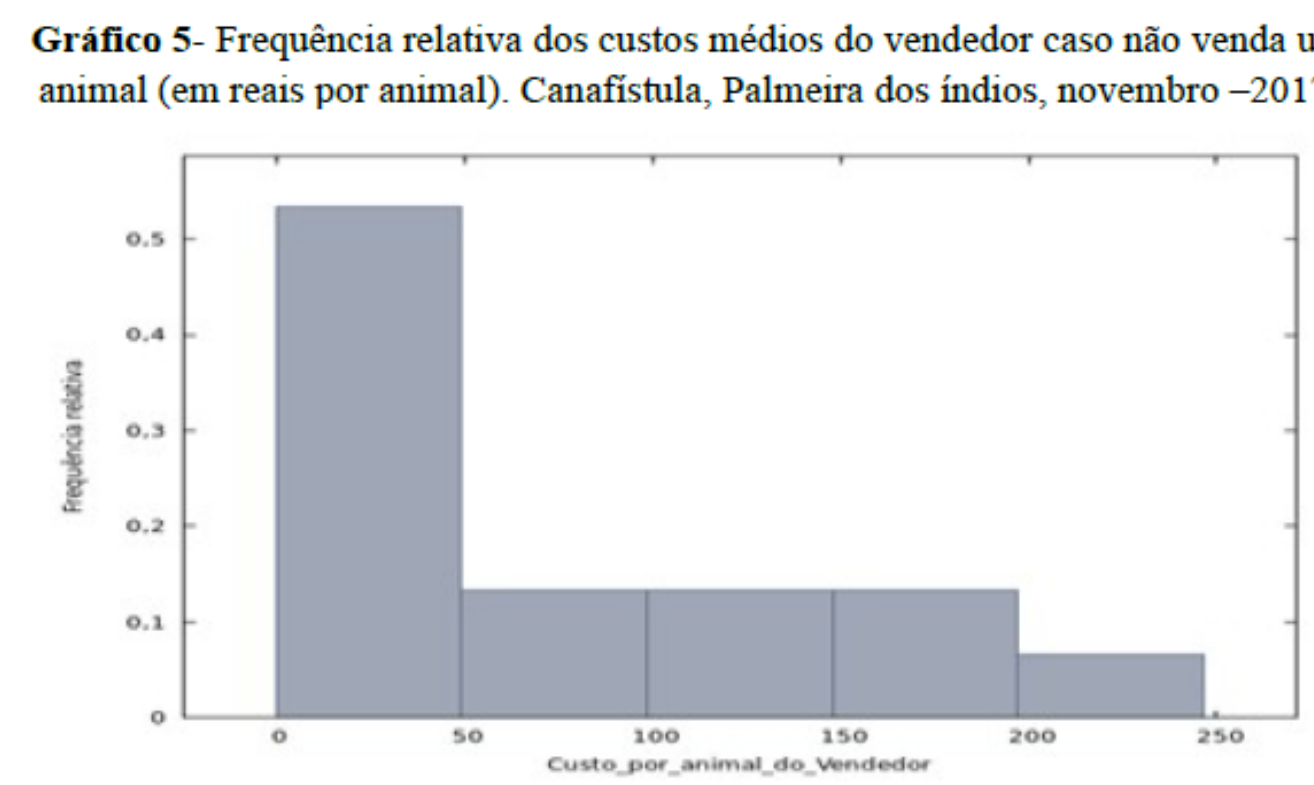

Fonte: Autores, 2017, a partir de dados primários da pesquisa. 
gráfico 5 acima mostra os valores por custo do animal do vendedor, caso não compre o animal, neste caso encontram-se somadas várias despesas. A frequência relativa dos custos é maior para valores entre zero e cinquenta reais com valores correntes de novembro de 2017, porém quase a outra metade dos resultados corresponde a valores acima de cinquenta reais.

Os resultados representam os custos do comprador e do vendedor, caso permaneçam no seu ponto de desacordo, portanto sem realizarem a negociação. Os resultados sugerem que as perdas para o vendedor sejam bem maiores, consequentemente, aplica-se um fator de desconto menor para o vendedor, a cada rodada de negociação, onde não há um acordo. Dessa forma, $\delta v<\delta c$ que reduz drasticamente seu poder de barganha, o que se supõe também, de forma empírica, o ato de flexibilizar o ponto de desacordo, em teoria, para que assim, o animal seja vendido.

\section{CONSIDERAÇÕES FINAIS}

Diante do exposto, conclui-se que as feiras de gado do interior de Alagoas, além de oferecer um importante canal para a comercialização de bovinos, também se trata de um mercado, onde a prática da barganha está intrinsecamente presente em seu sistema. Portanto, na existência de uma diferença sensível no poder de barganha entre vendedores e compradores, tal desequilíbrio tornar-se-ia determinante na resolução do preço final.

Ao se verificar, a partir de testes estatísticos, os valores médios de negociação dos animais, usando como referência a feira de Canafístula em Palmeira dos Índios - AL. Foi possível comparar com as teorias formuladas para o jogo cooperativo da barganha, sendo as teorias da solução de Nash e Rubinstein, que revelaram supostamente a existência de diferenças sensíveis no poder de barganha entre os vendedores e os compradores em média.

Assim, o trabalho diagnosticou que para adequação do preço correspondente com uma situação de igualdade no poder de barganha seria necessária uma virtual flexibilização do ponto de desacordo do comprador, portanto em comparação com o modelo da solução de Nash haveria uma diferença no poder de barganha. De outra forma, os resultados mostram também uma diferença na paciência do vendedor, que quando comparado com o teorema de Rubinstein revelaria uma taxa de desconto menor durante as rodadas de barganha, logo confirmando também uma desvantagem para o vendedor durante as comercializações.

Embora o trabalho tenha suas limitações, sendo apenas de intuito ilustrativo, ao utilizar para tal as teorias dos jogos cooperativos, no comparativo com dados empíricos, sem haver a possibilidade de 
atestar os fenômenos mediante o caráter representativo dos modelos utilizados. Os resultados podem ser importantes para colaborar no diagnostico, e causas, diante da hipótese da presença de falhas de mercado, em tais e respectivos eventos.

$\mathrm{O}$ artigo ensaio mostra as peculiaridades relativas a um tipo de ambiente de mercado spot no mercado interno brasileiro de bovinos, onde existem outros canais de comercialização até bem mais sofisticados, os leilões, por exemplo; quando são comercializados animais com qualidade genética geralmente superior. De qualquer forma os gráficos presentes nos apêndices mostram a abrangência regional de uma feira de gado no interior de Alagoas. Além disso, a fundamentação teórica permite um olhar diferenciado sobre o tema.

\section{REFERÊNCIAS}

BIERMAN, H. Scott; FERNANDEZ, Luiz. Teoria dos Jogos. 2ª edição. 2013.

DIAS, Marco Antônio Guimarães. Opções reais híbridas com aplicações em petróleo. Rio de Janeiro: PUC, Departamento de Engenharia Industrial, 2005. Disponível

em:<http:// marcoagd.usuarios.rdc.puc-rio.br/pdf/tese_doutor_marco_dias. pdf>. Acesso em 04 nov. 2014.

IBGE. Sistema IBGE de Recuperação Automática - SIDRA.

Disponível: em:<https://sidra.ibge.gov.br/pesquisa/ppm/quadros/brasil/2016>. Consultado em 13 dez. 2017.

IBGE. Cartas e Mapas.

Disponível:

site.<ftp://geoftp.ibge.gov.br/cartas_e_mapas/mapas_estaduais_e_distrito_federal/politico/20 15/al_se_politico450k_2015.pdf>. Acesso em 11 de fev. 2109.

MAIA, Doralice. S. A Feira De Gado Na Cidade: Encontros, Conversas E Negócios. Revista Formação, João Pessoa, vol. 1, n. 14, p. 12-30, 2007.

SANTOS, Andréa Maria dos. Falta de consciência em problemas de barganha de 2 jogadores.Recife2009. Tese de Doutorado. Universidade Federal de Pernambuco.

Disponívelem:<http://www.contabeis.ufpe.br/ppge/images/dissertacoes/dissertacao097.pdf>. Acesso em 05 jan. 2016.

LIRA, Fernando José. Formação da Riqueza e da Pobreza de Alagoas. Maceió: Edufal, 2007.

NASH JR, John F. The bargaining problem. Econometrica, v. 18, n. 2, p. 155-162, 1950. 
RUBINSTEIN, Ariel. Perfect equilibrium in a bargaining model. Econometrica: Journal of the Econometric Society, p. 97-109, 1982.

NOTAS DE AUTOR

\section{CONTRIBUIÇÃO DE AUTORIA}

José Adeilton da Silva Filho - Concepção. Coleta de dados, Análise de dados, Elaboração do manuscrito. André Maia Gomes Lages - Elaboração do manuscrito. Coleta de dados. Participação ativa da discussão dos resultados; Revisão e aprovação da versão final do trabalho.

Maria da Graca Derengowski Fonseca - Participação ativa da discussão dos resultados; Revisão e aprovação da versão final do trabalho.

\section{FINANCIAMENTO}

Não se aplica.

\section{CONSENTIMENTO DE USO DE IMAGEM}

Não se aplica.

\section{APROVAÇÃO DE COMITÊ DE ÉTICA EM PESQUISA}

Não se aplica.

\section{CONFLITO DE INTERESSES}

Não existem conflitos de interesse: financeiros, pessoais, entre possíveis revisores e editores, ou possíveis vieses temáticos.

\section{LICENÇA DE USO}

Este artigo está licenciado sob a Licença Creative Commons CC-BY. Com essa licença você pode compartilhar, adaptar, criar para qualquer fim, desde que atribua a autoria da obra. 


\section{NOTAS}

\section{Nota 1}

In this paper I will adopt the strategic approach. I will consider the following bargaining situation: two players have to reach an agreement on the partition of a pie of size 1 . Each has to make in turn, a proposal as to how it should be divided. After one party has made such an offer, the other must decide either to accept it or to reject it and continue with the bargaining. The players' preference relations are defined on the set of ordered pairs of the type $(x, t)$ (where 0 ' $x$ ' -1 and $t$ is a nonnegative integer). The pair $(x, t)$ is interpreted as "1 receives $x$ and 2 receives $1-x$ at time $t . "$ 


\section{Capítulo 5}

\section{PROGRAMA DE AQUISIÇÃO DE ALIMENTOS (PAA) NO ESTADO DO AMAPÁ: CONTRIBUIÇÕES AO DESENVOLVIMENTO RURAL $(2010-2017)^{1}$}

DOI: $10.37423 / 200300366$

Geovane Tavares dos Santos (Mestrando em Desenvolvimento Regional (MDR), pela Universidade Federal do Amapá (UNIFAP), Prof. Esp. Instituto Federal do Amapá (IFAP).

geovane.santos@ifap.edu.br

Antônio Sérgio Monteiro Filocreão (Prof. Dr. da Universidade Federal do Amapá (UNIFAP).

afilocreao@gmail.com

Resumo: O presente artigo tem como objetivo geral compreender as contribuições do Programa de Aquisição de Alimentos (PAA) para o desenvolvimento rural no Estado do Amapá (2010 - 2017). Neste sentido, seus objetivos específicos visam discutir as políticas públicas para agricultura familiar no Brasil; entender o processo de formação do estado do Amapá na ótica do planejamento urbano regional; analisar as contribuições do PAA para o desenvolvimento rural no Amapá. Deste modo, realizou-se levantamentos bibliográficos de livros, artigos científicos, dissertações, teses e documentos oficiais sobre a temática estudada, assim como coletou-se dados na Plataforma de transparência pública do PAA (consultaweb.conab.gov.br). Portanto, constatou-se uma vasta discussão do PAA no Brasil, porém no Amapá existe uma carência de referências sobre o tema. Assim, os resultados corroboram que no período de 2010 - 2017 o Amapá recebeu total de $\mathrm{R} \$ 32.784 .366,40$ em recursos do PAA, fundamental para fomentar a agricultura familiar e promover a segurança de mercado aos produtores, contribuindo para o desenvolvimento rural.

Palavras-chave: Programa de Aquisição de Alimentos (PAA). Estado do Amapá. Desenvolvimento rural. 


\section{INTRODUÇÃO}

No Brasil, o Programa de Aquisição de Alimentos (PAA) foi criado através da Lei no 10.696 , de 02 de julho de 2003 (BRASIL, 2003), com objetivo de fomentar a agricultura familiar e permitir que produtos cheguem aos consumidores com o custo baixo. Desta forma, o Decreto 7.775 de 04 julho de 2012 (BRASIL, 2012) discorre sobre as finalidades do PAA, são elas: incentivar a agricultura familiar, promovendo sua inclusão econômica e social; incentivar o consumo e a valorização dos alimentos da agricultura familiar; promover acesso à alimentação em quantidade e qualidade para pessoas em situação de vulnerabilidade social; promover o abastecimento alimentar por meio de compras governamentais; apoiar a formação de estoques como segurança na produção; fortalecer redes de comercialização locais e regionais; valorizar a biodiversidade e a produção agroecológica, bem como estimular o cooperativismo e o associativismo. Logo, percebe-se a dimensão e importância do PAA no âmbito do desenvolvimento rural, uma vez que a sua efetivação ou não, afeta a produção de alimentos e geração de renda nos municípios e estados brasileiros.

No contexto do estado do Amapá, dados da Companhia Nacional de Alimentos (CONAB) (2018), elucidam que as execuções dos recursos financeiros do PAA começaram em 2010. Neste sentido, o Plano Territorial de Desenvolvimento Rural Sustentável (PTDRS) do Centro Oeste do Amapá (MDA, 2011), afirma que era evidente em 2009 o interesse do estado em aderir ao programa, mas foi apenas em 17.05.2010 que o PAA foi aprovado pelo Conselho Estadual de Segurança Alimentar do Amapá (CONSEA-AP). Deste modo, a demora do Amapá em participar do programa, demostra o descaso do poder público e a fragilidade das lutas das organizações representantes dos produtores rurais junto as políticas públicas para agricultura familiar (MDA, 2011).

Neste sentido, dados coletados da plataforma da transparência pública do PAA (CONAB, 2018) demonstram que no período de 2010 a 2017 o Amapá recebeu total de R\$ 32.784.366,40 em recursos do programa. Os recursos recebidos pelo Amapá foram acessados através da modalidade denominada "Compra com Doação Simultânea", esta modalidade permite a compra de alimentos dos produtores familiares e realiza doação aos consumidores em condições de vulnerabilidade social. A participação dos produtores nesta modalidade pode ser de forma individual ou coletiva. O limite individual por Declaração de Aptidão ao Pronaf (DAP) durante 1 ano é de $R \$$ 6.500,00; para quem participa de cooperativas/associações, o limite do DAP/ano é de $\mathrm{R} \$ 8.000,00$ e por organização pode receber até R\$ 2 milhões (GRISA; PORTO, 2015). 
Estudo realizado por Silva e Filocreão (2014) sobre as perspectivas para agricultura familiar no Amapá, enfatiza o PAA como uma das políticas públicas mais importante para agricultura familiar amapaense. De acordo com os autores, no período de 2010 a 2011 o programa obteve aumento nos recursos de aproximadamente $100 \%$, este investimento refletiu diretamente na produção familiar, constatou-se aumento de áreas plantadas e da produção, assim promoveu segurança de mercado os agricultores familiares (SILVA; FILOCREÃO, 2014). Deste modo, o PAA no Amapá favoreceu não apenas o meio rural, mas também ofertou alimentos para abastecer escolas, creches, instituições filantrópicas, em áreas urbanas.

Além dos benefícios proporcionados pelo PAA, existem alguns entraves que dificultam a expansão e efetivação do programa, nos últimos anos observa-se uma crise política, econômica e institucional quando se trata do programa. Mudanças presidenciais, cortes orçamentários, extinção de instituições representantes de políticas públicas para agricultura familiar tem afetado diretamente 0 desenvolvimento rural nos estados brasileiros. No caso do Amapá, até o início do segundo semestre de 2018 não existia recurso disponível para este Estado (CONAB, 2018).

De acordo com Favareto (2007), para proporcionar o desenvolvimento rural precisa-se de mudanças nas visões e ações das instituições (órgãos representantes de políticas públicas), ou seja, órgãos gestores de políticas devem trabalhar em conjunto e em prol dos interesses coletivos, assim como deve permitir a participação dos envolvidos nos programas e atender suas necessidades. Pois, através de uma nova postura institucional se estimula as formas descentralizadas de produção e à diversificação das economias locais, são criados ambientes e instituições que possam favorecer a ampliação das possibilidades de participação dos indivíduos e proporcionar autonomia de gestores (FAVARETO, 2007).

Com intuito de compreender as contribuições do PAA para o desenvolvimento rural no Estado do Amapá (2010 - 2017), adotou-se a pesquisa bibliográfica (livros, artigos científicos, dissertações, teses e documentos oficiais) e documental (Plataforma de transparência pública do PAA/consultaweb.conab.gov.br), os dados coletados foram organizados e analisados com intuito de atender o objetivo deste estudo. Portanto, o referencial teórico aborda as políticas públicas para agricultura familiar no Brasil; os processos de formação institucional do estado do Amapá e as análises e discussões sobre as contribuições do PAA para o desenvolvimento rural no Amapá 2010 a 2017. 


\section{REFERENCIAL TEÓRICO}

\subsection{POLÍTICAS PÚBLICAS E AGRICULTURA FAMILIAR NO BRASIL: PAA EM FOCO}

De acordo com Muller e Surel (2002), as políticas públicas são ao mesmo tempo resultados de construções sociais (constructo social) e construções científicas (constructo de pesquisa), ou seja, a política no seu viés social é desenvolvida a partir das disputas de poderes coletivos e individuais. Enquanto que a política como construção científica é o caminho encontrado para compreender e organizar as ações públicas geradas pelas construções sociais. Desta forma, apontam três elementos fundamentais para definição das políticas públicas: uma política pública constitui um quadro normativo de ação; ela combina elementos de força pública e elementos de competência, assim como constitui uma ordem local (MULLER; SUREL, 2002).

O primeiro elemento da política pública, envolve os conjuntos de medidas concretas que formalizam tal política, envolvem as normas reguladoras, recursos financeiros, agentes participantes, os materiais, entre outros. O segundo elemento representa a expressão do poder público (ações estatais), através de suas forças coercitivas, mas que não deve ser tratada pelo Estado como homogênea e autônoma. O terceiro e último elemento das políticas públicas, envolve sua capacidade de ordem local, onde a política envolve indivíduos e/ou grupos, que forma espaço de interorganização e supera a concepção jurídico e administrativo das políticas (MULLER; SUREL, 2002).

Compreende-se que as políticas públicas não emergem de vontades individuais, mas são movidas no âmbito das relações de poderes, para suprir interesses econômicos, políticos, sociais, culturais de grupos e classes (BONETI, 2003). Assim, acredita-se que as políticas públicas são construídas por interesses coletivos e para atender necessidades coletivas. Em decorrência desta percepção entendese que no Brasil nem todas as políticas destinadas para a agricultura familiar são públicas. Por isso, nesta seção a discussão visa compreender como o PAA foi instituído como política pública para a agricultura familiar.

Segundo Grisa e Schneider (2015), historicamente os agricultores familiares ou "pequenos agricultores" como eram denominados, ficaram por muito tempo as margens das ações do Estado brasileiro, porque não eram reconhecidos pelos planos de desenvolvimento do país. Alguns acontecimentos foram importantes para a mudança de concepção sobre a agricultura familiar, tais como: a constituição de 1988, com novos espaços de participação e reconhecimento de direitos foram possíveis; o surgimento do PRONAF em 1995, que estimulou a criação de outras políticas para o 
desenvolvimento rural; criação do Ministério de Desenvolvimento Agrária (MDA) em 1999 e a Secretaria da Agricultura Familiar (SAF) em 2001; por fim a regulamentação da Lei da agricultura familiar em 2016, que definiu a agricultura familiar como categoria social e balizou as políticas públicas para este grupo.

De acordo com lei federal 11.326/2006, que estabelece as diretrizes para a formulação da Política Nacional da Agricultura Familiar e Empreendimentos Familiares Rurais, os agricultores familiares são todos aqueles que praticam atividades no meio rural, possuem área de até 4 (quatro) módulos fiscais, mão de obra oriunda da própria família e renda vinculada ao próprio estabelecimento gerido pela família. São também beneficiados pela lei: silvicultores, aquicultores, extrativistas, pescadores, indígenas, quilombolas e assentados da reforma agrária (BRASIL, 2016). A partir desta lei observa-se sua importância na definição legal da agricultura familiar, assim como demonstra que as políticas públicas para esta categoria emergiram tardiamente.

Entretanto, as políticas para agricultura no Brasil emergiram desde o período colonial. A lei das Sesmarias, uma das primeiras medidas, permitia a doação de extensões de terras a donatários que, em muitos casos, transformavam as mesmas em latifúndios escravistas. Depois da crise do regime escravocrata no final do século XIX, foi instituída a Lei das terras em 1850, que permitia a compra e a venda das terras devolutas (MARTINS, 1981; SANTOS, 1978; SILVA, 1981).

Tal medida governamental incentivou a imigração de colonos europeus para desenvolver o trabalho "livre" nas grandes lavouras do país. Após 1988, se inicia um novo processo econômico, que incentiva a implantação de pequenas fábricas para estimular a produção interna. A partir dos avanços industriais, consolida-se a produção mercantil de alimentos, desvinculados das fazendas de café (MARTINS, 1981; SANTOS, 1978; SILVA, 1981).

Desta maneira, a demora em proporcionar políticas públicas para agricultura familiar associa-se ao processo de desvalorização desse modo de produção no país. Segundo Welch et al. (2009), esta exclusão existia porque o modo de produção familiar não atendia o modo de produção defendido pela elite brasileira (industrialização da agricultura); por isso, produzir para o próprio sustento representava o atraso e a pobreza.

Grisa e Schneider (2015) defendem que a partir da década de 1950 surgem as primeiras manifestações de políticas públicas direcionadas para a agricultura familiar. Neste período, o Estado atuava na organização econômica do país, a fim de promover a industrialização urbana e rural. Após a ineficiência desta política econômica interna, os anos 60 foram marcados pelas reivindicações de 
movimentos sociais do campo, que culminou na criação da Confederação Nacional dos Trabalhadores na Agricultura (CONTAG) para atender as reivindicações sociais. Neste viés, Wanderley (2003) infere que os agricultores familiares apesar das suas exclusões pelo Estado, não foram e não são sujeitos passivos na sociedade atual. Pelo contrário, eles constroem suas histórias e fortalecem suas lutas para garantir seus direitos.

As pressões sociais fizeram com que o governo desenvolvesse políticas de crédito rural, seguro agrícola, assistência técnica, extensão rural. Porém, as garantias dos direitos ao agricultor familiar foram interrompidas com o golpe militar de 1964, marcado pela violência aos movimentos sociais e pela retomada da modernização agrícola. Logo, os militares incentivaram o uso de fertilizantes químicos como técnica de produção e mantiveram a concentração da posse da terra (PEREIRA; ALENTEJANO, 2014).

Segundo Silva (1981), depois dos anos 60 a agricultura brasileira mostrou um claro processo de diferenciação em três grandes regiões: o Centro-Sul onde a agricultura modernizou rapidamente pela incorporação de insumos industriais (fertilizantes e defensivos químicos, máquinas e equipamentos agrícolas, etc.); no Nordeste, onde não apresentava grandes transformações agrícolas; na Amazônia, incluindo parte da região Centro-Oeste (Mato Grosso e Goiás), onde representava a zona de expansão da fronteira agrícola.

No caso da Amazônia, ela foi usada como slogan de governo "integrar para não entregar", uma ideologia de segurança nacional para combater investidas comunistas. O governo militar criou agências reguladoras, políticas de substituição de importações e criação de zonas de livre comércio. Estas iniciativas procuravam atrair grandes investimentos privados nacionais e internacionais. Assim, facilitaram a acumulação de capital e a concentração da terra e renda na mão da elite (BROWDER; GODFREY, 2006; LOUREIRO, 2009).

Este período foi marcante também pela criação do Instituto Nacional de Colonização e Reforma Agrária (INCRA), em 1970. Sua proposta inicial era desenvolver o urbanismo rural, porém, lotes foram demarcados sem considerar às condições ambientais locais da Amazônia. As famílias assentadas em agrovilas sofreram com as péssimas condições de estradas, saúde, saneamento, entre outros. A ausência de assistências aos produtores revelou o desconhecimento da região por parte dos gestores do programa e permitiu abandonos de muitos assentamentos (BROWDER; GODFREY, 2006).

Para Hurtienne (2001), os programas governamentais de desenvolvimentos executados na Amazônia nos últimos 35 anos, apesar de serem insuficientes, contribuíram para mudanças profundas na 
estrutura econômica, demográfica e ecológica. Os fatores como construção de rodovias, os programas de colonização oficiais e privados, incentivos fiscais contribuíram para desmatamento de mais ou menos $14 \%$ da área amazônica, residem a maioria de população rural familiar.

Neste cenário, residem grande parte da população rural dos estados do Pará e Rondônia. A produção destes agricultores é destinada para os mercados locais, regionais e nacionais, apesar de suas práticas agrícolas (derrubada e queimada) sejam consideradas por muitos como danosas ao meio ambiente, atualmente tem conseguido alcançar a diversificação produtiva, através de pequena criação, extração vegetal e até pecuária (HURTIENNE, 2001).

A segunda geração de políticas públicas para agricultura familiar definidas por Grisa e Schneider (2015) está inserida na transição da ditadura militar para a democratização do país, em 1980. Os interesses econômicos se voltaram para o neoliberalismo, como meta dos governos de Fernando Collor de Mello e Fernando Henrique Cardoso. As medidas tomadas visavam a mínima intervenção na economia e fortaleciam a privatização de instituições públicas. Para atender as reivindicações rurais e amenizar a problemáticas do campo, foi desenvolvido, em 1996 o PRONAF, com o propósito de fomentar a agricultura familiar e gerar emprego e renda no campo.

Neste sentido, o PRONAF surgiu para atender às antigas reivindicações de políticas públicas para meio rural. O programa representava a legitimação dos interesses coletivos dos agricultores, em particular, de agricultores familiares, que até então eram excluídos dos benefícios das políticas agrícolas. Desta forma, apesar das dificuldades do PRONAF, ele propiciou avanços significativos para o fortalecimento da agricultura familiar e abriu espaço para novas políticas a fim de atender aos anseios dos movimentos sociais rurais (MATTEI, 2005).

De acordo com Veiga (2003), o PRONAF avançou mesmo diante das sabotagens. Para o autor, o programa viveu no governo de FHC duas dicotomias, uma de reconhecimento do verdadeiro salto de qualidade da política agrícola brasileira, no sentido de promover financiamentos de produção e de infraestrutura nos municípios; e outra refere-se as posturas tomadas por lideranças do governo que desmentiam os resultados do programa para favorecer interesses particulares.

Apesar da importância do programa para agricultura familiar e para o desenvolvimento rural no Brasil, Favareto (2007, p. 156) alerta que "o Pronaf sempre esteve vinculado às rubricas orçamentárias e aos fluxos da hierarquia administrativa federal relativos aos programas de combate à pobreza". Desta maneira, o PRONAF não conseguiu romper em sua totalidade com o enfoque setorial (isolamento 
institucional) das políticas para agricultura, pois inaugurou nos discursos políticos uma nova visão institucional sobre o enfoque territorial (gestão participativa), mas com práticas setoriais.

Já a terceira geração de políticas públicas para a agricultura familiar iniciaram em 2003, na gestão do presidente Luiz Inácio Lula da Silva. Devido à história de lutas sociais do presidente, gerou-se uma expectativa maior nos trabalhadores rurais e em movimentos sociais, no que se refere a melhorias no campo. Desta forma, como política social para atender as expectativas da sociedade brasileira foi desenvolvido o Programa Fome Zero, com a finalidade de assegurar alimentação saudável à população carente, para melhorar a renda da população e a disponibilizar alimentos produzidos pela agricultura familiar (GRISA; SCHNEIDER, 2015; PEREIRA; ALENTEJANO, 2014).

Assim, interligado ao PRONAF e ao Programa Fome Zero, surgiu PAA com intuito de melhorar a renda dos produtores rurais e fornecer alimentos com baixos custos aos consumidores. Os recursos são resultados de financiamentos do governo federal, administrado pela CONAB e pelo Grupo de Gestão do PAA (GGPAA) formado por representantes dos seguintes órgãos públicos: Ministério do Desenvolvimento Social (MDS), Ministério da Agricultura, Pecuária e Abastecimento (MAPA), Ministério do Planejamento, Orçamento e Gestão (MPOG), Ministério da Fazenda (MF) e Ministério da Educação (MEC), em parceria com os estados brasileiros (BRASIL, 2012).

Os produtores que podem participar do Programa são: assentados da reforma agrária, trabalhadores rurais Sem Terras, acampados, quilombolas, agroextrativistas, comunidades indígenas e famílias atingidas por barragens. Um dos documentos exigidos na adesão ao programa é o DAP, funciona como identificação do agricultor familiar, usado para as prestações de contas dos alimentos fornecidos junto aos órgãos gestores. Assim, a CONAB compra os alimentos e/ou sementes dos agricultores familiares associados e cooperados, e estimula a doação dos alimentos para entidades públicas de alimentação e nutrição, entidades da rede socioassistencial e famílias em situação de vulnerabilidade social (BRASIL, 2012).

Segundo Grisa e Porto (2015), para alcançar seus objetivos, o PAA divide-se em seis modalidades: 
Quadro 1 - Modalidades e objetivos do PAA

\begin{tabular}{|c|c|}
\hline $\begin{array}{l}\text { Compra } \\
\text { com Doação } \\
\text { Simultânea }\end{array}$ & $\begin{array}{l}\text { Compra alimentos dos produtores familiares e realiza doação aos consumidores. A participação } \\
\text { dos produtores nesta modalidade pode ser de forma individual ou coletiva. O limite individual } \\
\text { DAP/ano é de } R \$ 6.500,00 \text {; para quem participa de cooperativas/associações, o limite do } \\
\text { DAP/ano é de } R \$ 8.000,00 \text { e por organização pode receber até } R \$ 2 \text { milhões. }\end{array}$ \\
\hline $\begin{array}{c}\text { Formação } \\
\text { de estoques }\end{array}$ & $\begin{array}{l}\text { Serve como apoio financeiro para a constituição de estoques de alimentos por organizações } \\
\text { fornecedoras, para posterior comercialização e devolução de recursos ao Poder Público. Seu } \\
\text { limite por DAP/ano: } \mathrm{R} \$ 8.000,00 \text { e por organização/ano: } \mathrm{R} \$ 1,5 \text { milhão. }\end{array}$ \\
\hline $\begin{array}{c}\text { Compra } \\
\text { Direta }\end{array}$ & $\begin{array}{l}\text { Visa a compra de produtos definidos pelo Grupo Gestor do PAA com o objetivo de sustentar } \\
\text { preços. Modalidade executada pela Conab, com recursos do MDS e MDA. Limite por DAP/ano: } \\
\mathrm{R} \$ 8.000,00 \text {. Limite por organização/ano: } \mathrm{R} \$ 500 \text { mil. }\end{array}$ \\
\hline PAA Leite & $\begin{array}{l}\text { Possibilita a compra de leite que, após beneficiamento é doado aos beneficiários consumidores. } \\
\text { E operada por governos estaduais da região nordeste e Minas Gerais, com recursos do MDS. } \\
\text { Limite por DAP/semestre: } R \$ 4.000,00 \text {. }\end{array}$ \\
\hline $\begin{array}{c}\text { Compra } \\
\text { institucional }\end{array}$ & $\begin{array}{l}\text { Realiza a compra da agricultura familiar por meio de chamada pública, para o atendimento de } \\
\text { demandas de consumo de alimentos, de sementes e de outros materiais propagativos, por parte } \\
\text { de órgão comprador. Limite por DAP/ano/órgão comprador: } \mathrm{R} \$ 20.000,00 \text {. }\end{array}$ \\
\hline $\begin{array}{c}\text { Aquisição } \\
\text { de sementes }\end{array}$ & $\begin{array}{l}\text { Atua na compra de sementes, mudas e materiais propagativos para a alimentação humana ou } \\
\text { animal, para doação a beneficiários consumidores ou fornecedores. O limite por DAP/ano: R\$ } \\
16.000,00 \text { e por organização/ano: } R \$ 6 \text { milhões. }\end{array}$ \\
\hline
\end{tabular}

Fonte: Grisa e Porto (2015); Silva; Filocreão; Lomba (2016).

Segundo Salgado et al. (2017), as contribuições do PAA são evidentes, promovem segurança de mercado e renda aos agricultores familiares, assim como garante alimentos para aqueles que vivem em situação de vulnerabilidade social. Além dos pontos positivos, o autor aponta também as limitações que o PAA encontra ao longo de sua existência, são elas: insuficiência na abrangência do programa, desigualdade regional na distribuição dos recursos, falta de articulação com outros programas direcionados à agricultura, dificuldades relacionadas à operacionalização do programa e atraso na liberação dos recursos (SALGADO et al., 2017). Logo, para que o PAA propicie a segurança de mercado, alimentar e nutricional no país, é necessário reavaliar suas ações e minimizar suas limitações.

Portanto, percebe-se ao longo das trajetórias das políticas para agricultura familiar, que poucas delas conseguiram alcançar as características de políticas públicas, muitas ações foram tomadas para atender interesses políticos e ideológicos particulares, em contraposição aos interesses coletivos dos agricultores. De acordo com as literaturas consultadas, o PAA mesmo com suas limitações apresentase como um dos programas de maior eficiência no fomento da agricultura familiar no Brasil. Pois, além de estimular a produção e gerar renda para o agricultor, atua no combate a escassez de alimentos.

\subsection{PAA E SUAS POSSIBILIDADES DE DESENVOLVIMENTOS}

De acordo com Sen (2000), o desenvolvimento é a garantia das liberdades substantivas das pessoas, pois o desenvolvimento como liberdade colide com as concepções que valorizam apenas o Produto 
Nacional Bruto (PNB), aumento da renda das pessoas e os avanços na industrialização como os reais promotores do desenvolvimento.

Embora estes fatores sejam importantes para promover a liberdade e o desenvolvimento, eles não são os fatores determinantes para garantir a liberdade das pessoas. Assim, entende-se que o crescimento econômico contribui para o desenvolvimento, mas não se recomenda propor como o único indicador de desenvolvimento, existem outras maneiras tais como: sociais, culturais, políticos, entre outros (SEN, 2000).

Segundo Sen (2000), a garantia do desenvolvimento requer a superação dos principais entraves de liberdade, tais como: pobreza, falta de oportunidades, supressão de direitos, descasos dos serviços públicos, autoritarismo ou intolerância estatal. Pois, a promoção de oportunidades sociais adequadas, possibilitam que os indivíduos sejam ativos para planejar seus próprios futuros e como sujeitos participantes ajudem outras pessoas se desenvolverem. Por isso, a garantia e a descentralização dos fatores que promovem a liberdade são fundamentais para a efetivação do desenvolvimento. Logo, o Estado e a sociedade exercem papéis importantes na proteção das capacidades humanas, mas para que isso ocorra ambos precisam se desprender dos pacotes prontos de desenvolvimento, assim serão capazes de estimular a participação e a busca da liberdade (SEN, 2000).

Deste modo, pode-se afirmar que o PAA é um instrumento de desenvolvimento rural, porque promove o diálogo entre comunidade e Estado, motiva a participação dos agricultores em organizações sociais, bem como sua inserção em políticas públicas. O programa também ajuda na valorização dos produtos familiares e na segurança comercial. Segundo Valnier e Ricci (2013), com a participação do agricultor ao programa, ele não fica submetido às variações de preços do mercado, uma vez que a CONAB realiza a pesquisa de preço dos produtos e estipula os valores baseado nas variações dos mercados locais, caso o agricultor encontre outo mercado melhor é permitido a troca do produto que o mesmo prometeu a companhia, uma estratégia para evitar a desvalorização da produção familiar.

Segundo Cavallari et al. (2015), o PAA na Amazônia Legal brasileira é uma ferramenta fundamental para promover o desenvolvimento rural e regional, tendo em vista que é um programa atuante no fortalecimento da agricultura familiar em vários estados, em particular nos estados da Amazônia Legal (Acre, Amazonas, Amapá, Rondônia, Roraima, Pará, Tocantins, Mato Grosso e Maranhão), entre os primeiros e mais atuantes estados amazônicos estão Acre e Rondônia, que participam desde 2003.

Estudo realizado por Valnier e Ricci (2013) sobre o PAA no Acre e Rondônia, constatou que o programa foi importante para melhoria da qualidade de vida dos agricultores, por valorizar os produtos da 
agricultura familiar e por ter aproximado o produtor e o consumidor. Os agricultores destes estados antes da participação no PAA ou em outras políticas públicas para agricultura familiar, entregavam seus produtos a baixo custo e eram frustrados e desestimulados com o mercado local. De acordo com Cavallari et al. (2015), a participação dos estados da Amazônia é significativa e ao mesmo tempo instáveis, como demonstra o ano de 2011 (Figura 1).

Figura 1 - Municípios atendidos pelo PAA em 2011 na Amazônica Legal

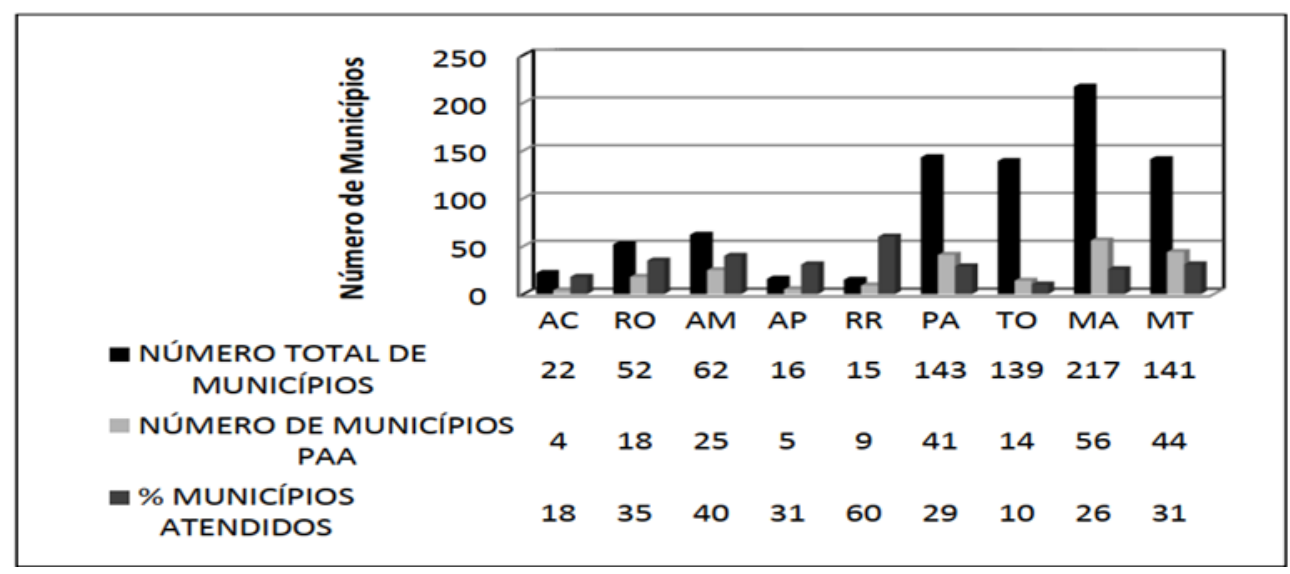

Fonte: Cavallari et al. (2015).

De acordo com a Figura 1, o estado de Roraima tinha 60\% de seus municípios atendidos pelo PAA, já Tocantins contava com a participação no programa de apenas 14 dos 139 municípios que o compõe. O estado do Maranhão também ficava abaixo das expectativas em comparação ao quantitativo de seus municípios e municípios vinculados ao programa. O estado do Mato Grosso apresenta apenas $31 \%$ de seus municípios participando do programa, apresentando a mesma participação que o estado do Amapá, no entanto a relação número total de municípios/número de municípios atendidos é diferenciada para ambos, sendo muito maior para o estado mato grosso.

Cavallari et al. (2015), observa que de 2003 a 2011 houve um aumento significativo na atuação do PAA na região da Amazônia Legal Brasileira, destaque para algumas oscilações de participação dos estados de Roraima e Amapá, o que indica a necessidade da realização de estudo aprofundado e pontual nestes Estados. Portanto, estudar o PAA sobre a ótica do desenvolvimento permite reconhecer sua capacidade de estimular o crescimento econômico da região ou local, assim como avaliar o grau de liberdade das pessoas que participam do programa. 


\subsection{ESTADO DO AMAPÁ E SEUS PROCESSOS DE FORMAÇÃO INSTITUCIONAL}

O Estado do Amapá foi criado em 1988, está situado na Amazônia Oriental, seu território representa uma área de 142. $815 \mathrm{~km}^{2}$, composto por 16 municípios, seus limites fronteiriços são dotados de características diversificadas, ao sul com rio Amazonas, Oeste com rio Jari e Pará (Monte Dourado), a Leste Oceano Atlântico, ao Norte com rio Oiapoque e França (Guiana Francesa) e a Noroeste com Suriname (TOSTES; FERREIRA, 2016; PORTO, 2007). Segue o Figura 2 com o Mapa das delimitações geográficas do Amapá e seus 16 municípios.

Figura 2 - Mapa de localização do estado do Amapá e seus municípios

Fonte: Elaborado Rosa (2018), a partir de base de dados IBGE e SEMA.

Segundo Tostes (2014a), o Amapá no seu processo de formação institucional

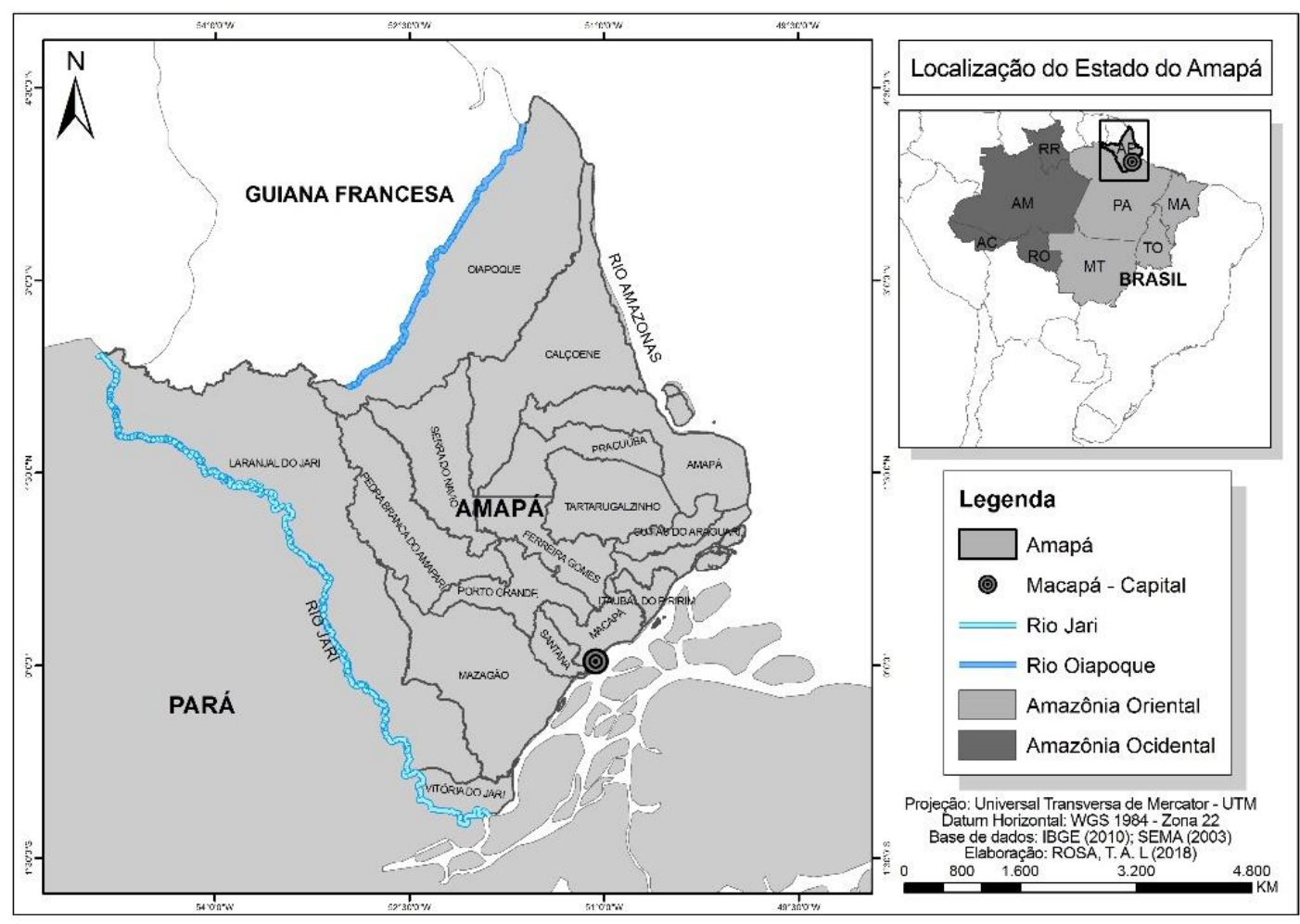

vivenciou três principais momentos: o primeiro representado pela criação da Vila de Macapá, com a posterior construção da Fortaleza de São José de Macapá para fins de defesa estratégica de proteção do território, que atendia os interesses dos colonizadores. O segundo momento marcado pela criação do Território Federal do Amapá em 1943, resultado das políticas desenvolvimentistas que promoveram a implantação dos projetos minerais e agroflorestais. E o terceiro momento, com a 
criação do estado do Amapá em 1988, e posterior criação da Área de Livre Comércio Macapá e Santana (ALCMS), que representa em parte a autonomia estatal e a intensificação do processo de urbanização, em particular as cidades de Macapá e Santana.

O momento inicial da institucionalização do Amapá esteve estritamente relacionado a proteção e a ocupação territorial. De acordo com Filocreão (2015a), “a intensa disputa pelas terras da Guiana brasileira determinou que o início do processo de ocupação do Amapá pelos portugueses fosse permeado por fins estritamente militares". As características deste período são representadas pelas fortificações construídas neste período (Fortaleza de São José de Macapá). Segundo Oliveira (2004), os resquícios do processo de colonização portuguesa, através da existência de fortificações que simbolizam as políticas coloniais, são as características principais das cidades de beira de rio.

No segundo momento de formação institucional, destaca-se as políticas e projetos destinados a exploração de minerais, principalmente pelo projeto de mineração do manganês no município de Serra do Navio, liderado pela Indústria e Comércio de Minérios S.A (ICOMI). Apesar da magnitude dos projetos destinados para Amapá, eles não garantiram o desenvolvimento da região, o fim das atividades minerais propiciou novas problemáticas, tais como: concentração de população nas cidades de Macapá e Santana, o aumento dos índices de pobreza urbana, entre outras (TOSTES, 2014b).

Corrobora Chagas et al. (2016), que a exploração mineral na década de 1950, transformou o Amapá em um dos principais polos de atração de migrantes do país, atingiu o maior crescimento demográfico de $83,82 \%$, valor superior ao crescimento do país $(36,3 \%)$ e do conjunto de estados que compõem a Amazônia Legal (52\%). As consequências desse crescimento demográfico desenfreado refletiram na má qualidade de vida dos moradores de alguns municípios amapaenses.

No caso de Serra do Navio, Tostes (2014b) reflete que a ICOMI representou o "sonho e o pesadelo", uma vez que no início do projeto a Vila de Serra do Navio foi construída com todos os requisitos necessários para implantação de um empreendimento de magnitude nacional e internacional. E após mudanças políticas e econômicas na década de 90, desencadearam duas grandes mudanças, a transformação do distrito de Serra do Navio em Município 1993 e a saída da ICOMI 1998, que simbolizou o fracasso da condição da vida sonhada no início do projeto.

O terceiro momento, caracteriza-se pela criação do estado do Amapá em 1988, que representa o início da ruptura administrativa com o território federal. De acordo com Porto (2007), este processo constitucional proporciona os primeiros passos da autonomia e capacidade de auto-organização do Amapá. 
Neste viés, dois programas de governos foram marcantes: O Plano de Ação Governamental (19921995), desenvolvido na gestão do governador Annibal Barcellos (PFL), com intuito de potencializar as políticas regionais do estado, afim de promover o desenvolvimento e o Programa de Desenvolvimento Sustentável - PDSA (1995), nos mandatos do governador João Alberto Capiberibe (PSB), onde seu principal foco foi planejar as questões ambientais e sociais a partir dos anseios das comunidades locais (PORTO, 2007).

Segundo Filocreão (2015b), as políticas de gestão ambiental direcionadas principalmente a mesorregião sul do Amapá, foram importantes para o reconhecimento estatal das áreas tradicionais de extrativismo vegetal, proporcionou a criação de "reservas extrativistas" na forma de Projetos, tais como: Assentamento Agroextrativista no rio Maracá (ATEX-MA); a Reserva Extrativista do rio Cajari (RESEX Cajari) e a Reserva de Desenvolvimento Sustentável do rio Iratapuru.

Neste viés, a criação de áreas protegidas apresenta-se como fundamental para legitimar o direito ao uso das terras por extrativistas, indígenas, pescadores, agricultores familiares, entre outros. Neste viés, Lima e Porto (2008) apontam quatro aspectos que devem ser considerados na gestão de áreas protegidas no Amapá, são eles: definir critérios apropriados (cientistas, social, político e econômico) para a criação de novas áreas; definição de modelos de gestão que sejam compatíveis com a política ambiental e agrária na Amazônia; propiciar estudos nas áreas de savana e definir critérios de ocupação e uso do solo; criar parâmetros viáveis de definição de "populações tradicionais", para não promover exclusão de grupos sociais em detrimentos de outros.

Chagas et al. (2016), a transformação do Amapá em estado federado, provocou um novo salto no crescimento demográfico em comparação com a região norte e com o país. Entre os fatores de estímulo ao crescimento demográfico encontram-se a criação da Área de Livre Comércio de Macapá e Santana - ALCMS (1991), a pavimentação de perímetros da BR-156, a abertura da rodovia BR-156 no trecho Macapá a Laranjal do Jari, que provocaram novos saltos demográficos no estado.

Em 1990, o índice de crescimento demográfico atinge 64,84\%, quase três vezes maior do que o crescimento ocorrido no conjunto dos estados da Amazônia Legal (23,95\%) e quatro vezes maior que o crescimento nacional (15,65\%). No ano de 2000 observa-se uma queda no crescimento populacional, resultado do fim de atividades minerais e pouca efetividade da ALCMS (CHAGAS et al., 2016).

No Censo 2010 (IBGE, 2010a), a população do estado atingiu 669.526 pessoas e a maioria dos habitantes ocupavam as áreas urbanas total de 601.036 e 68.490 áreas rurais. Os resultados preliminares do Censo Agro 2017 apontam um aumento de 141\% no número de estabelecimentos 
agropecuários, que ocupam uma área total de 1. 506. 294 hectares. Em comparação ao Censo Agro 2006, verifica-se que o crescimento da área ocupada atingiu $72 \%$ (equivalente a $97 \%$ da área de Macapá). Estes resultados prévios alertam que o meio rural amapaense está vivendo uma nova dinâmica, seja ela na perspectiva da expansão da agricultura familiar e/ou do agronegócio (IBGE, 2017). São necessários dados concretos para afirmar os reais fatores que motivaram o crescimento de áreas rurais ocupadas.

Na concepção de Veiga (2003), nas relações campo e cidade existe no Brasil uma visão vulgar e provinciana da agricultura familiar, que pouco valoriza a agricultura como geradora de emprego, renda e bem-estar no campo. Para garantir direitos, é necessário criar condições (saúde, escola, logística, entre outras) para a manutenção das famílias. A escassez da estrutura das famílias camponesas interfere diretamente no crescimento populacional das cidades, uma vez que a péssima condição das pessoas no campo estimula a busca por melhores condições nas cidades. Contudo, reconhecer o espaço rural e urbano como participantes do mesmo processo de desenvolvimento, ajuda diminuir o êxodo rural e potencializa a vida das pessoas no campo e nas cidades.

Todavia, compreender os processos históricos e geopolíticos de transformações do estado do Amapá, são necessários para refletir as políticas para agricultura familiar, em particular as contribuições do PAA, uma vez que a agricultura familiar praticada no mencionado estado é responsável pela produção de grande parte dos alimentos que abastecem o campo e a cidade, assim como desenvolve um papel importante na geração de emprego e renda, que contribui para a permanência dos agricultores em suas propriedades (SILVA; LOMBA, 2011).

\section{ANÁLISES E DISCUSSÕES}

\subsection{METODOLOGIA}

Para alcançar os objetivos propostos neste artigo, adotou-se a pesquisa bibliográfica e documental. Na pesquisa bibliográfica constatou-se uma vasta discussão do PAA no Brasil, com destaque para o livro “Políticas Públicas de Desenvolvimento Rural no Brasil” (GRISA; SCHNEIDER, 2015), que concentra uma diversidade de artigos sobre as trajetórias das políticas públicas no Brasil, em especial sobre o PAA. No Amapá, observa-se uma carência de referências sobre o tema, tendo em vista que apenas dois artigos aprofundaram discussão do programa, são eles: "Programa de Aquisição de Alimentos no Território da Cidadania Sul do Amapá" (SILVA; FILOCREÃO; LOMBA, 2016) e "Perspectivas para 
agricultura familiar no Amapá" (SILVA; FILOCREÃO, 2014). O PAA no Amapá é discutido também no Plano Territorial de Desenvolvimento Rural Sustentável (PTDRS) do Centro Oeste do Amapá.

Na pesquisa documental sobre o PAA encontra-se como ferramenta fundamental para visibilidade financeira do programa a Plataforma de transparência pública do CONAB/PAA (consultaweb.conab.gov.br). A plataforma do PAA permite verificar na primeira consulta, os valores destinados para cada estado do Brasil e seus respectivos anos, a modalidade do programa e os órgãos financiadores. A partir que o usuário seleciona o estado, é possível saber os municípios que participaram e seus respectivos valores anuais. Ao selecionar o município, o usuário tem acesso as organizações agroextrativistas que receberam recursos do programa, os produtos ofertados, os fornecedores/agricultores e os beneficiados com os alimentos. Desta forma, é possível saber a quantidade de recursos recebidos pelos estados e municípios, assim como os agricultores participantes, os produtos ofertados e as instituições beneficiadas.

As informações coletadas na Plataforma da CONAB/PAA foram organizadas quantitativamente (Quadro e Tabela) para compreender as contribuições do programa ao desenvolvimento rural no estado do Amapá. Desta maneira, foram analisadas as distribuições de recursos do PAA por municípios do Amapá, agricultores familiares fornecedores, instituições recebedoras e os anos de distribuição de recursos entre o período de 2010 a 2017.

\subsection{PAA NO ESTADO DO AMAPÁ E SUAS CONTRIBUIÇÕES AO DESENVOLVIMENTO RURAL}

Segundo a CONAB (2018), entre os anos de 2010 a 2017 o estado do Amapá recebeu R\$ 32.784.366,4 em recursos repassados as organizações agroextrativistas (Cooperativas e Associações). Deste montante já foram executados total de $\mathrm{R} \$ 30.202 .919,05$, sendo que $\mathrm{R} \$ 2.581 .447,35$ do valor, pertence aos recursos devolvidos, ausentes de prestação de conta ou em andamento na execução. Segue a Tabela 1, que específica os recursos recebidos pelo Amapá entre 2010 - 2017 e seus municípios beneficiados. 
Tabela 1: Recursos PAA no Amapá e municípios beneficiados entre 2010 a 2017

\begin{tabular}{cccc}
\hline $\begin{array}{c}\text { Valor } \\
\text { Formalizado } \\
(\mathbf{R} \mathbf{)}\end{array}$ & $\begin{array}{c}\text { Valor } \\
\text { executado } \\
(\mathbf{R} \$)\end{array}$ & \multicolumn{1}{c}{ Municípios beneficiados } \\
Ano & $1.583 .138,19$ & $857.042,52$ & $\begin{array}{c}\text { Amapá, Calçoene, Itaubal, Laranjal do Jari, Mazagão, Macapá, } \\
\text { Porto Grande, Santana e Tartarugalzinho }\end{array}$ \\
\hline $\mathbf{2 0 1 0}$ & & & \\
\hline
\end{tabular}

Continuação....

Continuação...

\begin{tabular}{lllll}
\hline $\mathbf{2 0 1 1}$ & $1.114 .502,33$ & $1.068 .103,56$ & $\begin{array}{l}\text { Amapá, Laranjal do Jari, Mazagão, Porto Grande, Santana e } \\
\text { Tartarugalzinho. }\end{array}$ \\
\hline $\mathbf{2 0 1 2}$ & $2.388 .900,43$ & $2.028 .404,95$ & $\begin{array}{l}\text { Amapá, Laranjal do Jari, Mazagão, Macapá, Santana e } \\
\text { Tartarugalzinho. }\end{array}$ \\
\hline $\mathbf{2 0 1 3}$ & $4.242 .534,53$ & $4.191 .651,84$ & $\begin{array}{l}\text { Amapá, Laranjal do Jari, Mazagão, Macapá, Porto Grande Santana, } \\
\text { Tartarugalzinho e Vitória do Jari. }\end{array}$ \\
\hline $\mathbf{2 0 1 4}$ & $9.299 .060,50$ & $9.298 .389,70$ & $\begin{array}{l}\text { Amapá, Cutias, Itaubal, Laranjal do Jari, Mazagão, Macapá, Porto } \\
\text { Grande, Santana, Tartarugalzinho e Vitória do Jari. }\end{array}$ \\
\hline $\mathbf{2 0 1 5}$ & $7.718 .916,64$ & $7.387 .403,97$ & $\begin{array}{l}\text { Amapá, Calçoene, Itaubal, Laranjal do Jari, Mazagão, Macapá, } \\
\text { Pedra Branca do Amapari, Porto Grande, Santana, Tartarugalzinho } \\
\text { e Vitória do Jari. }\end{array}$ \\
\hline $\mathbf{2 0 1 6}$ & $5.172 .028,81$ & $4.499 .267,44$ & $\begin{array}{l}\text { Amapá, Calçoene, Itaubal, Laranjal do Jari, Mazagão, Macapá, } \\
\text { Pedra Branca do Amapari, Porto Grande, Santana, Tartarugalzinho } \\
\text { e Vitória do Jari. }\end{array}$ \\
\hline $\mathbf{2 0 1 7}$ & $2.265 .284,97$ & $695.427,12$ & $\begin{array}{l}\text { Calçoene, Macapá, Mazagão, Porto Grande, Santana, } \\
\text { Tartarugalzinho e Vitória do Jari. }\end{array}$ \\
\hline & Total: R\$ & Total: R\$ & $\begin{array}{l}\text { Pendente: } \$ \$ \\
\text { R } \$ 2.581 .447,35\end{array}$ \\
\hline
\end{tabular}

Fonte: Dados obtidos da Plataforma de Transparência pública do PAA (CONAB, 2018).

A partir da tabela 1, percebe-se um aumento gradativo nos valores dos recursos repassados ao longo dos anos. No ano de 2011 observa-se a maior redução dos recursos recebidos (R\$ 1.114.502,33), enquanto que o ano de 2014 apresenta o maior recurso ( $R \$$ 9.299.060,50), com a inclusão de novos municípios. Porém, de 2015 a 2016, os valores repassados diminuíram e a quantidade de organizações beneficiadas aumentaram. Em 2017 o valor sofreu reajuste e a quantidade de municípios também diminuíram.

Em comparação 2011 e 2014, verifica-se o quanto a redução de recurso interferiu nas contribuições do PAA ao desenvolvimento rural Amapá. Em 2011 participaram 05 municípios (Laranjal do Jari, Mazagão, Porto Grande, Santana e Tartarugalzinho), através de 10 organizações agroextrativistas, 331 produtores/fornecedores foram beneficiados (agricultores familiares e extrativistas), e os principais produtos ofertados: raiz de mandioca, paçoca, milho, melancia. Estes produtos foram doados para 53 escolas (rurais e urbanas), 02 pré-escolas, 61 acampamentos (associações de bairros, igrejas e etc.), 
01 Associações de Pais e Amigos dos Excepcionais (APAEs) e similares, 10 outras categorias (Serviço Social do Comércio - SESC e Instituto do Câncer Joel Magalhães) (CONAB, 2018).

No ano de 2014 participaram 09 municípios (Cutias, Itaubal, Laranjal do Jari, Mazagão, Macapá, Porto Grande, Santana, Tartarugalzinho e Vitória do Jari), 23 organizações agroextrativistas, 1.333 produtores foram beneficiados (agricultores familiares e extrativistas), os principais produtos ofertados: raiz de mandioca, coco, farinha de mandioca, milho, galinha viva, peixe. Estes produtos foram doados para 104 escolas (rurais e urbanas), 02 pré-escolas, 103 acampamentos (associações de bairros, igrejas e etc.), 05 Associações de Pais e Amigos dos Excepcionais (APAEs) e similares, 01 instituição de Amparo, 28 outras categorias (Serviço Social do Comércio - SESC e Instituto do Câncer Joel Magalhães) (CONAB, 2018).

Através da comparação entre os anos de 2011 e 2014, verifica-se que em 2014 a quantidade de municípios, organizações agroextrativistas dobraram, assim como os números de consumidores beneficiados (escolas e acampamentos). A participação dos produtores beneficiados com os recursos do PAA aumentou 302, 7\%. Deste modo, fica evidente a importância que o programa exerce para o desenvolvimento no estado, assim como sua ausência desequilibra a produção e reduz a participação dos agricultores em organizações agroextrativistas.

De acordo com Silva; Filocreão; Lomba (2016), os principais motivos das instabilidades do programa no Amapá, estão associados aos ajustes financeiros realizados pelo Governo Federal. No período de 2011 a 2015 analisado pelos autores, foi possível verificar que o número de agricultores beneficiados alcançou 4.934 (Tabela 2).

Tabela 2: Valores do PAA e agricultores beneficiados no Amapá no período 2011-2015.

\begin{tabular}{c|cc}
\hline Ano & Agricultores beneficiados & Valores (R\$) \\
\hline 2011 & 977 & $2.613 .478,85$ \\
2012 & 1.276 & $4.971 .933,57$ \\
2013 & 727 & $4.541 .534,53$ \\
2014 & 1.318 & $9.299 .060,54$ \\
2015 & 636 & $4.938 .916,87$ \\
Total & $\mathbf{4 . 9 3 4}$ & $\mathbf{2 6 . 3 6 4 . 9 2 4 , 3 5}$ \\
\hline
\end{tabular}

Fonte: Adaptado de Silva; Filocreão; Lomba (2016). 
Segundo Silva; Filocreão; Lomba (2016), após estudo realizado sobre o PAA na Reserva Extrativista do Rio Cajari - AP, verificou-se que, mesmo com a ampliação do Programa, muitos agricultores não tinham acessado seus recursos. Entre os entraves encontrados apontados pelos agricultores, estão a burocracia imposta pelos órgãos gestores, a ausência dos serviços de assistência técnica e o corte nos repasses financeiros. Estas informações, corroboram as avaliações feitas por Salgado et al. (2017) sobre o PAA no Brasil, para o autor trata-se de um programa que promove garantias reais aos agricultores familiares, mas com dificuldades de estabilidades políticas, econômicas, regionais visíveis. Neste sentido, o Quadro 2 especifica os recursos recebidos pelos municípios amapaenses, assim como permite observar as continuidades e descontinuidades dos recursos de 2010 a 2017.

Quadro 2: Distribuição de recursos PAA por municípios 2010 a 2017

\begin{tabular}{|c|c|c|c|c|c|c|c|c|c|}
\hline \multicolumn{2}{|r|}{2010} & \multirow{2}{*}{$\begin{array}{l}\mathbf{2 0 1 1} \\
69.367, \\
10\end{array}$} & \multirow{2}{*}{$\begin{array}{l}\mathbf{2 0 1 2} \\
76.341, \\
45\end{array}$} & \multirow{2}{*}{$\begin{array}{l}\mathbf{2 0 1 3} \\
239.03 \\
2,23\end{array}$} & \multirow{2}{*}{\begin{tabular}{l}
\multicolumn{1}{c|}{$\mathbf{1 0 1 4}$} \\
343.997 \\
00
\end{tabular}} & \multirow{2}{*}{\begin{tabular}{l}
\multicolumn{1}{c}{$\mathbf{2 0 1 5}$} \\
176.000, \\
31
\end{tabular}} & \multirow{2}{*}{\begin{tabular}{l}
\multicolumn{1}{c|}{$\mathbf{2 0 1 6}$} \\
271.999, \\
18
\end{tabular}} & \multirow[t]{2}{*}{2017} & \multirow{2}{*}{$\begin{array}{c}\text { Total }(\mathrm{R} \$) \\
1.22 .610 \\
77\end{array}$} \\
\hline 愛 & $\begin{array}{l}50.873, \\
50\end{array}$ & & & & & & & & \\
\hline 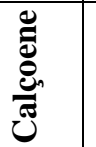 & $\begin{array}{l}124.88 \\
2\end{array}$ & & & & & $\begin{array}{l}246.000 \\
21\end{array}$ & $\begin{array}{l}\text { 120.605, } \\
91\end{array}$ & $\begin{array}{l}97.385, \\
60\end{array}$ & $\begin{array}{c}588.873 \\
72\end{array}$ \\
\hline 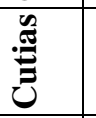 & & & & & $\begin{array}{l}40.942, \\
42\end{array}$ & & & & $\begin{array}{l}40.942 \\
42\end{array}$ \\
\hline 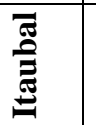 & $\begin{array}{l}117.32 \\
7,63\end{array}$ & & & & $\begin{array}{l}227.136, \\
91\end{array}$ & $\begin{array}{l}80.000, \\
03\end{array}$ & $\begin{array}{l}49.118, \\
74\end{array}$ & & $\begin{array}{c}473.583 \\
28\end{array}$ \\
\hline 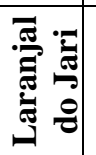 & $\begin{array}{l}153.18 \\
0\end{array}$ & $\begin{array}{l}89.895, \\
60\end{array}$ & $\begin{array}{l}259 . \\
840\end{array}$ & $\begin{array}{l}776 . \\
488, \\
09\end{array}$ & $\begin{array}{l}860.998, \\
15\end{array}$ & 307.608 & $\begin{array}{l}367.999, \\
88\end{array}$ & & $\begin{array}{c}2.816 .009 \\
72\end{array}$ \\
\hline 营 & $\begin{array}{l}44.264, \\
50\end{array}$ & & $\begin{array}{l}69.535 \\
72\end{array}$ & $\begin{array}{l}25.992, \\
65\end{array}$ & $\begin{array}{l}314.431 \\
85\end{array}$ & $\begin{array}{l}348.738 \\
52\end{array}$ & & $\begin{array}{l}185.138 \\
29\end{array}$ & $\begin{array}{c}\text { 988, 101, } \\
53\end{array}$ \\
\hline 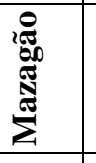 & $\begin{array}{l}181.17 \\
4,40\end{array}$ & $\begin{array}{l}283.38 \\
4, \\
92\end{array}$ & $\begin{array}{l}530.58 \\
2, \\
80\end{array}$ & $\begin{array}{l}2.089 . \\
908 \\
32\end{array}$ & $\begin{array}{l}4.413 . \\
951 \\
02\end{array}$ & $\begin{array}{l}2.365 . \\
999 \\
64\end{array}$ & $\begin{array}{l}1.682 .67 \\
9 \\
47\end{array}$ & $\begin{array}{l}895.488 n t \\
92\end{array}$ & $\begin{array}{c}\text { nudzẽă } 443 . \\
\mathbf{1 7 1} \\
\mathbf{4 9}\end{array}$ \\
\hline 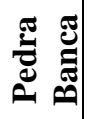 & & & & & & 324.998 & $\begin{array}{l}120.435, \\
98\end{array}$ & & $\begin{array}{c}445.433 \\
98\end{array}$ \\
\hline 象 & $\begin{array}{l}68.163, \\
50\end{array}$ & $\begin{array}{l}105.54 \\
0, \\
15\end{array}$ & & $\begin{array}{l}271 . \\
553, \\
90\end{array}$ & $\begin{array}{l}759.635, \\
22\end{array}$ & $\begin{array}{l}759.999, \\
93\end{array}$ & $\begin{array}{l}780.310 \\
74\end{array}$ & $\begin{array}{l}298.175 \\
30\end{array}$ & $\begin{array}{c}3.043 .378 \\
74\end{array}$ \\
\hline 䔍 & $\begin{array}{l}681.49 \\
0,97 \\
\end{array}$ & $\begin{array}{l}565.41 \\
0, \\
67 \\
\end{array}$ & $\begin{array}{l}1.161 .6 \\
40, \\
70\end{array}$ & $\begin{array}{l}574 . \\
207, \\
80\end{array}$ & $\begin{array}{l}1.697 .29 \\
8, \\
43\end{array}$ & $\begin{array}{l}2.653 .34 \\
9, \\
84\end{array}$ & $\begin{array}{l}826.183, \\
06\end{array}$ & $\begin{array}{l}418.114, \\
39\end{array}$ & $\begin{array}{c}\text { 8.577.695, } \\
95\end{array}$ \\
\hline 焉 & $\begin{array}{l}212.65 \\
5 \\
19 \\
\end{array}$ & $\begin{array}{l}\text { 69.367, } \\
10\end{array}$ & $\begin{array}{l}76 . \\
341, \\
45\end{array}$ & $\begin{array}{l}297 . \\
527, \\
73\end{array}$ & $\begin{array}{l}455.996, \\
80\end{array}$ & $\begin{array}{l}176.000, \\
31\end{array}$ & $\begin{array}{l}431.455, \\
60\end{array}$ & $\begin{array}{l}\text { 170.981, } \\
05\end{array}$ & $\begin{array}{c}1.737 .325 \\
23\end{array}$ \\
\hline
\end{tabular}




\begin{tabular}{|c|c|c|c|c|c|c|}
\hline 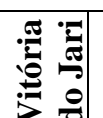 & $\begin{array}{l}155.97 \\
3,35\end{array}$ & $\begin{array}{l}527.998, \\
90\end{array}$ & $\begin{array}{l}124.709, \\
49\end{array}$ & $\begin{array}{l}147.857, \\
97\end{array}$ & $\begin{array}{l}199.998, \\
88\end{array}$ & $\begin{array}{c}976.538 \\
59\end{array}$ \\
\hline
\end{tabular}

Fonte: Dados obtidos da Plataforma de Transparência pública do PAA (CONAB, 2018).

No quadro 2, fica explícito as inconsistências das participações de alguns municípios (Calçoene, Cutias e Pedra Branca do Amapari) junto ao PAA, bem como revela uma constante participação e concentração dos recursos em outros (Mazagão, Santana, Laranjal do Jari e Tartarugalzinho). Porém, é necessário reconhecer que cada município tem suas particularidades: geográficas (ver Mapa), políticas, econômicas, culturais, entre outras, que podem interferir diretamente na participação do PAA.

Através dos dados do Quadro 2, verifica-se que os municípios com as menores participações nos recursos PAA, foram: Cutias (R\$ 40.942,42), Pedra Branca do Amapari $(445.433,98)$ e Calçoene (R\$ $588.873,72)$, juntos somaram $\mathrm{R} \$ 1$ 1.075.300,12. Destaca-se o município de Cutias com a menor participação, somente em 2014, em consequência recebeu o menor valor entre os 11 municípios no período de 2010 - 2017.

Em 2014, o município de Cutias participou com 01 organização agroextrativista, 07 produtores foram beneficiados (agricultores familiares e extrativistas), os principais produtos ofertados: raiz de mandioca, coco, farinha de mandioca, entre outros. Os produtos foram doados para 04 escolas (rurais e urbanas), 02 acampamentos (associações de bairros, igrejas e etc.), 01 outras categorias (CONAB, 2018).

Compreende-se que entre os fatores que explicam a pouca participação de Cutias no PAA, está relacionado as atividades econômicas que o município desenvolve. Segundo Dias (2011), as maiores fontes econômicas de Cutias advêm da pecuária (criação de gados bovinos e bubalinos). Em menores expressões ficam as atividades produtivas voltadas para agricultura e extrativismo, tais como: produção de farinha de mandioca, pesca, extração de madeira, entre outras.

Por outro lado, os municípios com as maiores participações no PAA, estão; Mazagão (R\$ 12.443.171,49), Santana ( $R \$ 8.577 .695,95)$ e Laranjal do Jari ( $R \$ 2.816 .009,72)$, destaque para Mazagão que participou em todos os anos e recebeu o maior valor entre os 11 municípios, juntos somaram valor R\$21. 023. 684, 16, representa 64\% do valor total do período de 2010 a 2017.

O município de Mazagão em 2014 participou com 04 organizações agroextrativistas, 635 produtores foram beneficiados (agricultores familiares e extrativistas), os principais produtos ofertados: farinha de mandioca, milho, açaí, entre outros. Os produtos foram doados para 26 escolas (rurais e urbanas), 
56 acampamentos (associações de bairros, igrejas e etc.), 03 Associações de Pais e Amigos dos Excepcionais (APAEs) e similares, 05 outras categorias (CONAB, 2018).

De acordo com Silva; Filocreão; Lomba (2016), os fatores que contribuem para maior concentração de recursos do PAA nos municípios de Mazagão e Laranjal do Jari estão relacionados ao processo de formação do Território da Cidadania Sul, que é composto por três municípios: Mazagão, Laranjal do Jari e Vitória do Jari. Neste território, estão situadas as reservas extrativistas, assentamentos extrativistas, terras indígenas, assentamentos rurais e unidades de conservação, que proporcionam a coleta, pesca, agricultura, entre outros. Segundo Brasil (2008), os Territórios da Cidadania são estratégias planejadas pelo governo em parceira com a sociedade para promover o desenvolvimento econômico das regiões e universalizar os programas básicos de cidadania.

Outros fatores influenciam na disparidade regional do PAA no Amapá, e principalmente na maior participação do município de Mazagão, refere-se ao processo de seleção dos projetos das organizações agroextrativistas, os critérios são: maior percentual de participação de mulheres, maior percentual de assentados da Reforma Agrária, maiores índices de Insegurança Alimentar e Nutricional (MapaINSAN), os menores valores no orçamento do projeto, maior percentual de produtos orgânicos ou agroecológicos. Em caso de empate na pontuação de projetos, são selecionados em 1 lugar o menor valor de índice de Desenvolvimento Humano Municipal (IDHM); 2ํ Menor valor de per capta por beneficiário Fornecedor e 3ำ critério proposta de participação enviada através do aplicativo via PAAnet (CONAB, 2018).

Segundo o Ministério de Desenvolvimento Social (MDS) (2018), no ano de 2014 Mazagão era considerado pelo MapaINSAN, como município de muito alta vulnerabilidade. Estimava-se que 1.039 famílias estavam em situação de insegurança alimentar e nutricional no Município, sendo 530 na área urbana e 509 na área rural, o que representava 3.112 pessoas. Logo, a alta taxa de vulnerabilidade alimentar e nutricional de Mazagão são um dos fatores que contribuem para sua significativa participação no PAA n estado do Amapá.

Contudo, as informações coletadas elucidam as contribuições do PAA para o fortalecimento da agricultura familiar e para promoção do desenvolvimento rural no estado do Amapá e seus municípios. Evidencia-se também que os cortes orçamentários, ausência dos serviços de assistência técnica, critérios de seleção dos projetos; são entraves que dificultam maior efetividade do programa. 


\section{CONSIDERAÇÕES FINAIS}

A discussão do PAA e suas contribuições ao desenvolvimento rural no Amapá, permitiu dialogar com uma diversidade de temáticas fundamentais para compreensão do programa, tais como: as políticas públicas para agricultura familiar no Brasil, que forneceu o contexto das trajetórias das políticas até a consolidação no PAA; o processo de formação do Estado do Amapá, que situou o lócus da pesquisa; e por fim a análise e discussão dos resultados.

Deste modo, percebe-se que o PAA surgiu com intuito de amenizar as ausências de políticas públicas para agricultura familiar no Brasil. Pois, atua no incentivo da agricultura familiar, para promover sua inclusão econômica e social, bem como incentivar o consumo e a valorização dos produtos da agricultura familiar. Estas características do programa demonstram que sua efetivação contribui diretamente para o desenvolvimento regional, rural e urbano, tendo em vista que promove a permanência das famílias em suas propriedades e fornece alimentos para escolas, associações, casas de apoios, entre outras.

Portanto, as literaturas consultadas e os dados analisados corroboram que a apesar dos entraves encontrados pelo PAA no período de 2010 a 2017 no estado do Amapá, o programa atua no fortalecimento da agricultura familiar, através melhorias socioeconômicas, participação social, valorização do produto oriundo da produção familiar e fornecimento de alimentos para escolas, associações, casas de apoios, entre outros, por isso suas contribuições são fundamentais para promover desenvolvimento rural. No caso das disparidades na participação dos municípios amapaenses, ressalta-se que não estão relacionados apenas a ineficiência do programa, deve-se considerar os aspectos sociais, políticos, econômicos, culturais de cada região/local. Assim, este artigo apresenta-se como uma fonte de conhecimento científico capaz de possibilitar novos estudos sobre as políticas públicas para agricultura familiar no Amapá, em particular sobre o PAA.

\section{REFERÊNCIAS}

BONNETI, L.W. O silêncio das águas: políticas públicas, meio ambiente e exclusão. 2. ed. Ijuí: Unijuí, 2003, p. 20.

BRASIL. Lei federal 11.326, de 24 de julho de 2006. Estabelece as diretrizes para a formulação da Política Nacional da Agricultura Familiar e Empreendimentos Familiares Rurais. Diário Oficial da União, Brasília, DF, 24 jul. 2006. Disponível em: http://www.planalto.gov.br/ccivil_03/_Ato20042006/2006/Lei/L11326.htm. Acesso em: 02 nov. 2018. 
BRASIL. Decreto no 7.775, de 04 junho de 2012. Regulamenta o art. 19 da Lei no 10.696, de 2 de julho de 2003 que institui o Programa de Aquisição de Alimentos, de 4 de julho de 2012. Diário Oficial da União, Brasília, DF, 04 jul. 2012. Disponível em:http://www.planalto.gov.br/ccivil_03/_ato20112014/2012/decreto/d7775.htm. Acesso em: 09 ago. 2018.

BRASIL. Lei no 10.696, de 2 de julho de 2003, repactuação e o alongamento de dívidas oriundas de operações de crédito rural, e dá outras providências, de 02 de julho de 2003. Diário Oficial da União, Brasília, DF, 02 jul. 2003. Disponível:http://www.planalto.gov.br/ccivil_03/LEIS/2003/L10.696.htm. Acesso em: 09 ago. 2018.

BROWDER, J; GODFREY, B. J. Geopolítica, desenvolvimento regional e urbanização: dinâmicas geográficas e históricas da fronteira amazônica. In: BROWDER, J. Cidades da floresta: urbanização, desenvolvimento e globalização na Amazônia brasileira. Manaus: EDUA, 2006, p.76 - 104.

CAVAlLARI, A. A. et al. Programa de Aquisição de Alimentos na Amazônia legal brasileira. Revista de Estudos Sociais, N. 34, V. 17, ano 2015, Pag. 181. Disponível em: http://periodicoscientificos.ufmt.br. Acesso em: 02 ago. 2018.

CHAGAS, M. et al. A articulação entre o complexo verde de Ab'Saber e o complexo urbano de Becker como desafio do desenvolvimento regional: Amapá como um caso amazônico. Revista Brasileira de Pós-Graduação, v. 13, n. 32, 2016. Disponível

em: http://ojs.rbpg.capes.gov.br/index.php/rbpg/article/view/1089. Acesso em: 28 mar. 2018.

COMPANHIA NACIONAL DE ABASTECIMENTO (CONAB). Transparência pública PAA. Brasília, DF, 2018. Disponível em: http://www.conab.gov.br/detalhe.php?a=1296\&t=. Acesso em: 14 ago. 2018.

DIAS, P. O Amapá em perspectiva: municípios do Amapá. Macapá: JM Editora Gráfica 2011.

FAVARETO, A. Paradigmas do Desenvolvimento Rural em questão. São Paulo: Iglu Editora, 2007.

FILOCREÃO, A. S. M. Formação Socioeconômica do Amapá. In: CASTRO, Edna R.; CAMPOS, Índio (Orgs.). Formação Socioeconômica da Amazônia. Belém: NAEA, 2015a, p. 100.

FILOCREÃO, A. S. M. (org.). Amapá 2000-2013. São Paulo: Editora Fundação Perseu Abramo, 2015b.

GRISA, C; SCHNEIDER, S. (Orgs.). Políticas públicas de desenvolvimento no Brasil. Porto Alegre: UFRGS, 2015.

GRISA, C; PORTO, S. I. Dez anos de PAA: As contribuições e os desafios para o desenvolvimento rural. In: GRISA, Catia; SCHNEIDER, Sérgio (orgs.). Políticas públicas de desenvolvimento no Brasil. Porto Alegre: UFRGS, 2015. p. 155-180.

HURTIENNE, T. P. Políticas públicas, sistemas de uso da terra, demografia e desenvolvimento rural sustentável. In: COELHO, M. C. N. et al. Estado e políticas públicas na Amazônia: gestão do desenvolvimento regional. Belém: Cejuo, 2001.

INSTITUTO BRASILEIRO DE GEOGRAFIA E ESTATÍ́STICA (IBGE). Censo demográfico brasileiro, estado do Amapá, Cidades@, 2010a. Disponível em: https://cidades.ibge.gov.br/brasil/ap/panorama. Acesso em: 30 ago. de 2018. 
INSTITUTO BRASILEIRO DE GEOGRAFIA E ESTATístICA (IBGE). Censo Agro, 2017. Disponível em: https://censos.ibge.gov.br/agro/2017/templates. Acesso em: 14 ago. 2018.

LIMA, R. A. P; PORTO, J. Ordenamento territorial amapaense: dinâmicas de um estado brasileiro na fronteira Amazônia. X Colóquio Internacional de Geocrítica,1999-2008, Barcelona, 26 - 30 de mayo de 2008. Disponível em: http://www.ub.edu/geocrit. Acesso em: 10 ago. 2018.

LOUREIRO, V. R. A Amazônia no século XXI: novas formas de desenvolvimento. 1. ed. São Paulo: Empório do Livro, 2009.

MARTINS, J. S. Os camponeses e as políticas no Brasil: as lutas sociais no campo e seu lugar na política. Petrópolis: Vozes, 1981.

MATTEI, L. Impactos do Pronaf: análise de indicadores. Brasília: MDA/NEAD, 2005.

MATTEDI, M.; THEIS, I. Cruzando fronteiras: Conhecimento e interdisciplinaridade na pesquisa em desenvolvimento regional. REDES, v. 7, n. 2, pp (77-94), mai/ago, 2002. Disponível em: https://online.unisc.br. Acesso em:15 mai. 2018.

MINISTÉRIO DO DESENVOLVIMENTO AGRÁRIO (MDA). Plano Territorial de Desenvolvimento Rural Sustentável (PTDRS) Centro Oeste do Amapá. Brasília - DF, 2011. Disponível em: http://sit.mda.gov.br/download. Acesso em: 08 out. 2018.

MINISTÉRIO DO DESENVOLVIMENTO SOCIAL (MDS). Relatório Municipal de Informações de Segurança Alimentar e Nutricional - SAN nos Municípios. Disponível em: https://aplicacoes.mds.gov.br/sagi. Acesso em: 27 dez. 2018.

MULLER, P; SUREL, Y. A análises das políticas públicas. Tradutores Agemir Bavaresco, Alceu R. Ferraro. Pelotas: Educat, 2002.

OLIVEIRA, J. A. A cultura na (das) pequenas cidades da Amazônia brasileira. In: VIII Congresso Lusoafro-brasileiro de Ciências Sociais, Coimbra, 16 a 18 de setembro, 2004.Disponível:http://www.ces.uc.pt/lab2004/inscricao/pdfs/painel74/JoseAldemirdeOliveira.pdf. Acesso em: 15 mai. 2018.

PEREIRA, J. M; ALENTEJANO, P. El agro brasileño: de la modernización conservadora a la hegemonía del agronegócio. In: ALMEYRA, Guillermo. et al. Capitalismo: tierra y poder em América Latina (19822012). Vol. I. Buenos Aires: Ediciones Continente, 2014.

PORTO, J. L. R. Amapá: principais transformações econômicas e institucionais (1943 - 2000). 2. ed. Macapá: Edição do Autor, 2007.

ROSA, T. A. L. Localização do Estado do Amapá. Bases de dados do IBGE (2003) e SEMA (2003), 2018.

SALGADO, R. J. S. F. et al. Focalização e Cobertura do Programa de Aquisição de Alimentos (PAA): avaliação de sua eficácia nas regiões brasileiras. RESR, Piracicaba-SP, Vol. 55, № 04, p. 661-678, Out/Dez 2017, Impressa em Dezembro de 2017. Disponível em: www.scielo.br/scielo.php?script=sci. Acesso em: 10 ago. 2018. 
SANTOS, J. V.T. dos. Colonos do Vinho: estudo sobre a subordinação do trabalho camponês. São Paulo: HUCITEC, 1978.

SEN, A. K. Desenvolvimento como liberdade. Trad. Laura T. Motta. Rev. Ricardo D. Mendes. São Paulo: Companhia das Letras, 2000.

SILVA, J. G. da. O que é questão agrária. São Paulo: Brasiliense, 1981.

SILVA, I. C; FILOCREÃO, A. S. M; LOMBA, R. M. Programa de aquisição de alimentos no território da cidadania sul do amapá. Anais do XXIII Encontro Nacional de Geografia Agrária. São Cristovão-SE, 2016. Disponível em: enga.com.br/anais. Acesso: 10 jul. 2018.

SILVA, I. C; FILOCREÃO, A. S. M. Perspectivas para a agricultura familiar no Amapá. In: LOMBA, Roni M. et. al. (orgs.). Conflito, territorialidade e desenvolvimento: algumas reflexões sobre o campo amapaense. Dourados, MS: Ed. UFGD, 2014.

SILVA, I. C; LOMBA, R. M. Aspectos da importância da agricultura familiar no Estado do Amapá. In: VII Encontro Internacional de Produção Científica, 2011, Maringá-PR. Anais eletrônicos do Centro Universitário de Maringá-CESUMAR. Maringá: CESUMAR, 2011. Disponível em: www.cesumar.br/prppge/pesquisa/epcc2011/anais/irenildo_costa_silva2.pdf. Acesso em: 10 ago. 2018.

TOSTES, J. A; FERREIRA, J. F. C. O corredor transfronteiriço entre o Amapá (BR) e a Guiana Francesa (FR). Revista de Geopolítica, Natal, v. 7, no 1, p. 152-170, jan/jun. 2016. Disponível:www.revistageopolitica.com.br/index.php/revistageopolitica/article/view/129/154.

Acesso em: 03 jun. 2018.

TOSTES, J. A. Formação institucional e desenvolvimento regional no estado do Amapá. Coleção Formação Regional da Amazônia, Belém, v. I, 2014a. Disponível em:pt.scribd.com/document/373994040/Cap-TOSTES-Jose-A-Formacao-institucional-e desenvolvimento-regional-no-estado-do-Ap-pdf. Acesso em: 03 jun. 2018.

TOSTES, J. A. Do tijolo nu ao concreto bruto. Macapá: UNIFAP, 2014b, 161 - 164.

VALNIER, A; RICCI, F. Programa de Aquisição de Alimentos (PAA): uma análise comparativa nos estados de Rondônia e Acre. Campo-Território: revista de geografia agrária, v. 8, n. 16, p. 198-228, ago., 2013. Disponível em: http://www.seer.ufu.br/index.php/campoterritorio/article/view/21732/13079. Acesso em: 02 ago. 2018.

VEIGA, J. E. Cidades Imaginárias: o Brasil é menos urbano do que se calcula. 2. Ed. Campinas, SP: Autores Associados, 2003.

WANDERLEY, M. N. B. Agricultura familiar e campesinato: rupturas e continuidade. Revista Estudos Sociedade e Agricultura, Rio de Janeiro, 21, outubro, 2003: 42-61. Disponível em: https://wp.ufpel.edu.br/leaa/files/2014/06/Texto-6.pdf. Acesso em: 20 ago. 2018.

WELCH, C. et al. Camponeses Brasileiros: leituras e interpretações clássicas. Vol. 1. São Paulo: UNESP, 2009. 


\section{Capítulo 6}

\section{ANÁLISE DA CADEIA DA CENOURA: UM ESTUDO DE CASO NO ESTADO DO PARANÁ}

DOI: $10.37423 / 200300367$

Greici Joana Parisoto - greiciarrosi@gmail.com

Samanta Ongaratto Gil - samantagil@hotmail.com

Ivaneli Schreinert Dos Santos - ivaneli.schreinert@ufrgs.br

Camila Soares Cardoso - camilascardoso@outlook.com

Paulo Vinícius de Miranda Pereira - paulo.pereira@ifac.edu.br

Laura Possani - laurapossani@gmail.com

Vania Di Addario Guimarães - vania.di@ufpr.br

Resumo: A cenoura (Daucus carota) qualifica-se como uma das principais olerícolas no Brasil e um dos impasses para o crescimento da cultura no país ainda é a falta de informações a respeito do mercado. Desta forma, o objetivo deste trabalho foi conhecer um pouco mais do comércio de cenoura, no Paraná, do ponto de vista de um comerciante e pela análise de preços e margens de comercialização. Foi feito um estudo exploratório-descritivo em duas etapas, sendo uma através de pesquisa primária e a segunda com a aplicação das análises de tendência, sazonalidade e margens de comercialização nos preços previamente deflacionados da cenoura, após serem coletados em nível de produtor, atacado e varejo, no período compreendido entre 2007 e 2016. 
De acordo com o estudo realizado, a falta de um padrão de preços para o mercado da cenoura é um agravante e faz com que estimule o abandono da atividade por parte de agentes atuantes no setor. Os preços da cenoura apresentaram tendência de alta ao produtor $(r=1,85 \%)$, no atacado $(r=2,53 \%)$ e no varejo $(r=1,50 \%)$, indicando aumento na demanda do produto no estado do Paraná, no período analisado. Há a ocorrência de um padrão de preços maiores no início do ano, entre fevereiro e abril principalmente, $20 \%$ a mais que a média anual, e em julho, novembro e dezembro $15 \%$ a menos, em média, nos três níveis estudados, segundo índices sazonais calculados.

Na média anual, cerca de $60 \%$ do preço pago pelo consumidor no quilograma da cenoura é destinado ao setor de comercialização, como atacado (18,14\%) e varejo (39,25\%).

Palavras-chave: Mercado da cenoura. Análise da Tendência. Sazonalidade. Margens de Comercialização. 


\section{INTRODUÇÃO}

Em termos do número de produtos gerados pelo setor agropecuário brasileiro, a olericultura se destaca com um volume negociado de aproximadamente 15 milhões de toneladas por ano. Segundo dados do Sistema de Informações dos Mercados de Abastecimento do Brasil (SIMAB), essas hortaliças são provenientes da produção nacional e importada, perfazendo um montante de mais de $\mathrm{R} \$ 10$ bilhões no atacado, o qual detém entre $55 \%$ e $60 \%$ do volume total de hortaliças comercializadas no país.

De acordo com Zamberlan et. al. (2014), a horticultura é um dos setores agrícolas que mais cresce mundialmente, acompanhado de seu consumo que tem amplo crescimento em comparação a outros produtos agrários. Como exemplo, tem-se o mercado de sementes desta área, que cresceu 700\% em 15 anos, a partir de 2001. No início desse período, estimava-se R\$114,4 milhões movimentados, enquanto em 2015, atingiu o valor de R\$ 800 milhões, segundo estimativas da Associação Brasileira do Comércio de Sementes e Mudas (ABCSEM).

Além disso, é uma atividade mais comum em pequenas propriedades rurais, envolvendo um grande número de famílias rurais. No entanto há poucos estudos sobre os mercados dos produtos desse setor. Pouco se conhece dos canais de comercialização desses produtos; quais os agentes envolvidos; como é o processo de formação de preços; critérios de qualidade, entre tantos outros aspectos relevantes. Segundo Souza et. al. (1998), o desconhecimento do mercado onde o produtor rural atua pode resultar em remuneração incompatível com o mercado e até mesmo em perda total da produção.

De acordo com Faria \& Souza (2014), o comércio de produtos hortifrutigranjeiros, até meados dos anos 60, era uma prática informal nos centros urbanos. Conforme o fluxo de pessoas, os produtores da região ofereciam seus produtos, de acordo com a época de produção, em locais planejados ou entregavam à domicílio. Complementar a isso, ainda ocorre a venda direta por produtores, normalmente aos sacolões, supermercados, feiras livres ou comércio em veículos de transporte.

Dentre os produtos do setor, a cenoura (Daucus carota) qualifica-se como uma das principais olerícolas no Brasil, estando entre as cinco mais comercializadas e a sétima mais exportada em 2016 (CARVALHO et. al., 2016). Também é considerada uma das hortaliças de raiz mais importantes por seu valor econômico e consumo anual de aproximadamente $4,29 \mathrm{~kg} /$ pessoa (FREITAS et al., 2009).

Segundo Silva \& Carvalho (2015), os principais estados produtores são Minas Gerais, São Paulo, Rio Grande do Sul, Paraná, Bahia e Goiás, que juntos, produzem cerca de $90 \%$ da produção nacional. A aferição da área plantada no Brasil em 2015 foi de 24,1 mil hectares, com produção de 760,6 mil 
toneladas de raízes e produtividade média de 31,6 toneladas por hectare, de acordo com o Instituto Brasileiro de Geografia e Estatística (IBGE).

Contudo, mesmo o Brasil sendo uma potência na agricultura e precursor das pesquisas na área rural, o setor encara inúmeras dificuldades por razão de doenças e pragas, planejamento de produção mal feito, logística ineficiente, entre outras. Desta forma, o objetivo geral deste trabalho foi conhecer um pouco mais do mercado de cenoura no estado do Paraná, apresentando o "modus operandi" de um comerciante de cenoura e a visão que ele tem desse mercado na sua área de atuação, além da análise de preços e margens de comercialização.

\section{PANORAMA GERAL DA CENOURA NA HORTICULTURA}

O ramo de atividade de olerícolas, segundo Mourão \& Magalhães (2011), é o que mais movimenta a economia brasileira, ganhando dos cereais, oleaginosas e de grandes empresas do setor varejista. Também é o setor que vem apresentando maior crescimento e maior aumento no consumo em comparação com os demais produtos agrícolas. Em 2009, segundo dados da Abracen (Associação Brasileira das Centrais de Abastecimento), o montante comercializado no atacado nacional foi de aproximadamente 17 milhões de toneladas, chegando próximo a R\$ 17 bilhões (US\$ 10,0 bilhões) movimentados.

A produção de frutas e hortaliças no Brasil é proveniente, em sua grande maioria, de pequenas propriedades, de várias origens. São culturas que viabilizam alto retorno econômico por área, alta taxa de emprego de mão de obra direta e indireta, com retorno do investimento rápido, favorecendo as propriedades familiares e o aumento do consumo (MOURÃO \& MAGALHÃES, 2011).

Desde 2005, o setor de horticultura passou a ter um apoio decretado pelo MAPA e operacionalizado pela Conab (Companhia Nacional de Abastecimento), por meio do Prohort ${ }^{1}$.

No Brasil, a cenoura é um exemplo da influência tecnológica positiva, resultante de estudos na área agrícola, que contribuem para a prosperidade de inúmeras localidades, por meio de proveitos socioeconômicos oferecidos para a comunidade. O mercado da cenoura, até meados de 1980, era restrito às classes de maior poder aquisitivo, devido ao plantio da mesma ser inviável no verão, na perspectiva técnica e econômica naquela época, pela ocorrência da doença de queima-das-folhas, de controle moroso (VILELA \& CARVALHO, 2015).

De 1976 a 1981 a Embrapa Hortaliças juntamente com a ESALQ/USP por meio de estudos em busca de novas cultivares, lançaram a cultivar chamada "Brasília', para cultivo na estação mais quente do 
ano. As cenouras conhecidas hoje como de verão ou do 'grupo Brasília', são resultados desse programa de melhoramento, que deu origem a diversas cultivares, partindo da seleção de seus genótipos. A cultivar de verão BRS Planalto, de mesa, lançada em 2009, por exemplo, é uma delas e mesmo apresentando alta capacidade de produção, alto grau de tolerância à doença mais severa da cultura e benefícios expressivos no desenvolvimento das raízes (VIEIRA et al., 2012), não compete com os modernos híbridos dominantes no mercado atualmente. Desta forma, a Embrapa tem buscado obter cultivares de verão a partir dos híbridos comerciais disponíveis (CARVALHO et. al., 2015).

Hortaliça da família Apiáceae e do grupo das raízes tuberosas, a cenoura (Daucus carota L.) consiste em uma raiz de aroma e sabor agradável, qualificando-se entre as olerícolas de maior importância para produção agrícola, pelo seu elevado consumo mundial, tamanho da área cultivada e vasto desenvolvimento socioeconômico dos olericultores. É considerada a quinta hortaliça mais cultivada no Brasil, manifestando maior produção no período de julho a novembro (OLIVEIRA et al., 2003; ALVES, 2013).

Segundo Vilela \& Borges (2008), a cenoura é evidenciada especialmente por possuir alta capacidade de criação de emprego e renda nos inúmeros segmentos de sua cadeia produtiva durante todo o ano. Para atingir o padrão de qualidade brasileiro, durante a comercialização, as raízes devem apresentar 16 a $22 \mathrm{~cm}$ de comprimento, $3 \mathrm{~cm}$ de diâmetro aproximadamente, forma cilíndrica, sem pigmentação roxa ou verde na porção superior (ombro), tonalidade alaranjada, etc. (LANA \& VIEIRA, 2000). Preferem-se raízes que propiciam uma vista agradável ao produto, em que as cores entre o xilema e o floema são racionadas de forma mais homogênea (CARVALHO et. al., 2017).

Segundo Filgueira (2008), o cuidado com a saúde e a busca por alimentos mais saudáveis são predisposições no mundo inteiro e a cenoura, que possui elevados índices de 'vitamina $A$ ', aspecto estrutural macio e gosto apetitoso pode ter aumento em sua procura.

Além do consumo in natura, também é empregada em indústrias de processamento de alimentos, como matéria prima, onde a comercializam como minimamente processados (mini cenouras, cubos, ralada, em rodelas) ou preparados para seleta de legumes, comidas infantis e sopas instantâneas (VIEIRA, 2008).

A cenoura é cultivada em grandes proporções nas regiões Sudeste, Nordeste e Sul do Brasil. Os municípios grandes produtores são: Carandaí, Santa Juliana e São Gotardo (Minas Gerais); Piedade, Ibiúna e Mogi das Cruzes (São Paulo); Marilândia (Paraná) e Lapão e Irecê (Bahia). Apesar de produzir mais em locais de clima mais frio, ultimamente, em vista do lançamento de cultivares tolerantes a 
maiores temperaturas além da resistência às doenças de maior importância, o cultivo de cenoura tem ganhado espaço também nos estados de Goiás e Bahia (SILVA \& CARVALHO, 2015).

Para cultivar essa raiz é essencial ter conhecimento da adequação de cada cultivar para o clima do local. Para o inverno, são recomendadas as cultivares do grupo Nantes, as quais exigem temperaturas amenas, não sendo tolerantes à pluviosidade e temperatura altas, pois favorecem o aparecimento da doença queima das folhas. Para o cultivo no verão, recomenda-se cultivares do grupo Brasília, como a Carandaí, Alvorara e Esplanada, resistentes à queima das folhas, adaptando-se à alta temperatura e maiores níveis de pluviosidade (FILGUEIRA, 2008; PAULUS, et. al., 2012).

Segundo Carvalho et. al. (2016) o bom desempenho no plantio de cenoura no ano de 2015 influenciou no acréscimo do cultivo da raiz no ano de 2016, chegando a pouco mais de 15 mil hectares plantados na safra 2016/2017, 3,29\% a mais que na safra 2015/2016.

De acordo com os dados de Produção Agrícola Municipal (PAM), do Instituto Brasileiro de Geografia e Estatística (IBGE), em 2015, produziram-se 760,6 mil toneladas de cenoura em todo o Brasil, ficando abaixo da média trienal antecessora de 780.300 toneladas. Ainda segundo Carvalho et. al. (2016), com dados do IBGE, a produtividade média nacional foi de 31,6 toneladas por hectare, em 2015. No estado de Minas Gerais, maior produtor da olerícola, o rendimento médio foi de 39,7 toneladas por hectare, colhendo cerca de 280 mil toneladas em pouco mais de sete mil hectares. Outros números de produção expressivos são encontrados nos estados de Rio Grande do Sul, Paraná, Bahia e Goiás.

Segundo Morgado et. al. (2004) para que a produção agrícola cresça, com aumento da produtividade e área plantada, é necessário também que haja expectativas sólidas de crescimento no consumo. Sendo assim, o mercado deve ser analisado, pois, devido às particularidades de produção e consumo de cada produto agropecuário, seus preços inclinam-se a reproduzir certos modelos de comportamento.

\section{MATERIAL E MÉTODOS}

O presente trabalho caracteriza-se como um estudo exploratório-descritivo, realizado em duas etapas, onde, segundo Vergara (2007), essa forma de pesquisa descreve especificadamente certo fenômeno, se deparando tanto com aspectos qualitativos quanto quantitativos, em que se analisa uma área em que se tem pouca clareza e conhecimento estruturado.

Desta forma, foi feita uma pesquisa primária através de entrevista com um comerciante intermediário, no setor de hortaliças, mais especificadamente no comércio de cenoura. Ele atua na região 
metropolitana de Curitiba, sendo seu principal ponto de comercialização a unidade da Central de Abastecimento (CEASA/PR) localizada na capital paranaense.

Foram feitas perguntas através de diálogo aberto para o comerciante a respeito de diferentes aspectos, como o número de membros e composição do núcleo familiar, grau de escolaridade, número de espécies de hortaliças comercializadas. Também foi questionado a respeito do seu processo de comercialização, desde a compra (origem, variedade e quantidade), busca, limpeza e classificação até a entrega da produção e o impacto na renda de modo a entender como se dão as relações nesse mercado e quais os serviços que são adicionados.

Para análise da segunda etapa, foram utilizadas as séries históricas dos preços nominais mensais da cenoura ao produtor e no varejo, no estado do Paraná, com dados obtidos junto à Secretaria Estadual de Agricultura e Abastecimento do Estado do Paraná (SEAB - PR). E a série histórica dos preços nominais mensais da cenoura, através da Central de Abastecimento do Paraná (CEASA/PR), unidade situada em Curitiba, com dados disponibilizados no PROHORT - CONAB. O período compreendido dos dados foi de janeiro de 2007 a dezembro de 2016.

Inicialmente os dados foram deflacionados utilizando o índice IGP - DI da FGV, atualizando-os para valores reais com base no mês de dezembro de 2016.

Para realizar a estimativa da tendência, utilizou-se o método dos mínimos quadrados, de acordo com Johnston (1977). Para calcular a tendência linear, foram considerados os preços médios anuais reais (deflacionados) da cenoura dos últimos 10 anos.

A determinação dos índices sazonais foi feita utilizando o Método da Média Aritmética Móvel Centralizada (MAM), como descrito por Hoffman (1980), seguindo esse modelo para 12 meses. Esta metodologia é recomendada para estimativas de curto prazo de modo que os elementos da tendência e sazonalidade sejam capazes de ser desprezados ou ilusórios (MAKRIDAKIS et. al., 1998) e busca aferir as cotações durante o ano e a flutuação média de modo que seja estatisticamente significativa (GUIMARÃES \& STEFANELO, 2003).

Por fim, estimou-se a Margem de Comercialização Relativa Total e a diferença entre o preço pago pelo consumidor e o preço recebido nos vários níveis do complexo de comercialização, no Atacado e no Varejo, baseados em Barros (1987). Essas equações demonstram o valor relativo do preço recebido nos vários níveis do complexo de comercialização, onde a remuneração a esses operadores é compatível aos serviços que eles acrescentam ao produto, ou seja, é a porção do preço pago pelo consumidor, que não chega ao produtor. 
Para o cálculo e sistematização dos presentes dados, foram utilizadas planilhas do software Microsoft Excel 2016.

\section{RESULTADOS E DISCUSSÃO}

\subsection{PESQUISA PRIMÁRIA}

O comerciante entrevistado é originário da Região Metropolitana de Curitiba, o qual trabalha com sua esposa e filhos e cerca de 10 funcionários fixos, entre motoristas e ajudantes, mais a mão-de-obra adicional contratada para períodos de maior demanda na lavagem dos produtos. Seu principal ponto de comercialização é na unidade da Central de Abastecimento (CEASA) localizada em Curitiba - PR. Trabalha com cenoura híbrida de alta qualidade o ano todo. Durante os meses de dezembro a março, seus fornecedores são principalmente da região sul e de março a novembro o maior volume vem dos estados de Minas Gerais e São Paulo, devido às dificuldades para se produzir na região sul, na época do inverno, segundo ele. A média do volume de vendas semanal é de quatro mil caixas com $20 \mathrm{Kg}$ cada, ou seja, de três a quatro cargas de caminhão por semana. Também trabalha com beterraba, batata salsa, cebola e outras olerícolas conforme a disponibilidade sazonal.

Segundo o entrevistado não há contratos formais ou informais entre produtores e comerciantes. 0 que ocorre é o aviso por parte dos produtores, aos compradores, no momento em que a lavoura está sendo instalada para que esses possam ir até a propriedade e acompanhar o andamento da lavoura, onde poderão deixar sinais de interesse, ou não, na compra. Porém, o produtor não é obrigado a vender sua produção a esse intermediador que o está visitando, entregando o produto de acordo com o maior preço que lhe é ofertado até o período de sua colheita.

Desta forma, o produtor fica à mercê do preço no mercado local no momento da colheita, correndo o risco ainda de não conseguir vender sua produção caso não haja comprador. Este tipo de mercado é caracterizado como sendo totalmente livre, onde os preços de compra e venda são negociados diariamente, sem restrição.

Segundo informações da entrevista, é de responsabilidade do comerciante: o frete, desde a lavoura até o comprador final/indústria/comércio, ou seja, realiza a busca e a entrega do produto; a limpeza e a embalagem das hortaliças, necessitando de estrutura para realizar ambas as operações e a cobertura dos custos até a entrega da produção, que serão repassados para o próximo comprador, por isso deve trabalhar com capital de giro alto. 
O veículo carregado na lavoura segue para o parking house ("lavador e classificador"), normalmente de propriedade do comerciante, onde as cenouras serão lavadas, com auxílio de máquina especializada para tal, separadas e embaladas de acordo com seu tamanho e qualidade. Após limpas e secas são colocadas em caixas de papelão devidamente identificadas com origem e nome da empresa para controle e rastreamento do produto agrícola, prontas para serem vendidas.

A operação de lavagem deve ser feita em, no máximo, dois dias após a colheita. Deve-se ter esse cuidado para evitar perdas na produção devido às doenças adquiridas ainda na lavoura, como por exemplo, a podridão mole causada pela bactéria Pectobacterium carotovora, entre outros fatores agravados pelo clima, já que no caso estudado, o comerciante não possui câmara frigorífica para estocagem dos produtos. Quando a cotação do mesmo está supervalorizada, utilizam a prática de aluguel de câmaras frigoríficas para não perderem totalmente a carga, caso ainda não a tenham vendido.

Quando um grande comprador, como uma Rede de Supermercados, por exemplo, solicita um volume " $n$ " para a semana e durante a semana reduz esse volume, faz com que sobrem produtos para o comerciante. Caso este não consiga vender rapidamente, gerará grandes prejuízos para ele, pois comprou mais matéria prima considerando o volume inicial "vendido", não tendo compradores reservas para substituir rapidamente.

Ainda, conforme informações obtidas com a entrevista, para a operacionalização do frete, o comerciante necessita ter veículos de carga disponíveis para buscar a produção na propriedade agrícola, onde o carregamento é de responsabilidade do produtor. A carga é encaminhada para lavagem, de responsabilidade do intermediador e após é carregado o caminhão novamente e enviada a carga até o próximo comprador, podendo ser de qualquer parte do país. Feito o descarregamento no destino final, que é de responsabilidade do cliente, está finalizada a obrigação do comerciante. As principais dificuldades apontadas pelo comerciante da região metropolitana de Curitiba, segundo entrevista realizada, são a volatilidade dos preços, existência de preço diário para diferentes regiões sem base para consulta, utilização de negociações realizadas no dia anterior e no atual como referências de preços, entre outras. A difícil fidelização de clientes, visto que o mercado é totalmente livre, possibilitando que qualquer pessoa feche negócio com produtores e compradores e a incerteza do volume de compra e venda, pelo fato de não existirem contratos, também são fatores agravantes do setor.

Desta forma, alguns impasses para o crescimento da cultura da cenoura no país ainda é a falta de informações a respeito do mercado, em todos os níveis de produção e comercialização da raiz. A falta 
de um padrão de formação de preços e sua volatilidade ao longo do ano dificultam o planejamento do cultivo e, em contrapartida, possibilitam grandes lucros ocasionais na comercialização da olerícola.

\subsection{ANÁLISE DAS TENDÊNCIAS}

Os preços reais (deflacionados) da cenoura ao produtor, no atacado e no varejo, no período de 2007 a 2016 (FIGURA 1), no estado do Paraná, apresentaram tendência de alta, devido à uma sucessão de picos a longo prazo e quedas pontuais, com uma taxa média de variação anual de 1,85\%, 2,53\% e $1,50 \%$, respectivamente, apontando o caminho em que os preços seguiram ao longo dos anos (GUIMARÃES \& STEFANELO, 2003).

A cenoura, assim como outros produtos hortícolas, não possui uma metodologia padronizada de formação de preços, devido à sua estrutura de mercado, a qual é sinalizada principalmente, pela oferta e demanda diária do produto, já que possui alta perecibilidade, dificultando as negociações em longo prazo, por isso as oscilações frequentes nas análises de tendência do produto.

Figura 1 - Preços reais (deflacionados) da cenoura ao produtor, no varejo e no atacado, no período de 2006 a 2016, no Paraná.

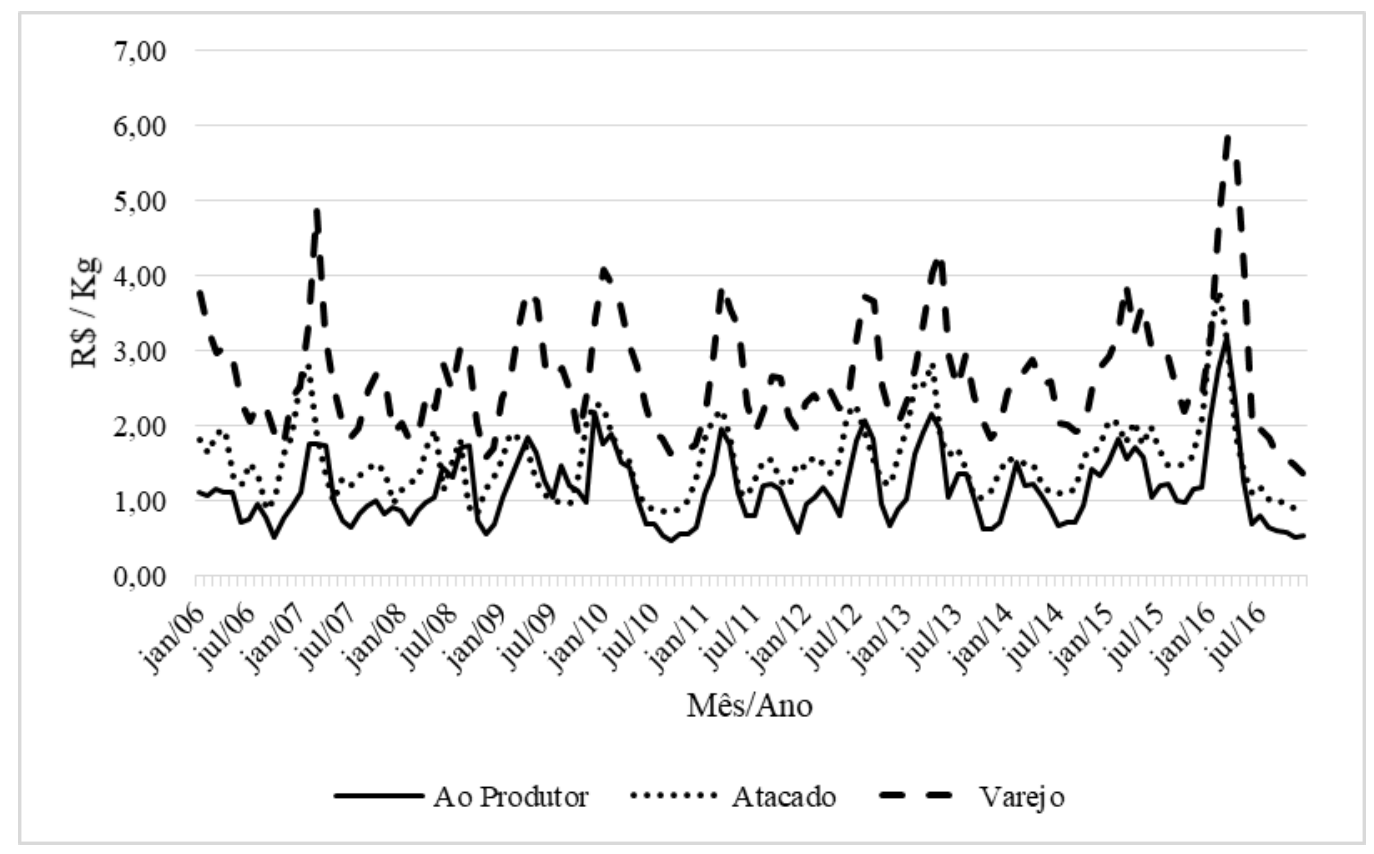

Fonte: Dados básicos SEAB/DERAL e PROHORT - CONAB, cálculo as autoras (2017).

Os preços reais ao produtor (FIGURA 2) apresentaram tendência linear positiva, com os maiores preços nos anos de 2009, 2015 e 2016, atingindo cotações médias anuais na casa de $R \$ 1,60$ e $R \$ 1,54$ por 
quilograma da cenoura, respectivamente. Os anos que apresentaram os menores valores médios foram o de 2008, 2010 e 2014, com $R \$ 1,22$, $R \$ 1,13$ e $R \$ 1,23$ / Kg de cenoura, na devida ordem.

Figura 2 - Tendência linear e preços reais da cenoura ao produtor, no estado do Paraná, no período de 2007 a 2016.

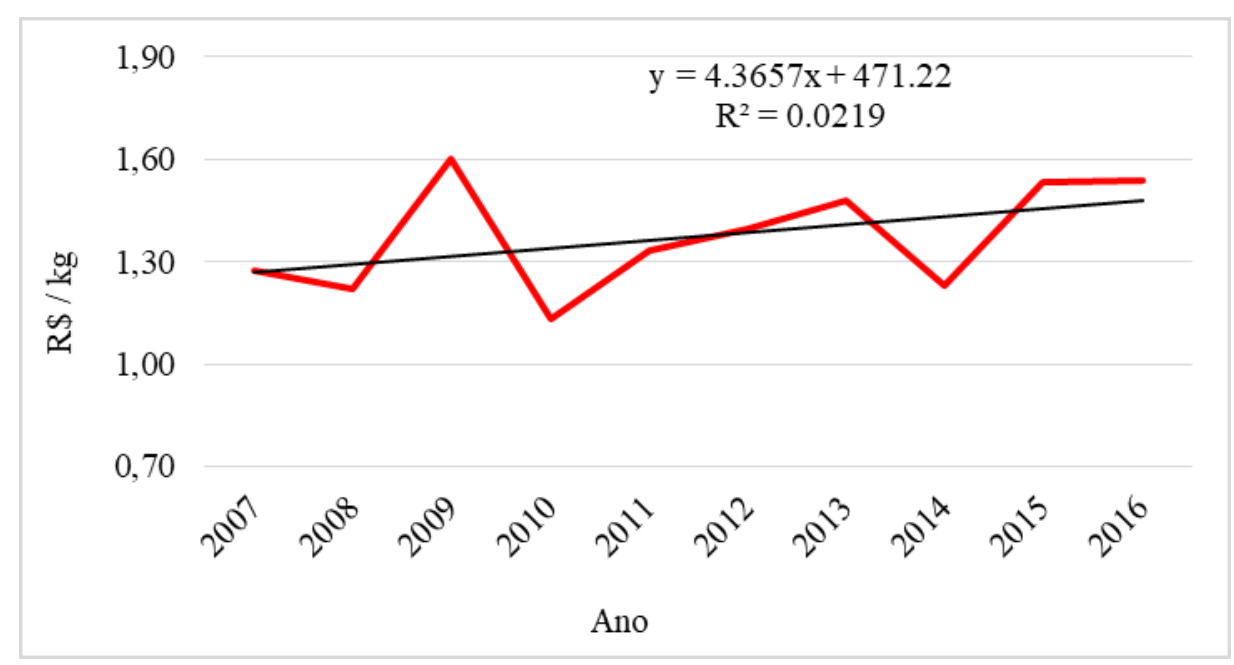

Fonte: Dados básicos SEAB/DERAL, cálculo as autoras (2017).

No atacado, os preços se comportaram de maneira semelhante ao nível de produtor no final do período, ocorrendo os picos médios anuais em 2013, 2015 e 2016 com preços acima de $\mathrm{R} \$ 1,77 / \mathrm{Kg}$. A cenoura comercializada in natura no Ceasa de Curitiba sofreu maior desvalorização nos anos de 2008, 2010 e 2014, chegando a importâncias menores que $R \$ 1,40 / \mathrm{Kg}$, como pode ser visto na Figura 3.

Figura 3 - Tendência linear dos preços da cenoura no atacado Ceasa de Curitiba-PR, 2007 a 2016.

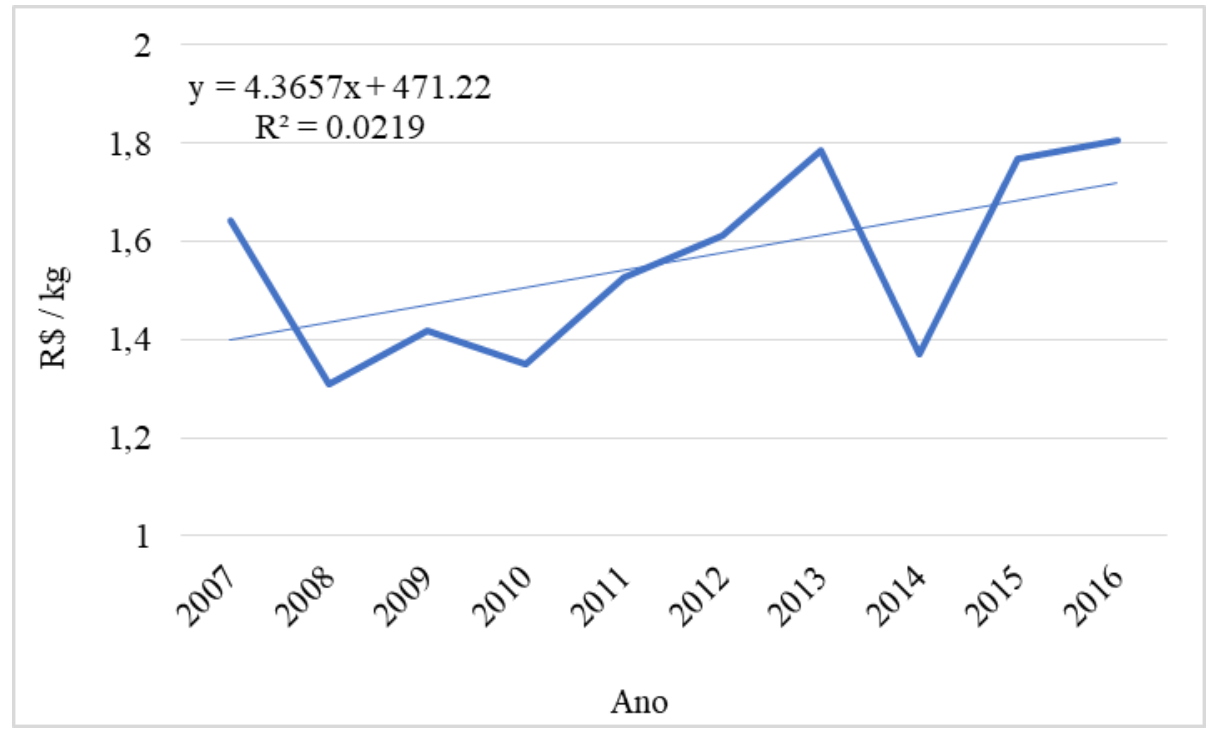

Fonte: Dados básicos PROHORT - CONAB, cálculo as autoras (2017). 
No mercado varejista, a cenoura obteve maior queda nas médias anuais de 2008 , chegando a $\mathrm{R} \$$ 2,26/Kg e em 2014 alcançando a média anual de $\mathrm{R} \$ 2,43 / \mathrm{kg}$, como pode ser visto na Figura 4. Os picos no varejo ocorreram nos últimos anos da série histórica, cotando a olerícola a R\$ 2,98 o kg em 2015 e $\mathrm{R} \$ 2,94$ o kg, em 2016.

Figura 4 - Tendência linear dos preços da cenoura no varejo, no estado do Paraná, 2007 a 2016.

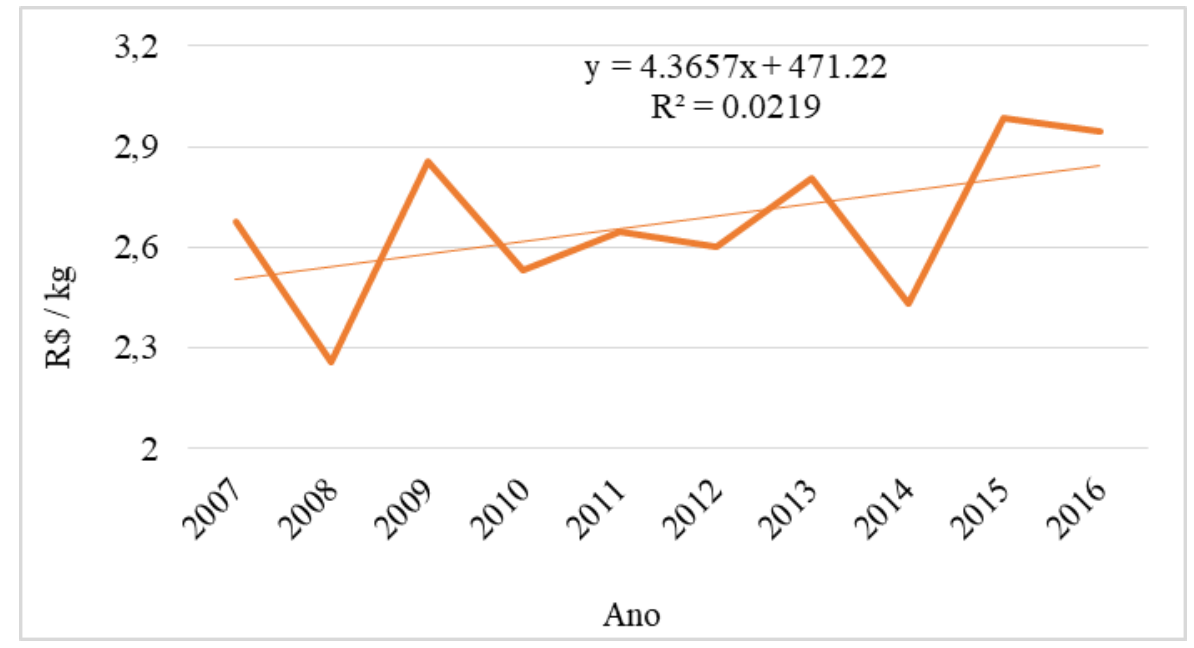

Fonte: Dados básicos SEAB/DERAL, cálculo as autoras (2017).

Os preços no período sofreram amplitudes menores, podendo ser explicadas pela regulação dos preços. Esta regulação é feita no varejo para que o consumidor não sinta, com tanta frequência, as oscilações que ocorrem na cadeia e não diminua seu consumo do produto por ter um preço instável.

\subsection{SAZONALIDADE E PROCEDÊNCIAS}

A sazonalidade dos preços, ou seja, a variação média destes dentro do ano, pode ser demonstrada pelo "Índice de Sazonalidade", onde visualiza-se a abrangência das oscilações com base no índice médio igual a 100 (VIANA et. al., 2010).

Os índices sazonais apresentados pelos preços médios da cenoura pagos ao produtor, no atacado e no varejo, no período de 2011 a 2015, apresentaram curvas semelhantes. As cotações mais altas se deram no período de fevereiro a abril, período de maior compra do produto a partir de outros estados e preços menores quando há maior oferta paranaense, nos meses de julho, novembro e dezembro.

Nos preços ao produtor no Paraná, houve maior remuneração aos produtores no mês de março, pois devido ao clima e a cultura ser muito sensível a doenças em épocas mais frias, inviabilizando sua produção, no verão é quando se produz a cenoura de maior qualidade no estado, chegando a receber 
valores de até $63 \%$ maiores que a média anual, segundo o padrão sazonal apresentado na Figura 5. Após esse período, os preços começam a cair a medida que a oferta da olerícola aumenta, pois realizase importação de outros estados, como Minas Gerais, São Paulo e Espírito Santo, que possuem calendário de produção diferente dos estados da região sul do Brasil. Os preços reagem no mês de julho e voltam a cair em setembro, ficando nessa situação até o início do próximo ano.

Figura 5 - Padrão sazonal dos preços da cenoura ao produtor, no Paraná, no período de 2011 a 2015 (Média Aritmética Móvel).

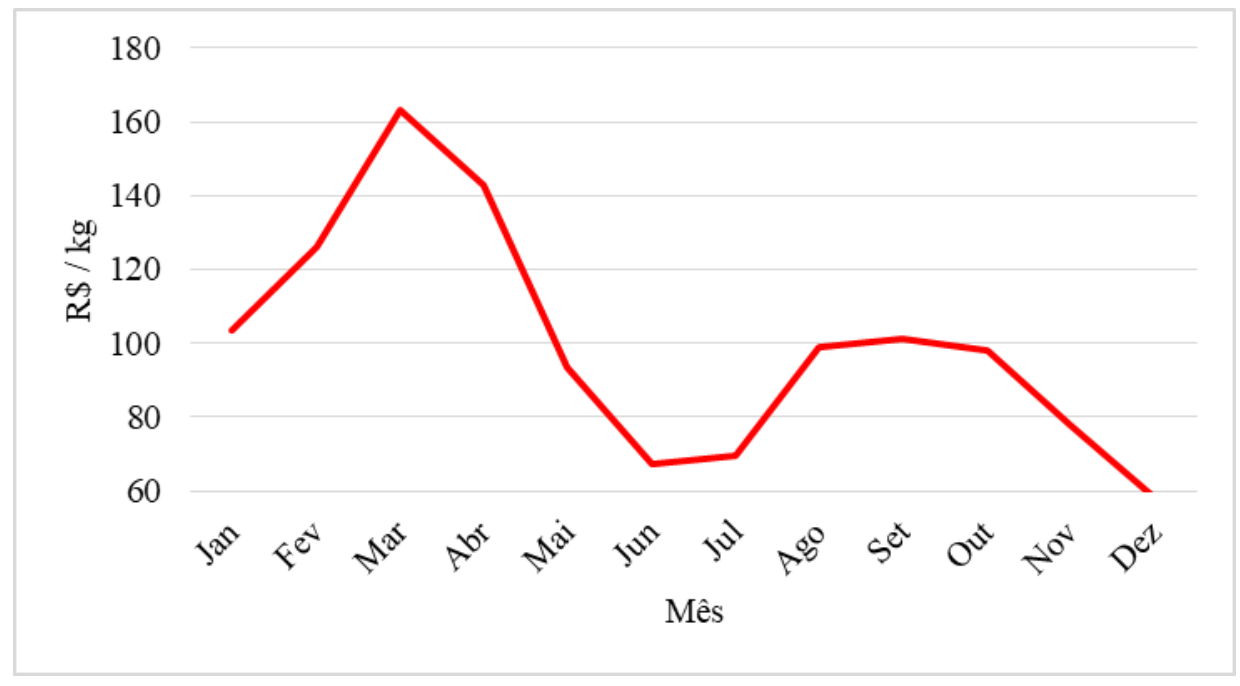

Fonte: Dados básicos SEAB/DERAL, cálculo as autoras (2017).

Uma saída para esses produtores contornarem essa tendência sazonal seria a utilização de novas cultivares adaptadas a épocas/regiões diferentes das mais comuns que se adaptassem a situações diversas possibilitando uma maior oferta do produto quando o mercado está mais favorável para ele. Mas para isso, seria ideal que houvessem mais estudos conjuntamente com os órgãos competentes e pessoas capacitadas para se adequarem a essa demanda.

A curva sazonal das cotações da cenoura no atacado de Curitiba pode relacionar-se com as procedências do produto no setor atacadista, mostrados na Tabela 1. Os preços cotados durante o segundo semestre se mostraram menores em relação ao primeiro semestre (FIGURA 6), pois a partir de junho a compra da cenoura paranaense, mais próxima ao atacado, geograficamente, possui menor custo de frete logicamente, mostrando-se mais competitiva, dominando o mercado e derrubando os preços nessa época. 
Figura 6 - Padrão sazonal dos preços da cenoura no atacado, em Curitiba, no período de 2011 a 2015 (Média Aritmética Móvel).

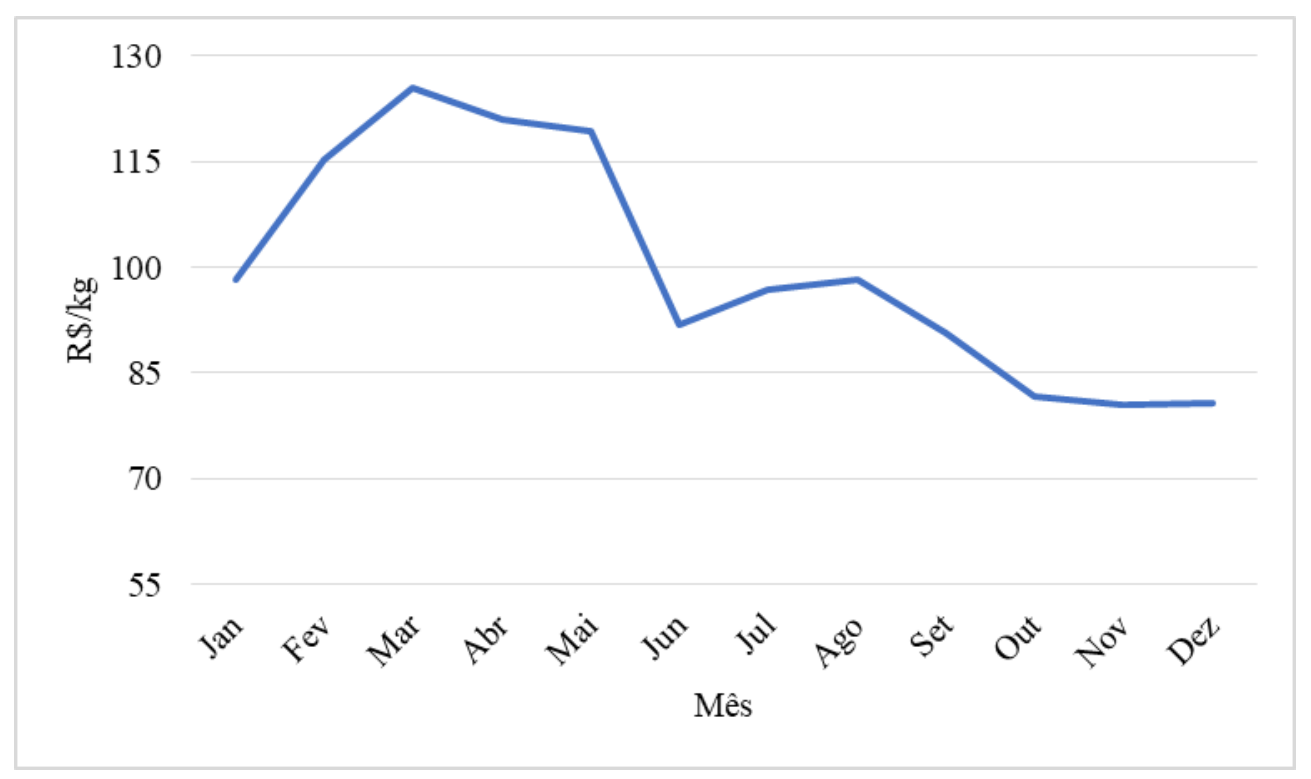

Fonte: Dados básicos PROHORT - CONAB, cálculo as autoras (2017).

Na Figura 6 observa-se uma variação da curva sazonal muito próxima à do atacadista, significando que os preços repassados ao consumidor são parecidos com os do atacado corrigidos pela margem de comercialização mais o lucro do varejista.

No caso dos comerciantes, estudos e práticas que possibilitassem o aumento do tempo de prateleira dos produtos, traria mais espaço para eles comercializarem, aumentando seu poder de negociação.

Segundo a Tabela 1 para as procedências da cenoura comercializada na CEASA de Curitiba, há maior volume de cenoura paranaense entre os meses de junho a dezembro, período em que os preços caem no estado, segundo as figuras discutidas anteriormente. $O$ segundo estado que mais fornece a raiz para o comércio do atacado em Curitiba é Santa Catarina, com oferta regular praticamente o ano todo, reduzindo nos meses mais frios, seguido por Rio Grande do Sul, Minas Gerais e São Paulo. 
Figura 7 - Padrão sazonal dos preços da cenoura no varejo, no Paraná, no período de 2011 a 2015 (Média Aritmética Móvel).

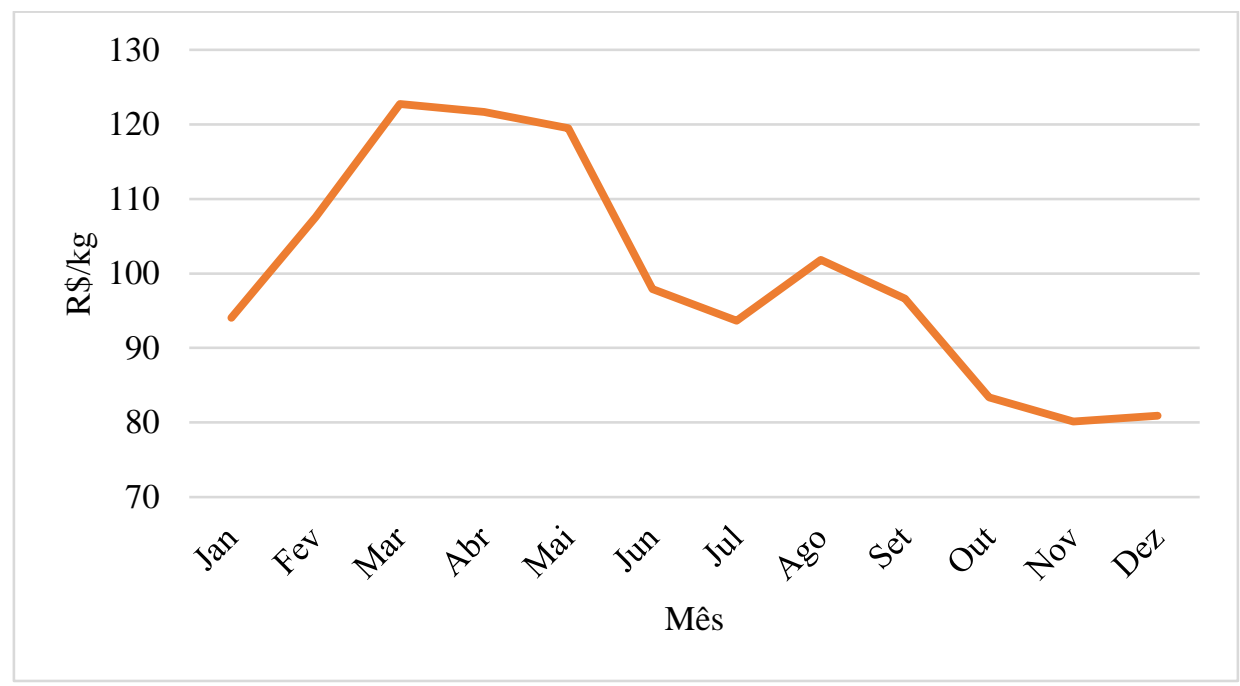

Fonte: Dados básicos SEAB/DERAL, cálculo as autoras (2017).

Tabela 1 - Médias das quantidades (t) e procedências da cenoura comercializada na Ceasa de Curitiba - PR, no período de 2011 a 2016.

\begin{tabular}{|cccccccccccccc}
\hline Estado & \multicolumn{1}{c}{ ES } & \multicolumn{2}{c}{ MG } & \multicolumn{2}{c}{ SP } & \multicolumn{2}{c}{ PR } & \multicolumn{2}{c}{ RS } & \multicolumn{3}{c}{ SC } & \multicolumn{3}{c}{ TOTAL } \\
Mês & (t) & (\%) & (t) & (\%) & (t) & (\%) & (t) & (\%) & (t) & (\%) & (t) & (\%) & (t) \\
\hline JAN & - & - & 255,2 & $14,7 \%$ & 169,4 & $9,7 \%$ & 716,4 & $41,1 \%$ & 394,6 & $22,7 \%$ & 205,5 & $11,8 \%$ & $\mathbf{1 7 4 1 , 1}$ \\
FEV & - & - & 169,7 & $11,1 \%$ & 133,8 & $8,7 \%$ & 686,4 & $44,8 \%$ & 369,3 & $24,1 \%$ & 144,9 & $9,5 \%$ & $\mathbf{1 5 3 1 , 8}$ \\
MAR & - & - & 458,8 & $26,3 \%$ & 185,9 & $10,6 \%$ & 661,3 & $37,9 \%$ & 278,6 & $16,0 \%$ & 162,1 & $9,3 \%$ & $\mathbf{1 7 4 6 , 7}$ \\
ABR & - & - & 346,9 & $21,7 \%$ & 190,3 & $11,9 \%$ & 682,4 & $42,7 \%$ & 224,0 & $14,0 \%$ & 156,3 & $9,8 \%$ & $\mathbf{1 5 9 9 , 9}$ \\
MAI & - & - & 225,1 & $13,5 \%$ & 172,9 & $10,4 \%$ & 776,0 & $46,6 \%$ & 343,4 & $20,6 \%$ & 136,8 & $8,2 \%$ & $\mathbf{1 6 6 5 , 1}$ \\
JUN & 4,6 & $0,3 \%$ & 192,8 & $11,5 \%$ & 164,1 & $9,8 \%$ & 832,1 & $49,6 \%$ & 328,5 & $19,6 \%$ & 127,3 & $7,6 \%$ & $\mathbf{1 6 7 7 , 0}$ \\
JUL & 7,5 & $0,4 \%$ & 167,0 & $9,7 \%$ & 150,7 & $8,8 \%$ & 927,1 & $54,1 \%$ & 328,3 & $19,2 \%$ & 133,7 & $7,8 \%$ & $\mathbf{1 7 1 4 , 3}$ \\
AGO & 9,0 & $0,5 \%$ & 289,2 & $16,7 \%$ & 217,9 & $12,6 \%$ & 984,1 & $56,7 \%$ & 146,4 & $8,4 \%$ & 88,6 & $5,1 \%$ & $\mathbf{1 7 3 5 , 1}$ \\
SET & 4,6 & $0,3 \%$ & 324,7 & $19,2 \%$ & 143,1 & $8,5 \%$ & 870,4 & $51,4 \%$ & 252,0 & $14,9 \%$ & 92,9 & $5,5 \%$ & $\mathbf{1 6 9 2 , 3}$ \\
OUT & 4,6 & $0,3 \%$ & 375,5 & $20,6 \%$ & 204,8 & $11,3 \%$ & 1008,9 & $55,5 \%$ & 110,6 & $6,1 \%$ & 100,5 & $5,5 \%$ & $\mathbf{1 8 1 8 , 6}$ \\
NOV & - & - & 289,9 & $17,0 \%$ & 175,6 & $10,3 \%$ & 978,7 & $57,3 \%$ & 124,3 & $7,3 \%$ & 139,9 & $8,2 \%$ & $\mathbf{1 7 0 8 , 5}$ \\
DEZ & - & - & 308,4 & $17,3 \%$ & 174,0 & $9,8 \%$ & 946,7 & $53,2 \%$ & 114,4 & $6,4 \%$ & 207,3 & $11,7 \%$ & $\mathbf{1 7 7 8 , 2}$ \\
\hline TOTAL & $\mathbf{3 0 , 2}$ & $\mathbf{0 , 1} \%$ & $\mathbf{3 4 0 3 , 2}$ & $\mathbf{1 6 , 7} \%$ & $\mathbf{2 0 8 2 , 4}$ & $\mathbf{1 0 , 2} \%$ & $\mathbf{1 0 0 7 0 , 6}$ & $\mathbf{4 9 , 3} \%$ & $\mathbf{3 0 1 4 , 3}$ & $\mathbf{1 4 , 8} \%$ & $\mathbf{1 6 9 5 , 8}$ & $\mathbf{8 , 3} \%$ & $\mathbf{2 0 4 0 8 , 6}$ \\
\hline
\end{tabular}

Fonte: Dados básicos PROHORT - CONAB, cálculo as autoras (2017).

\subsection{MARGENS DE COMERCIALIZAÇÃO}

Acredita-se que nos países subdesenvolvidos os mecanismos de comercialização são basicamente de exploração, ineficientes economicamente e trabalham com margens de lucro exageradas. Muitas vezes não são competitivos de modo que partes monopolísticas e especulativas resultem em preços desproporcionais. No entanto, a quantidade de intermediários comumente é alta, dificultando a existência de apenas um comprador para os diversos vendedores, podendo ser motivos das 
discrepâncias de preços de fatores como transporte ineficiente e/ou políticas públicas desfavoráveis ao setor, como tarifas na circulação de mercadorias (GUIMARÃES \& STEFANELO, 2003).

Visto que os dados de preços ao produtor e no varejo foram coletados em nível de estado e no atacado em nível de Curitiba, apesar deste apresentar um volume significativo, séries diferentes podem "mascarar" os resultados de comparação.

As margens totais na Tabela 2 mostram que na média anual, cerca de 55\% do preço pago pelo consumidor no quilograma da cenoura é destinado ao setor de comercialização, como atacado e varejo, e o restante (de um total de 100\%) é destinado à remuneração do produtor rural. O preço da cenoura em determinada região pode sofrer influência da oferta, demanda e valor do frete em todas as outras regiões.

Tabela 2 - Margens de comercialização para cenoura, no Paraná, no período de 2011 a 2016.

\begin{tabular}{cccc}
\hline Mês & $\begin{array}{c}\text { Margem Total - } \\
\text { MT }(\boldsymbol{\%})\end{array}$ & $\begin{array}{c}\text { Margem do Atacadista - } \\
\text { Ma }(\boldsymbol{\%})\end{array}$ & $\begin{array}{c}\text { Margem do Varejista - } \\
\text { Mv }(\boldsymbol{\%})\end{array}$ \\
\hline Jan & 49,55 & 28,93 & 20,62 \\
Fev & 46,30 & 18,67 & 27,64 \\
Mar & 50,17 & 7,29 & 42,87 \\
Abr & 53,08 & 5,57 & 47,51 \\
Mai & 61,16 & 4,87 & 56,29 \\
Jun & 61,51 & 21,21 & 40,30 \\
Jul & 54,71 & 18,01 & 36,70 \\
Ago & 54,09 & 8,48 & 45,61 \\
Set & 56,79 & 9,51 & 47,29 \\
Out & 59,80 & 18,51 & 41,29 \\
Nov & 58,53 & 18,94 & 39,58 \\
Dez & 58,44 & 32,02 & 26,42 \\
\hline Média & $\mathbf{5 5 , 3 4}$ & $\mathbf{1 6 , 0 0}$ & $\mathbf{3 9 , 3 4}$
\end{tabular}

Fonte: Dados básicos SEAB/DERAL e PROHORT - CONAB, cálculo as autoras (2017).

Sendo assim, nota-se que a partir do mês de março tem-se uma diminuição na margem do produtor rural, que pode ser explicado pelo fato de nos primeiros meses do ano, o preço da cenoura ao produtor ser mais alto e o varejo tender segurar esse repasse ao consumidor, diminuindo sua margem, para que não diminua o consumo do produto. Após os preços ao produtor caírem, a margem do varejista aumenta, pois é nesse momento que ele busca recuperar o gasto com o não repasse dos custos de comercialização dos meses iniciais ao consumidor, para evitar grandes oscilações no valor do produto no mercado final.

Nos meses de inverno, as cenouras provenientes de lugares com temperaturas mais altas nesta estação ganham espaço devido à maior qualidade apresentada, competindo com a cenoura 
paranaense e forçando os preços no estado a caírem, consequentemente diminuindo a margem dos produtores localizados no Paraná.

Na margem do atacadista também se observa este comportamento, onde há momentos em que sua margem fica negativa, de modo a manter um preço regular para seu produto e evitar a perda de clientes em nível de varejo.

\section{CONSIDERAÇÕES FINAIS}

A falta de uma metodologia e um padrão de preços diários para o mercado da cenoura, assim como a informalidade nas negociações, dificulta o planejamento da comercialização por parte do comerciante, que trabalha com cenoura híbrida de alta qualidade o ano todo. É de responsabilidade deste comerciante intermediário: o frete, a limpeza e a embalagem das hortaliças, necessitando de estrutura e capital de giro alto para realizar essas operações e a cobertura dos custos até a entrega da produção, que serão repassados para o próximo comprador. Trabalha com cenoura híbrida de alta qualidade $o$ ano todo.

Os preços da cenoura apresentaram tendência de alta no período analisado tanto para o produtor, como atacado e varejo. As causas para isso podem estar relacionadas ao aumento dos preços e da demanda do produto, no estado do Paraná ou a problemas climáticos no país que fizeram com que reduzisse a oferta nacional da raiz nos últimos anos.

As análises de sazonalidade indicaram que há um padrão de preços maiores no início do ano, entre fevereiro e abril, com média de aproximadamente $20 \%$ maiores que a média anual, e uma leve recuperação em agosto, sendo os períodos mais favoráveis para a venda da produção no estado. Em julho, novembro e dezembro, os preços apresentaram, em média, cotações 15\% menor que a média do ano.

Na média anual, $45 \%$ do valor pago pelo consumidor no quilograma da cenoura são repassados ao produtor paranaense, o qual obtém maiores margens nos primeiros meses do ano, devido a menor oferta da raiz no estado, nesse período.

Uma das limitações do presente trabalho foi o reduzido número de entrevistados encontrados, onde não se puderam gerar dados significativos para toda a cadeia da cenoura, resultando em um estudo de caso isolado para conhecimento de parte de seu processo de funcionamento. 
A metodologia aplicada neste estudo pode ser estendida para outras culturas, outros períodos e outras regiões com a finalidade de ajudar os agricultores a planejar sua comercialização de modo a diminuir as possíveis perdas que possam ocorrer por conta de um limitado planejamento da produção. Situações pontuais do mercado real, citadas pelo entrevistado, também podem ser temas a serem explorados mais profundamente em futuros trabalhos.

\section{REFERÊNCIAS BIBLIOGRÁFICAS}

AGUIAR, D. R. \& SANTOS, C. C. F. Importância econômica e mercado In.: BRUCKNER, C. H. (Ed.) Maracujá: tecnologia de produção, pós-colheita, agroindústria, mercado. Porto Alegre. Editora Cinco Continentes, 2001. p. $9-33$.

ALVES, V. Olhar Direto: Agricultura. 2013. Disponível em: <https://goo.gl/7W7GKR>. Acesso em: 26 jun. 2017.

BARROS, G.S.C. Economia da comercialização agrícola. Piracicaba: FEALQ, 1987. 306p.

BENTO, D. G. C.; TELES, F. L. A sazonalidade da produção agrícola e seus impactos na comercialização de insumos. Revista Científica do Centro de Ensino Superior Almeida Rodrigues, Rio Verde - Go, v. 1, n. 1, p.15-19, jan. 2013. Anual. ISSN 2317-7284. Disponível em: <https://goo.gl/kP2f2K>. Acesso em: 28 jun. 2017.

CARVALHO, A. D. F.; NOGUEIRA, M. T. M.; SILVA, G. O.; LUZ, J. M. Q.; MACIEL, G. M. \& RABELO, P.G. Seleção de genótipos de cenoura para caracteres fenotípicos de raiz. Hortic. Bras., Vitoria da Conquista, v. 35, n. 1, p. 97-102, Mar 2017. Disponível em: <https://goo.gl/uZ42Du>. Acesso em: 17 jun. 2017.

CARVALHO, A. D. F.; SILVA, G. O.; PEREIRA, R. B. \& PINHEIRO, J. B. Produtividade e tolerância à queimadas-folhas de diferentes genótipos de cenoura de verão. Hortic. Bras. 2015, vol.33, n.3, pp.299-304. Disponível em: <https://goo.gl/SvQM3n>. Acesso em: 16 jun. 2017.

CARVALHO, C. de.; et. al. Anuário brasileiro de hortaliças 2017. Santa Cruz do Sul: Editora Gazeta Santa Cruz, 2016. 56 p. Disponível em: <https://goo.gl/mqpG7v>. Acesso em: 16 jun. 2017.

FARIA, S. G.; SOUZA, A. C. S. Análise da centralidade da CEASA Minas e, relação aos fluxos hortigranjeiros em Minas Gerais. Revista E-xacta, Belo Horizonte, v. 7, n. 2, p. 139-150, 2014.

FILGUEIRA, F. A. R. Novo manual de olericultura: Agrotecnologia moderna na produção e comercialização de hortaliças. Viçosa: UFV. 402p. 2008.

FREITAS, F.C.L.; ALMEIDA, M.E.L.; NEGREIROS, M.Z.; HONORATO, A.R.F.; MESQUITA, H.C.; SILVA, S.V.O.F. Períodos de interferência de plantas daninhas na cultura da cenoura em função do espaçamento entre fileiras. Planta Daninha, Viçosa, v. 27, n. 3, p. 473-480, 2009.

GALLO, G. Análise da sazonalidade do preço do tomate no CEASA da grande Florianópolis. 2007. $58 \mathrm{f}$. Monografia (Graduação) - Curso de Ciências Econômicas, Departamento de Ciências Econômicas, 
Universidade Federal de Santa Catarina, Florianópolis, 2007. Disponível em: <http://tcc.bu.ufsc.br/Economia293476>. Acesso em: 26 jun. 2017.

GUIMARÃES, V. di A.; STEFANELO, E. L. Comercialização Agrícola. Notas de Aula. Curitiba: UFPR/SCA/DERE, 2003. 116 p.

HIGASHI, S. Y.; FAGUNDES, M. B. B.; CALEMAN S. M. de Q.; SAUER L.; SAES, M. S. M. Formas plurais de governança na ceasa - ms. In: $53^{\circ}$ Congresso da SOBER - Sociedade Brasileira de Economia, Administração e Sociologia Rural. João Pessoa - PB, julho de 2015. Disponível em: <http://icongresso.itarget.com.br/tra/arquivos/ser.5/1/5399.pdf>. Acesso em: 28 jun. 2017.

HOFFMANN, Rodolfo. Estatística para economistas. São Paulo: Pioneira, 1980.

JOHNSTON, J. Métodos econométricos. São Paulo: Atlas, 1977. 313p.

LANA, M. M.; VIEIRA, J. V. Fisiologia e manuseio pós-colheita de cenoura. Brasília:

EMBRAPA/CNPH, 2000. 15p. (Circular técnica, 21).

MAKRIDAKIS, S.; WHEELWRIGHT, S. C.; HYNDMAN, R. J. Forecasting: methods and applications. 3. ed. New York, USA: John Wiley \& Sons, 1998, pp 641.

MORAES, I. V. M. Conservação de hortaliças. Dossiê Técnico. Serviço Brasileiro de Respostas Técnicas -SBRT, 2006. Disponível em: <http://www.sbrt.ibict.br>. Acesso em: 26 jun. 2017.

MORGADO, I. F.; AQUINO, C. N. P.; TERRA, D. C. T. Aspectos econômicos da cultura do abacaxi: sazonalidade de preços no Estado do Rio de Janeiro. Rev. Bras. Frutic. Jaboticabal, v. 26, n. 1, p. 44-47, 2004. Disponível em: <http://dx.doi.org/10.1590/S0100-29452004000100013>. Acesso em: 28 jun. 2017.

MOTA, M. M. Sobre a cenoura. 2009. Disponível em: <http://marisamota.com/cenoura1.html\#top>. Acesso em: 26 jun. 2017.

MOURÃO, I. R. de A. \& MAGALHÃES, J. S. B. Breve História do Mercado atacadista de HortigranJeiros no Brasil. In: ABRACEN. Manual Operacional das CEASAS do Brasil. Belo Horizonte: AD2 Editora, 2011. p. 17-31.

OLIVEIRA, R. A.; ROCHA, J. B.; SEDIYAMA, G. C.; PUIATTI, M.; CECON, P. R.; SILVEIRA, S. F. R. Coeficientes de cultura de cenoura nas condições edafoclimáticas do Alto Paranaíba, no estado de Minas Gerais. Revista Brasileira de Engenharia Agrícola e Ambiental, v. 7, p. 280-284, 2003.

PAULUS, D.; MOURA, C. de A.; SANTIN, A.; DALHEM, A. R.; NAVA, G. A.; RAMOS, C. E. P. Produção e aceitabilidade de cenoura sob cultivo orgânico no inverno e no verão. Hortic. Bras., Vitoria da Conquista, v. 30, n. 3, p. 446-452, Sept. 2012. Disponível em: <https://goo.gl/LzR1WM>. Acesso em: 17 jun. 2017.

SILVA, G. O da. \& CARVALHO, A. D. F. de. Árvore do conhecimento: Importância cenoura. Agência Embrapa de Informação Tecnológica - AGEITEC. Brasília, 2015. Disponível em: <https://goo.gl/nrAhud>. Acesso em: 16 jun. 2017. 
SOUZA, R. A. M.; PITHAN E SILVA, R. O.; MANDELLI, C. S.; TASCO, A. M. P. Comercialização hortícola: análise de alguns setores do mercado varejista de São Paulo. Informações Econômicas, São Paulo, v. 28, n. 10, out. 1998.

VERGARA, S. C. Relatórios de pesquisa em administração. São Paulo: Atlas, 2007, 8a ed.

VIANA, J. G. A., ZEN, B., KARLEC, F. e SOUZA, R. S. de. Comportamento dos preços históricos do leite no Rio Grande do Sul, Brasil. Ciênc. agrotec., Lavras, v. 34, n. 2, p. 451-460, abr. 2010. Disponível em: <https://goo.gl/5cGQXN>. Acesso em 14 jun. 2017.

VIEIRA, J. V. Sistemas de Produção: Cenoura (Daucus carota) - Importância Econômica. 5. ed. Brasília: Embrapa Hortaliças, 2008. 16 f. Disponível em: <https://goo.gl/cGHfJn>. Acesso em: 26 jun. 2017.

VIEIRA, J. V.; SILVA, G. O.; CHARCHAR, J. M.; FONSECA, M. E. N.; SILVA, J. B. C.; NASCIMENTO, W. M.; BOITEUX, L. S.; PINHEIRO, J. B.; REIS A.; RESENDE, F. V.; CARVALHO, A. D. F. BRS Planalto: cultivar de cenoura de polinização aberta para cultivo de verão. Horticultura Brasileira 30: 359-363. 2012.

VILELA, N. J.; BORGES, I. O. Retrospectiva e situação atual da cenoura no Brasil. Brasília: Embrapa Hortaliças, 9p. 2008. (Circular Técnica, 59).

VILELA, N. J. \& CARVALHO, A. D. F. de. Árvore do conhecimento: socioeconomia cenoura. Agência Embrapa de Informação Tecnológica - AGEITEC. Brasília, 2015.

Disponível em: <https://goo.gl/jYhBeL>. Acesso em: 16 jun. 2017.

ZAMBERLAN, L.; SILVA, J. D.; SPAREMBERGER, A.; BÜTTENBENDER, P.L. Diagnóstico e contribuições para o desenvolvimento do setor hortigranjeiro no município de Santa Rosa RS. Disponível em: <https://goo.gl/RMnP2m>. Acesso em: 04 jul. 2017. 


\section{Capítulo 7}

\section{“MATA MATO" E NÃO MATA GENTE? A COMUNICAÇÃO DOS RISCOS DO GLIFOSATO NA LOGÍSTICA REVERSA DAS EMBALAGENS ${ }^{1}$}

DOI: $10.37423 / 200300376$

Daniela de Ulysséa Leal -dulyleal@gmail.com

Ivonete da Silva Lopes - ivonetesilvalopes@gmail.com

Resumo: Este artigo aborda a comunicação dos riscos do glifosato, feita por quatro fabricantes: Round up, Zavite, Atanor 48 e Nortox. Com base nas bulas desse produto, o agrotóxico mais vendido no mundo, analisa-se as instruções acerca da devolução das embalagens vazias pelo usuário final, que integra a cadeia da logística reversa. 0 estudo utiliza como procedimento metodológico a análise de conteúdo, e conta com o suporte do softwear Iramuteq. Os resultados apontam que os riscos são minimizados pelas agroquímicas, bem como as palavras "cuidado", "risco" ou "perigo" estão ausentes na comunicação das possíveis ameaças que o glifosato pode trazer à saúde e ao meio ambiente

Palavras-chave: Glifosato; Comunicação de Risco; Embalagem de Agrotóxico. 


\section{INTRODUÇÃO}

A naturalização do uso de agrotóxicos na agricultura brasileira tem afetado a saúde dos trabalhadores rurais, que lidam diretamente com estes produtos, assim como de consumidores. No país são registrados 3.125 casos de intoxicação por agrotóxicos por ano, sendo que, para cada caso notificado, acontecem 50 sem notificações (BOMBARDI, 2017). De acordo com o Instituto Nacional do Câncer (INCA), órgão do Ministério da Saúde, a presença residual do agrotóxico não se encontra apenas em alimentos in natura, mas também em produtos processados pela indústria alimentícia, que tem como ingredientes o trigo, o milho e a soja. Estes resíduos podem também aparecer em carnes e leites de animais que se alimentam de ração contaminada pelo agrotóxico (SILVA, 2016).

O atlas "Geografia do Uso de Agrotóxicos no Brasil e Conexões com a União Europeia" (2017) revela que foram utilizados no Brasil, entre 2012 e 2014, 8,33 Kg de agrotóxico por hectare, quando na União Europeia se aplica uma média de 0 a $2 \mathrm{Kg}$ por hectare. De acordo com Bombardi (2017), a quantidade do produto usado em solo brasileiro representa $20 \%$ de todo agrotóxico consumido no mundo neste período.

O mercado brasileiro, bem como a legislação, pode ser considerado pouco restritivo ao uso de agrotóxicos, se comparado, por exemplo, à União Europeia, onde são proibidos $30 \%$ dos ingredientes ativos (I.A.) com registros autorizados no Brasil. Não obstante às evidências dos males trazidos pelo uso de agrotóxicos, o governo federal, em janeiro de 2017, aprovou o registro de 277 novos produtos, representando um crescimento de 374\% comparado a 2015. Em 2018, foram registrados outros 450 e em 2019, mais 86. Circulam, também, no mercado brasileiro agrotóxicos falsificados vindos do Paraguai, sendo apreendidos anualmente mais de 30 toneladas de produtos nesta condição (BOMBARDI, 2017).

Dentre os agrotóxicos vendidos no Brasil, o glifosato, ( $\mathrm{N}$-fosfonometil glicina) é o mais vendido e seu volume comercializado supera a soma de todos os outros agroquímicos. Somente em 2016, o Brasil importou 119 mil toneladas deste princípio ativo, 69\% oriundo da China e o restante proveniente da indústria estadunidense ${ }^{2}$. O produto, um agrotóxico de largo espectro que funciona desidratando culturas, é popularmente conhecido como "Mata Mata” ou “Mata Mato".

A indústria agroquímica, de acordo com Ulrich Beck (2010), é uma das fontes de riscos que escapam à percepção da maioria da população, constituindo situações sociais de ameaça, especialmente nos países em desenvolvimento. Os riscos do produto se estendem a sua embalagem, visto que é 
concebido e rotulado em laboratório, e assim usa linguagem técnico-científica, o que potencializa o grau de dificuldades para se compreender as informações inerentes ao mesmo. Peres (1999) demonstrou em seu estudo que poucos usuários têm o conhecimento necessário para a manipulação destes produtos e somente alguns costumam ler o receituário agronômico e compreender as informações contidas na bula.

Apesar da ausência de uma política que vise esclarecer o usuário sobre os riscos do agrotóxico, o Decreto n. 4.074 de 2002 estabelece o compartilhamento das responsabilidades com as embalagens vazias entre agroquímicas, comerciantes e usuários desses produtos. Cabe às empresas informar aos consumidores sobre esta logística reversa através das bulas e rótulos de seus produtos. Envolver 0 agricultor no processo do correto descarte destas embalagens, que são tóxicas visto que cerca de 0,3\% da quantidade total de agrotóxico permanece na embalagem após sua utilização, demanda ações de comunicação que visem alertar sobre os procedimentos adequados, bem como sobre os riscos a que estão se submetendo.

Este artigo busca analisar como os riscos do glifosato são apresentados nas bulas de quatro marcas do produto: Round up, Zavite, Atanor 48 e Nortox, O estudo debruça-se sobre as instruções acerca da devolução das embalagens vazias, prática que envolve a manipulação direta por parte usuário, que, assim como, a indústria e o distribuidor, desempenha seu papel na cadeia da logística reversa do produto agrotóxico. Como procedimento metodológico utiliza-se a análise de conteúdo, procedimento sistemático para levantamento de indicadores que permitam a realização de inferência sobre determinado conjunto homogêneo de textos (BARDIN, 1977). Adota-se como procedimento complementar o softwear IRaMuTeQ ${ }^{3}$, que realiza análise de conteúdo através de análises estatísticas, formando nuvem de palavras a partir de um indicador de frequência.

\section{GLIFOSATO, O “MATA MATO”: UM RISCO PARA O ECOSSISTEMA}

Após a 2a Guerra Mundial, o avanço químico, industrial e farmacêutico, a reconstrução dos países destruídos pela guerra e o crescente aumento populacional proporcionaram as condições para a chamada Revolução Verde, que visava transformar a agricultura em um ambiente mais controlado, tornando o trabalho do produtor mais mecânico, através do uso de insumos químicos, sementes melhoradas (híbridas) e de máquinas e técnicas consideradas modernas (ALVES; TEDESCO, 2015). Alguns insumos eram sobras de produtos usados na guerra para combater os insetos, ou como arma química. De acordo com Carson (1969, p. 17), "a partir de meados de 1940 mais de 200 substâncias 
químicas de ordem básica foram criadas", para serem utilizadas, segundo a autora, na guerra do "homem contra a natureza". Antes deste período, os inseticidas provinham de minerais naturais e extratos de plantas, não tendo a enorme potência dos inseticidas sintéticos. Segundo Bonzi (2013), o sucesso prático dos químicos na agricultura, ao lado dos avanços da indústria farmacêutica, nos anos 1950, fez crescer a sensação de que é possível "uma vida melhor através da química". O autor complementa:

A confiança na química era tanta que crianças eram borrifadas com DDT a fim de combater pulgas e mosquitos. A publicidade exortava as donas de casa a se livrarem de baratas com a aplicação do pesticida. Um método seguro que podia ser aplicado até no quarto do bebê. No nível governamental, entomologistas e agentes da saúde envolvidos em campanhas de controle da malária chegavam a comer colheradas de DDT para convencer a população de que a substância não representava perigo (BONZI, 2013, p.209).

No Brasil, criação do Programa Nacional de Defensivos Agrícolas (PNDA), na década de 1970, tinha por objetivo estimular a produção e o consumo nacional dos produtos agrotóxicos, ao passo que condicionava a concessão do crédito rural à utilização obrigatória de uma parte deste recurso para a compra destes produtos (LIMA, AZEVEDO, 2013). As portas do mercado nacional se abriram também pela força falaciosa do discurso de que os agrotóxicos seriam a "tábua de salvação" contra a infestação de pragas e insetos, contudo, "naquele momento histórico, o desequilíbrio ecológico no campo era notado em escala bem reduzida, e a utilização de produtos agrotóxicos serviria, então, como medida profilática para o caso de uma infestação por pragas" (ROZEMBERG; PERES, 2003, p. 367).

Como resultado do grande uso de agrotóxicos, o Programa de Análises de Resíduos de Agrotóxicos em Alimentos (PARA), em 2011, concluiu que um terço dos alimentos consumidos cotidianamente pelos brasileiros estavam contaminados por agrotóxicos (em geral), ou seja, estavam com níveis de agrotóxico acima do aceitável. O parâmetro de segurança existente no cálculo da Ingestão Diária Aceitável (IDA) de cada ingrediente ativo (IA) é fruto de avaliações e classificações toxicológicas realizadas pela Agência Nacional de Vigilância Sanitária (Anvisa), sendo que uma dose diária aceitável equivale à quantidade máxima que, se ingerida diariamente durante toda a vida, parece não oferecer risco à saúde (ANVISA, 2013).

Para o Conselho Nacional de Segurança Alimentar e Nutricional (Consea), órgão extinto em 2019, as estimativas sobre um nível aceitável de agrotóxico são falhas, visto que as metodologias utilizadas pelo governo para estipular os limites da IDA de agrotóxicos têm como base um indivíduo médio de $60 \mathrm{~kg}$, ignorando impactos desses produtos sobre grupos mais vulneráveis como idosos e crianças (CONSEA, 2012). Além disso, o processo de aplicação do produto nas lavouras também gera danos, 
visto que parte dos agrotóxicos se espalha no meio ambiente por meio do vento ou das águas, a chamada "deriva", durante a operação. Segundo estimativas da Embrapa, pelo menos $30 \%$ do produto aplicado não atinge o alvo e sai pelos ares a contaminar o entorno (Grazziero et al, 2010).

Dentre os agrotóxicos utilizados no Brasil, o Glifosato é o herbicida mais vendido hoje em dia e permitido em mais de 130 países. Criado em 1950 na Suíça, só foi desenvolvido em 1969, por um funcionário da Monsanto. O glifosato entrou no mercado em 1974 patenteado por esta empresa, no entanto, no ano 2000 a patente expirou e muitas empresas agroquímicas resolveram explorar este segmento, sendo hoje produzido por mais de 300 marcas.

O glifosato é considerado pertencente à família geral de compostos organofosforados (OPs), mais especificamente um fosfanato (SAMSEL; SENEFF, 2013), embora esta classificação não seja unânime. Segundo empresas agroquímicas4, tal ingrediente ativo não se enquadra como organofosforado, mas sim como glicina substituída, pois a concentração de $0,5 \%$ de fósforo presente no metabólito do produto não é suficiente a caracterizá-lo como organofosforado nos termos da legislação pertinente. Os organofosforados apresentam como relevante preocupação seu caráter sistêmico, ou seja, a capacidade de permear todos os tecidos de um animal ou planta, tornando tudo tóxico, além de afetar a próxima geração de uma planta, produzindo sementes venenosas (CARSON, 1969). Além disso, dados apresentados pela Empresa Brasileira de Pesquisa Agropecuária (Embrapa) reafirmam que estes tipos de agrotóxicos produzem efeitos ao longo do tempo e podem sofrer transformações no período em que permanecem no meio ambiente, como alterações no nível bioquímico, demonstrando a importância do monitoramento de águas, solos, ar e alimentos (CARNEIRO, 2015).

O contato humano com o glifosato se dá pelas vias orais, respiratória e dérmica, e atingem, assim, os músculos do cérebro e glândulas, apresentando sequelas neurológicas (COSTA, 2012), contudo, apesar do perigo que representa consumir este produto, a contaminação da água pelo glifosato no Brasil tem um limite de tolerância 5 mil vezes superior ao que é permitido no continente europeu (BOMBARDI, 2017). Resíduos de glifosato são encontrados em alimentos como açúcar, milho, soja e trigo, desencadeando a maioria das doenças e condições associadas a uma dieta ocidental, que inclui distúrbios gastrointestinais, obesidade, diabetes, doenças cardíacas, depressão, autismo, infertilidade, câncer e doença de Alzheimer. (SAMSEL; SENEFF, 2013). Para os autores o "glifosato é o exemplo de livro didático da entropia semiótica exógena: o rompimento da homeostase pelas toxinas ambientais" (2013, p. 01), ou seja, como um corpo estranho pode destruir o equilibrio de um organismo. 
Segundo pesquisas realizadas no Rio Grande do Sul, os municípios que mais usam glifosato são os que apresentam os maiores índices de suicídio no estado, associando o contato com o produto e a incidência de casos de depressão (COSTA, 2012). Já foram identificados casos de contaminação por glifosato em amostras de leite materno em municípios com alto índice de uso do produto (LIMA, 2017). Em recente pesquisa estadunidense, Margaret, Bridget e Christy. (2017) afirmam que aves canoras (pássaros que têm a capacidade de cantar), que se alimentam de sementes contaminadas por glifosato, tem apresentado sinais de envenenamento, perda de massa corporal e alteração na capacidade de orientação durante voos migratórios. Percebe-se que os impactos do herbicida no ecossistema ainda estão sendo conhecidos pelaciência, cada vez mais, contudo, em velocidade inferior à que o agronegócio o aplica neste mesmo ecossistema. Algumas marcas trazem em seu rótulo o termo "Mata Mato", como o glifosato ficou popularmente conhecido. Com este deslocamento semântico promove-se a ideia de que o produto atinge apenas a parte indesejada do reino vegetal, sendo inofensivo para quem o aplica e consome. Contudo, apesar da indústria negar os males do glifosato em humanos, a inibição das enzimas do citocromo P450 (CYP), sistema de desintoxicação mais importante nos mamíferos, aumenta os efeitos prejudiciais de outros resíduos químicos de origem alimentar e toxinas ambientais. Desta forma, o impacto negativo sobre o corpo é insidioso e se manifesta lentamente com o tempo, à medida que a inflamação danifica os sistemas celulares em todo o corpo (SAMSEL; SENEFF, 2013). Sendo assim, os resíduos de glifosato nos alimentos, além de propiciarem doenças, dificultam o corpo humano a se livrar de outros contaminantes ambientais quando inibe as enzimas do sistema CYP. Além dos males já citados, o glifosato se decompõe em outras substâncias ainda mais tóxicas do que o próprio herbicida, AMPA (ácido aminometilfosfônico) e PMIDA ( $\mathrm{N}$-metilglifosato), que desencadeiam severos problemas que vão desde acúmulos em águas, como lagos, ao ser, por exemplo, excretado pela urina, até a intoxicação do ser humano (SAMSEL; SENEFF, 2013).

Em uma ação inédita, em 10 de agosto de $2018^{5}$, um júri da Califórnia condenou a multinacional Monsanto/Bayer, fabricante do Roundup, a indenizar em US\$ 289 milhões um homem com câncer terminal causado pela exposição ao produto. Em resposta à acusação, em nota publicada na imprensa ${ }^{6}$, a Monsanto defendeu o produto e afirmou que o glifosato "é seguro para o uso humano". Contudo, em março de 2019, por unanimidade dos juízes, foi decidido novamente na Califórnia que o herbicida contribuiu para o linfoma não Hodgkin (LNH) de E. Hardeman7. Samsel e Senef (2013) afirmam que o Roundup é mais tóxico do que o glifosato puro, pelo fato de incluir um surfactante ${ }^{8}$ que aumenta muito as propriedades citotóxicas do glifosato, demonstrando a amplificação da 
toxicidade deste herbicida através de adjuvantes. No território brasileiro, a Anvisa aprovou dia 26/02/2019 uma consulta pública ${ }^{9}$ com o resultado da reavaliação toxicológica do glifosato pelo órgão. O texto da Anvisa (NOTA TÉCNICA № 23/2018) traz propostas de mudanças para o uso do produto, principalmente em relação à segurança dos trabalhadores rurais, como rodízio de trabalhadores nas aplicações. Contudo, a nota afirma que "o Glifosato não apresenta características mutagênicas, teratogênicas e carcinogênicas, não é desregulador endócrino e não é tóxico para a reprodução" (ANVISA, 2019, p.01). A publicação da agência é contestada pela pesquisadora Larisssa Bombardi ${ }^{10}$ que afirma se tratar de tentativa de manipulação da opinião pública sobre o que é o glifosato, visto que os alimentos escolhidos para análise foram o arroz, manga e uva, deixando de lado a soja e o milho, cultivos transgênicos com altos índices de consumo do produto.

\section{AS EMBALAGENS AGROTÓXICAS E A COMUNICAÇÃO DOS RISCOS}

Para prevenir situações de risco ambiental, o governo brasileiro instituiu o compromisso com a destinação correta das embalagens vazias de agrotóxico entre os atores que operaram no seu ciclo de vida. Desta maneira, todos são responsáveis pela destinação das embalagens vazia por terem se beneficiado do produto (MACEDO e ROHLFS, 2013). Na cadeia da logística reversa das embalagens de agrotóxico, o agricultor tem a responsabilidade de devolver a embalagem num posto de recebimento e as indústrias são responsáveis pelo destino final destas embalagens, que podem ser recicladas ou incineradas. No Brasil, os fabricantes de agrotóxicos criaram em 2001 o Instituto Nacional de Processamento de Embalagens Vazias (Inpev), uma entidade sem fins lucrativos, com o objetivo de promover esta logística reversa e que recolheu, em 2017, 44.528 toneladas de embalagens de agrotóxicos em todo o pais (INPEV, 2017).

Nesta cadeia de logística reversa apresentada, as embalagens de agrotóxicos entram em contato com diversos atores, configurando um processo que apresenta inúmeros riscos em suas etapas, devido às diferentes interações entre sujeitos e embalagens. Estas interações são especificadas pela posição que cada sujeito ocupa nesta cadeia, de acordo com a responsabilidade legal que the é atribuída. 0 agricultor tem a tarefa de devolver a embalagem no prazo de um ano a contar da data da compra no local indicado na nota fiscal. Cabe também ao usuário realizar a tríplice lavagem das embalagens, prevista na norma da Associação Brasileira de Normas Técnicas (ABNT) 3.968, realizada logo após o uso. Se o agricultor não fizer a lavagem na hora em que agrotóxico é usado no pulverizador, ela passa a ser proibida, pois não há onde jogar essa água sem que se danifique o ambiente (FARIA e PEREIRA, 2012). Este é um processo meticuloso e passível de falhas e Bombardi (2017) alerta que muitas vezes 
estes objetos são lavados em água de múltiplo uso, o que pode vir a ser mais uma fonte da exposição humana ao risco. Além desta tríplice lavagem os agricultores devem também perfura as embalagens para que se tornem inutilizáveis.

Os postos de recebimento recolhem as embalagens vazias e classificam entre lavadas e não lavadas, separam segundo o tipo de material e são responsáveis por emitir um comprovante de entrega para os agricultores. As centrais também realizam estas classificações e compactam as embalagens, cabendo ao fabricante do produto, através do Inpev, encaminhar as embalagens lavadas para reciclagem e incinerar as contaminadas. (INPEV, 2017). Nas cooperativas de reciclagem, as embalagens vazias viram uma resina, aplicada em 33 artefatos, como: Pallets, embalagem para óleo lubrificante, conduíte, dutos, caixas, tubo para esgoto, barricas de papelão e plástica, entre outros (INPEV, 2017). O poder público também compartilha responsabilidade nesta cadeia, fiscalizando esta logística reversa. Silva et al (2016, p.160) destacam que alguns países optaram por comercializar os produtos agrotóxicos a granel, não utilizando mais as embalagens convencionais para distribuição dos produtos, e o "Brasil, por mais que esteja se empenhando em viabilizar a logística reversa, não está na vanguarda e, sim, reproduzindo processos obsoletos".

Para além de uma visão instrumentalista desta operação, a responsabilidade compartilhada entre agricultores, comerciantes e as indústrias não se configura um espaço de relações uniformes. Percebese que o agricultor, muitas vezes o menos capitalizado desta relação, é forçado a ocupar uma posição menos favorecida neste espaço, pois é responsável pela lida direta com embalagens tóxicas, inclusive sua lavagem e armazenamento até o momento da devolução. Sendo assim, a indústria agroquímica deve instruir o usuário do produto sobre como manipular a embalagem, bem como sobre todo o processo de devolução desta, de maneira clara, pois trata-se da lida com um objeto contaminado e uma prática que envolve riscos, que devem ser comunicados. Segundo Ulrich Beck (2010), a presença do risco em uma prática social estratifica a sociedade, não mais por diferenças sociais, econômicas e geográficas, mas pelo conhecimento do próprio risco, ou seja, o poder está nas mãos de quem o conhece. O setor empresarial tem a responsabilidade legal de promover educação ambiental da população consumidora, assim como divulgar informações referentes às formas de evitar, reciclar e eliminar os resíduos associados a seus respectivos produtos (MACEDO e ROHLFS, 2013), ou seja, comunicar sobre os riscos do seu produto. Os estudos mais recentes sobre a Comunicação dos Riscos (CR) consideram desde a elaboração de mensagens acerca da natureza do risco, bem como preocupações, opiniões e reações resultantes da divulgação das mensagens, e as questões legais que 
abordam o processo de gestão do risco (JESUS, 2016). Devido aos diversos riscos existentes a que as diversas sociedades estão submetidas, a CR precisa ter caráter dinâmico, se configurando uma relação baseada na troca de percepções e opiniões de vários atores sociais, no qual a linguagem deve ser adequada, reforçando a compreensão dos processos pelo público leigo. Para Batista (2007), a CR deve trazer a tenção do público para o problema e focar em aspectos de proteção ao indivíduo. Todavia, apenas a transmissão de informações, mesmo em grande quantidade, não apresenta elementos suficientes para garantir uma comunicação eficaz sobre os riscos. É necessário rever metas, configurações e ações institucionais, culturais e sociais para que a compreensão dos indivíduos seja plena (FURNIVAL et al., 2004).

Desta forma, para que a comunicação dos riscos seja efetiva, é preciso que haja um alinhamento entre a percepção do risco por parte do emissor e do receptor. Quando estes papéis são desempenhados por atores com valores socioeconômicos muito contrastantes este alinhamento torna-se mais difícil, geralmente prevalecendo a ótica do mais forte. Na opinião de DI GIULIO et al. (2012) a abertura de diálogo e do processo decisório aumenta a confiança da população neste processo, legitimando-o. Historicamente, a indústria e o Estado não têm trazido a sociedade para debates em relação a situações de riscos e de crise, com a intenção de "proteger" o público, em vez de integrá-lo nas tomadas de decisões (COVELO, 1993).

Segundo Fischhoff (1995, p. 144), se a comunicação de risco for efetiva "pode cumprir parte do contrato social entre aqueles que criam os riscos (como um subproduto de outras atividades) e aqueles que os irão suportar (talvez juntamente com os benefícios dessas atividades) ". Desta forma, numa sociedade estratificada pelo conhecimento dos riscos a que está submetida, a socialização desses debates pode se aproximar, analogamente, do ideal de justiça social.

As bulas e rótulos dos produtos agrotóxicos são ferramentas de comunicação com os usuários e poderiam colaborar na informação sobre riscos e na proteção à saúde. Peres e Rozemberg (2003, p.336) apresentam preocupações semelhantes ao presente estudo ao realizar uma pesquisa sobre o entendimento de agricultores acerca de pictogramas presentes em certas bulas de agrotóxicos. 0 resultado aponta para uma "não compreensão de tais informações, ou ainda para uma compreensão que, distorcida, resvala na direção oposta ao do objetivo do idealizador de tal produto". Como exemplo, o pictograma que significava "Lave e inspecione sempre os equipamentos no fim de cada dia de trabalho" era interpretado pelos pesquisados como "Preparando o remédio na máquina", "Enchendo o pulverizador, ou até "Tá com a marmita nas mãos". 


\section{A COMUNICAÇÃO DOS RISCOS NAS BULAS DE GLIFOSATO}

Para orientar empresas agroquímicas na elaboração de rótulos e bulas de acordo com o decreto, a Agência Nacional de Vigilância Sanitária (Anvisa) publicou o Guia para Elaboração de Rótulo e Bula de Agrotóxicos, Afins e Preservativos de Madeira, em janeiro de 2018, com caráter orientativo. O decreto determina a obrigatoriedade da frase "É obrigatória a devolução da embalagem vazia" nas bulas e rótulos, e a Anvisa orienta para a inclusão das seções "Precaução após a aplicação do produto" e "Informações sobre os procedimentos para a devolução e destinação de produtos impróprios para utilização ou em desuso" (ANVISA, 2018). Este estudo tem como recorte bulas de quatro importantes marcas, selecionadas pela disponibilidade on line de acesso ao material: Nortox, Zavite, Atanor 48 e Round up, que apresentam características conforme Quadro 01.

Quadro 1: Características básicas dos produtos a base de glifosato

\begin{tabular}{|l|l|l|l|}
\hline Marca & Formulação & $\begin{array}{l}\text { Classificação } \\
\text { toxicológica }\end{array}$ & Fabricante \\
\hline Nortox & Concentrado solúvel & $\begin{array}{l}\text { Classe IV- Pouco } \\
\text { tóxico }\end{array}$ & Monsanto Brasil \\
\hline Zavite & Granulado solúvel & $\begin{array}{l}\text { Classe I - } \\
\text { Extremamente tóxico }\end{array}$ & ALTA - China \\
\hline Atanor 48 & Concentrado solúvel & $\begin{array}{l}\text { Classe III - } \\
\text { Medianamente tóxico }\end{array}$ & $\begin{array}{l}\text { Atanor SA } \\
\text { Argentina }\end{array}$ \\
\hline Round up & Concentrado solúvel & $\begin{array}{l}\text { Classe II- Altamente } \\
\text { tóxico }\end{array}$ & Monsanto - Brasil \\
\hline
\end{tabular}

Fonte: Elaboração própria com base nas bulas dos agrotóxicos citados

Percebe-se as diferentes classificações toxicológicas acima, proveniente das concentrações de glifosato e de outras substâncias adjuvantes. Ambas as marcas apresentam dados relativos à proteção da saúde humana na seção "Precaução após a aplicação do produto", embora cada marca apresente um texto diferente conforme a Tabela 01. Nesta Tabela, destacamos os segmentos da seção considerados mais relevantes para este estudo. 
Tabela 01: Dados relativos a proteção da saúde humana nas bulas de glifosato

\begin{tabular}{ll}
\hline Nortox & Mecanismos de ação, absorção e excreção para o ser humano: aspectos \\
& toxicológicos: irritante dérmico e ocular. Pode causar danos hepáticos e \\
& renais, quando ingerido em doses altas. Efeitos agudo e crônico: dermatite \\
de contato. Sindrome tóxica após a ingestão de doses altas: Epigastralgia, \\
ulceração ou lesão de mucosa gástrica, hipertermia, anúria, oligúria, \\
hipotensão, conjuntivite, edema orbital, choque cardiogênico, pneumonite, \\
necrose tubular aguda, elevação de enzimas hepáticas, leucócitos, acidose \\
metabólica e hipercalemia. \\
Mecanismos de toxicidade: não são conhecidos os mecanismos especificos \\
de toxicidade do glifosato em humanos. O glifosato tem ação irritante aos \\
olhos e mucosas. Sintomas e sinais clínicos: o produto pode causar irritação \\
severa em contato com os olhos. Em contato com a pele, pode ocorrer \\
irritação em indivíduos susceptíveis, pode haver reação alérgica cutânea. \\
Quando inalado, pode ocorrer irritação do trato respiratório. \\
Intoxicações por glifosato - Toxicocinética: após a exposição oral única, \\
aproximadamente 35\% do volume ingerido e absorvido. Em exposição \\
cutânea, são absorvidos 5,5\% após 24 horas. do glifosato absorvido, 14- \\
29\% e excretado pela urina, e 0,2\% excretado pelo ar expirado. 99\% da \\
quantidade absorvida é eliminada em até 7 dias. Somente $0,3 \%$ do glifosato \\
absorvido é biotransformado, e seu único metabolito é o ácido \\
aminometilfosfonico (AMPA). As manifestações clínicas decorrentes da \\
exposição são diretamente proporcionais a concentração e a quantidade do \\
produto, assim como ao tempo de exposição do organismo ao glifosato. É \\
necessário observar a toxicidade inerente aos adjuvantes (produtos \\
utilizados em mistura com produtos formulados para melhorar a sua \\
aplicação) presentes na formulação, potencializando os efeitos adversos do \\
glifosato.
\end{tabular}

Round up

Vias de exposição: digestiva, dérmica e mucosas

Toxicocinética: o glifosato é metabolizado principalmente em AMPA que aparece no plasma cerca de 3,5 horas após a ingestão. Ambos, glifosato e seu metabólito, são excretados através da urina em até 7 dias. O glifosato é um herbicida sistêmico do grupo das glicinas substituídas que age sobre o citocromo P-450 alterando a síntese da membrana celular, tanto em vegetais como em mamíferos. Sintomas e sinais clínicos: por não ser de finalidade terapêutica, não há como caracterizar seus efeitos colaterais. Não são conhecidos sintomas de alarme, sendo recomendada a suspensão do produto se surgirem quaisquer sintomas durante a manipulação.

Fone: Elaboração própria com base nas bulas Nortox, Atanor 48, Zavite e Round up.

Pode-se perceber o uso de linguagem estritamente técnica, o que compromete o entendimento de um público leigo, e uma sutil diferença entre as informações referentes a cada laboratório. Segundo a marca Nortox, o produto pode causar danos hepáticos e renais quando ingerido em doses altas, portanto é possível inferir que não há problemas com uma ingestão moderada. Informação que leva 
a subentender que o problema não está no glifosato, pois não causa danos se usado corretamente. Ou seja, é atribuído ao operador, que exagera na dose do produto, os males que podem ocorrer.

A bula do glifosato Zavite afirma que em indivíduos susceptíveis, pode haver reação alérgica cutânea. Diante do exposto, pode-se deduzir que a empresa não está sendo honesta ao segmentar indivíduos susceptíveis. O produto é tóxico para todas as qualidades de pessoas, não sendo um predicativo do sujeito sofrer de alergia cutânea, e sim uma ação do produto. A afirmativa que "não são conhecidos os mecanismos específicos de toxicidade do glifosato em humanos" literalmente não significa que estes mecanismos não existem, mas explicita que a empresa não investe nesta pesquisa e ignora tantos dados já comprovados e publicados.

O Atanor 48 traz em sua bula a afirmação de que de todo o glifosato absorvido pelo usuário, de "14 a $29 \%$ é excretado pela urina, 0,2\% excretado pelo ar expirado e $99 \%$ da quantidade absorvida é eliminada em até 7 dias". Percebe-se que este suposto atenuante não invalida a contaminação do meio ambiente, já que o glifosato se decompõe em substâncias ainda mais tóxicas do que o próprio herbicida e que, sendo também eliminadas pela urina, podem contaminar o ambiente. Esta bula informa ainda que manifestações clínicas são proporcionais a concentração, quantidade e tempo de exposição ao glifosato, o que não diminui a toxidade do produto. O Atanor 48 também traz em sua bula informação para que o usuário observe a toxicidade inerente aos adjuvantes presentes na formulação, já que o concorrente mais famoso (Round up) faz uso de um surfactante que aumenta as propriedades citotóxicas do glifosato.

A bula do Round Up informa que o glifosato é metabolizado em AMPA mas não explica ao usuário a toxidade existente neste composto final, que será excretado pela urina. Apesar da Bayer/Monsanto ser uma grande corporação, consta na bula que o glifosato é um herbicida sistêmico que age sobre o citocromo P-450 alterando a síntese da membrana celular, tanto em vegetais como em mamíferos. $\mathrm{O}$ texto é claro, e a afirmação "tanto em vegetais como em mamíferos" reforça a ideia de igualdade, na qual vegetais e mamíferos sofrem os mesmos efeitos.

A seção "Dados Informativos sobre proteção ao meio ambiente" apresenta a classificação do glifosato quanto ao seu perigo para o meio ambiente. O produto está na Classe III (Perigoso ao Meio Ambiente) em todas as marcas, sendo que a Classe I significa "Altamente Perigoso ao Meio Ambiente" e a Classe IV “Pouco Perigoso ao Meio Ambiente". Nesta seção, semelhante em todas as marcas, aparecem as seguintes recomendações: Evite a contaminação ambiental; Preserve a Natureza; Não utilize 
equipamento com vazamento; Não aplique na presença de ventos fortes ou nas horas mais quentes; Aplique somente as doses recomendadas; Não lave as embalagens ou equipamento aplicador em lagos, fontes, rios e demais corpos d'água; Descarte corretamente as embalagens e restos de produtos. Embora se trate de frases de ordem e alerta, elas não vêm acrescidas de maiores informações que podem elucidar o usuário sobre a lida com o produto e sua embalagem. Desta forma, não esclarecendo os motivos para, por exemplo, não se aplicar o produto no sol quente ou sobre a contaminação ambiental, a indústria não promove um maior engajamento do usuário nestas questões, o que evita que este exerça reflexões mais profundas sobre os efeitos do agrotóxico no ecossistema.

O Atanor 48 traz também a frase: Este produto é altamente tóxico para algas. Este enunciado indica então, que o produto não deve ter contatos com águas correntes para não contaminar as algas, mas não esclarece ao usuário as muitas possibilidades que este pode poluir as águas e intoxicar estes seres. O Zavit e o Round up são as únicas marcas que alertam que: Não execute aplicação aérea de agrotóxicos em áreas situadas a uma distância inferior a 500 (quinhentos) metros de povoação e de mananciais de capitação de água para abastecimento público e 250 (duzentos e cinquenta) metros de mananciais de água, moradias isoladas, agrupamentos animais e vegetação susceptível a danos. Apesar da limitação espacial recomendada, a borrifação aérea tem sua segurança questionada, principalmente levando em conta a estimativa de $30 \%$ de deriva.

Esta seção apresenta também informações sobre os procedimentos de lavagem, armazenamento, devolução, transporte e destinação de embalagens vazias e restos de produtos impróprios para utilização ou em desuso. A tríplice lavagem (lavagem manual), prática prévia à devolução das mesmas, é instruída da seguinte forma:

Esta embalagem deverá ser submetida ao processo de Tríplice Lavagem, imediatamente após o seu esvaziamento, adotando- se os seguintes procedimentos: Esvazie completamente o conteúdo da embalagem no tanque do pulverizador, mantendo-a na posição vertical durante 30 segundo; Adicione água limpa à embalagem até $1 / 4$ do seu volume; Tampe bem a embalagem e agite- a por 30 segundos; Despeje a água de lavagem no tanque do pulverizador; Faça esta operação três vezes; Inutilize a embalagem plástica ou metálica perfurando o fundo. ${ }^{11}$

Percebe-se que a linguagem adotada, com viés técnico e pouco coloquial, não acompanha a possível pluralidades de usuários do produto, já que é o mais usado em todos os estados do Brasil e em diversos extratos sociais. Por se tratar de um produto que comprovadamente prejudica a saúde, esta instrução 
não deixa explicito que o conteúdo da embalagem é um veneno, que a água limpa ao ser inserida na embalagem torna-se contaminada, inclusive quando pulverizada para limpeza do equipamento. Desta forma, percebe-se que características importantes da $C R$, como o esclarecimento do risco para o usuário leigo e o engajamento público na prevenção de riscos, não estão sendo adotadas pelas empresas agroquímicas. Na CR a linguagem deve ser adequada para reforçar a compreensão dos processos.

Através da análise de conteúdo destas seções sobre a devolução das embalagens, nas bulas de glifosato, pelo software IRaMuTeQ, realizada através de análises estatísticas, foi obtido um corpus geral com emergência de 185 ocorrências (palavras, formas ou vocábulos). Este corpus foi estruturado em forma de nuvem de palavras, conforme figura 01, baseado na frequência das palavras.

Figura 01- Nuvem de palavras

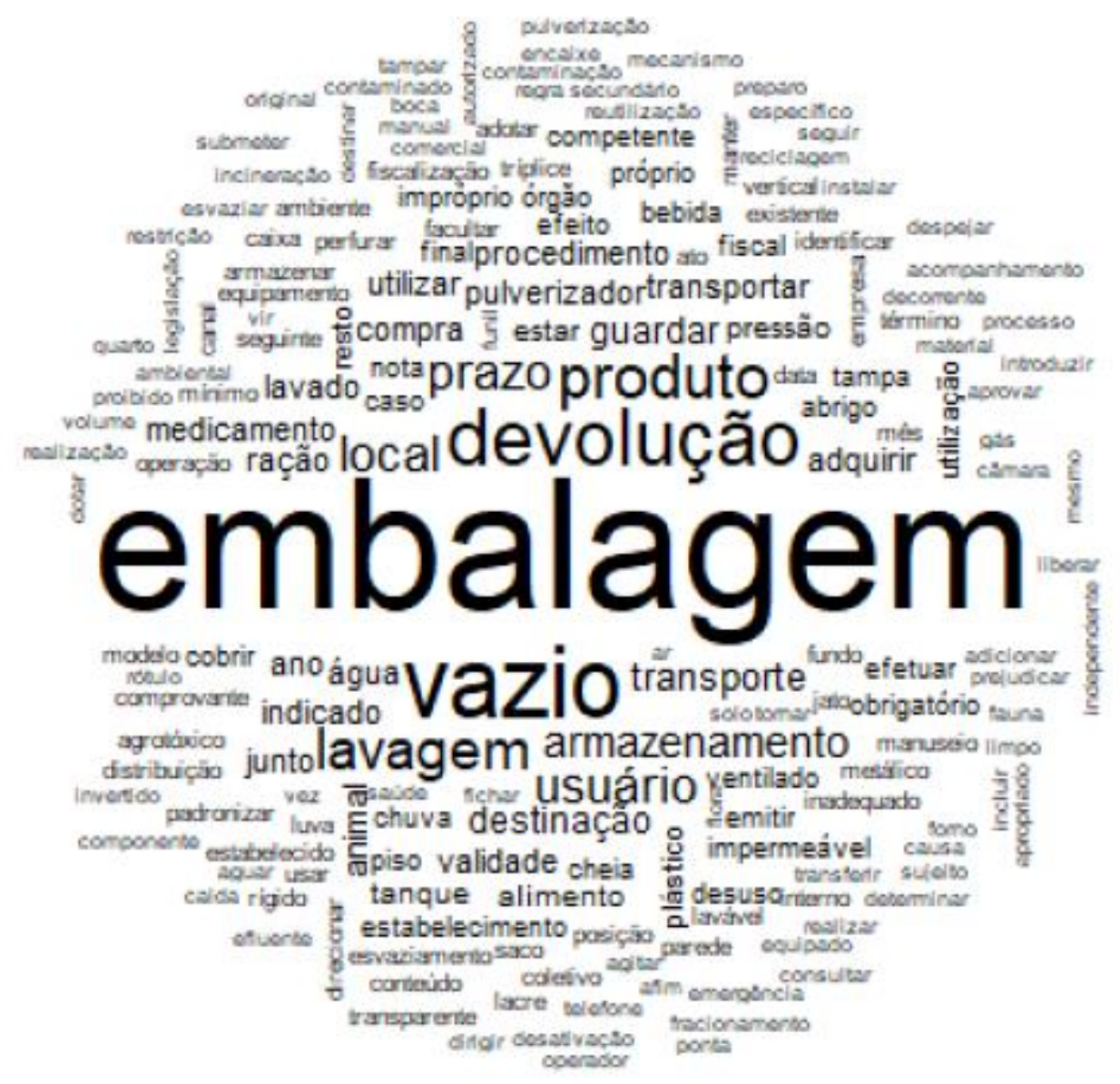

Fonte: Nuvem de palavras gerada pelo Iramuteq em 19-02-2019 
A figura 01 apresenta ao centro e em destaque a palavra "embalagem", com 204 ocorrências, seguida por "vazio" com 101 ocorrências. Percebe-se assim, o caráter utilitarista e instrumental desta comunicação ao se realizar uma comparação com termos como "contaminação", que só apresenta quatro ocorrências, ou seja, aparece apenas uma vez em cada bula das diferentes marcas de glifosatos estudadas. Observou-se, também, que o termo adotado pelas indústrias de glifosato estudadas para se referir ao produto é "agrotóxico" com oito ocorrências, não sendo utilizado nenhum eufemismo como "produto fitossanitário" ou "defensivo agrícola" para designá-los.

Outros termos que aparecem com frequência são devolução", 76 vezes, "produto" 57 e "lavagem" 50. Sinaliza que o foco da comunicação está mais voltado ao objeto do que ao risco que o envolve. Neste sentido, não foram utilizadas palavras como "risco", "cuidado" ou "perigo" para instruir o usuário sobre as práticas para a devolução das embalagens vazias. Desta forma, percebe-se que esta comunicação prioriza a mecânica e a operacionalização do trato com a embalagem, em detrimento a outros aspectos mais afins a saúde e sustentabilidade.

\section{CONSIDERAÇÕES FINAIS}

A problemática da disseminação de glifosato no ecossistema é ampla e bem complexa, transversalizando diferentes dimensões, e percebe-se sobre ela a mão pesada do capital, seja das grandes indústrias químicas ou do poder público, que tem liberado novos registros de agrotóxicos quase que semanalmente. A saúde da presente e das futuras gerações pode estar sendo comprometida silenciosamente, com a conivência dos que poderiam frear esta devastação.

Diante do estudo aqui apresentado, percebe-se que as indústrias agroquímicas não apesentam claramente os riscos relacionados ao uso e consumo do glifosato, levando-se em conta a frequente existência de interesses mercadológicos direcionando as estratégias de comunicação empresarial. A ênfase dos textos contidos nas bulas dos glifosatos estudados tem enfoque técnico e as instruções sobre a devolução das embalagens recaem mais sobre as embalagens do que sobre o produto tóxico contido nas mesmas. O usuário do glifosato, ponta da cadeia da logística reversa, ocupa uma posição menos privilegiada neste ciclo. Como a parte que lhe cabe demanda precisão, os textos das bulas deveriam ofertar aos agentes afetados pelo risco todas as informações necessárias para que as atitudes mais adequadas sejam tomadas, inclusive no tocante às prevenções dos riscos, de forma mais clara e mais didática. Assim, os usuários do glifosato ocupam um lugar vulnerável, não se apropriando de informações que poderiam contribuir na defesa da própria saúde e do meio ambiente. A exemplo 
de nem advertir o usuário que sua urina passa a estar contaminada (por AMPA). Este material informativo induz, ainda, o usuário do glifosato a assumir a culpa pelos males advindos do produto, atribuindo ao mau uso ou a uma possível sensibilidade as doenças que poderiam aparecer, bem como contaminações ambientais.

Ao fazer uso de "mata mato", sem que haja a promoção de uma reflexão acerca das possíveis consequências desta prática, o usuário pode afastar-se dos parâmetros de segurança indicados, entendendo que o produto causa danos apenas ao mato, ou seja, às ervas daninhas, entes totalmente diferentes de si próprio ou de seus familiares.

Como apenas a transmissão de informações não apresenta elementos suficientes para garantir a comunicação dos riscos, pois para tal seria necessário a realização de mudanças de configurações, bem como as de cunho cultural e social, afere-se que não há por parte destas industrias interesse em uma transformação mais profunda, já que o uso de agrotóxicos, mais que uma escolha individual, é uma imposição estrutural. Neste sentido, as agroquímicas não desempenham de forma prudente o papel de comunicar os riscos relacionados a seus produtos.

Hoje em dia técnicas alternativas de controle a pragas estão disponíveis, com bons resultados em termos de produtividade e custos, e sem contaminar o ecossistema, como a agroecologia. Esta prática social foge do modelo pregado pela modernização e se configura uma luta por autonomia diante dos atores hegemônicos que dominam o mercado, a política e a produção de valores, sendo uma possível solução para a contaminação bem como para o acúmulo de embalagens plásticas.

\section{REFERÊNCIAS BIBLIOGRÁFICAS}

ALVES, Clovis; TEDESCO, João. A revolução verde e a modernização agrícola na mesorregião noroeste do Rio Grande do Sul - 1960/1970. In: Teoria e Evidência Econômica - Ano 21, n. 45, p. 257-281, jul./dez. 2015;

ANVISA. Agència Nacional de Vigilância Sanitária. Programa de Análise de Resíduos de agrotóxicos em alimentos (PARA) - Relatório de Atividades de 2011 e 2012. 2013. Disponível em: www.anvisa.gov.br. Acessado em: 21-11-2018;

. Guia para elaboração de rótulo e bula de agrotóxicos, afins e preservativos de madeira. Guia número 12, Anvisa, 2018;

. Nota Técnica № 23/2018/SEI/CREAV /GEMAR/GGTOX/DIRE3/ANVISA. 2019;

BARDIN, L. Análise de conteúdo. Lisboa: Edições 70 Ltda, 1977; 
BATISTA, L. L. A comunicação de riscos no mundo corporativo e o conteúdo da mensagem. Organicom, São Paulo, v. 4, n. 6, p. 109-113, jan./jun.2007. Disponível

em: https://www.revistas.usp.br/organicom/article/view/138928/134276. Acesso em: 02 fev. 2019.

BECK, Ulrich. Sociedade de risco: rumo a uma nova modernidade. São Paulo: Ed. 34, 2010;

BIMBATI, T.; RUTKOWSKI, E. A responsabilidade compartilhada e seus instrumentos na promoção da reciclagem. X Simpósio Internacional de Qualidade Ambiental. Porto Alegre: PUCRS, 2016;

BOMBARDI, Larissa M. Geografia do Uso de Agrotóxicos no Brasil e Conexões com a União Europeia São Paulo: FFLCH - USP, 2017;

BONZI, R. S. Meio século de Primavera silenciosa: um livro que mudou o mundo. Desenvolvimento e Meio Ambiente, n. 28, p. 207-215, jul./dez. Editora UFPR, 2013;

BRASIL, 2002. Decreto n. 4.074, de 4 de janeiro de 2002. Disponível

em: http://www.planalto.gov.br/ccivil_03/decreto/2002/D4074compilado.htm. Acesso em 15/07/2018;

CARSON, Rachel. Primavera Silenciosa. São Paulo: Ed. Melhoramentos, 1969;

CARNEIRO, Fernando Ferreira (Org.) Dossiê ABRASCO: um alerta sobre os impactos dos agrotóxicos na saúde - Rio de Janeiro: EPSJV; São Paulo: Expressão Popular, 2015;

CONSELHO NACIONAL DE SEGURANÇA ALIMENTAR E NUTRICIONAL - CONSEA. Os impactos do agrotóxico na segurança alimentar e nutricional: Contribuições do Consea. Consea, 2002;

COSTA, Geovana Specht Vital da. Da regulamentação dos agrotóxicos. In: Âmbito Jurídico, Rio Grande, XV, n. 103, ago 2012. Disponível

em:<http://www.ambito-juridico.com.br/site/?n_link=revista_artigos_leitura\&artigo_id=11864>. Acesso em nov 2018;

COVELLO, V.T. Communicating risk information: a guide to environmental communication in crisis and noncrisis situations. In: Rao V. Kolluru, ed. Environmental strategies handbook: a guide to effective policies and practices. New York, 1993;

DI GIULIO, Gabriela Marques et al. Experiências brasileiras e o debate sobre comunicação e governança do risco em áreas contaminadas por chumbo. In: Ciênc. saúde coletiva, Rio de Janeiro, v. 17, n. 2, p. 337-349, fev. 2012;

FARIA, A.C.; PEREIRA R.S. O processo da logística reversa das embalagens de agrotóxicos: um estudo de caso sobre o Inpev. In: Organizações Rurais \& Agroindustriais, Lavras, v. 14, n. 1, p. 127-141, 2012;

FISCHHOFF, B. Risk perception and communication unplugged: twenty years of process. Risk Anal ,13745. 1995;

FURNIVAL, A. C; PINHEIRO, S. M.; JUNIOR, J. C. O. A Comunicação e Compreensão da Informação sobre Riscos. DataGramaZero- Revista de Ciência da Informação, Rio de Janeiro, v.5, n.2, 2004; 
GUIVAN, Julia Silvia. O legado de Ulrich Beck. Ambiente \& Sociedade n São Paulo v. XIX, n. 1 n p. 229$240 \mathrm{n}$ jan.-mar. 2016;

GAZZIERO,D.L.P.; ADEGAS,F.S.;VOLL,E.; CERDEIRA,A.; MATALO,M.; KARAM,D.; VARGAS,L ; OSIPE,R.; ALMEIDA,S.D.B ; FRANCO,D.A.S.; MOURA e MELO,M.A.M. Fitointoxicação causada por deriva de glyphosate em soja convencional. XXVII Congresso Brasileiro da Ciência das Plantas Daninhas. Ribeirão Preto, 2010;

INPEV. Relatório de sustentabilidade. 2017. São Paulo. Disponível

em: https://www.inpev.org.br/Sistemas/Saiba-Mais/Relatorio/inpEV_RS2017.pdf;

JESUS, SANDRA. Comunicação do risco: o que dizer, quando dizer. Instituto Politécnico de Lisboa. Universidade de Aveiro, 2016;

LIMA, Andrezza M.; AZEVEDO Camila F.; Impactos culturais e socioambientais deixados pela Revolução Verde na região do brejo paraibano - Brasil. Revista Verde de Agroecologia e Desenvolvimento Sustentável, v. 8, n. 5, p. 116 - 123, (Edição Especial) Mossoró, 2013. Disponível em: http://revista.gvaa.com.br ISSN 1981;

LIMA, I. P. Avaliação da contaminação do leite materno pelo agrotóxico glifosato em puérperas atendidas em Maternidades Públicas do Piauí. Dissertação de Mestrado, Coordenação do Programa de Pós-graduação em Saúde da Mulher, Centro de Ciências da Saúde da Universidade Federal do Piauí. Teresina, 2017;

LOFSTEDT, RAGNAR. Risk Management in Post-Trust Societies. Londres:Ed. Routledge, 2012;

MACEDO, M; ROHLFS, D. Responsabilidade Compartilhada, Logística Reversa e cadeias com obrigatoriedade imediata no âmbito da Política Nacional de Resíduos Sólidos. Pontifícia Universidade Católica de Goiás, Programa de Pós-graduação em Vigilância Sanitária. Disponível em www.cpgls.pucgoias.edu.br/8mostra/Artigos/SAUDE\%20E\%20BIOLOGICAS/Responsabilidade\%20Co mpartilhada,\%20Log\%C3\%ADstica\%20Reversa.pdf. 2013;

MARGARET L. E; BRIDGET J. M. S; CHRISTY A. M. Imidacloprid and chlorpyrifos insecticides impair migratory ability in a seed-eating songbird. Scientific Reports, volume 7, Article number: 15176, 2017;

PERES, F. É Veneno ou é Remédio? Os desafios da comunicação rural sobre agrotóxicos, Dissertação de mestrado, Rio de Janeiro: Escola Nacional de Saúde Pública, Fundação Oswaldo Cruz, 1999;

ROZEMBERG, B.; PERES, F. Reflexões sobre a educação relacionada aos agrotóxicos em comunidades rurais. In: PERES, F., and MOREIRA, JC., orgs. É veneno ou é remédio? agrotóxicos, saúde e ambiente [online]. Rio de Janeiro: Editora FIOCRUZ, 2003. p. 367-384. Disponível em : SciELO Books http://books.scielo.org;

SAMSEL, A.; SENEFF, S. Glyphosate's Suppression of Cytochrome P450 Enzymes and Amino Acid Biosynthesis by the Gut Microbiome: Pathways to Modern Diseases. In: Entropy, n. 15(4), p.14161463. Basel, 2013; 
SILVA, Mayra. Gestão de embalagens vazias de agrotóxicos- logística reversa em pequenos municípios brasileiros: O caso do município de Bom Repouso, MG. Dissertação de Mestrado, Escola de Engenharia de São Carlos, USP. São Carlos, 2016;

SILVA, I; BRESSAN I; PANTALEÃO E; PIRES, W; SILVA, J. Logística Reversa e Responsabilidade Compartilhada: O Caso das Embalagens de Agrotóxicos em Mato Grosso. Revista em Gestão, Inovação e Sustentabilidade, v. 2, n. 1, p. 156-174, jun. Brasília, 2016; 


\section{NOTAS}

\section{Nota 1}

Este trabalho recebeu apoio da CAPES

\section{Nota 2}

Disponível emhttps://www.agrolink.com.br/noticias/brasil-importou-119-mil-toneladas-de-glifosatoem-2016_394734.html. Acesso em 01/09/2018.

\section{Nota 3}

IRaMuTeQ (Interface de R pour les Analyses Multidimensionnelles de Textes et de Questionnaires) é um software livre ligado ao R para análise de dados textuais, desenvolvido pelo Laboratoire d'Études et de Recherches Appliquées en Sciences Sociales da Universidade de Toulouse. Por meio do seu ambiente $\mathrm{R}$, o softwear oferece conjunto de tratamentos e ferramentas de análise estatística que apontam o posicionamento, a estruturação e as relações de palavras no texto.

Nota 4

Disponível:emhttp://www.monsantoglobal.com/global/br/produtos/pages/mitos-verdadesglifosato.aspx. Acesso em 22/09/2018.

\section{Nota 5}

Disponível em https://g1.globo.com/ciencia-e-saude/noticia/2018/08/11/fabricante-de-agrotoxicose-condenada-a-pagar-mais-de-r-1-bilhao-a-americano-que-teve-cancer.ghtml.Acesso

em 18/08/2018.

\section{Nota 6}

Disponível em https://economia.uol.com.br/noticias/reuters/2018/08/11/monsanto-e-condenada-apagar-us289-mi-em-1-julgamento-de-cancer-relacionado-ao-roundup.htm. Acesso em 18/08/2018.

\section{Nota 7}

Disponível:emhttps://www.bbc.com/portuguese/geral47636506?fbclid=IwAR1R7cAyWHg6PqKbEcg1 IsudNXMQhOKtK7XED5qZ-MQoBkqgjIP-z-2Ni2U. Acessado em 26/03/2019.

\section{Nota 8}

Composto que reduza a tensão superficial de uma solução.

\section{Nota 9}

Disponível em http://portal.anvisa.gov.br/rss/-/asset_publisher/Zk4q6UQCj9Pn/content/id/5336025. Acessado em 11/03/2019. 
Nota 10

Larissa Bombardi é autora do atlas "Geografia do Uso de Agrotóxicos no Brasil e Conexões com a União Europeia" (2017).

Nota 11

Disponivel:Emhttp://www.adapar.pr.gov.br/arquivos/File/defis/DFI/Bulas/Herbicidas/GLIFOSATO_N ORTOX.pdf. Acesso em 01/12/2018. 


\section{Capítulo 8}

\section{O COMÉRCIO INTERNACIONAL BRASILEIRO EM CLUSTERS: APLICAÇÃO DO MODELO DE EATON E KORTUM}

DOI: $10.37423 / 200300377$

Júlio Vicente Catéia (Doutor em Economia pela UFPR e Pesquisador PhD Estagiário na Universidade de Sherbrooke (UdeS) - juliocateia@yahoo.com.br

Paulo Ricardo Feistel (Professor do Departamento de Economia e Relações Internacionais e do Programa de Pós-Graduação em Economia (PPGE\&D) da Universidade Federal de Santa Maria) - prfeistel@gmail.com

Clailton Ataides de Freistas (Professor do Departamento de Economia e Relações Internacionais e do Programa de Pós-Graduação em Economia (PPGE\&D) da Universidade Federal de Santa Maria) - caf@ccsh.ufsm.br

Resumo: O objetivo deste estudo é investigar empiricamente o comércio internacional do Brasil com seus parceiros comerciais e políticos utilizando o modelo de Eaton e Kortum (1997-2016) e os estimadores de máxima verossimilhança, Poisson Pseudo-Maximum Likelihood (PPML) e o sistema GMM. Investigamos o desempenho das exportações brasileiras para os quatro clusters intercontinentes: o comércio Brasil-Mercosul, Brasil-BRICS, Brasil-Zona do Euro e Brasil-Estados Unidos. O PPML reporta estimativas significativas e consistentes com a literatura gravitacional de que as rendas e populações dos países contribuem para a criação do comércio, enquanto o custo de transporte mais elevado tende a inibir os fluxos comerciais. 
A volatilidade cambial não mostra ser um impeditivo ao comércio, ao menos no modelo estático. A fronteira não tem um importante papel na determinação do padrão do comércio entre o Brasil e seus parceiros regionais, sugerindo que os clusters intercontinentais podem ser fundamentais para os fluxos de exportações brasileiras, fato este confirmado pelos resultados reportados pelo estimador do sistema GMM.

Palavras-Chave: Exportações. Comércio internacional. Modelo de Eaton e Kortum. Estimador PPML. Sistema GMM.

Classificação JEL: C33; F14; F15 


\section{INTRODUÇÃO}

Depois do tratado de Assunção no início da década de 1990, o comércio internacional brasileiro parece estar se movendo novamente, e não apenas para o antigo sistema de áreas regionais de livre comércio, mas para um sistema de grandes agrupamentos intercontinentais que facilitam o intercâmbio de bens e serviços. Além da sua entrada nos mercados asiáticos, o Brasil, por razões políticas e comerciais, procurou se inserir tanto na Europa do Leste quanto na Ásia Meridional e no continente africano por meio do BRICS. Com a expansão econômica desses países culminada com o declínio da prosperidade de seus parceiros comerciais da região, não há dúvida de que os clusters intercontinentes serão importantíssimos para fluxos de exportações brasileiros.

O objetivo deste estudo é investigar empiricamente o comércio internacional do Brasil com seus parceiros comerciais e políticos utilizando o modelo de Eaton e Kortum (2002) - cobrindo o período de 27 anos de 1989 a 2016 - e os estimadores de máxima verossimilhança, o estimador Poisson PseudoMaximum Likelihood (PPML) e o sistema método de momentos generalizados (GMM). O estimador Poisson Pseudo-Maximum Likelihood (PPML) foi desenvolvido para controlar a heterogeneidade persistente. Mais do que isso, a vantagem de se utilizar o estimador PPML no modelo de comércio internacional não decorre apenas do fato de ele permitir que se leve em conta a heterocedasticidade existente, mas também porque fornece estimativas não viesadas mesmo na presença de muitos zeros na variável dependente (SANTOS \& TENREYRO, 2006). O sistema GMM pode ser importante para o nosso propósito em função da endogeneidade presente em modelos gravitacionais, fornecendo estimativas que os estimadores tradicionais de modelos de painel estáticos não seriam capazes de reportar. Procuramos analisar se o esforço de inserção brasileira no BRICS teria sido suficiente para reduzir a importância do Mercosul e se o efeito fronteira ainda é importante para o atual padrão de comércio brasileiro. Conseguimos mostrar que a fronteira não tem um importante papel na determinação do padrão do comércio entre o Brasil e seus parceiros regionais e que os clusters intercontinentais podem ser fundamentais para os fluxos de exportações brasileiras.

O resto do estudo é estruturado como segue. A Seção 2 fornece uma revisão de literatura de modelos gravitacionais de comércio e suas aplicações. A Seção 3 descreve o modelo, mostra a base de dados e a estratégia de estimação que será empregada. A Seção 5 mostra os principais resultados obtidos. A Seção 5 conclui a discussão. 


\section{MODELOS GRAVITACIONAIS: UMA REVISÃO DE LITERATURA}

Em seu estudo seminal, Tinbergen et al. (1962) estendem a Equação de Gravidade de Newton para análise de fluxos de comércio, argumentando que os fatores que dificultam ou facilitam o comércio não devem se afastar muito das características dos países envolvidos. Do conjunto dos fatores que facilitam o comércio, o tamanho dos mercados e a estrutura produtiva eram considerados, pois havia um reconhecimento de que países com mercados amplos e rendas elevadas necessitam ofertar ou comprar do exterior com maior frequência. Por outro lado, tem-se um conjunto que contém fatores que dificultam o comércio bilateral, no qual a variável distância aparecia como a principal candidata a entraves.

A formalização dessas ideias por Tinbergen et al., tomando por base a equação de Newton, não apenas é uma incorporação de um novo instrumento para o entendimento da direção do fluxo de comércio e das variáveis que influenciam esse fluxo, mas, principalmente, representa uma alternativa ao tradicionail modelo de Heckscher e Ohlin.

Dando continuidade ao estudo de Tinbergen, Geraci e Prewo (1977) mostram que, em equilíbrio, o comércio bilateral entre dois países é influenciado por um conjunto mais amplo de variáveis, no qual as rendas brutas e componentes quantitativos (tarifas) e qualitativos (rea de livre comércio, passado histórico e língua comum) desempenhavam principal papel. Aitken (1973) foi um dos primeiros a utilizar o modelo gravitacional padrão para investigar dos determinantes de comércio bilateral.

Entretanto, os modelos gravitacionais receberam questionamentos dos economistas quanto aos seus fundamentos econômicos. Tais questionamentos pareceram cessar com o estudo de Anderson (1979), que forneceu os primeiros fundamentos microeconômicos com base nos pressupostos das teorias da estrutura de mercados perfeitos, tais como os de sistemas de gastos e de elasticidade de substituição constante. Desde então crescem as aplicações dos modelos gravitacionais.

Hamilton e Winters (1992) analisaram através do modelo de gravidade padrão o efeito da liberalização do comércio dos países do leste europeu e da União Soviética sobre o tamanho e a direção de fluxo de comércio dos países desta região com países da Europa ocidental e os Estados Unidos. Os autores concluíram que a abertura econômica desempenha papel importante no desenvolvimento econômico, pois tem o potencial de gerar a renda, introduz nova tecnologia e promove habilidades organizacionais, estimula a competição e é importante para as sociedades pluralistas. 
Wang e Winters (1992) utilizaram esta abordagem para analisar o volume potencial e direção de comércio do bloco-leste europeu (1984-86) e encontraram os resultados esperados e significativamente diferentes de zero.

Em um estudo anterior, Frankel et al. (1995, p.09) já haviam argumentado que não se pode investigar as formas como iniciativas políticas regionais estão a influenciar os padrões de comércio sem deixar alguns determinantes econômicos naturais, e que o modelo de gravidade de comércio fornece um quadro sistemático para mensurar quais padrões de comércio internacional são normais ao redor do mundo. Dentre as determinantes econômicas, os autores mostraram que a distância e os tamanhos dos dois países fornecem ao modelo o seu próprio nome e, portanto, explicam o comércio bilateral.

Em continuação ao estudo de Tibergen et al. (1962), Linneman (1967) e Frankel et al. (1995), MacCallum (1995) aplica o modelo de gravidade de comércio para um estudo de caso do impacto de fronteiras Canadá-Estados Unidos sobre os padrões de comércio regionais, ou seja, avaliar o comércio entre as províncias do Canadá e entre estas com os estados dos Estados Unidos. Os dados utilizados são de 1988 e são de importações e exportações de 10 províncias e 50 estados. Na equação incluindo o comércio interprovincial e com os Estados americanos, MacCallum mostra que variando a renda das províncias em 1\%, o comércio bilateral entre eles aumentaria em $1.21 \%$, ao passo que o impacto de variação de $1 \%$ na renda dos estados sobre o padrão de comércio é de $1.06 \%$ e da distância $-1.42 \%$. A conclusão é que as fronteiras continuam desempenhando papel importante no padrão do comércio internacional.

Os chamados modelos de gravidade aumentados ou modelos de gravidade estendidos têm sido um instrumento importante na avaliação do comércio desagregado (Hatab et al., 2010; Zhu e Gu, 2008). Alguns desses modelos têm como base a equação de gravidade generalizada de Bergstrand (1985), derivada do modelo de equilíbrio geral walrasiano, e tornaram-se muitos úteis na avaliação do comércio de produtos agrícolas que, segundo Moisé et al (2013), contribuiu significativamente para o crescimento econômico e segurança alimentar dos países em desenvolvimento.

Com base no modelo de gravidade aumentado de comércio internacional, Bergstrand (1985) avaliou os fluxos de comércio de 15 países da OCDE utilizando os dados Cross-Section de quatro anos - 1965, 1966, 1975 e 1976 - e encontrou coeficientes positivos para as rendas desses países e dummy e índice de preços do país exportador. Ou seja, rendas maiores e a presença de acordos de comércio são elementos que influenciam positivamente o fluxo de comércio dos 15 países da OCDE no período de 
1965-76. Concluiu-se que, sob alguns pressupostos, é possível encontrar uma forma reduzida da equação de gravidade consiste; conclusão essa também apresentada no seu estudo de 1989.

Neste último estudo, Bergstrand incorporou as variáveis de dotações na equação generalizada de 1985 objetivando avaliar os fluxos de comércio intra-indústria dos 15 países da OCDE através dos dados cross-section (1975-76). O estudo encontrou coeficientes positivos para rendas, câmbio e renda per capita do país importador e negativos para distância.

Já Eichengreen e Irwin (1998) examinaram a importância dos acordos regionais para o padrão de comércio utilizando a abordagem de gravidade para fluxos desagregados de exportações. O modelo foi estimado através dos dados de fluxos comerciais entre guerras (1928 e 1938) e pós-guerra (1949, 1954 e 1964). Foram estimadas elasticidades para cada um dos anos, tanto em diferenças de logaritmos quanto em nível; e os coeficientes apresentam certa semelhança e foram significativos para a maioria dos anos. Entretanto, em 1949 o coeficiente de renda per capita não foi significativo, $\mathrm{Na}$ visão dos autores, isto ocorreu por duas razões, a saber: (1) o comércio intra-indústria estava deprimido na Segunda Guerra Mundial com o progresso lento da reconstrução na Europa, o que impediu os países daquele continente exportar os produtos manufaturados no nível tradicionalmente dirigido para os Estados Unidos, e (2) a escassez de dólar impediu o intenso fluxo de comércio entre a Europa e os Estados-Membros. Os autores mostram que, no período entre guerras, $90 \%$ do comércio foi explicado pelas rendas brutas dos países ricos e 33\% pelas suas rendas per capitas, enquanto que a distância e a fronteira influenciaram respectivamente $-78 \%$ e $79 \%$ do comércio entre os países hoje membros da comunidade econômica europeia e entre os países europeus e dos Estados Unidos. Já em 1964, tal fluxo de comércio é explicado por $27 \%$ das rendas, $20 \%$ das rendas per capitas e $-30 \%$ de distância e $1 \%$ de fronteira. 
Quadro 1 - Resultados e variáveis utilizadas para investigação dos determinantes de exportações em bloco/agrupamento de países

\begin{tabular}{|c|c|c|c|c|c|}
\hline Autor & Objetivo & Problema & $\begin{array}{ll}\begin{array}{l}\text { Dados } \\
\text { período }\end{array} & \text { ou } \\
\end{array}$ & Método & Conclusão \\
\hline $\begin{array}{l}\text { Zarzoso e } \\
\text { Lehmann } \\
(2003)\end{array}$ & $\begin{array}{l}\text { Avaliar o comércio } \\
\text { MERCOSUL-União } \\
\text { Europeia. }\end{array}$ & $\begin{array}{l}\text { Quais são os } \\
\text { principais } \\
\text { determinantes } \\
\text { do comércio } \\
\text { entre os países } \\
\text { do } \\
\text { MERCOSUL e } \\
\text { a União } \\
\text { Europeia? }\end{array}$ & $\begin{array}{l}\text { Painel não } \\
\text { balanceado } \\
1988-1996) .\end{array}$ & $\begin{array}{l}\text { Modelo } \\
\text { gravitacional } \\
\text { padrão (MGP). } \\
\text { Modelo } \\
\text { gravitacional } \\
\text { aumentado } \\
\text { (MGA). }\end{array}$ & $\begin{array}{l}\text { A abordagem de efeitos fixos foi preferida a de } \\
\text { efeitos aleatórios. } \\
\text { Significativos - MGP: coeficientes positivos para } \\
\text { rendas e negativos para população (ou renda per } \\
\text { capita) e distância. } \\
\text { Significativos - MGA: câmbio, infraestruturas e } \\
\text { diferenças de renda são variáveis importantes para } \\
\text { determinação de fluxos de comércio entre os dois } \\
\text { blocos. }\end{array}$ \\
\hline Bikker (2009) & $\begin{array}{llr}\text { Analisar } & \text { fluxos } & \text { de } \\
\text { comércio } & \text { entre } & 178 \\
\text { países. } & & \end{array}$ & $\begin{array}{l}\text { Será que o } \\
\text { modelo } \\
\text { gravitacional } \\
\text { padrão é mais } \\
\text { consistente do } \\
\text { que o modelo } \\
\text { gravitacional } \\
\text { estendido? }\end{array}$ & $\begin{array}{l}\text { Dados em } \\
\text { painel, 2005. }\end{array}$ & $\begin{array}{l}\text { Modelo } \\
\text { gravitacional } \\
\text { padrão (MGP). } \\
\text { Modelo } \\
\text { gravitacional } \\
\text { aumentado } \\
\text { (MGA). }\end{array}$ & $\begin{array}{l}\text { Significativos - MGP: coeficientes positivos para } \\
\text { dummy, rendas e população do país exportador; } \\
\text { negativos para distância e população do país } \\
\text { importador. } \\
\text { Significativos - MGA: coeficientes positivos para } \\
\text { rendas, dummy e população do país exportador, } \\
\text { ex-relações coloniais, língua comum, passado } \\
\text { comunista, União Soviética, pacto de Varsóvia e } \\
\text { União Europeia; negativos para distância e } \\
\text { população do país importador. } \\
\text { MGA é preferido ao MGP. }\end{array}$ \\
\hline $\begin{array}{l}\text { El-Arish } \\
(2012)\end{array}$ & $\begin{array}{l}\text { Analisar o comércio do } \\
\text { Egito e alguns blocos } \\
\text { econômicos }\end{array}$ & $\begin{array}{lr}\text { O modelo } \\
\text { gravitacional } \\
\text { padrão } \\
\text { eficiente para } \\
\text { analisar o } \\
\text { comércio entre o } \\
\text { Egito, AFTA, } \\
\text { COMESA e } \\
\text { EU? } \\
\end{array}$ & $\begin{array}{lr}\text { Dados } & \text { em } \\
\text { painel: } & 2008- \\
2010 & \end{array}$ & $\begin{array}{l}\text { Modelo } \\
\text { Gravitacional } \\
\text { Padrão }\end{array}$ & $\begin{array}{l}\text { Significativos: o coeficiente para as rendas é } \\
\text { positivo, negativo para distância, renda per capita } \\
\text { e dummy. } \\
\text { No geral, há uma robustez nos resultados. }\end{array}$ \\
\hline $\begin{array}{l}\text { Khan, Haq e } \\
\text { Khan (2013) }\end{array}$ & $\begin{array}{lr}\text { Avaliar o } & \text { fluxo de } \\
\text { comércio } & \text { bilateral } \\
\text { entre o Paquistão e seu } \\
\text { principal } & \text { parceiro } \\
\text { comercial } & \end{array}$ & $\begin{array}{l}\text { Quais são os } \\
\text { determinantes } \\
\text { de fluxo de } \\
\text { comércio } \\
\text { bilateral do } \\
\text { Paquistão? }\end{array}$ & $\begin{array}{lr}\text { Dados } & \mathrm{em} \\
\text { Painel: } & 1990- \\
2010 & \end{array}$ & $\begin{array}{l}\text { Modelo } \\
\text { Gravitacional } \\
\text { Padrão }\end{array}$ & $\begin{array}{l}\text { Coeficientes significativos e negativos para renda } \\
\text { e renda per capita; negativo e não significativo } \\
\text { para distância. }\end{array}$ \\
\hline $\begin{array}{l}\text { Mirian et. al } \\
(2013)\end{array}$ & $\begin{array}{l}\text { Explicar a magnitude } \\
\text { dos fluxos comerciais } \\
\text { para uvas da Turquia e } \\
\text { de outros países que } \\
\text { exportam para os seus } \\
\text { principais países } \\
\text { importadores }\end{array}$ & $\begin{array}{l}\text { Como as } \\
\text { importações de } \\
\text { uva de alguns } \\
\text { países podem } \\
\text { influenciar as } \\
\text { exportações de } \\
\text { uva da Turquia? }\end{array}$ & $\begin{array}{l}\text { Dados rem } \\
\text { painel: de 1999- } \\
\text { 2008. }\end{array}$ & $\begin{array}{l}\text { Modelo } \\
\text { gravitacional } \\
\text { estendido. }\end{array}$ & $\begin{array}{l}\text { Coeficientes significativos para rendas, } \\
\text { populações e dummy e negativos para distância. } \\
\text { Os coeficientes são todos significativos. }\end{array}$ \\
\hline $\begin{array}{l}\text { Castilho } \\
\text { (2002) }\end{array}$ & $\begin{array}{lr}\text { Mensurar os efeitos da } \\
\text { proteção } & \text { europeia } \\
\text { sobre } & \text { suas } \\
\text { importações. } & \end{array}$ & & $\begin{array}{l}\text { Cross-section } \\
(96 \text { setores): } \\
1993-1995\end{array}$ & $\begin{array}{l}\text { Modelo } \\
\text { gravitacional } \\
\text { para fluxos } \\
\text { desagregados de } \\
\text { comércio. }\end{array}$ & $\begin{array}{l}\text { Língua comum, PIBs nominais e rendas per } \\
\text { capitais apresentam sinais esperados e } \\
\text { Significativos. Já o coeficiente de acordos de } \\
\text { comerciais tem seu sinal negativo, o que não era } \\
\text { esperado. }\end{array}$ \\
\hline
\end{tabular}

Fonte: Elaborado pelos autores com base nos estudos revistos.

Ademais, Farias e Hidalgo (2012) aplicaram a abordagem gravitacional para avaliar o comércio interestadual e comércio internacional brasileiro, concluindo que a formação do Mercosul aumenta o comércio da região em detrimento de mais parceiros. Esta crescente diversidade de equações de gravidade não apenas confirma a flexibilidade e a ampla aplicabilidade dessa modelagem, mas também representam certo avanço no sentido de encontrar outras variáveis que influenciam o 
comércio entre as nações e que permitem também investigar um conjunto mais amplo de questões relativas ao comércio bilateral.

\section{MÉTODO}

\subsection{MODELO TEÓRICO: MODELO DE EATON KORTUM}

Adotamos um modelo de tecnologia, preços e fluxos comerciais de Eaton e Kortum (2002) com bens contínuos. No modelo gravitacional de Eaton e Kortum, a fração de bens que o país ${ }_{n}$ compra do país $i$ é também a fração de suas despesas com bens do próprio país:

$$
\frac{X_{n i}}{X_{n}}=\frac{T_{i}\left(c_{i} d_{n i}\right)^{-\theta}}{\vartheta_{n}}=\frac{T_{i}\left(c_{i} d_{n i}\right)^{-\theta}}{\sum_{k=1}^{N} T_{k}\left(c_{k} d_{n k}\right)^{-\theta}}
$$

em que $X_{n}$ são gastos totais do país ${ }_{n}$ e $X_{n i}$ são gastos do mesmo país com a produção oriunda do país $i$. A distribuição varia entre os países e o parâmetro específico de país, $T_{i}>0$, governa a localização da distribuição. Um $T_{i}$ maior implica a possibilidade de um país se especializar na produção de um bem com mais eficiência. $T_{i}$ é assim um estado de tecnologia do país i ou a sua vantagem em relação aos seus parceiros comerciais. $\theta>0$ é o parâmetro (comum para todos os países), que indica o montante de variação dentro da distribuição. Um $\theta$ maior implica menor variabilidade. O parâmetro $\theta$ regula a heterogeneidade entre os bens nas eficiências relativas dos países (EATON e Kortum, 2002, p.1747). A ideia é que um menor valor de $\theta$ gera mais heterogeneidade, significando que a vantagem comparativa exerce uma força mais forte para o comércio contra a resistência imposta pelas barreiras geográficas $d_{n i}$. $c_{i}$ é um custo de insumo. O parâmetro $\vartheta_{n}$ contém informações muito importantes no modelo gravitacional. Ele traz informações relevantes como (i) estados de tecnologia em todo o mundo, (ii) custos de insumos em todo o mundo, e (iii) barreiras geográficas que governam os preços em cada país. Portanto, o comércio internacional é capaz de ampliar o estado efetivo de tecnologia de cada país com tecnologia disponível de outros países, descontada pelos custos de insumos e barreiras geográficas (EATON E KORTUM, idem, p.1748; BALDWIN E HARRIGAN, 2011).

Temos duas possibilidades. Em um extremo com um mundo de comércio gravitacional sem barreiras geográficas, isto é, $\forall d_{n i}=1$ para todo $i$ e $n, \vartheta$ é o mesmo em todos os lugares e a lei do preço único valeria em tal situação para cada bem comercializável. Em outro extremo oposto de autarquia com 
barrerias proibitivas, isto é, $d_{n i} \rightarrow \infty$ para $\forall i \neq n, \vartheta$ reduz-se apenas ao estado de tecnologia do país ponderado pelo seu custo de insumo, $T_{i} c_{i}^{-\theta}$. As vendas do país exportador são representadas como:

$$
Q_{i}=\sum_{m=1}^{N} X_{m i}=T_{i} c_{i}^{-\theta} \sum_{m=1}^{N} \frac{d_{m i}{ }^{-\theta} X_{m}}{\vartheta_{m}}
$$

Após algumas manipulações, como demonstrado por Eaton e Kortum (ibidem, p.1750), a expressão (1) é semelhante com a equação gravitacional padrão, estabelecendo que o comércio bilateral está relacionado com as despesas do país importador e com as barreiras geográficas. Na verdade, resolvendo (2) para $T_{i} c_{i}^{-\theta}$ e para todo índice de preço:

$$
p_{j}=\gamma\left(\vartheta_{j}^{-1 / \theta}\right)
$$

e substituindo o resultado obtido em (1) obtemos uma representação gravitacional

$$
X_{n i}=\frac{T_{i}\left(d_{n i} / p_{n}\right)^{-\theta} X_{n}}{\sum_{m=1}^{N}\left(d_{m i} / p_{m}\right) X_{m}} Q_{i}
$$

em que as barreiras geográficas entre o país $i$ e qualquer outro país importador $m$ é deflacionado pelo nível de preço do país importador $p_{m}$. A redução de $p_{m}$ opera da mesma maneira que uma barreira geográfica mais elevada: uma concorrência mais rígida no mercado $m$ reduz $p_{m}$, reduzindo o acesso do país $i$. As vendas totais do país exportador $Q_{i}$ e as compras do país importador $X_{n}$ entram com a elasticidade unitária. O tamanho de mercado do país destinatário $m$ percebido pelo país $i$ é todo o termo $\left(d_{m i} / p_{m}\right) X_{m}$. Dado o estado de tecnologia e assumindo a elasticidade de Armington unitária, o termo $\left(d_{n i} / p_{n}\right) X_{n}$ é o tamanho de mercado do país exportador $n$. Na perspectiva do país $i$ o denominador é o total do mercado mundial, de modo que a parcelado do país $n$ nas vendas totais do país $i$ é apenas igual à parcela do país $n$ do mercado mundial efetivo de $i$.

Em (4) a sensibilidade do comércio aos custos e as barreiras geográficas depende do parâmetro tecnológico (refletindo a heterogeneidade dos bens na produção) em vez do parâmetro de preferência (refletindo a heterogeneidade dos bens no consumo). A ideia é que as partes envolvidas respondem por custos e barreiras geográficas na margem extensiva: à medida que uma fonte se torna mais cara ou remota, a exportação torna-se mais restritiva a uma gama de bens. 
Alguém poderia arguir que se um país $i$ for capaz de abastecer um outro país $n$ a um custo relativamente mais baixo, então não haveria necessidade de ${ }_{n}$ demandar produtos de outros países, digamos, $m$. Para evitar quaisquer problemas desta natureza que podem surgir no nosso modelo, assumimos algumas preposições antigas em relação aos fluxos de comércio (ver Savage e Deutsch, 1960): (a) independência de remessas ou decisões. As remessas se movem de forma mutuamente independentes, ou seja, uma exportação de $i$ para $j$ não afeta a probabilidade de ocorrência da outra exportação de $i^{\prime}$ para $j^{\prime}$, sendo a probabilidade das remessas $\left(R_{1}, \ldots, R_{N}\right)$ ir de $i$ para $j$ definida por $P_{i j}$, cuja ocorrência também é independente do valor das remessas. Está implícito nesta premissa o argumento de que o comércio mundial é composto de muitas decisões por muitos países produtores e muitos países consumidores e, portanto, as decisões dos produtores ou dos consumidores são homogêneas, visto que cada decisão individual envolve apenas uma pequena proporção do comércio total. Disto segue que as remessas $R_{1}, \ldots, R_{N}$ são apenas as amostras aleatórias de população de possíveis remessas. A suposição para $R$ é a mesma da estatística clássica, ou seja, (1) todas as $R^{\prime} \mathrm{s}$ remessas são estatisticamente independentes, e (2) a distribuição de $R^{\prime}$ s tem valor médio finito, $\alpha$, e variância finita, $\sigma^{2}$. (b) Independência origem-destino: Evento de uma remessa proveniente de um país em particular não afeta a probabilidade de o outro país receber esta mesma remessa. No caso presente, os fatores que levam o Brasil a exportar para os demais países não interferem nas exportações dos mesmos produtos para outros mercados, desconsiderando a possibilidade de o Brasil (como o país remetente) receber suas próprias exportações.

\subsection{MODELO ECONOMÉTRICO GRAVITACIONAL}

O modelo gravitacional de painel à la Eaton e Kortum (2002) tem a seguinte forma estocástica:

$$
X_{i j t}=T_{i j t} \beta+\lambda_{i}+\tau_{i}+\varepsilon_{i j t}
$$

em que $X_{i t}$ é a variável dependente do modelo, isto é, o volume de exportações anual; $T_{i j t}=$ $Y_{i j t}, N_{i j t}, C_{i j t}$, Rat $_{i j t}$ é um vetor de variáveis explicativas estritamente exógenas, representado respectivamente rendas, populações, custos de comércio e volatilidade cambial; $\lambda_{i}$ são os efeitos fixos do país $i$; e $\tau_{i}$ são os efeitos fixos de período. A forma linear do modelo é:

$$
\ln X_{i j k}=\alpha_{0}+\alpha_{1} \ln Y_{i j t}+\alpha_{2} \ln N_{i j t}+\alpha_{3} \ln C_{i j t}+\alpha_{4} \ln R a t_{i j t}+\alpha_{5} \lambda_{i}+\alpha_{6} \tau_{i}+\ln \varepsilon_{i j}
$$


Os testes usuais de Hausman, o teste Chow e o teste de LM de Breusch-Pagan nos permitirá escolher o modelo econométrico mais adequado. Os estimadores de máxima verossimilhança e o estimador Poisson Pseudo-Maximum Likelihood (PPML) de Santos Tenrenyro (2006) serão aplicados.

Este estudo também emprega o estimador GMM desenvolvido por Arellano e Bover (1995) e Blundell e Bond (1998) para examinar a relação entre as exportações brasileiras e o custo de transporte, a volatilidade da taxa de câmbio, as rendas per capitas e as populações dos seus parceiros comerciais. Para captar esta relação, um modelo gravitacional de painel dinâmico é especificado como segue:

$$
X_{i j t}=\alpha+\delta X_{i j t-1}+\beta Y_{i j t}+\sum_{m=1}^{k} \phi_{m} Z_{m i j t}+\varepsilon_{i j t} ; j=1, . ., k ; i=1, \ldots . n ; t=1, \ldots, T
$$

em que $X_{i j t}$ é a variável dependente do país $i$ no período $t . X_{i j t-1}$ é a mesma variável defasada. $Y_{i j t}$ representa as rendas dos $i$ e jno tempot. $Z_{m j i t}$ denota todos os demais regressores incluídos no modelo como variáveis de controle para o país $i . m$ indica o número de variáveis de controle incluídas. Um efeito fixo específico do país assumido para o termo de perturbação é:

$$
\varepsilon_{i j t}=\tau_{i}+u_{i j t}
$$

em que $\tau_{i}$ representa os efeitos fixos do país $i$, que entram na expressão (7) como variáveis invariantes. $u_{i j t}$ é assumido ser normalmente distribuído e estocásticamente independente, cujos momentos $u_{i t} \approx\left(0, \sigma_{u}^{2}\right)$

Um modelo de painel dinâmico como na Equação (7) viola o pressuposto clássico de ortogonalidade, pois a variável dependente $X_{i j t-1}$ depende de $\varepsilon_{i j t-1}$ que é uma função de $\varepsilon_{i j t}$. Em (8), $\varepsilon_{i j t}=\tau_{i}+u_{i j t}$, então $E\left(X_{i j t-1} \varepsilon_{i j t}\right) \neq 0$. Esta correlação sugere que a estimação de dados em painel dinâmicos sofre de viés que desaparece apenas à medida que $t \rightarrow \infty$. O problema pode, porém, ser superado simplesmente diferenciado a Equação (7) como:

$$
\Delta \ln X_{i j t}=\alpha+\delta \Delta \ln X_{i j t-1}+\beta \Delta \ln Y_{i j t}+\sum_{m=1}^{k} \phi_{m} \Delta \ln Z_{m i j t}+\Delta u_{i j t}
$$

Entretanto, o termo de erro transformado $\Delta u_{i j t}$ é correlacionado com $\Delta \ln X_{i j t-1}$, uma vez que ambos contêm $u_{i j t-1}$. Como sugerido por Greene (2012) e Hsiao (2003) em painel estático o estimador OLS pode ser aplicado consistente. Contudo, o estimador OLS para dados em primeiras diferenças no modelo dinâmico gera estimativas de parâmetros inconsistentes. Vale notar que na Equação (9), $E\left(X_{i j t-h} \Delta u_{i j t}\right)=0$ para $\forall h \geq 2, t=3, \ldots, T$. 
Esse resultado fornece informações particularmente interessantes para a estimação. A diferenciação das variáveis requer assumir um ponto inicial em que começa o processo gerador dos dados, já que a forma dos instrumentos (IV-variáveis instrumentais) válidos se torna inteiramente dependente da condição dos momentos, que permite identificar se os regressores são predeterminados ou se eles simplesmente são estritamente exógenos (ARELLANO E BOND, 1991; ARELLANO E BOVER, 1995). Anderson e Hsiao (1982) prepuseram um estimador IV usando $\Delta \ln X_{i j t-2}$ como instrumento, já que $E\left(X_{i j t-2} \Delta u_{i j t}\right)=0$.

Alonso-Borrego e Arellano (1996), Blundell e Bond (1998, p.115) demonstraram que em modelos de dados de painel dinâmico onde o parâmetro autorregressivo é moderadamente grande e o número de observações de séries temporais é moderadamente pequeno, o estimador de GMM linear, tem um grande viés em amostras finitas e baixa precisão em estudos de simulação. Em tal situação, a variável dependente defasada é um instrumento fraco para as variáveis transformadas. Arellano and Bover (1995) apresentaram uma abordagem em que, para aumentar a eficiência do estimador é necessário assumir a condição de momento $E\left(\Delta I_{i j t} \lambda_{i}\right)=0$ para todo $i$ e $t$. Assim, mesmo o estimador GMM exibindo o viés nas amostras finitas, comparativamente ao estimador OLS, ele é assintóticamente mais eficiente, pois o viés do OLS opera em direção contrária, isto é, é crescente (ARELLANO-BOND, 1991). Em sistema de estimadores GMM é usado quando $N>T$. Um GMM dinâmico tem dois benefícios potenciais: (i) resolve o problema de endogeneidade do que nos modelos estáticos e estimador OLS que não permitem o uso de instrumentos internamente gerados (BOND, 2002; OSENI, 2016); (ii) todas as variáveis da equação não correlacionados com o termo de erro podem ser usados como instrumentos válidos (WOOLDRIDGE, 2002; BALTAGI, 2005; GREENE, 1993 e 2012).

O teste Sargan ou estatísticas J de Hansen têm sido amplamente utilizados para testar a restrição de sobreidentificação. Ademais, vamos empregar o teste de autocorrelação de Arellano-Bond para os erros na primeira diferença.

\subsection{FONTE E TRATAMENTO DE DADOS}

As variáveis do modelo são:

$X_{i j}$ : fluxos de exportações brasileiras para os seus parceiros comerciais. O total de fluxo de exportações tem o seguinte formato (Fonte: IPEA):

$$
X_{\text {TOTAL }}=\sum_{i, j=1}^{n} \alpha_{j} X_{i} \quad i \neq j
$$




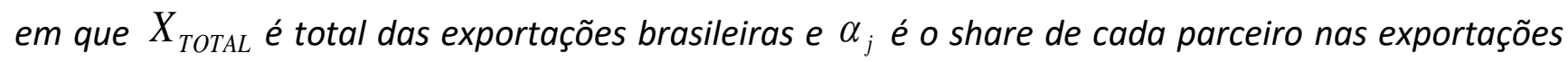
totais

As variáveis independentes do modelo são:

$Y_{i j}$ : a renda per capita dos parceiros comerciais do Brasil (Fonte: WB)

$N_{i j}$ : a população dos parceiros comerciais do Brasil (Fonte: WB)

$C_{i j}$ : custo de transporte do comércio internacional brasileiro - distância em $\mathrm{km}$. O cálculo da distância

varia de estudo para estudo, consideramos a distância em $\mathrm{km}$ entre o Brasil e seus parceiros comerciais; $e$

$R a t_{i j}$ : volatilidade cambial. Volatilidade da taxa de câmbio comercial para venda - RS /USȘ (Fonte: IPEA)

Efeito-Fronteira: uma variável dummy que assume valor 1 ou 0.

\section{RESULTADOS E DISCUSSÕES}

Esta seção apresenta as estimativas e discute os resultados dos modelos estático e dinâmico representados pelas expressões (6) e (9), respectivamente. Os testes iniciais para a escolha do melhor modelo de painel estático, bem como o teste sobre autocorrelação foram realizados na primeira subseção. O objetivo é escolher o modelo mais adequado para estimar o efeito fronteira. Nas três subseções seguintes são reportadas as estimativas através do método de máxima verossimilhança, método Poisson pseudo máxima verossimilhança (PPML) e método dos momentos generalizados (GMM).

\subsection{TESTES PRELIMINARES}

Conforme a Tabela 1, a estatística calculada do teste chow é estatisticamente significativa aos níveis de significância convencionais (1\%, $5 \%$ e 10\%), com valor $p$ de zero, sugerindo que, levando em consideração as idiossincrasias dos países do MERCOSUL, o modelo de efeitos fixos parece ser o mais adequado. Pelo teste de Hausman não foi possível rejeitar a hipótese nula aos mesmos níveis de significância de que as estimativas obtidas por OLS e GLS do parâmetro $\beta$ são significativamente diferentes, ou seja, não se rejeitou a hipótese nula de que o modelo de efeitos aleatórios é melhor do que o de efeitos fixos. Enquanto isso, o valor $p$ do teste LM é zero, sendo assim estatisticamente 
significante, levando a rejeitar a hipótese nula, o que aponta para o modelo de efeitos aleatórios em detrimento do modelo pooled.

Tabela 1: Testes preliminares para a escolha do modelo de dados em painel

\begin{tabular}{c|c|c|c|c|c}
\hline Teste & Modelo & Estimador & P-valor & Estatística & $\begin{array}{c}\text { Critério de } \\
\text { decisão }\end{array}$ \\
\hline Chow & $\begin{array}{c}\text { Pooled X } \\
\text { FE }\end{array}$ & OLS X LSDV & 0.000 & 36.871 & Rejeita-se $H_{0}$ \\
\hline Hausman & RE X FE & GLS X LSDV & 0.752 & - & $\begin{array}{c}\text { Não se rejeita } \\
H_{0}\end{array}$ \\
\hline $\begin{array}{c}\text { Breusch-Pagan } \\
\text { (LM) }\end{array}$ & $\begin{array}{c}\text { Pooled X } \\
\text { RE }\end{array}$ & OLS X GLS & 0.000 & 730.120 & Rejeita-se $H_{0}$ \\
\hline \begin{tabular}{c} 
Autocorrelação \\
\hline
\end{tabular} & & 0.000 & 148.274 & Rejeita-se $H_{0}$ \\
\hline
\end{tabular}

Fonte: Resultados da pesquisa. Elaborada pelos autores.

Os testes realizados forneceram resultados em termos de qual o melhor modelo a utilizar e o estimador correspondente. O modelo de efeitos aleatórios é o mais adequado. Ademais, a estatística calculada de Wooldridge é significativa aos níveis de significância convencionais, com um valor $\mathrm{p}$ de zero, permitindo a rejeição da hipótese nula de ausência de autocorrelação de primeira ordem nos resíduos. Eventuais problemas de heterocedasticidade são corrigidos mediante os erros padrão robustos com a correção da heterocedasticidade de White (White robust).

\subsection{EFEITO FRONTEIRA: ESTIMAÇÃO POR MÁXIMA VEROSSIMILHANÇA (MV) E POISSON PSEUDO-MAXIMUM LIKELIHOOD (PPML)}

Os testes anteriores foram realizados com a finalidade de encontrar o modelo mais adequado para análise de efeito fronteira, uma questão extremamente importante na discussão de políticas de comércio, pois a criação dos blocos econômicos regionais e muitos outros acordos bilaterais de comércio parecem não superar os custos de comércio impostos pelas fronteiras. O propósito aqui é verificar empiricamente se a fronteira ainda desempenha um papel crucial no comércio brasileiro.

A Tabela 2 reporta as estimativas da equação de comércio bilateral do Brasil com os países do Mercosul aplicando os estimadores de máxima verossimilhança (Coluna 2) e Poisson PseudoMaximum Likelihood (PPML) (Coluna 3). Para fluxos de comércio com poucas observações nulas, como o caso do nosso painel, o estimador de MV reportou estimativas maiores em magnitude comparativamente ao PPML. A diferença é mostrada na Coluna 4. Porém, o PPML gera estimativas 
estatisticamente mais significativas e maior poder explicativo (um R-quadrado mais alto). Concentramos a nossa discussão daqui em diante nos resultados fornecidos pelo PPML.

Os regressores em conjunto tem um alto poder de explicar a variável dependente, com um R-quadrado de 0.94; ou seja, 94\% das exportações brasileiras para o Mercosul consegue ser explicada pela renda per capita e população do bloco, pelo custo de comércio, pela volatilidade cambial e pelo efeito fronteira. Todos os coeficientes estimados pelo PPML são estatisticamente significativos e com os sinais consistentes com a literatura de comércio gravitacional. Um crescimento da população e uma variação de renda per capita dos países do Mercosul em 1\% geram um aumento do comércio brasileiro em 0.06 e 0.07 pontos percentuais, respectivamente. A volatilidade cambial não é um impeditivo de comércio, sendo seu efeito positivo e estatisticamente significativo ao nível de 1\%, enquanto uma variação do custo de comércio em $1 \%$ provoca uma redução de 0.16 pontos percentuais. Além disso, a fronteira não tem um importante papel na determinação do padrão do comércio entre o Brasil e seus parceiros regionais. Dados os demais fatores, o resultado confirma esta hipótese, reportando que o efeito-fronteira sobre as exportações, embora estatisticamente significativo a 1\%, é de -0.03 pontos percentuais, não corroborando com o estudo seminal de MacCallum (1995), que discute os impactos das fronteiras do Canadá - Estados Unidos sobre os padrões de comércio. Para o autor, apesar das crescentes formações de blocos econômicos e de acordos de comércio, as fronteiras continuam desempenhando papel importante na determinação dos fluxos comerciais; afirmação essa também confirmada por Helliwell (1997). Este último autor mostra que, em função da existência de efeitofronteira, o comércio interprovincial do Canadá no período de 1988-1990 é 20 vezes mais denso que o comércio entre províncias desse país e Estados dos Estados Unidos.

Tabela 2 - Estimativas do modelo de painel estático - Equação (6)

\begin{tabular}{|c|c|c|c|}
\hline${ }_{\text {Especificação }}^{\text {Estimador }}$ & $\begin{array}{l}\text { (2) } \\
\text { MV }\end{array}$ & $\begin{array}{c}\text { (3) } \\
\text { PPML }\end{array}$ & $\begin{array}{c}(4) \\
(\mathrm{MV}-\mathrm{PPML})\end{array}$ \\
\hline$Y_{i j}$ & $\begin{array}{c}1.0769 \\
(0.0981)^{* * *}\end{array}$ & $\begin{array}{c}0.06851 \\
(0.0017)^{* * *}\end{array}$ & 1.0083 \\
\hline$N_{i j}$ & $\begin{array}{c}1.1793 \\
(0.9219)^{* * *} \\
\end{array}$ & $\begin{array}{c}0.05931 \\
(0.0013)^{* * *}\end{array}$ & 1.1199 \\
\hline$C_{i j}$ & $\begin{array}{c}-2.7825 \\
(0.4022)^{* * *} \\
\end{array}$ & $\begin{array}{c}-0.1565 \\
(0.0046)^{* * *} \\
\end{array}$ & -2.626 \\
\hline$R_{a t}$ & $\begin{array}{c}0.0237 \\
(0.0302)\end{array}$ & $\begin{array}{c}0.0025 \\
(0.0013)^{* *}\end{array}$ & 0.0212 \\
\hline Efeito-Fronteira & $\begin{array}{l}-0.49621 \\
(0.2952)^{*}\end{array}$ & $\begin{array}{c}-0.02981 \\
(0.0032)^{* * *}\end{array}$ & -0.4664 \\
\hline Constante $\alpha_{0}$ & $\begin{array}{c}14.4436 \\
(3.1932)^{* * *}\end{array}$ & $\begin{array}{c}2.7251 \\
(0.03543)^{\text {*** }}\end{array}$ & 11.7185 \\
\hline
\end{tabular}




\begin{tabular}{ccc}
\hline$R^{2}$ & 0.9314 & 0.9442 \\
$\mathrm{~N}$ & 302 & 302 \\
\hline
\end{tabular}

Fonte: Resultados da pesquisa. Elaborada pelos autores.

Nota: As observações anuais são de 1989 a 2016. A variável dependente é volume de exportações. As variáveis independentes estão na primeira coluna. ${ }^{*} p<0: 10, * * p<0: 05, e^{* * *} p<0: 01$.

\subsection{ESTIMAÇÃO DO COMÉRCIO BILATERAL BRASILEIRO: MÉTODO POISSON PSEUDO MÁXIMUM LIKEHOOD (PPML)}

Através do método de estimação de Santos e Silva, o Pseudo poisson maximum likehood (PPML), as estimativas do modelo gravitacional de Eaton e Kortum representado pela Equação (6) estão reportados na Tabela 3. Em cada linha ou coluna da Tabela os valores fora de parênteses são os coeficientes estimados e os respectivos erros-padrão estão entre parênteses. Nela, as estimativas para a equação do comércio brasileiro com os demais países do Mercosul, países do BRICS, Zona do Euro e com os Estados Unidos estão reportados nas Colunas 2, 3, 4 e 5, respectivamente.

Os coeficientes estimados para a renda per capita, população e custo de transporte na Coluna 2 (países do Mercosul) são estatisticamente significativos ao nível de significância de $1 \%$. Os coeficientes para a renda per capita e população são pequenos em magnitude. Um aumento de um por cento na renda dos países do Mercosul aumenta as exportações em 0.07 pontos percentuais. O crescimento da população do Mercosul é associado com um aumento de 0.06 pontos percentuais nas exportações. $A$ variação do custo de transporte internacional dos produtos do Brasil em 1 por cento tem o impacto de -0.140 pontos percentuais nas exportações brasileiras para o Mercosul, enquanto o efeito da volatilidade cambial no fluxo de exportação estatisticamente insignificante é de 0.002 pontos percentuais.

O resultado na Coluna 3 obtido para os países do BRICS mostra que todos os coeficientes são estatisticamente significativos a 1\%. Um aumento de 1 por cento na renda per capita desses países é significativamente associado com um aumento de 0.70 pontos percentuais nas exportações, consistente com as magnitudes obtidas por Zhu e Gu (2008). Eles mostraram que aumentando em 1 por cento as rendas externas as exportações chinesas aumentam em 0.86 pontos percentuais. $\mathrm{Na}$ mesma coluna, os respectivos impactos do crescimento populacional e da volatilidade cambial são de 0.06 e 0.008 pontos percentuais. Um aumento do custo de transporte teria como resultado diminuir as exportações brasileiras em -0.10 pontos percentuais. 
Todas as estimativas do modelo de comércio brasileiro com a Zona do Euro (Coluna 4) foram significativas a $5 \%$, exceto o coeficiente da renda per capita que apenas foi significativo a $10 \%$. A variação da renda per capita dos países do Mercosul em 1\% explicaria em um aumento de 0.06 pontos percentuais do volume de comércio, enquanto que um crescimento da sua população em $1 \%$ provocaria um aumento de 0.75 pontos percentuais nesse volume. Assim como para o comércio BrasilMercosul e Brasil-BRICS, o coeficiente da volatilidade cambial para equação de comércio do Brasil com a Zona do Euro também é positivo, agora explicando 0.003 pontos percentuais de fluxo de comércio bilateral.

Concluímos a nossa apresentação de modelo de painel estático estimando o comércio bilateral BrasilEstados Unidos (Coluna 5). As estimativas pontuais sobre o impacto da renda per capital no volume de comércio brasileiro para aquele país é de 0.04 pontos percentuais, estatisticamente significativa a $5 \%$ de significância. O custo de transporte representado pela distância apresenta a colinearidade e foi computacionalmente excluído no processo de estimação assim como foi feito para caso da expressão representado o comércio Brazil-Zona do Euro. Ademais variáveis do modelo não foram significativas do ponto de vista estatístico. Além disso, o coeficiente da população não é consistente com a literatura gravitacional de que o tamanho de mercado representado pela população seria um fator de atração ao comércio. Entretanto, este sinal corrobora com a afirmação de Freitas e Hidalgo (2012) de que uma população grande do país exportador desenvolvido tem o consumo mais diversificado e demanda relativamente uma fração menor de bens produzidos no exterior do que a população de pequenos países insulares cuja demanda externa é limitada às necessidades básicas.

Tabela 3 - Estimativas do modelo de painel estático - Equação (6)

\begin{tabular}{|c|c|c|c|c|}
\hline Especificaçằ & $\begin{array}{c}(2) \\
\text { ppml } \\
\text { (Mercosul) }\end{array}$ & $\begin{array}{c}\text { (3) } \\
\text { pplm } \\
\text { (brics) }\end{array}$ & $\begin{array}{c}\text { (4) } \\
\text { ppml } \\
\text { (zona do euro) }\end{array}$ & $\begin{array}{c}(5) \\
\text { ppml } \\
\text { (Estados unidos) }\end{array}$ \\
\hline$Y_{i j}$ & $\begin{array}{c}0.0684 \\
(0.0018)^{* * * *}\end{array}$ & $\begin{array}{c}07016 \\
(0.0035)^{* * * *}\end{array}$ & $\begin{array}{c}0.0593 \\
(0.0342)^{*}\end{array}$ & $\begin{array}{c}0.0372 \\
(0.0158)^{* *}\end{array}$ \\
\hline$N_{i j}$ & $\begin{array}{c}0.0588 \\
(0.0014)^{* * * *}\end{array}$ & $\begin{array}{c}0.0638 \\
(0.0063)^{* * * *}\end{array}$ & $\begin{array}{c}0.7492 \\
(0.1552)^{* * * *}\end{array}$ & $\begin{array}{l}-0.0332 \\
(0.1106)\end{array}$ \\
\hline$C_{i j}$ & $\begin{array}{c}-0.1405 \\
(0.0045)^{* * * *}\end{array}$ & $\begin{array}{c}-0.0980 \\
(0.0284)^{* * * *}\end{array}$ & & \\
\hline$R a t_{i j}$ & $\begin{array}{c}0.0022 \\
(0.0014)\end{array}$ & $\begin{array}{c}0.0083 \\
(0.0026)^{* *}\end{array}$ & $\begin{array}{c}0.0033 \\
(0.0010)^{* * * *}\end{array}$ & $\begin{array}{l}-0.0006 \\
(0.0010)\end{array}$ \\
\hline Constante $\alpha_{0}$ & $\begin{array}{c}2.5858 \\
(2.812)^{* * * *}\end{array}$ & $\begin{array}{c}2.1668 \\
(0.1536)^{* * * *}\end{array}$ & $\begin{array}{c}13.4893 \\
(0.5311)^{* * *}\end{array}$ & $\begin{array}{c}3.4407 \\
(1.9834)^{*}\end{array}$ \\
\hline$R^{2}$ & 0.9342 & 0.8528 & 0.9403 & 0.8943 \\
\hline $\mathrm{N}$ & 302 & 106 & 25 & 35 \\
\hline
\end{tabular}

Fonte: Resultados da pesquisa. Elaborada pelos autores. 
Nota: As observações anuais são de 1989 a 2016. A variável dependente é volume de exportações. As variáveis independentes estão na primeira coluna. ${ }^{*} p<0: 10,{ }^{* *} p<0: 05, e^{* * *} p<0: 01$.

Para eliminar os efeitos específicos de tempo e de período dos países considerados na amostra e da possível endogeneidade comumente presente em modelos gravitacionais de comércio, procedeu-se com a estimação adotando a especificação do painel à lá Arellano-Bond (1991) aplicando o estimador GMM desenvolvido por Arellano e Bover (1995) e Blundell e Bond (1998) para examinar o comércio internacional brasileiro (Tabela 3).

As duas equações representando o comércio Brasil-Zona do Euro e Brasil-Estados Unidos foram excluídas, uma vez que há somente um grupo para cada expressão. Portanto, foi estimado somente as equações de comércio Brasil-Mercosul e Brasil-BRICS, Coluna 2 e Coluna 3, respectivamente.

Na Coluna 2 a renda per capital do Mercosul é um bom preditor das exportações brasileiras, com um coeficiente estimado de 0.31 pontos percentuais e estatisticamente significativo a $1 \%$. Um crescimento em $1 \%$ crescimento da população dos países do Mercosul gera ainda mais fluxos das exportações brasileiras para aquele bloco regional em 0.45 pontos percentuais, um coeficiente também significativo ao nível de significância de $1 \%$. Por outro lado, os coeficientes de custo de transporte e da volatilidade cambial não foram estatisticamente significativos considerando os níveis de significância convencionais.

Tabela 4 - Sistema GMM - Equação (9)

\begin{tabular}{|c|c|c|c|c|}
\hline Especificação & $\begin{array}{c}\text { (2) } \\
\text { GMM } \\
\text { (Mercosul) }\end{array}$ & $\begin{array}{c}\text { (3) } \\
\text { GMM } \\
\text { (brics) }\end{array}$ & $\begin{array}{c}\text { (4) } \\
\text { (GMM- } \\
\text { PPML) }\end{array}$ & $\begin{array}{c}\text { (5) } \\
\text { GMM-PPML }\end{array}$ \\
\hline$Y_{i j}$ & $\begin{array}{c}0.3112 \\
(0.0882)^{* * * *}\end{array}$ & $\begin{array}{c}0.4015 \\
(0.1388)^{* * * *}\end{array}$ & 0.2428 & -0.3001 \\
\hline$N_{i j}$ & $\begin{array}{c}0.4513 \\
(0.0936)^{* * *} \\
\end{array}$ & $\begin{array}{c}0.3171 \\
(0.15661)^{* *} \\
\end{array}$ & 0.3925 & 0.2533 \\
\hline$C_{i j}$ & $\begin{array}{c}-0.5543 \\
(0.2999)^{*}\end{array}$ & $\begin{array}{r}-0.04690 \\
(0.4657)\end{array}$ & -0.4138 & 0.0511 \\
\hline Rat $_{i j}$ & $\begin{array}{c}0.0354 \\
(0.0255)\end{array}$ & $\begin{array}{c}0.0514 \\
(0.3599)\end{array}$ & 0.0332 & 0.0431 \\
\hline Constante $\alpha_{0}$ & $\begin{array}{c}0.5104 \\
(1.8000)\end{array}$ & $\begin{array}{c}-2.1105 \\
(3.0889)^{* * * *}\end{array}$ & -2.0754 & 4.2773 \\
\hline L1. & $\begin{array}{c}0.8136 \\
(0.0624)^{* * * *}\end{array}$ & $\begin{array}{c}0.4445 \\
(0.0942)^{* * * *} \\
\end{array}$ & $\begin{array}{c}0.7302 \\
(0.1729)^{* * * *}\end{array}$ & \\
\hline L2. & $\begin{array}{c}-0.1107 \\
(0.0464)^{* * * *}\end{array}$ & $\begin{array}{c}0.2375 \\
(0.0682)^{* * *}\end{array}$ & $\begin{array}{l}-0.0896 \\
(0.2298)\end{array}$ & \\
\hline
\end{tabular}




$\begin{array}{lcccc}\begin{array}{l}\text { Números de } \\ \text { instrumentos }\end{array} & 80 & 80 & 49 & 65 \\ \text { Valor p Wald } & 0.00 & 0.00 & 0.00 & 0.000 \\ \begin{array}{l}\text { Teste de Sargan de } \\ \text { restrições de sobre- }\end{array} & 0.000 & 0.000 & 0.000 & 0.000 \\ \begin{array}{l}\text { identificação (p-valor) } \\ \begin{array}{l}\text { Teste de Arellano-Bond } \\ \text { de autocorrelação (Prob }\end{array}\end{array} & 0.018 & 0.0661 & 0.3173 & 0.3173 \\ >\text { z) }\end{array}$

Fonte: Resultados da pesquisa. Elaborada pelos autores.

Nota: As observações anuais são de 1989 a 2016. A variável dependente é volume de exportações. As variáveis independentes estão na primeira coluna. ${ }^{*} p<0: 10,{ }^{* *} p<0: 05, e^{* * *} p<0: 01$.

As principais alterações em relação aos modelos estáticos ocorreram tanto em termos da magnitude como também em termos de significância estatística dos parâmetros estimados. Essas diferenças estão apresentadas nas Colunas 4 e 5 . A Coluna 4 reporta Coluna 2 da Tabela 3 menos Coluna 2 da Tabela 2. Essa diferença mostra a mudança relativa da magnitude dos coeficientes estimados para o comércio Brasil-Mercosul quando se aplica o sistema GMM. A Coluna 5 reporta a diferença entre as estimativas mostradas na Coluna 3 da Tabela 3 e as estimativas da Coluna 3 da Tabela 2. Ela mostra a mudança relativa da magnitude dos coeficientes estimados, agora, para o comércio Brasil-BRICS quando aplicado o sistema GMM, ao invés do PPML.

Alguns coeficientes aumentaram de magnitude, enquanto outros tantos diminuíram. Na Coluna 4 é possível observar que o coeficiente associado a renda per capita gerado através do GMM é 0.24 vezes maior que aquele resultante da estimação por PPML. Os respectivos coeficientes da população do Mercosul e da volatilidade cambial foram 0.40 e 0.03 vezes maiores do que os obtidos pelo método PPML, enquanto que a estimativa do parâmetro de custo de comércio brasileiro aumentou em 0.4138 vezes. Enquanto isso, a Coluna 5 mostra que, para a equação de comércio brasileiro com os países que atualmente compõem o BRICS, as estimativas reportadas pelo GMM para os parâmetros de renda e custo de transporte diminuíram em magnitude, com magnitudes de -0.30 e 0.05 vezes menores, respectivamente. Os demais coeficientes obtidos pelo GMM continuam sendo maiores do que aqueles reportados pelo PPML.

Esses resultados sugerem que, um modelo gravitacional, de acordo com a especificação de Eaton e Kurtom (2002), considerando uma amostra expressiva, o método de estimação GMM fornece melhores resultados comparativamente ao método máxima verossimilhança de Silva e Tenreyro 
(2006). Entretanto, em termos de sinais, os parâmetros continuam sendo estáveis e bastante consistentes com a literatura empírica de comércio gravitacional. Por exemplo, Frankel et al. (1995) aplicaram o modelo de gravidade para avaliar o comércio bilateral dos blocos regionais, como União Europeia (UE), Mercado Comum da América Central (MCAC), Acordo de Livre Comércio da América do Norte (ALCAN), Associação Europeia de Livre Comércio (AELC), Associação Latina Americana de Livre Comércio (ALCA), Pacto Andino (ANDEAN, em inglês), Associação das Nações do Sudeste Asiático (ASEAN, em inglês) e o Mercado Comum do Sul (MERCOSUL) e concluíram que as rendas per capitas teriam impactos positivos $0.09 \%$ no comércio bilateral dessas áreas com seus parceiros comercias, enquanto a distância teria um impacto negativo de $-0.56 \%$ em 1990.

Já Paas (2000) comenta que as vantagens do uso da abordagem gravitacional decorrem da sua capacidade de explicar padrão de comércio internacional nas condições de pouco volume de dados e sua validade teórica para as economias em transição. $\mathrm{O}$ autor utilizou o modelo de gravidade padrão para analisar o padrão de comércio internacional da Estónia (1995-1997). Estimando o modelo pooled de painel, verificou-se as estabilidades nos parâmetros, sendo que uma variação da renda externa em 1\% explicaria um aumento de 0.829 pontos percentuais do volume de comércio, enquanto que uma variação de $1 \%$ do custo de transporte reduz esse volume em torno -1.67 pontos percentuais.

\section{CONSIDERAÇÕES FINAIS}

Procuramos testar se o esforço de inserção brasileira no BRICS teria sido suficiente para reduzir a importância do Mercosul e se o efeito fronteira ainda é importante para o atual padrão de comércio brasileiro. O modelo de Eaton Kortum é o mais adequado para este propósito porque permite verificar se as partes envolvidas respondem por custos e barreiras geográficas na margem extensiva, isto é, à medida que uma fonte se torna mais cara ou remota, a exportação torna-se mais restritiva.

A criação dos blocos econômicos regionais e muitos outros acordos bilaterais de comércio parecem não superar os custos de comércio impostos pelas fronteiras. Investigamos o efeito-fronteira aplicando os estimadores de máxima verossimilhança e os estimadores pseudo máxima verossimilhança (PPML). O PPML reporta estimativas mais significativas e consistentes com a literatura gravitacional de que as rendas e populações dos países contribuem para a criação do comércio, enquanto o custo de transporte mais elevado tende a inibir os fluxos comerciais. A volatilidade cambial não mostra ser um impeditivo ao comércio, ao menos no modelo estático. A fronteira não tem um importante papel na determinação do padrão do comércio entre o Brasil e seus parceiros regionais, 
sugerindo que os clusters intercontinentais podem ser fundamentais para os fluxos de exportações brasileiras.

Portanto, estendemos esta discussão considerando o comércio do Brasil com os quatro clusters internacionais: o comércio Brasil-Mercosul, Brasil-BRICS, Brasil-Zona do Euro e Brasil-Estados Unidos. As estimativas reportadas pelo PPML sugerem que a expansão econômica desses clusters pode ser dinamicamente importante para as exportações brasileiras. Essa é uma matéria de política de inserção internacional relevante, porque, à medida que o Brasil mantém a sua posição de uma economia importante na região, a busca por novos parceiros comerciais em outros continentes, principalmente nos países cujas economias estão se expandindo, poderá significar em novo estilo de comércio mais aberto a concorrência, implicando em exportações baseadas em produtos com alto conteúdo tecnológico. A confirmação desta hipótese requer mais estudos aprofundados. O que se tem neste estudo tanto para as estimativas do modelo dinâmico quanto para as estimativas reportados pelo GMM sugere a importância dos fatores externos na determinação das exportações brasileiras. O custo de transporte continua sendo um importante fator que gera queda nas exportações, enquanto a volatilidade cambial só é significativa no modelo representando o comércio Brasil-Mercosul e comércio Brasil-BRICS.

\section{REFERÊNCIAS}

AITKEN, N. D. The effect of the EEC and EFTA on European Trade: A Temporal Cross-Section Analysis. The American Economic Review, v. 5, p. 881-892, dec. 1973.

ALONSO-BORREGO, C., ARELLANO, M. Symmetrically normalised instrumental variable estimation using panel data. CEMFI Working Paper n. 9612, 1996.

ANDERSON, T.W.; HSIAO, C. Formulation and estimation of dynamic models using panel data. Journal of Econometrics, v.18, 47-82, 1982.

ARELLANO, M.; BOND, S. Some Tests of Specification for Panel Data: Monte Carlo Evidence and an Application to Employment Equations. The Review of Economic Studies, v. 58, n.2, p. 277-297, 1991.

ARELLANO, M.; BOVER, O. Another look at the instrumental variable estimation of error-components models. Journal of Econometrics, v. 68, p.29-51, 1995.

BALDWIN, R.; HARRIGAN, J. Zeros, Quality, and Space:Trade Theory and Trade Evidence. American Economic Journal: Microeconomics, V.3, p.60-88, 2011.

BALTAGI, B. Econometric analysis of panel data. Vasa, 2005.

BERGSTRAND, J. H. The gravity equation in international trade: Some microeconomic foundations and empirical evidence. The Reviews of Economics and Statistics, v.67, n.04, p.474-481, ago.1985. 
The generalized gravity equation, monopolistic competition, and the factor proportions theory in international trade. The Reviews of Economics and Statistics, v. 71, n.01, p. 143153, 1989.

BIKKER, J. A. An extended gravity model with substitution applied to international trade. Tjalling C. Koopmans Research Institute. Discussion Paper Series, n.215, 30p., 2009. Disponível em: <http://www.uu.nl/sites/default/files/rebo_use_dp_2009_09-17.pdf>. Acesso em: 12 de fev. 2015.

BM. Banco Mundial. Disponível em: <http://data.worldbank.org/>. Acesso em: 20 de março, 2017.

BLUNDELL, R.; BOND, S. Initial conditions and moment restrictions in dynamic panel data models. Journal of Econometrics, v.87, p.115-143, 1998.

BOND, S. Dynamic panel data models: a guide to microdata methods and practice. Portuguese Economic Journal, v.1, p.141-162, 2002.

EATON, J.; KORTUM, S. Technology, geography, and trade. Econometrica, v.70, n.5, p.1741$1779,2002$.

CASTILHO, M. R. O acesso das exportações do mercosul ao mercado europeu. Pesquisa e Planejamento Econômico, v.32, n.01, p.149-198, Abr/2002.

EICHENGREEN, B.; IRWIN, D. A. The Role of History in Bilateral Trade Flows, 1998. Disponível em: <http://www.nber.org/chapters/c7819.pdf>. Acesso em: 20 de Jan. 2017.

EL-ARISH, M. A. A Gravity Model Analysis of Egypt's Trade and Some Economic Blocks. International Conference on Applied Life Sciences, p.343-350, Set.2012. Disponível em: <http://cdn.intechopen.com/pdfs-wm/39918.pdf>. Acesso em: 21 de abril de 2015.

FARIAS, J. J.; HIDALGO, A. B. Comércio Interestadual e Comércio Internacional das Regiões Brasileiras: uma Análise Utilizando o Modelo Gravitacional. Documentos Técnico-Científicos, v.43, n.02, p.252265, Abril - Jun. /2012.

FRANKEL, F. et al. Trading blocs and the Americas: The natural, the unnatural, and the super-natural. Journal of Development Economics, v. 47, p.61-95, 1995.

GERACI, V. J.; PREWO, W. Bilateral Trade Flows and Transport Costs. The Review of Economics and Statistics, v. 59, n. 1, p. 67-74, Feb.1977.

GREENE, W. H. Econometric Analysis. New Jersey: Prentice HALL, 1993.

Greene, W. H. Econometric Analysis. England: Pearson, 2012.

HAMILTON, C. B.; WINTERS, L. A. Opening up international trade in Eastern Europe.Institute for International Economics Studies, Seminar Paper, n.511, 54p.. maio, 1992.

HATAB, A. A.; ROMSTAD, E.; HUO, X. Determinants of Egyptian Agricultural Exports: A Gravity Model Approach. Modern Economic, v.01, p.134-143, 2010.

HELLIWELL, J. F. National Borders, Trade and Migration. Pacific Economic Review, v.02, n.03, p.165185, 1997. 
HSIAO, C. Analysis of Panel Data. New York: Cambridge University Press, 2003.

IPEA. Instituto de Pesquisa Econômica Aplicada. IPEADATA. Temas: comércio exterior.

KHAN, S.; HAQ, I.U.; KHAN, D. An Empirical Analysis of Pakistan's Bilateral Trade: A Gravity Model Approach. The Romanian Economic Journal, ano XVI, n. 48, p.103-120, 2013.

LINNEMANN, H. An Econometric Study of International Trade Flows. Review by: S. J. PRAIS. The American Economic Review, v. 57, n. 01, p. 283-285, Mar., 1967.

MCCALLUM, J. National borders matter: Canada-U.S: regional trade patterns. The American Economic Review, v.85, n.03, p.615-623, 1995.

MOISÉ, E. et al. Estimating the Constraints to Agricultural Trade of Developing Countries. OECD Trade Policy Papers, n.142, 85p.; 2013. Disponível em: <http://dx.doi.org/10.1787/5k4c9kwfdx8r-en> . Acesso em: 29 de jul. 2017.

MIRIAN, B. et al.. An Analysis of International Raisin Trade: A Gravity Model Approach. Australian Agricultural and Resource Economics Society, 17P, 2013.

OSENI, I. O. Exchange rate volatility and private consumption in Sub-Saharan African countries: A system-GMM dynamic panel analysis. Future Business Journal, V.2, p.103-115, 2016.

PAAS, T. Gravity Approach for Modeling Trade Flows between Estonia and the Main Trading Partners. University of Tartu, Faculty of Economics and Business Administration. 48p., 2000.

SANTOS SILVA, J. M. C; TENREYRO, S. The Log of Gravity. The Review of Economics and Statistics, v. 88, n. 4, p.641-658., 2006.

SAVAGE, I. R.; DEUTSCH, K. W. A Statistical Model of the Gross Analysis of Transaction Flows. Econometrica, v.28, n. 03, p. 551-572, jul. 1960.

TINBERGEN, J. et al. Shaping the world economy; suggestions for an international economic policy. Books (Jan Tinbergen), Twentieth Century Fund, New York, 1962.

WANG, Z.K.; WINTERS, L.A. The trading potential of Eastern Europe. Journal of Economic Integration, v.7, n.02, p.113-136, 1992.

WOOLDRIDGE, J.M. Econometric analysis of crosssection and panel data. booksgooglecom, 58. MITPress, 2002.

WB: World Bank. World Development Indicator. World Bank Database,WorldBank, 2017.

ZARZOSO, I. M.; LEHMANN, F. N. Augmented gravity model: an empirical application. Journal of Applied Economics, v. VI, n.02, p. 291-316, 2003.

ZHU, H.; GU. H. China-US Border Effect of Agricultural Trade Using Gravity Model. Shanghai, p.891900, 2008. Disponível em: <http://dl.ifip.org/db/conf/ifip12/ccta2008-2/ZhuG08.pdf>. Acesso em: 29 de jun. 2017. 


\section{Capítulo 9}

\section{SISTEMAS AGROALIMENTARES EM TERRITÓRIO DA MONOCULTURA: ALTERNATIVAS LOCAIS DE COMERCIALIZAÇÃO DA AGRICULTURA FAMILIAR}

DOI: $10.37423 / 200300379$

Antonio Wagner Pereira Lopes

Vera Lúcia Silveira Botta Ferrante

César Giordano Gêmero

Maria Lúcia Ribeiro

Resumo: Este artigo propõe discutir a organização cooperativa existente no Projeto de Desenvolvimento Sustentável (PDS) Sepé Tiarajú, analisando sua importância para a permanência das famílias, para o desenvolvimento de formas de produção diferenciadas e de alternativas de sustentabilidade. A metoddologia baseou-se na aplicação de questionários semiestruturados, visitas a campo, reuniões, anotações em diário de campo e registros fotográficos compreenderam as técnicas de coleta dos dados e a metodologia aplicada. Constatou-se priorização do capital social entre as famílias e expressões de sociabilidade, tais como troca de serviços, "mutirões" e, especialmente, a constituição de cooperativas. Parcerias com instituições públicas, empresas, formação de cooperativas, planejamento do ano agrícola, implantação de novos projetos, (microbacias) e canais de comercializações são expressões de sustentabilidade do PDS Sepé Tiarajú.

Palavras-chave: Cooperativismo. Assentamentos rurais. PDS. Estratégias familiares. 


\section{INTRODUÇÃO}

Cooperativa é entendida aqui como modelo de estrutura organizacional do qual se originam sociedades constituídas sob a forma democrática para atingir fins específicos, ou seja, associação autogestionária de pessoas, regida por princípios de igualdade no que se refere à propriedade, gestão e repartição de recursos (CAMARGO, 1960; FLEURY, 1993; RIOS, 1976). Cooperativismo é um movimento social ou doutrina, que se caracteriza pela preocupação política de transformação social aceitando a ideia de que a infraestrutura pode determinar mudanças na superestrutura social e viceversa (CAMARGO, 1960; NOBRE et al., 2004). Cooperação é ação social articulada, alinhavada por objetivos comuns para solucionar problemas concretos que, por sua vez, é aqui entendida em dois sentidos: (a) como ação-padrão, racionalmente construída à luz de um código e desenvolvida no interior de cooperativas por sujeitos inseridos numa certa divisão social do trabalho, os quais têm objetivos comuns e compartilham benefícios ou prejuízos de forma equitativa, por exemplo, o que se pratica de acordo com o regimento interno; (b) como ação espontânea inerente a determinados grupos e derivada de suas tradições e costumes, pré-existente às instituições, fundamentada na reciprocidade adiada ou instantânea (BRUNI, 2005).

Camargo (1960) estudou a relação estabelecida entre cooperação e cooperativismo na zona rural do estado de São Paulo na primeira metade do século XX constatando que, embora existissem formas espontâneas de cooperação, especialmente o mutirão, a troca de dias e auxílios mútuos, não havia correlação positiva entre elas e o cooperativismo. Não havia um sistema de cooperação, pois, os diferentes tipos de cooperativas não se articulavam. Nas cidades rurais ou tipicamente rurais, predominava o cooperativismo de produção, mas as cooperativas não passavam de casas comerciais atacadistas que antecediam o comércio e desapareciam com o seu desenvolvimento. No Brasil, não é de hoje que o cooperativismo rural tem sido visto como mecanismo de modernização da agricultura, estratégia de crescimento econômico ou instrumento de mudança social. Muitos autores remeteramse à dupla face - popular e institucional - deste movimento, colocando em questão o seu caráter de contestação ou de controle social (SCOPINHO, 2012).

O presente artigo propõe discutir a organização cooperativa existente no Projeto de Desenvolvimento Sustentável (PDS) Sepé Tiarajú, analisando sua importância para a permanência das famílias, para o desenvolvimento de formas de produção diferenciadas e para a constituição de alternativas de sustentabilidade. 
No caso em estudo, o cooperativismo é expresso pelas estratégias dos assentados, influenciadas por diferentes movimentos sociais e tem um papel fundamental no desenvolvimento de diferentes formas de produção e comercialização. São os elos de sustentação do primeiro PDS implantado no Estado de São Paulo.

\section{METODOLOGIA}

Foi fundamental para que a pesquisa transcorresse em um clima de mútua aprendizagem, a priorização das continuadas visitas a campo e dos cursos de capacitação ministrados, voltados às perspectivas de uma transição agroecológica. A coleta de dados foi realizada no PDS constituído no estado de São Paulo, em 2014, assentamento Sepé Tiarajú (80 famílias), empregando como técnicas de pesquisa, na construção metodológica, anotações em diários de campo, reuniões, registros fotográficos e, principalmente, a preocupação de não constranger os assentados, em um exercício de metodologia participativa. Foram acompanhadas estratégias familiares e alternativas utilizadas pelas quatro organizações sociais (cooperativas e associação) existentes no assentamento: COOPERFIT, COOPERECOS, COPERAGROSEPÉ E FRATERRA.

Além de questionários com perguntas fechadas e abertas aplicados aos produtores, foram visitados os lotes e acompanhado o processo de preparação para a comercialização e as estratégias de gestão das cooperativas. A observação de atividades culturais e os resultados das capacitações podem ser incluídas na metodologia, pois têm o caráter de ser expressão viva do modo de vida deste assentamento.

Faz-se necessário reafirmar a conquista da confiabilidade por parte dos assentados, obtida, pouco a pouco, através de inúmeras visitas e de longas conversas em que prevaleceu a troca de experiências para a realização da pesquisa de campo, ponto fundamental para fidedigna coleta de dados.

\section{RESULTADOS}

\subsection{O ESPAÇO INVESTIGADO: HISTÓRIA E ORGANIZAÇÃO}

O assentamento Sepé Tiarajú, assim como tantos outros assentamentos, é resultante de um processo histórico de mobilização e de lutas sociais travadas pela terra. Ainda em 1999, com o apoio do grupo Amigos do Movimento dos Trabalhadores Rurais Sem Terra (MST), foi aberta a Secretaria Regional na cidade de Ribeirão Preto, bem como foi organizada a primeira ocupação do Movimento na região, na 
Fazenda Chimbó, município de Matão, construindo assim, o Acampamento Dom Hélder Câmara, que chegou a ter cerca de 1200 famílias.

Do ponto de vista ambiental, o PDS é uma excelente oportunidade no campo das políticas públicas voltadas à transição para uma produção agropecuária mais sustentável. Os PDS's ampliam o leque e o enfoque do desenvolvimento produtivo dos assentamentos, incluindo o componente ambiental no planejamento da geração de ocupações produtivas e de renda (ALY JÚNIOR, 2011).

O projeto dessa modalidade teve como base o atendimento das especificidades regionais (extrativismo tradicional, resgatar o valor econômico e social da floresta, do mangue, da várzea e outros, ao invés de considerar apenas o potencial agrícola da terra), o interesse ecológico, além do social, atendendo à legislação ambiental. Ressalta-se igualmente a valorização da organização social, do trabalho e gestão comunitária.

De acordo com Scopinho (2009), as condições essenciais para a oficialização do PDS Sepé Tiarajú foram: conceder o título de posse (e não de propriedade) da terra para evitar a venda e o arrendamento; produzir de modo cooperado e agroecológico para recuperar a área degradada pela monocultura da cana; criar uma empresa social para receber os recursos financeiros e realizar a prestação de contas para o Estado; formar um comitê gestor do assentamento composto por representantes dos poderes públicos estaduais e municipais, dos assentados, das cooperativas e do Instituto Nacional de Colonização e Reforma Agrária (INCRA).

A formação de um acampamento e a transição para assentamento como um caráter processual comporta um conjunto de valores e princípios construídos socialmente a partir das distintas trajetórias de cada sujeito - "os seus construtores eram portadores de uma história cuja característica marcante é a diversidade sócio-cultural" (SCOPINHO, 2009). Tais condições acabam por determinar os valores e princípios destes mesmos sujeitos, o que continua a ser o grande gargalo dos Movimentos Sociais de luta pela terra. Havia também um enfrentamento por parte das famílias a outros conteúdos da proposta do PDS, contidos na formulação do Termo de Ajustamento de Conduta (TAC), firmado com a promotoria do meio ambiente do município de Ribeirão Preto.

Todos os recursos (Crédito Apoio à Instalação, PRONAF e demais) deveriam ser acessados e aplicados coletivamente. Por fim, as famílias tiveram a opção de escolher a forma de acesso (individual ou coletivo) e de aplicação dos recursos; e o tamanho dos lotes, inicialmente pensado em áreas 
individuais de 1 hectare e áreas coletivas de 6 hectares. Posteriormente, ficou acordado que seriam áreas individuais de 3,5 hectares e áreas coletivas do mesmo tamanho (MAIA, 2013). Desse modo, em 2004, o INCRA, pela Superintendência Regional de São Paulo, efetuou a compra da área e formalizou a organização do Assentamento Sepé Tiarajú, tomando como base experiências desenvolvidas na região Amazônica, pautadas por interesses socioculturais, econômicos e ambientais, através dos PDS's (MAIA; FERRANTE, 2013).

Inicialmente, próximo ao município de Serrana/SP havia o Acampamento Dom Hélder Câmara, o qual se desfez, sendo que cerca de 70 famílias do referido acampamento se deslocaram para o acampamento Sepé Tiarajú, enquanto algumas se desligaram do MST e integraram novas lutas por terra organizadas por outros movimentos na região e outras voltaram para as cidades em vista da oferta de trabalho temporário. Diante da crítica de diversas famílias ao modo como a direção regional do MST estabelecia as diretrizes e regras para a oficialização do PDS e pela posse coletiva da terra, ocorreu o rompimento com o acampamento anterior, fato que possibilitou a organização da primeira cooperativa do assentamento: a AgroSepé, ocasionando relações de conflito ao lado das manifestações de cooperação.

Atualmente, as 80 famílias assentadas, nucleadas socialmente como fora proposto pelo TAC, ou seja, em quatro Núcleos de Moradia - Chico Mendes, Dandara, Paulo Freire e Zumbi dos Palmares experimentam uma nova forma de organização interna, que orienta as dimensões da vida política, econômica, produtiva, social e cultural das famílias. Essa nova organização interna conta com a formação de quatro organizações sociais (COOPERECOS, COOPERAGROSEPÉ, FRATERRA e COOPERFIT) que, por sua vez, expressam as principais concepções - divergentes, porém, não antagônicas - acerca do desenvolvimento do assentamento e congregam as principais lideranças da comunidade (MAIA, 2013). As famílias da comunidade estão vinculadas às organizações sociais por afinidade política, ou seja, são grupos que congregam famílias de diferentes núcleos de moradia, e nesses espaços debatem os rumos que definem tanto a atuação desses grupos específicos, quanto os rumos da comunidade como um todo. 
Figura 1 - Vista do alto do morro onde está a Área de Preservação Permanente (APP), imagem do assentamento Sepé Tiarajú

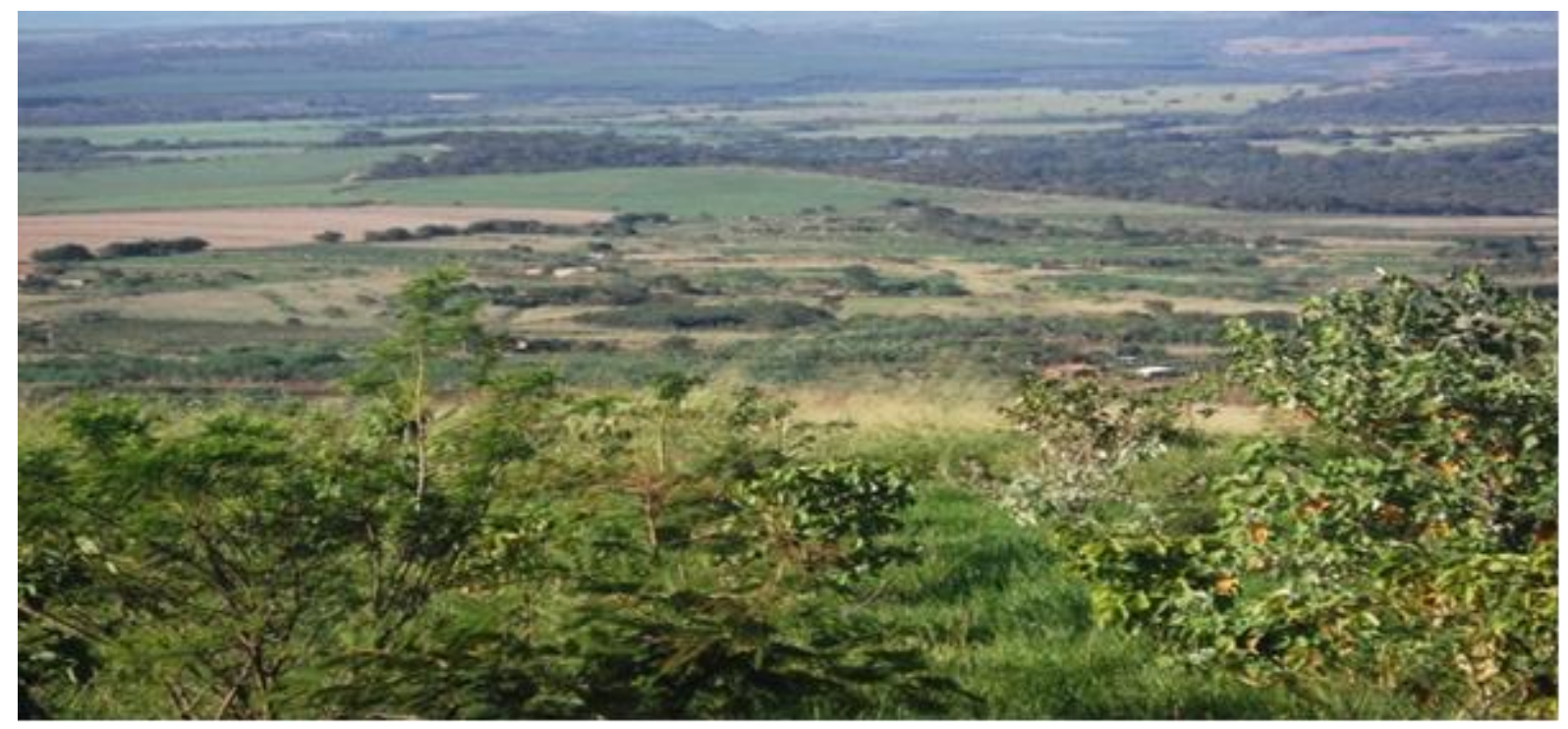

Fonte: Acervo fotográfico da pesquisa, 2017.

A falta de confiança política no MST e o estímulo do INCRA foram fundamentais para a fundação das quatro cooperativas. Havia um cenário de crise política entre o MST Ribeirão Preto e o INCRA neste período, sobretudo em vista da possibilidade de enfraquecimento da Direção Regional do MST pela perda desta importante base social.

Com vistas a cumprir os objetivos de sustentabilidade ambiental preconizados pela proposta de assentamento - Modalidade PDS, a comunidade assentada, o Movimento do MST, o INCRA, juntamente com o Grupo de Agroecologia da Empresa Brasileira de Pesquisa Agropecuária (EMBRAPA) Meio Ambiente, deu início ao processo de construção do conhecimento agroecológico no Sepé Tiarajú, adequando-o à realidade local (CARMO, 2008). Inicialmente, o trabalho realizado consistiu em intercâmbios que resultaram na implantação de uma Unidade de Observação Participativa (UOP) de Sistemas Agroflorestais em uma área coletiva do assentamento, na qual as famílias participaram de mutirões de implantação e formação do SAF.

Esta experiência contribuiu para que os conhecimentos apreendidos pela comunidade assentada fossem multiplicados e experimentados dentro do próprio assentamento, a partir dos lotes individuais. De acordo com Nobre et al. (2004) foi criada então, rica diversidade de experiências: desde sistemas mais simples com cultivos anuais, até sistemas mais complexos multiestratificados, com alta diversidade de espécies e com diferentes tamanhos. Essa diversidade reflete a multiplicidade de objetivos buscados, que vão do embelezamento do lote até a consolidação da principal fonte de renda. 
Cabe mencionar, que o trabalho desenvolvido tem possibilitado grande transformação na vida de muitas famílias, especialmente daquelas que deram continuidade aos SAF's, as quais têm participado de todo esse processo, não na condição de objetos de estudo, mas na condição de experimentadores, de agentes de seu próprio desenvolvimento.

As mulheres têm participação, planos de se organizar e têm uma produção capaz de gerar renda. Destaca-se Dona Arlinda, forte liderança na comunidade, mulher disposta que passa claramente sua facilidade de promover diálogos e tomar novas iniciativas. Constatou-se que a mesma tem, no presente, o projeto de uma cozinha comunitária, na qual são produzidos doces, pães e inclusive a potencialidade de fazer as refeições em todos eventos ocorridos no assentamento, dada a inexistência de restaurantes próximos na rodovia. Os dados obtidos com os questionários permitiram uma caracterização do sistema produtivo, das estratégias familiares, das práticas agrícolas que mostram expressões de sustentabilidade, da infraestrutura disponível, dos entraves e eficácias das políticas públicas, do significado de se privilegiar a cooperativa como unidade organizativa.

Todos os assentados levantaram como demanda prioritária dentro do assentamento a questão da distribuição da água - sofrem muito com o abastecimento irregular e informaram que nem as cooperativas resolvem este problema. As casas são todas padronizadas e isto agrada aos olhos e parece ser mais organizado estruturalmente. É importante salientar que a construção se deu com material alternativo através de mutirões, sendo, portando, expressão de que perspectivas não convencionais podem ser encontradas no assentamento, estimuladas pelas cooperativas.

\subsection{TRABALHO, PRODUÇÃO E ELEMENTOS DA TRANSIÇÃO AGROECOLÓGICA}

O Sepé Tiarajú tem uma proposta inovadora para a organização do assentamento. É pautado no compromisso firmado coletivamente entre os agricultores e o poder público (compromisso este materializado no TAC). Na gestão INCRA do estado de São Paulo de 2005 a 2008, a partir de uma parceria com a EMBRAPA Meio Ambiente, se desenvolveu um conjunto de ações de pesquisa e de capacitação para a implantação de uma UOP de SAF's no Sepé Tiarajú. Consequentemente, os agricultores foram capacitados também, para adotar práticas agroecológicas e respeitar os princípios ambientais.

Verificou-se a existência de um planejamento agrícola. Constatou-se que todos os produtores, de todos os grupos produtivos, realizam no início de cada ano agrícola, um planejamento mínimo do sistema produtivo, das culturas que serão cultivadas, das parcerias que serão estabelecidas e de um 
cronograma de execução das tarefas. Este planejamento sempre é informal e verbalizado, não foi observada a existência de planos escritos. Igualmente foi difícil obter itinerários técnicos, por dificuldades várias, entre as quais a de lidar com o linguajar contábil. Notou-se também, que este planejamento é feito em conjunto, um produtor procura os demais para alicerçar suas decisões. No entanto, esta associação é espontânea, não foi constituída através dos módulos coletivistas impostos pelo estado nos primeiros tempos do PDS. Deriva mais da forte densidade organizativa constatada no Sepé Tiarajú. Foram avaliados os mecanismos para manejo do solo utilizados pelos assentados. Numa visão geral verificou-se que $83 \%$ dos agricultores lançam mão da roçagem com foice e da capina manual, outros $6 \%$ efetivam o preparo do solo com carpideira de tração animal.

A análise comparativa de cada grupo demonstrou que na COOPERAGROSEPÉ todos os agricultores usam a capina manual, combinada com o uso da roçagem com foice. Os dados da Fraterra revelam que todos os assentados entrevistados efetivam o uso da roçadeira e que $67 \%$ utilizam também da capina manual. Estas proporções se invertem no caso da COOPERFIT e ganham outras magnitudes na COOPERECOS. Salienta-se que, mesmo com o uso destas ferramentas, os agricultores mantêm grande parte dos lotes cobertos por restos de cultivos e ou por plantas espontâneas. É importante que se fique claro que estas práticas não são excludentes.

Na sequência, buscou-se avaliar a forma pela qual o solo é preparado. Constatou-se que o principal maquinário utilizado por todos os agricultores é a grade de disco o que, tecnicamente é mais prejudicial à conservação do solo.

No geral, de acordo com a Figura 2, os mecanismos utilizados para a aração são: o arado de aiveca (11\%); carpideira tração animal de 1 linha (22\%); sulcador de arrastro (11\%); grade de disco (78\%); e arado de bacia ou disco (6\%).

Figura 2 - Manejo do solo nos lotes investigados

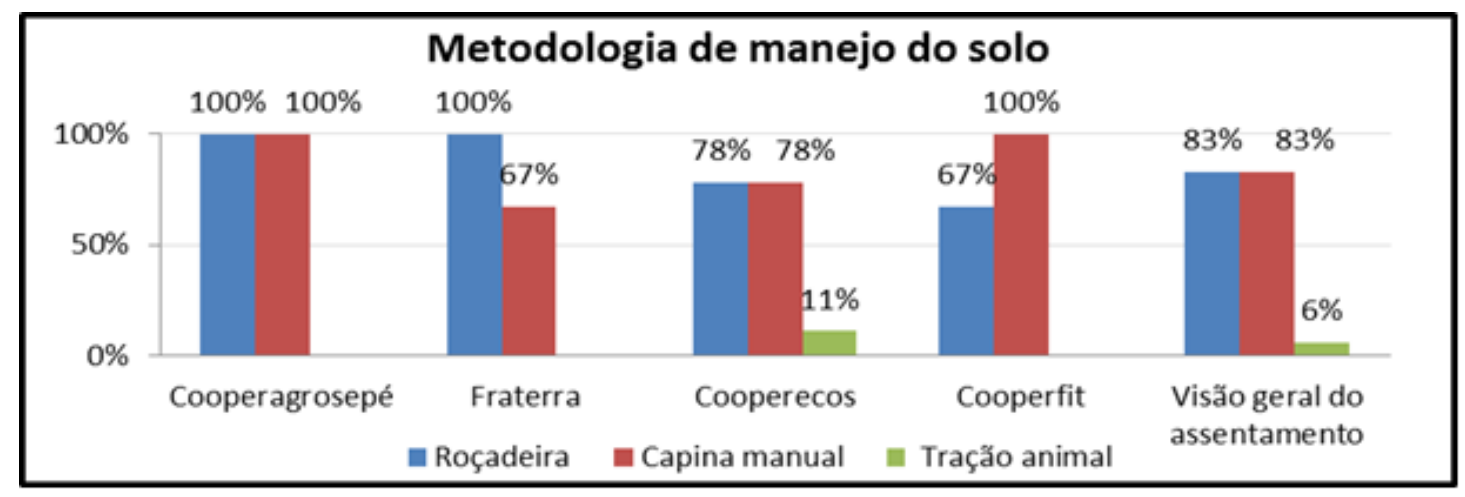

Fonte: Pesquisa de Campo, 2017. 
Constatou-se que para realizar a correção do solo, os agricultores do assentamento aplicam insumos, tais como calcário ( $45 \%$ dos agricultores utilizam este material); e pó de rocha (5\%). Observou-se também que a Fraterra não faz aplicação de insumo algum, enquanto que a COOPERAGROSEPÉ e a COOPERFIT utilizam apenas o calcário. Já a COOPERECOS tem $40 \%$ dos entrevistados utilizando o calcário e $10 \%$ utilizando o pó de rocha. Foi identificado pelos relatos dos agricultores, que a fertilização, em grande parte, se dá pelo uso de restos de plantas e adubos verdes. Ainda constatouse, que esta prática, agregando-se ao fato de que grande parte dos lotes estão cobertos por restos de cultivos e ou por plantas espontâneas, leva também ao controle de pragas.

A caracterização do sistema de irrigação indicou que os agricultores plantam culturas da época e quando há necessidade de complementação, utilizam os sistemas de aspersão e/ou gotejamento em todos os lotes. Outro ponto investigado foi o sistema de colheita, inferiu-se que parte da colheita é realizada por maquinário e parte é coletada manualmente. Por fim, o último ponto analisado nesta seção foi a existência ou não da plantação consorciada.

Os resultados apontados confirmam os resultados constatados pela pesquisa da EMBRAPA (2013). Em síntese, observou-se que, nos lotes, parte da superfície dos solos está sempre coberta, seja por serrapilheira ou por plantas de colonização espontânea, o que evita os processos erosivos causados por ventos e chuvas. No que diz respeito à adubação, tem-se que ela é feita predominantemente pelo incremento de matéria orgânica, na forma de restos de cultivos e resíduos de poda. O controle de pragas e doenças é feito de forma eventual por algumas famílias. Outro ponto observado é que com o aumento da diversificação dos cultivos nos SAF's, os agricultores estão aprendendo a incorporar as interações positivas das plantas que compõem o agroecossistema.

A respeito das práticas ecológicas, verificou-se que os únicos agricultores que não foram capazes de implantar a base ecológica com a mão de obra disponível pertencem à COOPERECOS (11\%) e à COOPERFIT (33\%). Constatou-se também, que todos tiveram interesse em adotar uma nova forma de produzir, e que os responsáveis pela implementação das mudanças, na visão dos entrevistados, foram os próprios agricultores através da capacitação recebida (56\% compartilham desta opinião) e os técnicos responsáveis pela capacitação (44\% defendem esta opinião).

Os dados coletados no Sepé Tiarajú configuram perspectivas de uma alternativa em direção a uma agricultura ecologicamente sustentável. Como relatado por autores que se dedicam à pesquisa da transição agroecológica, a agricultura alternativa se caracteriza por redução drástica do uso de insumos agroquímicos artificiais, por unidades produtivas de menor escala, pelo menor uso de 
energia, por alimentos minimamente processados e pela conservação de recursos não renováveis, dentre outros (BEUS; DUNLAP, 1990).

Neste sentido, Queda, Kageyama e Santos (2009) apresentam elementos-chaves que caracterizam a agricultura alternativa, em oposição à convencional tais como: descentralização, independência, comunidade, harmonia com a natureza, diversidade e conservação. A agricultura alternativa apresenta uma profunda preocupação com as questões ecológicas, dentre as quais se destacam as seguintes dimensões: dominação da natureza $\mathrm{x}$ harmonia com a natureza; especialização $\mathrm{x}$ diversificação; $\mathrm{e}$ exploração x conservação. Segundo tais autores, há possibilidade de se sugerir um conjunto de alternativas a serem implementadas nos assentamentos rurais para começar um outro arranjo produtivo que não aquele destacado pelo agronegócio.

Assim, "os atuais assentamentos rurais se constituem em organizações sociais e econômicas com as características adequadas ao desenvolvimento de uma agricultura alternativa" (QUEDA; KAGEYAMA; SANTOS, 2009). A favor, existe o saldo organizativo derivado da forte presença dos movimentos sociais na luta pela constituição do assentamento e pela sólida presença da cooperação e solidariedade entre as famílias. Como obstáculo, pode-se listar a necessidade de arranjos institucionais para que as políticas públicas se integrem concretamente.

Acrescenta-se, a importante difusão e implementação dos Sistemas Agroflorestais (SAF's) nas suas mais variadas diversificações, arranjos, experiências, cujo suporte, o conhecimento tradicional, muitas vezes, deixa de receber o auxílio necessário, por falta de apoio das políticas públicas e da pesquisa oficial. Como reiterado, as alternativas se mantêm, exigindo, mais e mais, o aproveitamento da biodiversidade existente combinada à preocupação de alimentos saudáveis. Por fim, sem o investimento das administrações municipais, a perspectiva de os assentamentos terem, de fato, uma agricultura alternativa, poderá se frustrar.

Os dados do Assentamento Sepé Tiarajú demonstram que a utopia pode se concretizar em pleno território do agronegócio.

\subsection{A EXPERIÊNCIA DOS SAF'S: UM CAMINHO POSSÍVEL DE TRANSIÇÃO AGROECOLÓGICA}

O PDS Sepé Tiarajú abrange práticas de cunho agroecológico, das quais os SAF's são um consistente exemplo.

O uso de SAF's pode se constituir em uma alternativa de estímulo econômico à recuperação florestal e incorporação do componente arbóreo nos sistemas produtivos dos assentados, que desta forma 
assumem o papel de protagonistas na transição para um desenvolvimento econômico sustentável, pois, ao mesmo tempo em que produzem alimentos, resgatam e conservam a biodiversidade.

De maneira simplificada, pode-se definir que um SAF é um sistema de produção que contém, obrigatoriamente, o consórcio de espécies florestais de porte arborescente com espécies agrícolas, plantadas simultaneamente ou em sequência, na mesma área. Os SAF's sucessionais e diversificados são modelos de uso do solo que mais se aproximam ecologicamente da floresta natural, e representam a interface à agricultura e à floresta, aliando a produção de alimentos à recuperação dos recursos naturais, entre eles, o solo e a biodiversidade (PENEIREIRO, 1999 apud RAMOS FILHO et al., 2010). Esta instalação deve ser acompanhada de um processo continuado de sensibilização e capacitação. No caso do Sepé Tiarajú, foi implantada uma Unidade de Observação Participativa (com a dimensão de 0,25 ha, localizada em área coletiva do assentamento) em SAF's para estudos e observação cotidiana dos agricultores e técnicos, visando à implantação de um conhecimento consistente sobre o uso de SAF's adequados à região (Figura 3).

Figura 3 - Sistema agroflorestal-SAF

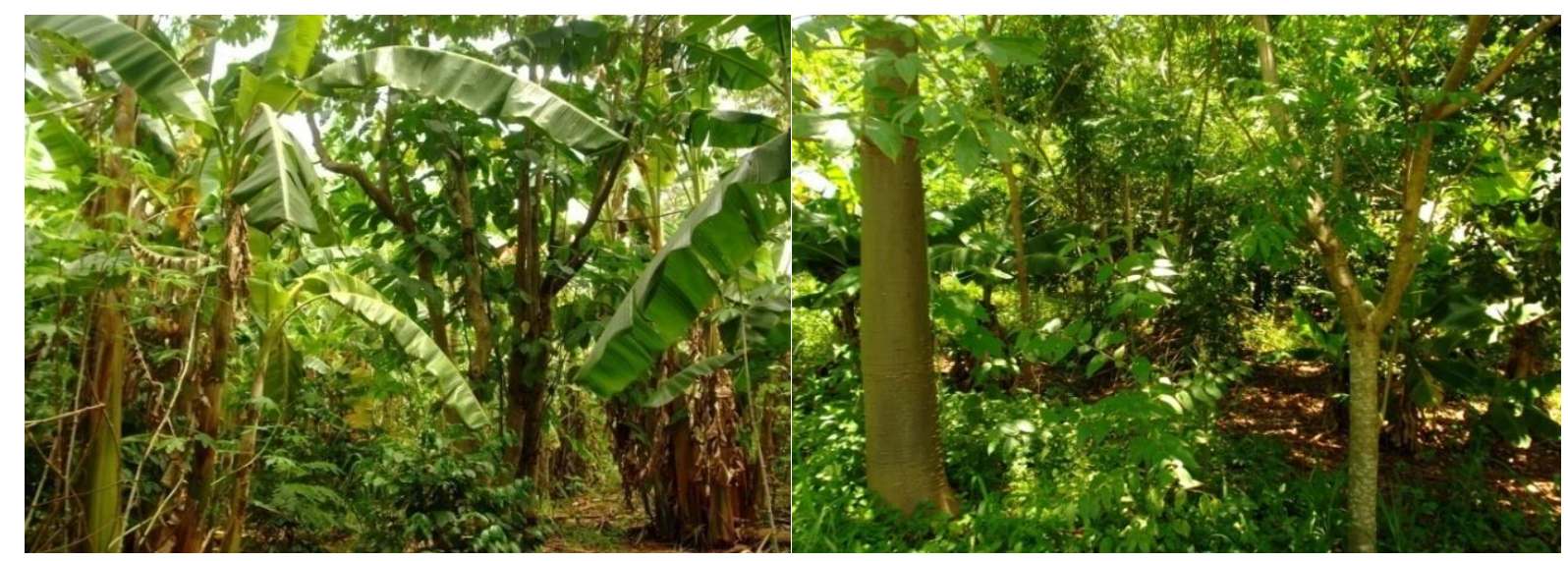

Fonte: Acervo fotográfico da pesquisa, 2017.

O processo de definição do desenho de SAF's a ser implantado foi substancialmente participativo, envolvendo aproximadamente 50 agricultores, tendo sido feita em grupo, em sistema de mutirão.

A adoção de SAF's faz parte do processo de transição agroecológica, o qual, segundo Gliessman (2000) implica em vários passos, desde a redução do uso de insumos químicos e sua substituição por outros de origem biológica, ao redesenho dos sistemas produtivos em decorrência do manejo da biodiversidade. O redesenho dos sistemas agrícolas baseado na incorporação de graus médio e alto de biodiversidade implica em outras condições, muitas das quais externas à unidade de produção. Não se pode, portanto, pura e simplesmente afirmar que o Sepé Tiarajú já realizou a transição agroecológica em sua plenitude. Há um conjunto de condições que passam pela formulação e a 
operacionalização de políticas públicas com enfoque agroecológico, de expansão da consciência, o que exige investimento continuado em capacitação e educação, para tanta demanda inovações referentes à legislação ambiental, dentre outros aspectos.

Em pesquisa realizada por Ramos Filho (2006), constatou-se que das famílias entrevistadas, a maior parte (84\%) participou das atividades relativas ao manejo de SAF's desenvolvidas no projeto coordenado pela Embrapa. Segundo depoimentos, esta participação proporcionou às mesmas um importante aprendizado e uma rica troca de experiência entre os participantes. Dentre as pessoas que participaram, o projeto influenciou de alguma forma o modo de produzir alimentos e a relação do assentado com o agroecossistema, seja no manejo do solo, com o aumento da utilização de adubos verdes, seja pela incorporação do componente arbóreo no sistema. Dos participantes, mais da metade $(55,5 \%)$ já implantaram em seu lote algum tipo de SAF, com desenhos que vão desde o plantio de árvores nativas aleatoriamente em meio aos cultivos, até sistemas mais fechados e complexos; com objetivos que variam da melhoria do microclima no entorno da casa até o de constituir a principal fonte de renda do assentado.

A produção de excedentes para o mercado é o principal objetivo das famílias que têm um SAF implantado, sendo que na época de seca e entressafra, os SAF's se mantiveram produzindo boas quantidades de abóbora, mandioca e banana, produtos estes escoados semanalmente para os programas institucionais, geridos pela Companhia Nacional de Abastecimento - CONAB, órgão do Governo Federal. Entre as vantagens percebidas pelos assentados que estão utilizando o SAF, destacase: baixo nível de danos causado por pragas e doenças, além de uma redução nos impactos da estação seca e do longo período de estiagem; criação de um microclima ideal, a maior retenção de umidade no solo, com isso influenciando o melhor desenvolvimento das culturas, mudas e árvores frutíferas e nativas (RAMOS FILHO et al., 2010). Entre as famílias que participaram do projeto, mas que ainda não têm SAF's (12 famílias entre as entrevistadas), a grande maioria (83,3\%) se mostrou interessada em implantar o sistema, porém citam como obstáculos a falta de água nos lotes (a rede de distribuição d'água ainda não foi finalizada), a falta de recursos para adquirir as mudas e a necessidade de garantir o sustento em curto prazo, sendo este último o fator mais limitante, pois muitas famílias enxergam o SAF como uma forma de renda apenas a longo prazo.

No ano de 2014, o assentamento Sepé Tiarajú foi contemplado com a aprovação do projeto de Microbacia II - viabilizado pelo Banco Mundial. Faz parte deste projeto o chamado grupão dos 30, formado por 30 assentados do Sepé Tiarajú. Os produtores deste assentamento e lideranças com maior experiência em SAF's começaram as articulações das fases do projeto. 
- 1a Etapa - Os assentados que fazem parte do projeto, escolhidos para fazer curso em São Paulo, capacitação em manejo de SAF's terão que concluir o curso, parte dos requisitos exigidos pelos gestores do projeto. Estão otimistas e fazendo seu planejamento, pois em um futuro breve o Sepé terá 30 novos SAF's, que lhes proporcionarão outras fontes de renda familiar em direção à sustentabilidade.

- 2a Etapa - Virão técnicos dos INCRA ou de outra instituição pública ministrar cursos de capacitação para manejo de SAF's, no próprio assentamento.

- 3a Etapa - Iniciar a implantação e manutenção dos SAF's em seus respectivos lotes.

- Entretanto, a sensação de entusiasmo sempre se sobrepôs ao sentimento de desânimo frente às dificuldades. A frequência com que usam a expressão luta, esperança, ajuda mútua é bem significativa.

Deste modo, a divisão do assentamento em quatros núcleos, a formação de grupos de trabalho por afinidade, e consequentemente a criação das cooperativas, promoveram um crescimento do grau de amizade e parcerias internas, as quais são expressão da criação das superações das dificuldades e de conquista mútuas.

\section{CONSIDERAÇÕES FINAIS}

Relações de solidariedade expressas em parentesco, em proximidades construídas nas trajetórias da luta pela terra, em afinidades ideológicas, justificam o desenvolvimento de uma economia moral (BARONE, 1996) e se traduzem em reciprocidades, em uma rede de relações fundamentais para a permanência dessas famílias na terra. Neste contexto, as cooperativas têm um papel fundamental.

Estas redes podem ser perturbadas quando em contato com uma lógica diferente, por exemplo, a dos técnicos do governo, como aconteceu no assentamento Sepé Tiarajú. As lideranças dos presidentes de cooperativas, especialmente da COOPERECOS, têm importância fundamental na tomada de decisões relativas aos sistemas produtivos e às outras esferas da vida social.

No assentamento, relação de compadrio, formalizada ou não através de cerimônias religiosas católicas reforçam laços familiares já existentes, como também se estende para outros (agregados ou parentes fictícios), ampliando a rede familiar. Pode-se mesmo falar da operação de duas lógicas na organização dos projetos de assentamentos. A primeira, a dos técnicos, agentes governamentais, responsáveis pela gestão dos mercados institucionais, em princípio obedeceria à racionalidade moderna, operando através da impessoalidade e das relações estritamente comerciais. A segunda, a dos assentados, 
implica em uma lógica permeada por elementos de caráter sociocultural. Nesta segunda perspectiva, conta efetivamente a ação das cooperativas, marcada por aproximações e/ou tensões.

Alternativas entendidas como estratégias familiares permeiam a dinâmica dos sistemas produtivos e, como bem salientou Antuniassi et al. (1993), as estratégias coletivas são entendidas como um fio condutor que dá sentido às diversas situações vividas pelos agentes sociais e não se reduzem a uma racionalidade estritamente econômica.

No assentamento Sepé Tiarajú, apesar do cerceamento das usinas e do investimento crescente na cana, a lógica das necessidades não foi deixada de lado; o bem-estar da família e a manutenção da terra como elemento vital de reprodução social somam-se à confiança nas direções das cooperativas que acabam ficando com um percentual da renda para novos investimentos.

As estratégias familiares e de produção têm íntima conexão. Princípios da cooperação autogestionária e da Agroecologia nas condições de vida dos trabalhadores rurais assentados interferem nesta relação. Há desafios para não ser interrompida a experiência organizativa da qual eles têm sido protagonistas, os quais têm sido enfrentados, com maiores ou menores dificuldades. O enraizamento, fato de contar com residência fixa, a alimentação farta e sadia, o convívio com os familiares, a perspectiva de gerir a vida com mais autonomia e segurança são fatores que dinamizam as relações de solidariedade e de confiança.

Não existe uma fórmula final de sucesso ou insucesso dos PDS's, mas há caminhos e exemplos importantes a serem seguidos que exigem nada mais do que uma boa articulação entre poder público: prefeituras municipais participativas que articulem projetos efetivos de geração de trabalho, renda e de qualidade de vida para as famílias, gestores que em pouco tempo demonstrem perspectivas de eficácia dos programas, ainda que essa não seja a situação predominante.

A temática ambiental - complexa e abrangente - pode ser identificada como um calcanhar de Aquiles (não necessariamente o único, mas o mais urgente) da política de assentamentos. Verificou-se uma ausência de soluções para vários dilemas relacionados ao tema, sejam eles o licenciamento ambiental, a outorga do uso da água, a educação ambiental, as práticas conservacionistas ou saneamento básico. Exigências de licenciamento ambiental não são cumpridas, nem sequer discutidas caminhos para sua viabilização. A conquista do projeto microbacias representou um degrau a mais no processo de transição agroecológica.

As informações coletadas indicam que há desafios para não ser interrompida a experiência organizativa da qual eles têm sido protagonistas, os quais têm sido enfrentados, com maiores ou menores dificuldades. O enraizamento, o fato de contar com residência fixa, a alimentação farta e 
sadia, o convívio com os familiares, a perspectiva de gerir a vida com mais autonomia e segurança são fatores que dinamizam as relações de solidariedade e de confiança.

A adesão à institucionalização da cooperação - através das cooperativas - não se deu sem resistência. A interferência do MST foi decisiva para que o cooperativismo fosse implantado. Função coercitiva expressa na exigência de assinatura do TAC também contou, em muito, pois a formalização das cooperativas era uma das condições para se ter acesso ao lote e à liberação de recursos financeiros, assim como o impedimento da realização de parcerias com as usinas do entorno para arrendamento das terras para o plantio de cana-de-açúcar.

A possibilidade de aquecimento da economia local, em decorrência da instalação de um assentamento rural - ser motivada pelos efeitos produtivos desta instalação ou pelos créditos e fomento acessados pelos assentados, além de gastos no comércio local (especialmente nos supermercados, para complementar o produzido para autoconsumo) mostrou-se significativo nos municípios do entorno do assentamento Sepé Tiarajú. Há efeitos no abastecimento, por conta das feiras, da relação com os programas de compras institucionais, principalmente o PAA.

Como desdobramento destes efeitos, pode-se concluir pela sinalização de impactos positivos na segurança alimentar, tanto pelas compras feitas pela população nas feiras, como pela destinação de alimentos a entidades filantrópicas e associações de bairro, implicando em uma melhoria substancial na alimentação de comunidades carentes.

Neste sentido, é possível perceber que nos assentamentos em que o tempo de execução das políticas públicas foi realizado de forma mais ágil, como no assentamento Sepé Tiarajú, o desenvolvimento social e produtivo vem acontecendo mais rapidamente e a integração com as cidades é mais intensa. Este fato se dá porque os assentados deixam de ser vistos como "sem terra" e passam a ser reconhecidos como consumidores e produtores rurais.

De forma genérica, pode-se dizer que a aplicabilidade das políticas públicas direcionadas à infraestrutura, principalmente em assentamentos novos, tem sido muito mais rápida no caso do crédito habitação e primeiros fomentos. Já em termos de infraestrutura como água, posto de saúde, escola, o processo é muito lento ou não tem acontecido.

A questão da assistência técnica foi apontada como uma atividade basicamente burocrática, especialmente pelo fato de pouca presença dos técnicos de campo nos lotes. Há uma forte demanda pela assistência no lote, mas as visitas e os acompanhamentos acabam se restringindo apenas às exigências burocráticas para projetos de financiamentos. Os técnicos acabam assumindo o papel de despachantes das normativas dos órgãos gestores. Talvez a maior crítica em relação à assistência 
técnica esteja no fato do distanciamento dos funcionários do campo. As gestões do INCRA têm priorizado mais a execução das atividades de escritório, deixando de lado a intervenção direta no lote. E pelo fato dos assentados não acompanharem de perto o trabalho destes funcionários, acabam entendendo que não há, ou existe pouca assistência técnica pela invisibilidade das ações destes técnicos.

De um lado, a criação dos PDS's representa uma grande inovação pela recusa, firmada na lei e na prática, do uso de agrotóxico. De outro, há necessidade de se pensar em outras dimensões de degradação ambiental que vêm sendo enfrentadas em alguns PDS's e a inevitabilidade de se considerar que diferentemente da Amazônia, São Paulo tem dificuldades concretas e falta de recursos de biodiversidade para explorar. Além disso, as discussões envolvendo o TAC mostram que há dilemas político-jurídicos a serem enfrentados pelos PDS's.

Deste prisma, o compromisso ambiental que as famílias assentadas carregam tem relação maior com os processos formativos pelos quais passaram, manifestados nas práticas agroecológicas desenvolvidas nos sistemas produtivos. O esforço parece ser decorrente da vontade das famílias, mais do que pela assistência técnica, ou pelo caráter coercitivo do TAC, o qual pode apresentar bloqueios ao desenvolvimento do assentamento Sepé Tiarajú.

As cooperativas têm um papel importante na organização da comercialização, e na formação de agroindústrias e no reforço dado às formas alternativas de o produzir para viver.

Tais considerações reforçam a hipótese deste artigo de que sistemas produtivos têm que ser analisados em conjunto com as estratégias familiares e com o modo de vida do assentamento, como as iniciativas das cooperativas, em grande parte condutoras deste processo inovador.

Tais iniciativas explicam as possibilidades de uma específica agricultura familiar inserir-se no processo de transição agroecológica, como vem acontecendo com o assentamento Sepé Tiarajú, e ir, passo a passo, conquistando caminhos não convencionais de desenvolvimento rural.

\section{REFERÊNCIAS BIBLIOGRÁFICAS}

ALY JÚNIOR, O. Projetos de Desenvolvimento Sustentável (PDS's) e os Desafios na Construção de Novas Políticas de Assentamento. Retratos de Assentamentos, Araraquara, v. 14, no. 2, p. 283-303, 2011.

ANTUNIASSI, M. H. A.; AUBRÉE, M.; CHONCOL, M. E. F. De sitiante a assentado: trajetórias e estratégias de famílias rurais. São Paulo em Perspectiva, v.7, n.3, p.125-132, 1993. 
BARONE, L. A. Revolta, Conquista e Solidariedade: A Economia Moral dos Trabalhadores Rurais em Três Tempos. Dissertação (Mestrado em Sociologia). Universidade Estadual Paulista Júlio de Mesquita Filho - Faculdade de Ciências e Letras, Araraquara, 1996, p.243.

BEUS, C. E.; DUNLAP, R.E. Conventional versus Alternative Agriculture: the paradigmatic roots of the debate. Rural Sociology, Provo (Utah), n.55, v.4, p.590-616, 1990.

BRUNI, L. Comunhão e as novas palavras em economia. São Paulo, SP: Cidade Nova, 2005.

CAMARGO, L. C. Cooperação e cooperativismo. Cadeira 20. São Paulo, SP: Editora da Universidade de São Paulo, 1960.

CANUTO, J. C. A experiência dos agricultores agroflorestais do assentamento Sepé Tiarajú. Revista Agriculturas (Impresso), v. 8:2, p. 18-23, 2011.

CARMO, M. S. Agroecologia: novos caminhos para a agricultura familiar. Tecnologia \& Inovação Agropecuária (Online), v. 1, p. 28-40, 2008.

EMBRAPA MEIO AMBIENTE. Assentamentos rurais sustentáveis: o processo de construção participativa do conhecimento agroecológico e o monitoramento de unidades de referência no Assentamento Sepé Tiarajú-SP. Brasília, 2013. 47p.

FLEURY, M. T. L. Cooperativas agrícolas e capitalismo no Brasil. São Paulo, SP: Global, 1993.

GLIESSMAN, S. Agroecologia: processos ecológicos em agricultura sustentável. Porto Alegre: Editora da Universidade - UFRGS, 2000.

MAIA, P. O. PAA em um Projeto de Desenvolvimento Sustentável, Arranjos e Conflitos na produção e reprodução da vida: um estudo no assentamento Sepé Tiarajú, município de Serrana e Serra Azul-SP. Dissertação (Mestrado em Desenvolvimento regional e Meio Ambiente). Araraquara, 2013.

MAIA, P. O.; FERRANTE, V. L. S. B. O programa de aquisição de alimentos no PDS Sepé Tiarajú: bloqueios e perspectivas. Retratos de Assentamentos, v. 16, p. 77-110, 2013.

NOBRE, H.; SOUZA, T.; LE MOAL, M.; CARRILLI, A. L.; RAMOS FILHO, L. O.; PINHO, D. B. O Cooperativismo no Brasil: Da vertente pioneira à vertente solidária. São Paulo, SP: Saraiva, 2004.

QUEDA, O.; KAGEYAMA, P. Y.; SANTOS, J. D. Assentamentos Rurais: Alternativas ao Agronegócio. Retratos de assentamentos. n. 12, 2009, p. 47-68.

RAMOS FILHO, L. O. (Org.). Agricultura, meio ambiente e inclusão social: Questões para debate. Jaguariúna - SP: Embrapa Meio Ambiente, 2006. 128p.

RAMOS FILHO, L. O. SZMRECSÁNYI, T.; PELLEGRINI, J. B. R. Biodiversidade e reforma agrária: uma experiência agroecológica na região canavieira de Ribeirão Preto, Brasil. Retratos de assentamentos, n.13, p.207-238, 2010.

RIOS, G. S. L. Cooperativas agrícolas no nordeste brasileiro e mudança social. Dissertação de Mestrado não-publicada, Programa e Pós-Graduação em Economia Rural, Universidade de São Paulo, Piracicaba, SP, 1976. 
SCOPINHO, R. A. Processo organizativo de assentamentos rurais: trabalho, condições de vida e subjetividade. São Paulo: Anaablume, 2012. 348p.

SCOPINHO, R. A. Em busca de "elos perdidos": projetos de assentamentos e modos de identificação entre trabalhadores rurais assentados. Cadernos de Psicologia Social do Trabalho, v. 12, n. 2, p. 257270, 2009. 


\title{
Capítulo 10
}

\section{FATORES QUE INCENTIVAM A PERMANÊNCIA DOS JOVENS NO MEIO RURAL: ANÁLISE DAS CARACTERÍSTICAS DA GESTÃO RURAL NO MUNICÍPIO DE SÃO CARLOS - SC}

DOI: $10.37423 / 200300384$

\author{
Silvana Dalmutt Kruger \\ Renata Lamb \\ Giana de Vargas Mores \\ Cleunice Zanella
}

Resumo: $O$ objetivo do estudo é identificar fatores que incentivam a permanência dos jovens no meio rural no município de São Carlos - SC. Os procedimentos metodológicos caracterizam a pesquisa como descritiva, de levantamento e de natureza quantitativa. Os dados foram coletados por meio de questionário aplicado a 200 produtores rurais do município de São Carlos - SC. Constatou-se que a maioria das propriedades rurais, 92,50\% é de pequeno porte com até 40 hectares. Verificou-se ainda que $67 \%$ dos gestores rurais utilizam anotações manuais, e apenas $6 \%$ utilizam meios eletrônicos para fins de gestão e 18,50\% não utilizam nenhum tipo de controle. Verificou-se que $53,50 \%$ dos respondentes não pagariam por serviços de contabilidade. Sobre o interesse por informações e controles, constatou-se que $37 \%$ teriam interesse no controle contábil relacionado com gastos das atividades e $31,50 \%$ em controles de produtividades. Os fatores de maior destaque que incentivam os jovens a permanecer no campo são: o rendimento financeiro $(64,50 \%)$, a qualidade de vida no campo $(56,50 \%)$, a possibilidade de ser dono do próprio negócio $(54,50 \%)$ e a estrutura da propriedade rural $(51,50 \%)$. 
Verificou-se que apenas $29,50 \%$ dos sucessores desejam permanecer na agricultura como proprietários rurais, sendo que $26 \%$ dos sucessores não pretendem continuar no meio rural. Nesse contexto destaca-se como forma de subsidiar a permanência dos jovens no meio rural, o uso de ferramentas de controle e gestão, no intuito de possibilitar o conhecimento dos resultados das atividades (rendimento financeiro), e contribuir com o processo de sucessão familiar.

Palavras-chave: Contabilidade rural. Atividades agrícolas. Sucessão familiar. 


\section{INTRODUÇÃO}

O Brasil está no ranking dos principais países produtores e exportadores de produtos agrícolas. De acordo com Crepaldi (2011), em países de grandes extensões territoriais e um clima favorável, como é o caso do Brasil, a agricultura tem um destaque socioeconômico, além de uma diversidade de atividades agrícolas. Conforme o último censo agropecuário do Instituto Brasileiro de Geografia e Estatística (2006), o estado de Santa Catarina tem o maior número de agricultores familiares do país. A produção ocupa 2,6 milhões de hectares, que representam $44,00 \%$ do total da zona rural catarinense.

As atividades agrícolas são relevantes para a economia dos pequenos municípios do interior catarinense. De acordo com Foguesatto et al. (2016), o trabalho nas pequenas propriedades rurais requer um elevado contingente de recursos humanos, situação preocupante devido ao envelhecimento das pessoas que trabalham no campo e ao êxodo rural da população jovem.

De acordo com Kruger et al. (2014), além de controlar o patrimônio, a contabilidade avalia o desempenho das atividades individualmente, melhorando os resultados obtidos pelo gestor rural. Nesse contexto emerge a contabilidade rural. Por mais que haja a predominância de pequenas propriedades no estado de Santa Catarina, para Dal Magro et al. (2014), essa ferramenta de gestão pode fazer diferença, fazendo com que o produtor tenha melhores resultados e mais informações para manter suas atividades. Com isso, aumentando o interesse do jovem em permanecer no meio rural.

Nesse cenário, esta pesquisa busca identificar fatores para a permanência dos jovens no meio rural no município de São Carlos - SC, considerando as características da gestão rural das propriedades pesquisadas. Desse modo, a pesquisa justifica-se pela relevância das informações fornecidas pela contabilidade rural, servindo como instrumento para a tomada de decisões no meio rural.

\section{REVISÃO DE LITERATURA}

\subsection{CONTABILIDADE RURAL}

A contabilidade rural é um ramo da contabilidade que controla o patrimônio rural e gera informações para a tomada de decisões, tanto para pequenas como grandes propriedades rurais. A contabilidade possibilita que o agricultor avalie suas atividades e, com o uso de controles, tende a potencializar os recursos da propriedade rural (LIMA; ZAMPROGNA; ANSCHAU, 2016). De acordo com Zanin et al. 
(2014), a contabilidade é um instrumento de apoio para a análise das atividades, fundamental para os produtores rurais e as agroindústrias, portanto, identifica-se a importância dos produtores procurarem ferramentas de apoio para facilitar o dia a dia nas propriedades rurais.

A agricultura vem passando por transformações, pois as atividades agrícolas têm apresentado um caráter mais empresarial, requerendo a utilização de ferramentas para auxílio na tomada de decisão, redução de custos e obtenção de uma maior rentabilidade do negócio (LIMA; ZAMPROGNA; ANSCHAU, 2016). Para Rodniski et al. (2014), como ocorre com a maioria das empresas, a atividade rural também precisa de informações contábeis, devendo o produtor conhecer as receitas e as despesas e como gerenciá-las, podendo assim fortalecer seus resultados.

De acordo com Dal Magro et al. (2013), as pequenas e médias propriedades rurais, em geral, são constituídas por agricultores familiares, em que o próprio proprietário realiza a gestão rural, muitas vezes, não conhecendo a contabilidade e os princípios contábeis, o que leva, por exemplo, a não separação dos gastos familiares com os da atividade rural. Para Kruger et al. (2014), tem-se um elevado nível de descumprimento do princípio da entidade por parte dos proprietários rurais, apresentam um grau baixo de conhecimento e do uso da contabilidade. Um provável fator é de que a contabilidade rural não se faz obrigatória para propriedades de pequeno porte, devido ao nível de faturamento.

\subsection{SUCESSÃO FAMILIAR RURAL}

O processo de sucessão familiar é determinado como a transmissão do poder e do patrimônio, em que geralmente essa passagem ocorre ao final da vida dos pais, ou quando estes estão incapazes de gerenciar os negócios os transferem para seus filhos (FOGUESATTO et al., 2016).

Segundo Matte e Machado (2016, p. 133), o processo de sucessão familiar rural "tem por objetivo garantir a continuidade das funções produtivas e sociais dos estabelecimentos, bem como das comunidades rurais a que pertencem". Além disso, os autores destacam a importância da continuidade das atividades e populações rurais, levando em consideração a sua importância no mercado brasileiro, considerando que o aumento de políticas públicas, estabelecimentos de estudo mais próximos da região rural e ferramentas que auxiliem no aumento dos rendimentos podem ter relevante influência na decisão de permanência dos jovens no meio rural.

A sucessão nas propriedades rurais caracteriza-se pelo prosseguimento do negócio de geração para geração de uma mesma família. Nesse processo são encontradas dificuldades, as quais podem 
influenciar na continuidade das propriedades rurais, o valor da terra e a sua valorização contribuem para o interesse do jovem em permanecer e continuar os negócios no meio rural (ALCÂNTARA; MACHADO FILHO, 2014).

Segundo Matte e Machado (2016), com o processo sucessório, ocorre a renovação da propriedade rural, sendo um ponto importante para diminuir o envelhecimento da população rural e o êxodo rural. Para Foguesatto et al. (2016), por mais que o meio rural forneça mais segurança, tranquilidade e custo de vida mais baixo, alguns fatores são destacados e influenciam no êxodo do jovem rural para o meio urbano, como a renda insatisfatória, os fatores climáticos e de mercado, a falta de políticas públicas, a falta de escolas técnicas/universidades. Propriedades rurais com maior porte geram mais renda e têm mais possibilidades de sucessão familiar (MATTE; MACHADO, 2016).

De acordo com Foguesatto et al. (2016), os jovens que concluíram a graduação ou pós-graduação salientam que a remuneração no meio rural não atinge o que recebem trabalhando no meio urbano, assim como as opções de lazer nos centros urbanos têm influenciado na decisão dos jovens.

Com a entrada de novas tecnologias no meio rural, os jovens ficam cada vez mais atraídos por esses meios, seguindo para o meio urbano, conduzidos pelas vantagens e facilidades do mesmo, sendo a tecnologia um fator importante que altera a configuração do meio rural. Outro fator que vem trazendo preocupações é a dependência das propriedades com as agroindústrias, que exercem pressão sobre os pequenos agricultores, devido ao avanço da tecnologia (PANNO; MACHADO, 2014).

\subsection{ESTUDOS CORRELATOS}

Nesse tópico abordam-se os estudos correlatos ao tema, contemplando a importância da contabilidade para os estabelecimentos rurais e os desafios do processo de sucessão familiar.

Winck et al. (2013) analisaram o processo sucessório e os possíveis fatores que motivam a permanência ou exclusão do jovem nas propriedades rurais da região Oeste de Santa Catarina. 0 estudo foi realizado em 12 municípios, por meio da aplicação de um questionário estruturado a 115 produtores rurais. Os resultados indicam que tem predomínio de pequenas propriedades rurais com mão de obra familiar. Embora a maioria dos produtores almeje que seus filhos sigam com as atividades rurais, tem ocorrido uma redução no percentual de propriedades rurais que possuem sucessores interessados. Dentre as possíveis causas estão: baixa remuneração, falta de valorização e reconhecimento por parte da população urbana, dos governos e das empresas privadas. Outro fator 
é a busca por uma vida mais estável, com salários fixos, direitos trabalhistas e com descanso nos finais de semana.

O estudo de Krüger et al. (2014) teve como objetivo identificar o uso da contabilidade como instrumento de gestão das propriedades rurais. Os dados foram coletados por meio de questionário com 150 produtores rurais do município de Erval Grande - RS. Foi constatado que 69,00\% das propriedades rurais são de pequeno porte com a predominância da mão de obra familiar. A pesquisa indica que os gestores rurais, em sua maioria, não separam seus gastos particulares dos gastos com as atividades rurais, e desconhecem os objetivos e as finalidades da contabilidade. Os autores indicam que uma possível causa desse desconhecimento deve-se ao fato da contabilidade não ser obrigatória para os produtores rurais, sendo que o faturamento mostra-se restritivo para incorporar os custos com serviços contábeis.

Panno e Machado (2014) abordaram o gradativo desinteresse dos jovens, filhos de pequenos agricultores, em permanecerem no meio rural. O estudo contempla três entrevistas de jovens da microrregião de Frederico Westphalen, Noroeste do estado do Rio Grande do Sul. Os resultados demonstram que os rumos seguidos pelos jovens agricultores afetam a região, pois se tem na agricultura familiar uma força econômica e social importante, uma vez que a característica territorial da região é de pequenas propriedades rurais. As tentativas para mitigar o problema da evasão do jovem não estão sendo eficazes e, em muitos casos, por falta de interesse da comunidade rural, da carência de projetos públicos, sociais, de extensão e suporte efetivo que vislumbrem nos jovens reais possibilidades de permanência e rentabilidade para continuarem as atividades rurais.

O estudo de Rodniski et al. (2014) teve como objetivo analisar as práticas de contabilidade gerencial em propriedades rurais, no contexto de sua receptividade e aplicação por parte dos gestores. O estudo foi desenvolvido em duas propriedades rurais do Oeste catarinense, sendo os dados coletados por meio de entrevistas e observação. Assim, constataram que o nível de escolaridade tem relação com o uso ou não da contabilidade rural.

A pesquisa de Zanin et al. (2014) teve como objetivo identificar as características da estrutura e gestão das propriedades rurais do Oeste de Santa Catarina. A coleta dos dados foi realizada por meio da aplicação de questionários a 210 proprietários rurais dos municípios de Quilombo, Coronel Freitas e Cordilheira Alta, SC. Constataram que $49,00 \%$ das propriedades rurais possuem filhos morando em casa e que ajudam nos trabalhos da entidade rural, sendo necessário o planejamento e as orientações 
quanto ao processo de sucessão familiar. Quanto à forma de gestão, falta estrutura de apoio ao processo decisório e de controles para o processo de gestão das atividades, não utilizam a contabilidade para análise dos resultados e a maioria não realiza a separação dos gastos particulares com os das atividades rurais. Os autores destacam a necessidade de realização de capacitações e treinamentos para os gestores rurais.

A pesquisa de Lisboa et al. (2015) realizou um diagnóstico acerca do uso de ferramentas de gestão por produtores rurais do município de Uberlândia - MG. Foram aplicados formulários a 23 produtores rurais. Constataram que a gestão pode ser melhorada de forma a ajudar na eficiência da propriedade rural, pois, com o uso de instrumentos de gerenciamento, as propriedades rurais tendem a diminuir custos e alavancar lucros.

A pesquisa de Foguesatto et al. (2016), teve por objetivo analisar quais são os principais fatores que contribuem para a ocorrência do êxodo rural jovem na região Noroeste do Rio Grande do Sul. Os dados foram obtidos por meio de questionário realizado com os filhos de agricultores que migraram para as cidades, com um total de 68 respondentes. Os resultados apontam que fatores relacionados à renda e à ausência de políticas públicas contribuíram para o êxodo rural, sendo considerados os dois principais fatores para a tomada de decisão dos jovens em não suceder as atividades de seus pais. A maior parcela dos entrevistados afirma estar em melhores condições socioeconômicas após a migração.

Lima, Zamprogna e Anschau (2016) demonstraram a importância do uso das tecnologias e de que maneira estas influenciam no processo de tomada de decisão dos gestores rurais localizados na região Oeste de Santa Catarina. Foram entrevistados 51 gestores rurais da referida região. Destes 69,00\% possuem entre 50 a 69 anos; 41,20\% possuem ensino fundamental incompleto; a maioria das propriedades rurais é de pequeno porte. Um resultado importante é de que $25,50 \%$ de produtores rurais recorrem ao computador com acesso à internet, mas nenhum utiliza softwares como ferramenta de busca e suporte à gestão das propriedades.

\section{PROCEDIMENTOS METODOLÓGICOS}

Nesse tópico apresentam-se os procedimentos metodológicos. A pesquisa caracterizou-se como descritiva, sendo realizadas a análise e a interpretação das características da amostra das propriedades rurais do município de São Carlos. Quanto aos procedimentos, caracterizou-se como de levantamento, 
pelo fato de aplicar questionários aos produtores rurais da amostra. A análise de dados foi considerada de cunho quantitativo.

O questionário foi aplicado a uma amostra de propriedades rurais do município de São Carlos, cidade do Oeste catarinense. A escolha desse município deu-se em virtude da relevância que a agricultura tem para a economia local. O município de São Carlos possui 1.043 propriedades rurais, conforme o Instituto Brasileiro de Geografia e Estatística - Agência de Palmitos, com dados de 2010, todavia, a amostra pesquisada é aleatória e totalizou 200 propriedades rurais. A coleta foi realizada por meio de visitas junto às propriedades rurais (78), assim como foram direcionados questionários para estudantes do ensino fundamental, que levaram aos pais (122). Após a coleta de dados, os mesmos foram organizados em tabelas, indicando as características das propriedades rurais e da gestão das atividades rurais

\section{ANÁLISE E INTERPRETAÇÃO DOS RESULTADOS}

A partir da coleta de dados junto à amostra de 200 respondentes, identificaram-se as principais características das propriedades rurais e a utilização de informações e controles das atividades rurais. Apresenta-se na Tabela 1 a identificação da idade e a escolaridade dos respondentes.

Tabela 1 - Identificação do respondente

\begin{tabular}{l|c|c}
\hline Idade & Frequência Absoluta & Frequência Relativa \\
\hline 16 a 19 anos & 01 & $0,50 \%$ \\
\hline 20 a 29 anos & 12 & $6,00 \%$ \\
\hline 30 a 39 anos & 50 & $25,00 \%$ \\
\hline Acima de 39 anos & 137 & $68,50 \%$ \\
\hline Total & 200 & $100 \%$ \\
\hline Escolaridade & Frequência Absoluta & Frequência Relativa \\
\hline Ensino Fundamental ( até $4^{\text {a }}$ Série) & 71 & $35,50 \%$ \\
\hline Ensino Fundamental ( ${ }^{\text {a }}$ a ${ }^{\text {a }}$ série $)$ & 51 & $25,50 \%$ \\
\hline Segundo Grau & 65 & $32,50 \%$ \\
\hline Ensino superior & 13 & $6,50 \%$ \\
\hline Total & 200 & $100 \%$ \\
\hline
\end{tabular}

Fonte: Dados da pesquisa.

Com relação à idade dos respondentes, observa-se que $68,50 \%$ dos respondentes possuem mais de 39 anos, $25,00 \%$ de 30 a 39 anos e 6,00\% têm entre 20 a 29 anos. A Tabela 1 também demonstra o nível de escolaridade dos respondentes, dentre os quais: $61,00 \%$ possuem o ensino fundamental, $32,50 \%$ cursaram o ensino médio e $6,50 \%$ possuem o ensino superior. Os resultados da pesquisa assemelham-se aos de Lima, Zamprogna e Anschau (2016), os quais também demonstram o baixo 
nível de escolaridade dos produtores rurais de uma amostra da região Oeste de Santa Catarina. A Tabela 2 apresenta o número de pessoas da família que atuam nas atividades rurais e quantos respondentes possuem filhos.

Tabela 2 - Identificação da família

\begin{tabular}{l|c|c}
\hline Trabalhadores da família & Frequência Absoluta & Frequência Relativa \\
\hline Até duas pessoas & 87 & $43,50 \%$ \\
\hline Três pessoas & 63 & $31,50 \%$ \\
\hline Quatro pessoas & 35 & $17,50 \%$ \\
\hline Mais de quatro pessoas & 15 & $7,50 \%$ \\
\hline Total & 200 & $100 \%$ \\
\hline Filhos & Frequência Absoluta & Frequência Relativa \\
\hline Sim & 193 & $96,50 \%$ \\
\hline 1 a 2 filhos & 135 & $67,50 \%$ \\
\hline 3 a 4 filhos & 52 & $26,00 \%$ \\
\hline Mais de 4 filhos & 06 & $3,00 \%$ \\
\hline Não & 07 & $3,50 \%$ \\
\hline Total & 200 & $100 \%$ \\
\hline
\end{tabular}

Fonte: Dados da pesquisa.

Os resultados da Tabela 2 evidenciam que 92,50\% das famílias rurais têm entre uma e quatro pessoas trabalhando nas propriedades rurais, indicando características de propriedades de pequeno porte e da agricultura familiar da região Oeste catarinense. Ainda sobre essa tabela, 96,50\% possuem filhos, dos quais, $67,50 \%$ possuem um ou dois filhos, $26,00 \%$ possuem três ou quatro filhos e $3,00 \%$ têm mais de quatro filhos. A Tabela 3 apresenta o tempo de atuação dos respondentes na agricultura.

Tabela 3- Tempo de atuação na agricultura

\begin{tabular}{|c|c|c|}
\hline Tempo & Frequência Absoluta & Frequência Relativa \\
\hline Até 20 anos & 40 & $20,00 \%$ \\
\hline Entre 21 e 30 anos & 54 & $27,00 \%$ \\
\hline Acima de 30 anos & 106 & $53,00 \%$ \\
\hline Total & 200 & $100 \%$ \\
\hline Gerações & Frequência Absoluta & Frequência Relativa \\
\hline $\mathrm{Da} 1^{\circ}$ a $2^{\circ}$ geração & 29 & $14,50 \%$ \\
\hline $\mathrm{Da} 2^{\circ}$ a $3^{\circ}$ geração & 62 & $31,00 \%$ \\
\hline Da $3^{\circ}$ a $4^{\circ}$ geração & 109 & $54,50 \%$ \\
\hline Total & 200 & $100 \%$ \\
\hline
\end{tabular}

Fonte: Dados da pesquisa.

Conforme a Tabela 3, observa-se que $80,00 \%$ dos respondentes atuam há mais de 20 anos no meio rural, os quais relataram que começaram desde crianças a ajudar nas atividades agrícolas. Apresentase na Tabela 4 o tamanho das propriedades rurais dos respondentes e as atividades desenvolvidas. Os 
resultados indicam que $92,50 \%$ dos entrevistados possuem propriedade rural de até 40 hectares, ou seja, o município tem, em sua maior proporção, propriedades de agricultura familiar e de pequeno porte em relação à mão de obra e ao tamanho.

Tabela 4 - Tamanho das propriedades rurais e atividades que geram renda

\begin{tabular}{l|c|c}
\hline Tamanho & Frequência Absoluta & Frequência Relativa \\
\hline Até 20 hectares & 126 & $63,00 \%$ \\
\hline Entre 21 e 40 hectares & 59 & $29,50 \%$ \\
\hline Acima de 40 hectares & 15 & $7,50 \%$ \\
\hline Total & 200 & $100 \%$ \\
\hline Atividades rurais & Frequência Absoluta & Frequência Relativa \\
\hline Leiteira & 128 & $64,00 \%$ \\
\hline Suinocultura & 71 & $35,50 \%$ \\
\hline Grãos & 66 & $33,00 \%$ \\
\hline Gado de corte & 56 & $28,00 \%$ \\
\hline Avícola & 34 & $17,00 \%$ \\
\hline Outras & 16 & $8,00 \%$ \\
\hline
\end{tabular}

Fonte: Dados da pesquisa.

A atividade leiteira tem maior destaque no município, desenvolvida em 64,00\% das propriedades, outras atividades de maior ocorrência são a suinocultura e a produção de grãos, com 35,50\% e 33,00\%, respectivamente, e, em seguida, o gado de corte com $28,00 \%$ e a atividade avícola com $17,00 \%$. Com $8,00 \%$ das atividades geradoras de renda estão o fumo, a ovinocultura, a silvicultura e os hortifrutigranjeiros. Assim, observa-se que ocorre a variação entre as atividades como forma de aumentar a renda familiar.

No que tange à identificação das características da gestão das propriedades rurais, inicia-se com a apresentação da Tabela 5, que contempla os tipos de controles utilizados nas propriedades rurais da amostra pesquisada.

Tabela 5- Controles para análise dos resultados das atividades

\begin{tabular}{|c|c|c|}
\hline Controles & Frequência Absoluta & Frequência Relativa \\
\hline Anotações manuais (caderneta, caderno, fichas, etc.) & 134 & $67,00 \%$ \\
\hline Controles exigidos pela empresa/agroindústria parceira & 38 & $19,00 \%$ \\
\hline Não utiliza controles ou não faz anotações & 37 & $18,50 \%$ \\
\hline Desenvolve planilhas eletrônicas & 12 & $6,00 \%$ \\
\hline Total & 200 & $100 \%$ \\
\hline
\end{tabular}

Fonte: Dados da pesquisa.

Os resultados da Tabela 5 demonstram que 67,00\% dos gestores utilizam anotações manuais e 6,00\% desenvolvem planilhas eletrônicas para controle. O percentual de respondentes que não utilizam 
controles e anotações é de 18,50\%, o qual, em sua maioria, declaram que na pequena propriedade não é necessário fazer controle ou que fazem o "controle de cabeça". Esse é uma situação preocupante, pois, mesmo sendo uma pequena propriedade, faz-se necessária a utilização de controles gerenciais para buscar a diminuição dos impactos gerados pelas oscilações de mercado.

Os resultados encontrados assemelham-se aos de Zanin et al. (2014) e Lima, Zamprogna e Anschau (2016), os quais também demonstram que a maioria dos produtores rurais se utilizam de controles manuais, e que lhes falta apoio de informações gerenciais para a gestão das propriedades rurais. Rodniski et al. (2014) destacam que a escolaridade tem impacto na utilização de ferramentas nas propriedades rurais e quanto a utilização de controles pode auxiliar nas decisões.

Na Tabela 6 são apresentadas algumas finalidades da contabilidade rural, em que o proprietário rural demonstra como conhece essa ferramenta; assim como tópicos da importância da gestão e controles nas propriedades rurais, mostrando a visão do agricultor perante a gestão diária de sua propriedade rural. Também são apresentados controles contábeis que podem ser utilizados nas propriedades rurais, ficando a critério de cada respondente e podendo ser escolhida mais de uma opção.

Como finalidade, a organização de custos e despesas das atividades tem 33,00\% das respostas, seguida pela forma de planejamento da propriedade com $26,50 \%$, o que indica que o produtor rural, em geral, busca saber sobre as saídas e os pagamentos que ocorrem na propriedade rural. Também há uma preocupação com o planejamento e a gestão, assemelhando-se ao estudo de Rodniski et al. (2014), o qual destaca a importância da contabilidade na tomada de decisões e no planejamento rural. A percepção dos entrevistados sobre a gestão e os controles nas propriedades demonstra os mesmos percentuais, em que o controle de custos e as despesas e a economia e o investimento correto ficaram com $38,50 \%$.

Tabela 6 - Finalidades da contabilidade rural

\begin{tabular}{l|c|c}
\hline Finalidades & $\begin{array}{c}\text { Frequência } \\
\text { Absoluta }\end{array}$ & $\begin{array}{c}\text { Frequência } \\
\text { Relativa }\end{array}$ \\
\hline Ajuda o produtor rural a se organizar com os custos e despesas & 66 & $33,00 \%$ \\
\hline Uma forma de planejamento da sua propriedade & 53 & $26,50 \%$ \\
\hline Melhora a gestão da propriedade rural & 33 & $16,50 \%$ \\
\hline Propicia maior conhecimento do produtor rural para a tomada decisão & 25 & $12,50 \%$ \\
\hline Desconhecem sua finalidade & 18 & $9,00 \%$ \\
\hline Para prestar contas ao fisco (governo) & 05 & $2,50 \%$ \\
\hline Total & 200 & $100 \%$ \\
\hline Serventia da gestão & $\begin{array}{c}\text { Frequência } \\
\text { Absoluta }\end{array}$ & $\begin{array}{c}\text { Frequência } \\
\text { Relativa }\end{array}$ \\
\hline
\end{tabular}




\begin{tabular}{l|c|c}
\hline Para poder se controlar as despesas e os custos & 77 & $38,50 \%$ \\
\hline Para economizar e investir corretamente & 77 & $38,50 \%$ \\
\hline Para se ter um maior desempenho do decorrer das atividades & 39 & $19,50 \%$ \\
\hline O importante é o trabalho a gestão não interfere & 07 & $3,50 \%$ \\
\hline Total & 200 & $100 \%$ \\
\hline Tipo de controle & $\begin{array}{c}\text { Frequência } \\
\text { Absoluta }\end{array}$ & $\begin{array}{c}\text { Frequência } \\
\text { Relativa }\end{array}$ \\
\hline Controle de gastos efetuados com cada atividade desenvolvida & 74 & $37,00 \%$ \\
\hline Controle de produtividade das atividades desenvolvidas & 63 & $31,50 \%$ \\
\hline Controles que permitem apurar resultados das atividades desenvolvidas & 54 & $27,00 \%$ \\
\hline Não tem interesse em implantar controles na propriedade & 52 & $26,00 \%$ \\
\hline Controle de caixa, apontando quando e como foram feitos os pagamentos & 46 & $23,00 \%$ \\
\hline Controle de gastos com cada maquinário existente na propriedade & 42 & $21,00 \%$ \\
\hline Separa contas da propriedade daquelas do proprietário (viagens, carros, etc.) & 18 & $9,00 \%$ \\
\hline Total & 200 & $100 \%$ \\
\hline
\end{tabular}

Fonte: Dados da pesquisa.

Apresentam-se também na Tabela 6 os controles que podem ser utilizados pelos produtores rurais, sendo que $37,00 \%$ dos respondentes optaram por controle de gastos com cada atividade; $31,50 \%$ o controle de produtividade das atividades desenvolvidas; $27,00 \%$ com controles que apuraram resultados das atividades desenvolvidas na propriedade; o controle de caixa ficou com 23,00\%; o controle de gastos com maquinário obteve $21,00 \%$; o controle que separa contas do proprietário com as da propriedade obteve $9,00 \%$. Os respondentes que não têm interesse em implantar controle somaram $26,00 \%$. Alguns respondentes alegaram que já praticavam alguns dos controles e não teriam interesse em outros; outros alegaram que como a propriedade era pequena, não havia necessidade de controles. Os resultados da pesquisa, em relação a não utilização de controles, assemelham-se aos de Zanin et al. (2014) e Kruger et al. (2014). Os respondentes foram questionados sobre o interesse em fazer cursos de qualificação, inclusive sobre contabilidade, conforme a Tabela 7.

Tabela 7 - Aceitação da contabilidade como prestação de serviço e cursos de qualificação

\begin{tabular}{|c|c|c|}
\hline Pagaria por serviço de contabilidade & Frequência Absoluta & Frequência Relativa \\
\hline Sim, independente do preço & 06 & $3,00 \%$ \\
\hline Sim, dependendo do preço & 87 & $43,50 \%$ \\
\hline Não pagaria & 107 & $53,50 \%$ \\
\hline Total & 200 & $100 \%$ \\
\hline Cursos de qualificação em gestão & Frequência Absoluta & Frequência Relativa \\
\hline Sim & 92 & $46,00 \%$ \\
\hline Já teve cursos, mas não em gestão & 58 & $29,00 \%$ \\
\hline Não & 50 & $25,00 \%$ \\
\hline Total & 200 & $100 \%$ \\
\hline
\end{tabular}

Fonte: Dados da pesquisa. 
A Tabela 7 demonstra que: $46,00 \%$ dos respondentes já tiveram cursos voltados à gestão, 29,00\% declararam que tiveram cursos, mas não voltados à gestão, 25,00\% responderam que não cursaram nenhum tipo de curso na comunidade ou propriedade em que residem. Assim, comparando com os resultados de Lisboa et al. (2015), salienta-se a necessidade da oferta de cursos de qualificação para o uso das ferramentas de gestão.

Os resultados mostram que boa parte dos respondentes não pagaria por serviços qualificados de contabilidade, sendo que o principal motivo alegado pelos respondentes refere-se ao tamanho da propriedade, que controles em propriedades de pequeno porte não seriam necessários. No entanto, 43,50\% dos respondentes pagariam por serviços contábeis, dependendo do preço, 3,00\% pagariam independente do preço. Apesar de mostrarem preocupação com os gastos, os respondentes não demonstram interesse por esse serviço, sendo os possíveis motivos: a não obrigatoriedade da contabilidade rural e o faturamento das propriedades rurais.

Na Tabela 8 são destacados possíveis fatores que incentivam os jovens a permanecerem no meio rural, sendo indicados os três principais fatores por cada respondente, e as decisões dos sucessores em continuarem ou não nas propriedades.

Tabela 8- Fatores que incentivam os jovens a continuar nas propriedades rurais

\begin{tabular}{|c|c|c|}
\hline Fatores & Frequência Absoluta & Frequência Relativa \\
\hline Rendimento financeiro das atividades rurais & 129 & $64,50 \%$ \\
\hline A qualidade da vida no campo & 113 & $56,50 \%$ \\
\hline A possibilidade de ser dono do seu próprio negócio & 109 & $54,50 \%$ \\
\hline Estrutura da propriedade rural & 103 & $51,50 \%$ \\
\hline Menor custo de vida & 56 & $28,00 \%$ \\
\hline Recursos oferecidos pelo governo & 54 & $27,00 \%$ \\
\hline Localização da propriedade próxima a cidade & 28 & $14,00 \%$ \\
\hline Controles contábeis na gestão da propriedade rural & 05 & $2,50 \%$ \\
\hline Outros: Quais? & 03 & $1,50 \%$ \\
\hline Total & 200 & $100 \%$ \\
\hline Decisão dos sucessores & Frequência Absoluta & Frequência Relativa \\
\hline Permanecer na agricultura como proprietário & 59 & $29,50 \%$ \\
\hline Um dos filhos quer permanecer, e outro quer sair do campo & 53 & $26,50 \%$ \\
\hline Sair do campo, pois nenhum demonstra interesse & 28 & $14,00 \%$ \\
\hline Morar no campo mas trabalhar na cidade & 24 & $12,00 \%$ \\
\hline Não sabem, tem filhos pequenos/ não possui filhos & 20 & $10,00 \%$ \\
\hline Morar no meio rural com atividades agrícolas/ não agrícolas & 16 & $8,00 \%$ \\
\hline Total & 200 & $100 \%$ \\
\hline
\end{tabular}

Fonte: Dados da pesquisa. 
Os resultados da Tabela 8 aproximam-se aos achados de Winck et al. (2013) e de Foguesatto et al. (2016), em que são identificadas as possíveis causas para a decisão de sair do campo, como a baixa remuneração, a falta de valorização e reconhecimento por parte da população urbana, dos governos e das empresas privadas. Outro fator consiste na busca por uma vida mais estável, com salários fixos, direitos trabalhistas e descanso nos fins de semana.

Na Tabela 8, também são apresentados os desejos dos sucessores, em que 29,50\% desejam permanecer na agricultura como proprietários rurais; $26,50 \%$ dos respondentes que têm mais de um filho percebem que parte quer permanecer e outra pretende sair do meio rural. A decisão de sair do campo, pois nenhum tem interesse em continuar na atividade, atingiu 14,00\%; a intenção de morar no campo e trabalhar na cidade representou $12,00 \%$, totalizando $26,00 \%$ dos sucessores que não pretendem continuar no campo e desenvolver atividades rurais.

Os resultados obtidos também foram observados por Panno e Machado (2014), demonstrando o gradativo desinteresse dos jovens em continuar nas atividades rurais, devido a fatores como baixa remuneração, pouco apoio de políticas públicas e procura de uma vida mais estável. Nesse sentido, a preocupação com fatores de valorização e retenção das famílias no meio rural deve ser prioridade no planejamento estratégico dos municípios interioranos e dependentes da renda agrícola.

\section{CONSIDERAÇÕES FINAIS}

Os resultados da pesquisa mostram que existe a predominância de pequenas propriedades rurais no município de São Carlos-SC, sendo que 75,00\% das propriedades têm até três pessoas da família desempenhando atividades no campo. Das atividades desenvolvidas nas propriedades rurais, a atividade leiteira é a que gera renda para a maioria dos respondentes, seguida da suinocultura e da produção de grãos, observando-se que ocorre a variação entre as atividades nas propriedades como uma forma de aumentar a renda.

Constatou-se que a remuneração, a estrutura e a qualidade de vida no campo são fatores decisivos para a permanência do jovem no meio rural. Nesse sentido, a contabilidade rural é uma alternativa para o produtor apurar custos e despesas e identificar a lucratividade das atividades, bem como para motivar os sucessores para a continuidade dos negócios. Não apenas no município de São Carlos, onde foi realizada esta pesquisa, mas a agricultura tem importância socioeconômica em todo o país, assim 
sendo, torna-se oportuna a realização de estudos referentes à gestão das propriedades rurais e à sucessão familiar rural.

De forma geral, conclui-se que a contabilidade rural é pouco utilizada pelos produtores rurais pesquisados, mas a cada dia as propriedades rurais estão se tornando empresas rurais, uma área de pesquisa a ser explorada, uma vez que $46,50 \%$ dos respondentes teriam interesse em serviços de contabilidade. Os avanços tecnológicos e a perspectiva de crescimento levam à necessidade da utilização de ferramentas contábeis, para que o produtor consiga acompanhar mais facilmente as mudanças do mercado.

\section{REFERÊNCIAS}

ALCÂNTARA, N. de B.; MACHADO FILHO, C. A. P. Processo de sucessão no controle de empresas rurais brasileiras: um estudo multicasos. Organizações Rurais \& Agroindustriais, v. 16, n. 1, p. 139-151, 2014.

CREPALDI, S. A. Contabilidade rural: uma abordagem decisorial. São Paulo: Atlas, 2011.

DAL MAGRO, C. B. et al. Contabilidade rural: comparativo na rentabilidade das atividades leiteira e avícola. Custos e @gronegócio online, v. 9, n. 1, p. 02-21, 2013.

FOGUESATTO, C. R. et al. Fatores relevantes para a tomada de decisão dos jovens no processo de sucessão geracional na agricultura familiar. Revista Paranaense de Desenvolvimento, v. 37, n. 130, p. 15-28, 2016.

KRUGER, S. D. et al. A contabilidade como instrumento de gestão dos estabelecimentos rurais. Reunir: Revista de Administração, Contabilidade e Sustentabilidade, v. 4, n. 2, p. 134-153, 2014.

LIMA, F. F.; ZAMPROGNA, L. M. B.; ANSCHAU, C. T. A influência do uso da tecnologia na tomada de decisões dos gestores rurais da região oeste de Santa Catarina. Revista Tecnológica, v. 5, n. 2, p. 1637, 2016.

LISBOA, F. C. et al. Diagnóstico do uso de ferramentas de gestão por proprietários rurais de Uberlândia - MG. Revista Verde de Agroecologia e Desenvolvimento Sustentável, v. 10, n. 2, p.132-138, 2015.

MATTE, A.; MACHADO, J. A. D. Tomada de decisão e a sucessão na agricultura familiar no sul do Brasil. Revista de Estudos Sociais, v. 18, n. 37, p. 130-151, 2016.

PANNO, F.; MACHADO, J. A. D. Influências na decisão do jovem trabalhador rural partir ou ficar no campo. Desenvolvimento em Questão, v. 12, n. 27, p. 264-297, 2014.

RODNISKI, C. M. et al. Uso das práticas de contabilidade gerencial em propriedades rurais: um estudo multicaso na região Oeste catarinense. Revista Unoesc e Ciência, v. 5, n. 1, p. 113-121, 2014.

WINCK, C. A. et al. Processo sucessório em propriedades rurais na região do oeste de Santa Catarina. Revista da Universidade Vale do Rio Verde, v. 11, n. 2, p. 115-127, 2013. 
ZANIN, A. et al. Gestão das propriedades rurais do Oeste de Santa Catarina: as fragilidades da estrutura organizacional e a necessidade do uso de controles contábeis. Revista Catarinense da Ciência Contábil, v. 13, n. 40, p. 09-19, 2014. 


\section{Capítulo 11}

\section{IMPACTOS DE UM POSSÍVEL ACORDO DE LIBERALIZAÇÃO COMERCIAL ENTRE O BRASIL, EUA, UNIÃO EUROPEIA E A CHINA SOBRE A ECONOMIA BRASILEIRA: UMA ANÁLISE DE EQUILÍBRIO GERAL COMPUTÁVEL}

DOI: $10.37423 / 200300391$

Abdoulaye Aboubacari Mohamed - abdeltoure2229@gmail.com

RayanWolf - rayanwolf@gmail.com

lan Michael Trotter - ian.trotter@gmail.com

Resumo: Este trabalho avaliou os efeitos da formação de um possível acordo de Área de Livre Comércio entre o Brasil, USA, União Europeia e a China no PIB no bem-estar e nas trocas comerciais dos países membros. A base utilizada foi equilíbrio geral computável, sendo modelado via Projeto de Análise de Equilíbrio Geral da Economia Brasileira (PAEG) para as regiões brasileiras desagregadas. Os resultados apontam para o crescimento do PIB, melhoria do bem-estar, bem como melhoria nas trocas comerciais brasileiras, representadas pela importação e exportação.

Palavras-chave: USA, União Europeia , China 


\section{INTRODUÇÃO}

Entender o papel do comércio internacional na explicação de grandes diferenças de produtividade entre os países continua sendo uma questão-chave na economia internacional. A literatura recente enfatiza os microfundamentos subjacentes a essa relação. Uma vertente da literatura destaca como as novas oportunidades de exportação e a dureza da concorrência geram ganhos agregados de produtividade realocando recursos de menos para empresas mais produtivas (Melitz \& Ottaviano 2008). Neste sentido, alguns estudos se interessaram em estudar os efeitos da liberalização do comércio sobre o crescimento das economias em desenvolvimento, como atestam Dutta \& Ahmed (2004) e Ozdemir (2005). As abordagens, variam amplamente compreendendo desde estudos que exploram os efeitos da liberalização comercial sobre a produtividade da economia até estudos que analisam os efeitos de tal liberalização sobre o bem-estar da população.

A economia brasileira passou por importantes transformações desde os anos 1990. Uma das principais foi o aumento do grau de internacionalização, associado ao crescimento, por um lado, dos fluxos de comércio e, por outro, dos fluxos de capitais. O crescimento dos fluxos de comércio resultou do processo de abertura comercial, conduzido a partir do início dos anos 90, mas sofreu forte influência das condições macroeconômicas vigentes no período fortemente relacionadas às flutuações da economia internacional (Estados Unidos, União Europeia e a China). O impacto da liberalização do comércio sobre a produtividade, estabelecendo a conhecida "controvérsia dos anos 1970", em que nfluenciar a vida dos agentes econômicos através dos diferentes efeitos que Fishlow $(1972,1973)$,

Hoffmann \& Duarte (1972), Bacha \& Taylor (1980) acreditavam que as mudanças observadas na produtividade eram de natureza cíclica, enquanto Langoni (1973), Tolipan \& Tinelli (1978) defendiam a tese das mudanças estruturais.

É claro que o comércio internacional pode i podem causar sobre o crescimento econômico. Embora a relação entre comércio e crescimento não esteja claramente demonstrada na literatura empírica, Rodrik (1997) destaca que, se ela existe, de algum modo influenciará a vida das famílias, seja através da renda, seja através das oportunidades de trabalho, seja através da redução da pobreza, seja através das oportunidades de consumo. Em suma, a literatura que analisa os canais de transmissão das mudanças relacionadas ao comércio internacional sobre a produtividade e o bem-estar das famílias aponta para diversas direções como já foi destacado em cima. 
Para Smith (1988), não é sempre necessário que um país obtenha excedentes de comércio exterior para que as trocas comerciais internacionais sejam vantajosas, e que as trocas voluntárias entre países podem beneficiar todos aqueles envolvidos na operação. Cada país deveria produzir bens que lhes conferissem vantagens absolutas, exportando o excedente e utilizando a receita equivalente para importar bens produzidos em países estrangeiros. A partir deste raciocínio, Smith concluiu que o comércio exterior eleva o bem-estar da sociedade.

Mas, em economias pequenas, qualquer nível tarifário reduz o bem-estar doméstico, enquanto que grandes economias (caso da economia brasileira por exemplo) podem obter ganhos de bem-estar, desde que gerem ganhos em termos de troca superiores à perda da tarifa. Nessa linha, a formação de áreas de livre comércio aumentará o bem-estar dos países membros caso haja aumento no volume de comércio no bloco. Por essa razão, o Brasil precisa de uma agenda econômica consistente e de longo prazo com seus três principais parceiros comerciais e de investimento, ou seja, China, Estados Unidos e União Europeia. Juntos, estes países representaram, em 2013, 50\% do comércio exterior e $72 \%$ dos investimentos estrangeiros diretos recebidos pelo país (Mre et al. 2014) ${ }^{1}$. No entanto, os números não refletem o potencial de negócios com esses parceiros, essenciais para o futuro da indústria brasileira, seja em matéria de crescimento econômico e geração de empregos, seja no que se refere ao fomento à ciência, tecnologia, inovação e educação de qualidade (Cni 2014)2.

Continuando nesta mesma linha de raciocínio, nos próximos anos, esses três parceiros representarão uma oportunidade única de crescimento via internacionalização. De acordo com projeções do Fundo Monetário Internacional, nos próximos quatro anos a China deve crescer, em média, 7,1\%, os Estados Unidos, 3,2\%, e a União Europeia, 1,6\%. O crescimento, sobretudo o chinês e o americano, será o fator central da economia internacional dos próximos cinco anos, e o Brasil deve utilizar essa oportunidade para expandir seu setor industrial com uma participação maior nos fluxos comerciais e de investimentos desses países (Cni 2014)².

Para aproveitar ao máximo os benefícios econômicos dessas parcerias, é preciso estabelecer e executar uma agenda bilateral ampla e integrada com cada um desses parceiros. As relações econômicas entre o Brasil, de um lado, e China, Estados Unidos e União Europeia, de outro, refletem diferentes padrões de comércio e investimento, assim como diferentes graus e formas de complementaridades entre essas economias. Por essa realidade, as agendas bilaterais do Brasil com 
esses parceiros devem incluir, sobretudo, os interesses econômicos ofensivos da indústria brasileira; e a agenda com cada parceiro deve refletir as oportunidades específicas em sua relação com o Brasil.

Para avançar os interesses ofensivos da indústria brasileira, é necessário que o Brasil utilize os instrumentos corretos nas relações com seus parceiros. Esses instrumentos incluem a negociação de acordos comerciais livres e de investimentos, a estruturação de mecanismos de cooperação e diálogo e a ampliação do acesso das empresas do país a esses mercados por meio da identificação, monitoramento e remoção de barreiras aos seus bens, serviços, investimentos e direitos de propriedade intelectual.

É importante aqui, classificar as diversas formas de integração econômica, sintetizadas por Pinto (2004): a. Área de livre comércio: caracteriza-se pela liberdade de movimentos de produtos entre os países integrados e pela existência de uma política comercial própria de cada país membro relativamente a países terceiros; $b$. União aduaneira: além da livre circulação de mercadorias, existe uma política comercial comum entre os países membros, traduzida na aplicação de uma tarifa externa comum às importações, por exemplo; c. Mercado Comum: além das características de união aduaneira, intensifica-se pela liberdade de circulação de pessoas, serviços e capitais; d. União econômica e monetária: caracteriza-se pela existência, entre vários Estados, de políticas económicas concertadas, de uma moeda única e de um banco central comum, que detém o poder de emitir moeda.

Considerando tudo o que foi mencionado como motivação, quais os impactos de um possível acordo de liberalização comercial entre Brasil, União Europeia, Estados Unidos e a China sobre a vida das famílias brasileiras desagregadas por classe de renda? A realização deste trabalho resulta de uma importância particular, na medida em que permitirá às autoridades brasileiras de diferentes níveis terem um conhecimento claro sobre os efeitos de um acordo de livre comércio com os principais parceiros do país sobre o crescimento econômico e o bem-estar da população, fornecendo também subsídios para o fortalecimento de alguns programas que estabelecem um acordo de livre comércio já em andamentos ou concluídos ${ }^{3}$.

O presente trabalho tem por objetivo avaliar os efeitos da formação de um possível acordo de área de Livre Comércio entre o Brasil, União Europeia, Estados Unidos e a China sobre o PIB, o nível de bemestar e as trocas comerciais dos países membros. De forma específica, pretende-se determinar a variação no bem-estar, crescimento econômico e volume de importação e exportação nos países membros, após a liberalização das tarifas à importação intra bloco. Essa análise é baseada em um 
modelo de equilíbrio geral computável (MEGC) no qual o agente doméstico é altamente desagregado. Portanto, considera-se uma abordagem de equilíbrio geral computável totalmente integrada. Para atingir tal objetivo são utilizados o modelo, o banco de dados e o software do Projeto de Análise de Equilíbrio Geral da Economia Brasileira (PAEG) para mensurar os efeitos nas regiões brasileiras.

Alguns trabalhos já foram feitos na área de comércio internacional, simulando choques, tais como eliminação de tarifas e subsídios (ou mesmo a sua criação) à importação e a formação de blocos comerciais.

Bueno (2013) avaliou o impacto que a adesão da Venezuela ao Mercosul terá sobre o bloco em termos de criação/desvio de comércio e de bem-estar, encontrando resultados positivos, particularmente para as indústrias automobilística, de bens de capital e têxtil brasileiras.

No que se refere à variação do bem-estar, Bitencourt (2000) afirma que a criação de comércio acarreta em um aumento de bem-estar, pois é resultado da transferência de um produtor menos eficiente para um produtor mais eficiente dentro do bloco, em virtude da eliminação das barreiras comerciais.

Ribeiro et al. (2014) descreve e discute no primeiro lugar os efeitos dos ganhos estáticos e dinâmicos de comércio, oriundos de uma abertura comercial na economia. E no segundo lugar o autor apresenta um modelo de mensuração do bem-estar produzido pela abertura comercial na economia brasileira durante os anos noventa. Os resultados sugerem que à medida que foi se aprofundando a abertura comercial, causada principalmente pela redução das tarifas legais, houve significativo aumento nos níveis de bem-estar na economia brasileira.

Por meio de modelagem de equilíbrio geral computável, Hap (2013) demonstra a relação entre a liberalização do comércio e o bem-estar social do Camboja. O resultado da simulação sugere que tanto o bem-estar da economia cambojana quanto o bem-estar social aumentam quando o governo reduz a alíquota de imposto de importação.

Choudhri et al. (2006) exploram a importância relativa dos efeitos de liberalização comercial no bemestar usando um modelo dinâmico de equilíbrio geral que captura os principais elementos do comércio internacional e dos modelos macroeconômicos. Os autores descobriram que o efeito da liberalização do comércio no bem-estar é decomposto em um ganho de eficiência estável e uma perda de transição associada à viscosidade do preço-salário. Segundo eles, a perda de transição é pequena em relação ao ganho de estado estacionário, e tende a ser menor sob taxas de câmbio flexíveis quando comparadas 
às taxas de câmbio fixas. Também eles mostram que a perda pode ser ainda mais reduzida por meio de uma regra de política de segmentação flexível no nível do preço.

Para cumprir os objetivos propostos, estruturou-se o trabalho em quatro seções, além desta introdução. Na seção 2 será exposta a metodologia do estudo. A terceira seção fornecerá os resultados, por fim, na seção 4, serão apresentadas as principais conclusões deste estudo.

\section{METODOLOGIA4}

Para alcançar os objetivos propostos, os instrumentos analíticos utilizados serão de natureza quantitativa, um Modelo Aplicado de Equilíbrio Geral. De acordo com Najberg et al.(1995), este tipo de modelo apresenta aspectos de modelos macroeconômicos e modelos de insumo-produto, modelos econômicos aplicados com o objetivo de capturar todas as relações existentes no sistema econômico. Eles são capazes de retratar os efeitos diretos e indiretos causados por mudanças nas políticas econômicas, bem como mudanças tecnológicas, distribuição de renda, impostos, subsídios, etc., assim, o uso desse modelo permite obter a variação total no nível de boa resposta econômica em resposta a uma liberalização comercial.

Através de relações matemáticas, segundo Gurgel (2013), os modelos de equilíbrio geral aplicados se propõem a retratar o funcionamento de uma economia. Diferentemente dos modelos de equilíbrio geral, há também as análises feitas por meio de equilíbrio parcial, mas o último método considera que a política impacta apenas o setor em que foi implementada, desconsiderando outros setores da economia e, portanto, as estimativas e conclusões obtidas pode ser enganosa e superestimada. As relações gerais de equilíbrio demonstram o comportamento dos agentes econômicos nos mercados de bens, serviços e fatores de produção.

O conjunto analítico utilizado foi o PAEG, um conjunto analítico de equilíbrio geral estático, multirregional e multissetorial e foi elaborado com base no Global Trade Analysis Project (GTAP). Essa modelagem permite a solução de problemas econômicos como um problema de complementaridade não-linear, em linguagem de programação GAMS (Pereira et al. 2013). No PAEG, a base de dados para a economia brasileira foi desagregada para representar suas cinco grandes regiões (Centro-Oeste, Norte, Nordeste, Sul e Sudeste), mantendo intactos os dados do GTAP para outras regiões do mundo e dados de fluxos comerciais entre o Brasil e outras regiões do mundo, especificamente os três principais parceiros do Brasil. A estrutura geral do PAEG sugere que a produção doméstica seja 
distribuída entre as exportações, serviços de transporte internacional, demanda intermediária, consumo privado, investimento e consumo do governo.

A produção inclui insumos intermediários, tanto domésticos quanto importados, fatores de produção móvel e consumo do governo (agente público). A renda dos fatores de produção é distribuída ao agente representativo. O equilíbrio do mercado de fatores de produção é observado quando o valor do pagamento dos fatores de produção está relacionado à sua renda. Já as condições de equilíbrio nos mercados internacionais (entre a oferta e demanda) implicam que as exportações de bens por região equivalem às importações do mesmo bem por todos os outros parceiros comerciais.

Para entender o funcionamento do modelo, é necessário descrever como os agentes e setores se comportam. A agregação dos setores e regiões do PAEG é apresentada na Tabela 1.

Tabela 1 - Agregação entre Regiões e Produtos/Setores do PAEG

\begin{tabular}{l|l}
\hline Produtos/Setores & Regiões \\
\hline Arroz (pdr) & Brasil - Região Norte (N) \\
Milho e outros cereais (gro) & Brasil - Região Nordeste (NE) \\
Soja e outras sementes oleaginosas (osd) & Brasil - Região Centro-Oeste (CE) \\
Cana de açúcar, beterraba, indústria açucareira & Brasil - Região Sudeste (SE) \\
(c_b) & Brasil - Região Sul (SUL) \\
Carne e animais vivos (oap) & Resto do Mercosul (RMS) \\
Leite e produtos lácteos (rmk) & Venezuela (VEM) \\
Outros produtos agrícolas (agr) & Estados Unidos da América (EUA) \\
Produtos Alimentícios (foo) & Resto da América (ROA) \\
Indústria têxtil (tex) & Europa (EUR) \\
Vestuário e calçado (wap) &
\end{tabular}

Madeira e mobiliário (lum)

Indústria de papel, celulose e papel (ppp)

Indústria química, borracha e plástico (crp)

Fabricado (homem)

Eletricidade, gás, distribuição de água (siu)

Construção (cns)

Comércio (trd)

Transporte (otp)

Serviços e Administração Pública (adm)
China $(\mathrm{CHN})$

Resto do Mundo (ROW)

Fonte: Elaboração própria com base do PAEG 2011. 
Neste modelo os setores produtivos combinam insumos intermediários e fatores primários de produção, ou seja, capital, trabalho (qualificado e não qualificado), terra e recursos naturais, isso para poder minimizar os custos, dada a tecnologia. A base de dados inclui fluxos bilaterais de comércio entre países e regiões, bem como custos de transporte, tarifas de importação e impostos de exportação (ou subsídios). Cada bem importado sendo demandado em uma região é um agregado de bens importados de diferentes regiões do modelo. A escolha entre importações de diferentes parceiros comerciais é baseada na pressuposição de Armington (bem importado de uma região é um substituto imperfeito do mesmo bem com origem em outras regiões).

No que se trata da oferta de empresas, ela é definida por um problema de otimização e visa minimizar os custos unitários, combinando insumos primários e insumos intermediários, nacionais e importados. Inicialmente, as empresas decidem a combinação de fatores primários que serão empregados, e a decisão é tomada com base na elasticidade de substituição entre os fatores de produção que compõem o valor agregado. Posteriormente, as empresas adquirem cestas de insumos intermediários, decidindo entre mercadorias nacionais e importadas, levando em conta a elasticidade da substituição. No bloco de produção responsável pela alocação de fatores entre diferentes regiões, em resposta a mudanças na economia, alocações de tipo de fator de todas as regiões estão disponíveis como insumo para serem transformadas em fatores regionais que serão usados especificamente em cada uma das regiões. Os insumos (fatores) apresentados possuem elasticidade de substituição igual a zero, ou seja, Leontief.

No modelo, a otimização pode ser definida como uma função de produção com elasticidade constante de substituição (CES), em que adicionado componentes de valor (factores de produção primária) pode ser substituído, sendo um tal processo determinado a partir de uma elasticidade. Os insumos intermediários e o valor agregado são combinados de uma função Leontief, na qual eles não podem ser substituídos um pelo outro. Cada insumo intermediário nesta função Leontief é uma combinação de uma parte doméstica e importada do mesmo bem, de uma função CES de elasticidade de substituição.

No modelo PAEG, a mensuração dos resultados é dada através de parâmetros e cálculos dos impactos do cenário implementado. A medida de variação equivalente ${ }^{5}$ é o parâmetro que armazena o resultado da variação percentual no bem-estar, medida que permite indicar o aumento da utilidade dos consumidores domésticos em termos de aumento do consumo. 
Serão analisados a variação ocorrida no bem-estar dos consumidores e no PIB após o choque, como alterações na importação e exportação. Cabe aqui explicação quanto à mensuração do bem-estar. Mensurado por meio da equação em baixo, a medida de variação equivalente expressa a mudança na renda do consumidor necessária para que se mantenha o mesmo nível de utilidade, aos preços do equilíbrio inicial, quando o consumidor enfrenta um novo conjunto de preços, Varian (1992).

$$
V E=\frac{\left(U^{f}-U^{0}\right)}{U^{0}} R A^{0}
$$

em que $V E$ é a variação equivalente de bem estar; $U f$ indica o nível de utilidade final; UOrepresenta o nível de utilidade inicial; e $R A 0$ representa a renda do agente privado no equilíbrio inicial.

Para o desenvolvimento da pesquisa foi utilizado o banco de dados regionalizado do PAEG para a economia brasileira para o ano de 2011 - PAEG 4.0, compatível com o banco de dados 9.0 do GTAP 9. O banco de dados do GTAP apresenta matrizes de insumo-produto (MIPs) para 140 países / regiões, incluindo o Brasil, 57 setores e cinco fatores principais. Na seção seguinte foram discutidos os resultados do presente trabalho.

Para simular o cenário EUA, União Europeia e a China, sendo estes considerados uma área de livre comércio, foram retiradas todas as tarifas à importação entre as 8 regiões do bloco (cinco regiões brasileira, EUA, União Europeia e a China). Foi também aplicada uma tarifa externa comum.

\section{RESULTADOS E DISCUSSÃO}

\subsection{VARIAÇÃO PERCENTUAL NO BEM-ESTAR E NO PIB}

Nesta subseção, será discutido os impactos macroeconômicos da liberalização total e bilateral do comércio exterior no bem-estar e no PIB. Sabe-se que, em modelos estáticos, os resultados da simulação são analisados em relação a uma situação de referência que é a reprodução do ano base. Por contra, em modelos dinâmicos, a economia evolui ao longo do tempo sob o efeito combinado de crescimento populacional, de acumulação de capital através da poupança e pelo ajuste de todos os outros fatores exógenos. Consequentemente, o impacto de um choque de político deve ser analisado em relação à trajetória esperada de crescimento sem choque. Em outras palavras, é o exame e a interpretação das diferenças percentuais entre o cenário da linha de base e o obtido após o choque de simulação que indicará o impacto da política estudada. Os resultados utilizando o PAEG são úteis 
para analisar-se o impacto da criação de uma zona de livre comércio entre o Brasil, União Europeia, Estados Unidos e a China.

A tabela 2 mostra a variação percentual no bem-estar e no PIB. Observa-se respectivamente uma variação percentual de $0,13 \%$ e $0,75 \%$ para as regiões norte e nordeste. Essas duas regiões terão um baixo nível de bem-estar com um tal acordo comercial. Já para as regiões centro-oeste, sudeste e sul, observa-se respectivamente uma variação percentual de 1.11\%, 1.26\% e 1\%. Pode-se dizer que essas três regiões beneficiaram mais com um tal acordo. As diferenças observadas nos resultados podem ser explicadas provavelmente ao tamanho econômico em geral menor dos estados da região norte e nordeste, comparativamente com os da região centro-oeste, sudeste e sul. De maneira geral, os resultados foram muito bons pois, todas as regiões brasileiras seriam beneficiadas com tal acordo comercial. Evidência no bem-estar melhor para as regiões centro-oeste, sudeste e sul, dada sua estrutura econômica mais sólida, que permite melhor aproveitar essa oportunidade. Esse resultado é corroborado pelo o trabalho da Cni (2014).

Concernente ao PIB, observa-se que todas as regiões apresentaram a variação percentual positiva, 0.01\%, 0.07\%, 0.095\%, 0.048\%, e 0.112\% respectivamente para as regiões norte, nordeste, centrooeste, sudeste e sul. Perceba-se que a região Nordeste, centro-oeste e sul iam pesar na definição do mapa econômico nacional com um tal acordo. De acordo com os resultados, essas três regiões cresceriam mais, que o Sudeste, que é tradicionalmente a mais rica, portanto tende a registrar variação baixa no Produto Interno Bruto (PIB), no entanto melhor que o PIB do Norte. Em geral, com um acordo comercial bilateral entre o Brasil e seus principais parceiros do país, o incremento seria marginal, porém positivo, para todas as regiões do país.

Tabela 2: Variação percentual no bem estar e no PIB, para o EUA, UE, e a China com regiões brasileiras. 


\begin{tabular}{lccr}
\hline Região & \multicolumn{2}{c}{ Bem Estar } & PIB \\
& \% & USS (bilhão) & \% \\
\hline Brasil -Norte & 0.131 & 0.128 & 0.011 \\
Brasil-Nordeste & 0.755 & 0.68 & 0.072 \\
Brasil -Centro-Oeste & 1.113 & 1.84 & 0.095 \\
Brasil - Sudeste & 1.262 & 12.327 & 0.048 \\
Brasil - Sul & 0.952 & 2.61 & 0.112 \\
Resto do Mercosul & -0.139 & -0.831 & -0.007 \\
USA & 0.016 & 2.663 & 0.002 \\
Resto do Nafta & -0.025 & -0.617 & 0.004 \\
Resto da América & -0.07 & -0.731 & -0.024 \\
Europa & 0.04 & 6.593 & 0.026 \\
China & -0.037 & -0.801 & -0.002 \\
Resto do Mundo & 0.106 & 5.875 & 0.064 \\
\hline
\end{tabular}

Fonte : Elaboração própria com base nos dados da PAEG 2011.

Os resultados encontrados para os três parceiros mostram um aumento no bem-estar da população e no PIB dos EUA e União Europeia que cresce 0,02\% e 0,04\% para o bem-estar e 0,002\% e 0,03\% para o PIB respectivamente. O resultado encontrado da China não é o esperado, observa-se uma tendência de redução no bem-estar e no PIB respectivamente de $-0.037 \%$ e $-0.002 \%$. Esse resultado é corroborado pelo o trabalho de Cypriano e Teixeira (2003), que verificaram aumento no bem-estar dos países membros do Mercosul e União Europeia com a formação do Mercoeuro.

Os resultados em relação ao Resto do Mercosul e o Resto da América apresentam uma tendência de redução no bem-estar e no PIB. Isso decorre da formação do bloco econômico proposto, que tende a intensificar as trocas comerciais entre os países membros, em detrimento dos demais. Esse é um resultado condizente com aquele verificado por Gurgel et al. (2002), ao determinar os impactos da formação da Alca e de um possível bloco de comércio do Mercosul com a União Europeia, para o Brasil, em particular, e para os demais países envolvidos em tais blocos, enfatizando os efeitos sobre o setor agrícola.

\subsection{VARIAÇÃO PERCENTUAL NAS EXPORTAÇÕES E NAS IMPORTAÇÕES}

Nesta subseção, será discutido os impactos setoriais da liberalização total e bilateral do comércio exterior nas exportações e nas importações.

A tabela 3 apresenta a variação percentual nas exportações das regiões analisadas. Percebe-se que os setores de arroz em casca, grãos, oleaginosas, cana de açúcar, produto de origem animal, leite, outros produtos agrícolas e alimentos apresentam um aumento do volume das exportações nas todas as regiões brasileiras. Os setores têxteis e de transporte apresentam um aumento na variação de 
exportação na região norte e uma diminuição nas regiões nordeste, centro-oeste, sudeste, e sul. É importante destacar que os setores como, arroz em casca, de grãos, de oleaginosas, e de alimentos, apresentam a maior variação percentual nas exportações. Já os setores como o de indústria química, outras manufaturas, água e distribuição de gás e eletricidade, e de serviços apresentaram uma grande redução na variação de exportação em todas as regiões brasileiras. O setor de comércio apresenta uma variação percentual nas exportações favorável para as regiões norte e nordeste, mas uma forte redução nas regiões sul, sudeste e centro-oeste. Em média, o setor agropecuário brasileiro, apresenta crescimento médio do volume exportado de 14,9\%, quando se considera arroz em casca, grãos, oleaginosas, cana de açúcar, produtos de origem animal, leite, outros produtos agrícolas e alimentos. Esse resultado é corroborado pelo o trabalho de Figueiredo et al. (2001) que demonstram que os benefícios de uma liberalização comercial entre Brasil e União Europeia seriam concentrados no agronegócio para o Brasil.

Todos os setores que apresentaram um aumento da variação percentual nas exportações favorável para as regiões brasileiras mostraram o resultado oposto para o EUA, União Europeia e a China. Já os setores como o de têxteis, vestuário de couro, celulose, madeira, de indústria química, outras manufaturas e água e distribuição de gás e eletricidade apresentaram um aumento da variação, exceto os setores de têxteis e vestuário de couro, onde pode-se notar uma redução de volume de exportação para a China.

Ao analisar os resultados para esses três parceiros principais, pode-se registrar uma redução do volume de exportação em -1,58\% por EUA, -0,87\% por Europa, e -4,49\% por a China todos os setores incluidos. Com relação aos países do Mercosul, Resto do Mundo, e o Resto da América nota-se uma redução média nas exportações respectivamente para todos os produtos, indicando assim uma intensificação do volume de comércio entre os países integrantes.

Tabela 3: Variação Percentual nas Exportações de cada commodity selecionada, para o USA, U. Europeia, e a China com regiões brasileiras. 


\begin{tabular}{|c|c|c|c|c|c|c|c|c|c|c|c|c|}
\hline \multirow[t]{2}{*}{ Produtos/Setores } & \multicolumn{12}{|c|}{ Região } \\
\hline & NOR & NDE & $\mathrm{COE}$ & SDE & SUL & RMS & USA & RNF & ROA & EUR & $\mathrm{CHN}$ & ROW \\
\hline Arroz em casca & 55.295 & 71.999 & 11.117 & 115.368 & 22.341 & 19.04 & -6.692 & & -0.312 & -3.336 & -36.224 & -15.142 \\
\hline Grãos & 103.11 & 125.706 & 73.754 & 149.506 & 67.497 & -7.532 & -9.996 & -4.418 & -2.745 & -4.162 & -16.088 & -13.593 \\
\hline Oleaginosas & 84.189 & 84.6 & 45.995 & 95.046 & 48.667 & -5.382 & -15.312 & -21.442 & -11.494 & -4.813 & -28.82 & -29.95 \\
\hline Cana de Açúcar & 21.397 & 4.729 & 6.831 & 3.581 & 9.425 & 0.73 & -0.547 & -0.152 & 0.167 & -0.59 & -0.594 & -0.418 \\
\hline Produtos de Origem Anir. & 17.132 & 6.767 & 8.632 & 1.992 & 13.939 & 0.688 & -0.2 & -0.046 & 0.552 & -0.545 & -0.238 & 0.164 \\
\hline Leite & 27.091 & 14.66 & 4.347 & 0.511 & 14.577 & 0.729 & -0.723 & -0.47 & -0.17 & -1.088 & -0.738 & 0.338 \\
\hline Outros Produtos Agricol & 21.899 & 15.035 & 6.305 & 21.349 & 10.377 & 5.39 & -0.383 & -1.776 & -0.991 & -0.62 & -0.751 & -0.256 \\
\hline Alimentos & 70.987 & 53.973 & 17.894 & 68.971 & 13.197 & -0.906 & -1.893 & -1.13 & -1.119 & -2.759 & -3.471 & -1.593 \\
\hline Têxteis & 27.195 & -26.139 & -13.419 & -6.135 & -14.28 & -3.615 & 1.185 & -0.189 & 0.271 & 0.181 & -0.082 & 1.728 \\
\hline Vestuário de Couro & 34.527 & 3.624 & -3.604 & 8.404 & -2.461 & 0.555 & 1.657 & -0.226 & 0.402 & -0.021 & -0.091 & 0.844 \\
\hline Madeira & 6.207 & -2.892 & -12.463 & 0.193 & -4.876 & 1.205 & 0.5 & 0.255 & 0.692 & 0.07 & 0.226 & 0.345 \\
\hline Cehulose & -3.474 & -7.93 & -15.924 & -5.895 & -6.123 & -1.77 & 0.392 & 0.232 & 0.395 & 0.236 & 0.246 & 0.396 \\
\hline Indústria Química & -1.932 & -18.55 & -13.932 & -4.212 & -8.545 & -2.51 & 1.377 & 0.006 & 0.026 & 0.306 & 0.023 & 0.585 \\
\hline Outras Manufaturas & -8.116 & -19.706 & -24.176 & -5.495 & -13.639 & -0.196 & 0.608 & 0.156 & -0.241 & 0.474 & 0.081 & 0.386 \\
\hline $\begin{array}{l}\text { Água e distribuição de } \\
\text { e Eletricidade }\end{array}$ & -0.522 & -10.88 & -12.457 & -4.999 & -4.214 & 4.114 & 0.113 & 0.336 & 0.551 & 0.019 & 0.385 & 0.295 \\
\hline Construção & 1.136 & -10.351 & -6.191 & 0.977 & -1.179 & 0.74 & -0.168 & 0.102 & 0.418 & -0.101 & 0.169 & 0.141 \\
\hline Comércio & 6.342 & 0.649 & -8.703 & -3.79 & -2.834 & 0.921 & -0.039 & 0.185 & 0.473 & 0.005 & 0.202 & 0.221 \\
\hline Transporte & 5.138 & -4.213 & -10.705 & -6.076 & -4.583 & 0.952 & 0.012 & 0.221 & 0.457 & 0.043 & 0.257 & 0.227 \\
\hline
\end{tabular}

Fonte : Elaboração própria com base nos dados da PAEG 2011.

Com relação às importações, a tabela 4 mostra que, considerando todas as regiões brasileiras, há um aumento médio de 5,32\% nas importações dos produtos agropecuários. Destaca-se que a região norte apresenta queda nas importações em todos estes produtos, com exceção de grãos, já as regiões sul, sudeste e centro-oeste são as regiões beneficiadas com a maior abertura comercial e acesso a novos mercados. Os demais países do Resto do mundo também apresentam aumento do volume importado com destaque para os setores de oleaginosas, e arroz em casca.

Com relação aos países do USA há um aumento do volume de importações dos alimentos, outros produtos agrícolas, leite, cana de açúcar e arroz em casca. Contudo, produtos como grãos, oleaginosas apresentam queda média de $-0,10 \%$ no volume importado. Países representativos como da União Europeia e China ambos apresentam queda no volume de importação dos produtos agropecuários com exceção alimentos, sendo de $-0,63 \%$ e $-0,23 \%$, respectivamente.

Tabela 4: Variação Percentual nas Importação de cada commodity selecionada, para o USA, U.

Europeia, e a China com regiões brasileiras. 


\begin{tabular}{|c|c|c|c|c|c|c|c|c|c|c|c|c|}
\hline \multirow{2}{*}{ Phodutos/Setores } & \multicolumn{12}{|c|}{ Região } \\
\hline & NOR & NDE & $\mathrm{COE}$ & SDE & SUL & RMS & USA & RNF & ROA & EUR & $\mathrm{CHN}$ & ROW \\
\hline Arroz em casca & -5.651 & 3.531 & 13.847 & 12.637 & 5.832 & -1.261 & 0.256 & -0.285 & -0.649 & -0.709 & -0.114 & 40.434 \\
\hline Grãos & 12.475 & 4.344 & 6.487 & 10.117 & 7.434 & -1.038 & -0.05 & -0.202 & -0.217 & -0.623 & -0.154 & 9.342 \\
\hline Oleaginosas & -1.068 & 1.624 & 11.327 & 13.031 & 4.366 & -0.499 & -0.165 & -0.311 & -0.574 & -1.425 & -0.923 & 34.575 \\
\hline Cana de Açúcar & -4.46 & 1.767 & 6.165 & 9.144 & 3.793 & -0.582 & 0.137 & -0.097 & -0.304 & -0.439 & -0.226 & 0.808 \\
\hline Produtos de Origem Anim & -0.316 & 1.607 & 8.3 & 12.598 & 5.147 & -1.193 & -0.023 & -0.105 & -0.422 & -0.757 & -0.066 & -0.129 \\
\hline Leite & -5.113 & -1.809 & 5.619 & 12.062 & 3.758 & -0.436 & 0.553 & 0.251 & 0.051 & -0.277 & 0.207 & -0.197 \\
\hline Outros Produtos Agricolas & 3.835 & 3.657 & 7.328 & 12.317 & 8.316 & -1.54 & 2.711 & -0.235 & -0.462 & -0.163 & -0.361 & 0.744 \\
\hline Alimentos & -1.902 & 1.086 & 6.353 & 4.19 & 9.204 & -1.639 & 0.538 & -0.128 & -0.341 & 1.349 & 0.169 & 2.843 \\
\hline Têxteis & 7.74 & 1.465 & 9.626 & 12.061 & 13.512 & -0.761 & 0.416 & -0.063 & -0.123 & 0.107 & 0.024 & 0.234 \\
\hline Vestuário de Couro & -3.502 & 0.86 & 7.095 & 0.856 & 47.949 & -1.498 & 0.432 & -0.101 & -0.49 & 0.117 & -0.553 & 0.083 \\
\hline Madeira & -2.93 & 0.646 & 6.648 & 0.409 & 20.454 & -1.55 & 0.132 & -0.07 & -0.567 & 0.088 & -0.255 & 0.076 \\
\hline Celubse & 0.141 & -1.384 & 1.684 & 20.036 & 6.316 & -1.111 & 0.088 & -0.118 & -0.35 & -0.031 & -0.179 & -0.038 \\
\hline Indústria Qúmica & 3.573 & 1.494 & 6.707 & 11.777 & 5.136 & -0.81 & 0.177 & -0.137 & -0.26 & 0.075 & -0.047 & 0.052 \\
\hline Outras Manufaturas & 2.136 & 2.548 & 2.527 & 15.271 & 4.287 & -0.99 & 0.182 & -0.052 & -0.258 & 0.136 & -0.051 & 0.097 \\
\hline $\begin{array}{l}\text { Água e distribuição de } \\
\text { e Eletricidade }\end{array}$ & -3.5 & 1.631 & 7.943 & -1.443 & 5.39 & -0.225 & 0.173 & -0.097 & -0.112 & 0.077 & -0.129 & -0.012 \\
\hline Construção & -3.772 & 5.172 & 6.899 & -0.845 & -0.631 & -0.347 & 0.105 & -0.03 & -0.193 & 0.049 & -0.077 & -0.05 \\
\hline Comércio & -1.53 & -2.037 & 4.816 & -0.291 & 2.274 & -0.478 & 0.156 & -0.073 & -0.173 & 0.085 & -0.039 & -0.052 \\
\hline Transporte & -2.496 & 1.618 & 6.96 & 0.636 & 5.1 & -0.444 & 0.076 & -0.07 & -0.124 & 0.064 & -0.068 & -0.007 \\
\hline
\end{tabular}

Tabela 4: Variação Percentual nas Importação de cada commodity selecionada, para o USA, U. Europeia, e a China com regiões brasileiras.

Fonte : Elaboração própria com base nos dados da PAEG 2011.

Os resultados de importação e exportação apresentados corroboram a hipótese inicial do trabalho, evidenciando que a formação de uma área de livre comércio entre o Brasil, Estados Unidos, União Europeia, e a China tende a intensificar as trocas comerciais entre os países membros.

Deve ser lembrado aqui que nossa simulação é feita assumindo que o saldo da conta corrente é fixo. Em outras palavras, analisa-se os efeitos da liberalização, assumindo que essa política não pode ser razoavelmente sustentada a longo prazo, se levar a uma deterioração do equilíbrio externo. Portanto, e dada essa restrição, um aumento nas importações terá que ser compensado por um aumento nas exportações. Isto só pode ser conseguido através de uma redução dos preços de exportação, a fim de melhorar a posição concorrencial dos exportadores brasileiros em relação aos seus concorrentes.

\section{CONCLUSÃO}

Esta pesquisa examinou os efeitos da formação de uma possível área de acordo de livre comércio entre o Brasil, União Europeia, Estados Unidos e a China sobre o PIB, o nível de bem-estar e as trocas comerciais dos países membros.

Os resultados apresentados no presente trabalho demonstram que a criação de uma área de livre comércio entre o Brasil, União Europeia, Estados Unidos e a China, seria salutar para os países membros. 
As variações no PIB e bem-estar foram positivas para a maioria dos países membros. Dentre as regiões brasileiras, destaque para o centro-oeste, sudeste e sul, com maior especialização produtiva e base econômica melhor estruturada que as demais.

Assim, os resultados nos levam a aceitar a hipótese de que a formação de blocos comerciais entre países tende a intensificar as trocas comerciais entre os países membros, aumentando a especialização produtiva naqueles produtos/setores que detenham vantagens comparativas, e também aumentando o bem-estar da população.

Em geral, Como se pode esperar, uma área de livre comércio melhora o bem-estar, porque em todas as economias os consumidores têm acesso os produtos relativamente escassos e relativamente abundantes em outra economia. Então, o comércio estimula o crescimento porque incentiva os países a se especializarem, e recursos econômicos são redistribuídos para o uso mais eficiente. Embora benéfica, essa redistribuição de recursos também gera custos de ajuste.

Uma das limitações do presente trabalho é a não considerar que, o ajuste pode ser caro e prolongado devido às barreiras à mobilidade da mão-de-obra (para os trabalhadores em uma mudança de atividade, setor ou região, mas também legislação sobre segurança do emprego) e a mobilidade do capital, ou más condições macroeconômicas. Quando o ajuste do mercado é dificultado, os efeitos negativos da concorrência das importações sobre algumas pessoas e comunidades podem ser importantes e sustentáveis, e os trabalhadores podem vivenciar longos períodos de desemprego.

A outra, concerne às restrições internas. As restrições internas, como instituições fracas ou subdesenvolvimento mercados de infraestrutura e de crédito, pode impedir a expansão das exportações. Estes obstáculos tornam mais difícil para os trabalhadores deslocados para encontrar um emprego no setor exportador e eles podem ter repercussões negativos nos salários e no emprego, agravando assim, os efeitos distributivos do comércio.

A última limitação deste estudo é ter considerando todos os setores num bloco sem levar aqueles setores que seriam mais beneficiados. No futuro, seria interessante uma investigação mais aprofundada, que possa considerar todas as limitações de presente estudo e revelar aqueles setores que seriam mais beneficiados, ensejando políticas públicas direcionadas.

\section{REFERÊNCIAS BIBLIOGRÁFICAS}

Amiti, M. \& Konings, J. (2007), Trade liberalization, intermediate inputs, and productivity: Evidence from Indonesia. American Economic Review, 97(5), 1611-1638. DOI: 10.1257/aer.97.5.1611. 
Bacha \& Taylor, L.(1978), Brazilian Income Distribution in the 1960s : Acts, Model Results, and the Controversy. Oxford: Oxford University Press. The Journal of Development Studies,14(3), 296-342. https://doi.org/10.1080/00220387808421676.

Bernard, A.B., Bradford, J.J., Stephen, J.R. \& Peter K. S. (2009), The margins of US trade (long version). National Bureau of Economic Research, 99(2), 487-93. (DOI): 10.3386/w14662.

Bitencourt, M. B. (2000), Impactos dos Acordos da Rodada do Uruguai, Mercosul, Alca e Rodada do Milênio na Triticultura Brasileira: aplicação do Modelo GTAP (Dissertação de Mestrado).Viçosa:UniversidadeFederaldeViçosa.

http://geodados.pg.utfpr.edu.br/busca/detalhe.php?id=32644

Bueno, E. U., Monteiro, S. M. M., \& Feijó, F. T. (2013), A Entrada da Venezuela no Mercosul: uma análise de equilíbrio geral computável sobre os impactos setoriais no Brasil (Dissertação de Mestrado). Porto Alegre, Universidade Federal do Rio Grande do Sul, Faculdade de Ciências Econômicas. http://hdl.handle.net/10183/79106.

Broda, C., Greenfield, J. \& Weinstein, D. (2006), From groundnuts to globalization: A structural estimate of trade and growth. [s.l.] National Bureau of Economic Research. https://EconPapers.repec.org/RePEc:nbr:nberwo:12512.

Choudhri, E. U., Hamid, F., Stephen, T. (2006), Trade liberalization, macroeconomic adjustment, and welfare: unifying trade and macro models. International Monetary Fund , 6(1), 304. https://ideas.repec.org/p/imf/imfwpa/06-304.html

Feenstra, R. C.(1994), New product varieties and the measurement of international prices. The American Economic Review, 84(1), 157-177. https://www.jstor.org/stable/2117976.

Figueiredo, A. M. R., Ferreira, A. V. \& Teixeira, E. C. (2001), Impactos da Integração Econômica nas Commodities da Economia Brasileira e da União Europeia. Revista Brasileira

de Economia (RBE), 55(1), 77-106. http://dx.doi.org/10.1590/S0034-71402001000100004.

Fishlow \& Albert. (1972), Brazilian Size Distribution of Income. American Economic Review, 62(2), 1972, 391-402.http://links.jstor.org/sici?sici=0002-8282\%281972\%...O\%3B2-0\&origin=repec.

Gurgel, A. C., Bitencourt, M. B. \& Teixeira, E. C. (2002), Impactos dos Acordos de

Liberalização Comercial Alca e Mercoeuro sobre os Países Membros. Revista Brasileira de Economia (RBE), 56(2), 335-369. file:///C:/Users/acer/Downloads/816-2743-1-PB.pdf. Hap S. (2013), Trade liberalization and social welfare: evidence from Cambodia. National graduate institute for policy studies macroeconomic policy program (Thesis for: working paper). DOI: 10.13140 / RG.2.1.2380.4325.

Hoffmann \& Duarte, J.C.(1972), A Distribuição de Renda no Brasil. Revista de Administração de Empresas, 12(2), 46-66. https://rae.fgv.br/rae/vol12-num2-1972/distribuicao-renda-no-brasil.

Melitz, M. J. \& Ottaviano, G. I. P. (2008), Market size, trade, and productivity. The review of economic studies, 75(1), 295-316. http://hdl.handle.net/10.1111/j.1467-937X.2007.00463.x 
Najberg, S., Rigolon, F. J. Z. \& Vieira, S. P. (1995), Modelo de equilíbrio geral computável como instrumento de política econômica: uma análise de câmbio $x$ tarifas. Paper (Bndes) https://web.bndes.gov.br/bib/jspui/bitstream/1408/13896/1/TD\%2030\%20\%20Modelo\%20de\%20e quil\%C3\%ADbrio\%20geral\%20comput\%C3\%A1vel\%20como\%20instrumento\%20de\%20pol\%C3\%ADti ca\%20econ\%C3\%B4mica_P_BD.PDF

Ossa, R. (2015), Why trade matters after all. Journal of International Economics, 97(2), 266-277. http://www.sciencedirect.com/science/article/pii/S0022199615001178.

Pavcnik, N. (2002), Trade liberalization, exit, and productivity improvements: Evidence from Chilean plants. The Review of Economic Studies, 69(1), 245-276.

https://www.jstor.org/stable/2695960.

Pinto, M. de S. (2004), A área de livre comércio das Américas e os interesses da União Europeia na América Latina.( Tese de doutorado). http://hdl.handle.net/1822/866.

Ribeiro S.F. A., Nunes, A., Moreira, S. \& Belchior, T. (2014), Liberalização comercial e melhorias de bemestar: o caso brasileiro na década de noventa. Universitas: Relações Internacionais,12(1),9,87-95. https://web.a.ebscohost.com/abstract?direct=true\&profile=ehost\&scope=site\&authtype=crawler\&jr $\mathrm{nl}=18072135 \& A N=116490015 \& \mathrm{~h}=T 5 D U L Z S 8 u s v a u 0 M f K d S z J F Q 1$ gury8vfydJp2v02Y5nqW0ymJzVaqPf 4fWPr87T59bQIO4nhJwIT0q1zM84rqfg\%3d\%3d\&crl=c\&resultNs=AdminWebAuth\&resultLocal=ErrCrl NotAuth\&crlhashurl=login.aspx\%3fdirect\%3dtrue\%26profile\%3dehost\%26scope\%3dsite\%26authtyp e\%3dcrawler\%26jrnl\%3d18072135\%26AN\%3d116490015.

Rivera-batiz, L. A. \& Romer, P. M.(1991), Economic integration and endogenous growth. The Quarterly Journal of Economics, 106(2), 531-555. http://hdl.handle.net/10.2307/2937946.

Rodrik, D.(1997), Trade, social insurance, and the limits to globalization. [s.I.] National Bureau of Economic Research. http://www.nber.org/papers/w5905.pdf.

Smith, A. (1988), A Riqueza das Nações (Coleção Os Economistas). São Paulo: Nova Cultural,1(1),1754.

https://edisciplinas.usp.br/pluginfile.php/4881/mod_resource/content/3/CHY\%20A\%20Riqueza\%20 das\%20Na\%C3\%A7\%C3\%B5es.pdf.

Langoni, C. G.(1973), Distribuição da renda e desenvolvimento econômico do Brasil: Uma reafirmação. Ensaios Econômicos EPGE, n 7 Rio de Janeiro: FGV/EPGE. http://hdl.handle.net/10438/631.

Teixeira, E. C., Pereira, M. W. G. \& Gurgel, A. C. (2013), (organizadores). A Estrutura do

PAEG.CampoGrande:LifeEditora.http://www.novoscursos.ufv.br/projetos/ufv/paeg/www/wpcontent/uploads/Technical-Paper-n.1_06dez2011.pdf.

Tolipan, R. \& Tinelli, A. C. (1978), A Controvérsia sobre a Distribuição de Renda e Desenvolvimento.RiodeJaneiro:ZaharEditores,1(2),319.https://searchworks.stanford.edu/view/7576 00 . 


\section{NOTAS}

\section{Nota 1}

Ministério das Relações Exteriores - Departamento de Promoção Comercial e Investimentos - Divisão de Inteligência Comercial e a Confederação Nacional da Indústria. Brasil Comércio Exterior.

Nota 2

Confederação Nacional da Indústria.

Nota 3

O Brasil e o Estados Unidos assinaram acordos inéditos de comércio bilateral (Mdic \& Doc, 2015). Ler Mdic o Ministério do Desenvolvimento, Indústria e Comércio Exterior; e o DoC o Departamento de Comércio dos Estados Unidos (DoC). O Brasil, como membro do Mercosul, negocia com a UE um Acordo de Associação. Este Acordo de Associação deverá impulsionar a integração comercial entre os países do Mercosul e criar novas oportunidades de comércio e investimento com a UE por meio da eliminação das barreiras pautais e não pautais ao comércio e ao investimento estrangeiro direto, Delegação da União Europeia no Brasil (2016). Segundo Cni (2019), o acordo com a União Europeia já está concluído em 95\%, mas ainda depende de um movimento do bloco europeu em torno de uma oferta agrícola mais favorável para os países do Mercosul. O Brasil e a China assinam acordo para facilitar o comércio bilateral, Conselho Regional de Contabilidade de Sergipe (2013).

Nota 4

Baseado em Pereira et al.(2013).

Nota 5

Veja Varian (1992) 


\section{Capítulo 12}

\section{UTILIZAÇÃO DO MÉTODO AHP PARA ANÁLISE DA COMPETITIVIDADE DA AGROINDUSTRIA DE FILETAGEM DE TILÁPIAS NO OESTE DO PARANÁ}

\section{DOI: $10.37423 / 200300394$}

Manoel João Ramos (Grupo de Estudos em Manejo na Aquicultura (GEMAq), Programa de Pós-Graduação em Recursos Pesqueiros e Engenharia de Pesca, Centro de Engenharias e Ciências Exatas, Universidade Estadual do Oeste do Paraná -UNIOESTE)-eng.major@hotmail.com

Aldi Feiden (Programa de Pós-Graduação em Desenvolvimento Regional e Agronegócio, Centro de Ciências Sociais Aplicadas, Universidade Estadual do Oeste do Paraná - UNIOESTE / Campus Toledo) - homero.oliveira@unioeste.br

Rui Manuel de Sousa Fragoso (Centro de Estudos e Formação Avançada em Gestão e Economia da Universidade de Évora (CEFAGE-UE), Universidade de Évora, (UÉVORA)-rfragoso@uevora.pt

Julyerme Matheus Tonin (Professor na Universidade Estadual de Maringá. Doutorando no Programa de Pós-Graduação em Economia Aplicada (PPGEA), Escola Superior de Agronomia "Luiz de Queiroz" (ESALQ/USP) - tonin@usp.br

Resumo: Esta pesquisa teve por objetivo avaliar como os fatores institucionais, organizacionais e tecnológicos podem contribuir para ampliar a competitividade em agroindústrias de filetagem de tilápias. $O$ estudo foi conduzido na microrregião de Toledo, no oeste do Paraná, onde está localizado um dos principais polos de produção de tilápias, em tanques escavados, do Brasil. A pesquisa se justifica pelo fato de analisar, empiricamente, as potencialidades de uma atividade agropecuária que apresenta expressivos sinais de crescimento, mediantes as ações organizacionais incipientes. 
O escalonamento hierárquico das variáveis, foi submetido à análise de decisão multicritério utilizando o método Analytic Hierarchy Process (AHP).

Os resultados indicaram que as alternativas com maior potencial para ampliar a competitividade da cadeia de valor consistem na realização de melhorias no processamento industrial, bem como, no desenvolvimento de melhores técnicas de manejo na produção agropecuária, obtendo uma representatividade de $36 \%$ e $17 \%$, respectivamente. O método AHP demonstrou-se eficiente para a análise e pode ser utilizado como base metodológica para estudos futuros para melhorias de competitividade no setor, utilizando-se de outras variáveis possíveis.

Palavras-chave: agroindústria, análise multicritério, cadeias produtivas, piscicultura. 


\section{INTRODUÇÃO}

A crescente complexidade do ambiente socioeconômico brasileiro faz com que a avaliação da competitividade seja considerada uma tarefa importante, porém, complicada. Quando se busca estabelecer prioridades estratégicas para ampliar a competitividade de uma cadeia de valor é comum se deparar com diferentes objetivos entre os atores. Existem muitos anseios por interesses comuns e abrangentes, como a ampliação da a margem de lucro, o aumento da participação no mercado, uma melhoraria na qualidade e na produtividade, etc. No entanto, existem também, interesses conflitantes sob diversos aspectos concorrenciais, organizacionais e de estratégias individuais, pois, além da qualidade do produto, do desempenho competitivo e do preço, alguns fatores influentes como a carga tributária, a informalidade no mercado, a diversidade de tecnologias empregadas no processamento agroindustrial e no manejo produtivo agropecuário, bem como, fatores organizacionais como integração vertical, cooperativismo ou associativismo devem ser levados em consideração, dado ao fato que uma ação sobre uma alternativa específica pode satisfazer a necessidade coletiva de todos os elos da cadeia de valor, porém, a ação em uma outra alternativa, pode não ter o mesmo desempenho e satisfazer apenas alguns elos da cadeia, em detrimento de outros, ocasionando assim, um conflito de interesses (Ramos et al., 2014).

Desta forma, a tarefa de avaliar hierarquicamente os fatores mais influentes na competitividade do setor de abate e processamento de pescado, compreende um problema de decisão multicritérios que envolve alguns objetivos ou atributos conflitantes e complicados. Não obstante, as carnes de aves, bovinos, suínos e pescado, conforme afirmam Carbonari \& Silva (2012), têm sido, respectivamente, as mais consumidas no Brasil. A competitividade entre estas cadeias produtivas por uma fatia dos mercados doméstico e internacional, tem sido muito acirrada. Entretanto, maior destaque se dá para as três primeiras, para as quais há uma maior diversidade de produtos industrializados e a cadeia de valor encontra-se melhor estruturada, em termos organizacionais (Saab et al., 2009; Melz \& Souza Filho, 2011).

A produção agropecuária de tilápias no Brasil está concentrada, basicamente, em três diferentes polos. Destes, dois concentram a produção no sistema de tanques-rede em reservatórios de usinas hidrelétricas e estão localizados na região nordeste do país e noroeste do estado de São Paulo e, o outro, no oeste do estado do Paraná, onde diferentemente dos demais, o sistema de produção mais utilizado é o de tanques escavados (Sussel, 2013). Destaca-se também, que nas regiões sul e sudeste, 
entre 75 e $85 \%$ da produção é vendida após o processamento do pescado transformado em filé, enquanto que na região nordeste, comercializa-se, principalmente, o peixe inteiro eviscerado.

Neste contexto, observa-se que Pequenas e Médias Empresas (PME) agroindustriais de processamento e filetagem de tilápias representam parte importante da economia regional do oeste paranaense, sendo responsáveis pela geração de tributos, empregos e renda. Neste grupo empresarial de notável importância econômica, encontra-se as agroindústrias de abate e processamento de pescado instalados na microrregião de Toledo, onde está localizado o principal polo de produção, abate e processamento de tilápias do Paraná (Schulter \& Vieira Filho, 2017).

Ao considerar a importância econômica da atividade na região, este estudo buscou evidenciar uma escala hierárquica de alternativas para ampliar a competitividade setorial ao responder a seguinte indagação: Como os critérios relacionados aos ambientes institucional, organizacional e tecnológico podem contribuir para ampliar a competitividade no sistema agroindustrial da filetagem de tilápias? Para responder a esta questão, foram associados a estes critérios, nove alternativas de competitividade no setor e delimitado como espaço de investigação, a microrregião de Toledo no oeste do Paraná. O estabelecimento da escala de prioridades entre alternativas e os critérios de competitividade, sob a ótica de especialistas do setor, em decorrência das decisões apontadas, podem ser utilizadas como alvo para o estabelecimento de políticas de promoção e desenvolvimento de melhorias no setor.

A busca por uma resposta se justifica pelo fato de analisar, empiricamente, as potencialidades de uma atividade agropecuária que tem apresentado expressivos sinais de crescimento e desenvolvimento regional, tanto em produção quanto em consumo, diante a uma apresentação de ações organizacionais incipientes. Além disso, acrescenta-se o fato da contribuição por parte das instituições de ensino, pesquisa e extensão para o entendimento desse fenômeno econômico regional, com vistas a contribuir para o auxílio na definição de estratégias empresariais e de políticas públicas para ampliar a competitividade na produção de pescado, tanto na região de estudo, quanto no Brasil.

\section{DESEMPENHO E COMPETITIVIDADE}

Em pesquisas relacionadas a competitividade de pequenas e médias empresas ( $P M E$ ), o desempenho é muitas vezes considerado como o objetivo e/ou critério final, tanto para estudos empíricos (Barkham, 1994; Box et al., 1994; Dyke et al., 1992) quanto para modelos teóricos (Herron \& Robinson, 
1993; Keats \& Bracker, 1987). As características demográficas, psicológicas, comportamentais e de relacionamento entre os agentes da cadeia de valor, bem como suas habilidades de gerenciamento e de conhecimento técnico são frequentemente citadas como os fatores mais influentes relacionados ao desempenho de uma PME. O relacionamento entre os agentes de uma cadeia de valor, também pode ser afetado por muitas características industriais, ambientais, específicas da empresa ou das estratégias entre as firmas, o que pode estar atrelado aos principais ambientes de competitividade, nos quais as empresas estão inseridas, tais como, o ambiente institucional, organizacional e tecnológico. Uma revisão mais abrangente acerca dos diversos fatores, potencialmente, influentes no desempenho competitivo pode ser encontrada em uma pesquisa de literatura de Cooper \& Gascon (1992).

A competitividade, conforme assevera Nelson (1992) possui um conceito atraente em vários níveis de estudo, seja no nível de empresa individual, microeconômico para as políticas industriais, ou mesmo, no nível macroeconômico para as posições competitivas das economias nacionais. Portanto, compreender a abrangência deste conceito e sua aplicabilidade nas relações empresariais é fundamentalmente importante. Uma revisão de Waheeduzzaman \& Ryans (1996) também aponta o conceito de competitividade envolvendo diferentes disciplinas, tais como: vantagem comparativa, perspectivas de competitividade de preços, estratégias e perspectivas de gestão, assim como, perspectivas históricas e de relacionamento sociocultural.

Considerando os aspectos relacionados ao desempenho e competitividade, uma pequena ou média empresa não pode ser vista como uma versão reduzida de empresas maiores. Empresas de grande porte são diferentes de empresas de pequeno e médio porte, seja em termos de suas estruturas organizacionais ou tecnológicas, respostas ao meio ambiente, estilos de gestão e, mais importante, as formas em que competem com outras empresas (Man \& Chan, 2002). Neste aspecto, os estudos de competitividade focados em grandes corporações podem não ser aplicados diretamente ao nível das PMEs. Portanto, os estudos de competitividade com foco nas PMEs têm aumentado significativamente nos últimos anos, visando identificar os diversos fatores que envolvem as organizações e suas estratégias de competitividade. Este enquadramento, corresponde a uma revisão da literatura recente, que distingue entre três aspectos fundamentais que conduzem à competitividade de uma PME, incluindo os fatores internos da empresa (ambiente tecnológico), o ambiente externo (ambiente organizacional) e, a influência das políticas públicas (ambiente institucional). Esses fatores, por sua 
vez, afetam o desempenho da empresa e, consequentemente, a sua competitividade (Man \& Chan, 2002).

\section{PROCEDIMENTOS METODOLÓGICOS}

Como técnica de pesquisa para o desenvolvimento deste estudo, aplicou-se o Analysis Hierarchical Process (AHP) que consiste em uma teoria quantitativa e estruturada de análise de decisão multicritérios, desenvolvida por Thomas Saaty para lidar com problemas tecnológicos, econômicos, sociopolíticos e complexos.

Saaty (1991) define o método AHP como uma ferramenta de apoio à decisão multicriterial, baseada em três princípios: a) construção de uma hierarquia; b) estabelecimento de prioridades; e c) consistência lógica das prioridades. Destarte, conforme assevera Power (2014), o Decision Support Systems Glossary (DSS) descreve o AHP como "uma abordagem para tomada de decisões que envolve estruturação de critérios de escolha múltipla em uma escala de hierarquia". Desta forma, o método permite uma avaliação sobre a importância relativa dos critérios, compara alternativas para cada critério e determina uma classificação geral das alternativas.

Saaty (1991), assevera que a operacionalização do AHP se dá a partir de uma sequência de procedimentos que se iniciam pela definição do problema e dos objetivos a serem perseguidos com a aplicação do método. Neste estudo, a aplicação do método AHP para o escalonamento hierárquico sobre a estratégias de maior importância para a melhoria do desempenho competitivo das agroindústrias de filetagem de tilápias, envolveu quatro etapas principais: a) montagem da hierarquia de decisões; b) comparação pareada dos critérios e alternativas; c) transformação das comparações pareadas em pesos (vetores de prioridade) e análise da consistência dessas comparações e, d) síntese das prioridades globais entre as alternativas. A primeira etapa consistiu em estruturar o problema por meio de uma hierarquia que indica a relação entre os elementos de um nível com aqueles do nível imediatamente inferior. Em sua raiz, encontra-se o objetivo principal do problema estudado.

Com base em uma análise qualitativa do ambiente competitivo, a figura 1 apresenta as estruturas hierárquicas separadas em três níveis. No primeiro nível encontra-se o objetivo principal, que é avaliar o desempenho competitivo das agroindústrias de filetagem, o segundo nível é composto pelos critérios de influência na competitividade, tais como os ambientes institucional, organizacional e 
tecnológico e o terceiro nível contempla as alternativas específicas à cada critério, que afetam a competitividade.

Esse arranjo gráfico, possibilita uma melhor visualização do problema e orienta os especialistas acerca das comparações par a par, ou paritárias, que devem ser efetuadas para que se obtenham uma hierarquia de prioridades de uma alternativa em relação a outra. Saaty \& Vargas (2001) explicam que atribuir preferência a uma alternativa envolve explicitar julgamentos referentes a questões de dominância de uma alternativa sobre a outra, quando comparados a uma prioridade.

Figura 1: Estrutura hierárquica do objetivo proposto

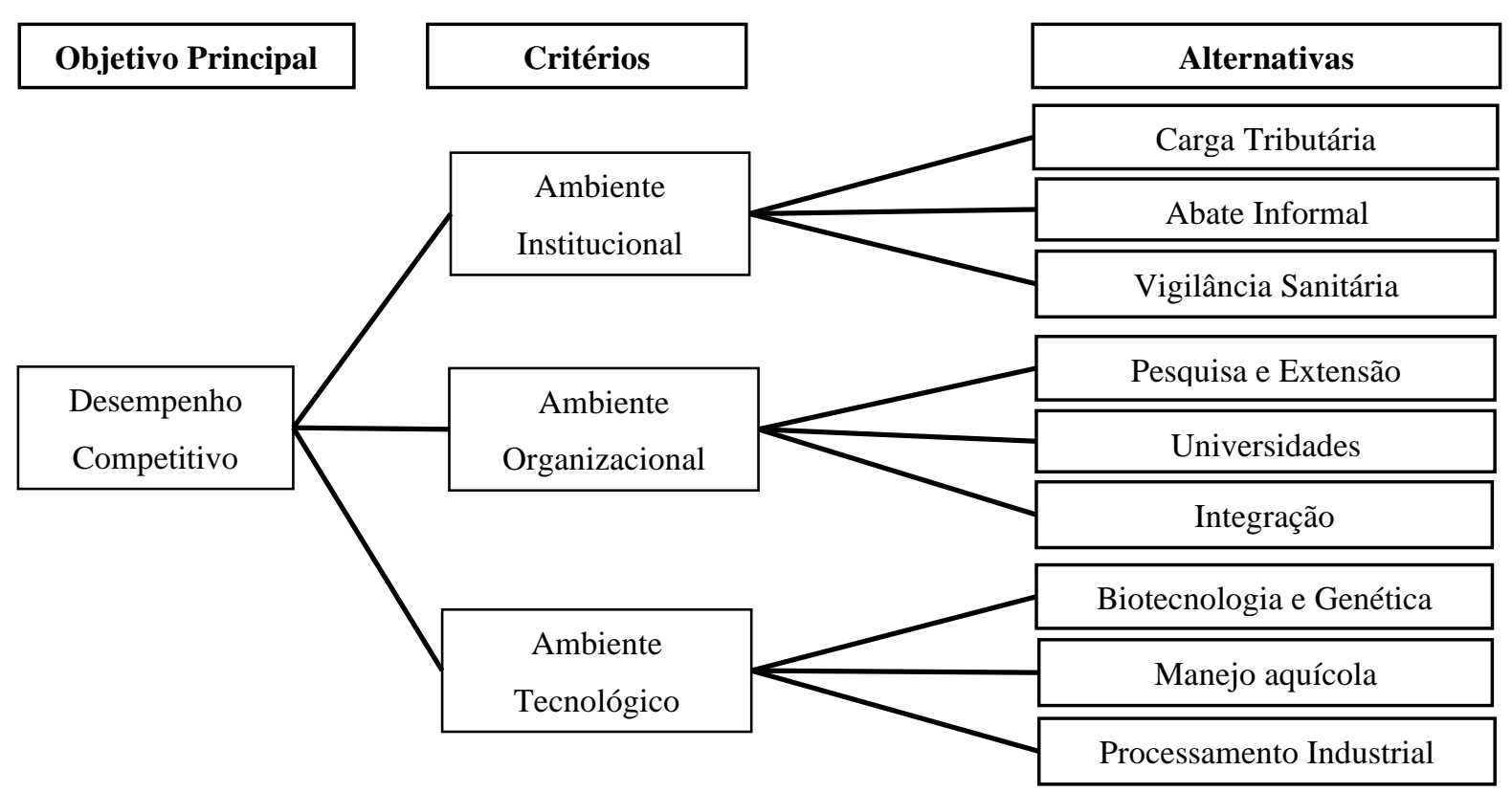

Fonte: Elaboração dos autores, 2017.

Após a estruturação da hierarquia gráfica que representa o problema decisório, a segunda etapa consistiu na comparação pareada dos elementos de um mesmo nível hierárquico com relação a seu impacto no elemento do nível superior à que ele se une. "[...] O processo básico de aplicação do AHP consiste em priorizar a importância relativa de $n$ elementos de

tomada de decisão em relação a um objetivo, através de avaliações parciais destes elementos, dois a dois, facilitando a análise pelos avaliadores (Francischini; Cabel, 2003, p.3). 
Para tanto, conforme recomenda Malhotra et al. (2007), foram convidados especialistas com conhecimento e domínio do problema abordado no foco principal, para analisar os critérios e as alternativas. Assim, as alternativas foram comparadas entre si com relação à cada um dos critérios e, para cada critério, uma matriz de comparações aos pares foi elaborada.

Saaty \& Vargas (2001) argumentam que por meio das comparações pareadas, as prioridades avaliadas pelo AHP capturam medidas subjetivas e objetivas e demonstram a intensidade de domínio de uma alternativa sobre outra.

O grupo de especialistas foi composto por: a) gestores de quatro unidades agroindustriais de abate e processamento de pescado instaladas na região oeste do Paraná, que representaram um estabelecimento de grande porte, um de médio porte e outros dois de pequeno porte; b) professores e pesquisadores de quatro instituições de ensino superior que representaram a Universidade Estadual do Oeste do Paraná (UNIOESTE), o Instituto Federal do Paraná (IFPR), o Instituto Superior de Ensino, Pesquisa e Extensão (ISEPE) e o Centro Universitário da Fundação Assis Gurgacz (FAG), sendo destas, duas instituições públicas e duas privadas; e c) representantes de três instituições de apoio como o Serviço Brasileiro de Apoio às Micro e Pequenas Empresas (SEBRAE), o Instituto Paranaense de Assistência Técnica e Extensão Rural (EMATER) e Programa Oeste em Desenvolvimento (POD), sendo este último ligado Fundação Parque Tecnológico de Itaipu (FPTI).

Na terceira etapa, mediante o entendimento teórico de cada um dos critérios e alternativas a serem julgadas, definiu-se como seria aplicada a escala de critérios, com o objetivo padronizar as respostas de cada um dos julgadores em decorrência da análise paritária. As escalas de julgamento de critérios e alternativas, possibilitaram aos avaliadores emitirem seus julgamentos de uma forma simples, utilizando uma linguagem naturalmente comum.

Mediante a atribuição de valores que variam de ' 1 ' a ' 9 ', conforme descrito na tabela 1, a escala determina a importância relativa de uma alternativa 'i' com relação à alternativa 'j' e, reciprocamente, da alternativa ' $\mathrm{j}$ ' em relação à alternativa ' $\mathrm{i}$ '. Assim, o primeiro passo consiste em elaborar uma matriz ' $\mathrm{n} \times \mathrm{n}$ ', na qual são comparadas as importâncias relativas

de cada alternativa, seguindo a escala sugerida por Saaty (1991) em que '1' equivale à igualdade entre os elementos do par; '9" indica absoluta dominância; e "1/9' a absoluta irrelevância de 'i' (linha) em relação à 'j' (coluna). 
Tabela 1 - Escala fundamental de números absolutos para julgamentos comparativos

\begin{tabular}{|c|c|c|}
\hline $\begin{array}{l}\text { Grau de } \\
\text { importância }\end{array}$ & $\begin{array}{l}\text { Definição do grau de } \\
\text { importância }\end{array}$ & Explicação \\
\hline 1 & Igual & A duas atividades contribuem igualmente para o objetivo. \\
\hline 3 & Moderada & $\begin{array}{l}\text { A experiência e o juízo favorecem uma atividade em } \\
\text { relação a outra. }\end{array}$ \\
\hline 5 & Grande & $\begin{array}{l}\text { A experiência e o juízo favorecem fortemente uma } \\
\text { atividade em relação à outra. }\end{array}$ \\
\hline 7 & Muito grande & $\begin{array}{l}\text { Uma atividade é muito fortemente favorecida em relação } \\
\text { à outra. Pode ser demonstrado na prática. }\end{array}$ \\
\hline 9 & Extrema & $\begin{array}{l}\text { A evidência favorece uma atividade em relação à outra, } \\
\text { como o mais alto grau de segurança. }\end{array}$ \\
\hline $2,4,6,8$ & $\begin{array}{l}\text { Valores } \\
\text { intermediários }\end{array}$ & $\begin{array}{l}\text { Quando se procura uma condição de compromisso entre } \\
\text { duas definições. }\end{array}$ \\
\hline
\end{tabular}

Fonte: adaptado de Saaty (2005), Saaty \& Vargas (2013).

Entretanto, mesmo quando os julgamentos paritários estão fundamentados na experiência e no conhecimento de profissionais (especialistas), podem haver inconsistências, principalmente, se existir um número muito elevado de variáveis. Portanto, considerando que a inconsistência é um fato inerente ao ser humano, deve existir uma tolerância para a sua aceitação. Desta forma, segundo a proposta de Saaty \& Vargas (2013) tolera-se uma Razão de Consistência (RC) inferior a 10\% $(R C>0,1)$. Na ocorrência de índice superior, recomenda-se a revisão do modelo e/ou dos julgamentos.

Para facilitar o processo de julgamento dos critérios e alternativas, foi utilizada uma planilha de cálculo (Excel for Windows TM) como ferramenta para registrar os valores atribuídos ao grau de importância relacionados às comparações paritárias, sendo que ao haver inconsistência superior a 10\%, imediatamente, os julgadores foram convidados a reavaliar suas decisões e chegarem à um novo consenso nas respostas. Este cálculo é de fundamental importância, pois revela como o tomador de decisão está consistente com suas escolhas. Desta forma, para as matrizes analisadas, verificou-se que todas as RC obtiveram valores abaixo de 0,1 indicando que os julgamentos foram devidamente consistentes.

A quarta e última etapa do método AHP consistiu em sintetizar as prioridades obtidas por meio de um modelo aditivo linear, apontando as hierarquias em razão da importância dada a cada variável do modelo. Uma vez que o instrumento de pesquisa é completado pelos tomadores de decisão e a matriz preenchida, vários cálculos precisam ser concluídos, nesta etapa, para gerar os resultados. As equações matemáticas do AHP não são aqui apresentadas, integralmente, pelo fato de serem 
amplamente divulgadas na literatura (Saaty, 1990; Saaty \& Vargas, 2001; Saaty, 2005; Saaty \& Vargas, 2013). Entretanto, as demonstrações no formato de planilhas eletrônicas Excel ${ }^{\circledR}$ são evidenciadas.

O método também pode ser aplicado como técnica de análise de decisão e planejamento de múltiplos critérios em diversas atividades da produção agrícola e agropecuária (Baracho et al, 2013; Bocca \& Galves, 2016).

\section{RESULTADOS E DISCUSSÕES}

Tendo definido o método AHP como ferramenta a ser utilizada na determinação da escala de prioridades, ou seja, na identificação das importâncias relativas entre as alternativas para o aumento da competitividade de PMEs da cadeia produtiva de filetagem de tilápias, procedeu-se, então, a busca por uma forma de operacionalizar este método, de acordo com as necessidades do caso em estudo. Assim, a análise iniciou-se pela determinação do peso relativo dos grupos de critérios iniciais (Institucional, Organizacional e Tecnológico) avaliados paritariamente.

A tabela 2, apresenta os dados de peso relativo entre os critérios, atribuídos conforme avaliação dos especialistas, participantes da pesquisa.

Tabela 2 - Matriz comparativa dos critérios de competitividade

\begin{tabular}{lccc}
\hline Critérios & Institucional & Organizacional & Tecnológico \\
\hline Institucional & 1,00 & 0,33 & 0,22 \\
Organizacional & 3,00 & 1,00 & 0,29 \\
Tecnológico & 4,50 & 3,50 & 1,00 \\
\hline Sum $\left(\boldsymbol{S}_{\boldsymbol{c}} \boldsymbol{)}\right.$ & $\mathbf{8 , 5 0}$ & $\mathbf{4 , 8 3}$ & $\mathbf{1 , 5 1}$ \\
\hline
\end{tabular}

Fonte: Elaboração dos autores, 2017

Os pesos relativos a cada critério, foram obtidos normalizando-se a matriz comparativa anterior. A normalização foi feita pela divisão entre cada valor da planilha com o total de cada coluna. Na tabela 3, estão apresentados os cálculos realizados, mediante a pontuação definida pelos especialistas na comparação paritária e a razão da somatória dos três indicadores (ambiente institucional, organizacional e tecnológico), obtendo desta forma, os indicadores normalizados. 
Tabela 3 - Matriz comparativa dos critérios de competitividade (normalizada)

\begin{tabular}{lccc}
\hline Critérios & Institucional & Organizacional & Tecnológico \\
\hline Institucional & $1,00 / 8,50=0,117$ & $0,33 / 4,83=0,068$ & $0,22 / 1,51=0,145$ \\
Organizacional & $3,00 / 8,50=0,352$ & $1,00 / 4,83=0,207$ & $0,29 / 1,51=0,192$ \\
Tecnológico & $4,50 / 8,50=0,529$ & $3,50 / 4,83=0,724$ & $1,00 / 1,51=0,662$ \\
\hline
\end{tabular}

Fonte: Elaboração dos autores, 2017

A determinação da contribuição de cada critério no objetivo geral foi calculada a partir do vetor de prioridade ou vetor de Eigen. Este vetor apresenta os pesos relativos entre os critérios e foi obtido através da média aritmética dos valores de cada um dos critérios, conforme apresentado tabela 4.

Tabela 4 - Cálculo do Vetor de Eigen (Vetor de Prioridade)

\begin{tabular}{lcc}
\hline Critérios & Vetor de Eigen (cálculo) & Vetor de Eigen (resultado) \\
\hline Institucional & $(0,117+0,068+0,145) / 3=0,11$ & $11 \%$ \\
Organizacional & $(0,352+0,207+0,192) / 3=0,25$ & $25 \%$ \\
Tecnológico & $(0,529+0,724+0,662) / 3=0,64$ & $64 \%$ \\
\hline
\end{tabular}

Fonte: Elaboração dos autores, 2017

O valor do vetor de Eigen determina a participação do critério avaliado no resultado em relação ao objetivo principal, ou seja, neste estudo os critérios tecnológicos representam $64 \%$ da meta global. Isto indica que uma avaliação positiva nesse critério contribui aproximadamente 6 (seis) vezes mais do que uma avaliação positiva no critério institucional (peso de 11\%).

O próximo passo foi verificar a consistência dos dados. Por exemplo, considerando que os julgadores afirmem que os critérios institucionais são mais importantes do que os critérios organizacionais e que os critérios organizacionais são mais importantes do que os critérios tecnológicos, seria inconsistente no julgamento se eles afirmassem que os critérios tecnológicos são mais importantes do que os critérios institucionais (se $A>B$ e $B>C$ é inconsistente afirmar que $A<C$ ).

O indicador de consistência tem como base o número principal de Eigen. Este número foi calculado através da soma do produto de cada elemento do vetor pelo total da respectiva coluna da matriz comparativa original (Tabela 2). A tabela 5 apresenta o cálculo do número principal de Eigen ( $\lambda \max$ ).

Tabela 5 - Cálculo do número principal de Eigen ( $\lambda \max )$.

\begin{tabular}{lccc}
\hline Vetor Eigen & 0,11 & 0,25 & 0,64 \\
Total & 8,50 & 4,83 & 1,51 \\
\hline Valor Principal & & $(0,11 * 8,50)+(0,25 * 4,83)+(0,64 * 1,51)=\mathbf{3 , 1 0}$ \\
\hline
\end{tabular}

Fonte: Elaboração dos autores, 2017

O cálculo do índice de consistência é dado pela equação 1: 


$$
C I=\frac{\lambda \max -n}{n-1}
$$

Em que $C l$ representa o índice de consistência, $\left(\lambda_{\max }\right)$ o número principal de Eigen e $n$ é a quantidade de critérios avaliados. Então, para este estudo, o resultado do índice de consistência $(C l)$ é obtido mediante a aplicação da equação 1 .

$$
C I=\frac{3,10-3}{3-1}=0,05
$$

Para verificar se o valor encontrado através do índice de consistência ( $C l$ ) é adequado, Saaty (2005) propõe avaliar a Razão de Consistência $(R C)$. Ela é determinada pela razão entre o valor do índice de consistência $(C l)$ e o índice de consistência aleatória ou randômica $(R I)$ dado pela equação 2:

$$
R C=\frac{\mathrm{CI}}{R I}<0,1
$$

A matriz somente é considerada consistente se a razão for inferior a $(0,1)$ o que indica um nível de inconsistência inferior a $10 \%$.

O valor de $R I$ é fixo e tem como base o número de critérios avaliados, conforme a tabela 6 , proposta por Saaty (1991).

Tabela 6 - Identificação do índice de consistência aleatória

\begin{tabular}{lcccccccccc}
\hline Tamanho da Matriz $\boldsymbol{n}$ & $\mathbf{1}$ & $\mathbf{2}$ & $\mathbf{3}$ & $\mathbf{4}$ & $\mathbf{5}$ & $\mathbf{6}$ & $\mathbf{7}$ & $\mathbf{8}$ & $\mathbf{9}$ & $\mathbf{1 0}$ \\
\hline Valor de $R I$ & 0,00 & 0,00 & 0,58 & 0,90 & 1,12 & 1,24 & 1,32 & 1,41 & 1,45 & 1,49 \\
\hline
\end{tabular}

Fonte: Saaty (1991).

Neste estudo, a Razão de Consistência $(R C)$ para a matriz do grupo inicial de critérios é obtida por meio da aplicação da equação 2:

$$
R C=\frac{0,05}{0,58}=0,0862=8,6 \%<10 \%
$$

Em um contexto geral, observa-se conforme o apontamento dos resultados obtidos na comparação pareada, que o ambiente tecnológico possui a preferência relativa em relação aos ambientes institucional e organizacional. Em seguida, maior importância é observada para o ambiente organizacional (Figura 2). 
Figura 2 - Resultados da matriz comparativa dos critérios de competitividade

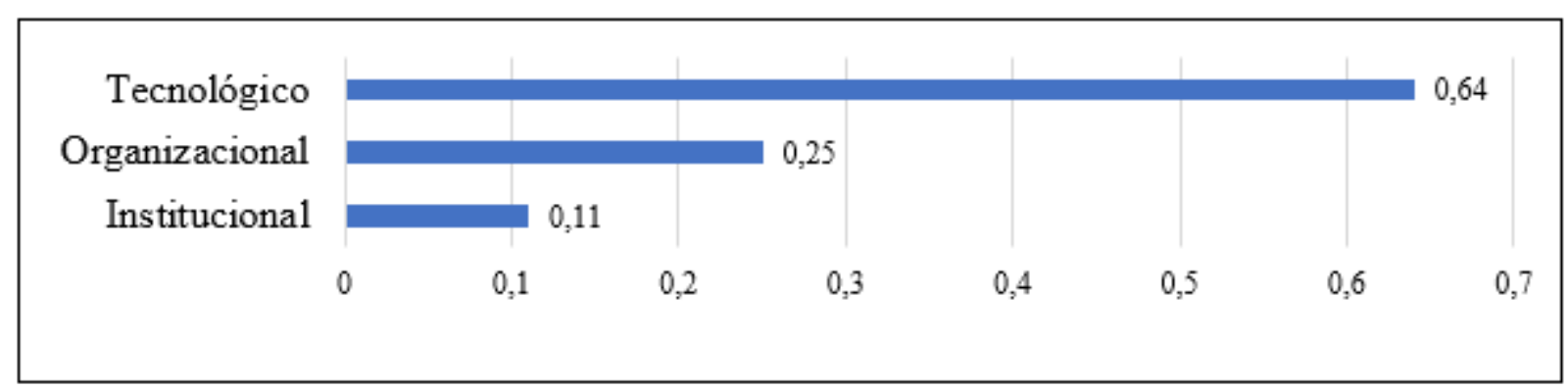

Fonte: Elaboração dos autores, 2017

Diante ao exposto, identifica-se que na opinião dos especialistas, o sucesso competitivo da atividade perpassa por meio de uma atenção maior ao que se refere às tecnologias de produção, que envolve desde o processamento do peixe na agroindústria de filetagem até a produção agropecuária, ou seja, a criação das tilápias nos tanques escavados, considerando o tipo de ração utilizada, o manejo, a genética dos animais, entre outros fatores tecnológicos.

Resultado semelhante foi descrito por Schiefer \& Hartmann (2008), que avaliaram o desempenho competitivo em indústrias de alimentos na Alemanha, envolvendo variáveis relacionadas a tecnologia e produção, poder de barganha, relacionamento com fornecedores e clientes, qualificação profissional, qualidade e inovação, entre outros fatores e, a variável relacionada à tecnologia e produção foi a que demonstrou exercer maior influência no desempenho das empresas, conforme a opinião dos especialistas participantes daquela pesquisa.

Em seguida, os resultados desta pesquisa, apontam maior importância às formas organizacionais da cadeia de valor do filé de tilápia. Neste aspecto, os julgadores avaliam que uma maior integração dos agendes é de fundamental importância para uma melhor competitividade no setor, o que pode influenciar decisivamente nas questões mercadológicas da cadeia com um todo. No estudo realizado por Schiefer \& Hartmann (2008), também foi apontado destaque para os relacionamentos entre as empresas, clientes e fornecedores, sendo que qualidade do relacionamento com os fornecedores demonstrou ser mais importante do que um bom relacionamento com os clientes.

E por último, avaliado com menor importância, encontra-se o ambiente institucional, contemplado pelas variáveis relacionada à legislação, políticas públicas e também variáveis macroeconômicas, que na opinião dos julgadores, dificilmente o grupo econômico representado pelos produtores de pescado, bem como pelas agroindústrias de filetagem da região oeste paranaense, teriam força para fazer alguma modificação substancial neste quesito, de forma que fica evidente, que uma ação sobre os 
outros dois fatores causariam maior impacto na competitividade da cadeia de valor. Entretanto, os julgadores não descartam a importância do ambiente institucional, apenas acreditam não ter força suficiente para mudar parâmetros atrelados ao quesito, o que poderia ser melhorado desenvolvendo ações de impacto com ênfase no critério organizacional.

Estudos realizados pela FAO (2017), apontam que o ambiente institucional do setor de pesca e aquicultura brasileiro encontra-se em fase de reestruturação e destacam que as políticas atuais do governo para o setor são baseadas, dentre outros aspectos, em critérios de sustentabilidade, inclusão social, estruturação adequada da cadeia produtiva, fortalecimento do mercado interno, abordagens territoriais para programas de gestão e produção, aumento da competitividade e consolidação das políticas estatais. Um êxito nestas ações, que tem fortes relações com as variáveis deste estudo, certamente elevariam, consideravelmente, a competitividade do setor produtivo da cadeia do filé de tilápia do oeste do Paraná, porém, estas ações são dependentes da iniciativa governamental, tendo uma participação inferior da iniciativa privada, o que de certa forma, também corrobora com a visão dos especialistas participantes da pesquisa, conforme aponta os resultados.

De maneira idêntica à que foi realizada para o grupo inicial de critérios, foram avaliados os pesos relativos às alternativas, que compõem o segundo nível da análise de hierarquia. Esse processo foi realizado de modo semelhante ao apresentado para o primeiro nível, portanto, não serão descritos detalhadamente os cálculos realizados. As tabelas e gráficos a seguir, demonstram as matrizes com os resultados comparativos entre as nove alternativas que compõem os critérios institucional, tecnológico e organizacional, feitas as comparações par a par realizadas pelos especialistas.

\subsection{AMBIENTE INSTITUCIONAL}

Em relação ao critério ambiente institucional, foram consideradas as alternativas, conforme as informações descritas na Tabela 7, sendo que os resultados podem ser analisados mediante a interpretação da figura 3, que aponta as comparações pareadas voltadas para a análise hierárquica de importância dos fatores relacionados a este critério, composto pelas alternativas: carga tributária, abate informal e vigilância sanitária.

Desta forma, é possível observar que na visão dos agentes que compõem a cadeia de valor, a elevada carga tributária incidente sobre as operações mercadológicas, têm maior importância, ou seja, os julgadores avaliam que uma medida efetiva na redução dos tributos poderia contribuir, substancialmente, para o favorecimento à competitividade no setor. 
Tabela 7 - Comparação pareada das alternativas relacionadas ao ambiente institucional

\begin{tabular}{lccc}
\hline Alternativas & Carga Tributária & Abate Informal & Vigilância Sanitária \\
\hline Carga Tributária & 1,00 & 4,00 & 1,18 \\
Abate Informal & 0,25 & 1,00 & 0,67 \\
Vigilância Sanitária & 0,85 & 1,50 & 1,00 \\
\hline Sum $\left(\boldsymbol{S}_{\boldsymbol{c} \text { i }}\right)$ & $\mathbf{2 , 1 0}$ & $\mathbf{6 , 5 0}$ & $\mathbf{2 , 8 4}$ \\
\hline
\end{tabular}

Fonte: Elaboração dos autores, 2017

A alternativa associada a tributação sobre a atividade de abate e processamento do pescado, tem uma representatividade de $50 \%$ sobre o desempenho competitivo da cadeia de valor, quando analisada paritariamente entre as alternativas de informalidade no abate e a ações de vigilância sanitária. A FAO (2017) corrobora com esta visão dos julgadores ao apontar que o crescimento do agronegócio brasileiro é prejudicado pelas fraquezas estruturais na economia, o que inclui um sistema tributário oneroso, baixos investimentos em infraestrutura, elevada burocracia em procedimentos administrativos e baixos níveis de educação e competências. Ações mais eficazes sobre estas alternativas podem propiciar um ambiente competitivo mais eficiente. Isto é o que aponta a análise, conforme a visão dos especialistas pesquisados.

Figura 3 - Resultados da matriz comparativa do ambiente institucional

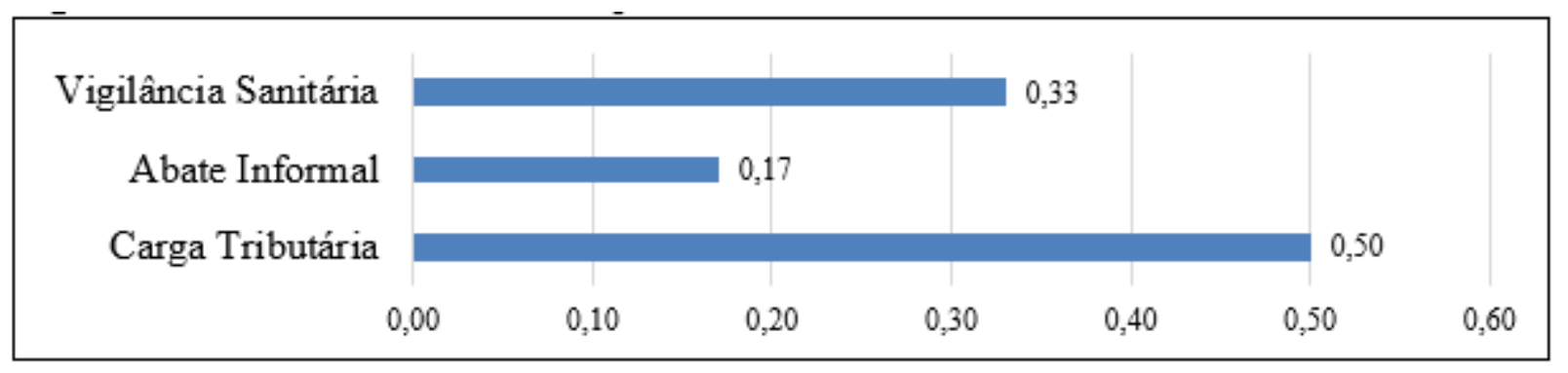

Fonte: Elaboração dos autores, 2017

De forma complementar, a FAO (2017) argumenta que melhorias nessas áreas representam um potencial de elevar, significativamente, as perspectivas em médio prazo, tanto no crescimento agrícola sustentável, como também no desenvolvimento econômico e regional.

Na segunda posição da hierarquia de importância no ambiente institucional, destaca-se a alternativa de vigilância sanitária, que de acordo com os integrantes da cadeia de valor, uma atuação mais efetiva dos organismos de fiscalização, poderia resolver de forma conjunta os problemas de informalidade que permeia o setor, pois esta que é a alternativa menos impactante na opinião dos julgadores e decorre de problemas relacionados ao abate e/ou comercialização do pescado sem o 
acompanhamento de fiscalização de órgãos de vigilância sanitária. Para Ramos et al. (2014), a prática da informalidade no setor de abate e processamento, pode comprometer a qualidade do produto final, neste caso, o filé de tilápia, além de apresentar riscos à saúde e à confiança dos consumidores, prejudicando, assim, a competitividade no setor produtivo. Desta forma, uma ação mais efetiva na alternativa de vigilância sanitária reduziria também os problemas de informalidade, de acordo com a opinião dos especialistas pesquisados.

\subsection{AMBIENTE ORGANIZACIONAL}

Conforme observa-se na tabela 8 e figura 4, em relação ao ambiente organizacional, que envolve as alternativas de pesquisa e extensão, participação das universidades e integração dos agentes envolvidos na cadeia de valor, os resultados apontam que a integração se apresenta como o fator de maior relevância para ampliar a competitividade setorial, participando com $40 \%$ em termos de importância, perante as demais alternativas associadas a este critério. Isto indica que as organizações somente conseguem atingir os resultados esperados quando existe a coordenação das ações de seus membros. Este resultado é corroborado com a visão de Kubo (2014), que destaca em sua pesquisa que o crescimento pleno da indústria de pescado depende da superação de uma série de gargalos e desafios, entre os quais destaca-se a necessidade de melhorar a organização do setor produtivo, de forma a compartilhar os resultados e os conhecimentos gerados no meio profissional em que se insere a cadeia produtiva.

Tabela 8 - Comparação pareada das alternativas do ambiente organizacional

\begin{tabular}{lccc}
\hline Alternativas & Pesquisa e Extensão & Universidades & Integração \\
\hline Pesquisa e Extensão & 1,00 & 1,00 & 0,67 \\
Universidades & 1,00 & 1,00 & 0,83 \\
Integração & 1,50 & 1,20 & 1,00 \\
\hline Sum $\left(\boldsymbol{S}_{\boldsymbol{c} \boldsymbol{i}}\right)$ & $\mathbf{3 , 5 0}$ & $\mathbf{3 , 2 0}$ & $\mathbf{2 , 5 0}$ \\
\hline
\end{tabular}

Fonte: Elaboração dos autores, 2017

Na sequência, o destaque é para a contribuição das universidades, pois a partir delas, são realizadas a formação de recursos humanos especializados na área e a maior parte das pesquisas e trabalhos de extensão, o que contribui significativamente para a evolução tecnológica e mercadológica do setor, na região do estudo. 
Figura 4 - Resultados da matriz comparativa do ambiente organizacional

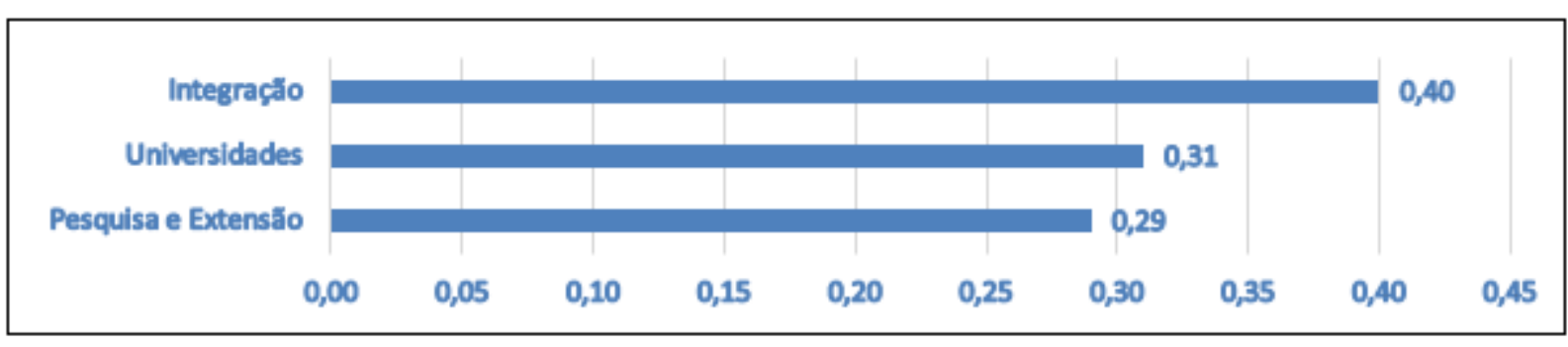

Fonte: Elaboração dos autores, 2017

\subsection{AMBIENTE TECNOLÓGICO}

Em relação ao ambiente tecnológico, que envolve as alternativas de biotecnologia e genética, manejo aquícola e processamento industrial, os resultados da pesquisa apontam que o processamento industrial possui maior importância para ampliar a competitividade no setor. Neste aspecto, consideram-se as tecnologias de ordem sanitária, como as boas práticas de fabricação, os procedimentos padrão de higiene operacional, a adequação das plantas frigoríficas às legislações vigentes, entre outros processos tecnológicos de produção. Fatores estes, que impactam diretamente na qualidade do filé e, por consequência, na maior visibilidade do produto e maior competitividade. A alternativa de preposição de mediadas relacionadas ao processamento industrial representa $57 \%$ da meta global do ambiente tecnológico e uma avaliação positiva nessa alternativa contribui aproximadamente 4 (quatro) vezes mais do que uma avaliação positiva na alternativa de biotecnologia e genética (peso de 16\%).

Tabela 9 - Comparação pareada dos subcritérios relacionados ao ambiente tecnológico

\begin{tabular}{lccc}
\hline & $\begin{array}{c}\text { Biotecnologia e } \\
\text { Genética }\end{array}$ & $\begin{array}{c}\text { Manejo } \\
\text { Aquícola }\end{array}$ & $\begin{array}{c}\text { Processamento } \\
\text { Industrial }\end{array}$ \\
\hline Biotecnologia e Genética & 1,00 & 0,50 & 0,33 \\
Manejo Aquícola & 2,00 & 1,00 & 0,40 \\
Processamento Industrial & 3,00 & 2,50 & 1,00 \\
\hline Sum $\left(\boldsymbol{S}_{\boldsymbol{c} i}\right)$ & $\mathbf{6 , 0 0}$ & $\mathbf{4 , 0 0}$ & $\mathbf{1 , 7 3}$ \\
\hline
\end{tabular}

Fonte: Elaboração dos autores, 2017

Para os julgadores, a alternativa biotecnologia e genética é de extrema importância, entretanto, não causará o impacto relativo se o processamento industrial não for de extrema qualidade e tecnologicamente evoluído. De maneira similar, os investimentos em biotecnologia e genética não terão os impactos positivos se o manejo na produção agropecuária não for satisfatório. 
Figura 5 - Resultados da matriz comparativa do ambiente tecnológico

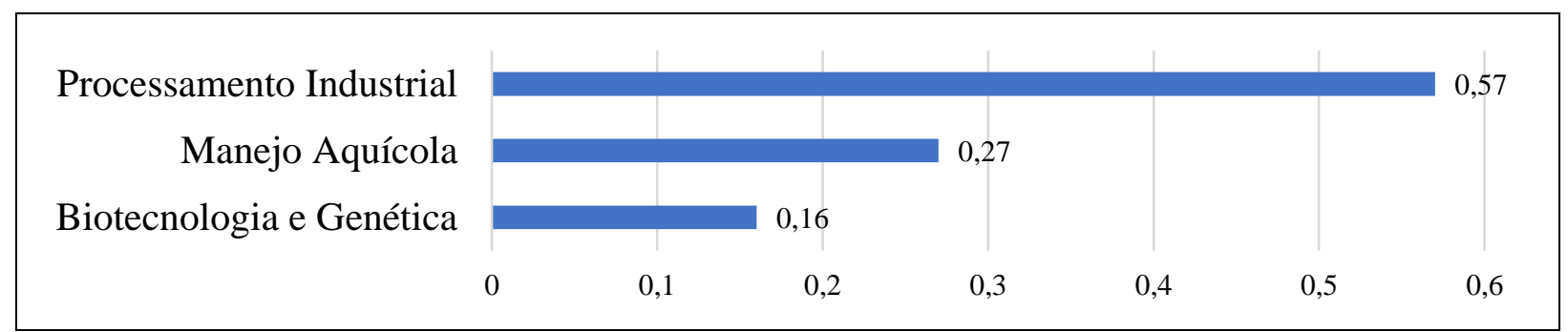

Fonte: Elaboração dos autores, 2017

Sendo assim, o segundo fator de maior importância do ambiente tecnológico consiste no manejo aquícola, pois o processamento industrial será mais eficiente se for provido de matéria prima de excelente qualidade.

Conforme descrito na tabela 10, os resultados gerais da pesquisa apontam, de forma resumida, que o critério que mais impacta na competitividade da cadeia de valor do filé de tilápia, da região estudada, relaciona-se ao atendimento de aspectos tecnológicos, com uma representatividade de $64 \%$ conforme a visão dos integrantes da cadeia produtiva. Também no ambiente tecnológico, encontra-se a principal alternativa para a melhoria no ambiente competitivo, ou seja, o processamento industrial que tem a maior representatividade entre as nove alternativas analisadas.

O critério de menor importância consiste no ambiente institucional, no qual a alternativa abate informal também é mais irrelevante, pois segundo os especialistas pesquisados, o atendimento à outras alternativas, tais como uma ação mais efetiva na vigilância sanitária atrelada a uma possível redução da carga tributária, poderiam inibir esta prática em defesa da concorrência leal, ampliando a competitividade, tanto no nível regional, como nacional. 
Tabela 10 - Síntese das prioridades globais do ambiente competitivo das agroindústrias de filetagem de tilápia da microrregião de Toledo, Paraná - Brasil.

\begin{tabular}{|c|c|c|c|c|c|}
\hline & Critérios & Peso & Alternativas & Peso & $\begin{array}{l}\text { Vetores de } \\
\text { Prioridade }\end{array}$ \\
\hline \multirow{3}{*}{ 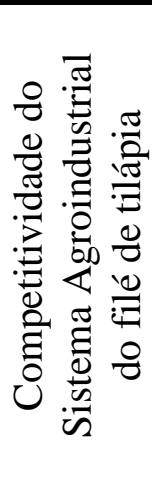 } & Institucional & 0,11 & $\begin{array}{l}\text { Carga Tributária } \\
\text { Abate Informal } \\
\text { Vigilância Sanitária } \\
\end{array}$ & $\begin{array}{l}0,50 \\
0,17 \\
0,33\end{array}$ & $\begin{array}{l}0,055 \\
0,018 \\
0,036\end{array}$ \\
\hline & Organizacional & 0,25 & $\begin{array}{l}\text { Pesquisa e Extensão } \\
\text { Universidades } \\
\text { Integração }\end{array}$ & $\begin{array}{l}0,29 \\
0,31 \\
0,40\end{array}$ & $\begin{array}{l}0,072 \\
0,077 \\
0,100 \\
\end{array}$ \\
\hline & Tecnológico & 0,64 & $\begin{array}{l}\text { Biotecnologia e Genética } \\
\text { Manejo Aquícola. } \\
\text { Processamento Industrial }\end{array}$ & $\begin{array}{l}0,16 \\
0,27 \\
0,57\end{array}$ & $\begin{array}{l}0,102 \\
0,172 \\
0,364\end{array}$ \\
\hline
\end{tabular}

Fonte: Elaboração dos autores, 2017

A figura 6 a seguir, complementa a síntese de prioridades globais apresentada na tabela 10 e demonstra uma escala hierárquica de prioridades, obtida mediante a aplicação do método de Saaty. Esta escala hierárquica pode ser utilizada como indicador para o estabelecimento de políticas públicas, corporativas ou uma combinação entre iniciativa pública e privada, com potencialidade para ampliar a competitividade do setor de abate e processamento de pescado na região de estudo, tendo como parâmetro os critérios e as alternativas indicadas.

Conforme destacado na figura 6, as alternativas de maior relevância para ampliar a competitividade das agroindústrias de abate e filetagem de tilápias, consiste no desenvolvimento de tecnologias mais eficientes para o processamento industrial, com uma avaliação de 36,4 \% sobre todas as demais alternativas, seguida pelo desenvolvimento de melhores técnicas de manejo aquícola para os produtores de tilápias, com uma participação de 17,2 \%. Já as alternativas menos relevantes são a informalidade no abate e a atuação da vigilância sanitária, que participam com apenas 1,8 e 3,6 \% respectivamente, em termos de importância, quando comparadas as demais alternativas. 
Figura 6 - Hierarquia de variáveis para a melhoria do ambiente competitivo da agroindústria de filetagem da microrregião de Toledo

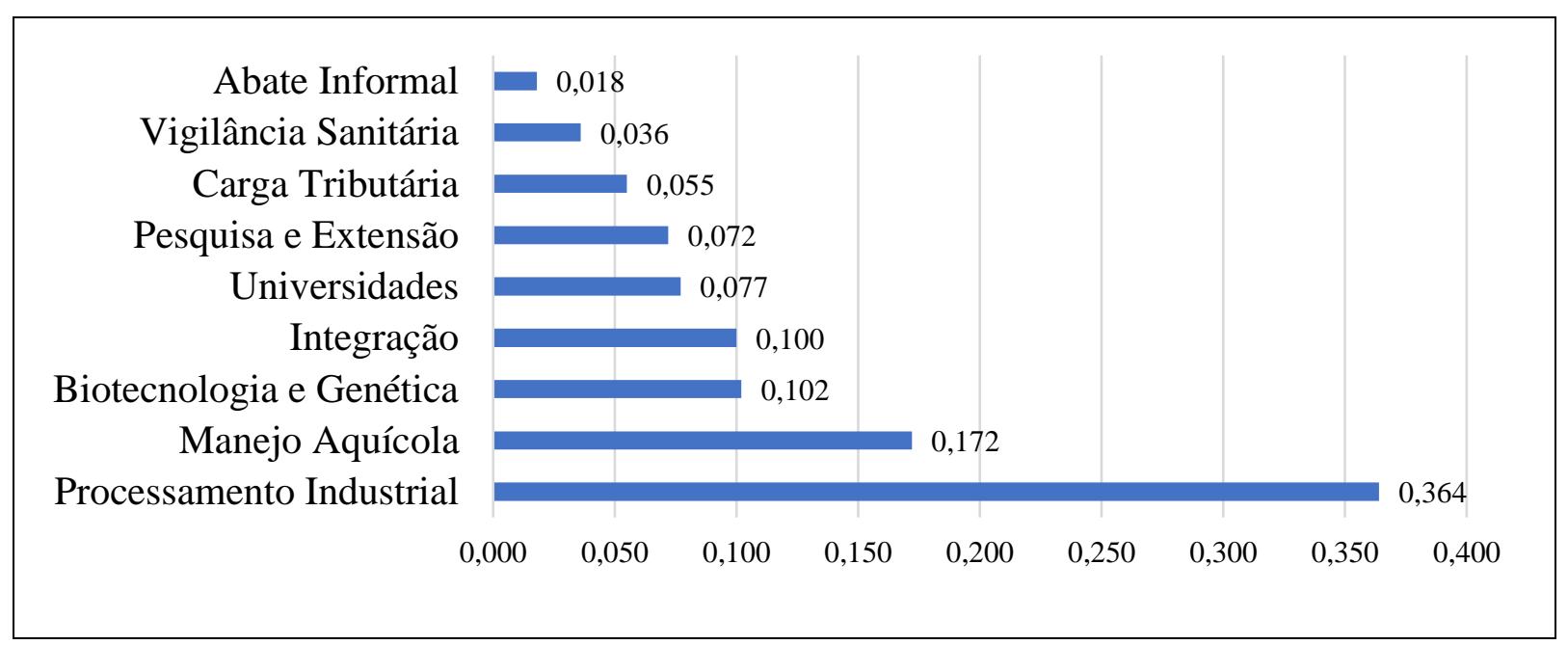

Fonte: Elaboração dos autores, 2017

Utilizando metodologia semelhante, Rafaeli e Müller (2010), estudaram a proposição de uma lógica de avaliação comparativa entre os indicadores de desempenho no departamento de engenharia de uma indústria automotiva, visando estabelecer uma medida de eficiência que caracterizasse o desempenho do departamento. O estudo foi viabilizado por meio da aplicação do método AHP e os autores concluíram que uma das principais possibilidades, mediante a aplicação do método, residiu na expansão do uso do AHP para outras áreas da empresa analisada, de modo que a alta gerência possa comparar o desempenho de cada unidade em relação às metas estabelecidas.

Desta forma, observa-se que a aplicação do método AHP é uma excelente ferramenta para lidar com problemas de decisão de multicritérios, em que é necessário o estabelecimento de prioridades, mediante uma gama de fatores decisórios de ordem tecnológica, econômica, sociopolítica e complexa.

\section{CONCLUSÃO}

Conforme os resultados obtidos por meio da aplicação do método de Saaty, conclui-se que os fatores institucionais, organizacionais e tecnológicos expressam grandes oportunidades para a articulação da cadeia de valor do filé de tilápia, em que a realização de trabalhos conjuntos entre organizações de apoio, instituições de ensino, pesquisa e extensão e outros órgãos públicos e privados, possibilitaria uma melhor coordenação entre os agentes envolvidos e o consumidor final, impactando diretamente na ampliação da competitividade do setor. Entretanto, investimentos e incentivos no desenvolvimento de técnicas de manejo na produção agropecuária e no processamento industrial 
mais eficiente, seriam as duas alternativas com maior potencial para tornar a comercialização dos produtos mais competitiva, obtendo uma representatividade de $17 \%$ e $36 \%$ respectivamente, ante os $1,8 \%$ de significância causado pela informalidade no setor, que seria a alternativa de menor impacto na escala hierárquica.

\section{AGRADECIMENTOS}

Os autores agradecem ao CNPq/CAPES pelo apoio financeiro.

\section{REFERÊNCIAS BIBLIOGRÁFICAS}

Baracho, M. S., Nääs, I. A., Neves, D. P., Cassiano, J. A., Lima, F. G., Moura, D. J., \& Garcia, R. G. (2013). Estimating the most important criteria for hatching eggs as function of broiler breeders age. Engenharia Agrícola, 33(3), 445-452. http://dx.doi.org/10.1590/\$0100-69162013000300002.

Barkham, R. J. (1994). Entrepreneurial characteristics and the size of the new firm: a model and an econometric test. Small Business Economics 6(2), 117-125.

https://doi.org/10.1007/BF01065184

Bocca, L. S., \& Galves, M. L. (2016). Multicriteria decision aid to implement an on-farm storage system for soybeans. Engenharia Agrícola, 36(6), 1250-1260. http://dx.doi.org/10.1590/1809-4430eng.agric.v36n6p1250-1260/2016.

Box, T. M., White, M. A., \& Barr, S. H. (1994). A contingency model of new manufacturing firm performance. Entrepreneurship Theory Practice, 18(2), 31-45.

Carbonari, T., \& Silva, C. R. L. D. (2012). Estimativa da elasticidade-renda do consumo de carnes no Brasil empregando dados em painel. Pesquisa \& Debate, 23(1), 154-178.

Cooper, A. C., \& Gascon, F. J. G. (1992). Entrepreneurs, processes of founding, and new-firm performance. In: Sexton, D. L., \& Kasarda, J. D. (Orgs.). The State of the Art of Entrepreneurship, p.301340.

Dyke, L. S., Fischer, E. M., \& Reuber, A. R. (1992). An inter-industry examination of the impact of owner experience on firm performance. Journal of Small Business Management, 30(4), 72-87.

Francischini, P. G., Cabel, G. M. (2003). Proposição de um indicador geral de desempenho utilizando AHP. In: Encontro Nacional de Engenharia de Produção, 23., 2003, Ouro Preto. Anais... Ouro Preto: UFOP, 2003. 1 CD-ROM.

Herron, L., \& Robinson, R. B. (1993). A structural model of the effects of entrepreneurial characteristics on venture performance. Journal of Business Venturing, 8(3), 281-294. https://doi.org/10.1016/08839026(93)90032-Z

Keats, B. W., \& Bracker, J. S. (1987). Towards a theory of small firm performance: a conceptual model. Entrepreneurship Theory Practice, 12 (4), 41-58. https://doi.org/10.1177/104225878801200403. 
Kubo, E. (2014). Pescados e derivados. In: Madi, L. F., \& Rego, R. (orgs.). Sustentabilidade e sustentação da produção de alimentos no Brasil: agroindústria de alimentos. Brasília: CGEE, p.75-84.

Malhotra, V., Lee, M. D., \& Khurana, A. (2007). Domain experts influence decision quality: Towards a robust method for their indentification. Journal of Petroleum Science and Engineering, 57, 181-194. https://doi.org/10.1016/j.petrol.2005.09.007.

Man, T. W. Y., \& Chan, T. L. K. F. (2002). The competitiveness of small and medium enterprises: A conceptualization with focus on entrepreneurial competencies. Journal of Business Venturing, 17, 123-142. https://doi.org/10.1016/S0883-9026(00)00058-6.

Melz, L. J., \& Souza Filho, H. M. (2011). Avaliação da competitividade da produção de carne de frango em Mato Grosso. Revista Brasileira de Gestão e Desenvolvimento Regional, 7(2), 25-57.

Nelson, R. (1992). Recent writings on competitiveness: boxing the compass. California Management Review, 34(2), 127-137.

Organização das Nações Unidas para Alimentação e Agricultura - FAO. (2017). Perspectivas agrícolas no Brasil: desafios da agricultura brasileira 2015-2024. Disponível em: <http://www.fao.org.br/download/PA20142015CB.pdf> Acesso em: 07 jun. 2017.

Power, D. J. (2014). Decision Support Systems Glossary: DSSResources.COM. Disponível em: http://dssresources.com/glossary. Acessado em mai 24, 2017.

Ramos, M. J., Rocha Júnior, W. F., Schmidt, C. M., \& Fagundes, M. B. B. (2014). Sistema agroindustrial da carne ovina no oeste paranaense. Revista de Política Agrícola, 23(1), 18-32.

Saab, M. S. B. L. M., Neves, M. F., \& Cláudio, L. D. G. (2009). O desafio da coordenação e seus impactos sobre a competitividade de cadeias e sistemas agroindustriais. Revista Brasileira de Zootecnia, 38, 412422. http://dx.doi.org/10.1590/S1516-35982009001300041.

Saaty, T. L. (1990). How to make a decision: the analytic hierarchy process. European Journal of Operational Research, 48(1), 9-26. https://doi.org/10.1016/0377-2217(90)90057-I.

Saaty, T. L. (1991). Método de análise hierárquica. Tradução e revisão técnica Wainer da Silveira e Silva. São Paulo: Makron Books, 326p.

Saaty, T. L., \& Vargas, L. G. (2001). Models, methods, concepts applications of the analytic hierarchy process. Norwell: Kluwer Academic Plublishers. http://dx.doi.org/10.1007/978-1-4615-1665-1.

Saaty, T. L. (2005). Theory and applications of the analytic network process: decision making with benefits, opportunities, costs, and risks. Pittsburgh: RWS Publications.

Saaty, T. L., \& Vargas, L. G. (2013). Models, methods, concepts and applications of the Analytic Hierarchy Process. London: Springer New York, Heidelberg Dordrecht London.

Schiefer, J., \& Hartmann, M. (2008). Determinants of competitive advantage for German food processors. Agribusiness: An International Journal, 24(3), 306-319. doi:10.1002/agr.20168. 
Schulter, E. P., \& Vieira Filho, J. E. R. (2017). Evolução da piscicultura no Brasil: diagnóstico e desenvolvimento da cadeia produtiva de tilápia. Instituto de Pesquisa Econômica Aplicada. IPEA. Disponível em: http://www.ipea.gov.br/portal/images/stories/PDFs/TDs/td_2328.pdf Acessado em out. 03, 2017.

Sussel, F. R. (2013). Tilapicultura no Brasil e entraves na produção. Agência Paulista de Tecnologia dos Agronegócios, Secretaria de Agricultura e Abastecimento do Estado de São Paulo. Disponível em: ftp://ftp.sp.gov.br/ftppesca/TilapiculturaEntraves.pdf. Acessado em mai. 24, 2017.

Waheeduzzaman, A. N. M., \& Ryans, J. K. (1996). Definition, perspectives, and understanding of international competitiveness: a quest for a common ground. Competitiveness Review: An International Business Journal, 6(2), 7-26. https://doi.org/10.1108/eb046333. 


\section{Capítulo 13}

\section{DPSIR COMO METODOLOGIA AVALIADORA DOS IMPACTOS SOCIOECONÔMICOS E AMBIENTAIS DE USINAS HIDRELÉTRICAS NO PARÁ}

DOI: $10.37423 / 200300395$

Edilson Máximo da Silva Junior - agroedilson@gmail.com

Vicente Celestino Pires Silveira - vcpsilveira@gmail.com.

RESUMO: Este trabalho tem como objetivo requerer e categorizar a metodologia DPSIR ((Driving Forces, Pressures, State, Impact e Response) como ferramenta de análise e identificação dos impactos socioeconômicos e ambientais de usinas hidrelétricas no Estado do Pará. Visto a ausência de uma metodologia integradora capaz de desvelar a diversidade constante dos grandes projetos desferidos sobre a Amazônia, que priorizam o acúmulo de capital e se colocam como essenciais ao processo de desenvolvimento, os quais nascem sobre o bojo dos programas de integração da região Amazônica junto às regiões sudeste e sul do Brasil, tendo sua base alicerçada no preceito de servir ao pólo mínero-metalúrgico que seria implantada na região oeste do Pará, a fim de trazer desenvolvimento econômico. Estas intervenções estão contidas em um processo de extração mineral e industrialização regional, implementado desde a abertura econômica da região, durante o governo militar - década de 1960, que teve as usinas hidrelétricas como fomentadoras de energia elétrica, fundamental à manutenção destes grandes empreendimentos com impactos nos sistemas de produção agropecuários locais. Portanto, o que se propõe é um arranjo metodológico que seja capaz de dirigir as bases socioeconômicas e ambientais das regiões afetadas por esses cometimentos de forma isonômica, possibilitando com que os fatores sociais e ambientais possam ser relevados no mesmo patamar que os econômicos. 
A metodologia DPSIR (Driving Forces, Pressures, State, Impact e Response), apresenta-se como uma possibilidade de agregar os fatores socioeconômicos e ambientais advindos da implantação das políticas de desenvolvimento aplicados a região, no intuito de balizar os estudos de viabilidade e desempenho destes empreendimentos, integrando, portanto, sua gama de impactos.

Palavras-chave: Amazônia, Socioeconomia, Geopolítica, Meio ambiente, Políticas públicas. 


\section{INTRODUÇÃO}

Os caminhos do desenvolvimento mundial, historicamente foram alicerçados exclusivamente pela proposição do crescimento econômico, esta fundamentação tem como conjectura a minimização do papel do Estado sobre a economia, trata-se do neoliberalismo econômico, no qual os índices de desenvolvimento social são unicamente o reflexo da produção econômica e do Produto Interno Bruto - PIB, permitindo assim que a sociopolítica do Estado seja gerida a partir de regulamentações mercadológicas (CAZELLA, 2011).

Aos países Latino americanos, este aditivo tomou seu espaço entre as décadas de 70-90, quando uma recessão econômica sentenciada pela pesada dívida externa, crise fiscal, hiperinflação e distorções na priorização de alocação dos recursos advindos do protecionismo estatal afetaram o equilíbrio econômico e expuseram de fato as fraturas da crise econômica disseminada pelo mundo (SOULÉ e MATTOS, 2007).

No Brasil, as investidas em busca de uma solução viável para desenvolver patamares de empregabilidade, saúde, educação e principalmente crescimento do PIB, só foram capazes de provar a ineficiência das políticas públicas e o desnivelamento dialético entre as classes políticas e econômicas que conduziam o processo (SALUM e KUGELMAS, 1991).

Neste cenário, a ascensão da doutrina neoliberal tornou-se inevitável, já que a mesma pressupõe a injeção de capital externo como saída á crise econômica, aliando com isso, definitivamente, o conceito de desenvolvimento à regulação do mercado. Esta presunção foi trilhada pelos caminhos abertos a partir da incapacidade de gestão socioeconômica dos primeiros governos brasileiros pós ditadura militar. Assim,

No caso brasileiro, a aceleração da inflação e a centralidade política da discussão sobre planos de estabilização econômica deram o tom aos primeiros governos civis posteriores ao regime autoritário, o de José Sarney (1985-1990) e o de Fernando Collor de Mello (1990-1992). A sucessão de planos econômicos frustrados condicionou o processo político em seu conjunto, lançando dúvidas e temores com relação à própria consolidação das instituições democráticas. (SALUM e KUGELMAS, 1991, p. 145).

Portanto, sequencialmente, a partir dos anos 90 o que se projetou foram grandes reformas liberais em busca de abertura estratégica econômica para financiamento do crescimento brasileiro fundamentadas pelo conceito neoclássico de desenvolvimento, no qual segundo Cazella (2011, p. 17) 
é "concebido sobre a teoria do crescimento e como sendo a arbitragem sobre os fluxos de consumo no tempo, ou seja, o equilíbrio entre a poupança e o investimento".

Seguindo esta proposição de desenvolvimento, as políticas públicas em todo o mundo passaram a ser dilatadas com base na construção de parques industriais e minerais, em busca do acúmulo de capital ativo e crescimento de seu produto interno, a partir da produção de bens manufaturados e agregação de valor aos seus produtos. Um dos instrumentos para o desenvolvimento desta política, por exemplo, foi a criação dos bancos de desenvolvimento que tinham como objetivo financiar investimentos destinados à indústria por meio de capital circulante de longo prazo (BACHILLER, 2016).

Formado o conceito de desenvolvimento refletido a partir dos dados de crescimento econômico, é válido pensar que a todo instante coexistiram outras partes do processo, que sempre estiveram à margem da discussão sobre o que se deve apresentar e construir junto às sociedades e que de fato irão contribuir no seu desenvolvimento, das quais segundo Cazella (2011, p. 17), podem ser concebidas a partir da "satisfação das necessidades fundamentais da população atual e futura, a redução das desigualdades socioeconômicas e à proteção ao meio ambiente".

Desta forma, ao associarmos estas esferas socioambientais ao fator economia é possível rescindir o paradigma neoclássico de desenvolvimento, onde os fatores alinhados para o crescimento econômico eram o centralizador das ações e assim revelar a discrepância entre suas distinções.

Portanto, ao se adotar a construção deste novo conceito é fundamental entender que o

Crescimento é uma parte indispensável, mas insuficiente, do desenvolvimento. As formulações do desenvolvimento realçam o fato de que, apesar das aparências de certa complementaridade, existem contradições profundas entre essas duas concepções. (CAZELLA, 2011, p. 16).

Contextualmente, dentre os fatores priorizados neste novo modelo de políticas públicas destaca-se o pleito energético, contudo há de se destacar que, mesmo com uma estrutura de geração consolidada, baseada em Usinas Hidrelétricas - UHE de alto porte, o acesso a energia no Brasil ainda é muito discrepante e sua geração além de apresentar altíssimos impactos ambientais, não consegue atingir beneficamente a população do entorno dos empreendimentos, ou seja, a maior parte de seu produto é direcionada à indústria de transformação que serve para mobilidade e desenvolvimento do eixo unicamente econômico.

O reflexo destas políticas públicas expansivas em termos nominais e relativos, sobre o território brasileiro segundo o $\operatorname{MME}$ (2007, p. 13), esteve concentrado "no início da década dos 80, quando o 
mundo sofria as consequências dos choques no preço do petróleo ocorridos na década anterior e se instalavam no país, grandes indústrias eletro-intensivas".

A partir desta evolução, já no século XXI, o Brasil tornou-se a terceira maior potência hidrelétrica mundial, atrás somente da Rússia e do Chile. Pouco mais de $60 \%$ de sua produção energética é sustentada por Usinas Hidrelétricas - UHE que alimentam mais de 190 milhões de brasileiros, apresentando um total de 1.309 empreendimentos em operação, totalizando 157.236,758 MW de potência instalada (ANEEL, 2017).

Esta evolução desvelou-se sobre o jargão do significativo potencial hídrico disposto sobre o país, concentrado principalmente na região Amazônica, que detém 70\% do potencial hidrelétrico brasileiro (ANEEL, 2017).

Contudo, trouxe também expressivos impactos socioambientais, ás regiões eleitas para receber estes empreendimentos, caso do Estado do Pará, que impetrou predicados como a perda de fauna e flora locais, o alagamento de sítios arqueológicos e áreas de comunidades tradicionais, perda da identidade local e o desenvolvimento apoiado ainda em seu conceito neoclássico, onde o fator econômico deve prevalecer ante a questão socioambiental.

Esta crescente formatação do eixo comercial vai de encontro aos processos de construção conceitual do Desenvolvimento Sustentável ${ }^{1}$, pois alijam as populações diretamente envolvidas no processo e suas relações sociais, políticas e ambientais, dos novos cenários que impulsivamente vão se formando no entorno da teoria centro-periferia.

Ainda, segundo Becker (2010a), estes cometimentos são os grandes responsáveis pela condução dos fluxos populacionais e estabelecimento dos centros econômicos de produção, pois geopoliticamente são capazes de definir o macrozoneamento regional a partir da injeção de capital público e privado, com vistas à manutenção do padrão linear advindo da década de 70, fruto da formação de eixos de transporte e infraestrutura industrial, que conformam terras indígenas, Unidades de Conservação UC, além de populações extrativistas e ribeirinhas.

Desta forma, trabalhar a graduação dos fatores socioambientais aos econômicos, agrupando-os a partir de uma metodologia que possa auxiliar a mudança paradigmática junto á construção geopolítica ${ }^{2}$ nas escalas nacional, regional e local é imprescindível à construção de políticas públicas que possam de fato apresentar um grau satisfatório de eficiência e amplitude. 
É neste contexto que emerge a metodologia DPSIR (Driving Forces, Pressures, State, Impact e Response). A justificativa para utilização desta ferramenta encontra-se debruçada sobre sua capacidade em avaliar e levantar multicritérios dos indicadores socioambientais e econômicos, o que pode permitir a integração de forma simples e expansiva das diversas ações e suas respostas frente a empreendimentos e atividades antrópicas.

Ainda, dentre as diferentes potencialidades desta ferramenta, é possível destacar sua capacidade de considerar que toda atividade humana provoca uma tensão sobre o meio ambiente, produzindo respostas que se debruçam sobre o estado de um recurso e o modificam provocando impactos de diversas ordens socioambientais e econômicas, estas ações antrópicas permitem respostas junto aos diversos fatores e grupos sociais direta e indiretamente afetados (LIRA e CÂNDIDO, 2008).

Assim, segundo KEMERICH (2014, p. 3729), "este modelo tem por objetivo fornecer informação sobre os diferentes elementos da cadeia DPSIR, demonstrar a sua interligação e avaliar a eficácia das respostas de forma integrada".

Á título conclusivo desta introdução conceitual cabe destacar o potencial explorativo quando se alia a metodologia DPSIR à base de formação geopolítica regional do Estado do Pará. Desta forma, as questões que irão emergir deste processo servirão para compor uma base de dados, capaz de ponderar a evolução dos impactos socioeconômicos e ambientais das Usinas Hidrelétricas - UHEs sobre a região, que posteriormente poderão ser utilizadas para o estabelecimento de seus pontos fortes e as possibilidades de melhoria, no que se refere à construção de políticas públicas de cunho sustentável para o território em questão.

\section{GEOPOLITICA AMAZÔNICA}

As redes de influência, aqui tratadas a partir do conceito de geopolítica, se formam nos países ditos desenvolvidos, os quais possuem e mantém uma ampla possibilidade de investimento econômico, técnico e científico em territórios potencialmente capazes de prover qualquer tipo de estrutura comercial a estes centros de poder. Com isso, são capazes de expandir suas convicções e determinar as configurações socioeconômicas e ambientais, locais e regionais, criando um ambiente propício à mercantilização da relação homem-natureza (BECKER, 2005).

Assim, esta distinção entre nações, a partir do conceito centro-periferia, encontra espaço justamente na complexidade dos planos de desenvolvimento, que pregam a evolução cientifica e tecnológica dos países centro, enquanto os periféricos devem manter o conceito conservacionista de seus recursos 
socioambientais, tudo isto realizado sobre o bojo da pressão geopolítica, que designa modelos de territorialização, ou seja, formas de organização e reorganização social dentro do espaço geográfico regional e local (BECKER, 2010a).

Ainda segundo a mesma autora, um grande exemplo deste modelo geopolítico regional sobrepõe-se junto a Amazônia brasileira, que após abertura econômica ao capital estrangeiro ainda na década de 50 pelos governos militares e seus projetos de integração territorial, está fadada a carregar o peso do processo de implantação de distritos industriais e exploração mineral em detrimento do modelo econômico histórico baseado no extrativismo e valorização dos recursos naturais. Uma inversão de acuidade, antes relacionada à analogia homem-natureza e que hoje procura valorar os recursos ambientais e tratá-los como fonte infinita de capital circulante.

Ao se analisar a geopolítica local, é possível perceber que os planos de gerenciamento territorial com vistas ao crescimento regional e desenvolvimento econômico amazônico, instituídos em 1950 e sustentados até a presente década, não foram capazes de provar sua eficiência, pois em grande parte a base local de arrecadação dos municípios nunca proveram uma estruturação digna junto aos setores de saúde, educação e saneamento básico á população, fato este que vai de encontro aos objetivos especificados à implantação e desenvolvimento dos projetos de autonomia regional e local (BECKER, 2000).

Com isso, os pólos mínero-metalúrgicos e hidrelétricos na Amazônia, aqui também identificados como grandes empreendimentos, são vistos como os potenciais subsidiários do processo de desenvolvimento regional e os detentores da aceleração econômica local.

Portanto, são tratados como sendo os únicos capazes de tangenciar e/ou agregar fatores de mudanças econômicas na base tecnológica e de capital humano, mesmo que para isso os impactos socioambientais advindos de suas atividades sejam imensuráveis e as perdas referentes à sociobiodiversidade decorrentes destes empreendimentos não sejam absorvidos por quaisquer tipos de programas de mitigação.

Portanto, um ponto crucial deve ser levado em consideração quando se trata da busca pela independência política e econômica entre união e municípios da região amazônica, já que historicamente, 
Os municípios não correspondem a uma força motriz em termos econômicofinanceiros, mas certamente correspondem a uma força política, na medida em que expressam o pacto entre novos pontos de poder local e as instâncias superiores da ordem federativa. Em outras palavras, têm de se tornar parceiros políticos, levando em conta a participação municipal na tomada e execução da decisão. (BECKER, 2010a, p. 59).

Levando em consideração este apanhado conceitual e histórico, há se definir que há uma interposição da importância de se estudar a geopolítica regional e local na Amazônia, assim como suas funções, já que as ações paternalistas do Estado durante décadas de formação territorial conseguiram delinear as relações sociais, econômicas e políticas, exercendo assim uma forte influência na organização do espaço, a partir do engendramento das novas dinâmicas territoriais.

Desta forma, segundo Programa das Nações Unidas para o Meio Ambiente - PNUMA (2008, p. 287),

A situação atual do ecossistema amazônico pode ser explicada pelo conjunto de forças motrizes que atuam na região, orientando a sua ocupação e o uso de seus recursos, tais como questões sociodemográficas, econômicas e políticoinstitucionais.

Cabe ainda ressaltar que a geopolítica atual representa a relação entre poder e espaço geográfico mundial, regional e local. No que concerne à Amazônia, a ineficiência dos projetos econômicos de desenvolvimento regional abandonara a ideia inicial e atualmente permeiam pelo fator de ocupação de cunho estritamente político, onde o uso do território tornou-se o ponto central nas discussões sobre os projetos de desenvolvimento propostos (BECKER, 2005).

Segundo Cardoso e Müller (2008, p. 1),

A penetração geográfica na Amazônia e a história da região devem ser vistas, portanto, relacionadas ao processo de expansão do capitalismo, em função da forma, ritmo e volume da acumulação ocorrida nas demais regiões brasileiras. Como, entretanto, o capital nada mais é do que uma relação social, a expansão do capitalismo na Amazônia depende da forma concreta que aquela relação social assume. Para sua análise são relevantes tanto o pioneirismo típico da Amazônia - a rudeza - da relação direta terra/homem e a violência da relação entre os homens - como o contexto político em que ocorre a ocupação da área.

Para Becker (2005), estes projetos de globalização da economia estão alicerçados na circulação das riquezas via fortalecimento dos territórios ditos periféricos, aqui tidos como os menos favorecidos em termos de detenção tecnológica regional, ou seja, esta posse econômica e consequentemente política, seria uma forma de manutenção da hegemonia territorial das nações investidoras sobre os territórios fragilizados.

São inegáveis as pressões que as mudanças provocadas por estes projetos exercem sobre a região, um fator latente a este processo e que pode ser tomado como exemplo, reporta-se a mudança de padrão 
no deslocamento das populações, que antes se formavam próximas aos canais fluviais e com o processo de urbanização e intervenção estatal em proposição a integração nacional das regiões, tomaram a abertura das estradas como oportunidade de dilatação de suas relações econômicas (BECKER, 2005).

Estes grandes empreendimentos na Amazônia consistem em um conjunto de investimentos que tem como objetivo a criação de um pólo de desenvolvimento baseado na agricultura empresarial e mineração em grande escala voltada à exportação, a fim de gerar saldos comerciais. Estes foram e são, suportados por bilhões de dólares de investimento, principalmente no que concerne à infraestrutura, onde encontramos as usinas hidrelétricas como sustentáculo da manutenção da viabilidade econômica destes projetos frente ao mercado internacional (Kitamura, 1994).

De tal modo,

\begin{abstract}
A fase recente de desenvolvimento da Amazônia, inaugurada nos anos oitenta, conjuga esforços voltados à mineração (colocada como o centro do desenvolvimento regional, à agroindústria e à reforma agrária. Nessa fase, foram implementados, entre outros, o Programa Grande Carajás (1980), o POLONOROESTE (1981) e o Projeto Calha Norte (PCN), em 1985, com objetivos de estabelecer uma presença militar permanente na área fronteiriça. Mas sem dúvida, é com o Programa Grande Carajás (PGC), baseado no tripé energiamineração-siderurgia, voltado essencialmente para o mercado externo, que aparece de forma clara a orientação no sentido de exploração mineral na Amazônia. (Kitamura, 1994, p. 39).
\end{abstract}

Á título conclusivo e com a intenção de qualificar a discussão acerca dos planos de desenvolvimento na Amazônia, cabe ainda agregar o argumento conceitual sobre territorialidade, onde, segundo Becker (2010b), Estado e capital apesar de estarem subitamente enraizados na semente progressista, não são entidades e sim relações, que se desenham dentro do arranjo institucional e determinam os diferentes atores e papéis, em busca da hegemonia mundial. Esta posse física se dá principalmente pela detenção dos meios de produção, assim,

A macrofísica do poder - o Estado, a corporação multinacional, a ordem militar - dominou os processos da escala global, planetária, e não atua apenas nela, mas em todos os outros níveis, não podendo, por esse motivo, ser isolada de processos ocorrentes nas demais escalas. (BECKER, 2010b, p. 20).

Ressaltar a metodologia de desenvolvimento regional implantada por anos é fundamental e categórico para o conhecimento das bases estruturais regionais explanadas por este trabalho, pois desvela os atores e seus papéis frente à composição dogmática progressista, encarada por décadas como a oportunidade de planificação dos ensejos socioeconômicos e ambientais na Amazônia. 


\subsection{O ESTADO DO PARÁ}

Segundo o IBGE (2017), o Pará possui 1.247.955,238 km² de área de unidade territorial, o equivalente a 14,66\% do território nacional, detendo com isso o título de 2 ㅇ maior estado do Brasil em extensão territorial, perdendo apenas para seu vizinho fronteiriço, o estado do Amazonas, com 1.559.146,876 $\mathrm{km}^{2}$.

Abriga uma população referenciada no ano de 2016 e estimada para o ano de 2017 em torno de 8.366.628, dos quais aproximadamente 5.668 .907 ou $68 \%$ estão residindo nos centros urbanos, enquanto que os outros $32 \%$ que somam 2.697.721, encontram-se na zona rural. Apresentando assim, uma densidade demográfica de 6,07 hab/ $\mathrm{km}^{2}$, ocupando, portanto, o 9o lugar no ranking dos estados brasileiros, no que concerne o índice "território e ambiente" determinado pelo IBGE (2017).

Ainda, segundo o mesmo instituto, o estado apresenta rendimento nominal mensal domiciliar per capita em torno de $\mathrm{R} \$ 708,00$ e conta com $32 \%$ de sua população de pessoas de 16 anos ou mais em postos de trabalho formal, fatores estes que quando comparados aos outros estados da federação, abanca o Pará na antepenúltima posição (25ㅇ) do ranking de trabalho e rendimento no país. Estes valores remetem a um Índice de Desenvolvimento Humano - IDH de 0,646, o que leva o estado a ocupar o 24임 lugar no ranking econômico frente aos outros 27 estados brasileiros.

Sociopoliticamente, ao se traçar uma linha histórica entre os séculos XVII e XX, já é possível perceber a atuação das grandes nações do cenário econômico no Pará tais como, Inglaterra, Holanda, França e Alemanha, que se dissimulam em instituições bancárias a fim de expandir suas fronteiras econômicas, políticas e geográficas. Para tanto, utilizam-se da capacidade de ater títulos do patrimônio estatal, impetrados através do financiamento infraestrutural produtivo das regiões ditas subdesenvolvidas, assumindo, a partir de então, o controle produtivo e geopolítico.

Um fator importantíssimo se deu por volta de 1920, o conhecido ciclo da borracha, aportado como essencial à abertura econômica do estado e sua integração ao mercado internacional, foi capaz de criar uma espécie de rede urbana dendrítica ${ }^{3}$. Assim, a capital do estado - Belém, exerceu o papel central na socioeconomia local, responsável por prover infraestrutura às cidades do entorno, as quais eram responsáveis pela coleta da matéria bruta (IDESP, 2011).

Ainda, segundo IDESP (2011), após este período, foi observado certa estagnação econômica, a partir da depauperação de seu ciclo econômico baseado no extrativismo, iniciando com isso a intervenção 
do Estado, por meio da criação de órgãos públicos capazes de manter a rotatividade da economia, como por exemplo, a Superintendência do Plano de Valorização Econômica da Amazônia - SPVEA.

Aliado a este processo houveram também intervenções pontuais para o planejamento regional, caso do processo de interligação territorial a partir da fissura espacial norte-sul com a constituição, no início dos anos 60, da estrada Belém - Brasília, que de forma geral, não passou da composição de uma nova versão da marcha para o oeste, realizada em 1938.

Em meados do século XX, na tentativa de recompor economicamente o estado do Pará, houve uma fase de intervenção federal, que se pautou, na agregação de um centro produtivo e industrial, capaz de aditar valores aos bens primários ali produzidos. Onde o potencial exclusivamente econômico mais uma vez entrou em cena como ponto essencial na estruturação do arranjo produtivo territorial, derrubando a tentativa de construção dos conceitos sobre um enfoque diferenciado, que pudesse depositar o desenvolvimento humano local como centro do processo (CASTRO e ROCHA, 2014).

Com este propósito funda-se um novo itinerário para o desenvolvimento regional paraense, a fim de incorporar definitivamente estas novas terras ao modelo econômico do centro-sul do país, dentro de um projeto de modernização de seus fatores produtivos e mobilidade das fronteiras, capazes de suprir a demanda de produtos agrícolas tanto para o mercado interno, quanto para o externo (CASTRO e CAMPOS, 2015).

Assim, as relações socioeconômicas se abonaram pela busca de integração dos atores frente aos novos processos produtivos, que se organizaram a fim de incrementar sua produção e consequentemente acompanhar a mobilidade das fronteiras agrícolas produtivas, com vistas ao atendimento do mercado externo, salvo-conduto as potencialidades regionais e o que se construiu de políticas públicas no decorrer da história de ocupação e formação territorial do estado (CASTRO, 2007).

Ainda, segundo Castro (1998), esta mudança paradigmática no modelo de relacionamento sociopolítico regional, produz e instala uma diversidade enorme de interesses que divergem da realidade, formando pontos de desequilíbrio irreparáveis sobre os direitos dos povos tradicionais, obtendo como reflexos as diferenciações internas e as perdas identitárias.

Portanto, o que se pode predizer é que as maiores dificuldades continuam, ainda, sendo os planos de gerenciamento socioeconômico e ambiental da região, que não conseguem prever os verdadeiros impactos e suas devidas densidades. Competindo aos governos criar dispositivos que possam aliar as demandas regionais ás diversas identidades ali presentes, no intuito de compreender os atores e seus 
diversos elos regionais, levando em consideração a formação social, política e econômica (CASTRO, 2012).

Um panorama muito ligado a esta política de verticalização econômica da região, está expresso pelos complexos hidrelétricos, que como dito anteriormente, servem ao fluxo energético da indústria de transformação primária do minério de ferro, extraído das diversas jazidas que cortam o estado e que são exportados aos países do continente Norte Americano, Europeu e Asiático.

\subsection{USINAS HIDRELÉTRICAS NO ESTADO DO PARÁ}

Segundo ANEEL - Agência Nacional de Energia Elétrica (2017), o Brasil possui um total de 4.722 empreendimentos geradores de eletricidade em operação, representando 154.112,693 MW de potência instalada. Está prevista para os próximos anos uma adição de 23.618,619 MW na capacidade de geração do País, proveniente dos 258 empreendimentos atualmente em construção e mais 555 MW em empreendimentos com construção não iniciada.

Em levantamento realizado pelo Operador Nacional do Sistema Elétrico - ONS (2017), foi constatado que o Brasil mantém capacidade produtiva via Usinas Hidrelétricas - UHEs, em torno de 101.598 MW de energia, este modelo de geração é responsável por $71,2 \%$ da produção total do país.

Ao tomarmos a capacidade de geração hidrelétrica instalada em operação por Unidade da Federação - UF e por rios, no ano de 2017, disposta pela ANEEL (2017) e isolarmos as usinas genuinamente brasileiras, encontramos as duas maiores aparelhadas sobre a bacia hidrográfica Tocantins-Araguaia, das quais se apresentam então a Usina de Belo Monte, a qual está instalada no Rio Xingu, precisamente no município de Vitória do Xingu - PA e possui capacidade geradora de $11.233 \mathrm{MW}$, além da UHE Tucuruí, que está edificada no rio Tocantins, tendo como sede o município de Tucuruí $\mathrm{PA}$, com uma estrutura capaz de gerar $8.535 \mathrm{MW}$.

Contudo, a operação e manutenção destes empreendimentos perpassam pela ocupação territorial de áreas que possuem características distintas e intrínsecas, as quais passam a existir sob a lógica destes cometimentos, com mudanças drásticas no que concerne a socioeconomia e ao meio ambiente. Parte daí então, a necessidade de exploração dos fatores geopolíticos formadores do processo de internalização progressista no estado do Pará, que há décadas deposita sobre as usinas hidrelétricas a possibilidade da industrialização regional globalizada. 
Como exemplo, podemos citar a UHE Tucuruí, que no intuito de manter a viabilidade econômica do empreendimento, seu projeto foi redimensionado várias vezes, levando em consideração os levantamentos de campo que à época foram subestimados.

Entre os fatores corrigidos ressalta-se a área de alagamento para criação do reservatório, que inicialmente estava prevista em $1.630 \mathrm{~km}^{2}$ e ao final apresentou $2.850 \mathrm{~km}^{2}$ de área inundada. Consequentemente, isto recaiu sobre a área de desmatamento que estava prevista em 43.000 ha e passou para 120.000 ha, aumento de mais de $250 \%$. Porém, deste valor foram viabilizadas somente 14.000 ha, pouco mais de $11 \%$, emergindo assim 2,5 milhões de $\mathrm{m}^{3}$ de madeira aproveitável (CMB, 2000). Segundo a Eletrobras/Eletronorte (2015), atualmente, o lago da UHE Tucuruí abrange 3.008,14 $\mathrm{km}^{2}$.

Também são destacados como fatores socioambientais diretos devidos à implantação da usina, mudanças significativas sobre a lâmina d'água disponível tanto à jusante, quanto a montante do barramento, aliados aos baixos níveis de colmatagem da matéria orgânica, que antes era proporcionada pelo movimento de enchente e vazante do rio e que influencia diretamente sobre o ciclo de fertilização e regeneração das florestas. Estes fatores negativos recaíram sobre uma enorme população no entorno do empreendimento, que viviam tanto da pesca e agropecuária, quanto da extração vegetal, causando mudanças expressivas no que concerne ao seu processo produtivo (CASTRO, 2015).

Portanto, mesmo após serem tomadas medidas mitigadoras junto área de influência, quando tomado o Índice de Vulnerabilidade Social - IVS ${ }^{4}$ determinado pelo Instituto de Pesquisa Econômica Aplicada - IPEA (2010), o qual mantém uma escala de zero a um, onde quanto maior o indicador maior a vulnerabilidade social, é possível retratar que os municípios diretamente afetados pela UHE Tucuruí e hoje atendidos pelas ações de mitigação - Breu Branco, Goianésia do Pará, Itupiranga, Jacundá, Nova Ipixuna, Novo Repartimento e Tucuruí - quase em sua totalidade, representam a realidade da região Amazônica do país, com um valor médio de 0,501, considerado muito alto na escala. Destoando apenas o município de Tucuruí, sede do empreendimento que apresenta o IVS em um patamar considerado médio $(0,3-0,4)$.

Logo, pode-se concluir que as justificativas para implantação de empreendimentos tão polêmicos, estavam dispostas sobre o papel que o projeto cumpriria, pois, segundo a cadeia empreendedora aqui aparelhada os agentes públicos e privados - este seria capaz de fornecer infraestrutura para o fortalecimento econômico, com alicerces na industrialização e consequente criação de postos de 
trabalho, permitindo a inserção da região no cenário mundial, combatendo com isso, os baixos índices de desenvolvimento humano das cidades do entorno das UHEs.

Entretanto, o que se abateu sobre a região foi uma famigerada corrida em busca da implantação de um modelo de desenvolvimento exclusivamente econômico e que estaria indo de encontro ao processo de formatação original da socioeconomia local e suas estratégias de extração de recursos naturais e produção agropecuária.

Assim, o que se presenciou foi uma migração desordenada, imbuída em um território desprovido de qualquer capacidade infraestrutural de alocação de pessoas, impactando diretamente sobre o inchaço populacional, êxodo rural, além do descontrole sobre a condução do projeto, aqui representado pelos vários momentos de correção da área de inundação, os quais implicaram em altos índices de desmatamento e perda territorial por parte das comunidades do entorno do empreendimento.

Ainda, cabe ressaltar as factíveis mudanças culturais sobre o processo produtivo regional, forçado pela exaustão de recursos naturais, antes tidos como a base da sobrevivência das populações tradicionais, que se encontravam assentadas sobre a região, conforme mostrado por Castro (2015).

\section{METODOLOGIA DPSIR}

Ao empregar a metodologia DPSIR neste trabalho, pretende-se gerar o cenário onde foram construídas as estratégias de desenvolvimento regional do estado do Pará e suas forças motrizes, já que este enquadramento possui um histórico moderado pela abrangência integrada dos fatores socioeconômicos e ambientais, exibindo com isso, as pressões advindas das ações antrópicas junto aos territórios.

Esta metodologia foi elencada, pois segundo Soares et al., (2011), a partir dela é possível dispor de um modelo de avaliação integrada dos fatores socioeconômicos e ambientais de uma atividade, já que engloba em seu desdobramento, de forma genérica, o reflexo dos empreendimentos, seus possíveis impactos e as respostas junto às pressões exercidas.

Para Fernandes e Barbosa (2011), os elementos postos na metodologia DPSIR podem ser descritos como Driving force (Força motriz) - D, na qual estariam contidas as influências humanas advindas de suas atividades diárias; Pressures (Pressão) - P, uma variável resultante das causas diretas dos projetos, sejam estes fatores positivos ou negativos; State (Estado) - S, que permite o conhecimento da condição inicial do ambiente; Impact (Impacto) - I, o qual descreve os efeitos da mudança de estado 
do ambiente; e por fim, Response (Resposta) - $R$, as quais são as diligências a fim de contornar os impactos diretos e indiretos advindos da atividade.

Portanto, segundo Kristensen (2004), ao abordar amplamente as várias fases do processo, o enquadramento DPSIR (Driving forces, Pressures, State, Impact e Response) é capaz de apresentar os indicadores necessários à avaliação dos resultados das políticas públicas, quanto à qualidade e o impacto resultante das escolhas feitas ou a serem feitas, pois

Dispõe uma cadeia de relações causais que principiam com as Forças motrizes (setores econômicos ou atividades humanas), as quais impõem Pressões (emissões ou resíduos) sobre um determinado Estado inicial, causando Impactos socioambientais (física, química e biológica), levando às Respostas na forma de políticas (fixação de metas e indicadores), descrevendo assim a cadeia causal da direção de forças. (KRISTENSEN, 2004, p. 1).

A fim de qualificar cada fator determinado pelo modelo DPSIR a European Environment Agency - EEA ${ }^{5}$ (1999) procurou mostrar a interligação destes fatores aqui colocados. Para isso, determinou que a Força motriz - D estaria ligada as causas mais diretas e relevantes para implantação da atividade produtiva, a qual pode estar relacionada a diferentes setores, dentre os quais a indústria, agricultura e produção energética.

Ao se abordar as forças motrizes podem-se melhor visualizá-las adotando uma subdivisão, onde as quais estariam dispostas em primárias e secundárias, assim, como exemplo é possível discorrer que,

Para um indivíduo, forças motrizes primárias são a necessidade para o abrigo, comida e água, enquanto que forças motrizes secundárias estão baseadas na necessidade de mobilidade, entretenimento e cultura. De modo geral, para um setor industrial, uma força motriz poderia ser o esforço desprendido pela administração para torná-la rentável e produzir a baixo custo. (KRISTENSEN, 2004, p. 2).

Em se tratando do coeficiente Pressão - $P$, este se encontra conceituado em sua predisposição para elencar as cargas negativas advindas dos fatores de produção da estrutura, levando em consideração que toda atividade humana exerce pressão sobre os fatores socioambientais. Neste item podem ser deparadas as emissões de gases, as perdas de fauna, de flora e suas derivações (EEA, 1999).

Além disso, segundo Kristensen (2004, p. 2), dentre os coeficientes configurados no processo de produção e consumo pode-se encontrar ainda o "uso excessivo de recursos ambientais, mudanças na utilização do solo, emissões de agentes químicos, resíduos, radiações e ruídos desprendidos sobre o ar, a água e o solo". 
Já o fator Estado - S, representa os elementos físicos, químicos e biológicos da região de influência do empreendimento, as quais levam em consideração toda a formação inicial do ecossistema e da socioeconomia local, com isso, são capazes de descrever a quantidade e qualidade física inicial de fenômenos como a temperatura, os estoques de peixes e as concentrações de gases atmosféricos em uma determinada área (SMEET e WETERINGS, 1999).

Qualquer deformação de um desses compartimentos pode afetar suas qualidades e o consequente estado do ambiente. Portanto,

O estado é a combinação das características físicas, químicas e biológicas do
ambiente, representados pela qualidade do ar (nacional, regional, local,
urbano, etc.), qualidade da água (rios, lagos, mares, zonas costeiras, águas
subterrâneas), ecossistemas (biodiversidade, vegetação, organismos do solo,
organismos aquáticos) e saúde humana, dentre outros. (KRISTENSEN, 2004, p.
3).

O fator Impacto - I está ligado às alterações do estado de um ambiente, proporcionados pela pressão imposta por uma determinada atividade humana sobre o desenvolvimento socioambiental e econômico de uma sociedade. Podem ainda se apresentar sequenciados como primários, secundários e terciários (SMEET e WETERINGS, 1999).

É primordial discorrer que este fator deve levar em consideração as mudanças locais e regionais da área de influência do empreendimento. Há necessidade também, que seja apresentado como uma resposta do indicador, o qual está diretamente relacionado à mitigação dos fatores adversos e como estes se comportam frente aos custos de manutenção dos programas e a repercussão econômica da atividade (EEA, 1999).

Logo,

Mudanças no estado podem ocasionar impactos ambientais ou econômicos sobre o funcionamento dos ecossistemas, e, em última instância, na saúde humana e no desenvolvimento econômico e desempenho da sociedade. (KRISTENSEN, 2004, p. 4).

Por conseguinte, e fechando o encadeamento DPSIR, o indicador Resposta - R, segundo a EEA (1999), compromete-se a medir as políticas macroeconômicas relacionadas às ações antrópicas locais, junto às medidas específicas do setor produtivo relacionado à atividade. Isto irá recair diretamente sobre seus impactos e as políticas voltadas à conservação do meio ambiente e valores socioeconômicos das comunidades do entorno. 
Estas respostas podem estar contidas em qualquer parte desta cadeia, que vão desde a Força motriz até os Impactos e devem abrolhar tanto do meio social e suas representações, quanto de quem toma a decisão sobre os possíveis empreendimentos e sua alocação sobre determinadas áreas, ou seja, sobre todos os grupos envolvidos direta e indiretamente na formulação e implementação das políticas públicas (KRISTENSEN, 2004).

Ainda segundo o mesmo autor, como exemplo de uma Resposta - $R$ ligada às Forças motrizes - $D$, seria uma decisão na mudança no sistema de transporte de uma determinada região, que deixaria de utilizar os automóveis particulares e passaria a priorizar o sistema coletivo. Assim como a regulamentação a níveis aceitáveis de emissão de gases advindos da combustão e nocivos ao meio ambiente, pode ser um exemplo de uma Resposta - $R$ relacionada com Pressões - $P$.

Em continuidade, Azevedo et al., (2013) corrobora com a importância da metodologia DPSIR, quando em seu estudo, determina que a mesma é capaz de promover uma conexão causa-consequência entre as atividades antropogênicas e o ambiente, além de se apresentar como um processo descritivo simples, organizando os procedimentos envolvidos em determinada atividade de produção e/ou consumo, as quais derivam em determinadas pressões sobre o ambiente que por sua vez, resultam em um estado e está diretamente ligado ao grau de qualidade ambiental, refletida em aspectos físicos, biológicos e químicos.

Segundo Song e Frostell (2012, p. 673), no enquadramento DPSIR

O desenvolvimento socioeconômico e as forças socioculturais funcionam como Motores (D) de atividades humanas que aumentam as Pressões (P) no meio ambiente. As pressões ambientais mudariam assim a Estado do meio ambiente (S) e resultam em Impactos (I) na saúde humana, nos ecossistemas e na economia. Isso pode levar a Respostas sociais (R) aos motores, pressões, estado de ambiente ou impacto através de várias medidas de mitigação, prevenção ou adaptação em relação aos problemas ambientais identificados.

Portanto, quando de sua utilização, é fato apresentar que esta metodologia debruça suas potencialidades no que concerne a

Grande flexibilidade de aplicação, podendo ser usada na escolha de medidas de resolução de um conjunto alargado de situações, como a recuperação do estado de massas de água superficiais ou subterrâneas, proteção de ecossistemas, gestão dos recursos hídricos, regularização de cursos de água, ou outras. (NOVO e OLIVEIRA, 2013, p. 848). 
Soares et al. (2011, p. 522), utilizaram a metodologia a fim de melhorar o "processo de tomada de decisão da gestão de comitês de gerenciamento de bacias hidrográficas", a qual foi capaz de auxiliar desde o levantamento das informações, até a fase de formulação e escolha de decisão multicritérios, assim, o modelo conseguiu

Estruturar, de maneira coerente, como as forças motrizes, pressões e estado estão distribuídos (espacial e temporalmente) como variáveis das bacias hidrográficas. Estas variáveis foram relevantes para o processo decisório, advindas dos resultados de modelos hidrológicos ou de outras fontes. (SOARES et al., 2011, p. 540).

Na figura 1, está colocada a visão da EEA (2007) segundo a qual, DPSIR seria uma representação da análise de sistemas, dos quais os desenvolvimentos sociais e econômicos exercem pressão sobre o meio ambiente e, como consequência, o estado do ambiente muda. Isto leva impactos sobre, por exemplo, a saúde humana, os ecossistemas e os materiais que podem provocar uma resposta social, a qual alimenta as forças motrizes, as pressões, o estado, ou os impactos, diretamente, através da adaptação ou ação mitigadora do processo produtivo.

Figura 1 - Representação esquemática da estrutura DPSIR e suas inter-relações.

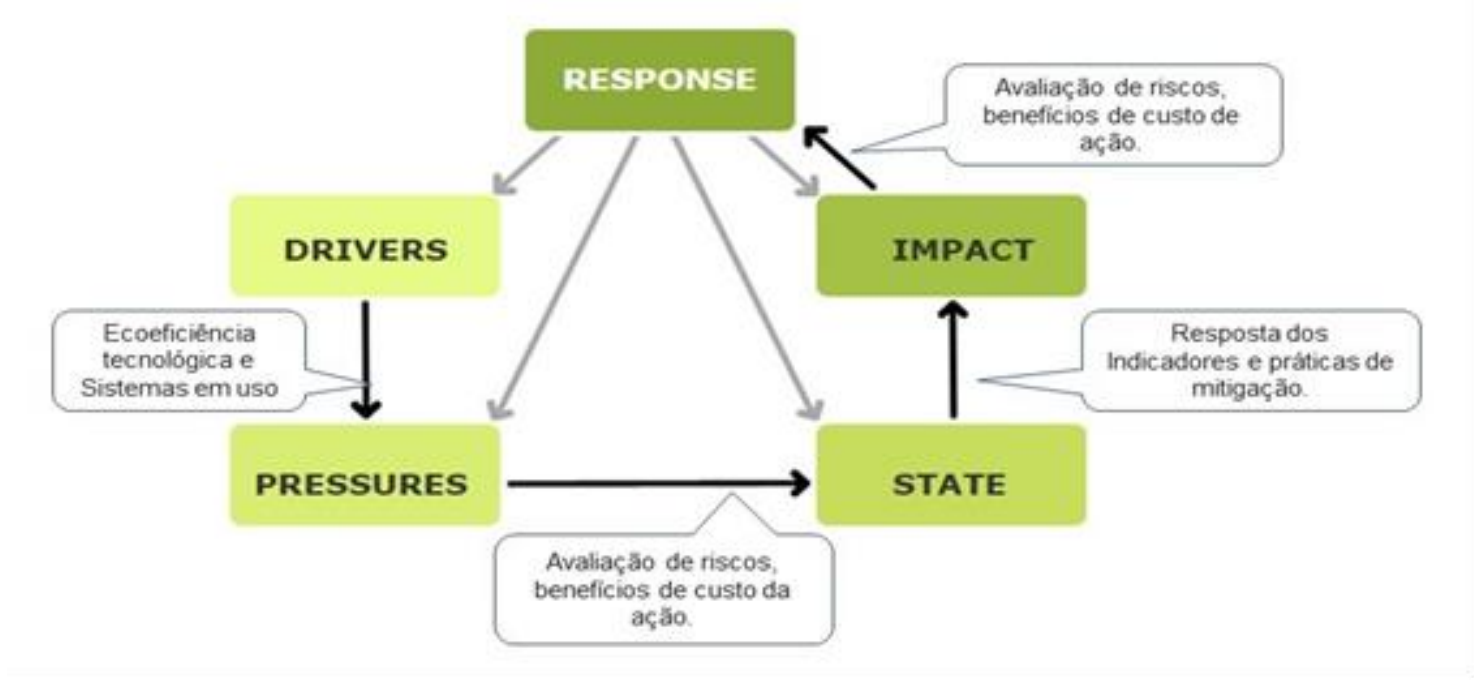

Fonte: EEA (2007).

Adaptado pelo autor.

\section{CONCLUSÕES}

O processo de implantação das Usinas Hidrelétricas - UHEs no estado do Pará, historicamente foi sustentado pelo processo de construção geopolítica e o conceito determinístico das regiões centroperiferia, onde a industrialização seria o vetor do desenvolvimento socioambiental. 
Entretanto, em um território formado por uma abissal diversidade social e ambiental, o processo de intervenção estatal baseado na unicidade dos projetos de desenvolvimento econômico foi categórico para o insucesso das investidas, inclusive teve seu papel fundamentado sobre o desmonte das características de produção agropecuária e extrativista regionais.

Portanto, o que se propõe é a utilização de uma metodologia capaz de tratar holisticamente os fatores socioambientais e econômicos, equalizando-os, de forma a influenciar sobre a construção das políticas públicas de desenvolvimento regional.

A metodologia DPSIR é capaz de agregar fatores socioeconômicos e ambientais, no intuito de qualificar a eficiência das políticas de desenvolvimento regional e o papel dos programas de mitigação dos empreendimentos hidrelétricos no Estado do Pará, levantando seus gargalos e reais possibilidades produtivas e mercadológicas.

Por estar constantemente em atividade a metodologia é capaz de agir sobre a mudança paradigmática da ciência unilateral, pois quando agrega e estuda de forma integrada os fatores sociais, econômicos e ecológicos, promove uma conexão entre os níveis de modernização, também tratados como consequências do desenvolvimento e a manutenção das características socioambientais de uma região.

Assim, é factível prescrever a metodologia DPSIR como ferramenta de acesso dos limites socioambientais e econômicos do Pará, para tanto, propõe-se na figura 2 os possíveis elementos para levantamento de indicadores da atividade hidrelétrica no estado.

Figura 2 - Indicadores passíveis para determinação DPSIR.

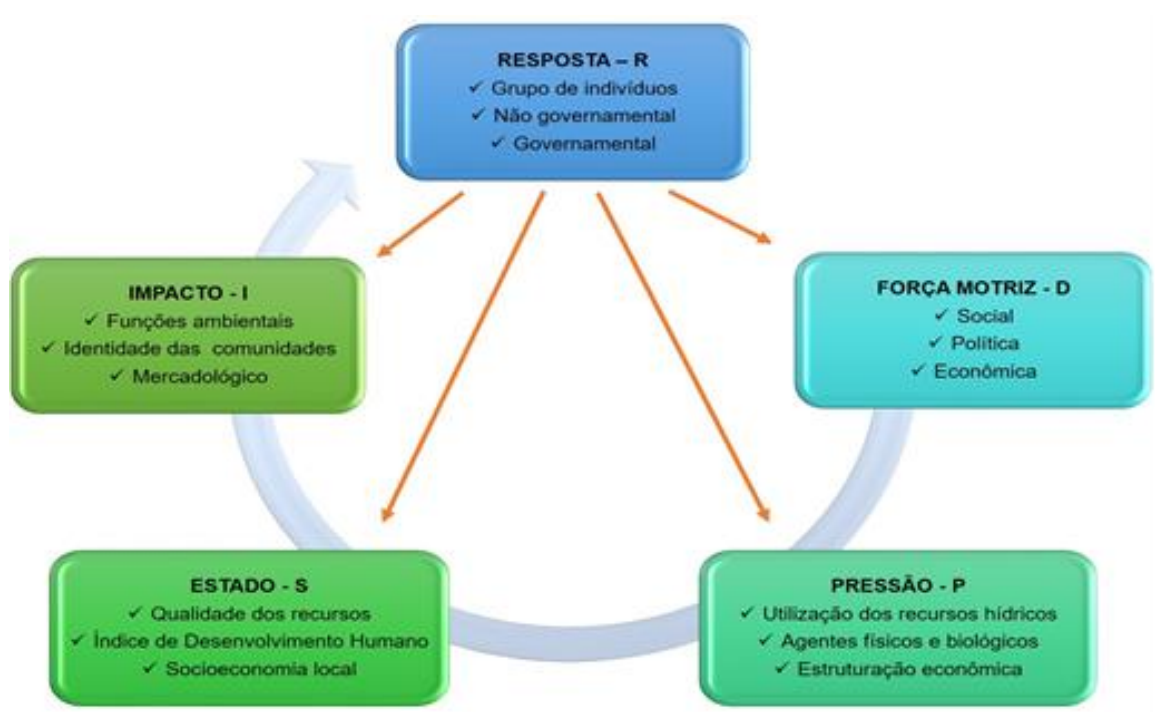

Fonte: Autor. 


\section{BIBLIOGRAFIA}

ANEEL - Agência Nacional de Energia Elétrica. Banco de Informações de Geração - BIG. Disponível em http://www.aneel.gov.br. Acessado em 27.09.2017.

AZEVEDO, A.; SOUSA, A. I.; LENCART E. S.; DIAS, J. M.; LILLEBO, A. I. Application of the generic DPSIR framework to seagrass communities of Ria de Aveiro: a better understanding of this coastal lagoon. In: Conley, D.C.; Masselink, G.; Russell, P. E.; O'Hare, T.J. (eds.). Proceedings 12th International Coastal Symposium (Plymouth, England) - Journal of Coastal Research. Special Issue № 65. pp. 19-24. 2013.

BACHILLER, J. V. Das privatizações à nova estratégia de desenvolvimento: A trajetória do BNDES entre os anos de 1990 e 2010. Revista Desenvolvimento em questão. Ano 14. № 36. pp. 5-30. 2016.

BECKER, B. K. Cenários de curto prazo para o desenvolvimento da Amazônia. In: ACSELRAD, H. (Editor) Cadernos do Instituto de Pesquisa e Planejamento Urbano e Regional da Universidade Federal do Rio de Janeiro - IPPUR. Ano XIV. № 1. pp. 53-86. Jan.-Jul. 2000.

BECKER, B. K. Geopolítica da Amazônia. Conferência do Mês do Instituto de Estudos Avançados da USP 19 (53). pp. 71-86. 2005.

BECKER, B. K. Ciência, Tecnologia e Inovação - Condição do Desenvolvimento Sustentável da Amazônia. 4a Conferência Nacional de Ciência, Tecnologia e Inovação. Seminário temático 1 Desenvolvimento Sustentável novos padrões de desenvolvimento via inovação. Brasília - DF. 2010a.

BECKER, B. K. Novas territorialidades na Amazônia: desafio às políticas públicas Bol. Mus. Para. Emílio Goeldi. Cienc. Hum. Belém, v. 5, n. 1, p. 17-23, jan.- abr. 2010b.

CARDOSO, F. H.; MÜLLER, G. Amazônia: expansão do capitalismo [online]. Rio de Janeiro: Centro Edelstein de Pesquisas Sociais, 68 p. ISBN: 978-85-99662-73-1. Available from SciELO Books <http://books.scielo.org>. 2008.

CASTRO, E. M. R. Território, biodiversidade e saberes de populações tradicionais. Papers do NAEA no 092. 1998.

CASTRO, E. M. R. Políticas de ordenamento territorial, desmatamento e dinâmicas de fronteira. Novos Cadernos NAEA v. 10, n. 2, p. 105-126, dez. 2007.

CASTRO, E. M. R. Amazônia: sociedade, fronteiras e políticas. Caderno CRH, Salvador, v. 25, n. 64, p. 916, Jan/Abr. 2012.

CASTRO, E. M. R.; ROCHA, W. M. Relações internacionais e cooperação descentralizada de cidades amazônicas: um enfoque teórico. In: CASTRO, E. M. R.; FIGUEIREDO, S. L. Sociedade, campo social e espaço público. Belém: NAEA. pp. 185-211. 2014.

CASTRO, E. M. R.; CAMPOS, I. Formação Socioeconômica do Estado do Pará In: CASTRO, E. M. R.; CAMPOS, I. Formação socioeconômica da Amazônia. Coleção Formação Regional da Amazônia, v.2. Belém: NAEA, 640 p. 2015.

CMB - Comissão Mundial de Barragens. Usina Hidrelétrica de Tucuruí (Brasil). Secretariado da Comissão Mundial de Barragens, Vlaeberg, South Africa. 297p. 2000. 
CAZELLA, A. A. As bases sociopolíticas do desenvolvimento territorial: Uma análise a partir da experiência francesa. In: FROEHLICH, J. M. (org.) Desenvolvimento territorial: Produção, identidade e consumo. Ed. Unijuí. pp. 15-52. 2011.

EEA - EUROPEAN ENVIRONMENT AGENCY. Environmental indicators: Typology and overview. Technical report № 25. Disponível em: http://reports.eea.eu.int/TEC25/en/tab_content_RLR. 1999.

EEA - EUROPEAN ENVIRONMENT AGENCY. Stop biodiversity loss by 2010: proposal for a first set of indicators to monitor progress in Europe. Relatório Técnico do EEE № 11/2007. Agência Europeia do Ambiente, Copenhagen. 2007.

EEA - EUROPEAN ENVIRONMENT AGENCY. The European Environment Agency (EEA) is an agency of the European Union. Disponível em: https://www.eea.europa.eu/pt/about-us/who. 2008.

FERNANDES, M. F.; BARBOSA, M. P. Aplicação dos indicadores socioeconômicos e ambientais do modelo DPSIR (Força motriz/Pressão/ Estado/Impacto/Resposta) e influências na desertificação nos municípios de Araripina-PI, Crato e Barbalha-CE e Marcolândia-PI. Revista Brasileira de Geografia Física, no 04. pp. 722-737. 2011.

IBGE - Instituto Brasileiro de Geografia e Estatística. https://cidades.ibge.gov.br/brasil/pa/panorama. Acessado em 20.09.2017.

IDESP - Instituto de Desenvolvimento Econômico, Social e Ambiental do Pará Estado do Pará. (di)visões territoriais, perspectivas sociais, econômicas, financeiras e ambientais - ocupação e uso do território, federalização territorial e recursos naturais. Lúcia Cristina Andrade (coord.). Belém. 2011.

IPEA - Instituto de Pesquisa Econômica Aplicada. Atlas da vulnerabilidade social dos municípios e regiões metropolitanas brasileiras. 2010. Disponível em: http://ivs.ipea.gov.br/index.php/pt/sobre. Acessado em: 09.10.2017.

KEMERICH, P. D. C; RITTER, L. G.; BORBA, W. F. Indicadores de sustentabilidade ambiental: métodos e aplicações. Revista do Centro do Ciências Naturais e Exatas - UFSM, Santa Maria - Revista Monografias Ambientais - REMOA. V. 13, N. 5. Edição Especial LPMA/UFSM, pp. 3723-3736. 2014.

KITAMURA, P. C. A Amazônia e o desenvolvimento sustentável. Empresa Brasileira de Pesquisa Agropecuária - EMBRAPA, Centro Nacional de Pesquisa de Monitoramento e Avaliação de Impacto Ambiental - Brasília. 182p. 1994.

KRISTENSEN, P. The DPSIR Framework. National Environmental Research Institute, Denmark, Department of Policy Analysis European Topic Centre on Water. European Environment Agency. 2004.

LIRA, W. S.; CÂNDIDO, G. A. Análise dos mode-los de indicadores no contexto do desenvolvimento sustentável. Revista Perspectivas Contemporâneas. Campo Mourão - PR. V. 3, № 1. pp. 31-45. jan./jul. 2008.

MME - Ministério de Minas e Energia. Plano Nacional de Energia 2030 / Ministério de Minas e Energia. Colaboração Empresa de Pesquisa Energética Brasília : MME : EPE, 2007.

NOVO, M. E.; OLIVEIRA, L. Desenvolvimento de matrizes de decisão para apoio à selecção de medidas de recuperação do estado de massas de água (caso de estudo: Melides). VIII Congresso Ibérico de 
Gestão e Planejamento da Água. Análise crítica do primeiro ciclo Europeu de planejamento hídrico e a expectativa dos planos comuns para a Espanha e Portugal em 2015. Livro de Atas. Lisboa. pp. 839849. 2013.

OLIVEIRA, A. da L.; ARAÚJO, A. M.; TEIXEIRA, C. U.; BATISTA, J. L. O.; CARNEIRO, R. B. Discussão teórica sobre o conceito de rede urbana. +Geografia's, Feira de Santana, n. 1, pp. 25-29, maio / nov. 2008.

PNUMA - Programa das Nações Unidas para o Meio Ambiente. Geo Amazônia - Perspectiva do meio ambiente na Amazônia. Organização do Tratado de Cooperação Amazônica - OTCA. Coord. Universidad Del Pacífico - Centro de investigación. 2008.

SALUM, B. JR.; KUGELMAS, B. O Leviathan declinante: a crise brasileira dos anos 80. Revista Estudos avançados. № 5(13). pp. 145-159. 1991.

SMETTS, E.; WETERINGS, R. Environmental indicators: Typology and overview. Centre for Strategy, Technology and Policy, the Netherlands - TNO. European Environment Agency - EEA. Copenhagen, 1999.

SOARES, A. B.; SILVA FILHO, J. C. L.; ABREU, M. C.; SOARES, F. A; Revisando a estruturação do modelo DPSIR como base para um sistema de apoio à decisão para a sustentabilidade de bacias hidrográficas. Revista em Agronegócios e Meio Ambiente, v.4, n.3, pp. 521-545, set/dez 2011.

SONG, X.; FROSTELL, B. The DPSIR Framework and a Pressure-Oriented Water Quality Monitoring Approach to Ecological River Restoration. Division of Industrial Ecology, KTH Royal Institute of Technology. pp. 670-682. Stockholm, Sweden. 2012.

SOULÉ, O. JR.; MATTOS, F. A. M. A influência das crises econômicas das décadas de 80 e 90, no Brasil, no mercado de trabalho dos profissionais ligados as tecnologias da Informação. VIII ENANCIB Encontro Nacional de Pesquisa em Ciência da Informação. Salvador-Bahia. 2007.

WCED - World Commission on Environment and Development . Report of the World Commission on Environment and Development: Our common Future. Oxford: Oxford University Press. 1987. 


\section{NOTAS}

\section{Nota 1}

"O conceito de Desenvolvimento Sustentável implica limites - não limites absolutos, mas limitações impostas pelo estado atual da tecnologia e organização social em recursos ambientais e pela capacidade da biosfera para absorver os efeitos de atividades humanas." (WECD, 1987).

\section{Nota 2}

"Geopolítica é um campo de conhecimento que analisa relações entre poder e espaço [...] e caracteriza-se pela presença de pressões de todo tipo, intervenções no cenário internacional desde as mais brandas até guerras e conquistas de territórios" (Becker, 2005, p. 71).

\section{Nota 3}

"A teoria das localidades centrais, desenvolvida por Chistaller em 1933, explica a formação e desenvolvimento dos centros urbanos. Características que determinam a relação dos centros urbanos com as demais localidades, como áreas de mercado, os quais designam sua ideia de importância". (OLIVEIRA et al., 2008, p. 27).

\section{Nota 4}

"O IVS é o resultado da média aritmética dos subíndices: IVS Infraestrutura Urbana, IVS Capital Humano e IVS Renda e Trabalho, cada um deles entra no cálculo do IVS final com o mesmo peso [...]: Este índice é resultado da agregação de 16 indicadores selecionados da Plataforma do Atlas do Desenvolvimento Humano - ADH e foram organizados em três dimensões da vulnerabilidade social Ia Infraestrutura Urbana do território em tela (seja ele um município, uma região, um estado ou uma Unidade de Desenvolvimento Humano); II- o Capital Humano dos domicílios deste território; e III - a Renda, o acesso ao trabalho e a forma de inserção (formal ou não) dos residentes nestes domicílios. Cada uma dessas dimensões reúne, por sua vez, um conjunto de variáveis obtidas nas bases dos Censos Demográficos do IBGE, que refletem diferentes aspectos das condições de vida". (IPEA, 2010).

\section{Nota 5}

"A Agência Européia do Ambiente (AEA) é uma agência da União Européia, criada em 1990, que tem como missão fornecer informação consistente e independente sobre o ambiente. Sendo a principal fonte de informação para todos aqueles que, de alguma forma, participam no desenvolvimento, adoção, implementação e avaliação de políticas ambientais, bem como para o público". (EEA, 2008, p. 5). 


\section{Capítulo 14}

\section{CIRCUITOS ALIMENTARES: A DINÂMICA DE ABASTECIMENTO ENTRE A AGRICULTURA FAMILIAR E A ALIMENTAÇÃO ESCOLAR.}

DOI: $10.37423 / 200300404$

Christiane Marques Pitaluga - christiane.pitaluga@ufms.br

Kelly Camila de Campos Boia -kellycamposadm@gmail.com

José Carlos de Jesus Lopes - jose.lopes@ufms.br

Caroline Pauletto Spanhol Finocchio - caroline.spanhol@ufms.br

RESUMO: agricultura familiar está em plena expansão e firmemente alocada na agenda das políticas públicas do Brasil. Diversas pesquisas científicas atestam que a agricultura familiar promove o dinamismo e o fortalecimento das economias locais, bem como tem fornecido alimentos mais seguros e com qualidade para a merenda das escolas públicas, contribuindo para a saúde da comunidade discente. Neste contexto, o trabalho objetiva investigar a dinâmica entre a agricultura familiar e as escolas públicas municipais, que oferecem merendas escolares. Esta pesquisa tem como motor de análise a aquisição de alimentos com Segurança Alimentar e Nutricional (SAN) produzidos pela agricultora familiar para a merenda escolar, destacando as construções dos circuitos alimentares, as potencialidades e fragilidades existentes. A metodologia consistiu em pesquisas bibliográficas, com objetivos exploratório e descritivo e com abordagem qualitativa. A coleta de dados deu-se através de entrevistas estruturadas junto aos atores envolvidos. Tomou-se como lócus, a municipalidade de Anastácio, localizada em Mato Grosso do Sul (MS). 
Utilizou-se a técnica qualitativa de análise. Os resultados apresentaram um aspecto relevante quanto ao modelo de comercialização, que consiste no fato de que os produtores filiados à Cooperativa obtêm maiores vantagens em relação aos produtores individuais. Conclui-se que os fatores como forma de pagamento, a falta de logística adequada e assistência especializada contribuem para o enfraquecimento dessa política pública. Constatou-se ainda que as fragilidades apontadas nessa ação pública podem ser transformadas em oportunidades, considerando-se a crescente preocupação com a segurança alimentar e qualidade dos alimentos. Verificou-se, também, que o fortalecimento e a expansão deste mercado proporcionam um acréscimo na geração de renda dos agricultores familiares e assim contribuem decisivamente com o dinamismo de consumo e com o desenvolvimento sustentável da economia local.

Palavras-chave: Segurança Alimentar e Nutricional; Agricultura Familiar; Compras Públicas Sustentáveis. 


\section{INTRODUÇÃO}

A construção de mercados agroalimentares e dinâmicas de consumo entre a alimentação escolar e a agricultura familiar configura-se como um setor que, no Brasil, tem se expandido, com o passar das décadas. Nota-se, cada vez mais, que esta dinâmica tem contribuído com o dinamismo econômico e com o desenvolvimento sustentável das economias locais, inclusive, na busca da justiça socioambiental (ACSELRAD, 2009). Sabe-se, que o alimento é o centro de um complexo sistema de normas, valores, crenças e ideologias, no qual interagem os aspectos fisiológico, nutricional, cultural, histórico, emocional e político (FINOCCHIO et al, 2015). Por sua vez, o Estado precisa assumir, como agente, provedor de mecanismos de defesa à saúde dos indivíduos, por meio da oferta segura dos alimentos (SPERS, 2003). Assim sendo e no que diz respeito ao aspecto político e da função do Estado, o Programa Nacional de Alimentação Escolar (PNAE) constitui-se como uma política pública que busca trabalhar em parceria com a agricultura familiar.

A literatura mais atualizada aponta que, nas últimas décadas, a agricultura familiar tem sido um dos segmentos responsáveis pela significativa dinamização na alimentação escolar, com recomendável princípios da SAN. Com base na definição legitimada na II Conferência Nacional da SAN, realizada em Olinda, em 2004, Maluf $(2011,19)$, coloca que o conceito da SAN converte-se em objetivo público, estratégico e permanente características que colocam entre as categorias nucleares para a formulação das opções de desenvolvimento local e mesmo de um país. Para ele, a construção do conceito está assentada em dois princípios: 1) o direito humano à alimentação adequada e saudável; e 2) à soberania alimentar. Assim, para o autor,

Segurança Alimentar Nutricional é a realização do direito de todos ao acesso regular e permanente a alimentos de qualidade, em quantidade suficiente, sem comprometer o acesso a outras necessidades essenciais, tendo como base práticas alimentares promotoras de saúde, que respeitem a diversidade cultural e que sejam social, econômica e ambientalmente sustentáveis (MALUF, 2011, p. 170).

Conforme exposto pelo autor, é possível também observar que o conceito de SAN baseia-se na concepção que não é possível dissociar segurança alimentos dos aspectos nutricionais, ao enfocar que sua compreensão permite "o acesso para todas as pessoas, em qualquer momento, de alimentação suficiente e de boa qualidade, para assim poderem manter uma vida sadia e ativa" (BRANCO, 2005, p. 19). Ainda de acordo com a autora organizadora, para tanto, são exigidos seis requisitos para compreender a SAN de uma população. São eles: 
1) Disponibilidade de alimentação suficiente;

2) Estabilidade do abastecimento de alimentação ao longo do ano e no curso dos anos;

3) Acesso à alimentação disponível;

4) Distribuição adequada da alimentação na família;

5) Boa qualidade de alimentação; e

6) Condições de saúde favorável à absorção de alimentos

Diante da conjugação, de forma eficaz e efetiva, esses seis requisitos potencializam a combinação de todos os elementos que exercem influência no consumo de dieta alimentar, na absorção dos alimentos com qualidade, com regularidade e no resultado quanto ao funcionamento sadio do corpo humano, para atender as diversas e complexas atividades da população. Neste sentido, advoga-se que a agricultura familiar ao produzir bens alimentícios com os propósitos da SAN, atua em consonância com o paradigma da sustentabilidade, ou seja, a força da SAN também está atenta às questões ligadas ao equilíbrio dos recursos naturais, bem como à justiça socioambiental (ACSELRAD; ET AL, 2009). Para os autores, justiça socioambiental

é a condição de existência social configurada através do tratamento justo e do
envolvimento significativa de todas as pessoas, independente de sua raça, cor
ou renda no que diz respeito à elaboração, desenvolvimento, implementação e
aplicação de políticas, leis e regulações ambientais. Por tratamento justo
entenda-se que nenhum grupo de pessoas, incluindo-se aí grupos étnicos,
raciais ou de classe, deva suportar uma parcela desproporcional das
consequências ambientais negativas resultantes da operação de
empreendimentos industriais, comerciais e municipais, da execução de
políticas e programas federais, estaduais e municipais, bem como das
consequências resultantes da ausência ou omissão destas políticas (ACSELRAD;
ET AL, 2009, p. 16). Neste contexto, esse resultado pode possibilitar aos estudantes da rede pública de todo o Brasil não apenas uma diversificação na alimentação, mas também um fator primordial que é proporcionar a eles o direito soberano à alimentação, com segurança alimentar e o consumo de alimentos saudáveis, cujo modelo de plantio é ecologicamente equilibrado e socialmente justo. Esses estudantes compõem um número que já ultrapassou 42,6 milhões e que envolve desde a educação básica até os adultos. 0 PNAE viabiliza a esses estudantes mais de 50 milhões de refeições por dia, chegando a um volume de recursos de R\$3,8 bilhões ao ano (MINISTÉRIO DO DESENVOLVIMENTO AGRÁRIO, 2015).

O PNAE está alicerçado na transparência dos recursos financeiros do Governo Federal e dos Municípios brasileiros, cujos montantes orçamentários devem, necessariamente, ser alocados à aquisição de 
gêneros alimentícios, com Segurança Alimentar e Nutricional (SAN), destinados ao abastecimento da merenda escolar, da rede pública de ensino (FNDE, 2015). Já o Fundo Nacional de Desenvolvimento da Educação (FNDE) é o órgão responsável pela regulamentação do PNAE. O seu papel é atuar de forma direta no auxílio financeiro, organização, cooperação técnica e consumação do PNAE. Logo, imprime um caráter de governança pública relevante para que os objetivos desse Programa sejam, eficazmente, atingidos.

Tal como descrito no art. 14 da Lei $n^{\circ}$ 11.947/2009, a utilização dos recursos financeiros repassados pelo FNDE, no total e âmbito do PNAE, a obrigatoriedade é de que no mínimo 30\% (trinta por cento) deverão ser utilizados na aquisição de gêneros alimentícios diretamente da agricultura familiar e do empreendedor familiar rural. De forma complementar, a Resolução FNDE $n^{\circ}$ 26/2013 coloca que a alimentação escolar é um direito de todos os alunos matriculados na rede pública de ensino, e desse modo passa a ser um dever de qualquer Estado Federativo do Brasil.

Diante do conjunto de Leis e Resoluções voltado ao consumo alimentar dos estudantes do País, há de se entender que todos os 5.570 municípios brasileiros (IBGE, 2018) devem estar de acordo com as diretrizes do PNAE. Assim sendo, cabe a cada um deles promover e incentivar uma alimentação saudável, atentando para o propósito do Programa estabelecido na citada Lei. Interessante observar que, o PNAE não se limita apenas a introduzir elementos vinculados à produção de alimentos. $O$ Programa aspira, sobretudo, proporcionar alimentação saudável aos estudantes das redes públicas de educação básica do Brasil. Ao fazer essa inserção, contribui-se e incentiva-se o desenvolvimento local, por conta do fortalecimento da agricultura familiar.

A temática, que está embasada a preocupação com os bens alimentícios com SAN advindos do modo de produção da agricultura familiar, vem sendo tratada na literatura por diversos autores nacionais e internacionais, tais como Cruz et al (2016), FINOCCHIO et al (2015), Zylbersztajn (2011), Maluf (2011), Triches e Schneider (2010), Zylbersztajn e Omta (2009), Spers e Zylbersztajn (2009), Neves; et al (2006), Branco (2005), Caswell (1998), Buzby et al (1998) Henson e Traill (1993), Spers (1993).

Triches e Schneider (2010), por exemplo, relatam que a preocupação da temática não está apenas no sentido do combate à fome, simplesmente; mas, também, com a constante inquietação para que os estudantes desenvolvam hábitos alimentares mais saudáveis derivados de modelos de plantios mais sustentáveis, prezando, assim, pelo consumo de bens alimentícios baseado na SAN. A esse respeito, Spers e Zylbersztajn (2009, p. 131) declaram que 
Food safety is the consumer's warranty to acquire food with quality and health attributes. Institution changes like new industrialization process, new consumer demands, industrialization and urbanization, increase in competitiveness, development of scientific research, decrease in income expenses on food and globalization demands increasing the consumer, government and private organization's interest for safety and quality.

Com relação ao foco da discussão sobre a segurança de um alimento com qualidade nutricional e o controle regulatório governamental, Caswell (1998, p. 409) coloca que,

The guarantee of food quality is a growing focus of governments, companies and standardization agentes. Efforts are addressed to control the attributes of a food product, with a peculiar care of the nutricion and safety characteristics. Guaranteeing quality is gaining notoriety as food consumption is being better appraised for the rulers, consumers and companies. This better evaluation suggest more voluntary quality assurances for companies and more regulation for the government.

Numa abordagem focada na logística do circuito entre o espaço da produção e do consumo, Cruz et al (2016, p. 10) assim se expressam, literalmente:

\begin{abstract}
Dentre algumas questões relevantes no que se refere à nova equação alimentar, uma constatação recorrente é a de que parte significativa dos problemas associados a esse debate têm como arena privilegiada os espaços urbanos, de modo que as estratégias alimentares e de abastecimento de grandes cidades e de espaços urbanos, vêm assumindo particular centralidade no contexto da crise de mobilidade, de energia e de saúde. $O$ abastecimento alimentar é um elo chave entre o uso de energia e mobilidade nos espaços urbanos, visto que a alimentação é uma necessidade diária inadiável dos humanos, que demanda sofisticada logística, seja para prover o acesso aos alimentos seguros.
\end{abstract}

Para Zylbersztajn (2011), os tomadores de decisões envolvidos com os mercados agroalimentares, assim como a produção de alimentos, de fibras e de energia têm assumido para si os compromissos socioambientais, que envolvem não somente o sistema agroindustrial, que tem como base a agricultura industrial; mas, em especial, aos produtores ligados à agricultura familiar, que sob condições edafoclimáticas apropriadas, podem produzir bens alimentícios de qualidade, a exemplo dos produtos orgânicos, sem agredir o meio ambiente, permitindo assim o desenvolvimento local, amplamente sustentável.

Assim, considerando este contexto e a necessidade emergencial de criar mecanismos de suporte e de construção de mercados agroalimentares sustentáveis, o município de Anastácio, que abriga em torno de 30 mil habitantes e que está distante 140 quilômetros de Campo Grande, capital do Estado de Mato Grosso do Sul, reconhece a importância e o imperativo de se garantir o direito à alimentação de qualidade e com segurança alimentar e nutricional. Busca-se, portanto, o atendimento às onze escolas 
nele situadas, sendo cinco Centros de Educação Infantil e seis escolas localizadas no município e também na zona rural. Ao executar esta demanda, comprando os alimentos dos agricultores familiares cumpre o que está determinado na Lei $n^{\circ}$ 11.947/2009 e proporciona aos pequenos agricultores familiares o desenvolvimento local concomitantemente a geração de renda.

Desta forma, o município se destaca por executar suas compras direto dos agricultores familiares, fomentando assim e fortalecendo os circuitos curtos alimentares e colocando-os como agentes propulsores do desenvolvimento local. Assim, diante desse contexto e considerando a relevância da agricultura familiar, do PNAE no combate à fome e a desigualdade, a transformação na vida dos agricultores locais e a qualidade da alimentação ofertada aos estudantes da rede pública de ensino das escolas municipais de Anastácio/MS, justifica-se o presente estudo no sentido de evidenciar a realidade e a veracidade da execução do PNAE junto às referidas instituições do município, propondose, assim, a investigar a relação, os trâmites e as dinâmicas de consumo entre a agricultura familiar e as escolas públicas, no que se refere à aquisição e abastecimento de alimentos SAN.

Diante do exposto, interessa responder a seguinte questão, tornando-a a problemática central desta pesquisa: Como se expressa a dinâmica entre a agricultura familiar e as políticas públicas voltadas à merenda escolar? Para responder a essa problemática, esta pesquisa objetiva investigar a dinâmica entre a agricultura familiar e as escolas públicas municipais, que oferecem merendas escolares. Esta investigação tem como motor de análise a aquisição de alimentos com segurança alimentar e nutricional (SAN) produzidos pela agricultura familiar para a merenda escolar, destacando as construções dos circuitos curtos alimentares, as potencialidades e fragilidades existentes.

Para que os objetivos, aqui anunciados, sejam alcançados, este texto está estruturado em seis partes, a iniciar-se por esta parte introdutória, que contextualiza a problemática central e declara o objetivo geral da pesquisa. Em seguida os tópicos que versam sobre a agricultura familiar e as compras públicas sustentáveis dão sustentação teórica para as discussões temáticas. Os procedimentos do delineamento da pesquisa são apresentados no tópico de Metodologia, que dão suporte para os resultados e análises provenientes. Por fim, as Considerações Finais e as Referências.

\section{AGRICULTURA FAMILIAR}

Em se tratando de agricultura familiar, pode-se notar que o conceito da mesma foi se modificando com o passar do tempo. Silva e Marques (2009), apontam que foi, a partir da década de 1990, em decorrência da expansão da globalização e da economia, e também no setor agrícola, tal complexo 
fenômeno gerou outros contornos no desenvolvimento agrário no Brasil do ponto de vista social, produtivo, tecnológico e socioambiental. Com isso, surge então o novo rural brasileiro, em alusão a emergência expressiva das atividades rurais agrícolas no meio brasileiro. Para Schneider (1999), houve um processo de deslocamento em relação aos proprietários de pequenos lotes de terras. Esses deixaram de ser identificados como mini fundiários e se tornaram os pequenos produtores, denominação essa que foi ressaltada à medida que crescia a capacidade do Estado, naqueles anos, de além de propor e executar políticas públicas para estas categorias, então chamados de produtores de baixa renda.

A Lei $\mathrm{n}$ - 11.326/2006 considera, conceitualmente, como agricultor familiar e empreendedor familiar rural,

aquele que pratica atividades no meio rural, atendendo determinados requisitos, a exemplo de daquele que utiliza predominantemente mão-de-obra da própria família nas atividades econômicas do seu estabelecimento ou empreendimento e que dirija seu estabelecimento ou empreendimento com sua família. A gestão da propriedade é compartilhada pela família e a atividade produtiva agropecuária é a principal fonte geradora de renda. Além disso, o agricultor familiar tem uma relação particular com a terra, seu local de trabalho e moradia.

Buainain, Romeiro e Guanziroli (2003), defendem que a agricultura familiar é um universo heterogêneo, pois possui uma variedade de recursos. Para os autores, trata-se de um segmento produtivo e de vital importância para os brasileiros, já que esses consomem grande parte dos alimentos produzidos pela agricultura familiar. Ganziroli, Cardim (2000), referem-se à visão do universo agrário como muito complexo, seja em relação a grande diversidade da paisagem agrária, ou em virtude da existência de diferentes tipos de agricultores, os quais têm interesses particulares nas suas estratégias de sobrevivência e de produção, e que reagem de maneira diferenciada a desafio e às restrições semelhantes.

A agricultura familiar abrange todas as atividades agrícolas de base familiar e estão vinculadas as áreas do desenvolvimento rural. Esta fundamenta-se em um meio de organização das produções agrícola, florestal, pesqueira, pastoril e aquícola que tem como principal característica ser gerenciadas e operadas por família e é, principalmente, dependente de mão de obra familiar (FAO, 2014). 0 agricultor familiar é caracterizado pelo Ministério do Desenvolvimento Agrário através da Declaração de Aptidão ao Pronaf (DAP). Nesse documento é feita sua identificação, sendo necessário ter a DAP para que o agricultor tenha acesso às políticas públicas (FNDE, 2015). 
Sob a perspectiva nacional, alguns fatores devem ser observados, pois são fundamentais para alcançar o bom desenvolvimento da agricultura familiar; dentre eles destacam-se: condições agroecológicas, as características territoriais, ambiente político, acesso aos mercados alimentares, acesso a terra e aos recursos naturais, acesso à tecnologia e socioculturais, disponibilidade de educação especializada, entre outros. Todos estes fatores são de suma importância, pois a agricultura familiar tem um notável papel socioeconômico, ambiental e cultural (FAO, 2014).

No que concerne à produção de alimentos SAN, faz-se importante ressaltar que a agricultura familiar responde por parte considerável do abastecimento interno. Ela compõe a dieta alimentar básica da população, ofertando uma grande contrapartida à produção nacional. No Brasil, é notável que, nas últimas décadas, o Estado tenha defendido modelos estruturantes sempre seguindo os conceitos de SAN, como eixo estratégico de desenvolvimento local. Dessa forma, o PNAE se torna uma grande potencialidade capaz de reintegrar os componentes, ou seja, uma maneira de enfrentar os problemas relacionados tanto no consumo como na produção de alimentos (TRICHES, SCHNEIDER, 2010).

A esse respeito, Finocchio et al (2015) ao citar Ortiz (1994), a faz entender que a valorização do tradicional vem sendo observada, nas últimas décadas, como o principal argumento na propaganda de alimentos e, comparativamente, com as duas décadas anteriores, foi o argumento que mais cresceu nas propagandas sobre produtos alimentícios. Mais, especificamente, a primeira autora-pesquisadora ressalta que,

a tradição alimentar vem sendo readaptada nos dias atuais, seja no modo de preparo de alimentos, seja nos produtos utilizados. Há uma simplificação nos procedimentos culinários e uma adaptação aos valores atuais, entre eles os relacionados à saúde e ao corpo (FINOCCHIO, et al 2015, p. 8).

Ademais, o agricultor familiar configura-se em um canal importante de comércio e geração de renda com regularidade. Ele contribui para a inclusão produtiva, a geração de emprego no meio rural e o estímulo ao cooperativismo e ao associativismo. Com relação aos alunos da rede pública de ensino, o agricultor familiar tem proporcionado o acesso regular e permanente de produtos alimentícios de melhor qualidade nas escolas públicas. Neste sentido, concebe-se como um passo importante rumo à garantia de alimentos e hábitos saudáveis, considerando a cultura e as práticas alimentares regionais (FNDE, 2015).

A crescente preocupação com a saúde da população discente abriu espaço para a integração de políticas públicas como o PNAE e acabou gerando a abertura de novos mercados para os agricultores 
familiares. No modelo de alimentação escolar brasileiro, a inserção dos produtos da agricultura familiar tem sido um meio encontrado para impulsionar a educação, a nutrição e o desenvolvimento social e econômico (MDA, 2015). Observa-se, que essa conexão entre o mercado da alimentação escolar e a produção agrícola local tem efeito considerável sobre a sustentabilidade dos Programas das políticas públicas, pois incentiva a economia local tanto diretamente, como através de meio de compra dos produtores locais ou indiretamente por meio do acréscimo de renda, que acaba sendo investido novamente na economia local (MDA, 2015).

Logo, a importância dessa parceria com as ações de Estado e a comercialização de alimentos junta às instituições escolares públicas vêm sendo indicada como vantajosa, especialmente, para a consolidação da agricultura familiar, e isso já é notável através das transformações que vem ocorrendo desde a inauguração do Programa de Aquisição de Alimentos (PAA) e da vinculação do abastecimento do PNAE (MARTINELLI et al, 2015). E para melhor elucidar como ocorre o processo de aquisição de alimentos da agricultura familiar para a merenda escolar e assim ser visto como agente transformador, a seguir serão expostos os mecanismos que apoiam as compras públicas sustentáveis e quais são as etapas e procedimentos necessários para a conclusão desse processo de aquisição.

\section{COMPRAS PÚBLICAS SUSTENTÁVEIS}

Na busca de proporcionar autonomia aos Estados Federativos e aos Municípios brasileiros, concedeuse a estes o direito de se autogovernar. Entretanto, os avanços se deram de forma incompleta. $\mathrm{Na}$ visão de Teixeira (2012), por mais que Estados e Municípios tenham ganhado autonomia administrativa e novas competências, os recursos gerados ou transferidos, com a ideia de se tornarem governos autônomos, de fato, foram insuficientes. Com isso, ainda permaneceu subordinação econômica em relação ao Governo Federal. Tal fato fez com que a autonomia administrativa ficasse incompleta, uma vez que não se tinha a autonomia financeira.

Conforme a Constituição Federal (CF/88), que traz em seu art.37, inciso XXI, com redação dada pela Emenda 19/1989, determina que a administração pública deva fazer o uso dos procedimentos licitatórios. Com isso, o papel da licitação se torna vital, pois ele deverá garantir o cumprimento do princípio constitucional da isonomia, a escolha da proposta que se tornará mais vantajosa para a administração e a promoção do desenvolvimento nacional sustentável. A licitação será processada e julgada em estrita conformidade com os princípios básicos da legalidade, da impessoalidade, da moralidade, da igualdade, da publicidade, da probidade administrativa, da vinculação ao instrumento 
convocatório, do julgamento objetivo e dos que Ihes são correlatos no art. 3o da Lei 8.666/1993 (BRASIL, 1993).

Advinda da atualização do mesmo artigo, redação dada pela Lei no 12.349/2010 empregou-se o termo e a metodologia para a execução, por parte dos órgãos públicos, as denominadas Compras Públicas Sustentáveis. Elas visam

o procedimento administrativo formal que contribui para a promoção do desenvolvimento nacional sustentável, mediante a inserção de critérios sociais, ambientais e econômicos nas aquisições de bens, contratações de serviços e execução de obras. De uma maneira geral, trata-se da utilização do poder de compra do setor público para gerar benefícios econômicos e socioambientais (BRASIL, MMA, 2010).

Por conta dessa atualizada normativa e com a ideia de promover a aquisição de alimentos com alta densidade de SAN provenientes da agricultura familiar para os demais órgãos públicos, como hospitais, penitenciarias, restaurantes, populares e universitários, o Programa de Aquisição de Alimentos (PAA), inaugura-se como uma modalidade de compra institucional (MARTINELLI et al, 2015). Neste quesito, pode-se observar que a compra pública sustentável da agricultura familiar torna-se, então, parte de um processo que evidencia a necessidade de se pensar em uma forma de produção de alimentos que atenda às demandas nutricionais da população e assegure a evolução social e econômica dos agricultores familiares, a partir de modelos alternativos de produção e comercialização de produtos oriundos da agricultura familiar, com desejos de remuneração mais justas, cuja produção lida de forma mais harmonizada com a natureza e aos valores do local (FNDE, 2015).

Em relação a estas formas alternativas que incluem a criação das cadeias curtas de produção e comercialização, que associa a relação entre produtores e consumidores, fortalecendo as relações sociais, e ainda enaltece a diversidade produtiva, atende às necessidades das instituições públicas. Este arranjo possibilita, de fato, o acesso a alimentos saudáveis e de qualidade para a população, na perspectiva de não apenas promover renda ao agricultor familiar; mas, também de forma complementar, garantir a segurança alimentar e nutricional dos estudantes. Logo, o resultado do processo alimentação escolar versus agricultura familiar tem proporcionado uma significante transformação na alimentação escolar, ao tornar possível que alimentos saudáveis e com vínculo regional, produzidos diretamente pela agricultura familiar, possam ser acessados e consumidos diariamente pelos estudantes da rede pública de todo o Brasil (FNDE, 2015).

Em 2010, quando a Lei 11.947/2009 entrou em vigor, representou para os agricultores familiares um grande passo e uma oportunidade, pois todos os agricultores de todos os municípios brasileiros 
passaram a orçar com um mercado institucional, que em princípio deveria ser impreterivelmente implantado (CAMARGO, BACCARIM, SILVA, 2015). A citada Lei é regulamentada pela Resolução $\mathrm{n}^{\circ}$ 4/2015, do Conselho Deliberativo do FNDE, que descreve quais são os procedimentos operacionais que devem ser observados para venda dos produtos oriundos da agricultura familiar para as entidades executoras. As compras são realizadas através dessas entidades que são as instituições da rede pública de ensino federal, estadual e municipal que recebem recursos diretamente do FNDE para a execução do PNAE, através das Secretarias Estaduais de Educação, Prefeituras, Escolas Federais (FNDE,2015).

É dentro deste cenário que se destaca, no Brasil, o interesse em fomentar os sistemas agrícolas produtivos localizados a partir do desenvolvimento das políticas públicas que disciplinam e motivam o circuito das compras públicas sustentáveis diretas dos agricultores familiares. Essas políticas iniciaram no país no ano de 2003, com a criação do PAA. Para Martinelli et al (2015), a experiência proporcionada por este Programa impulsionou o abastecimento do PNAE com alimentos da agricultura familiar e proporcionou grandes transformações tanto para os estudantes que são atendidos, como para os pequenos agricultores familiares.

\section{METODOLOGIA}

Como já declarado na parte introdutória, objetiva-se, nesta pesquisa, investigar a dinâmica entre a agricultura familiar e as escolas públicas municipais, que oferecem merendas escolares. Ela tem como motor de análise a aquisição de alimentos com Segurança Alimentar e Nutricional (SAN) produzidos pela agricultora familiar para a merenda escolar, destacando as construções dos circuitos alimentares, as potencialidades e fragilidades existentes. O estudo, no primeiro momento, iniciou-se com a etapa do levantamento bibliográfico Gil (2016), a qual buscou explorar temas relacionados à segurança alimentar e nutricional, a agricultura familiar e as compras públicas sustentáveis. Interessa também saber quais são os processos realizados para a aquisição da merenda escolar pela rede pública de ensino. Para elaboração do estudo utilizou-se diversos referenciais teóricos apontados tanto na literatura nacional com internacional e de forma complementar por legislações brasileiras vigentes, anunciados no corpo textual desta comunicação científica.

Tal como ensinam Marconi e Lakatos (2011), quanto aos objetivos propostos, esta pesquisa configurase como descritiva, haja vista a descrição dos mecanismos de aquisição dos alimentos da merenda escolar da rede municipal. Desta forma, visa compreender e expor as dinâmicas de consumo e os trâmites para assim apresentar as potencialidades e fragilidades que ocorrem durante todo o processo 
de aquisição e discorrer sobre os principais fatores que norteiam o processo de compras públicas sustentáveis provenientes da agricultura familiar. Ainda de acordo com os mesmos autores, esta pesquisa configura-se também como exploratória, uma vez que a mesma buscou conhecer as etapas da aquisição de alimentos para a merenda escolar e entender a sua integração e dinâmica com a agricultura familiar, com o consumo de alimentos SAN e com os paradigmas da sustentabilidade e da justiça socioambiental.

Em função dos esclarecimentos dados por Gil (2016), este trabalho consiste na utilização do método dedutivo, pois buscou-se estudar o contexto da agricultura familiar, das compras institucionais e das dinâmicas de consumo de modo geral, até chegar às especificidades observadas in loco, no que se refere aos processos relacionados ao manejo sustentável da produção de alimentos praticado pelos agricultores familiares, cujo escoamento são direcionados às compras públicas sustentáveis. O lócus da pesquisa é o município de Anastácio, localizado no Estado do Mato Grosso do Sul. A razão da escolha deste município reside no fato desse município participar do circuito alimentar da merenda escolar SAN que se utiliza das compras públicas sustentáveis dos agricultores familiares.

O estudo envolve a abordagem de pesquisa de ordem qualitativa (GIL, 2016). Para os procedimentos de coleta de dados, foram aplicadas entrevistas estruturadas, que foram divididas em três etapas e com a participação de atores chaves. A primeira consistiu em entrevistar a Coordenadora do Programa e nutricionista da rede municipal de ensino do município locus, pois entendeu-se a relevância das funções que a nutricionista desenvolve sendo a responsável não somente pela elaboração do cardápio da merenda escolar, mas também por outras atividades envolvendo o procedimento de aquisição de alimentos.

O segundo entrevistado foi o Presidente da Cooperativa dos Produtores Rurais da Região da Colônia Pulador de Anastácio/MS, (COPRAN), tendo em vista ser o profissional que faz a articulação entre os agricultores familiares e as escolas da rede municipal. Por fim, a terceira etapa consistiu nas entrevistas estruturas realizadas junto aos agricultores familiares, que vivem nos Assentamentos São Manoel, Monjolinho e Colônia Pulador todos situados em Anastácio. Este procedimento permite chegar ao entendimento de como ocorre o processo de aquisição de alimentos SAN proveniente do campo para o abastecimento da merenda escolar, bem como obter a descrição da relação entre os agricultores familiares e as escolas municipais de Anastácio.

Cabe destacar que as entrevistas foram realizadas com seis produtores rurais locais, não sendo possível entrevistar todos os 14 agricultores familiares que comercializam seus produtos para as 
escolas municipais devido à dificuldade de acesso e também as distâncias entre eles. Registrou-se que da totalidade dos produtores, nove são produtores filiados à Cooperativa e três constituem-se como produtores individuais que compõem o grupo informal de agricultores. Posteriormente, as entrevistas foram transcritas, o que permitiu a compreensão a respeito das dinâmicas de abastecimento, consumo e dos demais processos inerentes a esta relação. Na sequencia, serão expostas as análises dos dados e as discussões dos resultados provenientes das entrevistas realizadas com os atores chaves.

\section{RESULTADOS E ANÁLISES}

Diante do delineamento da pesquisa proposto e dos dados levantados, entendeu-se que o PNAE tem seu gerenciamento executado pelo Fundo Nacional de Desenvolvimento da Educação (FNDE) e visa a transferência, em caráter suplementar, de recursos financeiros aos Estados Federativos, ao Distrito Federal e aos Municípios destinados a atender, mesmo que parcialmente, as necessidades nutricionais dos alunos. É considerado um dos maiores Programas, na área de alimentação escolar no mundo e é o único com atendimento universalizado (FNDE, 2015).

No município de Anastácio (MS) são oferecidas ao agricultor familiar três opções de se trabalhar no âmbito da agricultura familiar. A primeira consiste em criar grupos formais, que podem se associar a uma Cooperativa ou Associação e estes os representarão nas chamadas públicas. A segunda consiste nos grupos informais, que se traduz na união de alguns agricultores e esses elaboram seus respectivos projetos de venda para o atendimento das chamadas públicas; e, por fim, o próprio agricultor familiar individual, que nessa modalidade pode participar dos certames, individualmente.

Para tanto, faz-se necessário que ele preencha os dados do seu projeto de venda e ter a posse da documentação necessária. Assim, em consonância com a legislação vigente, verificou-se através da pesquisa, que o processo de aquisição de alimentos oriundos da agricultura familiar para a preparação da merenda das escolas públicas de Anastácio/MS, assim como em outros municípios do Estado, possui diversas etapas. A seguir, o Quadro 1 que descreve as dez etapas do referido mecanismo.

Em Anastácio/MS, o cumprimento da meta relativa aos 30\% destinados à aquisição de produtos oriundos da agricultura familiar, vem sendo uma das principais tarefas da Secretaria de Educação, que busca ano após ano, atender o que é determinado por Lei. A nutricionista, que representa as escolas municipais, relata que faz reuniões, sempre no início do ano, com os produtores locais, informando a 
eles o que será necessário produzir durante o ano. Ela faz o acompanhamento da chamada pública, bem como faz a fiscalização dos alimentos produzidos e entregues.

Com relação à realização das reuniões, divergências nas respostas foram percebidas. Por exemplo, a nutricionista informou que faz reuniões com os produtores e os acompanha, durante o ano. Já os agricultores familiares informaram que ocorre apenas uma reunião, no início do ano, quando é informado a eles sobre os procedimentos do processo e estipulado os produtos e a quantidade que serão necessários produzir para atender a demanda das escolas municipais. Se assim for, esta situação revela uma fragilidade no processo, uma vez que se cria uma lacuna nas disseminações das informações, configurando-se assim como uma das dificuldades registradas no processo.

\begin{tabular}{|c|c|c|}
\hline Ordem & Macro-Atividade & Procedimentos: \\
\hline $1^{\mathrm{a}}$ Etapa & Orçamento & $\begin{array}{l}\text { Levantamento dos recursos orçamentários } \\
\text { disponíveis para a aquisição dos alimentos } \\
\text { SAN. }\end{array}$ \\
\hline $2^{\mathrm{a}}$ Etapa & Articulação entre os atores sociais & $\begin{array}{l}\text { Nutricionista, Agricultores Familiares e } \\
\text { Conselho de Alimentação Escolar. }\end{array}$ \\
\hline $3^{\mathrm{a}}$ Etapa & Formação de Cesta de Alimentos & $\begin{array}{l}\text { Após a definição dos produtos segue-se com a } \\
\text { elaboração do cardápio da merenda escolar. }\end{array}$ \\
\hline $4^{\text {a }}$ Etapa & Viabilidade Econômica & $\begin{array}{l}\text { Pesquisa de preço, atendendo a normativa do } \\
\text { PGPM da agricultura familiar. }\end{array}$ \\
\hline $5^{\text {a }}$ Etapa & $\begin{array}{l}\text { Comunicação e visibilidade da Política } \\
\text { Pública }\end{array}$ & $\begin{array}{l}\text { Divulgação da chamada pública nas escolas, } \\
\text { órgãos públicos e veiculadas em } \\
\text { jornal local e rádio. }\end{array}$ \\
\hline $6^{\text {a }}$ Etapa & Elaboração das Cláusulas Contratuais & $\begin{array}{l}\text { Elaboração do projeto de venda pelos } \\
\text { agricultores em atendimento aos requisitos da } \\
\text { chamada pública. }\end{array}$ \\
\hline $7^{\mathrm{a}}$ Etapa & Análise Técnica do Projeto & $\begin{array}{l}\text { Recebimento e seleção dos projetos de venda } \\
\text { pela Secretaria de Educação. }\end{array}$ \\
\hline $8^{a}$ Etapa & $\begin{array}{l}\text { Controle de Qualidade e de Segurança } \\
\text { Alimentar e Nutricional }\end{array}$ & $\begin{array}{l}\text { Coleta de amostra dos produtos para } \\
\text { verificação e controle de qualidade. }\end{array}$ \\
\hline $9^{\mathrm{a}}$ Etapa & $\begin{array}{l}\text { Celebração do Contrato de Compras } \\
\text { Públicas Sustentáveis }\end{array}$ & $\begin{array}{l}\text { Celebração e assinatura do Contrato de } \\
\text { Compra e de Venda entre os agricultores } \\
\text { familiares e as Unidades executoras. }\end{array}$ \\
\hline $10^{\mathrm{a}}$ Etapa & $\begin{array}{l}\text { Execução e finalização das cláusulas } \\
\text { contratuais. }\end{array}$ & $\begin{array}{l}\text { Entrega dos produtos e } \circ \text { respectivo } \\
\text { pagamento aos agricultores familiares. }\end{array}$ \\
\hline
\end{tabular}

Quadro 1: Etapas do processo de aquisição de bens alimentícios com segurança alimentar e nutricional produzidos por agricultores familiares.

Fonte: Elaborado pelos autores (2017).

Nas pesquisas de Real e Schneider (2011), apontam que ainda há municípios do Estado, que não conseguem atender a Lei, tendo em vista as inúmeras dificuldades encontradas no processo de aquisição destes alimentos. A investigação revelou que, no ano de 2016, haviam registrados um total 
de 2.300 alunos matriculados na rede pública de ensino e que todas as escolas recebiam alimentos provenientes da agricultura familiar; fato este que contribuiu para que a meta fosse atingida em sua totalidade.

E, conforme relatado pela nutricionista da Secretaria de Educação do município, a maior dificuldade está vinculada ao montante financeiro repassado, pois a alimentação que compõe o cardápio dos estudantes custa o dobro do recurso repassado Desta forma, o município precisa, na maioria das vezes, destinar uma complementação no montante de recursos financeiros, fato este que se configura como uma das grandes fragilidades reveladas nesse mercado alimentar.

Outra fragilidade apontada pelos entrevistados, tanto pelos agricultores locais, como pela nutricionista e igualmente pelo Presidente da COPRAN, reside na questão da logística dos alimentos. Muitos produtores alegaram que não existem vantagens quando se faz necessário a entrega direta dos produtos. Os mesmos relataram que necessitam dispor de seus próprios veículos para realizar o transporte. Tal prática incide em outros gastos, o que impacta diretamente na queda da lucratividade. Estes destacaram ainda outro elemento agravante: durante o período das chuvas as estradas, por diversas vezes, se tornam intransitáveis, haja vista que eles se encontram em Assentamentos distantes da cidade e que as despesas relacionadas ao transporte são arcadas por eles próprios.

Ainda sobre as dificuldades enfrentadas, os posicionamentos não caminham na mesma direção. Para a nutricionista, a dificuldade está na falta de planejamento da produção por parte dos agricultores familiares. A mesma se refere aos problemas que se relacionam com os fatores climáticos e que afetam diretamente os produtores. Muitas vezes, as intempéries climáticas fazem com que os agricultores percam toda sua produção. Já para o Presidente da Cooperativa, este possui uma visão e entendimento mais amplos no que se refere à estas questões. Entende ele que, o maior problema reside na ausência de instrução e de assistência especializadas destinadas aos agricultores familiares, pois muitas vezes esses produtores não dispõem de técnicas e conhecimentos que lhe permitam produzir um produto alimentício que seja atraente aos olhos do consumidor.

Também no entendimento do gestor, o pequeno produtor não dispõe de condições financeiras, que Ihe permitam uma a construção de uma estrutura adequada para a produção e como não recebem assistência técnica especializada, a consequência incide diretamente na qualidade da sua produção. $O$ produto final não tem o aspecto semelhante aos alimentos que são produzidos e comercializados por grandes produtores e vendidos em grandes mercados. O Presidente também se refere à necessidade de maior conscientização, por parte da população consumidora local, para com a agricultura familiar 
e sua importância no se que refere às garantias de segurança alimentar e suprimento nutricional contidos nos bens alimentícios, ofertados aos mercados, através das cadeias curtas de abastecimentos agroalimentares.

Para alguns produtores familiares existem outras barreiras. A própria burocratização também é uma dificuldade enfrentada por eles. Os agricultores que pertencem aos grupos informais (aqueles produtores que se unem e elaboram seus próprios projetos de venda) para que, assim, possam participar da chamada pública. Os produtores individuais também necessitam estar em conformidade com toda a documentação solicitada pela chamada pública. Assim, diante deste contexto, faz-se necessário destacar o baixo nível de conhecimento e de instrução dos agricultores familiares, realidade esta que imprime uma dificuldade maior no entendimento e cumprimento das exigências vigentes.

No que diz respeito à forma de pagamento, as respostas divergiram entre todos os atores entrevistados. Quando questionada sobre a forma de pagamento, a Coordenadora do Programa explica que os pagamentos são efetuados no prazo de quinze dias, após o recebimento dos produtos pelas escolas. Já o presidente da Cooperativa afirma que o prazo para efetuar o pagamento é normalmente um mês, após a entrega dos produtos. Já os agricultores familiares afirmam que o prazo para recebimento varia de um mês até seis meses. Estas discrepâncias nas informações vão ao encontro do fato da Prefeitura Municipal não dispor da verba necessária para realizar o pagamento no momento da entrega dos produtos alimentícios para a merenda escolar.

Logo, para os pequenos produtores rurais entrevistados, a morosidade nos repasses dos pagamentos constitui-se como uma vulnerabilidade e que põem dúvida à manutenção de tais relações. Para eles, a comercialização e o abastecimento dos produtos alimentares se configuram como uma complementação em suas rendas, haja vista que não há a garantia total do pagamento mediante a entrega dos alimentos e demais produtos processados. Se assim for, constata-se outro ponto relevante e frágil neste processo, uma vez que os recursos financeiros são determinantes em qualquer tipo de relação comercial e dinâmica de abastecimento alimentar.

Um exemplo que ratifica essa situação consiste no grupo de mulheres do Assentamento São Manoel, que realiza a entrega do pão de cumbaru, semanalmente. Elas relataram que se encontravam desmotivadas e desanimadas, pois o pagamento é efetuado apenas no fim do ano; sendo necessário que elas custeiem o valor da matéria prima, por todo esse período. Também informaram que o montante pago pelos produtos processados é considerado, por elas, abaixo do custo de produção, visto o trabalho necessário para a agregação de valor e produção do pão. 
Como mecanismo de alternativa, elas também comercializam seus produtos em uma feira livre, que é realizada, semanalmente, na cidade. Ainda de acordo com essas produtoras, elas não possuem forças e articulações necessárias para atuarem de forma direta nas decisões envolvendo produtores e Secretaria de Educação. Assim sendo, há que se considerar que estes fatores contribuem fortemente para o enfraquecimento do processo.

Contudo, as respostas dadas pelos respondentes da entrevista apontaram para a existência de sinergias. A relação existente entre os agricultores familiares locais e as escolas públicas municipais é descrita pela nutricionista como harmoniosa. As partes buscam proporcionar vantagens para ambos: escolas municipais que precisam ofertar a merenda alimentar com SAN e agricultores familiares. Ela ainda esclareceu que são realizadas reuniões com os produtores familiares para informar sobre esse canal de comercialização, ou seja, sobre essa dinâmica de abastecimento, bem como quais alimentos serão necessários produzir durante o ano, para que assim possa dar continuidade ao Programa.

A nutricionista afirmou que procura alternativas para negociação com os produtores quando esses, por alguma razão, não conseguem atender o que foi solicitado no contrato. São realizadas reuniões para que os agricultores familiares possam apresentar alternativas de substituir o produto, a exemplo o pão de castanha de cumbaru, quando é observado pelos produtores que não irão dispor da quantidade suficiente para atender as escolas municipais, durante o ano todo. Esse produto é substituído por outro, que passa previamente pelo teste de aceitabilidade dos estudantes. Após o teste, é informado para as merendeiras o alimento a ser substituído e que irá compor o cardápio escolar.

Outro aspecto positivo reside na divulgação realizada nas escolas municipais, a qual consiste em reuniões conduzidas pela nutricionista e que tem por objetivo levar ao conhecimento dos alunos o Programa de Alimentação. A ideia é que os estudantes repassem as informações sobre essa dinâmica de abastecimento e consumo aos seus pais, visto que muitos produtores locais têm seus filhos matriculados nestas escolas. Esta ação fortalece não apenas o processo de aquisição, como também informa para os alunos a origem e qualidade dos produtos. Esta ação contribui para uma maior aceitação e conscientização da importância da manutenção destes circuitos alimentares.

Quanto à verificação da qualidade do alimento ofertado, essa é realizada pelas profissionais que estão à frente da preparação dos alimentos, ou seja, as merendeiras das escolas, que observam a qualidade dos produtos que estão sendo entregues, bem como se os alimentos, as hortaliças, frutas, pães e leite estão apropriados para o consumo. Quanto às potencialidades existentes, os produtores locais, a 
nutricionista e o Presidente da Cooperativa da Colônia Pulador todos defenderam, amplamente, que a complementação de renda para os agricultores familiares, bem como a qualidade dos alimentos ofertados aos estudantes da rede municipal de ensino configuram-se como as mais significativas. Isso se justifica pelo fato de que a alimentação diferenciada proporciona mudanças nas práticas alimentares, haja vista a possibilidade de desenvolverem, nas crianças, hábitos alimentares saudáveis como o consumo diário de frutas, legumes e verduras, isentos de agrotóxicos.

Os produtores rurais dos Assentamentos justificaram a vantagem principal da complementação da renda, pelo fato de que o abastecimento às escolas municipais não permite que haja perdas dos alimentos, que são produzidos em suas terras. Outro aspecto positivo evidenciado é a consolidação desse mercado para a comercialização de seus produtos; fatos estes que se tornaram também uma forma de incentivo para os agricultores familiares expandirem e diversificarem suas culturas agrícolas, em bases sustentáveis. Afirmaram que, não obstante, toda a morosidade envolvida no processo de pagamento, o elemento central que sustenta a relação entre os produtores familiares e as escolas municipais e permitir assim a continuidade do processo é o estabelecimento de um vínculo de confiança. Mesmo com os constantes atrasos para se efetivar o pagamento e com todas as dificuldades apontadas, os produtores locais ainda carregam a certeza de que sempre receberão pelo seu trabalho na terra, o que para eles se configura como uma alternativa encontrada de não perder seus excedentes de produção e logrando um alargamento de suas rendas.

Ao longo da execução da pesquisa revelou-se que o relacionamento desenvolvido entre os agricultores familiares locais e a rede municipal de ensino escolar proporciona benefícios que extrapolam a complementação de renda dos produtores locais, tendo em vista que no momento em se legitimam os acordos comerciais, os montantes financeiros impactam sobremaneira no fortalecimento e dinamismo das economias locais. Os recursos destinados aos produtores são também direcionados para as práticas de consumo incrementando toda a cadeia do comércio local.

No município de Anastácio/MS, cabe destacar que a nutricionista realiza um trabalho de conscientização da importância da ingestão de alimentos saudáveis para a saúde das crianças, vinculando essa alimentação ao consumo dos alimentos abastecidos pela agricultura familiar. A ação da nutricionista consiste em realizar nas escolas municipais a Semana Vitaminada, cujos pais e alunos participam do projeto que busca orientar as crianças sobre a importância de uma alimentação equilibrada. Este fator é considerado relevante, tendo em vista à temática de se combater uma alimentação encontrada nos lanches das crianças que se caracteriza por serem pobres em nutrientes, 
repletos de corantes, conservantes, açúcares e que contribuem fortemente com as estatísticas nacionais no que se refere à obesidade infantil.

Diante deste contexto, permeado por conexões e relações ora amistosas, ora conflituosas e entendendo ser de suma importância a qualidade da alimentação escolar ofertada, acredita-se que esta investigação pôde cumprir com uma função social ao permitir novas indagações e reflexões por parte de todos os agentes envolvidos. Constatou-se que, além dos benefícios para com os agricultores familiares locais, que através do PNAE, passaram a se organizar, estrategicamente, em formas associativas, pensando em melhores resultados e em como expandir e diversificar suas rendas proporcionando também a eles melhorias nas condições da alimentação.

Assim, reconhece que o PNAE torna-se um importante instrumento de política pública que vem se robustecendo e ganhando força ao longo dos anos, apesar de ainda coexistirem fragilidades e desafios que necessitam da união de novos esforços coletivos, de estudos teóricos e práticos para que possam subsidiar a superação das deficiências inerentes aos processos de abastecimento de mercados agroalimentares.

\section{CONSIDERAÇÕES FINAIS}

Os diálogos e as discussões realizadas na esfera acadêmica acerca da segurança alimentar e nutricional, da incorporação dos circuitos curtos alimentares bem como a execução das políticas públicas nacionais na esfera municipal foram os elementos propulsores e norteadores para o surgimento desta investigação científica. Assim, inquietações e indagações motivaram inicialmente a leitura de outras pesquisas realizadas e, por fim, encorajaram o desenvolvimento do presente estudo. Desta forma, aqui investigou a conexão existente entre as escolas da rede municipal do município de Anastácio/MS juntamente com a Prefeitura Municipal e os agricultores familiares locais, com foco à perspectiva das compras públicas sustentáveis, via abastecimento e construção de mercados agroalimentares. O estudo permeou a investigação sobre os processos de aquisição de alimentos produzidos na perspectiva da segurança alimentar e nutricional, provenientes da agricultura familiar, para a elaboração da merenda escolar saudável fornecida aos estudantes da rede pública municipal.

Assim, buscou-se entender essa relação visando evidenciar as potencialidades conquistadas, bem como as fragilidades e deficiências percebidas inerentes a este processo que, dada sua natureza, envolve diversos agentes. Logo, ao se analisar os dados coletados foi possível compreender que ocorreram transformações e avanços nas políticas públicas direcionadas tanto para a agricultura 
familiar quanto para a educação, e em especial para as escolas municipais que oferecem os primeiros anos de ensino. A investigação permitiu inferir que o município de Anastácio/MS, ainda possui algumas fragilidades e deficiências, entre as principais destacam-se: a morosidade na realização dos pagamentos, via unidades executoras, para com os agricultores familiares, atrasos esses muitas das vezes ocasionado pela necessidade da Prefeitura Municipal precisar complementar o montante do preço final da alimentação proporcionada às escolas municipais.

Outro ponto constatado como vulnerável está assentado na ausência de protocolos relacionados à logística apropriada para a realização do correto transporte dos alimentos, em conformidade com as normas vigentes, partindo dos produtores rurais, dos Assentamentos até seus destinos finais: as instituições municipais de ensino. Ainda sob o enfoque das lacunas encontradas, faz-se necessário discorrer sobre as limitações constatadas para realização da pesquisa. Estas que se concentraram na dificuldade de acesso aos Assentamentos, haja vista que os arruamentos não possuem mínima estrutura, bem como na localização e disponibilidade dos agricultores familiares que comercializam seus produtos. Tendo em vista os inúmeros processos de luta e disputas pela conquista da terra, alguns agricultores familiares se negaram a fornecer as informações, sob a alegação de desconfiarem do teor da pesquisa; o que se confirma pela falta de conhecimento e nível de instrução de muitos deles.

Também pôde ser constatada uma deficiência por parte da Secretária de Educação em quantificar e mapear os produtores familiares rurais locais que comercializam seus produtos com o município, haja vista de não disporem de sistemas e ou softwares integrados, que poderiam, rapidamente, contribuir com o fornecimento de tais informações. Tanto a pesquisa bibliográfica quanto as entrevistas permitiram inferir que, desde 2010, o primeiro ano de obrigatoriedade da compra dos alimentos provenientes da agricultura familiar, com recursos do PNAE, muitos avanços ocorreram. Entretanto, ainda é possível identificar algumas fragilidades que precisam ser superadas. Para tanto, faz-se necessário o estabelecimento de agendas de discussão e que estas priorizem o diálogo com todas as partes envolvidas, especialmente, com os produtores familiares locais, que muitas vezes se autoexcluem dos processos, justamente por falta de conhecimentos técnicos e também devido a ausência de estratégias de aproximação.

Os dados da pesquisa apontaram também para a necessidade de construção de parcerias que envolvam as unidades executoras e os agricultores familiares, parcerias que ultrapassem o valor da obrigatoriedade e que contribuam efetivamente com o desenvolvimento local e regional, tendo em vista a importância da agricultura familiar para o abastecimento dos mercados e para a alimentação 
SAN de modo geral dos munícipes. Outros aspectos também devem ser analisados em estudos futuros, como por exemplo, propor mecanismos que se configurem como alternativas para o fortalecimento do processo vislumbrando não apenas garantir o desenvolvimento local, mas manter o objetivo do Programa, que consiste em garantir uma alimentação que atenda à segurança alimentar e às necessidades nutricionais da comunidade discente, tendo em vista a realidade do consumo de gêneros alimentícios dos brasileiros, que aponta para um perfil nutricional deficiente e fundado em uma má qualidade alimentar.

De qualquer forma, a presente investigação permitiu identificar o quão sensível são os agricultores familiares, sendo eles vinculados ou não à Cooperativa, organizados em grupos informais ou ainda individuais diante da questão da renda proveniente abastecimento agroalimentar junto às escolas municipais. Entendeu-se que a geração de renda, proveniente destas relações institucionais, configura-se com molas propulsoras para o dinamismo local e contribuem decisivamente com 0 desenvolvimento das economias locais e com a justiça socioambiental. As informações divergentes permitiram também inferir a presença de assimetria de informações entre eles, o que certamente resulta no enfraquecimento das relações contratuais. Assim, sugere-se que novos estudos sejam realizados no sentido de inicialmente provocar um enfretamento entre os pares, bem como de investigar como o PNAE tem sido executado nas demais cidades do Estado de Mato Grosso do Sul, quiçá no Brasil, visando mapear processos, potencialidades e desafios a serem superados.

\section{REFERÊNCIAS BIBLIOGRÁFICAS}

ACSELRAD, Henri; MELLO, Cecília Campello do A.; BEZERRA, Gustavo das Neves. O que é Justiça Ambiental. Rio de Janeiro: Garamond, 2009.

BRANCO, Telma Castello (Org.). Segurança Alimentar e Nutricional no Nordeste do Brasil. Algumas experiências. Ano 2, n. 2, 2005 (Coletânea CERIS, Ano 1, 2003).

BRASIL. Constituição da República Federativa do Brasil, de 5 de outubro de 1988, Disponível em: < http://www.planalto.gov.br/civil-03/constituição/constituição>. Acesso em: 25 fev, 2018.

. Fundo Nacional de Desenvolvimento da Educação (FNDE). Manual da aquisição dos produtos da agricultura familiar para alimentação escolar. Disponível

em: <file://C:/Documents\%20and\%20Settings/Carol/Meus\%20documentos/Downloads/pnae_man ual_aquisicao-de-produtos-da-agricultura-familiar_2_ed.pdf>. Acesso em: 27 fev, 2018.

. Lei no 8.666, de 21 de junho de 1992, que regulamento o art. 37, inciso XXI, da Constituição Federal, institui normas para licitações e contratos da Administração Pública e dá outras providências. Disponível em: < http://www.planalto.gov.br/ccivil_03/leis/l8666cons.htm>. Acesso em: mar, 2018. 
. Lei $n^{\circ} 8.913$, de 12 de julho de 1994, que dispõe sobre a descentralização da merenda escolar; revogada pela lei ordinária $n^{\circ} 11947 / 2009$. Disponível

em:<https://www.fnde.gov.br/fndelegis/action/UrlPublicasAction.phap?acao=abrirAtoPublico\&sgl_t ipo=LEI\&num_ato=010008913\&seq_ato $=000 \& v\left|r \_a n o=1994 \& s g\right|$ orgao=NI>. Acesso em: 27 dez, 2017.

. Lei no 11.326, de 24 de julho de 2006, que estabelece as diretrizes para a formulação da Política Nacional da Agricultura Familiar e Empreendimentos Familiares Rurais. Disponível em:< http://www.planalto.gov.br/ccivil_03/_ato2004-2006/2006/lei/l11326.htm>. Acesso em: mar, 2018.

. Lei no 11.947, de 16 de junho de 2009, que dispõe sobre o atendimento da alimentação escolar e do programa Dinheiro Direto na Escola aos alunos da educação básica. Disponível em: <http://www.fnde.gov.br/fnde/legislacao/leis/item/3345-lei-n\%C2\%BA-11947-de-16-de-junho-de2009 >. Acesso em: 20 jan, 2018.

- Ministério do Desenvolvimento Agrário (MDA). Secretária da Agricultura Familiar. Valor do Repasse FNDE por estado e município. Ano 2015. Disponível

em: < http://comunidades.mda.gov.br/portal/sal/arquivos/view/alimentação escolar/catalogo-AF-e AF-32587214.html>. Acesso em: 15 jan, 2018.

Ministério do Meio Ambiente (MMA). Compras Públicas Sustentáveis. Disponível em: < http://www.mma.gov.br/responsabilidade-socioambiental/a3p/eixos-

tematicos/licita\%C3\%A7\%C3\%A3o-sustent\%C3\%A1vel>. Acesso em: mar, 2018.

. Programa Nacional de Alimentação Escolar (PNAE). Programas e Projetos - PNAE- Alimentação Escolar histórico Disponível em:< http://www.fnde.gov.br/programas/alimentacaoescolar/alimentacao-escolar-historico>. Acesso em: 22 jun, 2017.

- Resolução FNDE $n^{\circ} 26$, de 17 de junho de 2013, que dispõe sobre o atendimento da alimentação escolar aos alunos da educação básica no âmbito do Programa Nacional de Alimentação Escolar (PNAE). Disponível em: <http://www.fnde.gov.br/fnde/legislacao/resolucoes/item/4620resolu\%C3\%A7\%C3\%A3o-cd-fnde-n\%C2\%BA-26,-de-17-de-junho-de-2013>. Acesso em: 10 fev, 2017.

BUAINAIN, Antonio Marcio; ROMEIRO, Ademar R.; GUANZIROLI, Carlos. Agricultura familiar e o novo mundo rural. Dossiê, Sociologias, ano 5, n. 10. Porto Alegre, 2003.

BUZBY, Jean; FOX, John A; READY, Richard C; CRUTCHFIELD, Stephen. Measuring consumer benfits of food safety risk regulation. Journal of Agriculture and Applied Economics. v. 30, n. 1, Cambridge University Pres, 1998.

CAMARGO, Regina Aparecida leite de; BACCARIM, José Giocomo; SILVA, Denise Bonito Pereira da. O papel do Programa de Aquisição de Alimentos (PAA) e do Programa Nacional de Alimentação Escolar (PNAE) no fortalecimento da agricultura familiar e promoção da

segurança alimentar. Temas de Administração Pública. vol. 8, n. 2, 2013. Disponível em:< https://periodicos.fclar.unesp.br/temasadm/article/view/6846>. Acesso em: fev, 2018. 
CASWELL, Julie A. Valuing the benefits and costs of improved food safety and nutrition. The Australian Journal of Agricultural and Resource Economics. v. 42, n.4, p. 409-424

Colocar os agricultores familiares em primeiro para erradicar a fome. Roma 2014. Disponível em: http://www.fao.org/news/story/pt/item/260821/icode/ . Acesso em: Set, 2017.

CRUZ, Fabiana Thomé da; MATTE, Alessandra e SCHNEIDERM Sérgio (Org.). Produção, consumo e abastecimento de alimentos: desafios e novas estratégias. Porto Alegre: Editora da UFRGS, 2016.

FINOCCHIO, Caroline Pauletto Spanhol; LIMA-FILHO, Dario de Oliveira; LIMA, Maria de Fátima Evangelista Mendonça. Escolha Alimentar. O papel da Intergeracionalidade. Campo Grande-MS: Ed. UFMS, 2015.

GIL, Antonio Carlos. Como elaborar projetos de pesquisa. 5. ed. São Paulo: Atlas, 2016.

GUANZIROLI, C.; CARDIM, S. E. (Coord.). Novo Retrato da Agricultura Familiar: O Brasil redescoberto. Brasília: Projeto de Cooperação Técnica FAO/INCRA, fev.2000. Disponível

em: <http://www.incra.gov.br/fao/pub3.html>. Acesso em: jan, 2018.

HENSON, S; TRAILL, B. The demand for food safety. Market imperfections and the role of government. Food Policy. v. 18. . 1, p. 151-162. Elsevier, 1993.

INSTITUO BRASILEIRO DE GEOGRAFIA E ESTATÍSTICA (IBGE). Cresce o número de municípios no Brasil. Ano 2018. Disponível em: < http://www.brasil.gov.br/economia-e-emprego/2013/06/cresce-numerode-municipios-no-brasil-em-2013>. Acesso em: mar, 2018.

KROEFF, Denise Reif. Ministério do desenvolvimento social e combate à fome. SeSan/Decon. Departamento de apoio a aquisição e a comercialização da produção familiar, 2014. Compra Institucional + Desenvolvimento local. Disponível

em:<http://www.mds.gov.br/segurançaalimentar/aquisiçãoecomercialização-da-agriculturafamiliar>. Acesso em: 20 jan, 2018.

MALUF, Renato Sérgio Jamil. Segurança alimentar e nutricional. 3. ed. São Paulo: Vozes, 2011.

MARCONI, Marina de Andrade; LAKATOS, Eva Maria. Metodologia científica: ciência e conhecimento, métodos científicos, teoria, hipóteses e variáveis, metodologia jurídica. 6. ed. rev. e ampl. São Paulo: Atlas, 2011.

MARTINELLI, Suellen Secchi. Potencialidades da compra institucional na promoção de sistemas agroalimentares locais e sustentáveis: O caso de um restaurante universitário. Segurança alimentar e nutricional, Campinas, 2015. Disponível

em: <http://periodicos.sbu.unicamp.br/ojs/index.php/san/article/view/8641574/9074>. Acesso em: $05 \mathrm{fev}, 2018$.

NEVES, Marcos Fava; ZYLBERSZTJN, Décio e NEVES, Evaristo Marzabal. Agronegócio do Brasil. São Paulo: Saraiva, 2005.

ORTIZ, R. Mundialização e cultura. 2. ed. São Paulo: Brasiliense, 1994. 
REAL, Luciana C. Vilela; SCHNEIDER, Sergio. O uso de programas público de alimentação na reapromixação do pequeno produtor com o consumidor. O caso do Programa de Alimentação Escolar. Disponível em:< http://www.univates.br/revistas/index.php/estudoedebate/index>. Acesso em: 10 fev, 2018.

SCHNEIDER, Sergio. Agricultura familiar e pluriatividade. Tese (Doutorado em Sociologia). Universidade Federal do Rio Grande do Sul - UFRGS, Porto Alegre, 1999.

. A Pluriatividade na Agricultura Familiar. 2. ed. Porto Alegre: UFRS, 2009.

SILVA, José Graziano da. O Novo Rural Brasileiro. Campinas-SP: Instituto de Economia\Unicamp, 1999. (Coleção Pesquisas 1).

SPERS, Eduardo Eugênio. A segurança alimentar ao longo da cadeia. Conjuntura alimentos, v. 5. n. 1, fev, p. 18-26.

Mecanismos de regulação da qualidade e segurança dos alimentos. Tese de Doutorado (Doutorado em Administração). Universidade de São Paulo (USP). São Paulo, 2003.

; ZYLBERSZTAJN, Décio. Public and Private Mechanisms in Food Safety. In: ZYLBERSZTAJN, Décio e OMTA, Onno. Advances in suplly chain analysis in agri-food systems. São Paulo: Editora Singular, 2009.

TRIBUNAL DE CONTAS DA UNIÃO (TCU). Licitações \& Contratos: Orientações e jurisprudência do TCU. 4. ed. Brasília: Secretária Especial de Editoração e Publicação, 2010.

TEIXEIRA, Marco Antônio Carvalho. Estado, Governo e Administração. Pública. Rio de Janeiro: FGV, 2012.

TRICHES, Rozana. Marcia e SCHNEIDER, Sergio. Alimentação Escolar e Agricultura Familiar: reconectando o consumo à produção. v. 19, n.4, p. 933-945. Revista Saúde e Sociedade. São Paulo, 2010. Disponível em: <http://www.scielo.br\pdf\sausoc〈v19n4\19.pdf>. Acesso em: 20, jan, 2018.

ZYLBERSZTAJN, Décio. Caminhos da agricultura brasileira. São Paulo: Atlas, 2011.

ZYLBERSZTAJN, Décio e OMTA, Onno. Advances in suplly chain analysis in agri-food systems. São Paulo: Editora Singular, 2009. 


\section{Capítulo 15}

O PROCESSO DE TOMADA DE DECISÃO E O EFEITO FRAMING: UM ESTUDO DE CASO NA COMUNIDADE QUILOMBOLA DO RAMAL DO CASTELO NA REGIÃO DO MARUPAÚBA, TOMÉAÇU/PA

DOI: $10.37423 / 200300411$

Josue De Lima Carvalho-josuecarvalho911@gmail.com Ticiane Lima Dos Santos - ticiane.ufra@gmail.com 


\section{INTRODUÇÃO}

Toda organização, para crescer e sobreviver no mercado precisa tomar decisões, e estas nem sempre são simples ou obtém sucesso. Uma escolha errada pode comprometer todo o futuro de uma entidade, causando grandes impactos ou até mesmo o fim de sua existência. Kahneman e Tversky apud Pontes et al. (2014) afirmam que um indivíduo possui decisões diversificadas no momento que se depara com diferentes elaborações de um mesmo problema. Os referidos autores desenvolveram a Teoria do Prospecto que objetiva estudar o processo decisório em diferentes situações, assim como aos relacionados com o efeito framing.

Para Mayer e Avila (2003), o efeito framing é a chance de influenciar um indivíduo em sua tomada de decisão, com mudanças em sua formulação, mas perante um mesmo problema. Nesse sentido, a decisão acaba sendo, em parte, monitorada pela forma de como é exposto o problema.

Na literatura acadêmica diversos autores tratam sobre como o indivíduo e/ou grupo se relacionam com a agricultura e a exploração de recursos naturais, sendo que através de uma breve definição pode se considerar essa relação como a artificialização pelo homem do meio natural, representado como todas as atividades de exploração das terras (BARROS, 1975). As práticas agrícolas são comuns a diversos grupos de diversas regiões do Brasil, com o intuito de fortalecer essas práticas a tomada de decisão se demonstra como uma ferramenta essencial de controle e gerenciamento, independentemente do tipo de produção ou das características de quem a pratica.

Entre os muitos praticantes de atividades rurais, as comunidades e povos tradicionais também se utilizam desse meio para a sua subsistência. Podem ser definidos de acordo com Decreto no 6.040/2007 como grupos que são diferenciados culturalmente, e se reconhecem como tais. Esses grupos possuem suas próprias formas de organização social, ocupando e usufruindo de territórios que são condicionados para a sua reprodução cultural, social, religiosa, ancestral e econômica, utilizando os seus conhecimentos, inovações e práticas gerados para a transmissão pela tradição (BRASIL, 2007). Conforme estudo feito por (SILVA E SOUZA, 2009) se estimam no Brasil que atualmente 4,5 milhões de pessoas pertencem a comunidades tradicionais, e ocupam cerca de $25 \%$ do território nacional.

Dentre as diversidades de povos tradicionais, este trabalho tem por objeto de estudo investigar a importância da figura dos povos quilombolas e as suas relações com o processo de tomada de decisão diante de problemas propostos. Esses grupos étnicos também são conhecidos como "Comunidades 
Remanescentes Quilombolas" são constituídas pelos descendentes dos escravos negros que, no processo de resistência à escravidão, originaram grupos sociais que ocupam um território comum e compartilham características culturais, sociais e econômicas até os dias de hoje. (FUNDAÇÃO PALMARES, 2007)

A tomada de decisão como já exposto, possibilita ao gestor opções de melhor gerenciamento em decisões cujo teor é a aplicação e o retorno dos recursos, sejam eles financeiros, matéria prima, entre outros. Com base nesse pressuposto, é possível ressaltar a importância que a tomada de decisão gera a qualquer empreendimento, mesmo que seja de pequeno porte. Eis estão a oportunidade de gestores rurais em utilizar essa ferramenta no seu dia a dia, para alavancar financeiramente seus resultados, promovendo também um controle efetivo de matéria prima, recursos naturais, e gastos relacionados às atividades agrícolas.

Sendo assim, a pesquisa objetiva analisar a influência da Teoria dos prospectos e o efeito framing, na perspectiva de ganhos e perdas, no processo de tomada de decisão na comunidade quilombola ramal do Castelo na região do Marupaúba, localizada no município de ToméAçu/PA.

\section{FUNDAMENTAÇÃO TEÓRICA}

\subsection{COMUNIDADES TRADICIONAIS}

O processo de colonização portuguesa a partir do século XVI plasmou características marcantes na população rural, criando um modelo de adaptação ao meio, apesar das diferenças regionais, percebese de acordo com (ARRUDA, 1999) que essas comunidades tradicionais possuem características em comum que ainda hoje marcam esses grupos isolados em distintas regiões do Brasil. $\mathrm{O}$ autor ressalta ainda que esse fato se deve a grande influência de populações indígenas e ao caráter cíclico e irregular do avanço da sociedade nacional sobre o interior do país.

Através do decreto 6.040/2007 se aferiu definições relevantes as comunidades tradicionais e como se dá o seu relacionamento com o ambiente ao redor delas. No Art. 3ำ, inciso II, se define os territórios tradicionais como sendo os espaços necessários para que os grupos se reproduzam culturalmente, socialmente e economicamente, seja de forma temporária ou permanente. Ainda no Art. 3으, no inciso III, o decreto explica a relação dos grupos tradicionais com o desenvolvimento sustentável com intuito de garantir a melhoria da qualidade de vida da geração, progredindo até as futuras gerações. 
Em anexo ao decreto se encontra a Política Nacional de Desenvolvimento de Povos e Culturas Tradicionais que tem grande importância na garantia de direitos sociais desses povos, o que bem se pode identificar junto ao seu objetivo:

A PNPCT tem como principal objetivo promover o desenvolvimento sustentável dos Povos e Comunidades Tradicionais, com ênfase no reconhecimento, fortalecimento e garantia dos seus direitos territoriais, sociais, ambientais, econômicos e culturais, com respeito e valorização à sua identidade, suas formas de organização e suas Instituições. (DECRETO № 6.040, 2007).

As técnicas de plantio desenvolvidas por esses grupos também sofrem fortes influências da população indígena (roça consorciada, itinerante, com base na queimada, tipo slash-andburn) e de artefatos como as peneiras, os pilões, o ralo, o tipiti e outros implementos que fazem parte da cultura rústica brasileira. (ARRUDA, 1999)

\subsubsection{COMUNIDADES QUILOMBOLAS}

O termo quilombo possivelmente se refere a um conceito próprio dos africanos bantos que vem sendo modificado através dos séculos, o significado está relacionado a acampamentos de guerreiros nas florestas.

Na tradição popular no Brasil há muitas variações no significado da palavra quilombo, ora associado a um lugar ("quilombo era um estabelecimento singular"), ora a um povo que vive neste lugar ("as várias etnias que o compõem"), ou a manifestações populares, ("festas de rua"), ou ao local de uma prática condenada pela sociedade

("Iugar público onde se instala uma casa de prostitutas"), ou a um conflito (uma "grande confusão"), ou a uma relação social ("uma união"), ou ainda a um sistema econômico ("localização fronteiriça, com relevo e condições climáticas comuns na maioria dos casos") (Lopes, Siqueira e Nascimento 1987: 15). A vastidão de significados,12 como concluem vários estudiosos da questão,13 favorece o seu uso para expressar uma grande quantidade de experiências, um verdadeiro aparato simbólico a representar tudo o que diz respeito à história das américas. A conquista da América não produziu uma única história; produziu, sim, "árvores de histórias". Os negros estavam inseridos no movimento colonial de "descobrir, resgatar, povoar e governar - só que como povos dominados" (GIUCCl, 1992)

O quilombo no Brasil teve a sua origem na época colonial como representação a resistência dos africanos ao escravismo praticado no período. E retorna à cena política no final dos anos 70 , durante a redemocratização do país. Trata-se, portanto, de uma questão persistente, tendo na atualidade importante dimensão na luta dos afrodescendentes. (LEITE, 2000) 
Como já foi supracitada, a divisão territorial é uma característica marcante principalmente na zona rural nacional, contudo os povos de descendência africana não foram contemplados na primeira lei das terras em 1850. Somente a partir da Constituição Federal 1988, foram promulgadas as Disposições Transitórias que preveem o reconhecimento da propriedade das terras dos "remanescentes das comunidades dos quilombos"

\subsection{TEORIA DOS PROSPECTOS}

Os indivíduos possuem decisões diversificadas a cada nova situação, e podem mudar de acordo com a apresentação do problema (LIMA, 2003). Dessa forma, várias são as teorias que nasceram com objetivo de explicar a influência que existe na forma de demonstrar o problema sobre a tomada de decisão do ser humano.

Nesse segmento, a teoria dos prospectos tem a sua importância no momento em que demonstra os vieses de percepção dos tomadores de decisão a contar de sua familiaridade com contextos problemas e conteúdos relativos a eles.

A teoria dos prospectos forma um apoio teórico essencial, no que diz respeito ao entendimento comportamental dos indivíduos. Macedo e Fontes (2009) entendem que esta teoria é capaz de esclarecer vieses intelectivos no processo decisório, tornando-se assim uma importante base às finanças.

Ainda no entendimento de Macedo e Fontes (2009), a decisão possui papel fundamental em uma organização, seus reflexos podem ser os melhores casos consiga resolver o problema, além de possuir a capacidade de afetar diretamente a vida de muitos indivíduos envolvidos.

A teoria de Kahneman e Tversky (1979) é um exemplo de teorias que objetivam uma melhor compreensão no momento da decisão, em relação ao comportamento do tomador de decisão.

Segundo a teoria dos prospectos no que diz respeito à Mineto (2005), o indivíduo possui duas fases de utilização no processo decisório, são elas: a fase de edição dos prospectos de risco e a fase de avaliação dos mesmos. A primeira fase equivale a um primeiro exame das possibilidades que são oferecidas no momento da exposição das possibilidades. A segunda fase acontece a avaliação dos prospectos editados, sendo escolhido o de maior valor. 
Os psicólogos Kahneman e Tversky (1979) desejavam entender como as pessoas realizam escolhas de risco, desde as opções intuitivas sem considerar nada em relação à racionalidade delas. A teoria dos prospectos surgiu como uma opção à teoria da utilidade esperada, sendo a certeza do que claramente as pessoas dão importância, sendo capaz de influenciar em suas decisões, não é a consequência esperada de sua escolha, mas sim as suas diferentes atitudes perante ganhos e perdas.

Conforme Lima (2003), a teoria dos prospectos, em sua essência, relata distintos estados mentais que são capazes de influenciar no processo decisório. Nesse sentido, a repugnância ao risco acontece somente quando se trata de ganhos, mas a partir do momento em que se fala em probabilidade de perda, há uma tendência em que a pessoa se arrisque.

Kahneman e Tversky (1979) afirmam que as pessoas possuem duas fases diferentes para decidir algo. A primeira fase é a edição do problema conforme as regras que servem para facilitar o processo decisório, e a segunda fase o tomador de decisão distribui padrões e princípios e opta pelo prospecto de maior valor.

A teoria dos prospectos surgiu como uma crítica aos modelos de processo decisório e está fundamentada pela razão de que para o igual valor de ganhos e perdas, o entendimento de valor em condições de perdas é claramente maior do que em condições de ganhos associados. (SANTOS; BOTELHO, 2011)

\subsection{EFEITO FRAMING.}

O efeito de enquadramento, ou efeito framing, se refere ao fato de que o processo decisório pode ser influenciado pelo modo como o problema é retratado e como as opções são expressas. De acordo com Mayer e Avila (2010), o efeito framing é a chance de influenciar a decisão de uma pessoa, apresentando as informações de modo verdadeiro, sem alterações, mas com mudanças sutis em sua forma, em um mesmo problema.

Kahneman e Tversky (1979) desenvolveram a Teoria do Prospecto (ou teoria da perspectiva), como forma de resposta aos modelos normativos do processo de tomada de decisão. O efeito framing foi formulado nesta teoria de Kahneman e Tversky (1979) e interpreta a presença de diferentes respostas das pessoas perante um mesmo problema decisório devido às mudanças no método de expor o problema. De acordo com os autores, o indivíduo muda de postura pela forma de como é apresentado o problema. 
De acordo com Carvalho Junior, Rocha e Bruni (2010), o efeito framing determina a noção de que o indivíduo possui diferentes respostas a um mesmo problema desde que haja alterações em sua exposição. Já para Ferreira Jr (2012), o jeito como a pessoa compreende o problema está relacionado com diferentes variáveis ambientais, são elas os hábitos da pessoa ou sociedade em geral, o código de ética acordado, as normas e leis, entre outros.

No entendimento de Daft apud Longaray e Beuren (1999), são várias as situações que influenciam no processo decisório, logo as pessoas precisam estudar melhor as probabilidades de errar, levando em consideração diferentes variáveis como: certeza, incerteza, risco e imprecisão.

Kahneman e Tversky (1979) desenvolveram um exemplo sobre o modo de anunciar um problema. Trata-se de como comunicar o impacto de uma epidemia na cidade.

Acham-se dois planos para conter certa enfermidade que foi responsável pela infecção de seiscentas pessoas e é necessário que você opte por um desses planos. Se optar pelo primeiro plano, é provável que duzentas pessoas sejam salvas, entretanto se escolher a segunda opção há uma possibilidade que um terço sejam salvos, porém dois terços perdem a vida. Qual sua decisão quantos as duas opções?

Verificou-se que a maior parcela de indivíduos preferiu o primeiro plano. Porém, e a situação fosse apresentada como a opção entre um terceiro plano, no qual quatrocentas pessoas perderiam a vida, e um quarto plano que seiscentas pessoas morreriam, tendo dois terços de chance, e livra todas as seiscentas com apenas um terço de chance, a maioria dos indivíduos preferem o quarto plano.

Nota-se que estamos falando de um mesmo problema, no entanto, estruturado de um jeito diferenciado, o que afetou na tomada de decisão de muitas pessoas.

\subsubsection{RISCO E RETORNO}

Conforme definição de Levin, Gaeth e Schreiber apud Martins et al. (2013) "Há três tipos de efeito framing: o de atributo que se refere ao sucesso e ao insucesso; o de Objetivo que se refere a à mensagem persuasiva e o efeito framing de escolha sob o risco. A relação de risco e retorno está intimamente ligada a diversas organizações, principalmente aquelas ligadas a finanças, diariamente grandes e pequenos investidores trabalham seu capital com o intuito de receber ganhos e evitar perdas. 
Ao se analisar estudos anteriores com essa temática, percebe-se que de um modo geral se chegou a um denominador comum no sentido que os investidores/tomadores de decisão "são afetos ao retorno, mas não aos riscos, o que leva a conclusão que somente investem em ativos mais arriscados, se esperarem obterem maior retorno nesse investimento. " (MARTINS et al., 2012)

Segundo Markowitz apud Macedo Jr (2003) risco define-se como uma variável eventual e se refere ao modo como risco e retorno reagem no momento em que ativos suplementares são incluídos a uma carteira.

Em todo momento decisões são tomadas sem muitos obstáculos, e estas geralmente têm seus resultados simples de calcular. Todavia nem todo processo decisório obtém sucesso, isso quando decisões são tomadas erroneamente, causando severas consequências.

O indivíduo, quando deparado com uma situação de risco, ou possui seu retorno incerto, não ordena suas escolhas de um modo que caracterize seus problemas. Pompian (2006) diz que as pessoas preferem métodos menos racionais, em um experimento de estabelecer o sentido da ação, conforme suas necessidades básicas.

Kahneman e Tversky (1979) entendem que a aversão à perda tem como base a apuração de que o indivíduo sofre mais com uma perda do que a satisfação de obter um ganho. Nesse sentido, observase que o ser humano não teme tanto ao risco, mas à perda.

Ainda no entendimento de Kahneman, a aversão à perda é concedida ao fato de que há uma maior atenção para os prejuízos do que para os ganhos, logo, esse comportamento tende a influenciar no processo decisório de várias maneiras.

As pessoas tendem a assumir riscos no interesse de não perder, isto é, tratando-se de vantagens o indivíduo tem aversão ao risco, porém perante uma probabilidade de perda, há uma aversão à perda (DAFT, 1999) apud Longaray e Beuren (1999).

É comum observar que um grande número de indivíduos não tem interesse em arriscarse objetivando um ganho, principalmente quando este ganho implique em possibilidade de perdas. As pessoas preferem perspectivas confiáveis, certas. 


\subsection{TOMADA DE DECISÃO}

O processo decisório é um processo intelectivo resultante da escolha de uma alternativa em meio a várias outras. Para Mintzberg et al apud Façanha (2007, p. 32)

"o processo de tomada de decisão é um conjunto de ações e elementos dinâmicos que começa com o reconhecimento de um estímulo que exige ação e finaliza com uma decisão."

Desse modo, tomar decisão está intimamente interligado com escolhas, para que essas escolhas possam ser satisfatórias, se faz necessárias informações tempestivas e confiáveis. O processo de escolha muitas vezes é dificultado pela escassez de informação que o sustente (PONTES et al, 2013), quanto mais escassas essas informações, mais difícil é para tomar uma decisão. Surge então a oportunidade da utilização das ferramentas gerenciais, que possibilitam ao tomador uma oportunidade de encontrar uma base para a sua decisão.

Segundo Pereira e Fonseca (1997), a decisão é um procedimento sistêmico, contraditório e contextual, impossibilitada de ter sua análise isolada das circunstâncias que a contornam. O que significa que a tomada de decisão não é um processo que se trabalha de maneira isolada, antes para que se possa tomar uma decisão, se faz necessário analisar cada ponto relevante se utilizando do método de visão holística, a fim de definir qual seria a escolha mais "satisfatória"

A forma como a decisão é estruturada representa a percepção do tomador de decisão sobre o elemento essencial que compõem a mesma, para se definir essa percepção se faz necessário entender fatores que influenciam o indivíduo, sejam eles: culturais, pessoais e/ou psicológicos. (SERPA E AVILA, 2014)

Conforme as informações supracitadas, a tomada de decisão é um processo que se comporta de maneira diferenciada, a depender do indivíduo e como o mesmo se relaciona com o ambiente e as situações ao seu redor.

Koontz e O’Donnell (1972) reconhecem a tomada de decisão como sendo o planejamento administrativo, diferente de Simon (1970) que compreende como sendo um processo administrativo. De acordo com Lucena et al. (2011), as probabilidades envolvendo um processo de decisão podem ter vários focos, ainda que os resultados apresentados sejam parecidos. 
Existem duas teorias principais de tomada de decisão, são elas as teorias racionais e as teorias não racionais. As teorias racionais são de primazia normativa, enxerga o tomador de decisão como uma pessoa de firmeza, já as teorias não racionais são de primazia descritiva, com heurísticas como processo intelectivo, apresentando um formato mais concreto dos processos de tomada de decisão.

Kahneman e Tversky (1979) criticaram a teoria da racionalidade ilimitada do indivíduo. Para eles, a pessoa usa de unidades de natureza humana quando encontram incertezas e situações arriscadas. Alegam ainda que há uma disposição de que os indivíduos apresentam mais repugnância ao risco do que ao ganho, ou seja, não arriscam trocar o certo pelo duvidoso, optando por um ganho pequeno, porém certo, do que um ganho superior, mas com possibilidade de não o alcançar.

\section{PROCEDIMENTOS METODOLÓGICOS}

\subsection{CARACTERÍSTICAS GERAIS}

Trata-se de uma pesquisa classificada como descritiva com dados analisados de forma quantitativa, pois foram aplicados questionários elaborados com perguntas relacionadas ao processo decisório e o efeito framing na comunidade quilombola estudada.

O objetivo da pesquisa descritiva é a análise, observação e registro dos fatos, sem que haja a intervenção dos pesquisadores. Perovano (2014) diz que a pesquisa descritiva pode ser compreendida como um estudo de caso em que, após colher os dados, realiza-se um estudo do elo entre as variáveis para mais tarde acontecer a definição dos impactos consequentes em uma organização.

\subsection{LÓCUS}

O estudo foi realizado em uma comunidade quilombola situada no município de ToméAçu/PA, na rodovia PA 140, comunidade Castelo. A comunidade se localiza na região do Marupaúba a aproximadamente $38 \mathrm{~km}$ da sede do município de Tomé-Açu. Foram aplicados questionários a 40 famílias da região, sendo esse o universo total da população, com $100 \%$ de respostas. 
Figura 01: Mapa da Comunidade Ramal do Castelo.

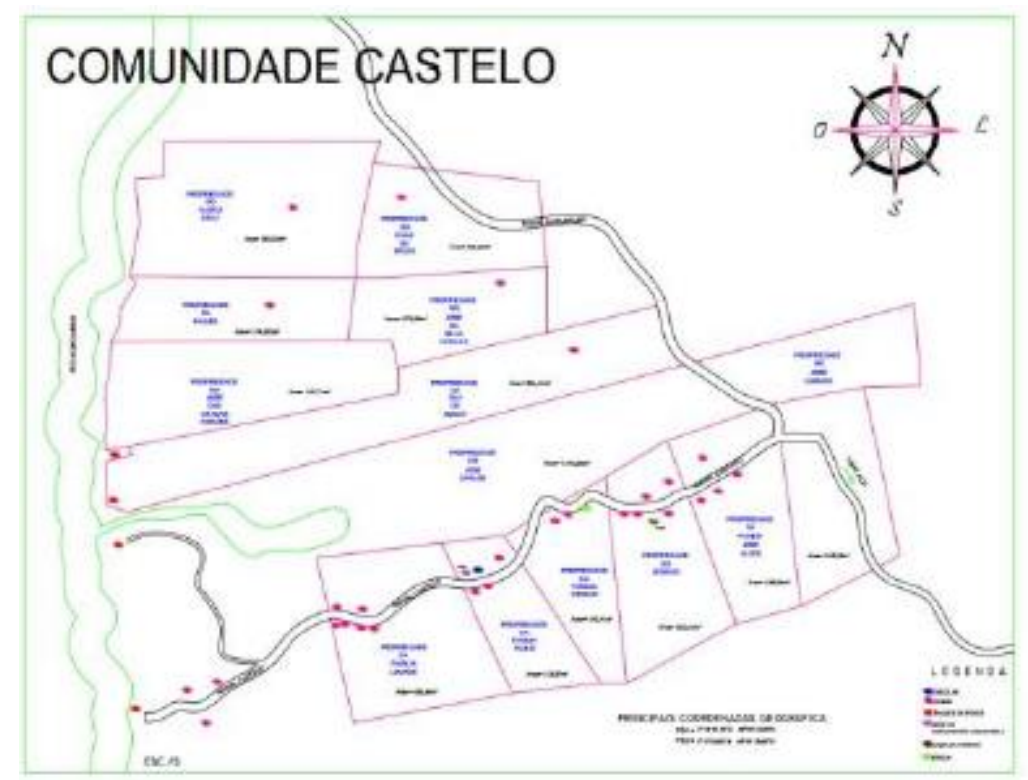

Fonte: Projeto de Pesquisa Governança e Modelos de Gestão de Recursos Comuns em Propriedades Comunais na Amazônia Paraense.

\subsection{COLETA DE DADOS}

A coleta de dados foi realizada através de dados tabulados de dois questionários distribuídos no local, estes baseados em Barreto et al. (2013). Para se chegar ao objetivo dessa pesquisa foram elaboradas diversas perguntas, e entre elas métodos de organização e controle para o exercício da atividade agrícola.

Os questionários foram elaborados com perguntas que mostram como as pessoas reagem ao efeito de enquadramento, com os mesmos problemas, entretanto apresentados de forma diferente, em situação de perdas e prejuízos e ganhos e vantagens, com objetivo de entender se o comportamento das famílias quilombolas estudados é influenciado perante as diferentes formas de expor o mesmo problema.

Em ambos os questionários (Tipo I e Tipo II), se intentou verificar os vieses relativos as escolhas, sendo que os mesmos possuem as mesmas perguntas, diferenciando na forma de apresentação das alternativas, uma em forma de ganho e outra em forma de perda. (Quadro 01). 


\section{Quadro 01 - Questionário da pesquisa.}

1-Você investiu $\$ 300,00$ (mão de obra) na sua produção de farinha de mandioca. Devido a uma enchente você deverá arcar com alguns custos. Algumas medidas deverão ser tomadas a fim de minimizar as perdas causadas pela "catástrofe". Escolha a alternativa (A ou B) que achar mais conveniente.

Tipo I

( ) Alternativa A: $40 \%$ de chances de recuperar $\$ 100,00$ e $60 \%$ de chances de recuperar $\$ 0$

( ) Alternativa B: $42 \%$ de chances de recuperar $\$ 100,00$ e $58 \%$ de chances de recuperar $\$ 0$

Tipo II

() Alternativa A: $40 \%$ de chances de não recuperar $R \$ 200,00$ e $60 \%$ de chances de não recuperar $\mathrm{R} \$ 300,00$

() Alternativa B: $42 \%$ de chances de não recuperar R $\$ 200,00$ e $58 \%$ de chances de não recuperar $\mathrm{R} \$ 300,00$

2-Você produziu uma quantidade de farinha de mandioca que pode lhe render $\mathrm{R} \$ 3.000,00$ em condições normais de mercado, porém a produção está em alta e o preço que o atravessador paga está bem abaixo do normal praticado. Diante disso the surgem duas opções:

\section{Tipo I} venda

( ) Plano A: Se essa opção for adotada, consegues receber R\$ $1.000,00$ nessa

( ) Plano B: Se essa opção for adotada, há $1 / 3$ de probabilidade de que consiga receber os $\mathrm{R} \$ 3.000,00$ e $2 / 3$ de probabilidade de perder toda a produção.

Tipo II

() Plano A: Se essa opção for adotada, R\$ 2000 mil serão perdidos.

() Plano B: Se essa opção for adotada, há $1 / 3$ de probabilidade de que nada seja perdido e $2 / 3$ de probabilidade de que tudo seja perdido.

3. Através de um esforço coletivo em prol da construção de uma sede para a associação a comunidade conseguiu produzir o suficiente pra render um montante de R\$ $5.000,00$, porém como a produção foi muito acima do que a demanda pode absorver, surgem 3 opções que podem ajudar a recuperar parte desse esforço envolvido

\section{Tipo I} de poupar $\mathrm{R} \$ 0$

() Alternativa A: $10 \%$ de chances de recuperar $\mathrm{R} \$ 4.500,00$ e $90 \%$ de chances

() Alternativa B: $45 \%$ de chances de recuperar $\mathrm{R} \$ 1.500,00$ e $55 \%$ de chances de poupar R\$0

() Alternativa C: $90 \%$ de chances de recuperar $\mathrm{R} \$ 500,00$ e $10 \%$ de chances de poupar R\$0

Tipo II

() Alternativa A: $10 \%$ de chances de perder $\mathrm{R} \$ 500,00$ e $90 \%$ de chances de perder $\mathrm{R} \$ 5.000$

( ) Alternativa B: $45 \%$ de chances de perder $\mathrm{R} \$ 3.500,00$ e $55 \%$ de chances de perder $\mathrm{R} \$ 5.000$

( ) Alternativa C: $90 \%$ de chances de perder $\mathrm{R} \$ 4.500,00$ e $10 \%$ de chances de perder $\mathrm{R} \$ 500.00$

Fonte: Própria adaptado de bareto et. Al. (2013) 
Na tabulação dos dados do questionário foi utilizado o software da IBM SPSS 20, em conjunto com o Software Action Stat integrado ao Microsoft Excel 2016.

\subsection{ANÁLISE E INTERPRETAÇÃO}

Conforme expresso nessa metodologia, a análise dos dados foi baseada no estudo de Barreto et al. (2013), sendo que o instrumento de análise se baseou a partir de uma contagem de frequências para cada alternativa das perguntas. Para se testar as hipóteses, se fez necessário utilizar como base o teste de diferenças de proporções apresentado por Stevenson (1981), utilizando como níveis de significância de $5 \%$ a 10\%, devendo respeitar o valor de $Z$ em um teste unicaudal, utilizando os níveis $-1,64$ ou $+1,64$ a $5 \%$ de significância e -1.28 ou $+1,28$ a $10 \%$ de significância.

Na formulação das nossas hipóteses, utilizando como base Barreto et al. (2013), se estabeleceu duas hipóteses bases, sendo elas:

- HO: A proporção da escolha de A ou B no questionário Tipo I é igual a proporção no questionário II;

- H1: A proporção da escolha da opção de maior certeza no questionário descrito no campo de ganhos é maior que a mesma opção no questionário tipo II, no campo de perdas.

\section{RESULTADOS}

\subsection{CARACTERÍSTICAS DA AMOSTRA}

Através da análise do universo dessa pesquisa, constatou-se conforme a (Tabela 01) que dentre os respondentes do questionário $100 \%$ cem por cento pertence a Comunidade Castelo, sendo 55\% da amostra do sexo feminino e $45 \%$ do sexo masculino.

Tabela 01: Distribuição de gênero dos entrevistados

\begin{tabular}{|l|l|l|}
\hline Feminino & $\mathbf{2 2}$ & $\mathbf{5 5 \%}$ \\
\hline Masculino & 18 & $45 \%$ \\
\hline Total & 40 & $100 \%$ \\
\hline
\end{tabular}

Fonte: Própria. 
Dentre a frequência da idade apresentada aos respondentes, constatou-se que: 22,5\% (4 entrevistados) da amostra se encontra na faixa de 23 a 27 anos, 5\% 2 entrevistados) de 28 a 32 anos, 10\% (4 entrevistados) de 33 a 37 anos, 15\% (6 entrevistados) de 38 a 42 anos e 47, 5\% (19 entrevistados) na faixa acima de 42 anos. Abaixo a tabela 02, sintetizada da relação entre os questionários respondidos e a forma de distribuição.

Gráfico 01: Distribuição de Faixa Etária dos Entrevistados

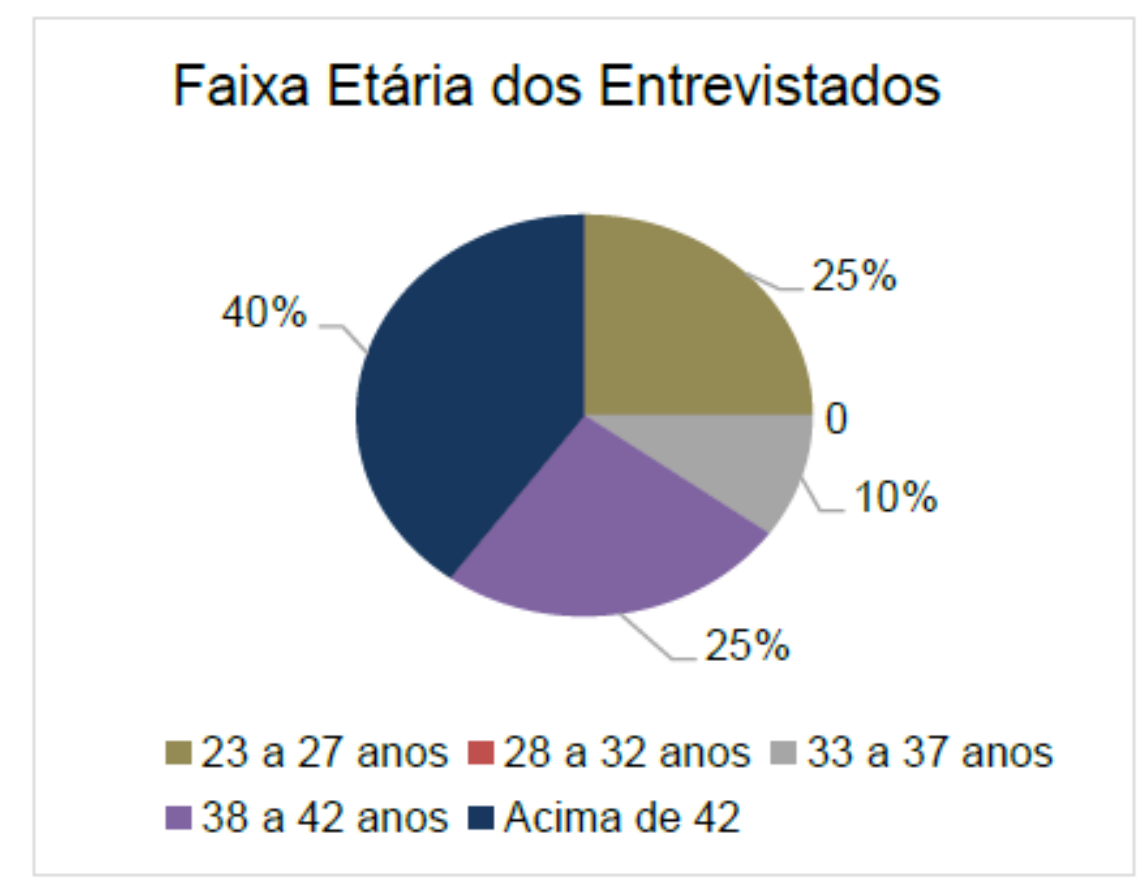

Fonte: Própria

\subsection{ANÁLISE DOS RESULTADOS FRAMING}

Para se realizar a análise do ponto de vista do efeito framing inicialmente se analisou as questões isoladas, comparando as com o estudo de Barreto et al. (2013), como já supracitado na metodologia desse trabalho o questionário utilizado para essa pesquisa, foi baseado no estudo de Barreto et. al. (2013), sendo o mesmo adaptado ao público de agricultores do universo dessa pesquisa. Após a análise individual, foram realizadas as análises em conjunto, relativa ao viés (Efeito Framing).

A manipulação da questão I se baseia na diferença de probabilidades. Conforme Barreto et al. (2013) expressa, essa questão se mantiverem os índices percentuais em termos médios, com pouca variação entre as alternativas com o objetivo de analisar se o comportamento dos respondentes seria similar 
ou distinto do trabalho que essa pesquisa se baseia em forma de análise comparativa do percentual respondido.

O questionário do Tipo I (que trabalha a relação de ganhos), na primeira questão (Questão que trata sobre uma produção de farinha de mandioca no valor de $\mathrm{R} \$ 300,00$ que sofreu perdas referente a uma enchente) em sua alternativa " $A$ " propunha que havia $40 \%$ de se recuperar $\mathrm{R} \$ 100,00$ e $60 \%$ de recuperar $\mathrm{R} \$$ 0. Em contraproposta a alternativa B propunha ao decisor $42 \%$ de recuperar $\mathrm{R} \$ 100,00$ e $58 \%$ de recuperar $\mathrm{R} \$$ 0. O questionário II (trabalha a relação de perdas) propunha ao entrevistado na alternativa "A" que havia 40\% de chance de não recuperar $\mathrm{R} \$ 200,00$ e $60 \%$ de chance de não recuperar $\mathrm{R} \$ 300,00$, no mesmo questionário a alternativa "B" concedia a possibilidade de $42 \%$ de não recuperar $\mathrm{R} \$ 200,00$ e $58 \%$ de não recuperar $\mathrm{R} \$ 300,00$.

Conforme o estudo utilizado como base dessa pesquisa de Barreto et al. (2013), é importante ressaltar que em ambos os casos a alternativa " $A$ " possuía o mesmo valor esperado, o que também se reflete na alternativa "B". Ressaltando ainda que em ambos os casos a alternativa "B" gerava o maior valor esperado percentual. Desse modo, nos questionários foi mantido o valor esperado em cada alternativa, configurando as alternativas como iguais, diferindo em pontos de referência distintos, sendo o Tipo I no campo dos ganhos e o Tipo II no campo de perdas.

Através da análise dessa questão, conforme estudo de Barreto et al. (2013) “Objetivase verificar o comportamento dos respondentes", no que tange a valores médios em observação a Teoria dos Prospectos, se fazendo presente nas alterações do padrão de resposta devido a mudança de cenário se o resultado implica na violação do princípio da utilidade esperada, que afirma que os agentes ponderam as utilidades "a partir das probabilidades de ocorrência de cada um dos resultados possíveis" (BARRETO et al. 2013).

Conforme análise do questionário I, o mesmo trabalha nos termos de recuperação de valor, o que caracteriza o campo dos ganhos, tendo a maioria dos respondentes optado pela escolha mais "certa" (alternativa B), tal fato ao se comparar com estudo base de Barreto et al. (2013) se demonstrou parecido, pois no estudo base a maioria dos respondentes optou pela escolha mais certa (Alternativa B), no entanto difere na frequência de escolhas, pois nesse estudo a questão I obteve $65 \%$ de frequência na alternativa B, e no estudo de Barreto et al. (2013) a frequência de escolha foi 81,94\%. No questionário Tipo II que dala sobre perdas, ao falar em valores não recuperáveis, os respondentes em sua maioria se posicionaram de modo diferente, estabelecendo uma relação na maioria de 
enfretamento ao risco, o que também se assemelha ao estudo base em uma análise comparativa, pois conforme análise de Barreto et al. (2013) os respondentes daquela pesquisa se posicionaram em sua maioria estabelecendo uma posição agressiva diante das perdas.

De posse dessas informações, pode-se concluir que no questionário Tipo I a maioria dos respondentes dessa pesquisa se comportou optando pelo maior (42\% de recuperar) valor esperado (65,0\% Alternativa B), o que se assemelha a pesquisa base desse estudo, onde a maioria (81,94\% Alternativa B) optou pela maior probabilidade de recuperar (42\% de recuperar). Conforme analise já realizada, 0 presente estudo se comportou de maneira assemelhada ao estudo de Barreto et al. (2013), apresentando diferença nas frequências.

Ao se analisar a resposta no questionário Tipo II, os respondentes dessa pesquisa se comportou reversa aos que responderam ao Tipo I, havendo preferência pela incidência de menor probabilidade (40\% Alternativa A) e de menor valor esperado, esse fato também contrasta positivamente aos fatos e dados obtidos no questionário Tipo II do estudo de Barreto et. al. (2013)

Os dados supracitados, estão expostos nas tabelas a seguir:

Tabela 02: Tabela referente a questão 01 - Perder ou não recuperar invest.

\begin{tabular}{|l|l|l|l|l|}
\hline Alternativas & Tipo I & $\%$ & Tipo II & $\%$ \\
\hline A & 7 & 35,0 & 12 & 60,0 \\
\hline B & 13 & 65,0 & 8 & 40,0 \\
\hline Total & 20 & 100,00 & 20 & 100,00 \\
\hline
\end{tabular}

Fonte: Própria.

Através dos fatos acima se é possível concluir que se encontrou um padrão diferente nas respostas para cada tipo de questionário (Tipo I e Tipo II), se levando em consideração que houve mudança significativa entre os resultados dos dois tipos de questionários o que configura a evidente presença do Efeito Framing. 
Analisando estatisticamente no teste de diferenças de proporções a questão de número 1, apresenta o valor de Z de -1,583119 o que segundo Stevenson (1981), se encontra dentro dos limites de aceitação 5\%, o que significa que nesse nível a hipótese mais aceita seria a HO (Não havendo diferença que possa ser considerada significante na diferença proporcional. Contudo por se tratar de uma população pequena, ao se analisar no nível de $10 \%$ o valor de Z ultrapassa os limites de significância $(-1,28)$, confirmando a Hipótese $\mathrm{H} 1$, e consequentemente atestando a ocorrência do Efeito Framing neste caso da questão 01.

A questão dois também baseada no estudo de Barreto et al. (2013) trata sobre uma questão típica da Teoria dos Prospectos, buscando através de seu enunciado analisar a posição do decisor diante do risco, utilizando como referência de manipulação um ponto norteador. Assim como na primeira questão, a questão dois apresenta resultados idênticos nos dois questionários, contudo no primeiro trata as perspectivas de ganho e no segundo de perdas.

Essa questão foi baseada na questão de Barreto et al. (2013), sendo que no estudo base era tratada como: "prejuízos de reclamações trabalhistas", e no presente estudo foi tratada como: "prejuízos com a desvalorização da mercadoria produzida", sendo que os valores do estudo base, foram adaptados à realidade local dos quilombolas deste presente estudo. No questionário do estudo de Barreto et al. (2013) o problema é tratado como uma redução de custos, sendo tratado de forma aparente nesse estudo. No questionário I se é tratado como valor poupado, no questionário II o valor é tratado como um valor perdido.

Como já expresso na metodologia desse trabalho o problema apresentado nos dois questionários é o mesmo, sendo que na primeira alternativa do questionário I (A) apresenta a possibilidade de poupar $\mathrm{R} \$$ 1.000,00 diante dos prejuízos, e na segunda opção (Alternativa B) existe a possibilidade 1/3 de poupar os $\mathrm{R} \$ 3000,00$ e de $2 / 3$ de que nada seja poupado. Ao se analisar a referida situação no campo dos ganhos (Questionário Tipo I) percebe-se que segue as projeções realizadas nos estudos de Kahneman e Tversky (1979) e Barreto et al. (2013), pois no framing relativo a recuperação de custos $80 \%$ da amostra buscou a opção que lhe desse mais segurança, o que contrasta com o Efeito Certeza de forma positiva, optando pela alternativa A que garantia a certeza de $\mathrm{R} \$ 1.000,00$ na operação realizada.

Em análise ao questionário Tipo II cuja framing se relacionava a perda de custos, a amostra dessa pesquisa se comportou em sua maioria $(65,0 \%)$ de forma a arriscar para que assim tivesse a chance 
de ter uma perda menor, optando pela alternativa $B$, que oferecia a probabilidade de 1/3 de evitar totalmente qualquer perda, no entanto havia a chance de $2 / 3$ de tudo ser perdido. $A$ alternativa garantia que $\mathrm{R} \$ 2.000,00$ seriam perdidos foi escolhida pela menor parcela $(35,0 \%)$ da amostra dessa pesquisa.

Conforme análise da questão proposta, percebe-se a influência do efeito Framing, pois ao se apresentar o mesmo problema de uma forma diferente entre ganhos e perdas, dependendo da maneira que o problema é exposto. Nota-se que como o estudo de Barreto et al. (2013) percebe-se que a mudança nos termos, apresentou uma mudança significativa na escolha da alternativa. É importante ressaltar que diferente da questão número 1, a questão de número 2 não há nenhuma opção de maior valor esperado, sendo que as duas opções oferecem o mesmo valor esperado. Configurando assim, que a decisão foi estipulada por preferência.

Os dados aqui expressos estão confirmados coma tabela abaixo:

Tabela 03 - Tabela referente a questão 02 - Desvalorização pelo mercado - prejuízos.

\begin{tabular}{|l|l|l|l|l|}
\hline Alternativas & Tipo I & $\%$ & Tipo II & $\%$ \\
\cline { 1 - 5 } A & 16 & 80,0 & 7 & 35,0 \\
\hline B & 4 & 20,0 & 13 & 65,0 \\
\hline Total & 20 & 100,00 & 20 & 100,00 \\
\hline
\end{tabular}

Fonte: Própria

Ao se realizar teste estatístico de diferença de probabilidades nessa questão, a nível de significância de $5 \%$, foi possível confirmar a presença do efeito framing, pois a manipulação do ponto de referência em comparação a forma de apresentação do problema afetou a decisão dos membros da comunidade quilombola apresentando um cálculo de Z 2,878619 o que significa a anulação da Hipótese H0 que infere que as proporções são nulas entre si, o que significa a adoção da Hipótese H1. Confirmando com esse resultado o Principio obtido na Teoria dos prospectos. 
Conforme a sequência das duas primeiras questões, a terceira também era a mesma questão nos dois questionários (Tipo I e Tipo II), porém a forma como era apresentada diferia de uma questão para a outra. O primeiro questionaria contém em suas alternativas o termo poupar, e o segundo questionário contém o termo perder, tal proposta segue os mesmos princípios das duas primeiras questões, para justamente analisar a influência da Teoria dos Prospectos na amostra da referida pesquisa.

Para o questionário Tipo I, a alternativa " $A$ " oferecia a oportunidade mínima de 10\% de poupar $\mathrm{R} \$$ 4.500,00 e 90\% de chance de nada ser poupado. A alternativa "B" propunha ao decisor, uma espécie de meio termo entre ganhar e perder, pois propunha $45 \%$ de chance de poupar $\mathrm{R} \$ 1.500,00$ e $55 \%$ de poupar $\mathrm{R} \$$ 0. Por fim, a alternativa " $C$ " oferecia ao quilombola a opção de $90 \%$ de poupar $\mathrm{R} \$ 500,00$ e $10 \%$ de poupar $\mathrm{R} \$ 0$.

No questionário Tipo II o problema era o mesmo, sendo tratado no campo de perdas. A alternativa "A" apresenta a opção de $10 \%$ de perder $R \$ 500,00$ e de $90 \%$ de perder o montante de $\mathrm{R} \$ 5.000,00$, a alternativa "B" assim como no questionário I, apresenta uma opção que pode ser considerada mediana, diante das outras duas, sendo que a mesma apresenta a opção de $45 \%$ de perder $\mathrm{R} \$ 3.500,00$ e 55\% de perder R\$5.000,00. Por fim, a alternativa " $C$ " apresentava as opções dentro do questionário que ofereciam maior propensão ao risco, de modo que a alternativa demonstrava $90 \%$ de chance de perder $\mathrm{R} \$ 4.500,00$ e $10 \%$ de chance de perder apenas $\mathrm{R} \$ 500,00$.

Para que se houvesse a percepção da Teoria dos prospectos nessa alternativa, se faz necessários que os respondentes variassem em suas respostas, conforme a manipulação, sendo necessário que a resposta diante do campo de perdas e ganhos, divergissem, comprovando assim teoria nessa terceira questão. No entanto, os resultados obtidos nessa pesquisa seguem conforme o estudo de Barreto et al. (2013), diferindo de Silva et al. (2009) que evidenciou a influência do Efeito Framing e da Teoria dos Prospectos, sendo que os resultados aqui obtidos se centralizaram na resposta "B", tanto no questionário I, quanto no II, e a diferença de probabilidades é nula, sendo o valor de $Z 0$ no teste, o que implica a adoção da Hipótese HO, que afirma que os respondentes dos dois questionários não diferiram estatisticamente, o que implica dizer que as respostas foram semelhantes, não evidenciando o Efeito Framing na terceira questão.

As tabelas abaixo, demonstram os resultados obtidos nesse estudo em comparativo com o estudo de Barreto et al. (2013). 
Tabela 04: Tabela referente a questão 03 - Vendas não absorvidas pelo mercado - Prejuízo

\begin{tabular}{|l|l|l|l|l|}
\hline Alternativas & Tipo I & $\%$ & Tipo II & $\%$ \\
\cline { 1 - 5 } A & 4 & 20,0 & 2 & 10,0 \\
\hline B & 14 & 70,0 & 15 & 75,0 \\
\hline C & 2 & 10,0 & 3 & 15,0 \\
\hline Total & 20 & 100,00 & 20 & 100,00 \\
\hline
\end{tabular}

Conforme expresso nos resultados dessa pesquisa, se foi possível notar uma diferença percentual nos resultados da primeira questão, para confirmar a hipótese, foi necessário efetuar um teste de diferença de proporcionalidade, onde a nível de $5 \%$ não se pode constatar diferença relevante estatisticamente, no entanto, como bem expressa Stevenson (1981) como o universo dessa pesquisa é pequeno cabe o teste a nível de $10 \%$, onde se identificou uma diferença proporcional na escolha da alternativa, a depender de como ela era expressa ao decisor (Ganhos ou perdas), evidenciando a presença do efeito framing. Na segunda questão a diferença das proporções a nível de $5 \%$ foi significativa, evidenciando o efeito framing entre os entrevistados. E por fim, na terceira questão a maioria dos entrevistados tanto do questionário I quanto o II, apresentaram uma frequência estatisticamente idêntica, não evidenciando a presença do efeito framing entre os respondentes.

Para o próximo capitulo as nossas considerações finais.Fonte: Própria

\section{CONSIDERAÇÕES FINAIS}

Em uma visão geral, notou-se que é presumível que haja uma mudança na decisão se ocultada for a possibilidade de perder, isto porque as famílias questionadas podem ser influenciadas pelo efeito certeza e ter a preferência pela alternativa mais provável.

Como podemos verificar nos resultados deste trabalho, há sempre duas opções, e elas levam o tomador de decisão a arriscar ou não arriscar, dependendo do modo como o decisor entende e avalia a situação. De forma geral, a pesquisa atendeu aos seus objetivos, pois conseguiu analisar a influência da teoria dos prospectos e efeito framing na perspectiva de ganhos e perdas no processo decisório da 
comunidade estudada. Notou-se que há um impacto nas escolhas do decisor a cada situação diversificada, pois essas escolhas podem mudar dependendo de como o problema é apresentado.

Foi identificado que o atual método decisório da comunidade é baseado em fatores comportamentais, com atitudes e comportamentos influenciadores no processo de decisão. Verificou-se que diante das duas primeiras questões do questionário, os quilombolas que compõe a amostra desta pesquisa apresentaram o impacto do efeito framing, pois ao se tratar de ganhos possuíam uma aversão a assumir riscos, e quando os mesmos foram expostos diante de situação de perdas, assumiram em sua maioria o risco no intuito de evitar qualquer perda.

O estudo atendeu também ao problema de pesquisa, ao identificar que a reação dos povos tradicionais quilombolas da região estudada foi diferenciada e influenciada pelo método em que foi apresentado o problema, com decisões diversificadas a cada nova situação, dessa forma possuindo características de influência da teoria dos prospectos e efeito framing.

Este formato de estudo possui grande influência e é indispensável no objetivo da compreensão de fatores relativos a forma de entendimento dos gestores e líderes. À vista disso, almejou-se, com os resultados deste estudo, nortear os líderes quilombolas do ramal Castelo para uma maior atenção ao processo decisório, visto que assim os mesmos podem ter as primeiras informações para tomar decisões que os direcionem aos seus objetivos.

Para novas pesquisas, sugere-se um estudo sobre contabilidade comportamental com profissionais da contabilidade que estão iniciando sua vida no mercado de trabalho, visto que a tomada de decisão pode ser considerada como planejamento administrativo, e seus planos e decisões têm o poder de influenciar o alcance de seus objetivos e sucesso profissional.

\section{REFERÊNCIAS}

ARRUDA, R. (1999). "Populações Tradicionais" E A Proteção Dos Recursos Naturais Em Unidades De Conservação. Ambiente \& Sociedade - Ano II - No 5, 7992.

BARROS, H. (1975). Os grandes sistemas de organização da economia agrícola. Lisboa: Livraria Sá da Costa Editora.

BARRETO, Patrycia Scavello; MACEDO, Marcelo Álvaro da Silva; ALVES, Francisco José dos Santos. TOMADA DE DECISÃO E TEORIA DOS PROSPECTOS EM AMBIENTE CONTÁBIL: UMA ANÁLISE COM FOCO NO EFEITO FRAMING. Revista de Gestão, Finanças e

Contabilidade, ISSN 2238-5320, Salvador, v. 3, n. 2, p. 61-79, maio. 2013. 
BRASIL. Constituição Federal de 1988 n. 91, de 05 de out. de 1988. Constituição Federal. Constituição. 91. ed. Brasil, p. 01-34, out. [outubro]. Disponível

em: <http://www.planalto.gov.br/ccivil_03/constituicao/constituicaocompilado.htm>. Acesso em: 07 dez. 2016.

BRASIL. (14 De 09 De 2017). Decreto № 6.040. Fonte: Decreto № 6.040, de 7 de fevereiro

De 2007. Disponível em: <http://www.planalto.gov.br/ccivil_03/_ato2007-

2010/2007/decreto/d6040.htm>. Acessado 01 jan. 2016.

CARVALHO JUNIOR, C. V. O.; ROCHA, J. S.; BRUNI, A. L. Efeito Framing em decisões gerenciais e aprendizado formal de controladoria: um estudo experimental. RIC - Revista de Informação Contábil, v. 4, n. 3, p. 35-36, jul-set/2010.

DECRETO № 6.040. (07 de fevereiro de 2007). Decreto no6040. Fonte: DECRETO №

6.040, DE 7 DE FEVEREIRO DE

2007: <http://www.planalto.gov.br/ccivil_03/_ato20072010/2007/decreto/d6040.htm>. Acesso em: 04 mar. 2016.

FAÇANHA, S. L. O. Contribuições para o Processo Decisório Estratégico de Fazer ou Comprar: Um estudo exploratório no contexto químico brasileiro. 2007. 165 f. Dissertação (Mestrado em Administração) - Faculdade de Economia, Administração e Contabilidade. Universidade de São Paulo, São Paulo, 2007.

FUNDAÇÃO PALMARES. (22 de novembro de 2007). FCP. Fonte: Fundação Palmares: <http://geografia.seed.pr.gov.br/modules/noticias/article.php?storyid=47>. Acesso em: 01 jam. 2016.

GIUCCI, G. (1992). Viajantes do Maravilhoso: O Novo Mundo. Companhia das Letras.

LEITE, I. B. (2000). Os Quilombos No Brasil: Questões Conceituais E Normativas. Etnográfica, Vol. IV, 333-354.

KAHNEMAN, D.; TVERSKY, A. Prospect Theory: Na Analysis of Decision under Risk. Econometrica, v. 47 (2), p. 263-291, 1979.

KOONTZ, Harold; O’DONNELL, Cyril. Princípios de administração: uma análise das funções administrativas. São Paulo: Pioneira, 1972.

LEITE, I. B. (2000). Os Quilombos No Brasil: Questões Conceituais E Normativas. Etnográfica, Vol. IV, 333-354.

LIMA, Murilo Valverde. Um estudo sobre as finanças comportamentais. RAE - eletrônica, v. 2, n.1, p. 1-19, jan. /jun. 2003. Disponível em:

<http://www.rae.com.br/eletronica/index.cfm?FuseAction=Artigo\&ID=1873\&Secao=2\%C2\%

BAPWC\&Volume $=2 \&$ numero $=1 \& A n o=2003>$. Acesso em: 22 jan. 2018. 
LONGARAY, A.A. BEUREN, I, M. Decisões Organizacionais: As Perspectivas Qualitativa, Quantitativa E A Abordagem Multicritérios. Programa de Pós-Graduação em Engenharia de Produção e Sistemas da Universidade Federal de Santa Catarina - Campus Trindade - Florianópolis - SC, 1999. Disponível em: < http://www.abepro.org.br/biblioteca/ENEGEP2001_TR62_0087> Acesso em: 10 jan. 2017.

LUCENA, W. G. L.; FERNANDES, M. S. A.; SILVA, J. D. G. A Contabilidade Comportamental e os Efeitos Cognitivos no Processo Decisório: Uma Amostra Com Operadores da Contabilidade. Revista Universo Contábil, ISSN 1809-3337, Blumenau, v. 7, n. 3, p. 41-58. Jul/set, 2011.

MACEDO, M. A. S.; FONTES, P. V. S. Analise do comportamento decisório de analistas contábilfinanceiros: um estudo com base na teoria da racionalidade limitada. RCC - Revista Contemporânea de Contabilidade, v. 6, n. 11, p. 159-186, 2009.

MACEDO JR., Jurandir Sell. Teoria dos Prospectos: : Uma Investigação Utilizando Simulação de Investimentos. 2003. 2018 p. Tese (Doutorado em Engenharia de Produção)-

Programa de Pós Graduação em Engenharia de Produção, Universidade Federal de Santa Catarina UFSC, Florianópolis, 2003. 1. Disponível em:

<https://repositorio.ufsc.br/bitstream/handle/123456789/85921/199597.pdf?sequence=1>. Acesso em: 13 set. 2017.

MARTINS, J. D. M.; SANTOS, T. L.; CARVALHO, D. R.; SILVA, J. D. G. O Efeito Framing

Na Tomada de Decisão Contábil: Perspectiva dos Profissionais da Contabilidade dos Estados do Rio Grande do Norte e Pará. Contabilidade comportamental: conceitos e aplicações / Coordenador, José Dionísio Gomes da Silva. - Natal, RN: POLYPRINT, 2016. 422 pp.: il

MAYER, V. F.; AVILA, M. G. A influência da estruturação da mensagem em comportamentos relacionados à saúde: um teste experimental. Saúde Soc., São Paulo, v. 2, n. 1, p.1-19, jan-jun/2003.

MINETO, C.A.L. Percepção ao risco e efeito disposição: Uma análise experimental da teoria dos prospectos. 2005. 153 f. (Doutorado) Universidade Federal de Santa Catarina (USFC), Florianópolis, $2005 . \quad$ Disponível em: <https://repositorio.ufsc.br/bitstream/handle/123456789/102956/223460.pdf?sequence=1>. Acesso em: 20 de jun. 2017.

PEREIRA, Maria José Lara de Bretas; FONSECA, João Gabriel Marques. Faces da decisão: as mudanças de paradigmas e o poder da decisão. São Paulo: Makron Books, 1997.

PEROVANO, D.G. Manual de metodologia científica para a segurança pública e defesa social. Curitiba: Juruá. 2014.

POMPIAM, M. Behavioral finance and wealth management: how to build optimal portfolios that account for investor biases. John Wiley \& Sons Inc., 2006.

PONTES, L. S., SANTIAGO J. S., SANTOS, J.F.L., \& PESSOA L.G.B. Efeito Framing: Um Estudo acerca da Variação nas Possíveis Decisões de Investimento de Estudantes de uma IES Pública na Paraíba. REUNIR: Revista de Administração, Contabilidade e Sustentabilidade. ISSN: 2237-3667 - Vol.4, no 3, pp. 113129, 2014. Disponível em: <http://www.spell.org.br/documentos/ver/38199/efeitoframing--um- 
estudo-acerca-da-variacao-nas-possiveis-decisoes-de-investimento-de-estudantes-deuma-iespublica-na-paraiba>. Acesso em: 18 fev. 2016.

SANTOS, J. H. F.; BOTELHO, D. Análise comparativa de preços: variáveis influentes na percepção de vantagem de compra. RAM - Revista de Administração da Mackenzie, v. 12, n. 2. São Paulo, mar. /abr. 2011.

SERPA, D. A. F., AVILA M. G. Efeito Framing E Influência Da Experiência Gerencial Em Marketing

Em Decisões De Compra: Um Teste Experimental. Revista de Administração, Contabilidade e

Sustentabilidade. ISSN: 2237-3667 - Vol.4, no 3, pp. 113-129, 2014. Disponível em:

<https://www.researchgate.net/profile/Daniela_Ferreira21/publication/281205429_EFEITO_FRAMI NG_E_INFLUENCIA_DA_EXPERIENCIA_GERENCIALLEM_MARKETING_EM_DECISOES_DE_COMPRA_U M_TESTE_EXPERIMENTAL/links/55db1f3008ae9d659492a3ca>. Acesso em: 04 nov. 2017.

SILVA, G. L., \& SOUZA, R. M. (2009). As Comunidades Tradicionais e as lutas pelos direitos étnicos e coletivos no Sul do Brasil. Revista da Faculdade de Direito da UFG, V.33, N. 2 - ISSN 01017187, 128142.

SIMON, H. A. Comportamento administrativo: estudo dos processos decisórios nas organizações administrativas. Rio de Janeiro: Aliança para o Progresso, 1965.

STEVENSON, Wiliam J. Teste de significância para proporções: Teste de duas amostras para proporpções. In: STEVENSON, William J. Estatística Aplicada à Administração. 01. ed. [S.I.]: HARBRA, 1981. cap. 12, p. 276-303. v. 01. 


\section{Capítulo 16}

\section{INDICAÇÃO GEOGRÁFICA (IG) E SUA RELEVÂNCIA PARA A PRODUÇÃO FAMILIAR INSERIDA NO MERCADO.}

DOI: $10.37423 / 200300414$

Bartholomeu Rebouças. Mestre em Administração e Doutorando em Planejamento Territorial (Universidade Católica do Salvador-UCSAL).

breboucas@gmail.com

Amilcar Baiardi (DSc, Professor da Universidade Católica do Salvador, UCSAL, e Professor Titular da Universidade Federal da Bahia, UFBA e Universidade Federal do Recôncavo da Bahia, UFRB).

amilcar.baiardi@gmail.com

RESUMO: A relevância da indicação geográfica, como elemento de diferenciação de produtos, serviços e processos, associados a territórios, apresenta considerável relevância quando concedida a produtos resultantes da produção familiar, notadamente em se tratando de agro produtos. Os processos de certificação, onde a indicação geográfica se insere, tem funcionado como diferencial comparativo e competitivo de produtores em geral, também os produtores familiares, como capazes de estabelecer singularidades e assimetrias em produtos, serviços e processos produtivos. Isso ocorre ao longo do tempo, em todo o mundo, sendo uma forma de avaliar-se, mediante critérios de amplo conhecimento, o atendimento a uma trilogia de características, que devem satisfazer à sua exigência, existência e evidência, como elementos factíveis de constatação por uma terceira parte (a certificadora) que atesta o atendimento aos itens necessários à diferenciação esperada. 
A produção familiar apresenta, junto a suas características, um rol de atributos que merecem uma reflexão quanto à sua gênese, no Brasil, com a regulamentação daí decorrente. O olhar do "empreendedor familiar", em substituição ao produtor familiar, mediante indiferenciação prevista em lei, favorece a sua inserção no mercado, mediante esforços individuais ou coletivos (cooperativas ou outras formas de associação) estimulando o uso de práticas de gestão adotadas por organizações capitalistas convencionais, que se utilizam de ferramentas administrativas em áreas como - produção, logística, distribuição e marketing - necessárias nas certificações da IG e de ampla importância para ressaltar sua existência.

Palavras-chave: Certificações de notoriedade dos atributos territoriais; Indicação geográfica; Cooperação na produção familiar; Governança de processos cooperativos gestão de organizações produtivas familiares. 


\section{INTRODUÇÃO}

Composto por itens como: A IG como reconhecimento de atributos diferenciais de produtos, processos produtivos, serviços e regiões; a trilogia de características para o alcance da IG; a produção familiar inserida no mercado; a gestão inovativa na inserção da produção no mercado: confiança e parcerias em logística, distribuição, composto de marketing e comunicação e finalizando com um perfil preliminar do território de conceição do Jacuípe, este texto pretende dar conta de uma pesquisa - ora encetada pelo primeiro autor, mediante orientação do segundo autor - e representa o estágio em que se encontra a elaboração de tese, apoiada pela FAPESB e desenvolvida dentro das diretrizes do programa de Pós Graduação da Universidade Católica do Salvador.

Traz em seu bojo o resultado de leituras e pesquisas, bem como uma revisão sistemática da literatura acerca dos temas em estudo, notadamente quando à sua aplicação à gestão de empreendimentos da produção familiar, ressaltando a grande potencialidade de gerar riqueza, se, e quando, a gestão de tais empreendimentos permitir a apropriação de informações e conhecimentos acerca da gestão contemporânea, notadamente na identificação de atributos e características relacionadas aos territórios onde os produtores estão inseridos, de forma cooperativa para a busca de certificações que demonstrem a assimetria da produção familiar, quando relacionada a outras formas de produção e apresentação de produtos e serviços.

O amplo registro dos estudos sobre co-operação, a partir da gênese e da morfologia do termo, indica com que a assunção de tais posturas colaborativas sejam necessárias e úteis aos produtores familiares, notadamente no município de Conceição do Jacuípe, na Bahia, onde se inicia a pesquisa em campo, num território de amplo interesse acadêmico e profissional, cujo perfil preliminar encerra este texto.

\section{A IG COMO RECONHECIMENTO DE ATRIBUTOS DIFERENCIAIS DE PRODUTOS, PROCESSOS} PRODUTIVOS, SERVIÇOS E REGIÕES.

O conceito da IG (Indicação Geográfica) parece novo, porém, sua origem remota a tempos idos. As indicações geográficas caminham juntamente com a história da humanidade, que, por muito tempo, quando se referia a um produto, relacionava-o ao seu local de origem. Desde a Bíblia são encontradas indicações de origem, como os vinhos de En-Gedi (Cânticos, I, 14) e o cedro do Líbano (Cânticos, III, 9, e Reis, V, 6) (BRUCH E COPETTI 2011). Há, também, relatos que remontam ao século IV a.C., na Grécia Antiga, os quais relacionam o produto com o local de produção, como os vinhos de Corinto, as 
amêndoas de Naxos, o mel da Sićlia e o mármore de Paros, enquanto no Império Romano, sob o reinado de Augustus, eram conhecidas as tâmaras do Egito, o presunto de Gália, as ostras de Brindisi e o mármore de Carrara

Desde o estudo de história, no ensino fundamental no Brasil, tem-se que a descoberta do país, no ano de 1.500 , foi motivada pelo ímpeto da navegação portuguesa que buscava novas rotas para a Índia, um grande provedor de especiarias, cuja procedência era reconhecida e valorizada.

O uso de um nome geográfico para designar um produto de origem de uma região que leva esse nome é explicado pelo fato de que o produto da região carrega um padrão que apresenta algumas assimetrias, quando comparado a outras origens, com características de qualidade e de originalidade que são o resultado da geografia, em sua visão ampla; das influências e/ou o resultado de fatores humanos, por meio do know-how (savoir-faire) e produção geograficamente restrita a um dado território. São conhecidos os exemplos a seguir, associados a territórios específicos: França: Champagne (vinhos espumantes); Bourdeaux (vinhos tintos); Rochefort, Comté, Cantal, Camembert (queijos); Cognac (destilado de vinho branco). Portugal: Porto (Vinho); Serra da Estrela (queijo). Itália: Parma (presunto); Parmiggiano Reggiano e Grana Padano (queijos). Espanha: Pata Negra (presunto cru); Alicante e Jijona (torrones); Cea (pão artesanal); Montes de Toledo azeite de oliva. África: Galmi (cebola violeta); Quênia (chá). Ásia: Basmati (arroz -Índia); Borseong (chá - Coréia do Sul). América Latina: Colômbia (café); Peru (Pisco); México (Tequila e café Vera Cruz); Jamaica (café Blue Mountain); Cuba (Charutos)

Algumas das designações usadas no passado foram abandonadas, para seguir evoluções econômicas ou sociais, mas, o emprego dos nomes geográficos continua e tem sido desenvolvido com o crescimento da produção e do comércio. Como resultado, acordos em nível internacional foram elaborados, começando com a Convenção de Paris de 1883, destinada a estabelecer formas para a proteção da propriedade industrial. O Brasil, país signatário original, aderiu à Revisão de Estocolmo em 1992.

Um dos benefícios esperados do produto com selo de IG é seu destaque dos demais, pois envolve um histórico e mexe com o pensamento das pessoas, à medida que remete ao local onde é produzido e, de alguma forma, faz recordar a paisagem, o clima ou o cheiro da região, cativando, desse modo, o consumidor. O valor mais elevado do produto passa a ser aceito pelos consumidores assim que percebem um diferencial, seja no paladar, visual, olfato, ou até mesmo no imaginário. A fidelização é 
a principal consequência, sendo a resultante de processos de indicação geográfica (Carvalho et al), 2018.

Maiorki e Dalabrida (2015) afirmam que, quando um território possui um produto ou serviço com diferencial e que este possa ser declarado como IG, são gerados impactos, não somente aos produtores e à cadeira produtiva ligada ao produto com IG, mas para todo território circundante. Assim, os produtos que possuem Indicação Geográfica são capazes de gerar um incremento no preço de venda e, com isso, contribuir para a agregação de renda e ainda fortalecer economicamente o desenvolvimento territorial. No entanto, os benefícios não estão relacionados apenas a um incremento de preço, pois os resultados econômicos para o território são bem superiores.

Baiardi e Teixeira (2010, p. 35-36), afirmam que o conceito de desenvolvimento local chama atenção para as necessárias relações que devem existir entre o crescimento econômico e o crescimento do capital humano, a participação dos atores locais e o uso sustentável dos recursos naturais. Nessa abordagem, o território desempenha um papel central. O local, nesse contexto, pode ser entendido como qualquer recorte territorial que se distingue por determinados elementos culturais de identidade. Tais elementos teriam a possibilidade de conferir à produção desses territórios a diferenciação necessária ao processo de construção de vantagens competitivas sustentáveis.

A Indicação Geográfica, ou simplesmente a IG, é um processo de certificação que visa atestar, por uma terceira parte (no caso brasileiro o Instituto Nacional de Propriedade Industrial - INPI), a existência de características e diferenciais associados a produtos e serviços originários de certa localidade. De uma maneira geral, identifica que a qualidade e a tradição destes se associam à sua origem.

O processo de obtenção de uma IG resulta num conjunto de ações a serem desenvolvidas pelos territórios pretendentes, que necessitam cumprir uma série de requisitos para a obtenção de um dos modos das Indicações Geográficas (IGs), concedidas pelo Instituto Nacional de Propriedade Industrial - INPI, que estabelece, em seus cadernos de 'Guia Básico - Indicação Geográfica' (INPI, 2017), a seguinte distribuição:

- Denominação de Origem: refere-se ao nome do local que passou a indicar produtos ou serviços, cujas qualidades ou atributos podem ser conferidos à sua origem geográfica. 
- Indicação de Procedência: alude ao nome do local que se tornou notório por produzir, extrair ou fabricar algum produto ou oferecer determinado serviço.

Como benefício, a IG atua como um fator relevante para a proteção do nome e origem, bem como para evidenciar a diferenciação dos produtos ou serviços de um determinado produtor ou uma determinada localidade.

Tem-se que um território que alcance uma certificação de IG pode obter alguns benefícios, como uma vantagem competitiva; a preservação da tipicidade do produto certificado; uma definição de paisagem e identidade; o reconhecimento de uma tradição ou adoção de elementos distintos de outras localidades; o interesse dos diversos stakeholders na manutenção do meio ambiente para a sustentabilidade ambiental e, por último (mas não menos importante), a contribuição para o crescimento e o desenvolvimento territorial.

Os atributos que acompanham o produto constituem um diferencial que passa a ser utilizado como estratégia num mercado capitalista altamente competitivo.

Especificamente quanto à Indicação Geográfica, Benko e Pecqueur (2001) citam que tal selo, além de conferir e resguardar os direitos de produção de um respectivo produto ou manufatura, tem um grande peso institucional para o território. Mediante esta interpretação, trabalha-se aqui com esta perspectiva trazida pelos autores supracitados, uma vez que, as IGs podem ser um instrumento que auxilia a organização dos muitos recursos de um território, até porque, de acordo com ambos, as "perspectivas de criação de riquezas estão relacionadas às capacidades dos grupos quanto à organização e à elaboração de processos originais de emergência de recursos" (BENKO ; PECQUEUR, 2001, p. 31).

A obtenção do selo de Indicação Geográfica, que promova benefícios, dar-se-á pela cooperação, confiança nas instituições, convergência de propósitos, conciliação e crença em valores sociais harmônicos com a maioria da sociedade. Isso se torna possível apenas se houver co-laboração (ou cotrabalho) de várias agentes produtivos.

Há também de considerar-se que o alcance da IG pode funcionar como elemento de coesão social na comunidade, pela incorporação de valores aliados ao progresso, mediante a interlocução qualificada daí decorrente. 
O pesquisador baiano Athayde Couto et al (2013) cita que um território estará apto à conquista da Indicação Geográfica se atender, simultaneamente, a quatro aspectos identificados a seguir:

i) existência de mercado consumidor para o produto;

ii) elementos específicos de produção e reconhecimento local da qualidade;

iii) organização dos produtores (associação, cooperativa ou outra entidade similar); e,

iv) uma rede de suporte, estatal e privado, de apoio à iniciativa.

Reis (2015), em sua tese de Doutorado sobre as Determinantes, Limites e Possibilidades da IG no Brasil, afirma que "A IG vem-se tornando uma tendência mundial na busca de competitividade, nos seus vários aspectos - qualidade, proteção, reputação, consumo consciente, dentre outros aspectos" pg 82.

Além disso, seu estudo (REIS, 2015) também aborda outras questões, como a visão de que as Indicações Geográficas representam um dos poucos mecanismos do sistema de propriedade intelectual usados para proteger singularidades, como qualidade e reputação. Cita a autora que, a IG é apresentada, especialmente, como forma de proteção e valorização da biodiversidade brasileira, valorizando produtos tradicionais, identitários e locais, como instrumento de proteção ambiental e desenvolvimento territorial. Com isso, o reconhecimento dos produtos georreferenciados, concedendo o direito de uso exclusivo do nome geográfico impede que terceiros se aproveitem da notoriedade alcançada por produtos singulares. Assim, o uso do seu nome de origem fica restrito aos produtores institucionalmente organizados que se encontram dentro da área delimitada da IG. Chama atenção, a pesquisadora, acerca do risco de apropriação dos benefícios da IG por parte do monopólio, o que também preocupa Moraes e da Costa (1984) que, em ensaio sobre temas clássicos da economia e da ciência politica referem-se ao conceito Ricardiano de renda diferencial, na qual produtores melhor localizados, seja em relação à sua distância do mercado, seja em função da qualidade dos seus solos, auferem uma renda excedente em relação ao conjunto dos produtores.

\section{A TRILOGIA DE CARACTERÍSTICAS PARA O ALCANCE DA IG.}

Os esforços que possibilitem a obtenção da IG, com atendimento aos requisitos propostos pelo INPI, de forma cooperativa entre os produtores familiares, devem constituir uma tarefa a ser encetada por 
um grupo de pessoas e organizações vinculadas ao território e seus valores, cultura, o saber fazer, o pertencimento e o compromisso com a busca de melhoria e desenvolvimento regional.

Há uma tríade a ser considerada. Consiste em: i) a Exigência (constante dos documentos oficiais emanados do INPI e aqui sumarizados); ii) a Existência de tais requerimentos, mesmo de forma implícita, incipiente ou descaracterizada; e, por último, iii) a Evidência, entendida como a forma objetiva de demonstrar que o rol de exigências será atendido em sua totalidade e de forma indubitável. Tais constatações podem ocorrer com observações empíricas em atividade acadêmica específica.

Uma amostra do rol de evidências necessárias encontra-se na tabela a seguir, extraída de documentos oficiais do INPI e sumarizado por Bruch e Copetti (2011).

REQUISITOS PARA O REQUERIMENTO DO REGISTRO DE UMA INDICAÇÃO GEOGRÁFICA, NAS MODALIDADES DE INDICAÇÃO DE PROCEDÊNCIA OU DENOMINAÇÃO DE ORIGEM

\begin{tabular}{|c|c|c|}
\hline DOCUMENTOS & ESPECIFICAÇÃO & RESPONSÁVEL \\
\hline \multirow{3}{*}{$\begin{array}{l}\text { Formulário de } \\
\text { requerimento }\end{array}$} & Nome geográfico & Entidade requerente \\
\hline & $\begin{array}{l}\text { Descrição dos produtos } \\
\text { ou serviços }\end{array}$ & Entidade requerente \\
\hline & $\begin{array}{l}\text { Características do } \\
\text { produto ou serviço }\end{array}$ & Entidade requerente \\
\hline $\begin{array}{l}\text { Regulamento de } \\
\text { uso }\end{array}$ & & Entidade requerente \\
\hline $\begin{array}{l}\text { Instrumento } \\
\text { comprobatório } \\
\text { da legitimidade }\end{array}$ & $\begin{array}{l}\text { Atos constitutivos e } \\
\text { demais documentos }\end{array}$ & Entidade requerente \\
\hline \multirow[t]{2}{*}{$\begin{array}{l}\text { Etiquetas } \\
\text { (opcional) }\end{array}$} & $\begin{array}{l}\text { Apresentar } \\
\text { representação gráfica ou } \\
\text { figurativa }\end{array}$ & Entidade requerente \\
\hline & $\begin{array}{l}\text { Apresentar } \\
\text { representação do local }\end{array}$ & Entidade requerente \\
\hline
\end{tabular}




\begin{tabular}{|l|l|l|}
\hline $\begin{array}{l}\text { Procuração } \\
\text { (opcional) }\end{array}$ & Entidade requerente \\
\hline $\begin{array}{l}\text { Instrumento } \\
\text { oficial }\end{array}$ & $\begin{array}{l}\text { Delimitação da área } \\
\text { geográfica }\end{array}$ & Órgão oficial \\
\hline & $\begin{array}{l}\text { Comprovação de que } \\
\text { tornou-se conhecido }\end{array}$ & Órgão oficial \\
\hline & $\begin{array}{l}\text { Descrição das } \\
\text { qualidades e } \\
\text { características } \\
\text { atribuídas aos fatores } \\
\text { naturais e humanos }\end{array}$ & Órgão oficial \\
\hline & $\begin{array}{l}\text { Descrição do método ou } \\
\text { processo de obtenção } \\
\text { do produto }\end{array}$ & Órgão oficial \\
\hline & $\begin{array}{l}\text { Apresentação de } \\
\text { Estrutura de Controle } \\
\text { (Governança) }\end{array}$ & Órgão oficial \\
\hline $\begin{array}{l}\text { Comprovação de que os } \\
\text { produtores ou } \\
\text { prestadores de serviços } \\
\text { estão estabelecidos na } \\
\text { área geográfica } \\
\text { delimitada e que estão } \\
\text { exercendo a atividade }\end{array}$ & Óro oficial \\
\hline
\end{tabular}

Fonte: BRUCH e COPETTI (2011)

Um trabalho de fôlego visando a obtenção da certificação de Indicação Geográfica consiste na pesquisa e elaboração, de forma coletiva, dos itens especificados pela entidade certificadora, neste caso o INPI Instituto Nacional de Propriedade Industrial, órgão estatal atualmente vinculado ao Ministério da Economia.

Cumprir e fazer cumprir o estabelecido pela entidade trará ao produtor familiar e seus parceiros de negócios os seguintes benefícios: i)afirmar e fixar a imagem autêntica de produto, processo, serviço ou território; ii) dispor de uma ferramenta de reconhecimento nacional e internacional; iii) facilitar a 
presença no mercado; iv)permitir acesso ao mercado por uma ação coletiva; v) favorecer a identificação, pelo consumidor, da marca, produto, serviço, processo ou localidade, dentre outros, e vi)Estimular a melhoria qualitativa da oferta futura. .

A introdução de inovação e de mecanismos de governança nos processos produtivos familiares, individual e coletivamente falando, propiciam que haja uma reflexão acerca da conveniência de se investir para que produtos, serviços, processos ou localidades se tornem aptos à obtenção da Indicação Geográfica.

3) A PRODUÇÃO FAMILIAR INSERIDA NO MERCADO. A GESTÃO INOVATIVA NA INSERÇÃO DA PRODUÇÃO NO MERCADO: CONFIANÇA E PARCERIAS EM LOGÍSTICA, DISTRIBUIÇÃO E COMPOSTO DE MARKETING E COMUNICAÇÃO.

\subsection{DE QUAL PRODUÇÃO FAMILIAR OU AGRICULTURA FAMILIAR ESTAMOS FALANDO?.}

A expressão produção familiar ou agricultura familiar não tem interpretação unânime entre nós. Alguns se referem a uma plantação feita por pequenos produtores, destinada basicamente à subsistência da família e que pode apresentar (mas nem sempre) um excedente comercializável. Outros podem vê-la como um arranjo entre membros da família e outros agregados, voltados à produção de itens (não apenas alimentares) que possam ser comercializados em espaços físicos (mercados) quando da presença física do líder no processo de venda e aquisição de outros insumos ou alimentos, notadamente em feiras do interior. As realidades de um novo tipo de arranjo para a produção familiar identificam características de empresas rurais de pequeno ou médio porte, com atuação simultânea de membros da família, agregados diversos e empregados subordinados a uma gerência, cumprindo carga horária e com atribuições previamente definidas. Ainda há outros (Baiardi) que a veem como intensivas em capital, possuindo equipamentos muito caros e que promovem a produção em larga escala, principalmente de comodities. São os "neo-farmers" que, embora com grande volume de produtos e valores envolvidos, tem na família o lastro do trabalho e renda. No Brasil o conceito é amplo e há referências a propriedades familiares com dimensão de 5 a 440 hectares por cada módulo fiscal, como veremos a seguir.

Conforme a lei no 11.326/2006, é considerado "agricultor familiar" e "empreendedor familiar rural" aquele que pratica atividades no meio rural, possui área de até quatro módulos fiscais, mão de obra 
da própria família, renda familiar vinculada ao próprio estabelecimento e gerenciamento do estabelecimento ou empreendimento pela própria família.

Também são considerados agricultores familiares: silvicultores, aquicultores, extrativistas, pescadores, indígenas, quilombolas e assentados da reforma agrária.

Um módulo fiscal é uma unidade de medida de área, em hectares, determinada pelo Instituto Nacional de Colonização e Reforma Agrária (INCRA) para cada município brasileiro, levando-se em conta:

1. O tipo de exploração predominante no município (hortifrutigranjeira, cultura permanente, cultura temporária, pecuária ou florestal);

2. A renda obtida no tipo de exploração predominante;

3. Outras explorações existentes no município que, embora não predominantes, sejam expressivas em função da renda ou da área utilizada; e

4. O conceito de "propriedade familiar".

Em resumo, o módulo fiscal equivale ao tamanho da área necessária para sustentar uma família com as atividades agropecuárias predominantes em cada município.

Por esses critérios, nos municípios em que predomina a produção de hortifrúti, o valor do módulo fiscal é menor do que nos municípios em que a soja é o carro-chefe, por exemplo.

O valor do módulo fiscal no Brasil varia de 5 a 110 hectares.

O módulo fiscal é um parâmetro para a classificação dos imóveis rurais quanto ao tamanho, de acordo com a Lei número 8.629 de 25 de fevereiro de 1993, que classifica os imóveis rurais da seguinte forma:

1. Pequena Propriedade: o imóvel rural de área compreendida entre 1 (um) e 4 (quatro) módulos fiscais;

2. Média Propriedade: o imóvel rural de área de área superior a 4 (quatro) e até 15 (quinze) módulos fiscais.; e

3. Grande Propriedade: o imóvel rural de área de área superior a 15 (quinze) módulos fiscais. 
A Lei $\mathrm{n}$ - 11.326 classifica como Agricultor Familiar apenas aqueles que possuem, de acordo com a Lei no 8.629, uma pequena propriedade rural. Ocorre que uma pequena propriedade rural não é necessariamente sinônimo de pequena produção. Em algumas culturas agrícolas, como no caso dos hortifrútis, e em algumas criações, como as de aves e suínos, é possível ser um grande produtor ou um grande criador em uma quantidade relativamente pequena de área.

Vê-se, então, a diversidade de cenários e conceitos para que a relevância da IG seja identificada e se torne referente.

\subsection{MÉTODOS CONVENCIONAIS X INOVAÇÃO}

É possível perceber, num primeiro momento, que a produção familiar, de uma maneira geral, se ressente de ações administrativas mais adequadas ao enfrentamento dos novos tempos. Vê-se que, em alguns mercados, não há facilidades na comercialização de produtos agrícolas transformados, sejam estes agroindustrializados ou processados por famílias de agricultores. Tal complexidade não se resolve pelo equilíbrio entre a oferta e a demanda, pois os agentes envolvidos nesses mercados tomam decisões com disparidade. Portanto, apesar dos agricultores individualmente produzirem bem, podem ter dificuldades ao enfrentar o mercado em razão do baixo poder de compra e venda e baixas quantidades ofertadas. Os métodos convencionais de condução de negócios familiares têm-se demonstrado inadequados, pois o uso de ações baseadas apenas em experiências anteriores (mesmo que exitosas) não promovem a garantia de resultados positivos diante dos novos cenários. Aqui se faz necessária a identificação e uso de ferramentas tecnológicas ou inovativas. A incorporação de inovações no processo de gestão como um todo e da produção familiar em particular deve ser vista como elemento adequado à mudança paradigmática necessária à relevante participação da Indicação geográfica para enriquecimento da produção familiar inserida no mercado.

A cada ano se verifica o aumento dos custos de produção, fazendo com que a pequena propriedade seja entendida como uma pequena empresa familiar rural, dirigida por um empreendedor familiar rural, conforme preceitua a Lei no 11.326, de 24 de julho de 2006.

Qualquer que seja o tamanho ou as atividades econômicas exercidas na propriedade, deve-se ter em consideração que a visão deve ser de um negócio rural, sendo a propriedade uma empresa rural. Pequenas mudanças operacionais de percepção são necessárias, como a separação do aspecto financeiro entre o caixa da família e o caixa da empresa, por exemplo, como elementos distintos. 
A chegada de novas gerações de agricultores familiares funciona como elemento novo no cenário, pois elas trazem, em tese, uma menor resistência às mudanças, menor dificuldade em utilizar sistemas informatizados e maior habilidade em buscar informações, com a busca de inovações de produtos, serviços e processos, possibilitando o alcance da IG como elemento diferencial e relevante para a produção familiar convencional, que pode evoluir para uma produção diferenciada, com agregação constante de valor.

Alguns exemplos são perceptíveis, por exemplo na melhoria na genética de criação de gado, cabras e ovelhas, bem assim na qualificação da produção de grãos, como café e cacau, alguns dos quais já dispõem de certificação de atributos característicos da produção especial, altamente valorizada no mercado, notadamente se lhe for atribuído o selo de Indicação geográfica adequado.

Constitui um desafio a transformação de uma propriedade agrícola em uma agroindústria de geleias e polpas de frutas. Ou um núcleo de estudos, inovação e produção dede cafés especiais. Ou a substituição da produção artesanal de queijos por um pequeno ou médio laticínio de queijos selecionados ou especiais?. No beneficiamento de cacau, como encarar o desafio da produção de chocolates especiais e que se adaptem a vários desejos dos consumidores (mais cacau, menos gorduras e açucares, por exemplo)?. Quando à produção de hortigranjeiros, como deixar de comercializar "in natura" e criar um benefício, com melhor seleção e apresentação em modos minimamente manipulados

A Agricultura Familiar pode, sim, ser lucrativa e empregar tecnologia de ponta sem perder suas tradições e costumes ou a diversidade de cultivos e criações. Tal objetivo se torna mais fácil, se e quando houver a presença de esforços individuais e coletivos atuando de forma co-operativa.

A co-laboração, numa visão morfológica do termo e prefixo - (preposição latina cum) indicando concomitância, companhia, ação conjunta, - indica o atributo de co-laborar (trabalhar com), sendo um fator típico das ações humanas voltadas a um resultado coletivo. Os seus sinônimos "co-operação" (operar com) e "com-partilhamentor", (dividir com) constituem aspectos também presentes em diversos ambientes produtivos.

Durkheim (2007) destaca, para isso, o grau de consenso produzido entre os indivíduos, bem como a própria coesão social, como elementos básicos para a existência de uma sociedade. 
Aborda a questão dos espaços sociais, com a identificação de elementos que motivam o indivíduo a cumprir o seu papel social, dentro de três tipos de sociedade: as normais (onde todos cumprem as leis e normas); as patológicas (onde alguns cumprem) e as anômicas (onde ninguém cumpre as normas).

Afirma que a vida em sociedade exige um consenso, representado como uma liga, uma amálgama, que une as pessoas e estimula a cooperação. A este consenso ele denominou de solidariedade.

Para ele existem duas formas de solidariedade:

mecânica e;

orgânica.

O primeiro tipo é uma característica das sociedades ditas "primitivas" ou "arcaicas", ou seja, em agrupamentos humanos tribais e formados por clãs. Em tais sociedades, os indivíduos compartilham as mesmas noções e valores sociais, tanto no que se refere às crenças religiosas como em relação aos interesses materiais necessários a subsistência do grupo. Essa correspondência de valores visa garantir a coesão social.

Já o segundo tipo - Solidariedade orgânica - diferentemente, é o tipo que predomina nas sociedades "modernas" ou "complexas" que apresentam uma maior diferenciação individual e social. Apesar de não compartilharem dos mesmos valores e crenças sociais, os interesses individuais são distintos e a consciência de cada indivíduo é mais voltada ao que, segundo Putnam (2006) pode constituir o Capital Cívico, centrado no capital Social e referente e a práticas sociais, normas e relações de confiança que existe entre cidadãos de uma dada sociedade. É um sistema de participação que estimula a cooperação. Quanto maior a capacidade dos cidadãos confiarem uns nos outros, além de seus familiares, assim como maior e mais rico for o número de possibilidades associativas numa sociedade, maiores o volume de capital social. (confiança), motivador e resultado da coesão social.

Nas sociedades deste tipo, a divisão econômica do trabalho social é mais desenvolvida e complexa e se expressa nas diferentes profissões e variedade das atividades de produção. Durkheim emprega alguns conceitos das ciências naturais, em particular da biologia (muito em uso na época em que ele começou seus estudos sociológicos) com objetivo de fazer uma comparação entre a diferenciação crescente sobre a qual se assenta a solidariedade orgânica. 
Concebe, ainda, as sociedades complexas como grandes organismos vivos, onde os órgãos são diferentes entre si (que neste caso corresponde à divisão do trabalho), mas todos dependem um do outro para o bom funcionamento do ser vivo. A crescente divisão social do trabalho faz aumentar também o grau de interdependência entre os indivíduos. O ambiente busca uma homeostase permitindo um equilíbrio necessário à "co-labor ação".

Olson (1999) indica que a ação coletiva com vistas a cooperar, reside no interesse pessoal, individual, levando os grupos a agirem em favor de seus interesses coletivos. A conduta racional e centrada nos próprios interesses é considerada como o comportamento padrão, que se torna amplo, notadamente por razões econômicas. O autor atenta também ao fato de que os indivíduos racionais e centrados nos próprios interesses não agirão voluntariamente para promover seus interesses comuns ou grupais, a menos que haja condicionamentos para tanto, entre eles intervenções externas como a coerção.

Para Olson (1999), é comum verificar-se que quase todas as organizações têm seus interesses, o que constitui a razão de sua existência. Isto se verifica tanto na esfera do Estado como da sociedade civil e vem desde tempos imemoriais, embora haja diferenças de motivações entre as sociedades primitivas e as associações voluntárias dos tempos atuais. Para o autor, o que uniria os dois impulsos é o "instinto", além do, que na modernidade as necessidades tornaram-se mais complexas, mais difíceis de serem alcançadas ou supridas pelos grupos tradicionais. Em continuação Olson (1999) conclui que grupos menores são mais eficientes para conseguir um retorno coletivo, comparativamente a grupos grandes, nos quais existe uma diluição do benefício. Propõe uma tipologia de grupos de acordo com a eficiência em promover a ação coletiva e obter benefícios, sendo estes classificados como "exclusivos" e "inclusivos", "privilegiados", "intermediários" e "latentes". Os inclusivos são aqueles nos quais não há perdas diante de defeç̧ões e os exclusivos aqueles que requerem a cooperação do conjunto para alcançar resultados. No caso do grupo "privilegiado", o benefício coletivo dispensa a organização, sendo uma exigência no caso dos intermediários. O latente, por sua vez, seria aquele no qual não existiria prejuízo para qualquer membro no caso da ação coletiva não gerar benefício.

Olson (1999) considera ainda que os incentivos econômicos não são os únicos passíveis de gerar interesse pela cooperação, pois o prestígio, o respeito e a amizade podem também se constituir motivações para a ação coletiva. $\mathrm{O}$ autor sugere que, além dos benefícios tangíveis, existam outras motivações, como as sanções e as recompensas, que funcionam com vistas a fortalecer a coesão e ensejar a cooperação. 
Uma abordagem complementar sobre os fundamentos da cooperação se encontra em Douglas (1996), que explora as questões de solidariedade e de cooperação entre os membros de um grupo, procurando estabelecer relação entre o pensamento individual e o pensamento dominante nas instituições da qual eles fazem parte. O conceito de instituições apresentado por Douglas (1996) diz respeito aos valores compartilhados por um grupo social qualquer, aquilo que se denomina também como intersubjetividade entre os indivíduos, sem que tenha o mesmo grupo a obrigatoriedade de apresentar uma estrutura organizacional para isso. A fundamentação de Douglas (1996) está no fato de não ser qualquer "ônibus lotado" ou ajuntamento aleatório de pessoas que merece o nome de sociedade. É imperativo que, além disto, exista entre seus membros algum pensamento e algum sentimento que os assemelhem, o que vai além da existência legal. O senso de pertencimento, a identidade, transcende a inserção mecânica no local de trabalho ou afiliação religiosa. Embora estes condicionamentos possam favorecer a cooperação é necessário que o indivíduo calcule racionalmente aquilo que melhor atende a seus interesses e aja de acordo com isso, o que não exclui a contribuição para o bem público como a generosidade, até mesmo sem hesitações, sem a intenção óbvia de obter um benefício próprio.

As visões dos dois últimos autores referem-se aos fundamentos e possibilidades da cooperação em qualquer situação, que teria como vertente ou determinação o indivíduo ou as instituições por ele criadas, aí inserida a busca pela relevância dos processos de Indicação geográfica como elemento relevante para a produção familiar inserida no mercado.

As formas mais habituais do exercício colaborativo na produção familiar são a Associação, a Cooperativa e o Consórcio.

As associações são voluntárias e podem ser de vários tipos, como para aquisição de animais, máquinas ou implementos agrícolas; de comercialização (compra e venda de produtos agropecuários); de beneficiamento da produção (armazenagem, farinheiras, serrarias, moinhos etc). Em geral a produção ocorre no lote familiar e a associação presta algum serviço de interesse comum.

Cooperativa de Prestação de Serviços, de crédito ou de comercialização. Esta forma de cooperação é um desdobramento da associação. Presta serviços de assistência técnica, fornece insumos agrícolas e serviços de máquinas, repassa crédito etc. Pode assumir a comercialização dos produtos, de forma coletiva e reguladora de preços. Por essas características, tem agregado muitos associados e atua regionalmente. 
Consórcios. Forma de cooperação em que há uma aplicação de recursos voltados à oferta de bens ou serviços de forma compartilhada, mediante utilização em períodos pré ou pós definidos. O uso de máquinas e ferramentas agrícolas, por exemplo, pode ser otimizado com uma gestão adequada de consórcios de colaboração, considerando que não há utilização simultânea de equipamentos em todo o tempo ou em todo o processo produtivo.

Quanto à confiança e parceria na produção, distribuição e composto de marketing e comunicação, tem-se que a prática de co-operação leva a uma confiança que contribui para a redução dos custos de transação (WILLIAMSON, 1993) beneficiando o conjunto de produtores.

O estabelecimento de padrões mínimos de aceitação, visando a certificação para a Indicação geográfica, notadamente com a elaboração coletiva e cooperativa dos manuais de práticas a serem submetidos à entidade certificadora, pode funcionar como elemento objetivo dessa prática. $\mathrm{O}$ uso intenso de cooperação, em detrimento da competição, amplia a confiança entre os produtores passando a constituir um benefício coletivo.

O zelo pelo nome e pelo selo da IG pode garantir a aceitação e compromisso com as melhores práticas de produção, armazenamento e distribuição, evitando a apropriação individual de benefícios, que se tornam amplos na economia da abundância, como um contraponto à economia da escassez , estabelecendo que o desenvolvimento e a apropriação de inovações entre diversos produtores familiares, unidos em associações, cooperativas ou consórcios, gerem acordos explícitos e implícitos, que reduzam os comportamentos oportunísticos com a apropriação, num primeiro momento, do esforço inovativo como vantagem temporária por um dos produtores.

O estabelecimento de sansões àquelas unidades produtivas familiares que deixarem de cumprir os protocolos de melhores práticas, se torna necessário para garantir a manutenção de padrões característicos dos produtos distintos que constituem a base para a certificação de IG

A cooperação, a partir do inserção e aceitação de itens a serem aplicados a todo o processo produtivo, por todos os elementos envolvidos, amplia a confiança entre as empresários e sub empresários participantes, possibilitando que o benefício seja estendido a todos os participantes desta ação coletiva, estabelecendo uma dinâmica virtuosa na produção familiar em tela.

Inserir inovação nesses processos, ambientes e territórios pode desenvolver ações de marketing, comercialização e comunicação que reforcem seus atributos naturais já conhecidos (e outros que 
possam ser potencialmente gerenciados) e que possibilitem a busca da Indicação Geográfica como elemento de confirmação desses diferenciais identificados.

Tal inovação pode ser caracterizada pelo aproveitamento do senso comum de alguns produtos, serviços ou ambientes diferenciados, que já se materializam como especiais. É o caso, entre nós, da carne de sol de Itororó, a carne de fumeiro de Maragogipe, o avoador (biscoito de polvilho) de Vitória da Conquista, o abacaxi de Itaberaba, o artesanato de fibra de Serrinha, as águas termais do Caldas do Jorro, o ambiente e paisagem de Lençois, Andaraí e Mucugê, na Chapada Diamantina, as hortaliças oriundas de Conceição do Jacuípe (Berimbau).

Apesar dos produtores familiares, individualmente, produzirem bem, podem ter dificuldades ao enfrentar o mercado, em razão da baixa capacidade de gestão, do baixo poder de compra e venda e de baixas quantidades ofertadas.

O fato é que os produtores familiares têm o desafio de entender a forma como são construídas e estruturadas as cadeias produtivas em que estão inseridos. Além disso, devem entender como interagem os organismos que estão nessas cadeias, como estão compostas as forças de mercado e devem vislumbrar o mercado apropriado para cada produto, bem como as estratégias específicas para comercialização de cada um.

A IG pode funcionar como elemento neutralizador de tais disparidades de mercado, pelo realce em sua condição de assimetria e especificidade. Daí resulta que o processo de certificação para a Indicação Geográfica pode se tornar relevante para a produção familiar inserida no mercado.

\section{PERFIL PRELIMINAR DO TERRITÓRIO DE CONCEIÇÃO DO JACUÍPE.}

O município de CONCEIÇÃO DO JACUÍPE (BERIMBAU), onde far-se-á um estudo do processo de produção de hortaliças folhosas, (que seja passível de reconhecimento e notoriedade), traz em sua trajetória interessantes aspectos que validam a contribuição da produção familiar voltada ao mercado.

Uma pesquisa eletrônica com utilização de aplicativo denominado XTR, cedido ao pesquisador pela empresa Consiste, indica que o território se origina de um distrito criado com a denominação de Conceição do Jacuípe (ex-povoado Lamarão), pela lei estadual no 628, de 30-12-1953, com terras desmembradas do distrito Traripe subordinado ao município de Santo Amaro. 
Em divisão territorial datada de 01-07-1955, o distrito de Conceição do Jacuípe, figura no município de Santo Amaro. Assim permanecendo em divisão territorial datada de 01-07-1960.

Elevado à categoria de município com a denominação de Conceição do Jacuípe, pela lei estadual no 1531, de 20-10-1961, desmembrado de Santo Amaro. Sede no antigo distrito Conceição do Jacuípe. Constituído do distrito sede. Instalado em 07-04-1963.

Por relato de moradores, constata-se que o município, cujo histórico tem, também como primeiras referências o ano de 1889, com a chegada do Sr. Tucides de Morais, que edificou a primeira casa no lugarejo, então um distrito do município de Santo Amaro. Inicialmente chamava-se Baixa do Jacuípe, pelo fato de localizar-se numa baixada onde nasce o Rio Jacuípe, ainda hoje fator de diferenciação territorial pela oferta de água em quantidade e qualidade para uso na produção de hortifrutigranjeiros que Ihes dão destaque regional e estadual.

Registra-se que, em 1914, surgiu uma feirinha que além da comercialização de pequenas mercadorias, contava com a animação de violeiros, pandeiristas e tocadores de berimbau. Nessa ocasião, aparece na então Baixada de Jacuípe, um poeta repentista e que não conhecia um instrumento, à venda na feira, composto por uma cabaça e arame e, após perguntar pelo nome, obteve a resposta de que se tratava de um berimbau. Daí fez uma trova interessante cujo final arrolava a frase: Feira de Berimbau. Surgiu aí o segundo topônimo do vilarejo, ainda hoje identificando também os produtos alí produzidos, como "hortifrútis de berimbau", que busca a notoriedade imaginada.

Essa feira, ainda hoje de impacto na oferta de produtos agrícolas para consumo doméstico e industrial (restaurantes, hotéis, hospitais, etc.), teve um grande incentivo em 1945, quando um coletor federal (equivalente hoje a auditor da receita), organizou a feira com o pessoal do povoado, dando como prêmio a soma de cem mil réis a cada feirante que participasse das 52 feiras realizadas durante o ano. Vários deles conseguiram o intento, destacando-se entre eles, Eliodoro Marques e Orlando Azevedo.

Em fevereiro de 1949, foi inaugurada a rede de energia hidrelétrica do povoado, após o que se instalou o Subdistrito Policial, da Lapa, dando início ao processo de organização urbana que se seguiu.

Localizado no Território de Identidade Portal do Sertão, o município foi criado pela Lei Estadual no 1.531 de 20/10/1961. Além de Conceição do Jacuípe, Água Fria, Amélia Rodrigues, Angüera, Antônio Cardoso, Conceição da Feira, Coração de Maria, Feira de Santana, Ipecaetá, Irará, Santa Bárbara, Santanópolis, Santo Estevão, São Gonçalo dos Campos, Tanquinho, Teodoro Sampaio e Terra Nova, 
são os municípios que compõem o Território de Identidade Portal do Sertão. Conceição do Jacuípe está localizado entre as coordenadas aproximadas de latitude -1219'00" e longitude 3846'00", a uma altura média de 219 m acima do nível do mar e caracteriza-se pelo clima subúmido a seco, úmido e úmido a subúmido. Faz divisa com os municípios de Coração de Maria, Teodoro Sampaio, Terra Nova, Amélia Rodrigues, Santo Amaro e Feira de Santana. Com uma área total de 117,5 km2 , Conceição do Jacuípe fica distante $97 \mathrm{Km}$ de Salvador, capital do Estado da Bahia. As rodovias BR-324 e BR-101 são as principais vias de acesso ao município, que não possui aeroporto. De acordo com Censo Demográfico 2010, Conceição do Jacuípe possuía 30.123 habitantes. Sua densidade demográfica era de 256,3 hab/km2. Em relação à situação do domicílio, 23.539 habitantes residiam em áreas urbanas e 6.584 habitantes residiam em domicílios rurais, perfazendo um grau de urbanização de $78,1 \%$. $\mathrm{Na}$ decomposição por gênero, a população era majoritariamente do sexo feminino, ou seja, em números absolutos eram 15.564 habitantes do gênero feminino e 14.559 do sexo masculino. De acordo com estimativas do Instituto Brasileiro de Geografia e Estatística (IBGE), o município de Conceição do Jacuípe conta com uma população de 33.624 habitantes, apresentando um acréscimo de 11,6\% em comparação ao ano de 2010.

Conceição do Jacuípe (Berimbau) foi considerada, durante anos, como a maior fornecedora de hortaliças da Bahia. A produção, eminentemente familiar ou composta por pequenos produtores, vê chegar, mais recentemente a diferenciação do modelo com a instalação de empresas agrícolas de médio e grande porte.

Por localizar-se em uma região rica em mananciais, além dos rios, o lençol freático oferece uma reserva gigantesca de água. Seguindo, entretanto, as técnicas de cultivo da terra, esta deve ser usada de forma autossustentável e com preservação dos recursos naturais. As áreas de produção são fiscalizadas, no uso da água, pela ANA (Agência Nacional de Águas) e pelo IBAMA (Instituto Brasileiro do Meio Ambiente).

O sistema utilizado por produtores mais contemporâneos é o de micro aspersão, onde a planta recebe a água através de gotejamento. Este é um sistema usado com sucesso para o cultivo até em locais áridos como em Israel, no Oriente Médio. Devido às características da região de Conceição do Jacuípe, esse processo tem de ser acompanhado de perto por trabalhadores que controlam a administração da água de acordo com as condições climáticas do período. 
Ao se refletir acerca do motivo pelo qual o território se dedica à produção de hortaliças folhosas, este pesquisador se vale de anotações feitas durante diálogo mantido com o Engenheiro Agrícola Herval Passos de Araújo (CREA 9928/D), em entrevista para informações preliminares sobre o tema. Informa Herval que após a segunda grande guerra (1945) o governo brasileiro acolheu imigrantes e concedeu o uso de terras no entorno de Salvador (citou núcleo JK em Mata de São João, a região do alto do ipê na BR 324 e em Conceição do Jacuípe). A origem dos imigrantes era a Polônia e o Japão, predominantemente. Em Conceição do Jacuípe ocorreu a desapropriação de 3 fazendas e a fixação de famílias (em lotes de 2 hectares) que se dedicavam à produção agrícola, normalmente em culturas de curto prazo, nas regiões de Rio Seco, Queimadas e Oitizeiro.

A produção exigia mão de obra, além dos imigrantes, que buscaram trabalhadores rurais locais que, com o tempo e a saída gradativa dos primeiros agricultores, passaram a assumir as tarefas de produção (observa o relator que os imigrantes originais passam a se dedicar mais à comercialização), sendo que parte das famílias dos primeiros beneficiários, com o passar dos tempos, não davam sequência aos negócios. Hoje quase já não se encontram indivíduos descendentes da ocupação original. As práticas e técnicas de plantio, entretanto, foram incorporadas pelos ex-empregados, hoje pequenos produtores.

O clima (tropical úmido, com a maioria dos meses do ano com uma significativa pluviosidade, avaliado pelo método Köppen e Geiger), a oferta de água(*) e a posição geográfica do município favorecem a produção de hortaliças folhosas, sendo que a malha rodoviária presente no território facilita o fornecimento de insumos, a circulação, distribuição e logística, quer a montante, quer a jusante dos pontos de produção.

(*)Especificamente com relação à oferta de água, no verão de 2018 registrouse uma crise hídrica na região, amenizada com o oferecimento, pelo poder público, de cisternas para captura e uso de água de chuvas, além de pequenos reservatórios (aguadas) ou a perfuração de poços.

Pelos contatos preliminares mantidos, foi possível perceber que a comunidade local apresenta perfil pouco coletivo. Raras são as iniciativas cooperativas e de colaboração entre os produtores, que parece, ao contrário, buscarem adequação aos mercados (quer fornecedor, quer consumidor) mediante esforços individuais.

Não existem, no município, organizações típicas de colaboração e diálogo, como Lions Cube, Rotary Clube ou Maçonaria. 
Nem mesmo para atividades de diversão e lazer, existem clubes ou espaços comunitários de destaque.

O único sindicato identificado (dos produtores rurais) se dedica predominantemente à emissão de documentos visando obtenção de benefícios sociais governamentais.

Algum grau de associativismo parece estar entre alguns produtores de hortaliças folhosas orgânicas, que apresentam possível propensão em maior nível que os produtores em geral. Esta observação empírica constitui, também, um objetivo de pesquisa preliminar.

Também deverão ser estudados aspectos do relevo, economia, transportes, etc, e demais fatores locais favoráveis à produção e distribuição de produtos agrícolas, notadamente hortifrutigranjeiros com destaque para hortaliças folhosas.

As principais hortaliças folhosas produzidas no município hoje (cujo volume, rol de produtores e respectivos volumes, origem e destino da produção, tendência de aumento ou redução nos últimos anos e a associação de fatores que motivaram essa dinâmica devem ser pesquisados), são: agrião, acelga, alface, almeirão, couve, espinafre, repolho e rúcula.

A incorporação de ferramentas administrativas nas áreas de produção, logística, distribuição e marketing, entre outras, bem como o estímulo à co-laboração para a busca de certificações da Indicação Geográfica para as "Hortaliças de Berimbau" facilitarão demonstrar a relevância para a produção familiar inserida no mercado por parte dos produtores familiares aí localizados.

\section{REFERÊNCIAS:}

AMARAL FILHO, Jair do. Desenvolvimento Regional Endógeno em um Ambiente Federalista, in Planejamento e Políticas Públicas, no. 14 - dez de 1996 - IPEA Instituto de Pesquisa Econômica Aplicada. Disponível em <http://www.ipea.gov.br/ppp/index.php/PPP/article/viewFile/129/131. Acesso 01/03/ 2019.

BAIARDI e TEIXEIRA. O Desenvolvimento dos Territórios do Baixo Sul e do Litoral Sul da Bahia: a Rota da Sustentabilidade, Perspectivas e Vicissitudes. Amílcar Baiardi, Francisco Teixeira. Salvador, outubro de 2010, disponível em http://www.observatorio.ufba.br/arquivos/desenvolvimento.pdf acessado em 13/03/2019

BAIARDI, Amilcar. Elinor Ostrom, a premiação da visão unificada das ciências humanas. Cad. CRH vol.24 no.61 Salvador Jan./Apr. 2011 disponível em < <http://dx.doi.org/10.1590/S010349792011000100014. Acesso em 13/03/2019.

BENKO, Georges. PECQUEUR, Bernard. Os recursos de territórios e os territórios de recursos. Geosul, Florianópolis, v.16, n.32, p 31-50, jul./dez. 2001 
BRASIL. INPI. GUIA BÁSICO DE INDICAÇÃO GEOGRÁFICA. Disponível em http://www.inpi.gov.br/menu-servicos/indicacao-geografica/guia-basico-de-indicacao-geografica acesso em 13 de março de 2017.

BRUCH, Kelly. COPETTI, Michele. Procedimentos de Registro das Indicações Geográficas, cap 6 INPI BRASIL (2011).

CARVALHO, Ramon. RIBEIRO, Marta. SANTOS, Mário Jorge. Potencialidade para concessão de indicação geográfica do bordado boa-noite na Ilha do Ferro/AL. Revista GEINTEC Vol 8, n.1 p.42834291 Aracaju-SE. 2018.

COUTO, Victor Athayde. REIS, Lívia Liberato de Matos. CUNHA, Luana Santa Inês. DENDÊ DE VALENÇA, BAHIA: INDICAÇÃO DE PROCEDÊNCIA. ANAIS DO VIII SOBER NORDESTE (Sociedade Brasileira de Engenharia Rural). Parnaíba, 2013.

DALABRIDA, W. GOVERNANÇA TERRITORIAL E DESENVOLVIMENTO: as experiências de descentralização político-administrativa no Brasil como exemplos de institucionalização de novas escalas territoriais de governança. Anais do I Circuito de Debates Acadêmicos (CODE 2011) IPEA. Brasília, DF - 23 a 25 de Novembro de 2011.

DALLABRIDA, Valdir Roque. Desenvolvimento e governança territorial; um ensaio preliminar sobre a necessidade da regulação no processo de gestão do desenvolvimento. In: REDES, Santa Cruz do Sul, v.15, n.3, p. 165-186, 2010.

DOUGLAS, Mary. Cómo piensam las instituciones. Alianza Universidad. Alianza Editorial S.A., Madrid, 1996.

DURKHEIM, Émile. 1858-1917. As regras do método sociológico I Émile Durkheim ; tradução Paulo Neves; revisão da tradução Eduardo Brandão. - 3a ed. - São Paulo: Martins Fontes, 2007.

ESTEVAM, Venessa; SPIAZZI DOS SANTOS, Guilherme; FELISBERTO, Zeli; ZILLI, Júlio Cesar; PIERI, Ricardo; e PINTO VIEIRA, Adriana Carvalho. GOVERNANÇA TERRITORIAL E INDICAÇÃO GEOGRÁFICA: Contribuições da Universidade do Extremo Sul Catarinense - UNESC disponivel em http://www.ucs.br/etc/conferencias/index.php/mostraucsppga/xvimostrappga/paper/viewFile/4817 /1644 acesso em 09 de março de 2019.

GONÇALVES, Alcindo. O Conceito de governança. [2012]. Disponível em: $<$ http://www.conpedi.org.br/manaus/arquivos/Anais/Alcindo\%20Goncalves.pdf. Acesso em 22/02/2019.

LASTRES, H.M.; CASSIOLATO, J.E. Novas Políticas na Era do Conhecimento: o foco em arranjos produtos e inovativos locais. Parcerias Estratégicas - Número 17 -Setembro/2003 (meio digital).

MAIORKI, Giovane J. DALLABRIDA, Valdir Roque. A indicação geográfica de produtos: um estudo sobre sua contribuição econômica no desenvolvimento territorial. REVISTA INTERAÇÕES, Campo Grande, v. 16, n. 1, p. 13-25, jan./jun. 2015.

OLSON, Mancur. A lógica da ação coletiva: Os benefícios Públicos de uma Teoria dos Grupos Sociais. EDUSP, São Paulo, 1999. 
PASCUAL ESTEVE, Josep Maria Governança democrática: construção coletiva do desenvolvimento das cidades / Josep Maria Pascual Esteve. Tradução: João Carlos Vitor Garcia, Fundação Astrojildo Pereira, São Paulo, 2015

PECQUEUR, Bernard: Pós-fordismo, território e sustentabilidade in Inovação, território, e arranjos cooperativos. Experiências de geração de inovação no Brasil e na França [em linea]. Marseille: OpenEdition Press, 2015 (generado el 18 marzo 2016). Disponível em http://books.openedition.org/oep/928. Acesso em 10/03/2019.

PRUGH, Tom; RENNER, Michael. (Org.) Estado do mundo 2014: como governar em nome da sustentabilidade. Worldwatch Institute. Salvador, 2014.

PUTNAM, Robert D. LEONARDI, Robert. NANETTI, Raffaella. Comunidade e democracia: a experiência da Itália moderna; tradução Luiz Alberto Monjardim. - 5 ed. - Rio de Janeiro: Editora FGV, 2006.

REIS, Lívia Liberato de Matos. Indicação Geográfica no Brasil: determinantes, limites e possibilidades / Tese de Doutorado. UFBA. - Salvador, 2015

SANTOS, Milton e SILVEIRA, Maria Laura. O Brasil: território e sociedade no início do século XXI. 5ạ. ed. Rio de Janeiro: Record, 2003

SANTOS, Milton. A natureza do Espaço: Técnica e tempo. Razão e emoção. São Paulo: EDUSP, 2012.

SEYLE, C. e KING, Matthew. O que é Governança. In: PRUGH, Tom; RENNER, Michael. (Org.) Estado do mundo 2014: como governar em nome da sustentabilidade. Worldwatch Institute. Salvador, 2014.

SEYLE, Conor e KING, Mattehew O que é governança. In: PRUGH, Tom; RENNER, Michael. (Org.) Estado do mundo 2014: como governar em nome da sustentabilidade. Worldwatch Institute. Salvador, 2014.

SILVA, Sylvio Bandeira de Mello e. (Org.). Estudos sobre dinâmica territorial, ambiente e planejamento. João Pessoa: Editora Grafset, 2011.

SILVA, Sylvio Bandeira de Mello e; SILVA, Barbara-Christine Nentwig Silva. Estudos sobre globalização, território e Bahia. 2.ed. Salvador: UFBA, 2006.

SILVA, Sylvio Carlos Bandeira de Mello Teoria de localização e de desenvolvimento regional, in: Revista Geografia, Vol. 1, n. 02. Rio Claro: Unesp, outubro de 1976.

VALENTE, LUCIANO. Hélice tríplice: metáfora dos anos 90 descreve bem o mais sustentável modelo de sistema de inovação, entrevista com HENRY ETZKOVITZ. Conhecimento \& Inovação v.6 n.1 Campinas 2010. Disponível em http://inovacao.scielo.br/scielo.php?script=sci_arttext\&pid=S1984$43952010000100002 \&$ Ing=pt\&nrm=is. Acesso em 02/10/2018. 


\section{Capítulo 17}

\section{CUSTO DE PRODUÇÃO DE SUÍNOS (FASE RECRIA) EM UMA PROPRIEDADE RURAL FAMILIAR DO OESTE DO PARANÁ}

DOI: $10.37423 / 200300415$

Germano de Paula (Dr.), Docente do CCSA, UNIOESTE-Campus de Marechal Cândido Rondon - germano5043@hotmail.com

Werner Engel (Ms), Docente do CCSA, UNIOESTE-Campus de Marechal Cândido Rondon -werner-engel@hotmail.com

Luana Regina Schaedler; Discente, CCSA, UNIOESTE-Campus de Marechal Cândido Rondon - luanaregina.sch@hotmail.com

Samoel Nicolau Hanel, Doutorando do PPGDRS, CCA, UNIOESTE-Campus de Marechal-Cândido Rondon, samonico@hotmail.com

RESUMO: A pesquisa tem por objetivo calcular o custo e o resultado da atividade de criação de suínos, na fase de recria, em uma propriedade rural familiar no município de Toledo, região oeste do Paraná. O estudo tem cunho exploratório e os procedimentos referiram-se as pesquisas bibliográficas, de endereços eletrônicos, documentais e de estudo de caso. Para a análise dos dados, utilizou-se a pesquisa qualitativa e na análise e desenvolvimento, recorreuse à forma quantitativa, com o uso de planilhas eletrônicas a fim de realizar os cálculos dos custos e despesas, da margem de contribuição, do ponto de equilíbrio contábil em quantidades e valores e da margem de segurança. Após todos os custos e despesas apurados, buscou-se identificar as receitas, para então calcular o resultado gerado pela atividade, no período de junho de 2016 a julho de 2017, tempo de produção dos 07 lotes de suínos. Para elaboração dos custos, utilizou-se o método de custeio por absorção, sendo possível identificar a participação de cada custo no resultado em cada lote e total. 
O produto entregue pelo produtor à empresa parceira foi o leitão com peso médio por lote de $169.838,37 \mathrm{~kg}$ e o preço médio nominal de venda por quilo do suíno vivo foi de $\mathrm{R} \$ 6,93$. O índice da margem de contribuição apresentou diferenças entre os lotes produzidos com média de 0,23. Constatou-se que a margem de contribuição total (MCT) média dos lotes produzidos foi de R\$ 469.882,11 e os destaques foram o lote 04 com a menor MCT (R\$ 368.301,51) e o lote 06 foi o que gerou a maior MCT para o produtor (R\$ 795.900,92). Quanto à quantidade necessária para atingir o Ponto de Equilíbrio Contábil (PEC), registrou-se que os lotes $05(97.928,13 \mathrm{~kg})$ e $01(107.535,09 \mathrm{~kg})$ apresentaram a menor e a maior quantidades de produção de leitões para atingir o equilíbrio entre a receita, custos e despesas. O lote 02 contabilizou a menor receita necessária para atingir o PEC (R\$ 668.759,51), enquanto o lote 06 foi aquele que necessitou da maior receita para atingir o PEC (R\$ 765.529,58). O lote 04 proporcionou a menor receita liquida (R\$ 1.081.640,92) e o lote 06 possibilitou a obtenção da maior receita liquida ( $R \$$

1.561.430,50). Em relação à margem de segurança (MS), o lote 04 (34,05\%) foi o que apresentou a menor margem e o lote $06(50,97 \%)$ a maior. Conclui-se e destaca-se que, com base nos cálculos realizados, todos os sete lotes produzidos apresentaram lucro ao produtor, mas o lote 06 , foi aquele que teve o maior tempo de alojamento dos animais, e também o que apresentou o maior lucro.

Palavras-chave: propriedade rural familiar; suínos fase recria; custos; margem de contribuição. 


\section{INTRODUÇÃO}

A crescente conscientização dos consumidores no processo de escolha dos bens e serviços que os mesmos têm a sua disposição no mercado como opções para consumo têm assumido importância nos diferentes mercados produtores e fornecedores desses bens. No contexto mundial, as preocupações desses consumidores que passaram a ter maiores exigências da origem e destinações desses bens cujas produções possam ser identificadas como aquelas que seguem padrões de qualidade em termos socioeconômicos e ambientais, também causaram mudanças nos processos produtivos dos fornecedores de bens e serviços.

Nesse contexto, os agentes econômicos que fornecem as diferentes categorias de bens, desde os primários aos mais elaborados ou de maior valor agregado, têm cada vez mais a necessidade de produzirem em mercados cada vez mais competitivos e com níveis tecnológicos que possam incorporar as demandas desse novo padrão de consumidores.

Conforme Yamaguchi et al. (2002), as mudanças exigidas pelo mercado têm sido o emprego da informação, associada às tecnologias facilitadoras dessa nova realidade. Ainda nesse assunto, conforme Machado (2002), no meio rural, essa situação é semelhante, pelo maior grau de competição à medida que incorporam a gestão de informação e o emprego de tecnologia.

Para manter a competitividade no mercado, é necessário que se tenha o conhecimento das expectativas dos clientes, essas expectativas já existem antes mesmo da compra ou contratação do bem ou serviço, pois é a partir delas que a empresa pode formular suas estratégias, e, posteriormente, oferecer a qualidade que o cliente espera ou deseja. A expectativa do cliente começa a ser suprida já no início do atendimento, o primeiro contato pode definir o restante. Por esse motivo, torna-se importante o conhecimento do cliente e de suas expectativas com a empresa (KOTLER; ARMSTRONG, 2003).

Atividade que engloba importante papel socioeconômico na economia brasileira, a agricultura, conforme Malavolta (1993, p. 89), "é a arte de modificar os ecossistemas, em termos econômicos e sem produzir danos irreversíveis". Nesse contexto, a produção agropecuária brasileira, envolve diferentes agentes produtivos, distribuídos nas diferentes cadeias produtivas, com diferentes níveis tecnológicos, de escala de produção, de ganho econômico, que refletem o crescimento socioeconômico do Brasil ao longo do tempo. 
Como segmento de agentes que constituem a produção agropecuária brasileira, destaca-se a agricultura familiar. $\mathrm{O}$ seu conceito tem diferentes e divergentes interpretações, conforme a matriz ideológica dos seus estudiosos. Em um dos conceitos mais tradicionais, para Wanderley (2001), a agricultura familiar se caracteriza quando a família é simultaneamente a proprietária dos meios de produção e assume o trabalho nas unidades produtivas. Assim, o sistema de produção familiar é aquele no qual a propriedade e o trabalho estão intrinsicamente relacionados com a família, tendo como característica primordial a diversidade produtiva, como base para sua adaptação às diversidades do sistema que lhes são próprias. Ainda, quanto à singularidade desse segmento produtivo, Guanziroli et al. (2001) destaca que a agricultura familiar tem vantagens na gestão da força de trabalho, particularmente relevantes em processos de produção intensivos em trabalho e que exigem tratos culturais delicados e cuidadosos, que dificilmente podem ser comparados com a firma patronal,

Conhecer quais os custos para produzir algo, é de extrema importância para os agentes produtivos, pois assim é possível calcular a margem de lucro que o produto pode gerar. A terminologia contábil da palavra custo condiciona o pensamento para uma empresa industrial ou comercial, mas, entretanto, sabe-se que os custos estão presentes em qualquer atividade, seja ela com fins lucrativos ou não.

Quando se trata da produção agropecuária a preocupação com os custos não é diferente para produzir um bem, seja ele, soja, milho, trigo, suinocultura, bovinocultura de leite, bovinocultura de corte e avicultura entre outros. Assim, é imprescindível identificar os gastos envolvidos na produção, para que se possa mensurar o custo do produto e, por consequência, sua receita. Então, ao se calcular o custo e a receita de determinada produção, o produtor tem condições de saber se ela vai gerar o lucro esperado ou prejuízo. Nesse contexto, segundo Nepomuceno (2004, p. 54):

A atividade rural, como a industrial, comercial e de produção de serviços, é atividade econômica e, como tal, requer controle financeiro e acompanhamento específico. Não basta saber que, em determinado ano, o empreendimento foi bem-sucedido, sem conhecer, especificamente, o nível de lucratividade ou de déficit de cada produção explorada. 
Atualmente a produção agropecuária brasileira é responsável por $23 \%$ do Produto interno bruto (PIB) brasileiro e o PIB desse setor deverá crescer 2\% em 2017. Ainda o mesmo é responsável por $33 \%$ da produção nacional, que representou $44 \%$ das exportações totais (OLIVEIRA, 2017).

Integrante do segmento da agropecuária brasileira e do segmento da suinocultura, a produção familiar alcança expressiva participação quanto aos aspectos de emprego, renda e de ocupação do espaço rural brasileiro. Assim, as grandes propriedades no Brasil produzem mais carne bovina, soja, cana de açúcar, laranja e arroz e as unidades familiares à frente das produções de milho, batata, feijão, mandioca, carnes suína e de aves, ovos, leite, verduras, legumes e frutas (IBGE, 2016).

No setor agropecuário, a importância da suinocultura brasileira tem destaque na Revista da Suinocultura (2016) que menciona que o produto interno bruto da suinocultura no Brasil somou R\$ 62.576 bilhões de Reais, a suinocultura brasileira gerou 923.394 empregos indiretos. No âmbito do consumo brasileiro de carne suína, Miele e Machado (2010) contataram que, ao contrário do perfil mundial, o consumidor de carne suína no Brasil é inferior ao das carnes de frango e bovina. Desse modo, para os referidos autores, o consumo (de carne suína) ocorre preferencialmente através de produtos processados em detrimento da carne suína in natura. Em termos de locais de consumo, $76 \%$ das despesas com alimentação do brasileiro ocorrem no domicílio e $24 \%$ fora dele em bares, restaurantes, lanchonetes e cozinhas industriais.

Nas ultimas décadas, a cadeia produtora de carne e de derivados de suínos passou por mudanças, que se manifestaram nas características dos produtos, na redução no número de atores da cadeia produtiva, no aumento das escalas de produção, e nos ganhos tecnológicos. Nessa perspectiva, conforme Rocha et al. (2007), a suinocultura brasileira é uma atividade cíclica, visto que alternam períodos de alta e baixa rentabilidade, definida pelo preço do insumo e do suíno. Assim, o suinocultor pode alcançar retornos positivos na atividade ou enfrentar prejuízos dado o maior custo de produção diante do preço recebido pelo suíno terminado.

Em relação ao desempenho da economia da Paraná, o PIB paranaense teve queda de

2,4\% no final de 2016 e, entretanto, o Instituto Paranaense de Desenvolvimento Econômico Social (Ipardes) estima que ocorrerá um crescimento de 1,6\% em 2017, e esse avanço deve decorrer em razão do aumento de 6,2\% esperado da agropecuária do estado (PARANÁ, 
2017). Ainda, estima-se que o Paraná gere em torno de 200.000 empregos diretos e 300.000 indiretos relacionados a carne suína (MOLIN, 2017).

Para Crepaldi (2012, p. 37) com o desenvolvimento tecnológico, a agricultura vem se desenvolvendo e produzindo cada vez mais, há redução de custos, com geração de empregos e renda ao setor. Ainda, para o mesmo autor, a contabilidade pode desempenhar um papel importante como ferramenta gerencial, pois fornece informações que auxiliam no planejamento e controle na tomada de decisão, garantindo o sucesso do empreendimento e da propriedade rural. Sobre os custos, Crepaldi (2012, p. 37) afirma que o estudo dos custos de produção é um dos assuntos mais importantes, pois fornece ao empresário rural um roteiro indicativo para escolha das linhas de produção a serem adotadas e seguidas.

Segundo informações da Secretaria de Estado da Agricultura e do Abastecimento (SEAB), e do Departamento de Economia Rural (DERAL/PR) (2017), a produção mundial de carne suína, em 2016, foi estimada em 109,8 milhões de toneladas. Dessa produção, a China produziu o maior volume (48,0\%), a União Europeia (21\%), os Estados Unidos das Américas

- EUA (10,0\%), o Brasil (4,0\%) e demais países $(17,0 \%)$.

De acordo com o levantamento de dados da Associação Brasileira de Proteína Animal- ABPA, o estado do Paraná ocupou o terceiro lugar dentre os estados exportadores de carne suína brasileira, que representou $13,18 \%$ do total e, $80,4 \%$ da produção suína é destinada ao mercado interno (MAPEAMENTO, 2017). Ainda, na conjuntura dos estados brasileiros, conforme a SEAB/DERAL (2017), o rebanho brasileiro de suínos abatidos, em 2016, somou

42.315.933 de cabeças, com destaque para a participação de Santa Catarina $(25,0 \%)$ que representou a maior do Brasil, em seguida, o Paraná (21,0\%), Rio Grande do Sul (20,0\%), Minas Gerais (13,0\%), Mato Grosso (6,0\%), São Paulo (5,0\%), Goiás $(4,0 \%)$ e os outros estados $(6,0 \%)$.Conforme a mesma fonte, em relação à produção brasileira de carne suína, em

2016, atingiu 3,71 milhões de toneladas, desse total, a oferta de Santa Catarina (26,0\%) representou a maior do Brasil, seguida pelo Paraná (21,0\%), , Rio Grande do Sul (20,0\%), Minas Gerais (12,0\%), Mato Grosso (6,0\%), São Paulo (5,0\%), Goiás $(4,0 \%)$ e os outros estados $(6,0 \%)$. O consumo per capita aparente de carne suína pelo brasileiro ( $\mathrm{kg} / \mathrm{habitante/ano)} \mathrm{teve} \mathrm{oscilação} \mathrm{média}$ de 14,6. kg/hab./ano, de 2010 a 2016. Em termos comparativos, em 2013 registou-se o menor consumo per capita, ou seja, 13,02 kg/hab/ano e o maior consumo ocorreu em 2012 (14,96 
kg/hab/ano). Na comparação a 2015, em 2016, a população brasileira teve um incremento de 0,8\%, enquanto o consumo per capita de carne suína aumentou 2,63\% (SEAB/DERAL, 2017),

Diante do contexto apresentado que expressa a importância, tanto no âmbito nacional e notadamente para o estado do Paraná, da importância socioeconômica da produção suína, esse estudo tem por objetivo calcular o custo e o resultado da atividade de criação de suínos, na fase de recria, em uma propriedade rural familiar no município de Toledo, região oeste do estado do Paraná. Mais especificamente, visa determinar a margem de contribuição (por quilograma - kg), o ponto de equilíbrio contábil e a margem de segurança dessa fase de produção.

\section{REFERENCIAL TEÓRICO}

\subsection{DEFINIÇÕES DE CUSTOS}

A contabilidade é uma ciência social, pois estuda a ação humana nos valores e patrimônios. Ela surgiu com a função de tornar a "saúde" econômico-financeira da empresa visível. A contabilidade é uma ferramenta responsável por fornecer informações para a tomada de decisões.

De acordo com Marion (2012), a contabilidade coleta todos os dados econômicos, mensurandoos monetariamente, registrando-os e sumarizando-os em forma de relatórios ou de comunicados, que contribuem sobremaneira para a tomada de decisões.

Para Oliveira (2010, p. 26):

A contabilidade tem por finalidade analisar, interpretar e registrar os fenômenos que ocorrem no patrimônio das pessoas físicas e jurídicas. Expõe aos seus usuários, por meio de relatórios próprios, as informações sobre o comportamento dos negócios para a tomada de decisões.

Segundo Marion (2012, p. 28), a contabilidade tem como objetivo principal permitir a cada grupo principal de usuários a avaliação da situação econômica e financeira da entidade, num sentido estático, bem como fazer interferências sobre as tendências futuras.

A contabilidade de custos nasceu da contabilidade financeira, quando da necessidade de avaliar estoques na indústria. Em relação a esse assunto, de acordo com Koliver (2009, p.

43): 


\begin{abstract}
A parte da contabilidade que trata da fundamentação teórico-doutrinária, das técnicas, métodos e procedimentos utilizados na apreensão, classificação e avaliação das mutações patrimoniais que ocorrem no ciclo operacional interno das entidades, com vista à correta delimitação dos agregados de valores a bens ou serviços produzidos e às funções exercidas na entidade, durante determinado período de tempo.
\end{abstract}

Vários autores apresentam definições semelhantes para as terminologias básicas encontradas em custos. Para Leone (1987, p. 20), a contabilidade de custos organiza, dimensiona e planeja a qualidade, a forma e as características dos dados dos setores fundamentais. Ainda, nesse tema, para Maher (2001, p. 44) um dos princípios da contabilidade de custos é que as diferentes necessidades exigem informações diferentes. Para esse autor, custos são sacrifícios de recursos, e difere-se de uma despesa, pois despesa é um custo lançado contra a receita de um período. Segundo Maher (2001), custo é um sacrifício de recursos; Despesa: é um custo lançado contra a receita de um período contábil e Custo dos Produtos Vendidos é o custo atribuído aos produtos vendidos no período.

Conforme Martins (2010, p. 24-25):

Gasto: é a compra de um produto ou serviço que gere sacrifício financeiro para a entidade; Custo: é o gasto relativo a bem ou serviço utilizado na produção de outros bens e serviços; Despesa: é o bem ou serviço consumido direta ou indiretamente para a obtenção de receitas; Desembolso: Pagamento resultante da aquisição do bem ou serviço; Perda: Bem ou serviço consumidos de forma anormal e involuntária; Investimento: é o gasto ativado em função de sua vida útil ou de benefícios atribuíveis a futuro período.

No segmento do setor primário, de acordo com Carneiro (1997, p. 2), a Contabilidade Rural é a especialização da Contabilidade que se ocupa dos atos e fatos administrativos das empresas rurais.

Nessa dimensão, a contabilidade agrícola é a parte da contabilidade aplicada às atividades agrícolas, tendo por objetivo o estudo, registro e controle da gestão econômica do patrimônio das empresas que se dedicam a essas atividades. (ALOE; VALLE, 1979).

Nessa abordagem, conforme Crepaldi (2012, p. 47), a contabilidade aplicada na atividade rural pode demonstrar toda a vida evolutiva da empresa. Por isso é imprescindível que também na agropecuária, a contabilização dos fatos e sua estruturação sejam realizados com o perfeito conhecimento.

Ainda, segundo Crepaldi (2012, p. 76): 
A Contabilidade Rural é um dos principais sistemas de controle e informação das Empresas Rurais. Com a análise do Balanço Patrimonial e da Demonstração do Resultado do Exercício é possível verificar a situação da empresa, sobre os mais diversos enfoques, tais como analises de estrutura, de evolução, de solvência, de garantia de capitais próprios e de terceiros, de retorno de investimentos, etc.

A Contabilidade Rural também fornece informações sobre condições de expandir-se, sobre necessidades de reduzir custos e despesas, necessidades de buscar recursos etc. Está aí outra finalidade da Contabilidade Rural: o planejamento.

Dentre os controles importantes para que se possa medir o resultado econômico e contábil de uma propriedade rural, Maher (2001, p. 69) classifica os custos diretos como os custos que podem ser relacionados diretamente com o objeto do custo; Custo indireto é qualquer custo que não pode ser relacionado diretamente com um objeto do custo.

Ainda, de acordo com Maher (2001, p. 69):

Custos variáveis: Custos que se alteram na proporção direta da alteração no volume, dentro de um intervalo relevante de atividade; Custos fixos: Custos que não se alteram quando o volume se altera, dentro de um intervalo relevante de atividade; Intervalo relevante: Níveis de atividades entre os quais dados custos fixos total ou custos variáveis não se alteram; Custo semivariável: Custo que contém componentes fixos e variáveis, também denominado custo misto; Custo em degraus: Custo que aumenta „em degraus" quando o volume aumenta. Também é denominado de custo semifixo; Custo pleno: A soma de todos os custos de fabricar e vender uma unidade do produto (inclui todos os custos fixos e variáveis); Custo por absorção: Todos os custos de produção, fixos e variáveis; é utilizado para calcular o estoque de produtos, de acordo com as PCGA.

A margem de contribuição é um conceito estudado por vários autores e expressa o valor (em unidade monetária) que o produtor ou empresa recebe para pagar as despesas fixas e ter lucro.

A margem de contribuição é tratada de duas formas, ou seja, unitária ou total. A primeira é a diferença entre o preço de venda e a soma dos custos variáveis unitários de um bem ou serviço, e a segunda é o resultado obtido pela multiplicação da margem de contribuição unitária pela quantidade vendida, que resulta a contribuição total de determinado item no resultado geral da empresa ou produtor, dado certo volume de venda.

Salienta-se que o cálculo da margem de contribuição torna-se possível, caso a contabilidade possa separar os custos e as despesas de fabricação em fixos ou variáveis, o que nem sempre é fácil, dado o contexto que a empresa atua (BRUNI, 2008). 
Outro coeficiente utilizado para dimensionar a situação econômico-financeira de um empreendimento produtivo, é o ponto de equilíbrio contábil. Esse é um dos parâmetros utilizados para verificar a viabilidade de uma empresa ou propriedade.

Conforme Martins (2010), o ponto de equilíbrio (Break-even Point), contábil também denominado ponto de ruptura, indica a capacidade mínima que a empresa deve operar ou produzir para não ter prejuízo. Delineia assim, a relação entre o volume de vendas e a lucratividade, que define o nível mínimo de vendas do bem para cobrir os custos operacionais.

A possibilidade de um empreendimento está operando com lucro baixo pode ser evidenciado ou não através do coeficiente denominado margem de segurança. Então, segundo Martins (2010), a margem de segurança é o espaço limitado pelo nível de produção e de vendas considerado normal e pelo nível do ponto de equilíbrio (Break-even Point) e esse nível está acima do ponto de equilíbrio e localiza-se entre este e o de capacidade máxima. Desse modo, a margem de segurança é o espaço que a empresa ou propriedade pode operar sem o risco de entrar na área de prejuízo.

\subsection{MÉTODOS DE CUSTEIO}

Para a apropriação dos custos, pode-se utilizar alguns métodos de apropriação, ou seja, métodos de custeio. Os métodos mais conhecidos são: Custeio por Absorção, Custeio Variável, ABC, RKW e outros.

De acordo com Martins (2010, p. 37), Custeio por absorção consiste na apropriação de todos os custos de produção aos bens elaborados, e só os de produção, ou seja, todos os gastos ocorridos na produção de um produto são distribuídos entre eles. Para o mesmo autor, no custeio variável, só são alocados aos produtos os custos variáveis, ficando os fixos separados e considerados como despesas do período, contabilizados diretamente para o Resultado.

O Custeio Baseado em Atividades $(A B C)$, é um método de custeio que procura reduzir sensivelmente as distorções provocadas pelo rateio arbitrário dos custos indiretos (MARTINS, 2010).

\subsection{AGRICULTURA FAMILIAR, SUINOCULTURA E FASES DE PRODUÇÃO}

Os pesquisadores atuais concordam que o suíno, ou porco, tenha surgido na Terra há mais de 40 milhões de anos. Na idade média o consumo da carne de porco era grande, passando a ser símbolo de gula, volúpia e luxúria, principalmente pelos romanos. Os suínos chegaram ao continente 
americano na segunda viagem de Colombo, que os trouxe em 1494 e soltou-os na selva. Foram introduzidos no Brasil por Martim Afonso de Souza em 1532 (ABCS, 2017).

Na evolução da ciência e do melhoramento genético envolvido no processo de criação do suíno existem inúmeras terminologias utilizadas, sejam elas para definir a qual cadeia produtiva 0 suíno pertence, como também a variedade de rações e medicações necessárias para a criação destes animais.

No Brasil a maior concentração de criadores de suínos localiza-se na região sul e sudeste do país. Na região sul encontram-se os pequenos produtores, geralmente da agricultura familiar e associados a algum tipo de cooperativa e responsáveis por uma fase da cadeia produtiva, enquanto na região sudeste localizam-se os produtores independentes, com o chamado ciclo completo (desde o nascimento até o abate).

Os produtores da agricultura familiar têm suas relações com o mercado, com diferentes níveis de dependência com os demais agentes da cadeia produtiva. Desse modo, procura-se analisar e compreender a dependência de mercado, que pode ser entendida da seguinte forma: existem agricultores que destinam toda sua produção para o mercado, ou seja, a produção é destinada para a venda. Há produtores que destinam a maior parte de sua produção para a venda e ficam com a menor parte para autoconsumo. E, finalmente, existem agricultores que destinam o essencial de sua produção para o autoconsumo e outra parte vai para o mercado (LAMARCHE, 1998 apud SANTOS, 2009).

A complexidade da caracterização do produtor da agricultura familiar e de suas múltiplas atividades produtivas, conforme Blum (1999, p. 57):

O agricultor familiar é todo aquele que tem na agricultura sua principal fonte de renda, ou seja, mais de $80 \%$ e cuja força de trabalho utilizada no estabelecimento venha fundamentalmente de membros da família. É permitido o emprego de terceiros temporariamente. Em caso de contratação de força de trabalho permanente, externo a família,, a mão de obra familiar deve ser igual a $75 \%$ do total utilizado no estabelecimento.

Para que o produtor familiar possa enquadrar-se como público-alvo de políticas públicas do governo brasileiro voltadas a esse segmento produtivo no Brasil, o Programa Nacional de Fortalecimento da Agricultura familiar (PRONAF), criado em 1996 e formulado como resposta às pressões do movimento sindica rural desde o início dos anos de 1990, nasceu com a finalidade de prover crédito agrícola e apoio institucional às categorias de 
pequenos produtores rurais que até então estavam excluídos das políticas públicas ao longo da década de 1980 e encontravam séria dificuldades de se manter na atividade (SCHNEIDER et al., 2003).

A complexidade de conceitos e de marcos divisórios da natureza de atividades desenvolvidas pelos produtores que se enquadram àqueles integrantes na categoria da agricultura familiar, no Manual Operacional do Crédito do PRONAF (BRASIL. MDA, 2002), os agricultores familiares devem apresentar os seguintes requisitos:

1. sejam proprietários, posseiros, arrendatários, parceiros ou concessionários da Reforma Agrária;

2. residam na propriedade ou em local próximo;

3. detenham, sob qualquer forma, no máximo 4 (quatro) módulos fiscais de terra, quantificados conforme a legislação em vigor e fixados de acordo com cada região;

4. obtenham o mínimo, $80 \%$ (oitenta por cento) da renda bruta familiar advinda da exploração agropecuária ou não agropecuária do estabelecimento;

5. apresentem, como base da exploração do estabelecimento, o trabalho familiar.

A produção de suínos abrange um universo diferenciado tais quais tipos de produtores de suínos diferenciam-se segundo categorias de produtores escalas de produção, nível tecnológico e tamanho da propriedade. Desse modo, quanto aos tipos de produtores, existem dois tipos principais, os produtores independentes que vendem as suas produções no mercado e os produtores integrados às agroindústrias que recebem das empresas insumos e assistência técnica, têm que realizar a produção conforme as especificações das empresas parceiras e destinam o produto (suíno) para as agroindústrias. Segundo Rocha (2007), os produtores que estão ligados ao sistema integrado têm uma situação mais estável entre os períodos de alta e baixa na atividade, mas com possibilidades reduzidas de altos retornos. Por outro lado, os produtores independentes, têm a possibilidade de enfrentar grandes perdas econômicas nos períodos de baixa, mas que podem ser compensadas pelos ganhos possíveis durante os períodos de alta da atividade.

Atualmente existem 3 tipos de sistemas de criação de suínos, o modelo centralizado nas cooperativas, o sistema de produção integrada e o de ciclo completo (independente). Assim, é possível 
identificar a diferença entre estes três modelos (MAPEAMENTO, 2017). No modelo de ciclo completo, ou produtor independente, trata-se de um sistema de produção suína onde o produtor/ proprietário é independente de qualquer assistência, sendo o responsável por adquirir a matéria prima e os insumos de terceiros, como sêmen, ração, medicação. Os suínos são gerados na propriedade onde permanecem até a fase de abate, quando o proprietário deve buscar por um frigorífico ou um mercado de porta, que realiza a compra desses animais. Em resumo, trata-se de um modelo onde o mesmo proprietário é responsável pela gestação, maternidade, creche e terminação dos animais.

O modelo de sistema integrado que refere-se à segregação de funções relacionadas à criação dos suínos, e nesse sistema os fornecedores matérias-primas $E$ de insumos negociam com a agroindústria que é a responsável por repassá-los aos seus integrados (pequenos produtores), classificados de acordo com a fase da atividade que desempenham em sua propriedade.

Tem-se a fase de Unidade de Produção de Desmame (UPD), onde o proprietário é responsável pelos leitões desde a gestação, seu nascimento, até a fase de desmame, onde são destinados a outro proprietário responsável pela fase de crechário ou Sistema Vertical de Crechário (SVC). Nessa fase, o leitão é cuidado, dos 6 quilos até os 24 quilos, até estar pronto

para ser remanejado para a fase de terminação. Nessa fase, o proprietário é responsável pela fase Unidade de Terminação (UT) e permanecerá com os animais até o período de abate.

Tem-se também a fase de Unidade de Produção de Leitões (UPL), onde o proprietário é responsável pela fase desde o nascimento do leitão até o período de destinação para a UT. O termo Wean To Finish não é muito praticado, mas, consiste da fase onde o produtor recebe os leitões de uma UPD e os cria até a fase de abate. A empresa agroindustrial é a responsável pelo abate dos animais e negociação com o mercado de consumo.

A suinocultura industrial engloba um grande diversidade de produtores (familiares, patronais e empresariais) e está localizada em diferentes regiões. Um traço comum a toda essa diversidade são as profundas transformações organizacionais e tecnológicas da última década. Até meados dos anos 1990, predominava a produção em ciclo completo (CC), onde o mesmo estabelecimento desenvolve todas as etapas de produção do animal. Verifica-se desde então um processo de mudança, com a agregação da produção em múltiplos sítios, em unidades produtoras de leitões (UPL) e unidades de crescimento e terminação (UT). Tem-se também a fase de Unidade de Produção de Leitões (UPL), onde o proprietário é responsável pela fase desde o nascimento do leitão até o período de 
destinação para a UT. Essa tendência á especialização nas etapas do processo produtivo ocorreu em todo o país, mas se dá de forma mais intensa entre as integrações na região Sul (MIELE; MACHADO, 2010).

\section{METODOLOGIA}

A pesquisa teve cunho exploratório e os procedimentos envolveram pesquisas bibliográficas, de endereços eletrônicos, documentais e estudo de caso.

A pesquisa de cunho exploratória contempla levantamento bibliográfico, realização de entrevistas, análise de exemplos e/ou estudo de caso que envolvam o problema estudado (GIL, 2002). Ainda nessa dimensão, Lakatos e Marconi (2003) destacam que a pesquisa bibliográfica procura inserir o pesquisador em contato com o seu objeto de estudo.

Para a análise dos dados, utilizou-se a pesquisa qualitativa e na análise e desenvolvimento do estudo, recorreu-se forma quantitativa,

\section{1 ÁREA DE ESTUDO}

O município de Toledo tem área de $1.197,016$ km2 e população de 135.538 , localiza-se na região oeste do estado do Paraná, com posição geográfica estratégica próxima das fronteiras com a Argentina e o Paraguai. Seus indicadores econômicos ligados à agropecuária e à agroindústria destacam-se no estado do Paraná: ocupa o 10 lugar do produto interno bruto (PIB) dentre todos os municípios do estado, o 1일 lugar em PIB agropecuário do Paraná e da região sul, o 11ㅇ lugar no país, o 10 lugar em VBP (valor bruto da produção) do Paraná, o 3ำ lugar em valor adicionado da agropecuária do Brasil, o 1 ㅇ lugar em rebanho suíno do Paraná, o 1 ㅇ lugar em plantel de frango do Paraná, o 5o maior produtor de leite do Paraná e o 30 lugar em Piscicultura Comercial do Paraná (TOLEDO, 2017). De acordo com a SEAB-DERAL (2017), em 2016, valor bruto da produção (VBP) da suinocultura do Paraná, de R\$

4.710.100.000,00, que correspondeu a 5,31\% do total do VBP do estado do Paraná (R\$

88.679.897.152,00), os núcleo das regionais de Toledo representou 47,4\%, de Cascavel $(18,0 \%)$ de Ponta Grossa $(13,8 \%)$ e de Francisco Beltrão $(5,1 \%)$. Ou seja, dos 22 núcleos regionais do estado do Paraná, esses quatro núcleos representaram $84,3 \%$ do VBP da suinocultura do estado. A propriedade analisada, situada no interior do município, surgiu em 1971, quando os primeiros proprietários vieram do Rio Grande do Sul em busca de novas oportunidades, compraram a 
propriedade na atualmente chamada Linha Guaçu, a terra foi adquirida da Fazenda Britânia, o estabelecimento rural têm 18,7 hectares (ha) com a seguinte distribuição:

11ha são utilizados para plantio, 3,7 ha correspondem a Área de Preservação Permanente (APP), 1,2 ha é de pastagem, 1,0 ha de construções no geral, 0,6 ha destinados ao plantio de alimentos. Em 1,2 encontra-se instalada ( $800 \mathrm{~m} 2$ cada, cujas construções são de pré-moldado e alvenaria cobertas por folhas de Eternit, e que têm capacidade de alojamento de 6.000 a 7.000 mil leitões.

\subsubsection{Sistema de produção de suínos}

Descreve-se nesse item como são realizadas as atividades e como ocorre ofuncionamento da produção dos suínos (fase de recria) na propriedade.

Geralmente o proprietário não tem empregados que residem em sua propriedade e a maioria das atividades produtivas é desenvolvida pelos membros de sua família (o casal e dois filhos). No entanto, durante o período de vacinação e de entrega dos animais, os proprietários, quando necessitam, contratam mão-de-obra temporária.

Na preparação das granjas (pocilgas) para alojamento, antes de receber os leitões, a pocilga deve ser higienizada para evitar problemas com doenças que permanecem nas instalações de um lote para outro. Esse período (varia de 4 a 5 dias) destinado a limpeza é denominado de vazio sanitário, período de tempo que o produtor tem para lavar e desinfetar a granja.

No processo de limpeza das instalações utiliza-se lavadores a jato de alta vazão e após essa atividade, com os mesmos equipamentos anteriores, realiza-se a desinfecção das baias, com uso de desinfetante até que se aloja a nova remessa de leitões. Nesse período de tempo, o proprietário realiza pequenas reformas tais quais manutenção de mangueiras, bebedouros,

comedouros, cortinas, piso plástico (grelhas), pintura, dentre outas.

Quanto ao período de alojamento e manejo (de 3 a 7 dias), tem-se o pré-alojamento: pelo fato da propriedade em estudo ter pocilgas que podem alojar de 6.000 a 7.000 mil animais. Antes de receber os animais, o proprietário deve deixar os bebedouros suspensos na altura dos animais que irão chegar e os comedouros cheios de ração inicial (SL01), pois como os animais fazem viagens longas até à propriedade, os mesmos chegam com fome e sede. 
No manejo dos suínos (classificação, medicação e alimentação) etapa que dura aproximadamente 15 dias, após a chegada de todos os animais à propriedade, o produtor faz a classificação, quando são separados por baia, machos e fêmeas, grandes, médios e leves. Os leitões mais fracos são remanejados para as chamadas UTIs onde recebem uma ração especial e suplemento como alimentos, quando são medicados, de acordo com a necessidade e a doença.

No decorrer do alojamento de cada lote, o proprietário deve fazer o manejo dos animais doentes, medicando-os, seja de forma injetável, ou nos casos de muitos animais, com medicação direta diluída na água que bebem, para que possam ser tratados.

Durante os períodos frios, quando a temperatura dentro da pocilga pode ser menor ou igual a 20 graus, o proprietário deve cuidar do abastecimento de lenha e regulagem do sistema de aquecimento da granja.

A produção de cada lote requer que o produtor realize a compra de insumos, a aquisição de Equipamento de Proteção Individual (EPIs) como botas, luvas, seringas, e materiais de reforma dentre outros. Os medicamentos, rações, leitões e suplementos são fornecidos pela empresa parceira e os valores são descontados automaticamente ao final do lote da venda de cada lote.

O processo de alimentação, o produtor procura manter o controle e estocagem de ração, quando faz pedidos à empresa parceira, conforme seja necessário, bem como anotar e regular a troca de categoria das rações.

No manejo de sanidade das granjas, os produtores contabilizam os animais mortos e fazem o registro em caderno (sistema de mossas que são marcações na orelha que indicam a propriedade de origem do animal). Em seguida são destinados à instalação da composteira (onde são desmembrados e cobertos por serragem ou maravalha), que serve para evitar o mau cheiro e acelerar a decomposição. Essa composteira é uma construção de alvenaria protegida por tela para evitar que insetos se alimentem da carne doente e venham a transmitir doenças para os animais da propriedade ou para outros animais nas imediações. Após o mínimo de 120 dias de compostagem, os resíduos podem ser utilizados como adubo orgânico em lavouras.

Após 45 dias (em média), os suínos que foram comercializados e entregues à empresa parceira, e essa enviará os leitões à fase de engorda, que acontecerá em outra propriedade conhecida como a fase de terminação até o período de abate. Uma semana antes do carregamento dos suínos ser agendado pela empresa parceira, o produtor deve repassar o número de suínos considerados 
"bons", ou seja, sadios que serão enviados para outros produtores, em separado por tamanho e sexo. Assim, como o número de animais considerados "refugos" que serão destinados para outros fins, esses leitões (refugos) devem ser classificados por peso, pois a empresa opera da seguinte forma: animais herniados (castrados), com peso acima de 15 (quinze) quilos, são destinados para o abate direto, por isso esses leitões devem estar em separado, para receber uma ração especial sem medicação durante 10 (dez) dias antecedentes a sua entrega à empresa. Os leitões considerados de baixo peso (menos de 15 quilos) e doentes são recolhidos pela empresa e levados para um produtor contratado pela empresa para cuidar destes leitões até que estes estejam em condições ou sejam vendidos para empresas que utilizam esses animais para outros fins.

Quanto ao transporte dos leitões para outra propriedade, no dia de entrega do lote, o produtor deve deixar os animais em jejum durante 6 horas para que eles não vomitem ou morram durante $o$ transporte. Carregamento ou entrega dos animais: dura em média um dia e os animais são pesados na propriedade. A balança, o agente que realiza essa atividade e o serviço de transporte dos leitões é contratado pela empresa parceira. O proprietário é responsável pela contratação da mão de obra necessário para o carregamento (em média, seis pessoas) e o pagamento dos mesmos realizado com base na quantidade de animais carregados.

O pagamento da venda do produto é realizado pela BRF por meio de depósito bancário em banco definido pela compradora dos suínos, no período de 15 dias após a entrega de cada lote, realizada 6 vezes por ano. Outras receitas da propriedade são através da venda de milho ou soja, realizada duas vezes ao ano.

Os pagamentos de menor valor ocorrem mensalmente, que são os recursos necessários para a sobrevivência da família. O pagamento de financiamentos ocorre no mês de maio de cada ano, pois todos os recursos de financiamento são provenientes do Banco de Desenvolvimento Econômico e Social (BNDES).

O controle financeiro é realizado através de extratos bancários. A emissão de nota fiscal ocorre através das notas de produtor rural fornecidas pela prefeitura do município de Toledo, que são preenchidas a cada venda dos animais. Na entrega do lote de suínos, é preenchida uma nota por carga de leitão (são preenchidas, em média, 11 notas por lote). 
O proprietário paga o Fundo de Assistência ao Produtor Rural (FUNRURAL) com a alíquota de 2,1\% que é descontado automaticamente na venda de cada lote. Ainda há o pagamento anual do Imposto sobre a Propriedade Territorial Rural (ITR).

O controle interno da propriedade é feito em caderno ou no caso do lote de suínos em ficha fornecida pela empresa parceira. Quanto aos controles financeiros legais (imposto de renda da pessoa física, elaboração de algum contrato, dentre outros) o produtor recorre aos serviços de terceiros (empresa da área de contabilidade).

\subsection{MÉTODOS DE ANÁLISE}

Para alcançar os objetivos propostos pelo estudo, aplicou-se o método de custeio por absorção em função do mesmo permitir a tomada de decisão para o produtor familiar (MARTINS, 2010).

\subsubsection{MARGEM DE CONTRIBUIÇÃO UNITÁRIA (MCU)}

Para calcular a Margem de Contribuição unitária utilizou-se a fórmula:

MCU = PVU - (CVU + DV), onde: MCU = Margem de contribuição; PVU = Preço de venda unitário;

CV U = Custo variável por unidade; DV = Despesas variáveis por unidade.

\subsubsection{PONTO DE EQUILÍBRIO CONTÁBIL (PEC)}

Para calcular o Ponto de equilíbrio contábil (PEC) utilizou-se a fórmula:

$\mathrm{PEC}=(\mathrm{CFT}+\mathrm{DFT}) / \mathrm{MCU}$, onde: $\mathrm{PEC}=$ Ponto de equilíbrio contábil; $\mathrm{CFT}=$ Custos fixos totais;

DFT = Despesas fixas totais;

$\mathrm{MCU}=$ margem de contribuição unitária .

\subsubsection{MARGEM DE SEGURANÇA (MS)}

Para calcular a Margem de segurança (MS) utilizou-se a fórmula:

$M s \%=(R A-R P E / R A) \times 100$, onde: Ms\% = Margem de segurança;

$\mathrm{RPE}=$ Receita atual no ponto de equilíbrio

$\mathrm{RA}=$ Receitas atuais no ponto de equilíbrio. 


\section{RESULTADO E DISCUSSÃO}

Esta etapa da pesquisa apresenta os resultados e discussão do estudo de caso realizado em uma propriedade rural familiar no município de Toledo. As analises tiveram como referência a produção de leitões (fase de recria) de sete lotes, no período de 09/06/2016 a 11/07/2017. Os seguintes parâmetros são apresentados nessa etapa: margem de contribuição, ponto de equilíbrio contábil e a margem de segurança. Utilizou-se o método de cálculo custeio por absorção, que permitiu os cálculos dos custos por lote e totais e as análises dos resultados.

O produto entregue pelo produtor à empresa parceira (BRF) foi o leitão com peso médio por lote de $169.838,37 \mathrm{~kg}$. O preço médio nominal de venda por quilo do suíno vivo foi de $\mathrm{R} \$$ 6,93 (preço nominal para esse produto e para os demais valores dessa pesquisa).

O custo variável médio dos sete lotes foi de $\mathrm{R} \$ 6,70$ por quilo. Em relação às despesas variáveis, a produção não incorreu na mesma. Estes dados podem ser visualizados na Tabela 1 bem como os custos médios por quilo por lote.

Tabela 1 - Preços de venda; custos variáveis; despesas variáveis; por quilo e margem de contribuição e média dos lotes de 01 a 07.

\begin{tabular}{|c|c|c|c|c|c|c|}
\hline & & $\begin{array}{l}\text { Preço de vendal } \mathrm{Kg} \\
\text { (RS) }\end{array}$ & $\begin{array}{l}\text { Custo } \\
\text { variável } / \mathrm{Kg}(\mathrm{R} \$)\end{array}$ & Desp.variavel/Kg(r\$) & $\begin{array}{l}\mathrm{CV}+\mathrm{DV} \\
\text { (RS) }\end{array}$ & $\begin{array}{l}M C=P V-(C V+ \\
D V)\end{array}$ \\
\hline Lote & $01-$ & & & & & \\
\hline $\begin{array}{l}09 / 06 / 16>29 / 07 / 16 \\
\text { Lote }\end{array}$ & $02-$ & 6,61 & 6,39 & & 6,39 & 0,22 \\
\hline $\begin{array}{l}08 / 08 / 16>24 / 09: 16 \\
\text { Lote }\end{array}$ & 03- & 6,65 & 6,42 & & 6,42 & 0,23 \\
\hline $\begin{array}{l}03 / 10 / 16>19 / 11 / 16 \\
\text { Lote }\end{array}$ & 04- & 6,91 & 6,68 & & 6,68 & 0,23 \\
\hline $\begin{array}{l}30 / 11 / 16>18 / 0117 \\
\text { Lote }\end{array}$ & 05 & 6,92 & 6,69 & & 6,69 & 0,23 \\
\hline $\begin{array}{l}26101 / 17>15103117 \\
\text { Lote }\end{array}$ & $06-$ & 7,12 & 6,08 & & 6,80 & 0,24 \\
\hline $\begin{array}{l}250317>19105117 \\
\text { Lote } \\
2505117>110717\end{array}$ & $07-$ & 7,62 & 7,37 & & 7,37 & 0,25 \\
\hline Nédia & & $\begin{array}{l}0,09 \\
6,93\end{array}$ & & & 6,70 & 0,2 \\
\hline
\end{tabular}

Fonte: Elaborado pelos autores com dados da pesquisa (2016/2017)

Observou-se que dos lotes produzidos, os lotes 01 e 06 apresentaram o menor e o maior custo por quilo ( $R \$ 6,39$ e $R \$ 7,37)$, respectivamente. Essa diferença de custo pode ser explicada em função do tempo de alojamento de cada lote. Assim o tempo médio dos lotes entregues foi de 48,6 dias. 0 lote de menor custo foi comercializado com 47 dias e o lote de maior custo foi com 55 dias. 
O índice da margem de contribuição (MC) apresentou diferenças entre os lotes e a média dos lotes produzidos foi de 0,23 . O mesmo representa o valor que absorve cada quilo produzido de custo fixo e despesas fixas. Os lotes que tiveram as menores contribuições foram 01 e 07, e com o de maior contribuição foi o lote 06 . Desse modo cada quilo produzido gerou um excedente de $R \$ 0,23$, para absorver os custos e despesas fixos e formação do lucro.

Contatou-se que o custo e despesa fixos médios por lote para a produção foi de $\mathrm{R} \$ 23.709,66$. Os lotes 02 e 06 foram os que apresentaram o menor e o maior custo mais despesa, ou seja $\mathrm{R} \$ 23.130,03$ e $\mathrm{R} \$ 25.115,80$ respectivamente. Em relação a quantidade necessária para atingir o Ponto de Equilíbrio Contábil (PEC), constatou-se que os lotes $05(97.928,13 \mathrm{~kg})$ e lote $01(107.535,09 \mathrm{~kg})$ apresentaram a menor e a maior quantidades de produção para atingir o equilíbrio entre a receita, custos e despesas.

Tabela 2 - Custos fixos e despesas fixos, quantidade de quilos no PEC, receita no PEC, Receita líquida, Margem de contribuição total e Margem de segurança em percentuais, média e total dos lotes de 01 a 07

\begin{tabular}{|c|c|c|c|c|c|c|}
\hline & $\mathrm{CF}+\mathrm{DF}(\mathrm{R} \$)$ & $\begin{array}{l}\text { Qt. de } \mathrm{Kg} \\
\text { no PEC }\end{array}$ & $\begin{array}{l}\text { Receita no } \\
\text { PEC(r\$) }\end{array}$ & $\begin{array}{l}\text { Receita Liquida } \\
\text { (RS) }\end{array}$ & $\begin{array}{l}\text { Margem de } \\
\text { Contribuição } \\
\text { total ( R\$) }\end{array}$ & $\mathrm{M} / \mathrm{S}(\%)$ \\
\hline Lote $01-09 / 06 / 16>29 / 07 / 16$ & $23.65 /, 72$ & $107.535,09$ & $710.806,94$ & $1.08 / .106,24$ & $376.299,30$ & $34,61 \%$ \\
\hline Lote $02-08 / 08 / 1652409 / 16$ & $23.130,03$ & $100.565,34$ & $668.159,51$ & $1.113 .418,43$ & $444.658,92$ & $39,94 \%$ \\
\hline Lote $03-03 / 10 / 16=19 / 11 / 16$ & $23.492,09$ & $-102.139,52$ & $705.784,08$ & $-1.169 .265,59$ & $463.481,51$ & $-39,64 \%$ \\
\hline Lote $04-30 / 11 / 16>18 / 01 / 17$ & $23.709,26$ & $105.083,73$ & $713.339,41$ & $1.081 .640,92$ & $368.301,51$ & $34,05 \%$ \\
\hline Lote $05-2601 / 17=15 / 03 / 17$ & $23.502,75$ & $97.928,13$ & $697.248,25$ & $1.148 .327,75$ & $451.079,50$ & $39,28 \%$ \\
\hline Lote $06-25 / 03 / 17>19 / 05 / 17$ & $25.115,80$ & $100.463,20$ & $765.529,58$ & $1.561 .430,50$ & $795.900,92$ & $50,9 / \%$ \\
\hline Lote $07-2505 / 17=1107117$ & $23.359,98$ & $106.181,72$ & $710.355,70$ & $1.099 .808,91$ & $389.453,21$ & $35,41 \%$ \\
\hline Mfédta & $23.709,66$ & $102.556,67$ & $710.260,49$ & $1.180 .142,60$ & $469.882,11$ & $-39,82 \%$ \\
\hline Total & $105.967,69$ & 17.896 & $971.823,47$ & $8.260 .998,34$ & $750-0$ & $-39,81 \%$ \\
\hline
\end{tabular}

Fonte: elaborado a partir dos dados da pesquisa (2016/2017)

A produção de leitões apresentou disparidades de receitas entre os lotes. Assim, a receita média necessária dos lotes produzidos para que o produtor não registrasse prejuízo foi de $R \$ 710.260,49$. 0 lote 02 apresentou a menor receita necessária para atingir o PEC (R\$

$668.759,51)$. Por outro lado o lote 06 foi aquele que necessitou da maior receita para atingir o PEC (R\$ 765.529,58). 
Quanto a receita liquida ou seja; quanto o produtor obteve de receita liquida operacional, constatou-se que a receita média dos lotes foi de $\mathrm{R} \$ 1.180 .142,60$. O lote 04 proporcionou a menor receita liquida ( $R \$ 1.081 .640,92)$ e o lote 06 possibilitou a obtenção da maior receita liquida (R\$ 1.561.430,50). Esta diferença de receita liquida justifica-se pela possível maior tempo de permanência dos leitões alojados do lote 06.

A margem de contribuição total (MCT) que representa a soma do custo e despesa fixos e o lucro ou seja, é o valor que o produtor disponibiliza para pagar os custos e despesas fixos e formação do seu lucro. No estudo constatou-se que a MCT média dos lotes produzidos foi de R\$ 469.882,11. O lote 04 foi o que apresentou a menor MCT $(\mathrm{R} \$ 368.301,51)$ e o lote 06 foi o que gerou a maior MCT para o produtor (R\$795.900,92).

A margem de segurança (MS) que representa para o produtor o percentual que permite uma redução na produção sem o mesmo incorra em prejuízo. Desse modo o lote 04 apresentou a MS (34,05\%) e o lote 06 apresentou a maior MS (50,97\%).

\section{CONSIDERAÇÕES FINAIS}

O presente estudo buscou auxiliar o proprietário a identificar os custos envolvidos na atividade de suinocultura, na fase de recria, desenvolvida em uma propriedade rural familiar, na região oeste do Estado do Paraná.

Buscou-se levantar os custos e despesas e receitas por lote e total bem como as quantidades de quilos produzidos na propriedade. Após a identificação dos custos e despesas e quantidades de leitões (em kg) e entregues à empresa parceira, esses foram classificados e separados em custos fixos e variáveis bem comem despesas fixas e variáveis.

A pesquisa utilizou-se do método do custeio por absorção como base de cálculo. Após todos os custos e despesas apurados, levantou-se os preços de vendas por quilo do leitão, custo e despesas variáveis, a fim de determinar a margem de contribuição (em kg). O período dos sete lotes produzidos foi de junho/2016 a julho /2017.

Determinou-se os custos e despesas fixas para calcular o ponto de equilíbrio contábil (em kg), a receita no ponto de equilíbrio e obter a margem de contribuição total e, por fim, calculou-se a margem de segurança dessa fase de produção. 
Constatou-se na pesquisa que os lotes apresentaram oscilações de custos, despesas e preços de vendas por quilo no período estudado. Os custos e despesas variáveis oscilaram de $R \$ 6,39$ a $R \$ 7,37$ por quilo. Percebeu-se uma variação entre os custos fixos e despesas fixas totais dos lotes produzidos e esses variaram de $\mathrm{R} \$ 23.130,03$ a $\mathrm{R} \$ 25.115,8$.

O preço de venda por quilo variou de $R \$ 6,61$ a $R \$ 7,62$. Já a receita líquida variou de $R \$ 1.087 \cdot 105,24$ para $\mathrm{R} \$ 1.561 .430,50$ entre os lotes. A receita mínima necessária para atingir o PEC variou de $\mathrm{R} \$$ $668.759,51$ a R4 765.529,58. A margem de contribuição variou de R\$

0,22 a $\mathrm{R} \$ 0,25$ por quilo de leitão vendido.

O produtor, com base na nos custos e despesas e na receita líquida, a propriedade operou com margem de segurança, que variou de $34,05 \%$ a $50,97 \%$.

Percebeu-se que o lote 06 foi aquele que proporcionou a maior rentabilidade em função do maior tempo de permanência dos animais alojados, em relação aos demais lotes.

\section{REFERÊNCIAS}

ABCS. Associação Brasileira de Criadores de Suínos. História dos suínos. Disponível em:

<http://www.abcs.org.br/producao/genetica/175-historia-dos-suinos>. Acesso em: 17 ago.2017.

ALOE, A.; VALLE, F. Contabilidade agrícola. 7. ed. São Paulo: Atlas, 1979.

BLUM, R. Agricultura familiar: estudo preliminar da definição, classificação e problemática. In: TEDESCO, João Carlos (Org.). Agricultura familiar: realidades e perspectivas. 3. ed. Passo Fundo: UPF, 2001. p. 57-106.

BRASIL. Ministério do Desenvolvimento Agrário. Manual operacional do PRONAF - Programa Nacional de Fortalecimento da Agricultura familiar. Brasília, 2002.

BRUNI, A.L. A administração de custos, preços e lucros. 2. ed. São Paulo: Atlas, 2008. CARNEIRO, E. Contabilidade rural. Rio de Janeiro: Ecar, 1997.

CREPALDI, S.A. Contabilidade rural: uma abordagem decisorial. 7. ed. São Paulo: Atlas, 2012.

GIL, A.C. Como elaborar projetos de pesquisa. 4. ed. São Paulo: Atlas, 2002. GUANZIROLI, C. et al. Agricultura familiar e reforma agrária no século XXI. Rio de

Janeiro: Garamond, 2001.

IBGE - INSTITUTO BRASILEIRO DE GEOGRAFIA E ESTATístICA. Censo Agropecuário 2006: Brasil, Grandes Regiões e Unidades da federação. Rio de Janeiro, 2007.777 p. Disponível em: 
<.http://WWW.ibge,gov,BR/home/esttistica/economia/agropecuária/censoagro/2006/agrário>. Acesso em: 15. fev. 2018.

KOLIVER, O. Contabilidade de custos. Curitiba: Juruá, 2009.

KOTLER, P.; ARMSTRONG, G. Princípios de marketing. 9. ed. São Paulo: Pearson Prentice Hall, 2003.

LAKATOS, E.M.; MARCONI, M.A. Fundamentos de metodologia de pesquisa. 5. ed. SãoPaulo: Atlas, 2003.

LAMARCHE, H. As lógicas produtivas. In: LAMARCHE, Hugues (Coord.). Agricultura familiar: comparação internacional. Do mito à realidade. Campinas: Ed. da Unicamp, 1998. v. 2, p.61-88.

LEONE, G.S.G. Custos: planejamento, implantação e controle. São Paulo: Atlas, 1987. MACHADO,J.G.C.F.A adoção da identificação eletrônica de animais na gestão do empreendimento rural: um estudo multicaso na pecuária de corte.2002. Dissertação (Mestrado) -Universidade Federal de São Carlos, São Carlos, 2002.

MAHER, M. Contabilidade de custos: criando valor para a administração. São Paulo: Atlas,2001.

MALAVOLTA, E. Fertilizantes, corretivos e produtividade: mitos e fatos. In: REUNIÃO BRASILEIRA DE FERTILIDADE DO SOLO E NUTRIÇÃO DE PLANTAS, 20., 1997, Piracicaba. Anais... Piracicaba: SBCS, 1997. p.89-153.

MAPEAMENTO da suinocultura brasileira. Revista da Suinocultura, Brasília, ano 5, n. 22, jan./fev. 2016. Disponível em:

<https://issuu.com/revistaabcs/docs/mapeamento_revista web_>. Acesso em: 07 set. 2017. MARION, J.C. Contabilidade empresarial. 16. ed. São Paulo: Atlas, 2012.

MARTINS, E. Contabilidade de custos.10. ed. São Paulo: Atlas, 2010.

MIELE, M.; MACHADO, J.S. Especial suinocultura. Panorama da carne suína brasileira. jan. 2010.

MOLIN, G.D. Na contramão da crise, agronegócio deve puxar PIB brasileiro. 12 abr.

2017. Disponível em: <http://www.gazetadopovo.com.br/agronegocio/agricultura/na- contramaoda-crise-agronegocio-deve-puxar-pib-brasileiro-120108yf1mom1oaf8vua57y9f>. Acesso em: 21 nov. 2017.

NEPOMUCENO, Fernando. Contabilidade rural e seus custos de produção. São Paulo: IOB-Thompson, 2004.

OLIVEIRA, K. CNA prevê expansão de 2\% do agronegócio em 2017. Brasília, 06 dez,2016. Disponível em: <http://agenciabrasil.ebc.com.br/economia/noticia/2016-12/cna-preve- expansao-de-2-doagronegocio-em-2017>. Acesso em: 02 dez. 2017.

OLIVEIRA, N.C. Contabilidade do agronegócio: teoria e prática. 2. ed. Curitiba: Juruá,2010.

PARANÁ. Casa Civil. PIB do Estado cai menos que o nacional e deve crescer 1,5\% em 
2017.Disponível em: <http://www.casacivil.pr.gov.br/2017/03/92963,10/PIB-do-Estado-cai- menosque-o-nacional-e-deve-crescer-15-em-2017.html>. Acesso em: 03.jul. 2017.

ROCHA, D.T.; MOURA, A.D.; GIROTTO, A.F. Análise de risco de sistemas de produção de suínos, integrado e independente em períodos de alta e baixa rentabilidade. Revista de Economia e Agronegócio, Viçosa, v. 5, n. 3, p. 401-424, 31 ago.2007. Disponível em:

<https://ageconsearch.umn.edu/biststreams/54593/2/5_artigo.pdf>. Acesso em: 25 fev. 2018.

SANTOS, J. A.G. Agricultura familiar e políticas públicas: uma análise socioeconômica do PRONAF. 2009. Dissertação (Mestrado) - Universidade Federal de Sergipe, Aracaju, 2009.

PARANÁ. Secretaria de Estado da Agricultura e do Abastecimento. Departamento de Economia Rural. Suinocultura paranaense. Curitiba, 2017. Disponível em:

<http://www.casacivil.pr.gov.br/2017/03/92963,10/PIB-do-Estado-cai-menos-que-o-nacional-edeve-crescer-15-em-2017.html>. Acesso em: 03 jul. 2017.

SCHNEIDER, S.; CAZELLA, A.A.A; MATTEI, L. Histórico, caracterização e dinâmica recente do Pronaf - Programa Nacional de Fortalecimento da Agricultura Familiar. In:. SCHNEIDER, S.; SILVA, M.C.; MARQUES, P.E.M. (Orgs.). Políticas públicas e participação social no Brasil rural. Porto Alegre: Ed. Universidade/UFRGS, 2004. p. 21-49.

TOLEDO. Prefeitura Municipal. Toledo em números. 12 dez. 2017. Disponível em:

<https://www.toledo.pr.gov.br/portal/cidade-conheca-toledo/toledo-em-numeros>. Acesso em: Out. 2017.

WANDERLEY, M.N.B. Raízes históricas do campesinato brasileiro. In: TEDESCO, J.C. (Org.). Agricultura familiar: realidades e perspectivas. Passo Fundo: EDIUPF, 2001. p. 23-56.

YAMAGUCHI, L.C.T.; CARVALHO, L.A.; COSTA, C.N. Situação atual, potencialidades e limitações do uso da gestão informatizada em fazendas e cooperativas agropecuárias no Brasil. In: AGROSOFT WORKSHOP O AGRONEGÓCIO NA SOCIEDADE DA INFORMAÇÃO. Brasília, DF, 2002. Disponível em: <http://www.agrosoft.com.br/agrosoft-202-situação-atual-potencial-e-uso-da-gestão-informatizadaem-fazendas-e-cooperativas agropecuárias>. Acesso em: 10 ago. 2017. 


\section{Capítulo 18}

\section{O DESENVOLVIMENTO DAS MICRORREGIÕES DO PARANÁ NO PERÍODO DE 2010 A 2016}

DOI: $10.37423 / 200300418$

Leandra Aparecida Perego Ostapechen (Unioeste/Toledo)

leandraperego@hotmail.com

Moacir Piffer ( Unioeste/Toledo)

mopiffer@yahoo.com.br

RESUMO: Este estudo teve como objetivo geral analisar o desenvolvimento das microrregiões do Estado do Paraná quanto a geração de emprego por atividades de exportação. Foram utilizados dados do Emprego da Relação Anual de Informações Sociais - RAIS, para o período de 2010 a 2016. Foi calculado o Multiplicador de Emprego. Como resultado, foi possível verificar que para cada posto de trabalho em um setor de atividade básica (que tem finalidade venda para outra região) em 2010 a indução de geração de emprego em atividades não básicas (produção destinada a demanda local) foi de 5 a 7 empregos em determinadas microrregiões do Estado. Já em 2016, esse multiplicador foi de 5 a 9 empregos. Quanto aos setores que mostraram destaque nos resultados do indicador, foram agricultura, extração mineral, produtos minerais não metálicos e indústria têxtil.

Palavras-chave: Desenvolvimento; Crescimento; Urbano-Rural; Paraná. 


\section{INTRODUÇÃO}

A economia paranaense historicamente baseada na agricultura, apresenta características heterogêneas em suas regiões. A partir da virada do século, avanços tecnológicos e inovações produtivas aliadas ao avanço logístico proporcionaram transformações setoriais, principalmente no contexto da agropecuária e da Indústria do Estado do Paraná. Essas transformações, de forma mais ou menos intensiva, impulsionaram novas atividades que se espraiaram pelo território paranaense (PIFFER, 2009).

O contexto do ano de 2016 foi de constantes inovações, de modo acelerado, principalmente após os anos 2010, cujo avanço tecnológico e a expansão da produtividade são cada vez mais elementos poupadores de mão de obra no longo-prazo. Essa adversidade, porém, é superada por um setor que tem um crescimento significativo ao longo do tempo e que gera encadeamentos que estimulam outros setores da economia possibilitando a realocação de mão de obra. Isso se deve à sua interação no espaço geográfico em que alguns setores demandam ou fornecem insumos a outros setores. Essas relações comerciais e de serviços fazem com que postos de trabalho perdidos em atividades básicas possam ser absorvidos por atividades não-básicas.

Conforme a Teoria da Base de Exportação de Douglas North (1977), que considera a existência em uma região, de atividades econômicas básicas e não básicas, no qual as atividades básicas são entendidas como base para exportação, ou seja, atividades que, de modo geral, tem por finalidade de produção a venda para o mercado externo, seja para outra região, estado ou país. As atividades não básicas são as atividades que produzem para suprir a demanda local ou própria da região.

Para analisar se as transformações ocorridas na economia paranaense seguem um padrão mais homogêneo ou não dessas transformações é preciso o fazer de modo comparativo entre microrregiões e entre setores de atividades. É neste contexto, que este trabalho analisa o desenvolvimento das microrregiões do Estado do Paraná a fim de verificar a existência e formação de novas bases econômicas. Com isso, ao final da pesquisa, pretende-se oferecer, aos gestores públicos, subsídio para adotarem novas políticas públicas nas microrregiões que apresentam economia com setores que se encontram estagnados ou apenas especializados. 


\section{METODOLOGIA}

Este trabalho apresenta um resultado parcial de pesquisa de Iniciação Científica. Neste primeiro momento da pesquisa foi realizada a coleta de dados por meio da Relação Anual de Informações Sociais - RAIS, disponibilizado pelo Ministério do Trabalho e Emprego - MTE, no Instituto Brasileiro de Geografia e Estatística - IBGE, e na Base de Dados do Estado disponibilizada pelo Instituto Paranaense de Desenvolvimento Econômico e Social - IPARDES. Seguindo a divisão de ramos de atividades do Cadastro Nacional das Atividades Econômicas- CNAE, foram coletados os dados referentes ao emprego formal nas 25 atividades econômicas, para os anos de 2010 e 2016. A abrangência desses dados é para as microrregiões do Estado do Paraná.

As atividades econômicas ou de base na economia dos municípios, elas tendem a se difundirem para outros ramos de atividades em seu território, especificamente nas atividades não básicas. Nesta perspectiva, no atual estágio da pesquisa, foi calculado indicador de Multiplicador de Emprego de acordo com Piffer (2012).

a) Multiplicador de Emprego: Utilizado para medir a sensibilidade da demanda dos produtos locais, diante dos impactos que determinadas medidas exógenas provocam nessa economia.

$$
M E=1 /(1-(\Delta E N B / \Delta E t))
$$

Sendo que: $\mathrm{ME}=$ Multiplicador de Emprego da região; $\Delta \mathrm{Et}=$ Variação do Emprego Total; $\mathrm{e}, \Delta \mathrm{ENB}=$ Variação do Emprego Não Básico.

O valor mínimo do Multiplicador de Emprego é um, o que ocorre quando $\Delta E N B / \Delta E t=0$, ou seja, quando a variação do emprego não básico por uma variação de emprego total for nula. Nesse caso, o acréscimo da procura local associado à expansão das exportações é integralmente satisfeito pelas importações. Quanto maior o acréscimo do emprego local gerado por uma unidade adicional do emprego total, levada pelo crescimento do emprego básico, menor será o nível total de fugas para o exterior da região e logo maior será o valor do multiplicador. Ou seja, quanto maior a propensão marginal à criação de empregos endógenos ( $\triangle \mathrm{ENB} / \Delta \mathrm{Et})$, maiores serão os efeitos multiplicadores, ou ainda, quanto maior a capacidade de criação do setor básico sobre o setor não básico (PIFFER, 2012). 
Para apresentação do resultado do indicador foi elaborado um mapa temático para melhor leitura e visualização das mudanças ocorridas no período de 2010 a 2016, nas microrregiões para cada setor. Para tanto foi feito o uso do software

\section{RESULTADOS}

\section{Q.GIS 2.18.}

O número total de empregos no Paraná aumentou 8,24\% no período de 2010 a 2016, sendo que os principais setores empregadores se mantiveram os mesmos nesse período. Na região metropolitana de Curitiba houve um aumento de empregos devido a ocorrência de novas atividades que foram significativas nas regiões principalmente rural-urbana como no caso da região Norte e Oeste do Paraná que tem sua estrutura produtiva baseada na agropecuária que possibilitou uma difusão para outros ramos de atividades mais especificamente no espaço urbano, industrial, de comércio e de serviços. Ao examinar as regiões que mais se distanciam da capital paranaense visualizam-se o incremento de novos empregos e uma nova imagem territorial, especificamente dos municípios de Londrina, Maringá e Cascavel.

Os principais setores empregadores do Paraná são do setor terciário da economia. Em 2010 eram os setores do comércio varejista (17,82\%), da administração pública $(15,13 \%)$, de alojamento e comunicação (8,15\%), e da administração técnica profissional $(8,08 \%)$. Somente na quinta posição é que aparecia a primeira atividade do setor secundário, da indústria de alimentos e bebidas, com 6,43\% de participação. Em 2016, eram os mesmos cinco setores os mais importantes, sendo que a administração técnica profissional ganhou uma posição na hierarquia: comércio varejista $(17,82 \%)$, administração pública (15,68\%), administração técnica profissional (9,33\%), alojamento e comunicação (8,19\%) e alimentos e bebidas (6,38\%) (BRASIL, 2018).

Todos os setores terciários apresentaram aumento no número de empregos, sendo que os que mais se destacaram foram: o comércio atacadista com $29,11 \%$ de aumento, a administração técnica profissional com $24,97 \%$, os serviços médicos odontológicos e veterinários com $24,27 \%$, o ensino com $23,92 \%$ e os serviços de transporte e comunicações com (20,56\%). Por outro lado, foram os setores industriais quem mais perderam: a indústria de material de transporte (-21,93\%), a indústria têxtil ($21,61 \%)$, aa indústria de material elétrico e de comunicação $(-17,61 \%)$, a extrativa mineral $(-15,51)$ e a indústria da madeira e mobiliário (-12,66\%) (BRASIL, 2018). 
O Multiplicador de Emprego para as microrregiões paranaenses, no ano de 2010, mostra que para cada emprego das atividades básicas, as microrregiões localizadas no Oeste paranaense e as microrregiões Umuarama, Francisco Beltrão, Pato Branco, Campo Mourão, Maringá, Londrina, Ponta Grossa e Curitiba, tem a indução de criação de 5 a 7 empregos considerados não básicos. A maioria dessas microrregiões tem como atividades com maior número de empregos a indústria de alimentos e bebidas, indústria têxtil e comércio de varejo. Sendo destaque para as microrregiões de Londrina e Maringá o setor de ensino. Já para a microrregião de Curitiba os setores que mais empregam são administração técnica profissional e administração pública, essas, se destacam como atividades básicas, como pode ser observado na Figura 1.

Figura 1 - Multiplicador de Emprego das microrregiões do Paraná - 2010 e 2016

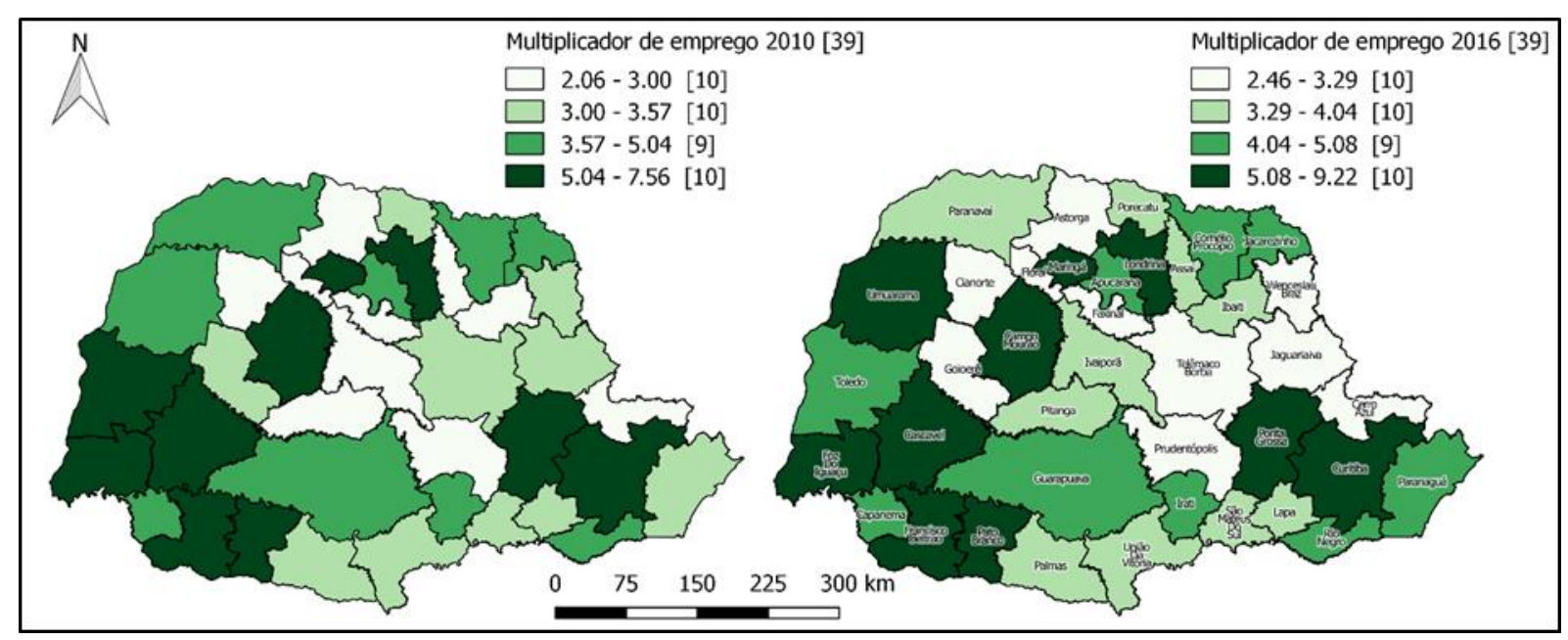

Fonte: Elaborado pelos autores com auxílio do software QGIS 2.18.

No ano de 2016 a capacidade de indução de criação de empregos não básicos foi maior, passou a abranger uma escala de 5 a 9 empregos, com destaque para as microrregiões de Cascavel, cujo resultado do Multiplicador de Emprego foi de 9,22, e apontamento para os setores de alimentos e bebidas e material de transporte e; Maringá, cujo resultado para o indicador foi de 8,20, e principais setores foram ensino e indústria têxtil.

De modo geral, no período de 2010 a 2016 as microrregiões apresentaram expansão de setores produtivos e assim possibilitaram maior diversificação dos setores produtivos paranaenses. As relações comerciais facilitadas pela era da logística contribuem para a descentralização das atividades industriais de seus polos de insumo ou demanda, abrindo fronteiras para a inserção de municípios 
menores e/ou microrregiões em diversos setores, como por exemplo, as microrregiões de Pitanga, Ivaiporã, Assaí e Ibaiti.

\section{CONSIDERAÇÕES FINAIS}

O objetivo deste trabalho foi analisar o desenvolvimento das microrregiões do Estado do Paraná a fim de verificar a existência e formação de novas bases econômicas.

Os resultados mostraram que as microrregiões que apresentaram os maiores valores para o Multiplicador de Emprego são o Norte Central, Oeste e Sudoeste paranaense, bem como metropolitana de Curitiba, evidenciando a capacidade de criação de empregos dos setores básicos para os setores não básicos. No período de 2010 a 2016, as microrregiões do Paraná apresentaram expansão de setores de atividades e assim possibilitando a diversificação da economia. As relações comerciais facilitadas pela era da logística contribuem para a descentralização das atividades industriais de seus polos de insumo ou demanda, abrindo fronteiras para a inserção de municípios menores e/ou microrregiões regiões em diversos setores.

De acordo com a teoria de North (1977), se confirma que a agricultura no crescimento econômico como base de exportação tem ocorrido nas microrregiões do estado do Paraná, e possibilita inferir que avanços maiores são passíveis de ocorrer, necessitando ainda mais de políticas de crédito aos produtores rurais e incentivos aos industriais. Assim, o subdesenvolvimento abre espaço para o real desenvolvimento acontecer de forma homogênea em todos as microrregiões do Paraná, extrapolando seus grandes centros.

\section{BIBLIOGRAFIA}

NORTH, D. (1977). A agricultura no crescimento econômico. In: SCHWARTZMAN, J. (Org.). Economia regional: textos escolhidos. Belo Horizonte, MG: CEDEPLAR/CETEDRE - MINTER. p. 333-343.

PIFFER, M. Indicadores de Base Econômica. In: PIACENTI, C. A. e LIMA J. F. (Org.) (2012). Análise regional: Metodologia e indicadores. Curitiba, Camões. p. 51-62.

- (2009). A teoria da base econômica e o desenvolvimento regional do Estado do Paraná no final do século XX. Tese (Doutorado em Desenvolvimento Regional) - Universidade de Santa Cruz do Sul.

BRASIL. Ministério do Trabalho e Emprego. Relação Anual de Informações Sociais. (2018). http://bi.mte.gov.br/bgcaged/login.php. Acesso em: 18 de Outubro de 2018. 


\section{Capítulo 19}

\section{AGRONEGÓCIO BRASILEIRO: UMA ANÁLISE SOB PERSPECTIVA DA STRUCTURE, DYNAMICS AND COORDINATION APPROACH (SDCA)}

DOI: $10.37423 / 200300423$

Antonio Carlos Dos Santos - acsantos@dga.ufla.br

RESUMO: O presente artigo tem com o objetivo de fazer uma reflexão sobre o agronegócio brasileiro sob a perspectiva da Abordagem de Estrutura, Dinâmica e Coordenação (SDCA). A abordagem ao analisar os negócios, leva em consideração aspectos ligados à definição, categorização, composição, evolução e gestão. Utiliza-se como base teórica fundamentos da economia institucional, organização industrial, alinhamento estratégico, redes organizacionais, entre outras teorias. O seu propósito é oferecer ao administrador, maior leque de informações sobre o negócio no qual a empresa está inserida. Ao aplicar a abordagem na análise do agronegócio brasileiro, verificou-se que em termos conceituais e de categorização, precisamos evoluir muito, diante das diferentes maneiras como este tem sido trabalhado. No que tange a estrutura, conclui-se que é necessário considerar as especificidades relativas ao local, tempo e atividade, já quanto à dinâmica, a conclusão é que não considera-la compromete a escolhas das ações gerenciais. Já com relação à coordenação, conclui-se que o agronegócio brasileiro carece de mecanismos que possibilitem alinhamento entre os agentes do setor e exija corresponsabilidade dos mesmos.

Palavras-chave: agronegócio, estrutura; dinâmica, coordenação. 


\section{INTRODUÇÃO}

O agronegócio sempre foi e continua sendo chamado a contribuir para o desenvolvimento de muitos países. No caso brasileiro, sua história está marcada pelos ciclos das especiarias, do pau-brasil, da cana-de-açúcar, do café, do café com leite, da soja, entre outros, em que a agricultura teve importância significativa no processo de desenvolvimento. Mais recentemente, o setor foi chamado a sustentar o processo de estabilização da economia (âncora verde) e o fez de forma brilhante. Nos últimos anos, o agronegócio voltou a ser o fiel da balança no saldo das transações internacionais.

Embora o setor tenha respondido à altura aos chamados, as dificuldades continuam aumentando, e questões como a abertura dos mercados, as preocupações ambientais, as mudanças de hábitos de consumo, requerem das organizações que o compõem, uma postura bastante competitiva para sua própria sobrevivência.

Estudiosos, pesquisadores, governos, políticos e leigos tem apresentado diversas ações para o setor enfrentar esse novo contexto. No entanto, as propostas que são apresentadas, muitas vezes, são realizadas sem um verdadeiro entendimento do que é o negócio agropecuário.

Na literatura encontramos vários conceitos e metodologias de análise, utilizados por diferentes agentes, na tentativa de explicarem o que vem a ser negócio agropecuário. Em muitos casos, os conceitos apresentados restringem a uma simples descrição da estrutura do setor ou mesmo da natureza de algumas organizações ligadas ao setor, como fazem aqueles que diferenciam agricultura familiar e agronegócio. Em outro tanto, os conceitos limitam-se a expressar opiniões e concepções de quem o conceitua.

No tocante à metodologia de análise, observamos, na literatura consultada, que existem várias abordagens sendo utilizadas para gerar informações sobre o negócio agropecuário. Dentre estas estão a CSA (Commodity System Approach), a CPA (Cadeia de Produção Agroindustrial), a CA (Complexo Agroindustrial), a Análise de Filière, a SCM (Supply Chain Management), netchain, entre outras. Acontece que, em função da complexidade do negócio agropecuário ou mesmo pela definição distorcida do mesmo, as abordagens desenvolvidas ainda deixam aspectos importantes sem análise.

A grande maioria das abordagens citadas tem como foco a estrutura, não considerando, em sua análise, aspectos relativos à dinâmica e à coordenação do negócio. Com isso, a interpretação do 
negócio agropecuário fica distorcida ou mesmo carente, em face da influência que a dinâmica e a coordenação exerce na competitividade do mesmo.

O presente artigo tem por o objetivo fazer uma análise do negócio agropecuário brasileiro sob a perspectiva da Structure, Dynamics and Coordination Approach (SDCA). O artigo está estruturado seis tópicos. Além dessa introdução, encontram a seguir, uma base teórica sobre os termos estrutura, dinâmica e coordenação; uma síntese da metodologia e das etapas utilizadas na análise dos negócios; a aplicação da abordagem na análise do agronegócio brasileiro; as conclusões tiradas; e, por fim, a bibliografia consultada.

\section{2) ESTRUTURA, DINÂMICA E COORDENAÇÃO}

\section{1) ESTRUTURA}

Estrutura é como algo está construído ou organizado. Entre os sinônimos para estrutura, existem as palavras sustentação, esqueleto, armação, suporte, alicerce e arcabouço. E também condição, natureza e índole, eixo, substância, fundamento, programação, projeto, construção e organização também são sinônimos para estrutura.

Uma estrutura pode estar referindo-se à natureza, às estruturas genéticas e biológicas, às geográficas, científicas. Também há estruturas relacionadas à entidades, organizações, órgãos governamentais ou não, empresas, universidades, entre outros.

Pode corresponder a uma conjunto de sistemas teóricos, da filosofia, economia, sociologia, e até mesmo das artes e da música, que configuram as estruturas de um campo teórico. São elementos que formam um sistema organizado, com etapas, uma base sólida, e patamares a se seguir.

Na área dos sistemas da informação e ciências da computação, a estrutura de dados é essencial para armazenar toda a informação e trabalhar os algoritmos e realizar as operações. Para a engenharia, existem diferentes tipos de estruturas de edificações envolvendo a construção civil, como as estruturas metálicas ou as estruturas de concreto. 


\section{2) DINÂMICA}

$\mathrm{Na}$ administração, pode-se conceituar dinâmica como o estudo dos movimentos dos agentes de uma cadeia produtiva e as interações causadas por forças resultantes ou de conflito, ocasionando mudanças na velocidade e/ou forma do desenvolvimento de um agente ou da cadeia como um todo.

A dinâmica de uma cadeia não pode ser compreendida apenas com base na identificação dos agentes atuantes e suas relações de compra e venda, o que pode levar a um retrato estático da cadeia. Também é necessária a análise do comportamento e relacionamento dos agentes com as organizações de apoio públicas e privadas, velocidade e evolução, impacto das mudanças tecnológicas e de ações de seus agentes, abordando a direção da cadeia, em função do ambiente institucional (Minéu, 2002:18).

Figueiredo \& Zambom, 1998: 29-30, diz que como as empresas encontram-se inseridas em um contexto organizacional dinâmico e complexo, onde as inter-relações e interdependências dos componentes do sistema ganham maior relevância que o comportamento de cada um isoladamente, a interação das soluções das partes distintas influencia no comportamento do todo.

Para identificar a dinâmica existente em uma cadeia de produção, é necessário assumir que a cadeia é um sistema onde os agentes agem e interagem em todo momento, influenciando e sendo influenciados pelos acontecimentos no seu segmento e nos demais. A ideia de estudar os movimentos dos agentes requer definir um conceito para dinâmica de cadeia, conceito este que procura na física as bases para sua criação.

O conhecimento da dinâmica da cadeia produtiva é de suma importância quando se analisa aspectos relacionados à competitividade, entrada, posicionamento e saída da cadeia; coordenação e definição de políticas para o setor. No que tange à competitividade, a abordagem sistêmica do negócio agropecuário propõe o foco não na empresa competitiva, mas, sim, na cadeia competitiva, em face do alto grau de dependência de um elo para com o outro. Portanto, para que qualquer empresa do setor seja competitiva, esta precisa fazer parte de uma cadeia competitiva. Se o empreendedor busca competitividade na produção de seu produto, o primeiro passo é participar de uma cadeia competitiva. Caso contrário, o prejuízo é certo.

A dinâmica de uma cadeia produtiva é influenciada por diferentes fatores. Entre estes estão cultura, mercado, tecnologia, preço, concorrência, entre outros. Com relação a cultura, esta influencia muito 
a velocidade com que as ações se desenvolvem na cadeia produtiva. A tradição é um desses aspectos culturais que dificulta o desenvolvimento da dinâmica da cadeia. A lógica da passagem de conhecimentos de pai para filho traz benefícios com relação aos aspectos operacionais da atividade, entretanto, costuma vir carregada de vícios e defeitos difíceis de serem corrigidos.

\section{3) COORDENAÇÃO}

A coordenação de sistemas produtivos não é uma característica intrínseca, mas sim o resultado de uma construção entre os agentes econômicos e tem a finalidade de conduzir uma determinada transação por meio de estruturas de governança. Além da coordenação vertical dos sistemas produtivos, deve-se considerar a coordenação horizontal entre segmentos de uma mesma indústria de produção.

Lazzarini, Haddad e Cook (2001) salientam que a análise da coordenação vertical de uma cadeia produtiva considera as relações entre os segmentos produtivos e pouco avalia as relações horizontais entre os segmentos. Por outro lado, a coordenação horizontal, também conhecida por rede de organizações, pouco considera as relações verticais.

Sauvèe, 1995, coloca que a coordenação é um processo altamente complexo. Segundo o autor, com a dinâmica e a incerteza ambiental e com informações incompletas sobre o oportunismo dos sócios e competidores, a escolha de um mecanismo de coordenação não deve ser entendida como um caminho puramente determinístico.

Em relação ao setor agropecuário, Zylbersztajn (1995) aponta os seguintes condicionantes da coordenação: a) ela não ocorre somente pelo sistema de preço; b) existe a presença das instituições como forte indutores; c) a competitividade de sistemas de agronegócio pode ser tratada como eficiência de sistemas comparados, além dos custos; d) devem ser levados em consideração o aspecto distributivo e a estrutura predominante de mercado de produtos agrícolas que exigem mecanismo para controlar a instabilidade da renda agrícola.

\section{3) STRUCTURE, DYNAMICS AND COORDINATION APPROACH (SDCA)}

A Abordagem de Estrutura, Dinâmica e Coordenação (SDCA) vem sendo trabalhada por um grupo de pesquisadores do Departamento de Administração e Economia da Universidade Federal de Lavras, desde o ano 2000. No Programa de Pós Graduação em Administração - PPGA, sob a coordenação do 
departamento, a abordagem é trabalhada pela disciplina Estrutura, Dinâmica e Gestão de Cadeias Produtivas com aplicação na análise do café Conilon no Espirito Santos, no estudo da cadeia produtiva do carvão vegetal, no estudo da logística sobre trilhos, entre outros trabalhos. Artigos científicos, dissertações, teses e capítulos de livros já foram disponibilizados em vários veículos de comunicação.

A SDCA, parte do princípio de que, no mundo dos negócios, grande parte dos agentes atua e interagem em todo momento, influenciando e sendo influenciado pelos acontecimentos, no seu e nos demais segmentos. E isso acontece em função de forças que moldam as estruturas dos negócios e que independem da vontade individual dos agentes e da existência de variáveis que atuam como força de atrito entre os agentes.

Na sua concepção, os negócios, numa dinâmica própria, modificam-se em função de fatores internos e externos. Eles se redesenham, de modo que apresentam novas configurações de períodos em períodos de tempo. Por isso, os negócios não podem ser compreendidos apenas com base nos agentes atuantes e nem apenas em suas relações de compras e vendas. É importante observar o comportamento e o relacionamento dos agentes entre si, com as organizações de apoio, com o ambiente institucional e com o ambiente consumidor. As inter-relações entre os agentes e os seus comportamentos em rede são, às vezes, mais importantes que as suas características individuais.

Desta forma, é fundamental, ao analisar negócios, levar em consideração aspectos ligados ao seu conceito, categorização, composição (estrutura), evolução (dinâmica) e gestão (coordenação). No que tange ao conceito, é fundamental que este seja claro, sem qualquer tipo de viés e que leve em consideração características peculiares do setor. Uma definição errada pode promover entendimentos divergentes e conflituosos, dificultando a atuação do gestor.

Em termos de estrutura é importante analisar aspectos relativos à cadeia produtiva e aos ambientes organizacional, institucional e consumidor. Conhecer as interfaces diretas e indiretas entre os agentes, e, dentro destas, aspectos ligados à transação, como frequência, riscos e incertezas, especificidades, racionalidade dos agentes, assimetrias de informações, formas de governança, mecanismos de incentivos, tipos de contratos, também é primordial.

No tocante à dinâmica, o conhecer a velocidade com que os processos se desenvolvem e evoluem, é de extrema importância, pois este, conforme já mencionados, apresentam movimentos próprios que modificam em função de fatores internos e externos. Isto vai influenciar na competitividade, entrada, 
posicionamento e saída do negócio, assim como, na coordenação e definição de políticas para o setor. Além do mais, a dinâmica é influenciada por variáveis como tradição, tecnologia, mercado, preços, mão de obra, entre outras e ela varia de acordo com o local, negócio e tempo.

Por fim, é importante verificar se existe coordenação ou não, e, se existir, quem faz e qual a forma utilizada. A coordenação tem um papel muito importante, pois ela busca: alinhar ou sintonizar os agentes envolvidos, em termos de dinâmica; criar um ambiente institucional adequado, ou seja, estabelecer regras claras; definir o papel dos agentes no contexto do ambiente organizacional; e, finalmente, verificar a corresponsabilidade dos agentes envolvidos no negócio.

A sua aplicação envolve quatro etapas básicas. A primeira, (E1), consiste em definir e categorizar o negócio em estudo ou análise. Ela é de grande importância, pois elimina vieses que podem levar a interpretações erradas do mesmo. Faz parte dessa etapa a especificação da atividade conduzida, a correta identificação da finalidade para a qual está sendo conduzida e se na condução estão sendo considerados aspectos técnicos, econômicos, sociais, ambientais, políticos e legais requisitos de uma produção sustentável. É importante, também, fazer a categorização do negócio quanto à natureza, volume, forma, etc., pois isto ajuda na escolha correta das ações a serem aplicadas no processo gerencial.

A segunda etapa, (E2), envolve a descrição da estrutura do negócio. Nesta etapa é primordial especificar os agentes envolvidos na cadeia produtiva, descrever o ambiente institucional, assim como o ambiente organizacional e consumidor. É importante identificar e caracterizar as interfaces entre os agentes, pois, na sua análise, é possível conhecer aspectos relacionados às transações como especificidade dos ativos, frequência, riscos, incertezas; racionalidade dos agentes; presença de assimetrias, mecanismos de incentivos e controles; e tipos e formas de contratos e estruturas de governança.

Na terceira etapa (E3), busca-se conhecer a dinâmica do negócio, ou seja, a velocidade com a qual o negócio se desenvolve, pois esta vária em função da atividade, tempo e local. É importante avaliar a evolução tecnológica, produtiva e mercadológica do setor. As informações geradas com essas avaliações serão fundamentais para um posicionamento competitivo no negócio e requisitos básicos para entrar, posicionar e sair do negócio sem grandes traumas. Conhecer a dinâmica é fundamental para a escolha dos mecanismos de incentivos (políticas) e na forma de coordenação. 
Na quarta etapa, (E4), avalia se o negócio é ou não coordenado, e, se for quem faz essa coordenação. Avalia-se também a forma utilizada, verificando se esta ocorre via mercado ou produção. A avalição da coordenação é realizada verificando se existe sintonia/alinhamento de conduta dos agentes envolvidos na cadeia produtiva; verificando se o ambiente institucional (regras do jogo) contribui para o bom funcionamento do negócio e controle das disputas; conhecendo o papel dos agentes que fazem parte do ambiente institucional; e, por fim, verificando se existe corresponsabilidade dos agentes envolvidos no negócio para como os atributos demandados pelo consumo.

A abordagem, ao analisar os negócios, utiliza como base teórica conhecimentos oriundos da economia institucional, organização industrial, teoria de agência, alinhamento estratégico, redes organizacionais, entre outras teorias. O propósito é oferecer, ao administrador, um ferramental de análise de negócios que amplia o leque de variáveis/atributos a serem utilizados no processo de gestão das organizações.

\section{4) ANÁLISE DO AGRONEGÓCIO BRASILEIRO SOB A PERSPECTIVA DA SDCA}

\section{1) DEFINIÇÃO E CATEGORIZAÇÃO DO AGRONEGÓCIO}

\subsection{1) DEFINIÇÃO}

Na perspectiva da abordagem de estrutura, dinâmica e coordenação, o agronegócio é definido como a atividade agropecuária conduzida segundo uma ou mais finalidade, considerando os aspectos técnicos, econômico, políticos, ambientais, legais e sociais. Nesta definição, três elementos básicos são fundamentais para caracterizá-lo. O primeiro é que a atividade agropecuária deve ser conduzida, para ter o caráter de agronegócio, do contrário, enquadra-se na modalidade extrativismo puro. 0 segundo é que a atividade agropecuária deve ser realizada segundo uma ou mais finalidade. Esse elemento tira do contexto aquelas propriedades utilizadas com mera especulação fundiária, ou seja, são utilizadas sem função social. O terceiro elemento é que a atividade agropecuária deve ser conduzida considerando aspectos técnicos, econômicos, sociais, ambientais, legais e políticos. São importantes essas considerações para diferenciar as organizações sustentáveis em termos econômico, social e ambiental.

Não devem ser consideradas como agronegócio, atividades agropecuárias que são conduzidas sem preocupações ambientais, sociais e que não possibilitem, para o país, condições de desenvolvimento. 
Essa concepção retira do bojo de organizações ligadas ao agronegócio, aquelas criadas e conduzidas de forma prejudicial à sociedade.

\subsection{2) CATEGORIZAÇÃO}

No que tange a categorização, muitas vezes, para fins de política pública, de apoio técnico, estudos, interesses ideológicos, etc., o agronegócio é diferenciado, por meio de categorias. Se este processo não for bem analisado pode levar a interpretações erradas ou mesmos escolha de ações desalinhadas. Com a definição proposta, pode utilizar na diferenciação aspectos finalísticos, formas de condução, agentes envolvidos, volume de negócio, atividade desenvolvidas, uso de tecnologia, entre outras.

Em termos finalísticos, o agronegócio pode ser classificado em de subsistência, para obtenção de lucro econômico, fonte de lazer, geração de qualidade de vida, entre outros. O agronegócio de subsistência é aquele em que as atividades agropecuárias são conduzidas visando a produção de alimentos para o consumo, comercializando apenas os excedentes. Já o voltado à obtenção de lucro econômico tem na condução das atividades agropecuárias a aferição de resultados positivo em termos monetários.

Quanto a natureza dos agentes que trabalham com agropecuária, pode-se classificar o agronegócio em público e privado. Privado, temos a grande maioria das atividades agropecuárias desenvolvida no país por agentes não públicos. Por outro lado, quando a atividade agropecuária ou parte dela é desenvolvida por agentes ligados ao estado, município ou federação, este é considerado agronegócio público.

Em termos de atividade desenvolvida, o agronegócio pode ser classificado como agrícola, pecuária e misto. O agrícola é aquele que desenvolve atividades voltadas para agricultura, como por exemplo, a produção de cereais, frutas, etc.; o pecuário envolve atividades voltadas para prestação de serviços ou produção de animais tais como leite, carne, avicultura, etc. Já o agronegócio misto tem como base atividades que envolvem tanto a agricultura quanto a pecuária.

No tocante a forma de condução, o agronegócio pode ser classificado em familiar e não familiar, considerando o tipo de mão de obra utilizado; pode ser intensivo em capital e com baixo nível de utilização do mesmo; pode ser de alto ou baixo nível tecnológico; pode ser orgânico ou convencional, dependendo do uso ou não de agrotóxico; pode ser coletivo ou individual, considerando a relação das pessoas envolvidas; Considerando o volume de negócio, o agronegócio pode ser classificado em micro, 
mine, pequeno e grande. Essa classificação é bastante utilizada na literatura, por estudiosos e governo, principalmente para direcionar políticas públicas ou mesmo estabelecimento de objetos de pesquisa.

Outra classificação que pode ser utilizada é com relação ao destino dos produtos ou serviços. Como os produtos e serviços do agronegócio podem ser voltados ao mercado interno, regional, local ou mesmo externo, podemos ter agronegócio de exportação e consumo nacional.

Em se tratando de finalidade pelo qual a atividade agropecuária é conduzida, podemos classificar o agronegócio em de subsistência, de lazer ou qualidade de vida, de lucro econômico e ou financeiro, entre outros.

Além das classificações já mencionadas, pode classificar quanto a complexidade da estrutura e do tamanho da cadeia produtiva. Dessa forma, temos agronegócio com estrutura simples, em que há poucos agentes envolvidos. Temos também agronegócio com estrutura complexa, envolvendo diferentes agentes na cadeia produtiva, bem como nos ambientes organizacional e institucional. Ainda em relação a estrutura, temos agronegócios que apresentam cadeias produtivas bastante curta (poucos agentes) e outros em que a cadeia é longa (vários agentes).

4.2) Análise da Estrutura do agronegócio brasileiro

\subsection{1) Cadeia produtiva}

Ao analisar a estrutura do agronegócio brasileiro, verifica-se que a mesma sofreu diversas modificações nos últimos tempos. No passado, a estrutura predimininate do agronegócio era unidivisional, na qual o proprietário de uma gleba de terra trabalhava as atividades explorando o potencial natural do solo com a sua força de trabalho e de alguns agregados. Esses agregados, na maioria das vezes, eram integrantes da família ou trabalhadores da região, contratados para tal.

O produto produzido, muitas vezes, era processado na própria propriedade, gerando outros produtos como queijos e manteigas. O armazenamento geralmente era realizado na propriedade e o consumo era feito pela família do proprietário e dos agregados. O excedente era comercializado na região em vendas e mercearia. De maneira geral, os produtos eram produzidos, armazenados, processados e consumidos na propriedade, comercializando só o excedente. 
Neste modelo de estrutura, a administração/coordenação era realizada pelo proprietário, que definia o que fazer, quanto fazer, quando fazer, como fazer e o fazer. Muitas das pessoas que ajudavam na atividade produtiva eram os principais consumidores. Porém, não tinham poder de decisão, já que quem "mandava" era o proprietário.

Com o passar do tempo, e, principalmente, com o advento da urbanização e da industrialização, muitas pessoas migraram para as cidades em busca de emprego, inclusive familiares dos proprietários. Esse novo grupo formado pelo êxodo rural se juntou aos da cidade, formando uma categoria especializada apenas em consumir produtos do agronegócio. Estas pessoas deixaram de participar no processo de produção, como fazia antes.

Como essa categoria de consumidores formou-se distante dos locais de produção, foi necessário que alguém buscasse os produtos do agronegócio nas propriedades e disponibilizar para os novos demandantes, que não tinha tempo e nem condições para ir até o local de produção. Com isso, surgiu uma nova categoria de agentes especializados em ir às propriedades buscar os produtos e colocar à disposição dos consumidores. Com o tempo, essa categoria foi se estruturando e transformando, hoje, no que chamamos de distribuidores.

Devido à natureza do trabalho nas cidades e do tempo disponibilizado no emprego, os trabalhadores não tinham tempo livre para preparar seus alimentos, como ocorria quando residiam na propriedade rural. Além disso, muitas mulheres ingressaram no mercado de trabalho, o que limitava ainda mais o tempo para busca e preparo dos alimentos. Somado a esses fatos, o aumento de renda e a inovação tecnológica fazem com que muitas empresas coloquem à disposição dos consumidores novas tecnologias e produtos com valores agregados. O próprio consumidor, com um poder aquisitivo maior, começou a exigir dos transformadores produtos mais processados e de maior qualidade.

Com o aumento das exigências dos consumidores, aquelas unidades de beneficiamento e de transformação existentes nas propriedades rurais não eram suficientes para atender a demanda. Muitas saíram das propriedades e se deslocaram para mais próximo das cidades, com a finalidade de agregar os valores desejados pelos consumidores aos produtos produzidos nas propriedades. Essa mudança foi construindo próximo aos centros consumidores, unidades especializadas em transformar a matéria-prima produzida no campo em produtos de maior valor agregado. Essas unidades vieram a constituir, na atualidade, o que denominamos de setor de transformação. 
Como a demanda no setor urbano passou a ser maior em quantidade e frequência, as unidades de transformação tiveram que dispor de produtos, em quantidade e qualidade, o ano todo. Tal fato apresenta dificuldade em função da sazonalidade da produção e da falta de padronização da matériaprima e mesmo dos baixos volumes produzidos pelas unidades produtivas individuais. Foi então que começaram a se estruturar as unidades especializadas em coletar os produtos nas unidades produtivas e armazenar em unidades especializadas para serem comercializados na época adequada. Essas unidades especializadas formaram o que hoje denominamos de setor de armazenagem. O próprio Governo estadual e federal passou a atuar fortemente nesse sentido, originando organismos como a Companhia Brasileira de Armazenamento (CIBRAZEM).

Com essas reestruturações, a unidade de produção, que antes produzia, armazenava, beneficiava e consumia grande parte dos produtos, ficou responsável apenas pela produção da matéria-prima, como o leite, por exemplo. A falta de mão de obra, de recursos e competência para armazenar, beneficiar e transportar os produtos até os centros consumidores fez com que a unidade de produção se especializasse na produção dessa matéria-prima, que a cada dia aumentava. O proprietário passou a ter que obedecer às exigências dos consumidores, que a cada dia ampliavam. Isso provocou uma revolução no campo, fazendo com que o produtor passasse a conduzir sua unidade de produção como empresa.

Em função do aumento da demanda por produtos e das exigências de qualidade e cuidados na produção, somado à carência de mão de obra e de insumos naturais, as unidades de produção tiveram que recorrer a organizações especializadas em tecnologias produtivas e mesmo insumos necessários no processo de produção. Essa exigência fez com que surgisse um setor especializado em produzir insumos necessários e complementares na atividade produtiva. Surgiram as indústrias de rações, fertilizantes, produção de máquinas, sementes, entre outros.

Com o deslocamento de diversas atividades realizadas na unidade produtiva para a competência de outros setores e organizações, a atividade produtiva deixou de ser unidivisional, passando a ser multidivisional, ou seja, composta por diversas divisões/setores interligadas. Essa nova estrutura responsável pela produção passou a ser chamada de cadeia produtiva, em face de um encadeamento de várias operações, realizadas por organizações de diferentes setores.

O que se observa com essa estrutura de cadeia é que o número de interfaces diretas e indiretas dos agentes aumentou em grande medida. Como os principais problemas da atividade acontecem nessas 
interfaces, percebe-se que a gestão das atividades ficou muito mais difícil, uma vez que ela transcende os limites da propriedade. Com isso emergiram outros custos, além do de produção. Hoje o agente da cadeia produtiva tem que controlar não só os custos de produção, como também os de transação que em alguns casos são superiores aos primeiros. Por isso, é importante, ao discutir cadeia produtiva, obedecer ao posicionamento correto do agente para conhecer suas interfaces diretas e indiretas.

\subsection{2) Ambiente organizacional}

Com a reestruturação da atividade de unidade individual para cadeia produtiva, desenvolveu-se um ambiente, formado por outras organizações envolvidas indiretamente com as atividades, para dar suporte ao processo de produção. Além dos insumos e serviços utilizados diretamente pelos agentes da cadeia produtiva, as atividades começaram a exigir também recursos financeiros, assistência técnica, transporte, coordenação, fiscalização, formação profissional, legalização, representação, entre outros tantos.

O estudo das diversas organizações corporativas, entidades representativas de classes, órgãos de pesquisa e assistência técnica é de fundamental importância para se conhecer o ambiente organizacional e as questões comuns inerentes aos diversos segmentos da cadeia. Parte da eficiência do conjunto dos diversos elos da cadeia é decorrente, de acordo com Simioni (2007), do ambiente organizacional.

Como esse ambiente é formado por diferentes organizações, é necessário definir claramente o papel e o posicionamento correto de cada uma. O que se observa, nessa nova estruturação das atividades, é o posicionamento equivocado de muitas organizações, o que tem comprometido o desempenho da cadeia produtiva. Um exemplo disso é a atuação da empresa cooperativista. No passado, ou seja, na época em que imperava a unidade unidivisional, a cooperativa exercia um papel de operacionalização dos serviços de transporte, agregação de valor e assistência técnica, para as unidades individuais. Com a transformação para unidade multidivisional, a cooperativa passou a ter um papel mais voltado para a coordenação do que para a operacionalização. Isso ocorre em função das características da organização cooperativa e da incompetência de muitas na tentativa de atuar na cadeia produtiva como operadora. Essa situação leva à incoerência de muitas organizações cooperativas competirem com os próprios donos (os cooperados) ou de serem menos eficientes que outros agentes da cadeia. 
O mesmo ocorre com o serviço de assistência técnica. As organizações ligadas à prestação de assistência técnica e consultoria exercem, atualmente, um papel importantíssimo no contexto das atividades, mas a orientação deve ser focada na cadeia e não apenas na unidade. Não é suficiente recomendar uma boa prática de produção ou de processamento se tal incremento não é valorizado na etapa seguinte. É muito comum o técnico recomendar que se produza com qualidade, mas sem definir essa melhoria com foco no agente seguinte da cadeia. Dessa forma há aumento nos custos de produção sem que o produtor alcance a agregação de valor esperada, o que leva comumente ao abandono do uso da prática, por parte do agente anterior.

Nessa nova estrutura das atividades, em forma de cadeia, o ambiente organizacional, ganha uma atribuição muito importante. É ele que vai coordenar as atividades a serem realizadas ao longo da cadeia produtiva, por meio do fluxo de informação. Cada agente passa a exercer um papel definido em função de um todo. É como um músico dentro de uma orquestra: o instrumento executado por cada músico produz um som necessário para se ouvir uma boa melodia.

No caso dos bancos, seu papel é criar recursos e mecanismos para financiar o custeio e o investimento da atividade. A universidade, por sua vez, tem como atribuição formar profissionais capacitados para exercerem funções técnicas e gerenciais na agropecuária. Às prefeituras, cabe a tarefa de oferecer infraestrutura rodoviária e de energia para que a tecnologia chegue ao campo e que os produtos cheguem aos consumidores. Dessa forma, cada agente passa a ter uma responsabilidade com o processo que vai da produção do produto até que este seja levado à mesa do consumidor de forma coerente e responsável.

Ao analisar o ambiente organizacional do agronegócio brasileiro, percebe-se que este ainda precisa evoluir muito, em face da importância que o mesmo tem no contexto do desenvolvimento dos negócios. Ainda temo agentes atuando sem saber qual a sua verdadeira competência, e, muitos atuando de forma não alinhada aos interesses do conjunto. A falta de corresponsabilidade, também, é percebida em diversas áreas e setores do agronegócio, o que compromete a competitividade do agronegócio brasileiro como um todo.

\subsection{3) Ambiente Institucional}


Entende-se que o ambiente institucional é construído por relações sociais manipuladas pelas forças históricas e culturais. Estas forças sustentam-se em costumes e convenções presentes nos indivíduos, contrapondo o parâmetro econômico neoclássico em que a receptibilidade e a coerência do sistema econômico decorrem de um padrão estável de interações sociais. Fato é que as interações são dinâmicas e formadas pelas macroinstituições e microinstituições que interferem no resultado do desempenho das organizações (Pondé, 1994).

As microinstituições analisam o processo econômico na dimensão local, envolvendo os agentes e atores circunscritos. Elas surgem por meio de interações humanas para reduzir as incertezas, o que não significa que os resultados sejam os melhores devido à presença da racionalidade limitada dos indivíduos e às características das transações (Pondé, 1994). Já as macroinstituições consideram o todo, envolvendo todos os agentes da cadeia produtiva e suas interfaces com os demais setores da economia formada.

As instituições não são neutras, afirmam Pondé (1994) e North (1994), e desempenham papel importante na organização da atividade econômica, estando ligadas ao conjunto de regras políticas, sociais e legais que estabelecem as bases da produção, troca e distribuição de bens entre as organizações. As instituições são as "regras do jogo" e as organizações são os "jogadores" (FARINA, 1997). Como regras do jogo, encontramos os contratos, que estabelecem os limites da atuação das organizações, padronizam os ativos, estabelecem cooperações tecnológicas, entre outras, reduzindo a incerteza dos negócios e podendo estabelecer as regras e a flexibilidade, no caso de mudança ambiental.

O ambiente institucional, de acordo com Farina (1997), irá orientar as ações da sociedade mais ampla onde operam os agentes econômicos envolvidos na cadeia. As instituições são representadas pelas leis, normas, tradições, entre outras, que caracterizam a sociedade e a sua compreensão é fundamental para a definição de estratégias e estabelecimento de políticas públicas. As instituições podem ser formais (leis, normas regras, etc.) ou informais (tradições, crenças, costumes e outros fatores socioculturais).

Em função da reestruturação das atividades agropecuárias, pela formação de uma cadeia produtiva e um ambiente com várias organizações apoiadoras e fiscalizadoras, foi necessário estabelecer regras e políticas para regulamentar o seu funcionamento. Nesse sentido, foram estabelecidas instruções normativas, leis, regulamentos e políticas, visando incentivar e fiscalizar a atuação dos agentes 
envolvidos em cada atividade produtiva. A finalidade é possibilitar a ação independente dos agentes, sem ações oportunistas de uns sobre os outros.

Além das regras e políticas, fatores culturais como tradição e costumes tiveram que ser desconstruídos ou instituídos, no intuito de atender o desejo do consumidor. Foram colocadas, também, à disposição dos agentes, estruturas públicas e privadas, para fiscalizar a conduta dos agentes com relação ao meio ambiente e à segurança social.

De acordo com Zylbersztajn e Neves (2000) as mudanças nas organizações podem ocorrer com maior velocidade e sem maiores dificuldades, ao passo que nas instituições, as mudanças são mais lentas e complexas. As organizações privadas ou não governamentais, por sua vez, adaptam-se ao ambiente institucional e, ainda, por meio de suas representações ou individualmente, exercem pressões para mudanças no ambiente institucional de acordo com seus interesses próprios ou da sociedade.

Olhando para o agronegócio brasileiro, observa-se que a falta de regras claras tem comprometido, até mesmo impedido, a atuação de muitos investidores no setor. Muitas vezes as regras estabelecidas não são coerentes como a estrutura e a dinâmica do setor, o que leva a baixa efetividade da sua aplicação. Outro ponto importante, neste contexto, é a falta ou mesmo a dificuldade de fazer valer as regras estabelecidas. A faltas de mecanismos específicos de arbitragem leva as ações para a justiça comum que no geral é lenta e cara.

\subsection{4) Ambiente Consumidor}

O ambiente consumidor para produtos do agronegócio brasileiro assume dimensões locais, regionais, estadual, nacional e internacional. No contexto local, predomina um ambiente de demanda focado na subsistência e mercado. Nestes casos, as produtivas são curtas, pouco especializadas e a dinâmica é determinada pelos hábitos de consumos presentes. Geralmente não há nenhuma forma de coordenação, pois muitos consumidores são os próprios agentes de produção/transformação, ou seja, produzem para próprio consumo. Alguns produtos são importados de outras regiões ou mesmo não são consumidos.

No âmbito regional, estadual e nacional, encontramos ambientes de consumos em que convivem consumidores de produtos com pouco valor agregado com outros que requerem atributos mais 
sofisticados, como padronização, certificação, embalagem e logística. Encontramos também, entre os dois polos, uma grande maioria que preocupam mais com quantidade e preços do que qualidade, segurança e logística.

Já em termos internacionais, observa-se que o ambiente consumidor dos produtos do agronegócio brasileiro é bastante amplo e diversificado. Exportamos para vários países e em diferentes continentes. Há predominância de demanda por commodities em relação aos com maior transformação, mas a procura por produtos com valor agregado está aumentando. São mercados que exigem padronização, qualidade, certificações e segurança. Desta forma, é necessário repensar as políticas voltadas ao mercado externo dos produtos do agronegócio, no sentido de alinhar aos interesses de seus consumidores.

\section{3) Dinâmica do agronegócio}

No agronegócio é muito comum encontrar produtores com capacidade dinâmica muito grande e buscando ser competitivo, integrando cadeias com baixa velocidade. O resultado é semelhante ao de um passageiro que entra no coletivo e começa a correr achando que vai chegar mais rápido. Por melhores condições físicas que ele tenha, a sua competitividade será a mesma dos demais e todos chegarão ao mesmo momento.

É comum, também, encontrar produtores cuja dinâmica é muito baixa, tentando se estabelecer em cadeias produtivas em que a velocidade é bem maior. O resultado é a sua expulsão pelos demais agentes, em face da competitividade. É semelhante à situação de um indivíduo que entra, a dez quilômetros por hora, em uma esteira rolante cuja velocidade programada é de vinte quilômetros por hora. O resultado é a expulsão do indivíduo, pela esteira, em face do não alinhamento de velocidade.

Quando se analisa a importância da dinâmica, no que se refere à entrada na cadeia produtiva, verificase que o alinhamento de dinâmicas é fundamental. É semelhante ao passageiro que utiliza ônibus coletivo. Ele só poderá entrar no veículo após o mesmo parar. Com o veículo em movimento, o risco de queda ou mesmo de morte é muito grande.

No agronegócio a situação é um pouco diferente, pois a dinâmica da cadeia produtiva não para, tornando necessário que o produtor entre em movimento. Se o produtor buscar lugar em uma cadeia 
cuja dinâmica é baixa, média ou alta, o risco da entrada vai depender da sua capacidade dinâmica. Se o mesmo tiver baixa capacidade e entrar em uma cadeia pouco dinâmica, o risco passa a ser baixo, mas existe. Porém, se for participar de cadeia com alta dinâmica o risco é muito alto, uma vez que a própria cadeia o expulsará. Por outro lado, se o empreendedor tiver alta capacidade dinâmica e entrar em uma cadeia lenta, pouco logrará em competitividade. Para que um empreendedor da cadeia produtiva possa entrar no negócio, sem muitos traumas, é necessário que as dinâmicas sejam compatíveis. Caso contrário, o resultado esperado é o seu insucesso.

Além da entrada, o conhecimento da dinâmica também é importante para o posicionamento na cadeia produtiva. No agronegócio, não basta entrar no negócio: é preciso, escolher a melhor forma de se posicionar para se desenvolver. É como o passageiro do ônibus coletivo que entra no veículo. Após entrar é preciso escolher a forma de viajar. Com isso surgem as questões: Preciso do subsídio de uma poltrona? Basta um suporte para segurar? Ou, consigo me equilibrar no veículo?

No agronegócio é preciso que o empreendedor responda a essas questões antes de entrar, pois não há como parar a cadeia produtiva. Se estas questões não forem refletidas anteriormente, o risco de um mau posicionamento é muito grande e as consequências poderão ser negativas.

Sugere-se ao empreendedor que, antes de entrar na cadeia produtiva, verifique se necessita de subsídio financeiro, técnico ou operacional para sustentar. Ou, caso necessite apenas de suporte, se este é de natureza técnica, financeira, logística, gerencial, entre outros. O que não deve ser feito (e, no entanto, é prática comum em muitas cadeias produtivas), é a entrada sem esta definição.

Percebe-se que o elevado número de empresas que deixam de funcionar no Brasil após o primeiro e segundo ano de criação pode dever-se a essa falta de conhecimento dos empreendedores sobre o posicionamento na cadeia. Muitos empreendedores, dos diversos setores da economia, entram no negócio sem entender, previamente, sua dinâmica e, consequentemente, a estratégia necessária para se posicionar. O resultado é o elevado gasto de recursos com posicionamento, em detrimento do desenvolvimento do negócio.

Além da importância do conhecimento da dinâmica da cadeia produtiva no ato de entrar e se posicionar, é preciso, também, conhecê-la quando se deseja sair do negócio. Aquele empreendedor que resolver sair da atividade, subitamente, em função de prejuízos, corre o risco de vê-los 
aumentados. É preciso analisar antes a dinâmica da cadeia produtiva da qual se participa para que se escolha a melhor saída, ou a menos traumática.

Isso ocorre com muitos empresários brasileiros. Desconhecendo a dinâmica da cadeia produtiva do qual faz parte, e, consequentemente, despreparados para deixá-la, abandonam o negócio inadvertidamente. O resultado, na maioria das vezes, é o esfacelamento com aumento do prejuízo. Para muitos esses prejuízos são fruto da falta de sorte, culpa do governo, do concorrente e até mesmo de ordem divina; nunca da falta de preparo e conhecimento.

Além dos empreendedores, os agentes dos ambientes organizacional e institucional também precisam conhecer a dinâmica da cadeia à qual pertencem. Como são agentes interfaciados com a cadeia produtiva, a conduta destes deve estar alinhada à dinâmica da cadeia ou deve respeitá-la.

É muito comum, no agronegócio brasileiro, principalmente o do leite, encontrar agentes do ambiente institucional ou organizacional, como universidades, assistência técnica, bancos, prefeituras, entre outras, atuando totalmente desalinhados da dinâmica da cadeia produtiva. Consequentemente, os resultados de suas ações ficam muito aquém do esperado.

Isso acontece quando o técnico recomenda determinada prática produtiva ou administrativa que não é coerente com a realidade do produtor; dificilmente obterá o resultado esperado. Por exemplo: exigir que o produtor conheça o seu custo de produção sem que esse tenha noção ou habilidade para calculá-lo; recomendar a produção de determinado produto visando auferir lucro, cuja demanda é restrita ou inexistente; emprestar recursos financeiros para o produtor financiar a produção de determinados produtos cuja demanda está em queda, entre outros tantos exemplos que podem ser citados e que acontecem diariamente no agronegócio brasileiro.

Além disso, as lideranças rurais e até mesmo os governantes precisam entender da dinâmica da cadeia produtiva para fazer a sua coordenação. Na definição de políticas públicas é imprescindível o entendimento da dinâmica atual e da que se pretende estabelecer com os instrumentos utilizados. Muitas vezes, alcançar o almejado depende de um conjunto de ações, e não de uma ação específica. É preciso entender a dinâmica dos agentes da cadeia produtiva, dos requisitos de seus empreendedores para que o instrumento ou instrumentos de política possam contribuir para o seu alinhamento. Se essa condição não for atendida, a política adotada gerará desordem de resultados. 
Fazendo uma analogia com o sistema de trânsito, onde o papel dos coordenadores é estabelecer um alinhamento entre o interesse dos motoristas dos veículos e dos pedestres, do local e destino da passagem e da intensidade e risco da mesma, percebe-se que os coordenadores do agronegócio precisam ter conhecimento de dinâmica, de alinhamento, de demanda, de oferta, de custos, entre outros. Muitos apresentam apenas vontade política, constituindo-se no principal problema da agropecuária brasileira. Muitos líderes rurais não logram se posicionar adequadamente na cadeia produtiva como empreendedores, o que resulta que esse posicionamento dificilmente será adequado também na função de representante. As consequências são semelhantes ao que acontecerá com a coordenação de trânsito realizada por alguém que não entende nada sobre o assunto: batidas, danos, atropelamentos, multas, mortes, danos materiais e físicos.

A dinâmica de uma cadeia produtiva é influenciada por diferentes fatores. Entre estes estão cultura, mercado, tecnologia, preço e concorrência. A cultura influencia a velocidade com que as ações se desenvolvem na cadeia produtiva. A tradição é um dos aspectos culturais que pode dificultar o desenvolvimento da dinâmica da cadeia. A lógica da transmissão de conhecimentos de pai para filho, por exemplo, traz benefícios com relação aos aspectos operacionais da atividade; entretanto, não raro vem carregada de vícios difíceis de serem corrigidos.

Muitos produtores agropecuários ainda conduzem suas atividades sob a chancela de "meus avós e meus pais fizeram assim, e tiveram sucesso, então, eu vou fazer da mesma forma". Esquecem que o ambiente organizacional e cultural, nos dias de hoje, são bem diferentes daqueles vividos pelos seus genitores. Com isso, as decisões cotidianas se tornam, muitas vezes, desalinhadas do contexto. A consequência é a produção de produtos cuja demanda não condiz com a vontade do consumidor, resultando em preços abaixo dos custos.

No que diz respeito ao mercado, este, na maioria das vezes, é que define o que produzir, como produzir e quando produzir. A não observância de aspectos ligados ao mercado de destino pode trazer consequências desastrosas para os empreendedores da atividade agropecuária. Dessa forma, é necessário, antes de investir na atividade, avaliar as características do mercado onde será comercializado o produto, para evitar desalinhamento entre o que será oferecido e o que está sendo demandado.

Com o processo de globalização dos mercados e a evolução dos sistemas de comunicação e transporte, a dinâmica de consumo de muitas regiões tem mudado com muita rapidez. Produtos que antes não 
saíam das proximidades das organizações produtoras, hoje estão sendo demandados e estão chegando aos mais distantes mercados, na expectativa de disputar parte da renda do consumidor. Por isso é necessário não só conhecer as características desses mercados, como também ter um controle de sua dinâmica no intuito de aproveitar os períodos de alta e baixa sazonalidade em termos de demanda. Alguns produtos têm sua dinâmica definida pelo mercado internacional, como a avicultura e a soja. Com isso, aqueles produtores que almejam investir na atividade, visando esse mercado, precisam conhecer as dinâmicas desses produtos para que não tenha problemas de produção e comercialização no futuro.

Quando se fala em variáveis tecnológicas, é bom frisar que a capacidade de inovação tem tomado proporções gigantescas, a ponto de determinar a sobrevivência de determinados empreendimentos, o que é perceptível quando se observa os produtos disponíveis hoje nas gôndolas de supermercados e aqueles que foram substituídos por outros de diferentes padrões. O que se percebe na atualidade é uma maior demanda por produtos com valores agregados, preocupados com a questão ambiental e social, adaptados aos estilos de vida, e, principalmente às condições de vida do cidadão. Com tais atributos, esses produtos nada mais são que pacotes tecnológicos à disposição dos consumidores.

Outra variável que influencia a dinâmica das cadeias produtivas é o preço. O preço pago pelo consumidor, assim como aquele pago ao produtor, é determinante na dinâmica da cadeia produtiva. No caso das atividades agropecuárias, a sensibilidade é muito maior. Basta lançar os olhos a determinados períodos do ano agrícola brasileiro. Uma leve mudança nos preços pagos aos produtores de leite pelas empresas transformadoras, por exemplo, no final do período da seca, é suficiente para gerar reflexo na compra de insumos, no uso de tecnologia e no aumento da produção, mostrando a alta sensibilidade do produto à variação de preços. O empresário do agronegócio que não for capaz de se adaptar a essas rápidas mudanças de preço corre o risco de ser expulso do mercado.

\section{5) COORDENAÇÃO}

No agronegócio, a coordenação toma importância extrema uma vez que ela busca sintonia entre os agentes explorando ganhos advindos da interação/cooperação. Como o produto oriundo do agronegócio a ser colocado à disposição do consumidor apresenta especificidade de tempo, local e produtos, é preciso haver corresponsabilidade dos agentes para com a entrega do mesmo. Um 
produto lácteo, por exemplo, só vai chegar à mesa do consumidor e gerar satisfação, se todos agentes agirem em suas unidades de forma corresponsável.

Infelizmente, no agronegócio brasileiro predomina, ainda, ações de oportunismo por parte de agentes. Como a coordenação é precária e as que existem são realizadas com foco na produção, gera margem de auto-interesse nas diferentes interfaces da cadeia produtiva.

Os governos federal, estaduais e municipais poderiam agir, no sentido de fiscalizar a conduta oportunística dos agentes, entretanto, falta-lhes competência (habilidades). Algumas tentativas governamentais realizadas, muito das vezes tem sido viesadas. Por outro lado, a coordenação pelas lideranças do setor, quando existe é confusa, em face de falta de habilidade e por não dispor de um bom sistema de comunicação. Como resultado, temos desordem no sistema, ficando a coordenação a cargo daquele que detêm maior poder sobre os demais.

Precisamos, urgentemente, de um sistema de coordenação focado no consumo, como é realizado em países de relevância internacional na produção e comercialização dos produtos agropecuários. A filosofia da coordenação nesses países é a de puxar o sistema pelo consumo, ou seja, só produzir o que o consumidor demanda e quando ele demanda. Para que isso aconteça, observa-se que o investimento em educação para o consumo é intenso e a atuação dos agentes do ambiente institucional e organizacional é forte e de forma corresponsável.

O Brasil não pode continuar com a filosofia de coordenação de empurrar a produção, ou seja, produzir para depois vender. Essa situação gera prejuízos a todos envolvidos no negócio agropecuário. Em face de termos nas estruturas dos negócios agropecuários agentes interessados, treinados, esforçados, inovadores e fiéis misturados a uma grande massa de preguiçosos, oportunistas, leigos e sem saber para que lado ir, a coordenação passa ser primordial para se conseguir competitividade.

\section{CONCLUSÃO}

Após análise do setor agropecuário segundo a abordagem de estrutura, dinâmica e coordenação pode-se tirar várias conclusões. Em termos de definição e categorização do negócio agropecuário conclui-se que é fundamental que estas sejam realizadas sem viés ideológico ou político. Uma definição e categorização dessa natureza facilita a análise do setor. A definição e categorização dever enquadrar todo tipo de negócio agropecuário. No caso do agronegócio brasileiro, encontramos muitas definições e categorizações sendo utilizadas, porém presença do viés ideológico é muito forte. 
No que tange a estrutura conclui que é fundamental considerar a cadeia produtiva e os seus ambientes institucionais, organizacionais e consumidor. Desta forma é possível mostrar os diferentes agentes envolvidos, bem como as interfaces entre eles. Conhecendo as interfaces é possível analisar a racionalidade dos agentes e a características das transações presentes e o papel de cada um. Concluise, também, que a mudança da perspectiva unidivisional do agronegócio brasileiro para uma perspectiva multidivisional aumentou as interfaces entre os agentes da cadeia produtiva, redefinindo a estrutura da cadeia, faz emergir custos de transação que não constituíam uma preocupação na atividade produtiva unidivisional.

Em termo da dinâmica, conclui-se que a sua análise é importantíssimo, pois esta influencia a competitividade, a entrada, posicionamento e saídas das empresas no negócio; e que a dinâmica é influenciada por várias variáveis. Compreender os papéis dos agentes é de extrema importância para definir uma dinâmica favorável para o desenvolvimento de todos os envolvidos na cadeia produtiva. No caso do agronegócio brasileiro, a dinâmica dos sistemas produtivos varia de acordo como o produto, região, volume de negócio, entre outras.

Em relação à coordenação conclui-se esta é imprescindível nos negócios agropecuário brasileiro cujas estruturas predominantes são multidivisionais. Muitos negócios agropecuários não são coordenados, os que são ainda adotam ao modelo de empurrar a produção. Ainda não temos negócios coordenados pelo modelo que puxa a produção pelo consumo. Como não tem como construir um agronegócio competitivo sem corresponsabilidade dos agentes, pode-se dizer que precisamos avançar muito em coordenação.

\section{REFERÊNCIAS BIBLIOGRÁFICAS}

ALENCAR, E. Complexos Agroindustriais. Lavras: UFLA/FAEPE, 2001. 90 p.

ARAÚJO, M. J. Fundamentos de agronegócios. 2 ed. rev. ampl. São Paulo: Ed. Atlas, 2007.

BATALHA, M. O. Sistemas agroindustriais: definições e correntes metodológicas. In: BATALHA, M. O. Gestão agroindustrial. São Paulo: Atlas, 1997.

BUZBY, J. C. and UNNEVEHR, L. (2004) "Introduction and overview" In: International Trade and Food Safety AER-828/ Economic Research Service/USDA.

CHIQUeTO, M. J.; PARADA, A. A. Física - mecânica, São Paulo: Scipione, 1991. 383p.

DAVIS, J.; GOLDBERG, R. A concept of agribusiness. Boston: Harvard University, 1957. 
FARINA, E.; ZYLBERSTAJN, D. Competitividade e organização das cadeias agroindustriais. Costa Rica: Instituto Interamericano de Cooperação para a Agricultura, 1994.

FARINA, E.M.M.Q.; AZEVEDO, P.F. \& SAES, M.S.M.: Competitividade: Mercado, Estado e Organizações. Ed. Singular, SP, 1997

FIGUEIREDO, R. S.; ZAMBOM, A. C. A empresa vista como um elo da cadeia de produção e distribuição. Revista de Administração, São Paulo, v. 33, n. 3, p. 29-39, jul./set. 1998.

KAGEYAMA, A. O novo padrão agrícola brasileiro: do complexo rural aos complexos agroindustriais. In: DELGADO, G et al (orgs.), Agricultura e políticas públicas. Rio de Janeiro: Ipea, 1990.

KAZUITO, Y.; FUKE, L. P.; SHIGEKIYO, C. T. Os alicerces da física - mecânica, 2 ed., São Paulo: Saraiva, 1995. 384p.

LABONNE, M. Sur le concept de filière en economie agroalimentaire. In: MSA-CEGET, 1985, Montpellier. Débats... Montpellier: Institut Nacional de La Recherche Agronomique, 1985.

LAUSCHNER, R. Agribusiness, cooperativa e produtor rural. São Leopoldo: Unisinos, 1993.

MENEGHETTI, F. K. O que é um Ensaio-Teórico? Revista de Administração Contemporânea, v.15 n.2, 2011, p.320-332.

MINÉU, H. F. S. Tecnologia de informação e estratégias de produtores rurais: um estudo multicaso em Uberaba, MG. 2002. 254p. Dissertação (Mestrado em Administração) - Universidade Federal de Lavras: Lavras, 2002.

MORVAN, Y. Filière de Production: fondementes d' economie industrielle. Paris: Economica, 1985.

MORVAN, Y. Fondements d'Economie Industrielle, 2e Edition, Economica, Paris, 1991.

NEVES, M. F,; SPERS, E. E. Agribusiness: a origem, os conceitos e tendências na Europa. In: MACHADO FILHO, C. A. P. et al. Agribusiness europeu. São Paulo: Pioneira, 1996.

NORTH, D.C. Custos de transação, instituições e desempenho econômico. Rio de Janeiro: Instituto Liberal, 1994. 38p.

PEDROZO, E. A. et al. O "sistema integrado agroindustrial" (SIAN): uma visão interdisciplinar e sistêmica. In: Workshop Brasileiro de Gestão de Sistemas Alimentares - Pensa, 2. 1999. Faculdade de Economia, Administração e Contabilidade de Ribeirão Preto, Universidade de São Paulo, p.21-32, 1999.

PONDÉ, J.L. Coordenação e inovações Institucionais. Campinas: UNICAMP, 1994. 58p. (Texto para discussão n.38).

RAINELLI, Michael. Les filiéres de production. In: ARENA, R.; BENZONI, L.; De BANDT, J.; ROMANI P. M. Traité d'économie industrielle, Paris:Economica, 1991, p. 222-226.

SILVA, S. M.; SANTOS, A C.; LIMA, J. B. Competitividade do agronegócio do café na região Sul de Minas Gerais. Organizações Rurais \& Agroindustriais, v. 3, n. 1, 2011. 
SIMIONI, F. J. Análise diagnóstica e prospectiva da cadeia produtiva de energia de bioamassa de origem florestal no Planalto Sul de Santa Catarina. Tese (Doutorado) Universidade Federal do Paraná. Curitiba, 2007.

SPILLER, A. (2002) "New guidelines for quality assurance in Agri-food chain", International Conference: Quality management in the Agri-food chain, Santiago.

ZIGGERS, G. W. and TRIENEKENS, J. H. (1999), "Quality assurance in food and agribusiness supply chains: developing successful partnerships", International Journal of Production Economics, 60-61, 271-279.

ZYLBERSZTAJN, D. Conceitos gerais, evolução e apresentação do sistema agroindustrial. In: ZYLBERSZTAJN, D.; NEVES, M. F. (orgs.). Economia e gestão dos negócios agroalimentares: indústria de alimentos, indústria de insumos, produção agropecuária, distribuição. São Paulo: Ed. Pioneira, 2000. p. 1-21 


\section{Capítulo 20}

\section{NÍVEL DE EFICIÊNCIA DO PROGRAMA BOLSA FLORESTA NAS UNIDADES DE CONSERVAÇÃO DO AMAZONAS: UMA ANÁLISE ENVOLTÓRIA DE DADOS}

DOI: $10.37423 / 200300424$

\section{Loiseane Santos Correia Pinto}

Elane Conceição de Oliveira

Neuler André Soares de Almeida

RESUMO: Este trabalho tem como objetivo analisar a eficiência socioeconômica do Programa Bolsa Floresta (PBF) desenvolvida nas Unidades de Conservação (UC's) do estado do Amazonas, no período de 2014 a 2017. E para isto utiliza-se o método Análise Envoltória de Dados (Data Envelopment Analisys - DEA) com retornos constantes de escala. Entende que a escolha do modelo é porque qualquer variação nas entradas (inputs) produzirá variação proporcional nas saídas (outputs). Isto porque um dos resultados esperados pelo PBF é promover o desenvolvimento sustentável e o bem-estar dos homens da florestal de forma proporcional aos recursos empregados nas UC's. Os resultados mostraram que das 11 UC's do tipo Reserva de desenvolvimento Sustentável (RDS) analisadas apenas 5 obtiveram 100\% de eficiência no sentido de pareto. Ademais, apesar de 4 UC's apresentaram resultados satisfatórios no sentido de reduzir o desmatamento, apenas 2 delas apresentaram 100\% de eficiência ou fronteira de pareto eficiente (RDS Piagaçu-Purus e Uatumã). O PBF representa uma política potente para promover a conservação das florestas e o desenvolvimento sustentável no AM, mas somente seguido de uma gestão eficiente.

Palavras-chave: Programa Bolsa Floresta; Análise Envoltória de Dados; Amazonas. 


\section{INTRODUÇÃO}

Com relação ao crescente aumento no nível de desmatamento na Amazônia, Alencar et al.(2004) e Higuchi et al.(2009) apontam diversos fatores responsáveis por esse fenômeno na região ocasionado por diferentes usos do solo, como: agropecuária, extração madeireira, produção de energia (hidrelétricas, petróleo e gás natural), exploração mineral, incêndios florestais. No caso do bioma Amazônia, Veríssimo e Pereira (2014) apontam que o desflorestamento, em meados do ano de 2012, já tinha atingido $19 \%$ dessa região.

Essa tendência do crescimento das taxas de desmatamento, no entanto, não é homogênea entre os Estados que compõem a região Amazônica. E mais recentemente, Estados que não tinham uma tendência alarmante do crescimento das suas taxas tem tido taxas em crescimento. $O$ estado do Amazonas (AM), por exemplo, de acordo com o INPE (2017), os dados do Prodes Monitoramento da Floresta Amazônica Brasileira por Satélite mostram que a taxa de 2016 para 2017 desacelerou em 15\%, muito embora ela tenha tido um crescimento de 54\%, de 2015 para 2016.

Nesse escopo, três questões merecem destaque: a) o AM pertence à região Norte do país, possui 62 municípios e uma área territorial de $1.559 \mathrm{mil} \mathrm{km2}$, o que corresponde a 18,45\% da área total brasileira, 40,76\% da área da região Norte e 30,87\% da área territorial da região Amazônica; b) as florestas do AM estão quase totalmente preservadas; dados do Sistema de Monitoramento da Floresta Amazônica Brasileira por Satélite (PRODES) mostram que, até 2011, o Estado tinha desmatado apenas 2,37\% de sua cobertura florestal, o que caracteriza um indicador de preservação da ordem de 97,63\% de florestas nativas; e, c) o AM é detentor de um dos grandes programas brasileiro voltado para a disseminação do desenvolvimento sustentável nas comunidades interioranas dos municípios amazonenses - o Programa Bolsa Floresta (PBF).

Para Oliveira (2008) e Almeida (2015), o surgimento do PBF no AM deveu-se, sobretudo, à importância da floresta para os ribeirinhos na nossa região, uma vez que os recursos provenientes da floresta ainda constituem um dos principais meios de sobrevivência para os homens da floresta. Tanto é que, segundo Viana (2008) o PBF implementa uma série de atividades pioneiras no campo da conservação ambiental e desenvolvimento sustentável na Amazônia; e sua concepção se insere no contexto das mudanças climáticas globais e de redução do desmatamento, com especial ênfase para as comunidades tradicionais da "Amazônia profunda". Juridicamente, a criação do PBF foi interposta pela Lei no 3.135 de 05/06/2007 que diz respeito a políticas sobre mudanças climáticas, conservação ambiental e desenvolvimento Sustentável no Estado do Amazonas; e pela Lei Complementar $n^{\circ} 53$ de 
05/06/2007 que se refere à institucionalização do Sistema Estadual de Unidades de Conservação (SEUC).

Hoje, o PBF é um dos maiores programas de Pagamento por Serviços Ambientais (PSA) do mundo, com mais de 35 mil pessoas atendidas em 15 UC's no AM, englobando uma área total de 10 milhões de hectares (FAS, 2016). O objetivo do PBF é de compensar, por meio de investimentos em geração de renda e desenvolvimento social, as populações tradicionais pela disposição em conservar as florestas, de forma a garantir a oferta de Serviços Ambientais local e globalmente, afirma a Fundação Amazônia Sustentável. Sua estrutura dar-se em quatro bolsas: Renda, Social, Familiar e Associação, nas quais objetivam oferecer suporte econômico e social, usando as bolsas como incentivos, às comunidades ribeirinhas que residem nas UC do AM por meio da valoração da floresta, cabendo a este último fator, um benefício ambiental (FAZ, 2015).

Em face disto, tornar-se indispensável estudos e análises sobre a eficiência das políticas públicas intergovernamentais implementadas na região, cujo fim de algumas dessas iniciativas, conforme Rivas (2014), é aliar qualidade de vida e conservação ambiental. E, nesse particular, avaliar a eficiência da gestão de recursos em Unidades de Conservação (UC's) surge como um objeto ímpar nesse tipo de análise, em geral, para a Amazônia e, em especial, para o estado do Amazonas (AM).

Muitos trabalhos tem analisado a eficiência do ponto de vista de várias temáticas, como: programas governamentais, saúde, educação, atividades produtivas, comércio, meio ambiente, entre outras temáticas, utilizando o modelo Análise Envoltória de Dados (Data Envelopment Analysis - DEA), que é uma ferramenta matemática para a medida de eficiência relativa das unidades tomadoras de decisão (Decision Making Units - DMU's), como são chamadas as unidades analisadas ou as unidades tomadoras de decisão ou unidades produtivas.

Brambilla e Carvalho (2017) analisaram a eficiência da gestão do Programa Bolsa Família nos municípios do Paraná no ano de 2013. Os autores ao utilizarem o modelo DEA, com retornos variáveis à escala orientado a output, tiveram como resultados que três dos 399 municípios paranaenses foram eficientes; e que o indicador que mais contribui para a gestão do PBF foi o de cobertura de cadastro no Cadastro Único.

Barbosa e Souza (2014) analisaram a eficiência técnica e de escala do setor agropecuário nos municípios cearenses por meio do DEA, obtendo como resultados que os municípios cearenses podem diminuir, em média, os custos com insumos em $45 \%$ e $35 \%$, respectivamente, nos modelos com retornos constantes e variáveis, sem reduzir o valor da produção. 
Mello et al. (2003) avalia a eficiência das companhias aéreas brasileiras, usando o DEA com os retornos de escala, através da comparação de cada companhia com as que operam em escala semelhante. Quanto a este trabalho, o objetivo é analisar a eficiência socioeconômica do Programa Bolsa Floresta desenvolvida nas Unidades de Conservação do estado do Amazonas, no período de 2014 a 2017. E para isto utiliza-se o modelo DEA com retornos constantes de escala. Entende que a escolha do modelo é porque qualquer variação nas entradas (inputs) produzirá variação proporcional nas saídas (outputs), uma vez que a intensão dos recursos injetados nas comunidades das UC's onde o bolsa floresta atua é produzir benefícios socioeconômicos e ambientais na mesma proporção ou razoavelmente superior.

\section{PROCEDIMENTOS METODOLÓGICOS}

\subsection{MODELO TEÓRICO DE ANÁLISE}

De acordo com Mello et al. (2016; 2003), Pindyck e Robisfield (2005), Tupy e Yamaguchi (1998), o estudo de análise de eficiência produtiva em economia baseia-se nos princípios da teoria da produção, especificamente no conceito de função de produção, que indica a relação técnica entre a produção máxima obtida em determinada unidade de tempo e os insumos utilizados no processo de produção. Dessa base conceitual deriva-se o desenvolvimento da técnica Data Envelopment Analysis (DEA) para análise de eficiência relativa de unidades. O método DEA é baseado no trabalho proposto por Farrell (1957), generalizado por Charnes et al. (1978), em que foram incluídos múltiplos insumos (inputs) e produtos (outputs). Essa técnica permite analisar a eficiência de unidades produtivas (decision making units - DMUs) com múltiplos insumos e múltiplos produtos através da construção de uma fronteira de eficiência.

De acordo com Mello (2016), para estimar e analisar a eficiência relativa das DMUs, a DEA utiliza a definição de ótimo de Pareto, segundo o qual nenhum produto pode ter sua produção aumentada sem que sejam aumentados os seus insumos ou diminuída a produção de outro produto, e, de forma alternativa, quando nenhum insumo pode ser diminuído sem ter que diminuir a produção de algum produto. A eficiência é analisada, relativamente, entre as unidades.

As funções de produção são à base da análise de eficiência conforme afirma Barbosa e Souza (2014). As considerações em torno dessas funções visam definir uma relação entre insumos e produtos. As hipóteses que são consideradas para a relação entre insumos e produtos determinam que haja retornos constantes, crescentes ou decrescentes à escala. A função apresenta retornos constantes à escala se, ao aumentar os fatores de produção, a produção aumentar na mesma proporção. Haverá 
retornos crescentes quando o aumento na produção for mais do que proporcional ao aumento nos fatores; caso contrário, haverá retornos decrescentes.

Para Charnes et al. (1994) a DEA pode ser definida com orientação-insumo ou orientação-produto. Com orientação-insumo caracteriza-se a tecnologia de produção pela minimização proporcional (contração) do vetor insumo, dado um vetor de produto, enquanto a DEA com orientação-produto caracteriza-se a tecnologia de produção pela maximização proporcional do vetor produto, dado um vetor de insumo. Ou melhor, pode-se usar um modelo orientado a outputs, no qual se obtém o máximo nível de outputs mantendo os inputs fixos (modelo BCC); ou usar um modelo orientado a inputs, que visa a obter um menor uso de inputs dado o nível dos outputs (modelo CCR). Para este estudo adotamos o modelo orientado a inputs.

\subsection{MODELO CCR (RETORNOS CONSTANTES DE ESCALA).}

O modelo CCR, apresentado originalmente por Charnes et al. (1978), constrói uma superfície linear por partes, não paramétrica, envolvendo os dados. Trabalha com retornos constantes de escala, isto é, qualquer variação nas entradas (inputs) produz variação proporcional nas saídas (outputs). Esse modelo é igualmente conhecido como modelo CRS - Constant Returns to Scale.

De acordo com Angulo meza (2002) Este modelo determina a eficiência pela otimização da divisão entre a soma ponderada das saídas (output virtual) e a soma ponderada das entradas (input virtual) generalizando, assim, a definição de Farrel (1957). O modelo permite que cada DMU escolha os pesos para cada variável (entrada ou saída) da forma que lhe for mais benevolente, desde que esses pesos aplicados às outras DMUs não gerem uma razão superior a 1.

Estas condições podem ser observadas nas equações (1) abaixo, onde Effo é a eficiência da DMU0 em análise; $v i$ e $u j$ são os pesos de inputs $i, i=1, \ldots, r$, e outputs $j, j=1, \ldots, s$ respectivamente; $x i k$ e $y j k$ são os inputs $i$ e outputs $j$ da DMU $k,=k=1, \ldots, n ; x i 0$ e yj0 são os in puts $i$ e outputs $j$ da DMU 0.

$$
\operatorname{MAXEff_{0}}=\left(\frac{\sum_{j=1}^{s} u_{j} y_{j 0}}{\sum_{i=1}^{r} v_{i} x_{i 0}}\right)
$$

Sujeito a:

$$
\begin{gathered}
\frac{\sum_{j=1}^{s} u_{j} y_{j k}}{\sum_{i=1}^{r} v_{i} x_{i k}} \leq 1, \forall k \\
v_{i}, u_{j} \geq 0, \forall i, j
\end{gathered}
$$


Segundo Lins e Silva (2001) o problema apresentado é de programação fracionária, que deve ser resolvido para cada uma das DMUs e pode ser transformado em um problema de programação linear (PPL). Para tal, obriga-se que o denominador da função objetivo deva ser igual a uma constante, normalmente igual à unidade. A formulação do modelo CCR é, então, apresentada em (2). Nesse modelo as variáveis de decisão são os pesos vi e $u j$.

$$
M A X E f f_{0}=\sum_{j=1}^{s} u_{j} v_{j 0}
$$

Sujeito a:

$$
\begin{gathered}
\sum_{i=1}^{r} v_{i} x_{i 0}=1 \\
\sum_{j=1}^{s} u_{j} v_{j k}-\sum_{i=1}^{r} v_{i} x_{i k} \leq 0, \forall k \\
v_{i}, u_{j} \geq 0, \forall i, j
\end{gathered}
$$

Conforme apresentado no modelo anterior, podemos evidenciar que a estrutura matemática do modelo, permite que uma DMU seja considerada eficiente a partir de vários conjuntos de pesos. De certa forma podemos atribuir peso zero a alguns inputs e outputs, o que significa que essa variável em questão foi desconsiderada na avaliação do modelo.

A primeira etapa do modelo DEA é definir o que se quer medir com as DMU's. Nessa pesquisa, as DMU's serão:

DMU's 1 = UC'S RDS.

DMU's 2 = comunidades beneficiadas dentro dessas UC's.

DMU's 3 = modalidades de bolsas florestas por comunidades ou por UC's.

A eficiência é analisada, relativamente, entre as unidades das DMU's. Para avaliar a eficiência, as DMU's devem realizar tarefas similares, de modo que a comparação entre elas faça sentido. Além disso, uma característica da técnica DEA é que os inputs (insumos) e outputs (produtos) sejam iguais, variando apenas na quantidade. 
As variáveis necessárias para a pesquisa são variáveis de cunho social, econômico e ambiental, geradas em virtude da implementação do PBF nas comunidades das UC's do estado do Amazonas, especialmente as RDS:

Input 1: INV UC = valor dos investimentos com infraestrutura e bens por RDS (R\$).

Input 2: INV BF = valor dos investimentos totais realizados por tipo de bolsa floresta (R\$).

Input 3: FAT UC = Faturamento bruto médio por família p/ RDS (R\$).

Output 1: FAM ATEN = no de famílias atendidas (un).

Output 2: DESEV COM = taxa de desmatamento evitado por RDS (\%).

Para o desenvolvimento da análise será utilizado o Software Frontier Analyst 4.0 que é uma ferramenta de análise de eficiência baseada, que usa a técnica chamada Data Envelopment Analysis (DEA) para examinar o desempenho relativo das unidades organizacionais, que desempenham funções similares. É, portanto, adequado para uso em organizações que operam através de um sistema de pontos de venda (como lojas de varejo, bancos, franquias, etc.) e para uso com organizações do setor público ou "sem fins lucrativos", como hospitais, escolas e outras organizações do setor público "baseadas em unidades". A técnica DEA evoluiu no setor público, onde medidas diferentes de medidas puramente financeiras eram necessárias para avaliar o desempenho.

\section{3 ÁREA DE ESTUDO DA PESQUISA}

A área de estudo para essa pesquisa será as UCs' do tipo RDS e RESEX localizadas no Estado do Amazonas (Figura 1). Uma Reserva de Desenvolvimento Sustentável (RDS) segundo Almeida (2015) é uma área natural que abriga populações tradicionais que vivem em sistemas de exploração sustentável dos recursos naturais.

Ao proteger o uso do ambiente desenvolvido ao longo de gerações e adaptado às condições ecológicas locais, esta categoria de unidade de conservação de uso sustentável contribui para a proteção da natureza e para a manutenção da diversidade biológica.

De acordo com a FAS (2016), as Reservas de Desenvolvimento Sustentável foram criadas pela Lei 9.985/00, o Sistema Nacional de Unidades de Conservação da Natureza (SNUC), que, por sua vez, é regulado pelo Decreto no $4.340 / 02$.

Segundo o Cadastro Nacional de Unidades de Conservação - CNUC (MMA, 2018), até o início de março de 2018, existem 39 RDS no país: 2 nacionais, 32 estaduais e 5 municipais. São exemplos: a Reserva de Desenvolvimento Sustentável Mamirauá (AM), a Reserva de Desenvolvimento Sustentável Veredas do 
Acari (MG), a Reserva de Desenvolvimento Sustentável Estadual Ponta do Tubarão (RN) e a Reserva de Desenvolvimento Sustentável do Rio Negro (AM).

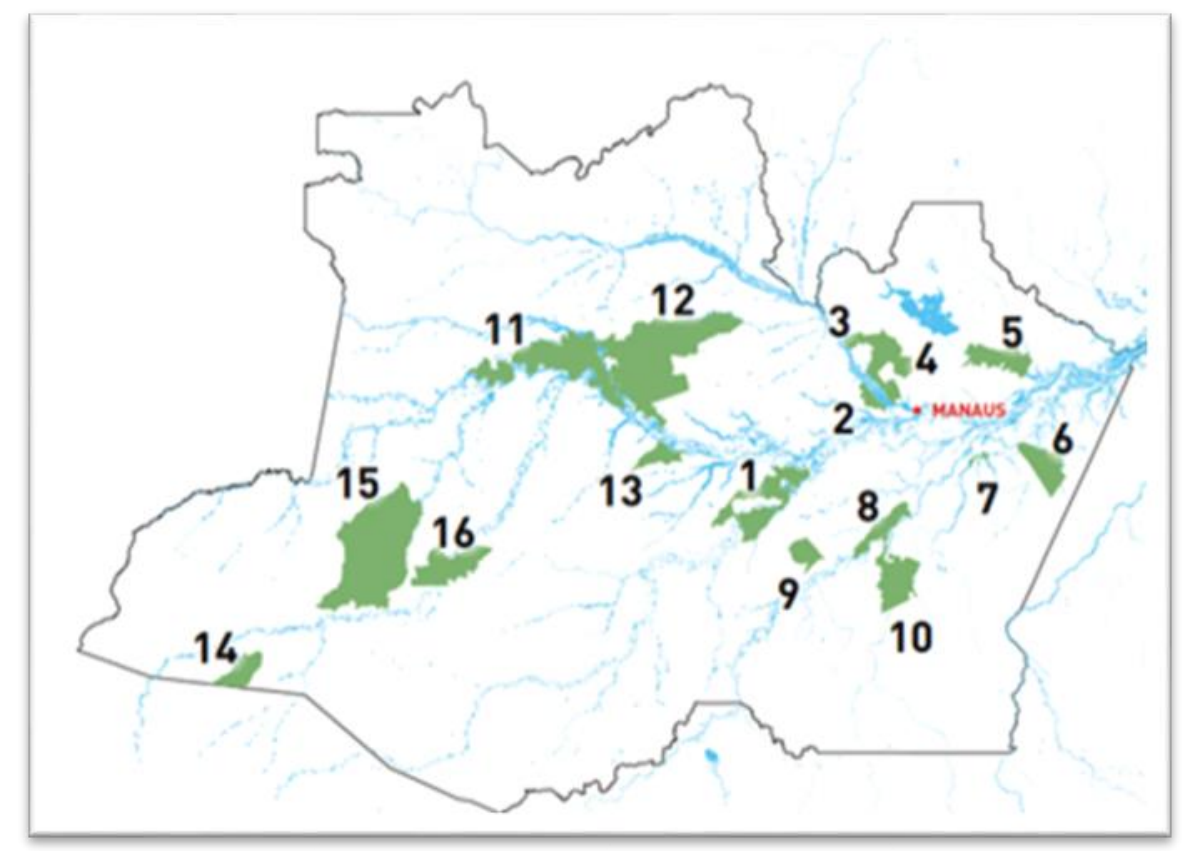

Figura 1. Unidades de Conservação do Estado do Amazonas. Fonte: Fundação Amazonas Sustentável, 2018.

\subsection{FLUXOGRAMA OPERACIONAL DA PESQUISA.}

O Fluxograma 1 mostra o caminho para melhor entender a pesquisa. A partir do conhecimento do PBF, é delimitado as UC's que estão localizadas no Estado do Amazonas que são do tipo RDS. Muito embora exista outras UC's em regiões, por exemplo, críticas de desmatamento1. As UC's RDS possuem muitas comunidades que são amparadas pelo PBF nas suas diversas modalidades de bolsas (renda, social, familiar, associação). Nesse ponto, a pesquisa se apropria das DMU's (RDS, comunidades e bolsas florestas), na linha tracejada, para realizar a análise de eficiência. Mas, as DMU's dependem totalmente das variáveis inputs e outputs que são geradas automaticamente, quando das aplicações das bolsas florestas nas comunidades das RDS. É necessário observar que possivelmente uma comunidade pode ser beneficiada simultaneamente por todas as modalidades de bolsa floresta como também por apenas uma ou duas, e assim sucessivamente. À medida que essas comunidades recebem recursos financeiros, com o fim de promover qualidade de vida com proteção ambiental, é gerado diversos dados como resultados da aplicação desses recursos. 


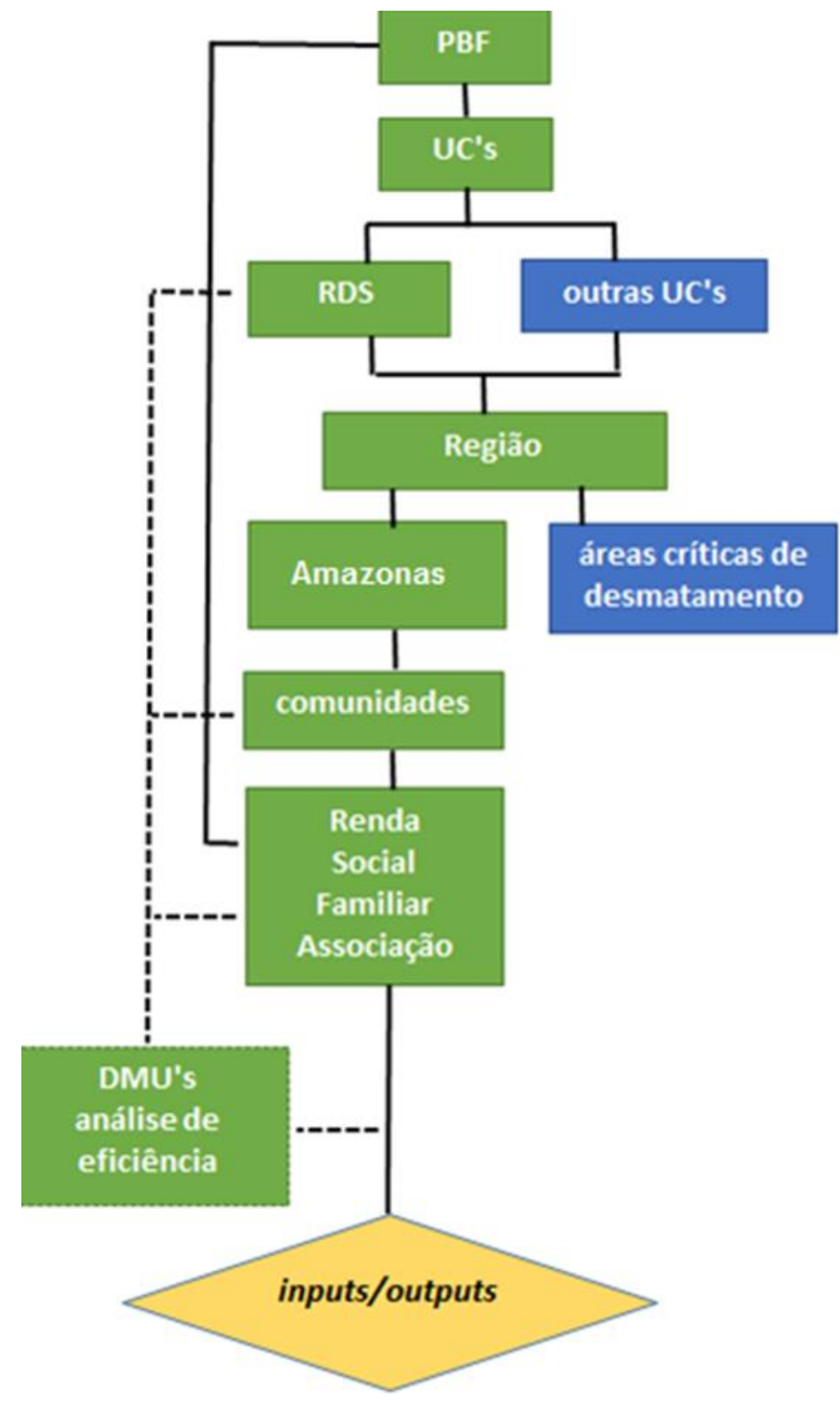

Figura 2. Fluxograma operacional da pesquisa.

Fonte: Elaboração própria.

Visando atender aos objetivos delineados por esta pesquisa, o presente estudo utilizará dados secundários obtidos junto aos Relatórios de Gestão da Fundação Amazonas Sustentável (FAZ) do ano de 2016 em vista deste ter sido o último ano de publicação disponível.

Também far-se-á uso de dados obtidos juntos a Instituto Brasileiro de Geografia e Estatística (IBGE) sobre renda, população e produção agropecuária, bem como os dados de desmatamento de 2015 à 2016 do Sistema de Monitoramento da Floresta Amazônica Brasileira por Satélite (PRODES) do Instituto Nacional de Pesquisas Espaciais (INPE) e também informações acerca dos municípios que fazem parte das referidas unidades de conservação através do anuário estatístico do Amazonas e 
Condensado dos municípios relatório este disponibilizado pela Secretaria de Estado de Planejamento, Desenvolvimento, Ciência, Tecnologia e Inovação (SEPLAN-CTI).

\section{RESULTADOS E DISCUSSÕES}

O primeiro passo da pesquisa foi levantar as Unidades de Conservação (UCs) do Estado do Amazonas, conforme apresentado na Tabela 1 a seguir.

Tabela 1. Unidades de Conservação do Amazonas, área(há), famílias e localidades

\begin{tabular}{|c|c|c|c|}
\hline UC & Área(ha) & Famílias & Localidades \\
\hline RDS Piagaçu-Purus & 1.008 .167 & 999 & 64 \\
RDS do Rio Negro & 102.979 & 693 & 19 \\
APA do Rio Negro & 611.008 & 220 & 10 \\
RDS Puranga Conquista & 76.936 & 346 & 12 \\
RDS do Uatumã & 424.430 & 337 & 20 \\
Floresta Estadual de Maués & 438.440 & 740 & 21 \\
RDS Canumã & 22.355 & 316 & 16 \\
RDS do Rio Madeira & 283.117 & 1.069 & 52 \\
RDS do Rio Amapá & 216.109 & 411 & 38 \\
RDS do Juma & 589.611 & 476 & 184 \\
RDS Mamirauá & 1.124 .000 & 2.332 & 817 \\
RDS Amanã & 2.350 .000 & 817 & 13 \\
Resex Catuá-Ipixuna & 217.486 & 234 & 27 \\
Resex do Rio Gregório & 427.004 & 210 & 2 \\
RDS Cujubim & 2.450 .380 & 48 & 30 \\
RDS de Uacari & 632.949 & 349 & \\
\hline
\end{tabular}

Fonte: Relatório de Gestão da Fundação Amazonas Sustentável (2016).

De acordo com dados apresentados na Tabela 1, podemos notar que no Amazonas existem 12 Reservas de Desenvolvimento Sustentável (RDSs); 2 Reservas Extrativistas (RESEX); 1 Floresta Estadual e 1 Área de Proteção Ambiental (APA). A RDS Cujubim é a Unidade de Conservação que possui a maior área por hectare (2.450.380). A RDS de Mamirauá é a Unidade de Conservação que possui o maior número de famílias (2.332) e por fim a RDS de Anamã é a que possui o maior número de localidades (817).

O segundo passo foi levantar o tipo de produção por unidade de conservação, produção por safra e o faturamento bruto médio das famílias. Nesta etapa, priorizaram-se somente as Unidades de Conservação (UCS) do tipo RDS, pois partimos do princípio que apenas estas unidades possuem atividade produtiva voltada para o desenvolvimento local, apesar de que na Unidade de Conservação 
Floresta Estadual de Maués e Reservas Extrativistas, possuírem atividade econômica voltada para a produção de guaraná e farinha.

Os dados apresentados na Tabela 2, nos mostram que das 12 Unidades de Conservação do tipo RDS a produção de farinha é dominante (5 unidades produzem farinha) seguido por 3 unidades que produzem pirarucu fresco e 1 unidade cada produz castanha, madeira e banana. Não foi possível obter dados de faturamento bruto médio por famílias da RDS Puranga Conquista.

Tabela 2. Reservas de Desenvolvimento Sustentável do Amazonas, produção por safra, faturamento bruto médio por família.

\begin{tabular}{|c|c|c|}
\hline UC & $\begin{array}{c}\text { Produção por } \\
\text { safra }\end{array}$ & $\begin{array}{c}\text { Fatur. bruto } \\
\text { Médio p/Família } \\
\text { (R\$̦) }\end{array}$ \\
\hline RDS Piagaçu-Purus & castanha & 2.533 \\
RDS do Rio Negro & madeira & 6.223 \\
RDS Puranga Conquista & Farinha & - \\
RDS do Uatumã & Farinha & 2.973 \\
RDS Canumã & Farinha & 1.297 \\
RDS do Rio Madeira & cacau & 1.375 \\
RDS do Rio Amapá & banana & 2.735 \\
RDS do Juma & Farinha & 2.579 \\
RDS Mamirauá & pirarucu & 2.994 \\
RDS Amanã & pirarucu & 1.996 \\
RDS Cujubim & Farinha & 1.098 \\
RDS de Uacari & pirarucu & 2.095 \\
\hline
\end{tabular}

Fonte: Relatório de Gestão da Fundação Amazonas Sustentável (2016).

Os dados nos mostram que a atividade que proporciona um maior faturamento bruto médio por família e a produção de madeira sustentável ( $R \$$ 6.223). A seguir os dados referentes a valor dos investimentos totais por bolsa em cada uma das unidades de conservação em análise. 


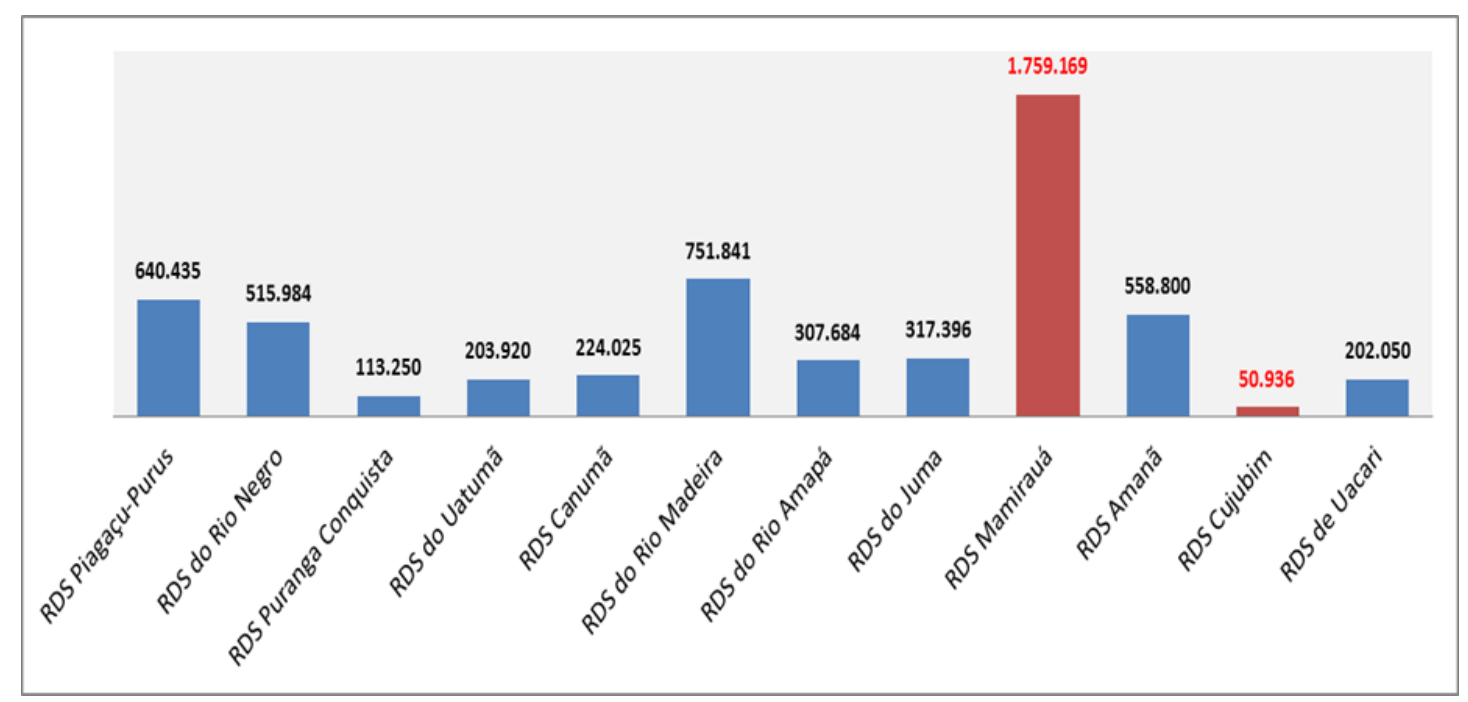

Gráfico 1. Investimentos totais por bolsa em cada Reserva de Desenvolvimento (RDS) emR\$1.000,00. Fonte: Relatório de Gestão da Fundação Amazonas Sustentável (2016).

$\left(^{*}\right)$ Estes valores são as somas dos 4 componentes bolsa floresta (familiar, associação, renda e social). Os dados do Gráfico 1 fazem referência ao somatório de todos os valores em Bolsa Floresta investidos nas RDS. Podemos notar que a RDS Mamirauá obteve um valor expressivo de investimentos da ordem de $\mathrm{R} \$$ 1.759.169 muito superior a todas as demais. Em parte, este resultado se deve pelo fato de que esta RDS possuir o maior número de famílias beneficiadas pelo programa. No Gráfico 2 a seguir veremos o comportamento das taxas de desmatamento de 2015 a 2016.

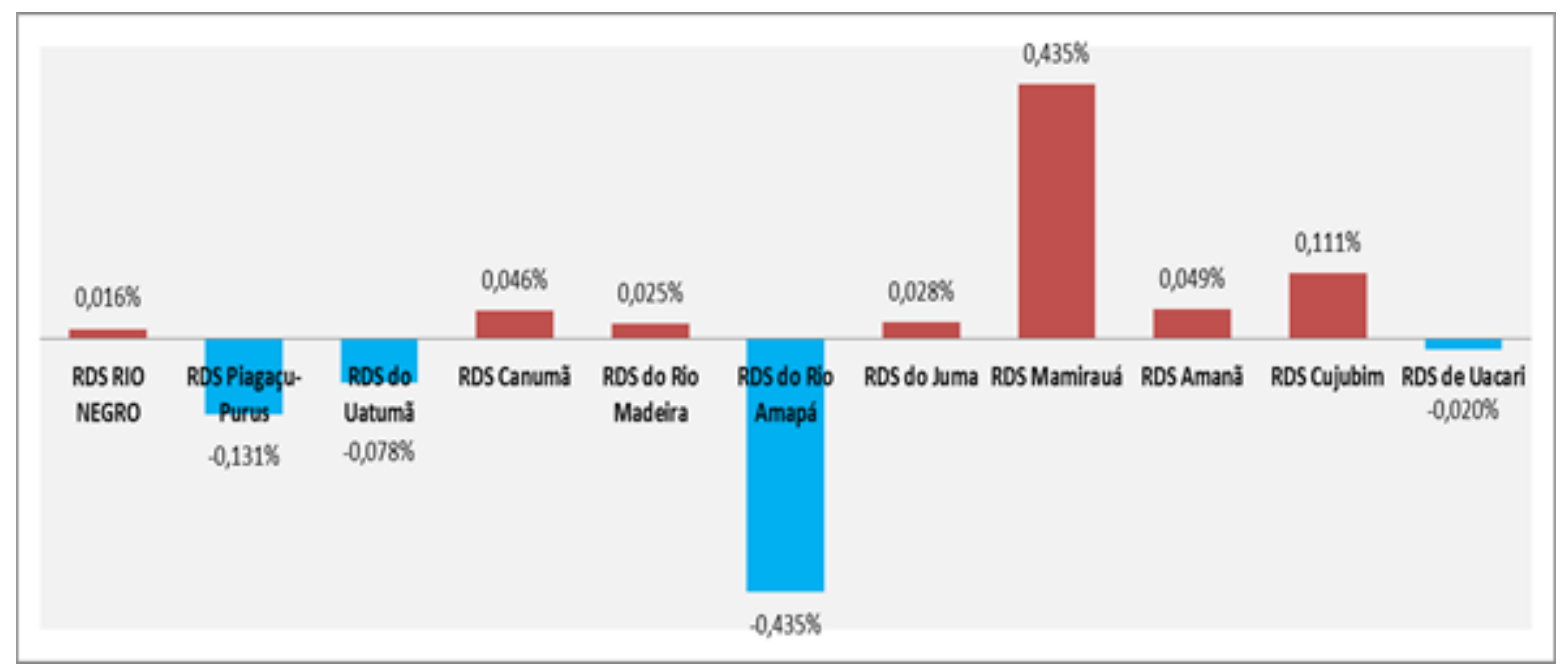

Gráfico 2. Taxa de desmatamento por Reserva de Desenvolvimento (RDS) de 2015 a 2016. Fonte: PRODES/INPE (2018). 
De acordo com os dados do Gráfico 2 podemos evidenciar que das 11 Unidades de Conservação do tipo RDS apenas 4 obtiveram taxa de desmatamento evitado no período em análise. As demais RDS's tiveram crescimento na taxa de desmatamento, sendo a RDS Mamirauá a que obteve a maior taxa (0,435\%). Agora apresentaremos os dados obtidos pelo método DEA utilizando o Software Frontier Analyst 4.0 para verificar o grau de eficiência obtido pelo Programa Bolsa Floresta em 2016 nas RDS selecionadas.

\subsection{RESULTADO DA ANÁLISE ENVOLTÓRIA DE DADOS (DEA)}

Inicialmente tínhamos 12 Reservas de Desenvolvimento Sustentável (RDS) para analisar, entretanto dados às limitações do Software Frontier Analyst 4.0 só poderíamos analisar no máximo 11 DMU's, sendo assim optou-se por excluir da análise a RDS Puranga Conquista, pois a mesma não apresentou dados de faturamento bruto médio por famílias segundo a Tabela 2. Desta forma organizaram-se os dados conforme Tabela 3 a seguir.

Tabela 3. Tabulações dos dados para análise.

\begin{tabular}{|c|c|c|c|c|}
\hline \multirow{2}{*}{ UC } & \multicolumn{3}{|c|}{ INPUTS } & OUTPUTS \\
\cline { 2 - 5 } & $\begin{array}{c}\text { Fatur. bruto } \\
\text { Médio p/Família } \\
\text { (R\$) }\end{array}$ & $\begin{array}{c}\text { Investimento com } \\
\text { Infraestrutura e } \\
\text { bens (R\$) }\end{array}$ & $\begin{array}{c}\text { Investimentos } \\
\text { totais por bolsa } \\
\text { em cada UC (R\$) }\end{array}$ & $\begin{array}{c}\text { N de familías } \\
\text { benefeciadas }\end{array}$ \\
\hline RDS Piagaçu-Purus & 2.533 & 208.938 & 640.435 & 999 \\
RDS do Rio Negro & 6.223 & 131.787 & $515.983,55$ & 693 \\
RDS do Uatumã & 2.973 & 55.077 & $203.920,40$ & 337 \\
RDS Canumã & 1.297 & 72.433 & $224.025,05$ & 316 \\
RDS do Rio Madeira & 1.375 & 245.057 & $751.840,92$ & 1069 \\
RDS do Rio Amapá & 2.735 & 105.755 & $307.684,33$ & 411 \\
RDS do Juma & 2.579 & 50.364 & $317.396,20$ & 476 \\
RDS Mamirauá & 2.994 & 590.892 & $1.759 .168,54$ & 2332 \\
RDS Amanã & 1.996 & 187.986 & $558.800,00$ & 817 \\
RDS Cujubim & 1.098 & 43.225 & $50.935,93$ & 48 \\
RDS de Uacari & 2.095 & 37.591 & $202.050,00$ & 349 \\
\hline
\end{tabular}

Fonte: Elaboração própria.

Desta forma trabalhou-se apenas com 11 RDS cujo, os dados de eficiência pelo método CCR (Retornos Constantes de Escala) apresentam-se na Tabela 4.

No primeiro momento utilizando as variáveis: faturamento bruto médio por família, investimentos com infraestrutura e bens, investimento total por bolsa em cada Unidade de Conservação do tipo Reserva de Desenvolvimento Sustentável (UC/RDS) como imput e tendo como output o número de 
famílias beneficiadas, tentou-se verificar o nível de eficiência do Programa Bolsa Floresta (PBF) no sentido de melhorar a qualidade de vidas das famílias que vivem e dependem do programa.

\section{Tabela 4. Resultado da Análise Envoltória de Dados pelo método CCR.}

\begin{tabular}{|l|c|c|c|}
\hline DMU's & Pesultados comparados & \\
\hline Descrição & Resultado & Condição \\
\hline RDS Amanã & 95,2 & - & Fracamente eficiente \\
\hline RDS Canumã & 87,7 & - & Ineficiente \\
\hline RDS Cujubim & 54,6 & - & Ineficiente \\
\hline RDS Mamirauá & 100,0 & Eficiente & Pareto eficiente \\
\hline RDS Piaguaçu-Purus & 100,0 & Eficiente & Pareto eficiente \\
\hline RDS de Uacari & 100,0 & Eficiente & Pareto eficiente \\
\hline RDS do Juma & 100,0 & Eficiente & Pareto eficiente \\
\hline RDS do Rio Amapá & 79,1 & - & Ineficiente \\
\hline RDS do Rio Madeira & 100,0 & Eficiente & Pareto eficiente \\
\hline RDS do Rio Negro & 77,8 & - & Ineficiente \\
\hline RDS do Uatumã & 95,7 & - & Fracamente eficiente \\
\hline
\end{tabular}

Fonte: Elaboração própria a partir do Software Frontier Analyst 4.0.

De acordo com os dados da Tabela 4 podemos perceber que das 11 RDS's apenas 5 obtiveram 100\% de eficiência no resultado. Em outras palavras qualquer variação nas entradas (inputs) produz variação proporcional nas saídas (outputs).

Podemos dizer que as RDS's que apresentaram resultados eficientes tiveram condição eficiente no sentido de pareto ou fortemente eficientes dado que, um aumento de $10 \%$ nos insumos provocou um aumento proporcional no produto. Por outro lado, as DMU's que apresentaram resultado sem caracterização tiveram condição consideradas fronteira fracamente eficiente e por fim as DMU's que apresentaram percentual ente $70-90 \%$ e condição ineficientes podemos considerar como fronteira não pareto eficiente ou simplesmente ineficientes.

Levando em conta que a filosofia do PBF é de compensar, por meio de investimentos em geração de renda e pagamento por serviços ambientais as pessoas que vivem e dependem da floresta para sua sobrevivência, cujo entendimento é que estas pessoas são os verdadeiros guardiões da floresta, tendo em vista que o programa, também busca, dotar as famílias atendidas de uma alternativa econômica que as possibilite produzir e gerar renda sem degradar o meio ambiente e destruir a floresta, foi que a pesquisa utilizou as mesmas variáveis para analisar a relação dos inputs (faturamento bruto médio por família, investimentos com infraestrutura e bens e investimento total por bolsa floresta) com as taxas de desmatamento evitado de 2015 a 2016 (outputs). 
Para esta análise, não se levou em consideração o total de Reservas de Desenvolvimento Sustentável (RDS's), pois segundo os dados apresentados no Gráfico 2 apenas 4 unidades obtiveram redução na taxa de desmatamento no período de 2015 a 2016.

Tabela 5. Organização dos dados tendo como Output a Taxa de desmatamento evitado.

\begin{tabular}{|c|c|c|c|c|}
\hline UC & $\begin{array}{c}\text { Fatur. bruto } \\
\text { Médio p/Família } \\
(\mathrm{R} \$)\end{array}$ & $\begin{array}{c}\text { Investimento com } \\
\text { Infraestrutura e } \\
\text { bens (RȘ) }\end{array}$ & $\begin{array}{c}\text { Investimentos } \\
\text { totais por bolsa } \\
\text { em cada UC(RS) }\end{array}$ & $\begin{array}{c}\text { TX desmatamento } \\
\text { evitado 2015-2016 }\end{array}$ \\
\hline RDS Piagaçu-Purus & 2.533 & 208.938 & 640.435 & 0,06 \\
RDS do Uatumã & 2.973 & 55.077 & $203.920,40$ & 0,05 \\
RDS do Rio Amapá & 2.735 & 105.755 & $307.684,33$ & 0,01 \\
RDS de Uacari & 2.095 & 37.591 & $202.050,00$ & 0,01 \\
\hline
\end{tabular}

Fonte: Elaboração própria.

Sendo assim levou-se em consideração na análise apenas as RDS's Piagaçu-Purus; Uatumã; Rio Amapá e Uacari. O resultado é apresentado na Tabela 6.

Tabela 6. Resultado da Análise Envoltória de Dados pelo método CCR tendo como Output a Taxa de desmatamento evitado.

\begin{tabular}{l|c|c|c|}
\hline DMU's & \multicolumn{3}{|c}{ Resultados comparados } \\
\hline Descrição & Percentual (\%) & Resultado & Condição \\
\hline RDS Piaguaçu-Purus & 100,0 & Eficiente & Pareto eficiente \\
\hline RDS de Uacari & 29,3 & - & Ineficiente \\
\hline RDS do Rio Amapá & 19,8 & - & Ineficiente \\
\hline RDS do Uatumã & 100,0 & Eficiente & Pareto eficiente
\end{tabular}

Fonte: Elaboração própria a partir do Software Frontier Analyst 4.0.

De acordo com os dados apresentados na Tabela 6, podemos evidenciar que apesar de que 4 Unidades de Conservação (UC's) terem apresentado um resultado satisfatório no sentido de reduzir o desmatamento, apenas 2 delas apresentaram 100\% de eficiência, ou como podemos dizer fronteira de pareto eficiente (RDS Piagaçu-Purus e Uatumã). As demais foram ineficientes no sentido de pareto (isto é, apesar de se dobrar os insumos o produto obtido não foi na mesma proporção). 


\section{CONSIDERAÇÕES FINAIS}

Uma das maiores inquietações mundiais a respeito da crise ambiental que se instaurou são as previsões catastróficas da mudança climática global, cujos efeitos indicam ser demasiadamente prejudicial para a humanidade, porém de forma diferenciada em diversas regiões do planeta. 0 mundo todo sofrerá com os impactos negativos da mudança do clima; mas nos países pobres, onde há grande incidência de fome, guerrilhas, subnutrição e falta geral de recursos de todas as ordens, esses impactos serão mais graves e catastrófico.

Em termos de bioma Amazônia, o ritmo de desmatamento e das queimadas na região causa preocupação em nível mundial e nacional. Isto porque preservar a floresta é importante para todos: o estado de equilíbrio dinâmico atual da atmosfera sobre a região amazônica depende do tipo de cobertura vegetal existente, ou seja, depende da floresta. Grandes alterações da cobertura vegetal poderão levar a alterações climáticas.

Recentemente, os Órgãos responsáveis pelo controle e monitoramento do desmatamento da região registraram taxas altíssimas se comparadas aos controles de outrora. Isto caracteriza àquela velha tendência do modelo de desenvolvimento na região - perda de florestas para produção agropecuária, entre outras atividades.

Políticas estratégicas de desenvolvimento - que venham simultaneamente oferecer algum benefício à sociedade local e ao clima mundial - em cada sub-região da Amazônia é o grande desafio do governo brasileiro. E as políticas ambientais - que defendem recursos financeiros destinados a fomentar políticas de desenvolvimento a partir do desmatamento evitado ou conservação de florestas parecem contribuir bastante para um dos grandes objetivos da Convenção do Clima, que é a responsabilidade comum, porém diferenciada dos países.

Assim, o PBF está inserido na Lei de Mudanças Climáticas, Conservação Ambiental e Desenvolvimento Sustentável do Amazonas, sendo construído de forma participativa, com ampla discussão tanto nas comunidades quanto com instituições governamentais e não governamentais em Manaus. Além disso, o PBF é considerado um programa de Governo do Estado do Amazonas, que busca a interiorização do desenvolvimento a partir da compensação, da valorização e do reconhecimento dos povos da floresta como um fator ímpar na luta a favor do equilíbrio mundial do clima, da manutenção da floresta em pé e do desmatamento zero.

O PBF é um conjunto positivo de ações que tem como objetivo oferecer uma compensação financeira para os serviços prestados pelas populações tradicionais e indígenas do Amazonas, ou seja, uma recompensa aos guardiões da floresta que se comprometem com a conservação ambiental e o 
desenvolvimento sustentável nas UC's do Estado do Amazonas. É o primeiro programa brasileiro de pagamento de serviços ambientais feito diretamente para as comunidades que residem nas UC's. Ao analisar a eficiência socioeconômica e ambiental do PBF do AM, no primeiro momento utilizou-se como variável o faturamento bruto médio por família, investimentos com infraestrutura e bens, investimento total por bolsa em cada UC do tipo RDS como input e tendo como output o número de famílias beneficiadas. E assim, buscou-se verificar o nível de eficiência do PBF no sentido de melhorar a qualidade de vidas das famílias que vivem e dependem do programa. Os resultados apontaram que das 11 RDS's apenas 5 obtiveram 100\% de eficiência no resultado, ou seja, qualquer variação nas entradas (inputs) produz variação proporcional nas saídas (outputs). Pôde-se avaliar que as RDS's que apresentaram resultados eficientes tiveram condição eficiente no sentido de pareto ou fortemente eficientes dado que, um aumento de $10 \%$ nos insumos provocou um aumento proporcional no produto. Por outro lado, as DMU's que apresentaram resultado sem caracterização tiveram condição consideradas fronteira fracamente eficiente e por fim as DMU's que apresentaram percentual ente 70-90\% e condição ineficientes podemos considerar como fronteira não pareto eficiente ou simplesmente ineficientes.

Ao analisar o desmatamento evitados nessas RDS por conta do PBF, considerou-se apenas as RDS's Piagaçu-purus; Uatumã; Rio Amapá e Uacari. No resultado, apesar de que 4 (UC's) terem apresentado um resultado satisfatório no sentido de reduzir o desmatamento, apenas 2 delas apresentaram 100\% de eficiência, ou como podemos dizer fronteira de pareto eficiente (RDS Piagaçu-Purus e Uatumã). As demais foram ineficientes no sentido de pareto (isto é, apesar de se dobrar os insumos o produto obtido não foi na mesma proporção).

\section{REFERÊNCIAS}

ALENCAR, Ane. et. al. Desmatamento na Amazônia: indo além da emergência crônica. Instituto de Pesquisa Ambiental da Amazônia (IPAM): Belém, 2004.

ALMEIDA, André Soares de. A dinâmica do desenvolvimento econômico: Desafios e Perspectivas. Manaus EDUA, 2015.

ANGULO MEZA, L. Um enfoque multiobjectivo para os modelos de determinação de alvos na Análise Envoltória de Dados. 2002. Tese (Doutorado em Engenharia de Produção) - COPPE, Universidade Federal do Rio de Janeiro, Rio de Janeiro.

BARBOSA, W.; SOUZA, E.P. S. Eficiência técnica e de escala da agropecuária no estado do Ceará. Cadernos de Ciências Sociais Aplicadas. Vitória da Conquista-BA n. 17 p. 153-185 2014. 
BRAMBILLA, M.A.; CARVALHO, S.C.C. Análise da eficiência da gestão do programa bolsa família nos municípios do paraná. Revista Brasileira de Estudos Regionais e Urbanos, vol. 11, n. 4, pp. 537-556, 2017.

CHARNES, A., COOPER, W.W., LEWIN, A.Y., SEIFORD, L.M. Data envelopment analysis: theory, methodology, and application. Dordrecht: Kluwer Academic, 1994.

FAS. Disponível em: http://fas-amazonas.org/

FAS, Fundação Amazonas Sustentável. Relatório de Gestão 2015. Disponível em: http://fasamazonas.org Acessado em: 23/01/2018.

FAS, Fundação Amazonas Sustentável. Relatório de Gestão 2016. Disponível em: http://fasamazonas.org Acessado em: 12/02/2018.

HIGUCHI, Niro. Governos locais amazônicos e as questões climáticas globais. Manaus: Edição dos autores, 2009.

INSTITUTO NACIONAL DE PESQUISAS ESPACIAL (INPE). Projeto PRODES Monitoramento da Floresta Amazônica por Satélite. Desmatamento nos Municípios (Amazonas). Disponível em http://www.dpi.inpe.br/prodesdigital/prodesmunicipal.php. Acesso em: 15/3/2017.

IPEADATA. Região Metropolitana de Manaus. Disponível em: http://www.ipea.gov.br/agencia/images/stories/PDFs/livros/livros/141125_atlas_manaus. Acesso em 10 set de 2017.

LINS, M.P.E.; SILVA, A.C.M. Evitando a inviabilidade em modelos DEA com restrições aos pesos. Relatório Técnico EP03/01-PO, Programa de Engenharia de Produção/COPPE/UFRJ, Rio de Janeiro, 2001.

MELLO, J. C. B. S; et al. Análise de envoltória de dados no estudo da eficiência e dos benchmarks para companhias aéreas brasileiras. Pesqui. Oper., Rio de Janeiro, v. 23, n. 2, p. 325-345, Aug. 2003.

MELLO, João Carlos Correia Baptista Soares de; et al. Curso de Análise Envoltória de Dados. XXXVII Simpósio Brasileiro de Pesquisa Operacional e o Desenvolvimento Sustentável. Gramado, RS, 27 a 30/09/2005. Disponível em: www.uff.br/decisao/sbpo2005_curso.pdf. Acesso em: 15. Out. 2016.

OLIVEIRA, Elane Conceição de. Desmatamento evitado: o caso do programa bolsa floresta do Estado do Amazonas como política ambiental para mitigar os gases de efeito estufa. - Universidade de Brasília, Centro de desenvolvimento. DINTER CDS/UNB-UEA. Dezembro, 2008.

OLIVEIRA, Elane Conceição de; et al. Deficit social e pobreza absoluta na Região Metropolitana de Manaus: governança para o desenvolvimento da região. IN: BARBOSA, Evandro; et al. Governança na Amazônia: socioeconômica, meio ambiente, segurança e defesa. Manaus: BK Editora, 2011.

PINDYCK, Robert S.; RUBINFELD, Daniel L. Microeconomia. 6a ed. São Paulo: Pearson Prentice Hall, 2005.

RIVAS. Alexandre. Economia e valoração de serviços ambientais utilizando técnicas de preferências declaradas. / - Manaus. EDUA, 2014. 
TUPY, Oscar; YAMAGUCHI, Luis Carlos T. Eficiência e Produtividade: conceitos e medição. Agricultura em São Paulo, v. 45, n.2, p. 39-41, 1998.

VERÍSSIMO, A.; PEREIRA, Denys. Produção na Amazônia Florestal: características, desafios e oportunidades. Parc. Estrat. Brasília-DF, v. 19, n. 38, p. 13-44, jan-jun, 2014.

VIANA, V. M.. Bolsa Floresta: Um instrumento inovador para a promoção da saúde em comunidades tradicionais da Amazônia. Estudos Avançados, 22(6), pp. 1-11, 2008. 


\section{Capítulo 21}

\section{POTENCIAL FRUTÍERO E DE BIOMASSA DAS PLANTAS DE MANGABA (HANCORNIA SPECIOSA GOMES) E MURICI (BYRSONIMA VERBASCIFOLIA) PELO SISTEMA DE PLANTIO: UM ESTUDO NO CERRADO GOIANO DOI: $10.37423 / 200300434$}

Cleci Grzebieluckas (UNEMAT - cleci@unemat.br

Raimundo Nonato Cunha de França - raimundo franca@unemat.br Josiane Silva Costa dos Santos (UNEMAT - josiane.santos@unemat.br) Magno Alves Ribeiro (UNEMAT) - magnoalves@unemat.br

RESUMO: O objetivo do estudo foi fazer uma análise da produção de mangaba (hancornia speciosa gomes) e murici (byrsonima verbascifolia) no sistema de plantio e estimar a biomassa e o carbono das plantas. Trata-se de uma pesquisa descritiva com abordagem quantitativa. As informações sobre os custos de implantação, manutenção e a produção dos frutos foram obtidas por meio de roteiros estruturados diretamente com o proprietário, observação direta em época de colheita e com visitas pela pesquisadora que acompanha a propriedade anualmente desde 2008. Para estimar a biomassa e o carbono das plantas foi utilizado o método indireto - modelo alométrico- testado por Guarino e Medeiros (2005). Os custos de implantação e manutenção da mangaba e do murici giram em torno de três mil por hectare e iniciaram a produção entre quatro e cinco anos de plantio. A receita bruta por hectare atingiu média de $\mathrm{R} \$ 33.026,00$ para a mangaba e $\mathrm{R} \$ 20.900,00$ para o murici. Quanto ao carbono em 2010 a mangaba e o murici geravam respectivamente 3,02 e 2,69 ton./ha e em 2012 10,78 e 6,64 toneladas por hectare. Identificou-se que as plantas possuem forte potencial produtivo, existe demanda pelos frutos e a atividade contribui significativamente para o equilíbrio econômico e ambiental.

Palavras-chave: Medição florestal. Equações Alométricas. Hotspots. 


\section{INTRODUÇÃO}

Apesar da importância para a conservação da biodiversidade, o Cerrado possui apenas $2 \%$ de sua expansão original protegida por parques e reservas federais e estaduais. A maior parte dessas reservas possuem extensão inferior a 100 mil hectares, o que coloca em evidência o grau de fragmentação do ecossistema (BEZERRA; VEIGA, 2000; Cl - BRASIL, 2008). O bioma Cerrado abriga o principal polo de produção de soja representando 63\% da produção nacional (EMBRAPA CERRADO,2013) ponto positivo para o cenário econômico do país, porém, o preparo da terra para a agricultura, que, além de destruir a cobertura vegetal, prejudica a manutenção de populações da fauna silvestre, a qualidade da água e o equilíbrio do clima e do solo aumentando os gases de efeito estufa (GEEs).

Os prejuízos biológicos gerados pelo desmatamento levaram o Cerrado brasileiro a fazer parte da lista dos 34 hotspots (regiões biologicamente mais ricas e ameaçadas do planeta), devido à sua riqueza biótica, nível de endemismo e grau de ameaça (MYERS et al., 2000). O conceito de hotspots surgiu pela primeira vez em 1988, quando o ecólogo inglês Norman Myers, tentava resolver um dos maiores dilemas dos conservacionistas, identificar quais as áreas mais importantes para preservar a biodiversidade na Terra (Cl-BRASIL, 2008). Ao observar que a biodiversidade não está igualmente distribuída no planeta, Myers procurou identificar quais as regiões que concentravam altos níveis de biodiversidade e onde as ações de conservação seriam mais urgentes. Myers et al. (2000) descrevem que para ser qualificada como um hotspot, uma área deve conter no mínimo 0,5\% ou 1,5 mil das 300 mil espécies de plantas endêmicas do planeta e que tenha perdido mais de três quartos de sua vegetação original. O cerrado brasileiro faz parte desta lista por abrigar $1,5 \%$ de plantas, $0,4 \%$ de vertebrados endêmicos e já ter perdido $80 \%$ de seu estado original (MYERS et al. (2000).

O cerrado brasileiro possui mais de 58 espécies de frutas nativas (AVIDOS; FERREIRA, 2000; SILVA et al 2001) que ocupam lugar de destaque pelo seu potencial de aproveitamento alimentar na forma de sucos, licores, sorvetes, geleias etc. O interesse por essas frutas atinge diversos segmentos da sociedade, tais como agricultores, indústrias, donas-de-casa, comerciantes, instituições de pesquisa e assistência técnica, cooperativas, universidades, órgãos de saúde e de alimentação, entre outros (AVIDOS; FERREIRA, 2000). Contudo, são necessários estudos que evidenciem melhor o potencial econômico e ambiental desses frutos (SOARES et al, 2006). A contínua pressão antrópica que assola do bioma Cerrado vem empobrecendo a fauna e a flora, fazendo com que os produtos florestais não- 
madeiráveis sejam eles frutos, fármacos, carbono entre outros, adquirem importância no cenário econômico e ambiental.

Preocupados com esse empobrecimento e a crescente demanda por tais produtos e serviços, agricultores do interior de Goiás iniciaram alguns plantios de espécies nativas do cerrado a fim atender a demandas por frutas nativas e seus derivados. Neste contexto, o objetivo do estudo foi fazer uma analise da produção de mangaba (hancornia speciosa gomes) e murici (byrsonima verbascifolia) no sistema de plantio e estimar a biomassa e o carbono das plantas em uma propriedade rural do interior de Goiás. Justifica-se o estudo em razão de que segundo Higuchi et al (1998) o manejo florestal está associado ao uso sustentável dos recursos florestais existentes, para atender as demandas da sociedade, por produtos madeireiros e não-madeireiros. E a estimativa de biomassa florestal são informações imprescindíveis nas questões ligadas entre outras, as áreas de manejo florestal e de clima.

\section{SUPORTE TEÓRICO}

\subsection{BIOMASSA VEGETAL}

Biomassa vegetal é a quantidade em massa de material vegetal existente em uma floresta (JUNIOR SETTE; GEROMINI; NAKAJIMA, 2004). O inventário de biomassa é um requisito básico para desenvolver projetos que tenham como objetivo a obtenção de certificados de crédito de carbono. Esse inventário quantifica o armazenamento de carbono em diferentes depósitos presentes em distintos usos da terra ou ecossistemas. Permite medir o impacto de determinado projeto na remoção (sequestro) do dióxido de carbono (CO2) presente na atmosfera, através de sua fixação na biomassa existente (RÜGNITZ; CHACÓN; PORRO, 2009).

Existem dois métodos principais para a estimativa de biomassa em áreas arbóreas: o método destrutivo direto e o não destrutivo indireto. 0 direto consiste em derrubar, secar e pesar um número significativo de árvores em uma área definida e convertê-lo em carbono, multiplicando-se a quantidade de biomassa seca por 0,5. A conversão de peso seco de biomassa em massa de carbono tem sido calculada baseada na relação de que em uma tonelada de biomassa seca de madeira encontra-se, aproximadamente, 0,5 tonelada de carbono e de que 1 tonelada de carbono absorve 3,67 toneladas de CO2 (MARTINS, 2004; IPCC, 2006b; RÜGNITZ; CHACÓN; PORRO, 2009).

No método indireto procura-se estabelecer uma relação entre dados dendrométricos (medição florestal) facilmente coletados em campo, tais como diâmetro e altura do fuste, medidas coletadas 
com a árvore em pé e com os pesos dos elementos componentes da árvore, como tronco, galhos, folhas e casca. Para aplicar esse tipo de modelo, algumas árvores são cortadas, medidas e pesadas. A partir desses dados, é possível, com a utilização de equações alométricas (modelos estatísticos), estabelecer uma relação entre os fatores medidos em campo, como, por exemplo, diâmetro e altura da planta para se obter a quantidade de biomassa de cada indivíduo de determinada composição florestal. Ao contrário do método destrutivo, a alometria é muito útil porque permite estimar a biomassa total de uma floresta, sem que haja a necessidade de destruir todas as árvores (ARES et al., 2002; MARTINS, 2004; RÜGNITZ; CHACÓN; PORRO, 2009).

As equações alométricas são geradas a partir da análise de regressão, em que se estudam as relações entre a massa (geralmente em peso seco) das árvores e seus dados dimensionais (ex.: altura, diâmetro). Dependendo do número de variáveis, a equação pode ser uma regressão linear simples, isto é, uma única variável dependente, por exemplo, o volume de biomassa em quilogramas, e uma variável independente, por exemplo, o diâmetro da planta (DAP) ${ }^{1}$ a uma altura de $1,30 \mathrm{~cm}$ do solo (altura do peito), ou regressão linear múltipla, com duas ou mais variáveis independentes, por exemplo, altura total da planta (HT) e DAP. Com base nessas variáveis, é possível calcular a biomassa da área total das plantas e posteriormente o carbono (RÜGNITZ; CHACÓN; PORRO, 2009).

\subsection{MAGABA E MURICI}

A mangabeira (Hancornia speciosa Gomes) é uma árvore frutífera de clima tropical, nativa do Brasil e é encontrada principalmente no cerrado e na caatinga (ALMEIDA et al, 1998), desde os Tabuleiros Costeiros e Baixadas Litorâneas do Nordeste, onde é mais abundante, até as áreas sob Cerrado da Região Centro-Oeste e ainda nas Regiões Norte e Sudeste (VIEIRA NETO et al 2002). No litoral, a especulação imobiliária e a implantação de monoculturas, a exemplo dos coqueirais e canaviais, e pastagens são as principais causas da redução da vegetação nativa e consequentemente do número de mangabeiras. Apesar disso, em algumas regiões esta frutífera é preservada após a erradicação da vegetação original, sendo encontrada em áreas de capoeira, pastagens e entre a vegetação cultivada (VIEIRA NETO et al 2002).

Na região Centro-Oeste, existe uma forte demanda pelos frutos da mangabeira e dos seus subprodutos, porém, devido à grande pressão antrópica sobre o bioma cerrado, a possibilidade de obtenção de frutos em quantidade e qualidade de forma extrativista tornou-se mais restrita (AQUINO; OLIVEIRA, 2006). Esta afirmação é corroborada pelos dados do Instituto Brasileiro de Geografia e 
Estatística (IBGE) que em 1996 apresentou produção extrativista de 1.364 toneladas de mangaba e em 2012 foi reduzida em mais de 50\% atingindo apenas 677 toneladas. $70 \%$ da produção nacional concentra-se nos estados de Sergipe e Bahia (IBGE,2012).

A mangaba é uma planta com grande potencial frutífero indicando ser uma das espécies do cerrado com maiores chances de ser trabalhada visando sua domesticação e incorporação ao sistema produtivo (ARAÚJO, et al., 2003; SILVA; NASCIMENTO; NAVES, 2006). Apresenta também grande potencialidade de mercado no segmento de frutas tropicais, com possibilidades de aproveitamento tanto para o mercado consumidor interno, quanto externo, já que seus frutos têm boa aceitação in natura ou processados na forma de polpas, sucos, sorvetes, doces, xarope, compotas, vinho, vinagre etc (ARAÚJO et al, 2003; VIEIRA NETO et al 2002). Sua utilização agroindustrial está sendo rapidamente difundida devido à grande aceitação, principalmente do suco e do sorvete e ainda o fato de que este fruto apresentar um alto rendimento de polpa, em torno de 94\%. (VIEIRA NETO et al 2002).

O seu cultivo oferece excelente oportunidade de renda, sobretudo para os pequenos agricultores, propiciando um ótimo incremento ao agronegócio familiar podendo ser cultivada em consórcio com outras atividades (SOARES et al, 2006). Segundo Silva, Nascimento e Naves (2006) é uma planta com grande capacidade frutífera e apresenta comportamentos produtivo e reprodutivo elevado indicando ser uma das espécies frutíferas do Cerrado com maiores chances de serem trabalhadas visando à sua domesticação e incorporação ao sistema produtivo. Sua planta atinge porte médio de 5 a 10 metros de altura (VIEIRA NETO et al 2002).

O murici (Byrsonima Verbascifolia) é uma espécie nativa do cerrado e se destaca por suas diversas propriedades, tanto medicinais, quanto comestíveis e também para a criação de móveis e construções. Chamado também de douradinha-falsa, mirici, murici, muricizinho, orelha-de-burro, orelha-de-veado, semaneira, é uma planta típica de cerrado sendo encontrado principalmente no Cerrado e Campo Sujo. A planta geralmente mede até 5 metros de altura, sua floração acontece de setembro a novembro e a frutificação de novembro a fevereiro e a produção de frutos é alta e irregular (ALMEIDA et al, 1998).

A casca de murici é utilizada como propriedade medicinal e também em tingimento de tecidos, 0 tronco fornece boa lenha e é própria para a construção civil e marcenaria de luxo. A planta é diurética, porém, tóxica se em doses elevadas, o fruto é de sabor agridoce e comestível ao natural, usado também para a fabricação de doces, licores, sucos e sorvetes. Por ser um produto adstringente 
também é empregado na indústria de curtume (ALMEIDA et al, 1998). Embora o murici não faça parte das estatísticas de produção de extração vegetal e silvicultura do IBGE, no ano de 2009 apenas em uma sorveteria de Goiânia foram processados e comercializados em forma de sorvetes, sucos e picolés mais de 8 toneladas do fruto (GRZEBIELUCKAS et al, 2010).

\section{MATERIAL E MÉTODOS}

\subsection{CAMPO DE APLICAÇÃO DA PESQUISA E COLETA DE DADOS}

A pesquisa foi realizada em uma propriedade rural localizada no município de Arenópolis, estado de Goiás, bioma Cerrado. O Município tem como cultura agrícola predominante a soja, e em 2008 abrigava um rebanho bovino de 92 mil cabeças (IBGE, 2012). As informações sobre os custos de implantação, manutenção e a produção dos frutos foram obtidas por meio de roteiros estruturados e entrevistas com o proprietário, observação direta em época de colheita e com visitas pela pesquisadora que acompanha anualmente desde 2008. A mangaba foi plantada em 2005 e o murici em 2006. A primeira colheita dos frutos aconteceu em 2009. Já a coleta dos dados para o cálculo do carbono aéreo das plantas ocorreu em 2010 e em 2012.

\subsection{CÁLCULO DA BIOMASSA E DO CARBONO}

Para estimar a biomassa e o carbono das plantas foi utilizado o (método indireto), modelo alométrico (Equação 1) testado por Guarino e Medeiros (2005) com plantas nativas do cerrado Cerrado sensu stricto e Campo Sujo na região de Corumbá IV (GO). Justifica-se este método em razão da área de estudo ser um plantio em fase de produção e o corte das plantas seria inviável do ponto de vista econômico e ambiental por se tratar de área experimental.

Ln PF $=-2.845+1.138$ Ln DA302 $\times$ Htotal

Onde:

$\operatorname{Ln}=$ Logaritmo natural

$\mathrm{PF}=$ Peso fresco em $\mathrm{kg}$ ou biomassa

( Equação 1)

DA30 = Diâmetro a $30 \mathrm{~cm}$ do solo

$\mathrm{HT}=$ Altura total 


\section{Exp = Elevada à potência de}

Destaca-se que na literatura (HIGUCHI et al., 1998; VELASCO; HIGUCHI, 2008; BARBEIRO; VIEIRA; SANQUETTA, 2009; RÜGNITZ; CHACÓN; PORRO, 2009) é comum o uso da medida do diâmetro da planta na altura do peito $(1,30 \mathrm{~cm}$ do solo), contudo, por se tratar de plantas baixas utilizou-se o DA30 (diâmetro a $30 \mathrm{~cm}$ do solo) assim como Guarino e Medeiros (2005) entre outros. Foram medidas a altura e a circunferência de 38 pés de mangaba e 30 de murici. Estas medidas aconteceram com as mesmas plantas em fevereiro de 2010 e fevereiro de 2012.

Depois de obtidas as medidas das plantas, o próximo passo foi calcular o DA30 (diâmetro a $30 \mathrm{~cm}$ do solo), dividindo-se a circunferência (CA) da planta pelo $\pi(\mathrm{PI})=3,14$ através da fórmula: $\mathrm{CA} / \pi$ (VELASCO; HIGUCHI, 2008). Após essas medidas e cálculos, aplicou-se a Equação 1 para se obter a quantidade de massa fresca (biomassa) das plantas. Para o cálculo do carbono seguiu-se o modelo sugerido por MacDicken (1997) e pelo IPCC (2006b) que consideram que 50\% da planta é água e $50 \%$ é peso seco e a base para o cálculo do carbono é 0,5 sobre o peso seco da planta.

\section{RESULTADOS E DISCUSSÕES}

\subsection{CUSTOS DE IMPLANTAÇÃO E MANUTENÇÃO}

A tabela 1 mostra os itens necessários para a implantação e manutenção de um hectare de mangaba e um de murici. A mangaba foi plantada a uma distancia de $6 \times 6$ (278 plantas por hectare) e o murici 5 x 5 (400 plantas por hectare). O preço médio das mudas foi de $\mathrm{R} \$ 2,00$ por planta.

Tabela 1 - Custo/ha de implantação e manutenção de mangaba e murici

\begin{tabular}{|c|c|c|c|c|}
\hline \multirow[b]{2}{*}{ Custos } & \multicolumn{2}{|c|}{ Mangaba } & \multicolumn{2}{|c|}{ Murici } \\
\hline & Implantação & Manutenção & Implantação & Manutenção \\
\hline Mão de obra permanente & & $2.468,20$ & & $2.468,20$ \\
\hline Energia elétrica & & 23,00 & & 23,00 \\
\hline Depreciação & & 141,20 & & 141,20 \\
\hline Custo da terra & & 300,00 & & 300,00 \\
\hline Outros custos de manutenção & & 30,00 & & 30,00 \\
\hline Combustíveis e lubrificantes & & 220,00 & & 220,00 \\
\hline Mão de obra temporária & 40,00 & 50,00 & 40,00 & 50,00 \\
\hline Instalações. máq. e ferramentas & $1.796,00$ & & 1796,00 & \\
\hline Poço artesiano & 240,00 & & 240,00 & \\
\hline Preparação do solo & 240,00 & & 240,00 & \\
\hline Mudas & 556,00 & & 800,00 & \\
\hline Reposição de mudas & 83,40 & & 80,00 & \\
\hline Total R\$/ha & $2.955,40$ & $3.232,40$ & $3.196,00$ & $3.232,40$ \\
\hline
\end{tabular}

Fonte: Dados da pesquisa 
A mão de obra permanente são os salários e os encargos de uma pessoa encarregada pela conservação tais como roçar, podar, colher etc. A energia elétrica é utilizada na bomba que envia água do reservatório para a irrigação das mudas. A depreciação se refere ao desgaste pelo uso do bem que deverá ser reposto futuramente. O custo da terra se refere à taxa de retorno que o capital investido na atividade teria caso fosse aplicado numa fonte alternativa de investimento. $O$ preço do hectare comercializado na região é de R\$ 5.000 (pesquisa, de campo). Segundo Werner (2007), na prática, para se calcular o custo da terra utiliza-se, como base, a Taxa Mínima de Atratividade (TMA) da aplicação tradicional no mercado financeiro, que nos casos agrícolas é de $6 \%$ a.a.

No item "outros custos de manutenção" estão incluídos os custos de reposição de peças para a manutenção das ferramentas, dentre outros. No grupo de combustíveis e lubrificantes encontram-se os custos referentes ao combustível e o lubrificante necessários para as máquinas roçadeiras. A mão de obra temporária se refere ao plantio de mudas e ajuda na colheita. As instalações são os bens móveis e imóveis necessários para a atividade. $\mathrm{O}$ poço artesiano é utilizado para regar as mudas. $\mathrm{O}$ item "preparação do solo" se refere ao serviço hora/máquina do trator para o plantio. As mudas das plantas se referem às mudas plantadas, e a reposição significa o replantio de mudas que não se desenvolveram.

\subsection{A PRODUÇÃO DOS FRUTOS}

As plantas frutíferas iniciaram sua produção em 2009, a mangaba com quatro anos de plantio e o murici com três. As mudas não foram enxertadas. A Tabela 2 apresenta os dados da produção e receita nos anos de 2009 a 2012.

\begin{tabular}{l|c|c|c|c|c|c|c|c|c}
\hline \multicolumn{6}{c}{ Tabela 2 - Produção e receita de mangaba e murici no período de 2009 a 2012} \\
\hline Frutos & $\begin{array}{c}\text { kg por } \\
\text { planta } \\
(2009)\end{array}$ & $\begin{array}{c}\text { kg por } \\
\text { planta } \\
(2010)\end{array}$ & $\begin{array}{c}\text { kg por } \\
\text { planta } \\
(2011)\end{array}$ & $\begin{array}{c}\text { kg por } \\
\text { planta } \\
(2012)\end{array}$ & $\begin{array}{c}\text { Produção } \\
\text { média }\end{array}$ & $\begin{array}{c}\text { Plantas } \\
\text { (ha) }\end{array}$ & $\begin{array}{c}\mathrm{kg} \\
(\mathrm{média/há)}\end{array}$ & $\begin{array}{c}\mathrm{R} \$ \\
(\mathrm{~kg})\end{array}$ & $\begin{array}{c}\text { Receita } \\
(\mathrm{R} \$) \\
\text { média } \\
\text { (ha) }\end{array}$ \\
\hline Mangaba & 36 & 30 & 54 & 56 & 44 & 278 & 12.232 & $2,70^{*}$ & 33.026 \\
\hline Murici & 23,5 & 70 & 68 & 60 & 55 & 400 & 22.000 & $0,95^{*}$ & 20.900 \\
\hline
\end{tabular}

* Preços praticados na região

Fonte: Dados da pesquisa

No ano de 2010 a produção de mangaba sofreu redução $(16,7 \%)$ em relação ao ano de 2009 . Segundo o proprietário do sítio, esta redução se deu em virtude da estiagem prolongada uma vez que as árvores 
adultas não são irrigadas. Os dados da produção de mangaba aqui encontrados corrobora com a declaração de Vieira Neto et al (2002) onde apontam que a mangabeira inicia a sua produção entre o terceiro e o quinto ano após o plantio e que a partir do quinto ano, a cultura pode proporcionar produtividades de 10 a 12 t/ha, dependendo das condições de clima e solo e do manejo adotado.

A produção de mangaba superou o estudo de Aguiar Filho, Bosco e Araújo (2010), que, em um plantio de mangaba com quatro anos de idade, obtiveram média de $700 \mathrm{~kg} / \mathrm{ha} / \mathrm{ano}$. Também foi superior a encontrada por Silva, Nascimento e Naves (2006) com plantas de 11 anos de plantio que produziram em 2003 e 2004, respectivamente, 1,29 e 1,46 kg/planta no sistema sem irrigação. Já o murici confirmou a declaração de Almeida et al. (1998) de que a produção é alta e irregular. Destaca-se aqui que essa produção é toda absorvida pela indústria de sorvetes e picolés do proprietário do sitio que atualmente cultiva mais de cinco mil pés de mangaba na propriedade.

\subsection{BIOMASSA E CARBONO DAS PLANTAS}

O estoque médio de biomassa fresca das plantas aqui encontrado foi superior aos índices encontrados por Guarino e Medeiros (2005), que, utilizando a mesma equação alométrica, identificaram 23,28 t/ha de biomassa fresca. Superou ainda três espécies também com três anos de idade (ingá ipê-amarelo e quaresmeira) das 16 variedades estudadas por Velasco e Higuchi (2008) no Projeto Pomar, em São Paulo.

Tabela 3 - Quantidade estimada de biomassa e carbono por hectare de mangaba e de murici nos anos de 2010 e 2012

\begin{tabular}{c|c|c|c|c|c|c|c|c|c|c|c|c}
\hline & \multicolumn{2}{|c|}{$\begin{array}{c}\text { DAP30 } \\
\text { (Média) }\end{array}$} & \multicolumn{2}{c|}{$\begin{array}{c}\text { Altura } \\
\text { (Média) }\end{array}$} & \multicolumn{2}{c|}{$\begin{array}{c}\text { Biomassa } \\
\text { fresca } \\
\text { (Kg/planta) }\end{array}$} & \multicolumn{2}{c|}{$\begin{array}{c}\text { Biomassa } \\
\text { seca } \\
\text { (Kg/planta) }\end{array}$} & \multicolumn{2}{c|}{$\begin{array}{c}\text { Carbono } \\
\text { (Kg/planta) }\end{array}$} & \multicolumn{2}{c}{$\begin{array}{c}\text { Carbono } \\
\text { (t/ha) }\end{array}$} \\
\hline & 2010 & 2012 & 2010 & 2012 & 2010 & 2012 & 2010 & 2012 & 2010 & 2012 & 2010 & 2012 \\
\hline Mangaba & 9,60 & 13,77 & 3,50 & 4,82 & 43,41 & 155,15 & 21,71 & 77,57 & 10,85 & 38,79 & 3,02 & 10,78 \\
\hline Murici & 8,38 & 11,14 & 2,92 & 3,77 & 26,94 & 66,37 & 13,47 & 33,19 & 6,74 & 16,59 & 2,69 & 6,64 \\
\hline \multicolumn{10}{c|}{ Fonte: Dados da pesquisa } \\
\hline
\end{tabular}

Observa-se que em dois anos a produção de biomassa e carbono da mangaba se elevou em $257 \%$ e o murici em $146 \%$. O estoque de carbono aqui encontrado foi inferior ao identificado por Paiva, Rezende e Pereira (2011) que identificaram 8,6 t/ha no cerrado sensu stricto também usando equação alométrica, diâmetro a $30 \mathrm{~cm}$ do solo e calculando o carbono correspondente a $50 \%$ da biomassa seca. 


\section{CONSIDERAÇÕES FINAIS}

Identificou-se que os custos que mais influenciaram na implantação do cultivo de mangaba e murici foram as máquinas e equipamentos seguido pelas mudas, e os de manutenção mão-de-obra e o custo da terra. A produção média de mangaba e murici no período de 2009 a 2012 atingiu respectivamente 12 e 22 toneladas inatura gerando, portanto, um montante/ha de $\mathrm{R} \$ 33.026$ com a mangaba e $\mathrm{R} \$ 20.900,00$ com o murici.

Quanto a produção de biomassa houve um aumento significativo de biomassa e carbono, uma vez que em 2010 a mangaba e o murici geraram respectivamente 3,02 e 2,69 toneladas de carbono enquanto que em 2010, usando-se as mesmas plantas e o mesmo método de cálculo a biomassa e o carbono da mangaba se elevou em $256,9 \%$ e o murici em $146,8 \%$.

Identificou-se que as plantas possuem forte potencial produtivo, existe demanda pelos frutos e a atividade contribui significativamente para o equilíbrio econômico e ambiental. Sugere-se que novos estudos usando este mesmo método sejam realizados em outras regiões do cerrado a fim de se fazer uma análise comparativa dos itens aqui estudados e assim consolidar mais as pesquisas nesta área.

\section{REFERÊNCIAS}

AGUIAR FILHO, S. P. de; BOSCO, J.; ARAÚJO, I. A. de. A mangabeira (Hancornia speciosa Gomez): domesticação e técnicas de cultivo. 2010. Disponível

em: <www.emep.org.br/public/mangabeira02.pdf>. Acesso em: 28 jul. 2010.

ALMEIDA, S. P. et al. Cerrado: espécies vegetais úteis. Planaltina: Embrapa-CPAC, 1998.

AQUINO, F. D. G; OLIVEIRA, M.C.D. Reserva Legal no Bioma Cerrado: uso e preservação. Empresa Brasileira de Pesquisa Agropecuária, Embrapa Cerrado Doc 158. 2006.

ARAÚJO, I. A. D. et al. Avaliação Fenológica dos Frutos de Progênies de Mangabeira Cultivadas no Litoral Paraibano. In: Anais. I Simpósio Brasileiro sobre a Cultura da Mangaba. Aracaju, SE: Embrapa semi-árido, dez.2003.

ARES, A. et al. Estimación de biomassa por métodos alométricos, nutrimentos y carbono en plantaciones de palmito en Costa Rica. Agronomía Costarricense, v. 26, n. 2, p. 19-30, 2002.

AVIDOS, M. F. D.; FERREIRA, L. T. Frutos dos cerrados: preservação gera muitos frutos. Ciência e Desenvolvimento, n. 15, p. 36-41, jul./ag. 2000.

BARBEIRO, L. da S. S.; VIEIRA, G.; SANQUETTA, C. R. Equações para estimativa da biomassa individual de Nectandra grandiflora ness (canela-amarela). Floresta, Curitiba/PR, v. 39, n. 4, p. 833-843, out./dez. 2009. 
BEZERRA, M. do C. L.; VEIGA, J. E. da. Agricultura sustentável. Brasília: Ministério do Meio Ambiente; Instituto Brasileiro do Meio Ambiente e dos Recursos Naturais Renováveis; Consórcio Museu Emílio Goeldi, 2000.

Cl-BRASIL. Conservação Internacional Brasil. As regiões biologicamente mais ricas e ameaçadas do planeta. 2008. Disponível

em: <http://www.conservation.org.br/publicacoes/files/HotspotsRevisitados.pdf>. Acesso em: 25 nov. 2008.

EMBRAPA CERRADOS. Plantio de soja no Cerrado é responsável por mais de $63 \%$ da produção nacional 2013. Disponível em: < http://www.cpac.embrapa.br/noticias/noticia_completa/444/> Acesso em 05 de abril de 2014

GRZEBIELUCKAS, C. ; CAMPOS, L. M. S. ; SELIG, P. M. ; ALBERTON, A ; MARINHO, S. V. . Análise Econômica do plantio de murici - Byrsonima verbascifolia: um estudo em Arenópolis/Goiás. In: XXX Encontro Nacional de Engenharia de Produção, 2010 São Carlos. Anais...São Carlos, São Paulo.

GUARINO, E. de S. G.; MEDEIROS, M. de. Levantamento da fitomassa dos estratos arbóreos e herbácioarbustivo da área de influência direta do aproveitamento hidrelétrico de Corumba IV (GO). Brasília DF: Embrapa Recursos Genéticos e Biotecnologia, 2005. p. 6-17.

HIGUCHI, N. et al. Biomassa da parte aérea da vegetação da floresta tropical úmida de terra-firme da Amazônia brasileira. Acta Amazônica, v. 28, n. 2, p. 153-166, 1998.

IBGE. Instituto Brasileiro de Geografia e Estatística. Produção da Extração Vegetal e da Silvicultura. 2009. Disponível em: <http://www.sidra.ibge.gov.br/bda/tabela/protabl.asp?c=289\&z=t\&o=18\&i=P>. Acesso em 22 de março de 2011.

IBGE. Pesquisa pecuária municipal. 2012. Disponível em: <http://www.sidra.ibge.gov.br/bda/acervo/acervo2.asp?e=v\&p=PP\&z=t\&o=23>. Acesso em: 30 ago. 2013.

IPCC. Grupo Intergubernamental de Expertos sobre el Cambio Climático Métodos complementarios y orientación sobre las buenas prácticas que emanan del Protocolo de Kyoto. 2006b. Disponível em: <http://www.ipcc-nggip.iges.or.jp/public/gpglulucf/gpglulucf/spanish/ch4.pdf>. Acesso em: 10 mar. 2010.

JUNIOR SETTE. C. R; GEROMINI, M. P; NAKAJIMA, N. Y. Quantificação de biomassa do tronco de pinus taeda em plantios com diferentes idades na região de Rio Negrinho-SC. Biomassa \& Energia, v. 1, n. 4, p. 343-346, 2004.

MACDICKEN. A Guide to Monitoring Carbon Storage in Forestry and Agroforestry Projects. 1997. Disponível em: <http:/www.forestclimatecenter.org/document_hit.pht?cnt=international\&lang=english\&dID=136>. Acesso em: 15 fev. 2013.

MARTINS, O. S. Determinação do potencial de sequestro de carbono na recuperação de matas ciliares na região de São Carlos - SP. 2004. 161 f. Tese (Doutorado) - Programa de Pós-Graduação em Ecologia e Recursos Naturais, Universidade Federal de São Carlos, São Paulo, 2004. 
MYERS, N. et al. Biodiversity Hotspots for Conservation Priorities. Nature, v. 403, p. 853-858, 2000.

PAIVA, A. O. REZENDE, A. V. PEREIRA, R. S. Estoque de Carbono em Cerrado Sensu Stricto do Distrito Federal. Revista Árvore, Viçosa-MG, v.35, n.3, p.527-538, 2011.

RÜGNITZ, M. T.; CHACÓN, M. L.; PORRO, R. Guia para determinação de carbono em pequenas propriedades rurais. Belém: Centro Mundial Agroflorestal (ICRAF); Consórcio Iniciativa Amazônica (IA), 2009.

SILVA, D. B. da et. al. Frutas do cerrado. Embrapa Informação Tecnológica, Brasília, 2001.

SILVA, S. M. da C. e; NASCIMENTO, J. L. do; NAVES, R. V. Produção da mangabeira (Hancornia speciosa Gomez) irrigada e adubada nas condições do estado de Goiás. Biosci. J., Uberlândia, v. 22, n. 2, p. 4351, 2006.

SOARES, F. P. et al. Cultura da mangaba (Hancornia speciosa Gomez). Boletim Agropecuário, LavrasMG, n. 67, p. 1-12, 2006.

VELASCO, G. D. N.; HIGUCHI, N. Estimativa de sequestro de carbono em mata ciliar: Projeto POMAR, São Paulo (SP). Ambiência, Guarapuava-PR, v. 5, n. 1, p. 135-141, 2008.

VIEIRA NETO, R.D.; CINTRA, F.L.D.; SILVA, A.L. da; SILVA JÚNIOR, J.F., COSTA, J.L. da S.; SILVA, A.A.G. da; CUENCA, M.A.G. 2002. Sistema de produção de mangaba para os tabuleiros costeiros e baixada litorânea. Disponível em: < http//www.cpatc.embrapa.br>. Acesso em 04 de abril 2014

WERNER, V. Análise econômica e experiência comparativa entre agricultura de precisão e tradicional. 2007. 134 f. Tese (Doutorado) - Programa de Pós-Graduação em Engenharia Agrícola, Universidade Federal de Santa Maria, Santa Maria- RS, 2007. 


\section{NOTAS}

\section{Nota 1}

DAP = medida da circunferência da planta a uma altura de 1,30 cm (altura do peito) dividida pelo $\pi=$ 3,14 . 


\title{
Capítulo 22
}

\section{VIABILIDADE ECONÔMICA DA INTRODUÇÃO DE EUCALIPTO EM SISTEMAS DE INTEGRAÇÃO LAVOURA-PECUÁRIA ${ }^{1}$}

DOI: $10.37423 / 200300438$

\author{
Mariana de Aragão Pereira 9Pesquisadora - Embrapa Gado de Corte - Campo \\ Grande/MS). \\ mariana.pereira@embrapa.br
}

Fernando Paim Costa (Pesquisador aposentado- Embrapa Gado de Corte - Campo Grande/MS).

gferpaim@gmail.com

Roberto Giolo de Almeida (Pesquisador - Embrapa Gado de Corte - Campo Grande/MS).

roberto.giolo@embrapa.br

RESUMO: Trabalhar com sistemas sustentáveis é um grande desafio para o setor agrícola. Os sistemas integrados (SI), além de promover a sustentabilidade, podem resultar em aumentos rápidos e significativos na oferta de carne, grãos e madeira simultaneamente. O objetivo deste estudo é analisar e comparar a viabilidade econômica dos SIs, por meio da análise de investimento e de sensibilidade de um sistema de integração lavoura-pecuária (ILP) e dois sistemas de integração lavoura-pecuária-floresta (ILPF), com densidades de 227 árvores de eucalipto/hectare (ILPF1 - arranjo 22 × 2m em linha simples) e 357 árvores/ha (ILPF2 - arranjo $14 \times 2 \mathrm{~m}$ em linha simples). 
Os resultados indicaram que todos os sistemas de produção, individualmente, se mostraram economicamente viáveis. Porém, na análise comparativa, o ILP mostrou-se mais atraente aos investimentos de capital do que os sistemas integrados com árvores, independente da densidade e arranjo espacial das árvores ou ainda em cenários alternativos de preço da madeira para serraria (15\% maior) e de taxa de atratividade do projeto. A conjuntura dos mercados de commodities desde 2016, com preços elevados para grãos e carne bovina e uma lenta recuperação dos preços dos produtos madeireiros, justifica esses resultados.

Palavras-chave: análise de investimento, intensificação sustentável, pecuária de corte. 


\section{INTRODUÇÃO}

O Brasil é um importante player no mercado mundial de commodities agrícolas, desenvolvendo florestas, lavouras e pastagens na forma de grandes monoculturas. Este modelo de produção tem sido eficiente do ponto de vista da oferta, dada a expansão conjunta em área e produtividade. Martha Junior, Alves e Contini (2012) demonstraram que, entre 1950 e 1975, a produtividade explicava apenas $14 \%$ do crescimento da produção de carne bovina no Brasil, enquanto a expansão da área de pastagem respondia por 86\%. Entre 1996 e 2006, as tecnologias poupadoras de terra permitiram grandes ganhos de produtividade, com aumento de $122 \%$ na produção de carne bovina, apesar das reduções na área total de pastagem. A terra liberada passou a ser ocupada com cana-de-açúcar, soja e outras culturas.

Esse crescimento da produtividade, no entanto, tende a se reduzir, dada a diminuição dos ganhos marginais decorrentes da intensificação tecnológica. Degradação de pastagens, pragas e doenças e outros problemas associados à monocultura destacam-se como pontos fracos desses modelos agrícolas, criando oportunidades para sistemas de produção alternativos, mais integrados e sustentáveis.

Trabalhar com sistemas sustentáveis é um grande desafio para o setor agrícola. Neste contexto, os sistemas integrados (SI) têm se destacado, dado o seu potencial para enfrentar este desafio. O SI, além de promover a sustentabilidade, pode resultar em aumentos rápidos e significativos na oferta de carne, grãos e madeira. Oliveira et al. (2014), por exemplo, mostraram que um sistema de integração lavoura-pecuária-floresta (ILPF) com 357 árvores/ha resultou em capacidade de suporte entre 0,8 e 1,0 unidade animal por hectare (UA/ha), semelhante à média brasileira, com o diferencial de viabilizar a produção de outras culturas na mesma área, agregando renda ao produtor.

A diversificação usando o SI é possivelmente a principal mudança de paradigma na agricultura brasileira, desde a revolução verde na década de 1960. O SI é conhecido há muito tempo e mundialmente, geralmente associado à produção em pequena escala (vide, por exemplo, Rana, 2015). No Brasil, no entanto, a adoção desse sistema tem ocorrido principalmente em fazendas comerciais de grande escala, onde práticas de conservação vem sendo realizadas com sucesso por décadas. Uma pesquisa com 7.909 agricultores estimou em cerca de 11,5 milhões de hectares (Mha) a área com SI no Brasil (Embrapa, 2016), estabelecidos principalmente nos seguintes estados: Mato Grosso do Sul (2,0 Mha); Mato Grosso (1,5 Mha); Rio Grande do Sul (1,4 Mha) e Minas Gerais (1,0 Mha). Os SI's em uso envolvem diferentes combinações de culturas, gado e silvicultura. A pesquisa apontou, ainda, que entre os pecuaristas que utilizam o SI, 83\% fazem integração lavoura-pecuária (ILP), 9\% combinam 
lavoura, pecuária e floresta (ILPF) e 7\% usam a integração pecuária-floresta (IPF). Entre os agricultores que usam o SI, 99\% adotam a ILP.

Dadas as grandes incertezas e as deficiências ainda presentes nos sistemas de apoio para o SI, acreditase que boa parte da adoção desses sistemas de produção tem se dado em virtude do perfil inovador e empreendedor de produtores pioneiros e seus seguidores, conforme nomenclatura definida por Rogers (2003). Esses produtores inovadores ajudam a "traduzir" as tecnologias dos centros de pesquisa para os ambientes comerciais (Garb e Friedlander, 2014; Pereira et al., 2016) e são, geralmente, menos avessos ao risco, sendo, portanto, cruciais para o processo de difusão das tecnologias. Considerando a área potencial de 67,8 milhões de hectares para a adoção do SI no Brasil (Balbino, Barcellos e Stone, 2011), há muito espaço para avanço mais generalizado desses sistemas. É preciso, contudo, municiar os produtores com informações técnico-econômicas consistentes para a tomada de decisão. Há de se lembrar que mudar a mentalidade e as práticas dos produtores, da especialização da produção à diversificação, combinando culturas, pecuária e silvicultura, é uma tarefa difícil. Costa et al. (2014) identificaram alguns fatores limitantes para a adoção dos sistemas integrados, com destaque para a necessidade de mudanças na infraestrutura, capacitação da mão de obra, e nas habilidades gerenciais, dada a complexidade do SI (ver Almeida et al. (2015) para comentários adicionais). Além disso, diferentes tipos de produtores têm diferentes valores, objetivos e metas. Pereira et al. (2016), por exemplo, afirmaram que os agricultores fortemente orientados para a preservação do meio ambiente, possivelmente, se interessam mais por práticas sustentáveis, incluindo os sistemas de integração com árvores, do que os agricultores fortemente orientados para a produção, onde a integração lavoura-pecuária pode ser uma alternativa mais compatível.

Para incentivar a adoção do SI no Brasil, políticas públicas e iniciativas do setor privado estão em andamento. O Plano Nacional de Baixas Emissões de Carbono na Agricultura (Plano $A B C$ ) é parte de uma estratégia para cumprir o compromisso voluntário do Brasil na COP 15 em reduzir as emissões de gases de efeito estufa (GEE) em 36-38\% até 2020 (Mello, 2015). Outra iniciativa foi o lançamento, em 2012, da Rede de Fomento ILPF, recém-transformada em Associação. A rede surgiu como uma parceria entre Embrapa e empresas do setor privado para promover e transferir tecnologias adaptadas ou desenvolvidas para sistemas integrados de produção para agricultores no Brasil, e agora, também com atuação internacional. No campo da pesquisa, um exemplo é o projeto "Rede Pecus", que estudou sistemas de produção de carne bovina, como monocultura ou em SI, capazes de mitigar GEE (CPPSE). Muitos outros estudos mostraram as vantagens biofísicas do uso do $\mathrm{SI}$, como melhoria no microclima 
e bem-estar animal (Karvatte Junior et al., 2016), na qualidade da pastagem (Almeida et al., 2014) e resiliência dos sistemas (Jose, Walter e Kumar, 2017), e ainda na produção de grãos, carne bovina e madeira (Franchini et al., 2014). No entanto, a maioria não apresenta análises econômicas de dados empíricos (Lazarotto et al., 2009; Martha Junior, Alves e Contini, 2011).

A adoção em escala acelerada de sistemas integrados requer mais informações sobre seu desempenho econômico, razão pela qual este estudo se concentra nesta questão. Tal preocupação é particularmente importante para o SI que inclui árvores, dado seu horizonte de longo prazo e incertezas associadas. Além disso, ao contrário da integração lavoura-pecuária, a silvicultura é uma atividade atípica para os agricultores e pecuaristas. O objetivo deste estudo, portanto, é preencher essa lacuna e avaliar a viabilidade econômica da introdução da cultura do eucalipto em sistemas integrados. A expectativa é contribuir para o aprimoramento do debate e auxiliar a tomada de decisão do produtor pautada em dados bio-econômicos e não apenas em percepções ou intuição.

\section{MÉTODO}

No ano agrícola 2008/2009, três sistemas integrados foram estabelecidos na região de Campo Grande/MS, como alternativas para recuperação de pastagens degradadas no Cerrado: ILP (lavoura + pecuária); ILPF1 (ILP + 227 árvores/ha); e ILPF2 (ILP + 357 árvores/ha). Os experimentos consistiram em três ciclos consecutivos de quatro anos: um ano com lavoura seguido de três anos com pastagem, com ou sem árvores (híbrido de Eucalyptus grandis $\times \mathrm{E}$.

urophylla). O eucalipto é a principal árvore plantada no Brasil, cobrindo 5,6 Mha do total de 7,7 Mha de florestas plantadas (IBA, 2017).

Os experimentos foram originalmente desenvolvidos para avaliar o efeito da densidade de árvores e arranjos espaciais na produção de carne e grãos, com árvores plantadas em fileiras simples, com $2 \mathrm{~m}$ entre árvores e 22 ou 14 m entre linhas, no ILPF1 e ILPF2, respectivamente. A cultura da soja, seguida de pastagens, foi semeada entre as fileiras de árvores. $O$ peso do gado e o período de pastejo foram controlados dentro de cada SI para estimar o ganho de peso médio anual. Taxas de lotação variadas foram aplicadas para manter uma disponibilidade mínima de forragem em torno de $1.800 \mathrm{~kg}$ de matéria seca (MS)/ha (sistema "put-and-take").

O cronograma experimental adotou o seguinte roteiro: em setembro de 2008, uma área experimental de 18 ha (6 ha por SI) foi preparada, subsolada e gradeada. Em novembro, foram aplicadas 3 t/ha de calcário, 1 t/ha de gesso, herbicidas pré-emergentes e $300 \mathrm{~kg} / \mathrm{ha}$ de fertilizante 05-25-15 (N-P-K). A 
soja foi cultivada de novembro de 2008 a março de 2009, associada ou não a árvores. Após a colheita da soja, foi semeado o capim Piatã (Urochloa brizantha cv. BRS Piatã). Na safra 2009/2010, produziuse feno para simular uma alternativa de renda ao produtor (ver Oliveira et al. (2014) e Pereira et al. (2014) para mais detalhes), tendo em vista que os animais não poderiam entrar na área antes de as árvores atingirem $7 \mathrm{~cm}$ de diâmetro à altura do peito (DAP) ${ }^{2}$. Em maio de 2010, novilhas da raça Nelore com média de $160 \mathrm{~kg}$ de peso vivo foram introduzidas em todos os tratamentos.

O segundo ciclo (2012/13 - 2015/16) repetiu o primeiro (2008/09 - 2011/12), mas incluiu adubação anual da pastagem com $300 \mathrm{~kg} / \mathrm{ha}$ da fórmula 05-25-15 (N-P-K) e $110 \mathrm{~kg} / \mathrm{ha}$ de ureia, dado que foi observada queda na capacidade de suporte das pastagens. O terceiro e último ciclo (2016/17 2019/20) encontra-se em curso e repete o segundo ciclo, porém com algumas alterações. O desbaste que deveria ter ocorrido no ano 8, por motivos de força maior, foi realizado no ano 9. Este desbaste reduziu em 75\% o número de árvores do ILPF2, por meio da eliminação de uma das linhas, o que resultou em um novo arranjo espacial de 28 × 4 m e uma redução na densidade de 357 para 89 arv./ha; já no ILPF1, a quantidade de árvores/ha diminuiu de 227 para 113 (50\%) e o arranjo espacial passou para $22 \times 4 \mathrm{~m}$. O atraso no desbaste impediu a entrada de animais na área e também acarretou em atraso no plantio de soja, que foi realizado apenas no ano 10 (ano agrícola corrente). A soja foi recémcolhida e sua produtividade, apresentada neste estudo, é uma aproximação, já que os números finais estão sendo processados. Nos próximos dois anos, os sistemas serão conduzidos como silvipastoris, no caso dos ILPFs, ou pecuária exclusiva, no caso do ILP.

A Tabela 1 apresenta as produtividades dos SI's e os preços médios das commodities em 2017/2018. 
Tabela 1 - Produções e preços dos produtos dos sistemas integrados (2017)

\begin{tabular}{|c|c|c|c|c|}
\hline \multirow{2}{*}{ Produtos } & \multicolumn{3}{|c|}{ Produtividade (ud/ha) } & \multirow{2}{*}{$\begin{array}{c}\text { Preços } \\
(R \$ / u d)^{1}\end{array}$} \\
\hline & $I L P$ & ILPF1 & $I L P F 2$ & \\
\hline Feno & \multicolumn{3}{|c|}{$\mathrm{t}$} & \\
\hline Capim Piatã (Ano 1) & 4 & 4 & 4 & 166,66 \\
\hline Grãos & \multicolumn{3}{|c|}{ Sacas (60 kg) } & \\
\hline Soja $(\text { Ano } 1)^{\mathrm{a}}$ & 35 & 35 & 35 & 66,20 \\
\hline Soja $(\text { Ano } 5)^{\mathrm{a}}$ & 49 & 38 & 34 & 66,20 \\
\hline Soja $(\text { Ano } 10)^{\mathrm{b}}$ & 60 & 50 & 55 & 66,20 \\
\hline Carne (médias anuais) & \multicolumn{3}{|c|}{ arrobas (@)² } & \\
\hline Produção - Ciclo $1\left(\right.$ anos 2 - 4) ${ }^{\mathrm{a}}$ & $16,0(1,00)$ & $13,2(0,83)$ & $11,4(0,71)$ & 130,95 \\
\hline Produção - Ciclo $2(\operatorname{anos} 6-8)^{\mathrm{a}}$ & $17,8(1,11)$ & $13,4(0,84)$ & $8,6(0,54)$ & 130,95 \\
\hline Produção - Ciclo $3(\operatorname{anos} 10-12)^{b}$ & $19,2(1,20)$ & $15,0(0,94)$ & $15,0(0,94)$ & 130,95 \\
\hline Madeira & \multicolumn{3}{|c|}{$\mathrm{m}^{3}$} & \\
\hline Carvão (desbaste - ano 9) $)^{\mathrm{a}}$ & - & 58 & 94 & 35,00 \\
\hline Carvão (corte - ano 12) & - & 130 & 78 & 35,00 \\
\hline Madeira serraria (corte - ano 12$)^{b}$ & - & 35 & 30 & 115,00 \\
\hline
\end{tabular}

${ }^{1} \mathrm{~A}$ unidade de medida do denominador é mostrada nas colunas de produtividade (por exemplo, $\mathrm{R} \$$ $35,00 / \mathrm{m}^{3}$ para carvão).

${ }^{2} \mathrm{O}$ índice mostra a proporção da produção de carne em cada ciclo, usando como referência a produtividade do ILP no primeiro ciclo.

aDados experimentais; bEstimativas.

Entre os ciclos 1 e 2, a produção de carne bovina nos sistemas integrados com árvores, primeiro diminuiu com o aumento da densidade de árvores e ao longo do horizonte temporal (Tabela 1). Em contraste, aumentou 11\% para o ILP. Já, no terceiro ciclo a produção de carne bovina estimada foi semelhante para ILPF1 e ILPF2, dado o número similar de árvores/ha após o desbaste, e alcançou $20 \%$ de aumento no ILP em relação à média do ciclo 1.

Quanto à produção de soja, entre o primeiro e o segundo ciclo, observou-se aumento para o ILP e, em menor escala, para o ILPF1, mas houve pouca alteração na produção para o ILPF2, cuja densidade de árvores gerou maior competição por recursos, corroborando os achados de Franchini et al. (2014). No terceiro ciclo, as estimativas de produção de soja levaram em conta o ambiente mais favorável para as culturas após o desbaste de árvores (ou seja, menos competição por recursos), embora permaneçam abaixo da estimativa do ILP.

A produção de madeira variou com a densidade e manejo das árvores (Tabela 1). Apesar do maior número inicial de árvores no ILPF2, a produção total de madeira foi menor do que a do ILPF1, com 
menos árvores, em decorrência da maior densidade, o que gerou árvores de menor diâmetro e, portanto, menor rendimento por árvore após o corte.

Considerando a natureza de longo prazo dos experimentos, um fluxo de caixa de 12 anos foi preparado usando todos os parâmetros acima. Adicionalmente, foi realizada uma análise de investimento, utilizando uma taxa de desconto anual de $10 \%$ para determinar o valor presente líquido (VPL), a relação benefício-custo (B/C) e o tempo de recuperação do capital ("payback") descontado (TRC) para os três SI. Como o fluxo de caixa da integração lavoura-pecuária-floresta apresentou mais de uma reversão de sinal, a taxa interna de retorno não foi calculada, dado o risco de inconsistência dos valores gerados (Rae, 1994).

Assumiu-se que a maioria dos agricultores tem a infraestrutura necessária para implementar o SI e, portanto, investimentos em máquinas e construções adicionais não foram considerados. Para operações agrícolas, utilizaram-se valores de aluguel de máquinas disponíveis em Richetti (2016), corrigidos pelo índice de inflação registrado em 2017. O fluxo de caixa incluiu apenas os custos diretos dos sistemas. Consequentemente, os custos de implementação (safra 2008/09) englobaram sementes/mudas, fertilizantes, produtos químicos e serviços. Os custos de mão-de-obra foram cotados a $\mathrm{R} \$ 73,00$ a diária. Os custos operacionais da produção de carne foram estimados em $\mathrm{R} \$$ 25,87/@, excluindo os desembolsos com a manutenção da pastagem, que foi computada como uma operação a parte no fluxo de caixa ${ }^{3}$. Dado que a receita da pecuária considerou apenas a produção adicional de carne dentro de cada $\mathrm{SI}$, os custos de produção não levaram em conta a compra de animais ${ }^{4}$. Ainda, o fluxo de caixa incluiu os custos de controle de formigas, desramas, desbaste das árvores (ano 9) e extração final de madeira (ano 12).

Análises de investimento em cenários alternativos (Olson, 2011) foram realizadas para verificar o efeito dos ciclos de preços e taxa de desconto na lucratividade dos sistemas integrados (análise de sensibilidade). No cenário I (CEN I), os preços da madeira aumentaram 15\%; no cenário II (CEN II), a taxa de desconto foi reduzida de $10 \%$ (equivalente a títulos de longo prazo, como o Tesouro direto) para 6,9\% (equivalente à remuneração da poupança em 2017).

\section{RESULTADOS}

Como esperado, os custos de implementação dos sistemas integrados aumentaram em 14\% e 21\% acompanhando a maior densidade de árvores dos sistemas ILPF1 e ILPF2, respectivamente, em comparação ao ILP (Tabela 2). Esse resultado pode ajudar a explicar, em parte, a menor adoção de SI 
com árvores em comparação com a integração lavoura-pecuária, conforme apontado na pesquisa mencionada anteriormente (Embrapa, 2016). Este custo pode ser proibitivo para alguns agricultores, particularmente, pequenos proprietários de terras ou aqueles que precisam de mais máquinas ou infraestrutura para iniciar o SI. Sem contar as incertezas associadas ao mercado madeireiro, que é exótico para o produtor tradicional.

Tabela 2- Custos de implantação ( $\mathrm{R} \$$ /ha) de pastagens, lavouras e árvores sob três SI, no estado de Mato Grosso do Sul, safra 2008/2009.

\begin{tabular}{|c|c|c|c|}
\hline Componente do custo & ILP & ILPF1 & ILPF2 \\
\hline Insumos $^{1}$ & 1.756 & 2.063 & 2.196 \\
\hline Serviços & 1.195 & 1.311 & 1.369 \\
\hline Total & 2.951 & 3.374 & 3.565 \\
\hline $\begin{array}{l}\text { Índice de custo } \\
(\text { ILP }=100)\end{array}$ & 100 & 114 & 121 \\
\hline
\end{tabular}

${ }^{1}$ Inclui fertilizantes, herbicidas, controle de pragas e doenças.

O benefício líquido anual (BLA = Receitas - Custos) e o perfil do fluxo de caixa também foram notavelmente diferentes entre os sistemas agrícolas, com e sem árvores (Figura 1). Enquanto o ILP apresentou maior estabilidade do BLA ao longo dos anos, frequentemente superior aos dos sistemas com árvore, o fluxo de caixa do ILPF1 e ILPF2 se beneficiaram decisivamente com a venda de madeira nos anos nove e 12, após o desbaste e o corte raso das árvores, respectivamente. É importante destacar que o uso de lavoura de soja nos sistemas de integração permitiu a amortização de quase 73\% do custo de implantação das pastagens, o que justifica, em muitos casos, o seu uso nos processos de recuperação de pastagens. 


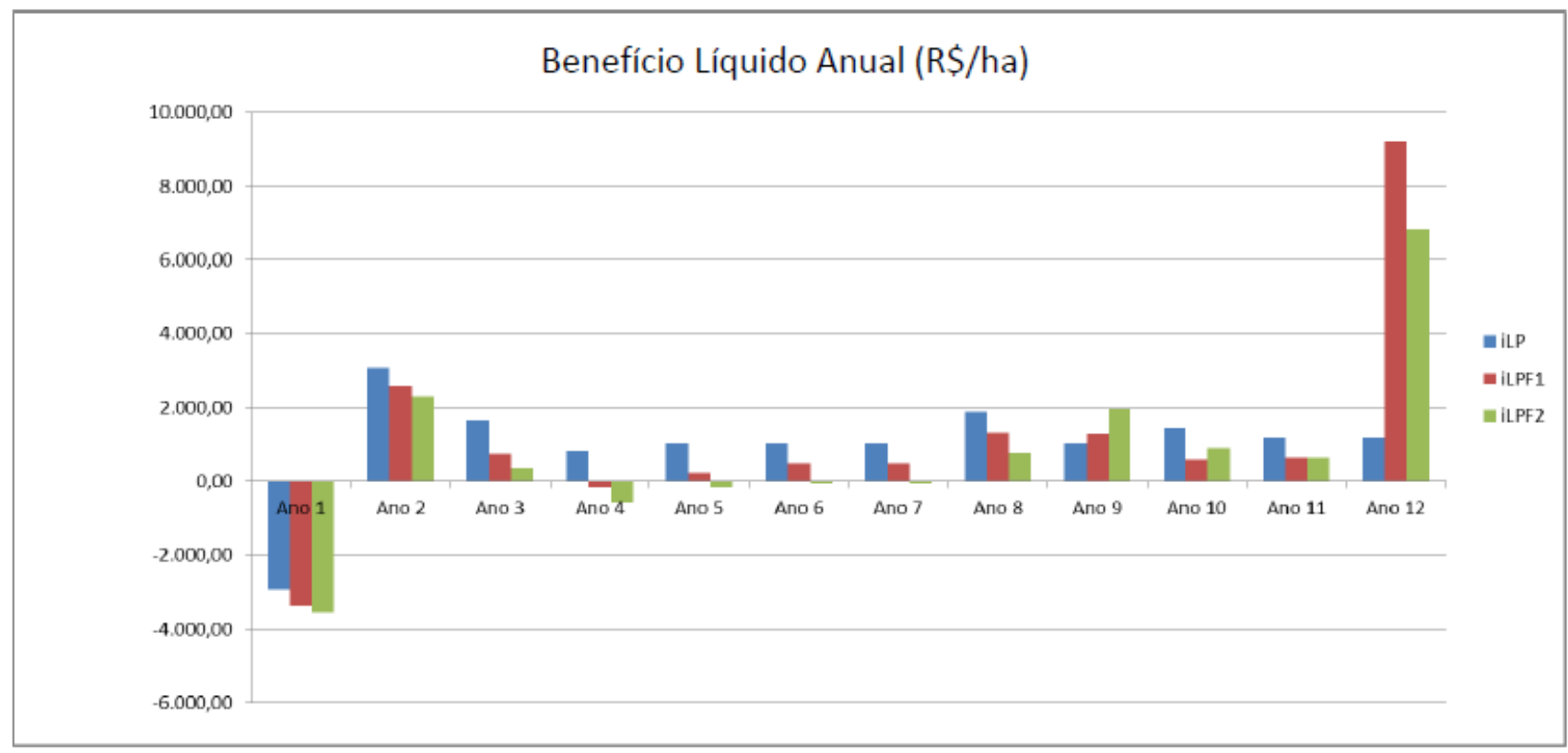

Figura 1 - Fluxo de caixa de três SI no estado de Mato Grosso do Sul, Brasil.

A Figura 1 mostra, ainda, que ambos os sistemas de ILPF apresentaram resultados líquidos negativos em alguns anos, devido aos seus custos contínuos, incluindo desramas, desbastes e controle de formigas, que nem sempre foram acompanhados da receita com o gado e/ou com a soja. Isso pode representar uma ameaça para a posição de fluxo de caixa dos agricultores e eles devem estar preparados para períodos em que, eventualmente, os custos possam exceder as receitas. Os resultados indicam que o ILPF2 ficou, de um modo geral, prejudicado. Possivelmente, a maior densidade de árvores reduziu o potencial de crescimento tanto das culturas integradas, quanto das próprias árvores, efeito que deverá ser parcialmente (e já tardiamente) revertido com o desbaste mais drástico desse sistema.

A consecução da análise de investimento trouxe esclarecimentos adicionais sobre os principais parâmetros de decisões de longo prazo dos agricultores. Os resultados demonstraram que os três SI, com e sem árvores, mostraram-se economicamente viáveis, dados os preços de mercado e coeficientes técnicos utilizados, uma vez que o valor presente líquido foi positivo (VPL) e relação Benefício/Custo maior que um para todos os sistemas (Tabela 3).

Benefício Líquido Anual (R\$/ha) 
Tabela 3 - Parâmetros de investimento de três SI, no estado de Mato Grosso do Sul, Brasil (2017).

\begin{tabular}{|l|c|c|c|}
\hline Parâmetros & ILP & ILPF1 & ILPF2 \\
\hline VPL (R\$/ha) & $6.670,78$ & $5.158,96$ & $2.541,74$ \\
\hline B/C & 3,26 & 2,47 & 1,61 \\
\hline TRC (anos) & 1,1 & 5,4 & 9,4 \\
\hline
\end{tabular}

Comparativamente, o SI de melhor desempenho foi a integração lavoura-pecuária (ILP), que apresentou maiores VPL e relação benefício/custo, e menor tempo de retorno do capital ("payback"). Entre o ILPF1 e ILPF2, o primeiro foi economicamente mais interessante que o último, sugerindo, que uma menor densidade de árvores e um espaçamento maior entre linhas tende a obter melhor desempenho econômico, ceteris paribus.

Esses resultados devem ser interpretados com cautela e dentro de seu contexto. Em 2016/2017, os preços dos grãos e da carne bovina aumentaram, enquanto os preços dos produtos à base de madeira reduziram-se (GWMI, 2016). Com isso, o SI mais dependente de madeira foi duplamente impactado neste cenário: (1) a redução dos preços da madeira reduziu a receita estimada da silvicultura (ou seja, quanto maior o número de árvores, maior a redução na receita relativa); e (2) o ILPF não se beneficiou totalmente do aumento dos preços dos grãos e da carne devido a seus rendimentos mais baixos destes produtos (Tabela 1).

Outro aspecto a considerar é que o exercício aqui apresentado pressupõe o corte raso no ano final do projeto (12 anos). Contudo, na prática, há certa flexibilidade na época de corte das árvores, pois os produtores podem atrasar este processo por até alguns anos, aumentando as chances de melhores preços e, portanto, melhores retornos. Nosso protocolo de pesquisa, no entanto, não permitia essa alternativa. Cabe ressaltar, ainda, que a taxa de desconto elevada (10\% ao ano), utilizada neste estudo, "penaliza" proporcionalmente mais os sistemas de integração com árvores do que o sem árvore, pois os principais benefícios econômicos daqueles ocorrem no longo prazo.

Considerando as questões postas acima, decidiu-se trabalhar com análise de sensibilidade de preços e de taxas de atratividade, em dois cenários alternativos: $15 \%$ de aumento no preço dos produtos florestais (simulação das condições de mercado em 2014) (CEN I); redução da taxa de desconto de 10\% para 6,9\% (CEN II). Os resultados são apresentados na Tabela 4. 
Tabela 4 - Parâmetros de investimento (VPL, B/C e TRC) sob dois cenários de alteração de preços e taxa de atratividade para os SI.

\begin{tabular}{|c|c|c|c|c|c|c|c|c|c|}
\hline \multirow{2}{*}{ Parâmetros } & \multicolumn{3}{|c|}{ CENÁRIO ORIGINAL } & \multicolumn{4}{c|}{ CENARIO I } & \multicolumn{4}{c|}{ CENÁRIO II } \\
\cline { 2 - 10 } & ILP & ILPF1 & ILPF2 & ILP & ILPF1 & ILPF2 & ILP & ILPF1 & ILPF2 \\
\hline VPL (R \$/ha) & 6.671 & 5.159 & 2.542 & 6.671 & 5.716 & 3.039 & 7.997 & 7.017 & 3.957 \\
\hline B/C & 3,26 & 2,47 & 1,61 & 3,26 & 2,63 & 1,73 & 3,71 & 3,00 & 1,93 \\
\hline TRC (anos) & 1,1 & 5,4 & 9,4 & 1,1 & 5,4 & 8,8 & 1,0 & 4,9 & 8,3 \\
\hline
\end{tabular}

As análises de sensibilidade sugeriram que todos os sistemas integrados, com e sem árvores, permaneceram economicamente viáveis (VPL>0 e B/C>1). De um modo geral, as tendências observadas no cenário original (Tabela 3) se mantiveram, com o sistema ILP apresentando melhor desempenho econômico que os sistemas integrados com árvores. É também notório o maior tempo de retorno do capital (TRC) quando o sistema integrado inclui o componente florestal, especialmente em arranjos mais adensados. Nota-se ainda na Tabela 4 que a mudança na taxa de atratividade considerada na análise dos sistemas impactou mais fortemente os resultados econômicos do que o aumento do preço da madeira. Quanto maior a taxa de atratividade, maiores são os descontos aplicados aos saldos anuais do fluxo de caixa, especialmente nos anos mais distantes do ano de investimento $(\mathrm{t}=0)$. Para os sistemas integrados com árvores, cujas principais receitas são geradas nos anos nove e 12, isso implica em uma grande redução para trazê-las a valor presente, impactando o VPL final desses sistemas.

\section{DISCUSSÃO}

À primeira análise, os dados parecem sugerir uma estável superioridade do sistema de integração lavoura-pecuária em comparação com os sistemas ILPF. Uma ressalva é importante. Martha Junior, Alves e Contini (2011) argumentam que o desempenho econômico do SI é uma função dos preços relativos de insumo/produto, o que nossos resultados corroboram. Aos preços de insumos considerados, e no contexto dos altos preços da carne bovina e dos grãos, o ILP teve um desempenho melhor do que os ILPFs, sendo ainda favorecido pela alta taxa de desconto originalmente usada neste estudo. Com um aumento nos preços dos produtos madeireiros, os resultados econômicos dos sistemas ILPF tiveram melhoras consideráveis, mas ainda insuficientes para suplantar o ILP, tudo mais permanecendo constante. 
Contudo, o preço dos grãos é altamente volátil (Lazarotto et al., 2009), dados os ciclos das commodities, as quebras de safra, as políticas públicas etc. Em 2016, estes preços atingiram seu pico, começando um movimento descendente a partir de 2017. No entanto, os preços baixos da madeira impediram resultados mais atraentes para os sistemas ILPF. O aumento de $15 \%$ nos preços da madeira beneficiou estes sistemas no CEN I, mas não garantiu, por si só, um resultado que superasse a ILP, dados os altos preços da carne e dos grãos na corrente análise. Resultados semelhantes foram obtidos por Pereira, Costa e Almeida (2018), que ao comparar esses três sistemas ${ }^{5}$, concluíram que, dados os preços e coeficientes técnicos utilizados no estudo, a ILP apresentou-se economicamente mais interessante que ambos os sistemas ILPF, exceto em um cenário de inversão de preços das commodities analisadas. Os autores argumentaram que, a partir de 2016, os sistemas, que vêm sendo acompanhados economicamente desde 2012 (Costa et al., 2012), sofreram pela primeira vez mudanças no ranking da rentabilidade em função do aumento dos preços de grãos e carne e redução do preço da madeira. Isto é confirmado por estudos anteriores realizados com base nos mesmos experimentos. Pereira, Costa e Almeida (2015), analisando esses três sistemas integrados, mas considerando as condições de mercado de 2014 (a saber, mercado de madeira aquecido e preços de carne e grãos suprimidos), concluíram que quanto mais árvores no SI, maior era sua rentabilidade. De 2014 a 2016, os preços da carne bovina e da soja cresceram 52\% e 34\%, respectivamente, enquanto os da madeira e do carvão vegetal diminuíram 19\% e 24\% (dados compilados pelos autores, com base no CEPEA). Costa et al. (2012), Silva (2014) e Pereira et al. (2015) também estudaram estes sistemas integrados e chegaram à conclusões semelhantes. Pereira et al. (2015), por exemplo, mostrou que o ILPF2 alcançou um VPL 1,5 vezes maior do que o ILP, cujo desempenho foi menor dentre todos os SI, o que contrasta fortemente com os resultados atuais.

Quando a análise se restringe aos sistemas integrados com árvores, os resultados indicam que o ILPF1 foi economicamente mais estável que o ILPF2, mesmo em cenários alternativos. Tomando-se o VPL como exemplo, nota-se uma variação de $36 \%$ no valor do VPL máximo e mínimo obtido pelo ILPF1 (Tabela 4), enquanto a variação chega a 55\% no caso do ILPF2. Uma análise dos estudos mencionados acima também corrobora essa argumentação, pois, frequentemente, o ILPF1 obteve rentabilidade intermediária ao ILP e ILPF2, nos mais variados cenários de mudanças de produtividade, preços de mercado das commodities, insumos e serviços e taxa de atratividade usada na análise de investimento. Esses resultados sugerem que o uso de uma densidade de árvores que possibilite índices técnicos favoráveis à lavoura e à pecuária associadas reverte em rentabilidades satisfatórias e relativamente estáveis, especialmente se comparadas a sistemas mais adensados (ex. ILPF2), ainda com possibilidade 
de agregação de valor (ex. CCN, madeira certificada etc.) e diversificação de renda (Nicoli et al., 2017), se comparada a ILP.

A questão que resta a ser respondida é se o cenário atual, da relativa alta de preço da carne bovina e dos grãos, e a baixa de preço dos produtos florestais, é provável permanecer ou cenários alternativos devam ser considerados. De fato, as oscilações de preço de mercado são comuns e alteram o panorama das expectativas de retorno. Nossas análises sugerem que as tendências da economia brasileira e do mercado de longo prazo para os produtos à base de madeira são importantes e devem ser observadas cuidadosamente pelos produtores que consideram introduzir a silvicultura nos SI. A crise econômica brasileira, em 2015, resultou em queda na comercialização dos produtos madeireiros (5\%) e nos preços (GWMI, 2016).

Apesar das incertezas em torno de novos desenvolvimentos da indústria madeireira, a economia brasileira começou a se recuperar. A inflação está controlada, os níveis de investimento aumentaram e uma taxa de crescimento econômico de $1 \%$ foi registrado para 2017, criando um ambiente favorável o crescimento da demanda por madeira. A indústria de celulose e papel, por exemplo, está se expandindo e se beneficiando do avanço do comércio internacional (The Economist, 2016). As exportações de outros produtos derivados de madeira aumentaram 21,6\% entre 2015 e 2016, alcançando US \$ 250 milhões (GWMI, 2017). Em 2017 (jan/fev), a produção e exportação de painéis de madeira aumentaram 8,5\% e 40\%, respectivamente, em relação a jan/fev 2016 (IBA, 2017).

Além dos mercados de commodities, outras iniciativas são necessárias para apoiar a introdução mais acelerada da silvicultura nos SIs. O crédito através do "plano $A B C$ " do governo está disponível e a adesão vem aumentando, com mais de 25.000 contratos aprovados entre 2010-2015 (Mello, 2015). Novas usinas siderúrgicas e outros projetos de investimento no Brasil aumentarão a demanda por produtos à base de madeira, embora em ritmo desconhecido. Outras iniciativas, como o protocolo Carne Carbono Neutro (CCN), podem agregar valor aos produtos SI, inclusive à madeira. A CCN abre caminho para o pagamento de prêmios para carne bovina certificada em sistemas silvipastoris ou agrossilvipastoris, seguindo as diretrizes de bem-estar e boas práticas, para que as árvores neutralizem as emissões do metano bovino (Almeida et al., 2016). As florestas plantadas também contribuem para reduzir a pressão pelo desmatamento, fornecendo serviços ambientais relevantes (por exemplo, evitar GEE). O mercado de serviços ambientais no Brasil é apenas incipiente, mas crescente, apoiado pela intenção do país de se estabelecer como uma "referência mundial no comércio de carbono" (GEF, 
2013; p. 14). Estas iniciativas certamente agregariam receitas adicionais aos sistemas ILPF, melhorando sua rentabilidade, contribuindo para a diversificação da renda do produtor rural.

Dadas as incertezas ainda presentes nos sistemas integrados, com mercados pouco definidos para produtos com potencial de agregação de valor e estudos econômicos ainda limitados, a difusão dos SI, particularmente incluindo árvores, parece depender principalmente de produtores inovadores, talvez menos avessos ao risco. Estes produtores líderes são relevantes para o sistema de inovação, pois têm em suas propriedades verdadeiras "vitrines tecnológicas" para outros adotantes em potencial (seguidores) (Pereira et al., 2016). Como tal, precisam do apoio da academia, dos centros de pesquisa e dos consultores rurais. Pesquisas econômicas adicionais, considerando mudanças nos preços, nos arranjos espaciais e densidade de árvores, rendimentos de insumos/produtos, e avaliações de riscos são também necessárias. Políticas para minimizar os riscos dos investidores florestais devem ser priorizadas para apoiar os produtores que desejarem introduzir árvores nos sistemas de integração.

\section{CONCLUSÕES}

Nossos resultados corroboram outras avaliações econômicas dos sistemas integrados que indicam que, a dados preços de insumos e produtividades, os preços relativos dos produtos influenciam fortemente a lucratividade do sistema integrado. Além disso, atenção especial deve ser dada à escolha da taxa de atratividade (ou de desconto) a ser utilizada na análise de investimento, já que esta exerce grande influência na rentabilidade do mesmo. Segundo Elevitvh e Wilkinson (2000), a escolha da taxa de atratividade em projetos florestais deve ser proporcional ao risco envolvido (quanto maior o risco, maior a taxa de desconto) e compatível com a taxa de retorno em atividades alternativas (oportunidade no uso do capital).

No aspecto técnico, ressalta-se que a densidade e o arranjo espacial das árvores impactam os parâmetros de investimento, dados os trade-offs entre os benefícios de longo prazo e os custos de implementação e condução dos sistemas. Estes devem ser avaliados criteriosamente, especialmente em sistemas mais adensados.

Em geral, a introdução de árvores em futuros sistemas integrados no Brasil é economicamente viável, desde que a indústria florestal da região esteja consolidada ou com perspectivas de crescimento. Considerando que a tomada de decisão do produtor é menos que ótima, devido à falta de conhecimento pleno de todos os possíveis cenários e suas implicações (Lazarotto et al., 2009), todos 
os sistemas integrados analisados são economicamente aceitáveis, embora em determinados momentos ou condições um possa se apresentar temporariamente melhor que outro. Cabe ressaltar ainda que o perfil de fluxo de caixa dos sistemas integrados pode ser bastante diversificado, conforme previsão de receitas e despesas de cada SI e, portanto, deve ser considerado como critério adicional no processo de tomada de decisão, além dos parâmetros tradicionais da análise de investimento.

A ampla adoção de sistemas de integração considerando o componente florestal depende de produtores inovadores, abertos à mudança de paradigma que vem acontecendo no Brasil em relação às monoculturas. Deve ainda contar com o apoio dos centros de pesquisa e desenvolvimento (P\&D), programas de transferência de tecnologia e políticas públicas de fomento aos sistemas integrados.

\section{REFERÊNCIAS}

ALMEIDA, R., BARBOSA, R., ZIMMER, A. e KICHEL, A. Forage grasses in integrated cattle production systems. In: Bungenstab, D. e Almeida, R., ed., Integrated crop-livestock-forestry systems - a Brazilian experience for sustainable farming, 1. ed. Brasília, Embrapa, p. 101-107, 2014.

ALMEIDA, R., GOMES, R., PORFÍRIO-DA-SILVA, V., ALVES, F., FEIJÓ, G., FERREIRA, A., OLIVEIRA, E. e BUNGENSTAB, D. Carbon Neutral Brazilian Beef: testing its guidelines through a case study. In: International Symposium on Greenhouse Gases in Agriculture, Campo Grande, Embrapa Gado de Corte, p. 277-281, 2016.

ALMEIDA, R., PEREIRA, M. A., KICHEL, A. e COSTA, F. Planejamento e gestão de sistemas pecuários integrados com agricultura. In: Simpósio Brasileiro de Produção de Ruminantes no Cerrado. Uberlândia, UFU, p. 106-123, 2015.

BALBINO, L., BARCELLOS, A. e STONE, F. Marco referencial integração lavoura-pecuária-floresta. Brasília, Embrapa, p. 132, 2011.

COSTA, F., ALMEIDA, R. G. DE, PEREIRA, M. A., KICHEL, A. N. e MACEDO, M. C. M. Avaliação econômica de sistemas de integração lavoura-pecuária-floresta voltados para a recuperação de áreas degradadas em Mato Grosso do Sul. In: Congresso latinoamericano de sistemas agroflorestais para a produção pecuária sustentável. Belém, UFPA. p. 523-527, 2012.

COSTA, F.P., CEZAR. I., MELO FILHO, G. e BUNGENSTAB, D. Cost-effectiveness of integrated production systems. In: Bungenstab, D. and Almeida, R., ed., Integrated crop-livestock-forestry systems - a Brazilian experience for sustainable farming, 1. ed. Brasília, Embrapa, p. 213-218, 2014.

EMBRAPA. Adoção de ILPF chega a 11,5 milhões de hectares. Disponível em: <https://www.embrapa.br/busca-de-noticias/-/noticia/17755008/adocao-de-ilpf-chega-a-115milhoes-de-hectares>. Acesso em: 10 fev. 2017. 2016.

EMBRAPA. Integrated Crop-Livestock-Forest Systems - ICLFS. Disponível em: <https://www.embrapa.br/en/tema-integracao-lavoura-pecuaria-floresta-ilpf/nota-tecnica>. Acesso em: 20 jan. 2017. 
ELEVITCH, C.R., WILKINSON, K. M. Economics of farm forestry: financial evaluation for landowners. Agroforestry Guides for Pacific Islands. Permanent Agriculture Resources, Halualoa, Hawaii. 31 p. 2000. Disponível em: <http://www.agroforestry.org/images/pdfs/EconomicsFF.pdf>. Acesso em 27 mar. 2017.

FRANCHINI, J. C., BALBINOT JUNIOR, A. A., SICHIERI, F. R., DEBIASI, H. e CONTE, O. Yield of soybean, pasture and wood in integrated crop-livestock-forest system in Northwestern Paraná State, Brazil. Revista Ciência Agronômica, 45 (5), p. 1006-1013. 2014.

GARB, Y. e FRIEDLANDER, L. From transfer to translation: using systemic understandings of technology to understand drip irrigation uptake. Agricultural System, 128, p. 13-24. 2014.

GEF. A strategy for investing in emerging market environmental industries. Disponível em: <http://globalenvironmentfund.com/wp-content/uploads/2013/02/Emerging

Market_Environmental_Industires.pdf>. Acesso em: 28 mar. 2017. 2013.

GWMI. Brazil: domestic economic crisis affecting timber industry. Disponível em: <https://www.globalwoodmarketsinfo.com/brazil-timber-industry/2/>. Acesso em: 12 fev. 2017. 2016.

GWMI. Brazil: exports of wood-based products up $21.6 \%$ in November. Disponível em: <https://www.globalwoodmarketsinfo.com/brazil-exports-of-wood-based-products-up-21-6-innovember>. Acesso em: 12 fev. 2017. 2017.

IBA. Cenários Ibá. Brasília, IBA, 34, 7 p. Disponível

em: <http://iba.org/images/shared/Cenarios/Cenarios_Mar_2017.pdf>. Acesso em: 05 abr. 2017. 2017.

JOSE, S., WALTER, D. e KUMAR, B. Ecological considerations in sustainable silvopasture design and management. Agroforest Systems, p. 1-15. 2017.

KARVATTE JUNIOR, N., KLOSOWSKI, E., ALMEIDA, R., MESQUITA, E., OLIVEIRA, C. e ALVES, F. Shading effect on microclimate and thermal comfort indexes in integrated crop-livestock-forest systems in the Brazilian Midwest. International Journal of Biometeorology, 60(12), p. 1933-1941. 2016.

LAZAROTTO, J., SANTOS, M., LIMA, J. e MORAES, A. Volatilidade dos Retornos Econômicos Associados à Integração Lavoura-Pecuária no Estado do Paraná. Revista de Economia e Agronegócio, 7(2), p. 259284. 2009.

MARTHA JUNIOR, G., ALVES, E. e CONTINI, E. Dimensão econômica de sistemas de integração lavourapecuária. Pesquisa Agropecuária Brasileira, 46(10), p. 1117-1126, 2011.

MARTHA JR., G., ALVES, E. e CONTINI, E. Land-saving approaches and beef production growth in Brazil. Agricultural Systems, 110, p. 173-177, 2012.

MELLO, F. ABC Plan - National Plan for Low Carbon Emissions in Agriculture - Brazilian Experience. [Presentation in the Joint Conference of the Organization for Economic Cooperation and Development]. 25 p. Disponível em: <http://www.ag4climate.org/programme/ag4climate-session-35-mello.pdf>. Acesso em: 28 jan 2017. 
NICOLI, C.M.L., PACHECO, A. R., REIS, C. A. F., VENTUROLI, F. Income Diversification through a CropLivestock-Forest Integration System in the Midwest Brazilian Region. Journal of Agricultural Science and Technology B, 7(6), p. 374-385. 2017. doi: 10.17265/2161-6264/2017.06.002

OLIVEIRA, C., VILLELA, S., ALMEIDA, R., ALVES, F., BEHLING NETO, A. e MARTINS, P. Performance of Nellore heifers, forage mass, and structural and nutritional characteristics of Brachiaria brizantha grass in integrated production systems. Tropical Animal Health and Production, 46(1), p. 167-72. 2014.

OLSON, K. Economics of Farm Management in a Global Setting. Hoboken, John Wiley \& Sons, 542 p. 2011.

PEREIRA, M. A., COSTA, F. e ALMEIDA, R. Economic viability of integrated crop-livestock- forest systems: a comparative analysis. In: World Congress on Integrated Crop-Livestock-Forest Systems. Brasília: Embrapa. p. 213. Disponível

em: <https://www.alice.cnptia.embrapa.br/alice/bitstream/doc/1037545/1/25941.pdf>. Acesso em: 27 jan. 2017. 2015.

PEREIRA, M. A., COSTA, F. e ALMEIDA, R. Is the "F Word" an option for Brazilian farmers? The place of forestry in future integrated farming systems. International Journal of Agricultural Management, 6 (34). pp. 134-140. 2018. DOI: 10.5836/ijam/2017-06-134.

PEREIRA, M. A., FAIRWEATHER, J., WOODFORD, K. e NUTHALL, P. Assessing the diversity of values and goals amongst Brazilian commercial-scale progressive beef farmers using Q-methodology. Agricultural Systems, 144(1), p.1-8. 2016.

RAE, A. N. Agricultural Management Economics. Activity Analysis and Decision Making. Oxon UK, CAB International, 196 p. 1994.

RANA, S. S. Recent Advances in Integrated Farming Systems. Palampur, College of Agriculture, CSK Himachal Pradesh Krishi Vishvavidyalaya, 204 p. 2015.

RICHETTI, A. Soja: viabilidade econômica para a Safra 2016/2017, em Mato Grosso do Sul. 1. ed., [ebook]. Dourados, Embrapa Agropecuária Oeste. Disponível em: <https://www.infoteca.cnptia.embrapa.br/infoteca/bitstream/doc/1055925/1/DOC2016134b.pdf>. Accesso em: 25 Nov. 2016. 2016.

ROGERS E. M. Diffusion of Innovations. 5. ed. New York, Free Press, 453 p. 2003.

SILVA, I. M. A contribuição de sistemas de integração lavoura-pecuária-floresta para a sustentabilidade da produção agropecuária no estado de Mato Grosso do Sul. Dourados/MS, UFGD. 57 p. Dissertação. 2014.

THE ECONOMIST. (2016). Pulp producers in Brazil: Money that grows on trees. Disponível em: <http://www.economist.com/node/21695530/print>. Acesso em: 12 fev. 2017. 


\section{NOTAS}

\section{Nota 1}

Esta pesquisa foi financiada com recursos SEG da Embrapa, da Fundect, da Rede de Fomento ILPF e da Fundação MS.

\section{Nota 2}

Optou-se em padronizar esta prática entre todos os sistemas integrados, mesmo sem árvore, para tornar a comparação mais uniforme.

\section{Nota 3}

Esta ação visou eliminar duplicação no cômputo dos custos associados à pecuária.

\section{Nota 4}

Logo, as receitas e os custos referem-se, exclusivamente, ao excedente produzido dentro de cada sistema produtivo.

\section{Nota 5}

O trabalho de Pereira, Costa e Almeida (2018) se diferencia do atual no que concerne ao uso de milho na simulação de resultados do ciclo 3 invés de soja; da previsão de desbaste de 67\% do ILPF2 (contra $75 \%$, de fato), além da atualização dos preços de mercado, que acabam por impactar posição relativa da relação insumo-produto. 


\section{Capítulo 23}

\section{REDES INTERORGANIZACIONAIS E AGRONEGÓCIO: UMA REVISÃO SISTEMÁTICA DE LITERATURA}

DOI: $10.37423 / 200300439$

Joelma Melo da Silva -joelmamelo.unb@gmail.com

Maria Júlia Pantoja Britto -jpantoja@unb.br

Edimar dos Santos de Sousa Junior - edagronomojr@gmail.com

Ana Maria Resende Junqueira - anamaria@unb.br

RESUMO: O setor de agronegócios é permeado de particularidades e abrange uma gama de atores, a montante e a jusante da porteira. Aspectos como inovação, competitividade, aumento de produtividade, posicionamento no mercado, eliminação ou permanência da figura do intermediário, gestão da informação, liderança, entre outros, costumam ser alvos de investigação por meio da análise de redes sociais, tomando-se os atores e suas relações, sejam elas formais ou informais, como objetos de análise para melhor compreensão de tais fenômenos. Este artigo tem como objetivo identificar e analisar os estudos realizados sobre redes interorganizacionais, no período compreendido entre os anos de 2011 a 2019, por meio de uma revisão sistemática da produção científica nacional. A pesquisa permitiu identificar o crescente interesse de gestores e pesquisadores em investigar e compreender como as relações interpessoais e interorganizacionais interagem entre si ou se configuram na economia e na sociedade, e como influenciam a formação, o desenvolvimento, a consolidação e até mesmo a dissolução de redes interorganizacionais.

Palavras-chave: Redes de cooperação; análise de redes; relações interorganizacionais; relações sociais interorganizacionais. 


\section{INTRODUÇÃO}

Baseando-se na ideia de que "as relações sociais em que cada indivíduo está inserido podem ser vistas como uma rede" (NEIVA; PANTOJA, 2008, p. 11) uma vez que "nas ciências sociais e psicológicas, redes sociais são formas específicas de interação entre indivíduos, redes urbanas, redes organizacionais, movimentos sociais, entre outras" (VIEIRA, 2008, p. 4), onde apesar da ampla possibilidade de conceituação, “[...] há um sentido predominante: a ideia de ligação, laço e integração" (VIEIRA, 2008, p. 4).

O principal atributo de uma rede é uma maior flexibilidade das organizações, elemento facilitador para o compartilhamento de informações, conhecimentos, habilidades e recursos, ambos essenciais ao processo de inovação, aumento de produtividade e atendimento aos consumidores (BEGNIS; ALIEVI; ESTIVALETE, 2011), além de ser fator determinante de vantagem competitiva (ESGUERRA PEREZ, 2017). A relação de comprometimento entre atores, por exemplo, é considerada um elemento estratégico por possibilitar que as organizações enfrentem, com êxito, situações de mudança ou de turbulência no mercado, como afirmam Genari, Faccin e Macke (2013) ao citarem Brito e Bastos (2001).

Diante do exposto, e considerando o crescente interesse de cientistas e gestores em compreender como os atores, neste caso, as organizações, estabelecem relações e interagem, configurando uma rede social (RIBEIRO; BASTOS, 2011, p. 282), o trabalho se propõe a identificar e analisar os estudos realizados sobre redes interorganizacionais, no período compreendido entre os anos de 2011 a 2019 através de uma revisão sistemática da produção científica nacional sobre redes sociais interorganizacionais, objetivando detalhar a abordagem de redes, com foco nas redes interorganizacionais; contextualizar os conceitos básicos de redes sociais, bem como algumas medidas de análise e descrever as redes informais interorganizacionais.

\section{ABORDAGEM DAS REDES SOCIAIS E SUAS APLICAÇÕES EM PESQUISAS NO AGRONEGÓCIO}

A análise de redes sociais (ARS) vem sendo amplamente utilizada para identificar e compreender as variáveis que influenciam o comportamento dos atores, sejam eles pessoas ou organizações, visto que estas relações podem influenciar os resultados individuais e/ou coletivos. Nesse sentido, a ARS possibilita a caracterização da estrutura da rede por meio das relações sociais existentes entre os atores (FREIRE; BALDI, 2014), com o objetivo de identificar e interpretar os padrões derivados dessas relações (AGUILAR-GALLEGOS et al., 2016). 
Pigatto et al. (2015) recomendam que as análises no âmbito de um contexto econômico não deveriam ignorar as interações sociais. Os autores explicam essa afirmação baseando-se em Siegel (2009) e Granovetter (2007 e 1973), ao justificar que as relações sociais são tão importantes quanto as relações econômicas, dado que o comportamento econômico é afetado pelas redes de relações entre os atores. Compreende-se então, que a análise de redes amplia as possibilidades de explicação do funcionamento de setores, como o agronegócio, configurando- se uma abordagem complementar aos estudos focados em características exclusivamente econômicas e de eficiência produtiva (PIGATTO; QUEIROZ; LOURENZANI, 2015).

Os indicadores adotados em pesquisas de análise de redes sociais podem variar de acordo com o foco de análise como se observa nos estudos sobre o tema. No entanto os indicadores podem ser macroestruturais, à exemplo o tamanho e a densidade da rede, ou microestruturais, como a centralidade dos atores (RIBEIRO; BASTOS, 2011).

O setor do agronegócio é permeado de particularidades e abrange uma gama de atores, a montante e a jusante da porteira, sendo assim, pesquisadores e gestores têm buscado compreender as relações existentes neste setor, e como elas interagem ou se configuram na economia e na sociedade.

\section{CONCEITOS BÁSICOS DA ABORDAGEM DE REDES SOCIAIS}

A frequência com que alguns termos se repetem nos estudos de redes sociais suscita a necessidade de conceituá-los para melhor compreensão deste trabalho, uma vez que são utilizados para analisar e descrever as conexões e relações entre as pessoas ou organizações.

Cunha et al. (2011) apontam a conceituação dos nós e elos para compreender as redes de forma sistemática, onde os nós são os pontos da rede, ou seja, os atores que a constituem, e os elos, as conexões entre os agentes. Assim, os nós são os atores que se agrupam em torno de um objetivo comum (RIBEIRO; BASTOS, 2011). Cunha et al. (2011) fazem referência a Marteleto e Silva (2004) ao analisarem as redes sob uma perspectiva organizacional, o nó/ator representaria a organização, e os elos, as ligações entre as organizações.

As ligações são também mencionadas por autores como vínculos ou relações (SILVA; NEVES, 2013; RIBEIRO; BASTOS, 2011) e conexões (DE ROLT; DIAS; PEÑA, 2017). O vínculo ou relação indicam a direção da relação por meio do fluxo, que pode ser unidirecional - relação onde não há reciprocidade entre os atores, ou bidirecional - relação recíproca em que os autores citam um ao outro (RIBEIRO; 
BASTOS, 2011). Por sua vez, as relações em uma organização podem ser caracterizadas como constelações, conjunto de ações e relações, rede, entre outras, e essas relações entre organizações formam a rede (CUNHA; PASSADOR; PASSADOR, 2011, p. 4). Com isso é possível entender que uma rede se trata um grupo de atores que se relacionam (RIBEIRO; BASTOS, 2011).

\subsection{MEDIDAS DE ANÁLISE EM REDES SOCIAIS}

A análise de redes se caracteriza como um conjunto de técnicas utilizadas para a verificação dos conjuntos de relações e o padrão das conexões entre os agentes (DE ROLT; DIAS; PEÑA, 2017), considerando interações concretas entre grupos e indivíduos (SILVA; NEVES, 2013) e pode ser realizada por meio de indicadores macroestruturais, como o tamanho e a densidade da rede, ou microestruturais, como a centralidade de grau e centralidade de intermediação, (RIBEIRO;BASTOS, 2011, AGUILLAR-GALLEGOS et al. 2016), centralidade de aproximação e centralidade de Bonacich (AGUILLAR-GALLEGOS et al. 2016).

O tamanho da rede se refere à soma dos nós e pode interferir na disponibilidade ou limitação de recursos, bem como na dificuldade de construir ou manter relações, e na capacidade de resolução de problemas (RIBEIRO; BASTOS, 2011). Já a densidade é a quantidade de relações existentes, diante das possibilidades de relações (RIBEIRO; BASTOS, 2011).

Ainda segundo os autores, se houver um aumento no tamanho da rede, possivelmente haverá uma redução na densidade, o que para Hanneman e Mark (2005), conforme citados por Ribeiro e Bastos (2011) aumenta as chances de formação de subgrupos. A densidade também indica o potencial de comunicação entre os atores, podendo delimitar os tipos e a quantidade de informações que podem ser transacionadas na rede (RIBEIRO; BASTOS, 2011). Com isso, Cunha et al. (2011) afirmam que se tratando da densidade, as relações podem ser fortes, onde há maior proximidade entre os agentes, ou fracas, tendo-se relações com pouca proximidade.

Quanto às medidas de centralidade, elas permitem compreender o papel dos atores na rede, o grau de acessibilidade desses atores, e a quantidade de fluxo de comunicação que podem transitar por eles (RIBEIRO; BASTOS, 2011). A centralidade de grau para De Rolt et al. (2017, p. 270) baseados em Hansen et al. (2011) "[...] mede a quantidade de agentes com os quais cada agente está relacionado". É o número de outros atores ao qual determinado ator está diretamente conectado por um vínculo, podendo ainda se identificar os graus de entrada - o número de vínculos que um ator recebe de outros 
atores, e o grau de saída - que se refere ao número de vínculos que o ator envia a outros atores (AGUILLAR-GALLEGOS et al. 2016) referenciando- se em Freeman (1979), Ranneman e Riddle (2011), De Nooy et al. (2005) e Jackson (2008).

Já a centralidade de intermediação se baseia na frequência em que um nó está localizado nos caminhos mais curtos (distância geodésica) que conectam outros pares na rede (AGUILLAR-GALLEGOS et al. 2016) referenciando-se em Freeman (1979), De Nooy et al. (2005) e Jackson (2008). Sendo assim, a centralidade de intermediação trata-se do grau em que um ator é ponte entre os demais atores (RIBEIRO; BASTOS, 2011; DE ROLT; DIAS; PEÑA, 2017). É a medida do controle exercido por determinado ator sobre as interações entre outros dois atores, medindo "o número de vértices impactados com a saída de um determinado vértice" (DE ROLT; DIAS; PEÑA, 2017, p. 270).

Para De Rolt et al. (2017, p.270) a centralidade de aproximação "mede o quão perto um vértice está de outro". Em uma outra visão, a centralidade de aproximação é o grau em que as relações de um ator fornecem acesso a outros atores, permitindo alcançá-los e inseri-los na rede (AGUILLAR-GALLEGOS et al., 2016). Baseando-se esse indicador no grau de entrada, considera não apenas as relações diretas em que os atores estão conectados, mas as interações que eles podem alcançar por meio desses contatos diretos.

Quanto à centralidade de Bonacich, Aguillar-Gallegos et al. (2016) referenciando-se em Bonacich (1987) explicam que o status de um ator dentro da rede se dá em função do status dos atores os quais está conectado e para essa análise utiliza-se um parâmetro que afeta o grau em que os vínculos distantes são considerados. Os autores explicam ainda, que esse parâmetro pode atingir valores positivos ou negativos, indicando a centralidade de grau de um ator, ou uma medida de poder, onde esse parâmetro é zero, onde tal medida é a centralidade de grau, todavia, se aumentar, os vínculos indiretos são mais relevantes. Pressupõe-se que esses vínculos indiretos são os vínculos passíveis de acesso por meio de intermediários, denotando a centralidade e o status do ator a partir da centralidade e do status de suas relações.

Cabe ressaltar que existem outros indicadores utilizados na análise de redes, no entanto, a escolha desses indicadores deve corresponder aos objetivos da pesquisa. 


\section{REDES INFORMAIS INTERORGANIZACIONAIS}

Como o próprio termo sugere, redes interorganizacionais são as redes formadas entre organizações, onde os arranjos formados por três ou mais organizações, públicas, privadas ou não governamentais buscam alcançar objetivos individuais e coletivos, e colaboram entre si, mantendo sua autonomia e independência, como afirmam Roth et al. (2012) fazendo referência ao exposto por Hibbert et al., (2008); Provan e Kenis, (2008).

De Rolt et al. (2017) citam Powell et al. (2015), para explicar que a rede interorganizacional se caracteriza por um padrão, passível de medida, de relações entre organizações em um ambiente social, onde normalmente as ações coletivas são fomentadas por fortes mudanças, quer sejam de ordem social, econômica ou tecnológica. Diante disso, pode-se perceber que os contextos interorganizacionais são diversos e passíveis de serem analisados a partir de diferentes perspectivas e condições (ESGUERRA PÉREZ, 2017).

Cunha et al. (2012) explicam que as redes interorganizacionais carregam ranços do passado, de relações sociais e econômicas que sustentam e intermedeiam as suas relações, fato que as diferenciam das demais redes em termos de competitividade e estrutura social. Essa abordagem remete à dimensão temporal, também discutida por De Rolt et al. (2017, p. 270) onde afirmam ser uma dimensão essencial, visto que "as relações são formadas por constantes mudanças de interesses e outras irregularidades". Sendo assim, as dimensões analisadas pelo método de análise de redes podem ser diversas.

A confiança, a aprendizagem e o conhecimento, influenciam a competitividade das redes e das organizações participantes, uma vez que melhoram a flexibilidade, a velocidade e o tempo de chegada, de um produto ou serviço diferenciado no mercado (ALVES et al., 2013). No entanto, segundo Estivalete et al. (2012), nos casos de aprendizagem interorganizacional, a atuação em rede, tanto poderá aumentar a vantagem competitiva, se houver simetria de aprendizagem, quanto levar à perda de habilidades e diluição do conhecimento, se houver assimetria, uma vez que a assimetria, no acesso ao processo de aprendizagem interorganizacional, torna desigual a distribuição dos riscos e benefícios na relação.

Jordão (2015) ao citar (TOMAÉL, 2005; PELUFÊ, 2005; VALKOKARI; HELANDER, 2007; BEHR; NASCIMENTO, 2008; JARDON; MARTOS, 2012, 2014), afirma que o compartilhamento da 
informação é essencial para que as organizações melhorem a capacidade de gerar valor e de fomentar a aprendizagem organizacional; além de ser fator determinante de vantagem competitiva (ESGUERRA PEREZ, 2017). Estivalete et al. (2012) fazem referência a Peters et al. (2010) ao afirmarem que, entre as razões para que as empresas colaborem umas com as outras em um ambiente competitivo, tem-se destaque a utilização do conhecimento coletivo a serviço de seus clientes, visando maior efetividade, onde indústrias colaboram com seus competidores, na busca por agregação de valor através da aprendizagem coletiva.

Por sua vez, Genari, Faccin e Macke (2013) ao citarem Brito e Bastos (2001) afirmam que qualquer processo organizativo depende de uma relação de compromisso entre os atores acerca das metas, missão e valores da organização e que o comprometimento é considerado um elemento estratégico, por possibilitar que as organizações enfrentem, com êxito, situações de mudança ou de turbulência no mercado. Corroborando a essa ideia, Klein e Pereira (2014) citam Dyer e Chu (2003) ao afirmar que o comprometimento e a confiança são capazes de criar um contexto colaborativo social propício ao compartilhamento de aprendizagem e informação, e referenciando-se em Lourenzani et al. (2006), complementam trazendo que o compromisso é condicionado pela confiança.

A confiança é considerada elemento fundamental em cooperação (CHILD; FAULKNER; TALLMAN, 2000 apud KUNZLER; BULGACOV, 2011), pois eleva as

possibilidades de resultados coletivos (KUNZLER; BULGACOV, 2011) e assim, a atuação em cooperação associativa entre empresas, viabilizada pela confiança, pode proporcionar uma série de benefícios às organizações, como por exemplo:

combinar competências e utilizar o know-how de outras empresas; dividir ônus de realizar pesquisas tecnológicas, compartilhando o desenvolvimento e o conhecimento adquirido; partilhar riscos e custos de explorar novas oportunidades, através da realização de experiências em conjunto; oferecer uma linha de produtos de qualidade superior e mais diversificada; exercer uma maior pressão sobre o mercado, de modo a aumentar a força competitiva em benefício ao cliente; compartilhar recursos, com destaque aos que estão sendo subutilizados; fortalecer o poder de compra; e adquirir mais força para atuar em outros mercados (AMATO NETO, 2000 apud KUNZLER; BULGACOV, 2011, p. 1367).

A formação de uma rede interorganizacional implica em desafios, como a adoção de novas práticas contratuais, a gestão de conflitos de interesses entre os envolvidos, os custos iniciais para a 
implantação da rede e a implantação de modelos de gestão, que delimitem a ação de cada agente (LUCARENA, 2010 apud DE ROLT; DIAS; PEÑA, 2017, p. 268). Entretanto, uma vez que a rede consiga superar os desafios, essa atuação em rede poderá servir de "vantagem competitiva sustentável", por combinar as diferentes competências dos atores e gerar um diferencial competitivo, podendo transformar o produto proposto pela ação da rede, "relativamente insubstituível" (DE ROLT; DIAS; PEÑA, 2017, p. 268).

Nessa perspectiva, os estudos sobre as formas de relações interorganizacionais, como a formação de redes de empresas, vem se solidificando como uma nova tendência no campo organizacional (AMATO NETO, 2000 apud ESTIVALETE; PEDROZO; BEGNIS, 2012).

Para Cunha et al.(2012), o tema redes interorganizacionais é de interesse também de formuladores de políticas públicas, que buscam no associativismo, especialmente de pequenas e médias empresas, um meio de promover o desenvolvimento local.

\section{REVISÃO SISTEMÁTICA DA PRODUÇÃO CIENTÍFICA NACIONAL SOBRE REDES SOCIAIS NO PERÍODO DE 2011 A 2019}

Esta seção apresenta o estado da arte da pesquisa em redes sociais no cenário nacional, no período compreendido entre 2011 a 2019, com o intuito de identificar os principais subtemas abordados e os métodos utilizados. Para tanto, foi realizada uma revisão da literatura, a qual se refere ao "estado da questão a ser investigada pelo pesquisador [...] uma caminhada pelo campo onde se faz um buquê com todas as flores que se encontra. É um percurso crítico, relacionando- se intimamente com a pergunta que à qual se quer responder" (LAVILLE; DIONNE, 1999, p. 112-113).

Guarnieri (2015, p. 9), ancorada em Webster e Watson (2002), sinaliza que a revisão da literatura constitui-se basicamente de duas perspectivas, a saber: 1) "revisões de tópicos que possuem um conhecimento acumulado, o qual requer uma análise e síntese; e, 2) revisões de assuntos emergentes, cuja contribuição é a exposição de fundações teóricas potenciais, a qual normalmente não é tão extensa como a primeira". Nesse sentido, o tema pesquisado neste estudo se enquadra na primeira perspectiva de revisão da literatura.

Guarnieri (2015) se baseia no que dizem Cronin et al. (2008) ao complementar que, em relação à técnica da pesquisa, existem dois tipos de revisão da literatura: 1) revisão narrativa ou tradicional da literatura - sumariza a literatura, porém não fica explícito os critérios utilizados para a seleção das 
fontes; e, 2) revisão sistemática da literatura - uma abordagem bem definida para revisar a literatura, a qual segue um protocolo para selecionar e analisar as fontes. A autora ressalta que "as revisões sistemáticas da literatura podem ser ancoradas em abordagens qualitativas ou quantitativas (metaanálise), a depender dos objetivos da pesquisa (De-la-Torre- Ugarte-Guanilo, Takahashi, \& Bertolozzi, 2011)".

Guarnieri (2015) descreve o protocolo de revisão sistemática proposto por Cronin et al. (2008), o qual envolve as seguintes etapas: • formulação da questão de pesquisa; • conjunto de critérios de inclusão e exclusão; • seleção e acesso da literatura;• avaliação da qualidade da literatura incluída na revisão; e, • análise, síntese e disseminação dos resultados.

Com base no protocolo, a Figura 1 apresenta uma síntese dos estudos analisados.

Figura 1. Protocolo da revisão sistemática da literatura

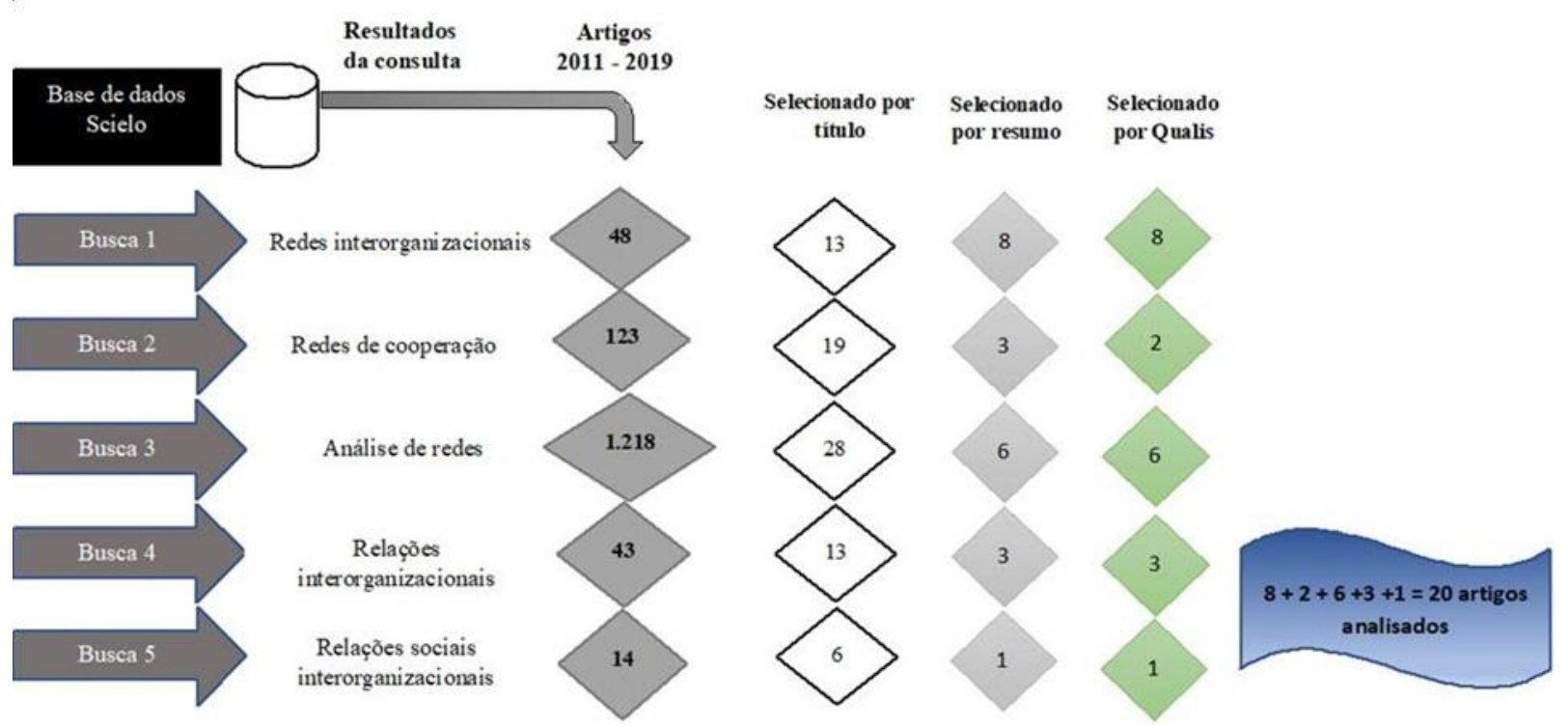

Fonte: Elaborado pelos autoroes, com base em Guarnieri (2015).

Conforme o protocolo apresentado na Figura 1, a seguir serão detalhadas as etapas seguidas para o alcance dos objetivos desta pesquisa:

Quanto aos critérios de inclusão e exclusão, a base de dados onde se realizou as buscas foi a Plataforma Scielo; as palavras-chave utilizadas foram: redes interorganizacionais, redes de cooperação, análise de redes, relações interorganizacionais, e relações sociais interorganizacionais; foram aplicados os filtros: descritores, período 2011-2019, localizado em todos os índices, mais novos 
primeiro. Na sequência foram selecionados os artigos pelos títulos que dialogassem de alguma forma com este estudo; apenas os artigos com títulos selecionados tiveram seus resumos lidos; após a leitura dos resumos, os que indicavam relevância para a pesquisa foram selecionados e os demais foram desconsiderados; os trabalhos selecionados por resumo foram avaliados com o critério de verificação do Qualis da Capes, dos seus respectivos periódicos, sendo selecionados apenas os artigos com classificação entre os estratos A1- B1, nas áreas de avaliação Interdisciplinar e/ou Administração Pública e de Empresas, Contábeis e Turismo.

Para a palavra-chave redes interorganizacionais foram encontrados 48 artigos; foram identificados 123 artigos para a palavra-chave redes de cooperação; 1.218 artigos para a palavra-chave análise de redes; 43 artigos foram identificados para o descritor relações interorganizacionais; e 14 para o descritor redes sociais interorganizacionais. Ressalta-se que alguns títulos se repetiram em determinadas palavras-chave, no entanto, foram selecionados e contabilizados por título em cada palavra-chave. Todavia, uma vez que tenham sido selecionados pela leitura do resumo em um primeiro descritor, automaticamente eram eliminados da próxima palavra-chave, não havendo sobreposição.

Na avaliação da qualidade da literatura incluída, dos 79 artigos selecionados por título, 58 foram eliminados pelo resumo, por não se enquadrarem com o problema desta pesquisa, restando 21 artigos que foram selecionados por resumo, dos quais, apenas 01 foi eliminado por não atender aos critérios do Qualis da Capes estabelecidos para esta pesquisa. Com isso 20 artigos compuseram a presente revisão sistemática.

Considerando-se que a configuração das redes interorganizacionais pode influenciar os processos de comunicação, e de comprometimento da rede, impactando no seu funcionamento e fortalecimento, todos os tipos de relações e interações (redes) analisadas nos artigos contribuíram de alguma forma para que este estudo fosse desenvolvido, evidentemente que algumas tiveram maior destaque por tratar diretamente das redes aqui analisadas.

Por fim, a análise, a síntese e disseminação dos resultados foram caracterizadas pela análise dos artigos selecionados, e identificação dos resultados encontrados, bem como algumas considerações sobre o artigo.

No quadro 1 são apresentados os 20 artigos selecionados, pela ordem de seleção, considerando a sequência de palavras-chave apresentadas na Figura 1, destacando: Autor(es/as), Ano, Título, Periódico e Qualis da Capes. 


\section{Quadro 1. Síntese dos artigos analisados}

\begin{tabular}{|c|c|c|c|}
\hline Autor(es)/Ano & Título & Periódico & Qualis Capes \\
\hline $\begin{array}{l}\text { DE ROLT; } \quad \text { DIAS; } \\
\text { PEÑA (2017) }\end{array}$ & $\begin{array}{l}\text { Análise de redes como ferramenta } \\
\text { de gestão para empreendimentos } \\
\text { interorganizacionais }\end{array}$ & Gestão e Produção & B1 \\
\hline JORDÃO (2015) & $\begin{array}{l}\text { Práticas de gestão da informação e } \\
\text { do conhecimento em pequenas e } \\
\text { médias empresas organizadas em } \\
\text { rede: um estudo multicasos na } \\
\text { indústria brasileira }\end{array}$ & $\begin{array}{l}\text { Perspectivas em Ciência da } \\
\text { Informação }\end{array}$ & B1 \\
\hline ALVES et al. (2013) & $\begin{array}{l}\text { Confiança, aprendizagem e } \\
\text { conhecimento nos relacionamentos } \\
\text { interorganizacionais: diagnóstico e } \\
\text { análise dos avanços sobre o tema }\end{array}$ & $\begin{array}{l}\text { Revista Eletrônica de } \\
\text { Administração, } \\
\text { Alegre }\end{array}$ & B1 \\
\hline $\begin{array}{l}\text { SILVA; } \quad \text { NEVES } \\
(2013)\end{array}$ & $\begin{array}{l}\text { Divisão do trabalho social e } \\
\text { arranjos produtivos locais: reflexos } \\
\text { econômicos de efeitos morais de } \\
\text { redes interorganizacionais }\end{array}$ & $\begin{array}{l}\text { RAM. Revista de } \\
\text { Administração Mackenzie }\end{array}$ & B1 \\
\hline $\begin{array}{l}\text { ESTIVALETE; } \\
\text { PEDROZO; BEGNIS } \\
(2012)\end{array}$ & $\begin{array}{l}\text { O processo de aprendizagem em } \\
\text { redes horizontais do elo varejista } \\
\text { do agronegócio: uma análise sob a } \\
\text { perspectiva das estratégias, dos } \\
\text { métodos e dos estágios evolutivos }\end{array}$ & $\begin{array}{l}\text { RAM. Revista de } \\
\text { Administração Mackenzie }\end{array}$ & B1 \\
\hline $\begin{array}{l}\text { CUNHA; } \\
\text { PASSADOR; } \\
\text { PASSADOR (2012) }\end{array}$ & $\begin{array}{l}\text { A presença de agentes } \\
\text { intermediadores na formação de } \\
\text { redes interorganizacionais: uma } \\
\text { análise sob a perspectiva temporal }\end{array}$ & Cadernos EBAPE.BR & $\mathrm{A} 2$ \\
\hline $\begin{array}{l}\text { RIBEIRO; BASTOS } \\
(2011)\end{array}$ & $\begin{array}{l}\text { Redes sociais interorganizacionais } \\
\text { na efetivação de projetos sociais }\end{array}$ & Psicologia \& Sociedade & $\mathrm{A} 2$ \\
\hline $\begin{array}{l}\text { CUNHA; } \\
\text { PASSADOR; } \\
\text { PASSADOR (2011) }\end{array}$ & $\begin{array}{l}\text { Recomendações e apontamentos } \\
\text { para categorizações em pesquisas } \\
\text { sobre redes interorganizacionais }\end{array}$ & Cadernos EBAPE.BR & $\mathrm{A} 2$ \\
\hline $\begin{array}{l}\text { ESGUERRA PÉREZ } \\
(2017)\end{array}$ & $\begin{array}{lcr}\text { Liderazgo y } & \text { conocimiento } \\
\text { compartido em } & \text { contextos } \\
\text { interorganizacionales } & \end{array}$ & $\begin{array}{l}\text { Revista Facultad de } \\
\text { Ciéncias Económicas }\end{array}$ & B1 \\
\hline ZANCAN et al. (2013) & $\begin{array}{l}\text { Condicionantes de consolidação de } \\
\text { redes de cooperação } \\
\text { interorganizacional: um estudo de } \\
\text { caso sobre o Rio Grande do Sul }\end{array}$ & $\begin{array}{l}\text { Revista de Administração } \\
\text { Pública }\end{array}$ & $\mathrm{A} 2$ \\
\hline $\begin{array}{l}\text { AGUILLAR- } \\
\text { GALLEGOS et al. } \\
(2016)\end{array}$ & $\begin{array}{l}\text { Análisis de redes sociales para } \\
\text { catalizar la innovación agrícola: de } \\
\text { los vínculos directos a la }\end{array}$ & Estudios Gerenciales & B1 \\
\hline
\end{tabular}




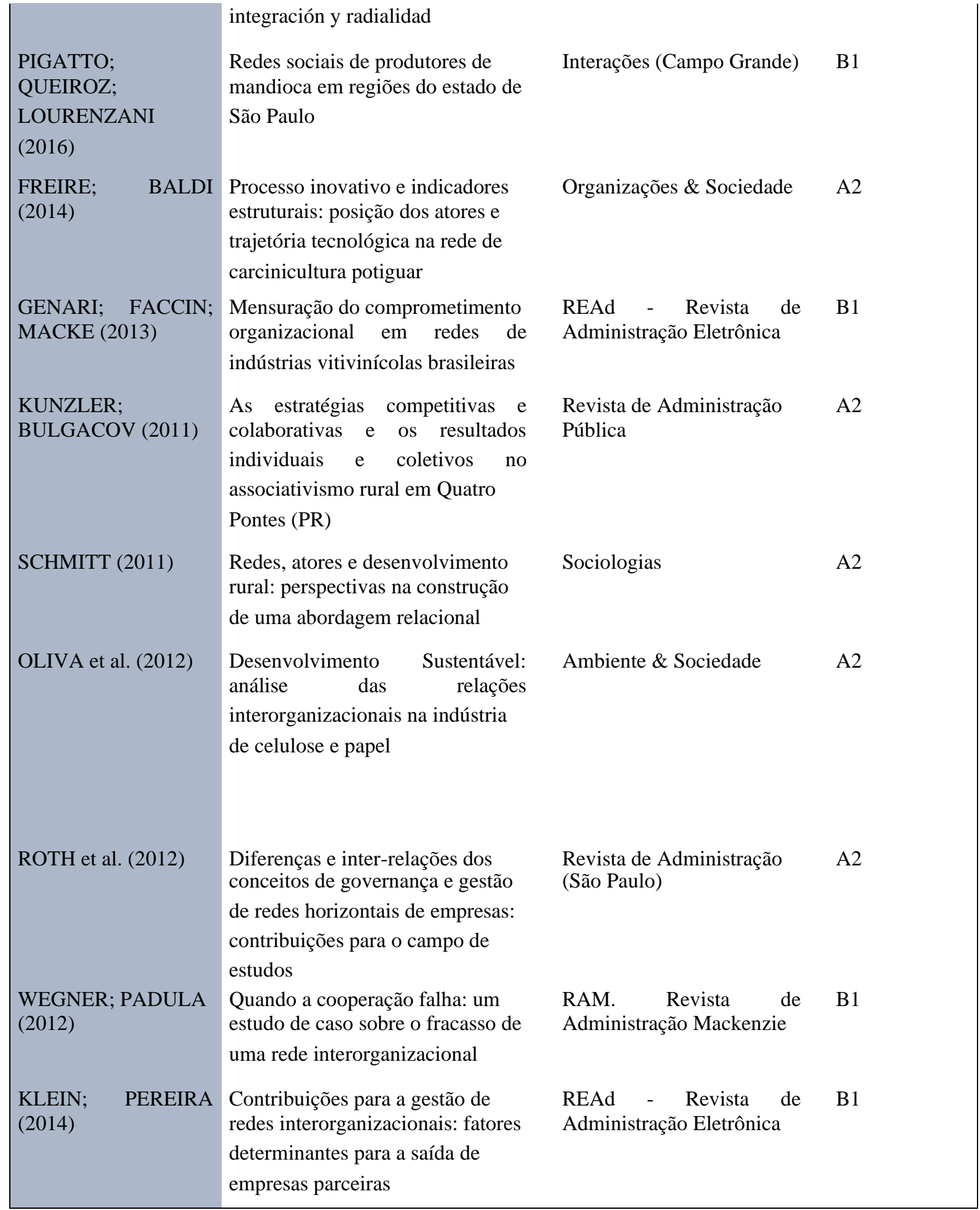

Fonte: Elaborado pelos autores

É apresentado a seguir o Estado da Arte das pesquisas sobre redes sociais, em âmbito nacional, no período entre os anos de 2011 a 2019, sendo importante ressaltar que entre os artigos selecionados não compuseram a presente revisão estudos publicados nos anos 2018 e 2019, além de que 2 dos artigos selecionados para análise são publicações internacionais, sendo assim, foram desconsiderados pelo critério de nacionalidade estabelecido, e não foram relacionados na Tabela 1. 
Tabela 1. Síntese da produção científica nacional sobre redes sociais no período de 2011 a 2019.

\begin{tabular}{ll}
\hline Autores/Ano & Subtemas \\
\hline DE ROLT; DIAS; & $\begin{array}{l}\text { Formação da rede, maturidade } \\
\text { PENganizacional, resiliência, modelo de } \\
\text { gestão e governança. }\end{array}$ \\
& \\
JORDÃO (2017) & Habilidades e competências, formas de \\
& relacionamentos entre atores, \\
& honestidade em compartilhar, a forma de \\
& fomentar e reter conhecimento, \\
& ferramentas e processos de criação de \\
& métodos e partilha de linguagem, \\
& incentivos ao compartilhamento de \\
& conhecimento, ganhos proporcionados \\
pelas redes, forma de partilha e \\
transmissão de conhecimento, \\
intercâmbio de informações e interações \\
formais e informais, e o efeito de culturas \\
similares.
\end{tabular}

ALVES et al. (2013) Confiança, aprendizado e conhecimento nos relacionamentos interorganizacionais.

SILVA; NEVES Divisão do trabalho, confiança, coesão, (2013)

solidariedade, regulação coletiva e oportunismo.

\begin{tabular}{|c|c|}
\hline $\begin{array}{l}\text { ESTIVALETE; } \\
\text { PEDROZO; } \\
\text { BEGNIS (2012) }\end{array}$ & $\begin{array}{l}\text { Aprendizagem em } \quad \text { redes, } \\
\text { comportamentos estratégicos de } \\
\text { evitação, acomodação, compromisso, } \\
\text { competição e colaboração. }\end{array}$ \\
\hline
\end{tabular}

CUNHA;

PASSADOR;

PASSADOR (2012)

RIBEIRO; BASTOS Rede Geral, Rede de consórcio, tamanho (2011)

CUNHA;

PASSADOR,

PASSADOR (2011) da rede, densidade, graus de centralidade dos atores, conectores centrais.

\section{Método Amostra}

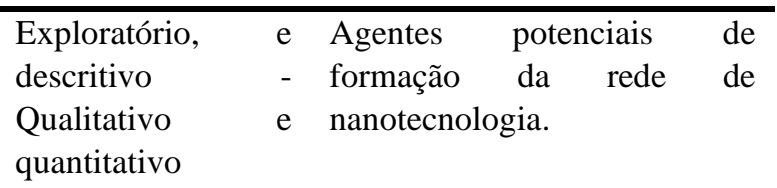

Estudo comparativo de rede de SMEs micro, casos

Principais executivos de uma pequenas e médias empresas (SMEs, do inglês small and medium enterprises) que receberam suporte técnico e de formação gerencial do Serviço Brasileiro de Apoio às Micro e Pequenas

Empresas (SEBRAE) do Estado do Espírito Santo (ES).

Pesquisa bibliográfica

Exploratório

Referencial teórico.

Estudo de casos múltiplos

Gestores das organizações inseridas nas redes supermercadistas do Rio Grande do Norte.

Gestores de pequenas e médias empresas do ramo calçadista de Birigüi.

Análise de redes Organizações integrantes sociais

do Consórcio Social da Juventude de Salvador e Região Metropolitana (CSJ/RM). O CSJ/RM é um Programa do Ministério do Trabalho e Emprego (MTE) Governo Federal.

Revisão Bibliografia disponível.
Síntese para categorizações em redes, formação, tipos de aliança, orientação da relação, orientação do elo da cadeia, presença de uma organização central, governança, institucionalização, unidade de análise, tipos de competição. 


\begin{tabular}{lll}
\hline Autores/Ano & Subtemas \\
\hline ZANCAN et & al. & $\begin{array}{l}\text { Redes de cooperação, condicionantes de } \\
\text { consolidação de redes de cooperação, } \\
\text { compartilhamento e complementaridade } \\
\text { de recursos, confiança e bem-estar } \\
\end{array}$ \\
& social, economias de escala.
\end{tabular}

PIGATTO;

QUEIROZ;

LOURENZANI

(2016)

FREIRE; BALDI Inovação, inovação de produto, inovação (2014)

GENARI; FACCIN; Comprometimento organizacional nas MACKE (2013)
Difusão de informação, confiança, Pesquisa de campo número de laços, coesão.

de processo, inovação de gestão, mudança tecnológica, mudança tecnológica incremental, mudança tecnológica radical; posição na rede, centralidade na rede.

dimensões: afetiva, instrumental e normativa.

Estudo de caso

Pesquisa descritiva
Método

Pesquisa

documental,

descritivo-

comparativo.

Funcionários das indústrias vitivinícolas associadas à APROVALE (Associação de Produtores de Vinhos Finos do Vale dos Vinhedos) e à APROBELO (Associação de Produtores de Vinho de Monte Belo do Sul) e situadas no Vale dos Vinhedos (RS/Brasil).

KUNZLER;

BULGACOV (2011)

Estratégias de competição e colaboração, rede top-down, rede de empresas flexíveis, coopetição, cooperação, coexistência, confiança, compartilhamento.
Estudo múltiplo de casos
Associados das Associações de produtores rurais de Quatro Pontes (PR), (Apuvitis, AAOQP, Associações de Linha), presidentes das associações e o dirigente da Secretaria de Desenvolvimento econômico da Prefeitura Municipal de Quatro Pontes (PR), o dirigente da Empresa de Assistência Técnica e Extensão Rural (Emater) local e o dirigente do Projeto de Desenvolvimento da Fruticultura Regional (Profrut) da Emater Toledo.

SCHMITT (2011)

Teoria do Ator-Rede, abordagem relacional, atores.

Revisão

Bibliografia disponível. 


\begin{tabular}{|c|c|c|c|}
\hline Autores/Ano & Subtemas & Método & Amostra \\
\hline OLIVA et al. (2012) & $\begin{array}{l}\text { Características das transações: } \\
\text { especificidade do ativo da transação, } \\
\text { frequência da consecução da transação e } \\
\text { incerteza advinda do ambiente, grau de } \\
\text { oportunismo e tipo de governança. }\end{array}$ & Pesquisa de campo & \\
\hline ROTH et al. (2012) & $\begin{array}{l}\text { Diferenças e inter-relações entre gestão e } \\
\text { governança, modelos de governanã, } \\
\text { gestão de redes interorganizacionais. }\end{array}$ & $\begin{array}{l}\text { Revisão } \\
\text { bibliográfica }\end{array}$ & Bibliografia disponível. \\
\hline $\begin{array}{l}\text { WEGNER; } \\
\text { PADULA (2012) }\end{array}$ & $\begin{array}{l}\text { Estratégias de competição e cooperação, } \\
\text { retornos relacionais, compartilhamento } \\
\text { de recursos e conhecimentos, fracasso na } \\
\text { cooperação empresarial, rivalidade, } \\
\text { oportunismo, complexidade gerencial, } \\
\text { confiança, comprometimento. }\end{array}$ & Estudo de caso & $\begin{array}{l}\text { Diretoria da rede de } \\
\text { minimercados de Santa Cruz } \\
\text { do Sul/RS, empresários, e a } \\
\text { consultora da rede. }\end{array}$ \\
\hline $\begin{array}{l}\text { KLEIN; PEREIRA } \\
\text { (2014) }\end{array}$ & $\begin{array}{l}\text { Fatores determinantes para a saída de } \\
\text { empresas de uma rede: Metas e } \\
\text { Objetivos não Alcançados; Falta de } \\
\text { Inovação e Geração de Valor; Falta de } \\
\text { Confiança e Comprometimento; Seleção } \\
\text { de parceiros não estruturada; } \\
\text { Oportunismo dos Integrantes; Gestão } \\
\text { Individualizada; Laços Fracos } \\
\text { Anteriormente; Legitimidade da Rede; } \\
\text { Individualismo dos Integrantes; Baixa } \\
\text { Aprendizagem Interorganizacional; } \\
\text { Baixa Troca de Recursos entre } \\
\text { Integrantes; Custo da Rede; a confiança } \\
\text { e o comprometimento. }\end{array}$ & $\begin{array}{l}\text { Pesquisa de campo } \\
\text { descritiva } \\
\text { quantitativa }\end{array}$ & $\begin{array}{l}\text { Empresários de empresas de } \\
\text { diferentes regiões do Rio } \\
\text { Grande do Sul que se } \\
\text { desligaram das redes de } \\
\text { cooperação às quais estavam } \\
\text { vinculadas. }\end{array}$ \\
\hline
\end{tabular}

Fonte: Elaborado pelos autores.

Kunzler e Bulgacov (2011) buscaram compreender como as estratégias de competição e de colaboração existentes nas associações de produtores rurais influenciam os resultados individuais e coletivos obtidos pelos produtores participantes. As organizações analisadas foram as associações de produtores rurais de Quatro Pontes (PR), e os subtemas mais discutidos foram a confiança, a cooperação e a coopetição. Onde a partir desse estudo os autores identificaram que nas associações pesquisadas existiam relações de "coopetição" (cooperação e competição simultaneamente); nos três estudos de caso havia alta colaboração e baixa competitividade; as relações interorganizacionais tem efeito indireto sobre o resultado, podendo influenciar a adoção de estratégias competitivas e colaborativas; a coopetição pode gerar tensões (pressão social) e resultados variáveis; o associativismo 
rural permite melhor integrar os segmentos do agronegócio (antes, dentro e depois da porteira), constituindo instrumento de competitividade devido às possibilidades de inovação a partir do acesso ao conhecimento e tecnologias, entre outras considerações.

Estivalete et al. (2012) analisaram as estratégias de aprendizagem, onde as unidades de análise foram duas redes supermercadistas, que estabelecem relacionamentos horizontais, formadas por pequenas e médias empresas que atuam no elo do varejo do segmento do agronegócio. Como resultados os autores identificaram que organizações as quais adotam estratégias de colaboração podem maximizar a aprendizagem interorganizacional, estando capacitadas para a criação, descoberta e compartilhamento de conhecimento; a confiança entre os atores (organizações) pode aumentar o compromisso das organizações com os relacionamentos estabelecidos na base da cooperação, assim, um maior nível de confiança pode proporcionar a co-evolução para os próximos estágios do processo de aprendizagem; confiança e cooperação foram considerados essenciais ao processo evolutivo da rede, bem como para manutenção e fortalecimento das relações interorganizacionais. Foi identificado também que em uma das redes analisadas, devido ao medo do conhecimento tácito ser copiado por outras organizações, o conhecimento pouco circula, o que pode prejudicar a aprendizagem entre as organizações, desestimulando assim a cooperação e a inovação.

Wegner e Padula (2012) utilizaram-se da abordagem de redes para analisar, não os benefícios da atuação em rede, mas o caso mal sucedido de uma rede de empresas do ramo de supermercados de Santa Cruz do Sul/RS, que não atingiu seus objetivos. Os conteúdos abordados na análise giram em torno da complexidade gerencial, do comprometimento, da maturidade do grupo, da cooperação e da coopetição.

Wegner e Padula (2012, p. 165) assinalam que a rivalidade entre as empresas não foi determinante para o fracasso da rede; "a complexidade gerencial, aliada às dificuldades de coordenação e ao desajuste estratégico, levou à redução no comprometimento, à baixa eficiência e, por fim, ao fracasso da rede"; na fase de pré-lançamento, questões como o perfil dos participantes selecionados, o número reduzido de empresas e o momento de lançamento da rede contribuíram para o fracasso, bem como no pós-lançamento, o desajuste estratégico, a perda de apoio de um programa público e a maturidade da rede também deram sua contribuição para o insucesso.

A análise feita por Wegner e Padula (2012), proporciona aos estudiosos e gestores uma melhor visualização das dificuldades inerentes ao processo de formação e manutenção de redes 
interorganizacionais, além de possibilitar uma reflexão sobre como minimizar as possibilidades de insucesso da rede.

Zancan et al. (2013) demonstraram interesse em investigar os condicionantes de consolidação de redes de cooperação interorganizacional. Assim, elaboraram um estudo de caso sobre a consolidação da rede Associação dos Produtores de Vinhos Finos do Vale dos Vinhedos - APROVALE, no Rio Grande do Sul. A partir desse estudo, os autores identificaram que, no caso da APROVALE - Vale dos Vinhedos/RS, caracterizado como espaço da agricultura familiar, os condicionantes da consolidação da rede foram, a produção em escala e a obtenção de recursos financeiros para reinvestimento. Apontaram que questões como confiança e bem- estar social ficaram em segundo plano, o que se justifica pelo grau de maturidade da rede no momento de sua consolidação. Outro aspecto importante, segundo os autores, é que por meio da rede, conseguiram a primeira IP - Indicação de Procedência no Brasil para vinhos finos e espumantes.

Silva e Neves (2013) analisaram os reflexos econômicos de efeitos morais de redes, tendo como foco de análise a divisão do trabalho social e arranjos produtivos locais. Os subtemas mais discutidos foram: a divisão do trabalho, a confiança, a coesão, solidariedade, regulação coletiva e oportunismo. Os autores abordaram a perspectiva de Durkheim, em que o mercado competitivo é também solidário. Apontaram que "a coesão social está presente nas relações de competição econômica que geram conflitos, especializam o trabalho e satisfazem as necessidades individuais" (SILVA; NEVES, 2013, p. 223); reforçam ainda a importância da coesão e da confiança, ao passo que acrescentam a solidariedade e a regulação coletiva (pressão estrutural).

Entre outras considerações, Silva e Neves (2013) assinalaram ainda, que o mercado se constitui de um aglomerado de organizações, as quais formam uma estrutura social, e que a abordagem evolutiva e funcionalista de Durkheim permite compreender melhor as relações sociais fundamentais que seriam condições essenciais para que o aumento e a densidade moral das organizações em rede, como o caso dos APLs, gerassem solidariedade interorganizacional, valorizando as individualidades de cada APL, aumentando a coesão social (SILVA; NEVES, 2013).

Outra dimensão analisada em 2013 foi o comprometimento organizacional, abordado por Genari et al. (2013), onde os autores buscaram identificar como o comprometimento organizacional se manifesta dentro das organizações de redes de indústrias vitivinícolas brasileiras, mais especificamente no Vale dos Vinhedos no Rio Grande do Sul, sendo objetos da análise as redes APROVALE e APROBELO. Segundo esses autores, o comprometimento organizacional influencia o 
comportamento e atitudes dos colaboradores e está relacionado com o sentimento do indivíduo, com a sua identificação com a organização, que se caracteriza pela aceitação e conviç̧ão dos valores e objetivos organizacionais e com o seu desejo em permanecer como membros da organização, estando relacionado também com a criação de vantagens competitivas.

Para a mensuração do comprometimento organizacional Genari et al. (2013) analisaram as dimensões: afetiva - relacionada ao sentimento de pertencimento do colaborador, identificação com os valores e objetivos da organização; instrumental - que se relaciona ao custo de saída da empresa; e normativa, que se refere ao sentimento de obrigação em permanecer na empresa. Nesse sentido, os autores identificaram que a dimensão afetiva tem maior representatividade nas redes estudadas; a dimensão instrumental não foi muito representativa devido à grande oferta de empregos na região; a dimensão normativa se demonstrou com maiores médias nos trabalhadores parentes da família fundadora.

Freire e Baldi (2014) analisaram como as relações sociais entre atores privados e públicos interferem na geração de inovação, tomando como foco de seu estudo o caso da carcinicultura potiguar, considerando o processo inovativo como socialmente imerso. Assim, os resultados apresentados pelas autoras apontaram que: a centralidade da rede nem sempre define a difusão de inovação; no caso em questão, a difusão de inovação ocorreu principalmente quando a rede estava menos centralizada, motivada pela mudança de posição de atores. Também encontraram evidências de que o comportamento oportunista e descrença nas possíveis vantagens de uma ação coletiva surgiram na rede, demonstrando, segundo as autoras, que aspectos relacionais do passado podem explicar os limites à geração de inovação na atualidade da rede. Complementaram ainda, que apenas o indicador de posição na rede não é suficiente para compreender todos os aspectos.

Os resultados encontrados por Freire e Baldi (2014) chamam a atenção para a necessidade de se analisar outros indicadores que possam complementar as informações geradas pela identificação da posição do ator na rede, visando à obtenção de maior clareza da situação, bem como trazem à luz a importância de se observar as relações passadas de um ator.

Klein e Pereira (2014) analisaram os fatores que levam uma empresa a sair da rede à qual estava inserido. Os autores partiram de 15 determinantes hipotéticas, das quais 12 foram confirmadas, 2 foram excluídas por não serem estatisticamente significantes (H9 - Assimetria de Investimentos e, H14 - Redução da Autonomia dos Integrantes), e 1 rejeitada (H14 - Imediatismo por Resultados e Expectativas de Ganhos de Curto Prazo). Os autores identificaram que a mais importante estatisticamente foi ‘Metas e Objetivos não Alcançados', seguida de 'Falta de Inovação' e 'Geração de 
Valor'; também foram aceitas como determinantes: 'Falta de Confiança e Comprometimento'; 'Seleção de parceiros não estruturada'; 'Oportunismo dos Integrantes'; 'Gestão Individualizada'; 'Laços Fracos Anteriormente'; 'Legitimidade da Rede'; 'Individualismo dos Integrantes'; 'Baixa Aprendizagem Interorganizacional'; 'Baixa Troca de Recursos entre Integrantes'; 'Custo da Rede' (quando o custo da manutenção supera o retorno obtido); Ressalta-se a 'Falta de confiança e o comprometimento'.

As hipóteses levantadas e aceitas por Klein e Pereira (2014) revelam a dimensão dos aspectos que podem interferir na formação e no desenvolvimento de uma rede, dada a complexidade inerente às relações interpessoais e interorganizacionais, constituindo assim uma importante reflexão para os interessados no tema.

Outro caso da aplicação da análise de redes no ramo de agronegócios é o estudo de Pigatto et al. (2015), onde analisaram e mapearam as redes sociais dos produtores de mandioca dos municípios de Assis e Tupã, no estado de São Paulo. Os principais subtemas analisados foram a difusão de informação, confiança, número de laços e a coesão. Ao comparar aspectos das redes dos dois municípios os autores identificaram que as redes coesas permitem maior acesso a informação, embora em redes difusas também seja possível; que a maturidade da rede e intensidade das relações interferem no processo de coesão e confiança, fazendo-se necessário, no caso de Tupã, recorrer a agentes intermediários (órgãos públicos) para estabelecer a confiança; e que no caso de Assis, a coesão era maior, devido ao tempo na atividade, o que diminui a presença de intermediadores.

Os resultados obtidos por Pigatto et al. (2015) ao realizarem uma análise comparativa das redes sociais dos grupos de produtores citados acima, conduziram a uma melhor apreciação, especialmente por parte dos formuladores de políticas públicas, sobre as reais necessidades dos produtores, podendo direcionar políticas públicas que supram essas necessidades, como exemplo, disponibilizando assistência técnica.

Por sua vez, De Rolt et al. (2017) analisaram as redes como ferramentas de gestão para empreendimentos interorganizacionais, onde os principais subtemas avaliados foram: a formação da rede, a maturidade organizacional, a resiliência, o modelo de gestão e a governança, tendo como objeto de análise a rede API-Nanotecnologia (Arranjo Promotor de Inovação de Tecnologia) do complexo tecnológico de Florianópolis/SC. Os autores sugerem no estudo, que a maturidade organizacional de uma rede cooperada impacta na resiliência da rede (baixa resiliência deixa a rede vulnerável) e é determinante para sua continuidade. A maturidade da rede foi observada a partir da 
consciência da existência da rede (que existia de forma empírica e inconsciente, sem gestão formalizada e política de governança), e da adoção de um modelo de gestão e governança. Em relação aos laboratórios de pesquisa que estão todos ligados à Universidade Federal de Santa Catarina - UFSC. Os autores consideraram que esse posicionamento é um fator de vulnerabilidade da rede, visto que, em caso de saída de um agente muito centralizado (UFSC, por exemplo), muitos outros serão afetados. Cabe ainda ressaltar sobre essa análise, que, segundo os autores, a independência das ações de um agente pode ser um ponto forte e ao mesmo tempo um distanciador dos agentes, prejudicando o fluxo de informação.

A análise de De Rolt et al. (2017) fornece uma melhor apreciação dos elementos que compõem uma rede interorganizacional e que podem ser determinantes para a sua continuidade. Nota-se que a maturidade de uma rede, a resiliência, o compartilhamento de conhecimento e informação são elementos importantes para a geração de inovação, bem como fica claro a pertinência da aplicação do método de análise de redes sociais para os processos de gestão e governança interorganizacional.

\section{CONSIDERAÇÕES FINAIS}

O levantamento revela diversas possibilidades de aplicação da análise de redes sociais interorganizacionais, onde pesquisadores utilizaram-se dessa abordagem para compreender as variadas situações que envolvem as organizações. Relações interorganizacionais como confiança, cooperação e a coopetição tem efeito indireto sobre o resultado, podendo influenciar a adoção de estratégias mais competitivas e colaborativas. O fator confiança foi bastante abordado nos artigos analisados, podendo este, maximizar a aprendizagem interorganizacional em organizações que adotam estratégias de colaboração além de fortalecer a rede.

A análise e compreensão das relações interorganizacionais favorecem o melhor planejamento estratégico das empresas, possibilitando aos gestores conhecer os fatores que estão contribuindo para o sucesso ou para o fracasso da rede, podendo então direcionar os esforços de maneira positiva, além de possibilitar a identificação das reais necessidades das organizações, permitindo, por exemplo, aos formuladores de políticas públicas melhor planejamento e direcionamento das mesmas de forma que supram as necessidades identificadas. Acredita-se que este trabalho contribui positivamente na compreensão de gestores e pesquisadores sobre a formação e funcionamento das redes interorganizacionais e como elas se interagem nos diversos ambientes provocando modificações nos resultados, bem como conhecer o estado da arte das pesquisas em redes interorganizacionais no 
período aqui abordado. Sugere-se a continuidade das pesquisas, considerado outras bases de dados para a análise.

\section{REFERÊNCIAS}

AGUILAR-GALLEGOS, N; MARTÍNEZ-GONZALEZ, E. G; AGUILAR-ÁVILA, J; SANTOYO-CORTÉS, H; MUÑOZ-RODRÍGUES, M; GARCÍA-SÁNCHES, E. I. Análisis de redes sociales para catalizar la innovación agrícola: de los vínculos directos a la integración y radialidad. Estudios Gerenciales, Cali, v. 32, n. 140, p. 197-207, Set. 2016. Disponível

em:<http://www.scielo.org.co/scielo.php?script=sci_arttext $\&$ pid=S012359232016000300002\&lng=e n\&nrm=iso>. Acesso em: 24 jan. 2019.

ALVES, J. N. et al. Confiança, aprendizagem e conhecimento nos relacionamentos interorganizacionais: diagnóstico e análise dos avanços sobre o tema. REAd. Rev. eletrôn. adm. (Porto Alegre), Porto Alegre, v. 19, n. 3, p. 709-737, 2013. Disponível

em:<http://www.scielo.br/scielo.php?script=sci_arttext\&pid=S141323112013000300007\&lng=en\&n rm=iso >. Acesso em: 29 jan. 2019.

BEGNIS, H. S. M; ALIEVI, R. M; ESTIVALETE, V. de F. B. Relacionamentos interorganizacionais horizontais e formação de valor em redes de agronegócios: o caso de uma rede de floriculturas. Estudos do CEPE, Santa Cruz do Sul, p. 34-68, dez. 2011. ISSN 1982- 6729. Disponível em: <https://online.unisc.br/seer/index.php/cepe/article/view/1904>. Acesso em: 04 jan. 2019.

CUNHA, J. A. C; PASSADOR, J. L; PASSADOR, C. S. Recomendações e apontamentos para categorizações em pesquisas sobre redes interorganizacionais. Cadernos EBAPE.BR, Rio de Janeiro, p. 505-529, jan. 2011. ISSN 1679-3951. Disponível

em: <http://bibliotecadigital.fgv.br/ojs/index.php/cadernosebape/article/view/5440>. Acesso em: 04 jan. 2019.

CUNHA, J. A. C; PASSADOR, J. L; PASSADOR, C. S. A presença de agentes intermediadores na formação de redes interorganizacionais: uma análise sob a perspectiva temporal. Cad. EBAPE.BR, Rio de Janeiro, v. 10, n. 1, p. 108-128, 2012. Disponível

em:<http://www.scielo.br/scielo.php?script=sci_arttext\&pid=S167939512012000100008\&lng=en\&n rm=iso>. Acesso em 28 jan. 2019.

DE ROLT, C. R; DIAS, J. da S; PEÑA, F. T. G. Análise de redes como ferramenta de gestão para empreendimentos interorganizacionais. Gest. Prod., São Carlos, v. 24, n. 2, p. 266-278, Jun. 2017. Disponívelem:<http://www.scielo.br/scielo.php?script=sci_arttext\&pid=S0104530X2017000200266 \&lng=en\&nrm=iso>. Acesso em: 04 jan. 2019. Pub 27 Mar 2017. http://dx.doi.org/10.1590/0104530x1885-16.

ESGUERRA PEREZ, G. A. Liderazgo y conocimiento compartido en contextos interorganizacionales. Rev. Facultad de Ciencias Económicas, Bogotá, v. 25, n. 1, p. 151-160, Jan. 2017. Disponívelem:<http://www.scielo.org.co/scielo.php?script=sci_arttext\&pid=S012168052017000100 011\&lng=en\&nrm=iso>. Acesso em: 19 Jan. 2019. http://dx.doi.org/10.18359/rfce.1768. 
ESTIVALETE, V. F. B; PEDROZO, E. A; BEGNIS, H. S. M. O processo de aprendizagem em redes horizontais do elo varejista do agronegócio: uma análise sob a perspectiva das estratégias, dos métodos e dos estágios evolutivos. REAd. Rev. eletrôn. adm. (Porto Alegre), Porto Alegre, v. 18, n. 1, p. 161-190, 2012.Disponível 23112012000100006\&lng=en\&nrm=iso>. Acesso em: 27 jan. 2019.

FREIRE, A. C; BALDI, M. Processo inovativo e indicadores estruturais: posição dos atores e trajetória tecnológica na rede de carcinicultura potiguar. Organ. Soc., Salvador, v. 21, n. 69, p. 235-254, 2014. Disponívelem<http://www.scielo.br/scielo.php?script=sci_arttext\&pid=S198492302014000200003\&l ng=en\&nrm=iso>. Acesso em: 02 Fev. 2019.

GENARI, D; FACCIN, K; MACKE, J. Mensuração do comprometimento organizacional em redes de indústrias vitivinícolas brasileiras. REAd. Rev. eletrôn. adm. (Porto Alegre), Porto Alegre, V. 19, n. 2, p. 351-383, 2013. Disponível

em:<http://www.scielo.br/scielo.php?script=sci_arttext\&pid=S141323112013000200004\&lng=en\&n rm=iso>. Acesso em: 19 jan. 2019.

GUARNIERI, P. Síntese dos Principais Critérios, Métodos e Subproblemas da Seleção de Fornecedores Multicritério. Rev. adm. Contemp., Curitiba, v. 19, n. 1, p. 1-25, 2015. Disponível em: $<$ http://www.scielo.br/scielo.php?script=sci_arttext\&pid=S1415-

65552015000100003\&lng=en\&nrm=iso>. Acesso em: 04 fev. 2019.

JORDAO, R. V. D. Práticas de gestão da informação e do conhecimento em pequenas e médias empresas organizadas em rede: um estudo multicasos na indústria brasileira. Perspectivas em Ciências da Informação, Belo Horizonte, v. 20, n. 3, p. 178-199, Set. 2015. Disponível em: $<$ <ttp://www.scielo.br/scielo.php?script=sci_arttext\&pid=S1413-

99362015000300178\&lng=en\&nrm=iso>. Acesso em:18 Jan.2019.

http://dx.doi.org/10.1590/1981-5344/1737.

KLEIN, L. L; PEREIRA, B. A. D. Contribuições para a gestão de redes interorganizacionais: fatores determinantes para a saída de empresas parceiras. REAd. Rev. eletrôn. adm. (Porto Alegre), Porto Alegre, v. 20, $\quad$ n. 2, p. 305-340, 2014. Disponível em: <http://www.scielo.br/scielo.php?script=sci_arttext\&pid=S141323112014000200305\&lng=en\&nrm= iso>. Acesso em: 04 fev. 2019.

KUNZLER, M. T; BULGACOV, S. As estratégias competitivas e colaborativas e os resultados individuais e coletivos no associativismo rural em Quatro Pontes (PR). Rev. Adm. Pública, Rio de Janeiro, v. 45, n. 5, p. 1363-1393, Out. 2011.

Disponível

em:<http://www.scielo.br/scielo.php?script=sci_arttext\&pid=S003476122011000500006\&lng=en\&n rm=iso>. Acesso em: 24 jan. 2019.

LAVILLE, C; DIONNE, J. A construção do saber: manual de metodologia da pesquisa em ciências humanas. Adaptação da obra: Lana Mara Siman. Porto Alegre: Artmed. 1999. 
LIMA, F. A. X; VARGAS, L. P. Alternativas socioeconômicas para os agricultores familiares: o papel de uma associação agroecológica. Rev. Ceres, Viçosa, v. 62, n. 2, p. 159-166, 2015. Disponível em: $<$ http://www.scielo.br/scielo.php?script=sci_arttext\&pid=S0034737X2015000200159\&lng=en\&nrm= iso>. Acesso em: 01 Fev.2019.

NEIVA, E. R; PANTOJA, M. J. Redes sociais e mudança em um grupo de produtores rurais do planalto central. Revista Psicologia: Organizações e Trabalho, Florianópolis, v. 8, n. 1, p. 5-24, dez. 2008. ISSN 1984-6657. Disponível em: <https://periodicos.ufsc.br/index.php/rpot/article/view/9067>. Acesso em: 05 jan. 2019.

PIGATTO, G. A. S; QUEIROZ, T. R.; LOURENZANI, A. E. B. S. Redes sociais de produtores de mandioca em regiões do estado de São Paulo. Interações (Campo Grande), Campo Grande, v. 16, n. 1, p.7586,jun. 2015. Disponível em: http://www.scielo.br/scielo.php?script=sci_arttext\&pid=S1518$70122015000100007 \&$ Ing=en\&nrm=iso>. Acesso em: 25 jan. 2019.

RIBEIRO, E. M. B. de A; BASTOS, A. V. B. Redes sociais interorganizacionais na efetivação de projetos sociais. Psicologia \& Sociedade, Florianópolis, v. 23, n. 2, p. 282-292, Ago. 2011. Disponível em: http://www.scielo.br/scielo.php?script=sci_arttext\&pid=S0102-

71822011000200009\&lng=en\&nrm=iso>. Acesso em: 18 Jan. 2019.

ROTH, A. L. et al. Diferenças e inter-relações dos conceitos de governança e gestão de redes horizontais de empresas: contribuições para o campo de estudos. Rev. Adm. (São Paulo), São Paulo, v. 47, n. 1, p. 112-123, 2012. Disponível em: <http://www.scielo.br/scielo.php?script=sci_arttext\&pid=S0080$21072012000100009 \&$ Ing=en\&nrm=iso $>$. Acesso em: 18 jan. 2019.

SILVA, G. M.; NEVES, J. A. B. Divisão do trabalho social e arranjos produtivos locais: reflexos econômicos de efeitos morais de redes interorganizacionais. RAM, Rev. Adm. Mackenzie, São Paulo, v. 14, n. 1, p. 202-228, Fev. 2013. Disponível

em:<http://www.scielo.br/scielo.php?script=sci_arttext\&pid=S167869712013000100009\&Ing=en\&n rm=iso>. Acesso em: 18 jan. 2019.

VIEIRA, S. R. F. Redes sociais no contexto de mudança organizacional. 2008. Dissertação (Mestrado em Psicologia Social, do Trabalho e das Organizações) - Instituto de Psicologia, Universidade de Brasília, Brasília. Disponível em: <http://repositorio.unb.br/handle/10482/8316>. Acesso em: 01 jan. 2019.

WEGNER, D; PADULA, A. D. Quando a cooperação falha: um estudo de caso sobre o fracasso de uma rede interorganizacional. RAM, Rev. Adm. Mackenzie, São Paulo, v. 13, n. 1, p. 145- 171, Fev. 2012. Disponível em: <http://www.scielo.br/scielo.php?script=sci_arttext\&pid=S1678$69712012000100007 \&$ Ing=en\&nrm=iso>. Acesso em 28 Jan. 2019.

YAMAUCHI, F. A gestão de pessoas no setor do agronegócio: um estudo sobre produtores de amendoim da região da Alta Paulista. 2017. Dissertação (Mestrado em Agronegócio) - Programa de Pós-Graduação em Agronegócio e Desenvolvimento, Universidade Estadual Paulista "Júlio de Mesquita Filho", Tupã. Disponível em: < https://repositorio.unesp.br/handle/11449/151079>. Acesso em: 05 fev. 2019. 
ZANCAN, C. et al. Condicionantes de consolidação de redes de cooperação interorganizacional: um estudo de caso sobre o Rio Grande do Sul. Rev. Adm. Pública, Rio de Janeiro, v. 47, n. 3, p. 647-669, 2013. Disponível

em:<http://www.scielo.br/scielo.php?script=sci_arttext\&pid=S003476122013000300006\&lng=en\&n rm=iso>. Acesso em: 31 jan. 2019. 


\section{Capítulo 24}

\section{CONSUMO ENERGÉTICO E EMISSÃO DE CO2 DO AGRONEGÓCIO DE MATO GROSSO DO SUL}

DOI: $10.37423 / 200300444$

Daniela Teixeira Dias - danielateixeiradias@hotmail.com

Mayra Batista Bitencourt Fagundes - bitencourtmayra@gmail.com

Leonardo Francisco Figueiredo - Iffneto@gmail.com

RESUMO: Admite-se que o agronegócio é uma das principais atividades do Mato Grosso do Sul. Essa atividade se demonstra como essencial a oferta de bens e serviços, diante dos desafios do crescimento populacional e com ele as preocupações ambientais. Dentre essas preocupações estão aquelas voltadas as emissões de CO2 pelo consumo energético. Assim, o objetivo deste artigo consiste em mensurar o consumo energético e emissão de CO2 do agronegócio de Mato Grosso do Sul. Para tanto utilizou-se o método quantitativo de pesquisa, a partir da matriz híbrida convencional para o Estado de Mato Grosso do Sul, advinda de dados do Balanço Energético e da Matriz Insumo-Produto estadual. Os principais resultados indicaram um consumo energético significativo, principalmente, do setor de transportes, em decorrência do escoamento dos produtos agropecuários pelas rodovias. Havendo dessa forma consumo de diesel, apesar disso, as maiores emissões de $\mathrm{CO} 2$, não ocorrem pelo consumo de fontes secundárias, mas pelo consumo de fontes primárias de energia, como pela queima de lenha e de bagaço de cana. Outros setores marcados pelo consumo energético e de emissão de $\mathrm{CO} 2$ foi a agricultura e a indústria de alimentos e bebidas. Cabe ressaltar assim, que a partir de informações como essas, há contribuições para as tomadas de decisões, tais como voltadas a tecnologias de energia limpa e metas de redução dos setores que mais poluem.

Palavras-chave: Requerimentos de energia; externalidade negativa; consumo setorial. 


\section{INTRODUÇÃO}

As questões ambientais, nos últimos anos, demonstram-se como desafios ao desenvolvimento e crescimento econômico mundial. De modo que, diante da projeção de crescimento populacional e com ela a necessidade de aumentar a oferta de bens e serviços, esses desafios tendem a se ampliarem.

No que se refere a oferta de bens e serviços, admite-se que desde a formação de Mato Grosso do Sul, o Estado possui sua vocação econômica voltada a produtos oriundos do agronegócio. A pecuária, extração vegetal, agricultura, indústria de alimentos e bebidas compõem suas principais bases para o desenvolvimento econômico (SEADE, 2001; FAGUNDES, 2012). Somente o PIB da agropecuária representa 15,44\% do PIB total de Mato Grosso do Sul (IBGE, 2013). Quando consideradas as indústrias e serviços originados da agropecuária, esse percentual se torna ainda mais significativo (FAGUNDES, 2012).

Sabe-se também que para que essas atividades se desenvolvam, há necessidade de energia. 0 consumo de energia emite CO2, conforme informações da SEEG (2015), no Estado, 57\% das emissões de gases do efeito estufa se concentram na agropecuária, $27 \%$ na mudança de uso da terra e floresta e $13 \%$ no setor de energia.

As emissões de $\mathrm{CO} 2$ são entendidas como geração de externalidade negativa, ao estarem associadas as mudanças climáticas e, consequentemente a danos na saúde humana, vegetação, escassez de recursos naturais, dentre outros temas em discussão na ONU (2016). De acordo com Collis e Jones (1998), entende-se por externalidade negativa a superação do custo privado pelo social, fato que implica dizer que o custo decorrente das questões ambientais tende a superar o custo da produção privada de cada setor.

Logo, questiona-se: Quais os setores do agronegócio que mais consomem energia e aqueles que mais emitem CO2? Para tanto, utilizou-se o método quantitativo de pesquisa, a partir da matriz híbrida convencional para o ano de 2010. Apesar dessas informações para o ano de 2010, as mesmas são válidas, uma vez que de acordo com Leontief (1983) as estruturas setoriais tendem a se alterarem a partir de cinco anos.

A matriz híbrida surgiu como uma extensão das técnicas de mensuração quantitativa da matriz insumo-produto e de informações do Balanço Energético Nacional (BEN). Nela, demonstram-se os fluxos energéticos e de CO2 entre os setores da economia (MILLER; BLAIR, 2009). 
Assim, tem-se como objetivo neste artigo, mensurar o consumo energético e emissão de CO2 do agronegócio de Mato Grosso do Sul. Cabe ressaltar que este artigo é originado da dissertação intitulada como: “Construção da matriz híbrida: Uma proposição para o agronegócio de Mato Grosso do Sul".

Isto porque, a partir do conhecimento, de acordo com CBPP - Center on Budget and Policy Priorities (2015), podem haver estímulos a políticas públicas voltadas a adoção de tecnologias de energia limpa e eficiência energética, a partir de parcerias público privada. Outro exemplo é o conhecimento do governo sobre a emissão de $\mathrm{CO} 2$, para que estabeleça metas de redução aos setores que mais poluem. Nas empresas, tecnologias que permitam menor emissão de $\mathrm{CO} 2$ na produção, podem ser valorizados por demandantes que se interessam pelas questões ambientais.

\section{MATRIZ HÍBRIDA: PRESSUPOSTOS TEÓRICOS E AVANÇOS}

Na matriz híbrida se conciliam tabelas com dados obtidos de especialistas, que possuem fontes de dados primárias e secundárias confiáveis, constituintes da MIP (matriz insumo-produto), como proposto por Leontief (1983), bem como do balanço energético (MILLER; BLAIR, 2009).

A matriz insumo-produto fornece um "retrato" da realidade econômica de uma região e a partir dessas informações são possíveis mensurações dos setores-chaves na geração de produto, emprego e renda; dos efeitos multiplicadores de um setor sobre os demais da economia; de elasticidade, em termos de sensibilidade de cada setor, em função de alterações na demanda final; o tamanho e o quanto de influência um setor exerce sobre outro (MILLER; BLAIR, 2009).

As relações fundamentais insumo produto foram descritas na Figura 1, em que se observa os insumos intermediários entre os setores compradores e vendedores da economia; a demanda final descrita pelo consumo, investimento (formação bruta de capital fixo), gasto do governo e exportações; os impostos indiretos; as importações diante de necessidades do abastecimento interno; e o valor adicionado representado pelas remunerações. 
Figura 1: Relações Fundamentais de Insumo Produto.

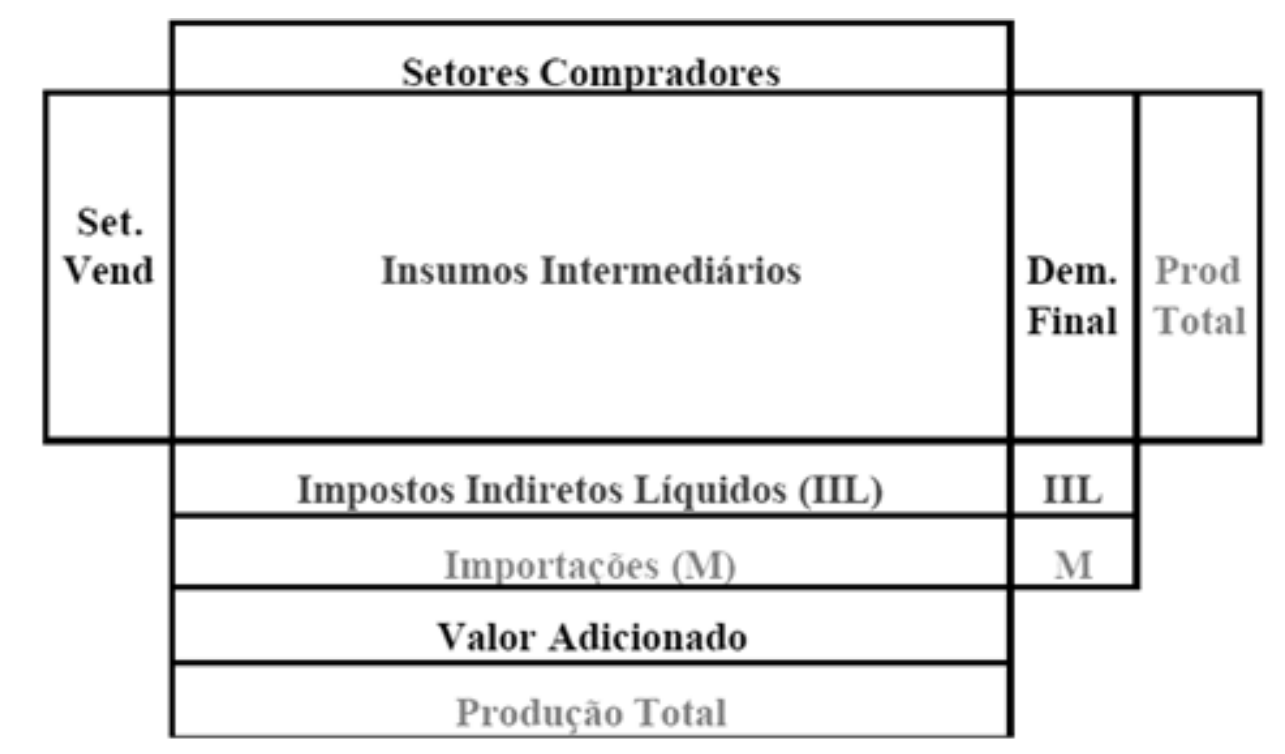

Fonte: Guilhoto (2004, p. 14).

No que se refere ao balanço energético, a Agência Internacional de Energia (AIE) teve um papel importante nesse processo, ao fomentar a cooperação internacional, segurança energética e fortalecimento energético. A partir dessa agência, outros institutos se formaram tais como: EUROSTAT (Gabinete de Estatísticas da União Europeia), OLADE (Organização Latino-americana de energia) e EPE (Empresa de Pesquisa Energética). Institutos esses voltados também a elaboração dos balanços energéticos. Essa elaboração, porém se difere pelos métodos aplicados.

O Brasil segue aos critérios da OLADE e os resultados advêm do Ministério de Minas e Energia (2015), por meio da Empresa de Consumo Energético. No caso de Mato Grosso do Sul, o Balanço Energético segue aos critérios brasileiros e sua formulação cabe a Secretaria de Estado de Infraestrutura e Governo de Estado (2014).

Independente da região o balanço é visualizado para 18 setores da economia: agropecuária; cimento; ferro-gusa e aço; ferro-ligas; mineração e pelotização; química; não-ferrosos e outros da metalurgia; têxtil; alimentos e bebidas; papel e celulose; cerâmica; outras indústrias; energético; comercial; público; residencial; transportes e serviços.

Admite-se que alguns dos algoritmos produzidos para as tabelas de matriz insumo-produto híbrida foram constituídos por Lahr (1998), ao comparar a sensibilidade da Inversa de Leontief (ver procedimentos metodológicos) a mudanças tecnológicas dos setores. Para cada setor considerado 
crítico ou de interesse, Lahr sugeriu buscar insumos e produtos intermediários, renda do trabalho e embarques intra-setoriais. Conciliando para tanto, diversas fontes de dados, até que fossem esgotadas todas as possibilidades. Diante da necessidade de maior detalhamento, começaram-se os algoritmos de entradas e saídas regionais híbridas para Washington (LAHR, 1998).

Isto ocorre, porque como já indagado por Rasmussen (1956), observam-se relações de dependência entre os setores da economia. De modo que segundo Casler (1997), as questões ambientais começaram a serem tratadas na MIP, por meio de mensurações, tais como das poluições medidas em emissões totais por dólar de produção para os setores da economia.

Essas emissões de CO2 são entendidas como geração de externalidade negativa. De acordo com Harris e Roach (2007), estão relacionados ao conceito de externalidades, os custos sociais. Assim, as externalidades são falhas de mercado, que afetam terceiros, positivamente ou negativamente, pela ação empreendida por outros indivíduos (SOBEL, 2003). No caso da emissão de CO2, negativamente, de modo que o verdadeiro custo econômico não se reflete nos preços, mas nos altos custos ambientais e sociais, envolvendo várias gerações (WORLD, BANK, 2016).

Logo, as externalidades negativas ocorrem, quando os custos sociais indiretos superam os benefícios privados. Nesses custos indiretos estão: diminuição da qualidade de vida, custos com a saúde e prejuízo ao desenvolvimento de outras atividades econômicas, como o turismo (FMI, 2012).

Sobre os custos sociais, Coase (1960, p.2, TRADUÇÃO NOSSA) admite que sempre ocorrerão e argumentou: "Será que haveria uma permissão de A para prejudicar B ou deveria B ser autorizado a prejudicar A?" A melhor solução para essa questão seria sempre evitar danos mais sérios, logo a necessidade de estratégias que visem a amenização desses danos.

Sabe-se ainda que o setor de energia viabiliza o desempenho da maioria dos outros setores da economia, seja para o funcionamento de máquinas, equipamentos, fornalhas, refrigeração ou mesmo para o transporte, saúde, agricultura, educação, dentre outros (SEEG, 2014; 2015), questiona-se: o setor energético, pode atuar de forma sustentável no crescimento econômico? O crescimento econômico e a proteção ambiental são metas conflitantes ou complementares? (FAO, 2016).

Logo, a matriz híbrida trata dos aspectos ambientais a partir da matriz insumo-produto. Apesar da MIP possuir pressupostos mais rígidos, a matriz híbrida se apresenta como um relaxamento das noções 
neoclássicas, ao incorporar na racionalidade econômica a racionalidade ambiental (MILLER; BLAIR, 2009).

Nesse relaxamento, está a combinação de unidades monetárias, provenientes da MIP, com unidades físicas de consumo do balanço energético (Figura 2). As construções das matrizes híbridas podem se estender para uma unidade federativa, país, entre países. (MILLER; BLAIR, 2009).

Figura 1: Composição da matriz híbrida.

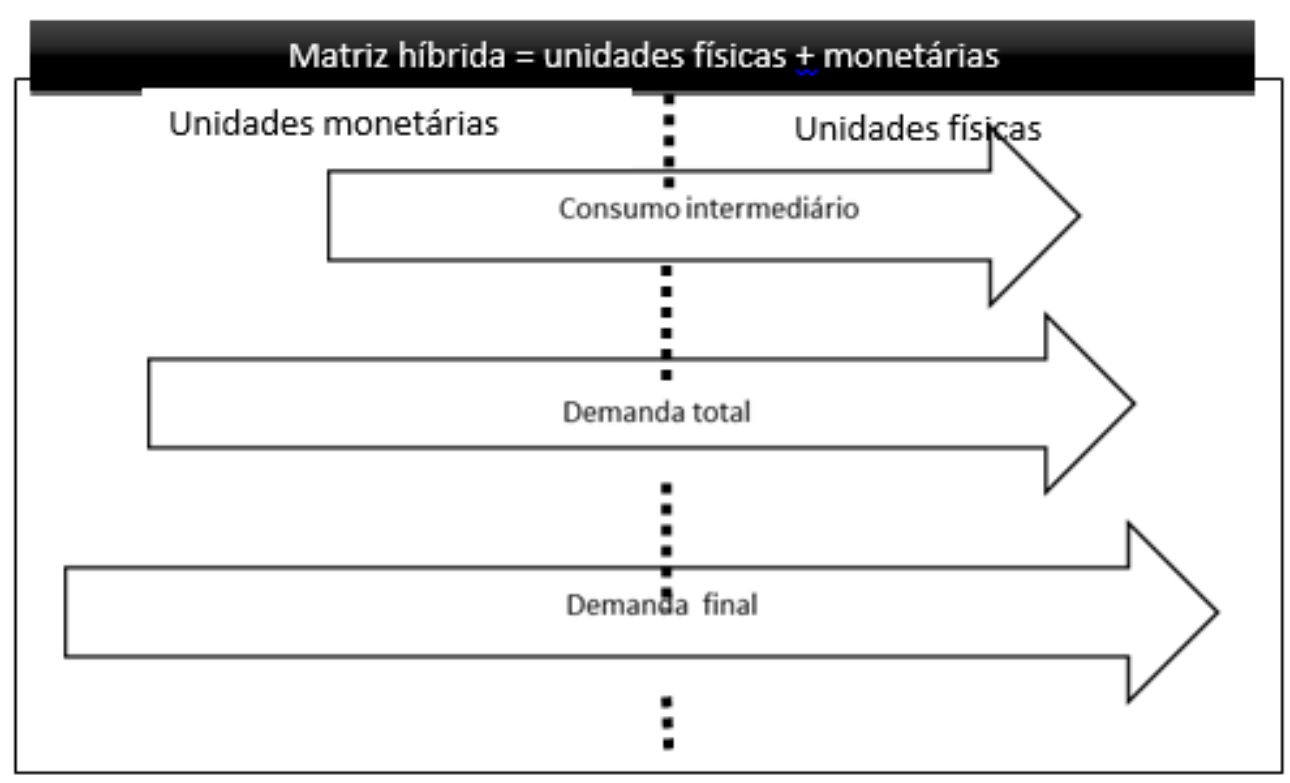

Fonte: elaborado a partir de Miller e Blair (2009).

Coube a Bullard e Heredden (1975) descrever um método para o cálculo do custo da energia. Por custo de energia, o autor fez referência a toda energia fóssil, híbrida e nuclear consumida. Logo um quadro foi desenvolvido, contendo registros de transações entre setores, os fluxos energéticos, definidos como intensidades energéticas expressas em unidades monetárias.

A matriz híbrida é uma das técnicas mais consistentes para a mensuração da matriz insumo-produto, com fluxos energéticos (BULLARD; HEREDEEN, 1975; CASLER; BLAIR, 1997; MILLER; BLAIR, 2009).

Esses fluxos energéticos foram definidos por Bullard (1974), Miller e Blair (2009) como requerimentos de energia necessários para viabilizar a produção das atividades econômicas. Tais requerimentos são incorporados a produção diretamente e indiretamente. Juntos, correspondem aos requerimentos totais, que são transformados em fluxos de $\mathrm{CO} 2$. 
Considerando o exemplo da soja em grão (Figura 3), o requerimento direto dessa soja se voltaria a energia utilizada na produção de soja, e a energia incorporada pelo processo de produção constituiria o requerimento indireto, proveniente da fabricação de fertilizantes e inseticidas em outras indústrias.

Figura 2: Composição dos requerimentos de energia para a soja.

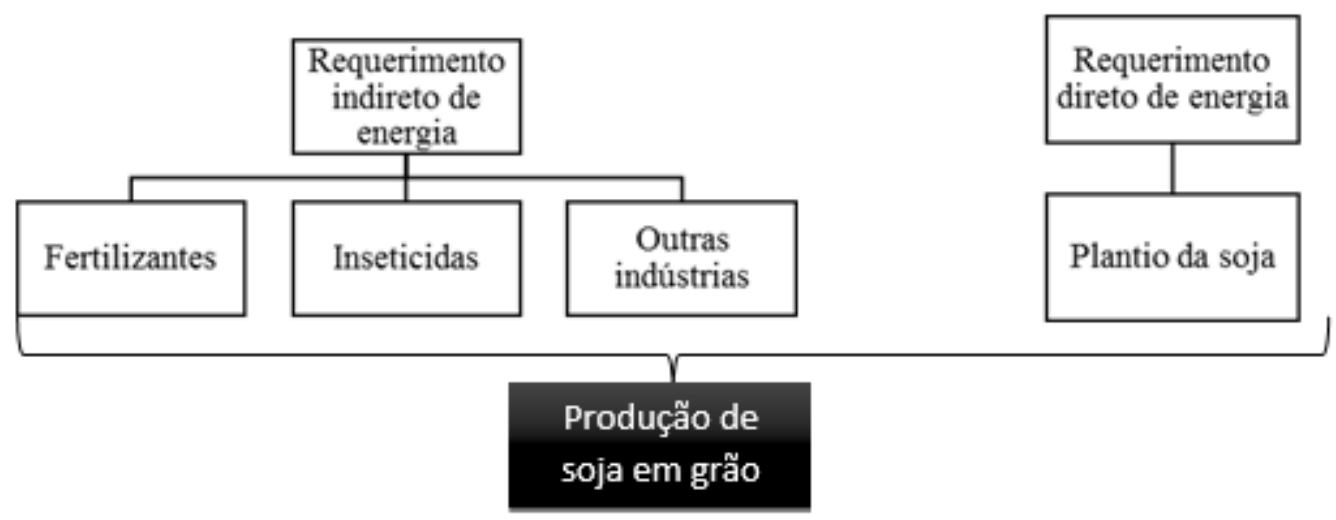

Fonte: elaborado a partir de Miller e Blair (2009).

Assim, para que haja requerimento de energia, setores precisam fornecer energia (Figura 4). Essas fontes de energia foram definidas pelo BEN (2015) como fontes primárias e secundárias e que resultam na emissão de CO2. Entende-se por fontes primárias: lenha; bagaço de cana; carvão vegetal; álcool etílico; outras fontes primárias renováveis. As fontes secundárias seriam descritas por: óleo diesel; óleo combustível; gás liquefeito de petróleo; nafta querosene; eletricidade; gasolina automotiva; gasolina de avião; outras energias secundárias de petróleo (coque de petróleo e outras não especificadas). 
Figura 3: Consumo de energia e emissão de $\mathrm{CO} 2$, por fonte de energia e setor da economia.

\begin{tabular}{|l|l|l|l|l|}
\hline Fontes/setores & Agropecuária & Álcool & Alimentos e bebidas & Papel e celulose \\
\cline { 1 - 2 } Primárias & \multicolumn{3}{|c|}{ Consumo energético } \\
\cline { 1 - 2 } Secundária & \\
\cline { 1 - 2 }
\end{tabular}

\begin{tabular}{|l|l|l|l|l|}
\hline Fontes/setores & Agropecuária & Álcool & Alimentos e bebidas & Papel e celulose \\
\cline { 1 - 4 } Primárias & \multicolumn{3}{|c|}{ Emissões de $\mathrm{CO}_{2}$} \\
\cline { 1 - 3 } Secundária & & \multicolumn{3}{|c|}{} \\
\hline
\end{tabular}

Fonte: elaborado a partir de Miller e Blair (2009).

Nesse sentido, assim como na matriz insumo-produto, a matriz híbrida é composta pelo consumo intermediário, pela demanda final, exportações para outros estados e outros países que são oriundas da produção que utilizou energia, também pelo consumo das famílias e formação bruta de capital fixo, como observado na Figura 5.

Figura 4: Esquematização da matriz insumo-produto híbrida.

\begin{tabular}{|c|c|c|c|c|c|c|c|}
\cline { 2 - 7 } \multicolumn{1}{c|}{} & $\begin{array}{c}\text { Uso } \\
\text { intermediário }\end{array}$ & \multicolumn{5}{c|}{ Uso final } & \multicolumn{2}{c|}{ Uso total } & \multicolumn{1}{c|}{ Produtos } \\
\hline $\begin{array}{c}\text { Setores } \\
\text { energéticos }\end{array}$ & $\begin{array}{c}\text { Consumo das } \\
\text { famílias }\end{array}$ & $\begin{array}{c}\text { Exportações } \\
\text { para outros } \\
\text { Estados }\end{array}$ & $\begin{array}{c}\text { Exportações } \\
\text { para outros } \\
\text { países }\end{array}$ & $\begin{array}{c}\text { Formação } \\
\text { bruta de } \\
\text { capital fixo }\end{array}$ & $\begin{array}{c}\text { Demanda } \\
\text { total }\end{array}$ & Importação & Produto \\
\hline $\begin{array}{c}\text { Fontes } \\
\text { energéticas }\end{array}$ & I & \multicolumn{2}{|c|}{ II } & III & IV & V \\
\hline
\end{tabular}

Fonte: Adaptado de Mayer (2007).

Pela ótica do produto, em I, demonstra-se o consumo intermediário, em que setores precisam consumir energia para viabilizarem suas produções, para que haja esse consumo, há necessidade que outros setores forneçam essa energia. As produções finais se voltam ao consumo final, esse consumo final se apresenta em II sob a forma de consumo das famílias, exportações para outros Estados e países e formação bruta de capital fixo. Para atender esse consumo, a produção consome energia diretamente e indiretamente.

A demanda total de III, nessas circunstâncias, é a soma de I com II. Pode-se dizer contudo, que quando demanda-se mais energia do que se oferta, ocorrem as importações representadas em IV, isto de modo a igualar a oferta a demanda em $\mathrm{V}$. 
A matriz híbrida já foi construída em alguns países e unidades federativas brasileiras. Dentre essas construções destacam-se da China (LINDNER, GUAN, 2014), Alemanha (MAYER, 2007), Espanha (ALCÁNTARA, PADILLA, 2003), Portugal (CRUZ, 2002), Índia (PAL, PAL, PAL, 2011), Pernambuco (ARAÚJO, 2009), São Paulo e Brasil (FIRME, PEROBELLI, 2012).

Observa-se um consenso entre esses autores no que tange a importância do entendimento para as tomadas de decisões e estratégias políticas, mas a realidade de cada Nação se diferencia. Além de impactos diferenciados, os setores-chaves do consumo energético e consequentemente da emissão de $\mathrm{CO}_{2}$, também se diferenciam, como na China. De acordo com Lindner e Guan (2014), a China é marcada por uma representação significativa das indústrias de produtos minerais, produtos químicos, fundição e prensagem, de modo que com essas indústrias ocorre uma elevada utilização de carvão.

Na Espanha os principais destaques foram: o transporte doméstico e o setor de construção civil (ALCÁNTARA; PADILLA, 2003). No caso da Índia, principalmente, a agropecuária, os serviços e indústrias associados a ela foram os destaques do consumo energético, que diante dessas circunstâncias, observou-se um consumo significativo de energia de fonte primária (SHUKLA, 2007). No que se refere a Pernambuco, há semelhanças ao cenário brasileiro e de São Paulo, uma vez que dentre os setores que mais consomem energia estão o siderúrgico e de transportes, as diferenças nessas circunstâncias ocorreriam nas proporções e nas suas próprias peculiaridades.

\section{PROCEDIMENTOS METODOLÓGICOS}

A fim de atender ao objetivo proposto, foram traçados os procedimentos metodológicos, que implicam nos meios, pelos quais a pesquisa será desenvolvida. A partir do qual definiu-se o método quantitativo de pesquisa. Essa natureza quantitativa pode ser entendida de acordo com Creswell (2007), como técnicas de pesquisa que tentam responder hipóteses a partir de variáveis, ou de uma forma geral dados objetivos que permitam por meio da validade e confiabilidade fazer alegações de conhecimento que resultem nas interpretações dos dados.

Enquanto base dados foi utilizada a matriz insumo-produto (2010) e o balanço energético da Secretaria de Estado de Infraestrutura e Governo de Estado (2010). Havendo padronização dessas fontes de informação para o ano de 2010, devido a disponibilidade da MIP.

\subsection{MATRIZ INSUMO-PRODUTO: INTERPRETAÇÃO MATEMÁTICA}


Para a construção da matriz insumo-produto (MILLER; BLAIR, 2009), considera-se algumas identidades:

1) $\mathrm{X}=\mathrm{Cl}+\mathrm{x}^{\prime}$

Em que, X:Produção; $\mathrm{Cl}$ : Consumo Intermediário; $x^{\prime}$ : Valor adicionado.

2) $\mathrm{X}=\mathrm{Cl}+\mathrm{Y}-\mathrm{M}$

Sendo, X: Produção; Cl: Consumo Intermediário; Y: Demanda Final; M: Importações.

3) $x^{\prime}=\sum R$

Logo, $\mathrm{x}^{\prime}=$ Valor adicionado; $\sum \mathrm{R}=$ Somatória das rendas.

O equilíbrio ocorre pela igualdade entre a oferta e demanda, ou origem e destino. De modo que a razão dos insumos consumidos por cada setor para viabilizarem suas produções, determinam os coeficientes técnicos de produção. Segundo Guilhoto e Sesso (2005) esses coeficientes são descritos por:

$a_{i j}=g_{i j} / g_{j}$

$\mathrm{a}_{\mathrm{ij}}=$ Coeficiente técnico;

$\mathrm{g}_{\mathrm{ij}}=$ Fluxos intersetoriais;

$\mathrm{g}_{\mathrm{i}}=$ Produção total.

Representados em uma economia composta por dois setores:

$$
\mathrm{A}=\left(\begin{array}{ll}
\mathrm{a} 11=\mathrm{g} 11 / \mathrm{g} 1 & \mathrm{a} 12=\mathrm{g} 12 / \mathrm{g} 2 \\
\mathrm{a} 21=\mathrm{g} 21 / \mathrm{g} 1 & \mathrm{a} 22=\mathrm{g} 22 / \mathrm{g} 2
\end{array}\right)
$$

É como se admitisse que para cada uma unidade monetária produzida pelo setor de alimentos e bebidas, houvesse a necessidade de consumo de insumo do setor agropecuário de 0,4 unidade monetária e do próprio setor de 0,1. Os 0,5 restantes se destinam as formas de remuneração e necessidades de importações.

Segundo Miller e Blair (2009) a função de produção de Leontief é uma aproximação da produção clássica, onde cada segmento possui uma produção limitada por combinações de insumos destinados a produção. Considerando os coeficientes técnicos (aij) e a quantidade efetivamente produzida (gj), assume-se, que:

$$
\begin{gathered}
g 1=a 11 g 1+\cdots+a 1 i g i+\cdots+a 1 n g n+f 1 \\
\cdots \\
g i=a i 1 g 1+\cdots+a i i g i+\cdots+\text { aingn }+f i
\end{gathered}
$$




$$
g n=\operatorname{an} 1 g 1+\cdots+\text { anigi }+\cdots+\text { anngn }+f n
$$

A matriz A seria a de coeficientes técnicos. De modo que para se obter a matriz inversa de Leontief, parte-se de:

$L=(I-A)^{-1}$

De modo que, L: matriz inversa de Leontief; I: matriz identidade; A: matriz de coeficientes técnicos.

\subsection{CONSTRUÇÃO DA MATRIZ HÍBRIDA}

Para a construção da matriz híbrida, utilizou-se como principais referências Miller, Blair (2009), Moura Filho (2014), Figueiredo, Araújo Júnior e Perobelli (2009). Assim, o primeiro procedimento para essa construção foi a coleta de dados secundários, provenientes da matriz insumo-produto, balanço energético e conversores de TEP. Entende-se por TEP toneladas equivalentes de petróleo, a principal unidade utilizada para o consumo físico de energia, conforme indicações de Miller e Blair (2009).

A partir disso, o segundo procedimento foi então de organização dos dados. Nessa organização, os consumos energéticos setoriais foram dispostos por fonte de energia. Fizeram parte dessa organização, 14 setores: Agropecuária; Energético; Outras indústrias; Alimentos e bebidas; Têxteis; Celulose e produtos de papel; Químicos; Mineração e pelotização; Ferro gusa e aço; Não ferrosos e outros da metalurgia; Comercial; Transportes; Público; Serviços.

Setores esses descritos em conformidade com as fontes de energia: Óleo Diesel; Óleo Combustível; Gás Liquefeito de Petróleo; Nafta Querosene; Gás de Coqueria; Gás Canalizado; Gás da Cidade; Carvão vegetal; Carvão vegetal e lenha; Carvão metalúrgico; Carvão metalúrgico; Coque de C. Mineral/Alcatrão; Eletricidade; Gasolina automotiva; Gasolina de avião; Querosene de avião; Álcool Etílico; Coque de petróleo; Outras Secundária de Petróleo; Outras Não-Especificadas.

Cabe ressaltar, que após essa estruturação, percebeu-se que algumas fontes de energia não eram consumidas pelos setores econômicos de Mato Grosso do Sul. Assim, das 25 fontes, apenas 13 foram selecionadas. De acordo com as características dessas fontes, originaram-se 3 categorias de agrupamento representadas pela agropecuária, outros da indústria e energia (quadro 1). 
Tabela 1: Fontes de energia utilizadas para a construção da matriz híbrida.

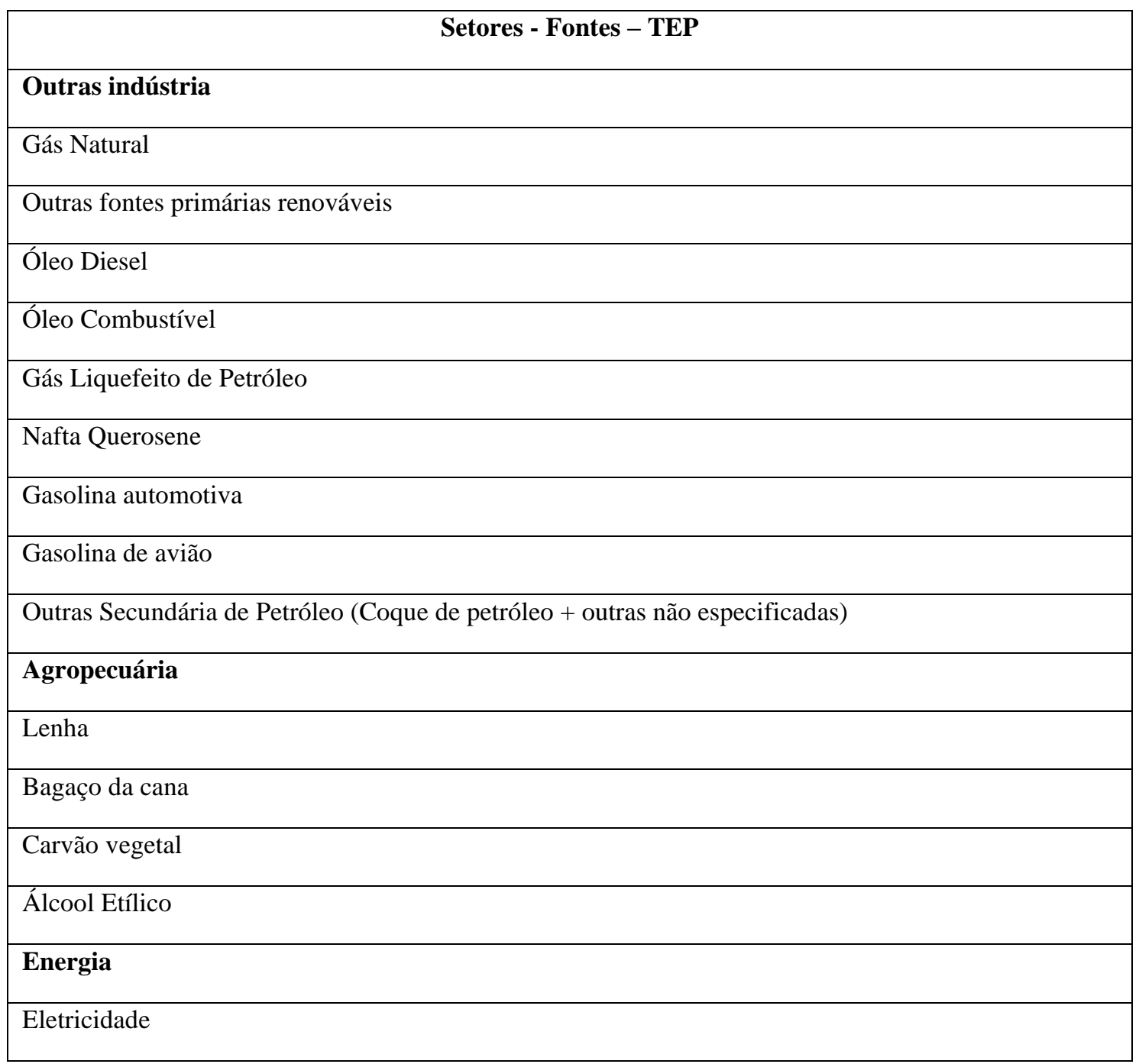

Fonte: Adaptado de Miller e Blair (2009).

A formação das categorias (outros da indústria, agricultura e energia) foi necessária para que posteriormente durante a construção da matriz híbrida, esses grupos de fontes energéticas fossem correspondentes aos mesmos três setores da matriz insumo-produto. A partir dessa etapa foi formada a matriz E 3 (fontes $=\mathrm{m}) \times 15$ (setores $=\mathrm{n}$ ) de consumo energético em TEP.

$$
\mathrm{E}=\left[\begin{array}{l}
\mathrm{TEP}_{1,1} \mathrm{TEP}_{1,2} \ldots \mathrm{TEP}_{1,15} \\
\mathrm{TEP}_{2,1} \mathrm{TEP}_{2,2} \ldots \mathrm{TEP}_{2,15} \\
\mathrm{TEP}_{3,1} \mathrm{TEP}_{3,2} \ldots \mathrm{TEP}_{3,15}
\end{array}\right]
$$

Exemplificando, tem-se a matriz E como: 
Tabela 2: Matriz E.

\begin{tabular}{|l|c|c|c|c|c|}
\hline \multicolumn{1}{|c|}{ Fontes/Setores } & 1 Agropecuária & $\mathbf{2}$ Energia & $\begin{array}{c}\text { 3 Outras } \\
\text { indústrias }\end{array}$ & $\mathbf{\cdots}$ & $\mathbf{1 5}$ Serviços \\
\hline 1 Agropecuária & $\mathrm{TEP}_{1,1}$ & $\mathrm{TEP}_{1,2}$ & $\mathrm{TEP}_{1,3}$ & $\cdots$ & $\mathrm{TEP}_{1,15}$ \\
\hline 2 Energia & $\mathrm{TEP}_{2,1}$ & $\mathrm{TEP}_{2,2}$ & $\mathrm{TEP} 2_{, 3}$ & $\cdots$ & $\mathrm{TEP}_{2,15}$ \\
\hline 3Outras indústrias & $\mathrm{TEP}_{3,1}$ & $\mathrm{TEP}_{3,2}$ & $\mathrm{TEP}_{3,3}$ & $\cdots$ & $\mathrm{TEP}_{3,15}$ \\
\hline
\end{tabular}

Fonte: Miller e Blair (2009).

Diante disso, a próxima etapa então permeou a compatibilização dos setores da matriz energética com os da matriz insumo-produto. Para tanto, agrupou-se os 32 setores da MIP nos 14 correspondentes da matriz energética. Alguns setores da matriz energética que não foram visualizados na MIP foram inseridos ao setor de outras indústrias. Essas adaptações ocorreram para os setores de cerâmica, cimento e ferro-ligas. Logo:

-Agropecuária: Agricultura, silvicultura, exploração mineral; Pecuária e pesca;

-Ferro-Gusa: Fabricação de aço e derivados;

-Química: Produtos químicos; Álcool;

-Não-Ferrosos e outros da metalurgia: Produtos de metal, exclusive máquinas e equipamentos;

-Alimentos e bebidas: Alimentos e Bebidas Alimentos e Bebidas;

-Papel e Celulose: Celulose e produtos de papel;

- Têxtil: Têxtil; Artigos de vestuário e acessórios;

- Outras indústrias: Artefatos de couro e calçados; Produtos de maneira, exclusive móveis; Jornais, revistas e discos; Artigos de borracha e plástico; Máquinas e equipamentos, inclusive reparo e manutenção; Máquina, aparelho material elétrico; Outros indústria de transformação; Extrativa mineral; Peças e acessórios automotores; Cimento; Cerâmica; Ferro-Ligas;

- Energético: Produção e distribuição de eletricidade, gás, água, esgoto e limpeza urbana;

-Comercial: Comércio e serviços de manutenção e reparação Comércio e serviços de manutenção e reparação;

-Público: Administração pública; Educação e saúde mercantil;

-Transportes: Transporte, armazenagem e correio;

-Serviços: Serviços de informação; Intermediação financeira, seguros e previdência complementar e serviços relacionados; Serviços de alojamento e alimentação; Serviços prestados às empresas; Outros Serviços; Construção civil; Atividades imobiliárias e aluguéis. 
$\mathrm{Na}$ etapa seguinte, o mesmo procedimento de agrupamento adotado para a construção da matriz $\mathrm{E}$ foi utilizado para a constituição da matriz de consumo intermediário (CEn) da matriz insumo-produto. $\mathrm{CEn}=\left[\begin{array}{l}\mathrm{CEn}_{1,1} * \mathrm{TEP}_{1,1} \ldots \mathrm{CEn}_{1,15} * \mathrm{TEP}_{1,15} \\ \mathrm{CEn}_{2,1} * \mathrm{TEP}_{2,1} \ldots \mathrm{CEn}_{2,15} * \mathrm{TEP}_{2,15} \\ \mathrm{CEn}_{3,1} * \mathrm{TEP}_{3,1} \ldots \mathrm{CEn}_{3,15} * \mathrm{TEP}_{3,15}\end{array}\right]$

Assim:

Tabela 3: Agrupamento da matriz de consumo intermediário.

\begin{tabular}{|l|c|c|c|c|c|}
\hline \multicolumn{1}{|c|}{ Fontes/Setores } & 1 Agropecuária & 2 Energia & 3 Outras indústrias & $\mathbf{\cdots}$ & 15 Serviços \\
\hline $\mathbf{1}$ Agricultura & $\mathrm{CEn}_{1,1}$ & $\mathrm{CEn}_{1,2}$ & $\mathrm{CEn}_{1,3}$ & $\boldsymbol{\cdots}$ & $\mathrm{CEn}_{1,15}$ \\
\hline 2 Energia & $\mathrm{CEn}_{2,1}$ & $\mathrm{CEn}_{2,2}$ & $\mathrm{CEn} 2,3$ & $\cdots$ & $\mathrm{CEn}_{2,15}$ \\
\hline 3Outras indústrias & $\mathrm{CEn}_{3,1}$ & $\mathrm{CEn}_{3,2}$ & $\mathrm{CEn}_{3,3}$ & $\cdots$ & $\mathrm{CEn}_{3,15}$ \\
\hline
\end{tabular}

Fonte: Miller e Blair (2009).

Multiplicando-se a matriz dos coeficientes de conversão (em Gg - gigagrama) pela matriz E, de consumo energético (em TEP), obtém-se a matriz e.

$\mathrm{e}=\left[\begin{array}{l}\mathrm{CEn}_{1,1} * \operatorname{TEP}_{1,1} \ldots \mathrm{CEn}_{1,15} * \operatorname{TEP}_{1,15} \\ \mathrm{CEn}_{2,1} * \operatorname{TEP}_{2,1} \ldots \mathrm{CEn}_{2,15} * \operatorname{TEP}_{2,15} \\ \mathrm{CEn}_{3,1} * \operatorname{TEP}_{3,1} \ldots \mathrm{CEn}_{3,15} * \operatorname{TEP}_{3,15}\end{array}\right]=\left[\begin{array}{l}\mathrm{e}_{1,1} \ldots \mathrm{e}_{1,15} \\ \mathrm{e}_{2,1} \ldots \mathrm{e}_{2,15} \\ \mathrm{e}_{3,1} \ldots \mathrm{e}_{3,15}\end{array}\right]$

Sendo:

Tabela 4: Matriz de emissão de CO2.

\begin{tabular}{|l|c|c|c|c|c|}
\hline \multicolumn{1}{|c|}{ Fontes/Setores } & 1 Agropecuária & 2 Energia & 3 Outras indústrias & ‥ & 15 Serviços \\
\hline 1 Agropecuária & $\mathrm{e}_{1,1}$ & $\mathrm{e}_{1,2}$ & $\mathrm{e}_{1,3}$ & $\ldots$ & $\mathrm{e}_{1,15}$ \\
\hline 2 Energia & $\mathrm{e}_{2,1}$ & $\mathrm{e}_{2,2}$ & $\mathrm{e} 2,3$ & $\ldots$ & $\mathrm{e}_{2,15}$ \\
\hline 3Outras indústrias & $\mathrm{e}_{3,1}$ & $\mathrm{e}_{3,2}$ & $\mathrm{e}_{3,3}$ & $\ldots$ & $\mathrm{e}_{3,15}$ \\
\hline
\end{tabular}

Fonte: Miller e Blair (2009).

Para facilitar os cálculos necessários da construção da matriz híbrida, adotou-se o mesmo ordenamento de setores que da matriz e, considerando as categorias agrupadas de fontes energéticas entre os três primeiros setores.

A partir disso, começou-se a construir a matriz híbrida efetivamente, misturando-se unidades físicas da matriz energética com unidades monetárias da matriz insumo-produto. Primeiramente foi formada 
a matriz $X^{*}(15(m) \times 1)$ que seria a de produção total híbrida, em que as três primeiras linhas da produção total da MIP foram substituídas pelas três de produção total da matriz energética, assim:

$$
\mathbf{x}^{*}=\left[\begin{array}{c}
\mathrm{TEP}_{1,1} \\
\mathrm{TEP}_{2,1} \\
\mathrm{TEP}_{3,1} \\
\mathrm{R} \$_{4,1} \\
\cdots \\
\mathrm{R} \$_{15,1}
\end{array}\right]
$$

O resultado dessa matriz $X^{*}$ foi diagonalizado na matriz identidade. Após isso houve a inversão dessa nova matriz resultante, de modo que:

$$
\begin{gathered}
\text { Diagonal de } x^{*}=\left[\begin{array}{ccccc}
\mathrm{TEP}_{1,1} & 0 & 0 & 0 & 0 \\
0 & \mathrm{TEP}_{2,1} & 0 & 0 & 0 \\
0 & 0 & \mathrm{TEP}_{3,1} & 0 & 0 \\
0 & 0 & 0 & \mathrm{R}_{4,1} & 0 \\
0 & 0 & 0 & 0 & \mathrm{R}_{15,1}
\end{array}\right] \\
\text { Inversa da Diagonal de } x^{*}=\left[\begin{array}{ccccc}
\mathrm{TEP}_{1,1} & 0 & 0 & 0 & 0 \\
0 & \mathrm{TEP} & 0 & 0 & 0 \\
0 & 0 & \mathrm{TEP} & 0 & 0 \\
0 & 0 & 0 & \mathrm{R} \$_{4,1} & 0 \\
0 & 0 & 0 & 0 & \mathrm{R} \$_{15,1}
\end{array}\right] \wedge-1
\end{gathered}
$$

Esse mesmo procedimento foi adotado para a demanda final $\mathbf{Y}^{*}$. Onde as três primeiras linhas da demanda final da MIP foram trocadas pelas três primeiras linhas da demanda final da matriz energética, logo:

$$
\mathrm{Y}^{*}=\left[\begin{array}{c}
T E P_{1,1} \\
T E P_{2,1} \\
T E P_{3,1} \\
R \$_{4,1} \\
\cdots \\
R \$_{15,1}
\end{array}\right]
$$

Seguindo esses raciocínio foi constituída a matriz de consumo intermediário, que levou a formação da matriz Z* $(15(\mathrm{~m}) \times 15(\mathrm{~m}))$, novamente aqui as três primeiras linhas foram substituídas pelas três de consumo energético das categorias: agropecuária, energia e outras indústrias. Desse modo: 


$$
Z^{*}=\left[\begin{array}{cccc}
\operatorname{TEP}_{1,1} \operatorname{TEP}_{1,2} & \ldots & \mathrm{TEP}_{1,15} \\
\mathrm{TEP}_{2,1} \mathrm{TEP}_{2,2} & \ldots & \mathrm{TEP}_{2,15} \\
\mathrm{TEP}_{3,1} \mathrm{TEP}_{3,2} & \ldots & \mathrm{TEP}_{3,15} \\
\mathrm{R} \$_{4,1} & \mathrm{R} \$_{4,2} & \ldots & \mathrm{R} \$_{4,15} \\
& \ldots & \\
\mathrm{R} \$_{15,1} & \mathrm{R} \$_{15,2} & \ldots & \mathrm{R} \$_{15,15}
\end{array}\right]
$$

Para formar a matriz $A^{*}$, semelhante a de coeficientes técnicos da matriz insumo-produto, considerase que:

$$
A^{*}=Z^{*}\left(\hat{x}^{*}\right)^{-1}=\left[\begin{array}{lll}
\text { TEP/TEP } & \text { TEP/R\$ } & \ldots \\
R \$ / T E P & R \$ / R \$ & \ldots
\end{array}\right]
$$

Lembrando que:

Z*: matriz híbrida de consumo intermediário;

$\hat{\mathrm{x}}^{*}$ : matriz híbrida estimada de produção total;

$A^{*}$ : matriz híbrida de coeficientes técnicos.

Após isso foram introduzidas noções referentes aos requerimentos de energia a partir de:

$$
F^{*}=\left[\begin{array}{ccc}
\mathrm{x}_{1} & 0 & 0 \\
0 & \mathrm{x}_{2} & 0 \\
0 & 0 & \mathrm{x}_{3}
\end{array}\right]
$$

Em que $\mathrm{F}^{*}$ representa os fluxos de energia na diagonal principal, sendo os demais elementos zero. Partindo de $F^{*}$, pode-se chegar ao requerimentos de energia totais $(\alpha)$, diretos $(\delta)$ e indiretos $(\gamma)$, representados, respectivamente por:

$$
\begin{aligned}
& \alpha=e F^{*} \widehat{x}^{-1}(I-A)^{-1} \\
& \delta=e F^{*}\left(\widehat{X}^{*}\right)^{-1} A^{*} \\
& \gamma=e^{*}\left(\widehat{X}^{*}\right)^{-1}\left[\left(I-A^{*}\right)^{-1}-A^{*}\right]
\end{aligned}
$$

\section{CONSUMO ENERGÉTICO E EMISSÃO DE CO2 DO AGRONEGÓCIO DE MATO GROSSO DO SUL}

O Mato Grosso do Sul posiciona-se como o 14 (3,50\%) nas emissões totais de CO2 do Brasil, de modo que o setor de energia contribui para tanto ao ocupar o terceira posição nessas emissões, o que equivale a mais de 8 milhões MtCO2e. São destaques do setor de energia nessas emissões, conforme o Gráfico 1: transportes (47,62\%), seguido pela geração de eletricidade $(22,74 \%)$, indústria $(14,66 \%)$ e agropecuária (11,68\%) (SEEG, 2015). 
Gráfico 1: Participação dos subsetores constituintes do setor energia nas emissões de CO2 de Mato Grosso do Sul, em \%, para o ano de 2015.

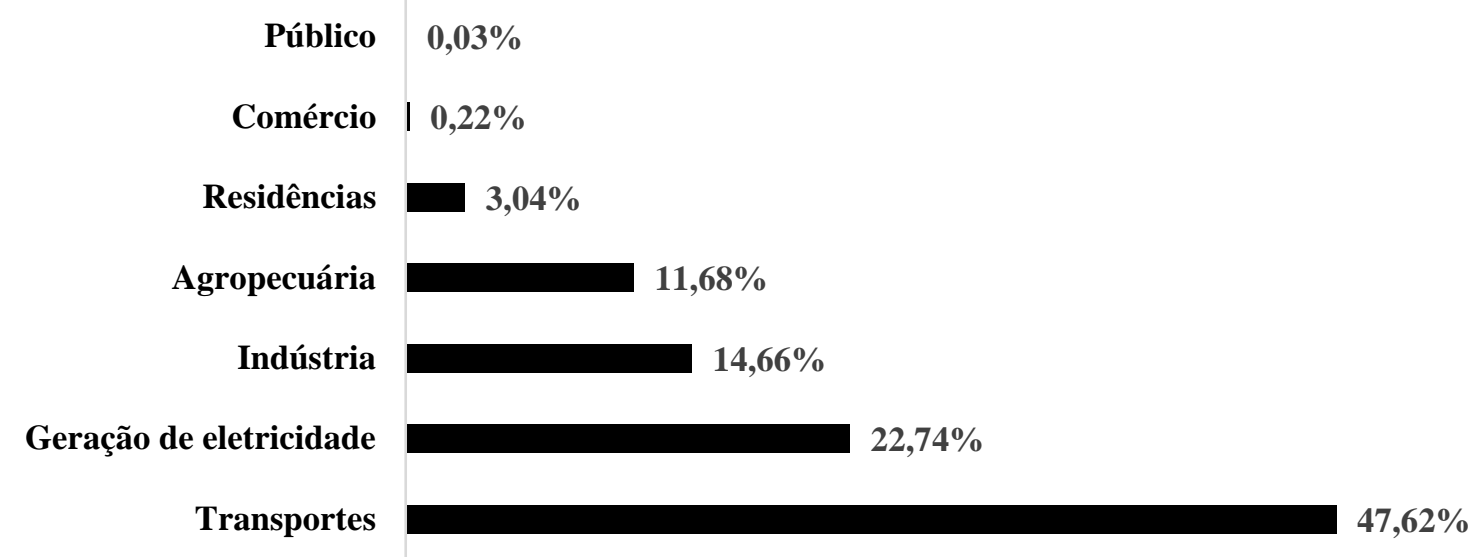

Fonte: SEEG, 2015.

Observa-se a partir dessas informações que o destaque ao subsetor de transportes ocorre, conforme também constatado no trabalho de Firme e Perobelli (2012) para o Brasil e de Araújo (2009) para Pernambuco, principalmente, em função da utilização de fontes secundárias de energia, descritas neste caso por: diesel mineral, gasolina automotiva, querosene de aviação, óleo diesel, álcool hidratado, gás natural seco e gasolina de aviação (SEEG, 2015 - Gráfico 2).

Gráfico 2: Participação da emissão de $\mathrm{CO} 2$ por fonte secundária de energia consumida pelo subsetor de transportes, em \% para o ano de 2015 no MS.

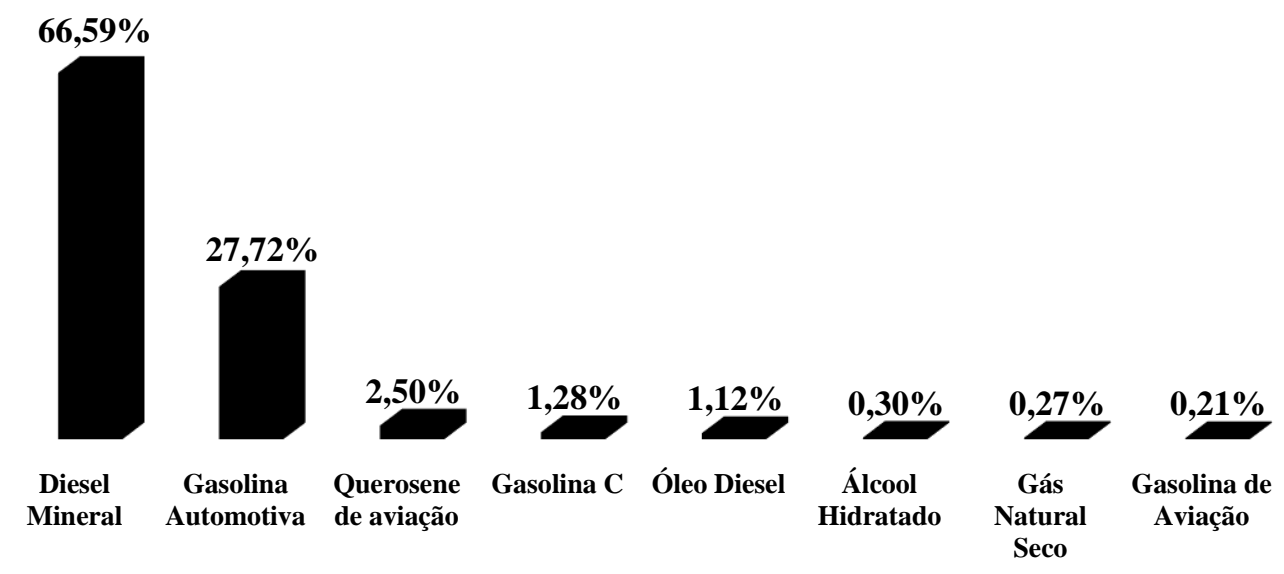

Fonte: SEEG, 2015.

Nesse sentido, admite-se que a maior fonte de energia secundária utilizada pelo subsetor de transportes é o diesel mineral (SEEG, 2015). Combustível esse, usado em caminhões e carretas. E um 
dos principais motivos para essa utilização mais significativa desse combustível se concentra na necessidade de escoamento da produção agropecuária.

Sabe-se por exemplo, que se cada caminhão detiver uma capacidade para transportar 40 toneladas de grãos e que havendo aproximadamente 2,36 milhões de toneladas de soja produzidas (CONAB, 2016), seriam necessários diariamente 163 caminhões. Soma-se a isso ainda, o escoamento de milho, cana-de-açúcar e carnes. Além disso, vale ressaltar que quase $70 \%$ da produção agropecuária de Mato Grosso do Sul é destinada a outros Estados Brasileiros (FADUNDES et al, 2012). Logo, estaria justificado o consumo do diesel mineral em maiores proporções que de outros combustíveis, pelas características do próprio Estado.

No entanto, cabe ressaltar que a média de emissão de CO2 para as fontes primárias de energia é de 3,98 mil TEP, enquanto que para as fontes secundárias essa média atinge 2,93 mil TEP. Nas fontes primárias, dentre os maiores emissores de CO2 se destacam: a lenha e o bagaço de cana, cada um com 4,52 mil TEP para cada unidade de energia consumida em TEP (ECONOMIA E ENERGIA, 2000).

Por esse exemplo já se pode considerar que as emissões de CO2 no agronegócio ocorrem mais de forma indireta pelo consumo energético secundário, advindo do setor de transporte, necessário para o escoamento da produção. Observa-se a partir desses resultados a possibilidade de geração de externalidade negativa.

Isto, porque cada vez mais as atenções do Brasil e do mundo tem se voltado as consequências das emissões provocadas por mudanças do uso do solo, florestas e atividades agropecuárias. Nessas atividades há planos setoriais para a consolidação de uma economia de baixo consumo de carbono para a geração e distribuição de energia elétrica, bem como para as diversas modalidades de transportes - Art. 11, Lei no 12.187/2009 (BRASIL, 2009).

Essa lei faz referência a Política Nacional sobre Mudança do Clima (PNMC), em que também o Brasil adotou metas voluntárias, direcionadas a uma redução dos gases do efeito estufa até 2020, entre $36,1 \%$ a $38,9 \%$. Para tanto, essas metas estipuladas foram comunicadas pelo Brasil a ConvençãoQuadro das Nações Unidas sobre a Mudança do Clima e tem utilizado instrumentos do Fundo Nacional sobre a Mudança do Clima (MMA, 2017).

Cabe ressaltar a necessidade de ações mais efetivas. No Brasil, de 2009 a 2015, houve uma redução nas emissões de CO2 de somente 1,26\%. No Mato Grosso do Sul, pelo ao contrário houve aumento de $1,93 \%$. No que se refere as emissões advindas do consumo energético, os aumentos foram 
respectivamente de $35,82 \%$ e $28,73 \%$ (SEEG, 2015). Admite-se nesse contexto ainda, que o CO2 representa apenas um dos tipos de gases do efeito estufa (EPA, 2016).

Com essas informações retoma-se as questões: o setor energético, pode atuar de forma sustentável no crescimento econômico? O crescimento econômico e a proteção ambiental são metas conflitantes ou complementares? (FAO, 2016). Alguns mecanismos se desenvolveram com vistas a essas ações mais eficazes, tais como pelo Mecanismo de Desenvolvimento Limpo - MDL e Ações de Mitigação Nacionalmente Apropriadas - NAMAS (MMA, 2017).

Para o Mato Grosso do Sul, há uma legislação específica, a Política Estadual de Mudança Climática Lei 4.555 , de 15 de julho de 2014, que tem por objetivo dispor condições para as adaptações necessárias, de modo a reduzir as emissões de gases do efeito estufa, levando em consideração: precaução, prevenção, participação da sociedade civil, desenvolvimento sustentável, reponsabilidades comuns, ação governamental, cooperação nacional e internacional, ampla publicidade, educação ambiental e do poluidor pagador. A primeira meta nessas circunstâncias se voltou a redução de 20\% das emissões de CO2 registradas de 2005 a 2020 (MS, 2014).

Ao observar essa lei tenta-se assegurar um crescimento compatível com a proteção climática, neste caso, crescimento econômico e proteção ambiental se manifestariam como metas complementares. Considera-se nesse sentido que a redução proposta pelas metas voluntárias brasileiras equivaleriam entre $14,60 \%$ e $15,74 \%$ e das metas totais $40,45 \%$ das emissões de CO2 do setor de energia de Mato Grosso do Sul, com base nas informações do SEEG (2015).

Dois aspectos foram relevantes para a construção da matriz híbrida, conforme informações do Secretaria de Estado de Infraestrutura e Governo de Estado (2010). Um, pela Tabela 5, referente a oferta de energia, uma vez que dentre as três fontes de energia (agricultura, outras indústrias e energia - elétrica) consideradas, a maior oferta ocorre pela agricultura $(63,61 \%)$, que constitui parte significativa da fonte primária de energia (lenha; bagaço de cana; carvão vegetal; álcool etílico; outras fontes primárias renováveis). 
Tabela 5: Oferta de energia por fonte.

\begin{tabular}{|l|c|}
\hline Fontes de energia do MS & $\%$ \\
\hline Agropecuária & $63,61 \%$ \\
\hline Energia - eletricidade & $5,46 \%$ \\
\hline Outras Indústrias & $30,93 \%$ \\
\hline
\end{tabular}

Fonte: Resultados da pesquisa.

E outro voltado ao consumo, de modo que dentre os quinze setores descritos (Agropecuária; FerroGusa; Química; Não-Ferrosos e outros da metalurgia; Alimentos e bebidas; Papel e Celulose; Têxtil; Outras indústrias; Energético; Comercial; Público; Residencial; Transportes; Serviços), a maior demanda por energia ocorre nos setores de: transporte $(27,07 \%)$; energético $(25,47 \%)$ e alimentos e bebidas $(23,47 \%)$ - Figura 6 .

Figura 6: Cinco setores com maior consumo energético de Mato Grosso do Sul, em \%.

\section{Cinco setores com maior consumo energético}

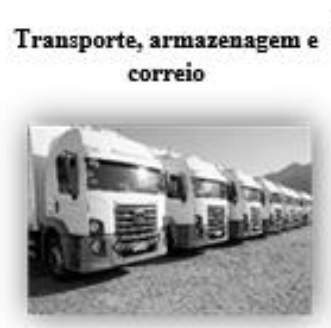

$27,07 \%$
Produção e distribuição de

eletricidade, gás, água, esgoto e limpeza urbana

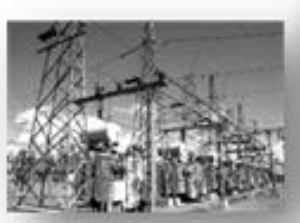

$25,47 \%$
Alimentos e bebidas

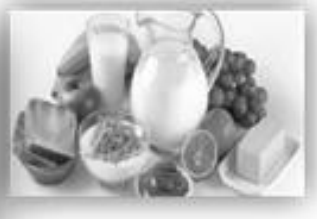

$23,47 \%$
Agropecuária

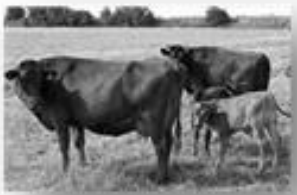

$8,00 \%$
Outras indústrias

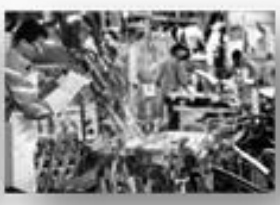

$7,96 \%$

Fonte: Resultados da pesquisa.

Para o setor de transporte, a demanda ocorre da fonte industrial, seguida pela agropecuária. No caso dos alimentos e bebidas, agropecuária, indústria e energia - elétrica. Por fim no setor de energia, agropecuária e energia. Como a fonte de energia agropecuária é a mais consumida, consequentemente, também é a que mais emite $\mathrm{CO} 2$, sendo responsável por 76,05\% dessas emissões - Tabela 6. No caso do setor de energia elétrica não ocorre emissão de CO2. 
Tabela 6: Emissões de CO2 por fonte de energia.

\begin{tabular}{|l|c|}
\hline \multicolumn{1}{|c|}{ Emissões de CO2 por fonte de energia em \% } & \% \\
\hline Agropecuária & $76,05 \%$ \\
\hline Energia & $0,00 \%$ \\
\hline Outras Indústrias & $23,95 \%$ \\
\hline
\end{tabular}

Fonte: Resultados da pesquisa.

Observa-se que não somente o consumo de energia define os setores que mais emitirão $\mathrm{CO} 2$, mas que tipo de energia é consumida. Assim, de acordo com a Figura 7, o principal setor que emite CO2 é o energético $(31,43 \%)$, seguido pela indústria de alimentos e bebidas $(27,30 \%)$ e pelos transportes, armazenagem e correios (20,66\%).

Figura 7: Cinco setores que mais emitem CO2, no Mato Grosso do Sul, em \%.

Cinco setores que mais emitem $\mathrm{CO} 2$

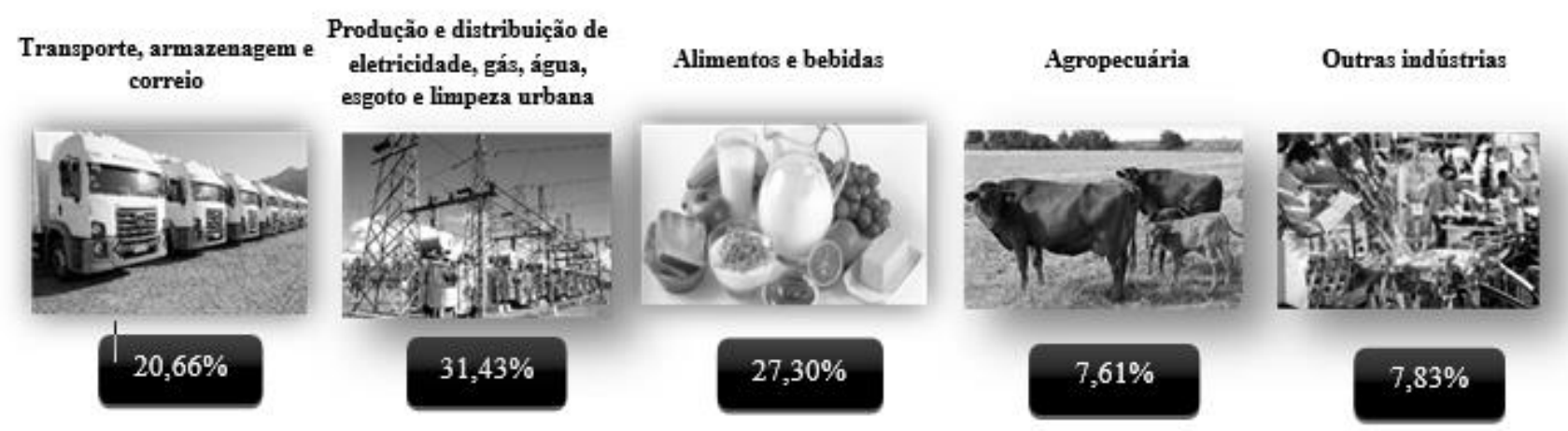

Fonte: Resultados da pesquisa.

Como há requerimentos diretos e indiretos de energia, também ocorrem emissões conforme o tipo de requerimento. Nesse sentido para os mesmos setores que mais consomem energia e emitem $\mathrm{CO} 2$, desagregou-se em emissões diretas e indiretas. Percebe-se a partir da Tabela 7, que com exceção do setor de alimentos e bebidas, os demais possuem um comportamento semelhante, sendo maior parte das emissões ocasionada de forma indireta. 
Tabela 7: Emissões diretas e indiretas de $\mathrm{CO} 2$, no Mato Grosso do Sul, por setor, em \%

\begin{tabular}{|c|c|c|c|c|}
\hline \multicolumn{5}{|c|}{ Emissões diretas de CO2 - em \% } \\
\hline $13,03 \%$ & $45,69 \%$ & $83,17 \%$ & $17,97 \%$ & $5,13 \%$ \\
\hline $\begin{array}{c}\text { Transporte, } \\
\text { armazenagem e } \\
\text { correio }\end{array}$ & $\begin{array}{c}\text { Produção e distribuição } \\
\text { de eletricidade, gás, } \\
\text { água, esgoto e limpeza } \\
\text { urbana }\end{array}$ & $\begin{array}{c}\text { Alimentos e } \\
\text { bebidas }\end{array}$ & Agropecuária & Outras indústrias \\
\hline $86,97 \%$ & $54,31 \%$ & $16,83 \%$ & $82,03 \%$ & $94,87 \%$ \\
\hline \multicolumn{5}{|r|}{ Emissões indiretas de CO2 - em \% } \\
\hline
\end{tabular}

Fonte: Resultados da pesquisa.

Diante disso, dentre os principais setores mais citados em termos de consumo de energia e emissão de CO2 estão: transportes; indústria de alimentos e bebidas; setor energético; outras indústrias e agropecuária. Isto para o Mato Grosso do Sul, em maiores proporções que quando comparado a Pernambuco (ARAÚJO, 2009), e em menores em relação a São Paulo (FIRME, PEROBELLI, 2012).

\section{CONSIDERAÇÕES FINAIS}

Admite-se que o objetivo de mensurar o consumo energético e emissão de $\mathrm{CO} 2$ do agronegócio de Mato Grosso do Sul foi atendido. Evidenciou-se no artigo o resultado dos cinco principais setores que mais consomem energia e que mais emitem $\mathrm{CO} 2$. Nesse sentido, os maiores valores foram auferidos pelo setor de transporte, armazenagem e correios; de produção e distribuição de energia, gás, água, esgoto e limpeza urbana; alimentos e bebidas; outras indústrias; agropecuária.

Também ficou evidente a partir desses resultados, que as fontes primárias de energia são as que mais emitem CO2, principalmente, no que se refere a lenha e bagaço de cana. No que tange a eletricidade, essas emissões não ocorrem. Cabe ressaltar ainda que, com exceção dos alimentos e bebidas, os demais setores detiveram um comportamento semelhante, uma vez que a emissões tendem a ocorrer mais significativamente pelos requerimentos indiretos de energia.

Ao comparar esses resultados àqueles das matrizes híbridas já construídas para Pernambuco e São Paulo, há a percepção de que foram evidenciados os mesmos setores, em proporções diferenciadas, conforme suas peculiaridades.

Nesse sentido ficam algumas questões: o que são essas outras indústrias? A essa questão desagregase o setor em: Artefatos de couro e calçados; Produtos de maneira, exclusive móveis; Jornais, revistas e discos; Artigos de borracha e plástico; Máquinas e equipamentos, inclusive reparo e manutenção; 
Máquina, aparelho material elétrico; Outros indústria de transformação; Extrativa mineral; Peças e acessórios automotores; Cimento; Cerâmica; Ferro-Ligas.

No entanto, mais importante do que é, está a necessidade de entender o quanto cada um dos subsetores das outras indústrias e da agropecuária consomem de energia e quanto emitem de CO2. Ficando assim, como proposta para trabalhos futuros, isto para que se entenda de uma forma mais robusta como funcionam esses quesitos no agronegócio de MS.

\section{REFERÊNCIAS BIBLIOGRÁFICAS}

ALCÁNTARA, V.; PADILLA, E. "Key" sectors in final energy consumption: an input-output application to the Spanish case. Energy Policy, Bellaterra, v.31, n.1, p. 1673-1678, 2003.

BEN. Balanço Energético Nacional. 2016. Disponível em: <https://ben.epe.gov.br/>. Acesso em: 18 maio 2016.

BULLARD, C.W.; HERENDEEN, R.A. The energy cost of goods and services. Energy Policy, v. 3, n. 4, p. 268-278, dez. 1975.

CARVALHO, T. S.; PEROBELLI, F. S. Avaliação da intensidade de emissões de CO2 setoriais e na estrutura de exportações: um modelo inter-regional de insumo-produto São Paulo/restante do Brasil. Economia Aplicada, Ribeirão Preto, v. 13, n.1, jan./mar. 2009.

CASLER, S. D e BLAIR, P. D. Economic structure, fuel combustion, and pollution emissions. Ecological Economics. 22: 19-27. 1997.

COASE, R. H. The problem of social cost. Chicago Journals, Chicago, v. 3, n.1, p. 1-4, out. 1960.

CONAB. Safras - séries históricas. 2016. Disponível

em: <http://www.conab.gov.br/conteudos.php?a=1252\&t=2>. Acesso em: 20 fev. 2017.

CRESWELL, John W. Projeto de pesquisa: métodos qualitativo, quantitativo e misto. 2. ed. Porto Alegre: Artmed, 2007.

EPA. Global Climate Change. 2016. Disponível

em: <https://www3.epa.gov/climatechange/kids/basics/today/greenhouse-gases.html>. Acesso em: 20 fev. 2016.

FAGUNDES, M.B.B. (coord.) Relatório Parcial de Pesquisa: Construção da Matriz de Insumo-Produto do Estado de Mato Grosso do Sul para o ano de 2010. Campo Grande, MS: UFMS/FUNDECT, 2015.

FAO. The role of livestock in climate change. 2016. Disponível

em: < http://www.fao.org/agriculture/lead/themes0/climate/en/>. Acesso em: 18 maio 2016. 
FIGUEIREDO, N. R. M.; ARAÚJO JÚNIOR, I. T.; PEROBELLI, F. S. Construção da matriz de insumo-produto híbrida para o Estado de Pernambuco e avaliação da intensidade energética e de emissões de $\mathrm{CO} 2$ setorial. Banco do Nordeste, Paraíba, v.1, n.1, p.1-20. 2009.

FIRME, V. A. C.; PEROBELLI, F. S. O setor energético brasileiro: uma análise via indicadores de insumoproduto e o modelo híbrido para os anos de 1997 e 2002. Planejamento e Políticas Públicas, Brasília, v.1, n.39, jul./dez. 2012.

FMI. Externalities: prices do not capture all costs. 2012. Disponível

em: < http://www.imf.org/external/pubs/ft/fandd/basics/external.htm>. Acesso em: 16 jun. 2016.

HARRIS, J. M; ROACH, B. The economics of global climate change. Medford: Global Development and Environment Institute e Tufts University, 2007.

IBGE. PIB: Tabelas Completas 2002-2013: Participação das atividades econômicas no valor adicionado bruto a preços básicos, por Unidades da Federação- 2002-2012. 2013. Disponível em: http://www.ibge.gov.br/home/estatistica/economia/contasregionais/2012/default_xls_2002_2012.s htm>. Acesso em: 20 fev. 2017.

LAHR, M. A strategy for producing hybrid regional input-output tables. New BrunswickNew Brunswick: Center for Urban Policy ResearchCenter for Urban Policy Research, 1998.

LEONTIEF, W. A. Economia de Insumo-Produto. São Paulo: Abril Cultural, 1983.

LINDNER, S.; GUAN, D. A hybrid-unit energy input-output model to evaluate embodied energy and life cycle emissions for China's economy. Journal of Industrial Ecology, [s.I.], v.18, n.2, p.201-211, 2014.

MAYER, $\mathrm{H}$. Calculation and analysis of a hybrid energy input-output table for Germany within the Environmental-Economic Accouting (EEA). Wiesbaden: Federal Statistical Office Germany e Environmental-Economic Accounting (EEA), 2007.

MMA. Política Nacional sobre Mudança do Clima. 2017. Disponível

em: < http://www.mma.gov.br/clima/politica-nacional-sobre-mudanca-do-clima>. Acesso em: 20 fev. 2017.

MILLER, R. E., BLAIR, P. D. Input-Output Analysis: Foundations and Extensions. 2a ed. Cambridge: University Press, 2009.

MS. Lei no 4.555, de 15 de julho de 2014.

ONU. A ONU e o meio ambiente. 2016. Disponível em: < https://nacoesunidas.org/acao/meioambiente/>. Acesso em: 18 maio 2016.

PAL, P.; PAL, D. P.; PAL, S. Energy intensity and structural change: analysis based on hybrid units. In: 19 th International Conference, 2011, Virginia. Anais...Vírginia: International Conference, 2011, p.1317.

RASMUSSEN, P. N. Studies in inter-sectorial relations. Amsterdam: North-Holland, 1956. 
SEADE. Agropecuária do Estado de Mato Grosso do Sul. Campo Grande: SEADE, 2001.

SEEG. Sistema de estimativa de emissão de gases de efeito estufa. 2015. Disponível em: http://seeg.eco.br/. Acesso em: 16 jun. 2016.

SEINFRA; CDE. Balanço Energético do Estado de Mato Grosso do Sul. Campo Grande: SEINFRA; CDE, 2016.

SEEG. Mato Grosso do Sul - 2015: Emissões. 2015. Disponível

em:<http://plataforma.seeg.eco.br/total_emission>. Acesso em: 20 fev. 2017.

SOBEL, R. S. Welfare economics and public finance. Virginia: West Virginia University, 2003.

WORLD BANK. Knowledge for development. 2016. Disponível

em:<http://web.worldbank.org/WBSITE/EXTERNAL/WBI/WBIPROGRAMS/KFDLP/0,,contentMDK:202 69026 menuPK:461205 pagePK:64156158 piPK:64152884 theSitePK:461198,00.html>. Acesso em: 3 abr. 2016. 


\section{Capítulo 25}

\section{A GERAÇÃO DE RIQUEZA NA AGROINDÚSTRIA - UM ESTUDO APLICADO AS MAIORES EXPORTADORAS DE CARNE DO BRASIL (2012 - 2016)}

DOI: $10.37423 / 200300450$

Jéssica Sonáglio (Universidade do Estado de Mato Grosso). jessicasonaglio@gmail.com

Tiane A/ves Rocha Gastardelo (Universidade do Estado de Mato Grosso). tianealvesrocha@gmail.com

Laércio Juarez Melz (Universidade do Estado de Mato Grosso). laercio@unemat.br

RESUMO: Agregar valor aos investidores é um desafio para qualquer empresa. O objetivo desta pesquisa foi verificar entre as três empresas exportadoras de carne que possuem maior cotação na bolsa qual gerou mais riqueza aos acionistas nos últimos cinco anos (2012 - 2016). Metodologicamente a pesquisa pode ser classificada como qualitativa e documental utilizando o método de Valor Econômico Agregado, os dados foram coletados pelo sistema Economatica e dos relatórios de Prêmio de Risco de Damodaran e tratados através do Excel. As empresas analisadas foram a BRF S.A., JBS S.A. e MARFRIG S.A., todas as empresas agregaram valor ao acionista no período analisado, sendo que em 2016 houve uma baixa na geração de riqueza das três empresas. A partir das análises dos dados a JBS S.A. foi à empresa que mais agregou valor ao investidor, tendo um crescimento de $247,03 \%$ no período analisado. A BRF S.A. cresceu $129,69 \%$ e a MARFRIG S.A. $86,22 \%$, no período analisado.

Palavras-chave: Valor econômico agregado, Geração de riqueza e economia. 


\section{INTRODUÇÃO}

De acordo com o Centro de Estudos Avançados em Economia Aplicada da Escola Superior de Agricultura Luiz de Queiroz da Universidade de São Paulo (CEPEA-Esalq/USP, 2016) o Produto Interno Bruto (PIB) do agronegócio brasileiro cresceu 4,48\% em 2016, a participação média do setor no PIB do país é $20 \%$ desde 1996. De acordo com o Ministério da Agricultura, Pecuária e Abastecimento o setor exportou 84,93 bilhões de dólares, uma queda de 3,7\% em relação ao ano de 2015 (BRASIL, 2017a).

Os setores mais importantes do agronegócio brasileiro quanto às exportações são: os complexos da soja, carnes, sucroalcooleiro e os produtos florestais. As exportações de carne movimentavam 14.211 milhões de dólares em 2016, sendo a carne de frango, bovina, suína e de perú as mais exportadas em valores e volume (BRASIL, 2017b).

Segundo a Associação Brasileira das Indústrias Exportadoras de Carne (2017) o Brasil é o segundo maior produtor mundial de carne bovina do mundo e um dos maiores exportadores. Em 2016 o país produziu $14 \%$ da carne bovina mundial, $9.561,6$ mil toneladas, e exportou $19,68 \%$ do total produzido, 1.882 mil toneladas.

Mato Grosso foi o estado brasileiro que mais exportou de janeiro a março em 2016 e 2017 conforme a Associação Brasileira de Frigoríficos - ABIEC (2017) com representatividade financeira de 16,9\% em 2016 e 19,6\% em 2017.

Conforme Nippon Meat Packers (2016) o Brasil, além de ser um dos maiores exportadores, também possui três dos dez frigoríficos que mais exportaram carne in natura em 2015, sendo eles, JBS S.A., Brasil Foods S.A. e Marfrig Alimentos S.A.. Tais empresas juntas comercializaram cerca de R\$ 231.268,800,00 milhões.

No início de 2017 foi deflagrada pela Policia Federal a Operação Carne Fraca que investigou cerca de 40 empresas do setor alimentício, em um emaranhado de corrupção que autorizava a venda de alimentos produzidos sem a devida fiscalização sanitária. Parte dessa investigação cita indícios de comercialização de carnes vendidas fora do prazo de validade, misturadas com papelão e inclusive contendo substâncias cancerígenas (EXTRA GLOBO, 2017).

Em decorrência da Operação Carne Fraca a carne nacional recebeu embargo de vários países, como Hong Kong, China, Chile, Egito e Coreia do Sul segundo o Canal Rural (2017). Entretanto o setor apresentou crescimento de $22 \%$ da receita e $20 \%$ do volume exportado em ralação a fevereiro de 
2016, embarcando cerca de 125 mil toneladas de carne, gerando receita aproximada de US\$ 501 milhões (ABIEC, 2017), demonstrando a sua força e relevância econômica

Segundo Almeida (2015) o mundo e a sociedade global são focados em criar Riqueza. Para Carvalho (2000) adicionar valor seria de fato produzir retorno financeiro do investimento, em taxas maiores que o custo de todo o capital designado para geração dos resultados, em um determinado período de tempo.

Diante da importância das exportações de carne para a economia do país e a necessidade de gerar riqueza para os investidores, o objetivo da pesquisa foi verificar entre as três empresas exportadoras de carne que possuem maior cotação na bolsa de valores do Brasil qual gerou mais riqueza aos acionistas nos últimos cinco anos (2012 - 2016).

Este trabalho está dividido em cinco seções sendo esta introdução a primeira, a segunda conta com uma referencial teórico, a terceira apresenta a metodologia utilizada, a quarta seção traz os resultados da pesquisa e a quinta a conclusão.

\section{REFERENCIAL TEÓRICO}

\subsection{VALOR ECONÔMICO AGREGADO}

Alfred Marshall (MARSHALL, 1890, p. 142 apud CARVALHO, 2000), em 1890, utilizou pela primeira vez o termo Renda Residual, como sendo uma medida representativa do ganho líquido menos os juros sobre o capital próprio investido à taxa corrente.

Soares (2014) explica que durante um longo período de tempo após o seu aparecimento, o EVA foi pouco explorado, só com a criação da marca pela empresa americana de consultoria Stern Stewart \& Co é que o interesse das empresas e autores foi reavivado. Diversos autores conceituam o EVA, conforme apresentado no quadro 5: 
Quadro 5: Conceitos de Valor Econômico Agregado (EVA).

\begin{tabular}{|c|c|}
\hline $\begin{array}{l}\text { Young e O'Byrne (2003, } \\
\text { p. 20) }\end{array}$ & $\begin{array}{l}\text { "O EVA mede a diferença, em termos monetários, entre o retorno sobre } \\
\text { o capital de uma empresa e o custo desse capital. É, portanto, similar à } \\
\text { mensuração contábil convencional do lucro, mas com uma importante } \\
\text { diferença: o EVA considera o custo de todo o capital, já o lucro líquido } \\
\text { considera apenas o custo do tipo mais visível de capital - os juros -, } \\
\text { ignorando o custo do capital próprio." }\end{array}$ \\
\hline Padoveze (2010, p. 587) & $\begin{array}{l}\text { "É a aplicação do conceito de custo de oportunidade do capital e do } \\
\text { conceito de manutenção do capital financeiro da empresa" }\end{array}$ \\
\hline Caete & $\begin{array}{l}\text { É uma medida da criação (ou destruição) de riqueza centrada num } \\
\text { período determinado. }\end{array}$ \\
\hline Davie & $\begin{array}{l}\text { O EVA traduz um resultado que demonstra se a empresa está } \\
\text { ganhando, em um exercício, mais do que o custo de capital imputado } \\
\text { aos seus recursos utilizados. }\end{array}$ \\
\hline Barros & $\begin{array}{l}\text { após a dedução dos impostos, deduzido o } \\
\text { gerar esse lucro }\end{array}$ \\
\hline $\begin{array}{l}\text { Assaf } \\
\text { p.270) }\end{array} \quad$ Neto $\quad(2015$, & $\begin{array}{l}\text { É o resultado apurado pela sociedade que excede à remuneração } \\
\text { mínima exigida pelos proprietários de capital (credores e acionistas). }\end{array}$ \\
\hline Stewart $(2005$, p.117) & $\begin{array}{l}\text { "É a real medida de desempenho que apropriadamente leva em } \\
\text { consideração todas as maneiras pelas quais o valor corporativo pode } \\
\text { ser agregado ou perdido é o valor econômico agregado (EVA). O EVA é } \\
\text { uma medida de receita residual que subtrai o custo do capital dos lucros } \\
\text { operacionais gerados em um empreendimento." }\end{array}$ \\
\hline $\begin{array}{l}\text { Brigham } \\
\text { p.64) }\end{array}$ & $\begin{array}{l}\text { E uma estimativa do efetivo lucro econômico da empresa para o período } \\
\text { e difere muito do lucro contábil. "O EVA representa o lucro residual que } \\
\text { permanece após o custo de todo o capital, incluindo o capital que tenha } \\
\text { sido deduzido, enquanto o lucro contábil é determinado sem se colocar } \\
\text { uma carga do capital próprio" }\end{array}$ \\
\hline $\begin{array}{l}\text { Faria } \\
415)\end{array}$ & $\begin{array}{l}\text { "É o resultado operacional líquido depois dos impostos, menos os } \\
\text { encargos do capital equivalente à quantia de lucro necessária para cobrir } \\
\text { as despesas de juros monetários e prover um retorno adequado aos } \\
\text { investidores" }\end{array}$ \\
\hline
\end{tabular}

Fonte: Elaborado pelos autores

Alfred Marshall (1890 apud KOLLER; GOEDHART; WESSELS, 2005, p. 63) defende que:

"O que permanece do lucro do proprietário depois de deduzir a remuneração do seu capital pela taxa corrente pode ser considerado seu ganho pelo investimento na empresa".

Segundo Carvalho (2000), o EVA é também é conhecido a nível mundial com termos como: Economic Profit - EP (Lucro Econômico); Residual Income - RI (Rendimento Residual) e Economic Value Management - EVM (Gestão do Valor Econômico).

De acordo Mota et al. (2010), o EVA é uma ferramenta de gestão extremamente importante. Ao confrontar a rentabilidade de um investimento com o seu verdadeiro custo, o gestor tem a noção clara do impacto das suas decisões no futuro da empresa, o que permite uma maior responsabilização. Desenvolve-se então uma relação mais estreita entre o gestor e os acionistas que tendem a consolidar- 
se se a remuneração deste estiver indexada ao EVA gerado, em que o gestor pensa e atua como se ele próprio fosse dono da empresa.

Para Malvessi (2000) compreender a criação de valor possibilita analisar com maior as alternativas de estrutura de capitais e dos recursos aplicados. Tem como intuito aumentar as vantagens competitivas do negócio, buscando diferenciação e/ou segmentação que proporcione melhoria e amplie a criação de valor, através de:

- Tomada de decisões, tecnicamente orientadas, sobre como investir e utilizar os recursos que criem valor para a empresa ou unidade de negócios (MALVESSI, 2000);

- Análise da estrutura dos recursos aplicados nos ativos, levando em consideração o desempenho e evolução da receita, com o controle dos gastos e com a melhoria do resultado operacional (MALVESSI, 2000);

- Análise da estrutura de capital, do custo de capital próprio e de terceiros e sua influência no resultado passado e futuro MALVESSI (2000);

- Transformação dos gestores, fazendo com que eles passem agir e se sentir como proprietários (MALVESSI, 2000).

- Segundo Regis, Santos e Santos (2010), as empresas precisam ter cautela quanto à implementação de métricas baseadas na criação de valor, pois mesmo através da reconhecida importância do EVA, o mesmo acaba apresentando limitações, dentre as quais se podem destacar:

- Restrição ao crescimento da empresa. A expectativa de resultados rápidos pode impedir projetos de maior vulto (REGIS; SANTOS; SANTOS, 2010);

- Dificuldades para a obtenção de empréstimos junto às instituições financeiras, pois o cálculo do EVA ${ }^{\circledR}$ demonstra a remuneração do capital de terceiros. Quanto mais endividadas, maior é o risco (REGIS, SANTOS E SANTOS, 2010);

- Ênfase exagerada na geração de lucros (REGIS; SANTOS; SANTOS, 2010);

- Empresas regidas apenas por propósitos econômicos (REGIS; SANTOS; SANTOS, 2010). 


\section{METODOLOGIA}

O presente trabalho trata-se de uma pesquisa descritiva. Segundo Aaker, Kumar e Day (2004), esse tipo de pesquisa, normalmente, usa dados dos levantamentos e caracteriza-se por hipóteses especulativas que não especificam relações de causalidade.

Tratando-se de uma pesquisa documental. De acordo com Pádua (1997) a pesquisa documental é aquela realizada a partir de documentos, contemporâneos ou retrospectivos, considerados cientificamente autênticos.

Na pesquisa os dados foram coletados no sistema Economatica e também nos relatórios de Prêmio de Risco de Damodaran (2012, 2013, 2014, 2015, 2016). O quadro 6 detalha as variáveis utilizadas.

Quadro 6: Variáveis utilizadas e suas fontes

\begin{tabular}{|l|l|}
\hline \multicolumn{1}{|c|}{ VARIAVEL } & \multicolumn{1}{|c|}{ FONTE } \\
\hline $\begin{array}{l}\text { Ebit (Earnings Before Interest and Taxes (Lucro antes dos Juros e } \\
\text { Tributos)) }\end{array}$ & Economatica (2017) \\
\hline Imposto de Renda e CSLL & Ipeadata (2017) \\
\hline $\begin{array}{l}\text { Nopat (Net Operating Profit After Taxes(Lucro Operacional } \\
\text { Líquido após Impostos) }\end{array}$ & Calculado pelos autores \\
\hline $\begin{array}{l}\text { Waac (WACC é Weighted Average Cost of Capital(CMPC Custo } \\
\text { Médio Ponderado do Capital) }\end{array}$ & Calculado pelos autores \\
\hline Ke (Custo de capital aos acionistas) & Elaborado pelo autor \\
\hline Kd (Custo da divida) & Economatica (2017) \\
\hline E (Total de patrimônio liquido) & Economatica (2017) \\
\hline D (Total da divida) & Economatica (2017) \\
\hline Rf (Retorno do ativo livre de risco) & Ipeadata (2017) \\
\hline Beta & Economatica (2017) \\
\hline P (Prêmio pelo risco de mercado) & $\begin{array}{l}\text { Damodaran (2012, 2013, 2014, } \\
2015,2016)\end{array}$ \\
\hline
\end{tabular}

Fonte: Elaborado pelos autores.

Quanto à análise dos dados a pesquisa classifica-se como qualitativa, utilizando o modelo Valor Econômico Agregado para identificar a criação de valor das empresas A e B, conforme equação apresentada abaixo:

$$
E V A=N O P A T-\$(\text { valor monetário }) \text { do custo de capital }
$$

Onde, NOPAT - Net Operating Profit After Taxes de acordo com Young e O’Byrne (2003, p.50) é o lucro líquido da empresa, após os impostos, sendo expresso pela seguinte equação:

$$
\text { NOPAT }=\text { EBIT }(1-\text { tax rate })
$$


Em que, EBIT: Lucro Antes dos Juros e Impostos de Renda e Tax rate é a alíquota de IR e CSLL.

O \$ (valor monetário) do custo de capital segundo Rossetti (2008) é encontrado a partir da multiplicação entre custo de capital e capital aplicado. O WACC - Weighted Average Cost of Capital, ou custo médio ponderado do capital é encontrado a partir da seguinte equação:

$$
W A C C=K e \frac{E}{(D+E)}+K d \frac{D}{(D+E)} x(1-t)
$$

Onde, Ke representa o custo de capital aos acionistas;

$K d$ é o custo da divida;

$E$ é total de patrimônio líquido; e

$D$ é o total da dívida;

$t$ é a alíquota de imposto sobre o lucro.

\section{RESULTADOS}

\subsection{VALOR ECONÔMICO AGREGADO DA BRF S.A.}

A BRF S.A. apresentou alta no seu NOPAT de 2012 a 2015, todavia em 2016 o Lucro Líquido após os impostos caiu de R\$2.790.750,60 em 2015 para R\$ 1.198.014,84 em 2016, uma queda de 57,07\% em relação ao ano anterior, e ficando acima apenas do NOPAT de 2012, conforme valores expressos gráfico 1. O maior percentual de alta no NOPAT da BRF S.A. ocorreu em 2014 comparado a 2013, ano este que tal índice cresceu 77,50\%, passando de R\$1.293.367 em 2013 para R\$ 2.295.690 em 2014.

Gráfico 1: NOPAT da BRF S.A. de 2012 a 2016, Milhares de R\$

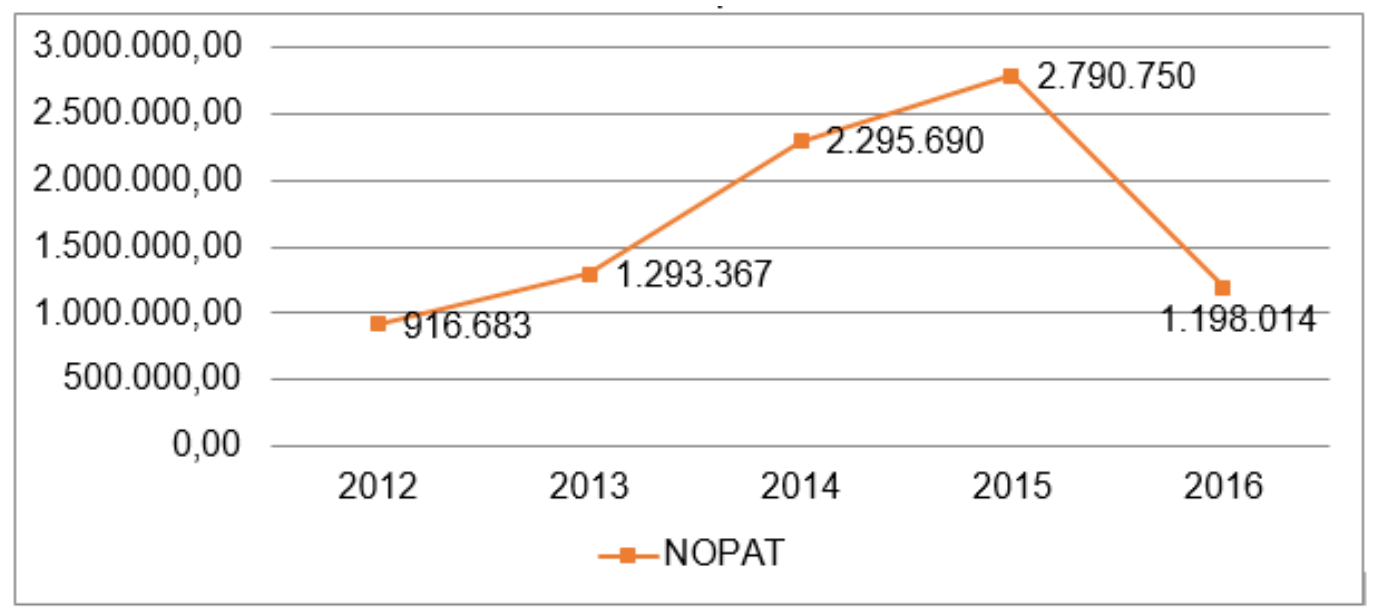

Fonte: Dados da pesquisa. 
Já o WACC da BRF S.A. apresentou crescimento entre 2012 e 2014, sendo que em 2013 ele cresceu 35,38\% quando comparado a 2012, já o crescimento em 2014 alcançou 14,82\% comparado a 2013. Em 2015 pode-se verificar uma leve queda de 0,15\% no custo de capital da empresa, e em 2016 essa queda foi de 20,72\% isto comparado a 2015, conforme gráfico 2.

Gráfico 2: WACC da BRF S.A. de 2012 a 2016, valores em \%

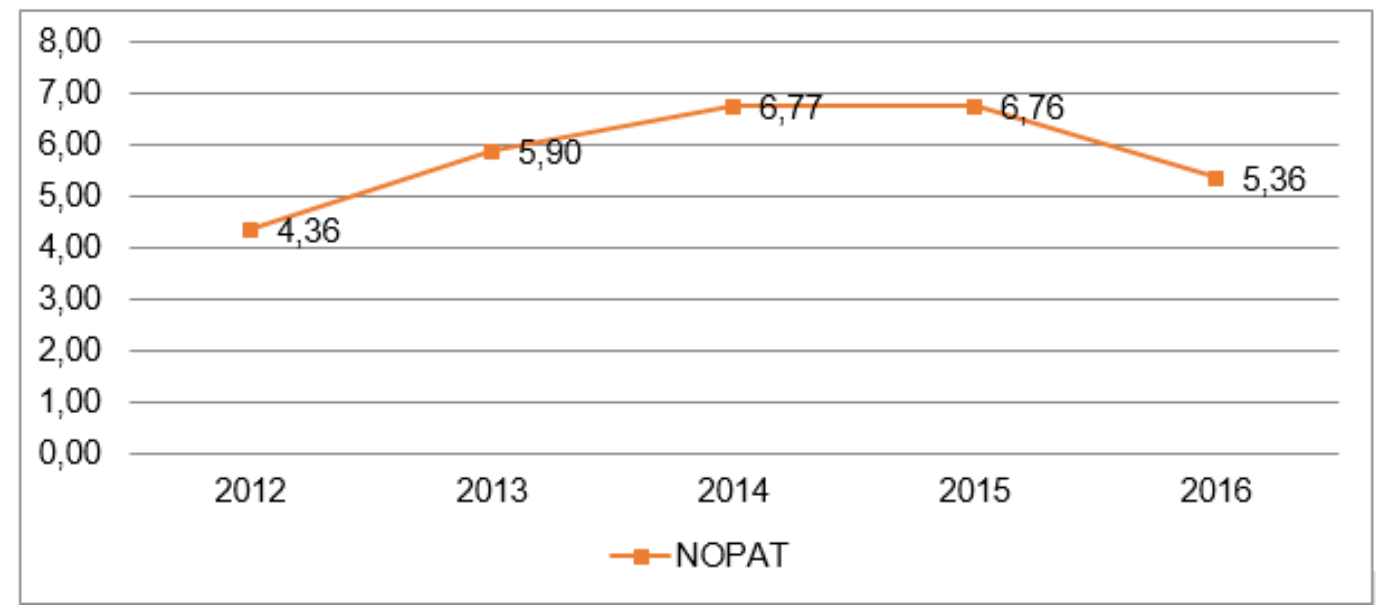

Fonte: Dados da pesquisa.

Na tabela 1 encontram-se os EVAs da Empresa BRF S.A. entre 2012 e 2016.

Tabela 1: Cálculo do EVA da empresa BRF S.A. (2012 - 2016), Milhares de R\$

CALCULO DO EVA DA EMPRESA BRF S.A. (2012 - 2016)

\begin{tabular}{|c|c|c|c|c|c|}
\hline \multicolumn{6}{|c|}{ NOPAT } \\
\hline Variável/ano & 2012 & 2013 & 2014 & 2015 & 2016 \\
\hline EBIT & 1.388 .915 & 1.959 .648 & 3.478 .319 & 4.228 .410 & 1.815 .174 \\
\hline (1-Tax Rate) & 0,66 & 0,66 & 0,66 & 0,66 & 0,66 \\
\hline NOPAT & $916.683,90$ & $1.293 .367,68$ & $2.295 .690,54$ & $2.790 .750,60$ & 1.198.014,84 \\
\hline \multicolumn{6}{|c|}{ WACC } \\
\hline Variável/ano & 2012 & 2013 & 2014 & 2015 & 2016 \\
\hline $\mathrm{KE}$ & 7,1530 & 9,9263 & 11,7180 & 14,1359 & 13,7136 \\
\hline $\mathrm{KD}$ & 0,127 & 0,148 & 0,177 & 0,295 & 0,220 \\
\hline $\mathrm{E}$ & 14.538 .528 & 14.655 .071 & 15.590 .477 & 13.516 .777 & 11.839 .978 \\
\hline $\mathrm{D}$ & 9.518 .321 & 10.181 .190 & 11.589 .335 & 15.179 .283 & 18.962 .380 \\
\hline $\mathrm{T}$ & 0,34 & 0,34 & 0,34 & 0,34 & 0,34 \\
\hline WACC & 4,36 & 5,90 & 6,77 & 6,76 & 5,36 \\
\hline \multicolumn{6}{|c|}{ EVA } \\
\hline Variável/ano & 2012 & 2013 & 2014 & 2015 & 2016 \\
\hline NOPAT & $916.683,90$ & $1.293 .367,68$ & $2.295 .690,54$ & $2.790 .750,60$ & $1.198 .014,84$ \\
\hline WACC & 4,36 & 5,90 & 6,77 & 6,76 & 5,36 \\
\hline (=) EVA & $916.679,54$ & $1.293 .361,78$ & $2.295 .683,77$ & $2.790 .743,84$ & $1.198 .009,48$ \\
\hline
\end{tabular}


A BRF S.A. também demostrou crescimento na geração de riqueza de 2012 a 2015, porém em 2016, ela teve uma queda e 57,07\% no EVA comparado ao ano de 2015.

A BRF S.A. teve um crescimento de 41,09\% em 2013 comparado a 2012, já em 2014 o EVA da empresa obteve um aumento de $R \$ 1.293 .361,78$ para $R \$ 2.295 .683,77$, ou seja, uma ascensão de 77,50\% em relação a 2013. Já em 2015 o crescimento no EVA continuou, houve um aumento 21,56\% em relação a 2014, porém em 2016 a empresa agregou menos valor ao acionista, gerando um EVA de R\$ 1.198.009,48.

\subsection{VALOR ECONÔMICO AGREGADO DA JBS S.A.}

Como expressado na metodologia o NOPAT é uma das variáveis do EVA, uma empresa que faz uso do NOPAT tem por intuito verificar qual é o resultado operacional da empresa diminuindo os impostos, ou seja, busca mensurar o valor que poderia ser distribuído aos acionistas se a empresa não tivesse dividas.

O NOPAT da JBS S.A. apresentou alta de 2012 a 2015, de 2012 para 2013 o indicador aumentou 53\%, já em 2014 o crescimento foi de 88\%, em relação a 2013, a maior alta percentual da empresa no período analisado. O crescimento continuou em 2015, com um aumento no NOPAT de $17 \%$ comparado a 2014, entretanto Lucro Líquido após os impostos caiu de R\$6.058.336,02 em 2015 para R\$ 4.453.474,74 em 2016 representando uma queda de 26\%. Em resumo em 2016 a JBS S.A. teve uma distribuição menor ao acionista em relação a 2015, conforme o gráfico 3.

Gráfico 3: NOPAT da JBS S.A. de 2012 a 2016, Milhares de R\$

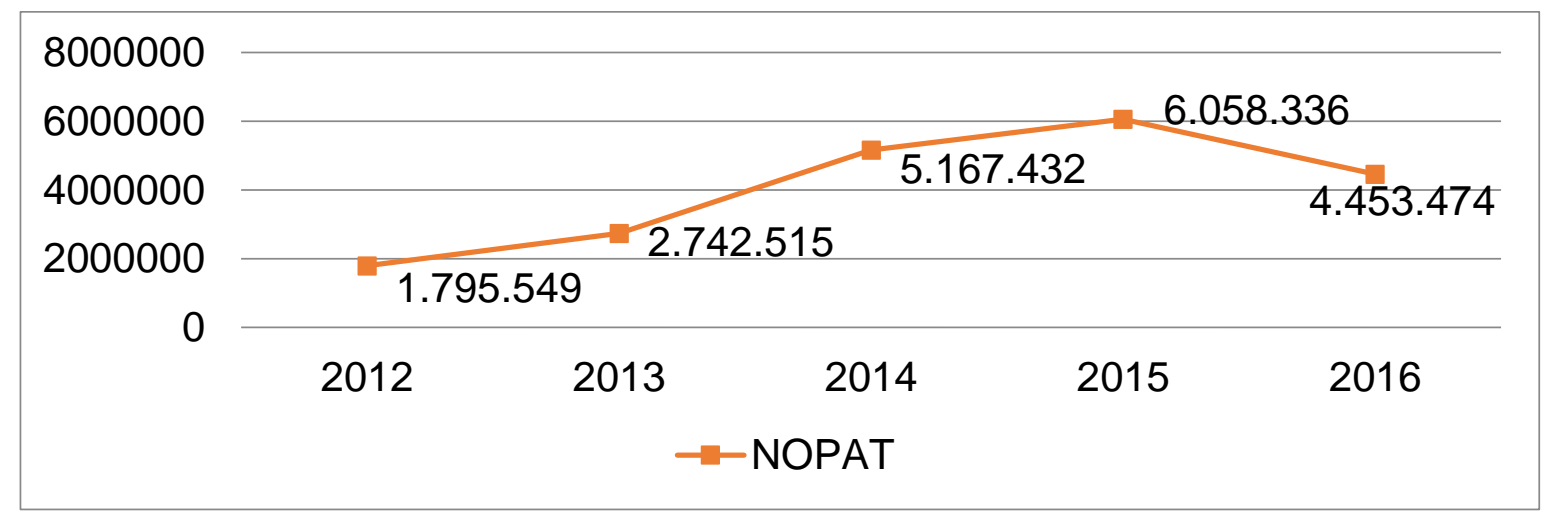

Fonte: Dados da pesquisa.

O WACC da JBS S.A. cresceu de 2012 a 2014, já em 2015 e 2016 o custo de capital da empresa caiu, como é possível visualizar no Gráfico 4. 
Gráfico 4: WACC da JBS S.A. de 2012 a 2016, valores em \%

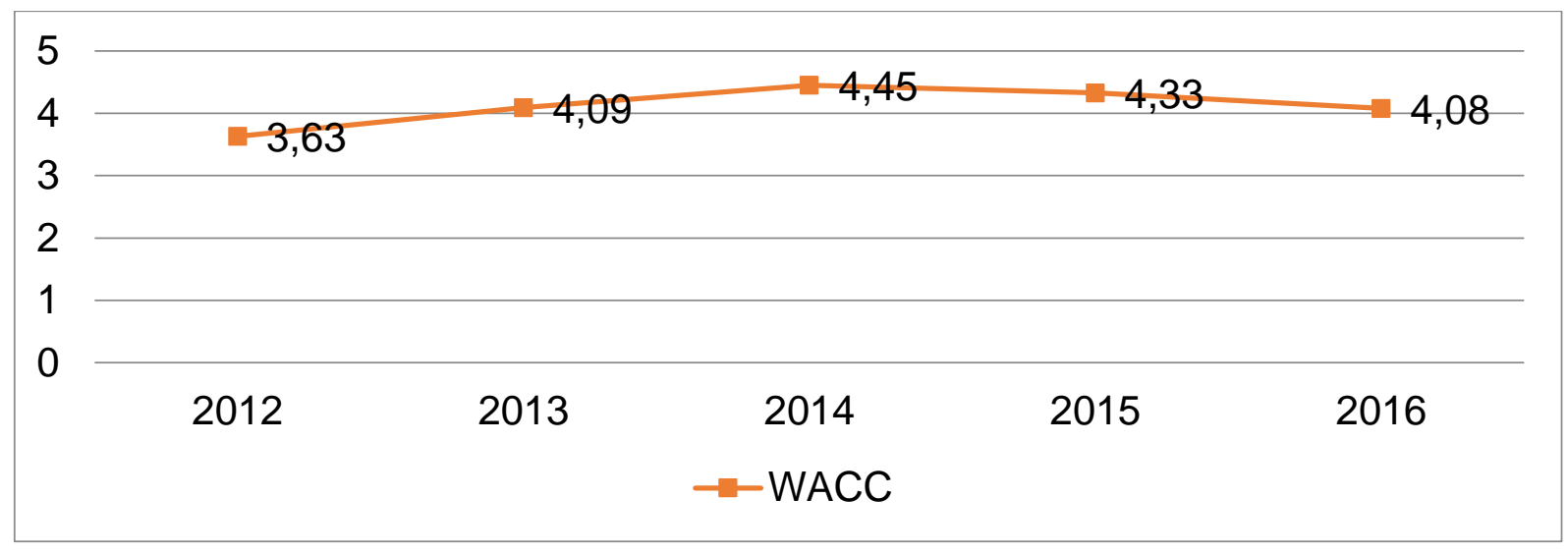

Fonte: Dados da pesquisa.

O custo de capital da JBS S.A. cresceu 12,67\% de 2012 para 2013, já em 2014 seu crescimento quando comparado ao ano anterior de 2013 foi de 8,8\%. O declínio no WACC da JBS S.A. se inicia em 2015, quando o custo de capital cai de $R \$$ 4,45 em 2014 para $R \$$ 4,33 em 2015, representando uma baixa de $2,70 \%$.

Em 2016 a redução do WACC da JBS S.A. continua, mostrando uma queda de 5,77\%, finalizando o ano com um custo de capital de $R \$ 4,08$. Prates (2016) explica que custo de capital é a taxa de retorno que uma empresa deve conseguir para manter o valor de mercado de sua empresa. Sendo assim, o WACC é o valor de retorno mínimo que a empresa deve ter para manter os seus investidores e atrair novos, pois ao superá-lo a empresa revela ser capaz de gerar valores acima do mínimo exigido para que os seus investidores tenham interesse em aplicar seu dinheiro.

O Valor Econômico Agregado positivo demonstra que a empresa criou riqueza para os seus investidores, na tabela 2 encontram-se os EVAs da Empresa JBS S.A. entre 2012 e 2016.

Tabela 2: Cálculo do EVA da empresa JBS S.A. (2012 - 2016), Milhares de R\$

CALCULO DO EVA DA EMPRESA JBS S.A. (2012 - 2016)

\begin{tabular}{l|c|c|c|c|c}
\hline \multicolumn{7}{c}{ NOPAT } \\
\hline Variável/ano & $\mathbf{2 0 1 2}$ & $\mathbf{2 0 1 3}$ & $\mathbf{2 0 1 4}$ & $\mathbf{2 0 1 5}$ & $\mathbf{2 0 1 6}$ \\
\hline EBIT & 2.720 .529 & 4.155 .326 & 7.829 .443 & 9.179 .297 & 6.747 .689 \\
\hline (1-Tax Rate) & 0,66 & 0,66 & 0,66 & 0,66 & 0,66 \\
\hline NOPAT & $\mathbf{1 . 7 9 5 . 5 4 9 , 1 4}$ & $\mathbf{2 . 7 4 2 . 5 1 5 , 1 6}$ & $\mathbf{5 . 1 6 7 . 4 3 2 , 3 8}$ & $\mathbf{6 . 0 5 8 . 3 3 6 , 0 2}$ & $\mathbf{4 . 4 5 3 . 4 7 4 , 7 4}$ \\
\hline \multicolumn{7}{|c}{ WACC } \\
\hline Variável/ano & $\mathbf{2 0 1 2}$ & $\mathbf{2 0 1 3}$ & $\mathbf{2 0 1 4}$ & $\mathbf{2 0 1 5}$ & $\mathbf{2 0 1 6}$ \\
\hline KE & 7,1870 & 9,9544 & 11,7397 & 14,2100 & 13,5906 \\
\hline KD & 0,091 & 0,251 & 0,088 & 0,194 & 0,095 \\
\hline E & 20.610 .547 & 21.951 .788 & 24.104 .328 & 28.029 .243 & 23.771 .325 \\
\hline D & 20.488 .944 & 32.761 .341 & 40.079 .140 & 65.882 .726 & 56.260 .414
\end{tabular}




\begin{tabular}{l|c|c|c|c|c} 
T & 0,34 & 0,34 & 0,34 & 0,34 & 0,34 \\
\hline WACC & $\mathbf{3 , 6 3}$ & $\mathbf{4 , 0 9}$ & $\mathbf{4 , 4 5}$ & $\mathbf{4 , 3 3}$ & $\mathbf{4 , 0 8}$ \\
\hline \multicolumn{7}{|c}{ EVA } \\
\hline Variável/ano & $\mathbf{2 0 1 2}$ & $\mathbf{2 0 1 3}$ & $\mathbf{2 0 1 4}$ & $\mathbf{2 0 1 5}$ & $\mathbf{2 0 1 6}$ \\
\hline NOPAT & 1795549,14 & 2742515,16 & 5167432,38 & 6058336,02 & 4453474,74 \\
\hline WACC & 3,63 & 4,09 & 4,45 & 4,33 & 4,08 \\
\hline (=) EVA & $\mathbf{1 . 7 9 5 . 5 4 5 , 5 1}$ & $\mathbf{2 . 7 4 2 . 5 1 1 , 0 7}$ & $\mathbf{5 . 1 6 7 . 4 2 7 , 9 3}$ & $\mathbf{6 . 0 5 8 . 3 3 1 , 6 9}$ & $\mathbf{4 . 4 5 3 . 4 7 0 , 6 6}$ \\
\hline \multicolumn{6}{c}{ Fonte: Elaborado pela autora. }
\end{tabular}

A empresa JBS S.A. apresentou ascensão na geração de riqueza de 2012 a 2015, ou seja, o retorno ao acionista aumentou, todavia em 2016, ela teve uma queda de 26,49\% no EVA comparado a 2015. A JBS S.A. teve um crescimento de 52,74\% em 2013 comparado a 2012, já em 2014 o EVA da empresa subiu de $R \$ 2.742 .511,07$ para $R \$ 5.167 .427,93$, totalizando um aumento de $88,42 \%$ comparado a 2013. O aumento não parou até 2015 , ano este que a empresa teve um aumento no EVA de $17,24 \%$ comparado a 2014, já em 2016 a tendência de alta não continuou, e a empresa finalizou o ano com um EVA de R\$ 4.453.470,66.

\subsection{VALOR ECONÔMICO AGREGADO (EVA) DA MARFRIG S.A.}

A MARFRIG S.A. teve um NOPAT de R\$ 766.673,16 em 2012 e em 2013 esse valor caiu 25,38\% alcançando o valor de $\mathrm{R} \$ 572.057,64$. Já em 2014 o Lucro Liquido após os impostos subiu 25,12\%, quase retornando ao valor perdido no ano anterior. 0 crescimento continuou em 2015, com aumento no NOPAT de 17,86\% comparado a 2014, porém em 2016 a variável caiu 20,73\% alcançando o valor de 668.692,20, o segundo menor valor expresso nos anos analisados. Os valores de alta e baixa constam no gráfico 5 .

Gráfico 5: NOPAT da MARFRIG S.A. de 2012 e 2016, Milhares de R\$

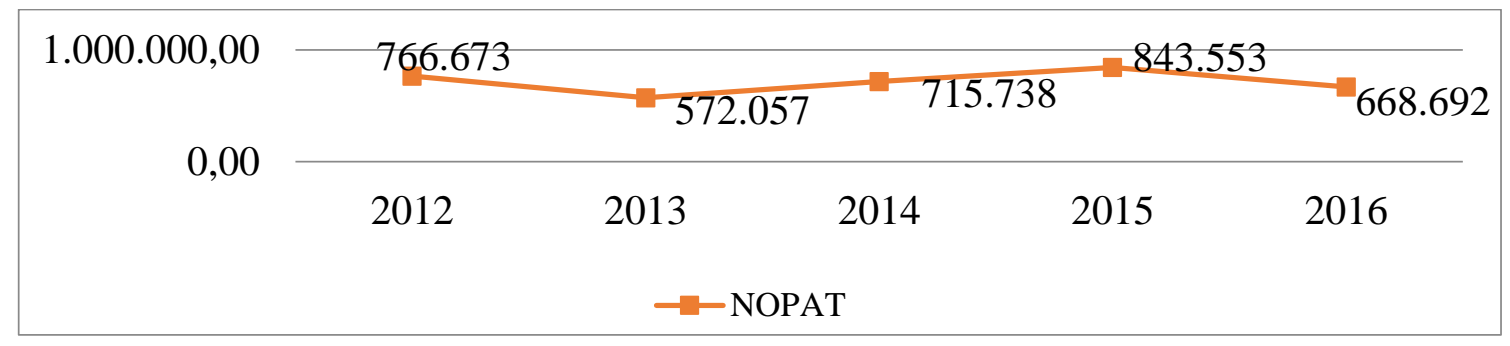

Fonte: Dados da pesquisa.

O custo de capital da MARFRIG S.A. cresceu 35,96\% de 2012 para 2013, já em 2014 seu o WACC caiu 25,58\%. O declínio no WACC da JBS S.A. continua em 2015, quando o custo de capital cai de 1,89 em 2014 para 0,94 em 2015, representando uma baixa de 50,52\%. 
Em 2016 o WACC da JBS S.A. volta a crescer, finalizando o ano com um custo de capital de 1,19, ou seja, uma alta de $27,27 \%$ quando comparada a 2015. No gráfico 6 é possível verificar as altas e baixas do WACC da MARFRIG S.A.

Gráfico 6: WACC da MARFRIG S.A. de 2012 a 2016, valores em \%

\begin{tabular}{|c|c|c|c|c|c|}
\hline \multirow{2}{*}{$\begin{array}{l}5,00 \\
0,00\end{array}$} & $\begin{array}{r}1,87 \\
-\end{array}$ & 2,54 & 1,89 & 0,9 & 1,19 \\
\hline & 2012 & 2013 & 2014 & 2015 & 2016 \\
\hline \multicolumn{6}{|c|}{$-\mathrm{WACC}$} \\
\hline
\end{tabular}

Fonte: Dados da pesquisa.

Na tabela 3 encontram-se os EVAs da Empresa MARFRIG S.A. entre 2012 e 2016.

Tabela 3: Cálculo do EVA da empresa MARFRIG S.A. (2012 - 2016), Milhares de R\$ Cálculo do Eva da Empresa Marfrig S.A. (2012 - 2016)

Cálculo do Eva da Empresa Marfrig S.A. (2012 - 2016)

\begin{tabular}{l|c|c|c|c|c}
\hline \multicolumn{7}{c}{ NOPAT } \\
\hline Variável/ano & $\mathbf{2 0 1 2}$ & $\mathbf{2 0 1 3}$ & $\mathbf{2 0 1 4}$ & $\mathbf{2 0 1 5}$ & $\mathbf{2 0 1 6}$ \\
\hline EBIT & 1161626,00 & 866754,00 & 1084453,00 & 1278111,00 & 1013170,00 \\
\hline (1-Tax Rate) & 0,66 & 0,66 & 0,66 & 0,66 & 0,66 \\
\hline NOPAT & $\mathbf{7 6 6 . 6 7 3 , 1 6}$ & $\mathbf{5 7 2 . 0 5 7 , 6 4}$ & $\mathbf{7 1 5 . 7 3 8 , 9 8}$ & $\mathbf{8 4 3 . 5 5 3 , 2 6}$ & $\mathbf{6 6 8 . 6 9 2 , 2 0}$ \\
\hline \multicolumn{7}{|c}{ WACC } \\
\hline Variável/ano & $\mathbf{2 0 1 2}$ & $\mathbf{2 0 1 3}$ & $\mathbf{2 0 1 4}$ & $\mathbf{2 0 1 5}$ & $\mathbf{2 0 1 6}$ \\
\hline KE & 7,1530 & 9,8198 & 11,7272 & 14,1476 & 13,6621 \\
\hline KD & 0,1810 & 0,1830 & 0,2710 & 0,3630 & 0,2760 \\
\hline E & 4.156 .238 & 3.029 .326 & 1.953 .465 & 643.258 & 906.616 \\
\hline D & 12.528 .247 & 9.092 .523 & 11.200 .899 & 12.183 .793 & 11.188 .897 \\
\hline T & 0,34 & 0,34 & 0,34 & 0,34 & 0,34 \\
\hline WACC & 1,87 & 2,54 & 1,89 & 0,94 & 1,19 \\
\hline \multicolumn{7}{|c}{ EVA } \\
\hline Variável/ano & $\mathbf{2 0 1 2}$ & $\mathbf{2 0 1 3}$ & $\mathbf{2 0 1 4}$ & $\mathbf{2 0 1 5}$ & $\mathbf{2 0 1 6}$ \\
\hline NOPAT & 766673,16 & 572057,64 & 715738,98 & 843553,26 & 668692,20 \\
\hline WACC & 1,87 & 2,54 & 1,89 & 0,94 & 1,19 \\
\hline (=) EVA & $\mathbf{7 6 6 . 6 7 1 , 2 9}$ & $\mathbf{5 7 2 . 0 5 5 , 1 0}$ & $\mathbf{7 1 5 . 7 3 7 , 0 9}$ & $\mathbf{8 4 3 . 5 5 2 , 3 2}$ & $\mathbf{6 6 8 . 6 9 1 , 0 1}$ \\
\hline \multicolumn{7}{|c|}{ Fonte: Elaborado pelos autores }
\end{tabular}

Fonte: Elaborado pelos autores.

A MARFRIG S.A. ao contrário da JBS S.A. e BRF S.A. gerou queda na geração de riqueza, de R\$ 766.671,29 em 2012 para R\$ 572.055,10 em 2013, ou seja, uma baixa de 25,38\%, e em 2014 a empresa apresentou um aumento de 25,12\%, comparado a 2013.

A empresa continuou a crescer em 2015, apresentando um aumento de 17,86\% comparado a 2014, já em 2016 o EVA da empresa cai de R\$ 843.552,32 em 2015 para $R \$ 668.691,01$, ou seja, uma queda de 
20,73\% em relação a 2015. Todas as empresas analisadas apresentaram EVA positivo nos anos estudados. Uma organização que possui EVA positivo em períodos sequenciais, demonstra que a mesma possui ações gerenciais sólidas e também tendenciosas e geração de riqueza.

\subsection{COMPARAÇÃO DO VALOR ECONÔMICO AGREGADO DAS EMPRESAS}

A utilização do EVA dá à empresa a possibilidade de analisar não só a organização em si, mas também quais atividades estão agregando ou destruindo valor ao acionista. Abaixo representado pela Tabela 4, consta a reunião dos resultados do EVA das empresas analisadas.

Tabela 4: Geração de riqueza das empresas BRF S.A., JBS S.A., e MARFRIG S.A. (2012 - 2016), Milhares de $R \$$

\begin{tabular}{|c|c|c|c|c|c|}
\hline \multicolumn{6}{|c|}{$\begin{array}{l}\text { GERAÇÃO DE RIQUEZA DAS EMPRESAS JBS S.A., BRF S.A. E MARFRIG S.A. } \\
(2012-2016)\end{array}$} \\
\hline & 2012 & 2013 & 2014 & 2015 & 2016 \\
\hline JBS & 795 & $742.511,07$ & 5.167 .427 & 6.058 .331 & 4.453 .470 , \\
\hline BRF & 4 & 1.293 .361 & 2.295 & 2.790 & 09,48 \\
\hline MARFRIG & $766.671,29$ & $572.055,10$ & $715.737,09$ & $843.552,32$ & $668.691,01$ \\
\hline
\end{tabular}

Fonte: Elaborado pela autora.

Gerar riqueza é item principal para um acionista investir em uma empresa, fato este que as empresas analisadas compreendem bem.

O crescimento do EVA da BRF S.A. entre 2012 e 2016 foi de 129,69\%, da JBS S.A. foi de 247,03\% e da MARFRIG S.A. foi de $86,22 \%$.

No gráfico 7 é possível verificar as variações das cotações das ações da JBS S.A., da BRF S.A. e da MARFRIG S.A. na bolsa de valores. Através disso é possível verificar que mesmo o EVA da JBS S.A. sendo maior que a BRF S.A. em todos os anos analisados, a cotação da bolsa de valores é menor. Já a MARFRIG S.A. era maior que a JBS S.A. de 2012 até meados de 2013, porém ao fim no ano de 2013 a JBS S.A. ultrapassou a cotação da MARFRIG S.A. continuando na frente até 2016.

A empresa JBS S.A., teve o EVA 95,87\% maior que a BRF S.A. e 134,20\% maior que a MARFRIG S.A. em 2012. Já em 2013 essa disparidade aumentou para 112,05\% entre JBS S.A e BRF S.A. e 379,41\% entre JBS S.A. e MARFRIG S.A.

Em 2014 e 2015, a JBS S.A. continuou em ascensão com EVA 125,09\% e 117,09\% pontos maior que a BRF S.A. nos respectivos anos. Já quando comparada a MARFRIG S.A. a JBS S.A. tem o EVA 621,97\% maior que a mesma em 2014 e 618\% maior em 2015. 
Gráfico 7: Cotações na bolsa de valores das ações da BRF S.A., JBS S.A. e MARFRIG S.A. de 2012 a 2016, em R\$

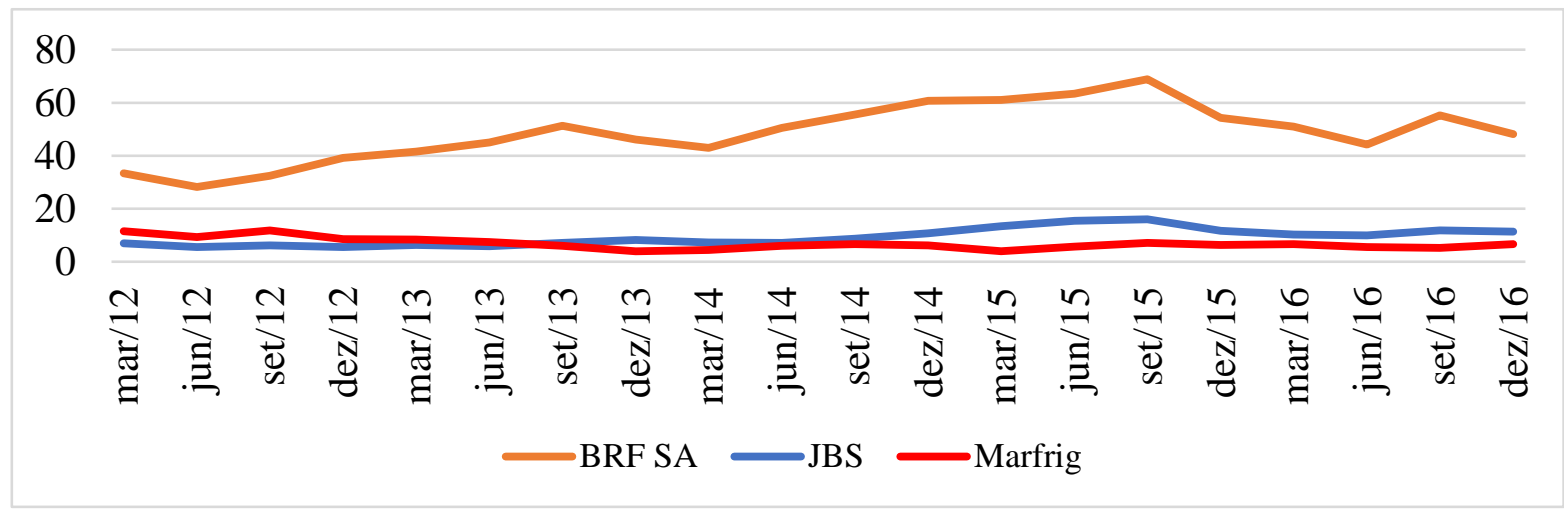

Fonte: Dados da pesquisa.

O ano de 2016 foi de regressão na geração de valor para as três empresas estudadas, a JBS S.A. teve queda $26,49 \%$, a BRF S.A. demonstrou queda de 57,07\% e a MARFRIG S.A. regrediu 20,73\% quando comparadas a 2015. Apesar do retrocesso na geração de valor a JBS S.A. manteve-se $271,74 \%$ maior que a BRF S.A. e 566\% que a MARFRIG S.A. em 2016.

O gráfico 8 mostra a variação do EVA das empresas analisadas no período de cinco anos (2012 - 2016), através dele é possível verificar os picos de geração de valor e também qual empresa agregou maior valor ao acionista no período.

Gráfico 8: A Geração de riqueza das empresas., BRF S.A., JBS S.A e MARFRIG S.A., Milhares de R\$

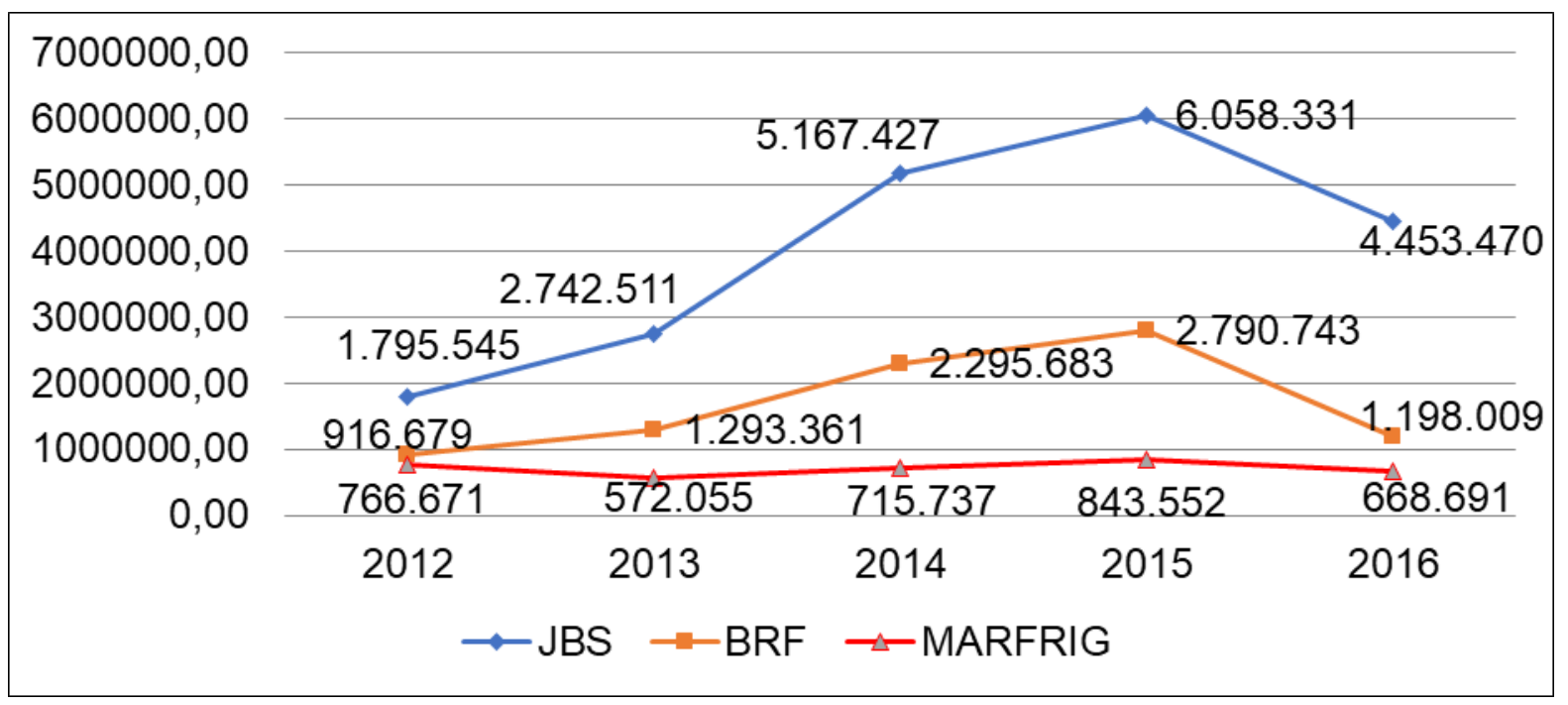

Fonte: Dados da pesquisa. 
A empresa que mais gerou riqueza para o acionista no período foi JBS S.A.. A organização possuiu um EVA positivo e maior que a BRF S.A. e a MARFRIG S.A. nos últimos cinco anos, ou seja, para o acionista o investimento na JBS S.A. no período analisado o remunerou mais que as concorrentes com o mesmo risco.

A BRF S.A. e a MARFRIG S.A. também apresentaram um EVA positivo, agregando valor ao acionista, porém com um retorno menor que os investidores da JBS S.A.

É possível visualizar através do gráfico 8 apresentado que todas as empresas sofreram queda na geração de valor em 2016. Tal comportamento do EVA pode ser aliado ao fato da crise econômica ter atingido aos frigoríficos do país desde 2015. Segundo Maruyama (2015), a crise econômica do Brasil chegou aos frigoríficos ocasionando inclusive a falta de sua matéria-prima, isto deve-se ao fato de que o rebanho brasileiro foi reduzido em mais de 2,5 milhões de cabeças nos últimos quatro anos (2012 2015).

Houve fechamento de frigoríficos em 2015, cerca de 26 unidades em todo o país, isto de acordo com a Associação Brasileira de Frigoríficos Para Joao Alberto Dias, presidente da Assocarnes de Mato Grosso do Sul a crise econômica, a redução da demanda e também a falta de animais prontos para o abate, levou diversos empresários a desistirem da atividade, ocasionando assim, as demissões em massa e efeitos em outros mercados que dependem do boi. (MARUYAMA, 2015).

A população brasileira assumiu um papel significativo na questão da demanda, pois a procura no mercado interno caiu 20\% de acordo com reportagem de Maruyama (2015), ou seja, os consumidores estão reduzindo o consumo de carne devido ao preço da mesma.

Como reflexo para a queda do EVA da JBS S.A. pode-se visualizar no gráfico 9, que a empresa teve redução no patrimônio líquido de $\mathrm{R}$ 28.029.243 de 2015 para $\mathrm{R}$ 23.771,325 em 2016, ou seja, uma queda de $15,19 \%$, todavia esse a queda também se manteve para o total da dívida da empresa que passou de $\mathrm{R} \$ 65.882,726$ em 2015 para $\mathrm{R} \$ 56.260 .414$ em 2016, representando 14,61\%. 
Gráfico 9: Variação do patrimônio líquido e total da dívida da JBS S.A. de 2012 a 2016, Milhares de R\$

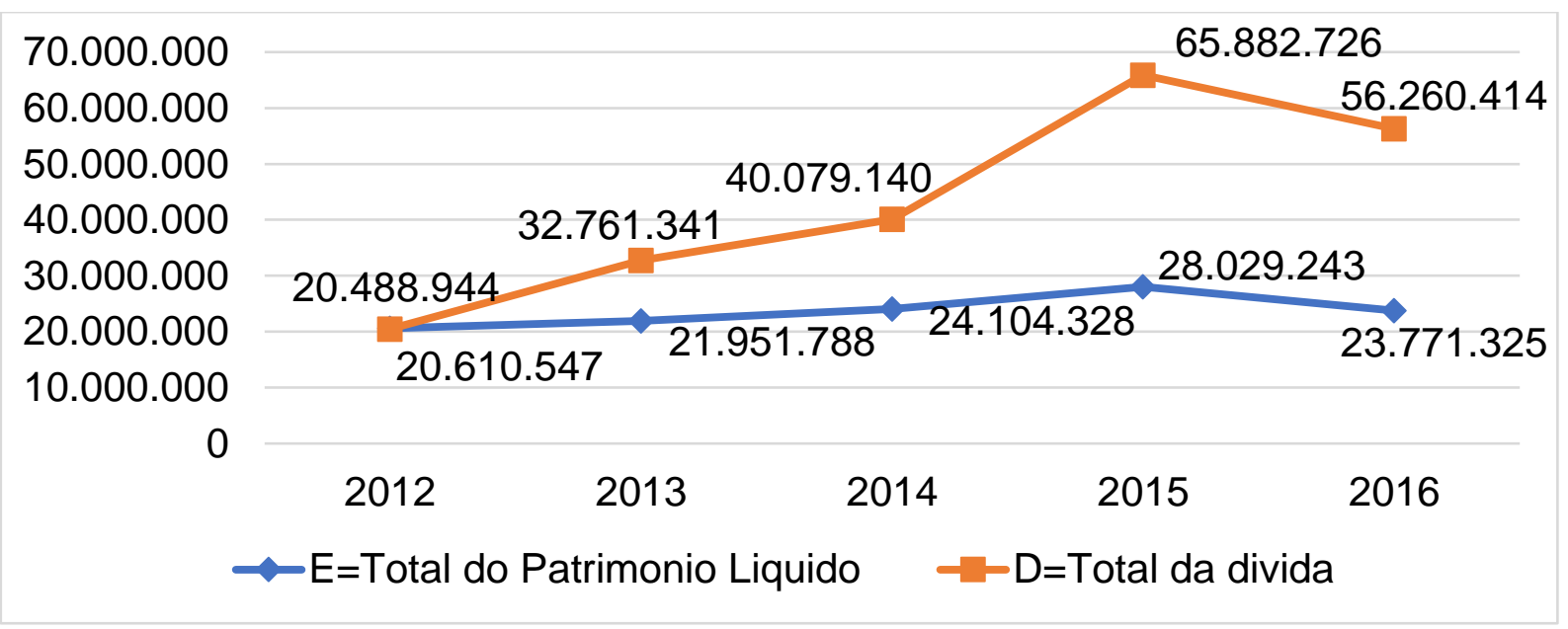

Fonte: Dados da pesquisa.

Já a BRF S.A. teve uma variação inversamente do Patrimônio líquido pelo Total da dívida, ou seja, enquanto o PL caiu 13,30\% de 2014 para 2015 a dívida subiu 30,98\%. Essa disparidade continuou em 2016, ano no qual o PL da BRF S.A. caiu mais 12,41\% em comparação a 2015 e a dívida subiu para 18.962.380, em 2016, totalizando uma alta de 24,92\% em relação a 2015, sugerindo que a empresa vinha crescendo de maneira não sustentável, além de ter criado menos valor em 2016 que nos anos 2013, 2014 e 2015 a empresa também passou a utilizar mais capital de terceiros que capital próprio. Tal variação pode ser visualizada através do gráfico 10.

Gráfico 10: Variação do patrimônio líquido e Total da dívida da BRF S.A. de 2012 a 2016, Milhares de $\mathrm{R} \$$

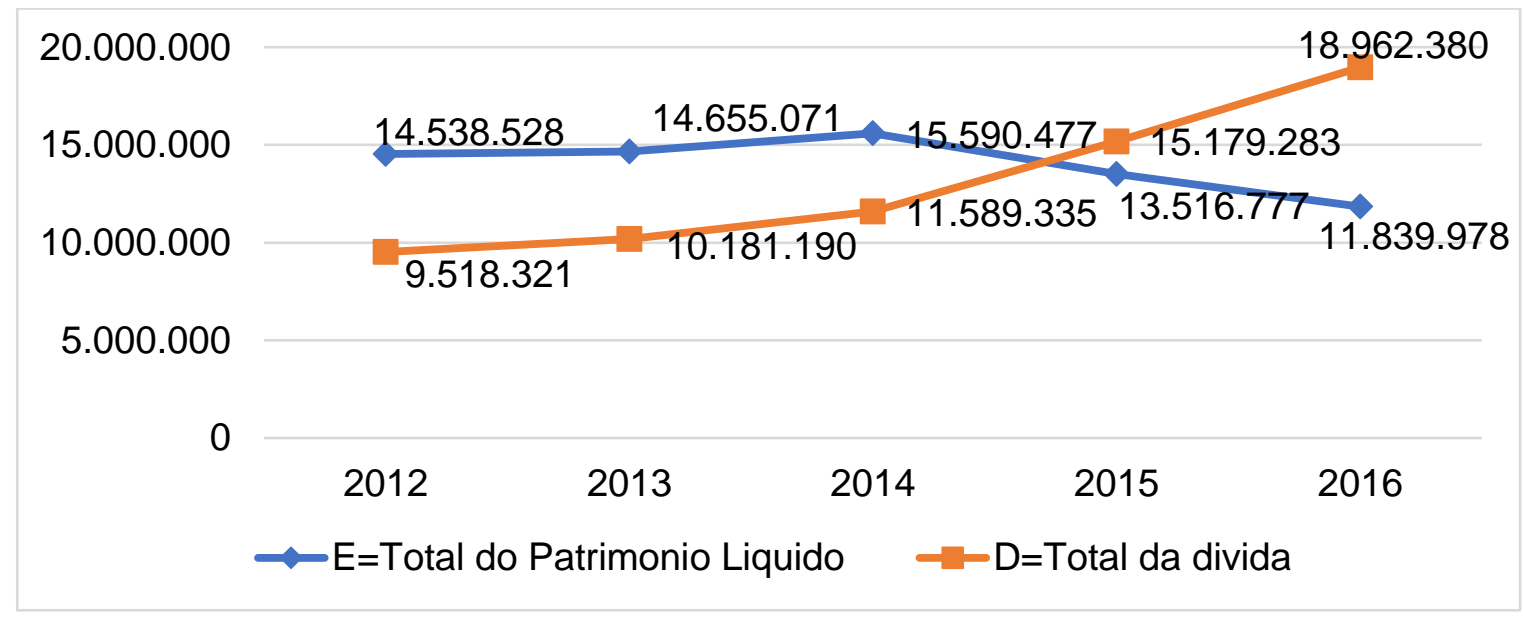

Fonte: Dados da pesquisa. 
A MARFRIG S.A. apresentou queda em seu patrimônio líquido de 2012 a 2015. Em 2013 o PL caiu de 4.156.328 de 2012 para 3.029.326, já em 2014 o PL regrediu para 1.953.465. No ano de 2015 a empresa continuou a diminuir o PL, finalizando o ano com R\$ 643.258, todavia em 2016 o patrimônio líquido da MARFRIG S.A. sobe para R\$ 906.616, uma alta de 40,94. Comparado a 2015.

Já o total da dívida da MARFRIG diminui de R\$ 12.528.247 em 2012 para R\$ 9.092.523 em 2013, representando uma baixa de 27,42\%, já em 2014 a dívida retorna a subir atingindo o valor de $\mathrm{R} \$$ 11.200.899. Em 2015 a dívida continuou a subir para 12.183.793, porém em 2016 ela diminuiu para 11.188.897, demonstrando uma queda de 8,17\%, conforme gráfico 11 .

Gráfico 11: Variação do patrimônio líquido e total da dívida da MARFRIG S.A. de 2012 a 2016, Milhares de R\$

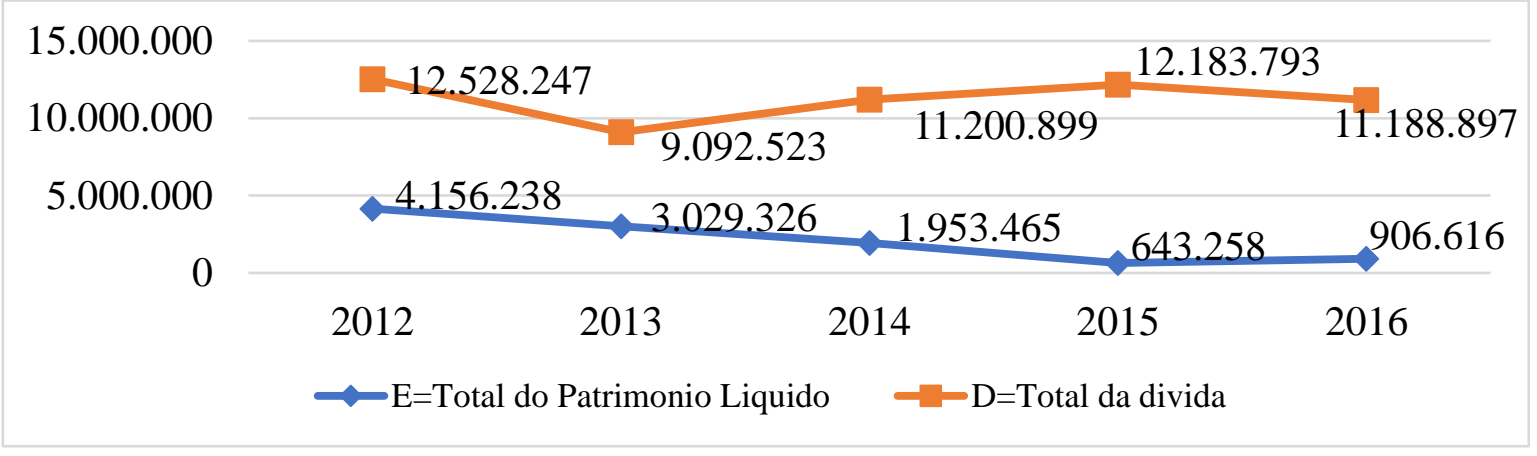

Fonte: Dados da pesquisa.

Através do gráfico 12 é possível verificar o EBIT de todas as empresas analisadas no período de 2012 a 2016. O indicador caiu $26 \%$ de 2015 para 2016 para a JBS S.A., a queda foi menor para a BRF S.A. que obteve 57\% de queda no EBIT. Já a MARFRIG S.A. caiu de R\$1.278.111 em 2015 para R\$ 1.013 .170 em 2016, proporcionando uma queda de $21 \%$ no EBIT da empresa.

Apesar das baixas evidentes em 2016, de 2012 a 2015 a JBS S.A. e a BRF S.A. apresentaram alta no EBIT. Em 2012 a BRF S.A. teve um EBIT de R\$ 1.388.915, aumentando para R\$ 1.959.648 em 2013, já em 2014 a alta foi de $22 \%$, alcançando o valor de R\$3.478.319. A BRF S.A. finalizou 2015 com um EBIT de $R \$ 4.228 .410$.

A JBS S.A. por sua vez teve um EBIT de R\$ 2.720 .529 em 2012 e em 2013 o valor alcançado foi de R\$ 4.155.326. Já em 2014 e 2015 a empresa obteve um EBIT de R\$ 7.829.443 e R\$ 9.179.297 respectivamente, um aumento de $17 \%$.

Ao contrário da JBS S.A. e BRF S.A. em 2013 a MARFRIG S.A. apresentou retrocesso no EBIT, caindo de R\$ 1.161.626 em 2012, para R\$ 866.754 em 2013, ou seja um queda de 25\%. Porém em 2014 o índice 
volta a subir e alça o valor de $\mathrm{R} \$ 1.084 .453$ e finaliza 2015 com 1.278 .111 de EBIT, uma alta de $18 \%$ comparado a 2014.

Gráfico 12: EBIT das empresas BRF S.A., JBS S.A. e MARFRIG S.A. de 2012 a 2016, Milhares de R\$

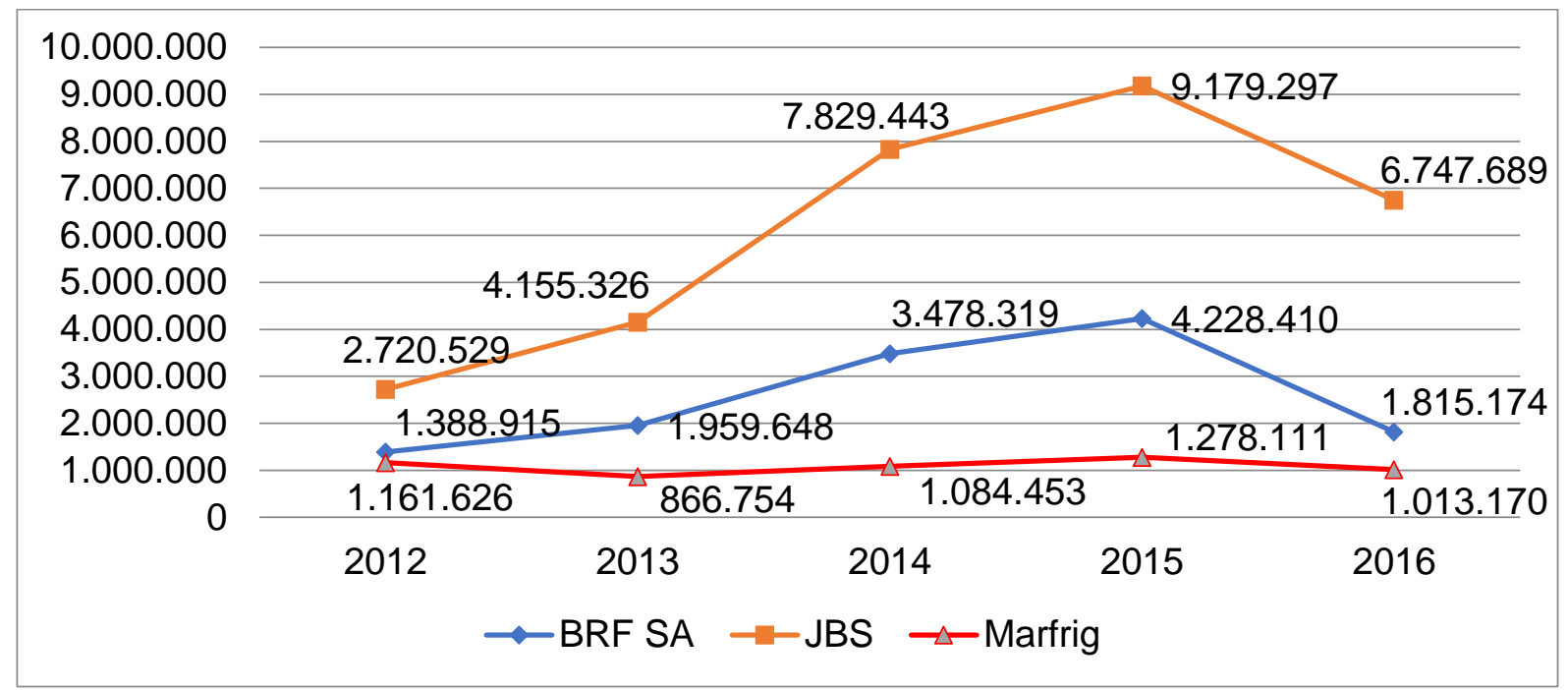

Fonte: Dados da pesquisa.

\section{CONSIDERAÇÕES FINAIS}

O objetivo desta pesquisa foi verificar entre as três empresas exportadoras de carne que possuem maior cotação na bolsa, a fim de, apontar qual gerou mais riqueza aos acionistas nos últimos cinco anos (2012 - 2016). Para isso foram utilizados dados do sistema Economatica e o Excel para realização dos cálculos de Eva de cada empresa. As empresas utilizadas foram BRF S.A., A JBS S.A. e a MARFRIG S.A.. Verificou-se que todas as empresas criaram valores para seus investidores nos períodos.

A BRF S.A. apresentou alta no seu EVA de 2012 a 2015, com um crescimento médio de 140,15\% no período, porém em 2016 ela expressou queda na geração de valor ao acionista, finalizando o ano com um retrocesso de 57,07\% quando comparado a 2015

A JBS S.A. também possuiu alta no EVA de 2012 a 2015, porém com o crescimento médio maior que a BRF S.A. ela teve 158,40\% de média de progresso. Todavia em 2016 ela também gerou desvalorização no EVA, concluindo o ano com R\$ 4.453.470,66, ou seja, um declínio de 26,49\% comparado a 2015.

Já a MARFRIG S.A. ao contrário da JBS S.A. e BRF S.A. que cresceram de 2012 a 2015, ela apresentou queda de 25,38\% de 2012 para 2013. Ela voltou a crescer em 2014, ano que progrediu 25,12\%, e continuou a ascensão até 2015, com uma média de crescimento de 17,59\% de 2012 a 2015. Todavia 
em 2016 a MARFRIG S.A. caiu como a BRF. S.A e JBS S.A., regredindo 21\% comparado a 2015, finalizando o ano com um EVA de R\$ 668.691,01

O crescimento do EVA da BRF S.A. entre 2012 e 2016 foi de 129,69\%, da JBS S.A. foi de 247,03\% e da Marfrig S.A. foi de $86,22 \%$. A JBS S.A. foi a empresa que mais gerou valor agregado ao acionista no período analisado apesar de possuir cotação na bolsa menor que a BRF S.A. de 2012 a 2016 e também menor que a MARFRIG S.A. de 2012 a meados de 2013.

Como limitação tem-se a falta de ajustes que o EVA pede e que não foram possíveis realizar. A Stern Stewart \& Co. identificou cerca de 160 ajustes alusivos a critérios contábeis, como o ajuste de P\&D, Leasing e de depreciação.

Para calcular o EVA, há dois pretextos principais para ajustes, que é transparecer a realidade econômica e separar atividades operacionais das financeiras. Há ajustes de gastos com P\&D, o objetivo deste ajuste é adicionar tais gastos ao lucro operacional liquido ao longo do tempo que é esperado os benefícios do P\&D.

O ajuste de Leasing visa aloca-lo como despesa de aluguel, pois de fato ele é uma dívida. Porém ao realizar tal ajuste de Leasing o custo médio ponderado do capital (WACC) é alterado, pois ao realizar a regulagem do mesmo as dívidas com terceiros e o capital próprio mudam, influenciando diretamente no cálculo do EVA.

A depreciação quando ajustada para ser distribuída ao longo do tempo de vida do bem, causa impacto direto no patrimônio, ou seja, influência o cálculo do WACC que é parte do cálculo do EVA.

\section{REFERÊNCIAS}

AAKER, D. A.; KUMAR, V.; DAY, G. S. Pesquisa de Marketing. São Paulo: Atlas, 2004.

ABIEC, Associação Brasileira das Indústrias Exportadoras de Carne. Pecuária brasileira.

Exportação De Carne Bovina Brasileira Registra Crescimento De 22\% Em Faturamento E 20\% Em Volume Em Março. Disponível em: <http://abiec.com.br/download/releaseexporta\%C3\%A7\%C3\%B5es-abril2017.pdf> Acesso em: 16 abr. 2017.

ALMEIDA, A S. Criar Riqueza ou Criar Valor Humano? Valor Humano. 2015- Disponivel em: <http://saalmeida.wordpress.com/2015/12/27/criar-riqueza-ou-criar-valor-humano/>. Acesso em: 22 mai. 2017. 
ASSAF NETO. Estrutura e Análise de Balanços: Um Enfoque Econômico e Financeiro. 11. ed. São Paulo: Atlas, 2015.

BARROS, G. EVA ("Economic Value Added") Um Novo Termômetro para as Empresas. Caderno Econômico Jornal do Brasil, Rio de Janeiro. 1997.

BRASIL - MINISTÉRIO DA AGRICULTURA, PECUÁRIA E ABASTECIMENTO. (a) Balança Comercial do Agronegócio - Dezembro/2016. 2016. Disponível em: <www.agricultura.gov.br/...36-6exportacao...2016/nota-dezembro-2016.docx>. Acesso em: 09 mai. 2017.

BRASIL - MINISTÉRIO DA AGRICULTURA, PECUÁRIA E ABASTECIMENTO. (b) Balanca Comercial do Agronegocio Resumida. Dezembro/2016. 2016. Disponível em: <http://www.agricultura.gov.br/noticias/com-aumento-36-6-exportacao-de-acucar-e-destaque-nabalanca-comercial-do-2016/dezembro-2016-balanca-comercial-do-agronegocio-resumida.xls/view>. Acesso em 09 mai. 2017.

BRIGHAM, E. F.; GAPENSKI, Louis C.; EHRHARDT, M. C. Administração Financeira: teoria e prática. São Paulo: Atlas, 2001.

CAETANO, J R. Sua Empresa Cria ou Destrói Riqueza? Revista Exame, São Paulo, 1998.

CANAL RURAL. Carne Fraca - Veja a Lista de Países que Barraram Carne Brasileira. 2017. Disponível em: <http://www.canalrural.com.br/noticias/pecuaria/veja-lista-paises-que-barraram-carnebrasileira-66632>. Acesso em: 05 mai. 2017

CARVALHO, L M S de. Valor Econômico Adicionado - EVA: Enfoque de Gestão Financeira. $9^{\circ}$ Semana de Contabilidade do Banco Central do Brasil. 2000. Disponível em: <http://www.bcb.gov,br/ftp/denor/luciano-bcb.pdf>. Acesso em: 22 mai. 2017.

CEPEA/ESALQ-USP. PIB do Agronegócio - Dados de 1995 a 2015. Publicação em meio eletrônico, p. 4. Disponível em: < http://www.cepea.esalq.usp.br/br/pib-do-agronegocio-brasileiro.aspx>. - Acesso em: 15 abr. 2017.

DAMODARAN, A. Equity Risk Premiums (ERP): Determinants, Estimation and Implications - The 2012 Edition. Disponível em: <https://papers.ssrn.com/sol3/papers.cfm?abstract_id=2027211>. Acesso em: 12 dez. 2017.

DAMODARAN, A. Equity Risk Premiums (ERP): Determinants, Estimation and Implications - The 2013 Edition. Disponível em: < https://papers.ssrn.com/sol3/papers.cfm?abstract_id=2238064>. Acesso em: 12 dez. 2017.

DAMODARAN, A. Equity Risk Premiums (ERP): Determinants, Estimation and Implications - The 2014 Edition. Disponível em: < https://papers.ssrn.com/sol3/papers.cfm?abstract_id=2409198>. Acesso em: 12 dez. 2017.

DAMODARAN, A. Equity Risk Premiums (ERP): Determinants, Estimation and Implications - The 2015 Edition. Disponível em: < https://papers.ssrn.com/sol3/papers.cfm?abstract_id=2581517>. Acesso em: 12 dez. 2017. 
DAMODARAN, A. Equity Risk Premiums (ERP): Determinants, Estimation and Implications - The 2016 Edition. Disponível em: < https://papers.ssrn.com/sol3/papers.cfm?abstract_id=2742186>. Acesso em: 12 dez. 2017.

DAVIES, E. M. Como Fazer Os Acionistas Mais Ricos Usando o Eva. Revista Fortune, 1996.

ECONOMATICA. Banco de Dados. Disponível em: <http://economatica.com/>. Acesso em: 12 dez. 2017.

EXTRA GLOBO. PF Revela Esquema de Carne Adulterada; Escandalo Preocupa Consumidor e Ameaça Exportações. 2017. Disponivel em: <http://extra.globo.com/noticias/economia/pf-revela-esquemade-carne-adulterada-escandalo-preocupa-consumidor-ameca-exportacoes-20177003.html>. Acesso em: 15 abr. 2017.

FARIA, A. C. de; COSTA, M. de F. G. Gestão de Custos Logísticos: custeio baseado em atividades (ABC), Balanced Scorecard (BSC), Valor Econômico Agregado (EVA). São Paulo: Atlas, 2005.

INSTITUTO DE PESQUISA ECONÔMICA APLICADA - Ipeadata. Dados macroeconômicos. Disponível em: <http://www.ipeadata.gov.br/Default.aspx>. Acesso em: 12 dez. 2017.

KOLLER, T.; GOEDHART, M.; WESSELS, D. Valuation: Measuring and Managing the Value of Companies. 4. ed. New Jersey: McKinsey \& Company, 2005.

LEAL, I. M. de A.. Análise de rácios financeiros e a sua influência na concessão de descontos aos lojistas. Universidade do Porto Faculdade de Economia do Porto. 2013. Disponível em: <file:///D:/Users/Admin/Downloads/INES_MARIA_DE_AZEVEDO_LEAL.pdf>. Acesso em 28 dez 2017.

MALVESSI, O.. Criação ou Destruição de Valor ao Acionista. Revista Conjuntura Econômica. São Paulo, vol. 54, n.1, janeiro 2000.

MARSHALL, A. Principles of Economics. New York: MacMillan \& Co., 1890.

MARUYAMA, A.. Crise econômica no país chega aos frigoríficos e falta até carne de boi. 2015. Disponível em: <http://g1.globo.com/jornal-da-globo/noticia/2015/06/crise-economica-no-paischega-aos-frigorificos-e-falta-ate-carne-de-boi.html>. Acesso em 07 jan. 2018.

MOTA, A.G; BARROSO, C.D; NUNES, J.P; FERREIRA, M.A; Finanças da Empresa: Teoria e Prática. 3a Edição; Edições Silabo. 2010.

NIPPON MEAT PACKERS, Inc. Annual Report 2016. Tokyo. Disponível em: <http://www.nipponham.co.jp/eng/ir/library/annual/pdf/2016_e_06.pdf>. 2016. Acesso em: 19 mai. 2017.

PADOVEZE, C. L.. Contabilidade Gerencial: Um enfoque em sistema de informação contábil. 7. ed. São Paulo: Atlas, 2010.

PÁDUA, E. M. M. de. Metodologia da pesquisa: abordagem teórico prática. 2. ed. Campinas: Papiros, 1997. 
PRATES, W. R.. O que é custo de capital de uma empresa. 2016. Disponível em: <http://www.wrprates.com/o-que-e-custo-de-capital-de-uma-empresa/>. Acesso em 05 jan. 2018.

REGIS, F.; SANTOS, R. F.; SANTOS, N. M. B. F.. Análise do Economic Value Added (EVA) no Setor Eletrônico - Utilização da Metodologia com Base na Criação de Valor Congresso Brasileiro de Custos. Belo Horizonte. 2010.

ROSSETTI, J. P.. Finanças Corporativas. Teoria e Prática Empresarial no Brasil. Rio de Janeiro: Elsevier, 2008.

SOARES, A. C. P.. EVA (Economic Value Added) VS Indicadores Financeiros Tradicionais. Relatório de Estágio de Mestrado em Gestão. Faculdade de Economia da Universidade de Coimbra. 2014.

STEWART, G. B. Em Busca do Valor: o guia de EVA para estrategistas. Porto Alegre: Bookman, 2005.

YOUNG, S. D.; O'BYRNE, S.. EVA e Gestão Baseada em Valor: guia prático para implementação. Tradução: Paulo Lustosa. Porto Alegre: Bookman, 2003. 


\section{Capítulo 26}

\section{ALINHAMENTO ESTRATÉGICO DE TECNOLOGIA DA INFORMAÇÃO: UM ESTUDO EM COOPERATIVAS AGROPECUÁRIAS}

DOI: $10.37423 / 200300470$

Sidney Verginio Da Silva - sid.si@hotmail.com

Nilton Dos Santos Portugal - nilton@unis.edu.br

Gideon Carvalho De Benedicto - gideon.benedicto@gmail.com

Sheldon William Silva - sheldonwilliamsilva@gmail.com

Lucio Garcia Caldeira - lucio.caldeira@unis.edu.br

RESUMO: Este trabalho apresenta uma discussão sobre o alinhamento estratégico de Tecnologia da Informação (TI) em cooperativas agropecuárias, analisando se existe o alinhamento nestas organizações. Para cumprir este propósito, este trabalho se pauta em um estudo de casos realizados em duas cooperativas agropecuárias, localizadas no Sul do estado de Minas Gerais. Sabe-se que o agronegócio é um setor de suma importância à economia brasileira, e, complementarmente, as cooperativas agropecuárias são organizações que contribuem sobremaneira para a produção e os resultados deste setor. E devido à várias especificidades, as cooperativas têm demandado uma gestão mais profissional, conhecedora do ambiente em que estão inseridas, exigindo um planejamento que leve a organização a buscar e atingir melhores resultados para seus cooperados. Um planejamento estratégico pode direcionar melhor o rumo e as ações destas organizações na busca por seus objetivos. Aliado a isso, a TI tem se mostrado como uma parceira capaz de auxiliar as organizações não só em suas atividades rotineiras, mas também na definição de estruturas organizacionais e de apoio ao planejamento e à tomada de decisão. 
No entanto, apenas adotar TI não significa necessariamente colher bons resultados. É necessário que a TI seja adquirida e utilizada de forma alinhada aos negócios e objetivos da organização, criando assim o alinhamento estratégico.

Dado este contexto, buscou-se verificar se a Tecnologia da Informação está sendo utilizada de forma alinhada às estratégias das cooperativas estudadas. Os resultados da pesquisa permitem agregar novas discussões ao tema de alinhamento estratégico e utilização de TI no agronegócio, preenchendo algumas lacunas existentes, principalmente em relação a um uso mais estratégico de $\mathrm{Tl}$ em cooperativas agropecuárias e a estruturação de uma governança.

Palavras-chave: Alinhamento estratégico. Tecnologia da Informação. Cooperativas agropecuárias. 


\section{INTRODUÇÃO}

O ambiente empresarial tem passado por grandes transformações nos últimos anos. A evolução tecnológica e a economia moderna têm exigido das organizações rápidas e constantes mudanças para sobreviver neste ambiente em constante transformação. Tais mudanças envolvem muitas vezes a quebra de paradigmas, melhoria de processos, novas estruturas e o aprimoramento das estratégias da organização. É necessário que as organizações se tornem mais competitivas para sobreviver no mercado e enfrentar a concorrência. A chamada "nova economia", baseada no conhecimento, faz com que a geração e a utilização do conhecimento possuam papel fundamental no desenvolvimento e na criação de bem-estar social (O’BRIEN; MARAKAS, 2013).

O desenvolvimento de novas tecnologias da informação possibilitou a manipulação, armazenamento e distribuição de informações e conhecimento codificados de maneira cada vez mais rápida, com maior qualidade e para um maior número de pessoas (O'BRIEN; MARAKAS, 2013). A Tecnologia da Informação (TI) mostra-se com uma grande mola propulsora das mudanças vividas pela sociedade, sendo um fator competitivo das organizações.

Este cenário não é diferente nas organizações do agronegócio, um setor de grande valor para o Brasil. Ao analisar os resultados do agronegócio, é possível identificar a preocupação das organizações agropecuárias com a busca por produção e prestação de serviços de qualidade, de forma competitiva e racionalizando os recursos disponíveis (MELLO, 2014). Nesse sentido, as cooperativas agropecuárias também têm um papel importante no agronegócio, uma vez que atuam como órgãos de união e apoio aos produtores.

Estudos têm sido feitos para entender como a TI impacta e tem sido utilizada na atividade agropecuária. Brito, Antonialli e Santos (1997), Zambalde (2000), Drummond (2003), Heinzmann et al. (2010) e Mello (2014), são apenas alguns exemplos de trabalhos que buscaram compreender a inserção da TI no agronegócio brasileiro. Mais do que utilizar TI, é necessário que as organizações a utilizem de forma alinhada aos seus objetivos. Não são raros os casos que se adotam novas tecnologias e Sistemas de Informação que, após certo tempo, acabam sendo subutilizados, pois não houve a análise da real necessidade de tais recursos, levando a uma perda de tempo e dinheiro (MELLO, 2014).

Desta forma, este trabalho busca contribuir com as discussões sobre adoção de TI em organizações do agronegócio, de forma a investigar, por meio de um estudo de casos, se as cooperativas agropecuárias 
têm utilizado a Tecnologia da Informação no âmbito estratégico, verificando se existe alinhamento da TI com o negócio da organização. Tal estudo foi feito em duas cooperativas agropecuárias, no sul do estado de Minas Gerais.

Assim, este trabalho traz como pergunta norteadora do problema de pesquisa: há alinhamento estratégico entre a Tecnologia da Informação e o planejamento estratégico das cooperativas agropecuárias? Busca-se identificar se, ao se definir as estratégias, a gestão das cooperativas leva em consideração os recursos de TI que possui, identificando ainda novas oportunidades de negócios por meio da TI. O objetivo principal deste estudo é, portanto, compreender o papel da Tecnologia da Informação nas cooperativas estudadas, identificando se há o alinhamento estratégico de TI.

Além de contribuir academicamente para as discussões sobre planejamento estratégico e Tecnologia da Informação, esta pesquisa se justifica ainda pela contribuição à comunidade e organizações do agronegócio, sobretudo as cooperativas. Os resultados contribuem para ajudar a preencher a lacuna existente sobre adoção de $\mathrm{Tl}$ em organizações do agronegócio, principalmente em cooperativas agropecuárias, mostrando os desafios que estas organizações possuem ao adotar um plano estratégico de negócios e de TI.

Estre trabalho possui, após esta Introdução, uma breve revisão teórica sobre planejamento estratégico de negócios, Tecnologia da Informação e o Planejamento Estratégico de TI. Em seguida, é discutida a questão do alinhamento estratégico. Posteriormente, apresentam-se os procedimentos metodológicos, onde se explicam a natureza da pesquisa e a forma de coleta dos dados. Por fim, apresentam-se os resultados encontrados nos estudos realizados, seguido das considerações finais e referências utilizadas.

\section{REFERENCIAL TEÓRICO}

Esta seção apresenta uma breve revisão teórica que fundamenta esta pesquisa.

\subsection{PLANEJAMENTO ESTRATÉGICO DE NEGÓCIOS (PEN)}

Para Oliveira (2011), o planejamento estratégico corresponde ao estabelecimento de um conjunto de providências que o executivo da organização deve tomar em situações onde o futuro tende a ser diferente do passado. "Planejar, no sentido amplo e estratégico do processo decisório, é reduzir riscos, 
otimizar esforços e tirar o melhor proveito possível dos recursos disponíveis" (ROSINI; PALMISANO, 2014, p. 134).

O Planejamento Estratégico de Negócio (PEN) é um sistema integrado de decisões, "capaz de produzir dados e informações para ajudar os gestores a pensar estrategicamente, apoiando a articulação das estratégias ou visões de futuro" (AFFELDT; VANTI, 2009, p. 206). São planos voltados à definição do posicionamento da empresa frente as mudanças ambientais e frente aos seus competidores. Podem cobrir toda a empresa ou unidades de negócios, como planejamento de negócios, planejamento estratégico de marketing, plano estratégico de recursos humanos ou planejamento estratégico de tecnologia da informação (BIO, 2008). Desta forma, o planejamento estratégico permite avaliar implicações futuras de decisões presentes em função dos objetivos da empresa. Em suma, envolve a redução da incerteza envolvida no processo decisório, buscando ainda o aumento da probabilidade de alcance dos objetivos e metas estabelecidas pela empresa (OLIVEIRA, 2011).

O planejamento estratégico parte das análises do ambiente empresarial (aspectos econômicos, tecnológicos, sociais), dos pontos fracos e fortes da empresa, de suas ameaças e oportunidades, e visa oferecer: uma visão precisa do negócios, visão e missão da empresa, princípios e valores básicos, estratégias e os objetivos estratégicos (AFFELDT; VANTI, 2009; BIO, 2008). O planejamento estratégico retrata a programação dos gestores para a organização, e tal programação deve ser elaborada a partir de diversas fontes (AFFELDT; VANTI, 2009). Assim, é necessário que as fontes de informações possam convergir para auxiliar o planejamento. As organizações devem levar em consideração recursos e tecnologias disponíveis, pois neles podem estar o diferencial que precisam e buscam (HEDERSON; VENKATRAMAN, 1993).

Se a informação é um ativo vital para o planejamento estratégico, há de se ter especial atenção a este ativo. Um dos motivos que levam ao insucesso do planejamento estratégico é a falta de estabelecimento do sistema de informações necessárias para o adequado controle e avaliação do planejamento estratégico. Isso relaciona-se diretamente às estratégias de utilização de Tecnologia da Informação (TI) pela empresa, para que esta possa dar suporte ao planejamento, execução e controle. Outro fator para tal insucesso é a falta de estabelecimento da interligação entre o planejamento estratégico e seus vários itens ou mesmo outros tipos de planejamento, como o planejamento estratégico de TI (OLIVEIRA, 2011). 
Portanto, a Tecnologia da Informação desponta como uma aliada ao planejamento e estratégias de negócio. A TI tem sido utilizada não só como ferramenta de apoio à gestão, mas também como diferencial competitivo, pois gera inovação e novos negócios, influenciando assim todo o contexto da organização (PINTO; GRAEML, 2010). Mas adotar TI não significa necessariamente garantia de sucesso. Cada vez mais é necessário utilizar recursos de TI de forma integrada às estratégias e objetivos da organização. Por isso, é vital a criação de um Planejamento Estratégico de TI, como discutido a seguir.

\subsection{PLANEJAMENTO ESTRATÉGICO DE TECNOLOGIA DA INFORMAÇÃO (PETI)}

Dado o avanço tecnológico e a necessidade de informações, não se pode mais aceitar que sistemas sejam isolados nas organizações (REZENDE, 2013). A integração entre sistemas, de acordo com o autor, pode levar à qualidade da organização (conformidade com os requisitos funcionais exigidos, adequação ao uso), produtividade da informação (relação entre resultados obtidos e recursos disponíveis consumidos, resultado auferido) e a efetividade da informação: somatório da eficiência (desempenho) e eficácia (resultado), baseada em regularidade, praticidade, durabilidade, economicidade e constância da informação.

Muitas empresas realizam esforços de melhoria de sistemas de informação com um nível precário de planejamento. As consequências deste tipo de conduta, que frequentemente são observadas, são: mudanças constantes de prioridades, com projetos não iniciados e descontinuados ou substituídos; sub ou superdimensionamento de recursos de processamento de dados; inadequado dimensionamento de recursos humanos na área de sistemas; implantações mal sucedidas, trazendo mais e novos problemas; desgaste e desmotivação de equipes; impossibilidade de avaliar benefícios e controlar o desenvolvimento de sistemas (BIO, 2008).

Para evitar tais problemas, as organizações devem atentar-se para a gestão de seus recursos de $\mathrm{TI}$, identificando não somente as necessidades de informações, mas também a tecnologia disponível para gerenciar tais informações. Assim, a TI "destaca-se como um recurso fundamental de competitividade empresarial, oferecendo um amplo leque de oportunidades" (HEINZMANN et al., 2004, p. 2). Isso mostra que é cada vez maior a necessidade de relacionar a tecnologia da informação aos negócios, conectando estratégias individuais, progredindo assim à procura por metodologias, abordagens e modelos que proporcionem processos ordenados sobre a estratégia de negócios e o planejamento da tecnologia da informação (MENDES; CALDAS; CÂNDIDO, 2011). A premissa fundamental é que o planejamento de TI deve considerar as necessidades dos usuários e a estratégia organizacional para 
então realizar seu próprio planejamento, semelhante ao PEN. Desta forma, o PETI pode ser entendido como

recurso utilizado para auxiliar o planejamento estratégico empresarial (PEE) na identificação de oportunidades de TI que apoiem os negócios empresariais, no desenvolvimento de arquiteturas de informação baseadas nas necessidades dos usuários e no desenvolvimento de planos de ação em longo prazo (PINTO; GRAEML, 2011, p. 263).

O principal objetivo do planejamento tecnológico é identificar oportunidades de aplicação de novas tecnologias, de forma a definir ações para sua implementação na empresa. Desta forma, durante o planejamento, deve ser feita uma análise das oportunidades de aplicação da tecnologia de informação, diretamente nos produtos ou serviços oferecidos pela empresa, sejam atuais ou potenciais, como forma de criar ou aumentar a vantagem competitiva (ROSINI; PALMISANO, 2014).

Percebe-se, portanto, que o PETI assume um papel de instrumento de planejamento de necessidades de recursos físicos, financeiros, técnicos e humanos de informatização, fazendo parte de um planejamento global voltado aos objetivos da empresa como um todo e auxiliando a organização em suas decisões estratégicas e operacionais. Se o planejamento estratégico de negócios pode garantir a sobrevivência das organizações, a forma como se apropria e utilizam os recursos de TI também podem ser apoio a esta sobrevivência. Desta forma, como base do planejamento de TI deve estar o processo de planejamento empresarial. Isso porque a elaboração do PETI estimula a participação de todos os níveis da organização no processo de planejamento e permite a conscientização sobre a sua importância como um instrumento para a realização das atividades-fim de uma empresa (CASSARRO, 2015). Isso justifica a necessidade de se preocupar com "a maneira com que a TI é planejada, adequada e adaptada para colaborar com a organização no alcance de seus objetivos e metas estratégicas" (PINTO; GRAEML, 2011, p. 263).

O PETI planeja os sistemas de informação da empresa (operacionais, gerenciais e estratégicos). A partir de tais sistemas, organiza-se a necessidade de infraestrutura de TI (hardware, software, telecomunicações e bases de dados e informações), juntamente com a definição de perfis das pessoas que sejam coerentes com as propostas da organização. Tais variáveis devem possuir sinergia entre si; os sistemas são planejados e devem estar relacionados com as estratégias e planejamento estratégico da organização (REZENDE, 2016). O PETI deve ser estruturado para não causar danos e investimentos desnecessários, efetivamente apoiando as organizações (REZENDE, 2016). As metodologias utilizadas no planejamento buscam facilitar o trabalho dos planejadores e gestores organizacionais nas atividades de alinhamento entre os recursos de tecnologia da informação com as estratégias da 
organização, identificando oportunidades para utilizar os recursos de TI na busca de vantagem competitiva (SEGARS; GROVER, 1998; BROADBENT; WEILL; CLAIR, 1999).

O PETI compreende então a concepção de planos de ação dos sistemas de informação e tecnologias da informação em longo prazo, de forma a suportar direção, consistência de propósito, flexibilidade e continuidade dos recursos de TI para apoiar o negócio. Este apoio da TI às atividades e estratégias de negócio é representado pelo Alinhamento Estratégico de TI (AFFELDT; VANTI, 2009), discutido a seguir.

\subsection{ALINHAMENTO ESTRATÉGICO DE TECNOLOGIA DA INFORMAÇÃO}

No final da década de 1970 começa a ser reconhecida a necessidade de alinhamento estratégico entre os planos de negócios e de TI. Nos últimos anos este tema tem estado presente nas discussões de executivos de diversas áreas, que reconhecem o alinhamento como importante ferramenta de gestão empresarial, capaz de oferecer à organização as condições necessárias para orientar atividades externas e internas, de forma a alcançar seus objetivos (CANEPA; RIGONI; BRODBECK, 2008; MENDES; CALDAS; CÂNDIDO, 2011). Para Henderson e Venkatraman (1993), a falta de habilidade das empresas em obter retornos consideráveis sobre os investimentos feitos em TI se deve, muitas vezes, à falta de alinhamento entre as estratégias de negócio e de TI. O alinhamento entre TI, estratégias de negócio e as estruturas internas da empresa é um processo dinâmico e contínuo ao longo do tempo. As empresas não conseguem obter vantagem competitiva apenas com a rápida alocação de novas tecnologias a seus ativos (KAPLAN; NORTON, 1997).

Assim, o alinhamento estratégico de Tecnologia da Informação se refere ao grau em a que a gestão de $\mathrm{Tl}$ entende as prioridades dos negócios e utiliza seus recursos, prossegue com projetos e fornece informações de acordo com prioridades. Para tanto, é necessário que a organização se preocupe em garantir que os investimentos em TI agreguem valor ao negócio. A isso, os autores chamam de governança de TI. A governança permite reduzir custos e diminuir os danos causados pelas falhas de $\mathrm{TI}$, bem como, melhorar a confiança e a qualidade do serviço das pessoas que utilizam TI. (TURBAN; VOLONINO, 2013).

Rezende (2016) afirma que o alinhamento entre Planejamento Estratégico de Negócios (PEN) e Planejamento Estratégico de Tecnologia da Informação (PETI) constitui-se a partir da relação vertical e horizontal com os respectivos ambientes externo e interno, promovendo assim o ajuste ou adequação estratégica para atender ao posicionamento de mercado da organização, conforme a Figura 1 a seguir. Isso ocorre a partir dos diferentes relacionamentos funcionais entre pessoas e 
habilidades pessoais, processos, arquitetura de tecnologia da informação e infraestrutura de apoio às estratégias organizacionais (BROADBENT; WEILL; CLAIR, 1999; HENDERSON; VENKATRAMAN, 1993).

Figura 1: Alinhamento estratégico de TI

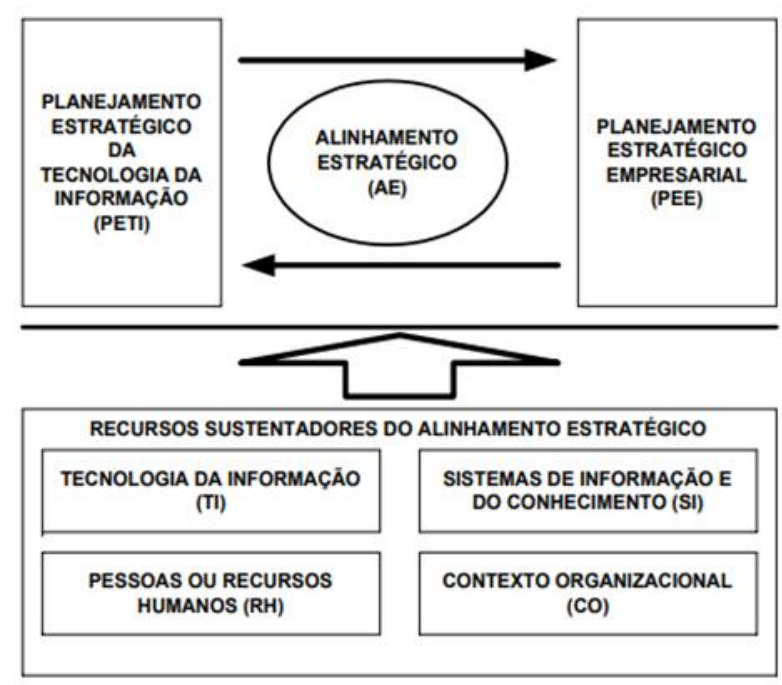

Fonte: Resende (2002)

Planos de negócio e de TI deveriam ser totalmente integrados pelo mapeamento de sistemas e das informações estratégicas relacionadas com as estratégias de negócios e pelo suporte de recursos informacionais aos objetivos de negócios (AUDY; BRODBECK, 2003). “O alinhamento estratégico é o elo entre o plano de negócio e o plano tecnológico das organizações, devendo ambos ser produtos de um plano corporativo" (AUDY; BRODBECK, 2003, p. 16). Promove, portanto, o ajuste ou adequação estratégica das tecnologias que a organização possui, como uma ferramenta de gestão organizacional. O alinhamento estratégico é uma complexa atividade de gestão, e esta complexidade aumenta com a crescente complexidade das organizações, conforme o ritmo de competição global e conforme as mudanças de tecnologia aumenta (TURBAN, VOLONINO, 2013).

Cabe destacar que, dependendo do setor de atuação das organizações, as práticas de alinhamento podem ser mais ou menos promovidas, já que dependerão da importância atribuída pelos gerentes de negócios e dos assuntos estratégicos relacionados a seu setor (PORTER, 1990). De qualquer forma, as estratégias de aquisição, desenvolvimento, implantação e uso de TI devem levar em consideração toda a estrutura, planejamento e objetivos da organização, de forma a fazer com que a TI não só possua um planejamento próprio, mas que também possa servir de alicerce às estratégias da 
organização e que possa ser incluída no momento de pensar em recursos ou tomar decisões. Estes fatores levaram pesquisadores a estudar e propor modelos para o alinhamento estratégico de TI.

\subsubsection{MODELO DE ALINHAMENTO ESTRATÉGICO DE TI}

Um modelo de alinhamento estratégico descreve como as estratégias de negócios e de $\mathrm{Tl}$ e a infraestrutura organizacional ajudam a alcançar o alinhamento entre negócios e TI (BRODBECK; 2001). Embora os modelos muitas vezes pressuponham a execução de tarefas para sua implantação, nem sempre os resultados serão satisfatórios. Em verdade, o alinhamento estratégico de TI deve ser estudado, discutido e adaptado à realidade da organização, visto que tal atividade não é fácil de ser realizada nas organizações (REZENDE, 2016). Muitas organizações tentam alinhar TI e negócio de forma empírica, sem apoio de metodologia e muitas vezes sem ao menos existir um planejamento de TI (BRODBECK; HOPPEN, 2003).

Vários estudos têm sido realizados com o intuito de propor modelos ou identificar formas de alinhamento estratégico, de forma a buscar a melhor forma de adequar o PETI ao PEN (AFFELDT, VANTI, 2009; BRODBECK, 2000; BRODBECK, HOPPEN, 2003; HENDERSON, VENKATRAMAN, 1993; LEAVITT, 1965; MENDES, CALDAS, CÂNDIDO, 2011; PINTO, GRAEML, 2011; REZENDE, 2002; ROCKART; SCOTT, 1984). As discussões convergem na ideia de que os recursos e infraestrutura de TI devem atuar de forma a suportar e serem suportados pelo plano de negócio.

Para o estudo de caso apresentado neste artigo, foi tomado como base teórica o Modelo Operacional de Alinhamento Estratégico - MOAE (BRODBECK, 2001). Tal modelo pressupõe não só o planejamento estratégico de negócios e TI, mas também a implementação e acompanhamento do planejamento, sendo assim um diferencial em relação a outros modelos. Mais detalhes do motivo de escolha deste modelo são apresentados na Metodologia.

\subsubsection{MODELO OPERACIONAL DE ALINHAMENTO ESTRATÉGICO (MOAE)}

Também conhecido como modelo de Brodbeck, foi proposto no trabalho de Brodbeck (2001), sendo apresentado posteriormente nos trabalhos de Audy e Brodbeck (2003) e Brodbeck e Hoppen (2003). Criado a partir do estudo da autora em empresas nacionais e internacionais, sendo construído a partir de vários modelos de alinhamento estratégico de $\mathrm{TI}$, mas principalmente, a partir do modelo de Henderson e Venkatraman (1993). No modelo de Brodbeck (2001), o alinhamento é formado por um elo multidimensional entre as estratégias de negócios e objetivos organizacionais e pelas estratégias 
e objetivos de TI, dependendo também do contexto organizacional e dos ambientes interno e externo. O modelo é apresentado como um cubo formado pelo ciclo de cada processo de planejamento, que representam a continuidade no processo de planejamento (BRODBECK, 2001), conforme a Figura 2.

\section{Figura 2: Modelo Operacional de Alinhamento Estratégico (MOAE)}

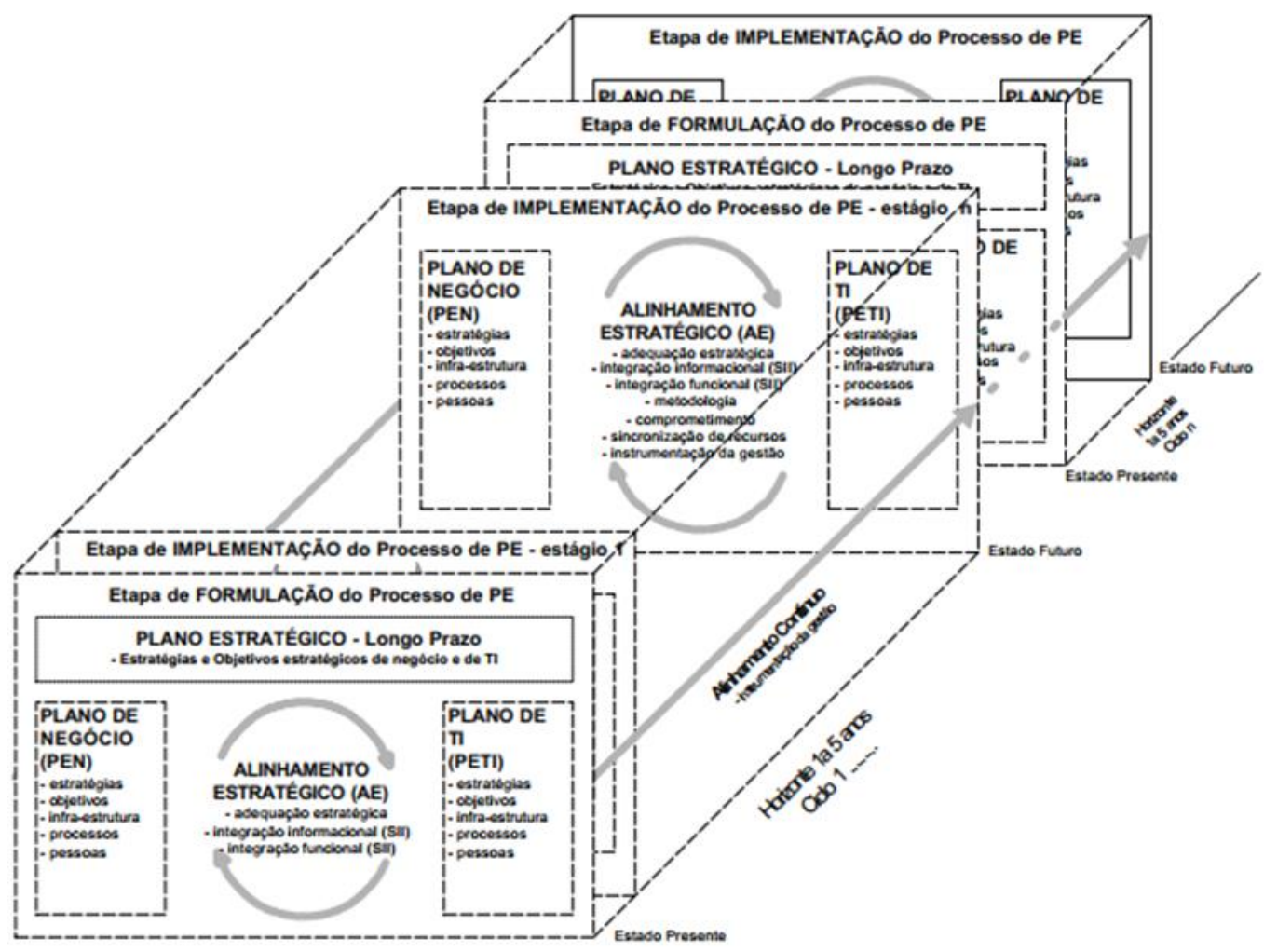

Fonte: Brodbeck (2001).

Neste modelo, o alinhamento entre os objetivos e as estratégias de negócio e de Tl é realizado em ambos os sentidos (TI para o negócio e negócio para a TI). Este alinhamento indica reciprocidade e movimento no tempo e espaço, enfatizando as mudanças de estados do presente para uma posição de futuro. O modelo é apresentado de forma tridimensional, onde o Eixo Z representa o tempo e o dinamismo do processo de planejamento, os eixos $X$ e $Y$ apresentam os processos de formulação e implementação do planejamento de forma estática. O tempo é que representa o dinamismo dos diversos ciclos de planejamento e alinhamento (AUDY; BRODBECK, 2003; BRODBECK, 2001; BRODBECK; HOPPEN, 2003).

Os elementos da etapa de formulação do processo de planejamento baseiam-se em três fatores: i) adequação estratégica entre objetivos de negócio e de Tl; ii) integração funcional da infraestrutura, processos e pessoas de TI para suporte dos objetivos do negócio; iii) integração informacional entre 
as informações dos sistemas e os objetivos organizacionais, de forma a permitir o controle do alcance das metas estabelecidas para cada um deles (BRODBECK, 2001). No Modelo Operacional de Alinhamento Estratégico (MOAE), o alinhamento ocorre de duas formas: circular e cíclica. $\mathrm{Na}$ característica circular há o ajuste contínuo dos objetivos e recursos organizacionais com os recursos e os projetos de TI. Este ajuste deve ser mantido por todo o tempo. Já a característica cíclica é representada pela execução de revisões do alinhamento, de acordo com os ciclos de planejamento. Com isso, o alinhamento deve ser promovido durante a execução do planejado, podendo existir mudanças ao longo do tempo, de acordo com o ciclo em que se está (BRODBECK, 2001).

O modelo proposto pela autora apresenta três grupos de variáveis, cada um com um conjunto de variáveis promotoras do alinhamento. O primeiro grupo é chamado de contexto organizacional. Neste grupo, encontram-se variáveis ligadas ao ambiente e à cultura da organização. O segundo elemento de alinhamento é a formulação do processo de planejamento estratégico, que incorpora variáveis sobre a estrutura dos itens nos planos e etapas utilizadas para o processo de planejamento. $O$ terceiro elemento compreende variáveis promotoras do alinhamento na etapa de implementação do processo de planejamento estratégico, subdivididas em: metodologia de implementação do plano estratégico; comprometimento; recursos dispendidos e processos (BRODBECK, 2001).

A sincronização PEN-PETI é obtida em reuniões de avaliação contínuas das estratégias e dos objetivos planejados. Brodbeck e Hoppen (2003) sugerem que nos casos de planejamento mais longo (de 3 a 5 anos), os objetivos estratégicos devem ser descritos por meio de projetos, divididos em objetivos de curto prazo (de até um ano). Isso permite melhor controle operacional de metas e ajuste mais apurado. O alcance do alinhamento estratégico total seria alcançado quando a tecnologia e os sistemas de informação da empresa passassem a fornecer todas as informações necessárias ao modelo de gestão estratégico da organização, permitindo assim o ajuste permanente das metas executadas (BRODBECK; HOPPEN, 2003).

\section{PROCEDIMENTOS METODOLÓGICOS}

Trata-se de um estudo descritivo, pois busca a "identificação, registro e análise das características, fatores ou variáveis que se relacionam com o fenômeno ou processo" (JUNG, 2004, p.152). Cervo, Bervian e Silva (2007) complementam afirmando que este tipo de pesquisa envolve não só o estudo, mas também a descrição de características existentes em uma determinada realidade.

Optou-se por uma abordagem de caráter qualitativo. Na pesquisa qualitativa, o pesquisador realiza a coleta de dados diretamente no contexto em que os atores vivem e participam. As ações de pesquisa 
são baseadas nas observações e vivências do pesquisador, sem o uso de estatísticas ou formas de quantificações (PEROVANO, 2016). A escolha desta abordagem deve-se principalmente à riqueza e profundidade dos dados, o que não seria possível de se obter com um estudo quantitativo (CERVO; BERVIAN; SILVA, 2007).

Foi realizado um estudo de casos em duas cooperativas agropecuárias. Este tipo de metodologia envolve a pesquisa sobre determinado grupo, indivíduo ou comunidade, de forma a examinar aspectos variados do objeto estudado (CERVO; BERVIAN; SILVA, 2007). Yin (2001, p. 19) considera os estudos de caso como sendo a estratégia preferida quando se colocam questões do tipo "como" e "porque", ou ainda, quando o foco da pesquisa se encontra "em fenômenos contemporâneos inseridos em algum contexto da vida real". Os estudos de casos caracterizam-se como descritivos, pois buscou-se apresentar um "relato detalhado de um fenômeno social" (GODOY, 2010, p. 24). Os estudos ocorreram em duas cooperativas agropecuárias, localizadas em cidades distintas, no sul do estado de Minas Gerais. A escolha destas cooperativas deu-se pelos resultados obtidos pelas mesmas no ano de 2016 e 2017 e por facilidade de acesso dos pesquisadores às cooperativas. A coleta de dados ocorreu no segundo semestre do ano de 2017 e a análise dos dados em janeiro e fevereiro de 2018.

Para coleta de dados, foram utilizados neste estudo entrevistas, análise de documentos e observações diretas. Optou-se pela realização de uma entrevista semiestruturada, onde os questionamentos básicos são apoiados em teorias e hipóteses de interesse à pesquisa (TRIVIÑOS, 1992). As entrevistas foram realizadas no segundo semestre do ano de 2017, na sede das cooperativas estudadas, com os responsáveis pela administração e com os responsáveis pelo Departamento de Tecnologia da Informação das cooperativas. As entrevistas foram registradas/gravadas para posterior análise de conteúdo, buscando identificar, no relato dos entrevistados, planos, ações ou rotinas que indiquem a existência das variáveis relacionadas ao alinhamento estratégico.

De forma a complementar os dados coletados com a entrevista, foi feita análise documental, com objetivo de buscar informações sobre o histórico das cooperativas, infraestrutura de tecnologia da informação, processos de negócios e outras informações relevantes para o estudo. Tal análise é recomendada por Yin (2001), que afirma que o uso mais importante dos documentos é corroborar e valorizar as evidências oriundas de outras fontes. As visitas às cooperativas também permitiram realizar observações diretas sobre o uso de tecnologia da informação na organização. Tais observações foram realizadas em reuniões, atividades de trabalho e durante as entrevistas e foram fundamentais para compreender melhor como se dá o alinhamento entre TI e estratégias da cooperativa. Para 
avaliar o grau do alinhamento, foram analisadas a presença de fatores constantes do modelo de Brodbeck (2001).

\subsection{O MODELO DE ALINHAMENTO ESTRATÉGICO ESCOLHIDO}

Optou-se, neste estudo, utilizar o modelo de Brodbeck (2001) para avaliar o grau de alinhamento estratégico de TI nas cooperativas estudadas. Trata-se de um modelo proposto a partir de outros modelos de alinhamento, sobretudo, o modelo de Henderson e Venkatraman (1997) - que tratam do alinhamento entre os planos de negócios e de TI, e o modelo de Teo e King (1997), que apresenta os estágios de integração entre os planos de negócio e de TI. Portanto, o modelo de Brodbeck (2000) reúne características e variáveis de diferentes abordagens e visões sobre o alinhamento estratégico. Os modelos tradicionais de planejamento estratégico muitas vezes não fazem referência às etapas do processo de planejamento para um horizonte de tempo (AUDY, BRODBECK, 2003). Nesse sentido, o modelo utilizado neste estudo, apresenta, além da promoção do alinhamento na fase de planejamento, a continuidade de tal alinhamento ao longo do tempo, de forma a promover os ajustes e adequações necessários para que TI e negócios continuem em sintonia. Estes fatores contribuíram para que este modelo fosse escolhido em detrimento de outros. Mas o fator de destaque é sem dúvida o acréscimo da dimensão tempo no modelo de Brodbeck (2001) e o reconhecimento da existência de alinhamento para as duas etapas do processo de planejamento - formulação e implementação, "não excludentes, que ocorrem sequencial e continuamente" (AUDY; BRODBECK, 2003, p. 108). A ausência de estudos aplicados utilizando o modelo Brodbeck (2001) também foi fator determinante para sua escolha.

\section{CARACTERIZAÇÃO DAS COOPERATIVAS ESTUDADAS}

A primeira cooperativa apresentada será tratada pelo nome de Cooperativa A, de forma a preservar sua identidade. A cooperativa A possui sua sede no sul de Minas Gerais, porém, atua no centro oeste e Chapada de Minas. Possui mais de 6.000 cooperados e, em média, mais de 1,2 milhões de sacas comercializadas por ano. Destaca-se na prestação de serviços diferenciados e de qualidade a seus cooperados, como escritórios de negócios, departamentos técnicos especializados, complexo industrial e capacidade de preparo de 1,6 milhões de sacas. Oferece ainda loja especializada de insumos, implementos e maquinário agropecuário. Desde 1993, promove concursos de cafés especiais, promovendo a produção, identificação e preparação destes cafés. 
A segunda cooperativa estudada (Cooperativa B) iniciou suas atividades em 1963. Trabalha com a comercialização de leite, café, milho, além de possuir um laticínio próprio para produção de derivados do leite. Atualmente, possui aproximadamente 480 funcionários e cerca de 7.000 cooperados. A sede conta com construções em armazéns para adubos, estocagem de café, silos graneleiros e silo de calcário, laboratório, lojas com produtos agropecuários, auto posto de abastecimento, complexo de grãos e laticínio. Possui filiais em seis cidades do sul de Minas Gerais. Entre os serviços oferecidos a seus cooperados, destacam-se: armazenamento e comercialização de milho; armazenamento, classificação, prova e comercialização de café; comercialização de leite e derivados; comercialização de combustível e implementos agrícolas, peças e maquinários agropecuários.

\section{RESULTADOS}

Esta seção apresenta a sintetização dos resultados encontrados nos estudos realizados nas cooperativas agropecuárias (Cooperativa A e Cooperativa B). As variáveis de alinhamento poderiam assumir valores de baixo, parcial ou alto, de acordo com o nível de existência daquela característica na cooperativa. A observação direta, análise dos documentos, entrevistas com responsáveis e o entendimento dos mesmos sobre as ações e práticas das cooperativas permitiram classificar cada uma das variáveis em relação ao seu grau de alinhamento. Os elementos do alinhamento estão subdivididos para melhor entendimento.

\subsection{ELEMENTOS DO CONTEXTO ORGANIZACIONAL DAS COOPERATIVAS}

Este elemento contempla variáveis que identificam o contexto organizacional das cooperativas estudadas. São utilizadas para evidenciar diferenças culturais, estruturais, organizacionais, dentre outras. O Quadro 1 a seguir apresenta os resultados obtidos.

Quadro 1: Variáveis do elemento de alinhamento "Contexto organizacional"

\begin{tabular}{|c|c|c|c|}
\hline $\begin{array}{l}\text { Elementos de } \\
\text { alinhamento }\end{array}$ & Contexto & Cooperativa A & Cooperativa B \\
\hline \multirow{5}{*}{$\begin{array}{l}\text { Definição do } \\
\text { negócio }\end{array}$} & Setor/Indústria & $\begin{array}{c}\text { Agronegócio (cooperativa de } \\
\text { produtores rurais) }\end{array}$ & $\begin{array}{c}\text { Agronegócio (cooperativa } \\
\text { de produtores rurais) }\end{array}$ \\
\hline & $\begin{array}{l}\text { Tamanho (total empregados }+ \\
\text { faturamento) }\end{array}$ & $\begin{array}{c}297 \text { empregados / } \\
\mathrm{R} \$ 810.744 .000,00 \mathrm{de} \\
\text { faturamento }(2016) \\
\end{array}$ & $\begin{array}{c}483 \text { empregados / } \\
\mathrm{R} \$ 525.878 .317,54 \mathrm{de} \\
\text { faturamento }(2016) \\
\end{array}$ \\
\hline & Estratégia do negócio & $\begin{array}{c}\text { Prestação de serviços de } \\
\text { qualidade a seus cooperados }\end{array}$ & $\begin{array}{l}\text { Fortalecimento do } \\
\text { cooperado }\end{array}$ \\
\hline & $\begin{array}{l}\text { Custos do negócio (operacional + } \\
\text { administrativo) }\end{array}$ & Não divulgado & Não divulgado \\
\hline & Investimentos realizados & Não divulgado & Não divulgado \\
\hline
\end{tabular}




\begin{tabular}{|c|c|c|c|}
\hline \multirow{7}{*}{ Estrutura } & Tipologia organizacional & Centralizada & Centralizada \\
\hline & $\begin{array}{l}\text { Satisfação dos usuários com as } \\
\text { informações }\end{array}$ & Parcial & Baixo \\
\hline & Tipologia da TI & Centralizada & Centralizada \\
\hline & - Tamanho (total de funcionários) & 10 & 5 \\
\hline & $\begin{array}{l}\text { - Foco da TI (operacional, mercado e } \\
\text { ambos) }\end{array}$ & Operacional & Operacional \\
\hline & $\begin{array}{l}\text { - SII e Supply Chain (EDI + e- } \\
\text { commerce) }\end{array}$ & $\begin{array}{l}\text { SI, e-commerce, ERP em } \\
\text { implantação }\end{array}$ & $\begin{array}{l}\text { SI, sistemas de } \\
\text { processamento de } \\
\text { transações }\end{array}$ \\
\hline & $\begin{array}{l}\text { - Workgroup - Interdependência (AE, } \\
\text { Workflow, E-mail) }\end{array}$ & $\begin{array}{l}\text { Parcial - utiliza de serviços } \\
\text { e-mail e algumas ferramentas } \\
\text { groupware }\end{array}$ & $\begin{array}{l}\text { Baixo - somente e-mail } \\
\text { e ferramentas de } \\
\text { comunicação instantânea } \\
\text { (mensageiros) }\end{array}$ \\
\hline \multirow{6}{*}{$\begin{array}{l}\text { Ambiente } \\
\text { externo }\end{array}$} & Estabilidade da organização (idade) & 59 anos & 55 anos \\
\hline & Crescimento de mercado (market growth) & $\begin{array}{l}\text { Aumento de } 78 \% \text { no lucro em } \\
\text { relação ao ano anterior }\end{array}$ & $\begin{array}{l}\text { Aumento de } 40,19 \% \text { no } \\
\text { lucro em relação ao ano } \\
\text { anterior }\end{array}$ \\
\hline & $\begin{array}{l}\text { - Agressividade (pioneirismo- } \\
\text { produtos/ações) }\end{array}$ & Médio & Médio \\
\hline & $\begin{array}{l}\text { - Proatividade (um passo à frente dos } \\
\text { competidores) }\end{array}$ & $\begin{array}{l}\text { Parcial (não há } \\
\text { monitoramento direto de } \\
\text { competidores) }\end{array}$ & $\begin{array}{l}\text { Parcial (há monitoramento } \\
\text { de competidores, repetição } \\
\text { de estratégias) }\end{array}$ \\
\hline & $\begin{array}{l}\text { - Inovação (Experimentação, } \\
\text { criatividade) }\end{array}$ & Alto & Médio \\
\hline & - Competidores (market share) & Não divulgado & $\begin{array}{l}\text { Cooperativas de grande } \\
\text { porte, cooperativas } \\
\text { tradicionais da região do } \\
\text { sul de Minas Gerais }\end{array}$ \\
\hline
\end{tabular}

\section{Fonte: dados da pesquisa (2018)}

Percebe-se que ambas as cooperativas carecem de melhor entendimento de seu ambiente organizacional. A Cooperativa A relatou não dispender esforços para conhecer melhor seu ambiente, sobretudo em relação à concorrência, como afirmado pelo gerente administrativo da mesma. Não foram divulgados dados referentes a investimentos e custos; entretanto, ambas apresentaram aumento no lucro de suas atividades, em relação ao exercício anterior. Com média agressividade, as cooperativas buscam meios de melhorar seus processos internos e oferecer melhores serviços a seus cooperados, mas sem compreender como fazer isso de uma maneira mais eficaz. A inovação da Cooperativa A consiste em melhorar processos, utilizar práticas de gestão estratégica e capacitar seus cooperados para utilizar de forma mais eficiente os recursos e serviços da cooperativa, e ainda, aprimorar suas práticas de produção e gestão em suas propriedades. Já a Cooperativa B busca a inovação e diferenciação em seus produtos, oferecendo ao mercado diversos produtos variados de leite e café gourmet, por exemplo. Não há preocupação com a capacitação dos cooperados, sendo que a cooperativa apenas atua no suporte ao mesmo, sem buscar novas formas de agregar valor à relação com seus cooperados. 
Em suma, as variáveis encontradas no elemento de contexto organizacional de ambas as cooperativas já sugerem uma baixa promoção do alinhamento estratégico, visto que seus ambientes internos e externos apresentam características, princípios de gestão e investimentos em $\mathrm{TI}$ abaixo do que se espera para uma maior promoção de alinhamento. Embora possuam estratégias de atuação definidas, não se observou, na Cooperativa $B$, esforços de investimentos em TI ou melhores práticas de gestão para atingir os objetivos propostos. A Cooperativa A, embora afirme não se atentar aos concorrentes, busca sempre estar à frente, por meio de práticas de gestão mais profissionais, buscando ainda agregar valor ao relacionamento com os cooperados, como afirmando pelos próprios diretores.

\subsection{ELEMENTOS DA ETAPA DE FORMULAÇÃO DO PROCESSO DE PLANEJAMENTO ESTRATÉGICO}

Nesta etapa, as variáveis relacionam-se ao grau de alinhamento na etapa de formulação do processo de planejamento estratégico. A análise permitiu identificar as variáveis presentes no Quadro 2:

\section{Quadro 4: Variáveis da etapa de formulação do processo de planejamento estratégico}

\begin{tabular}{|l|c|c|}
\hline A - Itens de elo & Cooperativa A & Cooperativa B \\
\hline $\begin{array}{l}\text { A1 - Missão dos planos de negócios e TI estão fortemente } \\
\text { vinculadas entre si }\end{array}$ & Parcial & Baixo \\
\hline A2 - Estratégia e plano de TI estão bem documentados & Baixo & Baixo \\
\hline A3 - O plano de negócio situa necessidades de TI e vice-versa & Baixo & Baixo \\
\hline A4 - O plano de negócio e de TI definem priorizações de ações & Baixo & Baixo \\
\hline $\begin{array}{l}\text { A5 - Os itens do plano de TI são fechados com os itens do plano } \\
\text { de negócios }\end{array}$ & Baixo & Baixo \\
\hline $\begin{array}{l}\text { A6 - Os gerentes de linha e de topo participam ativamente do } \\
\text { planejamento de TI }\end{array}$ & Baixo & Baixo \\
\hline A7 - CIO participa do desenvolvimento de novos produtos & Baixo & Baixo \\
\hline $\begin{array}{l}\text { A8 - O recurso tempo dos planejamentos de negócio e de TI } \\
\text { encontram-se sincronizados }\end{array}$ & Parcial & Baixo \\
\hline $\begin{array}{l}\text { A9 - O gerenciamento de topo é educado para a importância da } \\
\text { TI }\end{array}$ & Parcial & Baixo \\
\hline A10 - A TI está adaptada para mudanças estratégicas & Parcial & Baixo \\
\hline $\begin{array}{l}\text { A11 - Compreensão dos objetivos organizacionais tanto pelo } \\
\text { gerenciamento de topo do negócio pelos de TI }\end{array}$ & Parcial & Baixo \\
\hline $\begin{array}{l}\text { A12 - Elevada visão do relacionamento das funções de TI com a } \\
\text { organização (SII) }\end{array}$ & Baixo & Baixo \\
\hline $\begin{array}{l}\text { A13 - Avaliação da importância estratégica de tecnologias } \\
\text { emergentes }\end{array}$ & Parcial & Baixo \\
\hline
\end{tabular}

Fonte: dados da pesquisa (2018)

Identificou-se, em ambas as cooperativas, pouca (ou nenhuma) participação e preocupação com a TI no processo de planejamento. Embora apresentem um plano de ações gerais, as cooperativas carecem 
de um processo mais otimizado, com participação maior dos líderes e responsáveis, principalmente da área de $\mathrm{TI}$.

A Cooperativa A possui um horizonte de planejamento anual, onde são traçados metas e objetivos da cooperativa ao longo do ano. Não existe um planejamento com horizonte de tempo maior, sendo as metas e resultados analisados mensalmente, para ao final de cada ano, serem traçadas metas para o ano seguinte. Nessa fase, junto ao planejamento de negócios, são traçados os objetivos de TI, que posteriormente são repassados à coordenadora do setor. No entanto, cabe destacar a total ausência de um Planejamento Estratégico de Tecnologia da Informação. As atividades de TI são essencialmente suporte às rotinas operacionais e execução do planejamento traçado pela diretoria. A TI também possui um orçamento financeiro anual, de valor não divulgado, mas variável a cada ano. De posse deste orçamento, cabe à coordenação de TI gerenciar os recursos que serão utilizados, tentando alocalos de forma a atingir aos objetivos traçados pela gestão da cooperativa. Embora haja preocupação com a TI, a falta de um planejamento próprio e a não participação da equipe (coordenador) de TI na elaboração do planejamento estratégico fazem com que o elemento de planejamento estratégico possua um nível parcial de alinhamento.

No caso da Cooperativa B, a situação ainda é mais crítica: embora a cooperativa também trace um planejamento a longo prazo (geralmente, abarcando a duração do mandato da diretoria), não há qualquer preocupação ou inserção da TI no mesmo. O gestor e equipe de TI não conhece os objetivos e metas organizacionais, não há dimensionamento de recursos para a TI ou estudo sobre novas tecnologias, nem mesmo existe um planejamento estratégico de TI. As demandas do departamento são basicamente manter os atuais sistemas de informação e processamento de dados em funcionamento, realizando mudanças nos mesmos conforme necessidade dos diretores e setores, sem que isso esteja documentado ou previsto ao longo de um período. Novas necessidades de TI (geralmente, mudanças de relatórios ou atendimento de legislação fiscal e/ou contábil) são comunicadas pela diretoria de maneira informal ao gerente de $\mathrm{TI}$, que acaba alocando sua pequena 
equipe para atender à demanda solicitada, sem qualquer previsão de entrega ou mesmo alocação de recursos para atender a tal projeto. Esta situação e as características apresentadas no Quadro 2 faze Ainda na etapa de formulação, é necessária a análise da consistência entre os objetivos de negócios e as informações geradas pelos sistemas de informação, conforme mostrado no Quadro 3:

\section{Quadro 3: Variáveis de consistência entre os objetivos básicos de negócios e as informações} geradas pelos sistemas

\begin{tabular}{|l|c|c|}
\hline $\begin{array}{l}\text { B - Consistência entre os objetivos básicos de negócios e as } \\
\text { informações geradas pelos sistemas }\end{array}$ & Cooperativa A & Cooperativa B \\
\hline B1 - Controle e redução de custos & Parcial & Baixo \\
\hline B2 - Aumento do faturamento & Parcial & Baixo \\
\hline B3 - Eficiência & Parcial & Baixo \\
\hline B4 - Serviços & Alto & Baixo \\
\hline B5 - Supply Chain & Parcial & Baixo \\
\hline B6 - Vantagens competitivas & Baixo & Baixo \\
\hline B7 - Qualidade do produto & Baixo & Baixo \\
\hline B8 - Produtividade & Baixo & Baixo \\
\hline
\end{tabular}

Fonte: dados da pesquisa (2018)

Na questão das informações geradas pelos sistemas de informação, nota-se um quadro crítico nas cooperativas agropecuárias. O estudo revelou que os sistemas são utilizados essencialmente para controle de operações (registro de vendas, estoque, finanças, entrada de mercadorias, dentre outros) sem que os resultados de tais operações sejam utilizados de forma estratégica. O diretor financeiro da Cooperativa A informou, durante as entrevistas, que os atuais sistemas não permitem qualquer simulação ou projeção de cenários futuros. Isso é feito utilizando os resultados consolidados das movimentações diárias da cooperativa, cujos dados são incorporados diariamente a software de planilha eletrônica, para então serem trabalhados e analisados manualmente. Há sistemas de controle de estoque, mas que não dão suporte à toda a cadeia de supply chain. Controles para faturamento, redução de custos e eficiência operacional são medidos utilizando controles auxiliares, fora dos sistemas de informação. Tal cenário levou a cooperativa, no ano de 2017, a realizar uma parceria com uma empresa multinacional de software, para implantação de um ERP na cooperativa. Segundo a diretoria, trata-se de uma parceria inédita e que permitirá à cooperativa implantar sistemas de informações gerenciais e auxiliares para tomada de decisão.

Na Cooperativa B, o cenário é ainda mais crítico: os sistemas não atendem às demandas de gestão. Faltam relatórios consolidados, há incoerência de informações, não há integridade nos dados, além da ausência de um suporte à tomada de decisões, como relatado pelos próprios diretores. Há excesso 
de controles paralelos, e durante o período de observação, foi possível constatar que os fechamentos contábeis e fiscais da cooperativa ocorriam com mais de três meses de atraso. Tal situação faz com que a cooperativa consolide seus resultados mensais ou anuais com grande atraso, prejudicando de sobremaneira as decisões de investimento, que ocorrem de maneira empírica por parte da diretoria. Desta forma, há total ausência de alinhamento entre as informações geradas pelos sistemas de informação e os objetivos de negócios.

\subsection{ELEMENTOS DA ETAPA DE IMPLEMENTAÇÃO DO PROCESSO DE PLANEJAMENTO ESTRATÉGICO}

Sem dúvida esta etapa é um diferencial do modelo de alinhamento estratégico de Brodbeck (2001) em relação aos demais. Após a formulação, a efetiva implantação e acompanhamento, bem como ajustes do PEN e PETI são essenciais para que haja a contínua e efetiva promoção do alinhamento estratégico de tecnologia da informação (AUDY; BRODBECK, 2003). Com base nos estudos e observações realizados nas cooperativas, foi possível elencar as seguintes características da fase de implantação do planejamento estratégico, conforme descrito no Quadro 4:

Quadro 4: Variáveis do elemento de implementação do processo de planejamento estratégico

\begin{tabular}{|l|c|c|}
\hline C - Metodologia & Cooperativa A & Cooperativa B \\
\hline C1 - leva em conta os objetivos e estratégias organizacionais & Baixo & Baixo \\
\hline C2 - requer envolvimento dos gerentes e usuários & Parcial & Baixo \\
\hline C3 - identifica novos projetos & Parcial & Baixo \\
\hline C4 - determina uma base uniforme para a priorização dos projetos & Baixo & Baixo \\
\hline $\begin{array}{l}\text { C5 - inclui um plano global de hardware, software e comunicação para } \\
\text { a organização }\end{array}$ & Baixo & Baixo \\
\hline $\begin{array}{l}\text { C6 - os resultados estão de acordo com as expectativas do } \\
\text { gerenciamento de topo }\end{array}$ & Parcial & Baixo \\
\hline C7 - consultores externos & Parcial & Baixo \\
\hline
\end{tabular}

\begin{tabular}{|l|c|c|}
\hline D - Gerenciamento & Cooperativa A & Cooperativa B \\
\hline D1 - ferramentas de TI para execução do planejamento & Baixo & Baixo \\
\hline D2 - frequência das revisões e ajustes & Alto & Baixo \\
\hline D3 - acompanhamento das revisões (documentação e itens atendidos) & Alto & Baixo \\
\hline E - Comprometimento & Cooperativa A & Cooperativa B \\
\hline E1 - atendimento dos objetivos & Parcial & Baixo \\
\hline E2 - motivação (incentivos) & Baixo & Baixo \\
\hline $\begin{array}{l}\text { E3 - dificuldade de garantir a implementação e o comprometimento } \\
\text { dos gerentes de topo }\end{array}$ & Alto & Baixo \\
\hline E4 - patrocinadores da área de negócio & Alto & Baixo \\
\hline
\end{tabular}




\begin{tabular}{|l|c|c|}
\hline F - Processos & Cooperativa A & Cooperativa B \\
\hline $\begin{array}{l}\text { F1 - identificação de oportunidades de melhorias nos processos de } \\
\text { negócios através da TI }\end{array}$ & Parcial & Baixo \\
\hline $\begin{array}{l}\text { F2 - monitoramento das necessidades internas do negócio e das } \\
\text { capacidades de TI para atender estas necessidades }\end{array}$ & Parcial & Baixo \\
\hline
\end{tabular}

Fonte: dados da pesquisa (2018)

A fase de implementação do planejamento estratégico e do planejamento de tecnologia da informação é tão importante quanto a etapa anterior, de planejamento. Isso porque a implementação deve ser embasada em mecanismos que possam colocar em prática as estratégias traçadas, e mais, garantir o feedback e os ajustes que se fazem necessários.

Percebe-se, pelo Quadro 4 acima, que esta é uma fase crítica para ambas as cooperativas, sobretudo para a Cooperativa $B$, que não possui qualquer mecanismo de controle e acompanhamento do que fora planejado. O fato da TI não possuir um planejamento próprio torna o processo ainda mais caótico, visto que não há projetos que possam colocar as ações planejadas em prática. Incentivos à equipe são inexistentes, não há participação do gerente de TI nas decisões ou planejamento de ações para o setor, não há acompanhamento de novas tecnologias ou oportunidades de melhorias dos processos de TI ou da organização como um todo. A falta de comprometimento da diretoria com os serviços de TI também revelou-se ser um fator crítico, pois, de acordo com a diretoria, "A gente gasta, gasta, gasta com a Tl e os sistemas continuam do mesmo jeito. A gente não sabe porque gasta dinheiro e eles não dão conta". Essa fala resume bem a situação encontrada na Cooperativa B: total e completa falta de alinhamento entre direção e TI. Negócios e tecnologia, diretoria e gestor de TI andam em direções opostas, apenas discutindo sobre quem tem razão.

No caso da Cooperativa A, o cenário só não é parecido pois a atual diretoria possui um alto comprometimento com o planejamento estratégico da organização. São feitas reuniões mensais de alinhamento, de forma a verificar o "planejado x realizado". Segundo um dos diretores, neste momento, "A gente vê tudo que deu certo e cobra dos responsáveis aquilo que não deu certo, e ajustamos as ações durante as próximas semanas para voltar ao curso desejado". A organização carece de ferramentas avançadas de acompanhamento e controle estratégico e de projetos para a área de TI, no entanto, os responsáveis de cada setor realizam esforços e controles manuais para monitorar as ações planejadas. Cabe destacar o alto comprometimento da diretoria com a TI, uma vez que essa é entendida como parceira de negócios e agente de suporte às mudanças. Melhores resultados poderiam ser obtidos se o planejamento estratégico de TI fosse elaborado, em consonância com o 
PEN, de forma a fornecer todas as ferramentas e suporte necessário para a total implementação de nova estratégicas de negócios. No entanto, são notáveis os esforços em levar a organização para um maior nível de alinhamento estratégico: a aquisição de novos softwares, a capacitação dos cooperados e a busca por melhorias processuais são ações que mostram que a Cooperativa A está no caminho correto.

\section{CONSIDERAÇÕES FINAIS}

O uso eficiente de Tecnologia da Informação e de técnicas profissionais de gestão sempre foi um desafio para o agronegócio, sendo que ainda hoje várias regiões produtoras ainda perecem frente a estes desafios (ALMEIDA et al., 2016). No entanto, este desafio é posto para organizações de diferentes segmentos, que ainda tem na TI apenas um apoio operacional (CANÉPA; RIGONI; BRODBECK, 2008).

Este trabalho buscou mostrar os resultados obtidos a partir de um estudo de casos realizado em duas cooperativas agropecuárias localizadas no sul do estado de Minas Gerais, quanto à promoção do alinhamento estratégico de TI. A importância das cooperativas para a região é notória, sendo duas organizações de destaque no cenário mineiro e nacional. Esperava-se que ambas apresentassem um bom grau de alinhamento entre TI e negócios, devido principalmente a seus resultados. Entretanto, a análise mostrou que ainda há um bom caminho a ser percorrido.

O alinhamento estratégico de TI é um dos maiores desafios da gestão, e no agronegócio isso não se mostrou diferente. A primeira cooperativa estudada apresenta processos de gestão mais profissionais, com uma diretoria preocupada em traçar planos e metas de longo prazo, monitorar as ações para verificar se estão dentro do esperado, de forma a alcançar os resultados. Junto a isso, a organização passou a dar maior importância à $\mathrm{Tl}$, tornando-a uma companheira de negócios e tirando a $\mathrm{TI}$ de um processo operacional, levando-a a um status de parceira estratégica. No entanto, ainda carece de um planejamento próprio de $\mathrm{Tl}$, alinhado às metas e objetivos do planejamento estratégico e que possa de fato dar a TI condições de entregar resultados ainda melhores. A participação dos gestores também é um ponto fundamental para que haja um maior alinhamento estratégico.

No extremo desta situação, a segunda cooperativa estudada apresenta uma preocupante situação de falta de planejamento de TI e ausência de mecanismos de controle. Falta um planejamento estratégico que de fato mostre onde a cooperativa deseja chegar. A falta desta definição, aliada a um baixo uso 
de TI e falta de compromisso com seus cooperados coloca a cooperativa estudada em um cenário de total falta de alinhamento estratégico, pois o futuro pensado para a cooperativa não é compartilhado, com isso, as ações não são executadas visando alcançar os resultados. Trata-se de uma organização que atua de forma operacional, tendo a TI como mero suporte às operações rotineiras.

Situações como estas são exemplos de como o uso estratégico de TI ainda é um desafio para as cooperativas agropecuárias. Há organizações, de porte internacional, que são pioneiras na adoção de $\mathrm{Tl}$, tendo muitas vezes suas estratégias copiadas, sem muito sucesso. Em sua maioria, as pequenas e médias cooperativas começam a traçar esforços para deixar de serem operacionais e passar a ter na Tl uma aliada mais estratégica, sobretudo para dar suporte à tomada de decisões e um planejamento a longo prazo.

Este estudo não busca apresentar generalizações ou projeções de como a TI atuará nas cooperativas ou no agronegócio como um todo, mas buscou apresentar uma fotografia real de situações ainda muito corriqueiras neste segmento, servindo de alerta para uma mudança de pensamento e atitude destas organizações. O avanço tecnológico no agronegócio é notável, no entanto, não deve ficar somente nas lavouras ou criações. Urge a necessidade de que toda a cadeia produtiva atue de forma mais profissional, estratégica, organizada e colaborativa, tendo a Tecnologia da Informação como uma parceira capaz de promover mudanças, apoiando todos os agentes do agronegócio na busca pelos melhores resultados, tanto para si mesmos quanto para a sociedade brasileira.

\section{REFERÊNCIAS}

AFFELDT, F. S.; VANTI, A. A. Alinhamento estratégico de tecnologia da informação: análise de modelos e propostas para pesquisas futuras. Revista Gest. Tecn. Sist. Informação, v.6, n.2, p. 203-226, 2009.

ALMEIDA; L. F, et al. Direcionadores de mudança na cafeicultura: passado, presente e desafios futuros. In: ZYLBERSZTAJN, D.; GIORDANO, S. R.; DE VITA, C. L. R. Cadernos Universidade do Café. Universitá del Caffé, v. 8, 2016.

AUDY, J. N.; BRODBECK, A. F. Sistemas de Informação: Planejamento e Alinhamento Estratégico nas Organizações. Porto Alegre: Bookman, 2003.

BIO, Sérgio Rodrigues. Sistemas de Informação: um enfoque gerencial. 2 ed. São Paulo: Atlas, 2008.

BRITO, M. J.; ANTONIALLI, L. M.; SANTOS, A. C. Tecnologia da informação e Processo Produtivo de Gestão em uma Organização Cooperativa: um enfoque estratégico. RAC, v.1, n.3, p. 77-95, set./dez. 1997. 
BROADBENT, M.; WEILL, P.; CLAIR, D. S. The implications of information technology infraestructure for business process redesign. MIS Quartely, Minneapolis, v. 23, p. 159-182, jun. 1999).

BRODEBCK, A. F. Alinhamento estratégico entre os planos de negócio e de tecnologia da informação: um modelo operacional para implementação. 2001. 332 p. Tese. (Doutorado em Administração) Universidade Federal do Rio Grande do Sul, Porto Alegre, 2001.

BRODBECK, A. F.; HOPPEN, N. Alinhamento estratégico entre os planos de negócio e de tecnologia da informação: um modelo operacional para implementação. RAC, v.7, n.3, p. 9-33, jul./set. 2003.

CANEPÁ, P. C. V.; RIGONI, E. H.; BRODBECK, A.F. Práticas de alinhamento estratégico: um estudo exploratório em organizações industriais e de serviços. RAM - Revista de Administração Mackenzie. v. 9, n. 1, 2008, p. 107-129.

CASSARRO, A. C. Sistemas de Informações para Tomadas de Decisões. 4. ed. rev. e ampl. São Paulo: Cengage Learning, 2015.

CERVO, A. L.; BERVIAN, P. A.; SILVA, R. Metodologia Científica. 6. ed. São Paulo: Pearson Prentice Hall, 2007.

DRUMMOND, R. L. A. Estratégia competitiva e difusão de tecnologia no setor produtivo cafeeiro do Sul de Minas Gerais. 2003. 82 p. Dissertação (Mestrado em Administração) - Universidade Federal de Lavras, Lavras, 2003.

GODOY, A. S. Estudo de caso qualitativo. In: GODOY, C. K.; BANDEIRA-DE-MELLO, R.; SILVA, A. B. (Orgs.). Pesquisa qualitativa em estudos organizacionais: paradigmas, estratégias e métodos. 2. ed. São Paulo: Saraiva, 2010. p. 115-146.

HEINZMANN, C. et al. Adoção de sistemas de informação como estratégia competitiva nas grandes empresas do setor do agronegócio da região oeste do estado do Paraná, Brasil. In: Congresso LusoBrasileiro de Tecnologia de Informação e Comunicação na Agropecuária, 1., 2004, Santarém Portugal. Anais... Santarém: CNEMA, 2004. p. 2-11.

HENDERSON, J. C.; VENKATRAMAN, N. Strategic alignment: Leveraging information technology for transformig organizations. IBM System Journal, v. 32, n.1, p. 4-16, 1993.

JUNG, C. F. Metodologia para pesquisa \& desenvolvimento: aplicada a novas tecnologias, produtos e processos. Rio de Janeiro: Axcel Books, 2004. 328 p.

KAPLAN, R. S.; NORTON, D. P. A estratégia em ação: balanced scorecard. Rio de Janeiro: Elsevier, 1997.

LEAVITT, H. J. Applied organizational change in industry: structural, technological, and humanistic approaches. In: MARCH, James G.. Handbook of organizations. Chicago: Rand McNally \& Co., cap. 27, p. 1144 - 1170, 1965.

MELLO, R. B. Sistemas de informação na comercialização do café em uma cooperativa agrícola no sul de Minas Gerais. 2014. 73 p. Dissertação (Mestrado em Sistemas de Produção na Agropecuária) Universidade José do Rosário Vellano, Alfenas, 2014. 
MENDES, J. N. S.; CALDAS, P. T.; CÂNDIDO, G. A. Alinhamento Estratégico entre negócios e Tecnologias da Informação e Comunicação em Micro e Pequenas Empresas de Base Tecnológica. In: ENCONTRO DE ESTUDOS EM ESTRATÉGIA, 5., 2011, Porto Alegre. Anais... Porto Alegre, ANPAD, 2011. Disponível em: <http://www.anpad.org.br/admin/pdf/3Es4.pdf>. Acesso em: 05 jun. 2017.

O'BRIEN, J. A.; MARAKAS, G. M. Administração de Sistemas de Informação. 15. ed. Porto Alegre: AMGH, 2013.

OLIVEIRA, D. P. R. Planejamento estratégico: conceitos, metodologia, práticas. 2.ed. São Paulo: Atlas, 2011.

PEROVANO, D. G. Manual de metodologia da pesquisa científica. Curitiba: InterSaberes, 2016.

PINTO, G. J. S.; GRAEML, A. R. Alinhamento entre tecnologia da informação e negócios: o caso de uma cooperativa médica no Paraná. REGE, São Paulo, v.18, n. 2, p. 259-24, abr./jun. 2011.

PORTER, M. Competitive Strategy. New York, Free Press, 1990.

REZENDE, D. A. Alinhamento do planejamento estratégico da tecnologia da informação ao planejamento empresarial: proposta de um modelo e verificação da prática em grandes empresas brasileiras. 2002. 278 f. Tese (Doutorado). Universidade Federal de Santa Catarina, Florianópolis.

Planejamento de Sistemas de Informação e Informática: Guia Prático para planejar a tecnologia da informação integrada ao planejamento estratégico das organizações. 5. ed. São Paulo: Atlas, 2016.

Sistemas de Informações Organizacionais: Guia prático para projetos em cursos de Administração, Contabilidade e Informática. 5. ed. São Paulo: Atlas, 2013.

ROCKART, J. F.; SCOTT, M.M. S. Implications of Changes in Information Technology for Corporate Strategy. Interfaces, v. 14, n. 1, 84-95, 1984.

ROSINI, A. M.; PALMISANO, A. Administração de Sistemas de Informação e a gestão do conhecimento. 2.ed. São Paulo: Cengage Learning, 2014.

SEGARS, A. H.; GROVER, V. Strategic information system planning success: an investigation of the constructor and its measurement. MIS Quartely, Minneapolis, p. 139-163, jun. 1998.

TEO, T. S. H.; KING, W. R. Integration between business planning and information systems planning: an evolutionary-contigency perspective. Journal of Management Information Systems, v. 14, n. 1, p. 185-214, Summer 1997.

TRIVIÑOS, A. N. S. Introdução à pesquisa em ciências sociais. São Paulo: Atlas, 1992.

TURBAN, E.; VOLONINO; L. Tecnologia da Informação para Gestão: Em busca do melhor desempenho estratégico e operacional. 8.ed. Porto Alegre: Bookman, 2013.

YIN, R. K. Estudo de caso: planejamento e métodos. 2.ed. Porto Alegre, Bookman, 2001. 
ZAMBALDE, A. L. A informática na modernização do sistema agroindustrial do café no Estado de Minas Gerais. 2000. 182 p. Tese (Doutorado em Engenharia de Sistemas e Computação). Universidade Federal do Rio de Janeiro, Rio de Janeiro, 2000. 


\section{Capítulo 27}

\section{USO DE PNEUMÁTICOS EM LOGÍSTICA REVERSA: UM BREVE MOSAICO DA REALIDADE BRASILEIRA}

DOI: $10.37423 / 200300477$

Marcos Carneiro da Silva (Instituto Federal de Eduacação, Ciência e Tecnologia do Amazonas, Brasil).

marcos.carneiro@ifam.edu.br

Elane de Souza Mafra (Instituto Federal de Eduacação, Ciência e Tecnologia do Amazonas, Brasil).

mafra@ifam.edu.br

Tássia Patricia Silva do Nascimento (Instituto Federal de Eduacação, Ciência e Tecnologia do Amazonas, Brasil)

tassiapatricia.tp@gmail.com

RESUMO: O crescente interesse pela proteção ambiental aportou novas necessidades aos processos logísticos. Isso se deveu, entre outros, a crescente consciência ecológica empresarial, pelo impacto de seus produtos, embalagens e acessórios no meio-ambiente e a possibilidade no desenvolvimento de alternativas que permitissem reduções de custo, gerando benefícios econômicos e ambientais. Por outro lado, a prática da logística reversa não se confunde com a da gestão ambiental, haja vista que esta se preocupa principalmente em recolher e processar rejeitos, refugos e resíduos de itens para os quais não há outro uso, enquanto que aquela se concentra em itens com valor a recuperar. Desse modo, a logística reversa além de contribuir com a sustentabilidade mediante a diminuição dos impactos ambientais, ainda agrega valor econômico ao bem inservível. 
Nesse sentido, este artigo tem como objetivo discutir o uso de pneumáticos em logística reversa. A pesquisa apresenta um breve mosaico da realidade brasileira, descrevendo, sobretudo às principais ações do poder público quanto ao uso e a destinação correta desse produto. O estudo busca responder ao seguinte questionamento: Diante do aumento do descarte de pneumáticos na natureza, há alguma ação efetiva por parte do governo no gerenciamento correto desse tipo produto e se há, quais são? A importância do estudo se justifica pela preocupação crescente por parte dos governos, empresas e sociedades na destinação correta de produtos, pós-venda ou pós-consumo. Foi realizada uma pesquisa exploratória por meio de consulta a referências bibliográficas tradicionais e análise documental, além de outras fontes secundárias (Rede Mundial de Computadores).

Palavras-chave: logística reversa; meio ambiente; pneumáticos. 


\section{INTRODUÇÃO}

O crescente interesse pela proteção ambiental aportou novas necessidades aos processos logísticos por parte das empresas no mundo todo. Isso se deveu, entre outros, graças a crescente consciência ecológica empresarial, pelo impacto de seus produtos, embalagens e acessórios no meio-ambiente e a possibilidade no desenvolvimento de alternativas que permitissem reduções de custo aos utilizadores, gerando benefícios econômicos e ambientais (LEITE, 2003).

Na Europa, apoiados por diretrizes legais, o enfoque ambiental dado à logística de reciclagem e reutilização de materiais avançou mais do que nas demais partes do mundo. Segundo Slijkhuis (2004), a Comunidade Europeia, com o uso da Diretiva 94/62, estabeleceu uma hierarquia de medidas para a redução de resíduos em prazos estabelecidos: reduzir os resíduos na origem; utilizar materiais recicláveis; reutilizar os materiais, maximizando o giro; implementar sistemas de recuperação; e reciclar os materiais.

No caso do Brasil, a legislação exige o retorno de produtos considerados perigosos após o término da vida útil, por conter metais pesados, tais como pilhas e baterias, e de produtos considerados problemáticos como é o caso de pneus que apresentam poucas opções de tratamento, além do que, sua composição, quantidade e volume mostram-se extremamente prejudiciais ao meio ambiente. Tendo ainda o agravante de que expostos na natureza se constituem como ótimos reservatórios de doenças infecto-contagiosas. Sendo, nestes casos, do fabricante a responsabilidade pela logística e pelo tratamento dos resíduos (CONAMA, 2017) Nesse contexto, destaca-se a importância da logística reversa que pode ser explicada pela grande quantidade e variedade de produtos que vão para o mercado visando satisfazer seus diversos micros segmentos e retornam a cadeia de suprimento resultante de pós-consumo ou pós venda para seu reaproveitamento sob diferentes formas.

A indústria de pneumáticos é responsável pela logística reversa dos pneus inservíveis pós-consumo e pela prevenção à degradação ambiental causada por estes pneus. Segundo dados do Ministério do Meio Ambiente, o Brasil é responsável pelo destino de aproximadamente 40 milhões de pneus usados por ano. A Resolução 416/2009 do CONAMA dispõe sobre a prevenção a degradação ambiental causada por pneus inservíveis e sua destinação ambiental adequada, e estabelece as regras para as empresas fabricantes e as importadoras de pneus em relação à obrigatoriedade da coleta e destinação final aos pneus inservíveis existentes no território nacional. 
A logística reversa tem papel importante na aplicação das avaliações do ciclo de vida dos produtos através da diminuição da geração de resíduos sólidos e de seu adequado gerenciamento, auxiliando os processos de obtenção dos insumos e do equacionamento para os produtos pós-consumo.

Assim, de acordo com Leite (2009), nos últimos anos, a logística reversa experimentou grande transformação, deixando de ser uma área operacional para se transformar em uma área de estratégia empresarial. Dessa maneira, a logística reversa tornou-se uma potente ferramenta estratégica de competitividade empresarial, quando a sua atuação é utilizada sob a forma de agregação de valor econômico ou de obediência à legislação ou de reforço de marca e imagem empresarial.

\section{LOGÍSTICA - UM CONCEITO EM CONSTRUÇÃO}

Diante da importância e complexidade que envolve o macroprocesso de Logística dentro das organizações, em franco desenvolvimento, passando por notáveis evoluções em nível mundial, tais como: globalização, impacto de novas tecnologias de informação e comunicação, novos métodos de otimização de processos, novas filosofias etc., faz-se necessário sintetizar o conhecimento teórico sobre a Logística e as decisões inerentes a esta área que afetam o resultado econômico das organizações.

Para que se possa compreender a logística e sua importância, é necessário que, inicialmente, estejamos bem fundamentados sobre o que é a Logística, quais seus principais objetivos, e como foi sua evolução no meio empresarial. De acordo com Christopher (1997) Somente há bem pouco tempo (desde o início dos anos 1990), no Brasil, as organizações começaram compreender que o adequado gerenciamento logístico pode apresentar um impacto vital para a obtenção de vantagens competitivas duradouras.

De acordo com Faria (2015) a logística é um conceito em constante evolução, atrelado à busca de ganhos de competitividade e níveis de custos reduzidos, em função do desafio global e da necessidade de agir de modo rápido, frente às alterações ambientais. Até há pouco tempo, a Logística era, essencialmente, considerada em seu clássico papel de suporte operacional e de marketing, exercendo funções de transportar, armazenar e disponibilizar bens para os processos de transformação e consumo. Atualmente, segundo o autor, é cada vez mais essencial para alcançar e sustentar a vantagem competitiva nas organizações, passando a ser considerada por seu caráter estratégico. 
Sobre o assunto, Razzolini Filho (2011), afirma que a visão da logística ainda passa por um processo de amadurecimento e que precisa de muitas novas contribuições, principalmente no Brasil, onde os organismos públicos responsáveis pela infraestrutura logística necessária para suportar o crescimento econômico têm feito muito pouco, comparativamente em relação àquilo que é necessário. $\mathrm{O}$ autor finaliza, afirmando que é possível concluir que o correto gerenciamento dos sistemas logísticos pode determinar, inclusive, o sucesso ou o fracasso organizacional a respeito do atingimento de seus objetivos globais, e não apenas em relação aos aspectos logísticos.

Diversos outros autores vêm contribuindo para conceituar a Logística, que se acredita ter origem em atividades militares. Em ocasiões diferentes, muitos termos foram usados para designar a Logística, tais como, por exemplo, "Distribuição Física”, "Administração de Materiais", "Logística de Marketing e Administração da Cadeia de Abastecimento", entre outros. A conceituação mais aceita entre os profissionais relacionados a este processo é a dos profissionais de Gestão da Cadeia de Suprimentos (2005):

\footnotetext{
"Logística é a parte do processo da cadeia de suprimentos que planeja programa e controla, de forma eficiente e eficaz, a expedição, o fluxo reverso e a armazenagem de bens e serviços, assim como o fluxo de informações relacionadas, entre o ponto de origem e o ponto de consumo, com o propósito de atender às necessidades dos clientes".
}

Existem muitas maneiras de conceituar a Logística, para Christopher (1997) a Logística é o processo de gerenciar, estrategicamente, a aquisição, movimentação e armazenagem de materiais, peças e produtos acabados (e os fluxos de informações correlatas) por meio de organização e seus canais de marketing, de modo a poder maximizar as lucratividades, presente e futura através do atendimento dos pedidos a baixo custo.

Conforme acentua Razollini Filho (2011) que, apesar de existirem diferentes conceitos para a expressão "gerenciamento logístico", existe a concordância de que o objetivo da Logística é a disponibilidade de produtos na data e no local necessários. Nesse sentido, o papel dos sistemas logísticos é tornar produtos ou serviços disponíveis, criando assim, as utilidades de espaço (local) e de tempo (momento).

Para Ballou (1993), a logística trata de todas as atividades de movimentação e armazenagem, que facilitam o fluxo de produtos desde o ponto de aquisição da matéria-prima até ao ponto de consumo final, assim como dos fluxos de informação que colocam os produtos em movimento, com o propósito 
de providenciar níveis de serviço adequados aos clientes a um custo razoável. O autor argumenta ainda, que a novidade no conceito de logística deriva do conceito da gestão coordenada de atividades inter-relacionadas e do conceito de que a logística agrega valor a produtos e serviços essenciais para a satisfação do consumidor e o aumento das vendas.

Entretanto, essa definição pressupõe que a logística faz parte do processo de Gerenciamento da Cadeia de Suprimento. Assim, surge um termo mais recente e mais amplo em que o gerenciamento da cadeia de suprimento destaca as interações logísticas que ocorrem entre as funções de marketing, logística e produção no âmbito de uma empresa, e dessas mesmas interações entre as empresas legalmente separadas no âmbito do canal de fluxo de produtos. Assim, entre leituras e interpretações, conclui-se que a logística é um processo que trás vantagem competitiva. E a empresa que melhor gerir sua cadeia de suprimento/logística, conseguirá ser mais competitiva se tornando mais eficiente e eficaz, se destacando em um mercado que está cada vez mais acirrado. Portanto, o objetivo da logística é prover ao cliente os níveis de serviço por ele requeridos, com a entrega do produto certo, no lugar certo, no momento certo, nas condições certas e pelo custo certo (FARIA, 2015).

\section{LOGÍSTICA REVERSA - IMPORTÂNCIA, CONCEITUAÇÃO E CARACTERIZAÇÕES}

De acordo com Leite (2009), o interesse de empresários, praticantes e pesquisadores por logística reversa tem aportado novas perspectivas ao debate e ainda não se chegou a uma visão unificada sobre o tema. Para se entender a Logística reversa é preciso saber que os sistemas Logísticos são mais abrangentes e extrapolam o intramuros das organizações. Isto é, iniciam-se no fornecimento de matéria prima e passam por todas as etapas produtivas dentro da organização, percorrendo os canais de marketing (ou distribuição) até chegar ao cliente, sendo que modernamente, continuam até o retorno do produto para o reinício do processo produtivo ou a sua destruição final pela organização, a chamada Logística reversa (LEITE, 2003).

Para Daugherty et al (2002), a Logística reversa tem sido associada a operações de reciclagem e a interesses de preservação ambiental, principalmente quanto a retornos de produtos não-consumidos ou de itens com defeitos de fabricação ou projeto, os recalls. Se estes itens não forem recolhidos, o consumidor, por falta de outros meios, poderá fazer a disposição de modo inadequado.

A literatura conceitua logística reversa em seu sentido mais amplo, como todas as operações relacionadas com a reutilização de produtos e materiais. Neste artigo, o conceito de logística reversa 
se concentrará no exame dos fluxos reversos, ou seja, naqueles que fluem no sentido inverso ao da cadeia direta, a partir dos produtos descartados, após seu consumo, visando agregar valor de diversas naturezas, por meio da reintegração de seus componentes ou materiais constituintes ao ciclo produtivo (KRIKKE et al., 2003).

Logística Reversa trata dos fluxos reversos dos produtos, é o gerenciamento do fluxo de materiais do seu ponto de consumo até seu ponto de origem. Segundo Chaves e Martins apud Costa (2006, p.4) “o processo gerencial da Logística Reversa é responsável por tornar possível o retorno de materiais e produtos, após sua venda e consumo a seus centros produtivos e de negócios, por meio de canais reversos de distribuição, agregando valores aos mesmos".

A aprovação da lei № 12.305/2010 - Política Nacional dos Resíduos Sólidos (PNRS) surge como um reforço ao processo de reciclagem no Brasil, dando suporte legal e incentivo a esta crescente atividade no país. Esta lei constitui a Política Nacional dos Resíduos Sólidos, que entre seus decretos determina a logística reversa:

[...] XII - Instrumento de desenvolvimento econômico e social caracterizado por um conjunto de ações, procedimentos e meios destinados a viabilizar a coleta e a restituição dos resíduos sólidos ao setor empresarial, para reaproveitamento, em seu ciclo ou em outros ciclos produtivos, ou outra destinação final ambientalmente adequada (BRASIL, 2010).

Logística reversa é o movimento de bens que partem do consumidor e seguem em direção ao produtor, em um canal de distribuição que opera na direção oposta à original. No entanto, a fronteira entre logística direta e reversa não é estritamente definida, na medida em que os conceitos de matéria-prima e de cliente final podem ser relativizados em algumas cadeias produtivas.

\section{O USO DE PNEUMÁTICOS EM LOGÍSTICA REVERSA NO BRASIL - EVOLUÇÃO HISTÓRICA E} CARACTERIZAÇÕES

De acordo com Leite (2009) com o desenvolvimento da indústria automotiva em todas as partes do mundo, a produção de pneus experimentou crescimento equivalente com a possibilidade de reaproveitamento até o final do ano 90 ainda baixa. As reutilizações de pneus não impediram esse produto de exercer, ao fim da vida, papel poluidor, em função das quantidades e do volume. Disposições pouca claras marcaram muitos anos da existência desse produto e um grave problema para a sociedade e governos. 
Com o desenvolvimento de tecnologia de filtração de gases provenientes da queima de pneus, foi possível a regulamentação de legislação modificadora do mercado no Brasil em 2000. Com o envolvimento de todos os agentes da cadeia produtiva de pneumáticos, o setor adotou uma política de trabalho de acordo como o modelo 'pool de empresas do setor' na organização da logística reversa dos pneus usados. As primeiras regras de retorno previstas pela legislação dificultaram a captação dos produtos. Sucederam-se diversas alterações, de forma a confortar as necessidades do setor.

Sobre o assunto, o artigo de Oliveira e Castro, versando sobre o estudo da destinação e da reciclagem de pneus inservíveis no Brasil (ENEGEP, 2007) afirma que a quantidade de pneus descartados no Brasil tem motivado a proposição de medidas amenizadoras dos impactos ambientais e a realização de pesquisas sobre possíveis métodos de seu reaproveitamento. Segundo os autores, os pneus inservíveis são depositados inteiros em aterros de lixo comum ou jogados em vias públicas, rios e córregos. Quando empilhados em quintais ou terrenos baldios, propiciam a proliferação de animais que podem transmitir doenças como a leptospirose e dengue, quando queimados emitem gases tóxicos.

Conforme já evidenciado, no caso do Brasil, a legislação exige o retorno de produtos considerados perigosos após o término da vida útil, por conter metais pesados, tais como pilhas e baterias, e de produtos considerados problemáticos como é o caso de pneus que apresentam poucas opções de tratamento, além do que, sua composição, quantidade e volume mostram-se extremamente prejudiciais ao meio ambiente. Sendo, nestes casos, do fabricante a responsabilidade pela logística e pelo tratamento dos resíduos.

Na Constituição Federal Brasileira de 1988 (2017), as questões ambientais são consideradas como patrimônio nacional e das futuras gerações. Prevê obrigações, principalmente com relação aos resíduos sólidos que são produzidos em grandes quantidades diárias e determina que a manutenção da qualidade ambiental seja de competência conjunta do Governo Federal, dos Estados e dos Municípios. Contudo, apesar das responsabilidades estarem definidas na legislação, efetivamente muito pouco se vê por parte dos organismos públicos a respeito da preservação do meio ambiente.

Ainda, sobre a realidade brasileira, a ANIP (Associação Nacional da Indústria de Pneumáticos) inicialmente encarregou-se de organizar o retorno de pneus usados. Em 2007 foi criada a empresa Reciclanip, especialmente concebida para esse fim e sob os auspícios das principais fábricas de pneus atuantes no Brasil. Ainda segundo o autor, até 2008, foram reprocessados, pelo sistema de 
incineração, 1.840 milhões de pneus usados, e esse se tornou o destino de $84 \%$ de todo o parque de pneus usados no país (ANIP, 2007).

No Livro Branco da Indústria de Pneus da ANIP (2015), identificam-se pelo menos três tipos de origens para os pneus usados: a coleta informal, a devolução nos pontos de venda de pneus e para pneus de grande tamanho (caminhões, tratores e equivalentes), um ciclo de reutilização por meio de remanufatura (recauchutagem, recapagem, entre outras denominações e técnicas utilizadas), até o fim de vida do pneu, quando é conduzido ao eco ponto. A reciclagem, nesses casos de trituração do pneu usado, resulta em sua desmontagem ou desmanche; as partes de aço dos fios componentes da maior parte dos pneus atuais são destinados à reciclagem de aço e o composto de borracha ao coprocessamento, ou seja, à incineração em fornos de cimenteiras ou usinas.

Além desse emprego, que representa a grande parte de reaproveitamento de pneus usados, constituem destinações de reuso do material: a fabricação de solados de sapatos, borrachas de vedação, dutos pluviais, pisos para quadras poliesportivas, pisos industriais, tapetes de automóveis, manta asfáltica.

\section{O CRESCIMENTO DA PRODUÇÃO E VENDAS DE PNEUMÁTICOS NO BRASIL - CONSEQUÊNCIAS E REFLEXÕES}

Sobre o crescimento da produção e vendas de pneumáticos no Brasil, através do gráfico 1 abaixo, verifica-se que entre os anos de 2005 a 2014 houve um crescimento de transações de pneus no Brasil, passando de 53,3 milhões de unidades transacionadas para 68,8 milhões. Um aumento considerável de cerca de $20 \%$. Por sua vez, o último relatório divulgado pela ANIP, mostra que a produção de pneus de todos os tipos cresceu no Brasil próximo de 25\% num período compreendido entre os anos de 2006 a 2016, e as vendas totais (milhões de unidades) cresceram em média cerca de 13.5\%. Por outro lado, com relação a evolução da produção de veículos automotivos no Brasil, que impactam diretamente na produção e vendas de pneus, a produção desse produto teve uma tendência de crescimento, sobretudo entre os anos de 2004 a 2007. 


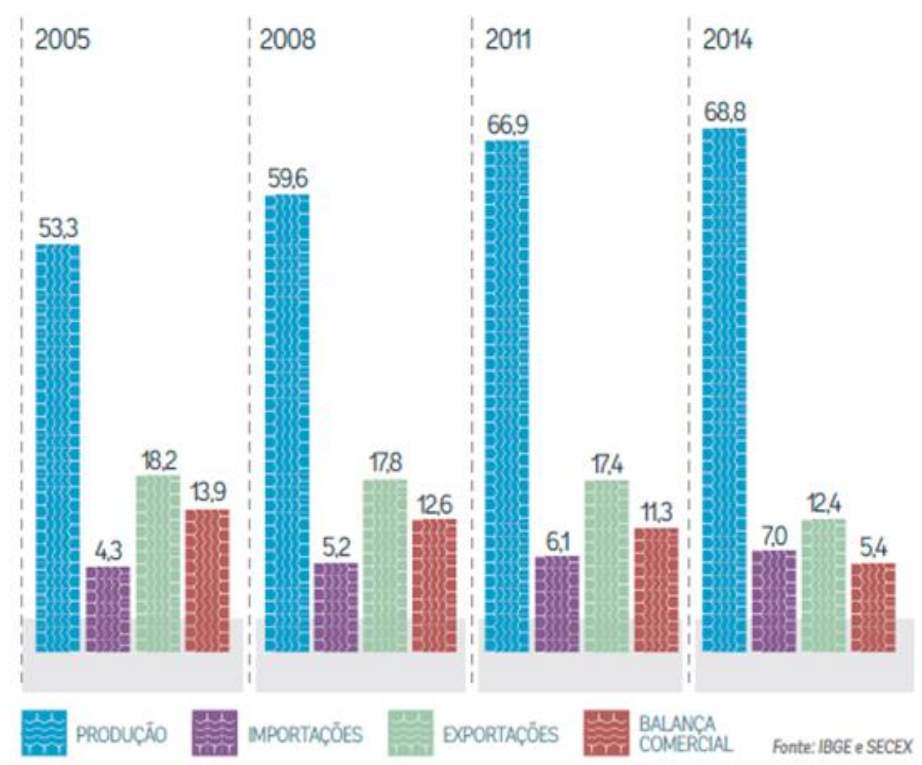

Gráfico 1 - Brasil: Balança comercial total de pneus

Fonte: Secex apud ANIP, 2015

Por sua vez, segundo resultados do relatório 2013 produzido pelo observatório das metrópoles do Instituto Nacional de Ciência e Tecnologia - INCT sobre a evolução da frota de automóveis e motos no Brasil verificou-se que o Brasil terminou o ano de 2012 com uma frota total de 76.137.125 veículos automotores. Em 2001 havia aproximadamente 34,9 milhões de veículos. Houve, portanto, um incremento da ordem 28,5 milhões, ocorrendo, assim, um crescimento superior a $138,6 \%$ entre esses dois anos. Vale lembrar, que o crescimento populacional no Brasil, entre os dois últimos Censos demográficos (2000 e 2010), foi de 11,8\%.

O número de automóveis passou de pouco mais de 24,5 milhões, em 2001 , para 50,2 milhões, em 2012. Isso significa que a quantidade de automóveis exatamente dobrou, com um crescimento de 104,5\%. Em toda a séria histórica, merece destaque o aumento de 3,5 milhões de automóveis em 2012. Assim, a frota brasileira passa de aproximadamente 46,7 milhões para os 50,2 milhões já mencionados em apenas um ano. Neste caso, é importante destacar que, de todo o crescimento ocorrido nos últimos 10 anos (acréscimo de 24,2 milhões de autos), 14,6\% ocorreram apenas em 2012. Esse crescimento elevado em 2012 também ocorre nas principais regiões metropolitanas, como veremos nos próximos itens do relatório. Em síntese, os resultados desses dados apontam que o crescimento da produção e vendas de Pneus vem aumentado vertiginosamente no Brasil. 
Assim, como se pode constatar pelos significativos exemplos citados, a descartabilidade é crescente atualmente, e tanto a logística reversa de pós-consumo como a de pós venda serão decisivas no equacionamento dessas enormes quantidades de bens descartados (LEITE, 2009). Além disso, a relação desses resultados com a questão ambiental deve produzir algumas outras reflexões por parte do governo e da sociedade. Nessa conjuntura, segundo Berté (2012) torna-se urgente se reexaminar e redimensionar os projetos de crescimento econômico, com base na perspectiva do desenvolvimento humano e da conservação ambiental, além de algumas das seguintes reflexões:

- Crescimento da responsabilização e da preocupação do governo e da sociedade brasileira quanto ao uso e a destinação ambientalmente correta de pneus inservíveis;

- Atuação mais eficaz do Conselho Nacional de Meio Ambiente (CONAMA), responsável pelo o disciplinamento desse passivo ambiental;

- Aperfeiçoamento das ações de políticas públicas de meio ambiente com estabelecimento de projetos a curto, médio, sobretudo, um trabalho que desenvolva à conscientização sobre a importância da temática ambiental e da responsabilidade social de todos, bem como à capacitação de indivíduos para atuar, intervindo e agindo com conhecimento técnico e científico, com competência gerencial e, sobretudo, com plena responsabilidade social (BERTÉ, 2012).

\section{O CONSELHO NACIONAL DO MEIO AMBIENTE (CONAMA) E O GERENCIAMENTO REVERSO DE PNEUS INSERVÍVEIS NO BRASIL}

Sobre o assunto Leite (2009) afirma que até pouco tempo atrás, a cadeia reversa de pneus usados, em todo mundo e em particular no Brasil, apresentava-se com baixa eficiência e taxas de reaproveitamento muito baixas e, embora não apresentasse nocividade ao meio ambiente, exceto pelo fato de mais recentemente ter se tornado um problema sanitário pelo acúmulo de água e geração de mosquito, apresentava poluição por excesso. Poder-se-ia encontrar pneus usados em pistas de corrida, em ancoradouros e em outros locais que, mesmo com interesse local, não apresentavam consumo suficiente para absorver as quantidades descartadas.

Em 1999, o CONAMA (Conselho Nacional do Meio Ambiente) publicou uma legislação na qual responsabilizava os fabricantes, importadores e distribuidores pela coleta e reciclagem dos pneus usados de uma forma gradativa ao longo de quatro anos, condicionando sua produção ou comercialização à posse de certificados de reciclagem. Inicialmente, a cada quatro pneus produzidos 
ou comercializados, deveria constar o certificado de um pneu reciclado, sendo essa quantidade aumentada anualmente até a condição de quatro pneus para cinco certificados de reciclagem.

Essa legislação deu origem à organização de pool empresarial para o equacionamento do retorno por meio da instalação de postos de coleta, consolidação e operações industriais de reciclagem, bem como a destinação ao mercado de reciclagem energética pela incineração em fornos com sistema de filtros tecnicamente adequados ao processo. A eficiência da cadeia reversa aumentou significativamente apresentando resultados adequados no país em 2009. Observa-se, dessa forma, que o fator tecnológico, traduzido pela autorização de incineração com filtração adequada, e o fator legislativo, responsabilizando os fabricantes e importadores de pneus pelo equacionamento do retorno e reciclagem de pneus usados, (logística reversa), modificou de forma significativa as condições de mercado, aumentando o valor do produto de pós-consumo e melhorando as quantidades recicladas (LEITE, 2009, pág. 93).

Hoje, o CONAMA por meio da resolução no 416, de 30 de setembro de 2009 atualizou o disciplinamento e o gerenciamento dos pneus inservíveis no Brasil. Essa resolução dispõe sobre a prevenção à degradação ambiental causada por pneus inservíveis e sua destinação ambientalmente adequada. O conselho em sua resolução entendeu que havia a necessidade de disciplinar o gerenciamento dos pneus inservíveis, pois considerou que os pneus dispostos inadequadamente constituíam passivo ambiental, que podiam resultar em sério risco ao meio ambiente e à saúde pública. Em sua resolução considerou ainda a necessidade de assegurar que esse passivo fosse destinado o mais próximo possível de seu local de geração, de forma ambientalmente adequada e segura.

Nesse sentido, dentre as principais resoluções do CONAMA que tratam da destinação ambientalmente adequada de pneus inservíveis se destacam as relacionada a seguir:

- A importação de pneumáticos usados é proibida no Brasil;

- Os pneus usados devem ser preferencialmente reutilizados, reformados e reciclados antes de sua destinação final adequada;

- É imposto pena de multa por unidade de pneu usado ou reformado importado; 
- A liberdade do comércio internacional e de importação de matéria-prima não deve representar mecanismo de transferência de passivos ambientais de um país para outro;

- Os fabricantes e os importadores de pneus novos, com peso unitário superior a 2,0 kg (dois quilos), ficam obrigados a coletar e dar destinação adequada aos pneus inservíveis existentes no território nacional, na proporção definida na resolução;

- Os distribuidores, os revendedores, os destinadores, os consumidores finais de pneus e o poder público deverão, em articulação com os fabricantes e importadores, implementar os procedimentos para a coleta dos pneus inservíveis existentes no País;

- A contratação de empresa para coleta de pneus pelo fabricante ou importador não os eximirá da responsabilidade pelo cumprimento das obrigações previstas na resolução;

- Os fabricantes, importadores, reformadores e os destinadores de pneus inservíveis deverão se inscrever no Cadastro Técnico Federal - CTF, junto ao IBAMA. numa periodicidade máxima de 01 (um) ano e que o não cumprimento pode acarretar a suspensão da liberação de importação;

- O saldo resultante do balanço de importação e exportação poderá ser compensado entre os fabricantes e importadores definidos;

- O descumprimento da meta de destinação acarretará acúmulo de obrigação para o período subsequente, sem prejuízo da aplicação das sanções cabíveis;

- Poderá ser considerado o armazenamento adequado de pneus inservíveis, obrigatoriamente em lascas ou picados, desde que obedecidas as exigências do licenciamento ambiental para este fim e, ainda, aquelas relativas à capacidade instalada para armazenamento e o prazo máximo de 12 meses para que ocorra a destinação final;

- Os fabricantes e importadores de pneus novos deverão elaborar um plano de gerenciamento de coleta, armazenamento e destinação de pneus inservíveis (PGP), o qual deverá ser amplamente divulgado e disponibilizado aos órgãos do SISNAMA;

- Os fabricantes e os importadores de pneus novos, de forma compartilhada ou isoladamente, deverão implementar pontos de coleta de pneus usados, podendo envolver os pontos de comercialização de pneus, os municípios, borracheiros e outros; 
- Os fabricantes e os importadores de pneus novos deverão implantar, nos municípios acima de 100.000 (cem mil) habitantes, pelo menos um ponto de coleta no prazo máximo de até 01 (um) ano, a partir da publicação desta Resolução;

- Os municípios onde não houver ponto de coleta serão atendidos pelos fabricantes e importadores através de sistemas locais e regionais apresentados;

- Os estabelecimentos de comercialização de pneus são obrigados, no ato da troca de um pneu usado por um pneu novo ou reformado, a receber e armazenar temporariamente os pneus usados entregues pelo consumidor, sem qualquer tipo de ônus para este, adotando procedimentos de controle que identifiquem a sua origem e destino;

- É vedado o armazenamento de pneus a céu aberto;

- Com o objetivo de aprimorar o processo de coleta e destinação dos pneus inservíveis em todo o país, os fabricantes e importadores de pneus novos devem: I - divulgar amplamente a localização dos pontos de coleta e das centrais de armazenamento de pneus inservíveis; II - incentivar os consumidores a entregar os pneus usados nos pontos de coleta e nas centrais de armazenamento ou pontos de comercialização; III - promover estudos e pesquisas para o desenvolvimento das técnicas de reutilização e reciclagem, bem como da cadeia de coleta e destinação adequada e segura de pneus inservíveis; IV - desenvolver ações para a articulação dos diferentes agentes da cadeia de coleta e destinação adequada e segura de pneus inservíveis;

- Os fabricantes e os importadores de pneus novos podem efetuar a destinação adequada dos pneus inservíveis sob sua responsabilidade, em instalações próprias ou mediante contratação de serviços especializados de terceiros;

- A simples transformação dos pneus inservíveis em lascas de borracha não é considerada destinação final de pneus inservíveis;

- A licença ambiental dos destinadores de pneus inservíveis deverá especificar a capacidade instalada e os limites de emissão decorrentes do processo de destinação utilizado, bem como os termos e condições para a operação do processo;

- É vedada a destinação final de pneus usados que ainda se prestam para processos de reforma, segundo normas técnicas em vigor; 
- É vedada a disposição final de pneus no meio ambiente, tais como o abandono ou lançamento em corpos de água, terrenos baldios ou alagadiços, a disposição em aterros sanitários e a queima a céu aberto;

- A utilização de pneus inservíveis como combustível em processos industriais só poderá ser efetuada caso exista norma especifica para sua utilização.

\section{CONSIDERAÇÕES FINAIS}

Apesar dos avanços na questão da necessidade da preservação ambiental é possível verificar que as periferias das cidades, embora sofram um alto impacto de degradação ambiental, tem uma população que ainda não consegue se mobilizar adequadamente pois não consegue relacionar alguns problemas sociais como consequências diretas da degradação ambiental. Por sua vez, a literatura apresenta várias soluções com relação à reciclagem de pneus usados, algumas até sendo empregadas com sucesso, como é o caso da construção de muros ecologicamente corretos por meio das chamadas células verdes, conforme apresentado no presente estudo. No entanto, verifica-se ainda que são ações pontuais e muito pequenas em relação à quantidade de pneus usados descartados anualmente no Brasil e à necessidade de uma destinação correta. A metodologia utilizada mostrou-se adequada à proposta do trabalho, voltada ao conhecimento sobre a destinação dos pneus inservíveis e das alternativas sustentáveis para o seu bom aproveitamento. Verificou-se que o projeto células verdes além de contribuir para a solução dos problemas ambientais agrega um outro valor fundamental, que é o processo de educação ambiental inserido na população local.

Estabelecendo de forma permanente, competente e planejada a destinação correta dada aos resíduos provenientes da manufatura da borracha, que, em sua maioria, ainda são lançados no principais lixões das periferias das grandes cidades. A importância do estudo se justifica pela preocupação crescente por parte dos governos, empresas e sociedades na destinação correta de produtos, quando de sua pós venda ou pós consumo, como é o caso dos pneumáticos. No entanto, na prática ainda muito pouco tem se feito nessa área. Na verdade, a estagnação é geral, tanto das empresas, quanto do governo e consequentemente da população. Em linhas gerais, a minimização do descarte de pneus inservíveis requer uma significativa mudança de comportamento, tanto em nível de processo industrial como também do consumidor, associada a um plano de gerenciamento ambientalmente adequado. 
A nova visão do mundo dos negócios é decorrente de uma mudança de modelo de desenvolvimento que está ocorrendo na sociedade. Para atender as exigências desse novo paradigma, países e empresas têm se alinhado, obrigando-se a otimizar os processos produtivos, articular a cadeia produtiva e repensar os próprios produtos. Embora existam legislações ambientais, há falta de políticas públicas nos vários níveis de governo, objetivando-se eliminar de forma mais eficaz o passivo ambiental. Finalmente, é importante separar que este artigo teve o mérito de discutir e revelar que apesar das dificuldades que se tem no destino de pneus usados no Brasil, é possível dizer que soluções simples e baratas podem de fato contribuir com a solução ambiental, sobretudo do ponto de vista local, a exemplo disto é o caso da construção de muros ecologicamente corretos que como foi visto além de melhorar a qualidade de vida da população local, traz a reboque outras soluções e reflexões sobre o tema em pauta como: poluição visual, degradação ambiental, mobilização popular, formação cultural, educação ambiental entre outros. Com isto, espera-se que estas informações subsidiem outros estudos mais afundados sobre o tema e contribua para a melhoria desta realidade.

\section{REFERÊNCIAS}

ANIP. Associação Nacional de Indústrias de Pneumáticos. Disponível em: http://anip.com.br. Acesso: 18 fev. 2018.

BALLOU, R.H.(1993). Logística empresarial: transportes, administração de materiais e distribuição física. São Paulo: Atlas.

BARDIN, L. (2009). Análise de Conteúdo. Lisboa, Portugal; Edições 70, LDA.

BERTÉ, R. (2012) Gestão Socioambiental no Brasil. Curitiba: Ibpex, São Paulo: Saraiva.

CHRISTOPHER, M. (1997). Logística e Gerenciamento da Cadeia de Suprimento: estratégias para redução de custos e melhoria dos serviços. São Paulo: Pioneira.

BRASIL. Política Nacional dos Resíduos Sólidos (PNRS). Lei № 12.305/2010.

CÉLULAS VERDES. Laboratório de Engenharia. Disponível em https://celulasverdes.droidinformer.org/. Acesso em 01 de maio de 2017.

BRASIL. CONAMA - Conselho Nacional do Meio Ambiente. Resolução CONAMA no. 416, de 30 de setembro de 2009. Resoluções. Disponível em http://www.mma.gov.br. Acesso em 29 de abril de 2017.

CONSTITUIÇÃO FEDERAL BRASILEIRA DE 1988. Art. 225 da Constituição da República Federativa do Brasil. Disponível em: http://www.senado.gov.br/sf/legislacao/const/. Acesso: 16 fev. 2007.

DAUGHERTY, P.J; MYES, M.B.; RICHEY, G. R. (2002). Information support for reverse logistics: the influence of relationship commitment. Journal of Business Logistics v. 23, n.1. 
OLIVEIRA, O. J.; CASTR, R. de . ENEGEP. Estudo da destinação e da reciclagem de pneus inservíveis no Brasil. Disponível em: http://enegep.com.br. Acesso: 28 abr. 2018.

FARIA, A. C. de, COSTA. (2015). Gestão de Custos Logísticos. Ana Crisitna de Faria, Maria de Fátima Gameiro da Costa. 1‥ ed. - 12. Reimpr. São Paulo: Atlas.

Instituto Nacional de Ciências e Tecnologia. Evolução da frota de automóveis e motos no Brasil 2001 2012 (relatório - 2013). Disponível em http://www.observatoriodasmetropoles.net/download/auto_motos2013.pd. Acesso: 02 de Maio de 2017.

LEITE, P.R. (2003). Logística reversa: meio ambiente e competitividade. São Paulo: Pearson Prentice Hall.

LEITE, P. R. (2009). Logística reversa: meio ambiente e competitividade. São Paulo: Pearson Prentice Hall.

MARRONE, P. V. (2015). Livro Branco da Indústria dos Pneus - Uma Política Industrial para o Setor. São Paulo. ANIP.

MOUSINHO, P. Glossário. (2003). In: Trigueiro, A. (Coord.) Meio ambiente no século 21. Rio de Janeiro: Sextante.

RAZOLLINI FILHO, E. (2011). Logística Empresarial no Brasil. Tópicos especiais: Curitiba: Ibpex. 


\section{Capítulo 28}

\section{ANÁLISE DO EFEITO DO CRÉDITO RURAL NA PRODUÇÃO AGRÍCOLA DOS ASSENTAMENTOS NA REGIÃO DO MATO GROSSO DO SUL}

DOI: $10.37423 / 200300479$

\section{Autor: Elias Ribeiro de Souza}

Orientador: Prof. Dr. Carlos Vinícius Santos Reis

RESUMO: O crédito rural é um financiamento designado a produtores rurais e cooperativas ou associações de produtores rurais. Seu objetivo é incentivar investimentos rurais realizados por produtores ou por suas cooperativas, e assim estimular a geração de renda melhorando a qualidade de vida do agricultor e sua família, fomentando a economia e gerando empregos. Desse modo, o objetivo é verificar qual a impacto do crédito rural na geração de renda dos assentamentos do Mato Grosso do Sul. Para estimar os retornos sobre a renda, o modelo clássico de capital humano de Mincer foi ajustado, apresentando como variáveis de controle: educação formal, experiência, assistência técnica e o crédito. Como resultado verificou-se que políticas de crédito, assistência técnica, cooperativismo entre outras, somente surtirá o efeito desejado se o beneficiário obtiver um nível de escolaridade mínimo de quatro anos de estudo formal. Assim, o crédito rural se comporta como uma importante ferramenta para o aumento da produção, beneficiando o produtor, o comércio e a comunidade.

Palavras-chave: Crédito rural. Assentamentos. Capital humano. Assistência técnica. 


\section{INTRODUÇÃO}

É sabido que o crédito rural é de grande importância para os assentamentos rurais em todo país. E que se não houvesse a disponibilidade de tais programas direcionados aos assentados a distribuição de terras seria inútil, pois a maioria predominante envolvida em tais programas é de baixa renda e pouco nível de escolaridade.

Pensando a este respeito, surge a curiosidade em conhecer como aconteceu, até então, o processo de distribuição do crédito rural no Brasil. Tendo como amostra específica os assentamentos do Mato Grosso do Sul, busca descobrir se o crédito rural fornecido tem realmente feito uma diferença positiva quanto ao nível de produção e a qualidade de vida dos assentados.

Como consequência será analisada o impacto do crédito rural, visando uma abrangência que poderá fornecer informações sobre a distribuição de renda aos assentamentos, ou seja, qual o retorno que a comunidade usufruirá decorrente dos programas de financiamento rural desses assentamentos.

Para aqueles que praticam políticas públicas direcionadas aos assentados, a expectativa é que juntamente com outras políticas haja uma considerável produção de renda e emprego nos assentamentos rurais, vindo a tornar tangíveis os objetivos idealizados, trazendo oportunidade e possibilitando uma renovação tecnológica na agricultura local, modernizando o campo, trazendo estímulo ao agricultor e tonificando o processo hereditário da agricultura. Trazendo também inclusão social aos assentados, o que fortalece a permanecia dessas famílias no campo.

Mediante tais informações surgem perguntas como:

As políticas de crédito rurais tratadas neste projeto produzem o efeito esperado?

Se sim, que se abram as portas e estimulem a continuação desses programas. Se não, onde podem ser melhorados? E quais os caminhos e atitudes devem ser tomados para que haja uma melhora nos rendimentos dos assentados?

O objetivo deste trabalho será analisar o impacto do crédito rural na produção agrícola dos assentamentos do Mato Grosso do Sul. E para os objetivos específicos será verificado se o crédito rural tem sido o suficiente para que o agricultor assentado conquiste os objetivos almejados, o que o manterá no campo gerando renda para sua família e alimentos para a comunidade. 
Para tais fins, será utilizado o modelo de Mincer (1974) para analisar como tem se comportado a produção dos assentados em relação ao crédito rural.

Além dessa cessão de introdução, este trabalho compreende mais três partes, e em se-quência, será apresentada uma revisão da literatura contendo em seu corpo três tópicos, onde será tratado primeiro sobre assentamentos, segundo um breve histórico, falando sobre o crédito rural no Brasil, buscando compreender ao longo da história como eram cedidos os financiamentos públicos rurais e em terceiro será tratado sobre como se torna importante, a busca pela eficiência na produção para que haja melhora na renda dos assentados, depois será exposta a metodologia, onde será explicado o modelo escolhido para fazer as análises necessárias, neste caso o modelo minceriano, e por fim serão apresentados os referenciais.

\section{REVISÃO DA LITERATURA}

\subsection{UMA VISÃO GERAL DOS ASSENTAMENTOS}

Baseando-se em cálculos econométricos ao estilo neoclássico Delfim Netto (1963) advogando pela modernização das grandes propriedades não via sentido em um processo de divisão de terras.

Simultaneamente, o embate por terras aconteceu em vários lugares sendo marcantes alguns casos como dos posseiros, na Amazônia, das ligas camponesas, no Nordeste entre outros.

Em 1964 tivemos, com o golpe da ditadura militar, o encerramento desse contexto, pois o País passou a modernizar rapidamente sua agricultura, tendo por base a chamada revolução verde e o clássico tripé pesquisa, crédito e expansão. Nesse mesmo período, foi apresentado o Estatuto da Terra, que ditou a estrutura governamental ao qual aconteceria a execução do projeto, garantindo, ao mesmo tempo em sua estrutura a perspectiva da reforma agrária. Tendo algumas colonizações por exceção, a reforma não ocorre em até uma década depois da ditadura.

Nesse contexto, em 1970, temos o nascimento do Instituto Nacional de Colonização e Reforma Agrária (INCRA), que mesmo tendo a implantação de assentamentos por prioridade, desenvolve uma lista de outras atividades como a fiscalização, georrefeicimento dos imóveis, cadastros e pela normalização fundiária. Ao considerarmos que ainda existe uma quantidade imensa de terrenos públicos que ainda não foram catalogados, as conhecidas como terras devolutas, e que $20 \%$ dos imóveis são obtidos como posse, nota-se a importância da regularização fundiária. 
Com a implantação de uma nova democracia no País, em 1985, nota-se um surgimento com maior intensidade pela luta da terra, tendo como protagonista o Movimento dos Trabalhadores Sem-Terra (MST), que nascido em 1984, propunha trazer uma organização aos setores com menos renda do meio rural, passando também a pressionar o INCRA pela desapropriação de terras. O que por vários motivos como financeiros, jurídicos e políticos não conseguiu o êxito almejado até meados do ano de 1995, já com o governo Fernando Henrique Cardoso. Nesse momento, nota-se uma aceleração no crescimento do MST, por motivos político, e um desenrolar positivo também no governo Luiz Inácio Lula da Silva (2003-2010).

Em contradição, (NAVARRO, 2009) afirma que 20\% dos 5 milhões de estabelecimen-tos, foram resultados de um processo de reforma agrária recente, basicamente executada entre 1995 e $2010 . E ́$ sabido que a grande concentração fundiária, em relação ao comentado obteve pouca mudança até então. Tida como o grande emblema esquerdista, a reforma agrária medida pelo índice de Gini (0,854 para o ano de 2006) se mostra muito desigual em um processo histórico, e tida socialmente como revoltante.

Nas décadas de 1950 e 1960 o debate agrário nacional conta com uma porção de expli-cações sobre a conhecida como reforma agrária. Tinham então algumas perspectivas girando em torno de uma questão agrária clássica, com correspondência marxista, destacando a irracionalidade que a renda da terra retratava para reprodução acrescida do capital, o que colocava em oposição, proprietários de terra e capitalistas (MARTINS, 2003).

Assinalava-se para o aumento da capacidade de produção no País uma mudança estrutu-ral, o que evitaria a possibilidade de desabastecimentos, dado ao seguimento inelástico da oferta de alimentos (BRASIL, 1962).

Alegando que a distribuição de terras é um importante meio de combate à pobreza, Abramovay (2005) propõe uma reforma agrária no Brasil, deixando bem claro que o funcionamento desse processo só seria possível se os beneficiados (assentados) estivessem cientes de que os ativos (terra, tecnologia e crédito) ao qual estão tomando posse, terão de ser pagos, pois somente assim, tendo o conhecimento de que seus projetos serão avaliados e em caso de maus investimentos, sofreram sansões futuras, mesmo sendo pobres, fará com que valorizem o investimento a eles confiado, levando-os a um esforço, para a conquista da produção proposta, e ao mesmo tempo conseguiram ressarcir os cofres públicos, mesmo em longo prazo. 
Tendo em vista que, Abramovay e Favareto (2010) comprovaram que as áreas tidas como fundamentalmente rurais (representando em média 30\% da população brasileira e a imensa maioria do território brasileiro) produziram resultados econômicos mais promissores.

Também propondo a reforma agrária, Martins (2003) enxerga a possibilidade da cons-trução de um comunitarismo moderno, visando uma relação virtuosa em que agricultores produtivos e eficientes se uniriam a suas características de reciprocidade, produção de valores humanos, para um bem pessoal e social.

Tendo como resultado do antigo debate sobre a questão agrária, surge um País com uma razão capitalista robusta, eficiente e produtiva (NAVARRO 2010). Podendo-se perceber mudanças significativas na conjuntura agropecuária brasileira, citados por alguns pesquisado-res como (GASQUES et al 2010) que destacam a participação da Empresa Brasileira de Pesquisa Agropecuária(EMBRAPA) em contribuições tecnológicas relevantes, levando a um aumento da produtividade; temos também uma redução considerável nos preços reais arrecadados por agricultores.(BALESTRO; LOURENÇO,20140) comentam sobre a ampliação de riscos, onde o aumento da dificuldade na compreensão do mercado na qual crédito, pesquisa e comercialização estão crescentemente ligados ao sistema financeiro.

Tal mudança redirecionou a produção agrícola a um ponto mais competitivo e intricado, onde o acesso, por menor que seja o financiamento, se torna inatingível à maioria deles. De maneira que, um procedimento competente e uma boa administração passou a ser de principal importância, necessitando relevantes investimentos financeiros, e um auto grau de alfabetização dos agricultores, o que não é o caso, pois somente a minoria deles tem alcançado tais exigências (MELLO; GOMES, 2011).

Em sua tese de Doutorado (REIS, Carlos Vinicius Santos. 2014) relata que políticas públicas (Crédito Rural, Assistência técnica, diversificação e Associativismo) para agricultores que possuem nível de escolaridade formal inferior ao quarto ano são ineficazes para almejar ganhos de produtividade, não utilizando os recursos de maneira eficiente, e neste caso se encontram $80 \%$ dos estabelecimentos agrícolas. Esse verídico bloqueio, acaba sendo um grande problema aos assentados e aos financiadores. 
se que, por motivos da rápida urbanização e ao mesmo tempo a modernização de grandes propriedades, cada vez mais compactas constata-se uma estrutura fundiária, se não fixa, de penosa remodelagem. Analisando dados do Censo Agropecuário 2006, 8,2\% das instalações rurais no Brasil produzem $83 \%$ do valor bruto da produção (VBP) total, frente a isto, $77 \%$ deles não atingem $4 \%$ da produção (ALVES; ROCHA, 2010).

Em síntese, temos uma carência de pesquisas bem detalhadas sobre a renda e a produ-ção dos assentamentos, sobressaindo ainda sobre a desigualdade interna, tendo justificativas equivocadas como se não necessitasse crítica. Em contramão é sabido que assentados passam por dificuldades imensas, ao que tange renda e produção principalmente por falta de estrutura e de programas de implantação eficiente, graças a relações de dominação interno e em espaço de mediação (MELLO, 2016).

\subsection{CRÉDITO RURAL NO BRASIL}

Os primeiros contatos de crédito rural no Brasil estão registrados em meados dos anos 30, porem, entre 1940 e 1960 nota-se uma mudança onde foram transferidos recursos do setor agrícola para outros setores da economia, mudando para outro conjunto de investimentos, a urbanização. A ausência de programas gerou na agricultura, falta de investimentos, o que levou a uma crise de abastecimento em meados dos anos 50, ocorrendo contínuos aumentos nos preços dos produtos rurais, resultando em uma queda no suprimento de alimentos em 1959 (SPOLADOR, 2001; BARROS, 1979; MEYER et al 1977).

Com o objetivo de fomentar a produção agrícola no Brasil, o Banco Central e o Ministé-rio da Fazenda criaram, nos anos 60, um grupo de medidas que traria força financeira aos produtores rurais, viabilizando a aquisição de tecnologia corrente ao meio rural. Em 1965 foi criada a lei 4.829 que estabeleceria que $10 \%$ dos depósitos à vista dos bancos comerciais estariam direcionados a empréstimos agrícolas, alterado para 15\% com a resolução 260 do mesmo ano, contendo garantia de que as taxas cobradas não passariam de $75 \%$ dos empréstimos que eram cedidos ao comércio, o que acabou por aumentar os recursos de financiamento para o crédito rural, gerando um maior interesse por parte das instituições financeiras em prover tais financiamentos. Destacando a função do Banco do Brasil que tinha como responsabilidade $90 \%$ dos financiamentos rurais, tornando-o mais disponível aos pequenos produtores (SPOLADOR,2001). 
A partir de 1965, constata-se um rápido crescimento da cota de crédito rural no montan-te destinado a economia do País, saindo de 53,3\% para 71\% entre 1966 a 1968.

Nos anos 70 com a crise petrolífera e o aumento inflacionário no país, a agricultura perde novamente a prioridade, o que gerava uma concentração de crédito somente em posse daqueles que tinham uma vasta concentração de terras (SAYAD, 1978; BARROS, 1979),

Na tentativa de contenção inflacionária, na década de 80, o governo estabeleceu como meta da política monetária a diminuição da oferta dos meios de pagamento. A suspensão do crédito rural teria por fim maior eficiência na contenção do avanço da oferta monetária, quanto superior fosse à participação no total das aplicações das autoridades monetárias (ESPOLADOR 2001, P.7).

Na década de 90, o que se nota de mais relevante, é o lançamento ao mercado interna-cional, com a baixa nas tarifas de importação e a depreciação do valor da moeda no governo Collor e a extremada valorização do câmbio em 1999. Ressaltando também nesse período o processo de calmaria dos preços e a progressiva saída do governo do financiamento agrícola. Tendo como objetivo, para esse comportamento a política fiscal e o esforço de modernização do Estado e do controle de gastos públicos (MELO 1997; SHOUCHANA; PEROBELLI, 2001; GASQUES, 2000).

Tendo como muito carente o montante de crédito, para financiamentos da atividade agrícola, principalmente o proveniente do Tesouro Nacional, Sistema Nacional de Crédito Rural de 1965 está totalmente não dinâmico (SOBER, 2008). Necessitando de uma reestruturação para que haja novas formas de financiamento agrícola, tendo as cooperativas por destaque nessa empreitada, tanto no sistema de crédito como no informal.

\subsection{CAPITAL HUMANO}

Tendo como definição atributos como capacidade, conhecimentos, competências e propriedades de personalidade que beneficiam a execução do trabalho de modo a gerar valor econômico. São as peculiaridades adquiridas por um trabalhador por meio da experiência, perícia e educação.

Ao longo do tempo tem-se notado uma expansão no que se refere à teoria do capital humano ao decorrer de decênios, especialmente sobre o aspecto da educação. A teoria do capital humano relaciona-se ao conjunto de concepções que uma pessoa pode fazer de si próprio, através de sua escolaridade, qualificação profissional, treinamento e outros tipos de valorização particular desse 
indivíduo. Atributos esses, são vistos na teoria do capital humano como investimentos, que são adquiridos através da qualificação acumulada ao longo do tempo. O desenvolvimento na capacitação do capital humano se dá quando um indivíduo inicia o processo de adquirir conhecimento e habilidades, através do treinamento e aprendizado. Assim suas habilidades podem ser reproduzidas tanto com relação ao pensamento tecnológico e cientifico, quanto da evolução da mão-de-obra qualificada, que apresenta efeitos positivos na produtividade do trabalho e, por conseguinte um resultado na renda dos indivíduos. Na teoria do capital humano a perspectiva quantitativa não é a causa determinante da produtividade, mas sim a visão qualitativa é que de fato gera valor, melhorando o produto e o trabalho em uma comunidade. Assim, o crescimento econômico está diretamente ligado ao investimento em educação, porque esse alcança melhoras no nível de produtividade, desenvolvimento tecnológico e uma comunidade melhor orientada e melhor qualificada para o mercado de trabalho. Notavelmente se percebe que existe uma relação positiva entre a qualidade de educação e o crescimento econômico da renda per capta.

Não seria sensato vincular a teoria do capital humano a somente uma corrente de pen-samento, durante décadas pensadores de diversas linhas de pensamento discorreram sobre o assunto. Adam Smith é quem primeiramente dá início a esse assunto considerando habilidades humanas como um bem de essência econômica, para ele, o homem tem que sobreviver através de seu trabalho. Para isso, sua remuneração precisa ser satisfatória para que consiga garantir sua subsistência, apesar de que a força de trabalho na visão capitalista seja entendida como uma um capital, assim o capital é o resultado do apoderamento do trabalho alheio, de modo que o trabalho é tratado como uma mercadoria. Alfred Marshall delineia como capital toda acumulação de bens que tiveram resultado provindo de esforço e sacrifício humano, designado em especial para assegurar proveitos futuros (Marshall, 1957). Já para Marx (1978), a força do trabalho só se converte em capital quando necessariamente se torna mercadoria para o respectivo trabalhador, isto é, com o objetivo de conquistar lucro para o próprio trabalho do indivíduo.

Conforme Carvalho e Souza (1999, p.2), “o capital humano é a capacidade, habilidade, criatividade, conhecimento e experiência própria dos funcionários e gerentes convertida em produtos e serviços que são a razão pela qual os compradores procuram a empresa e não suas concorrentes". Assim este capital, nas companhias, será, em muitos casos, ainda mais importante que os capitais físicos, sendo de maneira relevante para o sucesso das organiza- ções. Werneke, Lembeck e Bronia $(2003$, p.5) relatam que o capital humano é "o valor acumulado de investimentos em treinamento, competência 
e futuro de um funcionário. Também pode ser descrito como competência do funcionário, capacidade de relacionamento e valores. " As companhias também podem reunir o valor do capital humano, possibilitando o treinamento com a intenção de trazer maior retorno em produtividade e menor desperdício.

Outro capital humano que influência na renda de produção na agricultura de base fami-liar dos assentamentos é a assistência técnica que é uma atividade de propagação de conhecimentos às pessoas do meio rural, tendo em vista um avanço nos processos tecnológi-cos de produção e comercialização. Destinando-se à solução de problemas recorrentes do agricultor. Para compreender melhor a assistência técnica rural, será necessário produzir um breve histórico das instituições e seus modelos de atuação. Nos anos de 40 e 60 foram desenvolvidas algumas organizações de ATER (Assistência Técnica e Extensão Rural), que em seguida foram enquadradas no sistema Embraer (Empresas Brasileira de ATER) tinham como posse um alicerce hierarquizado do tipo militar, com o propósito de arraigar a chamada revolução verde ao longo do também conhecido como período do produtivismo modernizador (Aumento de produção com uso intensivo de insumos).

Segundo Watts (1987) apud Caporal e Ramos (2006, p.17) quanto maior é o nível de funcionamento autoritário da administração central, tanto menos eficiente será a função educacional do ampliamento e tanto será sua aplicação como propagador de política estatal. As deliberações acerca de onde fazer, com quem fazer o que fazer, e como servir-se dos recursos; devem ser de maior importância à assistência técnica e aos agricultores, sendo acompanhados pelo governo para que sigam as principais diretrizes. Consentindo-se que como CHAMBERS aupud COPORAL e RAMOS (2006) quando fala que os órgãos de análise, extensão pública e especialmente as universidades e escolas técnicas devem participar com seus docentes e alunos às comunidades, especialmente quando solicitadas, para aprender, reescrever livros entre outros, ou seja, dar menos aulas e mais auxilio no aprendizado. E isso também serve para as ONGs e políticos.

Com a intenção de ser a relação na ligação entre produtores rurais e as bases de pesquisa experimental, criado em 1914 por influência do governo americano o trabalho cooperativo de extensão rural, que difundia para as populações rurais conhecimentos úteis e práticos para a legitimação de métodos mais produtivos e eficientes. Fonseca (1985) tomando por base as ideias de Figueiredo para retratar o alicerce da proposta onde "o aumento do nível de conhecimento dos 
agricultores e seus parentes, levando-os a ter vivência de novos hábitos e atitudes, assim também o desenvolvimento de novas habilidades em sua atividade de produção" (FIQUEIREDO 1974, P.1).

Este modelo tinha como objetivo expandir os conhecimentos adquiridos em campos de experimento para os produtores rurais, viabilizando o contato dos tais às novas tecnologias. Pensava-se que assim seria provável um aumento no nível produtivo proporcionando frutos econômicos mais promissores. Buscando solucionar o problema do elevado nível de pobreza e o atraso tecnológico de produção dos países subdesenvolvidos, foi utilizado o modelo norte americano que já havia tido um bom êxito através desse modelo.

Fonseca (1985) esclarece que a diferença entre aceitar e adotar uma tecnologia recém-adquirida aponta para uma atividade extensionista direcionando-a para o âmbito psicológico, onde somente uma transformação na mente do homem do campo o tornaria hábil para uma vida progressista.

Alentejano (200) desaprova o fato que o Programa Nacional de Fortalecimento da Agri-cultura Familiar (PRONAF) omitir os agricultores que auferiam mais de $20 \%$ de seu faturamento vem de atividades não agrícolas o que deixava de fora maior parte dos pluriativos. É considerável também citar que ALVES et al.apud ALENTEJANO (2000) averiguam que a baixa remuneração da agricultura, pactuada com a atração das cidades esta conduzindo a um evacuar do campo.

Contudo a indispensabilidade da extensão rural se concretizar como meio para a solução de problemas sociais rurais e para a evolução da atitude da própria população sucedeu em uma modificação do modelo inicial, na qual as atividades de extensão rural passaram a se direcionar para um projeto comunitário instrutivo. Contudo acreditava-se que o avanço na qualidade de vida seria consequência dos ganhos econômicos vindos do aumento da produção adquirida através dessa extensão e da assistência técnica oferecida.

\section{METODOLOGIA}

Os dados empíricos utilizados para este trabalho foram extraídos de entrevistas sobre os temas socioeconômicos e ambientais em 24 assentamentos agrícolas em que para cada assentamento foi selecionado aleatoriamente de 20 a 30 assentados para pesquisa, totalizando em 429 assentamentos agrícolas de 18 municípios da região do Mato Grosso do Sul - Brasil durante o período de 2009-2010. 
Com o objetivo de verificar o impacto do crédito rural na produção agrícola em assen-tamentos do Mato Grosso do Sul será especificada uma equação tendo como base o modelo de Mincer (1974). A equação minceriana de salários serve como alicerce de uma ampla literatura empírica de economia do trabalho. O modelo de Mincer (1974) é uma equação que apresenta estrutura para estimar retornos de educação, experiência, entre outras variáveis de capital humano que determinam a renda do trabalho.

Criando uma equação para rendimentos que seria dependente de condições explicativas associadas à escolaridade e a experiência, além de outros atributos que podem influênciar a os rendimentos como, raça, sexo, crédito entre outros. No que se refere ao efeito de educação temos esse modelo de equação por base, sua estimação já trouxe razão a várias pesquisas, que tentam absorver diferentes custos educacionais como, custo de oportunidade, financiamentos, mensalidades, impostos etc. Assim como a insegurança e a expectativa dos agentes participantes das decisões, o aperfeiçoamento tecnológico, não linearidades no grau de instrução, entre outros. Discernindo os custos da educação e as receitas do trabalho, tornou possível o cálculo da taxa interna de retorno da educação, que deve ser confrontada com a taxa de juros do mercado, para definir a quantidade ótima de capital humano. A equação minceriana também é usada para pesquisar a relação entre crescimento e o nível de escolaridade de uma comunidade, e mais ainda, dos causadores da desigualdade.

Para estimar os retornos a pesquisa utilizou-se da equação minceriana modificada dos rendimentos de salário esta pesquisa utilizará como proxi para variável dependente o valor da produção.

Então será apresentado, o modelo de regressão no formato log-nível, ou seja, a variável dependente (a produção) está em logaritmo e variáveis independentes mais relevantes como (a escolaridade) está em nível. Logo o coeficiente $\beta 1$ mede o quanto um ano a mais na educação causa de variação proporcional na produção do indivíduo. A título de exemplo, se $\beta 1$ é estimado em 0,12 , isso representa que cada ano a mais de estudo está relacionado, em média, com um aumento na produção de $12 \%$.

Neste caso, como será analisado o efeito do crédito rural na produção em assentamentos do Mato Grosso do Sul, a equação será moldada da seguinte forma:

$$
\operatorname{Ln} Y_{i=} \beta_{0}+\beta_{1} \text { educ }_{i}+\beta_{2} e_{i}+\beta_{3} a t_{i}+\beta_{4} \text { cred }_{i}+\varepsilon_{i}
$$


onde $Y$ é a produção das unidades agrícolas dos assentamentos; Educ é a sua escolarida-de medida por anos de estudo do gestor ou do proprietário da produção; Ex é a sua experiência; AT é assistência técnica; Cred é o crédito rural, financiamento destinado a produtores rurais e cooperativas ou associações de produtores rurais, que tem por objetivo estimular os investimentos e amparar no custeio da produção e comercialização de produtos agropecuários; e $\varepsilon$ é um erro estocástico normalmente distribuído.

A variável rendimento de produção, $Y$, é encontrada através da multiplicação do preço a ser comercializada e da quantidade de cada cultivo.

A variável educação é medida através dos anos de escolaridade, é também o estoque de capital humano acumulado, encontrada através da medição em quantidade dos anos de estudo formal que possui o gestor da propriedade, neste caso representado pelo coeficiente $\beta 1$, tem por objetivo medir o retorno da escolaridade na produção do gestor, ou seja, para cada ano a mais de escolaridade formal, o quanto irá se alterar,em média, a produção desse agricultor assentado ?

A experiência $\beta 2$, é mais uma variável correspondente ao acumulo de capital humano, essa explica se o produtor já possuía alguma experiência em atividades agrícolas antes de receber o lote, buscando verificar o quanto essa variável afetará na produção.

A variável $\beta 3$, Assistência técnica, busca descobrir se o produtor rural obteve ou não o amparo técnico, e se essa causa mudanças no resultado final da produção.

Por fim encontramos a variável $\beta 4,0$ crédito rural, que tem por finalidade explicar o efeito dessa variável na produção dos agricultores rurais, verificando o quanto cada valor monetário a mais investido irá aumentar no resultado final da produção desse agricultor.

Assim, como parte da equação será exposta como uma análise quantitativa e parte serão expostas como análise qualitativa, precisará fazer uso do método conhecido como variáveis dummy ou variáveis binárias.

Tais fatores aparecem regularmente em modelos de rendimentos na forma de informa-ções binárias: uma pessoa é do sexo masculino ou feminino; um assentado possui assistência técnica ou não; receberá assistência técnica rural ou não; recebe uma pensão mensal ou não. Em todos esses exemplos, a informação considerável pode ser apanhada pela definição de uma variável Binária ou um 
variável zero-um. As variáveis binárias são em geral conhecidas como variáveis dummy (GUJARATI, 1970).

Ao definirmos uma variável dummy, precisamos direcionar a qual evento será fixado o valor um; e a qual evento será fixado o valor zero, que apresentaram neste caso em especifico sim ou não. Exemplificando, o lote 12 recebeu assistência técnica fornecida pelo Estado? Como resposta, será definido que o número um quer dizer sim, e número zero quer dizer não. Esse mesmo modelo será utilizado para analisarmos se há, ou não, experiência prévia desses que serão assentados, assim, será verificado a disparidade daqueles que possuem experiência para aqueles que não possuem.

\section{ANÁLISE DOS RESULTADOS}

A amostra é gerada em sua integralidade por assentados, definidos como de pequena propriedade, imbuídos em fornecer produtos de origem animal e vegetal para o estado do Mato Grosso do Sul, possuem administração do estabelecimento na esfera familiar, e os rendimentos são predominantes de atividades desenvolvidas no âmbito do próprio estabeleci-mento.

A estimativa do efeito do crédito rural na produção agrícola foi obtida através do mode-lo minceriano ajustado. De acordo com os resultados apresentados na Tabela 1, a variável valor de produção foi adquirida através apuração da área colhida do produto por ano, multiplicado pelo valor do produto por hectare, produção essa, composta para a venda e o consumo particular, convertendo para um valor mensal. A média do valor da produção foi de $\mathrm{R} \$ 11.225,30$ por propriedade assentada, com o mínimo de $\mathrm{R} \$ 15,10$ e o máximo de $\mathrm{R} \$ 15.335,00$ para o ano de 2009.

Na educação formal, os gestores têm em média 4,7 anos de estudo formal, com o míni-mo de zero e o máximo em dezesseis anos de estudo formal. Aqueles que possuíam experiência na atividade agrícola antes da posse dos lotes representam em média $77 \%$ da amostra. E $22 \%$ em média, foi o valor daqueles que receberam assistência técnica.

Por fim, a média de créditos recebidos pelos gestores, foi de $\mathrm{R} \$ 11.065,38$, para utiliza-ção em custeamento ou investimento no estabelecimento. 
Tabela 1: Estatística descritiva das variáveis para o modelo

\begin{tabular}{lcccc}
\hline Variação de produção & Média & Erro-padrão & Mínimo & Máximo \\
\hline Valor da produção & $11.225,30$ & 1382,1 & 15,1 & $15.335,00$ \\
Educação (por ano) & 4,72 & 3,52 & 0 & 16 \\
Experiência na agricultura (dummy) & 0,77 & 0,42 & 0 & 1 \\
Assistência Técnica (dummy) & 0,22 & 0,41 & 0 & 1 \\
Crédito & $11.065,38$ & 905,1 & 0 & 100 \\
\hline
\end{tabular}

Fonte: Total de 390 estabelecimentos agrícolas no ano de 2009-2010

Variável dummy (1=sim; 0=não)

Na Tabela 2, encontram-se os resultados para a análise dos fatores que afetam a produção dos agricultores assentados, nesse modelo foi examinada uma amostra com 395 assentados. No teste de distribuição F observa-se um modelo que tem resultados consistentes com o valor de F em 6,39 e valor P aproximadamente zero.

O coeficiente de determinação (R2) indica que 61\% da variação na produção pode ser explicada pelas variáveis explicativas do modelo. Já (R2) ajustado, que é o coeficiente de determinação penalizado pelo acréscimo de variáveis, ratifica que $51 \%$ de variação na variável dependente pode ser explicado pelas variáveis explicativas.

Na Tabela 2, o resultado produzido a partir da estimação do parâmetro de educação formal do gestor agrícola indica que para um ano a mais de escolaridade formal aumenta em média 3,15\% em sua produção, mantendo todas as demais variáveis explicativas constantes.

Na variável experiência notamos que aqueles gestores que já tinham experiência agrícola antes de ser assentados tiveram uma produção 33\% maior que aqueles que não tinham experiência prévia.

Outra variável de capital humano que é a assistência técnica afeta favoravelmente contribuindo para o aumento da produção dos agricultores em $24,8 \%$.

Por fim, o fator positivo da variável crédito rural atesta que os recursos financeiros adquiridos pelos gestores, são de grande valia para o aumento da produção dos assentados, isto é, para $\mathrm{R} \$ 1.000,00$ em crédito rural nos últimos 12 meses da pesquisa, nota-se um aumento, em média, de 1,07\% na produção ao mês. 
Tabela 2. Estimação de MQO para análise de produção dos assentamentos do MS.

\begin{tabular}{lcccc}
\hline Produção(logarítmica) & Coef. & Std. Err & $\mathbf{t}$ & P>/t / \\
\hline Educação( por ano) & 0,0315 & 0,0125 & 2,5100 & 0,0130 \\
Experiência(dummy) & 0,3332 & 0,1078 & 3,0900 & 0,0020 \\
Assistência Técnica(dummy) & 0,248 & 0,1062 & 2,3300 & 0,0200 \\
Crédito(em R\$1.000,00) & 0,0107 & 0,0049 & 2,1800 & 0,0300 \\
Constante & 6,0647 & 0,1306 & 46,4400 & 0,0000 \\
\hline
\end{tabular}

\begin{tabular}{l} 
Número de observações $=\mathbf{3 9 4}$ \\
\hline $\mathrm{F}(4,390)=6,3900$ \\
Prob $>\mathrm{F}=0,0001$ \\
$\mathrm{R} 2=0,6150$ \\
$\mathrm{R} 2$ ajustado $=0,5180$ \\
\hline
\end{tabular}

Fonte: Total de 390 estabelecimentos agrícolas no ano de 2009-2010

\section{CONCLUSÃO}

O crédito rural tem como objetivos o financiamento de insumos de produção, investimentos em capital humano para melhor gerenciamento das atividades no campo, entre outros.

E como foi analisado nesse presente trabalho tem importância fundamental no aumento da produção desses que participam com grande ênfase na alimentação de boa parte da população.

Notamos nesse modelo, que todas as variáveis estão bem ajustadas, vimos também que todas se mostraram de grande importância para o crescimento da produção dos assentados. Tendo como ênfase, analisar a importância do crédito rural para o aumento da produção do assentado, foi analisada também a importância da educação para o esse crescimento da produção, em lotes onde o gestor possui acima do nível primário, toda a política de crédito rural, assistência técnica, cooperativismo entre outras, são bem aderentes e bem aproveitáveis, nota-se também que o crédito rural se ajusta melhor aos produtores que já adquiriam experiência agrícola prévia. A assistência técnica é de suma importância para o produtor rural, pois o atualiza quanto relação às novas tecnologias, o que eleva sua produção, e como consequência, seus rendimentos. 
O crédito rural é uma ferramenta que possibilita os produtores rurais um maior desenvolvimento econômico, facilita o acesso às novas técnicas, melhorando sua capacidade de produção e como consequência aumentando sua renda. O aumento da renda traz ao produtor rural uma maior qualidade de vida, mantendo-o assim imbuído e dedicado aos trabalhos do campo, diminuindo a evasão desses, para as metrópoles, garantindo o aumento da produção e a competitividade dos preços, aumentando a circulação de alimentos, o que gera tributos para o Estado, elevando os investimentos e aumentando a quantidade de pessoas empregadas.

Assim, fica esplanada a notável importância do crédito rural para o aumento da produ-ção dos assentados, fazendo com que esse instrumento seja de suma importância para a economia, trazendo aos produtores rurais ferramentas para o aumento da produção, e consequentemente da rentabilidade, gerando assim um avanço social e cultural.

\section{REFERÊNCIAS}

ABRAMOVAY, R. Um novo contrato para política de assentamentos. In: OLIVA, P.M (Org.). Economia brasileira: perspectivas do desenvolvimento. São Paulo: Centro Acadêmico Visconde de Cairu, Universidade de São Paulo, 2005.

ALENTEJANO, P. R. R. O que há de novo no rural brasileiro? Terra Livre, São Paulo, n.15, p.87- 112, 2000.

ALMEIDA, P.W.A. Fronteira de produção e eficiência técnica da agropecuária brasileira em. 2011(Tese de Doutorado).

ALVES, E; ROCHA, D.de P.Ganhar tempo é possível? In: GASQUES, J.G; VIERIA FILHO,

ALVES, E; SILVEIRA, J.M.da; NAVARRO, Z. O mundo rural no Brasil no Século 21: a formação de um novo padrão agrário e agrícola. Brasília, DF: Embrapa, 2014. Pag.242-264

ALVES, Janice; FIGUEIREDO, Adriano Marcos Rodrigues; ZAVALA, Arturo Alejandro Zavala. Análise de Eficiência em Assentamentos Rurais no Estado de Mato Grosso. Revista de Estudos Sociais, [S.I.], v. 11, n. 21, p. 75-97, jun. 2011.

ARAUJO. C; BONJEAN. C.A. Mesure de 1 eficacité comomique des modes de faire voloir au Brésil.Jornal canadense de economia agrícola,v.47, n2,P.181-197,1999.

BALESTRO, M.V; LOURENÇO, C.B. Notas para uma análise da finaceirização do agronegócio: além da volatilidade dos preços das commodities. IN: BUAIANAIN, A.M;

BARROS, J. R. M. Política e desenvolvimento agrícola no Brasil. In: VEIGA, A. Ensaios sobre Política Agrícola. São Paulo: Secretaria da Agricultura, 1979 a. 
BRASIL. Presidência da República. Plano trienal de desenvolvimento econômico e social: 1963-1965: síntese [Brasília, DF], dez.1962.195p.

CAPORAL, F. R.; COSTABEBER, J. A. Agroecologia e desenvolvimento Rural Sustentável: Perspectivas para uma Nova Extensão Rural. Agroecologia e Desenvolvimento Rural Sustentável, Porto Alegre, v.1, n1, jan./mar.2000. Disponível em: < http://www.agroecologia.uema.br/publicacoes/ CaporaleCostabeberUm.pdf> Acesso em 20/10/2006.

CAPORAL, F. R.; RAMOS, L. de F. Da Extensão Rural Convencional À Extensão Rural Para o Desenvolvimento Sustentável: Enfrentar Desafios Para Romper a Inércia. Brasília, Set/2006. Texto em Fase de Publicação. Disponível em: Acesso em 01/11/2006 - 17:24.

CARVALHO, Ana Cristina Marques de, SOUZA, Leonardo Pellegrino de. Ativos intangíveis ou capital intelectual: discussões da contradição na literatura e proposta para sua avaliação. Em: Prescpect. Cienc. Inf., Belo Horizonte, v.4, n.1, p.73-83,jan./jun. 1999.

DELFIM NETTO, A. Problemas econômicos da agricultura brasileira. São Paulo: Universi-dade de São Paulo, Faculdade de Ciências Econômicas e Administrativas, 1963. (Boletim, 46).

Empresa Brasileira de Pesquisa Agronegócio Departamento de Pesquisa e Desenvolvimento Ministério da Agricultura, Pecuária e Abastecimento: Assentamentos rurais no Brasil uma releitura, texto para discussão 45 Embrapa, DF 2016. Pag. 28.

Evolução do crédito rural no Brasil e o papal das cooperativas agropecuárias no financiamen-to dos produtores rurais. , Rio Branco-Acre, 2008. Anais. Brasília: SOBER, 2008.

FIQUEIREDO, R.P. Fundamentos de extensão rural no Brasil: assistência técnica e transferência de tecnologia. Brasília: ABCAR. 1974. (documento mimeografado)

FONSECA, M.T.L. A extensão rural no Brasil, um projeto educativo para o capital.São Paulo: Edições Loyola.1985.

GASQUEZ, J. G. CONCEIÇÃO, J. C. P. R. Fatores que afetam a oferta de recursos do crédito rural. Revista Preços Agrícolas, v. 14, n. 161, 2000.

GUJARATI, D.Use of Dummy Variables in Testing for Equality between Sets of Coefficients in Two Linear Regressions note. The American Statistics Vol.24, n.1, pp.50, 1970 a.

GUJARATI,D.Econometria básica.São Paulo-SP: Ed. Campos,2004.819p.

MARINHO, E.L.L. CARVALHO, R.M. Comparações inter-regionais da produtividade da agricultura brasileira. 1970-1995. Pesquisa e planejamento econômico. V34, n.1,2004.

MARSHALL, A. Princípios de Economia. Madrid: Aguilar, 1957.

MARTINS, J de S. O sujeito oculto: ordem e transgressão na refirma agrária. Porto Alegre: Ed. Da UFRGS, 2003. 238P.

MARX, K. O Capital - Livro I: Capítulo VI (Inédito). São Paulo: Livraria Editora Ciências Humanas Ltda., 1978. 
MELLO, P.F. GOMES, M.C. Reforma agrária na Bahia: o difícil caminho do desenvolvimen-to. In: SEMINÁRIO INTERNACIONAL DINAMICA TERRITORIAL E DESENVOL-VIMENTO SÓCIOAMBIENTAL, 2011, Salvador.

MELO F. B. H. Agricultura brasileira nos anos 90: o real e o futuro. Revista de Economia Aplicada, v.2, n.1, 1998.

MEYER, R. L.; ADAMS, D.; RASK, N.; ARAÚJO, P. F. C. Mercados de crédito no Brasil e os pequenos agricultores no Brasil. In: ARAÚJO, P. F. C.; SCHUH, E. Desenvolvimento da agricultura: análise de política econômica. São Paulo: Pioneira, 1977.

MINCER, Jacob B. Schooling, Experience and Earnings. Columbia University Press, New York, 152 p.1974.

NAVARRO, Z. Meio século de transformação do mundo rural brasileiro e a ação governa-mental. Revista de Política Agrícola, ano 19, n.esp. pag. 106-1015, jul.2010.

NAVARRO, Z.Expropriating land in Brasil.In: BINSWANGER-MKHIZE, H.P; BOURGUINON, C.; BRINK, E.van den, (org.).Agricultural land redistribution: toward greater consensus. Washington, DC: World Bank, 2009.p.267-289.

GASQUES, J.G; VIEIRA FILHO, J.E. R; NAVARRO. Produtividade total dos fatores e transformação da agricultura brasileira: análise dos dados dos censos agropecuários. Z(Org.). A agricultura brasileira: desempenho, desafios e perspectivas. Brasília, DF: IPEA, 2010.

REIS C.V. S, Fatores determinantes para eficiência da agricultura familiar. Pró- reitoria de PósGraduação e Pesquisa Programa de Pós-Graduação Stricto Sensu em Economia Tese de Doutorado 2014.

SAYAD, J. Crédito rural no Brasil. Brasília: Ministério da Agricultura, 1978. . Crédito rural e taxas de juros reais positivas. In: Encontro Nacional de Economia, Olinda, 1981. Anais. Brasília: ANPEC, 1981.

SCHOUCHANA, F.; PEROBELLI, F.S. O financiamento da agricultura e o mercado futuro. Resenha BM\&F, n. 142, 2001.

SCHULTZ, T.W. A transformação da agricultura tradicional. Trade J.C Teixeira Rocha. Rio de Janeiro Zahar Editores, 1965.

SOUZA, G.S.; GOMES, E.G.; GAZZOLA, R.. Eficiência técnica na agricultura brasileira: uma abordagem via fronteira estocástica. In: SIMPÓSITO DE PESQUISA OPERACIO-NAL E LOGISTICA DA MARINHA, 13, 2010, Rio de Janeiro, Anais... Rio de Janeiro: 2010.

SPOLADOR, H. F. S. Reflexões sobre a experiência brasileira de financiamento da agricultura. (Dissertação de Mestrado), Piracicaba: ESALQ/USP, 2001 a.

WERNKE, Rodney, LEMBECK, Marluce, BORNIA, Antonio C. As considerações e comentários acerca do capital intelectual. Em:Revista FAE, Curitiba, v.6,n.1, p-15-26, jan./abr. 


\section{APÊNDICE - QUESTIONÁRIO PARA OS ASSENTAMENTOS DOS MUNICÍPIO DO MATO GROSSO DO SUL.}

Data:

Nome do assentamento:

Local da propriedade: ( )

Município

(1) Nova Alvorada

(2) Bela Vista

(3) Santa Rita do Pardo

(4) Juti

(5) Itaquiraí

(6) Betagassú

(7) Três Lagoas

(8) Paranaiba

(9) Campo Grande

(10) Sindolândia

(11) Sonora

(12) Jaraguari

(13) Ponta Porã

(14) Ladário

(15) Rio Brilhante

(16) São Gabriel do Oeste

(17) Nioaque

(18) Tacuru

\section{Sustentabilidade econômica}

1. Qual é a área de sua propriedade?

2. Quantos lotes o possui?

3. Desde que ano trabalhando em sua propriedade? 
4. O que fazia antes de vir nesse assentamento?

( ) Era agricultor em terra própria.

( ) Era agricultor autônomo, mas na terra de outro.

( ) Era empregado agrícola.

( ) Trabalhava numa empresa de alimentos.

( ) Trabalhava numa área sem relação com agricultura.

( ) Não trabalhava.

5. Produção anual e destino da produção vegetal:

Cultura:

Área cultivada:

$\%$ para venda:

$\%$ para consumo:

Venda para qual cidade:

Para quem? (atacado, varejo):

Ultimo preço (R\$ por ton):

Produção (própria ou comunitária):

6. Produção anual e destino da produção animal:

Espécie animal:

Área ocupada:

Numero de animais:

$\%$ animais para venda:

$\%$ animais para consumo:

Venda para qual cidade:

Para quem? (atacado, varejo):

Ultimo preço (R\$ por ton):

Produção (própria ou comunitária):

\section{Sustentabilidade social}

7. Perfil trabalhista da família:

Número de homens 
$<14$ anos: na propriedade. ; fora

$14-18$ : ; fora

$19-25$ : fora

$26-35$ : ; fora

$36-55$ : ; fora

Número de mulheres ; fora

$<14$ anos: na propriedade

$14-18$ : fora

$19-25$ : ; fora

$26-35$ : ; fora

$36-55$ : ; fora

8. Tem empregados contratados permanentes (fora da industrialização) $(\mathrm{S} / \mathrm{N})$.

Quantos:

Sálario mensal (R\$/mês):

9. Você contrata mão de obra temporária (fora da industrialização) $(\mathrm{S} / \mathrm{N})$

Quantos dias por ano (dia homem):

Diária $(\mathrm{R} \$ / \mathrm{dia})$ :

\section{Perfil educacional}

10. Quantos anos de estudo formal tem?

11. Qual a escolaridade do gestor do estabelecimento?

Sem escolaridade [ ] Incompleto: ano [ ]

Ensino Fundamental completo [ ] Incompleto: ano [ ]

Ensino Médio completo [ ] Incompleto: ano [ ]

Especialização Completo [ ] Incompleto: ano [ ]

Mestrado Completo [ ] Incompleto: ano [ ]

Doutorado completo [ ] Incompleto: ano [ ]

\section{Sustentabilidade política}

12. Existe uma associação no assentamento $(\mathrm{S} / \mathrm{N})$ : 
13. Você participa dessa associação $(\mathrm{S} / \mathrm{N})$ :

14. Você participa da diretoria dessa associação $(\mathrm{S} / \mathrm{N})$

15. Você participa das reuniões da associação:

( ) $100 \%$ das vezes

( ) $75 \%$ das vezes

( ) $50 \%$ das vezes

( ) $25 \%$ das vezes

( ) Nunca

16. O que você acha das atividades da associação?

( ) Muito ruins

( ) Ruim

( ) Razoável

( ) Boa

( ) Muito boa

17. Existe uma cooperativa no assentamento $(\mathrm{S} / \mathrm{N})$ :

18. Você participa dessa cooperativa $(\mathrm{S} / \mathrm{N})$ :

19. Você participa da diretoria da cooperativa $(\mathrm{S} / \mathrm{N})$ :

20. Você participa das reuniões da cooperativa:

( ) $100 \%$ das vezes

( ) $75 \%$ das vezes

( ) $50 \%$ das vezes

( ) $25 \%$ das vezes

( ) Nunca

21. O que você acha das atividades da cooperativa?

( ) Muito ruins

( ) Ruim 

( ) Razoável
( ) Boa
( ) Muito boa

\section{Informação de renda}

22. Quando você se instalou, recebeu algum tipo de financiamento fora da construção da casa $(\mathrm{S} / \mathrm{N})$ :

Qual?

Valor recebido $(\mathrm{R} \$)$

23. Atualmente você está com algum tipo de financiamento $(\mathrm{S} / \mathrm{N})$ :

Qual?

Valor recebido $(\mathrm{R} \$)$

24. Você recebe algum tipo de visita técnica:
( ) Nunca raramente
( ) As vezes
( ) Com frequência
( ) Sempre

25. De quem?

( ) AGRAER

( ) Prefeitura

( ) Outro

Especificar?: 


\section{Capítulo 29}

\section{TRAJETÓRIA E DINÂMICA COMPARADA DA AGROECOLOGIA NO BRASIL E NA FRANÇA ${ }^{1}$}

DOI: $10.37423 / 200300511$

\section{Lucimar Santiago de Abreu}

Claire Lamine

Stéphane Bellon

Alfio Branderburg

Maria Chéophas de F. de Alencar

Jean-Paul Billaud

RESUMO: Na década de 70 na França e no Brasil emergem novos estilos de produção ecológicos, em oposição ao modelo de agricultura convencional, apoiados por ONGs e por profissionais especialmente das ciências agrárias. No Brasil evolui progressivamente sob a influência do guia conceitual da agroecologia, contudo essa evolução é mais tardia na França. O objetivo deste trabalho é o de descrever as características, os elementos históricos e determinantes da dinâmica de desenvolvimento da agroecologia no Brasil, e na França. Visa também desvendar suas diferentes concepções e analisar as controvérsias atuais. Mostramos o lugar central que a agroecologia ocupa nas controvérsias, onde a questão alimentar, a relação ao meio ambiente, à biodiversidade (funcionalidades agroecosistemicas) e o modelo social são cruciais e, provoca a redefinição do sistema de ecologização da agricultura. 
Complementamos com análise das trajetórias e interações entre cientistas, movimento social e a construção de políticas públicas. Essas trajetórias geram interpretações concorrentes da agroecologia que podem ser classificadas e diferenciadas em três aspectos principais: concepções sobre processos de transição da agricultura; público alvo e, por último, a visão sobre a inserção da produção no mercado. Concluímos que as diferenças de entendimento da agroecologia estão diretamente relacionadas a distintas formações teóricas e trajetórias sócioprofissionais específicas, ao papel desempenhado pelas redes profissionais na construção de políticas públicas.

Palavras-chaves: Sistemas agroalimentares, agricultura familiar; trajetórias. 


\section{INTRODUÇÃO}

A agroecologia, em alguma de suas mais disseminadas interpretações, apresenta um quadro conceitual para o desenho de uma agricultura que concilia metas de produção com objetivos ecológicos e sociais (justiça social, geração de emprego e qualidade de vida das populações, segurança alimentar, relações harmônicas entre produtores e consumidores etc.). O desenvolvimento da Agroecologia diz respeito a diferentes atores sociais: produtores, cientistas, técnicos do governo, pesquisadores, consumidores e setores interessados da sociedade, governos locais, estaduais e federais etc. Neste sentido, o tema da agroecologia enquanto projeto social para uma agricultura contemporânea e respeitosa do meio ambiente tende a contribuir para uma rediscussão das questões agrárias, uma vez que propicia o ambiente favorável para a construção de soluções inovadoras para problemas cruciais ligados ao emprego e às migrações (internas e externas), a busca de soberania alimentar, a preservação dos distintos biomas pela ativação dos agroecosistemas.

No caso do Brasil, Brandenburg (2002), identificou três importantes fases: i) a emergência de um movimento contra a industrialização da produção agrícola; ii) o surgimento de novos grupos e de formas de organização social; iii) a institucionalização da agricultura ecológica, acompanhada por uma diluição parcial de seus princípios. Contudo, atualmente, pode-se argumentar que há um quarto momento, caracterizado pela redefinição e recomposição de diferentes versões da agricultura alternativa, no qual a agroecologia ocupa um lugar importante e influencia o desenvolvimento rural (Ollivier \& Bellon, 2013). Na França, a agricultura biológica (AB) é a principal representante histórica, institucionalizada desde a década de 80. Trata-se de um movimento social e, simultaneamente, de um setor profissional e econômico estruturado. Surge, mais recentemente, notadamente a partir de 2010, uma nova vertente no movimento social de ecologização da agricultura francesa, associada às redes de economia solidária, visando uma diferenciação em relação à agricultura orgânica (Lamine \& Abreu, 2009).

O objetivo deste trabalho é descrever as características, os elementos históricos e determinantes da dinâmica de desenvolvimento da Agroecologia no Brasil e na França. Visa também desvendar suas diferentes concepções e analisar as controvérsias atuais na questão alimentar, na relação com o meio ambiente (funcionalidades agroecosistêmicas) e em relação ao modelo social no processo de ecologização da agricultura. Busca-se aqui qualificar a importância e o significado da Agroecologia no 
Brasil e na França, a partir da interpretação do seu processo de estruturação e de suas manifestações científicas, técnicas e políticas.

Para tanto, será apresentado, na primeira seção, o contexto específico dos dois países, notadamente sobre o lugar das agriculturas de base ecológica e sobre as formas de institucionalização assim como sua relação com a agricultura familiar ou camponesa. Em seguida, será abordada a trajetória da Agroecologia nos dois países: a partir da agricultura alternativa no Brasil, na década de 70, identificando seus sucessivos momentos e características; e a trajetória de desenvolvimento diferente da agricultura ecológica/orgânica francesa. A terceira seção analisa as diferentes concepções de Agroecologia nos dois países e alguns dos embates científicos e políticos recentes que evidenciam que a questão alimentar e o modelo social estão no centro das controvérsias propostas pela Agroecologia.

\section{METODOLOGIA}

A abordagem analítica desta pesquisa é das ciências sociais, mas precisamente da sociologia compreensiva inspirada em Max Weber, clássico da sociologia, mas se abre às colaborações mais amplas, em especial das ciências agronômicas, tendo em conta a formação disciplinar da equipe do projeto, bem como as dimensões interdisciplinares da Agroecologia. Para a realização da pesquisa, foi realizada consulta à bibliografia específica e documentos provenientes de fontes governamentais, movimentos sociais e organizações não-governamentais, bem como realizadas entrevistas com atores chaves nos dois países um conjunto de 30 entrevistas com pesquisadores, agentes de desenvolvimento, representantes de organizações sociais não governamentais, incluindo lideranças sociais e científicas, durante o ano de 2012, 2013, 2014 e 2015, em ambos os países.

\section{RESULTADOS E DISCUSSÃO}

\section{CONTEXTO HISTÓRICO E INSTITUCIONAL}

Na América Latina, a produção de alimentos baseados em princípios ecológicos tem crescido nos últimos 20 anos. No caso brasileiro, a origem deste modo de produção pode ser interpretada como parte da herança de modelos europeus (Brandenburg, 2002), adaptados ao contexto brasileiro, ao mesmo tempo em que convive com outras formas originais estabelecidas sob condições específicas do contexto local (Bellon, \& Abreu, 2006). 
Vale destacar que emergem distintos estilos de agricultura, onde constata se vários referenciais de conhecimento: biodinâmico, natural, orgânico, permacultura, sistemas agroflorestais, inspirados em princípios da agroecologia, etc. Essa diversidade de formas de produção foi reconhecida pela legislação brasileira que regulamenta a produção de alimentos denominada de sistemas orgânicos de produção, um aparato legal construído a partir de intensas consultas das partes interessadas. A lei da produção orgânica reconhece também a diversidade de sistemas de certificações, a saber: terceira parte/por empresas privadas, sistemas de garantia da qualidade participativa (SPGs) e, vendas diretas com controle social.

Na França, os primeiros movimentos da agricultura de base ecológica surgem no final de 1950, envolvendo principalmente produtores e agrônomos. Em 1964, a associação francesa de agricultura orgânica ( $A F A B$ ) é fundada. Em seguida, um desmembramento ocorreu entre os partidários do método Lemaire-Boucher e Nature \& Progrès. O método recomendado LemaireBoucher é inspirado pela associação de solo inglesa. A sua originalidade é a utilização de "lithotamne" (alga calcária) como fertilizante. Em resposta à crescente industrialização da agricultura, os cidadãos envolvidos (consumidores e ambientalistas urbanos), criam à associação Nature \& Progrès para o desenvolvimento da agrobiologia e, de alimentos com qualidade.

Em 1972, a associação desenvolveu as primeiras especificações das normas da agricultura orgânica francesa, prelúdio para o desenvolvimento de novas práticas agrícolas, bem como sua menção (Nature \& Progrès). Uma revisão divulga informações técnicas e debates sociais (http://www.natureetprogres.org/50ans-nature-progres/). Em 1980 a agricultura biológica ou orgânica $(A B)$ é reconhecida oficialmente na França. Os produtos passam a usar o selo $A B$ e a certificação torna se obrigatória. O primeiro regulamento europeu que concerne a AB data de 1991 (Reg. CE 2092/91), e enquadra as práticas produtivas, a etiquetagem dos produtos orgânicos, e a duração do processo de conversão (geralmente em três anos, ao curso do qual a orientação relativa ao modo de produção orgânica tem que ser aplicada).

Para se obter um selo da $A B$, as unidades de produção devem ser certificadas por um organismo certificador recomendado pelo Estado (mais conhecido atualmente é a Ecocert, também presente no Brasil). Esse novo dispositivo regulamentar não implica mais a participação de consumidores, como era na regulamentação que precedia a européia. Esse último, foi revisto em 2008 (Reg. CE 889/2008), foi avaliado em 2013, para dar lugar a um novo regulamento ( $C E, 2014)$. A inserção crescente da $A B$ 
no mercado desenhou, assim como em inúmeros outros países, uma oposição entre uma $A B$ qualificada de "convencionalizada", pois seguiu a mesma tendência: concentração e aumento da especialização; recurso crescente aos insumos externos, tal qual a agricultura convencional.

Coexistindo com outro "tipo" de agricultura orgânica, muitas vezes denominada "resistente" constituída por pequenas unidades de produção em geral diversificadas. Esta oposição que esquematizamos é notadamente visível nos debates que permeiam os meios orgânicos, em especial nos momentos de discussão e revisões das normas e regulamentos europeus (1999 na elaboração das normas francesas, a partir do regulamento de 1994 e, entre 2006 e 2008, na revisão deste regulamento). Isto foi também desenvolvido através de numerosas interações e relações diretas entre produtores e consumidores, como foi no caso da AMAP (Associação para manter a agricultura camponesa) e, contribuiu para a emergência de numerosas experiências de certificação participativa (Mundler \& Bellon, 2011; Lamine et al., 2012).

No Brasil, os primeiros organismos certificadores foram a Cooperativa Ecológica Colméia (RS), fundada em 1978, nos anos posteriores são organizados os Encontros da Agricultura Alternativa em 1981, 1984, 1988. Durante esse período é a sociedade civil (Técnicos, ONGs, Organizações de Agrícolas) que assumem o processo de garantir a qualidade dos produtos a partir das referências estabelecidas na Europa. Apesar de algumas iniciativas governamentais foi necessário esperar até 1999, para que aparecesse a instrução normativa 07/99, texto pioneiro do setor. Resultado de um amplo debate entre interessados da sociedade e de um processo participativo, o texto estabelece as regras de produção e transformação, condicionamento, de transporte dos produtos orgânicos. É criada a comissão nacional da produção orgânica (CNPOrg) e as Comissões Estaduais da Produção Orgânica composto por membros do governo e da sociedade civil. Mas foi a Instrução Normativa de 2002 (IN 006/02) sobre os critérios de acreditação dos organismos de certificação dos produtos orgânicos que abre o debate inicial da lei federal, fortemente apoiado por instituições do estado de São Paulo, o texto dá lugar a inúmeras discussões e inclui o sistema de avaliação da conformidade pelo processo participativo (SPGs).

Esse processo é legitimado pela participação de diversos atores (produtores, pesquisadores, extensionistas, estudantes, coletivos de consumidores). A legislação brasileira é tardia, somente em 2003 (lei 10.831/2003), é lançado o decreto lei, regulamentada em 2009, sendo aprovada em final de 2010. Foi inspirada nos princípios da Agroecologia e destaca além dos aspectos técnicos da produção 
de base ecológica, a integridade cultural das comunidades rurais, equidade social, o valor econômico da agricultura familiar e, o respeito aos recursos naturais (Abreu, et al. 2009). A originalidade do dispositivo legal é que os produtores passaram a dispor de três opções de mecanismos de controle, após a regulamentação em 2009: Organismos Certificadores (OCs), Organismos Participativos de Avaliação da Conformidade (Opac) ou Organismo de Controle Social (OCS). A avaliação através de OPACs permite ao produtor a comercialização em todo o território nacional, assim como através de certificadoras de terceira parte. As OCSs são regulamentadas exclusivamente para vendas diretas.

A proposta da agroecologia tem estimulado interações múltiplas entre sistemas agroalimentares de alta diversidade de produtos, práticas e experiências. No Brasil a área total com certificação orgânica representa 1,5 milhões de hectares, segundo o Ministério da Agricultura, Pecuária e Abastecimento (MAPA). Um aumento no mercado estimado em 35\% anual. O trabalho é predominantemente baseado na gestão familiar (Willer \& Yussefl, 2008). Na França, a AB (agricultura orgânica) ocupa atualmente 3,9\% da área total útil da agricultura, representa 5,4\% das propriedades e mais de $7 \%$ do emprego agrícola (Agence Bio, 2014). A partir de 1990, a AB conheceu um processo de institucionalização devido à estruturação progressiva das instâncias profissionais e associativas (Pirou, 2002) e do padrão público nacional e europeu, e das políticas públicas para o desenvolvimento do setor. Esta "normatização" da AB é geralmente um meio de assegurar sua presença em outros mercados, evitando o confinamento em pequenas redes, aumentando a difusão da produção no sistema alimentar do país.

De fato, a tomada em conta da $A B$ através das políticas públicas, supõe igualmente o reconhecimento público dos seus benefícios. Isto é explicitado nos preâmbulos do regulamento europeu 834/2007 e, também as condições sobre as quais esses benefícios são produzidos e estabelecidos. O desempenho ambiental está inscrito na definição mesma da $A B$ que alia às melhores práticas ambientais, alto nível de biodiversidade, a preservação dos recursos naturais (regulamento (CE 834/2007). As políticas públicas uma simplificação da $A B$, que é concebida não mais como um dispositivo de formalização de princípios para uma base operacional estabelecida, mas como "bens públicos", abrindo expectativas de se reduzir aos serviços ambientais sem considerar, os efeitos sociais, esses são mais difíceis de serem formalizados (entretanto, alguns projetos territoriais tomam mais em conta essas dimensões sociais). 
Assim na Europa, as ajudas à conversão ou a manutenção da $A B$, entram no quadro das medidas agroambientais (a partir do Regulamento EU 2078/199, até o atual Regulamento de Desenvolvimento Rural). Os planos franceses sucessivos de desenvolvimento da $A B$, objetivaram a promoção e o avanço da $A B$, dando suporte às organizações de produtores e às cadeias de produção, desenvolvimento, formação e pesquisa. O plano atual "Ambição Bio 2012" integra o projeto agroecológico e a ideia "Produzir de outra forma. (2012)".

No Brasil o reconhecimento político da importância social e econômica da agricultura familiar (AF) é tardio. Somente em 1996, foi criado o Programa Nacional de Fortalecimento da Agricultura Familiar (PRONAF). Antiga reivindicação das organizações dos trabalhadores rurais - demandavam políticas específicas para o setor e legitimação por parte do Estado, portanto, foi nas duas últimas décadas, que o processo de democratização política promoveu o aumento da participação desses atores sociais na definição e gestão das políticas públicas. O Estado se ajusta a nova realidade com o objetivo de racionalizar as ações e ampliar os resultados das políticas sociais, mediante políticas públicas de Combate à pobreza e de promoção do desenvolvimento rural, assim as políticas de interface com o mundo rural, ganham espaço, em especial entre 2003-2010. Neste período foi criado também o Ministério do Desenvolvimento.

Além desses programas indicados deve se salientar algumas medidas do governo. Em 2006, foi criado o seguro agrícola para a Agricultura Familiar (SEAF) que visa diminuir riscos com intempéries que afetam a produção agrícola. O Programa Garantia Safra, visa proteger a renda daqueles que perderam mais de $50 \%$ da sua produção na área do Semiárido. O PAA (Plano de Aquisição de Alimentos) consiste em uma Política Pública que articula atores de vários ministérios visando garantir a compra da produção de agricultores familiares, bem como formar estoques para dar sustentação à política de segurança alimentar e nutricional, assim como suprir demandas de outros programas públicos, populações carentes em condições de pobreza. O PAA foi concebido no bojo de um grupo de políticas estruturantes do Programa Fome Zero, visando programar ações no âmbito das políticas agrícolas e de segurança alimentar, fortalecer a política global de combate à fome. Incentivando a AF, através de ações de distribuição de alimentos aos grupos sociais em situação de insegurança familiar. Além de facilitar o processo de comercialização no âmbito local e promover formação de estoques estratégicos. Os agricultores ecológicos recebem um prêmio de $5 \%$ + no preço definido. 
Também o PNAE (Programa Nacional da Alimentação Escolar), se traduz numa inovação social brasileira que existe oficialmente desde 1950, mas a lei específica número 11.947 de 16\06\2009, toma a questão da alimentação como direito fundamental igualando à ao direito à educação pública. O fundo nacional de desenvolvimento escolar repassa para a compra direta dos produtos da AF, o montante de $30 \%$ do total do fundo, preferencialmente no local da produção e paga se um prêmio de $5 \%$ até $30 \%$ se for da agricultura ecológica. Existem prefeituras em que $100 \%$ dos produtos da agricultura local ou regional, é o caso das cidades de Ipê e Antônio Prado, SC. Trata se da criação do mercado institucional (Mattei, L, 2014). Assim a produção familiar tem uma forte importância social e econômica no Brasil, sendo que $80 \%$ da produção certificada de base ecológica são oriundas da produção familiar, uma multiplicidade de contextos locais e grupos diferenciados de produtores familiares, caracterizados pela sua forte heterogeneidade tanto social e cultural como pela diversidade de estilos de produção de base ecológica. É inquestionável, a contribuição da agricultura familiar para a segurança alimentar e nutricional dos países. A importância de tal segmento social para a segurança alimentar vai além da produção primária, mas envolve também a forma de distribuir a renda e gerar empregos.

Na França, a agricultura familiar não representa uma categoria de análise como no Brasil, a agricultura é constituída por produtores em sua maioria familiares, que foram largamente incluídos no movimento da modernização agrícola, bem que sejam desenvolvidas em paralelo novas formas de agricultura de firmas (Hervieu et Purseigle, 2009). De fato, a política de modernização agrícola dos anos 1960 e 1980, tem precisamente objetivado modernizar o conjunto da profissão, favorecendo os gestores agrícolas, com expectativas de nível de vida, igual à de outras classes sociais. Isto excluiu produtores que não puderam acompanhar o movimento de modernização (relativos aos investimentos) com uma queda da população ativa da agricultura, de $29 \%$ do conjunto dos ativos em 1949 para 3\% em 2007 (Instituto Nacional de Estatística da França, INSEE). Além disto, é na França que a agricultura dita "paysanne" ou camponesa reivindicada notadamente por sindicatos agrícolas "confederação ligada à via campesina" e pelo conjunto de estruturas alternativas (exemplos: Civam e Amaps) que corresponderia provavelmente à noção brasileira mais próxima da agricultura familiar, que mostraremos mais adiante que compartilham inúmeros valores culturais. 


\section{TRAJETÓRIA DA AGROECOLOGIA NO BRASIL E NA FRANÇA}

Buscando retraçar a trajetória da agroecologia no Brasil e na França, nesta seção, salientamos a emergência do processo de reagrupamento progressivo das agriculturas alternativas direcionadas para o guarda-chuva da $A E$, no caso brasileiro. Entretanto, a trajetória francesa da $A E$ é muito diferente e resulta das interações distintas entre movimento social, mundo acadêmico e políticas públicas. No Brasil, a partir da década de 1970, com a emergência de críticas sobre a revolução verde emerge o movimento de defesa de uma diversidade de estilos de produção de base ecológica denominada agricultura alternativa. A agroecologia enquanto proposta e guia conceitual para o redesenho da agricultura surge em 1983, no Chile com a obra de Altieri e, passa ser conhecida aos poucos no meio acadêmico. Agroecologia surge gradualmente como movimento social associada a um conjunto de práticas agrícolas. O movimento agroecológico diz respeito tanto aos grupos de agricultores que buscam segurança, soberania e autonomia alimentar, como aos movimentos sociais que reivindicam políticas públicas comprometidas com a aplicação de seus princípios.

As organizações não governamentais (ONGs) associadas em especial, a igreja católica (Comunidades Eclesiais de Base), sindicatos, ambientalistas e profissionais do meio agronômico, foram responsáveis pelas iniciativas em agricultura alternativa ou ecológica, buscavam apoiar pequenos produtores que se encontravam em situações precárias e marginalizadas pela revolução verde. Mais tarde novos atores são constituídos por uma elite de produtores neorurais (Karan, 2001; Brandenburg, 2002).

No Brasil a agricultura ecológica foi inicialmente conhecida como agricultura alternativa. O conceito era vago, significando simplesmente um conjunto de técnicas que deveria ser utilizada de forma integrada e, em equilíbrio com o meio ambiente. Tratava-se de resgatar técnicas tradicionais de domínio da agricultura familiar e que fora marginalizada pela modernização conservadora. A agricultura alternativa foi animada pelo Projeto Tecnologia Alternativa - PTA, ligado à FASE. Entretanto, as experiências práticas eram poucas significativas, foram também inspiradas nos seguidores da agricultura biodinâmica, baseadas em ensinamentos de R. Steiner e, de Fukuoka e Omiti Okada.

No Brasil, o conceito de agricultura alternativa foi gradualmente sendo substituído por agricultura sustentável e, depois pelo conceito da Agroecologia. A ideia de um sistema de agricultura focada em técnicas alternativas, do movimento da agricultura alternativa aos poucos perde espaço e, ocorre uma ruptura cultural no movimento, saindo fortalecida a visão do grupo que defendia a estratégia de 
ampliar as experiências no território nacional para fortalecer o movimento, em especial junto aos agricultores familiares menos favorecidos pelas políticas agrícolas da modernização.

Na América Latina o movimento se fortalece com a abordagem de agroecosistemas, no final da década de 80 , com a contribuição de M. Altieri, em articulação com ONGs latino americanas. Em 1989, foi criado no Chile o Consórcio Latino Americano de Agroecologia e Desenvolvimento Sustentável (CLADES), ocasião que já tinha sido lançada em inglês, a obra denominada "Agroecologia: bases científicas da agricultura alternativa”, de M. Altieri, traduzida no Brasil, em 1989. Mas foi no início da década de 90, durante uma grande reunião organizada pela CLADES, que contou com representantes de mais de 12 ONGs, que a proposição científica da agroecologia foi apresentada por Miguel Altieri. (Almeida, et, al., 2001).

O movimento agroecológico constituído pelas ONGs e profissionais da agronomia (associações de engenheiros agrônomos), portanto, se divide pelo fato de que existiam intensas críticas ao modelo da revolução verde, mas pouca experiência prática de agricultura de base ecológica (Almeida, et, al.,2001). Neste contexto, a construção de projetos junto às comunidades de produtores familiares se tornou uma importante estratégia de ação do movimento e, foram criadas estruturas de organização em diversos países latinos, fato que resultou no aumento considerável de experiências, no Brasil.

Deve se salientar o papel decisivo de organizações não governamentais, em particular da AS-PTA, pelo seu protagonismo. Esta organização visava atingir os seguintes objetivos: 1) Controlar a expansão dos latifundiários e do êxodo rural e apoiar os agricultores familiares; 2) Estimular o processo de organização e conscientização dos agricultores familiares; 3) Promover a adoção de um novo modelo de desenvolvimento. Propunham-se para atingir esses objetivos as estratégias de ação: i) Local: construir novas alternativas para a produção rural. (ii) Global: revelar a situação dos produtores familiares latinos americanos, iii) Política: Influenciar a formulação de políticas públicas. Assim, na década de 90, o cenário é de evolução e redefinição de métodos e conceitos. Inicialmente, o termo da agroecologia foi introduzido no Chile, por Miguel Altieri, num quadro de articulação e colaboração entre equipes de projetos de ONGs alternativos (brasileiros, chilenos) (Abreu \& Bellon, 2013).

De acordo com entrevistas realizadas com o representante da Associação Brasileira de Agroecologia (ABA), membro da Articulação Nacional de Agroecologia (ANA) e, também com a visão de participantes do movimento social de defesa da agroecologia, a noção de transferência de tecnologias deveria ser substituída pela ideia de processos sociais de inovação agroecológica. Para esses atores 
sociais a tecnologia não é algo externo, mas notadamente o resultado de relações ecológicas e socioculturais. A adoção parcial da proposição da agroecologia passa a ser motivada por um conjunto de organizações políticas comprometidas com a construção de um projeto social, baseada em reivindicações por equidade e justiça social. São às condições de vida dos produtores familiares, associadas aos fatores ecológicos e técnicos que configuram a dinâmica da emergência da agroecologia, fazendo com que agricultores empenhados com a transição em certas situações de uso da terra enveredem por trajetórias diferenciadas.

Esses agricultores em certas localidades são apoiados por organizações, as quais estão envolvidas diretamente com os processos de desenvolvimento rural e com a institucionalização da agroecologia, no Brasil. Essa força social é um dos elementos fundamentais das evoluções intensas identificadas nos últimos anos. Tais organizações lutam pelo reconhecimento destas formas ecológicas de produção. Tais avanços são consubstanciados no quadro institucional, mais especificamente, no caso brasileiro, no âmbito da legislação dos sistemas orgânicos já referidos e, num conjunto de políticas que foram inspiradas no conceito e abordagem da agroecologia e agricultura orgânica, uma vez que reconhecem a importância da integridade cultural das comunidades rurais, da equidade social, da valorização econômica das produções familiares, além do respeito aos recursos naturais (Bellon, \& Abreu, 2005).

Como apresentaremos em seguida, numerosos pesquisadores brasileiros que se dedicam a agroecologia aprofundaram seus interesses sobre o tema, realizando estudos de pós-graduação em universidades estrangeiras, notadamente em Córdoba (ES). Com a eleição de Lula em 2002 e, posteriormente de Dilma, para a Presidente da República do Brasil, líderes deste grupo de pesquisadores em articulação com setores do Partido dos Trabalhadores (PT), passaram a ocupar cargos políticos no Ministério do Desenvolvimento Agrário, fato que Ihes permitiu influenciar diretamente em programas públicos, em especial, na área de extensão rural e, de pesquisa agropecuária (Abreu \& Bellon, 2013). As políticas de desenvolvimento rural abrem espaços para ONGs e, estabelecem interações.

Alguns dos membros das organizações participaram do movimento pioneiro da agricultura alternativa, no Brasil, por exemplo, a Associação Nacional de Agroecologia (ANA), criada em 2004. Também, foi possível, obter acordos entre as diversas partes interessadas, na ocasião da formulação do Programa Nacional de Pesquisa em Agroecologia da Embrapa, integrando pesquisa em sistemas de produção orgânica, de permacultura ou agroflorestais . Recentemente, ocorreu a construção participativa do 
PLANAPO (Plano Nacional de Agroecologia e Produção Orgânica), envolveu diferentes órgãos de governos e representantes da sociedade civil, lançado pela presidenta Dilma Rousseff, no dia 17/10/2013. E o principal instrumento de execução da Política Nacional de Agroecologia e Produção Orgânica (www.mda.gov.br, novembro de 2013). Esse plano nacional busca integrar e qualificar as políticas e programas de dez ministérios, fortalecendo parcerias, articulando programas e ações indutoras da transição dos sistemas orgânicos, como contribuição para o desenvolvimento sustentável

Concretamente observa se claramente avanços na produção de base ecológica no Brasil, mas requer uma investigação aprofundada sobre a efetividade dos projetos, planos e discursos institucionais e, verificar em que medida poderá impactar positivamente e, contribuir para a transição da agricultura. Na França, sobretudo, como vimos, à agricultura orgânica teve sua institucionalização finalizada na década de 2000. No entanto, houve um movimento agroecológico pioneiro, liderado por Pierre Rabhi, que possuí uma trajetória marcada por uma visão da Agroecologia fundamentada na ética, suas ideias são difundidas através de conferências, publicações e, atualmente tem se envolvido no campo político partidário (Bellon \& Ollivier, 2014). P. Rabhi teve inspiração baseada em pressupostos da biodinâmica, e se diferencia da agricultura biológica ( $A B)$. Ele se considera mais focado sobre a situação empírica, é a favor da agroecologia. Suas propostas são de aplicação local, na França e no exterior. No entanto, as questões técnicas são secundárias e, as pesquisas cientificas não são presentes na sua abordagem.

Também na França ocorreu recentemente a institucionalização da agroecologia, que tornou se uma palavra-chave. O processo de institucionalização da agroecologia na França, ainda é de fraca visibilidade, o tema passou a ocupar espaço mais recentemente, em algumas instituições públicas (INRA, CIRAD, AFD, dentre outras). De maneira esquemática, a partir de um levantamento realizado em 2011, em sítios da web de autores que recorrem ao termo de agroecologia. Foi identificado dois polos (Belo \&Olivier, 2012). No primeiro pólo, os sítios correspondem principalmente ao meio associativo e aos movimentos sociais, com uma forte centralidade em torno de P. Rahbi (sítios "Terra \& Humanismo" e do movimento social denominado "Os Colibris", da Associação "Nature et Progrès", e outros que se ocupam de trabalhos com sementes crioulas). Atualmente a menção a "Nature e Progrés" garantiu o funcionamento dos Sistemas Participativos de Garantia (SPG) favorece as trocas horizontais com agroecologia camponesa que tece mais fortemente as interações entre os cidadãos mais comprometidos que os selos franceses (AB) ou europeu. 
Esses sítios desenvolvem proposições críticas a respeito da modernização agrícola. Alguns deles funcionam como sítios "intermediários" (por exemplo, a Fundação Nicolas Hulot, Agrisud Internacional) com o outro pólo na medida em que compartilham links com outras instituições. $O$ segundo pólo abriga sítios de instituições de alto nível, com mandados internacionais (FAO, AFD e CIRAD). A Agência Francesa de Desenvolvimento (AFD) destaca-se pela quantidade importante de links. Esses sítios estão associados a sítios de institutos de pesquisa, de ensino agrícola e de atores econômicos (serviços agrícolas, bancos), inseridos historicamente no dispositivo de modernização agrícola. Encontram-se também sítios de associações que promovem a agricultura de conservação, dentre os quais o sítio da BASE (Bretanha Agricultura Solo Meio Ambiente) e da AEI (especialmente, a Associação Internacional para a Agricultura Ecologicamente Intensiva [AEI] criada em 2009).

A atualização desta imagem das redes confirmaria certamente essa polarização, revelando ao mesmo tempo novos atores ( "Rede de Agroecologistas Sem Fronteiras" de um dos lados e, MAAF e INRA do outro); ou situações intermediárias como o "Coletivo para o Desenvolvimento da Agroecologia". Anunciado em dezembro de 2012, o plano "Produzir de outra maneira" encarna a nova política agrícola francesa e tem como objetivo colocar a agroecologia no coração do sistema. $O$ anúncio deste plano, conferências e reuniões que se seguiu, durante esse ano, gerou forte polêmica: em janeiro de 2013, um grupo de porta-vozes representantes dos movimentos sociais, entregou ao ministro da Agricultura uma "carta aberta" onde o acusa de apoiar uma forma de agroecologia, distante dos ideais defendidos pelo grupo, em relação à agricultura, a alimentação e o desenvolvimento dos territórios.

Tal reação é uma resposta ao destaque dado pelo governo, às práticas da agricultura como o plantio direto, principalmente, pois essa tem uma forte necessidade de utilização de insumos químicos. Os signatários desta comunicação decidiram constituir um coletivo de atores sociais para defender uma "agroecologia camponesa". Outra dinâmica social relativa à agroecologia é o desenvolvimento de ações coletivas. Eles podem envolver grupos de compras (para competir ou negociar preços) ou para melhorar os meios e as condições de produção (CUMA), ou para obter acesso a mercados (circuitoscurtos), complementaridades entre fazendas (Associação Policultura- Pecuária), ou para incorporar questões de serviços ambientais ou ecossistêmicos (água, biodiversidade).

O edital "mobilização coletiva para a agroecologia" lançado em 2013 pelo Ministério da Agricultura, da Alimentação e da Floresta (MAAF) estabeleceu como foco alvo projetos elaborados por coletivos de agricultores que desejavam desenvolver formas de agricultura que aplicam, dentro de uma 
abordagem sistêmica, os princípios da agroecologia. O edital buscava também preparar a implantação das GIEE (Grupamentos de Interesse Econômico e Ambiental), visando agriculturas duplamente eficientes. No entanto, as comunidades profissionais agroecológicas ainda são pouco organizadas na França. A diversidade de projetos aprovados (cem no total) no Edital demonstra a grande diversidade de visões de agroecologia, práticas e de procedimentos aplicados.

Por exemplo, a importância dos movimentos sociais e ONGs na construção de uma "marca agroecológica" foi tomada em conta tardiamente por instituições que obscurecem a questão de valores relacionados aos princípios e conceitos da agroecologia e as perspectivas para a transição, que possibilite o envolvimento de outros atores além dos agricultores; uma política Intersetorial, portanto, não só agrícolas. Diferenças também aparecem na estruturação da comunidade profissional, mais viva no Brasil, do que na França. Na França o conceito de desempenho econômico permanece dominante e, se expandiu em comunidades profissionais. No Brasil, as práticas alternativas, hoje ecológicas, expandiram-se primeiramente entre as agriculturas e na relação entre as práticas e as políticas públicas, predomina a visão da agroecologia política, com estratégias para legitimação da agroecologia.

No Brasil, recentemente movimentos rurais (Via Campesina, Movimentos Sem Terras (MST), Movimento Pequenos Produtor Agrícolas (MPA) etc.) adotaram a proposição da agroecologia, buscando incluir em suas agendas o tema, especialmente, a questão da soberania alimentar. Atualmente, parece não haver espaço acadêmico na área de ciências agrárias (professores e pesquisadores, extensionistas) no país que não encontre profissionais comprometidos com a agroecologia. Trata se de profissionais que buscam conhecimentos sobre alternativas e tecnologias inovadoras do ponto de vista ambiental e adequadas aos produtores familiares. Interessam-se também por mercados locais alternativos. Tal conhecimento na perspectiva da agroecologia depende de uma interação forte entre o conhecimento técnico-cientifico e as experiências locais das organizações de produtores de base ecológica.

Mas, geralmente, o movimento brasileiro em defesa da agroecologia tem como objetivo influenciar a construção de políticas que estimulem a soberania alimentar e o desenvolvimento rural sustentável. A ANA trabalha em articulação com um conjunto de instituições não-governamentais e é apoiada por movimentos sociais, visando promover o desenvolvimento da base científica da agroecologia. Os grandes temas abordados dizem respeito à soberania alimentar, a conservação de recursos naturais e 
a diversidade biológica na agricultura. Assim, a agroecologia visa tornar se uma referência e propor mudanças no modo de produção, visando conciliar desenvolvimento e interesses sociais, tais como segurança alimentar e o empoderamento das populações rurais. Existem laços de colaboração entre a ANA e diversas organizações não governamentais na América Latina (MAELA) e movimentos sociais organizados (Via Campesina, MPA-Brasil, ANAP-Cuba, ANPE-Peru, entre outros). Portanto, espera se que essas articulações possam fornecer elementos para as organizações de agricultores e permitam subsidiar e reorientar as políticas de produção e o desenvolvimento de mercados inovadores.

Em suma, o desenvolvimento da agroecologia no Brasil tem sido orientado por estratégias políticas de diferentes atores envolvidos e um interesse crescente da sociedade, em particular dos consumidores. Esse desenvolvimento tem combinado a construção de programas científicos interdisciplinares, práticas agrícolas e movimentos sociais para influenciar a construção de políticas públicas. Na França, as questões de soberania alimentar e do modelo social aparece cada vez mais associada à agroecologia (Lamine, 2014), como mostra um estudo sobre os discursos das redes ligadas à agricultura camponesa e na agroecologia "paysanne". Embora o conceito de soberania alimentar não esteja presente na Carta da Confederação Camponesa (1998), ele aparece com destaque na definição dada pela confederação da Agricultura Camponesa

No âmbito internacional, a Declaração de Nyeleni em 2007 foi um ponto de virada na trajetória do conceito de soberania alimentar, ali definida como o direito dos povos à alimentação saudável e culturalmente apropriada, produzida de forma ecológica e sustentável, destacando o direito da população definir seus próprios sistemas alimentares e agrícolas. A segurança alimentar refere-se ao equilíbrio entre a produção agrícola, mas destaca os desafios atuais como as questões de equidade no acesso e autonomia alimentar, as quais são também destacadas no Relatório Especial da ONU do Direito à Alimentação, Olivier de Schutter (2009)

A agroecologia também ganhou destaque nos discursos de diversas organizações nos últimos anos. A partir de 2011, a Confederação Camponesa passou a fazer referência à agroecologia e, desde 2013, alia-se a outros movimentos sociais numa versão "camponesa" da agroecologia. Para a Via Campesina, a agroecologia camponesa é definida como um sistema social e ecológico que abrange uma grande variedade de técnicas e práticas arraigadas culturalmente e geograficamente.

A agroecologia vem figurando em discursos recentes de algumas redes de produtor/consumidor, como AMAP (Associação de Manutenção da Agricultura Camponesa). Isto é o resultado de 
controvérsias que ocorrem em tais redes em torno das boas formas de agricultura (Lamine et al., 2012) e de uma tendência de maior diferenciação dentro dos movimentos relacionados com a agricultura biológica. A trajetória relativamente conjunta da noção de agroecologia na Confederação Camponesa e nas AMAP também pode ser explicada pelas ligações frequentes e locais entre as duas redes, bem como os vários eventos e alianças que os ligam a os outros movimentos sociais (por exemplo, na Plataforma francesa para a Soberania Alimentar, fundada em 2013).

\section{AS DIFERENTES CONCEPÇÕES DE AGROECOLOGIA}

O aporte teórico da agroecologia recebeu influências da agronomia, ecologia, antropologia e sociologia (Altieri, 1995). A agroecologia é considerada como uma proposição científica emergente e um campo de conhecimento transdisciplinar. A agroecologia é interpretada para alguns atores sociais como ciência que estuda os agroecossistemas ou as unidades agrícolas de forma abrangente, nas quais ocorrem os ciclos minerais, as transformações energéticas. Nos agroecossistemas, assim como nos ecossistemas naturais, ocorrem processos ecológicos como ciclagem de nutrientes, interações animais, insetos (fauna), competição, comensalismo e sucessões ecológicas (flora). Porém nos agroecossistemas, o grau de resiliência e estabilidade não são determinados unicamente por fatores ambientais e bióticos, mas também por fatores sociais e econômicos, tais como: posse da terra, inserção em mercados e, com a possibilidade concreta dos produtores de colocar em práticas princípios da agroecologia, etc. Outros elementos são destacados como condicionantes da estabilidade, tais como o patrimônio cultural dos produtores, suas tradições relacionadas ao uso e manejo da terra (Abreu, et. al. 2012). Portanto, segundo os fundadores desta proposição, os sistemas agroalimentares inspirados pela agroecologia, promovem biodiversidade, resiliência, eficiência energética e justiça social. Também são planejados para (Altieri, 2001).

A origem da matriz conceitual da agroecologia está fortemente vinculada a três instituições universitárias, duas se encontram na Califórnia, EUA e, a última na Andaluzia, Universidade de Córdoba, Espanha. i) (Universidade de Berkeley onde Miguel Altieri ministra cursos; ii) Universidade de Santa Cruz, onde se encontra S. Gliessman. Esse último focaliza a agroecologia, como uma ciência e um conjunto de práticas (Gliessman, 2000). Ainda se identificou uma nova interpretação para a agroecologia como ciência (centrada na concepção de sistemas agroalimentares, que agrega o nível cinco, ao processo de transição ESR, ou a noção de sistema agroalimentar), prática (experiência local) e mudança social (movimento) (Abreu, et. al., 2012). Salienta se também, nas pesquisas coordenadas 
por Eduardo Sevilla Guzman, da Universidade de Córdoba (ES), mencionada, as inter-relações profissionais entre Miguel Altieri e Eduardo Sevilla Guzman, entre outros, que desenvolveram estudos fortemente articulados com a problemática latina americana.

Na França e no Brasil, a institucionalização da agroecologia estimula o desenvolvimento do ensino/formação e capacitações. Mas cabe destacar a fabulosa influência no país de algumas instituições universitárias, entre as quais, destacamos a formação científica no Programa de Doutorado em "Agroecologia, sociologia e desenvolvimento rural sustentável", da Universidade de Córdoba, que teve início em 1991, que se fortaleceu devido às inter-relações entre grupo de pesquisadores de diferentes países, e do Brasil. Este fato permitiu a realização de três objetivos principais: 1) formação e investigação científica, 2) ações com os movimentos sociais, especialmente com o movimento dos sem terras, no Brasil (MST) e, 3) pesquisas em modelos alternativos de agricultura, que foram desenvolvidas com a colaboração dos pesquisadores e técnicos de extensão rural, no Brasil. Na França também se observa a formação em agroecologia, mas de forma mais modesta, o que possibilita que centenas de ONGs têm se inspirado na abordagem da agroecologia para promover a agricultura sustentável

De acordo com acadêmico da Universidade de Córdoba, com a evolução do trabalho empírico no ISEC, o programa de pós graduação integra no mesmo programa científico, ciências sociais e metodologias da educação de cunho participativas. A mudança de paradigma se deu a partir da necessidade de compreender a natureza da agricultura convencional e, seu impacto vis-à-vis os recursos naturais e a própria sociedade. Foi essa escola de pensamento que introduziu no conceito de agroecologia o sentido sociopolítico de desenvolvimento da agricultura, vinculando o, aos processos históricos, resultado da crítica social ao atual contexto do neoliberalismo e da globalização. A nosso ver essa é a dimensão privilegiada desta escola de pensamento.

Assim, a busca de soluções para as várias formas de degradação socioambiental estimulou um grupo de pesquisadores associados ao ISEC, a construir projetos de pesquisas que tivessem como objetivo desfazer a dualidade da ciência (como a epistemologia e estrutura de poder) e, ao mesmo tempo desenvolver ações de investigação e intervenção, reconhecendo e valorizando o conhecimento local e camponês indígenas. Naturalmente também, ocorreram outras contribuições de pesquisadores que tiveram papel importante, relacionadas na obra sobre agroecossistemas (Suzanne B. Hecht, 1997). A proposição teórica denominada agroecologia foi assim formulada, enquanto que a metodologia 
necessita ser ainda melhor qualificada para se atender o objetivo crucial de promover ações e intervenções locais e, portanto, de ampliar a visibilidade das experiências exitosas.

Entretanto, a agroecologia vai além do estudo de agroecossistemas. Para Francis et al. (2003) a agroecologia é uma ciência que estuda todo o sistema de produção de alimentos. Nesta perspectiva, produtores e consumidores estão diretamente inter-relacionados. Consequentemente o autor contribui para o debate conceitual a partir de uma perspectiva mais ampla da agroecologia. Trata se do estudo que integra a disciplina da ecologia ao sistema de produção de alimentos, incluindo também as relações sociais e institucionais relacionadas à produção, à distribuição e ao consumo desta produção. Ademais, a agroecologia não é vista por muitos autores apenas como ciência, mas também como movimento social e prática agrícola.

Segundo Wezel et al. (2009) as três dimensões estão presentes na agroecologia, ocorrem interações entre a visão política (movimento social), a aplicação tecnologias inovadoras (práticas) e a produção de conhecimentos (a ciência). Essas dimensões não são observadas em todos os contextos na mesma intensidade. A agroecologia elege como conceito chave a transição agroecológica expresso pela idéia de redesenho. A grande maioria dos autores brasileiros e latinos americanos, embora envolvidos no desenvolvimento rural, rejeita o fato da agroecologia ser apresentada muitas vezes, como modo alternativo de produção (Caporal \& Costa Beber, 2004).

Portanto, a agroecologia pode ser considerada para certos autores e atores de uma visão pontual menos interdisciplinar, como o cruzamento da agronomia e da ecologia, de onde decorre sua grafia agro-ecologia (Soussana, 2013), como é o caso, em um documento de orientação do INRA de 2010. Embora reconhecendo o interesse da posição anterior, com vistas no "reequilíbrio ecológico dos sistemas produtivos agrícolas", alguns autores brasileiros (Caporal et al., 2006) apresentam a agroecologia como matriz que articula diversas disciplinas $(n=10)$ e campos do conhecimento $(n=31)$, além de integrar saberes empírico. A abordagem inter ou transdisciplinar representa um primeiro divisor de águas, dependendo também da função ocupada pelas ciências sociais e pelos saberes dos agricultores e outros atores (consumidores, ambientalistas...) nos roteiros de pesquisas.

Outra acepção, mais restrita, seria a de uma agronomia que se preocupa com questões ambientais, ou ainda, sua definição simétrica, uma ecologia aplicada aos sistemas agrícolas. Ela induz a certa confusão entre agroecologia e agroambiente. Ela reduz as dimensões sociais (Wezel et al., 2014). Essa visão, normativa de alguma sorte, pode ser contraposta a uma análise integra ao programa da $\mathrm{AE}$ 
perspectivas de reconcepção e de transição de sistemas agrícolas e alimentares (Hill \& e Mac Rae, 1995; Levidow et al., 2013), transformativa, que especificadas adiante no texto. A integração (ou não) da questão alimentar representa outro elemento de diferenciação. As definições propostas por Francis et al. (2003) e Gliessman (2007) destaca a "ecologia dos sistemas alimentares" cujos componentes (técnico, socioeconômico e político) são declinados em diferentes níveis de organização e, as abordagens não se referem mais à uma escala espacial privilegiada (campo cultivado, unidade de produção, agroecossistema). Outros autores estendem o campo da AE ao direito à alimentação (de Schutter, 2011) ou à soberania alimentar (Altieri \& e Toledo, 2011), (Toledo, 2010).

Existem concepções bastante constrastantes sobre agroecologia. Além das análises da literatura cientifica e documentos de políticas públicas sobre a $A E$ nos dois países, foram realizadas diversas entrevistas com atores chave da agroecologia na Brasil e na França (trinta no Brasil e, uma dezena na França) que nos permitiu identificar três tipos de trajetórias (Lamine \& Abreu, 2009); (Abreu, et. al., 2013).

Com base nestas entrevistas, são identificadas e descritas a seguir.

\section{IDENTIFICAÇÃO DE TRÊS DIFERENTES CONCEPÇÕES:}

Concepção 1: Os brasileiros entrevistados em geral iniciaram seus percursos em ONGs e movimentos sociais (projetos da agricultura familiar) da década de 70 à década de 90 e a partir dos anos 2000 passaram a participar diretamente ou indiretamente da elaboração de políticas, em conexões permanentes com redes científicas (muitos passaram pela academia em programas de doutorado, fato que favorece a legitimação destas posições). No caso dos entrevistados militantes franceses, não está ainda bem elucidada a relação desses com o movimento pioneiro, liderado por Pierre Rabhi (cf supra). A presença de representantes de instituições públicas na França surge tardiamente. Um dos entrevistados, fortemente articulado com o movimento agroecológico e figura central na organização do primeiro evento da agroecologia do Colóquio de agroecologia de Albi/2008, fez referência aos princípios da agroecologia, apresentado por Pierre Rabbi, sem mencioná-lo. Para o entrevistado, o movimento social articulado em torno de Pierre Rabbi apresenta uma dimensão fortemente espiritual "light", sentido contrário às ações do movimento em torno da associação linha de "Horizon et les Amis de François Partant", cuja instituição adota uma estratégia política focada na defesa dos trabalhadores sem terra e pequenos produtores familiares de países distantes, especialmente no Brasil e na América 
Latina. Outro entrevistado que interage com movimento social afirma que a agroecologia tem necessariamente uma dimensão política. Sua ação é associada à Confederação Camponesa.

Concepção 2: A origem das trajetórias do segundo grupo é acadêmica em alguns casos, apresentam fortes ligações com os movimentos sociais e políticos, através da construção de projetos de pesquisas participativas e o envolvimento pessoal com algumas organizações não governamentais. Estes projetos têm sido dedicados principalmente à agricultura familiar. No caso francês, o grupo é formado por professores, alguns com experiência profissional inicial em ONGs, e outros atuam, simultaneamente, como produtores e militantes. Um dos entrevistados teve formação (inusitada para a época: década de 80) em ecologia de agroecossistemas e mantem ligações com o movimento social agroecológico. Anteriormente, esteve desenvolvendo pesquisas em áreas de montanhas com agricultores familiares tradicionais no México - e afirma ter sido a experiência fora da França e a convivência com líderes do movimento camponês mexicano que o influenciou a pensar a agricultura a partir de uma visão da agroecologia, antes mesmo dela ter sido anunciada cientificamente. A experiência entre pesquisadores e acadêmicos franceses em outros países foi também mencionada por outros atores entrevistados, como fator importante a abertura para o enfoque da agroecologia.

Concepção 3: Atores chaves brasileiros que atuam unicamente no âmbito da pesquisa científica ou no ensino em universidades mostram forte interesse pela agricultura ecológica e, mais precisamente, se referem fortemente à agricultura orgânica (apresentando exemplos práticos da produção orgânica) e interagem em menor grau com os movimentos sociais e políticos; poucos possuem envolvimentos com projetos de abordagem participativa. Nesta categoria também encontramos um entrevistado francês que orienta seus estudos para o papel das leguminosas nos sistemas de culturas e visa contribuir com a diminuição do uso de insumos.

Para identificar as concepções concorrentes da agroecologia, selecionamos três aspectos principais: concepções sobre processos de transição da agricultura; tipo de produtores e, por último, visão sobre a inserção da produção no mercado.

\section{CONCEPÇÕES SOBRE A TRANSIÇÃO}

Para o grupo atores-chave das categorias 1 e 2, a agroecologia se encontra muito além da agricultura orgânica, cujo entendimento sobre esse modo de produzir, é na melhor das hipóteses "uma etapa no caminho para se chegar a agroecologia". A transição é identificada como um processo progressivo. 
Neste caso, a agricultura orgânica consiste na substituição de insumos, etapa posterior à diminuição da dependência de insumos externos. Alguns entrevistados acadêmicos não defendem a transição progressiva, mas, uma visão da transição radical bem surpreendente à primeira vista. No entanto, no geral é uma visão baseada numa menor autonomia dos agricultores. Segundo esse ponto de vista, o conhecimento dos agricultores sobre a ecologia dos processos produtivos já foi perdido e, por conseguinte, outro modelo teria que ser completamente redefinido, construído e transferido, a partir do progresso da ciência, tendo a ecologia como fundamento central.

\section{O TIPO DE AGRICULTORES}

Para os atores chaves dos grupos 1 e 2, a agroecologia está claramente ligada à agricultura familiar (ou paysanne, na França). Para esses, a agroecologia não é possível ser desenvolvida fora da agricultura familiar. Por outro lado, alguns atores chaves do grupo 3 e cientistas do grupo 2 no Brasil consideram que a aplicação de programa de desenvolvimento com base na agroecologia, que privilegia agricultores familiares (assentamento da reforma agrária) focaliza um grupo específico de produtores, sendo preciso universalizar e atender demandas abrangentes para solucionar questões relacionadas à pobreza rural. Neste sentido, a definição de um grupo de agricultores é considerada como algo restritivo. Outros cientistas argumentam que as soluções agroecológicas devem ser encontradas para as propriedades maiores e especializadas. Um desses entrevistados conduz projetos de pesquisas no setor de cana-de-açúcar, que normalmente é excluído pelo outro grupo, uma vez que trabalham principalmente em unidades de produção mistas (gado, legumes, frutas e, eventualmente, café). Estas duas posições são também encontradas entre pesquisadores franceses, mas o grau de heterogeneidade no mundo agrícola e da divisão social, profissional e institucional entre pequenas e grandes propriedades, é menos forte.

As relações com mercados e consumidores

Para os atores-chaves dos grupos (1 e 2), a agroecologia também supõe uma redefinição dos modos de comercialização, transportes e de organização dos circuitos, bem como de hábitos de consumo. Um argumento importante é o de se evitar os problemas do processo da convencionalização da agricultura orgânica. A produção ecológica deve ser comercializada através de circuitos locais e sem adesão aos processos de certificação, substituindo-os por processos participativos não regulamentados. Na França, essa visão é encontrada principalmente entre os membros e atores das redes alternativas de produtores e consumidores e as de agricultura alternativa (CIVAM, Confederação 
Camponesa, AMAP). No Brasil, a agroecologia também tem uma posição crítica em relação à agricultura orgânica, embora desde 2003 estejam agrupadas no mesmo mecanismo institucional de regulação da produção e do mercado, já mencionado anteriormente. A crítica centra-se, sobretudo, na visão minimalista da agricultura orgânica, na medida em que ela é vista como substituição de insumos, em detrimento de um redesenho dos sistemas agrícolas. Apesar dessas críticas, a conversão para a agricultura orgânica é frequentemente lembrada para ilustrar as perspectivas de transição agroecológica (Abreu, et al, 2012). Parte dos técnicos mais críticos teve em sua formação uma passagem (formação) pela Universidade de Córdoba, que integra a dimensão política, na análise dos processos da transição.

\section{CONCLUSÕES}

A proposição da agroecologia está sendo aplicada fortemente no universo da agricultura familiar, onde a família desempenha um papel fundamental na gestão e na condução das atividades agroecológicas. A agroecologia se desenvolve também ancorada em movimentos sociais e aborda questões de desenvolvimento através de redes sociotécnicas que legitima um conjunto de formas de agricultura, transformando a paisagem agrária contemporânea. Além disso, desencadeia uma ruptura paradigmática, promove a emergência de debates e de críticas à agricultura convencional e reforça um conjunto de valores políticos e sociais associados ao ideário de uma sociedade justa e igualitária. A agroecologia é legitimada no Brasil e na América Latina por sua forte relação com o movimento social. O tema agroecologia coloca no debate público a questão do poder da ciência sobre o desenvolvimento da sociedade, destacando a natureza política do que está por trás das opções tecnológicas dos diferentes modelos utilizados na agricultura. Portanto, a agroecologia coloca a questão mais geral da importância da relação entre sociedade e ciência. Em essência o significado do movimento em defesa da agroecologia se traduz nos tempos atuais em um processo de desenvolvimento rural de dimensões múltiplas que vêm recompondo o mundo rural, na medida em que reconstrói paisagens e preserva recursos naturais e resgata saberes associados à produção de alimentos. Entretanto, essa análise é datada, o material da pesquisa foi recolhido até o final, de 2015, depois da mudança de governo no Brasil, muitas incertezas vicejam quanto ao avanço do desenvolvimento da agroecologia, especialmente neste país. 


\section{AGRADECIMENTOS}

Á Capes-Cofecub o nosso agradecimento pelo financiamento dos programas de trabalhos e estadias de estudentes e pesquisadores brasileiros e franceses em 2011, 2012, 2013 e 2015.

\section{REFERÊNCIAS}

ABREU, L. S. de; LAMINE C.; BELLON, S.; BRANDENBURG, A.; OLLIVIER, G. O papel de cientistas e de lideranças do movimento social na construção da agroecologia no Brasil e na França. Cadernos de Agroecologia, Cruz Alta, v. 8, n. 2, VIII Congresso Brasileiro de Agroecologia, Porto Alegre, 2013. 5p.

ABREU, L. S. de; BELLON, S. The dynamics and recomposition of agroecology in latin america. In: HALBERG, N; MULLER, A. (Ed.). Organic agriculture for sustainable livelihoods. Londres: Routeledge, 2013. p. 223-245.

ABREU, L. S. de; BELLON, S; BRANDENBURG, A.; OLLIVIER, G.; LAMINE, C.; DAROLT, M. R.; AVENTURIER, P. Relações entre agricultura orgânica e agroecologia: desafios atuais em torno dos princípios da agroecologia. Desenvolvimento e Meio Ambiente, Curitiba, v. 26, p. 143-160, 2012.

ABREU, L. S. de; KLEDAL, P.; PETTAN, K.; RABELLO, F.; MENDES, S.C. Trajetória e situação atual da agricultura de base ecológica no Brasil e no Estado de São Paulo. Cadernos de Ciência \& Tecnologia, Brasília, DF, v. 26, n.1/3, p. 149-178, 2009.

ALMEIDA, S. G; PERTENSEN, P.; CORDEIRO, A. Crise socioambiental e conversão ecológica da agricultura brasileira: subsídios à formulação de diretrizes ambientais para o desenvolvimento agrícola. Rio de Janeiro: AS-PTA, 2001. 122 p.

ALTIERI, M. Agroecologia: a dinâmica produtiva da agricultura sustentável.Porto Alegre: Editora da UFRGS, 2001. $110 \mathrm{p}$.

ALTIERI, M. Agroecologia: bases científicas para uma agricultura sustentável. Guaíba: Agropecuária, 1995. $592 \mathrm{p}$.

AVENTURIER, P.; ALENCAR, F. M. C. Uso e gestão de fontes bibliográficas de agroecologia em trabalhos técnicos científicos. Oficina apresentada na VIII Congresso Brasileiro de Agroecologia, Porto Alegre, 2013.

BRANDENBURG, A. Movimento agroecológico: trajetória, contradições e perspectivas. Desenvolvimento e Meio Ambiente, Curitiba, v. 6, p. 11-28, 2002.

BRASIL. Ministério do Desenvolvimento Agrário. Política Nacional de Assistência Técnica e Extensão Rural: versão final. Disponível em:<http://www.mda.gov.br/saf/arquivos/0878513433.pdf>. Acesso em: 12 dez.

2009.

CAPORAL, F. R.; COSTABEBER, J. A. Agroecologia: alguns conceitos e princípios. Brasília, DF: MDA, Secretaria da Agricultura Familiar, 2004. 
COMMISSION EUROPÉENNE.Proposal for a regulation of the European Parliament and of the Council on organic production and labelling of organic products.Brussels, 2014. 73 p. Disponível em: <http://ec.europa.eu/agriculture/organic/documents/eu-policy/policydevelopment/report-andannexes/proposal_en.pdf>. Acesso em: 12 jul. 2014.

GLIESSMAN, S. R. Agroecologia: processos ecológicos em agricultura sustentável. Trad. Maria José Guazzelli. Porto Alegre: UFRGS, 2000. 653 p.

GRISA, C., C.J. Schmitt, L. Mattei, R. Maluf and S. Leite (2011) Brazil's PAA: policy-driven food systems. Farming Matters 27(3) pp. 34-36

HECHT, S. La evolución del pensamiento agroecológico. In: ALTIERI, M.. (Ed.). Agroecologia: bases científicas para una agricultura sustentable. La Habana: ACAO-CLADES, 1997. p. 15-30.

HERVIEU, B.; PURSEIGLE, F. Pour une sociologie des mondes agricoles dans la globalisation. Études rurales, Paris, n. 183, p. 177-200, 2009.

LAMINE C. Sustainability and resilience in agrifood systems: reconnecting agriculture, food and the environment. Sociologia Ruralis, 2014. No prelo.

LAMINE, C.; ABREU, L. S. de. Compared trajectories of agro-ecology in Brazil and France: The role of scientists and social movements. In: ESRS CONGRESS, 23., 2009, Vaasa, Finland. Re-inventing the rural: between the social and the natural: book of abstracts. Vaasa: European Society for Rural Sociology, 2009. p. 222

LAMINE, C.; DAROLT, M.; BRANDENBURG, A. The civic and social dimensions of food production and distribution in alternative food networks in France and Southern Brazil.International Journal of Sociology of Agriculture and Food, Pullman, v. 19, n. 3, p. 383-401, 2012.

MATTEI, L. O papel e importância da agricultura familiar no desenvolvimento rural brasileiro contemporâneo. Revista Econômica do Nordeste. (aceito para publicação em maio) 2014.

MUNDLER P.; BELLON S. Les systèmes participatifs de garantie : une alternative à la certification par organismes tiers ? Pour, Paris, n. 212, p. 57-65, 2011.

OLLIVIER, G.; BELLON, S. Dynamiques des agricultures écologisées dans les communautés scientifiques internationales: une rupture paradigmatique à rebondissem Nature, Sciences et Sociétés, Les Ulis, v. 21, n. 2, p. 166-181, 2013.

PLOEG, J. D. van der. Camponeses e impérios alimentares: lutas por autonomia e sustentabilidade no século XXI. Porto Alegre: Editora da UFRGS, 2008. 372 p.

TOLEDO, V. M. As experiências agroecológicas do México: uma visão geopolítica. Agriculturas, Rio de Janeiro, v. 7, n. 1, p. 40-45, 2010.

WEZEL, A.; BELLON, S.; DORÉ, T.; FRANCIS, C.; VALLOD, D.; DAVID, C. Agroecology as a science, a movement and a practice: a review. Agronomy for Sustainable Development, Paris, v. 29, n. 4, p. 503515, 2009. 
WILLER, H.; YUSSEFI, M. The world of organic agriculture: statistics and emerging trends. In: IFOAM ORGANIC WORLD CONGRESS, 2008, Modena. Cultivating the future based on science: proceedings... Modena: IFOAM: ISOFAR, 2008. 


\section{Capítulo 30}

\section{ANÁLISE COMPARATIVA DO DESENVOLVIMENTO SUSTENTÁVEL NA RIBA* UTILIZANDO O BARÔMETRO DA SUSTENTABILIDADE}

DOI: $10.37423 / 200300518$

Abner Vilhena de Carvalho - abnervilhena@hotmail.com

Erick Rodrigo Porto Pinho - rodrigo.rpcd-pinho@hotmail.com

Rhayza Alves Figueiredo de Carvalho - carvalho.rhayza@gmail.com

Aline de Jesus Canto - aline_aline57@hotmail.com

Edwilson Oliveira dos Santos - edwilsonoliveira17@gmail.com

Luan Gomes de Oliveira - luangomes.oliveira@hotmail.com

Jarsen Luis Castro Guimarães -jarsen@bol.com.br

Mario Tanaka Filho - tanakafi@gmail.com

Ednéa do Nascimento Carvalho - edneancar@yahoo.com.br

Andréa Simone Rente Leão - asgrente@yahoo.com.br 
Resumo: O objetivo deste artigo consiste em analisar os resultados do Barômetro da Sustentabilidade (BS) na Região de Integração do Baixo Amazonas (RIBA), procurando identificar a participação de cada município que compõe a região de integração, considerando os 9 temas (saúde e população; riqueza; conhecimento e cultura; comunidade; equidade; terra; água; ar, espécies e utilização de recursos naturais), como também as 2 dimensões de bem estar (humano e ambiental) de análise do BS. Tal análise, foi feita de forma descritiva com base nas médias dos temas e dimensões considerados no documento Barômetro da Sustentabilidade da Região de Integração do Baixo Amazonas, produzido pela Fundação Amazônia de Amparo a Estudos e Pesquisas (FAPESPA, 2017). Os resultados dos graus dos indicadores nos revelaram a dinâmica socioambiental dos municípios que compõe a RIBA e, a partir dos valores agregados dos municípios se construiu, via média, o grau de sustentabilidade desta Região de Integração.

Palavras-chave: Desenvolvimento. Sustentabilidade. Barômetro. Sustentável. RIBA. 


\section{INTRODUÇÃO}

Após a Conferência das Nações Unidas sobre o Meio Ambiente e o Desenvolvimento, popularmente conhecida como Rio-92, o conceito de sustentabilidade apareceu muito forte na comunidade cientifica e abrange uma pluralidade de dimensões que integram as relações ecológica, direitos humanos, qualidade de vida, justiça social e autodeterminação das comunidades e das nações. E uma metodologia que passou a ser amplamente utilizada para analisar os indicadores que compõem tais dimensões é o Barômetro da Sustentabilidade (BS).

Nesse contexto, o objetivo do artigo é analisar os resultados do Barômetro da sustentabilidade (BS) na Região de Integração do Baixo Amazonas (RIBA), procurando identificar a participação de cada município que compõe a região de integração, considerando os 9 temas (saúde e população; riqueza; conhecimento e cultura; comunidade; equidade; terra; água; ar, espécies e utilização de recursos naturais), como também as 2 dimensões de bem estar (humano e ambiental) de análise do BS.

O cálculo da média, daqueles(as) temas e dimensões para a RIBA, permitirá identificar quais os municípios encontram-se em situação 'melhor/pior' (acima/abaixo) da média da RIBA. Com o diagnóstico, busca-se identificar as semelhanças e diferenças existentes entre os municípios no que diz respeito aos seus indicadores de desenvolvimento e sustentabilidade, possibilitando, direcionar as estratégias de desenvolvimento, com foco na melhora das temas e dimensões individuais a nível municipal, o que promoverá, por sua vez, a melhora ampliada no nível de desenvolvimento sustentável do território que compõe a Região de Integração do Baixo Amazonas.

\section{FUNDAMENTAÇÃO TEÓRICA}

\subsection{TEORIA DO DESENVOLVIMENTO SUSTENTÁVEL - MEDIDAS E INDICADORES}

A ciência econômica nasce tendo com foco central o crescimento econômico. Adam Smith um dos precursores do pensamento econômico, em sua obra "A Riqueza das Nações" procurou identificar justamente isso, as causas do crescimento econômico e de como ele contribuía para a elevação do bem-estar geral da população. Não só nas obras de Adam Smith, outros economistas clássicos como David Ricardo e Thomas Malthus, a preocupação com crescimento econômico é central (SOUZA, 2008). 
Dada a importância que o crescimento econômico possui na teoria econômica desde sua formulação foi natural que logo se assimilasse o processo de crescimento como sinônimo do desenvolvimento econômico, embora hoje tratados como processos distintos, foi por muito tempo dominante essa similaridade dentro da literatura econômica. Tanto que o PIB per capita foi por muito tempo um indicador usado para medir o desenvolvimento e servir de comparações entre os países, até que no final da década de 1990, o Programa das Nações Unidas para o Desenvolvimento (PNUD) lançou o Índice de Desenvolvimento Humano (IDH) como uma alternativa a visão unidimensional da renda (VEIGA, 2010).

Essa visão de similaridade entre crescimento e desenvolvimento parte do pressuposto de que os benefícios do crescimento se espalham automaticamente por todos os segmentos da sociedade, esse pensamento ficou sendo conhecido como teoria do trickle-down. Esse pensamento foi dominante durante as décadas de 1950 e 1960 e serviram de base para formulação das políticas econômicas a época (PINTO; OLIVEIRA, 2010; SANTOS, 2012).

Segundo Veiga (2010), até o início da década de 1960 não se tinha a necessidade tão clara de distinguir desenvolvimento de crescimento econômico, pois naquela época as poucas nações consideradas desenvolvidas eram justamente aquelas que tinham experimentado um intenso processo de industrialização, o que reforçava a ideia de similaridade entre crescimento e desenvolvimento.

No entanto existe hoje um consenso na literatura empírica sobre desenvolvimento econômico, de que embora o aumento da renda seja condição necessária, não é por si só, condição suficiente para a redução da pobreza (MANSO et al., 2008; SOUZA, 2008; VINOD et al., 2002). O que marca essa mudança na literatura, da necessidade de se distinguir crescimento econômico do processo de desenvolvimento econômico, foi justamente a experiência de diversos países semi-industrializados na década de 1950, a exemplo do Brasil, onde os mesmos tiveram nesse período um intenso crescimento econômico, mas esse crescimento não veio acompanhado de melhorias sociais, em especial para as camadas mais pobres da sociedade. E nesse período que surge a economia do desenvolvimento, como um campo de estudos dentro da economia, tendo como foco de análise principal as causas do subdesenvolvimento (VEIGA, 2010; MOREIRA; CRESPO, 2012).

O fenômeno do desenvolvimento pode ter muitas definições e explicações de acordo com vários autores, que a cada dia procuram descobrir a principal definição para essa palavra que na visão de 
muitos pode mudar o mundo. Segundo Veiga (2010), a resposta para o que vem a ser desenvolvimento segue três formas básicas de formulações que pode ou não ser a resposta real para a interrogativa:

a) Primeiramente, a crença de o desenvolvimento ser comparado ao crescimento econômico, encontrando-se brechas para duvidarmos de tal exposição, pois se trata de duas definições totalmente diferentes (VEIGA, 2010).

b) A segunda resposta é a afirmação de que o desenvolvimento é um grande mito ou uma manipulação da realidade. Aqui, segundo Veiga (2010), as pessoas que seguem esse raciocínio não são passíveis de estudar o desenvolvimento sustentável.

c) A terceira afirmativa diz respeito ao caminho do meio, ou seja, seria a tentativa de contrapor que o desenvolvimento não é reles ilusão e nem se compara ao crescimento (VEIGA, 2010).

Portanto, alguns estudiosos tendem a encontrar a solução para o verdadeiro significado de desenvolvimento, descartando as hipóteses anteriores e formulando suas próprias teorias desenvolvimentistas (VEIGA, 2010).

\subsection{AS MEDIDAS DO DESENVOLVIMENTO E AS GERAÇÕES DOS INDICADORES}

A primeira geração de indicadores, é marcada pela consagração do PIB como indicador de crescimento, e o PIB per capita de desempenho econômico e do próprio desenvolvimento, em seu caráter stritu sensu, por confrontar o tamanho do produto com o tamanho da população, sobretudo em uma ciência que nasce com o foco central no crescimento econômico.

Essa hegemonia do PIB per capita como indicador do desenvolvimento, veio perdurar até início da década de 1990, quando então surge a alternativa do IDH, pelo PNUD, com objetivo de oferecer uma alternativa a visão unidimensional da renda, com isso, além da renda per capita, passa a englobar no seu cálculo as dimensões: da saúde, através da expectativa de vida; educação, através índices de escolaridade, dando início a segunda geração de indicadores. (PAULANI, 2007; VEIGA, 2010)

A partir do IDH surge o Índice de Desenvolvimento Humano Municipal (IDH-M), como uma expansão do IDH para os municípios. Das limitações existentes no IDH-M, surge os indicadores de terceira geração, os quais se distinguem do IDH pela sua metodologia, em procurar ampliar as dimensões, bem como criar pesos para cada indicador, não se limitando a uma média final de três dimensões como o IDH (VEIGA, 2010). 
A quarta geração dos indicadores de desenvolvimento, é marcada pela tentativa de fugir da ideia de medir o grau de desenvolvimento por meio de um índice sintético, baseada, também na ampliação das dimensões de análise do desenvolvimento. Como exemplo desses indicadores temos o DNA Brasil, proposto pelo Núcleo de Estudos de Políticas Públicas (NEPP) da Unicamp, que se trata não só de uma medida, mas de um comparativo da distância do grau de desenvolvimento do Brasil em relação a Espanha (país escolhido pela disponibilidade de dados), usando 24 indicadores referentes à sete dimensões diferentes.

Outro exemplo é o Índice de Desenvolvimento Social (IDS) criado no mesmo período, trabalha com cinco componentes com pesos iguais, cuja principal diferença com os indicadores de segunda e terceira geração é a inclusão de mais indicadores na composição do índice relativos a: desigualdade de renda; desemprego; e habitação com disponibilidade de água, energia elétrica, geladeira e televisão (VEIGA, 2010).

\subsection{AS MEDIDAS DA SUSTENTABILIDADE E O FENÔMENO DO DESENVOLVIMENTO SUSTENTÁVEL}

Conforme expõe Veiga (2010), há um movimento internacional liderado pela Comissão para o Desenvolvimento Sustentável (CSD) das Nações Unidas e envolvendo a participação de diversos atores - governos nacionais, instituições acadêmicas, ONGs e especialistas de todo o mundo - com o objetivo de construir indicadores com informações que integrem as questões socioeconômicas e ambientais, os quais servirão de subsídio para a tomada de decisões necessárias ao desenvolvimento local, sustentável e integrado. Tal objetivo visa a pôr em práticas algumas das ações estabelecidas durante a Conferência das Nações Unidas sobre o Meio Ambiente e o Desenvolvimento, popularmente conhecida com Rio-92.

Como resultado, a CSD conseguiu concretizar um documento com 57 indicadores, acompanhados de fichas metodológicas e diretrizes de utilização, o qual contribuiu para o Instituto Brasileiro de Geografia Estatística (IBGE) lançar, em 2002 e 2004, os primeiros indicadores brasileiros de desenvolvimento sustentável. Estes últimos inovaram ao incluir a dimensão ambiental junto das dimensões social, econômica e institucional, apresentando 17 indicadores fundamentais, organizados em cinco temas: "atmosfera", "terra", "oceanos, mares e áreas costeiras", "biodiversidade" e "saneamento". (VEIGA, 2010) 
Veiga (2010) chama atenção para a importância de o observador do desenvolvimento sustentável monitorar diversos indicadores ao invés de juntá-los em um único índice, ou, então, elaborar um índice de sustentabilidade ambiental que o permita comparar com outros índices de desenvolvimento, como o IDH, IDH-M, IDS e o IDESE (Índice de Desenvolvimento Socioeconômico).

A ideia do Índice de Sustentabilidade Ambiental (ESI), que foi apresentada ao Fórum Econômico Mundial, em 2002, possui 68 variáveis referentes a 20 indicadores e considera cinco dimensões: sistemas ambientais (que envolve ar, água, solo e ecossistema), estresses (estágio crítico de poluição ou exploração de recurso natural), vulnerabilidade humana (situação nutricional ou doenças associadas ao ambiente), capacidade social e institucional (capacidade de lidar com problemas e desafios ambientais) e responsabilidade global (esforços e esquemas de cooperação internacional). (VEIGA, 2010)

Diferentemente do IDH, que resulta da média aritmética dos três índices mais específicos que captam renda, escolaridade e longevidade, o ESI utiliza-se do método de análise de clusters, a partir do qual se identificam grupos de países com perfis semelhantes. O ESI-2002 foi aplicado considerando 142 países, dividindo-os, ao final, em 5 grupos em função do grau de sustentabilidade ambiental, e obteve resultados satisfatórios e mais significativos, quando comparado, inclusive, com a dimensão socioambiental do Índice DNA Brasil (VEIGA, 2010).

\section{METODOLOGIA}

A pesquisa está delineada conforme a natureza aplicada, visando produzir um diagnóstico da condição dos municípios, a partir de seus indicadores de desenvolvimento e sustentabilidade. Tal diagnóstico poderá servir de subsídio para a tomada de decisão, com foco na melhora dos temas e dimensões individuais, possibilitando a melhora ampliada no nível de desenvolvimento sustentável do território que compõe a Região de Integração do Baixo Amazonas.

Para tal, utilizou-se da técnica de pesquisa de revisão bibliográfica e documental, valendo-nos, principalmente, de teóricos que discutem os temas sustentabilidade e desenvolvimento. Para os indicadores, partiu-se de uma análise descritiva com base nas médias dos temas e dimensões considerados no Barômetro da Sustentabilidade da Região de Integração do Baixo Amazonas, produzido pela Fundação Amazônia de Amparo a Estudos e Pesquisas (FAPESPA) nos anos de 2016 e 2017. 


\section{1 ÁREA DE ESTUDO E BASE DAS INFORMAÇÕES (DADOS)}

O governo do estado do Pará, com objetivo de melhorar a gestão estadual, e na promoção de políticas públicas (locais, setoriais e regionais) adotou a proposta de regionalização, como isso foi criado 12 Regiões de Integração, sendo estas: Araguaia, Baixo Amazonas, Carajás, Guamá, Guajará, Lago de Tucuruí, Marajó, Rio Caeté, Rio Capim, Tocantins, Tapajós e Xingu. (FAPESPA, 2017).

A Região de Integração do Baixo Amazonas (RIBA), que é o local de análise desta pesquisa, é composto pelos municípios de Alenquer, Almerim, Belterra, Curuá, Faro, Juruti, Mojuí dos Campos, Monte Alegre, Óbidos, Oriximiná, Prainha, Santarém, Terra Santa.

Abrange uma área de, aproximadamente, $315.852,94 \mathrm{~km}^{2}$, correspondente a $25,31 \%$ do território paraense, dos quais 72,91\% é composta por área protegida. Estima-se que no ano de 2016 contabilizou uma população de 715.807 mil habitantes, sendo a terceira maior população entre as demais RI's. A região possui densidade demográfica de $60,21 \mathrm{hab} . / \mathrm{km}^{2}$, mantendo-se acima da média estadual (6,07 hab./ $\mathrm{km}^{2}$ ) e nacional (22,43 hab./km²) (FAPESPA, 2017; INPE, 2015).

Figura 1 - Localização da RI Baixo Amazonas no estado do Pará

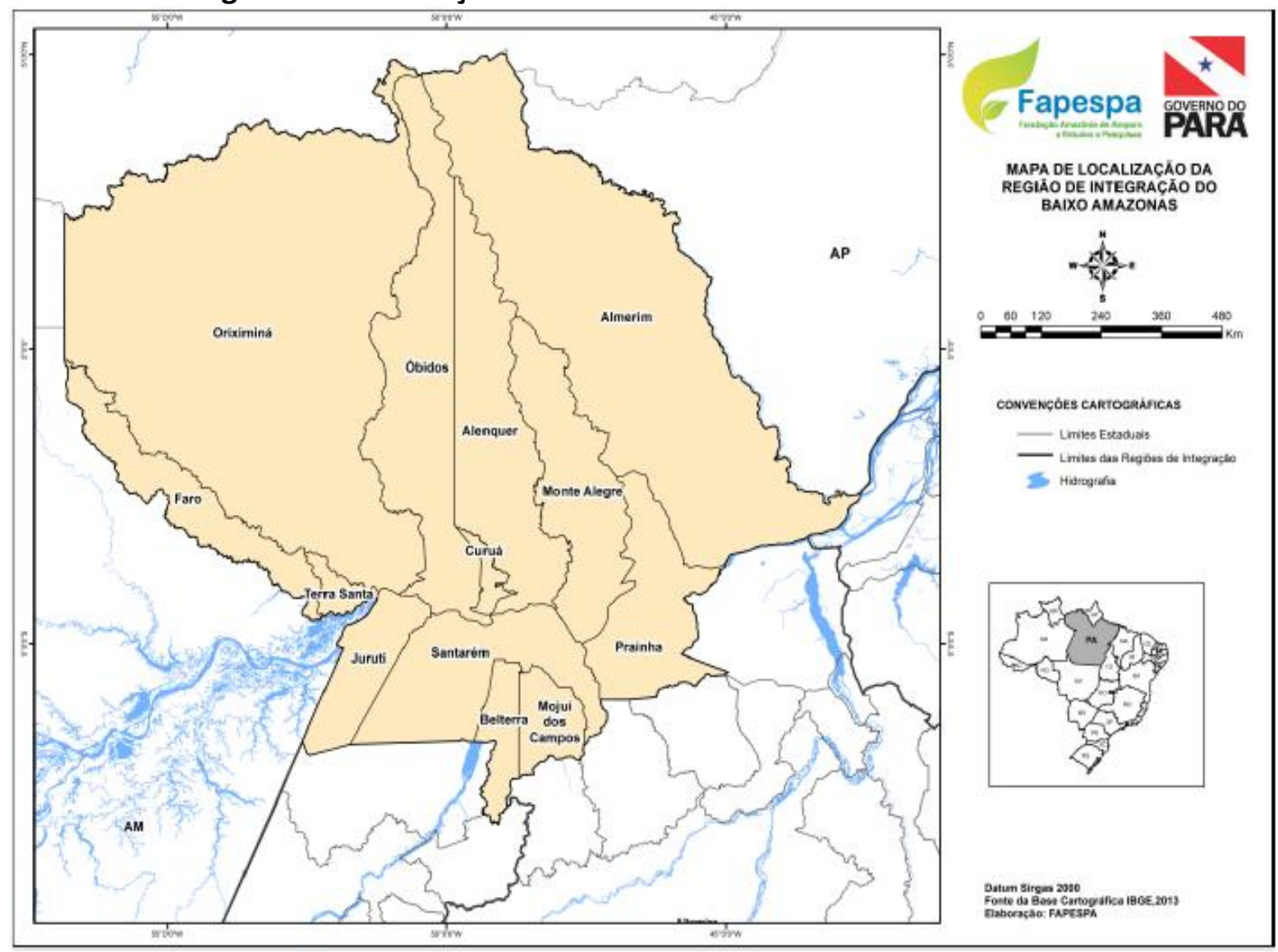

Fonte: FAPESPA (2017, p. 20) 
No contexto econômico, a RIBA registrou um Produto Interno Bruto (PIB) de R\$ 9,4 bilhões em 2014, terceiro maior do estado entre as demais regiões, correspondendo a 7,5\% do PIB estadual. O setor de Serviços respondeu pela maior parcela de participação do Valor Adicionado Bruto (VAB), com 34,8\%, seguido pela Administração pública com $23,6 \%$, agropecuária com $22,8 \%$ e da Indústria com 18,8\% (FAPESPA, 2017).

No âmbito educacional a RIBA apresentou a segunda menor taxa de analfabetismo por grupo de idade (15 anos ou mais) $(10,42 \%)$ entre as demais regiões, abaixo da média estadual (11,74\%). Ressalta-se ainda que, apesar da diminuição em 16,4\% da incidência de mortalidade infantil (até 5 anos) entre os anos de 2007 e 2013, a RI possui a quarta maior taxa (FAPESPA, 2017).

No mercado de trabalho, constatou-se que a região detém 6,7\% dos empregos formais do estado, 75.282 vínculos empregatícios, terceiro maior do Pará. Quando divididos por setor de atividade, temse a seguinte distribuição: Administração pública com $37,72 \%$ dos vínculos, maior parcela de participação; Comércio (22,84\%); Serviços (20,17\%); Indústria de Transformação (7,92\%), na qual ocorre com maior frequência nos municípios de Almeirim, Oriximiná e Santarém; Agropecuária $(5,28 \%)$ e extrativa mineral $(2,81 \%)$. Destaca-se a importância do município de Santarém a nível regional por concentrar 58,03\% dos empregos formais, 43.683 vínculos (MTE, 2015).

Vale ressaltar que o município de Mojuí dos Campos foi integrado à Região de Integração do Baixo Amazonas no ano de 2012, e por isto não foi incorporado nas análises do estudo.

\subsubsection{BASE DE DADOS}

Os dados e informações referente aos indicadores dos municípios da RIBA e ao Barômetro da Sustentabilidade, serão extraídos das analise dos resultados do relatório do BS da região de integração da RIBA, que é publicado anualmente pela Fundação Amazônia de Amparo a Estudos e Pesquisas FAPESPA.

\subsection{TÉCNICA METODOLÓGICA}

\subsubsection{INDICADORES E ÍNDICES: DEFINIÇÃO, OBJETIVOS E SIMILARIDADE.}

Os indicadores podem ser definidos como uma “[...] 'modelização' da realidade, isto é, uma representação simplificada de um aspecto da mesma [...]" (JANUZZI, 2014, p. 20), uma vez que mensuram, quantificam, qualificam e servem de base para análises elaboradas sobre determinado 
aspecto. No que se refere a sustentabilidade desses indicadores, Siche et al. (2007) afirma ser necessário a utilização de indicadores que medem diferentes conjuntos de fatores, tais como aspectos ambientais, econômicos, sociais, éticos e culturais, criando padrões sustentáveis importantes para o desenvolvimento.

Em relação aos índices, Siche et al. (2007, p. 139) definem como "um valor numérico que representa a correta interpretação da realidade de um sistema simples ou complexo", isto é, uma representação quantificada e objetiva dos aspectos da sociedade. No tocante a sustentabilidade, os autores afirmam que a metodologia adotada para a sua mensuração deve conter um conjunto de fatores - econômicos, sociais e ambientais - e corresponder a indicadores de aspectos semelhantes.

\subsubsection{BARÔMETRO DA SUSTENTABILIDADE: HISTÓRICO, ESTRUTURA E METODOLOGIA DE APLICAÇÃO}

O Barômetro da Sustentabilidade (BS) é uma ferramenta de avaliação desenvolvida por pesquisadores do World Conservation Union (IUCN) e a International Development Research Center (IDRC), que consiste em avaliar de forma bidimensional o nível de desenvolvimento sustentável, mensurando o progresso das nações em direção a esse determinado fim. Leva em conta o nível de bem-estar humano (indicadores socioeconômicos) e o nível de bem-estar ecológico (indicadores de bem-estar ambiental).

Desenvolvida por Prescott Allen, pesquisador do IUCN e do IDRC, a metodologia para construção do BS é considerada uma das mais flexíveis. Em sua composição não existe um número fixo de indicadores e a escolha dos que serão utilizados ocorre de acordo com a possibilidade de construção de escalas de desempenho, da área de estudo e da disponibilidade de informações (FAPESPA, 2016).

Dois grandes eixos formam o Barômetro: o Bem-estar Humano e o Bem-estar Ambiental. Cada um daqueles eixos subdivide-se em outras cinco dimensões. Primeiramente, considera-se: saúde e população, riqueza, conhecimento e cultura, comunidade e equidade. No segundo, considera-se: terra, ar, água, espécies e utilização de recursos. Além disso, a construção do BS obedece as seguintes etapas: 1) Seleção dos indicadores, 2) Construção e utilização das escalas de desempenho, 3) Cálculo e ordenação dos resultados e 4) Construção do gráfico bidimensional (PRESCOTT-ALLEN, 2001). 


\subsubsection{A DESCRIÇÃO DAS VARIÁVEIS E OS INDICADORES DO BARÔMETRO DA SUSTENTABILIDADE}

Para a construção do Barômetro foram selecionados 27 indicadores, em sua maioria, ligados aos Objetivos do Desenvolvimento Sustentável $(\mathrm{ODS})^{1}$, dos quais 20 são indicadores relacionados à dimensão do Bem-estar Humano e 7 à dimensão do Bem-estar Ambiental (FAPESPA, 2016).

A dimensão Bem-estar Humano, está subdividida em cinco temas, abrangendo 20 indicadores, conforme é especificado na Tabela 1:

Tabela 1 - Dimensão Bem-estar Humano: Temas e indicadores

\begin{tabular}{|c|c|}
\hline TEMAS & INDICADORES \\
\hline \multirow{5}{*}{$\begin{array}{c}\text { Saúde e } \\
\text { População }\end{array}$} & Mortalidade Infantil (0 a 5 anos) \\
\hline & Mortalidade materna (por 100 mil nascidos vivos) \\
\hline & Número de Médicos (por 1.000 hab.) \\
\hline & Leitos hospitalares (por 1.000 hab.) \\
\hline & Gravidez na infância e adolescência (\% de mulheres até 17 anos) \\
\hline \multirow{5}{*}{ Riqueza } & Extremas pobreza (\% da população) \\
\hline & Taxa de atividade (\%) (18 anos ou mais) \\
\hline & Trabalho infantil (\%) (10 a 14 anos) \\
\hline & PIB (per capita) \\
\hline & Renda (per capita) \\
\hline \multirow{6}{*}{$\begin{array}{c}\text { Conhecimento } \\
\text { e Cultura }\end{array}$} & Analfabetismo (\%) (15 ou mais) \\
\hline & Ideb (séries iniciais) \\
\hline & Ideb (séries finais) \\
\hline & Evasão escolar no ensino fundamental $(\%)$ \\
\hline & Evasão escolar no ensino médio (\%) \\
\hline & Acesso à internet $(\%)$ \\
\hline \multirow{3}{*}{ Comunidade } & Roubos (por 100 mil hab.) \\
\hline & Homicídios (por 100 mil hab.) \\
\hline & Acesso à energia elétrica (\% da população) \\
\hline Equidade & Índice de Gini \\
\hline
\end{tabular}

A dimensão do Bem-estar Ambiental também é subdivida em cinco temas, mas, com uma abrangência menor de indicadores, apenas 7, conforme é detalhado na Tabela 2. 
Tabela 2 - Dimensão Bem-estar Ambiental: temas e indicadores

\begin{tabular}{|c|c|}
\hline TEMAS & INDICADORES \\
\hline \multirow{2}{*}{ Terra } & Cadastro Ambiental Rural (\%) \\
\cline { 2 - 2 } & Desmatamento $\left(\mathrm{km}^{2}\right.$ por ano) \\
\cline { 2 - 2 } & Estoque de floresta $(\%)$ \\
\hline \multirow{2}{*}{ Água } & População em domićlios com água encanada (\% da população) \\
\cline { 2 - 2 } & $\begin{array}{c}\text { População em domicílios com banheiro e água encanada }(\% \mathrm{da} \\
\text { população) }\end{array}$ \\
\hline Ar & Focos de calor (por 1000 km² ao ano) \\
\hline $\begin{array}{c}\text { Utilização de Recursos } \\
\text { Naturais }\end{array}$ & Coleta de lixo (\% da população) \\
\hline
\end{tabular}

Fonte: FAPESPA, 2017

Após a escolha dos indicadores, constrói-se as Escalas de Desempenho Municipais.

\subsubsection{A CONSTRUÇÃO DAS ESCALAS DE DESEMPENHO MUNICIPAIS (EDM)}

Para avaliação do desempenho municipal é feito Escalas de Desempenho Municipais (EDMs), as quais são utilizadas para avaliar a situação do indicador em relação à meta ou ao padrão estabelecido e aplicado a diferentes períodos (FAPESPA, 2017).

Após a escolha dos indicadores, construíram-se as Escalas de Desempenho Municipais (EDMs), as quais são utilizadas para avaliar a situação do indicador em relação à meta ou ao padrão estabelecido e aplicado a diferentes períodos, que apresenta os valores reais e as escalas de desempenho para cada indicador.

As EDMs possibilitam o monitoramento de avanços e retrocessos em direção ao desenvolvimento sustentável e a definição dos seus limites foi feita a partir de valores pesquisados na literatura especializada, tais como padrões definidos na legislação ou metas estabelecidas nacionalmente. As EDMs, para todos os indicadores, foram compostas a partir da divisão do intervalo entre os extremos em cinco setores iguais, variando de insustentável a sustentável (KRONEMBERGER et al., 2004 apud FAPESPA, 2016; 2017).

Portanto, o Barômetro da Sustentabilidade transforma os índices reais de 27 indicadores socioeconômicos e os índices reais de 07 indicadores de bem estar ambiental, em novos índices para cada indicador. Estes novos índices mensuram o nível do desenvolvimento sustentável do local pesquisado, classificando-os em: Insustentável, Potencialmente Insustentáveis, Intermediário, Potencialmente Sustentável e Sustentável, conforme apresentados na Figura 2: 
Figura 2 - Escala de desempenho do Barômetro da sustentabilidade

\begin{tabular}{|c|c|c|c|c|}
\hline \multicolumn{5}{|c|}{ Escala de desempenho do Barômetro da Sustentabilidade } \\
\hline $\mathbf{0 - 2 0}$ & $\mathbf{2 1 - 4 0}$ & $\mathbf{4 1 - 6 0}$ & $\mathbf{6 1 - 8 0}$ & $\mathbf{8 1 - 1 0 0}$ \\
\hline Insustentável & $\begin{array}{c}\text { Potencialmente } \\
\text { insustentável }\end{array}$ & Intermediário & $\begin{array}{c}\text { Potencialmente } \\
\text { sustentável }\end{array}$ & Sustentável \\
\hline
\end{tabular}

Fonte: FAPESPA (2017, p. 15).

\subsubsection{CÁLCULO (TRANSFORMAÇÃO) DA ESCALA MUNICIPAL PARA A ESCALA DO BARÔMETRO DA SUSTENTABILIDADE}

Após a elaboração das EDMs, é feita a transposição do valor numérico do indicador municipal (DMx) para a Escala de Desempenho do Barômetro da Sustentabilidade (EBS), por meio de interpolação linear simples, de forma a atribuir grau ao indicador na EBS (FAPESPA, 2017 adaptado de KRONEMBERGER et al., 2004):

$$
B S_{X}=\left\{\left|\frac{\left(D M_{A-D M_{X}}\right)-\left(B S_{A-B S_{P}}\right)}{\left(D M_{A-D M_{P}}\right)}\right| x(-1)\right\}+B S_{A}
$$

Onde:

EBS: Escala de desempenho do Barômetro da Sustentabilidade;

EDM: Escala de Desempenho Municipal;

BSX: Valor na escala BS;

DMA: Limite anterior na escala municipal (intervalo que contém $\mathrm{x}$ );

DMP: Limite posterior na escala municipal (intervalo que contém $\mathrm{x}$ );

DMX: Valor do indicador na escala municipal;

BSA: Limite anterior na escala BS (intervalo que contém $\mathrm{x}$ );

BSP: Limite posterior na escala BS (intervalo que contém $\mathrm{x}$ ).

Cabe ressaltar que a agregação dos índices sintéticos num único indicador nos permite analisar os resultados dos graus dos indicadores revelando, dessa maneira, a dinâmica socioambiental dos municípios que compõe a RIBA. E, portanto, a partir dos valores agregados dos municípios se construirá, via cálculo da média, o grau de sustentabilidade da RIBA. 


\section{RESULTADOS}

A tabela 3 mostra a média dos 27 indicadores de sustentabilidade, em conformidade com os 9 temas em que estão agrupados:

Tabela 3 - Média dos temas por município

\begin{tabular}{|c|c|c|c|c|c|c|c|c|c|}
\hline \multirow[b]{2}{*}{$\begin{array}{l}\text { MUNICÍPIOS } \\
\text { (TEMAS) }\end{array}$} & \multicolumn{5}{|c|}{ DIMESÃO: Bem-estar Humano } & \multicolumn{4}{|c|}{ DIMENSÃO: Bem-estar Ambiental } \\
\hline & $\begin{array}{l}\text { Saúde } \\
\text { e } \\
\text { Popu- } \\
\text { lação }\end{array}$ & $\begin{array}{c}\text { Rique- } \\
\text { za }\end{array}$ & $\begin{array}{l}\text { Conhe- } \\
\text { cimento } \\
\text { e } \\
\text { Cultura }\end{array}$ & $\begin{array}{l}\text { Comu- } \\
\text { nidade }\end{array}$ & $\begin{array}{l}\text { Equi- } \\
\text { dade }\end{array}$ & Terra & Água & Ar & $\begin{array}{c}\text { Utilização } \\
\text { de recursos } \\
\text { naturais }\end{array}$ \\
\hline Alenquer & 49,85 & 33,97 & 32,17 & 57,45 & 35 & 92,0 & 24,33 & 78 & 43 \\
\hline Almeirim & 59,03 & 10 & 31,86 & 2 & 30,8 & 89,17 & 25,72 & 90,94 & $\overline{65,84}$ \\
\hline Belterra & 48,67 & 3,17 & 36,58 & 9,99 & 35 & 89,40 & 15,45 & 35 & 19 \\
\hline Curuá & 26,90 & 29,45 & 36,86 & 3,38 & 34 & 87,90 & 22,17 & 18 & 11 \\
\hline Faro & 47,13 & 35,16 & 30,79 & 67,82 & 37 & 83,20 & 23,16 & 96 & 16 \\
\hline Juruti & 45,31 & 40,51 & 39,65 & $\overline{59,22}$ & 34,76 & 93,76 & 16,07 & 23,34 & 87,54 \\
\hline Monte Al & 33,37 & 33,18 & 35 & 68,92 & 35 & 86,80 & 25,25 & 23 & 32 \\
\hline Óbidos & 45,12 & 36,70 & 33,45 & 48,94 & 35 & 91,0 & 13,54 & 52 & 45 \\
\hline \begin{tabular}{|l|} 
Oriximina \\
\end{tabular} & 37,12 & 45,30 & 37,03 & 62,21 & 31,48 & 83,80 & 13,57 & 91,17 & 42,01 \\
\hline Prainha & 25,32 & 30,51 & 26,86 & 57,76 & 29 & 78,30 & 11,43 & 43 & 15 \\
\hline Santarém & 44,11 & 44,78 & 40,05 & 46,45 & 35 & 90,70 & 29,64 & 19 & 83 \\
\hline Terra Santa & 48,49 & 48,40 & 39,36 & 86,87 & 35 & 82,70 & 34,17 & 32 & 88 \\
\hline \begin{tabular}{|l|} 
RIBA \\
\end{tabular} & 42,54 & 38,02 & 34,97 & 62,61 & 33,92 & 87,39 & 21,21 & 50,12 & 45,62 \\
\hline
\end{tabular}

Fonte: Elaboração dos autores com base nos dados da FAPESPA (2017).

O tema Saúde e População engloba, sobretudo, indicadores que mensuram o nível da qualidade do atendimento médico e constata uma média de 42,54 na RIBA ${ }^{2}$. Os municípios Almeirim $(59,03)$, Alenquer $(49,85)$ e Terra Santa $(48,49)$, relativamente, se destacam de forma positiva. Entretanto, os municípios de Prainha $(25,32)$, Curuá $(26,90)$, Monte Alegre $(33,37)$ e Oriximiná $(37,12)$ deslocam a média desse tema para baixo. Significa, portanto, que os municípios de Prainha, Curuá, Monte Alegre e Oriximiná oferecem uma qualidade aquém aos outros municípios da RIBA, neste tema.

No tema Riqueza, a RIBA possui uma média de 38,02. Segundo a tabela 3, Terra Santa $(48,40)$, Oriximiná $(45,30)$ e Almeirim $(45,10)$ são os municípios que mais relativamente se destacam. Em contrapartida, Curuá $(29,45)$, Prainha $(30,51)$ e Monte Alegre $(33,18)$ são os municípios que se destacam negativamente neste tema. A renda per capita $(22,54)$ e o PIB per capita $(24,57)$ são os indicadores que fazem de Prainha o município que apresenta os piores números no tema.

O tema Conhecimento e Cultura engloba indicadores que medem, basicamente, o nível educacional e possui uma média na RIBA é de 34,97 . Santarém $(40,05)$ e Terra Santa $(39,36)$ são os municípios que relativamente apresentam uma melhor qualidade, de acordo com os dados. Prainha $(26,86)$ mais uma vez fica aquém em relação aos seus municípios vizinhos, sendo o indicador Analfabetismo $(25,98)$ no município um dos que ficaram aquém da RIBA $(36,88)$. 
O tema Comunidade engloba indicadores que avaliam a violência e o acesso à energia elétrica, e possui uma média de 62,61 na RIBA, sendo esta a mais alta entre todos os temas do Bem-estar Humano. Infere-se, portanto, que a área urbana da RIBA é relativamente pacífica. O município com a melhor avaliação é Terra Santa $(86,87)$ e os municípios com as piores avaliações são Óbidos $(48,94)$ e Almeirim $(52,32)$, sendo estes também os únicos que apresentam uma descrença negativamente grande em relação à média da RIBA.

No tema Equidade (índice de Gini), a média da RIBA é de 33,92, sendo a menor de todos os temas do Bem-estar Humano. Constata-se a desigualdade econômica bastante elevada na região. O município da RIBA com o maior nível de desigualdade é Prainha (29). Mostra-se no tema Riqueza, que a RIBA possui em média um poder aquisitivo médio baixo $(38,02)$.

O tema Terra apresenta uma média geral alta $(87,39)$, revelando indicadores que, na EBS, se destacam como sustentáveis - como o desmatamento e o estoque de florestas. Pode-se observar que os municípios de Faro $(83,20)$, Monte Alegre $(86,80)$, Oriximiná $(83,80)$, Prainha $(78,30)$ e Terra Santa $(82,70)$ estão abaixo da média da RIBA, sendo puxados, principalmente, pelo indicador de Cadastro Ambiental Rural (CAR) - que monitora e regula as propriedades rurais.

No que refere ao tema Água, a média geral na RIBA $(21,21)$ encontra-se, na EBS, em um grau potencialmente insustentável. Os municípios de Belterra $(15,45)$, Juruti $(16,07)$, Óbidos $(13,54)$, Oriximiná $(13,57)$ e Prainha $(11,43)$ acentuam-se abaixo na média e em um grau de insustentabilidade, sendo puxados pelo indicador de população em domicílios com banheiros e água encanada.

O tema Ar, por sua vez, apresenta sua média geral na $\operatorname{RIBA}(50,12)$ sob o indicador de focos de calor, revelando um grau intermediário de sustentabilidade. Entretanto, alguns municípios, como Curuá (18) e Santarém (19) encontram-se em grau insustentável, enquanto outros como Almeirim $(90,94)$, Faro (96) e Oriximiná $(91,17)$ em um grau plenamente sustentável.

O tema Utilização de Recursos Naturais também apresenta-se no grau intermediário de sustentabilidade. Sendo mensurado pelo indicador de coleta de lixo, apresenta uma média de 45,62 na RIBA. Em alguns municípios como Belterra (19), Curuá (11), Faro (16) e Prainha (15) o tema possui um grau de insustentabilidade, enquanto em outros, como Juruti $(87,54)$, Santarém (83) e Terra Santa (88), o grau é sustentável.

A tabela 4 mostra a média dos eixos (dimensões) de Bem-estar Humano e Bem-estar Ambiental por município: 


\section{Tabela 4 - Indicadores Médios Municipais por Dimensão do Bem-estar}

\begin{tabular}{|l|c|c|c|}
\hline \multirow{2}{*}{ MUNICÍPIOS } & \multicolumn{2}{|c|}{ DIMENSÕES } & \multirow{2}{*}{$\begin{array}{c}\text { Média do grau dos } \\
\text { indicadores }\end{array}$} \\
\cline { 2 - 3 } & Bem-estar Humano & Bem-estar Ambiental & \\
\hline Alenquer & 42 & 59 & $\mathbf{5 0 , 5 0}$ \\
\hline Almeirim & 44 & 68 & $\mathbf{5 6 , 0 0}$ \\
\hline Belterra & 46 & 40 & $\mathbf{4 3 , 0 0}$ \\
\hline Curuá & 40 & 35 & $\mathbf{3 7 , 5 0}$ \\
\hline Faro & 44 & 55 & $\mathbf{4 9 , 5 0}$ \\
\hline Juruti & 44 & 55 & $\mathbf{4 9 , 5 0}$ \\
\hline Monte Alegre & 41 & 42 & $\mathbf{4 1 , 5 0}$ \\
\hline Óbidos & 40 & 50 & $\mathbf{4 5 , 0 0}$ \\
\hline Oriximiná & 43 & 58 & $\mathbf{5 0 , 5 0}$ \\
\hline Prainha & 34 & 37 & $\mathbf{3 5 , 5 0}$ \\
\hline Santarém & 42 & 56 & $\mathbf{4 9 , 0 0}$ \\
\hline Terra Santa & 52 & 59 & $\mathbf{5 5 , 5 0}$ \\
\hline RIBA & $\mathbf{4 2 , 6 7}$ & $\mathbf{5 1 , 1 7}$ & $\mathbf{4 6 , 9 2}$ \\
\hline
\end{tabular}

Fonte: Elaboração dos autores com base nos dados da FAPESPA (2017).

A Dimensão do Bem-estar Humano da RIBA, apresenta a menor média, 42,67. Como foi exposto a cima, os temas Equidade $(33,92)$, Conhecimento e Cultura $(34,97)$ e Riqueza $(38,02)$, estão aquém da avaliação intermediária do Barômetro da Sustentabilidade. Portanto, deslocam a média da dimensão do Bem-estar Humano da RIBA para baixo, revelando o baixo nível socioeconômico da região.

Terra Santa (52) é o município que apresenta o maior nível de Bem-estar Humano, destacando-se nos temas, Comunidade $(86,87)$, Saúde e População $(48,49)$ e Riqueza $(48,40)$. Prainha $(34)$, Curuá $(40)$ e Óbidos (40) são, respectivamente, os municípios que apresentam os mais baixos níveis de Bem-estar Humano da RIBA. Prainha está abaixo da média em todos os temas da RIBA de Bem-estar Humano. Enquanto, Curuá fica abaixo da média nos temas, Saúde e População, e Riqueza; e Óbidos apresenta um baixo desempenho nos temas, Riqueza e Comunidade.

No que se refere ao Bem-estar Ambiental, alguns municípios encontram-se num grau de potencialmente insustentável, como Belterra (40), Curuá (35) e Prainha (37). Nota-se que todos os municípios estão abaixo da média da RIBA nos temas Ar e Utilização de Recursos Naturais e apresentam-se, na EBS, um grau insustentável, potencialmente insustentável e, no caso de Prainha, em um grau intermediário.

Pode-se observar também que o município de Almeirim (68) é o único que encontra-se, segundo a EBS, em um grau de potencialmente sustentável, destacando-se nos temas Terra $(89,17)$, Água $(25,72)$, $\operatorname{Ar}(90,94)$ e Utilização de Recursos Naturais $(65,84)$. O município está acima da média da RIBA em 
todos os temas do eixo do Bem-estar Ambiental e, com exceção do tema Água, encontra-se em graus sustentáveis ou potencialmente sustentáveis.

A figura abaixo demostra o grau de sustentabilidade de cada município, considerando as duas dimensões:

Figura 3 - Gráfico bidimensional do Barômetro da RIBA

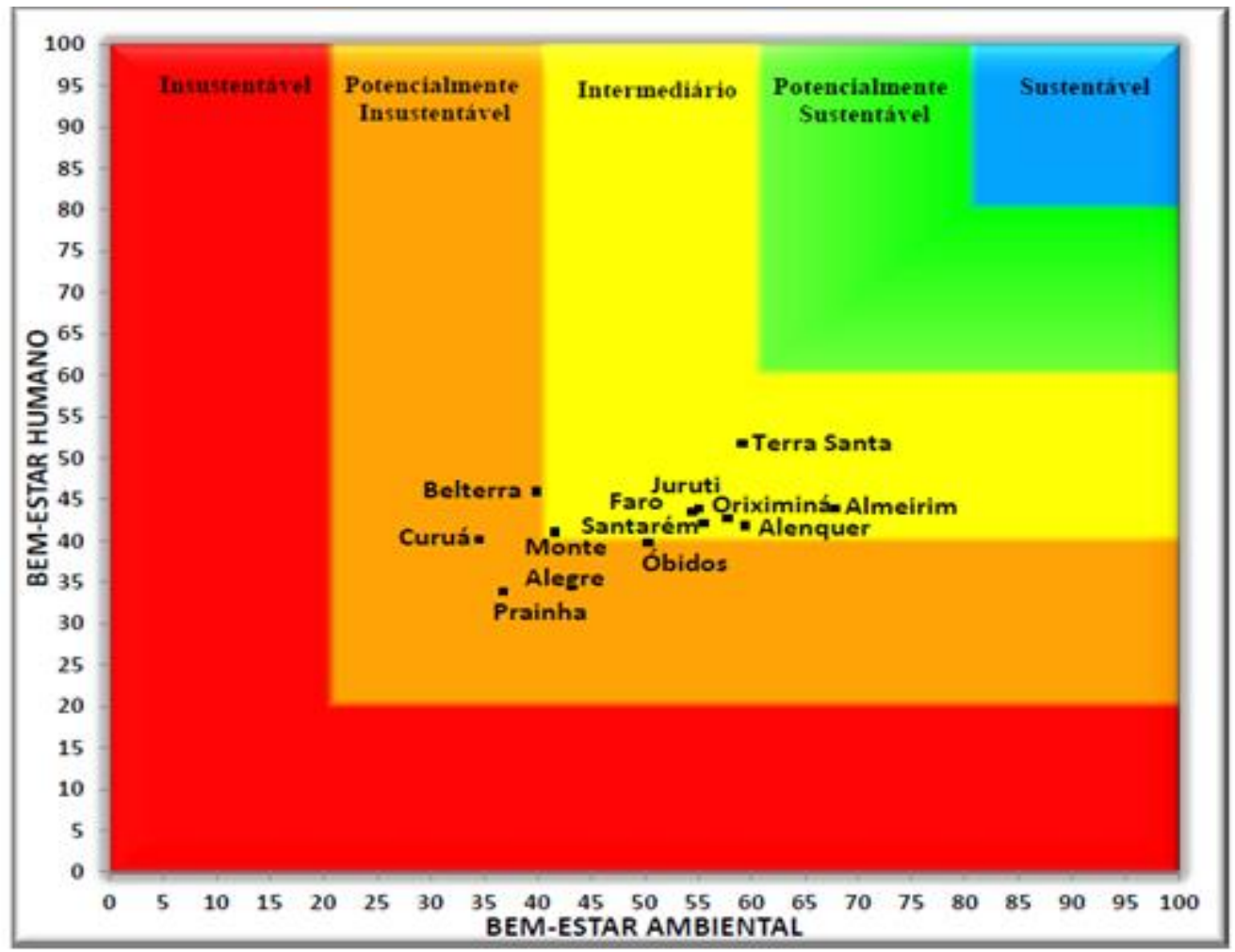

Fonte: FAPESPA, 2017.

Nota-se que os municípios Belterra, Curuá, Óbidos e Prainha estão localizados num grau potencialmente insustentável, demostrando o baixo nível de desenvolvimento sustentável, uma vez que os dois eixos de bem-estar desses municípios estão abaixo da média geral da RIBA. Por outro lado, Terra Santa é o município que, mesmo estando em um grau de sustentabilidade intermediário, possui um nível maior de Bem-estar Humano e Ambiental e está acima da média da RIBA.

De maneira análoga aos resultados dispostos na figura 3, abaixo, encontra-se o mapa da sustentabilidade dos municípios da RIBA, gerado com base em seus níveis de sustentabilidade. 
Figura 4 - Mapa da sustentabilidade dos municípios da RIBA

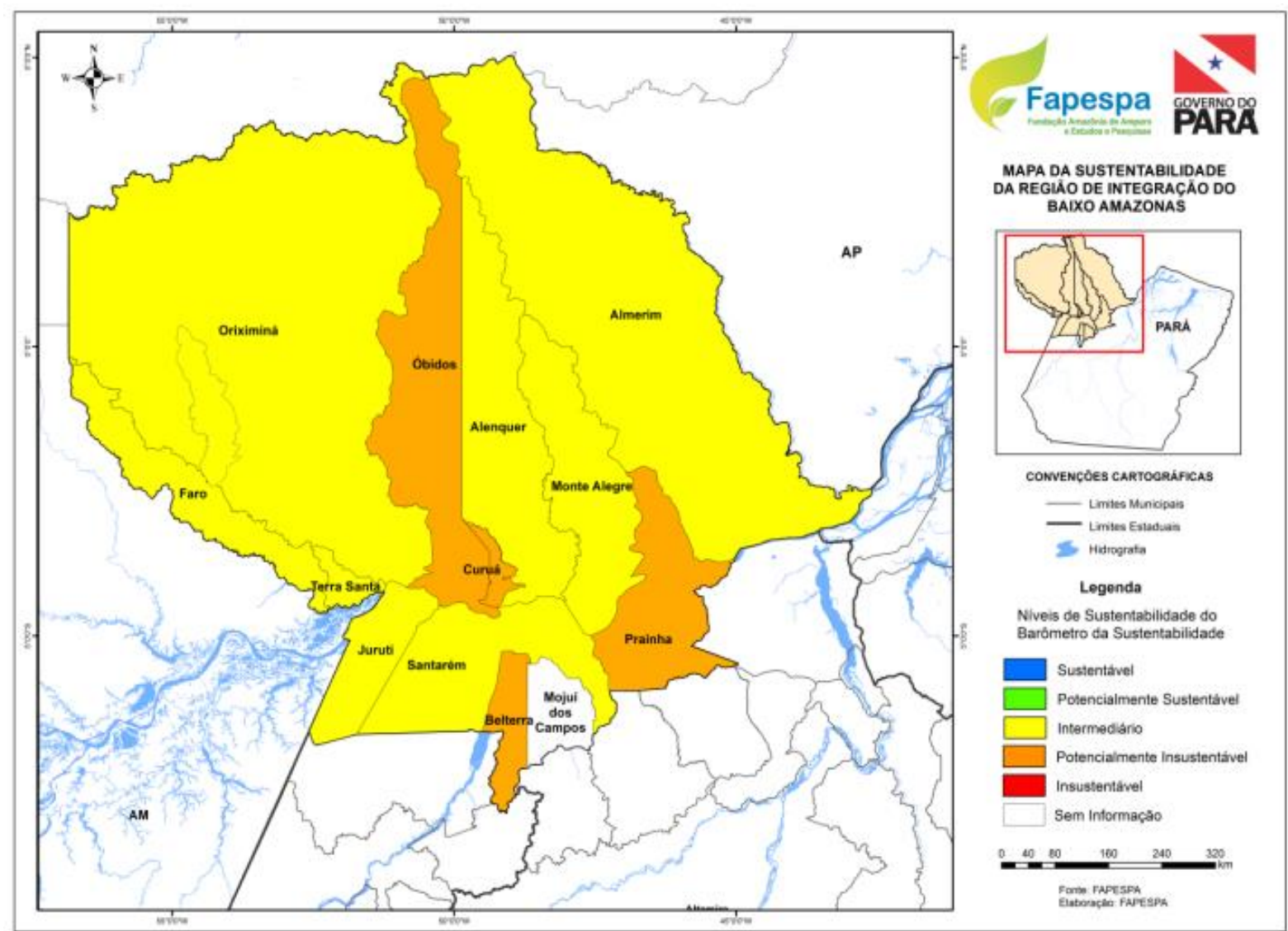

Fonte: FAPESPA, 2017.

Percebe-se que os municípios Belterra, Curuá e Prainha, de fato, encontram-se num grau potencialmente insustentável, demostrando o baixo nível de desenvolvimento humano e ambiental. Por outro lado, os demais municípios encontram-se no grau intermediário de sustentabilidade.

\section{CONSIDERAÇÕES FINAIS}

A análise do desenvolvimento sustentável na RIBA utilizando o Barômetro da Sustentabilidade permitiu verificar, de forma comparativa, a participação dos municípios para a composição da média da RIBA, destacando-se na:

i) Análise por tema:

Considerando o tema Saúde e População que engloba os indicadores da qualidade do atendimento médico, constatou uma média de 42,54 na RIBA. Aqui, os municípios de Prainha, Curuá, Monte Alegre 
e Oriximiná foram os responsáveis por deslocarem a média desse tema para baixo, significando que tais municípios ofereceram uma qualidade aquém aos outros neste tema.

No tema Riqueza, tendo como principal indicador a renda per capita, a RIBA apresentou uma média de 38,02. Neste tema, Curuá, Prainha, Monte Alegre foram os municípios que tiveram destaque abaixo da média da região, destacando negativamente para a composição da média da RIBA, no referido tema.

O Conhecimento e Cultura englobando os indicadores do nível educacional (analfabetismo) exibiu uma média na RIBA é de 34,97. Prainha, esteve aquém dos demais municípios.

No tema Comunidade, abarcando os indicadores que avaliam a violência e o acesso à energia elétrica, a RIBA possuiu uma média de 62,61, constituindo esta a mais alta média entre todos os temas do Bemestar Humano. Infere-se, portanto, que a área urbana da RIBA é relativamente pacífica. Os municípios com as piores avaliações são Óbidos e Almeirim, sendo estes os únicos que apresentam uma participação negativa em relação à média da RIBA.

No tema Equidade, levando em consideração o índice de Gini, a média da RIBA foi de 33,92, sendo este a menor dentre todos os temas do Bem-estar Humano, evidenciando o alto nível de desigualdade de rendimentos entre os municípios da Região. O município da RIBA com o maior nível de desigualdade é Prainha

O tema Terra apresentou uma média geral alta, em torno de 87,39 na RIBA, revelando indicadores que, na EBS, se destacam como sustentáveis - como o desmatamento e o estoque de florestas. Podese observar que os municípios de Faro, Monte Alegre, Oriximiná, Prainha e Terra Santa estão abaixo da média da RIBA, sendo puxados, principalmente, pelo indicador de Cadastro Ambiental Rural (CAR) - que monitora e regula as propriedades rurais.

No que refere ao tema Água, a média geral na RIBA foi de 21,21, sugerindo em um grau potencialmente insustentável na EBS. Os municípios de Belterra, Juruti, Óbidos, Oriximiná e Prainha destemperam-se abaixo na média e em um grau de insustentabilidade, sendo puxados pelo indicador de população em domicílios com banheiros e água encanada. 
O tema Ar, por sua vez, apresenta sua média geral na RIBA de 50,12 sob o indicador de focos de calor, revelando um grau intermediário de sustentabilidade. Entretanto, os municípios de Curuá e Santarém encontram-se em grau insustentável.

O tema Utilização de Recursos Naturais também apresenta-se no grau intermediário de sustentabilidade. Sendo este mensurado pelo indicador de coleta de lixo, a RIBA apresentou uma média de 45,62. Nos municípios de Belterra, Curuá, Faro e Prainha o tema possui um grau de insustentabilidade.

ii) Na Análise por Dimensão destaca-se:

Em suma, percebe-se que, com exceção de Belterra e Curuá, todos os municípios possuem um grau de Bem-estar Ambiental superior ao grau de Bem-estar Humano. Isso ocorre, principalmente, porque os temas que compõem o Bem-estar Humano estão num grau médio baixo, enquanto que no Bemestar Ambiental apenas o tema Água se encontra no mesmo grau.

De forma geral, os resultados do Barômetro da Sustentabilidade evidenciaram que os municípios Belterra, Curuá e Prainha, de fato, encontram-se num grau potencialmente insustentável, demostrando o baixo nível de desenvolvimento sustentável. Por outro lado, os demais municípios encontram-se no grau intermediário de sustentabilidade, o que coloca a média de sustentabilidade da RIBA no intervalo daqueles dois extremos - insustentável à intermediário.

\section{REFERÊNCIAS BIBLIOGRÁFICAS}

FAPESPA. Fundação Amazônia de Amparo a Estudos e Pesquisas. Barômetro da Sustentabilidade dos Estados da Amazônia. Diretoria de Estudos e Pesquisas Ambientais. Belém, 2016.

Barômetro da Sustentabilidade da Região de Integração do Baixo Amazônas. Diretoria de Estudos e Pesquisas Ambientais. Belém, 2017.

JANNUZZI, Paulo de Martino. Indicadores socioeconômicos na gestão pública / Paulo de Martino Jannuzzi. - 3. ed. rev. atual. - Florianópolis: Departamento de Ciências da Administração / UFSC; [Brasília]: CAPES: UAB, 2014.

KRONEMBERGER, D. M. P.; CARVALHO, C. N.; JUNIOR, J. C. Indicadores de sustentabilidade em pequenas bacias hidrográficas: uma aplicação do barômetro da sustentabilidade à bacia do Jurumirim (Angra dos Reis, RJ). Geochimica Brasiliensis, v.18, n.2, p.86-98, 2004.

MANSO, Carlos Alberto; DE SENA PEREIRA, Dílson José; BARRETO, Flávio Ataliba Flexa Daltro. Crescimento pró-pobre: diferenças de intensidade entre rural e urbano no período 2002-2005. Revista Econômica do Nordeste, v. 39, n. 4, p. 365-385, 2008. 
MOREIRA, Sandrina Berthault; CRESPO, Nuno. Economia do Desenvolvimento: das abordagens tradicionais aos novos conceitos de desenvolvimento. Revista de economia, v. 38, n. 2 (ano 36), p. 2550, 2012.

PAULANI, Leda Maria; BRAGA, Márcio Bobik. A nova contabilidade social. Saraiva, 2007.

PINTO, Mauricio Silveira; OLIVEIRA, Júlio César de. Crescimento pró-pobre: análise dos estados brasileiros entre 1995 e 2007. Revista de Economia Contemporânea. v. 14, n. 2 (maio/ago. 2010), p. 327-358, 2010.

PRESCOTT-ALLEN, R. Wellbeing of Nations. (The): A country by country index of quality of life and the environment. Washington, IDRC/Island Press, 350 p. 2001.

SANTOS, Wesley Oliveira. Crescimento pró-pobre no Brasil (1981-2009). [Maringá]: Pós-Graduação em Economia da Universidade Estadual de Maringá, 2011. Disponível em: http://www.apec.unesc.net/VI_EEC/sessoes_tematicas/TemaEconomia\%20Social\%20e\%20Politicas \%20Publicas/Artigo-6-Autoria.pdf. Acesso em: 12 set. 2017.

SICHE, Raúl; AGOSTINHO, Feni; ORTEGA, Enrique and ROMEIRO, Ademar. Índices versus indicadores: precisões conceituais na discussão da sustentabilidade de países. Ambient. soc. [online]. 2007, vol.10, n.2, pp.137-148.

SOUZA, Nali de Jesus de. Desenvolvimento econômico. 5a ed. São Paulo: Atlas 2008.

VEIGA, José Eli da. Desenvolvimento sustentável: o desafio do século XXI. Editora Garamond, 2010.

VINOD, Thomas et al. A qualidade do crescimento. São Paulo: Editora UNESP, 2002. 


\section{NOTAS}

\section{Nota 1}

Os objetivos de Desenvolvimento Sustentável, são constituídos de 17 objetivos que foram construídos com o sucesso dos Objetivos de Desenvolvimento do Milênio, incluindo novos temas, como a mudança global do clima, desigualdade econômica, inovação, consumo sustentável, paz e justiça, entre outras prioridades, todos interconectados. Os ODS entraram em vigor em janeiro de 2016, e eles continuarão a guiar as políticas e o financiamento do PNUD nos próximos anos. http://www.br.undp.org/content/brazil/pt/home/sustainable-development-goals.html

\section{Nota 2}

Estimado com base na média dos municípios que contemplam a Região de Integração do Baixo Amazônas. 


\section{Capítulo 31}

\section{TEORIA DOS JOGOS E PARADOXOS DE AÇÃO COLETIVA ENTRE PECUARISTAS E PESCADORES PROFISSIONAIS DE POCONÉ-MT}

DOI: $10.37423 / 200300525$

André L. Ribeiro Lacerda - CLIQUE/UFMT ((Pesquisa financiada pelo MCTIC e administrada pelo CPP -Centro de Pesquisa do Pantanal).

ribeirolacerda66@gmail.com

RESUMO: Este trabalho investiga dilemas de ações coletivas de duas ocupações fundamentais na estrutura social da cidade de Poconé-MT. Uma localizada no topo, os pecuaristas e a outra na base da estrutura social, os pescadores profissionais. Baseia-se na hipótese de que ambos enfrentam paradoxos de ação coletiva. Os pescadores enfrentam os desafios de estabeleceram "cooperação" no sentido de jogos de soma não zero, por exemplo, se vão pescar distante, se pescam a noite, se pescam no período de cheia. Os pecuaristas quando lutam por melhores vias de acesso às suas fazendas e na divisão de custos de reposição das cercas de suas propriedades. Dados coletados por entrevistas estruturadas entre pecuaristas $(n=28)$ e pescadores $(n=68)$ sustentam as hipóteses sobre paradoxos de ação coletiva apresentadas. Mas, novas investigações com os pecuaristas não sindicalizados e com os pescadores profissionais em situações que parecem força-los a jogar jogos de soma não zero poderão enriquecer melhor as hipóteses envolvendo os dois statuses sociais. 


\section{CONSIDERAÇÕES INICIAIS}

Este trabalho fez parte da pesquisa que desenvolvemos para o Centro de Pesquisas do Pantanal (CPP) da Universidade Federal de Mato Grosso para entender a dinâmica social dos statuses de pecuarista e pescador profissional no Pantanal Mato-grossense. Como um ator social importante no processo de criar políticas públicas de conservação do pantanal, o CPP queria entender quem são os pecuaristas e pescadores pantaneiros - suas estratificações sociais, seus conflitos de interesse enquanto grupos e subgrupos, suas heterogeneidades ou homogeneidades em termos de statuses sociais.

Os pescadores e pecuaristas pantaneiros sobrevivem em um ecossistema dominado pelo ciclo das águas. Eles conseguiram criar estratégias para lidar com o período de cheia, o período intermediário e quando a água está baixa. Os pecuaristas estabeleceram estratégia entre o boi e a água, a ponto de terem se tornado grandes criadores de gado; os pescadores profissionais criaram estratégias de cooperação para lidar com o rio cheio que contrariam a visão geral dos pescadores de que a pesca é uma atividade exclusivamente solitária.

O pantanal é uma planície alagável com extensão em torno de 250.000 km2, estando a uma média de $100 \mathrm{~m}$ acima do nível do mar. Sua localização inclui áreas no sul do estado de Mato Grosso, nordeste de Mato Grosso do Sul no Brasil e áreas no norte do Paraguai e leste da Bolívia, onde é conhecido como chaco boliviano.

No Brasil, chama-se o pantanal de Mato Grosso de pantanal norte e o de Mato Grosso do Sul de pantanal sul. Em Mato Grosso, pertencem ao pantanal norte os municípios de Poconé, Cáceres, Barão de Melgaço, Livramento e Santo Antônio do Leverger, Lambari do Oeste, Livramento e Itiquira, conforme classificação de Vila Silva \& Abdon (1998).

Poconé é um município localizado a 100 km da capital de Mato Grosso, Cuiabá, e que constitui a porta de entrada da rodovia transpantaneira, uma estrada parque que atravessa o pantanal, ligando o município de Poconé a Porto Jofre, na divisa de Mato Grosso com Mato Grosso do Sul. A transpantaneira tem 147 km de extensão e constitui, para os pecuaristas de Poconé, uma das principais vias de acesso ao pantanal.

Pecuaristas e pescadores profissionais são statuses sociais localizados no topo e na base da estrutura social da sociedade poconeana respectivamente. Os pecuaristas enfrentam um processo social de perda de prestígio social enquanto os pescadores profissionais têm se organizado em suas colônias. 
Em Poconé, ser um pescador profissional é uma opção para aqueles que não encontram outra oportunidade numa sociedade economicamente estagnada com o desaparecimento dos grandes fazendeiros de outrora. O garimpo representa outra opção, mas a pesca profissional é atrativa para aqueles que não pretendem se submeter às restrições do emprego assalariado.

A pecuária tem sido praticada há mais de duzentos anos no pantanal mato-grossense. Embora seja considerada uma atividade que produz impactos ambientais indesejáveis, isto não ocorre no pantanal de Poconé, segundo os pecuaristas poconeanos, pois ali a conservação é garantida por eles, que se consideram protetores do pantanal e se autodenominam "pantaneiros".

Os pecuaristas poconeanos classificam o pantanal em três áreas: (1) o baixo pantanal, terras alagadas todo o tempo e, portanto, com sérias limitações para a prática da pecuária; (2) pantanal intermediário, terras alagadas às vezes e o (3) alto pantanal em que as terras são alagadas apenas no ciclo das cheias. Esta classificação implica uma estratificação no valor das terras para a pecuária. Se uma fazenda está localizada integralmente no baixo pantanal tende a ter um valor mais baixo e se está alto pantanal tem maior valor.

Pode-se dizer que os pecuaristas simbolizam muito do que é identificado como características da cultura pantaneira: as festas, os trajes, a linguagem, a religião e os valores.

Os pecuaristas pantaneiros já tiveram grande poder e prestígio social. Em um tempo em que predominavam as grandes propriedades, os pecuaristas tinham elevado prestígio social expresso na política e no financiamento das festas, símbolos da cultura pantaneira.

Em uma visita a Poconé é possível atestar o declínio socioeconômico dos pecuaristas poconeanos. Os espaços sociais de grande prestígio reservados ao status social de pecuarista não existem mais ou estão abandonados. Com a divisão de propriedades entre as sucessivas gerações, aqueles que faziam da pecuária sua ocupação exclusiva têm hoje dificuldades. Se antes, o regime das águas do pantanal propiciava criar o gado solto em um ambiente que favorecia o gado, hoje os custos são muito elevados e inviabilizam a pecuária, dizem aqueles que insistem em viver exclusivamente da pecuária, conforme fizeram seus antepassados.

$\mathrm{O}$ status de pescador nunca teve alto prestígio. Era uma atividade realizada por muitos em geral e muito vinculada ao lazer, "todo poconeano gosta de pescar", mas nos últimos tempos, a organização dos pescadores profissionais em colônias tem levado a um processo de formalização da ocupação. 
Olhando para a grande planície alagável que é o pantanal, sabendo que todos os anos o ciclo das águas exige de todos os atores sociais que lá vivem estratégias para lidar com o período de cheia, vazante e seca, é possível dizer que pescadores profissionais e pecuaristas poconeanos lidam com paradoxos de ação coletiva para lidar com os ciclos das águas?

\section{SOCIOLOGIA DA AÇÃO COLETIVA E UMA HIPÓTESE}

Visualizamos os pecuaristas e pescadores profissionais de Poconé como atores sociais desempenhando papéis em um status ocupacional, pois entendemos a sociedade humana como uma rede de statuses sociais (Bierstedt, 1957; Turner, 2000; Martin, 2009).

Ser um pescador profissional ou ser um pecuarista no pantanal de Poconé é ocupar uma posição social no grupo daqueles que fazem da pesca e da criação de gado uma ocupação. O objetivo deste trabalho é investigar situações sociais em que estes statuses ocupacionais lidam com paradoxos de ação coletiva.

Mas em que consiste um paradoxo de ação coletiva? O argumento básico criado por Mancur Olson nos anos de 1960 defende que nem sempre os interesses dos indivíduos coincidem com os interesses dos grupos a que eles pertencem, o que gera paradoxos na construção de ações coletivas. Ou seja, mesmo que todos os indivíduos de um grupo estejam centrados em seus próprios interesses, e que saiam ganhando se, como grupo, agirem para atingir seus objetivos comuns, ainda assim eles não agirão voluntariamente para promover esses interesses comuns e grupais (Olson, 1999).

Estudos empíricos em torno da teoria formal de ação coletiva têm conhecido enorme crescimento nas últimas décadas (Oliver, 1993; Heckathorn, 1996; Smith, 2003; Fehr \& Leibbrandt, 2011). Todas as espécies sociais enfrentam vários problemas de ação coletiva, ou seja, várias oportunidades que podem produzir benefícios, mas que podem ser impedidas por free riding e outras formas de egoísmo e também por uma coordenação fracassada. Em comparação com outros vertebrados, os seres humanos parecem ser notavelmente bons para resolver problemas de ação coletiva (Smith, 2003).

No nível sociológico é possível dizer então que os indivíduos enfrentam muitas situações sociais que podem ser classificadas como paradoxos de ação coletiva. É como se nas mais diferentes situações sociais os indivíduos avaliassem se os interesses coletivos em jogo combinam com seus interesses individuais. Robert Wright, psicólogo evolucionista, propôs que as interações sociais têm a estrutura 
de um jogo, conforme a teoria dos jogos, ou seja, é como se os indivíduos em suas interações sociais estivessem tomando decisões como em um jogo.

A teoria dos jogos tornou-se popular em 1944, quando Von Newmann e Morgenstern publicaram o livro Teoria dos Jogos e Comportamento Econômico (Von Newmann \& Morgenstern, 2004). Segundo a teoria dos jogos, a característica básica dos jogos é que há sempre pelo menos dois jogadores e, cada jogador, ao final de cada jogo, obtém um payoff, que é o montante que foi ganho ou perdido.

As estratégias de jogo consistem de listas de escolhas ótimas para cada jogador, prevendo-se as possíveis situações que ele enfrentará. Os jogos podem ser classificados em dois tipos, os jogos de soma zero e os jogos de soma não zero.

Os jogos de soma zero são aqueles jogos em que a soma dos payoffs dos jogadores é zero, ou seja, um jogador só pode ganhar se o outro perder, como ocorre, por exemplo, no jogo de pôquer e de xadrez.

Robert Wright diz que, a partir da teoria dos jogos, é possível olhar a interação social entre seres humanos em componentes de soma zero e soma não zero. Segundo ele, a vida social está repleta de cálculos de soma não zero. Cálculos inconscientes conforme a psicologia evolucionista, mas que fazem parte da natureza humana. O conceito de altruísmo recíproco expressa esse tipo de cálculo (Wright, 2000).

Pelo altruísmo recíproco as pessoas têm comportamentos altruístas porque esperam que as outras façam o mesmo por elas. Ou seja, uma forma de comportamento de ajuda onde um sujeito que ajudou outro recebe ajuda posteriormente daquele que ele ajudou (Voland, 1993; Wright, 2000).

Para Wright (2000), a seleção natural, por meio do altruísmo recíproco incorporou à natureza humana uma série de impulsos que tem por objetivo prático propiciar trocas vantajosas.

Na intricada relação entre jogos de soma zero e jogos de soma não zero que constitui a vida cotidiana, pode-se argumentar que os jogos de soma zero pressupõem indivíduos competitivos enquanto os jogos de soma não zero pressupõem indivíduos cooperativos. Mas, Wright (2000) sugere cuidado com esta classificação. Cooperar pode ter um sentido enganoso. Por exemplo, a divisão do trabalho nos proporciona situações enganosas nesse sentido. Se um indivíduo compra em Mato Grosso um suco de uva cultivado e fabricado no Rio Grande do Sul, pode-se exemplificar esta ação como uma troca social no sentido de Cosmides \& Tooby (1992) ou como um comportamento cooperativo, mas nem o 
indivíduo consumidor nem os vendedores do suco no Rio Grande Sul optaram por cooperar. Por isto, Wright (2000) prefere o termo "soma não zero", ao invés de cooperar, que ele acha vago.

Relacionamento de soma não zero não é um relacionamento em que a cooperação necessariamente se dê. A soma não zero é um potencial que pode ou não ser explorado dependendo do comportamento dos jogadores. Por outro lado, quando a soma não zero ocorre, ela cria mais potencial para somas não zero.

Todas as espécies sociais enfrentam problemas de ação coletiva, caraterizados como as várias oportunidades para cooperação que podem produzir benefícios, mas podem ser impedidas por aproveitadores, e outras formas de egoísmo e também por fracasso na coordenação (Smith, 2003; Pinker, 2013).

Jogos de soma zero e não zero entre membros de pequenos grupos é comum nas sociedades nãohumanas (Voland, 1993; Smith, 2003) e nas sociedades humanas (Horton \& Hunt, 1980; Voland, 1993; Smith, 2003). Mas se pensarmos na diversidade de grupos que se formam nas sociedades e nas situações sociais potenciais para formação de grupos sociais que não se realizam, podemos perguntar com Axelrod (1986), sob que condições os jogos de soma não zero emergem? Ou, em que situações ações coletivas se realizam?

A partir dessa incursão teórica, é possível formular uma hipótese geral: HO - pescadores profissionais e pecuaristas desenvolverão estratégias de jogos de soma não zero para lidar com situações sociais em que individualmente eles não conseguem resolver. Por que em algumas situações eles promovem jogos de soma não zero e em outras, eles não conseguem, é uma questão a ser investigada. Mas uma outra possível hipótese, $\mathrm{H} 1$, defende que jogos envolvendo dois jogadores tenderão a produzir mais facilmente jogos de soma não zero do que jogos com múltiplos jogadores.

\section{METODOLOGIA}

Entre outubro de 2014 e março de 2015, 28 entrevistas estruturadas foram realizadas com pecuaristas membros do Sindicato Rural de Poconé. Trata-se de uma amostra por conveniência (Levine et al., 2008).

Segundo o posto do Indea (Instituto de Defesa Agropecuária do Estado de Mato Grosso) em Poconé existem 2113 propriedades no município, 1556 na terra firme e 557 no pantanal. No baixo pantanal 
existiam muitas propriedades abandonadas e algumas propriedades têm sido adquiridas por um mesmo proprietário, o que pode indicar que talvez exista um número menor de propriedades, mas nem o Indea, nem a prefeitura de Poconé, nem o sindicato rural souberam informar com precisão.

Em função da falta de informações sobre o número preciso de propriedades e da dificuldade de ter acesso a elas, pois as propriedades localizadas no baixo pantanal, muitas vezes, só são acessíveis com veículos $4 \times 4$ ou trator, a opção por uma amostra de conveniência pareceu a melhor opção viável nas circunstâncias.

Segundo a direção do sindicato rural, eles tinham em torno de 110 membros, mas apenas cerca de 30 frequentavam o sindicato com certa regularidade.

Na confeç̧ão da amostra, buscou-se ter representatividade no número de entrevistados entre os três pantanais, o baixo, o médio e o alto.

A colônia de pescadores de Poconé (Z11) tinha, conforme informação de seu presidente, cerca de 500 pescadores profissionais. A meta da pesquisa foi entrevistar cerca de $10 \%$ da população. As 68 entrevistas foram realizadas nos diferentes lugares em que se concentravam os pescadores e segundo o modelo de amostragem por conglomerado (Levine et al., 2008), conforme Gráfico 1.

Gráfico 1: Locais de entrevistas dos pescadores profissionais de Poconé-MT.

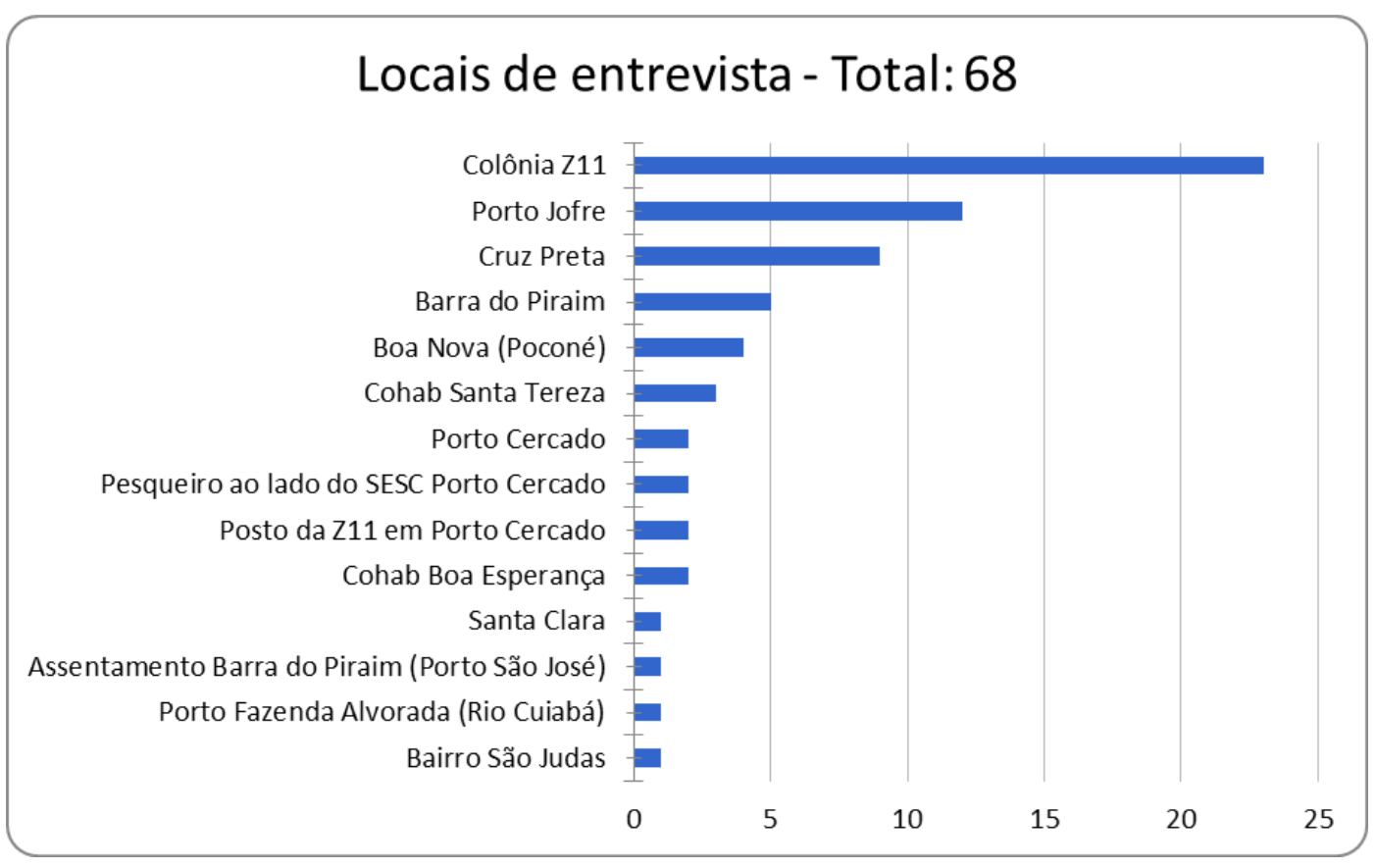

Fonte: Pesquisa de Campo $(2014,2015)$. 
Para testar a hipótese $\mathrm{HO}$ de que pescadores profissionais e pecuaristas desenvolvem estratégias de jogos de soma não zero para lidar com situações sociais em que individualmente eles não conseguem resolver, algumas perguntas foram feitas que permitissem a pescadores e pecuaristas se posicionarem a respeito.

Pescadores: (1) se ele(a) pesca sozinho, em dupla e em grupo; (2) se pesca sozinho ou em grupo, por que pesca desta maneira?

Uma pergunta que não foi feita, foi quando ele(a) pesca em dupla ou em grupo e por que. Esta informação foi disponibilizada nas respostas da pergunta 1, mas não foi realizada separadamente. As duas perguntas feitas permitem testar $\mathrm{HO}$ e H1. Se pesca em dupla, por exemplo, é um jogo que envolve dois jogadores. Se pesca em grupo é um jogo que envolve múltiplos jogadores.

Pecuaristas: (1) participa regularmente das atividades do sindicato rural?; (2) se não participa das atividades do sindicato rural, por que não participa?

Como as entrevistas foram realizadas para se ter uma descrição da estrutura social dos pecuaristas, questões mais específicas que envolvessem paradoxos de ação coletiva ou que levassem a jogos de soma não zero infelizmente não foram realizadas. Mas, as perguntas realizadas permitem testar $\mathrm{H} 1$, pois envolve jogos de múltiplos jogadores.

\section{RESULTADOS}

Os dados foram organizados segundo os dois statuses ocupacionais. Os dados relacionados aos pescadores são apresentados no Gráfico 2 e Tabela 1. 
Gráfico 2: Se pescadores pescam sozinhos, em dupla ou grupo

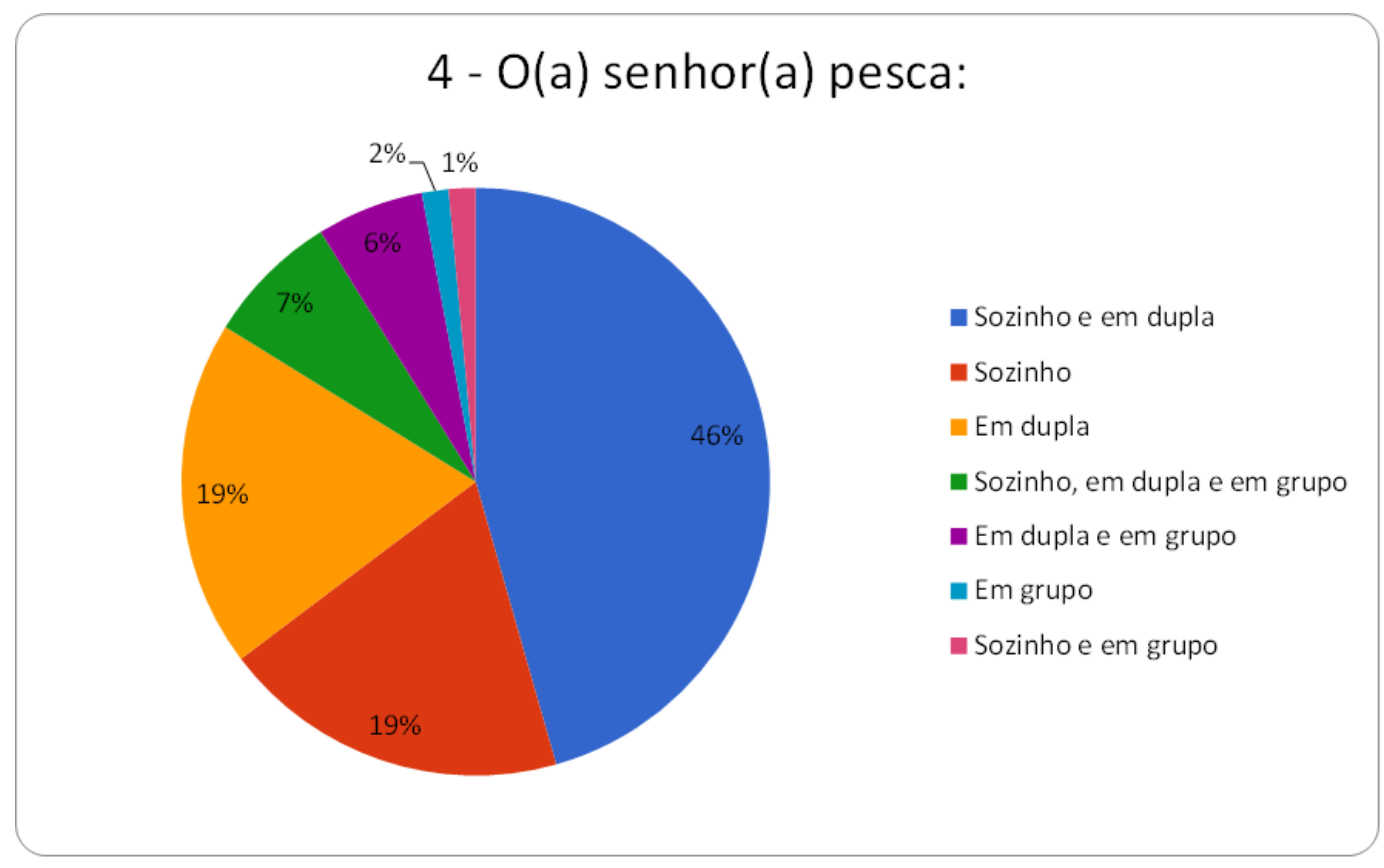

Fonte: Pesquisa de Campo (2017).

Tabela 1: Por que pescar sozinho ou em dupla/grupo

\begin{tabular}{|l|l|}
\hline Explicação & Proporção \\
\hline Sozinho é mais perigoso & $27,94 \%(19)$ \\
\hline Em grupo é mais viável & $33,82 \%(23)$ \\
\hline Sozinho é melhor & $27,94 \%(19)$ \\
\hline Pesco com parentes & $10,29 \%(07)$ \\
\hline
\end{tabular}

Fonte: Pesquisa de campo (2017)

Os dados relacionados aos pecuaristas são apresentados nas Tabelas 2 e 3 .

Tabela 2: Participa do Sindicato?

\begin{tabular}{|l|l|}
\hline Sim & Não \\
\hline $50 \%(14)$ & $50 \%(14)$ \\
\hline
\end{tabular}

Fonte: Pesquisa de Campo (2017) 
Tabela 3: Porque não participa do sindicato?

\begin{tabular}{|l|l|}
\hline Explicação & Proporção \\
\hline Não representa meus interesses & $71,42 \%(10)$ \\
\hline Abdicou & $14,28 \%(02)$ \\
\hline Só quando convidam & $7,14 \%(01)$ \\
\hline Depende de quem é o presidente & $7,14 \%(01)$ \\
\hline
\end{tabular}

Fonte: Pesquisa de Campo (2017)

\section{DISCUSSÃO DOS RESULTADOS}

A maioria do(a)s pescadore(a)s profissionais de Poconé pesca sozinho(a) e em dupla, seguidos daqueles que só pescam sozinhos.

Quando perguntados por que pescam daquela maneira, aqueles que pescam apenas sozinhos dizem que sozinho é melhor. Não tem barulho, não tem que dividir o produto do pescado, não tem que combinar lugar de pesca, enfim, que ele(a) podem administrar o seu tempo da maneira que quiserem. Talvez, estejam aqui expressando os custos dos jogos de soma zero.

Entre aqueles que optam por pescar com alguém, ou seja, jogar jogos de soma não zero, a maior proporção defende que pescar em grupo é mais viável (33,82\%). Um ajuda o outro, pode-se precisar de alguém, a parceria viabiliza deslocamentos, se um deles tem um veículo, carro ou moto, a divisão dos custos para viabilizar a estadia em algum acampamento.

O segundo argumento mais presente nas entrevistas, entre aqueles que defendem jogos de soma não zero é que pescar sozinho(a) é perigoso (27,94\%). Argumento muito destacado pelas pescadoras, mas também por pescadores, que mencionam receio de onças, do perigo de pesca à noite e de pescar na época da cheia.

Finalmente, 10,29\% preferem pescar com parentes. Eles não explicam por que. Apenas dizem que gostam de pescar com a esposa, com o filho ou com o irmão.

Em relação aos pecuaristas, embora os dados sejam provenientes de uma amostra por conveniência, o que poderia indicar que a maioria dos entrevistados frequentam o sindicato, os dados não mostram isso. A metade dos 28 entrevistados não frequenta o sindicato. Isso sustenta a desconfiança 
alimentada pelo pesquisador de que o número de frequentadores regulares é menor que 30 e, portanto, mostra uma situação difícil do sindicato em termos de organização de ações coletivas. Jogos de múltiplos jogadores.

A principal explicação do porquê o pecuarista não frequenta o sindicato com regularidade, embora seja associado, é que ele não representa os interesses do sindicalizado (71,42\%). É um dado preocupante. Relembrando Olson (1999), se os interesses coletivos não coincidem com os interesses individuais e os interesses coletivos (do sindicato) não representam o interesse da maioria dos sindicalizados, por que frequentá-lo? Entre os argumentos mais recorrentes além da não representação dos interesses, está o de que o sindicato não traz benefícios, não ajuda.

Em relação ao argumento de que abdicou, parece haver também uma certa falta de interesse por parte do entrevistado. Abdicou porque deixou para os filhos ou abdicou porque pretende dar mais espaços "para os novos".

\section{CONCLUSÃO}

Os pecuaristas poconeanos têm experimentado um declínio econômico, perda de prestígio e, atualmente, o Sindicato de Produtores Rurais de Poconé não tem mais o papel protagonista que já teve na vida política da cidade. Não obstante esta situação, o sindicato enfrenta dificuldades para mobilizar os pecuaristas.

Todas as espécies sociais enfrentam problemas de ação coletiva, caraterizados como as várias oportunidades para cooperação que podem produzir benefícios, mas podem ser impedidas por aproveitadores, e outras formas de egoísmo e também por fracasso na coordenação (Smith, 2000; Pinker, 2013).

Os pecuaristas do pantanal de Poconé-MT enfrentam situações sociais que podem ser vistas como problemas de ação coletiva ou como dificuldade de jogar jogos de soma não zero, o que exemplifica o que se tem chamado de problema do aproveitador. Na estrutura da teoria dos jogos, pode-se visualizálos como jogos envolvendo dois jogadores ou jogos com múltiplos jogadores (Pfeiffer et al., 2005; Alencar \& Yamamoto, 2008).

Comecemos pelo último. No ano de 2013, a colônia de pescadores de Poconé contabilizava 400 pescadores profissionais. Ou seja, 400 indivíduos estavam registrados como pescadores profissionais com direito a usufruir das guias de pesca (declaração de pesca individual) que permitem a eles passar pelos postos de fiscalização com $125 \mathrm{Kg}$ de pescado por semana e comercializá-lo. 
Ser registrado como pescador profissional confere ao indivíduo algumas vantagens: quatro salários durante os meses de outubro, novembro, dezembro e janeiro, quando ele não pode pescar por causa da piracema, acesso a financiamentos de instrumentos relacionados à pesca, como barcos, por exemplo. Mas durante período da piracema alguns indivíduos pescam escondido, principalmente à noite. Proprietários de estabelecimentos comerciais em Poconé-MT afirmaram que recebiam oferta de pescado durante a piracema. "Ontem mesmo um pescador me ofereceu $100 \mathrm{kgs}$ de peixe", contoume a proprietária de um restaurante. Como vigora a proibição da atividade pesqueira, o peixe se torna escasso e seu preço mais alto, o que constitui uma tentação para os aproveitadores do dilema do prisioneiro (free riding).

Muitos indivíduos registram-se como pescadores, mas apenas para receber os benefícios dos quatro salários durante o período da piracema (chamado de defeso), pois desenvolvem outras atividades ocupacionais.

E alguns pescadores profissionais registram suas esposas, embora elas também não sejam pescadoras, para que elas recebam os quatro salários. Em janeiro de 2015, o ministro do Gabinete Civil da Presidência da República anunciou mudanças no controle do registro profissional de pescadores, pois eles descobriram cidades na região norte do Brasil que tinham mais pescadores do que moradores.

Fenômenos sociais como este são conhecidos como problemas do pescador (Gordon, 1954), problemas de ação coletiva (Smith, 2003; Penn \& Mysterud, 2007), tragédia dos comuns (Hardin, 1968; Alencar \& Yamamoto, 2008) e dilemas sociais (Kollock, 1998).

Outro exemplo de paradoxo de ação coletiva envolvendo múltiplos jogadores diz respeito às dificuldades de locomoção. As fazendas dos pecuaristas pantaneiros tem um acesso difícil por ser o pantanal uma planície alagável. Conforme já foi dito, eles classificam o pantanal em alto, baixo e médio. $O$ baixo pantanal vive permanentemente alagado, o médio alaga algumas áreas permanentemente e outras não e o alto pantanal alaga na cheia e tem áreas não alagadas.

Conforme foi afirmado, o pantanal de Poconé-MT tinha cerca 557 propriedades em 2014 (Dados do Indea). O sindicato rural de Poconé tinha cerca de 110 membros, mas destes menos de 30 pecuaristas frequentavam o sindicato. Embora tenham que promover ações coletivas para lutar pela melhoria das vias de acesso, que no período da cheia (quase seis meses todos os anos) deixa um grande número de fazendeiros ilhados, "brigar" com a fiscalização dos órgãos estadual e federal de meio ambiente que muitas vezes inviabiliza a prática da pecuária, o sindicato enfrenta fracassos na sua coordenação, pois os pecuaristas que tem suas propriedades localizadas próximas às principais vias de acesso, 
pecuaristas que desenvolvem outras atividades econômicas em Poconé e Cuiabá e pecuaristas que vivem fora do pantanal, geralmente proprietários de empresas de grande porte, não têm interesse em participar do sindicato. Por isso, a convocação para ações coletivas não atinge 30 pecuaristas e isto só reforça a desmotivação. Dificuldade de se implementar jogos de soma não zero com múltiplos jogadores $(\mathrm{H} 1)$.

Duas armadilhas estão embutidas nos jogos de soma não zero. A primeira é chamada de problema do aproveitador (free riding). O indivíduo não contribui, mas usufrui o que é gerado pela ação coletiva. Alguns exemplos mencionados acima ilustram o problema do aproveitador. Enquanto alguns pescadores zelam pela piracema, abdicando da pesca, outros pescam escondido (H1).

A segunda armadilha dos jogos de soma não zero é que embutido em seu âmago, no que se refere à vida social, existe uma dimensão de soma zero (Wright, 2000). Os pecuaristas pantaneiros nos fornecem outro exemplo.

Um problema enfrentado pelo pecuarista pantaneiro do baixo e médio pantanal é dividir com seu vizinho o custo de reconstrução das cercas. Como se encontram em uma planície alagável, as cercas têm que ser reconstruídas a cada dois anos, pois o arame e os mourões apodrecem. É muito difícil para ele sozinho arcar com os custos relacionados a arame, mourões e mão de obra quando ele divide com seu vizinho digamos $7 \mathrm{~km}$ de cerca.

O ideal para ele é dividir os custos pela metade. Ele constrói 3,5 km de cerca e seu vizinho o restante, mas isto nem sempre é possível. Algumas vezes o vizinho não tem recursos para dividir o custo, e em outras situações a negociação demora e um dos fazendeiros ou terá que construir mais da metade da cerca ou terá que entrar com mais recursos (mão de obra ou arame ou mourões) se não quiser perder cabeças de gado. Ou seja, a transação é uma soma não zero em termos gerais, pois os dois pecuaristas saem ganhando quando cooperam ( $\mathrm{H0}$ ). Nenhuma deles teve que arcar com os custos de construir a cerca sozinho. Porém, existe uma negociação. $O$ ideal dos dois vizinhos seria arcar com a metade, que é um valor de mediana entre arcar sozinho ou simplesmente repassar o custo total para o vizinho. No espaço de discussão racional que existe entre arcar com a metade da cerca ou parte dela, os vizinhos jogam um jogo de soma zero. O ganho de um representa a perda do outro.

Na utilização da teoria dos jogos para estudar problemas de ação coletiva, a tragédia dos comuns, problemas de pescador e dilemas sociais não podemos esquecer que, embora a teoria dos jogos defenda o princípio da maximização da utilidade, regra de decisão também expressa na 
microeconomia, os mecanismos psicológicos evoluídos operam fundamentalmente ocultos em nosso pensamento consciente (Kanazawa, 2001).

Tsebelis (1998) explora este argumento quando analisa casos em que um ator social, confrontado com uma série de escolhas, não segue a alternativa que parece ser a melhor, ou seja, as escolhas subótimas. A explicação de Tsebelis (1998) é que os atores não escolhem a alternativa aparentemente ótima porque estão envolvidos em jogos ocultos, ou seja, fatores contextuais ou institucionais têm uma importância predominante. Brosnan \& de Waal (2002) discutem casos parecidos e defendem que o estudo do altruísmo recíproco requer atenção de explicações evolucionistas e de mecanismos próximos.

A investigação em questão constituiu uma pesquisa exploratória e, por isso, apresenta algumas limitações. Seria importante entrevistar os pecuaristas que não são membros do sindicato rural para verificar que estratégias eles desenvolvem para resolver alguns dos paradoxos de ação coletiva que eles enfrentam.

E em relação aos pescadores profissionais, seria interessante explorar uma hipótese que emergiu da coleta de dados: parece que quando enfrenta situações em que ele não consegue controlar, mesmo aqueles pescadores que só gostam de pescar sozinhos (a) optam por jogos de soma não zero. E que situações são essas? Ter de pescar a noite, quando o rio está cheio, ter de se deslocar grandes distâncias que exigem, entre outras coisas, que eles acampem.

\section{AGRADECIMENTOS}

Os dados aqui apresentados foram coletados por uma pesquisa financiada pelo MCTIC e administrada pelo Centro de Pesquisa do Pantanal (CPP).

\section{REFERÊNCIAS BIBLIOGRÁFICAS}

Alcock, J. (1998). Animal Behavior, Massachussetts: Sinauer Associates, Inc. Publishers.

Alencar, A. \& Yamamoto, M. E. (2008). “A teoria dos jogos como metodologia de investigação científica para a cooperação na perspectiva da psicologia evolucionista", Psico, V.39, n.4, pp. 522-529, out./dez.

Axelrod, R. (1986). The Evolution of Cooperation, Ney York: Basic Books, Inc., Publishers.

Axerold, R., \& Hamilton, W.D. (1981). “The evolution of cooperation”, Science, 211, 1390-1396.

Becker, H. (1956). Man in reciprocity, New York: Prager.

Bierstedt, R. (1957). The Social Order, New York: McGraw-Hill. 
Boudon, R. \& Bourricaud, F. (1993). Dicionário Crítico de Sociologia, São Paulo: Editora Ática.

Brosnan, S. F. \& de Waal, F. B. M. (2002). "A proximate perspective on reciprocal altruism”, Human Nature, Vol. 13, N.1, pp.129-152.

Cosmides, L \& Tooby, J (1992). “Cognitive adaptations for social exchange”, Barkow, J \& Cosmides, L. \& Tooby, J. (1992) - The Adapted Mind, New York/Oxford: Oxford University Press.

Fehr, E. \& Leibbrandt, A. (2011). "A field study on cooperativeness and impatience in the tragedy of the commons", Journal of Public Economics, Vol.95, Issues 9-10.

Gordon, H.S. (1954). "The economic theory of a common-property resource: the fishery", J.Polit.Econ, 62: 124-142.

Gouldner, A. (1960). "A norm of reciprocity: a preliminary statement", American Sociological Review, Vol.25, No.2, Apr.

Hamilton, H. (1964). "The genetical evolution of social behavior", Parts I, II. Journal of Theoretical Biology, 7, 1-52.

Hardin, G. (1968). “The Tragedy of Commons”, Science, 162, 1243-1248.

Heckathorn, D. D. (1996). "The dinamics and dilemmas of collective action", American Sociological Review, Vol.61 (April: 250-277).

Hopcroft, R. (2010). Sociology - A Biosocial Introduction, London: Paradigm Publishers.

Horton, P. \& Hunt, C. (1980). Sociologia, São Paulo: McGraw-Hill.

Kanazawa, S. (2001). "Where do social structures come from?" Advances in Group Process, volume 18, pages 161-183.

Krebs, N.B. \& Davies, N.B. (1996). Introdução a Ecologia Comportamental, São Paulo: Atheneu.

Kollock, P. (1998). "Social dillemas: the anatomy of cooperation", Annual Review of Sociology, 24, 183214.

Levine, D. M. et al. (2008). Estatística: teoria e aplicações. Rio de Janeiro: LTC.

Martin, J. L. (2009). Social Structures, Princeton: Princeton University Press.

Maynard Smith, J. (1982). Evolution and Theory of Games, Cambridge: Cambridge University Press.

Oliver, P. (1993). "Formal models of collective action", Annual Review of Sociology, Vol.19, pp.271300.

Olson, M. (1999). A Lógica da Ação Coletiva. São Paulo: EDUSP.

Penn, D.J. \& Mysterud, I. (2007). Evolutionary Perspectives on Environmental Problems, New Brunswick/London: Aldine Transaction. 
Pfeiffer, T. et al. (2005). "Evolution of cooperation by generalized reciprocity", Proc. R. Soc. B, 1151120.

Pinker, S. (2013). Os Anjos Bons da Nossa Natureza, SP: Companhia das Letras.

Smith, E. A. (2003). "Human Cooperation - Perspectives from Behavioral Ecology”, in Hammerstein, P. (Editor), Genetic and Cultural Evolution of Cooperation, London: The Mit Press.

Trivers, R. (1971). "The evolution of reciprocal altruism", Quarterly Review of Biology, 46, 35-57.

Tsebelis, G. (1998). Jogos Ocultos, SP: Edusp.

Turner, J.H. (2000). Sociologia - Conceitos e Aplicações, São Paulo: Makron Books.

Vila Silva, J. dos S. \& Abdon, M.M. (1998). "Delimitação do pantanal brasileiro e suas sub-regiões", Pesq. Agropec. Bras., Brasília, v.33 Número Especial, p.1703-1711.

Voland, E. (1993). Elementos de Sociobiologia, Lisboa: Instituto Piaget.

Von Neumann, J. \& Morgenstern, O. (2004). Theory of Games and Economic Behavior, Princeton: Princeton University Press.

Wrigt, R. (2000). Não Zero, RJ: Editora Campus. 


\section{Capítulo 32}

\section{MULHERES NA ECONOMIA SOLIDÁRIA: MOTIVAÇÕES, DESAFIOS E PARTICIPAÇÃO NA REDE MATA ATLÂNTICA NO TERRITÓRIO BAIXO SUL DA BAHIA}

DOI: $10.37423 / 200400579$

Adriana Vilas - Bôas Borges (Doutoranda do Programa de Pós-Graduação em Estado e Sociedade da Universidade Federal do Sul da Bahia/UFSB).

adrianaguerrieri@hotmail.com

Sandra Adriana Neves Nunes (Doutora em Psicologia pela Universidade Federal de Santa Catarina. Professora adjunta da Universidade Federal do Sul da Bahia (UFSB), do Centro de Formação de Tecnologias Ciências e Inovação e do Programa de Pós-Graduação em Estado e Sociedade - PPGES).

Carlos Henrique Leite Borges (Doutorando do Programa de Pós-Graduação em Estado e Sociedade da Universidade Federal do Sul da Bahia/UFSB e Professor Assistente do Departamento de Ciências Econômicas da Universidade Estadual deSanta Cruz/UESC).

chlborges@uesc.br

RESUMO: objetivo deste estudo foi investigar o que levou as mulheres da Rede Mata Atlântica no Território Baixo Sul da Bahia a fazerem parte de um Empreendimento de Economia Solidária, bem como identificar as suas principais dificuldades de permanência nesses empreendimentos. Os procedimentos metodológicos foram pesquisas exploratória, descritiva, por meio de instrumento de questionários. 
As conclusões apontaram um panorama das condições socioeconômicas das mulheres pesquisadas e demonstraram que a participação das que fazem parte dos EES está ligada a alternativa ao desemprego, necessidade de possuir renda, promover o sustento da família e para complementar a renda. Assim, nos contextos das relações entre capital e trabalho e a falta de oportunidades que acentua quadros de desigualdades e exclusão social, as mulheres buscaram alternativas de sobrevivência através da participação em EES.

Palavras-chave: Economia Solidária; Participação Feminina; Dilemas; Desafios. 


\section{INTRODUÇÃO}

O campo de investigação da Economia Solidária é vasto, complexo e tem sido objeto de crescente interesse por parte de pesquisadores. De modo geral, como pano de fundo de qualquer discussão em torno do tema está a noção de que o modo de produção de uma sociedade determina sua organização em classes e que a organização em classes determina como se darão as relações sociais entre as pessoas e entre essas classes, condicionando as práticas culturais e as formas de subjetividade na sociedade. Dessa forma, a partir de uma perspectiva mais sociológica, discutir a Economia Solidária envolve pensar formas alternativas de produção econômica que potencialmente geram novas formas de se relacionar, de produzir culturas e modos de subjetivação na sociedade.

Do ponto de vista conceitual ela pode ser compreendida a partir de diversas abordagens que suscitam múltiplas definições, como atividades econômicas organizadas coletivamente pelos trabalhadores, os quais, de forma associada praticam a autogestão de seus empreendimentos. Ou ainda, como uma proposta de trabalho e de vida que visa transpor a lógica da acumulação capitalista por meio do estabelecimento de relações solidárias e cooperativas, levando em conta a dimensão humana e considerando o contexto socioambiental (SINGER, 2002).

Nas últimas décadas a Economia Solidária tem sido considerada por diversos autores como "uma outra economia possível", principalmente no que diz respeito ao enfrentamento aos vários problemas econômicos e sociais que afetam famílias e pessoas ao redor do mundo e, assim, vem sendo encarada de forma plural. Dentro dessa perspectiva, a economia solidária insere-se em um quadro mais amplo de movimentos de resistência e transição civilizatória, social e ecológica (ESCOBAR, 2015) e oferece instrumentos emancipatórios e de luta contra a exclusão social, a exploração do trabalho humano e reforçando o combate aos efeitos negativos do capitalismo. Assim, em busca de respostas aos variados desafios da inclusão social digna e ao resgate do trabalho como suporte identitário por meio da economia solidária, um novo contexto baseado no trabalho associativo e cooperado tem permeado a construção e produção, de práticas que valorizam a autonomia e a solidariedade, constituindo pessoas e comunidade de aprendizagem no trabalho em suas variadas formas, inclusive as invisibilizadas.

No entanto, conforme mostram estudos já conduzidos no Brasil e no exterior (GAIGER, 2004; SANTOS; RODRIGUEZ, 2002) inúmeros obstáculos dificultam o desenvolvimento dos propósitos ligados ao campo da economia solidária, apesar das evidências dos modos solidários de produção, distribuição e 
consumo demonstrarem potencialidades positivas e também gerar novos processos de subjetivação num sentido emancipatório.

O caráter contraditório das relações sociais na contemporaneidade abre espaços para que distintos atores sociais busquem oportunidades para o encaminhamento de suas demandas, incluindo aqueles que se vêem sem possibilidades de inclusão digna no mercado de trabalho predominantemente capitalista. É neste cenário, que emerge o debate acerca da mulher enquanto protagonista de iniciativas e experiências solidárias e a contribuir na construção de caminhos que as tem tornado sujeitos políticos, participativos e empoderados, ressignificando seus papéis na superação da exclusão e a invisibilidade social. Neste sentido, neste trabalho buscou-se investigar os principais dilemas e desafios da participação das mulheres nos Empreendimentos Econômicos Solidários (EES) na Rede Mata Atlântica do Território Baixo Sul da Bahia, bem como identificar o que as levou a fazer parte de um empreendimento solidário e suas principais dificuldades de permanência. Ademais, descreve as condições socioeconômicas dessas mulheres e como estas condições influenciam diretamente nos principais desafios a serem enfrentados na condução de suas atividades produtivas.

A emergência das discussões acerca do papel da mulher no contexto da economia solidária, das potencialidades emancipatórias que contribuem para a construção de uma sociedade mais igualitária e democrática, através de um modelo que supere o economicismo, leva em consideração aspectos de sustentabilidade social, política, cultural e ambiental, por meio da ressignificação dos papéis da mulher, da reescrita de suas trajetórias de socialização, em consonância com o pressuposto de que o trabalho coletivo não se constitui apenas como gerador econômico, mas, sobretudo, através de novas sociabilidades, identidades e subjetividades, bem como do enfrentamento às contradições inerentes ao modo de acumulação capitalista.

Apesar de muitos autores, estudos e correntes acerca da economia solidária apontarem para um sentido de alternativa de produção de via emancipatória e de inclusão dos sujeitos, conforme será apresentado neste artigo, nem sempre as práticas e experiências vivenciadas pelos atores envolvidos com as atividades associadas e cooperadas demonstram uma emancipação de fato. Muitas vezes empreendimentos e empreendedores solidários surgem e realizam escolhas por este tipo de atividade produtiva como alternativa de sobrevivência familiar, como alternativa ao desemprego e complementação de renda, o que traz à luz reflexões e indagações sobre se, de fato, a Economia 
Solidária e suas Políticas têm se tornado instrumentos de emancipação e inclusão social para os atores sociais, grupos e comunidades que atuam com este tipo de atividade produtiva.

Este estudo está organizado em seis seções iniciando por esta introdução, em seguida discorre sobre as múltiplas abordagens da Economia Solidária, seus conceitos e estratégias de desenvolvimento; na terceira seção é feita uma abordagem sobre as mulheres, subjetividades e sua participação em atividades produtivas solidárias. A quarta seção traz os aspectos metodológicos do estudo, seguida da seção dos resultados e discussões e por fim na sexta seção as considerações finais.

\section{ECONOMIA SOLIDÁRIA: MÚLTIPLAS ABORDAGENS, CONCEITOS E ESTRATÉGIAS DE}

\section{DESENVOLVIMENTO}

O capitalismo se tornou dominante há tanto tempo que suas contradições e os efeitos delas advindos são naturalizados. A esse respeito, nada explicaria de forma mais esclarecedora senão o fato de existir um processo alienante imposto pelo capital aos indivíduos. Harvey (2018) explica que o processo alienante faz parecer que muitos dos poderes inerentes do trabalho e da natureza pertencem a ele e se originam dele, porque é o capital que lhes conferem significado. Até mesmo a mente e as funções corporais do trabalhador, assim como todas as forças naturais livremente investidas na produção, aparecem como poderes contingentes do capital, porque é ele que as mobiliza, dessa forma, “...a alienação da relação com a natureza e com a natureza humana é, portanto, uma pré-condição para a afirmação da produtividade e dos poderes do capital" (Idem, p.201).

Singer (2002, p. 8) alerta que "a apologia da competição chama a atenção apenas para os vencedores [...] estes acumulam vantagens e os perdedores desvantagens nas competições futuras". O autor questiona o que acontece com empresários e empregados, por exemplo, de empresas que quebram? Empresários que falidos não possuem capital próprio, tampouco crédito em bancos, bem como pretendentes a emprego que ficaram desempregados por longos períodos e que já não possuem a mesma chance de serem aceitos por diversos fatores como qualificação idade, experiência, etc (Idem). Portanto, pode-se perceber o quanto são crescentes as desigualdades produzidas pelo capitalismo, como também a polarização entre os "ganhadores" e os "perdedores", de acordo com os critérios desse sistema.

Diversos autores têm se debruçado sobre estudos voltados a outras economias que oferecem alternativas concretas ao modo de desenvolvimento economicista e submetido ao capital. Alternativas 
estas baseadas na solidariedade. Dentre eles, destaca-se Paul Singer, considerado um dos principais autores brasileiros que aborda o conceito da Economia Solidária. De acordo com Singer, esse conceito casa o princípio da "unidade entre posse e uso" dos meios de produção e distribuição [...] com o "princípio da socialização destes meios" (SINGER, 2000, p. 13). Ainda, de acordo com o mesmo autor, “é uma criação em processo contínuo de trabalhadores em luta contra o capitalismo"(Idem, ibidem).

Euclides Mance (2000) discorre sobre a Economia Solidária por meio da proposta de um modelo alternativo ao mercado capitalista, em forma de redes interligadas e interdependentes, pautada nos princípios da cooperação e solidariedade, cujas redes de colaboração solidária poderiam se retroalimentar através dos produtos próprios, desenvolvidos e disponibilizados, onde o consumo dos produtos que possuem a mesma qualidade que similares, independente do preço fossem consumidos pelos seus membros, promovendo assim o bem viver da coletividade. Esse bem viver poderia ser traduzido em termos de manutenção dos empregos, redução das jornadas de trabalho e preservação dos ecossistemas, por exemplo.

Para Lima (2013) a Economia Solidária deve ser entendida como uma proposta de trabalho e de vida que visa transpor a lógica capitalista, diante das fragilidades que tal sistema apresenta, por meio do estabelecimento de relações solidárias e cooperativas, levando em conta a dimensão humana e considerando o contexto sócio ambiental. Assim, entende que devem ser consideradas outras formas de desenvolvimento econômico e social que vão além do modelo do trabalho assalariado.

Outro autor que também se dedica aos estudos e pesquisas no campo da Economia Solidária é Luís Inácio Gaiger, cujas ideias convergem para a defesa de iniciativas de Economia Solidária denominadas por ele de empreendedorismo popular, é uma das formas mais ambiciosas e promissoras de organização de setores populares. Nessa modalidade de economia se criam alternativas sustentáveis de geração de trabalho e renda, apoiados na autogestão, democracia interna, igualitarismo, cooperação, autossustentação, desenvolvimento humano e responsabilidade social, uma vez que o compromisso com o todo social é realizado através de práticas geradoras de efeito irradiador e multiplicador (GAIGER, 2004).

Alguns autores trazem uma abordagem antropológica da economia solidária e, neste caso, divergem das perspectivas puramente economicistas e levam em consideração outros aspectos do comportamento econômico, levando em consideração aspectos que alimentam uma pluralidade da economia não reduzindo as atividades econômicas unicamente ao princípio mercantil, por meio de 
um mercado autorregulável que funciona apenas através da oferta e da procura acentuando as invisibilidades que a economia puramente mercantil pode provocar ficando visível somente o modo de produção capitalista, enquanto que são invisibilizadas (especialmente no caso das mulheres) outras formas de organização da vida material, como, por exemplo, a domesticidade, as relações reciprocidade, a cooperação, dentre outros (POLANYI, 2012; HESPANHA; SANTOS, 2016). Portanto, percebe-se que a Economia Solidária pode ser compreendida a partir de diversas abordagens que suscitam múltiplas definições, o que a torna um conceito complexo, multifacetado e em constante construção.

A análise dessas abordagens permite identificar diferentes experiências humanas relacionadas às distintas formas de economia existentes, algumas considerando-a como atividade econômica que vai além do mercado e além do monetário, outras apresentando-a como uma alternativa nas relações de trabalho, emprego e renda, ou como alternativa de estilo de vida ou, ainda, como um novo modelo de convivência social. No entanto, também é possível identificar, como fruto do esforço de análise, algumas características comuns a todas as abordagens e definições apresentadas pautadas na cooperação, democracia, participação, autonomia, solidariedade e autogestão.

\section{A MULHER, SUBJETIVIDADES E SUA PARTICIPAÇÃO EM ATIVIDADES PRODUTIVAS SOLIDÁRIAS.}

O caminho percorrido pelas recentes pesquisas tem direcionado o campo da Economia Solidária a conhecer e tentar compreender o sujeito que se constitui nos processos autogestionários de trabalho, fortemente impregnado nos princípios da economia solidária, como um contexto em construção, no qual circulam discursos e produzem-se práticas que valorizam a autonomia e a solidariedade, buscando a constituição de uma comunidade de aprendizagem no trabalho, como também as relações que se estabelecem os modos de trabalhar, as emoções, cognições, papéis e ações dos sujeitos (VERONESE, 2005).

Sobre esses aspectos Tittoni (1994, p. 29) salienta a importância da vivência, como a dimensão subjetiva da experiência, ressaltando que os significados atribuídos à experiência de trabalho compõem a maneira como o sujeito apreende e expressa seu recorte singular do mundo, vivenciandoo no espaço da subjetividade e sendo assim, "existe uma dinâmica da construção da cultura que está vinculada, de modo direto, às experiências vividas em um determinado momento". A análise dos processos de subjetivação não pode ser dissociada de uma análise societal, tampouco sócio histórica, 
que possa contextualizar o momento e o espaço-tempo onde as relações sociais e as subjetividades são produzidas.

Dentro deste cenário abrem-se parênteses para as discussões acerca dos processos de subjetivação, bem como da participação feminina no contexto solidário, uma vez que as mulheres cada vez mais têm conquistado espaço em atividades cooperadas e associativas ligadas à Economia Solidária. As projeções em números de mulheres atuando em empreendimentos solidários têm crescido consideravelmente, levando-as a um patamar de participação cada vez maior nos espaços públicos e coletivos e, assim, tornando-as protagonistas das suas histórias, promovendo a (re) significação de seus papéis e obtendo o reconhecimento do seu trabalho.

A presença das mulheres na Economia Solidária, inclusive à frente dos EES, tem trazido reflexões acerca do papel da mulher na geração de vínculos econômicos e sociais, como também no reconhecimento e na construção da sua própria cidadania e daqueles que as circundam. Traz reflexões sobre como essas mulheres podem atuar como agentes de desenvolvimento, buscando valorização social e produtiva, além de reelaborem a autoestima feminina, processos de autonomia e capacidade de influência e um novo status de participação política e social (TOURAINE, 2007).

Com efeito, a participação das mulheres nos EES e atividades ligadas a Economia Solidária nos últimos anos tem sido bastante expressiva e de acordo com Lima e Soares (2011), o aumento dessa participação nessas atividades tem se dado principalmente em função da divisão sexual do trabalho, em que, tais mulheres buscam o enfrentamento da redução da invisibilidade e da marginalização produtiva. Dessa forma, a Economia Solidária sugere o rompimento da divisão social do trabalho, bem como também criar espaços de socialização mais amplos, calcados em uma proposta democrática e no estabelecimento de novas formas de distribuições da riqueza como bases para uma economia e uma sociedade mais justa e solidária, buscando assim a construção de relações horizontais nas esferas de produção e distribuição, fazendo com que se exercitem novas práticas e convivências de igualdade e autonomia para as mulheres. Tais valores têm como foco possibilidades para construção de relações de gênero mais igualitárias no mundo do trabalho (LIMA; SOARES, 2011).

Bonumá (2015) aponta a participação das mulheres na economia solidária, em especial em espaços de comercialização e representação, que tem aumentado gradativamente. Elas compõem parte dos membros associados desses empreendimentos demonstrando a sua relativa participação nestes espaços. No entanto, ainda é pouco visível a participação dessa mulher nos cargos de diretoria dos 
empreendimentos, de acordo sua pesquisa, através de dados apontados pelo SIES entre os anos de 2007 a 2015. Segundo a mesma autora, por meio desses dados que foram disponibilizados pelo SIES, as mulheres predominam nos EES, principalmente quando se trata de grupos menores e nos informais, já os homens predominam mais nas cooperativas e empresas solidárias maiores e formalizadas.

Outro ponto que suscita discussão é que apesar da crescente participação da mulher em atividades ligadas a economia solidária e, além do que já foi citado, no que diz respeito à sua tímida participação nos cargos de diretorias de EES, e de sua participação em empreendimentos menores, há ainda a questão do cuidado com os filhos no horário de trabalho, a falta de contribuição dos esposos ou companheiros, sendo elas obrigadas a levarem os filhos para o EES ou contar com as redes informais de parentesco e vizinhança (Idem).

Contudo, grande parte dessas mulheres são responsáveis por importante fatia da renda para sustentar a família, isso quando não ocorre de ser a principal e única renda familiar.

Assim, ao se empreender discussões acerca da mulher a partir do lugar da divisão sexual do trabalho e das questões que permeiam as relações de gênero, também no contexto da Economia Solidária, pode-se perceber que ainda que sejam considerados tímidos os ganhos financeiros, bem como a sua participação em cargos vistos como de importância e visibilidade junto aos EES (BONUMA, 2015; LIMA; SOARES, 2011; VERONESE, 2015; TOURAINE,2007), a participação feminina nos espaços solidários tem proporcionado outras conquistas como os sentimentos de inclusão social, de engajamento, de emancipação, pertencimento, dentre outros, capazes de ressignificar suas vidas e trazer-lhes autonomia e novas perspectivas por meio da cooperação e da solidariedade.

\section{ASPECTOS METODOLÓGICOS}

O tratamento metodológico considerou a pesquisa tanto exploratória quanto descritiva, de acordo com os objetivos. Quantos aos procedimentos foram utilizadas técnicas quantitativas para coleta e análise dos dados. $O$ instrumento de pesquisa foi um questionário semiestruturado, aplicado a 33 Empreendimentos Econômicos Solidários que integram a Rede Mata Atlântica no Território Baixo Sul da Bahia, em que foram selecionados de três a cinco entrevistados de cada empreendimento, de acordo com a acessibilidade aos pesquisados, totalizando 80 participantes. A análise dos dados foi realizada a partir de um recorte voltado ao público feminino que compunha a amostra, o que totalizou 58 mulheres pesquisadas. Um recorte também foi feito para selecionar dentre as questões contidas 
no questionário, aquelas que indicam as motivações em fazer parte e permanecer em um EES e, também, questões que tratam o tipo de atividade desenvolvida, tipo do empreendimento, zona de atuação e formas de comercialização, dentre outras. Além disso, foram também selecionados dados socioeconômicos e demográficos das participantes, permitindo assim apresentar um perfil das mulheres que compõem a rede de empreendimentos solidários no território estudado.

Também foram utilizados dados secundários a partir de fontes oficiais, o que permitiu identificar no Território Baixo Sul da Bahia um quadro de desalento em relação aos indicadores sociais no que se refere à vulnerabilidade social, educação, qualificação profissional e oportunidades de trabalho, renda e emprego (IBGE, 2016; BAHIA, 2016; PNUD, 2010).

\section{A PRESENÇA DA MULHER E O TRABALHO NA ECONOMIA SOLIDÁRIA NO BAIXO SUL DA BAHIA}

Ao realizar a análise descritiva dos dados, a primeira constatação a chamar atenção foi a expressiva participação das mulheres nos EES que compõem a Rede no Território estudado, representando 72,5\% da amostra, enquanto a proporção de homens foi da ordem de 27,5\%. A despeito das circunstâncias que forçam mulheres a ingressar no setor produtivo sob condições precárias e de forma não espontânea, a participação e o engajamento das mulheres nos EES são destacados como faz Culti (2004) ao enfatizar a expressividade e liderança das mulheres neste campo, assim como a sua representatividade em setores considerados como masculinos, contribuindo assim para desconstruir a ideia assimilada socialmente da superioridade masculina nas atividades laborais.

No Território estudado não foram encontrados em nenhuma base oficial, dados atualizados acerca da participação das mulheres nos empreendimentos solidários, muito menos o percentual de ocupação das mesmas em cargos de direção. Sobre esse aspecto é importante destacar que as últimas pesquisas e levantamentos feitos acerca de dados estruturais dos empreendimentos solidários no Brasil foi realizado entre os anos de 2010 e início de 2013, conforme aponta Relatório do IPEA sobre Análise das Dimensões Sócio estruturais dos Empreendimentos Solidários no Brasil, publicado no ano de 2017 (SILVA, 2017). O fato é que por estar defasado, o banco de dados pode não retratar a atual realidade sobre os empreendimentos solidários no país, bem como no território estudado, uma vez que esta base de dados deixou de ser alimentada desde 2013. Para piorar, no Governo Temer os investimentos na Pasta da Economia Solidária foram diminuídos e a situação se agravou ainda mais com a extinção da Secretaria Nacional de Economia Solidária. Os dados então, deixaram de ser atualizados. 
No entanto, de fato, cada vez mais é perceptível a inserção do público feminino no desenvolvimento dessas atividades e esse dado tem se expressado desde o I Encontro Nacional de Empreendimentos de Economia ocorrido em Brasília em 2004, onde dos 2.500 participantes, 57\% eram mulheres, de acordo o Fórum Brasileiro de Economia Solidária (2004). Apesar da participação das mulheres em cargos diretivos e de mulheres sócias serem consideradas tímidas em relação à participação masculina, dados retirados do SIES (2013) apontaram para um número de 1.481 mulheres na condição de sócias, superando os homens nesta mesma condição (1.293). Outro dado importante é que desde essa época o número de mulheres que ocupavam funções de direção ou coordenação do empreendimento já se fazia bastante significativo no território estudado, pois, dos 46 empreendimentos cadastrados no SIES (2013), o número de mulheres que ocupavam funções na direção e coordenação destes eram de 48 mulheres. No entanto, é importante destacar aqui, neste caso, que desde o ano de 2013, e após a extinção da Secretaria Nacional de Economia Solidária (SENAES), esses dados não foram mais atualizados nesta plataforma (SIES) o que pode comprometer a representação da realidade atual.

Para efeito de análise observa-se os dados coletados, a Tabela 1 apresenta de forma integrada as variáveis selecionadas e suas respectivas categorias, de modo a caracterizar o perfil e a inserção das mulheres nos EES pesquisados. Levou-se em conta a atuação do empreendimento de acordo com a zona, o tipo de EES (Cooperativa ou Associação), função diretiva, escolaridade, Renda familiar e atividade desenvolvida pelos EES. No tocante ao que foi discutido anteriormente, constatou-se que dentre os empreendimentos pesquisados a proporção de mulheres que assumem função diretiva foi de 34,5\%, o que não é um número ruim, pelo contrário, considerando os vários papéis e atribuições a elas vinculados. Contudo, considerando o número de mulheres pesquisadas (72,5\%) ser maior que os homens $(27,5 \%)$, quando se trata dos cargos diretivos dos empreendimentos, os homens lideram a ocupação desses cargos com $(65,5 \%)$, demonstrando que a função diretiva dos cargos dos EES no território estudado ainda é predominantemente masculina. 
Tabela 1- Caracterização socioprodutiva associada a participação das mulheres nos EES da Rede Mata Atlântica no Território Baixo Sul, Bahia, 2019.

Continua...

\begin{tabular}{lcc}
\hline $\begin{array}{l}\text { Participação das mulheres de acordo com as } \\
\text { variáveis selecionadas }\end{array}$ & Participação/Frequência & Percentual válido \\
\hline Zona de atuação do empreendimento & & \\
\hline Rural & 44 & $75,9 \%$ \\
Urbana & 7 & $12,1 \%$ \\
Rural e Urbana & 7 & $12,1 \%$ \\
Total & 58 & $100,0 \%$ \\
\hline
\end{tabular}


Conclusão

\begin{tabular}{|c|c|c|}
\hline \multicolumn{3}{|l|}{ Tipo do empreendimento } \\
\hline Cooperativa & 6 & $10,3 \%$ \\
\hline Associação & 52 & $89,7 \%$ \\
\hline Total & 58 & $100,0 \%$ \\
\hline \multicolumn{3}{|l|}{ Função diretiva no EES } \\
\hline Sim & 20 & $34,5 \%$ \\
\hline Não & 38 & $65,5 \%$ \\
\hline Total & 58 & $100,0 \%$ \\
\hline \multicolumn{3}{|l|}{ Escolaridade } \\
\hline Primeiras Series do Ensino Fundamental $\left(1^{\mathrm{a}}\right.$ a $\left.4^{\mathrm{a}}\right)$ & 6 & $10,9 \%$ \\
\hline Últimas Series do Ensino Fundamental $\left(5^{\mathrm{a}}\right.$ a $\left.8^{\mathrm{a}}\right)$ & 13 & $23,6 \%$ \\
\hline Ensino Médio/Técnico incompleto & 10 & $18,2 \%$ \\
\hline Ensino Médio/Técnico completo & 20 & $36,4 \%$ \\
\hline Ensino Superior incompleto & 2 & $3,6 \%$ \\
\hline Ensino Superior Completo & 3 & $5,5 \%$ \\
\hline Pós-Graduação completo & 1 & $1,8 \%$ \\
\hline Total & 55 & $100,0 \%$ \\
\hline \multicolumn{3}{|l|}{ Renda familiar } \\
\hline Até 1 salário mínimo & 43 & $81,1 \%$ \\
\hline Mais de 1 e até 2 salários mínimos & 9 & $17,0 \%$ \\
\hline Mais de 2 até 3 salários mínimos & 1 & $1,9 \%$ \\
\hline Total & 53 & $100,0 \%$ \\
\hline $\begin{array}{l}\text { Participação das mulheres de acordo com as } \\
\text { variáveis selecionadas }\end{array}$ & Participação/Frequência & Percentual válido \\
\hline \multicolumn{3}{|l|}{ Atividade desenvolvida } \\
\hline Artesanato & 4 & $6,9 \%$ \\
\hline Cozinha produtiva & 8 & $13,8 \%$ \\
\hline Produção Agricultura Familiar & 13 & $22,4 \%$ \\
\hline Beneficiamento mandioca & 1 & $1,7 \%$ \\
\hline Outros & 2 & $3,4 \%$ \\
\hline Pluriatividade & 30 & $51,7 \%$ \\
\hline Total & 58 & $100,0 \%$ \\
\hline
\end{tabular}

Fonte: Dados da pesquisa, 2018.

A partir dos dados foi possível constatar que cerca $76 \%$ das mulheres estavam envolvidas em empreendimentos da zona rural, $13 \%$ atuando em EES da zona urbana e $11 \%$ em empreendimentos 
com atuação tanto na zona rural quanto na zona urbana. A Agricultura Familiar é predominante no território estudado e é também uma atividade que faz parte da maioria dos empreendimentos da Rede, onde estão localizados diversos assentamentos e comunidades quilombolas. Além disso, a maioria dos empreendimentos pesquisados estão fortemente vinculados aos programas PAA (Programa de Aquisição de Alimentos) e PNAE (Programa Nacional de Alimentação Escolar), do Governo Federal.

Do mesmo modo, os dados permitiram identificar que 89,7\% das mulheres estavam participando de empreendimentos constituídos como associações, o que reflete uma dependência ainda maior dos programas do PAA e PNAE, em comparação com as cooperativas. Apesar das associações serem formalizadas, ou seja, legalizadas, já que essa é uma necessidade para se ter acesso a recursos públicos e aos programas governamentais, as cooperativas, por sua vez, de acordo com a pesquisa, demonstraram ter uma maior organização, autonomia, rede de contatos de potenciais compradores para comercializar os produtos, além de serem formalizadas. Isso significa que as cooperativas podem fornecer para redes varejistas e atacadistas, entre outras, o que amplia o campo de comercialização. Além disso, muitas delas têm a possibilidade de fornecer notas fiscais, o que para a maioria dos clientes é uma condição necessária. No caso das associações, em decorrência da sua própria forma constitutiva, a impossibilidade de emissão da nota fiscal ainda é um dos principais fatores limitantes à comercialização.

Outra informação bastante relevante em relação às associações dos mais diversos tipos de atividades foi a observação de que muitas das associadas não demonstravam envolvimento com as atividades das associações. Ou seja, muitas não conheciam informações básicas sobre as ações desenvolvidas pelo governo em termos das políticas voltadas a apoiar os empreendimentos solidários, ficando essa informação muito mais centralizada no corpo diretivo do empreendimento (presidente, secretários, tesoureiros etc), e muitas vezes tais informações eram usadas como instrumento de "promoção" para alguns desses membros de direção, como se os incentivos, recursos, equipamentos, materiais adquiridos, entre outros, através dos programas e políticas de fomento à economia solidária tivessem sido disponibilizados por conta do "prestígio" de parte desses membros da direção. Essa estratégia, em alguns casos, tinha inclusive, intenções de uso político para exercer possíveis cargos públicos, como por exemplo, um possível cargo de vereador ou vereadora. 
Quanto ao nível de escolaridade, nota-se que a soma dos percentuais das mulheres que não chegaram a concluir o ensino médio totalizou $52,7 \%$, sendo que deste percentual a maior proporção (34,5\%) é formada por quem possui apenas o nível fundamental (completo e incompleto). Importa reconhecer que a baixa escolaridade ${ }^{1}$ verificada nos dados desta pesquisa está intrinsecamente vinculada ao contexto da educação básica dos municípios que compõem o território. A esse respeito, os resultados do IDEB - Índice de Desenvolvimento da Educação Básica para o Estado da Bahia no ano de 2017 indicam problemas sérios de qualidade da educação básica. Embora a projeção para o índice tenha sido estabelecida em 4,3, a nota média obtida foi de 3,0, ficando abaixo da média nacional que alcançou o valor de 3,8 no mesmo ano. Ainda mais grave e preocupante é o fato de que a Bahia obteve o pior índice de ensino médio do país e no Território Baixo Sul da Bahia os resultados suscitam preocupações ainda maiores por apresentar um valor médio de 2,5 (MEC/INEP, 2017). Tal fato permite inferir que o Estado enfrentará desafios enormes quanto à empregabilidade dessa massa de trabalhadores no futuro.

A formação escolar para a população é de fundamental importância, uma vez que é através da educação que os indivíduos podem buscar melhorias em termos de qualidade de vida, como também o pleno exercício da cidadania. Indicadores de renda mensal também estão associados ao grau de escolaridade dos trabalhadores, uma vez que quanto maior a escolaridade, maiores são as chances e oportunidades de emprego e melhores condições de salário e renda.

Sobre o envolvimento das mulheres com tipo de atividade socioprodutiva praticada, verificou-se as principais atividades foram a produção da Agricultura Familiar $(22,4 \%)$, cozinha produtiva $(13,8 \%)$ e artesanato $(6,9 \%)$ quando consideradas, de forma exclusiva, como única opção de inserção no trabalho associativo e solidário. No entanto, como é muito comum e cada vez mais, destaca-se o envolvimento das mulheres com várias atividades de forma simultânea e, disso decorrente, verificouse que $51,7 \%$ das mulheres estavam envolvidas nas mais diversas formas de ocupações produtivas (artesanato, cozinha produtiva, agricultura familiar, beneficiamento da mandioca etc.). Constata-se, neste caso, a ocorrência daquilo que tem despertado atenção principalmente nas unidades rurais que é a diversificação das atividades produtivas, o que é conhecido por pluriatividade.

Há que se notar que nas últimas décadas, um significativo número de mulheres se inseriu no mercado de trabalho, resultado das transformações econômicas e, também, culturais, uma vez que o trabalho feminino se restringia aos cuidados com o lar e educação dos filhos. Assim, diante de tais 
transformações, muitas mulheres passaram a ser também provedoras financeiras de seus lares, apesar das inúmeras desigualdades ainda por elas enfrentadas. Pode-se pensar que, após o surgimento da Economia Solidária como uma alternativa voltada àqueles e àquelas que ficaram excluídos do sistema produtivo capitalista, a possibilidade de reinserção de tais indivíduos, vítimas do desemprego, subemprego e da falta de renda para atender suas necessidades básicas, passa a se efetivar cada vez mais. Hespanha e Namorado (2009), a esse respeito, entendem que a economia solidária pode ser entendida como uma forma de os trabalhadores e trabalhadoras satisfazerem suas necessidades econômicas e de existência sem sucumbirem ao mercado ou a lógica da competição, podendo assim, ser entendida como uma forma de resistência política à imposição do mercado global.

Nesta direção, as mulheres têm despontado com efetiva participação e protagonizado iniciativas e experiências solidárias e construído caminhos que as tem tornado sujeitos políticos, participativos e empoderados, ressignificando seus papéis na superação da exclusão e a invisibilidade social.

No entanto, não podemos nos furtar de refletir que apesar da inserção produtiva das mulheres no mercado e também nas atividades solidárias, elas ainda enfrentam muitos obstáculos, principalmente os relacionados à questão de gênero diante de uma sociedade predominantemente machista. Mesmo nas iniciativas solidárias e com a sua expressiva participação e, a despeito de muitas vezes serem responsáveis pelo sustento e renda familiar derivada do trabalho associativo, as mulheres ainda representam menor número em alguns EES.

Sobre a comercialização dos produtos dos empreendimentos da Rede no território, a pesquisa constatou que a maior proporção dos empreendimentos $21,30 \%$ comercializam seus produtos em feiras livres dos municípios e na loja mantida pela Rede, 16,30\% comercializam apenas nas feiras livres dos municípios e 6,30\% somente na loja mantida Rede. O fator comercialização foi bastante citado durante a coleta de dados devido à grande importância dada pelas empreendedoras solidárias, uma vez que, na sua grande maioria, necessitam de ações e incentivos para que possam comercializar seus produtos, proporcionando assim inclusão produtiva, trabalho e renda. A importância da comercialização no âmbito da Economia Solidária é bastante significativa para os atores envolvidos por ser essa, em grande parte dos casos, a única forma de troca da qual os grupos dependem ou percebem.

No entanto, é importante ressaltar que outras formas de trocas podem ser contempladas e até encorajadas dentro dos preceitos da economia solidária, visando com que os empreendimentos não 
privilegiem exclusivamente a comercialização via mercado tradicional e aprisionados às trocas monetárias. Sobre este aspecto, Luís Inácio Gaiger (2004) e Euclides Mance (2000) descrevem as iniciativas de economia solidária voltadas a formas mais ambiciosas de organização dos setores populares, em que sejam levados em consideração os aspectos de igualitarismo, democracia e cooperação, por meio das alternativas de redes de cooperação, onde possam os empreendimentos estar interligados entre movimentos de consumo e de produção e não somente visando o dinheiro oficial. Parece pertinente aqui também, para referenciar neste contexto, as discussões empreendidas por Polanyi (2012) acerca dos princípios que alimentam a pluralidade da economia para além do mercado, baseados nos princípios de domesticidade, reciprocidade e redistribuição. De igual forma, são pertinentes as considerações de Santos e Hespanha (2016) sobre o alargamento epistemológico da economia quando propõem outras formas de realizar trocas econômicas, como por exemplo, as economias comunitárias, os clubes de troca, as moedas complementares e outras formas de se remunerar o trabalho.

Por fim, retornando aos dados da pesquisa, quando entrevistadas a respeito do que as levaram a fazer parte de um empreendimento solidário, as opções mais citadas, como mostra a Figura 1, foram assim distribuídas: "Complementar a renda familiar" (42 vezes mencionada); "como ideal de vida" (24 vezes citada); "sustentar a família" (23 vezes); "motivações filantrópicas e religiosas" (12 citações); "desemprego" (12 citações) e "incentivo público" (9 menções).

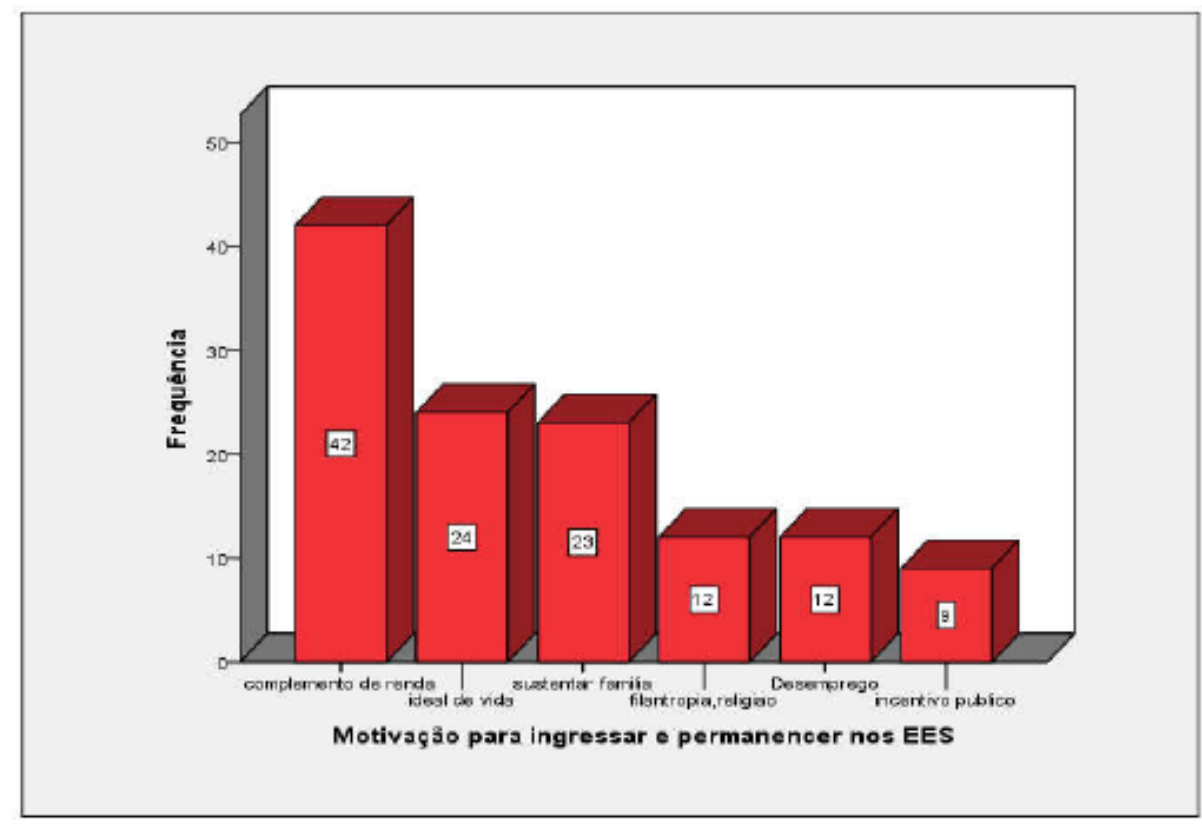

Figura 1 - Motivações para ingressar e permanecer em um EES, por frequência de resposta, na Rede Mata Atlântica de empreendimentos solidários, Território Baixo Sul, Bahia. 
Fonte: Dados da pesquisa.

Merece atenção o fato de que as condições economicas parecem ter sido determinantes para o ingresso dessas mulheres em atividades ligadas à Economia Solidária. Ao considerar o somatório das opções relacionadas ao complemento de renda familiar, ao sustento da família e ao desemprego, fica evidente que para os que estão em condição de pobreza ou afetados pela falta de trabalho e renda, a Economia Solidária signifa uma saída mesmo que transitória para reverter esse quadro de adversidades.Sobre esse aspecto é importante destacar que apesar das mais diversas correntes e estudos apontarem para a Economia Solidária como uma outra alternativa possível de via emancipatória, no caso da pesquisa, especificamente no território estudado, a práxis dos EES do Baixo Sul tem corroborado com iniciativas como respostas pontuais de grupos populares em situação de exclusão social, que reflete um paradigma de política pública no campo das relações de trabalho, conforme aponta Silva (2018).

O motivo "complemento de renda" como sendo o mais citado é revelador e ao mesmo tempo confirma o que a literatura e a experiência informam sobre a mulher cada vez mais impulsionada a contribuir ou se responsabilizar com o orçamento familiar. Os resultados apresentados na Tabela 1 reforçam o peso do fator econômico quando permitem percerber que cerca de $81 \%$ das mulheres pesquisadas informaram uma renda familiar de até um salário mínimo. Embora procupe o carater transitório e possivelmente descompromissado com os valores sociais e solidários, há de se reconhecer a importância da Economia Solidária mesmo sendo estas as condições motivadores pois se constitui como instrumento de superação da miséria. Ademais, pode representar uma alternativa viável e sólida de inclusão socioprodutiva com efeitos positivos e permanentes sobre o bem estar destas pessoas.

Diante disso, entende-se que o trabalhador vai procurar um "modus vivendi" (Wautier, 2013) vai tentar encontrar as atitudes mais adequadas para atender tanto à sua sobrevivência quanto suas expectativas no trabalho combinando interesses pessoais e coletivos. A partir dos resultados apontados pode-se concluir que diante dos contextos e das relações entre capital e trabalho e a falta de oportunidades que acaba por acentuar os quadros de desigualdades e exclusão social, as trabalhadoras, buscam alternativas de sobrevivência através da participação em empreendimentos solidários. Outro aspecto destacado nas falas das mulheres é que apesar das políticas públicas de Economia Solidária institucionalizadas no Estado da Bahia ainda são muitas as dificuldades para se permanecer em tais empreendimentos como, por exemplo, dificuldade de acesso a informações e ao crédito, a falta de investimentos no território pesquisado, a falta de continuidade de algumas ações 
de incentivo e fomento aos empreendimentos o que denota uma falta de atendimento da Política Pública de Economia Solidária do Estado aos anseios e necessidades de quem é assistido por ela.

\section{CONSIDERAÇÕES FINAIS}

Nos últimos anos o campo da Economia Solidária evoluiu e continua evoluindo, expressando diversas formas de organização econômica, seja na prestação de serviços, como também na produção, nas finanças, na comercialização, no consumo, bem como tem demonstrado a importância das discussões acerca da mulher no contexto da economia solidária, da produção de novas subjetividades, trajetórias, ressignificação de papéis e da sua participação em atividades associadas e cooperadas, do papel das mulheres na sociedade e de como a identidade a elas relacionada, apesar de não ser um movimento ou ação coletiva apenas de mulheres, tem ampliado o olhar sobre a Economia Solidária levando em conta as relações sociais de gênero, sua participação em EES e também sua presença como dirigentes nestes empreendimentos.

Por meio do estudo pode-se verificar os principais dilemas e desafios da participação das mulheres na Economia Solidária na Rede Mata Atlântica do Território Baixo Sul da Bahia, bem como o que as levou a fazerem parte de um empreendimento solidário na região,suas principais dificuldades de permanência em empreendimentos deste setor, como também foi possível descrever as condições sócio econômicas dessas mulheres que podem influenciar diretamente nos principais desafios a serem enfrentados por elas no desenvolvimento de suas atividades produtivas. Neste sentido, a pesquisa corrobora parte das informações da pesquisa nacional do SIES para o ano de 2013, quando sinaliza em um recorte local a expressiva participação das mulheres nos EES, inclusive ocupando cargos diretivos, contribuindo assim para a caracterização dessas trabalhadoras da Economia Solidária no Território Baixo Sul da Bahia.

Os dados secundários demonstraram que o Território de Identidade Baixo Sul da Bahia é carente, e possui um alto índice de vulnerabilidade social e extrema pobreza. Já os dados descritivos colhidos em campo por meio das entrevistas aos empreendimentos e às mulheres entrevistadas apontaram em relação à participação feminina nesses empreendimentos, uma expressiva participação em comparação à participação masculina. No entanto, não podemos nos furtar de refletir que apesar da inserção produtiva das mulheres no mercado e também nas atividades solidárias, elas ainda enfrentam muitos obstáculos, principalmente os relacionados à questão de gênero diante de uma sociedade predominantemente machista. 
Quando analisados os dados sobre o grau de escolaridade dos entrevistados pôde-se identificar que há uma baixa escolaridade entre os pesquisados no território e empreendimentos pesquisados. Os índices da educação básica no território apontam para uma má qualidade da educação básica o que indica uma reflexão dos desafios a serem enfrentados por aqueles que possuem uma parca escolaridade para gerirem seus empreendimentos, além de que é importante refletir sobre que é por meio da educação que mulheres e homens podem buscar melhorias em sua qualidade de vida, melhoria de renda e oportunidades mais igualitárias.

A pesquisa também apontou que a maior parte dos empreendimentos atuam na zona rural, tendo como atividade predominante a Agricultura Familiar, seguida de Cozinha Produtiva, o que demonstra uma diversificação e pluriatividade nos empreendimentos solidários pesquisados. Além disso, os empreendimentos comercializam seus produtos principalmente nas feiras livres dos municípios e na loja mantida pelo grupo/rede solidária.

Diante do principal objetivo do estudo, percebe-se que as principais motivações que levaram a maioria das mulheres a fazerem parte de um empreendimento solidário na rede estudada se deu por conta da alternativa ao desemprego, necessidade de possuir uma renda, necessidade de promover o sustento da família e para complementar a renda. Contudo, as mulheres também apontaram como fator de importância os valores, princípios e ideais que balizam a economia solidária como aspectos muito relevantes para que elas pudessem escolher as atividades ligadas ao associativismo e cooperativismo, como fonte de realização de trabalho, renda, emprego, produção de novas subjetividades, ressignificação de seus papéis e consolidação de novos laços econômicos e sociais.

A partir dos resultados apontados pode-se concluir que diante dos contextos e das relações entre capital e trabalho e a falta de oportunidades que acaba por acentuar os quadros de desigualdades e exclusão social, as mulheres apontaram que buscam alternativas de sobrevivência econômica, mas também criar novos laços, tentando superar a exclusão seja de gênero ou da divisão sexual do trabalho, bem como saírem dos processos de invisibilização a que são submetidas, por meio da participação em empreendimentos solidários. No entanto, segundo as mulheres entrevistadas na pesquisa, apesar das políticas públicas de Economia Solidária institucionalizadas no Estado da Bahia existem diversas dificuldades para que se permaneça em tais empreendimentos, a exemplo da falta de acesso a informações e ao crédito, falta de investimentos no território pesquisado e continuidade das ações de incentivo e fomento aos empreendimentos solidários. Infere-se, portanto que é 
necessário ampliar as ações de implementação de políticas públicas de Economia Solidária no Território.

\section{REFERÊNCIAS BIBLIOGRÁFICAS}

ABRAHIM, Gisele.S. et. al. As Estratégias dos Empreendimentos Solidários da Agricultura Familiar do Baixo Tocantins na Comercialização do Açaí Orgânico. In: Encontro Nacionalde Engenharia de Produção. A integração de cadeias produtivas com a abordagem da manufatura sustentável, 28. 2008, Rio de Janeiro. Anais... RJ: ENEPEG, 2008.

ARAUJO, Cíntia. R. M. de, CASTRO João Gabriel. S. Desafios Enfrentados pelos Empreendedores Sociais da Incubadora Pública de Empreendimentos Populares e Solidários de Osasco (IPEPS) para Consolidar seus Empreendimentos. Revista Administração em Diálogo, São Paulo, V.18, n.2, p.59-91, 2016.

BAHIA, SUPERINTENDÊNCIA DE ESTUDOS ECONOMICOS E SOCIAIS DA BAHIA (SEI). Perfil dos Territórios de Identidade da Bahia. Disponível

em:<https://www.sei.ba.gov.br/index.php?option=com_content\&view=article\&id=2000\&ltemid=28 4>. Acesso em: 25 Fev. 2019.

BONUMÁ, H. As Mulheres e a Economia Solidária: a resistência no cotidiano tecendo uma vida melhor.2015. 97 f. Trabalho de Conclusão de Curso - TCC (Ciências Sociais) Universidade Federal do Rio Grande do Sul, 2015. Disponível

em:<https://www.lume.ufrgs.br/bitstream/handle/10183/132849/000984396.pdf?>. Acesso em: 10 Nov.2018

BRASIL, MINISTÉRIO DA EDUCAÇÃO E CULTURA - MEC. Índice de Desenvolvimento da Educação Básica na Bahia - IDEB, 2017. In. Instituto Nacional de Estudos e Pesquisas Educacionais Anísio Teixeira/INEP, 2017. Disponívelem:<http://ideb.inep.gov.br/> Acesso em 06 Nov. 2018.

BRASIL Ministério do Trabalho e Emprego. Secretaria Nacional de Economia Solidária. Avanços e desafios para as políticas públicas de economia solidária no governo federal 2003/2010. Brasília, SENAES/MTE, 2013.

CULTI, Maria.N. Mulheres na Economia Solidária: Desafios Sociais e Políticos. IN. Congresso Europeu, 4, 2004. Bratislava-República Eslovaca Anais... Bratislava-República Eslovaca: CEISAL de Latino americanistas, 2004.

ESCOBAR, Arturo. Degrowth, postdevelopment, and transitions: a preliminary conversation. Sustainability Science, n. 10, p. 451-462, 2015.

GAIGER, Luiz. I.Sentidos e Experiências da Economia Solidária no Brasil.Porto Alegre: UFRGS, 2004.

HARVEY, David. A loucura da razão econômica Marx e o capital no século XXI. São Paulo: Boitempo, 2018. 
HESPANHA, Pedro; SANTOS, Luciane. L. dos. O nome e a coisa: sobre a invisibilidade e a ausência de reconhecimento institucional da economia solidária em Portugal. In: Revista de Economia Solidária. As relações entre Economia Solidária e o Estado. Portugal,n. 09,Junho 2016. p.22-65

LIMA, Maria.I.R. Economia Solidária e Vínculos. São Paulo: Ideias\&Letras, 2013.

LIMA, Girlani. de. SOARES, Maria. L. de. Mulheres, História e Saberes: construindo economia solidária. In: Estado Desenvolvimento e Crise do Capital, 23 a 26, 2011. Anais... V Jornada Internacional de Políticas Públicas, PPGSS/UFPB, 2011. Disponível em:<www.joinpp.ufma.br/...>. Acesso em: 22 de Nov.2018.

MANCE, Euclides.A.A. A Revolução das Redes: a colaboração solidária como alternativa pós capitalista à globalização atual. Petrópolis: Vozes, 2000.

POLANYI, Karl. A grande transformação: as origens de nossa época. 2. Ed. Rio de Janeiro: Elsevier, 2012.

PROGRAMA DAS NAÇÕES UNIDAS PARA O DESENVOLVIMENTO - PNUD. Atlas do Desenvolvimento Humano, 2010. Disponível em:<http//atlasbrasil.org.br>. Acesso em: 26 Out. 2017.

RUTKOWSKI, Jaqueline. Sustentabilidade de empreendimentos econômicos solidários: como garantir? In. Encontro Nacional de Engenharia da Produção: A integração de cadeias produtivas com a abordagem da manufatura sustentável, 28, 2008. Anais... Rio de Janeiro,

ENEPEG, 2008. Disponível em: < abepro.org.br/publicacoes/> Acesso em: 12 de Mar, 2018.

SINGER, Paul. Economia solidária: um modo de produção e distribuição. In: SINGER, Paul \& SOUZA, André R. de. A economia solidária no Brasil: a autogestão como resposta ao desemprego. São Paulo, Contexto, 2000.

. Introdução à economia solidária. São Paulo: Editora Fundação Perseu Abramo, 2002.

SILVA, Sandro. P. Análise da Dimensões Socioestruturais dos Empreendimentos de Economia Solidária no Brasil. Rio de Janeiro: IPEA, Texto para Discussão, 2017. p.7-57

Sandro. P. O campo de Pesquisa da Economia Solidária no Brasil: abordagens metodológicas e dimensões analíticas. Rio de Janeiro: IPEA, Texto para Discussão, 2018. p. 7-37.

TITTONI, Jaqueline. Subjetividade e trabalho. Porto Alegre: Ortiz, 1994.

TOURAINE, Alain. O mundo das mulheres. Tradução de Francisco Morás. Petrópolis: Vozes, 2007

VERONESE, Marilia.V. Psicologia social e economia solidária. São Paulo: Idéias\& Letras. 2007. 


\section{NOTAS}

\section{Notas 1}

Alguns pesquisadores têm feito referência à baixa escolaridade dos empreendedores solidários no Brasil (ABRAHIM et al., 2008; RUTKOWSKI, 2008; ARAÚJO; CASTRO, 2016). Esses autores, em geral, realizam uma reflexão acerca dos desafios que esses empreendedores enfrentam, dada a parca escolaridade, para se capacitarem tecnicamente como futuros empreendedores solidários. Rutkowski (2008), em outra frente de discussão, alerta para o fato que trabalhadores desprovidos ou com poucos anos de educação formal, são normalmente preparados para ser mão de obra absorvida pela indústria sob o risco, neste caso, de se transformar em peça da engenharia produtiva, dentro do modelo Taylorista-Fordista de produção. 


\section{Capítulo 33}

\section{VALORAÇÃO AMBIENTAL DO PARQUE ESTADUAL DO UTINGA - PA: ANALISANDO A DISPOSIÇÃO A PAGAR DOS USUÁRIOS}

DOI: $10.37423 / 200400585$

Leônidas Pompeu Leão Velloso (Doutor em Economia pela Universidade Federal do Pará (UFPA). Professor Adjunto da Universidade Federal Rural da Amazônia (UFRA).

Márcia Jucá Teixeira Diniz (Doutora em Desenvolvimento Sustentável do Trópico Úmido pelo Núcleo de Altos Estudos Amazônicos (NAEAUFPA). Professora Adjunta da Universidade Federal do Pará (UFPA).

Diogo Ferraz (Economista. Doutor em Engenharia de Produção pela Universidade de São Paulo (USP). Ph.D. candidate na Universidade de Hohenheim (Stuttgart/Alemanha). Professor Adjunto da Universidade Federal Rural da Amazônia (UFRA).

RESUMO: O Parque Estadual do Utinga - PEUT é uma unidade de conservação da natureza pertencente a categoria de proteção integral segundo o Sistema Nacional de Unidades de Conservação (SNUC) e com a responsabilidade de manter os mananciais de água que abastecem 70\% da Região Metropolitana de Belém - RMB. O PEUT vem sofrendo com as pressões da urbanização, gerando uma preocupação crescente para os usuários do Parque que no ano de 2018 aumentou significativamente em virtude da abertura do PEUT para visitação pública, após grande reforma. 
Não obstante, o desconhecimento dos benefícios gerados pelos serviços ecossistêmicos promovidos pelo PEUT influi na possibilidade de ações mais efetivas de preservação não só pelo poder público, mas também, da população em geral, seja ela frequentadora do parque ou que vive em seu entorno. Assim, tendo como pano de fundo esse cenário, o objetivo de pesquisa desta pesquisa, voltou-se a estimar o valor econômico do PEUT, tendo como aporte metodológico principal o método de valoração contingente. Nesta direção, foi calculada a disposição a pagar pelo parque através de metodologia benefício-custo e obteve-se um valor médio per capta de $\mathrm{R} \$ 15,75$ e, ainda, um Valor Econômico Total(VET) por sua preservação de R\$ 5.670.000,00/ano ao utilizar-se o Valor Presente Líquido(VPL), com um taxa de 4\% ao ano ao longo de 100 anos o VET é de R\$ 144.613.344,3 .

Palavras-chave: Amazônia, floresta, Unidade de Conservação. 


\section{INTRODUÇÃO}

O Parque Ambiental do Utinga (PEUT), representa uma área verde, cuja biodiversidade ali contida é capaz de oferecer preservação, conservação, lazer, educação ambiental e condições de despertar a consciência ambiental das pessoas que o frequentam.

O PEUT se encontra entre dois municípios da Região Metropolitana de Belém - RMB e apresenta importância significativa na manutenção dos mananciais que abastecem $70 \%$ dessa região metropolitana, além disso, por suas características é bastante representativa do ecossistema florestal do Bioma Amazônia, ocupando uma área de 1340 hectares.

Após um ano de abertura, a estimativa é de que o PEUT recebeu a visita de 600.000 pessoas, e o reconhecimento crescente da população da RMB da importância do PEUT, contrastam com as pressões direcionadas ao interior do Parque devido sua inserção na RMB. Assim, nesta direção, segundo Rocha (2011) o crescimento populacional da RMB, assim como o adensamento de empreendimentos imobiliários no centro urbano de Belém vem sendo vetorizado para as áreas periféricas da cidade, onde se esta localizado o PEUT. Ao mesmo tempo, como destaca Trindade (1998), o aumento da população urbana passa por um processo sincronizado com a mudança no modo de vida de grande parte da população, construindo assim um fenômeno de readaptação no viver das pessoas nas cidades. .

O crescimento do número de ocupações no entorno do PEUT aliado a ausência de saneamento básico e o desmatamento, compõem uma fórmula em que o resultado é a poluição dos cursos de água que serão despejados no PEUT e com isso prejudicando ainda mais a qualidade da água dos mananciais que abastecem a RMB e a vida dos animais e plantas que vivem no seu interior.

Diante das questões que envolvem as pressões sofridas pelo PEUT, destaca-se a preocupação com o bem-estar social, pois este é um princípio constitucional básico e um Parque ambiental tem condições plenas de contribuir para a geração deste princípio através de seus serviços ecossistêmicos. Liu et al. (2010) e Santana (2014) reportam a importância da valoração de reservas ambientais, e o mesmo pode ser dito em relação aos parques ambientais. Desse modo, o objetivo deste trabalho é por meio de um estudo de caso, obter como reposta a relação benefício-custo que a existência do PEUT gera para o bem-estar da população da Região Metropolitana de Belém, por meio de seu valor econômico total 
(VET) atribuído ao PEUT pela disposição a pagar (DAP) das pessoas e o VET obtido pelo preço da madeira e no mercado de crédito de carbono no parque.

Para responder estes questionamentos, recorreu-se a valoração de recursos naturais, com o uso da valoração contingente observando a disposição a pagar de pessoas que foram entrevistadas para informar sua percepção acerca do PEUT ser um ativo ambiental com grau significativo de importância.

\subsection{O PARQUE ESTADUAL DO UTINGA (PEUT)}

O PEUT ocupa um espaço de alta densidade urbana em seu entorno, ao passo que essa condição impõe riscos à biodiversidade e a vida da flora, da fauna e dos recursos hídricos através das fortes pressões antrópicas produzidas pela população do entorno.

O PEUT constitui um espaço rico de possibilidades para desenvolver pesquisas científicas, atividades culturais, recreativas, turísticas e educativas. A Biodiversidade é um destaque importante dentro do PEUT, com mais de 320 espécies identificadas da fauna Amazônica, com possibilidades de encontrar capivaras, preguiças, macacos, cutia, jacuruxi, diversas espécies de aves, répteis, anfíbios, borboletas e outros insetos. Possui a maior biodiversidade de peixes em parques em todo o mundo, com 90 espécies já catalogadas nos lagos Água Preta e Bolonha (PLANO DE MANEJO DO PEUT, 2015, p. 209).

Em relação a flora, predomina a floresta ombrófila densa de terra baixa, dividida em floresta de terra firme $(54,15 \%)$, floresta de igapó $(6,78 \%)$ e floresta secundária (4,33\%). Ainda conta a presença de vegetação aquática sobre os lagos Água Preta e Bolonha, que correspondem a quase $10 \%$ da paisagem, existindo cerca de 151 espécies de plantas identificadas, com predomínio de embaubarana, quaruba, breu, capuí, tatapirica, ucuúba, ingá, matamatá, entre outras. Esses dados atestam que a floresta do Parque Estadual do Utinga apresenta uma alta diversidade da flora, com um Índice de Diversidade de Shannon $H^{\prime}=4,1$, considerado um valor alto para florestas tropicais.

Também é possível encontrar uma grande diversidade animal no Utinga. São aproximadamente 400 espécies de animais mamíferos terrestres, aves, peixes, répteis e insetos. Algumas delas também estão ameaçadas de extinção, como as ararajubas, o gato-maracajá e o soin-preto. 


\section{MÉTODO}

\section{1 ÁREA DE ESTUDO E DADOS UTILIZADOS}

A população considerada nesse trabalho foi de 360.000 pessoas, este valor é referente a média do número de pessoas que visita o Bosque Rodrigues Alves que também fica na Região metropolitana de Belém e que apresenta características semelhantes ao PEUT. Usando um erro amostral de (5\%) e um nível de confiança de 95\%, obteve-se uma amostra de 319 questionários, entre homens e mulheres, por meio de

$$
n=\frac{N \cdot Z^{2} \cdot p(1-p)}{Z^{2} \cdot p(1-p)+e^{2} \cdot(N-1)}
$$

onde, $n$ : tamanho da amostra, $N$ : população; Z: variável normalmente padronizada associada ao nível de confiança (1,96); p: probabilidade do evento (50\%); e: erro amostral (5\%).

A aplicação dos questionários ocorreu justamente dentro do PEUT e nas comunidades do entorno informando os entrevistados os principais elementos que motivam a existência do PEUT e sua importância, cujo cuidado foi deixar bem informado o entrevistado para diminuir ao máximo alguns problemas já citados anteriormente por Carson et al. (2001, p. 17). Assim foi possível ter na pesquisa, indivíduos que percebam os serviços ecossistêmicos oferecidos pelo PEUT como forma de contribuição efetiva para o seu bem-estar, isso evita viéses de hipótese na pesquisa.

\subsection{MODELO ECONOMÉTRICO}

Para a realização dos objetivos desse trabalho foi utilizado o Método da Valoração Contingente (MVC), especificamente um método da função de demanda, indicado para valorar recursos não-comerciais, com a aplicação do método da Disposição a Pagar (DAP) (SANTANA et al., 2015, 2017).

A partir dos questionamentos e amostras coletadas, o modelo econométrico para DAP foi inicialmente composto a partir do modelo baseado em Santana (2014). Dessa forma, o MVC captou os efeitos socioeconômicos, ecossistêmicos e ambientais, mudanças de comportamento e propriamente econômicos, de acordo com as dimensões em estudo e gerou um Valor Econômico Total (VET) para os ativos naturais; a partir da equação de DAP (SANTANA, 1999; SANTANA et al., 2016, 2017):

$$
D A P=(D S E ; D A ; \alpha)
$$


onde, DSE: Dimensão socioeconômica; DA: Dimensão Ambiental; e $\alpha$ o vetor de parâmetros estimados (modelo baseado em SANTANA, 2014).

Para calcular a DAP utilizou-se o Modelo de Regressão Linear Múltipla, neste modelo pode ocorrer a não inclusão de algumas variáveis que geram erros nos valores dos parâmetros estimados por mínimos quadrados ordinários, dessa forma a influência dessas variáveis ausentes deve ser representada por uma componente aleatória $u_{i}$. O modelo empírico (com todos os pressupostos sendo satisfeitos) trabalhado nesta tese é o que segue abaixo:

$$
\begin{gathered}
D A P=c+b_{1} \text { sexo }+b_{2} \cdot \text { idade }+b_{3} \cdot e d u+b_{4} \cdot \text { Est }_{\text {civil }}+b_{5} \cdot \text { Atv }_{\text {pri }} \\
+b_{6} \text { renda }+b_{7} I A+b_{8} I E C O+u_{i}
\end{gathered}
$$

onde: DAP - variável dependente; Sexo, idade, edu, Estado civil, Atividade principal, renda, Indicador Ambiental, Indicador Ecossistêmico - variáveis explicativas; $u_{i}$ é o termo de erro aleatório; $e^{b(i=1,2, \ldots . ., 7)}$ é o vetor de parâmetros a ser estimado. C - é o intercepto ou valor médio de Y quando X1 e X2 forem iguais a zero; $b_{1}$ - Mede a mudança no valor médio de $D A P, E(D A P)$, resultante da variação unitária no sexo, mantendo-se as demais variáveis constantes; $b_{2}$ - Mede a mudança no valor médio de DAP, E(DAP) resultante da variação unitária em idade, mantendo-se as demais variáveis constantes. $b_{3}$ - Mede a mudança no valor médio de $D A P, E(D A P)$, resultante da variação unitária no edu, mantendo-se as demais variáveis constantes; $b_{4}$ - Mede a mudança no valor médio de DAP, E (DAP), resultante da variação unitária no est_c, mantendo-se as demais variáveis constantes; $b_{5}$ - Mede a mudança no valor médio de $D A P, E(D A P)$, resultante da variação unitária no Ati_principal, mantendose as demais variáveis constantes; $b_{6}$ - Mede a mudança no valor médio de $D A P, E(D A P)$, resultante da variação unitária na renda, mantendo-se as demais variáveis constantes; $b_{7}$ - Mede a mudança no valor médio de $D A P, E(D A P)$, resultante da variação unitária no IA mantendo-se as demais variáveis constantes; $b_{8}$ - Mede a mudança no valor médio de $D A P, E(D A P)$, resultante da variação unitária no IECO, mantendo-se as demais variáveis constantes;

\subsection{A CONSTRUÇÃO DO INDICADOR ATRAVÉS DA ANÁLISE FATORIAL EXPLORATÓRIA}

O modelo econométrico foi construído a partir da Análise Fatorial e da Regressão Múltipla. A Análise Fatorial Exploratória (AFE) foi usada para a construção do indicador ambiental (IA) e do indicador ecossistêmico (IECO) extraídos das variáveis que compõem a equação de DAP.

A construção do indicador é justificada pela demasiada quantidade de variáveis categóricas contidas na dimensão ambiental e na dimensão socioeconômica. Para essa redução foi aplicada junto a AFE a 
análise de componentes principais, corrigindo inclusive qualquer problema de forte multicolinearidade entre essas variáveis (SANTANA et al., 2016, 2017). Johnson e Wichern (2007) apontam que a AFE permite a redução das variáveis sem que haja perda significativa de informação; a AFE, portanto, permite agrupar as variáveis da dimensão ambiental em subgrupos de novas variáveis mutuamente não correlacionadas, denominadas de fatores (MINGOTI, 2013; SANTANA, 2007).

Assim, Os indicadores (IA e IECO) representando a percepção ambiental e ecossistêmica dos entrevistados no Parque Estadual do Utinga foi determinado pela combinação linear dos escores fatoriais e a proporção da variância explicada por cada fator em relação à variância comum, dada pela expressão dos escores fatoriais (SANTANA, 2007):

$$
I_{f a t}=\sum_{j=1}^{n}\left(\frac{\lambda_{i}}{\sum_{i=1}^{n} \lambda_{n}} F P_{i}\right) ;(i=1,2,3, \ldots . N)
$$

onde: I_fat5 representa os escores fatoriais; $\lambda$ representa a variância explicada por cada fator, $\sum \lambda$ é o total da variância explicada a partir dos fatores comuns; e I_ap é cada um dos escores fatoriais padronizados gerados para cada entrevistado e é dado por:

$$
I_{a p^{6}}=\left(\frac{F_{i}-F_{\min }}{F_{\text {máx }}-f_{\min }}\right) ;(i=1,2,3, \ldots, N)
$$

Onde F é um dos escores fatoriais padronizados; e representam, respectivamente, os valores máximos e mínimo observados para cada um dos entrevistados.

\section{RESULTADOS E DISCUSSÕES}

A correlação de Spearman, se mostrou significativamente positiva entre a renda e a Disposição a Pagar pela preservação, com o coeficiente apresentando o valor de $(\rho=0,261 ; p<1 \%)$, assim como o Indicador Ambiental (IA) , o mesmo teve um comportamento significativamente positivo em relação a disposição a pagar pelos serviços ambientais, com o coeficiente apresentando valor de coeficiente $(\rho=0,232$; p<1\%).Por sua ver o coeficiente de Spearman para relação entre o Indicador Ecossistêmico (IECO) e a DAP foi de 0,149; $p<1 \%$ ) e para a relação entre DAP e EDU aferiu o coeficiente em 0,292; $p<1 \%$ ). 


\section{1 - DIMENSÕES E INDICADORES}

A pesquisa utilizou na construção do modelo como já exposto acima dois indicadores, o primeiro foi o indicador ambiental que contemplou as questões envolvendo a percepção do entrevistado para a presença de animais de espécies raras, a existência do Parque como um fator de geração de conhecimento, o parque como um espaço de geração do bem-estar. O segundo indicador é referente ao parque como um espaço que de fator vem produzindo condições ecossistêmicas dentro de sua condição de existência, como influência na quantidade de chuvas na Região Metropolitana de Belém, sua real influência na mudança de hábito das pessoas, valorização imobiliária das áreas do entorno.

Os resultados da análise fatorial estão reunidos nas Tabelas 4 e 5 . As duas matrizes de correlação apresentaram determinantes diferentes de zero, logo admitem inversa e a solução resultante além de única é a que melhor representa o fenômeno (JOHNSON; WICHERN, 2007; SANTANA et al., 2014; FERREIRA et al., 2016). De acordo com os testes KMO de 0,711 e 0,787 (superior ao limite aceitável de 0,50 ) e os testes de esfericidade de Bartlett significativos a 1\%, a amostra adequa-se à análise fatorial. As cargas fatoriais estimadas apresentaram significância a 1\%, confirmando a adequação dos modelos. Todas as comunalidades situaram-se acima de 0,50, o que valida suas participações na definição dos fatores latentes (JOHNSON; WICHERN, 2007; HAIR JR et al., 2009). Por fim, os fatores extraídos nos dois modelos fatoriais explicaram mais de $60 \%$ da variância total dos dados. Sendo assim, considerase que o modelo foi bem especificado e os resultados revelam a realidade do fenômeno estudado.

\section{3 - INDICADOR AMBIENTAL}

Dentre as (13) variáveis (9) apresentaram comunalidades iguais ou superiores a 0,50, representando a contribuição de cada variável ao modelo construído pela AFE gerando três fatores. As explicações da variância total dos dados por cada fator encontradas foi para: F1 (25,34\%), F2 (23,84\%), F3 (20,45\%). A soma dessas variâncias dos fatores representa precisamente 69,64\%. Esses resultados demonstram que os resultados são apropriados para a realidade do fenômeno estudado e que o modelo está apropriado. O F1 aponta a presença de espécies como fator atrativo e de geração de conhecimento sobre o ecossistema Amazônico em destaque no PEUT, o F2 expressa a observação do entrevistado quanto a condição de cuidar da saúde no espaço do parque, uma menor poluição do ar promove melhor condição de caminhar, correr, pedalar, dentre outras práticas esportivas, o F3 aborda o PEUT como um espaço capaz de atrair pessoas pela sua fauna e flora em destaque. 
Tabela 4 - Matriz de cargas fatoriais do modelo representativo das condições ambientais do PEUT (2018).

\begin{tabular}{|c|c|c|c|c|}
\hline Variável & Fator 1 & Fator 2 & Fator 3 & Comunalidade \\
\hline Presença de espécies raras & ,867 & , 106 & , 110 & ,773 \\
\hline Presença de animais atrativos & ,866 & 012 & 128 & ,765 \\
\hline Conhecimento sobre Amazônia & 642 & 222 & 249 &, 523 \\
\hline Poluição do ar &, 114 & ,830 & 189 &, 767 \\
\hline Espaço para saúde & ,008 & ,806 & 233 &, 775 \\
\hline Valoriza o entorno &, 170 & 694 &,- 125 & ,526 \\
\hline Paisagem atrativa &, 182 & 052 & 859 &, 738 \\
\hline Preserva biodiversidade & 195 &, 155 & ,838 & ,705 \\
\hline Soma do Quadrado das Cargas & 2,027 & 1,908 & 1,637 & 5,571 \\
\hline Percentual do traço (\%) & 25,34 & 23,844 & 20,458 & 69,643 \\
\hline Adequação da amos & $=0,787$ & \multicolumn{3}{|c|}{ Batlett'stest $=1058,596(\mathrm{vp}<1 \%)$} \\
\hline
\end{tabular}

Fonte: dados da pesquisa.

O Fator 1 (F1), explica 25,34\% da variância comum, e representa conjuntamente três variáveis (sp_raras, anim_atr e com_az), todas ligadas ao aspecto da visão que os entrevistados têm a respeito da existência do Parque ao longo do tempo, ou seja, papel que o Parque cumpre em virtude da sua presença no espaço da Região Metropolitana de Belém, em relação aos serviços ecossistêmicos produzidos. Ainda com referência a produção ecossistêmica foram obtidos dois Fatores, o primeiro foi (F2) que explica 24,84\% da variância comum e contabiliza três variáveis (pol_ar, saúde e vlz_ent) e o Fator (F3) que explica 10,95\% da variância comum e envolve duas variáveis (pai_a e prs_bio).

\section{4 - INDICADOR ECOSSISTÊMICO}

A Análise Fatorial Exploratória (AFE) para construção do Indicador Ecossistêmico (IECO) foi construída a partir da matriz de correlação dentre 13 variáveis (componentes) gerando quatro fatores, e foi possível o uso da AFE, pois o determinante apresentou valor diferente de $1(0,34)$ - admitindo-se assim a matriz inversa e que as variáveis são correlacionadas entre si na amostra analisada O teste KMO no valor de 0,787 aponta que são adequadas as amostras. E os resultados do teste de esfericidade de Bartlett (igual a 1058,596) são significantes $(p<0,001)$ e explicam 63,04 \% da variância total dos dados.

Dentre as 13 variáveis, 12 apresentaram comunalidades iguais ou superiores a 0,50 , representando a contribuição de cada variável ao modelo construído pela AFE gerando três fatores. As explicações da variância total dos dados por cada fator encontradas foi para: F1 (25,92\%), F2 (15,72\%), F3 (11,85\%) e F4(9,54). A soma dessas variâncias dos fatores representa precisamente $63,04 \%$, como visto anteriormente. Esses resultados demonstram que os resultados são apropriados para a realidade do fenômeno estudado e que o modelo está apropriado. 
O F1, expressa a presença do PEUT como um instrumento de ação na diminuição das ações de poluição direcionadas ao PEUT, o F2 expressa o quanto o PEUT tem contribuído para a valorização do Turismo e da valorização imobiliária na RMB, o F3 aponta as ações ecossistêmicas diretas do PEUT e o F4 expressa a presença do PEUT no despertar da consciência ambiental das pessoas.

Tabela 5 - Matriz de cargas fatoriais do modelo representativo do potencial multifuncional do ativo ambiental, estado do Pará, 2018.

\begin{tabular}{|c|c|c|c|c|c|}
\hline Variável & F1 & $\mathrm{F} 2$ & F3 & F4 & Comunalidade \\
\hline Diminuição da quantidade de lixo queimado & ,825 &,- 007 & 210 & ,018 & ,666 \\
\hline Diminuição da quantidade de lixo próximo & 807 &,- 076 & , 195 & 044 & ,715 \\
\hline Surgimento de hortas & ,753 & 221 &,- 030 &,- 055 & ,542 \\
\hline Aumento na quantidade de projetos & ,734 & 263 &,- 020 &,- 035 & ,838 \\
\hline Aumento no número de pessoas saindo &, 587 & ,406 & 009 &, 147 & ,725 \\
\hline Aumento no número de chegada de pessoas & ,492 & , 456 & 013 & 239 & 697 \\
\hline Aumento na quantidade de turistas & 102 & ,752 & 117 &,- 123 & 513 \\
\hline Pessoas que defendem a existência do PEUT &, 130 & ,703 &,- 007 & ,038 &, 507 \\
\hline Manutenção da preservação da biodiversidade & 088 &, 556 & , 453 & 142 &, 530 \\
\hline Melhoria das vias próximas & 229 & 147 & ,763 & 244 & 609 \\
\hline Influência na quantidade de chuvas &,- 017 & 019 & ,734 &,- 356 & 620 \\
\hline Aumento da consciência ambiental das pessoas &, 014 & 015 &,- 010 & ,915 & 604 \\
\hline SQ Cargas & 3,111 & 1,886 & 1,422 & 1,146 & 7,565 \\
\hline \%Variância & 25,929 & 15,720 & 11,850 & 9,549 & 63,048 \\
\hline $\mathrm{KMO}=, 787$ & \multicolumn{5}{|c|}{ Batlett'stest $=1058,596(\mathrm{vp}<1 \%)$} \\
\hline
\end{tabular}

O Indicador ecossistêmico capta o quanto a presença do PEUT contribui para mudanças de paisagem e hábito das pessoas, o Fator 1 (F1) obtido explica 25,92\% da variância comum através de quatro variáveis(lixo_que, lixo_px, hortas, pj_sc_amb e sad_pes), o Fator 2 (F2) explica 15,72\% da variância comum e soma três variáveis(aum_tur, exi_peut e pres_bio), os Fatores (F3) e (F4) de forma respectiva explicam 11,50\% e 9,54\% da variância comum, assim como (F3) expressa as variáveis(ml_via e chuvas) e (F4) a variável(csc_amb).

\section{5 - INDICADORES DAS DIMENSÕES AMBIENTAL E ECOSSISTÊMICA}

Os resultados encontrados confirmam a inclusão dos Indicadores Ambientais para a determinação do valor econômico total dos serviços ecossistêmicos promovidos pelo Parque Estadual do Utinga. O indicador sinaliza a perspectiva atual dos usuários do PEUT e da comunidade do entorno perante a situação apresentada (SICHE et al., 2007). O dado pela interação dos fatores supracitados, vai além dos preceitos da Economia Ambiental, a qual admite que os recursos naturais são ilimitados e capazes de substituição. $O$ indicador construído, porém, considera os ativos ambientais como recursos 
limitados, segundo preceitua a Economia Ecológica (COSTANZA, 1994; DALY; COOB JUNIOR, 1989; BEDER, 2011).

\begin{tabular}{lcccc}
\hline Intervalo do Indicador & $\begin{array}{c}\text { Dimensão } \\
\text { Ambiental }\end{array}$ & $\begin{array}{c}\text { Percentual } \\
(\%)\end{array}$ & $\begin{array}{c}\text { Dimensão } \\
\text { Ecossistêmica }\end{array}$ & $\begin{array}{c}\text { Percentual } \\
(\%)\end{array}$ \\
\hline Valor Maior ou igual a 0,8 & 167 & 52,351 & 74 & 23,197 \\
Valor de 0,6 a 0,79 & 133 & 41,693 & 177 & 55,486 \\
Valor de 0,4 a 0,59 & 19 & 5,956 & 62 & 19,436 \\
Valor de 0,2 a 0,39 & 0 & 0,000 & 6 & 1,881 \\
Valor menor que 0,2 & 0 & 0,000 & 0 & 0,000 \\
\hline Amostra total & 319 & 100 & 319 & 100 \\
\hline
\end{tabular}

Fonte: dados da pesquisa

\subsection{O VALOR DA DISPOSIÇÃO A PAGAR}

Os entrevistados foram questionados a ter Disposição a Pagar (DAP) um valor mensal à um fundo ou mesmo associação, ou ainda uma cooperativa com destino a manutenção das condições ambientais, assim como da preservação dos recursos naturais existentes.

Assim, a equação da DAP representou a demanda dos consumidores, ou seja, visitantes do PEUT e moradores do entorno, dessa forma a especificidade da demanda ficou especificada pela seguinte regressão múltipla, de acordo com Bentes et al. (2014) e Santana et al. (2015):

$$
D A P=-36+1,601 e d u+0,002 \text { renda }+27,055 I A+6,961 I E C O+u_{i}
$$

onde: DAP - variável independente; Edu, renda, IA, IECO - variáveis explicativas; $u_{i}$ é o termo de erro aleatório; $e^{b(i=1,2, \ldots . ., 7)}$ é o vetor de parâmetros a ser estimado.

Diante das condições e os parâmetros observados, fez-se a substituição dos valores médios das variáveis independentes na equação da (tabela 6) e obtém-se a DAP média per capta de $R \$ \$ 15,75 /$ mês e de $R \$ 189,00 / a n o$. Considerando que 360.000 pessoas visitam o Bosque Rodrigues Alves durante o ano, o valor obtido é de $\mathrm{R} \$ 68.040 .000,00 /$ ano, a ser pago para que o PEUT possa receber ações de preservação, garantido os serviços ecossistêmicos e ambientais para a geração do bem-estar das famílias, dos visitantes e dos moradores do entorno. Este resultado é coerente com o obtido por (Morgado, Abreu, Réquia e Aravéchia, pg.6-7,2011) para valoração ambiental do Parque Ecológico de Usos Múltiplos Águas Claras - DF: analisando a disposição a pagar dos usuários. Além disso, o Valor 
Econômico Total (VET) por sua preservação de R\$ 5.670.000,00/ano ao utilizar-se o Valor Presente Líquido (VPL), com uma taxa de 4\% ao ano ao longo de 100 anos o VET é de R\$144.613.344,3.

\section{CONCLUSÃO}

A contribuição de destaque deste trabalho é mostrar a importância de um ativo ambiental na Região Metropolitana de Belém para geração de serviços ambientais e ecossistêmicos geradores de bemestar para a população. A mostra da importância pode ser obtida através da valoração do ativo ambiental utilizando pelo menos três formas metodológicas, ou seja, através da DAP, do mercado de crédito de carbono e do preço da madeira no mercado.

A metodologia de DAP captou entre moradores do entorno, visitantes e pessoas que trabalham no PEUT a informação de 319 pessoas que se manifestaram dizendo ter disposição de pagar um valor para garantir a preservação do PEUT, observando este como um espaço que gera bem estar. $O$ valor médio per capita da DAP foi estimado em R\$ 15,75/mês e de R\$ 189,00/ano. Extrapolando este valor para 360.000 pessoas obtém-se o valor de $\mathrm{R} \$ 5.670 .000,00 /$ ano.

\section{REFERÊNCIAS}

BEDER, S. Environmental economics and ecological economics: the contribution of interdisciplinarity to understanding, influence and effectiveness. Environmental Conservation, v. 38, n. 2, p. 140-150, jun. 2011.

BENTES, E.S. et al. A pesca artesanal a jusante da Usina Hidrelétrica de Tucuruí, estado do Pará. Novos cadernos do NAEA, v.17, n.2, p.167-187, 2014.

CARSON, D. et al. Qualitative Marketing Research. London: Sage Publications, 2001.

COSTANZA, R. Economia ecológica: uma agenda de pesquisa. In: MAY, P. H.; HERMAN, P.; MOTTA, R.S. (Org.). Valorando a natureza. Rio de Janeiro: Campus, 1994.

DALY, H.E.; COOB JUNIOR, John. B. For the common good: redirecting the economy toward community, the environment, and a sustainable future. Boston: Beacon Press, 1989.

FERREIRA, M.B.M.; SALES, A.O.T. Política Ambiental Brasileira: análise histórico institucionalista das principais abordagens estratégicas. Revista de Economia, v. 43, n. 2, mai./ago. 2016.

JOHNSON, R. A.; WICHERN, D. W. Applied multivariate statistical analysis. 6. ed. Pearson Prentice Hall, 2007.

HAIR, Joseph F. Análise multivariada de dados. Tradução Adonai Schlup Sant'Anna. - 6. ed. - Dados eletrônicos. - Porto Alegre: Bookman, 2009. 2009. 
LIU, S.; COSTANZA, R.; FARBER, S.; TROY, A. Valuing ecosystem services: theory, practice, and the need for a transdisciplinary synthesis. Ecological Economics Reviews, v.1185, n.1, p. 54-78, 2010.

MINGOTI, S.A. Análise de dados através de métodos de estatística multivariada: uma abordagem aplicada. Belo Horizonte: Editora UFMG, 2013.

Morgado, R.C. Abreu, L.M, Réquia, W.J. e Aravéchia, J.C. VALORAÇÃO AMBIENTAL DO PARQUE ECOLÓGICO DE USOS MÚLTIPLOS ÁGUAS CLARAS - DF: ANALISANDO A DISPOSIÇÃO A PAGAR DOS USUÁRIOS PELO SEU USO. Revista de Estudos Ambientais. 2011

QUARESMA, J. L. CONTRIBUIÇÃO METODOLÓGICA PARA A VALORAÇÃO DO CAPITALFLORESTAL MADEIREIRO DA AMAZÔNIA. Trabalho de conclusão de curso apresentado ao Curso de graduação em Engenharia Ambiental \& Energias Renováveis da Universidade Federal Rural da Amazônia como requisito para obtenção do grau de Engenheiro Ambiental,2017.

ROCHA, E.B. Sócio-Ambiental à Luz Do Sensoriamento Remoto: O Caso Da Comunidade Jardim Nova Vida $\mathrm{Na}$ Área De Proteção Ambiental Metropolitana Do Município De Belém, Estado Do Pará.Dissertação (Mestrado) - Universidade Federal do Pará, Núcleo de Meio Ambiente, Programa de Pós-Graduação em Gestão de Recursos Naturais e Desenvolvimento Local na Amazônia, Belém, 2011.

SANTANA, A.C. Recent changes in the relations of Brazilian meat demand system. Revista de Economia e Sociologia Rural, v. 37, n. 2, p. 161-184, 1999.

SANTANA, A.C. Análise do desempenho competitivo das agroindústrias de polpa de frutas do Estado do Pará. Teoria e Evidência Econômica, v. 14, n. 14, p. 36-62, jul./dez., 2007.

SANTANA, A.C. Valoração ambiental da área de savana metalófila, ou canga, da Flona de Carajás para fins de indenização. Belém: UFRA, 2014.

SANTANA, A.C. et al. Valoração dos danos ambientais causados por hidrelétricas para a produção de energia na bacia do Tapajós. Reflexões Econômicas, v. 1, n. 1, abr./set., p. 31-48, 2015.

SANTANA, A.C. et al. O valor econômico total da área de savana metalófita, ou "Canga", da Floresta Nacional de Carajás, estado do Pará: uma contribuição teórica e metodológica da avaliação contingente. Papers do NAEA, n. 361, Belém, 2016.

SANTANA, A.C. et al. Theoretical and methodological contributions to the contingent evaluation of the natural resources of the Carajás National Forest. International Journal of Development Research, v. 7, n. 4, p. 12468-12474, 2017.

SICHE, R. et al. Índices Versus Indicadores: precisões conceituais na discussão da sustentabilidade de países. Ambiente e Sociedade, Campinas, v. 10, n. 2, p. 137-148, jul./dez. 2007.

TRINDADE, JR. Saint-Clair Cordeiro. A cidade dispersa: os novos espaços de assentamentos em Belém e a reestruturação metropolitana. Tese de doutorado.

Universidade de São Paulo, 1998. 
